\title{
Colección Congresos y
}

Homenajes Serie Homenajes

\section{La investigación acompañando a la vida Estudios en Homenaje a Emigdia Repetto Jiménez}

Pastora Calvo Hernández

Víctor Manuel Hernández Suárez

Juana Rosa Suárez Robaina

(Coordinadores) 

La investigación acompañando a la vida Estudios en Homenaje a Emigdia Repetto Jiménez 

La investigación acompañando a la vida Estudios en Homenaje a Emigdia Repetto Jiménez

\author{
Pastora Calvo Hernández \\ Víctor Manuel Hernández Suárez \\ Juana Rosa Suárez Robaina \\ (Coordinadores)
}


ESTUDIOS en homenaje a Emigdia Repetto Jiménez : la investigación acompañando a la vida / Pastora Calvo Hernández, Víctor Manuel Hernández Suárez, Juana Rosa Suárez Robaina (coordinadores). -- Las Palmas de Gran Canaria : Universidad de Las Palmas de Gran Canaria, Servicio de Publicaciones y Difusión Científica, 2021

1 archivo PDF (727 p). - (Congresos y homenajes. Serie Homenajes)

ISBN 978-84-9042-417-9

1. Repetto Jiménez, Emigdia (1935-2020) - Homenajes I. Calvo Hernández, Pastora, coord. II. Hernández Suárez, Víctor Manuel, coord. III. Suárez Robaina, Juana Rosa, coord. IV. Universidad de Las Palmas de Gran Canaria, ed. V. Título: La investigación acompañando a la vida VI. Serie

082.2Repetto Jiménez, Emigdia

Thema: GBD, GT, 4CT

La edición impresa de este HOMENAJE ha sido posible gracias a la colaboración de la Facultad de Ciencias de la Educación, el Departamento de Psicología, Sociología y Trabajo Social, el Departamento de Didácticas Específicas, el Departamento de Educación y el Departamento de Matemáticas de la Universidad de Las Palmas de Gran Canaria

\section{Colección Congresos y Homenajes Serie Homenajes}

\section{(C) de los textos: sus autores}

(C) de la edición:

Universidad de Las Palmas de Gran Canaria Servicio de Publicaciones y Difusión Científica serpubli@ulpgc.es · http://spdc.ulpgc.es

Primera edición [versión electrónica PDF]. Las Palmas de Gran Canaria, 2021

eISBN: 978-84-9042-417-9

ISBN: 978-84-9042-416-2

https://doi.org/10.20420/1656.2021.430

Maquetación y Diseño:

Servicio de Publicaciones y Difusión Científica de la ULPGC

\section{Producido en España. Produced in Spain}

Queda rigurosamente prohibida, sin la autorización escrita de los titulares del «Copyright», bajo las sanciones establecidas por las leyes, la reproducción parcial o total de esta obra por cualquier medio o procedimiento, comprendidos la reprografía y el tratamiento informático. 


\section{ÍNDICE}

Presentación Del Rector

Lluís Serra Majem

Excmo. y Mgco. Sr. Rector de la ULPGC ................................................13

\section{FAMilia García RePETTO}

Emigdia Repetto Jiménez, in memoriam ......................................................15

\section{RAFAel ROBAINA ROMERO}

Emigdia Repetto Jiménez, in memoriam …................................................17

\section{ANTONio García Correa}

Emigdia Repetto Jiménez, in memoriam ......................................................19

SEMblanZa BIOBIbLIOGRÁFICA

Juana Rosa Suárez Robaina ................................................................21

\section{ArTí́culos}

\section{Teresa Anguera}

De la entrevista en profundidad a la observación sistemática: una pincelada de comunicación multimodal desde los mixed methods

Andamana Bautista García

Reflexiones en torno a la competencia literaria en la primera infancia 


\section{Daniel Becerra Romero}

La profesión de maestro en la vińeta española del siglo XX:

el profesor Tragacanto y su clase, que es de espanto.

Perspectiva didáctica de antaño

Ismael Betancor Almeida, José Abreu Alemán

y Juan Luis Jiménez González

Efectos de la Covid-19 en los músicos profesionales de Canarias.

José Ramón Calvo Fernández y Cecilia Kindelán

Reflexiones, enseñanzas y aprendizajes en tiempos de pandemia

\section{Pastora Calvo Hernández y Ciro Gutiérrez Ascanio}

La necesidad de formación del profesorado en habilidades

sociales, dinámica de grupo y trabajo cooperativo

José Luis Correa Santana

Óleo de mujer con espejo

Manuel de Armas Hernández

La supervisión de la intervención en el campo de la

Educación Social

\section{Lía de Luxán Hernández}

Literatura de viajes y turismo académico. Diseño de tres

actividades de aprendizaje

\section{Ramón Díaz Hernández}

La natalidad y las políticas pro-poblacionistas durante la

Segunda República

José Luis A. Eiroa Martínez

Biodiversidad en Canarias: fuente de productos naturales .205

\section{María del Pilar Etopa Bitata, Elena Chirino Alemán y Gabriel Díaz Jiménez}

La formación del profesorado de la ULPGC para favorecer la inclusión educativa 
$M^{a}$ del Sol Fortea Sevilla

Investigaciones sobre el autismo realizadas en la Facultad de

Ciencias de la Educación de la ULPGC

\section{Ángela García Cabrera}

Principales tendencias del desarrollo turístico rural en la región canaria: un estudio de casos en varios municipios de la isla de

Gran Canaria

\section{Luis Alberto García García y José Juan Castro Sánchez}

La creatividad y su comprensión

\section{Rosario García Repetto}

Enseñanza de las Ciencias en el Grado de Criminología:

laboratorio criminalístico

\section{Ma Isabel González Cruz}

Más contribuciones a la bibliografía inglesa sobre Canarias:

el texto de Daniel J. Browne (1804-1867), primer naturalista norteamericano en Europa

\section{Ma del Pilar González de la Rosa}

Integración de competencias profesionales en el currículum de Ingeniería: una propuesta didáctica

\section{Juana Teresa Guerra de la Torre y Adán Rafael Martín Dueñas}

Activación inconsciente de desconfianza en el personal de enfermería por la organización cognitivo-esquemática del concepto en español. Hacia una nueva salud cultural desde las Neurohumanidades

\section{Santiago Ramón Guerra Guillén}

Un acercamiento didáctico a la cognición cuántica: un modelo

matemático para entender cómo aprendemos a tomar decisiones

\section{Santiago J. Henríquez Jiménez}

La estética de las luces: dibujantes, apuntes y bocetos que ilustraron la ciencia. 
Fernando Hernández Guarch

Kepler y un universo ordenado

Víctor Manuel Hernández Suárez y Rosa María Hernández Suárez

Historia y didáctica de las Matemáticas.

Manuel Lobo Cabrera

Los comienzos de la Educación en Canarias

\section{Gonzalo Marrero Rodríguez y Ofelia Santiago García}

La cuestión de Dios: teísmo y ateísmo

P. Martel, H. Alonso, M. A. Arnedo, A. Tejera y J. G. Rubiano.

Gran Canaria, una isla radiactiva ...como el resto del planeta.

\section{Francisco Martínez Navarro}

Reflexiones sobre la evolución de la vida profesional de un profesor investigador de enseñanza secundaria e importancia de las influencias recibidas de su maestra Emigdia Repetto Jiménez

\section{Joaquín Meco Cabrera}

Los tres grados de conocimiento: aplicación a la geología paleoclimática de Canarias

\section{Ma Dolores Medina Benítez}

La creatividad como operación básica de la inteligencia: teorías relacionadas con la experimentación artística como experiencia formadora

\section{Rafael Millán Gómez y Francisco Martínez Navarro}

Introducción a la química del carbono: una propuesta de unidad didáctica de física y química de $4^{\circ}$ de la ESO basada en situaciones problemáticas de aprendizaje

\section{Ivalla Ortega Barrera}

Comunicación y aprendizaje a través del arte en aulas multiculturales y multilingües: ArtiCULan 


\section{Indice}

Fernando Luis Peligero Escudero

Sobre la antropología filosófica y la antropología pedagógica

Jesús Miguel Pérez Ceballos

La Educación de la Sociedad en la era de la globalización.

Educating society in the time of globalization

$\mathrm{M}^{\mathrm{a}}$ Esther Pérez Martell, $\mathrm{M}^{\mathrm{a}}$ Olga Escandell Bermúdez

y Francisco Rubio Royo

Reflexiones de unos autodidactas

Antonio S. Ramos Gordillo, Marta Ramos Sosa

y Claudia Ramos Sosa

Lo que aproxima a la enfermedad: los factores de riesgo

Francisco Robaina Palmés, Alicia Soledad Robaina Espino

y Francisco Domingo Robaina Espino

La familia, el conflicto y la mediación familiar

\section{María Nayra Rodríguez Rodríguez y Didac Martín Martínez}

Emigdia Repetto pionera de la metodología neuroeducativa de la

ULPGC: estudio de campo en alumnos de postgrado del máster

de español de la ULPGC (promoción 2019-2020)

\section{Fermín Romero Navarro}

La autoridad. Deconstrucción y construcción.

Familias de alta conflictividad judicializadas en

contextos de coordinación de parentalidad

Victoriano Santana Sanjurjo

Un decálogo sobre las frases hechas a partir de un dicho paterno

Martín M. Socas Robayna, M. Mercedes Palarea Medina

y Josefa Hernández Domínguez

El Álgebra en la Educación Primaria y Secundaria desde

la perspectiva competencial 


$$
\text { Indice }
$$

\section{Juana Rosa Suárez Robaina}

Lengua y agua de arroz. Un estudio de caso sobre los Realia con escritura y su perspectiva multimodal

\section{BREVE BIOGRAFÍA DE EMIGDIA REPETTO JIMÉNEZ}

Víctor Manuel Hernández Suárez ..........................................................723

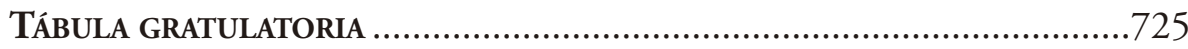




\title{
PRESENTACIÓN
}

\section{EMIGDIA REPETTO JIMÉNEZ, IN MEMORIAM}

\author{
Lluís Serra Majem \\ Rector de la ULPGC
}

No creo que exista mejor homenaje a un maestro que contemplar cómo ha fructificado la semilla que ha plantado en sus discípulos. En este caso, el recuerdo, la presencia de nuestra compañera universitaria Emigdia Repetto queda plasmada en este volumen donde sus discípulos que devinieron en compañeros, le rinden un sentido homenaje por su vocación universitaria y por lo mucho que les transmitió durante su vida.

Emy Repetto nació en Sevilla y murió en Gran Canaria, su tierra de adopción desde el año 1968 donde comenzó a trabajar en la entonces denominada Escuela de Magisterio. Era Licenciada en Química y una apasionada de la enseñanza, como lo demostró eligiendo el tema de su tesis doctoral: "Diseño, aplicación y evaluación de módulos de aprendizaje para la formación inicial del Profesorado de EGB de Ciencias".

Catedrática de Escuela Universitaria fue una incansable docente e investigadora, además de participar activamente en el gobierno y gestión no sólo de su centro, sino en los órganos generales de la ULPGC donde ejerció de Directora de Calidad e Innovación Docente (1999-2002) y de Jefa de Inspección del Servicio de Inspección (2003-2007).

Sus méritos le hicieron merecedora del nombramiento como profesora emérita, lo que hizo que cumpliera casi 50 años de compromiso con la ULPGC, tanto en la Facultad de Ciencias de la Educación como en la Estructura de Teleformación.

Ese reconocimiento trascendió la propia ULPGC, ya que en el año 2010 la Consejería de Educación, Universidades, Cultura y Deportes del Gobierno de Canarias le otorgó la distinción 'Viera y Clavijo', en reconocimiento a su valía en la docencia y por la consecución de objetivos de participación y calidad en el sistema educativo de Canarias. 
Recuerdo su figura singular, su carácter tenaz e inquebrantable, su mirada tan expresiva y penetrante, su inmensa vocación docente que seguro nunca caerán en el olvido. Emigdia Repetto ha trabajado intensamente por lograr la ULPGC que ahora tenemos, por lo que la comunidad universitaria le debe agradecimiento y reconocimiento. Sirva este volumen como un pequeño homenaje a nuestra compañera y maestra Emy Repetto, orgullo para su familia y amigos, orgullo para nuestra ULPGC. 


\title{
EMIGDIA REPETTO JIMÉNEZ, IN MEMORIAM
}

\author{
Familia García Repetto
}

Escribo estas palabras en una mañana fría y lluviosa del otoño del 2020. Son las palabras más difíciles que he escrito nunca y lo hago haciendo mía la voz de mi familia.

Uno nunca piensa en el final de la vida, uno no cree que eso vaya a pasar $y$, sin embargo, sabemos, es inevitable. Todo ello dificulta que nos podamos enfrentar a su realidad desgarradora. Nos queda el dolor, la ausencia y el silencio. $\mathrm{Y}$, sin embargo, su recuerdo es el mejor homenaje.

Doña Emy como era conocida en la Universidad, nuestra hermana, madre, suegra y abuela fue una mujer excepcional que habiendo nacido en una época en la que la mayoría de las mujeres espańolas no llegaban a estudiar en la Universidad fue capaz de desarrollar una prolífica y extensa carrera profesional a la vez que ser el pilar fundamental de su familia.

Ella, sevillana de nacimiento, se declaraba canaria consorte y con suerte reconociendo así la perfecta simbiosis que creó conjuntamente con Rubén, su amor del alma y compañero de vida.

Todos ustedes conocen su rigor científico, capacidad didáctica, su entrega y tesón por el trabajo. Disfrutaron también de su mirada alegre y la sonrisa con la que se enfrentaba a los problemas cotidianos. Nos consta que muchos de los lectores de este libro compartieron muchos momentos de su vida, creciendo con ella y aprendiendo de ella. Disfrutamos siempre de su ingenio y su gracia, muestra de su gran inteligencia.

Para nosotros, su familia, ella fue esa mano que evita que te caigas cuando empiezas a caminar pero que te sostiene mientras creces y que te da un empujoncito hacia delante cuando hay que hacer frente a las dificultades de la vida. Nos enseñó que la vida consiste en seguir siempre hacia delante con la mejor sonrisa. Ella fue confidente y maestra, heredamos de ella el interés por la ciencia 
y por la disciplina en el esfuerzo ya que, siguiendo lo afirmado por Louis Pasteur, ella también creía que el azar sólo ayuda a las mentes preparadas. Reconozco que todos nosotros necesitamos que su mirada nos siga iluminando como el faro que permite la llegada a buen puerto.

Toda la familia quiere reconocer el interés y trabajo asumido por los coordinadores de este libro homenaje. Esta iniciativa la apoyamos sin la menor duda. Asimismo, queremos dar las gracias a todos los amigos y compañeros que han contribuido con sus aportaciones a que este libro sea una realidad.

Finalmente, es para nosotros un honor y un orgullo que la Universidad de Las Palmas de Gran Canaria, y especialmente el Excmo. y Mgco. Sr. Rector D. Lluís Serra Majem y el anterior Rector D. Rafael Robaina Romero, desde el primer momento hayan apoyado la idea de los coordinadores y hecho posible la publicación de este libro homenaje.

\section{Emigdia Repetto Jiménez (Emy)}

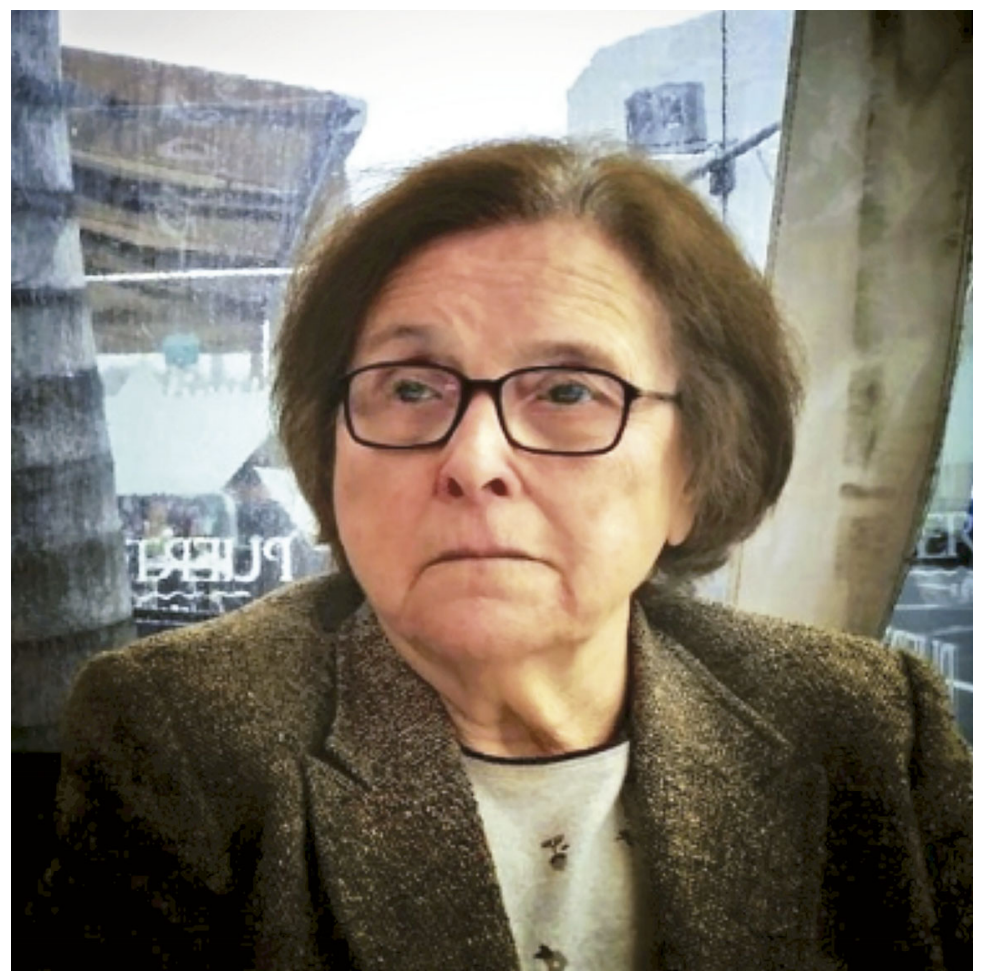

Fuente: colección particular de la familia García Repetto. 


\title{
EMIGDIA REPETTO JIMÉNEZ, IN MEMORIAM
}

\author{
Rafael Robaina Romero \\ Rector de la ULPGC (2017-2021)
}

Hace unas fechas lamentábamos comunicar en la página web de la universidad el fallecimiento de la Dra. Dńa. Emigdia Repetto Jiménez (carińosamente, Emy Repetto). Catedrática de Escuela Universitaria de nuestra Universidad, en el Departamento de Didácticas Especiales, área de Didáctica de las Ciencias Experimentales, profesora emérita y muy involucrada en toda la actividad académica de nuestra institución durante más de 40 años, tanto en la Facultad de Ciencias de la Educación como en la Estructura de Teleformación.

Emy Repetto se licenció en Ciencias Químicas por la Universidad de Sevilla en el año 1958, y se diplomó como Maestra Nacional en 1970, en la Escuela de Magisterio de Las Palmas. Defendió su tesis doctoral en el año 1990, en la Facultad de Químicas de la Universidad de La Laguna.

Fue entusiasta colaboradora de la revista científica El Guiniguada, revista de investigaciones y experiencias en Ciencias de la Educación, contribuyendo en los volúmenes $09,10,11,12,13,14,17,18$. Su última aportación, hace cinco años, versaba sobre el Quijote, quizás porque, como al personaje de Cervantes, la distinguía su carácter perseverante, recio e inquebrantable. Desde luego a nadie dejaba impasible.

En estos momentos en el que las Tecnologías de la Información y la Comunicación se nos han vuelto imprescindibles, nos parece estar viéndola diciendo por los pasillos de la actual Facultad de Ciencias de la Educación o del Rectorado: "ven ustedes, la implantación de la Teleformación en la ULPGC fue todo un acierto". Emigdia Repetto Coordinó la Diplomatura y el Grado de Maestro de Educación Primaria en Teleformación desde su implantación en 2005 hasta 2014, año de su jubilación.

En 2010, el Gobierno de Canarias le otorgó la distinción 'Viera y Clavijo' por su aportación a la calidad de la enseñanza en el Archipiélago. Se había es- 
pecializado en el fracaso escolar y ejercía su actividad investigadora a través del Grupo de Investigación Severo Ochoa de la ULPGC. También fue autora de numerosas artículos y colaboraciones, destacando las siguientes publicaciones Blas Cabrera Felipe, El poema del Atlántico y Actualización en la didáctica de las Ciencias Experimentales.

Esta edición especial, en forma de contribuciones de compañeros y compañeras de la ULPGC que la apreciábamos, es nuestro sentido homenaje en memoria de Emy Repetto. 


\title{
EMIGDIA REPETTO JIMÉNEZ, IN MEMORIAM
}

\author{
Antonio García Correa \\ Catedrático de Psicología Evolutiva y de la Educación \\ Universidad de Murcia
}

La Asociación Universitaria de Formación de Profesorado tiene la reconfortante y entrañable misión de rendir homenaje póstumo a una mujer destacada, sensible y de especial rigor científico como ha sido Emy Repetto.

Su pérdida tan rápida, nos ha conmovido profundamente, pero fue estupendo compartir parte de su vida, de su habilidad profesional y de sus valores éticos y humanos.

Quienes tuvimos el privilegio de conocerla, quererla, respetarla, admirarla y compartir días de trabajo, estamos seguros de que su existencia no ha terminado ni se ha extinguido con su inesperada muerte; es más, estamos seguros de que todo su trabajo en el campo de la Educación trascenderá y perdurará.

Su vida brinda oportunidades en momentos irrepetibles y posiblemente, muchos amigos, profesores... no hayamos tenido la oportunidad de agradecerle su labor, pero hoy no debemos perder esta posibilidad. En este momento y con este escrito, se hace necesario expresar a Emy unas palabras de agradecimiento y retribución por los años dedicados al estudio cotidiano que directamente redundó en beneficio de los formadores de profesores. No es lo que uno tiene lo que hace a la persona, sino lo que la persona hace por los demás.

Emy vivió la vida con entrega, integridad y convicción. En nuestro modo de pensar existe una trilogía muy bien conocida que dice que un hombre y una mujer deben considerar exitoso su paso por esta vida cuando ha escrito libros y artículos, creado y plantado ideas y tareas y engendrado familia. Emy supo escribir varios artículos y editoriales, poseyó habilidades sociales creativas y tuvo hijos y un esposo admirable. Vivirá en cada libro y artículos, en cada uno de sus hijos, familia y su existencia se verá prolongada.

Tenemos el honor con este escrito de rendir homenaje a quien en su vida fue nuestra colega, profesora y compañera y que en todos los años de su vida que 
la conocimos nos demostró que podíamos confiar en ella y en las situaciones difíciles contar con su ayuda desinteresada, natural y espontánea.

Por Emy, por los compañeros muertos y por todos los que notamos sus ausencias, mantengámonos siempre unidos y sigamos trabajando por la Educación y Formación del Profesorado. 


\title{
EMIGDIA REPETTO JIMÉNEZ (1935-2020) SEMBLANZA BIOBIBLIOGRÁFICA
}

\author{
Juana Rosa Suárez Robaina \\ Universidad de Las Palmas de Gran Canaria
}

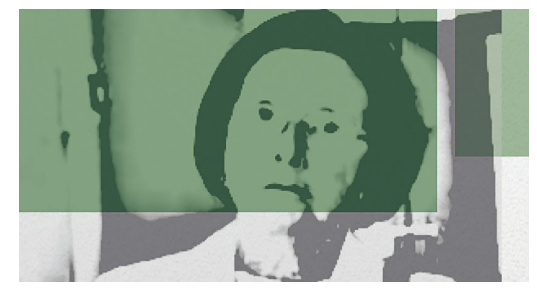

Research goes on in laboratories and libraries, in jungles and ocean depths, in caves and in outer space, in offices and, in the information age, even in our own homes.

Research is in fact the world's biggest industry. Booth, W., Colomb, G. y Williams, J., (2008. p. 9)

Esta semblanza, a modo de glosa, propone un recorrido biobibliográfico por la dilatada trayectoria de la docente e investigadora homenajeada Doña Emigdia Repetto Jiménez (1935-2020). No pretende agotar exhaustivamente su rico curriculum: tan solo persigue testimoniar las múltiples dimensiones profesionales que jalonaron su discurrir, desde la docencia propiamente dicha, en diferentes etapas, modalidades y ámbitos educativos, hasta su mentoría en investigación con la dirección tanto de cursos como de Tesis doctorales y otros trabajos especializados, sin dejar atrás su importantísimo papel en la gestión académica o su liderazgo en la creación de materiales y en la difusión de la cultura científica.

Pero empecemos por el principio, por la instrucción que inició su camino formativo y que pronto vislumbró la dicotomía que perfiló, prácticamente, toda su trayectoria: entre la especialización y una intensa vocación docente.

En efecto, Emigdia culminó sus estudios de Licenciatura en Químicas en la Facultad de Química de la Universidad de Sevilla (1958), su ciudad natal, pero sería doce años más tarde, en 1970 y en su otro escenario de vida, el archipiélago canario, donde concluiría la titulación de Maestra Nacional, concretamente en la por entonces denominada Escuela del Magisterio, en Las Palmas de Gran Canaria, escenario que vendría a configurarse como su destino 
profesional —y también de vida— (hoy Facultad de Ciencias de la Educación), hasta su fallecimiento.

No acabó aquí su formación académica pues veinte años después, en 1990, obtuvo su doctorado en Ciencias Químicas en la Universidad canaria de La Laguna, con la Tesis doctoral denominada Diseño, aplicación y evaluación de módulos de aprendizaje para la formación inicial del Profesorado de EGB de Ciencias.

Su carrera profesional como docente arranca en el curso académico 19681969 y su vinculación directa con el aula no cesará hasta prácticamente el 2014, año de su jubilación.

Sus primeras materias impartidas fueron, todas ellas, del denominado Plan 50, Fisiología e Higiene, Quimica y Agricultura e Industrias rurales. Las materias de "Didáctica" en las que volcó buena parte de su compromiso de investigación y mejora constante, no llegarían hasta el siguiente Plan educativo, el Plan 67, con asignaturas como Didáctica de la Física y Química o Didáctica de las Ciencias Naturales, ya en el período 1969-1972, y que la acompañarían durante su recorrido académico junto a otras materias.

Su consolidación como profesora de plantilla le llega en 1981, año en que obtiene la plaza de Profesora Agregada de Escuelas Universitarias del Profesorado de EGB, tras oposición, en convocatoria nacional, celebrada en Madrid. Un nuevo espaldarazo le llega apenas once años después, en 1992, con la obtención de la Cátedra de Escuela Universitaria, en el área de Didáctica de las Ciencias Experimentales. Y un nuevo nombramiento, ya el último, le llegaría durante el verano del año 2006, cuando se le concede la condición de Profesora Emérita de la Universidad de Las Palmas de Gran Canaria.

En su ejercicio docente es importante destacar que su dilatada trayectoria le permitió conocer distintos Planes educativos: el Plan 1950, el Plan 1967, el Plan 1971 y, finalmente, el Plan 1991 con el que concluyó su camino profesional; conoció, asimismo, durante su trayectoria, varias de las múltiples denominaciones (Martel, 1995-1998) que obtuvo el Centro donde ejerció toda su carrera docente presencial: de la Escuela del Magisterio con la que inició su singladura, pasando por la Escuela Universitaria de Formación del Profesorado de EGB (a partir del curso 1972-1973), el Centro Superior de Formación del Profesorado (CSFP) de la ULPGC (una vez que se desvincula de la ULL), la Facultad de Formación del Profesorado (FFP) en el año 2001, hasta la actual denominación de Facultad de Ciencias de la Educación, obtenida en el año 2016.

Vivió, por tanto, primeramente, la integración de la "Escuela", en 1972, en la Universidad de La Laguna (ULL) y, posteriormente, en 1989, su incor- 
poración a la recién fundada Universidad de Las Palmas de Gran Canaria (ULPGC).

Estos datos son importantes para ubicar a una docente comprometida con los distintos programas y singladuras de la historia educativa de su Centro de trabajo presencial y en los que participó activamente como detallaremos más adelante.

Pero también desarrolló una consistente trayectoria docente en la modalidad académica on line: primeramente, con su desempeño en la asignatura de tres créditos europeos (ECTS) Recursos didácticos multimedia: diseño, elaboración y evaluación. Esta asignatura del Programa Interdepartamental de Doctorado "Formación y Perfeccionamiento de Profesorado", impartida ininterrumpidamente desde el curso académico 2002-2003 hasta el 2008-2009, a través de la plataforma educativa de la ULPGC, supuso para Emigdia una constante defensa de las ventajas formativas del aprendizaje mediado por las TIC, en la línea de Coll, Mauri y Onrubia (2008).

$\mathrm{Su}$ segunda apuesta fuerte por la formación on line se derivó de su pertenencia al equipo docente del Título de Maestro, en la Estructura de Teleformación, desde el curso académico 2005-2006 y prácticamente hasta su jubilación.

Muchísimas horas dedicó Emigdia al acompañamiento e instrucción de tantísimos profesores en formación "de la on line" a lo largo de sus años de dedicación, y en asignaturas diferentes; así, aquí pudo desempeñar su "magisterio" en materias optativas como la Educación Ambiental y su Didáctica, sin duda una de sus pasiones o la Historia de la ciencia como recurso didáctico junto a otras troncales como el Practicum I y el Practicum II. Aquí pudo, también, consolidar su creencia en las fortalezas de una acción tutorial renovada, tal y como en los últimos años se viene defendiendo (Anta y García, 2018).

Una de sus tareas académicas más significativas fue sin duda su desempeño en el ámbito del Doctorado. Primeramente, en cuanto a los cursos de Doctorado y junto al ya mencionado (de carácter on line), y desarrollado con continuidad desde el año 2003 hasta el año 2008, hay que recordar otros tantos en los que se involucró, justamente en la década anterior: desde el año 1991 hasta el 2000. Todos ellos fueron proyectos diferentes y de carácter presencial, mayoritariamente impartidos en la localidad de Las Palmas de Gran Canaria, como correspondía por pertenecer al Programa de Doctorado "Formación y Perfeccionamiento de Profesorado" de nuestra Universidad, y relacionados todos con el Departamento de Didácticas Especiales (hoy Didácticas Específicas) y algunos de ellos con los Departamentos de Educación y de Psicología y Sociología (hoy Psicología, Sociología y Trabajo Social). Alguno incluso fue 
impartido en la localidad de Arrecife de Lanzarote. El referido al año 1995 correspondió a una colaboración con el Programa de Doctorado de la Universidad hermana de La Laguna, concretamente con el Programa "Didáctica de las Ciencias Experimentales” del Departamento de Didácticas Especiales de la Universidad de La Laguna. Un repaso por los títulos de estos cursos de Doctorado evidencia la fuerza investigativa de nuestra homenajeada, así como su impulso a la labor académica de una universidad sentida, cómo no, como compromiso con una educación transformadora (Manzano y Bacal, 2014). Recogemos aquí varios de esos cursos de Doctorado: Planificación didáctica del D.C.B. en Ciencias Experimentales, La experimentación en el aula como recurso didáctico, Medio ambiente y salud, Didáctica de las Ciencias Experimentales, Elaboración de materiales curriculares para la enseñanza de la Física y Química, Recursos didácticos en el área de Ciencias de la Naturaleza, Implicaciones didácticas de la Historia de la Ciencia, Resolución de problemas de lápiz y papel como pequeñas investigaciones, Historia de la Ciencia: sus aplicaciones didácticas, Metodología didáctica, Conocimiento científico escolar y vida diaria.

$\mathrm{Y}$, en segundo lugar, hay que recordar que en un período de apenas doce años se defienden en la Universidad de Las Palmas de Gran Canaria ocho Tesis doctorales dirigidas por Emigdia (dos de ellas en coautoría). La primera corresponde al año 2004 y la última en el 2015. Ello revela, una vez más, la fortaleza pedagógica de nuestra homenajeada en la dimensión instructiva e investigativa. Gracias además a esa tutela muchos de estos doctorandos consolidaron su labor docente, tanto en la etapa educativa de Enseñanzas medias como en la propia Universidad, lo que subraya sin duda la eficacia didáctica de la profesora Emigdia.

Otros Posgrados, como el Máster en Educación para la Salud, el Máster de Pediatría Social (a distancia), el Experto en Educación y Promoción de la Salud, el Máster Interuniversitario de Mediación Familiar o el Máster de Intervención y Mediación familiar ocuparon asimismo su labor con la dirección de sus respectivas Tesinas y Trabajos Fin de Título.

Y otras acciones docentes relevantes en su trayectoria fueron el diseño, la impartición o bien la dirección de numerosos cursos, tanto de Formación didáctica como de Actualización científica o de Especialización didáctica del Profesorado, Extensión universitaria o Armonización de conocimientos, en su mayoría en el ámbito universitario, pero también vinculados a otros organismos educativos (CEP y Fundación ICEPSS) y desarrollados sobre todo en el período 1996-2000.

En paralelo a esta intensa acción docente, hay que destacar su implicación en la publicación, tanto de libros (monografías completas) como de capítulos 
en obras colectivas, junto a artículos en publicaciones periódicas de carácter divulgativo y científico. Por citar unos cuantos ejemplos, de los primeros queremos recordar sus contribuciones monográficas, de carácter académico, en editoriales como Afortunadas (1999, Ciencias de la Naturaleza. 10 ESO), Dykinson (2006, Guía Académica), CamPDS Editores (2008, Guía Académica Doctorado Formación Profesorado), Anaga (2004, Los recursos didácticos multimedia: diseño, elaboración y evaluación) o las ediciones del Gobierno de Canarias (1995, Los aspectos medioambientales y la enseñanza de las Ciencias; 2006, Biografias de Científicos Canarios. Guía de Recursos Didácticos). Y en esta voluntad pedagógica de divulgar y compartir sus conocimientos no podemos dejar de mencionar la activa colaboración de Emigdia con los proyectos editoriales de su propia Universidad. Así, desde el año 1991 con Meteorología escolar. Conceptos y experiencias básicas o El poema del Atlántico: su utilización en el área de Ciencias hasta sus últimos años productivos, se sucede un amplísimo abanico de publicaciones universitarias referidas a sus grandes líneas de investigación e interés: la Educación Ambiental y su didáctica, la Didáctica de la Física y Química, la historia de la ciencia como recurso didáctico, la formación del profesorado o la implementación de las tecnologías en el proceso de enseñanza-aprendizaje; no nos olvidamos de los diez manuales docentes para el título del Grado en Educación Primaria, específicos de la Estructura de Teleformación de la ULPGC.

Su compromiso con el Servicio de Publicaciones y Difusión científica de la ULPGC también se fraguó especialmente a través de su asidua participación en una de las revistas del actual Portal digital de Revistas científicas de la ULPGC. Así, sus aportaciones a la revista El Guiniguada pueden seguirse desde el volumen 1 (1984) hasta el volumen 24 (2015): en el camino, una veintena de artículos. La propia Emigdia especificaba así, en su última contribución a la revista (volumen 24 correspondiente al año 2015, p. 23), uno de los objetivos didácticos que se debe perseguir en el estudiantado "lograr que sean capaces de establecer las relaciones existentes entre Ciencia, Tecnología, Sociedad y Medio Ambiente”, objetivo sin duda en clara coherencia con su propia trayectoria profesional.

Otras revistas del ámbito educativo que también atrajeron su atención fueron Revista Interuniversitaria de Profesorado, Aula de Innovación Educativa, An Esp Pediatr (Anales españoles de Pediatría) o Alambique.

Afirmábamos en páginas precedentes que el haber sido partícipe de distintos hitos de la historia educativa de su Centro de trabajo le iba a resultar provechoso de cara a su desempeño en la gestión académica. Su compromiso con esta fue, sin duda alguna, otro de los aspectos que definió y marcó sobremanera la trayectoria profesional de Emigdia. 
Con cuarenta y un años aborda su primer puesto, el de Jefa de Estudios de la E. U. de Profesorado de Las Palmas de Gran Canaria y en el que permanece hasta 1983: son sin duda siete años de aprendizaje que la prepararán para nuevos retos, tales como la dirección del Departamento de Didácticas Especiales de la ULL (período de febrero de 1989 a febrero de 1990) o el posterior (tránsito al cargo homólogo) con el pleno funcionamiento del Departamento ya en el contexto de la recién fundada universidad grancanaria, desde ese mismo 1990 y hasta el 2003.

Su gran capacidad de trabajo le permite simultanear otras representaciones como la Dirección de Calidad e Innovación Docente de la ULPGC (de 1999 hasta el 2002), la pertenencia a la Junta de Gobierno de la ULPGC (1989 hasta 2002) o la Codirección del Programa Interdepartamental de Doctorado "Formación y Perfeccionamiento de Profesorado" desde su implantación (curso1996-1997), hasta el ańo 2010.

Otra dimensión de la gestión la adquirirá con una responsabilidad singular, la Jefatura de Inspección del Servicio de Inspección de la ULPGC (2003 a 2007). De ahí en adelante - y prácticamente hasta sus últimos años en activo- , se sucede su presencia en Comisiones técnicas, CAD... junto con la coordinación académica, en la Estructura de Teleformación (desde su creación en 2005), de la Titulación de la Diplomatura de Maestro (primeramente) y del Grado en Educación Primaria, después.

Su experiencia y juicio experto fueron también requeridos para oficiar en múltiples Tribunales y Comités, tanto de acceso a la función pública (Oposiciones al Cuerpo de Profesores de E.G.B.) como de plazas docentes universitarias de distintas categorías y Centros (Universidad de Las Palmas de Gran Canaria, Universidad de La Laguna, Universidad del País Vasco, Universidad de Murcia o Universidad de Cantabria).

También fue significativa su presencia en una veintena de tribunales nacionales de Tesis doctorales (ULPGC, ULL, UV). E igualmente consta en su haber la pertenencia a diferentes Comités científicos (Bienales, Congresos, Encuentros Ibéricos, Reales Sociedades, Instituto Canario de Evaluación...).

Su interés por la difusión científica se materializó igualmente en su participación en Encuentros, Jornadas, Simposios y Congresos internacionales, tanto celebrados en la región canaria (La Laguna, Puerto de la Cruz, Santa Cruz de Tenerife, Las Palmas de Gran Canaria) como en otros puntos del territorio español (Málaga, Valencia, Murcia, Santiago de Compostela, Jaca, Cáceres, Almagro, Cádiz, Teruel, Zaragoza, Madrid, Barcelona, San Sebastián o Logroño). Su interés traspasó asimismo la frontera nacional con su implicación en eventos académicos en París o Boston. 
Desarrolló diversas líneas de investigación dentro del Grupo de la ULPGC Severo Ochoa, especialmente en el período 1986-2003. Varios de los diferentes Proyectos de investigación en los que participó recibieron financiación por parte de instituciones diversas (Dirección General de Universidades e Investigación. MEC, Consejería de Educación de la Comunidad Autónoma de Canarias, Consejería de Economía y Comercio, Dirección General de Comercio y Consumo, ULPGC, Dirección General de Universidades e Investigación, Instituto Canario de Evaluación y Calidad, Unión Europea, Funcis, Instituto Canario de Investigación en cáncer, Academia Canaria de Seguridad). El total de las subvenciones recibidas alcanzó una cifra aproximada de 1.255.000 euros.

Debemos, finalmente, mencionar los reconocimientos y distinciones recibidos por nuestra homenajeada. Así, en el año 1987 recibió el segundo Accésit en la IV Convocatoria de Premios de Investigación pedagógica y Experiencias Didácticas, convocado por los Colegios Oficiales de Doctores y Licenciados y el MEC, por el trabajo Incidencia de la didáctica moderna en la enseñanza de la Física.

Cinco años más tarde, en 1992, recibió el Primer Premio de la Asociación Canaria para la Enseñanza de las Ciencias "Viera y Clavijo" por el trabajo (en coautoría): El aula taller como medio para abordar los contenidos en Educación Secundaria Obligatoria.

Y en 2010 le llega la Distinción "Viera y Clavijo" otorgada por la Consejería de Educación, Universidades, Cultura y Deportes del Gobierno de Canarias en función de los méritos de docencia y consecución de objetivos de participación y calidad en el sistema educativo de Canarias.

Un camino, el de Emigdia Repetto Jiménez, jalonado de su deseo y tesón, alineado con las premisas de la UNESCO, por reivindicar, especialmente, "el imperativo estratégico que supone la enseñanza de las ciencias y las tecnologías" (López y Cámara, 2009, p. 30).

...Sin duda, la investigación acompañando a la vida. 


\section{REFERENCIAS BIBLIOGRÁFICAS}

Anta, JL. y García, A. (2018). Herramientas, planificación y modelos para una educación universitaria más crítica e implicada. En Cantalapiedra, B., Aguilar, P. \& Requeijo, P. (Coords.) Fórmulas docentes de vanguardia. Gedisa.

Booth, W., Colomb, G. y Williams, J. (2008). The Craft of Reseacrh. The University of Chicago Press.

Coll, C., Mauri, T. y Onrubia, J. (2008). El análisis de los procesos de enseñanza y aprendizaje mediados por las TIC: una perspectiva constructivista. En Barberá, E., Mauri, T., Onrubia, J. \& Aguado, G. (Coords.) Cómo valorar la calidad de la enseñanza basada en las TIC. Pautas e instrumentos de análisis. Graó.

López, JA. y Cámara, M. (2009). La cultura científica en España, en El español, lengua para la ciencia y la tecnología. Presente y perspectiva de futuro. Instituto Cervantes-Santillana.

Manzano, V. y Bacal, A. (2014). Universidad y movimientos sociales: la universidad absurda y la esperanza de las praxis universidad-calle. Universidad y movimientos sociales. Revista Interunivesitaria de Formación del Profesorado, 80(28.2), 15-23.

Martel, J. (1995-1998). La escuela Normal de Las Palmas: bosquejo histórico, El Guiniguada, 6/7, 13-42. Disponible en:

https://dialnet.unirioja.es/ejemplar/9957

Repetto, E. (2015). La ciencia y El Quijote: su utilización como recurso didáctico, El Guiniguada, 24, pp.16-26. doi 10.20420/GUIN.2015.0074. Disponible en:

https://ojsspdc.ulpgc.es/ojs/index.php/ElGuiniguada/article/view/336 


\section{ARTÍCULOS}





\title{
DE LA ENTREVISTA EN PROFUNDIDAD A LA OBSERVACIÓN SISTEMÁTICA: UNA PINCELADA DE COMUNICACIÓN MULTIMODAL DESDE LOS MIXED METHODS
}

\author{
M. Teresa Anguera \\ Facultad de Psicología, Instituto de Neurociencias, \\ Universidad de Barcelona, Barcelona. \\ A Emy, querida profesora y amiga, \\ tu inteligente mirada la tengo grabada en mi mente, \\ y el eco de tu cálida voz resuena en mi alma \\ cada vez que te recuerdo. jHasta siempre!
}

\section{Resumen:}

En este trabajo se parte de los avances realizados en los últimos años sobre la perspectiva multimodal de la comunicación, que la enriquece enormemente, incorporando niveles de respuesta antes escasamente estudiados, y desde el planteamiento actual de los mixed methods, que integran elementos cualitativos y cuantitativos. Con estas premisas, sustantiva y metodológica, proponemos dar un paso adelante en la consideración de la entrevista en profundidad, siguiendo las tres macroetapas CUAL-CUAN-CUAL. De esta forma, la transcripción de la entrevista en profundidad se habría sistematizado hasta dar lugar a una matriz de códigos, que todavía están formados por información cualitativa, pero altamente sistematizada, y que se pueden someter a análisis cuantitativos adecuados para datos categóricos. Mediante este procedimiento se logra detectar la estructura que subyace a la entrevista en profundidad, así como averiguar el mapa de interrelaciones entre códigos/categorías que se desvela con los resultados del análisis.

Palabras clave: CUAL-CUAN-CUAL, instrumento de observación ad hoc, matriz de códigos, análisis de datos categóricos.

\section{Abstract:}

This work is based on the advances made in recent years on the multimodal perspective of communication, which enriches it enormously, incorporating levels of response scarcely studied before, and from the current approach of mixed methods, which integrate qualitative and quantitative elements. From these substantive and methodological premises, we propose to take a step 
forward in considering the in-depth interview, following the three macro-stages QUAL-QUAN-QUAL. According this, the transcription of the in-depth interview would have been systematized to have a matrix of codes, which are still made up of qualitative information, but highly systematized, and which can be subjected to quantitative analysis suitable for categorical data. Through this procedure, it is possible to detect the structure underlying the in-depth interview, as well as to find out the map of interrelationships between codes/categories that is obtained with the results of the analysis.

Keywords: QUAL-QUAN-QUAL, ad hoc observational instrument, matrix of codes, analysis of categorical data.

\section{INTRODUCCIÓN}

La comunicación humana constituye un proceso complejo de indudable riqueza, está formado por una sucesión de episodios que tienen lugar en un contexto determinado, que pueden influenciarla en gran medida, siempre tiene unos actores entre los cuales se desencadena, y es indudablemente multimodal, dado que pueden especificarse diferentes niveles de respuesta, como intercambio de mirada, distancia interpersonal, conducta gestual, vocalizaciones, conducta verbal, etc. (Anguera e Izquierdo, 2006).

El estudio científico de la comunicación humana requiere garantizar la objetividad, su capacidad de descubrimiento, y su rigurosidad. Su complejidad conceptual y experiencial genera dudas e incertezas a nivel metodológico, y además requiere un cierto grado de audacia.

La entrevista en profundidad ha implicado habitualmente presencialidad de entrevistador y entrevistado, motivo por el cual se activaban la conducta verbal, sin prestar atención a la conducta gestual, las vocalizaciones diversas, la distancia interpersonal, los intercambios de mirada, etc., es decir, los niveles de respuesta propuestos por Weick (1969), que tan relevantes han sido para el estudio de la comunicación humana. Por otra parte, la entrevista requería la atribución de los roles de entrevistador y entrevistado, que estaban bien delimitados. Y, en tercer lugar, aunque era habitualmente presencial, existían otras posibilidades de realización, como la telefónica, que no era más que un preludio de las actuales posibilidades telemáticas de comunicación face-to-face.

Según Rogers y Cummings (2017), la comunicación es un proceso constitutivo por el cual diferentes miembros interrelacionados ofrecen definiciones de sí mismo respecto al otro, y crean simultáneamente la naturaleza continuada de sus relaciones. En el transcurso del día-a-día, estas definiciones se pueden 
aceptar, resistir, o modificar, detectándose como cada uno de los miembros influencia activamente al otro en sus líneas de acción. Y esta influencia puede implicar un control (Escudero et al., 1997; Friedlander \& Heatherington, 1989), sea o no simétrico (Sluzki \& Beavin, 1965), y con diferenciación de mensajes de protagonismo o de sumisión (Haley, 1963). Estos mensajes, considerados individualmente, se hallan contextualizados mediante afirmaciones, instrucciones, negociaciones, aceptaciones, etc. (Ellis et al., 1976) y sus formas gramaticales (Rogers, 1972), lo cual tiene indudables implicaciones metodológicas, que interesaron ya en aquella época que hoy día podemos considerar como clásica (Rogers \& Farace, 1975).

Grawitz (1975), gran conocedora de la metodología de las Ciencias Sociales, clasificaba las técnicas de investigación social en documentales, dedicadas al análisis de documentos en sus diferentes versiones, clásica y de contenido, y vivas, que podían ser individuales, como la entrevista o la observación participante, y grupales, como los sondeos, y dentro de los seis niveles que proponía para la entrevista, la entrevista en profundidad se ubica en un extremo (primer nivel), frente a la entrevista sistematizada de preguntas y respuestas prefijadas, que se ubica en el extremo opuesto (sexto nivel).

La decisión, obviamente, vendría determinada por el objetivo, alcance, perfil, y contexto del estudio que se realizase.

Transcurrido casi medio siglo desde entonces, y publicados innumerables trabajos sobre la entrevista, y en concreto sobre la entrevista en profundidad (Márquez, 2004; Moreno Rosset y Ramírez Uclés, 2019; Perpinyá, 2012; Taylor y Bogdan, 1992), sabemos que algunas de las técnicas vivas, como la entrevista, una vez transcrita, se convierte en una fuente documental sobre la cual se puede realizar trabajo de investigación.

\section{ENTREVISTA EN PROFUNDIDAD DESDE UNA MIRADA ACTUAL}

La entrevista en profundidad es una modalidad comunicativa que durante décadas se consideraba que estaba posicionada en el polo claramente cualitativo, cuando la comunidad científica estaba dicotomizada entre investigadores cualitativos y cuantitativos, mientras que en la actualidad la situamos en el ámbito de los mixed methods. Durante las dos últimas décadas se ha avanzado exponencialmente en el desarrollo de los mixed methods, aunque también se han generado algunas brechas, producidas esencialmente, a nuestro entender, por una crisis de crecimiento, que deberá saldarse con un nuevo paso adelante una vez se resuelvan las múltiples preguntas que siguen formulándose los investigadores (Anguera et al., 2020). 
La entrevista en profundidad convencional se entiende como reiterados encuentros cara a cara entre el investigador y los informantes, encuentros éstos dirigidos hacia la comprensión de las perspectivas que tienen los informantes respecto de sus vidas, experiencias o situaciones, tal como las expresan con sus propias palabras (Taylor y Bogdan, 1992, p. 100). Las entrevistas en profundidad siguen el modelo de una conversación entre iguales (aunque por supuesto hay diferencias importantes entre ambas), y no de un intercambio formal de preguntas y respuestas. Es decir, no se produce una elicitación de la respuesta, que es la principal característica propia de la metodología selectiva, y, además, transcurren en un contexto habitual, desenvolviéndose de forma espontánea. Esta elicitación de la respuesta no la necesitamos, es totalmente sobrante, dado que la cuestión clave radica en que necesitamos disponer de la riqueza que suponen las respuestas del entrevistado, por la objetivación que podemos obtener, y tratando de evitar la carga de subjetividad.

En la entrevista en profundidad el rol del entrevistador implica no sólo obtener respuestas, sino también aprender qué preguntas hacer y cómo hacerlas. $\mathrm{Al}$ principio se avanza lentamente, y el entrevistador debe tratar de establecer un rapport con los informantes, formulando preguntas no directivas, en un plano horizontal, como si fuera una conversación (Sidnell \& Stivers, 2013).

Taylor y Bogdan (1992) distinguieron entre diferentes tipos de entrevistas en profundidad, en función de los objetivos que se pretenden: a) para tener historias de vida, b) obtención de relatos actuando los entrevistados como informantes, y c) para obtener un cuadro relativamente amplio de una gama de escenarios, situaciones o personas. Sin embargo, en los tres tipos el perfil de la realización de la entrevista es similar en sus aspectos esenciales, y las diferencias entre ellas no afectan a la vertiente metodológica, que es la que aquí nos interesa.

Para Mondada (2013), una diferencia con la conversación está en que las entrevistas en profundidad ofrecen reconstrucciones post hoc y racionalizaciones, debido en buena medida a las constricciones que impone el formato (Suchman \& Jordan, 1990). Considera además que la conversación no está concebida en términos de investigación como fuente de recogida de información (Zimmerman \& Pollner, 1971). No obstante, nuestra opinión es que la entrevista en profundidad y la conversación pueden corresponder a dos niveles contiguos, con pequeńa diferencia, en cuanto al grado de espontaneidad, que no afectan al proceder metodológico, y que entre la metodología observacional y la selectiva es evidente que se ubican en la primera.

En este trabajo focalizamos nuestro interés en el análisis metodológico de entrevista en profundidad, conscientes de que nos hallamos inmersos en la 
perspectiva de la multimodal communication, otorgando una posición predominante, aunque no única, al habla entre entrevistador y entrevistado, es decir, los participantes, que no disponen de guión preestablecido, y que, por consiguiente, actúan con espontaneidad, aunque deba ser dentro de las reglas del juego en función del contexto en que se lleva a cabo dicha entrevista.

Schegloff (2002, p. 288), en este sentido, afirma lo siguiente: For studying co-present interaction with sound recording alone risked missing embodied resources for interaction (gesture, posture, facial expression, physically implemented ongoing activities, and the like), which we knew the interactants wove into both the production and the interpretation of conduct, but which we as analysts would have no access to. With the telephone data, the participants did not have access to one another's bodies either, and this disparity was no longer an issue. Esta frase de Schegloff (2002) nos conduce a una ampliación de la dimensionalidad de la entrevista en profundidad, ensanchando el horizonte más allá de la conducta verbal.

En efecto, podemos aplicar la propuesta de Weick (1968), mencionada anteriormente, y en lugar de considerar únicamente la entrevista en profundidad como generadora de conducta verbal, entendemos que hay que tener en cuenta los trabajos de los teóricos de la comunicación (Mondada, 2013; Selting, 2013). Este posicionamiento nos debe hacer reflexionar, por una parte, en cuáles son los elementos que pueden llegar a confluir en una entrevista en profundidad, con la finalidad de ser conscientes acerca de cómo se va a delimitar cada caso, y tomando nota de las enormes repercusiones procedimentales (Anguera, 2020). En el caso de la conversación, los participants in interaction use verbal, vocal and visual cues in co-ocurrence and concurrence in order to organize their interaction (Selting, 2013, p.590), aunque se debe matizar que la delimitación de los niveles de respuesta — término propuesto por Weick (1968), y al cual nos volveremos a referir-, no siempre es tema pacifico a nivel científico, pues mientras que el nivel verbal de la conducta en la interacción que se produce en situación de entrevista en profundidad podría considerarse semejante al conversacional (Schefloff, 2005), incluyendo los aspectos retórico, léxicosemántico, sintáctico, fonético segmental y fonológico, el nivel vocal se refiere a la prosodia y calidad de voz, de acuerdo a relaciones sintagmáticas entre sílabas que no vienen determinadas por la estructura de las palabras y las frases, y que algunos autores, como Kelly \& Local (1989), consideraron como señales comunicativas. Sin embargo, el tema no está aún resuelto respecto a las visual cues (Selting, 2013), dado que algunos autores utilizan en este ámbito la expresión nonverbal communication, que ha sido criticada por inducir a un sesgo. 
No obstante, la delimitación y asignación de los diferentes elementos o pistas comunicativas es una cuestión analítica, y no un problema práctico de entrevistador y entrevistado.

Lo que sí es interaccionalmente relevante es la multiplicidad de niveles que entran en juego en la entrevista en profundidad, sea cruzándose entre sí, o bien como niveles yuxtapuestos o en paralelo, y esto no se ha tenido habitualmente en cuenta en este ámbito, aunque sí en el de la conversación (Anguera, 2020). La complejidad de la situación se dimensiona si reflexionamos sobre las palabras de Sidnell: current work on multimodality focuses on questions of integration (or "reassembly" as Schegloff 2005 put it) by putting at the forefront the question of how different modalities are integrated so as to form coherent courses of action (Sidnell, 2006, p. 379f). El propio Sidnell apunta hacia una vía para resolverlo: To investigate mutimodality, one need to pay attention to the level of structured activities: those situated activity systems within which analysts and the coparticipants encounter gestures, directed gaze, and talk working together in a coordinated and differentiated way. This is a unit of interaction that is relatively discrete; has a beginning, middle, and end, and provides a structure of opportunities for participation (Sidnell, 2006, p. 380).

Los recursos multimodales que se movilizan en la entrevista en profundidad son variados (gestos, mirada, movimientos de cabeza, expresiones faciales, postura corporal, manipulación de objetos, etc.). Son diversos los autores - ya clásicos-, que se han interesado por incrementar las posibilidades y rigurosidad en estudios realizados en el ámbito de la conversación, como Bressem (2013), Heath (1986, 1989), Poyatos (2002a, 2002b), o Sidnell \& Stevers (2014), y son relativamente extrapolables a la entrevista en profundidad.

Por estos motivos, podemos abordar la entrevista en profundidad desde la metodología observacional, dado que se cumplen sus dos principales requisitos (comportamiento espontáneo y contexto habitual), lo cual nos abre un amplio espacio a nivel procedimental. En primer lugar, permite integrar la observación directa y la indirecta; en segundo lugar, tienen un perfecto encaje las etapas CUAL-CUAN-CUAL desde el desarrollo de los mixed methods; y en tercer lugar, como consecuencia de los anteriores, y a modo de conclusión, nos permitirá considerar la entrevista en profundidad como una comunicación multimodal sistematizada y rigurosa, con una previsión de tratamiento cuantitativo potente de material cualitativo. 


\section{INTEGRACIÓN DE LA OBSERVACIÓN DIRECTA Y LA INDIRECTA EN LA ENTREVISTA EN PROFUNDIDAD}

Los distintos niveles de respuesta a los que nos hemos referido anteriormente implican una predominancia de la conducta verbal en la entrevista en profundidad, pero sin descartar ni minimizar los demás que se hallan presentes, y parecen revelarse como estructuras que operan básicamente en paralelo y de forma co-ocurrente para la construcción de los turnos de palabra de entrevistador y entrevistado, aunque nos interesan asimétricamente los del entrevistado.

La opción metodológica idónea es la observacional, por garantizar una elevada rigurosidad y flexibilidad. Permite captar las conductas perceptibles a nivel de imagen y sonido, y desarrollar un procedimiento científico que permita estudiar y analizar los comportamientos espontáneos que se producen en los episodios de conversación (Anguera, 1979, 2003, 2020, Anguera \& Izquierdo, 2006; Portell et al., 2015; Sánchez- Algarra \& Anguera, 2013). El propio Sidnell (1983, p.78) afirmó en este sentido que $I$ then consider the importance of observation as a means for identifying a collectable, researchable phenomenon or practice.

A su vez, en la entrevista en profundidad deberá diferenciarse entre observación indirecta y directa, integrándose ambas en el análisis, y siendo conscientes de que el grado de perceptividad es diferente. Este grado de perceptividad es parcial en la observación indirecta (a la conducta verbal, por su propia naturaleza y la necesidad de interpretación, siempre se le atribuye un grado parcial de perceptividad) y total en la observación directa (gestos, mirada, movimientos de cabeza, expresiones faciales, postura corporal, manipulación de objetos, etc.), que incorporamos en el estudio de la entrevista en profundidad.

La observación indirecta (Anguera, en prensa; Anguera et al., 2018) tiene un papel prioritario, aunque no único, en el análisis de la entrevista en profundidad, y se focaliza en el contenido de la respuesta del entrevistado. La entrevista en profundidad consiste focalmente en la conducta verbal y/o el material textual generado a partir de las transcripciones de audio de las respuestas a las preguntas / comentarios del entrevistador, dado que no se realizan narraciones escritas del entrevistado. Se trata de un material extraordinariamente rico, que necesitará sistematizarse y tratarse cuantitativamente sin pérdida de información relevante. Y a esta información se le añadirá la de otros niveles de respuesta, correspondientes a la observación directa, que se integrarán en un mismo instrumento de observación. 
En el seno de la observación indirecta se ubican tres grandes tipos de materiales (materiales verbales, textos hablados, y textos escritos), teniendo en cuenta que el formato es muy variado, y que además son heterogéneas las maneras en que se utiliza uno u otro tipo de documento, a la vez que recomendamos con insistencia el uso de fuentes complementarias (Darbyshire, MacDougall, \& Schiller, 2005).

Las transcripciones, a las cuales en muchas ocasiones no se les presta la suficiente atención, son enormemente relevantes. Según Hepburn y Bolden (2013), las transcripciones son selectivas en innumerables detalles, y nos permiten preservar los datos - la conducta hablada - tal y como se produce. Ahora bien, a medida que se han incrementado exponencialmente los desarrollos tecnológicos en los últimos años, se ha producido una ampliación de las posibilidades del dato a transcribir. Como indica Bohle (2013), el contenido fundamental sería:

a) Selección de lo que se transcribe, con la información contextual adecuada.

b) Segmentación del flujo de conducta observable en unidades significativas.

c) Estructura o disposición del texto, es decir, turnos de los hablantes, acompañado de las modulaciones de la información contextual.

d) Códigos.

Enfatizamos la gran importancia que tiene la decisión acerca de lo que se transcribe, dado que deberá tener cabida en el instrumento de observación elaborado. Las decisiones acerca de dicho contenido habrán estado influenciadas por el marco teórico en que nos ubiquemos, así como por las preconcepciones de quienes transcriben, por el objetivo del estudio, y por consideraciones metodológicas (Cook, 1990; Ochs, 1979).

Estamos de acuerdo con O'Connell y Kowal (2000), así como con Bohle (2013), en que las transcripciones son fuentes de datos terciarias, sean videográficas o magnetofónicas (Anguera, 2020). Las nuevas tecnologías han permitido alcanzar unos altos estándares de precisión, haciendo posible un interest in interactional details that would have been overlooked in the past (Duranti, 1997, p. 123). Sin embargo, es material sensible no exento de problemas (Cook, 1990). 


\section{MACROETAPAS CUAL-CUAN-CUAL EN LA ENTREVISTA EN PRO- FUNDIDAD}

Por suerte, desde el inicio de siglo y milenio, la emergencia y rápida expansión de los mixed methods ha dado lugar a múltiples conceptualizaciones, $\mathrm{y}$, como ejemplo, están las 19 definiciones de mixed methods que aportan prestigiosos autores en el trabajo de Johnson, Onwuegbuzie y Turner (2007), o las vanas pretensiones de búsqueda de simetría entre las vertientes cualitativa y cuantitativa (Anguera, Camerino, et al., 2017).

Asimismo, el recorrido de los mixed methods en las dos últimas décadas ha dado lugar a avances procedimentales diversos que han generado una cantidad ingente de publicaciones. Después de algunas fluctuaciones en los primeros años, ahora existe un consenso mayoritario respecto a la necesaria integración entre elementos cualitativos y cuantitativos, aunque todavía existan interrogantes acerca de cómo lograrlo. Consideramos que tiene un extraordinario valor esta frase de Creswell \& Plano Clark (2011, p. 7): There are three ways in which mixing occurs: merging or converging the two datasets by actually bringing them together, connecting the two datasets by having one build on the other, or embedding one dataset within the other so that one type of data provides a supportive role for the other dataset. (el resaltado es nuestro).

Este mixing, en la opción de connecting, tomado tanto literalmente como desde una perspectiva más amplia, constituyen un punto de apoyo central para realizar un replanteamiento acerca de cómo operar. Además, se constata cómo el connecting permite fundamentar el quantitizing, lo cual consolida propuestas anteriores que han permitido constatar cómo la metodología observacional (directa e indirecta) se puede considerar como mixed method en sí misma (Anguera, Camerino, et al., 2017; Anguera y Hernández-Mendo, 2016), pero desde un planteamiento en donde no se combinan ni métodos ni técnicas, ni tampoco datos procedentes de diversas fuentes, sino que se transforma la información de forma diferente a como se describe en la literatura de los mixed methods (Anguera et al., 2020).

En Anguera et al. (2020) presentamos una propuesta de quantitizing, adaptable a todas las situaciones que posibilitan la utilización de la metodología observacional como método científico (Anguera, Blanco-Villaseñor, Losada, y Portell, 2018). Todas ellas se apoyan en el planteamiento inicial (Anguera, 2003), diseño observacional (Anguera et al., 2001), construcción de instrumento a medida (Anguera, Magnusson, y Jonsson, 2007), registro y codificación (Anguera y Blanco-Villaseñor, 2003), control de calidad del dato (Blanco-Villaseñor y Anguera, 2003), y análisis de datos (Blanco-Villaseñor et 
al., 2003). Existen además sistemas de revisión de la calidad de estudios observacionales, como el GREOM (Portell et al., 2015) y el MQCOM (Chacón- Moscoso et al., 2019). El conjunto de las etapas que configuran el procedimiento propio de la metodología observacional conforman la alternancia CUAL-CUAN-CUAL, que legitima el planteamiento genérico de los mixed methods, en tanto que se logra una integración total entre elementos cualitativos y cuantitativos.

Nuestra propuesta para la entrevista en profundidad consiste en contemplar la sucesión de las tres macroetapas CUAL-CUAN-CUAL (Figura 1), de acuerdo con la vía connecting (Creswell \& Plano Clark (2011) mencionada, pero, tal como se ha indicado, transformando la información de forma diferente a como se describe en la literatura de los mixed methods (Anguera et al., 2020).

Figura 1. Macro etapas CUAL-CUAN-CUAL del proceso metodológico desde la perspectiva connecting de los mixed methods

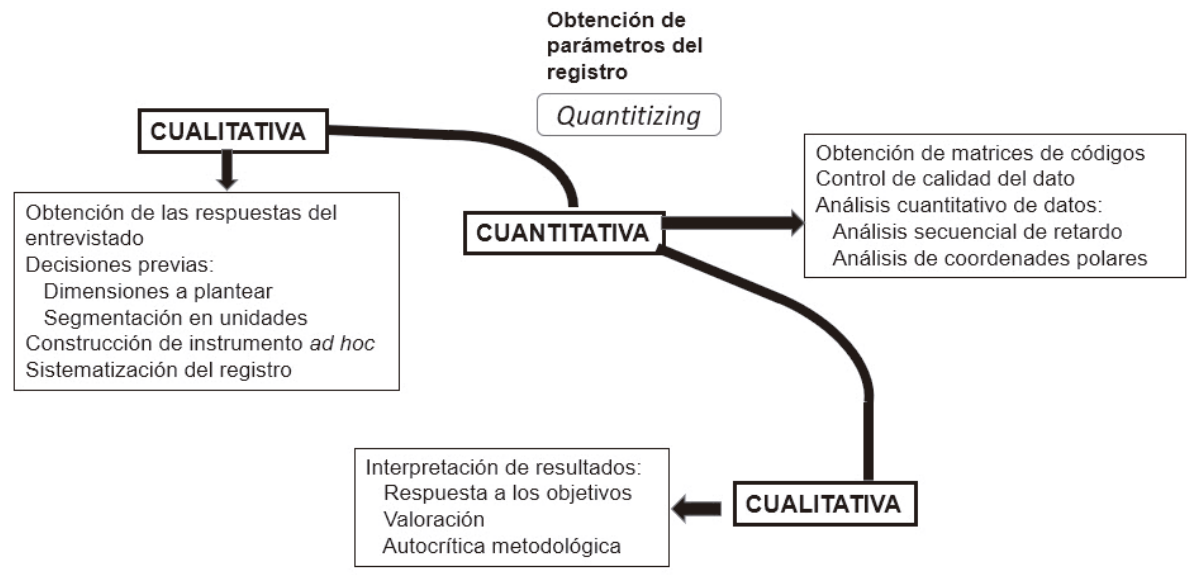

Fuente: elaboración propia.

CUAL (Figura 1): En la primera macroetapa CUAL, después de adoptar las importantes decisiones sobre dimensiones y criterios de segmentación, se construiría a medida un instrumento de observación multidimensional (incluso en aquellas ocasiones en que solamente interesara la conducta verbal, después se debería desplegar en subdimensiones, las cuales funcionarían como dimensiones en las operaciones metodológicas a realizar a partir de este momento) que integrara la observación directa y la indirecta, para poder sistematizar el registro. 


\section{Decisiones previas (Figura 1).}

Primera decisión: En función del contenido de las preguntas de la entrevista en profundidad, así como del marco teórico en que nos ubicamos, se planteará cuáles deben ser los niveles de respuestas o dimensiones del instrumento de observación, y cada una de ellas se puede seguir desplegando en subdimensiones de segundo, tercer, etc. nivel. Insistimos en que una o varias dimensiones corresponderían a la observación directa (como ejemplo, podrían referirse a gestualización, direccionalidad de la mirada, postura, silencio, llanto, respiración, manejo - compulsivo o no- de objetos, como llavero, bolígrafo, etc.), y lo mismo para la indirecta, que podría transitar desde un nivel periférico (respuestas afirmativas, respuestas negativas, aportación de justificación, etc.) a otros más profundos. En entrevistas terapeuta-paciente, como ilustración, se pueden consultar Del Giacco, Anguera et al. (2020) y Del Giacco, Salcuni et al. (2019). Además, pueden ser relevantes dimensiones relativas al contexto (físico, social, organizativo, institucional, ...), y que en un momento dado en cada momento- nos pueden aportar información. En los estudios de observación sistemática nos referimos a esta decisión como la propuesta de las dimensiones o criterios (desplegables en subdimensiones), que son los elementos que sostienen conceptualmente el estudio, y a partir de las cuales se iniciará la construcción del instrumento de observación a medida.

Segunda decisión: Se refiere a la segmentación en unidades, no es nada fácil, y se halla en función del grado de molecularización/molarización que nos convenga. Además, dado que coocurren diferentes dimensiones o subdimensiones, cada una de ellas requerirá un tipo de unidad adecuada. Como dice Norris (2013), The essence in multimodal (inter)action analysis is always the linking of the multitude of modes that are used in (inter)action when social actors act and communicate. (Norris, 2013, p.281). Para esta segunda decisión proponemos una estructura jerarquizada (Anguera, 2020), a modo de diferentes estratos de una pirámide, sea bottom-up, en donde a ras de suelo se hallarían las unidades más molecularizadas, las cuales se molarizan progresivamente a medida que ascendemos de nivel, o top-down, en donde partimos de una serie de episodios conversacionales que se van progresivamente molecularizando. Resulta obvio comprender que el rango de molecularidad/molaridad estará en cada entrevista en profundidad vinculado a los objetivos que se pretenden. Siguiendo a Krippendorf (2013), hemos propuesto (Anguera, en prensa) los criterios ortográfico, sintáctico, contextual e interlocutorio, siendo posible combinar algunos de ellos (como inerlocutorio y sintáctico). 


\section{Construcción de instrumento ad hoc (Figura 1).}

Una vez se han propuesto las dimensiones (y posibles desplegamientos de subdimensiones) a contemplar, la construcción de un instrumento ad hoc (a medida) materializa un "diálogo" entre el marco teórico, si está especificado, y la materialidad de las respuestas obtenidas (si no está especificado se requerirá un buen bagaje empírico). Al ser un instrumento realizado a medida se garantiza la absoluta especificidad para las respectivas entrevistas. Existen dos posibilidades (Anguera, 2020, en prensa; Anguera et al., 2018; Anguera, Camerino, et al., 2017; Sánchez- Algarra \& Anguera, 2013):

Instrumento de formato de campo: A partir de cada una de las dimensiones (o, en su caso, de las subdimensiones derivadas de desplegamientos), se prepara un catálogo de conductas, o relación de nombres de conductas, con sus correspondientes códigos, que han de cumplir la mutua exclusividad. La lista es abierta, y se puede ir completando de forma indefinida. Cada unidad (resultante de aplicar la decisión mencionada anteriormente sobre segmentación en unidades) dará lugar a una coocurrencia de códigos, con un número mínimo de uno, y un máximo correspondiente al número de dimensiones del formato de campo.

Instrumento de formato de campo combinado con sistemas de categorias: A partir de una, varias, o todas las dimensiones (o, en su caso, de las subdimensiones resultantes), se prepara un sistema de categorías (que forzosamente es unidimensional en sí mismo), con sus correspondientes definiciones y códigos, y han de cumplir las condiciones de exhaustividad y mutua exclusividad. La lista de categorías de un sistema de categorías es cerrada, y no se puede modificar; además es importante indicar que el sistema de categorías requiere forzosamente de marco teórico, y además no funciona bien cuando nos hallamos estudiando un proceso, pues la versatilidad que comporta no encajaría con la inmutabilidad de las categorías). En caso de que solamente alguna de las dimensiones/subdimensiones permitiera la elaboración de sistemas de categorías, las demás dimensiones/subdimensiones darán lugar a catálogos de conductas, como en el formato de campo, y dichos catálogos sí mantienen el carácter de listas abiertas. Es relevante que de cada dimensión/subdimensión "cuelga" o bien un sistema de categorías o bien un catálogo de conductas. Cada unidad (resultante de aplicar la decisión mencionada anteriormente sobre segmentación en unidades) dará lugar a una coocurrencia de códigos, con un número mínimo de uno, y un máximo correspondiente al número de dimensiones/subdimensiones.

Se han realizado instrumentos de observación ad hoc, tanto en observación directa como indirecta, en múltiples ámbitos, como clínico (Arias-Pujol \& An- 
guera, 2017, 2020; Del Giacco, Anguera, et al., 2020; Del Giacco, Salcuni et al., 2019; Roustan et al., 2013), educativo (García-Fariña et al., 2018), evolutivo (Escolano-Pérez et al., 2019), social (Moya et al., 2020), laboral (SeneMir et al., 2019), deportivo (Castañer et al., 2016), etc.

Sistematización del registro (Figura 1).

El instrumento de observación construido es la pieza central para poder sistematizar el registro, que se lleva a cabo asignando cada unidad obtenida en la segmentación al código/categoría correspondiente del instrumento de observación. Obviamente, dada la mutua exclusividad de los catálogos de conducta y de los sistemas de categorías, a cada unidad le corresponderán tantos códigos como coocurrencias se produzcan en las diferentes dimensiones contempladas (conducta verbal, conducta vocal, gestos, etc.), y sus respectivas subdimensiones.

A partir de la afirmación de Sidnell (1983, p. 78), I then consider the importance of observation as a means for identifying a collectable, researchable phenomenon or practice, resulta obvio que el registro sistematizado de cada parcela de las respuestas a una entrevista en profundidad se expande de forma poliédrica mostrando una inusitada riqueza de datos, y deberemos establecer los adecuados filtros y canalizaciones con el fin de eliminar redundancias o informaciones no deseadas o irrelevantes, y con el objetivo de alcanzar un equilibrio entre la profusión informativa que puede quedar grabada a nivel de imagen o de sonido, el filtrado de dicha información, y la necesaria sistematización en forma de matrices de códigos (Anguera, 2020). Código, en palabras de Burgoon, Guerrero, y Floyd (2010, p. 19), es a set of signals that is usually transmitted via one particular medium or channel, por lo que existe un amplio margen de decisión del investigador acerca del tipo de códigos (Burgoon, Guerrero, \& White, 2013) que se pueden utilizar (literales, numéricos, mixtos, icónicos, etc.).

CUAN (Figura 1): En la macroetapa CUAN se obtendrán las matrices de códigos, se controlará la calidad del dato, y se analizará cuantitativamente.

Obtención de matrices de códigos (Figura 1).

Partimos del registro sistematizado, y en esta etapa del proceso tiene lugar el quantitizing que deriva del planteamiento mixed methods en que nos situamos. Se puede materializar por la obtención de los parámetros primarios del registro, que planteó Bakeman (1978). Los parámetros primarios del registro son frecuencia, orden y duración, pero aquí abogamos por el orden o secuencia, que resulta fundamental para la obtención de las matrices de códigos, dado 
que deben estar formadas secuencialmente por sucesivas coocurrencias de códigos. Schegloff (2007, p. 9) dice que una secuencia es a course of action implemented through talk, y lógicamente el curso del habla, cuando responde el entrevistado, se ajusta perfectamente al requerimiento metodológico. De acuerdo con nuestro planteamiento (Anguera, 2017), se formarán cadenas de códigos para cada unidad, en función de su coocurrencia, que constituirán las filas de las matrices de códigos resultantes del trabajo de codificación de las conversaciones. Por supuesto que estas matrices raramente son regulares. Su perfil es habitualmente irregular, dado que no sería esperable que en cada una de las sucesivas unidades se dispusiera de un código correspondiente a cada una de las dimensiones y/o subdimensiones resultantes del desplegamiento, sino que habrá "casillas vacías".

La materialización de la codificación se puede realizar de forma manual o informatizada, que prácticamente en la actualidad asume la casi totalidad de situaciones. Existe una oferta muy amplia de posibilidades, que prácticamente son todas libres, en observación directa, y especialmente resultan idóneos los siguientes: GSEQ5 [http://bakeman.gsucreate.org/] (Bakeman \& Quera, 2011), LINCE [http://lom.observesport.com/] (Gabin et al., 2012), LINCE PLUS [http://lom.observesport.com/] (Soto et al., 2019), y HOISAN [www.menpas.com] (Hernández-Mendo et al., 2012). No obstante, en observación indirecta existen algunos programas comerciales que son ampliamente utilizados, como ATLAS.ti, AQUAD, NUDIST, NVIVO, etc., y destacamos algunas en que se combina exitosamente el instrumento de observación con el de registro, como NEUROGES+ELAN (Lausberg and Sloetjes, 2016). Como hemos indicado en algún trabajo anterior (Anguera, Jonsson, et al., 2017), una excelente opción, novedosa, y que hemos utilizado (Moya et al., 2020), consiste en aprovechar la disposición de los códigos que se muestran en la ventana derecha del ATLAS.ti para llevar a cabo el análisis cuantitativo posterior, aunque todavía no está implementado en el programa (se espera en una próxima versión) y debe efectuarse manualmente.

\section{Control de calidad del dato (Figura 1).}

Después de que disponemos del registro en forma de matrices de códigos, y antes de analizar los datos, deben someterse a un control de calidad. La metodología observacional requiere un indudable esfuerzo por detectar sesgos en el registro, así como faltas de concordancia entre los observadores, en su tarea de asignar los códigos del instrumento de observación a las respectivas unidades delimitadas en las dimensiones/subdimensiones (Blanco-Villaseñor et al., 2014). Esta cautela aumenta de intensidad en la observación indirecta, debido 
a que es mayor el riesgo de inferencia, y se exigen al menos tres registros en las operaciones de cálculo de la concordancia.

Existen numerosos coeficientes para verificar cuantitativamente la calidad del dato. Uno de los más utilizados en observación directa es el Kappa (Cohen, 1960), y en observación indirecta el coeficiente de concordancia canónica (Krippendorf, 2013), que permite calcular la concordancia de tres o más registros. En observación directa es recomendable calcular la concordancia de tres registros (preferentemente de tres observadores distintos, aunque también podrían ser intraobservador, realizados por el mismo observador, con el mismo instrumento de observación, en tres momentos de tiempo distintos). En observación indirecta, se exige que sea de tres registros (en observación directa es únicamente recomendable). El coeficiente kappa se puede calcular mediante los programas LINCE, LINCE PLUS, GSEQ y HOISAN. El coeficiente de concordancia canónica se puede calcular mediante el programa HOISAN.

Existe también la opción de la concordancia consensuada (Anguera, 1990), que se está utilizando cada vez con más profusión en observación indirecta. En este caso, tres observadores (o más) discuten los códigos a asignar a cada unidad, hasta que alcanzan consenso (Anguera et al., 2018). La concordancia consensuada tiene la ventaja de que se produce un único registro, resultante del consenso alcanzado. Sin embargo, existen riesgos derivados de cuestiones externas, como desestimiento de discutir un determinado código, prurito de "llevar la contraria", etc. La aplicación de la concordancia consensuada se puede complementar por medidas cuantitativas de concordancia (Arana et al., 2016).

\section{Análisis cuantitativo de datos (Figura 1).}

En esta macroetapa CUAN, se materializa el significado auténtico de la via connecting de los mixed methods, tal como se ha indicado anteriormente, mediante análisis cuantitativos a partir de datos categóricos. Somos muy conscientes de que en entrevistas en profundidad tradicionalmente no se ha seguido este camino, debido a que han sido feudo de posiciones claramente cualitativas, pero somos consecuentes con el planteamiento CUAL-CUAN-CUAL. En Blanco-Villaseñor et al. (2003) se proponen diversas técnicas cuantitativas de análisis, y destacamos dos de ellas por su especial adecuación para detectar estructuras subyacentes de relaciones entre codigos (conductas/categorías, según el instrumento de observación construido): Análisis secuencial de retardos y análisis de coordenadas polares.

Análisis secuencial de retardos: Propuesto por Bakeman (1978), pretende detectar la existencia de regularidades (patrones de conducta) en datos categóricos 
(Bakeman \& Gottman, 1986; Bakeman \& Quera, 2011), y puede aplicarse diacrónicamente en entrevistas en profundidad completas, partes de sesión, agregación de sesiones (por ejemplo, varias entrevistas en distintas sesiones a la misma persona) (Anguera et al., in press). Se requiere, por supuesto, partir de matrices de códigos, con las coocurrencias de códigos ordenadas secuencialmente. Se puede realizar prospectivamente (hacia adelante, a partir de determinado código) o retrospectivamente (hacia atrás, antes de determinado código). Debe proponerse una conducta criterio (o varias), que es aquélla que, por hipótesis, suponemos que será la inicializadora de un potencial patrón de conducta; asimismo deben proponerse conductas condicionadas, para saber si formarán parte de los patrones de conducta que se detecten; y también se propondrán retardos positivos (en el análisis prospectivo) o negativos (en el análisis retrospectivo), que corresponden a lugares de orden en el registro (contados hacia adelante o hacia atrás, respectivamente) a partir de cada ocurrencia de la conducta criterio. Para llevar a cabo el análisis secuencial de retardos se hallan las frecuencias de transición a partir de cada conducta criterio y en el número de retardos que se determine, respecto a cada una de las conductas condicionadas que se consideren. Después se hallan las probabilidades incondicionadas o esperadas, que marcan el "techo" que corresponde al efecto del azar, y las probabilidades condicionadas (Anguera y Losada, 1999) que genera el registro. Una vez se han obtenido, las probabilidades incondicionadas y condicionadas se contrastan mediante la prueba binomial, aplicándose la corrección propuesta por Allison \& Liker (1982), que permite obtener como resultados los residuos ajustados entre la conducta criterio y las conductas condicionadas, los cuales podrán tener o no significación estadística. El análisis secuencial de retardos se puede realizar mediante los programas libres GSEQ5 y HOISAN. Ejemplos recientes de aplicación en situaciones terapéuticas se pueden hallar en Arias $\&$ Anguera (2020) y en Del Giacco, Anguera et al. (2020).

Análisis de coordenadas polares: Propuesto por Sackett (1980), pretende obtener un mapa de interrelaciones entre los códigos (conductas/categorías) de un registro observacional, y representarlas mediante vectores. Igual que el análisis secuencial de retardos, requiere partir de un registro previo en que se disponga secuencialmente de las ocurrencias/coocurrencias de códigos (ocurrencias si nuestro instrumento de observación tuviera una dimensión, y coocurrencias si tiene varias dimensiones) (Anguera at al., in press). Se propone inicialmente una conducta focal, en función del objetivo, y unas conductas condicionadas. Primero se debe llevar a cabo un análisis secuencial de retardos (en donde la actual conducta focal será la conducta criterio propia de este análisis, las con- 
ductas condicionadas serán las mismas (Sackett, 1980), y a partir de los residuos ajustados obtenidos, y teniendo en cuenta el mismo número de retardos positivos (perspectiva prospectiva) y negativos (perspectiva retrospectiva), que al menos han de ser cinco, se calcula el parámetro Zsum (Cochran, 1954) prospectivo y retrospectivo, respectivamente, para cada una de las conductas condicionadas y para cada retardo, permitiendo lograr una gran reducción de datos. A partir de los valores obtenidos se halla la longitud y ángulo de cada uno de los vectores, que permiten graficar la interrelación entre la conducta focal y cada una de las conductas condicionadas (Sackett, 1980). La interpretación de estos vectores se realiza teniendo en cuenta su ángulo, y, en consecuencia, el cuadrante en que se ubican, el cual indica la naturaleza de la interrelación entre la conducta focal y cada conducta condicionada, y teniendo también en cuenta su longitud, que indicará la presencia o ausencia de significación estadística. El análisis de coordenadas polares se puede realizar mediante el programa libre HOISAN. Ejemplos recientes de aplicación en situaciones terapéuticas y sociales se pueden hallar, respectivamente, en Del Giacco, Anguera et al. (2020) y en Moya et al. (2020).

CUAL (Figura 1): En la segunda macroetapa CUAL, después de la obtención de los resultados cuantitativos, se interpretan los resultados obtenidos, valorándolos en función de los objetivos, teniendo en cuenta la literatura científica idónea, y efectuando siempre una autocrítica del estudio realizado. El retorno a una fase cualitativa de la entrevista en profundidad cierra el "circuito" de la vía connecting de los mixed methods.

\section{CONCLUSIÓN: ENTREVISTA EN PROFUNDIDAD COMO COMUNI- CACIÓN MULTIMODAL}

Las posibilidades de considerar la entrevista en profundidad como comunicación multimodal encajan en lo que Norris (2013) considera la simultaneidad horizontal de acciones, dado que el entrevistado puede estar usando diferentes recursos y mencionando diferentes contextos, y puede tener 'vida propia', en el sentido de que puede estar introduciendo en sus respuestas a diferentes personas y escenarios. Es la realidad de la entrevista en profundidad, tal cual ocurre, que debemos tratar adecuadamente, en su 'completitud', o seleccionando únicamente aquellos segmentos que nos resulten de interés en nuestro estudio (por ejemplo, filtrando, si es el caso, aquellas respuestas que no responden a lo que se ha preguntado). Dicho con otras palabras, la multimodalidad comunicativa es un hecho, y quizás en ocasiones parecería una utopía captarla en su totalidad, pero es realista decidir los elementos que consideramos relevantes en cada caso. 
Tradicionalmente, se ha considerado la entrevista en profundidad como una fuente de información verbal, discutible desde determinadas escuelas psicológicas, y desperdiciando la inusitada riqueza que pueden aportar otros niveles de respuesta, desde una perspectiva multimodal de la comunicación, los cuales se pueden estudiar con objetividad desde la observación directa, y que incluso pueden coadyuvar a reducir el riesgo de subjetividad de la observación indirecta mediante el plus de información aportado.

En este trabajo se presenta una propuesta metodológica innovadora para la entrevista en profundidad, aprovechando la potencia de la metodología observacional (directa e indirecta), aplicable claramente al estudio de la observación indirecta, y que puede considerarse como mixed method en sí misma (Anguera, Camerino, et al., 2017; Anguera y Hernández-Mendo, 2016). El iter del procedimiento permite conducir metodológicamente el proceso y hacerlo mucho más potente para la entrevista en profundidad, que ya resultó enriquecida al ampliar sus dimensiones, antes relegadas a la conducta verbal, y ahora habiendo restablecido las demás informaciones (vocalizaciones, gestualizaciones, intercambios de mirada, postura, etc.) que en cada caso se consideren relevantes. Las enormes posibilidades de sistematización, gracias al instrumento de observación construido a medida, y la robustez del tratamiento cuantitativo de los datos, abren un nuevo período para la entrevista en profundidad que auguramos fecundo.

\section{REFERENCIAS}

Allison, P. D. \& Liker, J. K. (1982). Analyzing sequential categorical data on dyadic interaction: a comment on Gottman. Psychological Bulletin, 91, 393-403. Anguera, M.T. (1979) Observational Typology. Quality \& Quantity. EuropeanAmerican Journal of Methodology, 13(6), 449-484.

Anguera, M.T. (1990) Metodología observacional. En J. Arnau, M.T. Anguera y J. Gómez. Metodología de la investigación en Ciencias del Comportamiento (pp. 125236). Murcia: Secretariado de Publicaciones de la Universidad de Murcia.

Anguera, M.T. (2003). Observational Methods (General). In R. FernándezBallesteros (Ed.), Encyclopedia of Psychological Assessment, Vol. 2 (pp. 632637). London: Sage.

Anguera, M.T. (2017). Transiciones interactivas a lo largo de un proceso de desarrollo: Complementariedad de análisis. En C. Santoyo (Coord.), $\mathrm{Me-}$ canismos básicos de toma de decisiones: Perspectivas desde las ciencias del comportamiento y del desarrollo. Ciudad de México: CONACYT 178383/ UNAM. I.S.B.N. 978-607-02-9426-6. 
De la entrevista en profundidad a la observación sistemática: una pincelada de comunicación...

Anguera, M.T. (2020). Is It Possible to Perform "Liquefying" Actions in Conversational Analysis? The Detection of Structures in Indirect Observation. In L. Hunyadi \& I. Szekrényes (Ed.), The Temporal Structure of Multimodal Communication (pp. 45-67). Intelligent Systems Reference Library, vol. 164. Springer Cham. DOI https://doi.org/10.1007/978-3-030-22895-8_3 Anguera, M.T. (en prensa). Desarrollando la observación indirecta: Alcance, proceso, y habilidades metodológicas en el análisis de textos. En C. Santoyo (Coord.), Patrones de habilidades metodológicas y conceptuales de análisis, evaluación e intervención en ciencias del comportamiento. Ciudad de México: UNAM/PAPIIT, IN306715.

Anguera, M.T., y Blanco-Villaseñor, A. (2003). Registro y codificación en el comportamiento deportivo. En A. Hernández Mendo (Coord.), Psicología del Deporte (Vol. 2). Metodología (p. 6-34). Buenos Aires: Efdeportes (www.efdeportes.com).

Anguera, M.T., Blanco-Villaseñor, A., y Losada, J.L. (2001). Diseños Observacionales, cuestión clave en el proceso de la metodología observacional. Metodología de las Ciencias del Comportamiento, 3(2), 135- 161.

Anguera, M.T., Blanco-Villaseñor, A., Losada, J.L., y Portell, M. (2018). Pautas para elaborar trabajos que utilizan la metodología observacional. Anuario de Psicología, 48, 9-17.

Anguera, M.T., Blanco-Villaseñor, A, Losada J.L., \& Sánchez-Algarra, P. (2020). Integración de elementos cualitativos y cuantitativos en metodología observacional. Ámbitos. Revista Internacional de Comunicación, 49, 49-70. doi: 10.12795/Ambitos. 2020.i49.04

Anguera, M.T., Blanco-Villaseñor, A., Losada, J.L., Sánchez-Algarra, P., \& Onwuegbuzie, A.J. (2018). Revisiting the Difference Between Mixed Methods and Multimethods: Is It All in the Name? Quality \& Quantity, 52, 2757-2770. doi: 10.1007/s11135-018-0700-2.

https://doi.org/10.1007/s11135-018-0700-2

Anguera, M.T., Camerino, O., Castañer, M., Sánchez-Algarra, P., \& Onwuegbuzie.

A.J. (2017). The Specificity of Observational Studies in Physical Activity and Sports Sciences: Moving Forward in Mixed Methods Research and Proposals for Achieving Quantitative and Qualitative Symmetry. Frontiers in Psychology, 8:2196.

Anguera, M.T. y Hernández-Mendo, A. (2016). Avances en estudios observacionales en Ciencias del Deporte desde los mixed methods. Cuadernos de Psicología del Deporte, 16(1), 17-30. 
Anguera, M.T. \& Izquierdo, C. (2006). Methodological approaches in human communication: From complexity of perceived situation to data analysis. In G. Riva,

M.T. Anguera, B.K. Wiederhold \& F. Mantovani (Coord.), From Communication to Presence. Cognition, Emotions and Culture towards the Ultimate Communicative Experience (pp. 203-222). Amsterdam: IOS Press.

Anguera, M.T., Jonsson, G.K., \& Sánchez-Algarra, P. (2017). Liquefying Text from Human Communication Processes: A Methodological Proposal Based on T-Pattern Detection. Journal of Multimodal Communication Studies, 4 (1-2), 10-15.

Anguera, M.T. y Losada, J.L. (1999). Reducción de datos en marcos de conducta mediante la técnica de coordenadas polares. En M.T. Anguera (Ed.), Observación de la conducta interactiva en situaciones naturales: Aplicaciones (pp. 163-188). Barcelona: E.U.B.

Anguera, M.T., Magnusson, M. S., y Jonsson, G.K. (2007). Instrumentos no estándar.

Avances en Medición, 5(1), 63-82.

Anguera, M.T., Portell, M., Chacón-Moscoso, S., \& Sanduvete-Chaves, S. (2018). Indirect observation in everyday contexts: Concepts and methodological guidelines within a mixed methods framework. Frontiers in Psychology, 9:13. doi: 10.3389/fpsyg.2018.00013

Anguera, M.T., Portell, P., Hernández-Mendo, A., Sánchez-Algarra, P., and Jonsson,

G.K. (in press). Diachronic analysis of qualitative data. In A.J. Onwuegbuzie and B. Johnson (Eds.), Reviewer's Guide for Mixed Methods Research Analysis. London: Routledge.

Arana, J., Lapresa, D., Anguera, M.T., and Garzón, B. (2016). Ad hoc procedure for optimising agreement between observational records. Anales de Psicología, 32(2), 589-595.

Arias-Pujol, E. \& Anguera, M.T. (2017). Observation of interactions in adolescent group therapy: A mixed methods study. Frontiers in Psychology, 8:1188. DOI: $10.3389 /$ fpsyg.2017.01188

Arias-Pujol, E. \& Anguera, M.T. (2020). A Mixed Methods Framework for Psychoanalytic Group Therapy: From Qualitative Records to a Quantitative Approach Using T-Pattern, Lag Sequential and Polar Coordinate Analyses. Frontiers in Psychology, 11:1922. doi: 10.3389/fpsyg.2020.01922

Bakeman, R. (1978). Untangling streams of behavior: sequential analysis of observational data. In G.P. Sackett (Ed.), Observing Behavior, Vol. 2 Data 
De la entrevista en profundidad a la observación sistemática: una pincelada de comunicación...

Collection and Analysis Methods (pp. 63-78). Baltimore, MD: University Park Press.

Bakeman, R., \& Gottman, J.M. (1986). Observing interaction: An introduction to sequential analysis. Cambridge, England: Cambridge University Press.

Bakeman, R., \& Quera, V. (2011). Sequential analysis and observational methods for the behavioral sciences. Cambridge, England: Cambridge University Press. Blanco-Villaseñor, A., Castellano, J., Hernández Mendo, A., Sánchez-López, C.R., y Usabiaga, O. (2014). Aplicación de la TG en el deporte para el estudio de la fiabilidad, validez y estimación de la muestra. Revista de Psicología del Deporte, 23(1), 131-137.

Blanco-Villaseñor, A., Losada, J.L., \& Anguera, M.T. (2003). Analytic techniques in observational designs in environment-behavior relation. Medio Ambiente y Comportamiento Humano, 4(2), 111-126.

Bohle, U. (2013). Approaching notation, coding, and analysis from a conversational analysis point of view. In C. Müller, A. Cienki, E. Fricke, S.H. Ladewig, D. McNeill, \& S. Teßendorf (Eds.), Body - Language Communication. An International Handbook on Multimodality in Human Interaction, vol. 1 (pp. 992- 1007). Frankfurt: De Gruyter.

Bressem, J. (2013). 20th century: Empirical research of body, language, and communication. In C. Müller, A. Cienki, E. Fricke, S.H. Ladewig, D. McNeill, \& S. Teßendorf (Eds.), Body-Language - Communication. An International Handbook on Multimodality in Human Interaction, vol. 1 (pp. 393-416). Frankfurt: De Gruyter.

Burgoon, J., Guerrero, L.K., \& Floyd, K. (2010). Nonverbal communication. Boston: Allyn \& Bacon.

Burgoon, J.K., Guerrero, L . K. , \& White, C.H. (2013). The codes and functions of nonverbal communication. In C. Müller, A. Cienki, E. Fricke, S.H. Ladewig, D. McNeill, \& S. Teßendorf (Eds.), Body-Language - Communication. An International Handbook on Multimodality in Human Interaction, vol. 1 (pp. 609-626). Frankfurt: De Gruyter.

Castañer, M., Barreira, D., Camerino, O., Anguera, M.T., Fernandes, T., \& Hileno, R. (2017). Mastery in goal scoring, T-pattern detection and polar coordinate analysis of motor skills used by Lionel Messi and Cristiano Ronaldo. Frontiers in Psychology, 8:741. doi: 10.3389/fpsyg.2017.00741.

Cochran, W.G. (1954). Some methods for strengthening the common $\$ 2$ tests. Biometrics. 10, 417-451. doi: 10.2307/3001616

Cohen, J. (1960). A coefficient of agreement for nominal scales. Educational and Psychological Measurement, 20, 37-46. 
Cook, G. (1990). Transcribing infinity. Problems of context presentation. Journal of Pragmatics, 14, 1-24.

Chacón-Moscoso, A., Anguera, M.T., Sanduvete-Chaves, S., Losada, J.L., Lozano- Lozano, J.A., \& Portell, M. (2019). Methodological quality checklist for studies based on observational methodology (MQCOM). Psicothema, 31(4), 458-464. doi: 10.7334/psicothema2019.116

Del Giacco, L., Anguera, M.T., \& Salcuni, S. (2020). The Action of Verbal and Non- verbal Communication in the Therapeutic Alliance Construction: A Mixed Methods Approach to Assess the Initial Interactions With Depressed Patients. Frontiers in Psychology, 11:234. doi:

10.3389/fpsyg.2020.00234

Del Giacco, L., Salcuni, S., \& Anguera, M.T. (2019). The Communicative Modes Analysis System in Psychotherapy from Mixed Methods framework: Introducing a New Observation System for Classifying Verbal and Nonverbal Communication. Frontiers in Psychology, 10:782. doi: 10.3389/fpsyg.2019.00782

Duranti, A. (1997) Transcription: From writing to digitized images. In A. Duranti (Ed.),

Linguistic Anthropology (pp. 122-161). Cambridge: Cambridge University Press.

Ellis, D.G., Fisher, B.A., Drecksel, G.L., Hoch, D.D., \& Werbel, W.S. (1976). Rel/Com: A system for analyzing relational communication (Unpublished coding manual). University of Utah, Salt Lake City.

Escolano-Pérez, E., Herrero-Nivela, M.L., \& Anguera, M.T. (2019). Preschool metacognitive skill assessment in order to promote educational sensitive response from mixed-methods approach: complementarity of data analysis. Frontiers in Psychology, 10:1298. doi: 10.3389/fpsyg.2019.01298

Escudero, V., Rogers, L.E., \& Gutiérrez, E. (1997). Patterns of relational control and nonverbal affect in clinic and non clinic couples. Journal of Personal and Social Relationships, 14, 5-29.

Friedlander, M.L. \& Heatherington, L. (1989). Analyzing relational control in familiy therapy interviews. Journal of Counseling Psychology, 36, 139-148.

Gabin, B., Camerino, O., Anguera, M.T., \& Castañer, M. (2012). Lince: Multiplatform sport analysis software. Procedia - Social and Behavioral Sciences, 46, 4692-4694. doi: 10.1016/j.sbspro.2012.06.320

García-Fariña, A., Jiménez Jiménez, F., \& Anguera, M.T. (2018). Observation of physical education teachers' communication: Detecting patterns in verbal behavior. Frontiers in Psychology, 9:334. doi: 10.3389/fpsyg.2018.00334 
De la entrevista en profundidad a la observación sistemática: una pincelada de comunicación...

Grawitz, M. (1975). Métodos y técnicas de las Ciencias Sociales, Vol. II. Barcelona: Editorial Hispano Europea.

Haley, J. (1963). Strategies of psychotherapy. New York: Grune \& Stratton.

Heath, C. (1986). Body movement and speech in medical interaction. Cambridge: Cambridge University Press.

Heath, C. (1989). Pain talk: The expression of suffering in the medical consultation.

Social Psychology Quarterly, 52(2), 113-125.

Hepburn, A. \& Bolden, G.B. (2013). The conversation analytic approach to transcription. In J. Sidnell and T. Stivers, T. (Eds.), The handbook of conversation analysis (pp. 57-76). New York: Wiley.

Hernández-Mendo, A., López-López, J.A., Castellano, J., Morales-Sánchez, V., \& Pastrana, J.L. (2012). Hoisan 1.2: Programa informático para uso en metodología observacional. Cuadernos de Psicología del Deporte, 12, 55-78.

Johnson, R.B., Onwuegbuzie, A.J., \& Turner, L.A. (2007). Toward a definition of mixed methods research. Journal of Mixed Methods Research, 1, 112.113.

Kelly, J. \& Local, J. (1989). Doing phonology. Observing, recording, interpreting. Manchester: Manchester University Press.

Krippendorff, K. (2013). Content analysis. An introduction to its methodology (3rd. ed.). Thousand Oaks, CA: Sage.

Lausberg, H. and Sloetjes, H. (2016). The revised NEUROGES-ELAN system: An objective and reliable interdisciplinary analysis tool for nonverbal behavior and gesture. Behavior Research Methods, 48, 973- 993.

Márquez, M.O. (2004). La entrevista. En R. Fernández-Ballesteros (Ed.). Evaluación psicológica. Conceptos, métodos y estudio de casos. Madrid: Pirámide.

Mondada, L. (2013). The conversation analytic approach to data collection. In J. Sidnell and T. Stivers, T. (Eds.), The handbook of conversation analysis (pp. 48-56). New York: Wiley.

Moreno Rosset, C. y Ramírez Uclés, I.M. (Eds.) (2019). Evaluación psicológica. Proceso, técnicas y aplicaciones en áreas y contextos. Madrid: Sanz y Torres.

Moya, J., Anguera, M.T., Fornells, E., De Armas, M., y Catalá, M. (2020). Análisis prospectivo de los cambios en las relaciones interpersonales en el contexto de la pandemia COVID-19. Barcelona: Real Academia Europea de Doctores.

Norris, S. (2013). Multimodal (inter)action analysis: An integrative methodology. In C. Müller, A. Cienki, E. Fricke, S.H. Ladewig, D. McNeill, \& S. Teßendorf (Eds.), Body - Language - Communication. An International Handbook on Multimodality in Human Interaction, vol. 1 (pp. 275-286). Frankfurt: De Gruyter. 
O'Connell, D.C. \& Kowal, S. (2000). Are transcripts reproducible? Pragmatics, 10, 247-269.

Ochs, E. (1979). Transcription as theory. In E. Ochs \& B. Schieffelin (Eds.), Developmental Pragmatics (pp. 43-72). New York: Academic Press.

Perpinyá, C. (Ed.) (2012). Manual de la entrevista psicológica. Saber escuchar, saber preguntar. Madrid: Pirámide.

Portell, M., Anguera, M.T., Chacón-Moscoso, S. \& Sanduvete-Chaves, S. (2015). Guidelines for Reporting Evaluations based on Observational Methodology (GREOM). Psicothema, 27(3), 283-289.

Portell, M., Anguera, M.T., Hernández-Mendo, A. \& Jonsson, G.K. (2015). Quantifying biopsychosocial aspects in everyday contexts: an integrative methodological approach from the behavioral sciences. Psychology Research and Behavior Management, 8, 153-160.

Portell, M., Sene-Mir, A.M., Anguera, M.T., Jonsson, G.K., \& Losada, J.L. (2019). Support system for the assessment and intervention during the manual material handling training at the workplace: Contributions from the systematic observation. Frontiers in Psychology 10:1247. doi: 10.3389/fpsyg.2019.01247

Poyatos, F. (2002a). Nonverbal Communication across Disciplines, Volume I: Culture, Sensory Interaction, Speech, Conversation. Amsterdam: John Benjamins.

Poyatos, F. (2002b). Nonverbal Communication across Disciplines, Volume II: Paralanguage, Kinesics, Silence, Personal and Environmental Interaction. Amsterdam: John Benjamins.

Rogers, L.E. (1972). Dyadic systems and transactional communication in a family context (Unpublished doctoral dissertation). Michigan State University, East Lansing.

Rogers, L.E. \& Cummings, J.A. (2017). Relational communication control. In C. A. VanLear and D.J. Canary (Eds.), Researching interactive communication behavior. A sourcebook of methods and measures (pp. 93-106). Los Angeles, CA.: Sage.

Rogers, L.E. \& Farace, R.V. (1975). Analysis of relational communication in dyads; New measurement procedures. Human Comnunication Research, 1, 222-239.

Roustan, M., Izquierdo, C. \& Anguera, M.T. (2013). Sequential analysis of an interactive peer support group. Psicothema, 25(3), 396-401.

Sánchez-Algarra, P. \& Anguera, M.T. (2013). Qualitative/quantitative integration in the inductive observational study of interactive behaviour: Im- 
De la entrevista en profundidad a la observación sistemática: una pincelada de comunicación...

pact of recording and coding predominating perspectives. Quality \& Quantity. International Journal of Methodology, 47(2), 1237-1257.

Schegloff, E.A. (2002). Beginnings in the telephone. In J. E. Katz \& M. A. Aakhus (Eds.), Perpetual contact: Mobile communication, private talk, public performance (pp. 284-300). Cambridge: Cambridge University Press.

Schegloff, E.A. (2005). On integrity in inquiry ... of the investigated, not the investigator. Discourse Studies, 7(4-5), 455-480.

Schegloff, E.A. (2007). Sequence organization in interaction: A primer in conversation analysis. Cambridge: Cambridge University Press .

Selting, M. (2013). Verbal, vocal and visual practices in conversational interaction. In

C. Müller, A. Cienki, E. Fricke, S.H. Ladewig, D. McNeill, \& S. Te- endorf (Eds.), Body - Language - Communication. An International Handbook on Multimodality in Human Interaction, vol. 1 (pp. 589-609). Frankfurt: De Gruyter.

Sidnell, J. (2006). Coordinating gesture, talk, and gaze in reenactments. Research on Language and Social Interaction, 39(4), 377-409.

Sidnell, J. \& Stivers, T. (Eds.) (2013). The handbook of conversation analysis. New York: Wiley.

Sluzki, C. y Beavin, J. (1965). Simetría y complementariedad: Una definición operacional y una tipología de parejas. Acta Psiquiatrica y Psicología de América Latina, 11, 321-330.

Soto, A., Camerino, O., Iglesias, X., Anguera, M.T., \& Castañer, M. (2019). LINCE PLUS: Research software for behavior video analysis. Apunts. Educación Fisica y Deportes, 137(3), 149-153. doi:

https://dx.doi.org/10.5672/apunts.2014- 0983.es.(2019/3).137.11

Suchman, L. \& Jordan, B. (1990). Interactional troubles in face-to-face survey interviews. Journal of the American Statistical Association, 85, 232-241.

Taylor, S.J. y Bogdan, R. (1992). Introducción a los métodos cualitativos en investigación. La buisqueda de los significados. Madrid: Paidós.

Weick, K.E. (1968). Systematic observational methods. In G. Lindzey \& E. Aronson (Eds.), Handbook of Social Psychology, Vol. I (pp. 357-451). Reading, Mass.: Addison-Wesley.

Zimmerman, D. H., \& Pollner, M. (1971). The everyday world as a phenomenon. In J.

D. Douglas (Ed.), Understanding everyday life: Toward the reconstruction of sociological knowledge (pp. 80-104). Chicago: Aldine. 



\title{
REFLEXIONES EN TORNO A LA COMPETENCIA LITERARIA EN LA PRIMERA INFANCIA
}

\author{
Andamana Bautista García \\ Facultad de Ciencias de la Educación. Universidad de Las Palmas de Gran Canaria
}

La educación tendrá en cuenta que estamos ante un nuevo mundo en el que la base de la riqueza ya no es los recursos naturales o los activos fisicos de que un pais disponga sino la capacidad de generar, desarrollar y aplicar conocimientos que tengan sus ciudadanos. (Repetto, 2001, p.136).

Lo que está en juego en el desarrollo de la lectura, en particular entre los jóvenes hombres y mujeres para los que leer no es algo natural, no me parece reducirse a una cuestión 'social'. Lo que está en juego creo yo que atañe a la ciudadanía, a la democratización profunda de una sociedad.

(Petit, 1999, p.104).

\section{Resumen:}

La competencia literaria no solo es importante desde el punto de vista académico, sino que también lo es desde el punto de vista del desarrollo integral de las niñas y de los niños. Reflexionar sobre esto y sobre las propias carencias que a este respecto presenta el estudiantado de los grados de Educación Infantil y Educación Primaria se hace necesario para avanzar y para consolidar propuestas creativas que cubran esa necesidad. Literatura infantil variada y estrategias que favorezcan el pensamiento libre y creativo se convierten en herramientas para alentar transformaciones que pueden nacer en las escuelas, pero que van más allá de las escuelas.

Palabras clave: competencia literaria, primera infancia, formación docente, pensamiento libre.

\begin{abstract}
:
Literary competence is important not only under an academic point of view, but also under the point of view of the comprehensive development of children. Reflections about this and about the lack of literary competence of students in the degrees of Early Childhood Education and Primary Education need to
\end{abstract}


be done to improve and to strengthen creative proposals that may fulfill this need. A wide-ranging children's literature and strategies that encourage free and creative thinking become tools to boost transformations that can originate in schools, but that travel much further than schools.

Keywords: literary competence, early childhood, teacher training, free thinking.

\section{BREVÍSIMA INTRODUCCIÓN}

La lectura del artículo “¿Realmente estamos formando maestros?” de Emigdia Repetto despertó en nosotras varias reflexiones, principalmente, algunas relacionadas con las carencias de distinta naturaleza con la que llega a nuestras aulas el estudiantado de los grados de Educación Infantil y Educación Primaria. En aquel artículo, la autora trata de buscar explicación a esas carencias y señala sin titubeos que "los objetivos de los niveles educativos anteriores no han sido totalmente cubiertos por nuestros estudiantes" y que esto puede comprobarse en la cotidianidad del aula porque "se evidencia que cuestiones de esos niveles son ignoradas y que destrezas que deberían haberse desarrollado no lo están" (Repetto, 2001, p.133). Con esto en mente y en lo que respecta al Área de Lengua en la que desempeñamos nuestra labor dentro del Departamento de Didácticas Específicas, el estado de la competencia literaria de nuestras alumnas y de nuestros alumnos mueve las líneas que siguen. En más ocasiones de las deseables, esta competencia literaria (a veces también incluso la competencia lectora) es muy rudimentaria y, lo que es más relevante aún, esta precariedad en las habilidades para relacionarse con la letra escrita no es en ningún momento objeto de análisis por parte de los futuros maestros y futuras maestras. Iniciamos aquí, pues, una serie de reflexiones sobre la importancia de la competencia literaria desde edades tempranas.

Los objetivos que nos sirven de punto de partida abarcan desde despertar en nuestro alumnado la necesaria reflexión sobre su propia capacidad crítica y su propia capacidad para abordar sus lecturas hasta presentar propuestas para trabajar la competencia literaria en los primeros años de escolarización. Asimismo, uno de los pilares esenciales de este pequeño trabajo es entender que una efectiva relación con la letra escrita que implique capacidad crítica y empoderamiento constituyen elementos esenciales en la formación de una ciudadanía consciente y madura capaz de afrontar de forma creativa los retos que, como sociedad, tenemos por delante. 


\section{PRIMERAS REFLEXIONES}

Si leer es interaccionar y si en este proceso de interacción la recepción es fundamental, debemos detenernos con Antonio Mendoza un instante para establecer qué queremos decir con esto. Así,

La recepción es un proceso de interacción entre el texto y el lector, es decir, entre los modelos textuales y los saberes del receptor. El receptor es, básicamente, un interpretador múltiplemente condicionado por factores lingüísticos, culturales, sociales, vivenciales, etc., capaz de construir - a través del proceso de interacción con el texto- una interpretación propia y personal para cada texto recibido. (Mendoza, 1998, p.171).

$\mathrm{Al}$ entender esto de esta manera, la escuela y la familia verán con claridad que, cuanto antes comience la integración progresiva de las referencias textuales que van conformando nuestro intertexto lector personal (Mendoza, 1998), mejor preparación tendremos para convertirnos en lectores competentes. La clave reside, pues, en de qué manera podemos en casa y en el cole asegurarnos de que nuestras intervenciones como adultos que median entre los niños y sus lecturas suman y no restan, construyen puentes y no aversiones. El didactismo, la sensiblería, la escasa significatividad, las selecciones de obras inapropiadas o la repetición tediosa de estrategias vinculadas a las lecturas ponen en peligro el desarrollo de relaciones productivas y enriquecedoras de la infancia con la literatura.

Para que los niños y las niñas establezcan con la palabra en todas sus manifestaciones relaciones ricas, ellos y ellas deben ser en todo momento protagonistas de esos escenarios de aprendizaje. Escuchar lo que tienen que decir, validar sus intervenciones y permitir que manipulen lo que leen se vuelven aspectos indispensables para fortalecer ese vínculo con lo escrito que tanto aporta.

Del mismo modo en que hemos propuesto una mirada concreta hacia el lector, debemos también posicionarnos, ya sea brevemente, en cómo entendemos la literatura. Así, nuestra posición se sostiene sobre ideas como la siguiente:

Mediante la literatura los niños reciben las primeras pruebas de que hay otra realidad dentro de la realidad, en la que se puede entrar y salir al antojo, y que es infinitamente más bella, pese a sus contradicciones, que la de todos los días, tan engastada en la rutina. Por esa puerta, que es la puerta de lo bello, se llega con más seguridad y con más dulzura al conocimiento. (Guerra, 2002, p.57). 
Se observa en esta aportación de nuestro compañero Oswaldo Guerra la fuerza que pueden tener las representaciones que de la realidad nos ofrece la literatura infantil. La literatura y sus metáforas constituyen herramientas con las que transitar de forma amable todo aquello que nos asusta, que nos inquieta, que nos preocupa, que nos emociona en general. Es como si lo literario se convirtiera en sí mismo en un entorno seguro en el que explorarnos en interacción con el mundo sin tener que experimentar directamente las consecuencias de no haber desarrollado por completo nuestras capacidades para garantizarnos interacciones siempre satisfactorias. Para que la literatura cumpla esta función, debemos ser conscientes de que estamos ante una representación de la realidad mediada "por el lenguaje, la ideología, la cultura, el poder, la convención, el deseo" (Ellsworth, 2005, en Acaso, 2012, p.53). Cuando reconocemos este hecho, "la representación se vuelve reconocible y disponible como un sitio crucial de luchas sociales, políticas y educativas acerca de cómo se produce el significado de las personas, acontecimientos y experiencias específicas" (Ellsworth, 2005, en Acaso, 2012, p.53). Al darnos cuenta de esto, vemos el escenario y podemos subirnos para explorarnos, aprender, crecer, enriquecernos y, al bajarnos de él, continuar viviendo nuestras vidas fortalecidos y habiendo aumentado nuestra propia estatura.

\section{UNA PROPUESTA PARA TRABAJAR LA COMPETENCIA LITERARIA EN LA PRIMERA INFANCIA}

Si el niño es un ser "en pleno proceso de adquisición de autonomía de pensamiento, de un horizonte de expectativas, de competencia literaria y de juicio estético, que lo capacitan para enfrentarse a textos polifónicos/abiertos/ambiguos" (de Amo, 2003, p.54), debemos convertirnos en mediadores efectivos entre la infancia y sus lecturas. Como ya hemos comentado en alguna otra ocasión (Bautista, 2017), "ya no es el niño aprendiz y sumiso el que nos interesa, sino el nińo libre, creador y poeta” (Escarpit, 1973, citado en Blanco, 2009, p.41) que habrá de convertirse en adulto librepensante en una sociedad que nos presenta retos que requieren de creatividad y de pensamiento divergente. Esa autonomía de pensamiento que buscamos y esa capacidad para el abordaje de textos diversos requieren que quienes hacemos de puente entre los jóvenes lectores y los textos nos tomemos muy en serio nuestro papel y lo desempeñemos con coherencia y profesionalidad.

Con todo esto en mente, retomamos una serie de pautas y de prácticas que conforman una propuesta nacida del más puro sentido común y que ya com- 
partimos en el simposio "Más allá de la competencia lectora: lectores, lecturas y educación literaria" celebrado en el marco de la 20 Conferencia Europea sobre Lectura y Escritura en 2017.

Estas pautas son sencillas:

1. Tengamos en cuenta que en la infancia permanecemos presentes y nos implicamos si, de la manera que sea, nos vinculamos emocionalmente con lo que leemos (o con los nos es leído).

2. No olvidemos que seleccionar un libro por lo que se puede trabajar a partir de él suele fracasar como criterio de auténtica animación a la lectura.

3. Pensemos que la sensiblería aburre.

4. Convirtámonos en defensores de la gratuidad de la lectura, es decir, leamos, sin más, por el placer de leer.

5. Elijamos libros por los que los niños y las niñas puedan viajar tanto solos como en nuestra compañía para que el viaje sea más largo, más rico.

6. Preparemos espacios físicos de lectura y de libros que formen parte de espacios físicos asociados a lo lúdico, de forma que tenga sentido decir “ ¿Vamos a jugar a leer!” o “Jugamos al parchís, a los coches, a las cartas, a las casitas o a leer un cuento?”.

7. Leámosles libros disfrutando y apasionándonos.

8. Interesémonos por lo que el libro le hace al niño o a la niña en su proceso de interacción.

9. Validemos todas las respuestas de todos los niños y de todas las niñas a preguntas que indaguen en su proceso de recepción.

10. Estemos abiertas a sentir con intensidad nosotras mismas para poder así acompañar desde la honestidad a los niños y las niñas a sentir las emociones y los sentimientos que nacen de las lecturas. (Bautista, 2017, pp.89-90).

Observando estas pautas, percibimos que son una apuesta por la emoción, por la escucha, por la honestidad y por la creación de espacios de lectura asociados a lo lúdico. Todo ello se inicia, necesariamente, con la selección de obras que acercamos a las niñas y a los niños y con las reflexiones previas que debemos hacer para poder realizarla con garantías de éxito. En esta línea, solemos preguntar al estudiantado universitario de los grados de Educación Infantil y Educación Primaria acerca de qué libros llevarían a las aulas de la escuela y siempre se da la respuesta de que atenderían a los gustos del grupo para acomodar las lecturas a esas preferencias. A pesar de que esta idea suena valiosa, 
lo cierto es que los niños y las niñas necesitan que la escuela les abra puertas y ventanas y los lleve mucho más allá de sus gustos. Solo les puede gustar lo que conocen y la escuela, junto con las familias comprometidas, han de procurarles a los más pequeños experiencias que partan de donde los niños y las niñas están para impulsarlos hacia adelante y hacia arriba. Esto se consigue con literatura que sorprenda, que respete, que escuche a quienes leen, que favorezca el necesario compromiso con el acto de leer. Al final, si la historia les gustó o no les gustó y si las ilustraciones les parecieron preciosas u horribles, no es tan relevante como pudiera parecer; si leyeron con atención (o si se mantuvieron en la escucha) y nos interesó honestamente lo que tuvieron que decir acerca de la lectura, estamos contribuyendo a que esos lectores sean buenos lectores (Bautista, 2017).

Al bajar a tierra este ideario, asumimos que a los pequeños lectores y a las pequeñas lectoras conviene presentarles variedad de libros, géneros, estilos, estéticas, historias... Observemos un instante esta diminuta muestra (McAnulty y Lew-Vriethof, 2018; Daynes y Álvarez, 2017; Charro, 2014; Gil y Gusti, 2012):

Figura 1. Algunos ejemplos de obras de literatura infantil para trabajar en Educación Infantil.
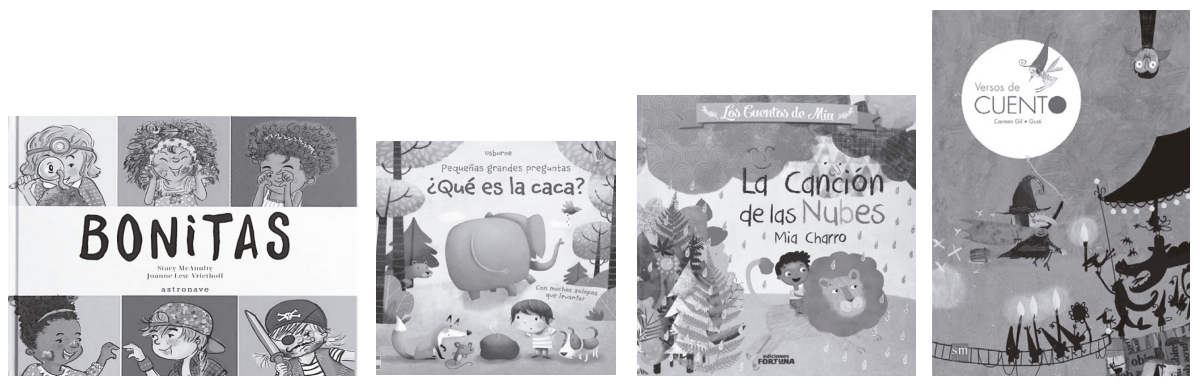

Con los cuatro, en casa y en el cole, hemos leído, hemos escuchado y hemos deseado volver a abrirlos en más de una ocasión. Con el primero hemos disfrutado de un juego fabuloso del texto con la ilustración en el que el uno no se entiende sin la otra. El segundo nos ha regalado momentos de risa y de aprendizaje abriendo solapas que despliegan contenidos en torno a un tema que apasiona a nińos y niñas de la etapa de Infantil. El tercer libro nos ha emocionado como canto a la colaboración y a la solidaridad, y ha dado lugar a in- 
teresantes dramatizaciones riquísimas no solo en valores, sino también en el manejo de lo literario. Con el cuarto, un libro de versos, no solo hemos admirado el uso de las palabras y de las rimas, sino que también nos hemos acercado de otra manera a elementos e historias de siempre y, en ese nuevo acercamiento, hemos redefinido personajes que ya formaban parte de nuestro intertexto lector. De todos nos hemos enriquecido, de todos hemos aprendido y a todos hemos tenido que agradecerles momentos llenos de vida y de crecimiento.

Si ampliamos la mirada dentro de la oferta editorial disponible para el público infantil, nos encontramos con el cómic. Con este género, igual que cuando hablamos de álbum ilustrado, disponemos de un recurso en el que gran parte del peso de la narración o todo el peso de la narración recae sobre la ilustración, sobre la imagen. La principal aportación de este está bien definida: dominar el código escrito no es necesario para trabajar habilidades muy relacionadas con la lectura y la competencia literaria como, por ejemplo, el establecimiento de inferencias y expectativas:

Leer es bastante más que saber reconocer cada una de las palabras que componen el texto: leer es, básicamente, saber comprender, y, sobre todo, saber interpretar, o sea, saber establecer las personales opiniones, valoraciones y juicios. Por ello, leer es participar en un proceso activo de recepción. Leer es más que descifrar o descodificar signos de un sistema lingüístico. La lectura no es un acto de descodificación de las combinaciones de letras, palabras, oraciones, enunciados que presenta el texto, sino un proceso complejo apoyado en expectativas y en inferencias personales sobre el significado que establece el lector en función de su intertexto. (Mendoza, 1998, pp.170-171).

Todo esto que Antonio Mendoza establece para el acto de leer se da perfectamente cuando es la imagen la que nos habla. Así, las siguientes páginas del precioso cómic Dino y Pablo. Juegos prehistóricos de Dauvillier y Amsallem (2010) nos ponen fácil el imaginarnos a una niña o a un niño construyendo con su particular interpretación una narración a partir de lo que lee en la secuenciación de imágenes, independientemente de que ya tenga adquiridas las habilidades para descodificar grafías o no las tenga: 
Figura 2. Cuatro páginas de Dino y Pablo.

Juegos prehistóricos de Dauvillier y Amsallem, 2010.
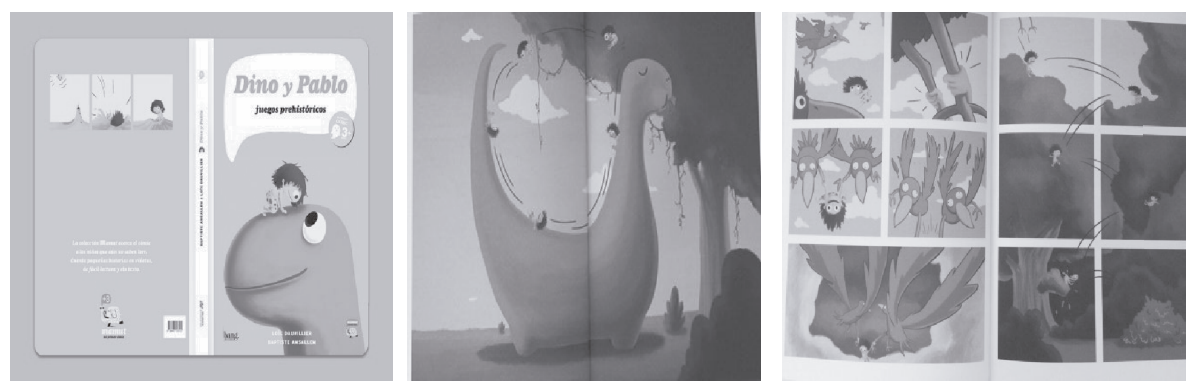

Si en obras como esta que acabamos de ver de Bang Ediciones y su colección Mamut, mi primer cómic el color está muy presente y también desempeña su función, este ingrediente no existe siempre en las obras para niños y niñas. De este modo, en obras como Buh, estamos ante libros con viñetas y muy pocas palabras, en blanco y negro, con secuenciaciones más complicadas y con contenidos que rebosan ternura, conciencia ecológica, sensibilidad.

Figura 3. Portada y tres páginas de uno de los volúmenes de Bub de Andy Runton, 2012.
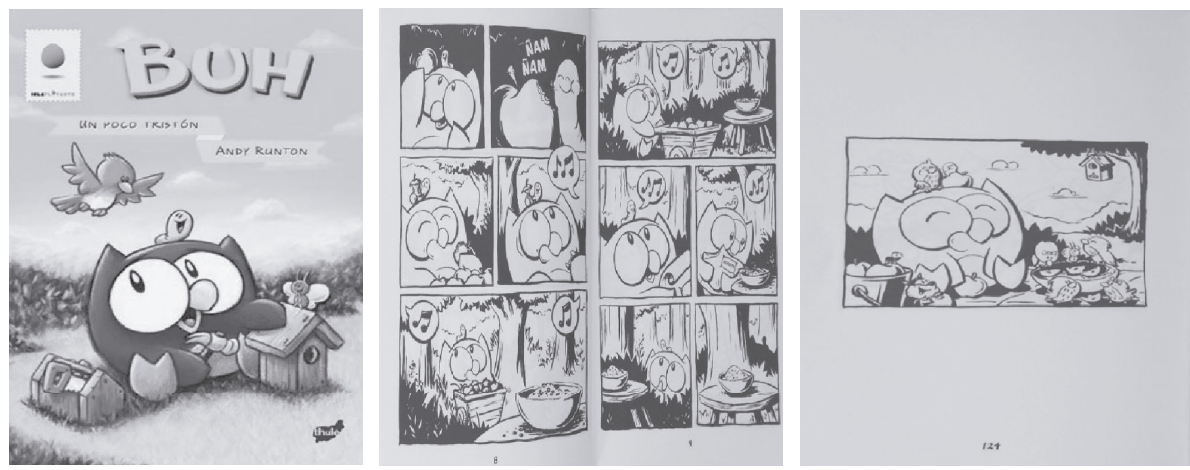

Vemos que este cómic ofrece, al igual que Dino y Pablo, cambios de ritmo al lector al alternar, por ejemplo, páginas con imágenes en secuencia deliberada como la que se muestra en el centro con otras en las que solo hay una viñeta. Además, volvemos a ver que la construcción del relato se va gestando en un juego de interacción imagen-lector, esta vez sin ayuda del color. Con obras 
como estas, el niño y la niña lectores no solo interpretan las imágenes y tejen un relato sin necesitar para ello descifrar el código lingüístico, sino que también se vinculan con un personaje entrańable que nos ayuda a trabajar las relaciones interpersonales y la educación emocional.

A modo de valoración amplia, tenemos que cada lector actualiza el texto con cada acercamiento a cada obra. Es más, los niños entrenados en competencia literaria no solo sienten permiso para interpretar las historias, sino que poseen una mirada crítica y constructiva que los lleva a transformar por completo los cuentos que otros les cuentan si no les gustan nada. No quieren deshacerse de Caperucita Roja, sino que quieren convertirla en algo con lo que puedan disfrutar. A lo mejor el lobo es vegetariano y solo quiere la receta de galletas de la abuelita o quizá el cazador es el malo y el lobo es el bueno o tal vez el lobo, que es el miedo, se va cuando nos enfrentamos a él de frente y nos sentimos grandes y poderosas.

Esto se consigue facilitando en las aulas y en los hogares estrategias en las que haya cabida para jugar con lo narrado, para manipularlo y para intervenir en la historia de una manera activa. Este papel tan de acción en el proceso de recepción de una obra guarda relación con una estrategia que cogemos prestada de Rodari (2001) y que consiste en presentar un binomio fantástico con, por una parte, elementos de una historia conocida por los lectores y las lectoras y, por otra parte, un elemento discordante. Es un trabajo muy interesante presentar dos posibilidades que juegan con un cuento clásico y un elemento ajeno a él:

a. niña-ositos-sopa-sillitas-pirata

b. bruja-casa de chocolate-hermanos-bosque-sable láser

Podemos establecer la serie con elementos de cualquier historia con la que el grupo esté familiarizado. Con esta propuesta, ponemos a prueba su capacidad para reaccionar ante un elemento nuevo, inesperado, rompedor. Además, la nueva palabra ha de ser absorbida por la historia conocida y este es un ejercicio precioso ante el que cada niño, cada nińa aporta una respuesta distinta e igual de válida que las demás. Junto con esto, las palabras de la serie de la historia conocida también se ven forzadas a reajustarse para encontrar su sitio en el nuevo contexto que ha sido creado. Así, una historia ya manida puede reanimarse para que siga viviendo en nosotras un poco más. Y lo que es más importante: el reto implica que tenemos permiso para jugar con el lenguaje y con lo que conocemos y damos por sentado. Esto es valiosísimo porque empodera a los niños y a las niñas validando habilidades que poseen como la imaginación, 
la libertad para transgredir sin miedo en un contexto seguro, la voluntad de cambiar lo que no les gusta, la facilidad para borrar límites entre lo posible y lo imposible, entre lo real y lo irreal. En este ejercicio de transformación y de libertad, hay empoderamiento y, cuando favorecemos adecuadamente el empoderamiento de niños y niñas, contribuimos a ir conformando una sociedad que piensa constructivamente, una ciudadanía bien despierta abierta a transformar el mundo y capaz de hacerlo.

\section{BREVE CONCLUSIÓN}

Detectamos con frecuencia carencias en todas las etapas y ciclos del sistema educativo. Como consecuencia de esto, miramos y arremetemos contra el marco legal, contra las autoridades, contra la escasa implicación de las familias o contra el reducido presupuesto destinado a Educación. Sin embargo, pocas veces la mirada se vuelve a la formación del cuerpo de docentes o a los procesos de selección de quienes entran a las aulas a acompañar a niños y niñas en su desarrollo.

En las páginas que cerramos con estas líneas, nos hemos dejado inspirar por algunas de las aportaciones de Emigdia Repetto para llevarlas a nuestra área de conocimiento y, desde ella, proponer nosotras también reflexiones que puedan animar a otras personas a pensar en respuestas que sumen para la mejora que la escuela necesita. En la medida en que en las aulas universitarias se observan carencias en la competencia literaria y una inquietante ausencia de reflexión a este respecto, nos hemos centrado en la relación con la letra escrita y en cómo trabajarla desde la primera infancia.

Hemos procurado darles a la lectura y al contacto con lo literario una dimensión amplia que va mucho más allá de lo académico para tocar de pleno nuestra naturaleza como seres sociales y para entender la educación en todo su potencial como agente favorecedor de transformaciones profundas. La literatura y sus metáforas nos permiten, como hemos visto, construir escenarios de experimentación de nosotras mismas en contacto con el mundo.

Además, las pautas y prácticas que hemos presentado se asientan sobre pilares importantes como el cuidado de la emoción, la escucha, la honestidad o la asociación de la lectura con lo lúdico. Por su parte, las distintas propuestas concretas que hemos esbozado abarcan no solo literatura infantil de distinto tipo, sino también estrategias en las que las niñas y los nińos se relacionan con sus lecturas en libertad sin que haya por parte del mediador una intención de homogeneizar las interpretaciones o de validar solo un tipo de reacción/respuesta ante los textos. Con esto se ha pretendido alentar que las aulas se pueblen de 
estudiantes librepensantes que se sientan con fuerza para cuestionar y reescribir lo escrito en todas las etapas educativas.

Es posible que llegue a pensarse que es poco realista o muy subjetiva la idea de que la literatura y un buen acceso a lo literario desde edades tempranas puede contribuir a la conformación de una ciudadanía más libre y más capaz de afrontar los retos que tenemos por delante. No nos parece relevante entrar a valorar si esto es así o no porque entendemos que creer en lo poco realista, en lo muy subjetivo o, incluso, en la utopía es ya en sí misma una posición que favorece la transformación.

\section{REFERENCIAS BIBLIOGRÁFICAS}

Acaso, M. (2012). Pedagogías invisibles. El espacio de aula como discurso. Madrid: Los Libros de la Catarata.

Bautista, A. (2017). ¿Competencia literaria en la primera infancia? En E. D’Angelo y L. Benítez (coords.), 20 Conferencia Europea sobre Lectura y Escritura. Libro de actas, 87-93.

Charro, M. (2014). La canción de las nubes. Bizkaia: Ediciones Fortuna.

Dauvillier, L. y Amsallem, B. (2010). Dino y Pablo. Juegos prehistóricos. Barcelona: Bang Ediciones.

Daynes, K. y Álvarez, M. (2017). ¿Qué es la caca? Reino Unido: Usborne.

De Amo, J.M. (2003). Literatura infantil. Claves para la formación de la competencia literaria. Málaga: Ediciones Aljibe.

Gil, C. y Gusti (2012). Versos de cuento. Madrid: SM.

Guerra, O. (2002). Senderos de lectura. Memoria y hermenéutica literaria. Madrid: Ediciones La Discreta.

McAnulty, S. y Lew-Vriethof, J. (2018). Bonitas. Barcelona: Astronave. Mendoza, A. (1998). El proceso de recepción lectora. En A. Mendoza (coord.), Conceptos clave en didáctica de la lengua y la literatura. Barcelona: SEDLL, ICE Universitat de Barcelona, Edit. Horsori, 169-189.

Petit, M. (1999). Nuevos acercamientos a los jóvenes y la lectura. México D.F.: Fondo de Cultura Económica.

Repetto, E. (2001). ¿'Realmente estamos formando maestros? El Guiniguada. Revista de investigaciones y experiencias en Ciencias de la Educación, 10, 127-137. Rodari, G. (2001). Gramática de la fantasía. Introducción al arte de contar historias. Barcelona: Ediciones del Bronce.

Runton, A. (2012). Buh. Barcelona: Thule. 



\title{
LA PROFESIÓN DE MAESTRO EN LA VIÑETA ESPAŃOLA DEL SIGLO XX: EL PROFESOR TRAGACANTO Y SU CLASE, QUE ES DE ESPANTO. PERSPECTIVA DIDÁCTICA DE ANTAÑO.
}

\author{
Daniel Becerra Romero \\ Universidad de Las Palmas de Gran Canaria
}

\begin{abstract}
Resumen:
Las imágenes, como sabemos, son el elemento desencadenante de la creación de los símbolos, pero, igualmente, estos hacen referencia o terminan siendo la representación de una realidad histórica e interpretable. La naturaleza de las viñetas no es ajena a este hecho. En el caso que nos ocupa nos referimos a esas viñetas que conocimos en nuestra juventud y representan al maestro de antaño. A prácticas docentes del pasado, a ejercicios, materiales, contenidos y metodologías de una época que ya no existe, pero que habría de contribuir a construir un imaginario iconográfico, en ocasiones cercano, pero en otras muy lejano a la realidad a la que pertenecen.
\end{abstract}

Palabras clave: viñeta, tebeos, enseñanza, historieta, didáctica.

\begin{abstract}
:
The images, as we all know, are the triggering element for the creation of symbols; but equally they refer to or end up being an interpretable representation of a historical reality. The nature of the vignettes is not unaware of this fact. In this case we are referring to those vignettes that we knew in our youth and represent the teacher of yesteryear. To the teaching practices of the past, to exercises, materials, contents and methodologies of a time that no longer exists, but that would contribute to the building of an iconographic imaginary, sometimes close, but sometimes very distant to the reality to which they belong.
\end{abstract}

Keywords: cartoon, comics, teaching, comic strip, didactics.

Un antiguo y popular dicho sostiene que una imagen vale más que mil palabras y aunque no sea cierto del todo - como bien sabemos la perspectiva es muy engańosa-, algo de verdad tiene. Si bien podríamos remontarnos a la Prehistoria para encontrar que desde esos momentos ya podía considerarse un elemento esencial para la creación y transmisión de información, las pinturas 
y grabados rupestres podrían interpretarse, desde una óptica formativa, como la pizarra con la que aprender a conocer y reconocer determinadas especies faunísticas o posibles patrones de comportamiento de carácter social. A modo de ejemplo, baste recordar las escenas reflejadas en las paredes y en los abrigos del Parque Nacional del Tassili n’Ajjer (Argelia) para hacerse una idea. No es difícil imaginar una reunión ante dichas escenas en la que una persona con mayor conocimiento podría explicar a sus interlocutores su significado al igual que hoy día realizan diversas comunidades, con la diferencia de que los primeros estarían en su contexto original.

No obstante, no hace falta que vayamos tan lejos. Las viñetas y las ilustraciones que conforman el espacio del aula y la escuela a lo largo del siglo XX, campo que es el que ahora mismo nos ocupa, son igualmente significativas. A través de ellas podemos observar y apreciar los cambios sociales, de mentalidad y de metodología que tuvieron lugar en ese lapso, pero, también, la continuidad de aquellos materiales que aún consideramos claramente didácticos; por mucho que apreciemos las bondades de la tecnología de última generación que cada día invade un poco más nuestras aulas.

$\mathrm{Y}$ es que como bien expuso el célebre historiador del Arte Ernest Gombrich: "Todas las imágenes deben más a otras imágenes que a la propia naturaleza" (1968:20), de ahí que las páginas de nuestras lecturas de juventud, de aquellas historietas que conformaron nuestros primeros referentes, sirvieran para configurar y reconfigurar una serie de convencionalismo culturales que se retroalimentan entre sí. Ahora bien, eso no quiere decir que neguemos los procesos de incorporación, innovaciones que se situarían en la órbita del agregado con connotaciones densamente codificadas.

En suma, hablamos de esas viñetas que habrían servido para agrupar a través de sus textos y, particularmente, de sus dibujos un constructo claramente inmerso en la estructura social de la que participan los lectores a la que se dirige, que (re)produce y (re)activa todo ese conjunto de percepciones, influencias, relaciones, valores y expectativas heredado y asentado de etapas anteriores. Fig.1. 
Fig. 1. Más de cien años separan ambas imágenes.

$\mathrm{Y}$, sin embargo, el imaginario sigue siendo el mismo.

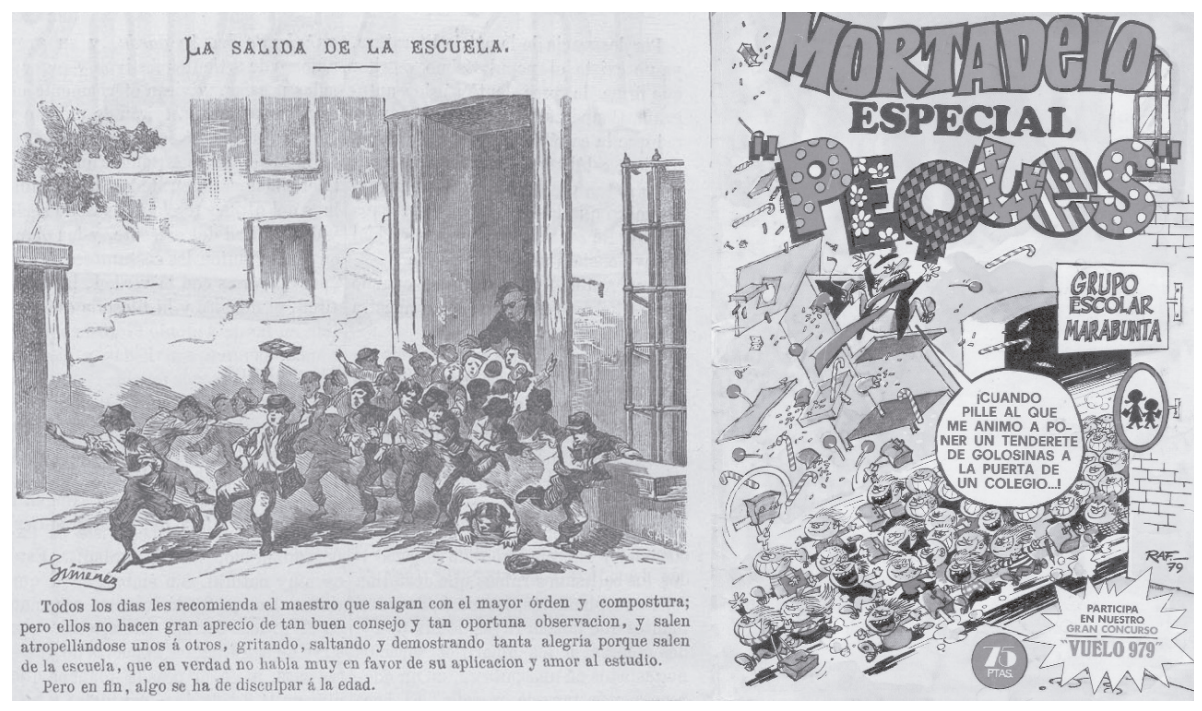

Fuente: Los niños (Madrid), 1870, Tomo II, 26, p. 200.

Portada de Mortadelo especial: Peques, 18 de marzo de 1979.

El tebeo, voz con la que hasta hace unos años se conocía a lo que hoy se denomina en nuestro país con el vocablo anglosajón cómic, no es ajeno a este hecho. Sus dibujos y líneas de texto — que, en palabras del conocido catedrático y miembro de la Real Academia de Bellas Artes de San Fernando, Roman Gubern, vendrían a representar el cine de los pobres - atesoran múltiples universos que nos hablan de como fuimos y como hemos cambiado a lo largo de los siglos XIX y XX. Como ocurre con la vińeta fílmica, en cuyo celuloide quedaron plasmadas las vivencias, sueños y esperanzas de sus protagonistas, sus homólogas de papel —que en realidad son sus antecedentes (Martin, 2000; Gubern Garriga-Nogues, 2014) — representan un recurso fundamental para este propósito, aunque su lectura, en algún momento, haya sido menospreciada o sencillamente no fuera vista con buenos ojos (Fernández Sarasola, 2019).

Para abordar su examen optamos por seguir la metodología establecida por Roger Chantier (1992) para el análisis de la Historia Cultural. Para este autor su objeto principal consiste en identificar el modo en cómo, en diferentes lugares y momentos, una determinada realidad social se construye, se piensa y 
se da a leer. Una forma de estudio basada en la utilización de tres conceptos en interacción: práctica, identificado con lo real, representación, con el discurso, y apropiación, con la lectura.

En nuestro caso la imagen del docente, la forma de impartir docencia, las técnicas pedagógicas, su grupo clase y hasta los materiales asociados. De acuerdo con Escolano, vienen a recoger parte de ese grupo de características significativas "de la educación formal en su dimensión práctica o real; no sólo porque es una categoría que "materializa» las concepciones y los modos de educación, sino también porque esa misma materialidad instituye un discurso pedagógico y cultural' (1992:55). Ahora bien, entre las numerosas imágenes vinculadas al ámbito académico, quizás, entre la más icónicas se encontraría la que se asocia a la falta de conocimiento, es decir, al mítico capirote. Nos referimos a aquel gorro con forma de cucurucho invertido al que se ańadían orejas de burro que, simbólicamente, venía a representar al estudiante poco dispuesto al aprendizaje. Un imaginario presente ya a mediados del siglo XIX en nuestras aulas, que recoge la mano del pintor y dibujante Francisco Ortego y Vereda como se puede observar en la ilustración de la revista Los niños editada en Madrid. Fig. 2.

Figura 2. El clásico gorro con orejas de borrico, símbolo del alumno que no quiere estudiar.

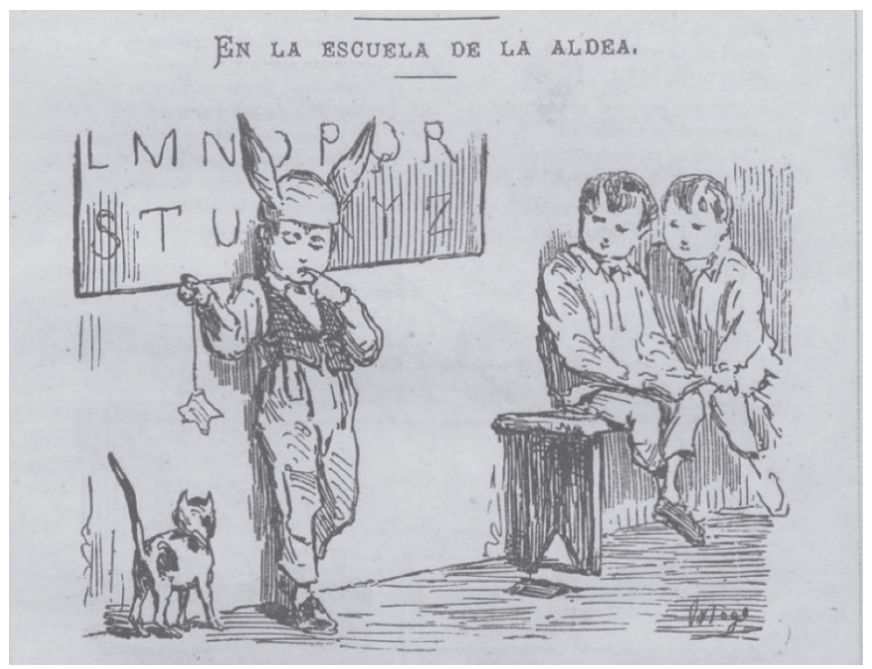

Fuente: Los niños (Madrid), 1870, Tomo I, 14, p. 267. 
Una forma de castigo que habría de dar paso a aquel otro que consistía en situar al alumnado de rodillas en el suelo con los brazos en cruz. En ocasiones acompańado de sendos libros en cada mano. Una imagen muy ligada, en lo que a la viñeta se refiere, a los célebres Zipi y Zape Zapatilla, la pareja de gemelos creada por José Escobar en $1948^{1}$. Una práctica social que bien podía extenderse más allá de las paredes del aula, para alcanzar el hogar familiar de la mano de la autoridad paterna, como se puede observar en la portada del número 545 de la revista Lily, editada en 1972. No en vano un antiguo dicho rezaba "la letra, con sangre entra". Un ideario que recoge claramente el dibujante Manuel Conti en La educación de la infancia, plancha publicada en el semanario humorístico Can Can de la editorial Bruguera en $1959^{2}$ y que los hermanos Zapatilla, muy gráficamente al menos en sus inicios, habrían de conocer muy bien.

Ciertamente, mucho antes de que Martz Schmidt creara en 1959 al personaje de Tragacanto — para el primer número de la efímera revista Ven y Ven de la citada y poderosa editorial Bruguera- la presencia de la escuela y sus vicisitudes ya había sido objeto de la mirada de autores muy conocidos en el panorama grafico de la prensa estadounidense. Hablamos de dibujantes como el padre del popular Yellow Kid, Richard F. Outcault, con sus series The Country School (1898) y Kelly's Kindergarten (1898), al que seguirían Charles W. Kahles con The Little Red School-House (1901) y Clare Victor Dwiggins en School days (1909), más tarde reconvertida en School Days and Ophelia y en Oh, You Ophelia! Obras que verían la luz en las páginas dominicales de diferentes cabeceras de prensa estadounidenses, caso de St. Louis Post Dispatch y The Philadelphia Inquirer, entre otros.

1 Por ejemplo, Pulgarcito 1847, p. 30, con fecha del 26 de noviembre de 1966 y 1857, p. 30, publicado el 5 de diciembre de 1966.

2 Nos referimos a Can Can, 66, con fecha de publicación del 11 de mayo de 1959, p. 7. 
Fig. 3. Une petite école, de Joseph Beaume. Obsérvese los materiales clásicos citados que conforman parte del imaginario adquirido.

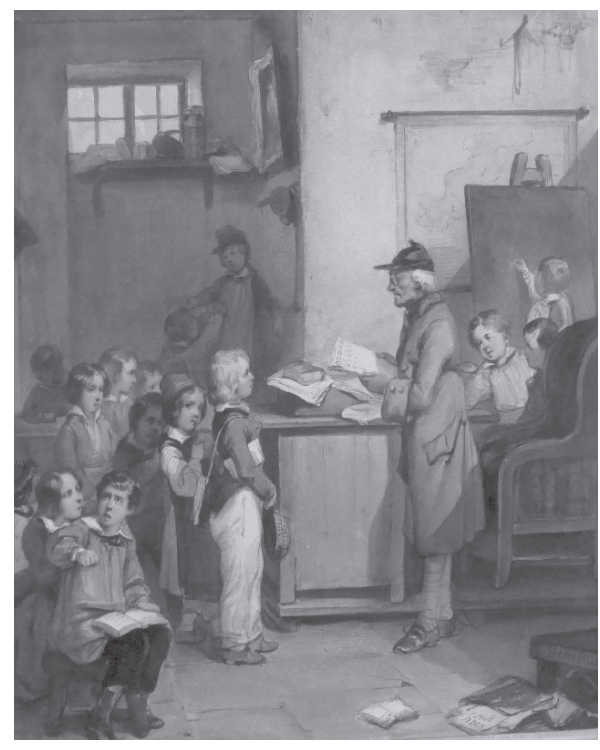

Fuente: Wikimedia commons.

Series que tuvieron una longevidad muy dispar y que recogen en sus páginas la crítica social, el bullicioso y tradicional comportamiento del alumnado e inclusive su clara diferenciación por causas económicas, pero, también, muchos de esos elementos que veremos posteriormente: desde la enorme pizarra de pared y la tiza para escribir, con su trapo para limpiarla, hasta los pupitres unidos, la tarima para el docente y el imprescindible globo terráqueo con los mapas correspondientes. Una construcción del espacio cuyo referente podemos localizarlo en la obra de Henry Barnard, uno de los reformadores de la educación estadounidense en el siglo XIX. De su bibliografía la que nos concierne es School architecture, publicada en 1848. En ella analiza y expone los principios organizativos y espaciales para la convivencia escolar, que abarcan desde la maquinaria a la constitución del aula, siempre con la mente enfocada en la salud de sus ocupantes. 
La profesión de maestro en la viñeta española del siglo xx: el profesor Tragacanto y su clase, que es ...

Fig. 4. Das Schulexamen, de Albert Anker. Nótese el pupitre característico de numerosas escuelas adaptado al cuerpo de los infantes, como indicaba Barnard.

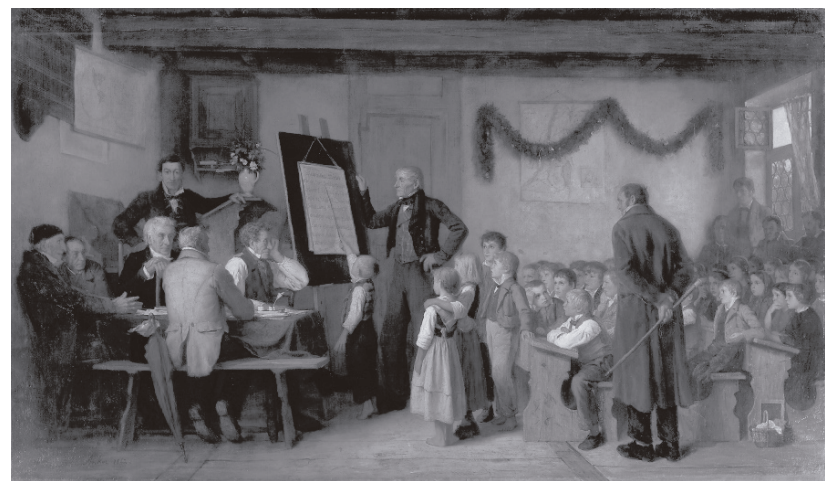

Fuente: Wikimedia commons.

En la misma línea, el pizarrón y el mapa de pared ya eran parte del sistema educativo hacia 1830, como se pude observar en la acuarela Une petite école, obra de Joseph Beaume, del Musée National de l'Education de Rouen (Francia) y hacia mitad de siglo en Das Schulexamen, óleo sobre tabla de la mano de Albert Anker, perteneciente a la colección del Musée des Beaux-Arts de Berna (Suiza). Fig. 3 y 4.

Centrándonos en la obra de Schmidt ${ }^{3}$, puede decirse que la publicación de las desventuras del profesor y de su grupo clase tuvieron una vida bastante azarosa. Sus páginas se reparten en numerosas cabeceras semanales de las que destacarían Pulgarcito, Suplemento del DDT y Din Dan, todas de la mencionada Bruguera. Revistas dirigidas a la juventud, a lo que se unía la política de la editorial de repetir historietas ya publicadas con anterioridad o sencillamente guionizadas y dibujadas por otras manos, muy distintas a la de su creador. Una práctica que viene a dificultar el seguimiento cronológico de la obra y obliga a observar y analizar con detalle cada plancha. Por dicho motivo únicamente nos ocuparemos de sus primeras historietas, que abarcarían un periodo aproximado entre el final de la década de los cincuenta hasta mitad de la década del sesenta, momento en que Schmidt abandona temporalmente Bruguera, es

3 Cabe señalar que los guiones no siempre se corresponden con este autor. Según el momento sería Francisco Serrano, así como otras manos quienes estuvieran tras esta labor. 
decir, en torno a sus primeros años de vida en el que el trazo del dibujante, incluso dentro del proceso evolutivo natural, es fácilmente distinguible. Ahora bien, cabe señalar que hacia el final de esta etapa se puede apreciar claramente que no todas las historietas provendrían de su mano.

Para este periodo hablamos de relatos de una sola página, esquema que mantendrá prácticamente estable a lo largo de toda su vida editorial. Únicamente se modificará hacia el final de la serie debido a la reducción de formato de la revista Pulgarcito en 1981. La segunda etapa se inicia en 1971 con el retorno del autor a la empresa hasta el inicio los ańos ochenta en que deja de editarse. En este periodo se intercalan nuevas historias con la reedición de las antiguas.

A diferencia de otros conocidos personajes de la vińeta, como pudieran ser el célebre y despistado Tornasol, figura creada por Hergé (1943) y presente en las aventuras del conocido reportero del Petit Vingtième, Tintin; Philip Mortimer, el físico nuclear escocés que comparte protagonismo con Francis Blake, oficial del Ministerio de Inteligencia británico, en la genial obra de E.P. Jacobs (1946); el profesor Bacterio, el desastroso inventor ligado a las desventuras de Mortadelo y Filemón concebidos por Francisco Ibáñez en (1969); o sencillamente Franz de Copenhague (1935), cuyos alocados descubrimientos — de la mano de diversos autores - sirvieron para estimular e inspirar la imaginación a cientos de sus lectores en las páginas de la revista TBO y que, su vez, podría remontarse a Inventions of Professor Lucifer Gorgonzola Butts, obra de Rude Golberg (1914), o con mayor seguridad, como señalan Giralt y Guiral (2017:56), a la sección Le inventions du Pêle-Mêle de la revista francesa Le Pêle-Mêle (18951930). Ahora bien, el imaginario construido alrededor de Tragacanto nos retrotrae a otras fuentes, como la mencionada The Little Red School-House de Kahles. No obstante, la influencia de los docentes citados se dejaría notar en sus estudios sobre "artefactos atómicos" y en la realización de experimentos por su cuenta, con resultados muy diversos, en línea con la formación continua que se esperaba de todo docente ${ }^{4}$.

Por lo que atañe a su fisonomía, nuestro protagonista es bajito, calvo, con una gran barba blanca y bigote, reflejo distintivo de su halo de sabiduría como herencia del mundo clásico, al igual que otros pedagogos que ocasionalmente le visitan ${ }^{5}$ cuyo aspecto físico es similar. Precisamente la ausencia del cabello, su ocultamiento, el estilo de corte, el color, área corporal, etc. nos remiten a transformaciones físicas o simbólicas basadas en rituales de paso, el sacrificio,

4 Por ejemplo, Pulgarcito 1507, p. 7, publicado el 21 de marzo de 1960.

5 Véase, por ejemplo, a Perico Narigudo en Pulgarcito 1510, p. 4, publicado el 11 de abril de 1960. 
el control social... que en este caso vendrían a representar no solo los años dedicados a la profesión sino, también, el esfuerzo por alcanzar el conocimiento. De ahí la importancia del contexto sociocultural a la hora de valorar todos los aspectos que conforman a este personaje, siempre vestido con un traje oscuro al que acompańa con el tradicional birrete con borla, simbólicamente un signo de autoridad. Una imagen que no se aleja mucho de las palabras que Miguel de Unamuno redactó en Recuerdos de niñez y de mocedad (1908):

Fue mi primer maestro, mi maestro de primeras letras, un viejecillo que olía a incienso y alcanfor, cubierto con gorrilla de borla, que le colgaba a un lado de la cabeza, narigudo, con largo levitón de grandes bolsillos —el tamańo de los bolsillos de autoridad—, algodón en los oídos y armado de una larga caña, que le valió el sobrenombre de el pavero. Los pavos éramos nosotros, naturalmente; iy tan pavos!...

Repartía cańazos, en sus momentos de justicia, que era una bendición. En un rinconcito de un cuarto oscuro, donde no les diera la luz, tenía la gran colección de cañas, bien secas, curadas y mondas. Cuando se atufaba cerraba los ojos, para ser más justiciero, y cañazo por acá, cañazo por allá, a frente, a diestro y siniestro, al que le cojía le cojía o cogía, y luego la paz con todos. Y era ello una verdadera fiesta, porque entonces nos apresurábamos todos a refugiarnos del cañazo metiéndonos debajo de los bancos.

Esto era para el juicio general o colectivo; mas para el juico individual, para las grandes faltas y para los grandullones, tenía guardado un junquillo de Indias, no huero como la cańa, sino macizo y que se cimbreaba de lo lindo cuando sacudía el polvo a un delincuente (1995:398-399).

Todo un conjunto de características que lo hacen identificable en la mente del lector al que se dirige y que acude a su memoria visual para rememorar la figura a la que se alude en el texto. Imagen alejada de otros conocidos docentes de la historieta más cercanos en el tiempo como Don Minervo, el maestro de los citados Zipi y Zape Zapatilla, que si bien viste traje de chaqueta y pajarita, el birrete ya había desaparecido. Son los años sesenta, una época de transformaciones y cambios culturales que culminaría en la siguiente década. Curiosamente la vara, como símbolo de autoridad y disciplina, podría remontarse al menos a 1510 momento en que Alberto Durero plasma su arte en El maestro de escuela. En cuanto al resto de la descripción, igualmente nos recuerda al licenciado Cabra que describe Francisco Quevedo en la conocida Historia de la vida del Buscón (1626): 
Él era un clérigo cerbatana, largo sólo en el talle, una cabeza pequeña; pelo bermejo — no hay nada más que decir-; los ojos avecindados en el cogote, que parecía que miraba por cuévanos, tan hundidos y oscuros que era buen sitio el suyo para tiendas de mercaderes; la nariz, entre Roma y Francia, porque se le había comido de unas bubas de resfriado, que aun no fueron de vicio porque cuestan dinero; las barbas, descoloridas de miedo de la boca vecina, que de pura hambre parece que amenaza a comérselas; los dientes, le faltaban no sé cuántos, y pienso que por holgazanes y vagabundos se los habían desterrado; el gaznate largo como de avestruz; una nuez tan salida que parece que forzada de la necesidad se le iba a buscar; los brazos, secos; las manos como un manojo de sarmientos cada una; mirado de medio abajo parecía tenedor o compás; las piernas, largas y flacas; el andar, muy espacioso: si se descomponía algo, le sonaban los huesos como tablillas de San Lázaro; la habla, hética; la barba, grande, y nunca se la cortaba por no gastar, y él decía que era tanto el asco que le daba ver la mano del barbero por su cara, que antes se dejaría matar que tal permitiese: cortábale los cabellos un muchacho de nosotros. Traía un bonete los días de sol, ratonado con mil gateras y guarniciones de grasa; era de cosa que fue pańo, con los fondos en caspa. La sotana, era milagrosa, porque no se sabía de qué color era. Unos, viéndola tan sin pelo, la tenían por de cuero de rana; otros decían que era ilusión: desde cerca parecía negra y desde lejos entreazul. Traíala sin ciñidor; no traía cuello ni puños. Parecía, con los cabellos largos y la sotana mísera, lacayuelo de la muerte. Cada zapato podía ser tumba de un filisteo. Pues su aposento, aun arañas no había en él. Conjuraba los ratones de miedo que no le royesen algunos mendrugos que guardaba. La cama tenía en el suelo; dormía siempre de un lado por no gastar las sábanas. Al fin, él era archipobre y protomiseria (2007:17).

En el caso de Tragacanto puede observarse como conserva parte de los elementos recogidos por los autores citados, si bien la cańa ha desaparecido como principio pedagógico, lo que no evitará el castigo corporal si lo considera oportuno, es decir, básicamente de rodillas con los brazos en cruz, sin dejar de lado el cuarto de los ratones. Hecho que tampoco excluye su enfado, según las circunstancias del guion, y en ocasiones la persecución con la tradicional cachiporra en la última viñeta, típico de las publicaciones de Bruguera de la época. No obstante, no es lo frecuente y atiende básicamente al factor humorístico de la revista y a las reacciones estereotipadas y exageradas de numerosas series de la casa. 
Otra diferencia que le separa de los profesores de ficción citados — más centrados en el ámbito de la investigación que en la docencia- es que nuestro protagonista, cuyo nombre remite a la goma que se extrae del arbusto del género Astragallus, es en realidad — como se deduce de la edad de su alumnado- un maestro de escuela, con cuarenta años de servicio a sus espaldas ${ }^{6}$. Un docente querido y reconocido en su comunidad por su municipio y por la alcaldía, hasta con un monumento en su honor, en el parque del pueblo, en virtud de los méritos contraídos por su labor educativa ${ }^{7}$. Ahora bien, no se trata de una escuela urbana, al contrario, se trataría de una rural o unitaria, que al mismo tiempo es la vivienda habitual del propio docente y que, por su distribución, se encontraría dispuesta en el mismo edificio o adosada al mismo, que cuenta, además, con un gran patio para las actividades fuera del aula habitual. Igualmente, sabemos que se trataría de un pequeño colegio de carácter privado - por el contexto cronológico no podría ser concertado- pero sometido a un control externo en la figura del temido inspector ${ }^{8} \mathrm{o}$ inspectora, dado que no siempre aparece como figura masculina?

De hecho, aún dentro de la ficción, el plan de estudios vigente —al margen de la fecha de inicio de la publicación de la serie- debería de ser la Ley sobre Enseñanza Primaria de 1945. Precisamente uno de sus principios fundamentales se centraba en la formación continuada del maestro y en el ejercicio sus labores docentes, siempre bajo la atenta mirada y ayuda del inspector de enseñanza (Leal Canales, 2014:53), que debía de velar que todo fuera correcto. Su visita, que podía ser mensual como se recoge en las viñetas, alcanzaba a provocar cierta ansiedad en el profesorado ante el temor de una evaluación negativa. Casi podría decirse un antecedente de los informes estadísticos y/o evaluativos de la labor docente. Por dicho motivo Tragacanto llega a intentar falsear los resultados con las consecuencias adversas derivadas de la comicidad de la serie ${ }^{10}$.

6 El dato se cita en Pulgarcito 1522, p. 20, publicado el 4 de julio de 1960.

7 Véase, Pulgarcito 1508, p. 18, publicado el 6 de junio de 1960; 1522, p. 20, publicado el 4 de julio de 1960; 1530, p. 5, publicado el 29 de agosto de 1960 y 1574, p. 13, publicado el 3 de julio de 1961.

8 Por ejemplo, Pulgarcito 1519, p. 11, publicado el 13 de junio de 1960.

9 Véase Pulgarcito 1529, p. 20, publicado el 22 de agosto de 1960.

10 Un buen ejemplo de la repetición de planchas por parte de la editorial lo encontramos en este caso. Lo que como seńalábamos antes dificulta el seguimiento de la serie. El mismo gag se repite en Ven y Ven, 10, p. 13, con fecha del 4 de mayo de 1959 y Pulgarcito 2159, p. 30, con fecha de 25 de septiembre de 1972 . 
Nuestro maestro cuenta con la ayuda de un bedel, Petronio, que realiza diversas funciones, en un amplio abanico que abarca desde la limpieza de la clase y su mantenimiento hasta vigilar a los nińos. Las quejas por el hecho de que en ocasiones los padres no quieran pagar los estudios de sus hijos por cuestiones de diversa índole, unido a las que expresa el propio profesor Tragacanto a causa de las deudas contraídas por los recibos de luz, agua corriente o directamente en la tienda del pueblo ${ }^{11}$, son mucho más que una crítica al escaso sueldo que recibían los maestros en la época, que en ocasiones complementaban con clases particulares y de las que nuestro protagonista tampoco escapa ${ }^{12}$.

Estampa que se repite en varias de sus viñetas y que no deja de recordar al dicho "pasas más hambre que un maestro de escuela", que remite al momento en que se vuelve a congelar el sueldo de este cuerpo como producto del Plan de Estudios de Magisterio de julio de 1940, práctica continuada desde tiempo atrás. Este es un hecho que recoge muy bien Lozano Seijas (1995) cuando seńala que a comienzos de la década del sesenta el sueldo de un maestro era menor que treinta ańos antes. Un aspecto que analiza en profundidad Arias Gómez (2017), junto a otros problemas de la época. Una situación que no es nueva y que podría remontarse a finales del siglo XIX, momento en que el semanario satírico El Motín publica una plancha centrada en las penurias de un maestro de escuela, que hasta a de comerse los propios carteles que utiliza para formar a su alumnado, reflejo del sentir popular. Fig. 5 y 6 .

11 Véase, Pulgarcito 1506, p. 5, con fecha del 14 de marzo de 1960 y 1547, p. 14, publicado el 26 de diciembre de 1960.

12 Por ejemplo, Pulgarcito 1535, p. 18, publicado el 3 de octubre de 1960. 
La profesión de maestro en la viñeta española del siglo xx: el profesor Tragacanto y su clase, que es ...

Fig 5. El imaginario popular construido alrededor de la figura del docente y el poco valor que se le daba a su trabajo no es nuevo. La publicación satírica únicamente incide en la herencia de dicho imaginario.
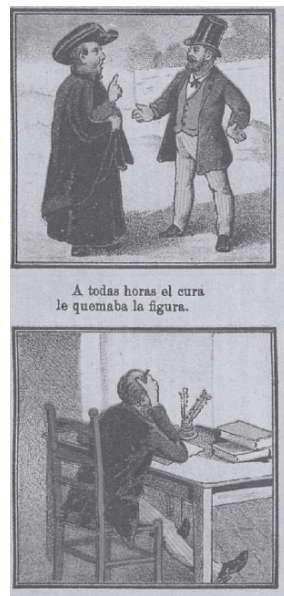

X vomo niunea cobrabs,

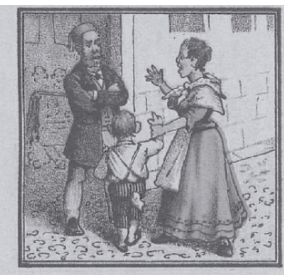

Si algin brato no aprendia,
madre le esearneefa.

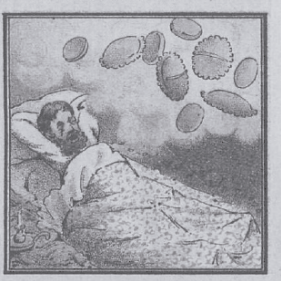

Al dormir, sus pesadillas
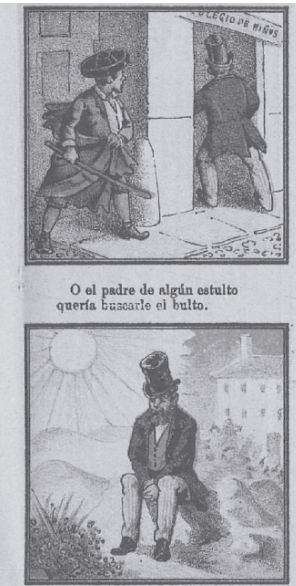

Se ibs al sol frecuentemente

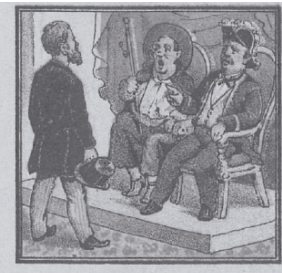

Su sueldo pedía en balde

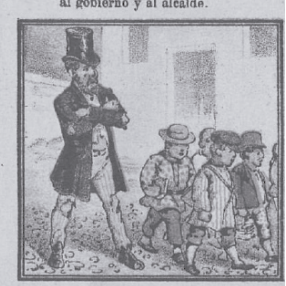

Ls libertad de ensañanse

Fuente: El motin (Madrid), 1889, 11, p. 2.

En el caso de nuestro protagonista y a pesar del tiempo transcurrido, nada parece haber cambiado como se puede observar en su espartano mobiliario. Unos pocos libros, un sillón, una mesa... vendrían a ser sus exiguas posesiones. No obstante, el deseo y el sueño por ascender en el escalafón docente se hace muy patente ${ }^{13}$, dada la subsiguiente mejoraría de sueldo. Un objetivo que, pese a sus intenciones, no llega a lograr motivado por la dinámica humorística de la serie, las contradicciones derivadas del "quiero y no puedo"14.

13 Por ejemplo, Pulgarcito 1512, p. 12, publicado el 25 de abril de 1960, 1514, p. 12, publicado el 9 de mayo de 1960 y 1534, p. 18, publicado el 26 de septiembre de 1960.

14 Por ejemplo, Pulgarcito 1519, p. 11, publicado el 13 de junio de 1960. 
Fig. 6. F: El motin (Madrid), 1889, 11, p. 2.

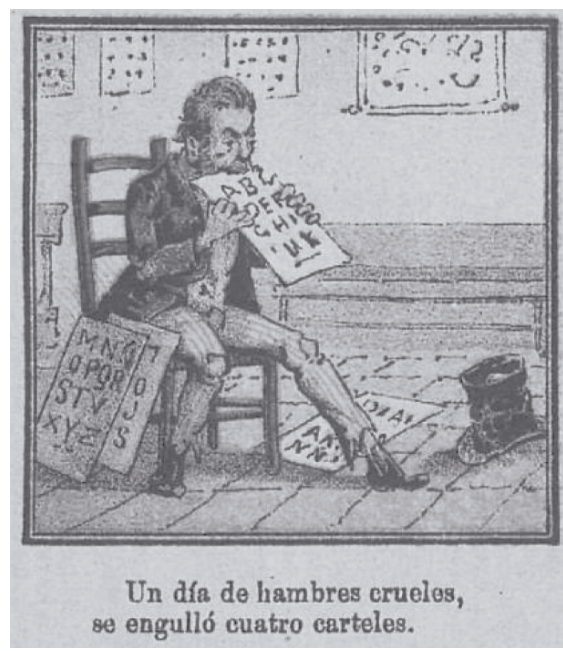

Por el contexto geográfico, la escuela debería de estar situada en la zona norte de la Península, posiblemente en un pueblo pequeño con un río en sus inmediaciones, pero también cerca de la costa. Justamente la propia escasez de recursos económicos nos ayuda a situarla en un territorio en el que se puede pescar trucha común (Salmo trutta Linnaeus) o salmón atlántico (Salmo salar L.). Así se reconoce en una de sus historietas, en el que el protagonista le revela al bedel: "Petronio hay que tomar una resolución heróica. Toma la caña y ve al rio a pescar, porque de lo contrario, hoy no podremos comer" ${ }^{15}$ indicándole que puede traer una trucha o un salmón con el que aliviar sus estómagos. De hecho, las cuencas salmoneras se encuentran en un marco que abarca desde el Miño al Bidasoa, es decir, un extenso territorio que abarca desde Galicia, Asturias y Cantabria hasta Bizcaia, Guipuzcoa y Navarra. En tanto que la trucha, además de otras zonas del centro y sur, se localizaría en las cabeceras de los ríos de las cuencas cantábricas y de Galicia.

Estos datos nos permiten delimitar mucho más la ubicación en la zona noroeste peninsular, quizás el área cántabra. Sabemos que en una de las historietas se aborda el tema de la "Prehistoria" y que la clase de desplazará en coche a las "Cuevas de Cañamón”, para profundizar en el conocimiento sobre la vida de

15 Nos referimos a al ejemplar número 1547, p. 14, publicado el 26 de diciembre de 1960. 
los cavernícolas, lo que hoy se conocería como una salida de campo ${ }^{16}$. Excursiones que a lo largo de la serie se repiten tanto al entorno rural -el escenario más inmediato - como a la costa, lo que vendría a favorecer competencias y habilidades como la empatía, el trabajo colaborativo y la creatividad como se aprecia en las vińetas. Por otra parte, no debemos olvidar que Tragacanto es un amante de la Naturaleza y así se desprende de sus enseñanzas a su alumnado, a quienes quiere inculcar el respeto y amor hacia los animales ${ }^{17}$.

Como se puede observar a simple vista, la escuela segrega por sexos. Todo su alumnado es de género masculino. Cuando aparece un personaje femenino es, en general, para indicar que o bien se trata de la madre de algún alumno, rara vez un padre, o es una maestra, caso de Dońa Petronila. Caracterizada con los estereotipos de la época — mońo, traje de falda cerrado al cuello y solteranunca la veremos impartir docencia ni tampoco a su grupo clase, aunque asumimos que también sería una escuela de las mismas características que la de nuestro protagonista. Como sabemos, el plan de estudios vigente imponía la separación de género basado en razones de tipo moral pero también de eficacia pedagógica. Tendríamos que esperar hasta el cambio de ley impulsado por Villar Palasí en 1970 para que la "coeducación" (como se conoció en sus inicios a ese ideal pedagógico que propugnaba la escolarización conjunta de ambos sexos) regresara y se superasen las tesis franquistas alrededor de las escuelas mixtas. Un hecho que tampoco escaparía al ojo crítico de la vińeta cuyo mejor ejemplo lo encontramos en la serie La señorita Ana, igualmente editada por Bruguera, de la mano de Rafael Morales, Galileo, en 1971.

Volviendo de nuevo a la clase del docente que nos ocupa, cabe señalar que la ratio del alumnado es dinámica pero constante, es decir, aumentó ligeramente con el tiempo. Si originalmente puede apreciarse que es baja, en torno a los nueve alumnos, a medida que la serie se desarrolla va a aumentar de manera poco significativa. No debemos olvidar que a fin de cuentas se trataba de una escuela de carácter rural. Esta situación permite una enseñanza en la que todos los niveles estarían en la misma aula, si bien dichas diferencias no se observan en el progreso del día a día en las viñetas. Como sabemos la Ley de Enseñanza Primaria de 1945 establecía cuatro periodos: Maternal y parvularios, que comprendería a niños hasta los 6 años; el periodo Elemental para niños de entre 7 a 10 ańos; de Perfeccionamiento, concretado entre los 10 y 12 ańos

16 Hablamos de Pulgarcito, número 1566, p. 14, publicado el 8 de mayo de 1961.

17 Por ejemplo, Pulgarcito 1509, p. 12, publicado el 4 de abril de 1960. 
y, finalmente, el de Iniciación profesional, centrado entre los 12 a 14 años (Egido Galvez, 1994). La clase, a raíz de su comportamiento, se situaría en ese periodo indefinido entre los siete y los doce años. Del análisis de sus vińetas no se deduce ninguna referencia clara, salvo por la conducta y el conocimiento del alumnado.

Entendemos que Tragacanto suele preguntar a su alumnado por diversas cuestiones, con el objetivo de verificar sus logros dentro del proceso de enseñanza y aprendizaje. Sin embargo, no se aprecia que medie ninguna distinción de edad, ciclo o etapa. La única diferencia clara se refleja en el estereotipo del éxito o el fracaso simbolizado, por un lado, en la matrícula de honor y en las hojas de laurel, por otro lado, su opuesto, la calabaza. Ambos prácticamente suelen recaer siempre en los mismos personajes, Vicente Fenelón, el clásico empollón, y Jaimito Buitrago, respectivamente a quien podría considerarse el elemento disruptivo de la clase. Otros alumnos que les acompañan son Pepito Huevofrito, Cocoliso Chupete, Mendrugo Rebollo, Pirulo Pompón y Pequenajo Pimentón ${ }^{18}$, entre otros. Entre los estereotipos cabe mencionar que tampoco falta la referencia a la clásica "chuleta" como medio para superar un examen ${ }^{19}$, que bien podía ser oral o sin previo aviso como fórmula para valorar la adquisición de los contenidos ${ }^{20}$.

Aspecto que nos lleva a las enseñanzas que imparte y a su metodología. Por lo que se refiere a las materias, como sabemos, estás venían establecidas por el Cuestionario para las escuelas, de obligado seguimiento tanto para la pública como la privada, establecido en la Ley de 1945 por parte de la por entonces Dirección General de Enseñanza Primaria. La Instrumentales engloban Lectura, Expresión gráfica (escritura, redacción y dibujo) junto con Cálculo); Formativas que comprendían Religión, FEN (formación del espíritu nacional que a su vez incluía Geografía e Historia), Matemáticas, Lengua nacional y Educación física y, finalmente, las Complementarias, caso de Ciencias Naturales, Artísticas (música, canto y dibujo) y Utilitarias, centradas en trabajos manuales, taller y labores.

En las viñetas observamos a Tragacanto referirse a temas centrados en la escritura, la ortografía, la caligrafía, la redacción y el dibujo, así como Geografía e Historia, Matemáticas, Educación Física, Ciencias Naturales y de carácter

18 Véase Pulgarcito 1498, p. 6, publicado el 18 de enero de 1960 y 1510, p. 4, publicado el 11 de abril de 1960.

19 Por ejemplo, Pulgarcito 1570, p. 15, publicado el 5 de mayo de 1961.

20 Véase Pulgarcito 1573, p. 17, publicado el 3 de julio de 1961. 
artístico, caso de música y canto, sin que se dejen de lado las prácticas de taller. No obstante, en alguna ocasión también menciona materias que no tenían cabida en el proyecto docente, como latín y trigonometría que más bien se encontrarían centrados en la etapa de Secundaria, y otras que encuentran su presencia únicamente motivada por las características de la propia serie, caso de otorrinolaringología elemental o vegetalogía ${ }^{21}$. Contenidos que se abordan siempre desde el conocimiento del docente de forma expositiva, si bien, como ya señalamos, no se excluyen las salidas de campo.

Respecto a la distribución de las aulas, sabemos que dispone de gimnasio, aula de Botánica, aula de Física, laboratorio y biblioteca, entre otros espacios, que se complementan, visualmente, con el tradicional esqueleto humano de pie — clásico en las clases de Biología—, diversos mapas de pared donde aparecen representados territorios en la proyección de Mercator o bien el globo terráqueo, en su eje de paralelos y meridianos, además del tradicional orbe esférico de salón y libros de texto o consulta. Como buen maestro, pone su creatividad al servicio del alumnado y suele ir a pasear por las inmediaciones de la escuela en busca de ejemplares y materiales para enriquecer las colecciones del centro o acudir a la costa para recolectar crustáceos para las clases de Ciencias Naturales, por ejemplo ${ }^{22}$.

En cuanto a la conformación del espacio, desde el primer instante se aprecia que el aula se encuentra dividida en dos sectores. Una primera con una tarima, donde se sitúa la mesa y el sillón del maestro, de forma que de un solo vistazo controle y vigile la actuación del alumnado en línea con lo que proponía Barnard, al tiempo que facilita la labor de impartir su docencia desde una posición más elevada, como correspondía a su categoría de inspirador del conocimiento y principio de autoridad. En el segundo sector se localizan los asientos del alumnado, esos pupitres dobles, con su escritorio adaptado a su anatomía. En las paredes los mapas y la pizarra.

Respecto al calendario académico, lo que en el momento de desarrollo de la serie se conocía como almanaque escolar, y el horario, es decir, el tiempo dedicado a recibir docencia, de acuerdo con Escolano, vienen a erigirse como las primeras pautas de comportamiento que aparecen para organizar las iniciales percepciones cognitivas de la temporalidad presente en todas las culturas. "Sus códigos no son sólo un sistema de la escuela, sino las claves de la crono-

21 Véase Pulgarcito 1564, p. 20, publicado el 24 de abril de 1961 y 1565, p. 6, publicado el 1 de mayo de 1961.

22 Por ejemplo, Pulgarcito 1587, p. 14, publicado el 2 de octubre de 1961. 
biología y la cronocultura" (1992:57). Aspecto que siguiendo a este autor puede decirse que no ha cambiado, prácticamente en nada, desde el XIX. De hecho, como bien conocemos, se continua con la jornada semanal dividida en horas.

Al respecto la Ley de Educación Primaria establecía, siguiendo a Parraga (2010), que el horario de clases habitual era de cinco horas repartidas en dos sesiones, sin incluir las complementarias. La primera de 9:30 a 12:30 y, la segunda, de 15:00 a 17:00 para las escuelas de capital y provincias. También se especificaba que únicamente habría un único horario de mañana, concretamente de 9:00 a 13:00, desde el día 1 de julio y desde el 14 al 30 de septiembre. Por último, tres serían los periodos vacacionales: Navidad, Semana Santa y verano, a lo que se ańadían los domingos y festivos oportunos. Algunos de estos momentos pueden apreciarse en la serie. En una línea similar sus viñetas también nos sirven para recordar otras prácticas sociales que se realizaban antaño como el aguinaldo navideño o el obsequio por finalizar el curso con buenas notas que realizaban los maestros. Pero también aquellos regalos que las madres solían hacer al docente al finalizar el curso ${ }^{23}$.

Fig. 7. Fragmento de la portada de Pulgarcito, 1571. Se observa a Tragacanto, con su indumentaria tradicional. En primer plano, los nińos Jaimito Buitrago y Vicente Fenelón, reconocible por sus gafas.

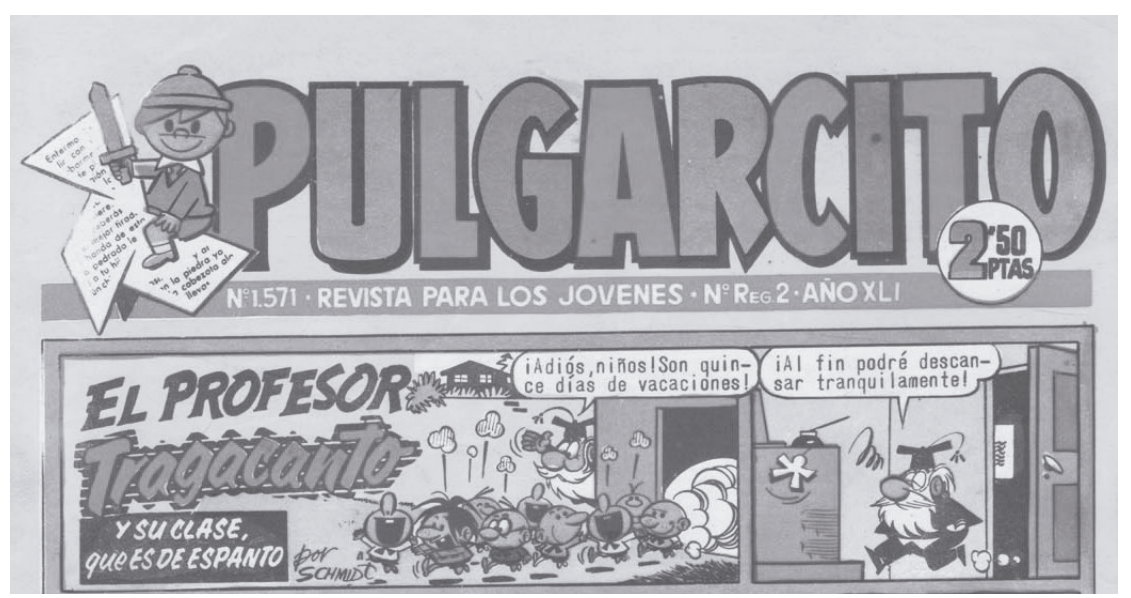

23 Por ejemplo, Pulgarcito 1582, p. 1, publicado el 28 de agosto de 1961. 
Pero el alumnado crece y otras series como Benito Boniato, estudia Bachilerato (1977) de los hermanos Fresno, Carlos y Luis, —también para Bruguerau Olegario Gandaria, profesor de Secundaria (2003) de Albert Pallares, ya para la revista El jueves, nos habrían de contar las andanzas de otros protagonistas y quién sabe si entre algunos de esos niños y niñas se encontrarían los antiguos discentes de Tragacanto o sus hijos. A partir de entonces el camino hasta llegar al reciente éxito de Maestra de pueblo (2017), con los lápices de Cristina Picazo, viene a representar la continuidad de un ejercicio sobre la viñeta que nos sirve como fuente para conocer la realidad del día a día de la profesión, alejada de los imaginarios de antaño.

\section{BIBLIOGRAFÍA}

Alonso, C., Gortázar, J. y García de Jalón, D. (2017). Trucha común-Salmo trutta. En J. J Sanz y B. Elvira (Eds.), Enciclopedia Virtual de los Vertebrados Españoles. Museo Nacional de Ciencias Naturales, Madrid. Recuperado el 25 de octubre de 2020 de:

http://www.vertebradosibericos.org/

Álvarez, J.J. et alii (2010). Atlas de los ríos salmoneros de la Peninsula Ibérica. Xunta de Galicia, Gobierno del Principado de Asturias, Gobierno de Cantabria, Diputación Foral de Bizcaia, Diputación Foral de Guipuzkoa y Gobierno de Navarra: Ekolur, S.L.

Arias Gómez, B.C. (2017). Historia de vida del maestro rural Alejo García: vocación, aptitudes y valores. Tesis doctoral. Universidad de Málaga. Recuperado el 16 de octubre de 2020 de:

https://riuma.uma.es/xmlui/handle/10630/15319

Barnard, H. (1848). School architecture; or contributions to the improvements of school-houses. New York: Barnes \& Co.

Cortada Andreu, E. (1999). De las escuelas de niñas a las políticas de igualdad. Cuadernos de Pedagogía, 286, 43-47.

Chartier, R. (1992). El mundo como representación. Historia cultural: entre práctica y representación. Barcelona: Gedisa.

Dussel, I. y Caruso, M. (1999). La invención del aula. Una genealogía de las formas de enseñar. Buenos Aires: Santillana.

Egido Galvez, I. (1994). La evolución de la Enseñanza Primaria en España: organización de la etapa y programas de estudio. Tendencias pedagógicas, 1 , 75-85.

Escolano, A. (1992). Tiempo y Educación. Notas para una genealogía del almanaque escolar. Revista de Educación, 298, 55-79. 
Fernández Sarasola, I. (2019). El pueblo contra los cómics. Historia de las campañas anticómic (de Norteamérica a Europa). Sevilla: ACT ediciones.

Garrido Palacios, M. (2005). Historia de la Educación en España (1857-1970), una visión hasta lo local. Contraluz: Revista de la Asociación Cultural Arturo Cerdá y Rico, 2, 89-146.

Gombrich, E. (1968). Meditaciones sobre un caballo de juguete. Barcelona: Seix Barral.

Gubern Garriga-Nogues, R. (2014). De los cómics a la cinematografía. Espacio, Tiempo y Forma, Serie V, Historia contemporánea, 26, 377-399.

Guiral, A. y Giralt, L. (2017). 100 años de TBO: La revista que dio nombre a los Tebeos. Madrid: Ediciones B.

Leal Canales, J.A. (2014). El maestro en la escuela rural en la narrativa española del siglo XX. Tesis doctoral. Universidad de Extremadura. Recuperado el 12 de octubre de 2020 de:

https://redined.mecd.gob.es/xmlui/bitstream/handle/11162/133556/TDUEX _2014_Leal_Canales.pdf?sequence $=1$ \&isAllowed $=\mathrm{y}$

Lozano Seijas, C. (1995). La Educación en España 1945-1992. En A. Puiggrós y C. Lozano (coords), Historia de la Educación Iberoamericana (Tomo I). Buenos Aires: Miño y Dávila Editores, 253-277.

Martin, A. (2000). Los inventores del comic español, 1873/1900. Barcelona: Planeta de Agostini.

Parraga Pavón, C. (2010). La educación durante el Franquismo. Temas para la Educación. Revista digital para profesionales de la enseñanza, 11, 1-16. Recuperado el 14 de octubre de 2020 de:

https://www.feandalucia.ccoo.es/docu/p5sd7543.pdf

Pelegrin, A. (1989). Libro de estampas. Almanaque de los niños. Madrid: Comunidad de Madrid.

Quevedo, F. (2007). El Buscón: edición crítica de las cuatro versiones. Madrid: Consejo Superior de Investigaciones Científicas.

Unamuno, M. (1995). Obras completas. Madrid: Turner. 


\title{
EFECTOS DE LA COVID-19 EN LOS MÚSICOS PROFESIONALES DE CANARIAS
}

\author{
Ismael Betancor Almeida ${ }^{1}$ \\ José Abreu Alemán ${ }^{2}$ \\ Juan Luis Jiménez González ${ }^{3}$ \\ Universidad de Las Palmas de Gran Canaria
}

\section{Resumen:}

$\mathrm{Al}$ igual que en el resto de las profesiones, la del músico profesional también se ha visto perjudicada por los efectos negativos generados por la pandemia de la COVID-19. En este trabajo conoceremos y profundizaremos en las consecuencias que el confinamiento ha tenido en los músicos de Canarias, incluyendo docentes de instrumentos en conservatorios y escuelas de música, profesores pertenecientes a orquestas sinfónicas y bandas profesionales de Canarias, freelance, etc. Para ello disponemos de una muestra cercana a 800 instrumentistas, 136 de ellos en Canarias. Entre otros resultados, un tercio de los encuestados teme quedarse sin trabajo, mientras que la mayoría considera que su calidad artística se ha visto afectada negativamente por la pandemia.

Palabras claves: Covid-19; Música; Canarias.

\begin{abstract}
:
As in the rest of the professions, the professional musician has also been affected by the negative effects produced by the COVID-19 pandemic. In this article we will learn about and delve into the consequences that confinement has had on musicians in the Canary Islands, including instrument teachers in conservatories and music schools, teachers belonging to symphony orchestras and professional bands of the Canary Islands, freelance, etc. For this we have a sample around 800 instrumentalists, 136 of them in the Canary Islands.
\end{abstract}

1 Departamento de Didácticas Específicas. Facultad de Ciencias de la Educación. ismael.betancor@ulpgc.es

2 Doctorando en Economía. Universidad de Las Palmas de Gran Canaria. jose.abreu101@alu.ulpgc.es

3 Departamento de Análisis Económico Aplicado. Universidad de Las Palmas de Gran Canaria. juanluis.jimenez@ulpgc.es 
Among other results, a third of those surveyed fear being fired, while the majority consider that their artistic quality has been negatively affected by the pandemic.

Keywords: Covid-19; Music; Canary Islands.

\section{INTRODUCCIÓN}

La pandemia de la COVID-19, y en concreto el período de confinamiento que muchos países están implementando durante 2020, ha producido cambios muy significativos en la vida de todos los trabajadores, que han visto afectada no solo su situación profesional, sino también la personal. Muchos de ellos han tenido que adaptarse y/o modificar la forma de ejercer su profesión y, sobre todo, con la irrupción de un concepto poco desarrollado en muchos sectores hasta el momento: el teletrabajo.

Esta crisis sanitaria ha traído consigo consecuencias económicas y sociales negativas de manera generalizada en todas las regiones. A pesar de los resultados mostrados por Oliver et al. (2020) donde, para finales de marzo del presente año, el 43\% de los casi 140.000 encuestados en Espańa consideraba que la crisis aún no les había afectado económicamente de manera significativa, lo cierto es que varios meses después, los efectos han sido notables. De hecho, en el mes de agosto de 2020, España encabezaba la tasa de paro en Europa, alcanzando un $16,2 \%$, y duplicando así el dato de la eurozona $(8,1 \text { por ciento })^{4}$. Es necesario resaltar también que, hasta el mes de agosto de este mismo año, 968.452 trabajadores se vieron afectados por expedientes de regulación de empleo (ERE), una cifra casi veinte veces más alta que la registrada en el mismo mes del año 2019. De dichos trabajadores, el 99,4\% se encontraban en situación de suspensión de contrato o reducción de jornada por fuerza mayor temporal $(\text { ERTE })^{5}$. Estos indicadores se reflejan en el Producto Interior Bruto (PIB), donde para el segundo trimestre de 2020, España tuvo una reducción del

4 Véase:

https://ec.europa.eu/eurostat/documents/2995521/10663603/3-01102020-APEN.pdf/f45c24be-3304-e6b7-80c8-04eae7529519. La tasa de paro de Espańa en agosto de 2019 era del $14,3 \%$, en tanto que el desempleo juvenil era del $32,8 \%$. En la eurozona ambos indicadores eran del $7,5 \%$ y el $15,5 \%$, respectivamente.

5 Véase https://www.epdata.es/datos/trabajadores-afectados-ere-graficos/450. A finales de septiembre de 2020 se comunicó que más de 700.000 trabajadores continuaban en ERTE. 
18,5\%, frente al 11,4\% de la Unión Europea y el 11,8\% de la eurozona. Y las perspectivas no son muy halagüeñas ${ }^{6}$.

Pero, ¿cómo ha afectado esta crisis económica a un sector altamente dependiente de la presencialidad, como es el de la música? Hasta donde conocemos, no existe base de datos que centralice información relativa específicamente al sector, con lo que se necesita la elaboración propia de bases de datos para tratar de inferir resultados con significatividad estadística. Y eso precisamente es lo que hemos realizado en este trabajo, para ofrecer respuesta a esa pregunta general.

En el presente capítulo nos centraremos no solo en las consecuencias profesionales, sino también artísticas y personales que el confinamiento ha causado en los músicos profesionales de distintos estilos, para la Comunidad Autónoma de Canarias. Para ello contamos con una muestra total en torno a los 800 individuos, obtenida mediante un cuestionario online, entre los que se encuentran profesores de orquesta y de banda, componentes de grupos de cámara, de grupos de jazz, Pop/Rock, profesores de escuelas y conservatorios, etc. De esta encuesta, más del 16\% correspondía a profesionales del sector situados en Canarias, sobre los que centraremos nuestro análisis.

Los resultados muestran, entre otros, que un tercio de los encuestados en Canarias temen quedarse en el paro como consecuencia de la pandemia. Además, perciben su profesión como de riesgo medio-alto en relación con la propagación de la COVID-19, ya que determinados instrumentos de viento y la disposición de los músicos de orquesta, por ejemplo, favorecen la producción de aerosoles y, por ende, el contagio. Por otra parte, el confinamiento ha afectado, en general, negativamente a la calidad artística y dedicación en términos de horas de estudio. Por último, hay que destacar que algunos instrumentistas se han recuperado parcialmente de sus problemas físicos relacionados con el instrumento que tocan, como pueden ser los que derivan en dolores de espalda o cuello. Las comparaciones entre profesionales en Canarias y España apuntan resultados de interés.

Tras esta introducción, la sección segunda muestra una revisión de la situación de los músicos profesionales durante la pandemia y las hipótesis a plantear para contrastarlas en la tercera sección, en la que mostramos los principales resultados de la explotación estadística de la base de datos conformada. En la sección cuarta se desarrollan las principales implicaciones del trabajo.

6 Véase https://www.imf.org/es/Publications/WEO/Issues/2020/09/30/world-economic-outlookoctober-2020 


\section{LOS MÚSICOS PROFESIONALES (EN CANARIAS) Y LA PANDEMIA}

Para los músicos profesionales, su carga de trabajo habitual se puede resumir en dos grandes áreas. De una parte, las horas de práctica instrumental, incluyendo tiempo de trabajo y de estudio, que dedica el músico profesional. De hecho, como cualquier otra profesión donde la actividad física forme parte de los resultados a obtener, durante el confinamiento los instrumentistas profesionales han continuado su práctica instrumental, como veremos en la sección posterior.

Y de otra, las actividades relacionadas con la actividad docente, en el caso de aquellos músicos profesionales que bien realizan su actividad profesional complementariamente con la de instrumentista, o bien de forma única.

Teniendo en cuenta que ninguna de las situaciones laborales en las que la actividad musical está presente fue considerada en España como trabajadores esenciales, ${ }^{7}$ resulta posible realizar una distinción fundamental entre ellas:

1. Trabajadores sin posibilidad de adaptación: todas aquellas agrupaciones de músicos que, debido al confinamiento y posteriores restricciones, no han podido trabajar conjuntamente para poder desempeñar su función profesional, como son orquestas, bandas y grupos musicales de diferentes estilos.

2. Trabajadores con posibilidad de adaptación: Todos los profesores de los diferentes instrumentos de escuelas y conservatorios que han empleado las nuevas tecnologías para continuar a distancia con las clases de instrumento.

De hecho, según Oliver et al. (2020), los menos afectados por la pérdida de su trabajo a principios de la pandemia han sido los trabajadores de educación y de la administración pública, en general. En la mayoría de los casos, los docentes han podido adaptar la enseñanza de forma telemática y continuar con su desempeño.

Esta situación, muy probablemente, puede haber causado problemas de estrés, sobre todo en docentes, derivados no solo de la conciliación sino de la necesidad de desarrollar, en un muy reducido espacio temporal, las habilidades tecnológicas de los profesores y adaptación a nuevos formatos de docencia e

7 En el Real Decreto-ley 10/2020 se establecieron qué actividades eran consideradas como "esenciales", permitiendo de esta forma la realización habitual de sus profesiones. Véase: https://www.boe.es/boe/dias/2020/03/29/pdfs/BOE-A-2020-4166.pdf 
incluso evaluación. De hecho, los profesores destacan la necesidad de un contacto físico con el alumno para un proceso óptimo de aprendizaje de la técnica del instrumento. Además, puede resultar en una experiencia negativa, con un aumento potencial de conflictos entre el trabajo y las necesidades familiares, tal y como expresan Arntz et al. (2020).

Añadido a lo anterior, debemos tener en cuenta que el cierre de escuelas y guarderías ha aumentado drásticamente la necesidad del cuidado de los niños en casa, lo cual ha dificultado aún más el desempeño laboral en todos los sectores. Sobre la base de la distribución existente de las responsabilidades del cuidado de los niños en la mayoría de las familias, es probable que las madres realicen más de estas tareas que los padres. Y se espera que, en particular, las madres solteras, que con frecuencia se encuentran en una situación económica desfavorecida, sean las más afectadas (Alon et al., 2020). Este resultado es habitual en tiempos de grandes recesiones, donde parece que la mayor parte de los cuidados recaen sobre las madres, tal y como estimaron Aguiar et al. (2013) durante la Gran Recesión.

Por su parte y en el caso de los trabajadores sin posibilidad de adaptación, como puedan ser los músicos de bandas, orquestas sinfónicas profesionales, directores, coros y diversos tipos de agrupaciones (populares, pop/rock, etc.), la situación ha sido significativamente distinta. La necesidad de trabajar juntos para desarrollar su trabajo ha determinado la imposibilidad del trabajo desde sus hogares, aunque la actividad física se debe mantener, con el objetivo de no empeorar resultados artísticos tras este período.

Así, otro aspecto que ha dificultado la incorporación al trabajo son las exigencias físicas que requiere tocar un instrumento, frecuentemente comparados con los atletas (Queiroz y Marques, 2000; Ińesta et al., 2008), y que pueden ser motivos para facilitar el contagio al tener la necesidad de trabajar tan cerca unos de otros.

Parece existir formación de partículas en suspensión en algunos instrumentos de viento que aumentarían las probabilidades de contagio de la enfermedad, motivo por el que, durante el confinamiento, se han reducido a prácticamente ninguna el número de agrupaciones que pueden ensayar conjuntamente. Las diferencias físicas en la fabricación de cada uno de los instrumentos determinan un mayor riesgo de infección en unos más que en otros (Kaehler y Hain, 2020). De cualquier forma, hay que extremar las precauciones tomadas a la hora de trabajar con estos instrumentos (Firle et al., 2020), como la observación de síntomas, limpieza de salas, distancia de seguridad y ventilación, entre otras.

Una muestra más de la dificultad para trabajar en este sector se encuentra en los cantantes y coros. Los riesgos asociados con la reunión en grupos grandes 
y los riesgos adicionales relacionados con la producción de pequeñas gotas respiratorias a través de la vocalización dificultan su desempeño (Becher et al., 2020).

Consecuentemente, los músicos instrumentistas han tenido que recurrir a alternativas como la visibilidad en las redes sociales y recurrir al empleo de programas de edición de vídeo. En España aproximadamente la mitad (49,36\%) ha realizado algún tipo de acción en streaming de manera gratuita, según la Asociación de músicos profesionales de España (2020).

En cuanto a la situación laboral de los instrumentistas sin posibilidad de adaptación a su puesto de trabajo, probablemente los más afectados por el confinamiento han sido aquellos que no tenían un contrato estable y de larga duración, como los que sí que poseen los componentes de bandas y orquestas profesionales, y que dependen de las actuaciones para sus ingresos personales. Siguiendo nuevamente a la Asociación de músicos profesionales de España (2020), el 36,25\% de los instrumentistas que dependen de actuaciones se han encontrado sin derechos a ningún tipo de ayudas.

Observando las dificultades protocolarias a las que actualmente se enfrenta este sector de músicos profesionales, coincidimos con Pensa (2020) en que las instituciones culturales deben redefinir sus espacios, además de utilizar, distribuir, combinar y modificar el material disponible, para lograr un impacto determinante en la idea actual de público. Este necesita ser reconsiderado, debe beneficiarse de nuestro patrimonio, utilizarlo, transformarlo y reelaborarlo para generar innovación social y económica. En definitiva: aprovechar el capital humano cultural disponible, a pesar de las restricciones de movilidad que existan.

A estas hipótesis planteadas anteriormente, que describen la situación de los músicos profesionales durante la pandemia de la COVID-19, trataremos de dar respuesta en la sección siguiente para el caso de Canarias.

\section{BASE DE DATOS Y RESULTADOS: LA COVID-19 EN CANARIAS (Y ESPAÑA)}

La información se ha obtenido a partir de una encuesta online, enviada a todos los Conservatorios Superiores y Profesionales (321), Escuelas de música (fue enviado a algunas, pues el total de ellas es un dato no disponible), Orquestas Sinfónicas (26) y Bandas Profesionales (27) de España, además de a profesorado e instrumentistas individuales.

La encuesta estuvo disponible entre los días 7 de junio y 3 de julio de 2020, y para su realización se requería alrededor de 12 minutos. En total se recibieron 818 cuestionarios válidos, aunque no todas las preguntas fueron respondidas 
en todos los cuestionarios, con lo que el total se reduce a 799 cuestionarios completos, también por no haber expuesto su región de origen. La representatividad muestral se recoge en la Tabla 1, donde hemos estimado cuántos profesionales hay en orquestas, bandas y conservatorios.

En el caso de Canarias, existen actualmente (octubre de 2020), 36 escuelas de música, tres conservatorios profesionales, dos conservatorios superiores, dos orquestas y tres bandas profesionales, además de trabajadores individuales (freelance y profesorado diverso).

Tabla 1: Representatividad muestral

\begin{tabular}{lcccccc}
\hline \multirow{2}{*}{ Comunidad Autónoma } & \multicolumn{2}{c}{ Número de profesionales en } & \multirow{2}{*}{ Conservatorios } & \multicolumn{2}{c}{ Representatividad } \\
\cline { 2 - 3 } \cline { 6 - 7 } & Orquestas (1) & Bandas (2) & & En (1) & En (2) \\
\hline Resto de Espańa [663] & 1.747 & 629 & 316 & $9,7 \%$ & $9,2 \%$ \\
Canarias [136] & 157 & 20 & 5 & $29,9 \%$ & $110,0 \% *$ \\
\hline Total Nacional [799*] & 1.904 & 649 & 321 & $10,4 \%$ & $13,7 \%$ \\
\hline
\end{tabular}

Fuente: Elaboración propia. Entre corchetes el número de cuestionarios. * Vea el párrafo siguiente. Para el Resto de Espańa se muestra la representatividad promedio.

Como se puede observar, el cuestionario fue respondido por el 10,4\% de los profesionales de las orquestas y el 13,7\% de los de las Bandas. Los resultados para Canarias son mucho mayores $(29,9$ y $110 \%)$ debido probablemente a la mayor proximidad de los autores del estudio con la región.

Destacamos que el $110 \%$ se debe a lo siguiente: hay que tener en cuenta que estamos comparando músicos que forman parte de Orquestas y Bandas Profesionales, respecto al total de trabajadores que conforman esas plantillas. Por ese motivo, los porcentajes de representatividad pueden superar el 100\%, al disponer el numerador de freelances y similares que incluso pueden trabajar simultáneamente en diferentes agrupaciones.

Algunos resultados generales de la encuesta: El 65\% de los encuestados en el resto de España son hombres (en Canarias asciende al 68\%). ${ }^{8}$ El 17\% de las encuestas se concentra en Canarias, porcentaje algo más alto que en el resto de Comunidades Autónomas.

El cuestionario, además de las cuestiones sociodemográficas, extrajo información de tres grandes áreas. En primer lugar, las cuestiones laborales y la re-

8 Esta proporción es similar a otros estudios, como el de Fishbein et al. (1988), en cuya muestra encontramos un $66,6 \%$ de hombres, o Crnivec (2004), con un 69\% de hombres. 
lación del encuestado con la COVID-19; en segundo término, las cuestiones relacionadas con la actividad artística y sus efectos sobre la salud; y en último término, los hábitos saludables. Analicemos separadamente estos tres grandes bloques:

Bloque 1: Situación laboral y relación con la COVID-19 de los músicos profesionales en Canarias (versus España)

En cuanto a las relaciones profesionales, en la muestra el 15\% trabaja en Conservatorios, el 25\% en Escuelas Municipales, el 34\% en Orquestas Profesionales y el 16\% en Bandas Profesionales. El 9,6\% de los que responden no tienen empleo en el momento de realizar la encuesta, bien sea por estar en un ERTE o directamente en situación de desempleo, porcentaje que es algo inferior para el resto de Espańa (8,9\%).

Para las personas que se encuentran empleadas, los resultados en Canarias presentan algunas diferencias respecto al resto de España. Así, para las Islas, el $58 \%$ disponen de contrato fijo, dos puntos porcentuales menos que en el resto de España; un 30\% son empleados temporales, porcentaje que es del $23 \%$ en el grupo comparativo; un 7\% son autónomos (4,5\% en el resto de España) y el porcentaje restante no respondió acerca de su situación laboral específica.

En el momento de realizar la encuesta, el $34 \%$ ya se encontraba reincorporado a su trabajo, en tanto que este porcentaje alcanzaba el 37\% en el resto de Espańa. No obstante, lo anterior, uno de cada tres profesionales $(33,3 \%)$ en Canarias temía perder su trabajo en el futuro por culpa de la pandemia, en tanto que estas negativas perspectivas se reducían al $29 \%$ en el resto del territorio nacional.

En cuanto al desarrollo de la enfermedad en este sector, según la encuesta, los resultados van en línea con los datos generales mostrados por regiones en España, donde Canarias estuvo en una menor tasa de contagios que el resto a principios de la pandemia. Así, el 7\% señala que ha tenido síntomas de la COVID-19, un 2,9\% ha convivido con personas que presentaban síntomas, un $1,5 \%$ de los individuos ha sido diagnosticado y el 0,07\% han estado ingresadas por este motivo. Para el resto de España, los dos primeros porcentajes son mayores, a saber: 12 y 4 por ciento.

Uno de los principales hándicaps en este sector, sobre todo en la práctica instrumental, está en las posibilidades de contagio por las emisiones de aire en instrumentos de viento-madera y viento-metal, tal y como explicamos con anterioridad. Es por ello por lo que la percepción que los individuos dispongan sobre el riesgo en su trabajo sea relevante. En una escala de 1 a 6 , siendo 6 el 
máximo riesgo, la media se sitúa en 3,9 puntos, lo que sustenta un riesgo medio-alto, aunque inferior al obtenido para el resto del territorio nacional (4,3 puntos).

El 15,4\% de los encuestados canarios explica que su empresa no dispone de protocolo para la atención a la situación de la COVID-19, porcentaje superior al resto del Estado (12,3\%). No obstante, para los que sí disponen, la evaluación media acerca de si consideran adecuado dicho protocolo es de 3,8 puntos, en una escala donde 5 es el máximo. Esto señalaría que, quienes se han adaptado, muestran resultados satisfactorios para los trabajadores.

\section{Bloque 2: La actividad artística de los músicos profesionales en Canarias (versus España)}

La actividad y calidad artística de los instrumentistas puede verse afectada durante un período de inactividad laboral como el sufrido en el confinamiento, al igual que ocurre en los deportistas, en los cuales los periodos sin entrenamiento inducen una reducción en la aptitud aeróbica, fuerza muscular, rendimiento de velocidad, flexibilidad y adaptaciones fisiológicas (Andreato et al., 2020). Por ello, el cuestionario planteó preguntas acerca del desempeño artístico del individuo antes y durante el confinamiento, además de los cambios en hábitos de estudio y físicos que pudiera haberle ocasionado.

En general, el 59\% de los encuestados considera que el confinamiento no ha afectado positivamente a su calidad artística (valores inferiores a 4, en escala 6), siendo cinco puntos porcentuales mayor ese porcentaje para el resto de España. En media, los instrumentistas canarios redujeron sus horas de estudio diarias más que en las restantes regiones, alcanzando un valor medio de $44 \mathrm{mi}$ nutos, 3 más que en el resto. Esta reducción supone un descenso del 18\% respecto a los valores medios antes de la pandemia en Canarias que, a su vez, ya eran inferiores al resto de España.

$\mathrm{Y}$, ¿cuáles fueron las principales dificultades encontradas por los músicos profesionales para desarrollar su actividad? Pues como se muestra en la Tabla 2, la falta de motivación y la conciliación familiar, afectó a un tercio de los encuestados. ${ }^{9}$

9 Recordemos que casi la mitad de los encuestados $(47,6 \%)$ estuvo confinado con pareja e hijos. 
Tabla 2: Dificultades derivadas del confinamiento (1: Nada; 6: Bastante)

\begin{tabular}{lccc}
\hline Dificultades & Valor medio & \% Respuestas >3 & \% Respuestas "Nada" \\
\hline No tener espacio adecuado & $2,3(2,2)$ & $27 \%(24 \%)$ & $55 \%(55 \%)$ \\
No disponer de instrumento & $1,4(1,3)$ & $6 \%(7 \%)$ & $83 \%(86 \%)$ \\
Conciliación familiar & $2,5(2,6)$ & $29 \%(34 \%)$ & $48 \%(46 \%)$ \\
Falta de motivación & $2,6(2,7)$ & $26 \%(32 \%)$ & $36 \%(35 \%)$ \\
Aburrimiento & $2,0(2,1)$ & $14 \%(18 \%)$ & $48 \%(51 \%)$ \\
Falta de tiempo & $2,1(2,6)$ & $21 \%(32 \%)$ & $56 \%(48 \%)$ \\
\hline
\end{tabular}

Fuente: Elaboración propia.

Entre paréntesis figuran los datos para el resto de las regiones españolas.

Pero desarrollar las actividades sin dificultades es uno de los hándicaps que se presentan en el confinamiento y que afectan a situaciones como el teletrabajo. En este caso, aunque los valores no apuntan ser muy elevados, la conciliación familiar es la principal dificultad para el 29\% de los encuestados, porcentaje que aumenta hasta el $42 \%$ si solo se considera a quienes tienen hijos. El no disponer de espacio adecuado $(27 \%)$ y la falta de motivación $(26 \%)$ son los dos siguientes problemas que encontraron los encuestados. En general, las dificultades son menores para el caso de los profesionales en Canarias que para el resto (Véase Tabla 2).

Finalmente, el cambio en las actividades durante el confinamiento puede afectar a la situación física de los instrumentistas, en uno u otro sentido. Es por ello por lo que preguntamos acerca de si ha tenido problemas o dolor en algunas partes del cuerpo originados por la práctica instrumental, tanto antes como durante el confinamiento. En la tabla 3 mostramos los cambios sucedidos al pasar al confinamiento. 
Efectos de la Covid-19 en los músicos profesionales de Canarias

Tabla 3: Consecuencias físicas del confinamiento

\begin{tabular}{llcl}
\hline Consecuencias sobre... & Empeora & Permanece igual & Mejora \\
\hline Cuello & $22 \%(19 \%)$ & $53 \%(57 \%)$ & $25 \%(24 \%)$ \\
Espalda & $25 \%(10 \%)$ & $48 \%(51 \%)$ & $23 \%(39 \%)$ \\
Hombros & $22 \%(10 \%)$ & $62 \%(63 \%)$ & $16 \%(17 \%)$ \\
Brazos & $14 \%(7 \%)$ & $71 \%(69 \%)$ & $15 \%(24 \%)$ \\
Muńecas & $10 \%(7 \%)$ & $75 \%(76 \%)$ & $15 \%(17 \%)$ \\
Oídos & $18 \%(6 \%)$ & $72 \%(74 \%)$ & $10 \%(20 \%)$ \\
\hline
\end{tabular}

Fuente: Elaboración propia.

Dependiendo la parte del cuerpo analizada que, obviamente, estará relacionada con el instrumento que trabaja o la actividad docente desempeñada, más de la mitad de las personas permanecen sin cambios físicos tras el confinamiento, sobre todo para el caso de las muñecas y los oídos, o incluso mejoran, como en el caso de la espalda y el cuello. Entre Canarias y el resto de las regiones hay relevantes diferencias, sobre todo en el grado de empeoramiento.

\section{Bloque 3: Hábitos saludables}

Por último, tratamos de responder a la pregunta sobre la forma en que modificó el confinamiento los hábitos saludables de los encuestados. Para el 35\% su condición física no varió por el confinamiento $(36 \%$ en el resto de las regiones), mejoró para el $25 \%$ ( $20 \%$ en otras regiones) y empeoró para el resto. No obstante, los minutos medios semanales dedicados a hacer ejercicio aumentaron en torno al $0,2 \%$ en Canarias, disminuyendo casi un $15 \%$ en otras regiones.

Existe un patrón significativo de ansiedad, depresión y conductas de salud que requieren atención en las políticas y programas de salud y seguridad laboral en las orquestas sinfónicas (Kenny et al., 2014). De hecho, el 36\% (38\% en el resto de España) afirma haber aumentado sus niveles de estrés durante el confinamiento, en tanto que sobre el $20 \%$ mantiene el mismo nivel. El resto, mejoró.

\section{RESUMEN DE RESULTADOS Y CONCLUSIONES}

La dimensión de la pandemia por la COVID-19 ha tenido impactos socioeconómicos significativos en todo el mundo. De hecho, España lidera la 
caída generalizada en 2020 de las principales potencias económicas avanzadas en términos de tasa de desempleo o PIB.

Por ello, los países se han visto obligados a implementar distintas políticas para salvaguardar la salud de sus ciudadanos, así como reducir, en la medida de lo posible, las consecuencias negativas que el desarrollo de dicha enfermedad pueda tener en la economía y el mercado laboral de su tejido productivo. Entre esas medidas se encuentran el confinamiento domiciliario, la reducción de la movilidad y actividad en las zonas con mayor transmisión, el distanciamiento social, el uso de mascarillas o la recomendación, siempre que sea posible, de emplear la figura del teletrabajo.

En relación con esto último, el Gobierno de España aprobó un Real Decreto-ley a finales de marzo de 2020 por el que determinadas actividades tenían la consideración de "esenciales", de manera que permitía la realización habitual de sus profesiones. Sin embargo, ninguna de las situaciones laborales en las que la actividad musical está presente fue considerada como un servicio esencial.

El presente capítulo tiene como objetivo analizar las consecuencias personales, laborales, artísticas y físicas que la pandemia ha tenido en el sector musical de Canarias, especialmente en el caso de aquellos músicos que, por su idiosincrasia, han tenido más dificultades para adaptarse a dicha coyuntura, es decir, bandas, orquestas sinfónicas profesionales, directores, coros y diversos tipos de agrupaciones (populares, pop/rock, etc.) que necesitan trabajar juntos para desarrollar su actividad con plenitud. Para ello se cuenta con una base de datos conformada por las respuestas en un cuestionario online de en torno a 800 profesionales de las distintas regiones españolas, de los cuales aproximadamente un $16 \%$ corresponden a individuos que radican en Canarias.

Así, un 34\% de los encuestados canarios se había reincorporado a su puesto de trabajo en el momento de la elaboración del cuestionario, mientras que un $33,3 \%$ temía quedarse en paro como consecuencia de la pandemia. Además, la temporalidad de los contratos muestra una mayor precariedad laboral de los instrumentistas canarios respecto al resto del Estado.

Además, consideran que el desarrollo de su actividad puede ser calificado con un riesgo medio-alto, en tanto que hay estudios que sustentan un incremento de las probabilidades de contagio con el uso de determinado tipo de instrumentos. Los trabajadores de empresas que han implementado protocolos contra la COVID-19 se muestran satisfechos con dichas medidas en términos generales.

Por otro lado, los instrumentistas canarios consideran que su calidad artística se ha visto afectada negativamente, aunque dicha percepción es mayor en el resto de España. Además, los encuestados en Canarias han reducido sus horas 
de estudio diarias en comparación con las otras regiones, un hecho que supone una disminución del 18\% respecto a los valores medios antes de la pandemia. La conciliación familiar, el no disponer de un espacio adecuado y la falta de motivación se erigieron como los principales motivos por los que no pudieron desarrollar su actividad artística con garantías.

En cuanto a las consecuencias físicas del confinamiento, más de la mitad de los encuestados no experimenta cambios, e incluso determinadas partes del cuerpo desarrollan una mejora, como es el caso de la espalda o el cuello.

Un $0,2 \%$ de los instrumentistas canarios considerados mejoró sus hábitos saludables practicando más ejercicio, mientras que en el resto de España este dato cayó un $15 \%$. Por su parte, un 36\% afirmó haber aumentado sus niveles de estrés durante el confinamiento.

La pandemia de la COVID-19 ha supuesto un gran reto para los países, que tienen como objetivo regresar a la "vieja normalidad" con plenas garantías. Mientras la "nueva normalidad" perdure, los gobiernos y la sociedad han de adaptarse a las nuevas circunstancias. La reapertura del comercio, la industria, las industrias educativas y públicas deben ir acompañadas de la reanudación de las actividades culturales en condiciones de seguridad. En el caso de las bandas, orquestas y distintas agrupaciones musicales, las instituciones deben ofrecer espacios, materiales y alternativas para poder seguir dando respuestas seguras a la demanda cultural que los ciudadanos canarios han tenido hasta antes del confinamiento. Por otro lado, el intérprete debe innovar y desarrollar ideas para acercar la música, siendo su mejor aliado las nuevas tecnologías.

\section{BIBLIOGRAFÍA}

Aguiar, M., Hurst, E. y Karabarbounis, L. (2013). Time use during the great recession. American Economic Review, 103(5), 1.664-1.696.

Alon, T., Doepke, M., Olmstead-Rumsey, J. y Tertilt, M. (2020). The Impact of COVID-19 on Gender Equality. National Bureau of Economic Research, No. w26947.

Arntz, M., Ben Yahmed, S. y Berlingieri, F. (2020). Working from Home and COVID-19: The Chances and Risks for Gender Gaps, ZEW Expert Brief20-09, 03.06.2020.

Andreato, L. V., Coimbra, D. R., \& Andrade, A. (2020). Desafíos para los atletas durante el confinamiento domiciliario causado por la pandemia Covid-19. Entrenamiento de fuerza y acondicionamiento: Journal NSCA Spain, (17), 28-35. 
Asociación de músicos profesionales de España (2020) Músicos profesionales y crisis Covid-19. Recuperado el 20 de agosto de 2020 de:

https://ampemusicos.com/2020/05/08/resultados-analisis-y-propuestas-dela-encuesta-realizada-por-la-asociacion-de-musicos-profesionales-de-espana-ampel

Becher L., Gena, A.W., Vöelker, C. y Richter, B (2020). Risk assessment of the spread of breathing air from wind instruments and singers during the COVID-19 pandemic.

Crnivec, R. (2004). Assessment of health risks in musicians of the slovene philharmonic orchestra, Ljubljana, Slovenia. Medical Problems of Performing Artists, 19(3), 140-145.

Firle, C., Jabusch, H-C., Grell, A., Fernholz, I., Schmidt, A. y Steinmetz. A (2020). Make music during the SARS-CoV-2 pandemic. Recommendations of the German Society for Music Physiology and Musicians Medicine (DGfMM) to protect against infection when playing music. Berlin, Germany: German Society for Music Physiology and Musicians' Association.

Fishbein, M., Middlestadt, S. E., Ottati, V., Straus, S. y Ellis, A. (1988). Medical problems among ICSOM musicians: Overview of a national survey. Med Probl Perform Art, 3(1), 1-8.

Iñesta Mena, C., Terrados, N., García, D. y Pérez, J. A. (2008). Heart rate in professional musicians. Journal of Occupational Medicine and Toxicology, 3(16).

Kaehler, C. J y Hain, R. (2020). Singing in choirs and making music with wind instruments - Is that safe during the SARS-CoV-2 pandemic? University of the Bundeswehr Munich, Germany.

Kenny, D., Driscoll, T., \& Ackermann, B. (2014). Psychological well-being in professional orchestral musicians in Australia: A descriptive population study. Psychology of Music, 42(2), 210-232.

Oliver, N., Barber, X., Roomp, K., y Roomp, K. (2020). The Covid 19 Impact Survey: Assessing the Pulse of the COVID-19 Pandemic in Spain via 24 questions. arXiv preprint arXiv:2004.01014.

Pensa, I. (2020) Survival strategies for cultural institutions: making space and open licenses. TOURISM FACING A PANDEMIC: FROM CRISIS TO RECOVERY, 167.

Queiroz, E. y Marques, J. G. (2000). Artista-atleta: Reflexôes sobre a utilização do corpo na performance dos instrumentos de cordas. PER MUSI - Revista Acadêmica de Música, Belo Horizonte, 2(2), 118-128. 


\title{
REFLEXIONES, ENSEÑANZAS Y APRENDIZAJES EN TIEMPOS DE PANDEMIA
}

\author{
Dr. José Ramón Calvo \\ Asesor Estratégico del Barcelona Supercomputing Center \\ Centro Nacional de Supercomputación. \\ Presidente del Instituto de Relaciones Internacionales de la \\ Real Academia Europea de Doctores. \\ Dra. Cecilia Kindelán \\ Profesora de la Universidad de Barcelona \\ Profesora de Ubbiquo Global Business School \\ Académica de la Real Academia Europea de Doctores
}

\section{Resumen:}

La crisis provocada por el SARS-COV-2 ha afectado a la sociedad de una manera nunca antes conocida. Los sistemas de salud se han tensionado, la economía se ha resentido como si reviviéramos la crisis de 1929 o las posguerras. Los gobiernos, en general no actuaron con rapidez, los ciudadanos, en muchos casos, no demostraron la responsabilidad que se esperaba de ellos y las consecuencias han sido nefastas. Mas de un millón de muertos en menos de diez meses, es el triste resultado de esta cadena de errores e inacciones, de imprevisiones logísticas y de falta de aprovechamiento de los recursos existentes. Las empresas han tenido que lidiar con la realidad del teletrabajo y los niños y adolescentes se han visto con dificultades en su proceso de escolarización. Esperamos que los errores cometidos sean parte de un aprendizaje que evite que, si vuelve a pasar algo así, no estemos preparados para ello.

Palabras Clave: COVID, pandemia, logística, investigación.

\begin{abstract}
:
The crisis caused by the SARS-COV-2 has affected society in a way never known before. Health systems have been stressed, the economy has suffered as if we were reliving the crisis of 1929 or the postwar period. Governments, in general, did not act quickly; citizens, in many cases, did not demonstrate the responsibility expected from them, and the consequences have been dire. More than one million deaths in less than ten months, is the sad result of this
\end{abstract}


chain of errors and inactions, of logistical unforeseen events and of lack of use of existing resources. Companies have had to deal with the reality of teleworking and children and adolescents have faced difficulties in their schooling process. We hope that the mistakes made will be part of a learning process that prevents that if something like this happens again, we will be prepared for it.

Keywords: COVID, pandemic, logistics, research.

Contribuir con la elaboración de un capítulo de un libro dedicado a Emy Repetto, representa un sentimiento dual, por un lado, significa rendir un tributo imprescindible a la memoria de una gran maestra de la docencia, que ya no está, lamentablemente nos dejó este año aciago que acabamos de dejar atrás y eso nos provoca, mucha pena y un sentimiento de vacío y tristeza ya que Emy era una amiga muy querida con la que compartimos, ilusiones, sinsabores, proyectos, traiciones, alegrías y éxitos personales y profesionales. Este homenaje, por otro lado, también nos genera un sentimiento de alegría: la recordamos de la manera que a ella más le hubiese gustado, a través de la ciencia y del conocimiento a los que tanto tiempo dedicó a lo largo de su vida. Sus alumnos, sus compańeros y sus amigos recordaremos siempre su manera de comunicar y transmitir, su pasión por la didáctica y sobre todo su capacidad crítica, su inteligencia y el ser, en cualquier circunstancia, la mejor amiga de sus amigos.

Elegir para esta ocasión un tema de actualidad científica de interés para los lectores nos ha llevado a centrarnos en la pandemia que estamos viviendo y a la que estamos dedicando desde sus inicios, tiempo, esfuerzo, estudio y trabajo. En una reciente publicación: La Gran Pausa. Gramática de una Pandemia. (Ed. Malpaso 2020) los autores de este capítulo elaboramos, junto a otra serie de destacados participantes, una serie de reflexiones que ahora, cinco meses más tarde las retomamos para utilizarlas como hilo argumental de este capítulo. Por desgracia este tema sigue siendo actual.

La situación inédita que está viviendo el planeta, con más de un tercio de la población confinada, y que continúa como una pesadilla recurrente en forma de oleadas de contagios con los que cada día nos ilustran los medios de comunicación, hace que sea ahora un buen momento para reflexionar sobre nuestras prioridades como sociedad: lo que importa y lo que no, lo trascendente y lo intrascendente, lo útil y lo inútil, porque sin duda alguna no parece que ésta vaya a ser, la única pandemia que viva esta generación.

Este tiempo de incertidumbre debería servir para que cada uno de los seres humanos seamos capaces de establecer un nuevo paradigma social, una nueva 
forma de ver la vida, de relacionarnos con otros seres humanos, de cambiar nuestra visión cortoplacista y puramente consumista por otra en la que se prioricen otros valores. Es la hora de cambiar algunas cosas y entender que, en cierto modo, la naturaleza nos ha dado un aviso. Cuán frágiles somos si una partícula que, en sensu estricto, no tiene vida propia, sino que necesita otras células vivas para poder reproducirse, ha sido capaz de ocasionar una hecatombe mundial que ha puesto en solfa el mundo tal como lo conocemos, ha paralizado los sistemas productivos, ha ocasionado que los gobiernos hayan decidido medidas nunca vistas antes para contener la expansión de este virus y hecho "de facto" una auténtica " gran parada" que es como le llaman en aviación al momento en el que un avión debe someterse, tras un numero establecido de ańos volados, al completo desmontaje para revisar pieza a pieza y zona a zona, como está cada una de sus partes y garantizar de esa manera su seguridad.

La naturaleza nos ha impuesto, de manera obligada, esta gran parada. Es, sin duda, hora de recapacitar sobre algunos puntos críticos y descubrir si, aquellas cosas que entendíamos como verdades absolutas son tales o si, por el contrario, podemos analizarlas a la luz de la nueva situación que nos ha tocado vivir.

La COVID-19 está reescribiendo el mundo y eso también ha afectado al mundo empresarial y al tejido productivo. Parece increíble que un ser nanométrico, haya sido capaz de ponernos a todos del revés. Su presencia ha limitado nuestros derechos y libertades. Ha afectado a nuestra economía, al modo en que nos relacionamos, a nuestra seguridad, a nuestros hábitos y por ejemplo, está potenciando conductas donde la tecnología tiene todo el protagonismo (compra online, educación a distancia, teletrabajo...). En el ámbito más concreto del mundo de la economía, esta pandemia ha sido como un jarro de agua fría para las empresas, una especie de bramido para obligarlas a revisar sus estrategias, sus políticas y sus procedimientos, con la finalidad de aportar más seguridad a sus empleados y proporcionar una mejor respuesta a sus clientes en un futuro inmediato. Ahora bien, sólo las empresas y las organizaciones que revisen y se replanteen su misión saldrán reforzadas; por el contrario, las que piensen sólo en términos de eficacia (a corto plazo y a cualquier precio) tienen ante sí un oscuro futuro, porque se habrán deshumanizado.

A pesar de la contundencia de los hechos y la ingente cantidad de información científica generada en estos meses, siguen apareciendo falsos gurús que, sin conocimientos científicos del tema, minimizan la trascendencia del problema ofreciendo explicaciones peregrinas sobre la causa original de la COVID-19. Estas intervenciones añaden más confusión entre los ciudadanos. Afortunadamente también han aparecido plataformas de profesionales sanitarios y de ex- 
pertos que estudian, analizan, verifican y desmienten esos bulos, lo que ocurre es que su capacidad para difundir sus hallazgos y el altavoz mediático que pueden utilizar, no llega, lamentablemente ni de lejos, al que usan los negacionistas y partidarios de las teorías de conspiración.

Más grave ha sido lo ocurrido con la mayoría de los gobernantes. Incapaces, necios o simplemente ignorantes, decidieron al inicio, que en sus países no había que dedicarle una atención especial a esta pandemia. Algunos han comprobado por si mismos cuán equivocados estaban y otros están sufriendo la debacle ante un virus que no entiende de fronteras ni de querencias nacionalistas. La realidad de los hechos es contundente, por su inanición y su falta de previsión se habrán llevado por delante vidas humanas que podrían haberse salvado y alguno hay aún, que a pesar de las abrumadoras evidencias, siguen contumazmente negando lo obvio y haciendo padecer a su población su lenidad.

Dentro de este proceso de análisis de un mundo que se nos ha vuelto del revés en un tiempo record, creemos que es pertinente también, referirnos a la situación climática y su relación con la pandemia. Hay un hecho claro que no podemos olvidar, ni siquiera en medio de esta crisis. El mundo estaba y sigue estando en una emergencia climática, que no puede quedar en absoluto ni olvidada ni diluida por el estado de emergencia planetaria en la que vivimos. La suma de estos dos factores, el clima y el virus, pueden acabar con nuestra civilización, o al menos con la manera en que la conocemos y con las libertades de las que disfrutamos en los países de nuestro entorno y puede llegar a dar pie a lo que la Dra. Rosalía Arteaga, ex presidenta de Ecuador, denomina, el inicio de una nueva era.

Cuando los expertos nos cuentan como durante el primer confinamiento (primavera del 2020) las concentraciones de determinados gases de efecto invernadero, $\left(\mathrm{NO}_{2}, \mathrm{CO}_{2}\right)$ se redujeron más de un $25 \%$ debido a la escasa circulación de vehículos en zonas del mundo altamente contaminadas, se confirma que, los que llevamos ańos defendiendo la existencia del calentamiento global por causa antropogénica no exagerábamos sino mostrábamos una situación evidente con una causa y un efecto. No éramos por tanto unos alarmistas indocumentados como se encargaban de pregonar los negacionistas. Es la dura y cruda realidad, por lo que ahora sería un buen momento para reconsiderar como utilizar los paquetes de ayuda económica que llegan desde Europa para paliar los devastadores efectos de esta crisis y convertirlos en prácticas comerciales, sociales y personales que sean más sensibles a la situación climática y evitar a toda costa que esos "brotes" de aire más limpio vuelvan otra vez a la situación pre-pandemia. Es necesario que la transición ecológica que 
hay que abordar de manera inmediata sea fluida, eficaz y rápida ya que quien lo agradecerá será el planeta y las nuevas generaciones.

Es oportuno también, recordar las palabras del Papa Francisco, cuando dijo "Dios perdona siempre, los hombres, a veces, pero la Naturaleza no perdona nunca". Si volvemos a nuestras prácticas y no cambiamos la forma de afrontar este desafío es probable que esta generación lo pague con más vidas humanas y con nuevas pérdidas económicas.

Otro aprendizaje de esta crisis es el relativo a la educación. La Dra.Teresa Freixes, catedrática Jean Monnet de Derecho constitucional, a través del concepto que denomina "sostenibilidad del espíritu crítico" defiende que todas las personas, a través de la educación, sean conscientes de sus derechos y obligaciones, en tiempos de bonanza y en tiempos de calamidad. De este modo, los ciudadanos podrán discernir cuando se puede y se debe renunciar y aceptar la restricción de determinados derechos, porque en esa renuncia va implícita la consecución de un bien superior que trasciende del "yo" al "nosotros". Por otro lado, esa formación en el espíritu crítico debe servir igualmente para ayudar a las jóvenes generaciones a tener criterio propio y evitar seguir de manera ciega las informaciones falsas que aparecen en las redes sociales e impedir votar a aquellos representantes de la voluntad popular que con su ignorancia y atrevimiento ponen en riesgo a sus ciudadanos.

Es muy importante que los jóvenes sean capaces de tener una opinión documentada en fuentes fidedignas para que puedan saber qué camino tomar en cada momento. Si no conseguimos transmitir los valores de la cultura, del esfuerzo y de la necesidad de salir del egocentrismo en el que muchos viven inmersos tendremos unas generaciones futuras que verán aún más incrementados los problemas. El mundo en el que vivimos es finito y es muy frágil.

La otra gran lección que debemos extraer tiene que ver con la inversión en salud y en investigación. Parece obvio que los recortes en salud y en investigación que se han hecho en los últimos años, en aras de la austeridad y la contención de gasto público, no es la mejor de las opciones y así ha quedado demostrado en el devenir de esta crisis. Los investigadores, tanto de ciencias básicas como aplicadas necesitan una regularidad financiera para poder conseguir resultados a medio o largo plazo. Cuanto más dinero se recorta, menos líneas de investigación pueden abrirse. La prueba de esto es que otros países con una inversión significativamente más alta dentro de su PIB han sido capaces en tiempo muy corto, de adaptarse y estimular la búsqueda de soluciones diagnósticas y terapéuticas dentro de sus propios grupos de investigación ya que disponen de los recursos materiales y humanos necesarios para ello. Eso no 
significa que no deban existir controles férreos sobre el destino de los fondos dedicados a la investigación. No se trata de dar "el mismo café para todos". A aquellos grupos que son capaces de demostrar, con los medios usualmente aceptados por la comunidad científica, básicamente producción de resultados validados por pares, sean en ciencia básica o aplicada hay que darles los recursos necesarios para que sigan su crecimiento investigador y no se vean compelidos a mendigar recursos o a prescindir de personal de investigación en formación, que además suelen recibir emolumentos muy precarios, y que lastran sus capacidades para producir trabajo de calidad. Es obvio que en países como España, que sufrieron drásticos recortes en este terreno a partir de la crisis del 2008 y en donde la inversión en $\mathrm{I}+\mathrm{D}+\mathrm{i}$ no fue nunca una prioridad, ser competitivos a nivel mundial en el desarrollo de vacunas ha dependido casi en exclusiva de la capacidad y habilidad de los científicos para obtener grandes resultados con medios precarios. Y a modo de muestra, un botón. Desde que apareció el virus del Coronavirus de Medio Oriente en el ańo 2012, el Centro Nacional de Biotecnología, concretamente el equipo de trabajo dirigido por Luis Enjuanes e Isabel Sola, lleva trabajando en vacunas contra el coronavirus. Estos científicos han conseguido desarrollar en fase experimental una excelente vacuna de administración nasal. El problema es que, al disponer de menos fondos y menos personal que otros países, su investigación avanza a una velocidad más lenta, lo que les hace imposible competir con las grandes farmacéuticas y con países que si han apostado una parte importante de su PIB para financiar la investigación. Evidentemente esas grandes empresas y sus países juegan en otra liga superior, pero el talento que aquí tenemos, si fuera convenientemente ayudado, podría posicionarnos en el primer nivel, pero eso parece que, por el momento, no es una prioridad para ningún gobernante.

Una reflexión que creo que ahora es pertinente discutir, al hilo de lo anteriormente expuesto sobre la precariedad del tejido investigador, es el hecho que Espańa por ejemplo sólo ha recibido hasta ahora, 1 Premio Nobel por cada 21 millones de habitantes (y eso considerando a Severo Ochoa como Premio Nobel Español, aunque su carrera, sus descubrimientos y su ciudadanía fuera de los EEUU). Si lo comparamos con Suiza que tiene 1 Premio Nobel por cada 440.000 habitantes; Austria, 1 por cada 470.000; Hungría 1 por cada 900.000; Israel, 1 por millón de habitantes; Bélgica, 1 por cada dos millones; Francia, 1 por cada 3,5 millones; Italia 1 por cada 4,6 millones o Polonia con 1 por cada 6 millones, vemos cuán alejados estamos de la media de países de características similares al nuestro. Por todo ello, parece pertinente identificar las causas de tan escaso número de galardonados porque, en el fondo, esos 
datos son fiel reflejo de una ciencia que está tradicionalmente infravalorada cuando no francamente maltratada por los poderes públicos, y ahora, en esta situación de crisis, estamos sufriendo esas consecuencias, que llevan al extremo la escasamente afortunada aseveración de Miguel de Unamuno en su ensayo titulado "El pórtico del templo" cuando dijo "Que inventen ellos, pues, ellos y nosotros nos aprovecharemos de sus invenciones, pues confio y espero en que estarás convencido, como yo lo estoy, de que la luz eléctrica alumbra aqui tan bien como alli donde se inventó". Esa frase, tan impropia de un pensador culto y refinado, como sin duda lo fue Unamuno, ha pesado en el imaginario popular mucho más que algunas de las frases del único español que ganó este premio en la disciplina de Fisiología o Medicina, habiendo hecho todo su trabajo en España, D. Santiago Ramón y Cajal, como aquella que decía "Razonar y convencer, iqué difícil, largo y trabajoso! ¿Sugestionar? 'Qué fácil, rápido y barato!" o en la que afirmaba "Se conocen infinitas clases de necios; la más deplorable es la de los parlanchines empeñados en demostrar que tienen talento" o "Al carro de la cultura española le falta la rueda de la ciencia", o "Las ideas no duran mucho. Hay que hacer algo con ellas".

Si analizamos cada una de esas frases, que en las circunstancias actuales adquieren además un especial significado y son de plena aplicación a este momento crítico que nos ha tocado vivir, destilan cordura, inteligencia, sentido común y una claridad de pensamiento meridiana. Lamentablemente vemos que ha pesado mucho más la percepción "acomodaticia" del filósofo que las afortunadas, clarividentes y atinadas del científico, escritor, y librepensador más ilustre que ha dado hasta ahora la ciencia española al mundo.

Esta falta de la rueda de la ciencia en el "carro-país" al que se refería Cajal, sigue pesando enormemente en nuestra cultura popular y en las gentes que con su voto eligen a aquellos que han de gobernarnos y por tanto decidir donde se destinan las inversiones, donde se aplican los recursos o donde se recortan los fondos. Si esos próceres del estado no tienen grabado a fuego en su mente que un país que no investiga y en donde no se fomenta de manera decidida y casi obsesiva la ciencia y la investigación, es un país que languidece y está a merced de otros qué si lo hacen, seguiremos muchas generaciones más sufriendo estas carencias y viendo como otros estados con menos potencial nos superan porque creen mucho más en la necesidad de esta apuesta.

Por otro lado, esta crisis tan inesperada para la mayoría de gobernantes, fue prevista por analistas y científicos como los que redactaron el informe del Grupo de monitorización de situaciones globales (GPMB) de la Organización Mundial de la Salud, en Octubre de 2019 en el que se decía que " Los gobiernos 
y las instituciones internacionales deben adoptar medidas audaces para preparar al mundo para las emergencias sanitarias, reconociendo que invertir en la preparación antes de que se produzca una crisis, salva vidas y ahorra dinero... ya es hora de que se tomen medidas urgentes y sostenidas. Esto debe incluir el aumento de la financiación a nivel comunitario, nacional e internacional para prevenir la propagación de los brotes. También requiere que los líderes tomen medidas proactivas para fortalecer los mecanismos de coordinación de la preparación en todos los gobiernos y la sociedad para responder rápidamente a una emergencia...".

Esa incapacidad para prever lo que iba a pasar que ha demostrado ser generalizado, nos lleva a pensar que el mundo debería, a partir de ahora, dotarse de un sistema de inteligencia, que prime no sólo los aspectos militares o de contraterrorismo, sino que sea capaz, utilizando las poderosísimas herramientas que ponen a nuestra disposición los superordenadores, de crear modelos, analizar en tiempo real y simular situaciones como la que estamos viviendo para poder anticipar necesidades futuras de cosas tan elementales como equipos de protección adecuados para todos aquellos que están en la primera línea de fuego, sanitarios, personal de protección civil, cuerpos y fuerzas de seguridad y emergencia del estado.

La escasa capacidad de reacción rápida que demostró la UE en los inicios de esta crisis para dar una respuesta común, inmediata y eficaz, y las inoportunas peleas entre la Europa del norte y la del sur, con acusados tintes de nacionalismo e insolidaridad, fueron un reflejo del fracaso de la gobernanza mundial a la que se tendió con la creación de la ONU en Septiembre de 1945 y posteriormente la creación de la Unión Europea con el tratado de Maastricht en 1993. Afortunadamente ese rumbo erróneo inicial se corrigió y hoy podemos decir que gracias a la UE, estados como el nuestro ven un horizonte menos oscuro que el que tendríamos si no estuviéramos en ella.

Otro ejemplo de lentitud y burocracia lo tenemos en el papel que ha jugado la OMS en esta pandemia. Esta organización nació en 1948, justamente para liderar iniciativas que ayudaran a proteger el bien más preciado de los individuos, su salud. Hasta ahora sus acciones han sido siempre de recomendación, porque no pueden hacer otra cosa, según su estatuto fundacional y esa ha sido una de sus debilidades. Tal vez una de las lecciones que podríamos extraer de esta crisis sanitaria, económica y social, es qué hace falta para lidiar con situaciones como esta que además se repetirán dada la interacción e interconexión mundial, un mando único en el ámbito de la salud global y eso tal vez nos llevaría a valorar la necesidad de convertir a la OMS en un auténtico "consejo de seguridad", dotándola de capacidades ejecutivas para poder "forzar", de cierta 
manera, a los estados miembros a actuar de manera consonante y coordinada y no con la disparidad de criterios con la que ahora cada país está abordando una crisis mundial como esta.

¿Verdad que a ningún país se le ocurriría ir a una guerra sin pertrecharse antes de las armas y municiones que necesita? ¿Verdad que se planifica en los altos estados mayores hasta el último detalle de logística que es necesaria para los diversos escenarios que pueden darse en una contienda bélica? ¿Por qué entonces no aprendemos de esa capacidad y la volcamos en que, nunca más, una situación como la que estamos viviendo, pueda repetirse? ¿Por qué nos encontramos con situaciones absurdas como que en países de Europa y en algunas regiones de España, las vacunas llegaron en el momento anunciado, pero no fueron distribuidas o aplicadas con la rapidez requerida?, ¿porque no se hizo la previsión logística necesaria de congeladores especiales, de personal entrenado, o en las simples estrategias de actuación, planificación detallada y previsión, que cualquier cadete de una escuela militar estudia en sus primeros años? ¿Por qué no se ha involucrado a los veterinarios, que son personal sanitario cualificado, aunque sus pacientes, sólo a veces parezcan distintos que nosotros, y que están acostumbrados a hacer campañas masivas de vacunación por las pandemias que han vivido, gripe aviar, peste porcina, etc. y en la misma línea, las empresas que se dedican a la medicina veterinaria han mostrado desde hace años, una gran capacidad logística para producir millones de dosis de medicamentos...

La UE ha decidido establecer al máximo nivel, un comité de expertos epidemiólogos y virólogos que representan a diversos organismos de la Unión y que asesoran a la presidencia, pero esos expertos trabajarán desde sus despachos, analizando los datos que les llegan y honestamente creemos que eso no será suficiente en el futuro.

Creemos que la UE debe dar un paso más y liderar otro tipo de iniciativas. A modo de otro ejemplo de propuestas para la discusión y el aprendizaje, surgen una pregunta a ese respecto ¿por qué no se fomentó y sacó más partido a un cuerpo de detectives epidemiológicos, creado hace varios años, llamado Servicio de Inteligencia Epidemiológica (EIS), que son profesionales sanitarios formados y capacitados para detectar, detener y prevenir brotes de enfermedades infecciosas y que han sido claramente infrautilizados en estas situaciones? Este cuerpo sanitario de élite debió ser la avanzadilla especializada para detectar con anticipación mediante trabajo de campo, las amenazas que llegaban y adelantarse a ellas e incluso plantear respuestas logísticas y de acción a las instituciones y gobiernos a los que sirven. 
Si sumamos los esfuerzos de profesionales formados y preparados específicamente para luchar contra estas situaciones, con las nuevas y poderosas herramientas que nos suministra el análisis del "big data", a través del uso de los superordenadores, es posible que podamos iniciar una nueva era de prevención y control de pandemias como la que ahora nos azota.

Creemos que es hora de exigir a los gobernantes que, con el enorme potencial que tienen los países de nuestro entorno y nos referimos específicamente a la UE, saquen partido a este tipo de equipos especializados, que analicen de manera exhaustiva potenciales amenazas y sobre todo, que prevean con el tiempo suficiente los temas de logística fundamentales para afrontar este tipo de catástrofes. Los virus nuevos no se acaban con el coronavirus. La naturaleza tiene más "artillería" esperando a que se produzcan las condiciones necesarias para que afloren estos nuevos y dañinos elementos.

Dice el politólogo y analista Bertrand Badie en su última obra, L'Hégémonie contestée, que la crisis actual nos tiene que abrir los ojos sobre la importancia de la dimensión social de la mundialización, abandonando el dogma neoliberal que se limita a concebir al ser humano como un simple actor económico para abrazar un multilateralismo inclusivo. Eso significa, en su opinión, que hemos entrado en un mundo que ya no es el de la hostilidad ni de la competencia, sino necesariamente el de la solidaridad, porque ahora, si se quiere sobrevivir y ganar, hay que asegurarse de que el otro sobrevive y gane.

Bertrand Badie también cree que hemos vivido durante siglos con la idea de que lo que nos amenaza es siempre de naturaleza militar y prueba de ello es que en el mundo se gastan alrededor de dos billones de dólares anuales en armamento. En un informe de 1994, el Programa de Naciones Unidas para el Desarrollo(PNUD), determinó que la principal amenaza para el mundo eran las crisis alimentarias y del agua, la sanitaria y la medioambiental y ningún líder parece haberse tomado en serio esta advertencia. Si al menos esta situación actual que nos ha tocado sufrir, sirviera para que los dirigentes que hasta el momento no habían estado a la altura de su responsabilidad, y que no habían querido ver lo que tenían delante de los ojos, se lo tomen en serio, entonces toda esta tragedia y sus terribles y dolorosas consecuencias, habrá servido para algo.

Por otro lado, la falta de previsión y la escasa capacidad de gestión que han demostrado los gobernantes de la mayoría de los países, con notables y destacadas excepciones, como Nueva Zelanda o Alemania, ambos por cierto gobernados por mujeres, por la ausencia de un liderazgo claro para resolver problemas cómo las que nos ocupan, proteger la salud y la vida de los ciuda- 
danos, preservar la paz mundial, cuidar de los niños, de los ancianos, de los migrantes de todos aquellos más desfavorecidos, velar porque todos y cada uno de los habitantes del mundo tuvieran derecho a una existencia digna y a un final de vida acorde a esa dignidad, nos ha conducido a esta situación de catástrofe planetaria en la que estamos inmersos.

Se han sacudido los cimientos de un supuesto "estado del bienestar" para los países desarrollados y se han acentuado los graves problemas humanitarios y existenciales de los que aún no han podido alcanzar, este nivel de desarrollo. Se ha constatado cuán lejos estamos, como sociedad global, de cuidar adecuadamente a aquellos que con su trabajo, esfuerzo y sacrificio nos permitieron llegar hasta donde hemos llegado, abandonándolos a su suerte y enterrando, por imposibilidad de gestionarlo, a muchos de los fallecidos en fosas comunes, tal como ha pasado en el paradigma de primer mundo, los EE.UU.

Hemos sido testigos como la desindustrialización de muchos de nuestros países ha ocasionado que todos los sistemas de protección personal estén en manos de unos pocos y como hasta en una situación de drama como ésta, las reglas implacables del mercado se imponen, subiendo los precios de productos necesarios para salvar las vidas de aquellos que están dando la suya por proteger las de sus semejantes. Ellos son los que deberían ser objeto de todo el mimo y las atenciones del sistema y de las administraciones, pero no ahora, cuando truena y diluvia, en medio de esta tormenta, sino en épocas de calma y bonanza, porque ellos siempre están y han estado ahí, de manera callada, abnegada y aguantando las restricciones, los recortes absurdos y brutales que han sufrido en aras de una austeridad que debió evitar, cuando los responsables de promoverla hicieron sus cálculos económicos, que afectara a lo más básico que tiene el ser humano, que es su salud y su educación. Sin ellas, todo lo demás importa poco.

Hemos comprometido la posibilidad de que productos agrícolas y ganaderos no pudiesen llegar a los mercados por falta de mano de obra para recolectarlos, al tiempo que hemos comprobado como el desprecio con el que tratábamos a los productores de productos alimentarios básicos, hurtándoles un beneficio digno, se convertía en arma arrojadiza. Ahora sin ellos y sin sus productos tendríamos dificultades para alimentarnos. Tal vez una lección que habrá que aprender sea cómo revitalizar y potenciar la agricultura con ayuda de las nuevas tecnologías y estimular a que más jóvenes desempleados la consideren como una buena opción laboral.

A menos que queramos volver a la edad de piedra, en cuanto a la incomunicación global y a la gestión tribal, nos tendremos que adaptar a que situa- 
ciones como las que ha provocado esta crisis sanitaria, pueden seguir ocurriendo.

El mundo se ha vuelto global, mal que les pese a los localistas de pandereta, que siguen viendo en su ombligo lo único redondo que hay en su particular visión del cosmos, ya que todo lo que sucede en un rincón del globo, tienen su reflejo, pocas horas después en el otro lado, aunque tal como predice la teoría de caos y más concretamente el "efecto mariposa", lo que sucede en un sitio del mundo de una manera no tiene porque ser igual en el otro, es seguro que le afecta. El virus por lo que conocemos de él hasta el momento, aunque también sabemos que estas no son verdades absolutas, prefiere a hombres qué a mujeres, a ancianos antes que, a jóvenes, pero no hace la menor distinción entre nacionales de un lugar o de otro y esa lección de geografía universal que choca frontalmente con los intentos de establecer determinadas fronteras o barreras, es algo que también deberemos empezar a discutir en esta nueva era en la que nos adentramos. Esta pandemia ha dejado en evidencia que no podemos adoptar soluciones locales a problemas globales. Todo lo que se hace en un lugar, va a afectar de una u otra forma a los otros, y da igual lo cercanos o lejanos que estén.

Puestos a considerar prioridades a cambiar, desde luego, no parece de recibo que, en el siglo de las tecnologías, de las comunicaciones, de los más grandes avances médicos que haya registrado la humanidad, dejemos que nuestros mayores, gracias a los cuales hemos alcanzado nuestro nivel de bienestar, puedan morir de la manera que lo están haciendo, abandonados, sin ser una prioridad para el sistema y demostrando cuán alejados estamos como sociedad de una de las principales características que nos diferencia de otros seres vivos, la capacidad de empatizar con el prójimo, de pensar en "nosotros" antes que en "yo", de priorizar la vida antes que la economía... de entender, compartir y preocuparnos del sufrimiento de otros...

Esta crisis ha mostrado una faceta maravillosa de los seres humanos, aquella en la que individuos anónimos han puesto al servicio de sus semejantes lo que tenían y lo que podían, y da igual que hayan sido modestos empresarios o grandes fortunas. Cada una de esas buenas personas han dado lo que estaba a su alcance y lo han hecho con la generosidad que es característica o debiera ser, del ser humano, sin ser forzados, ni tener ninguna obligación legal de hacerlo. Lo han hecho porque han considerado que ayudar en un momento como éste era algo que ni había que cuestionarse. Había que remar en una única dirección, la de salvar vidas y salir de esta situación con el menor daño posible, y eso es una cadena que involucra desde el hostelero que suministra víveres gratuitos en las autopistas a los camioneros que deben transportar productos de 
primera necesidad en agotadoras jornadas en soledad, a empresarios que cambiaron sus sistemas de producción para fabricar a toda velocidad el material de protección necesario para los que están en primera línea y ni siquiera lo valoran en términos de economía o de ganancia o los dueños de hoteles que deciden utilizaros para desatacar las saturadas salas de internamiento e los hospitales u otros que han puesto sus instalaciones a disposición de personas sin techo. $\mathrm{Ni}$ esperan nada a cambio, ni quieren salir en las noticias. Lo hacen y punto.

Pero también esta crisis ha mostrado el rostro y el aspecto más ruin y despreciable de esos seres a los que cuesta llamar humanos, porque habría que asimilarlos a los anteriores y la verdad es que no lo merecen, que han aprovechado esta situación inédita y crítica para intentar aprovecharse, unos, subiendo los precios de productos básicos de manera desaforada siguiendo una lógica ultra liberal: a mayor escasez, mayor precio, más ganancia; otros tratando de estafar a gente sin recursos con toda clase de timos tanto presenciales, como por teléfono o internet, y otros demostrando porque no deben ocupar el mismo escalafón de seres humanos que los que citamos en el párrafo anterior que son los que se permitían humillar y mandar notas anónimas a personas que viven en sus mismos bloques de casas pidiéndoles que se fueran porque trabajaban en un supermercado o eran médicos o enfermeras o auxiliares de clínica y no quieren que su "estatus" de persona sana se ponga en supuesto riesgo por la vecindad de estos profesionales.

Esos individuos, además de estar movidos por un miedo irracional y primitivo y tener un comportamiento éticamente reprobable y penalmente punible por delito de odio, son incultos irredentos, porque les bastaría con oír noticias por cualquier medio, leer un periódico o consultar a un profesional para saber que no existe ninguna posibilidad de contagiarse por tener la gran suerte de tener de vecinos a buenas gentes como esas que están sacrificando su propia seguridad personal para que el mundo siga funcionando y a pesar de todo individuos como ellos puedan seguir vivos. Y qué decir de los cientos de miles de descerebrados en todo el mundo, algunos lamentablemente con altas responsabilidades de gobierno, que se saltan las medidas de confinamiento, alardean de ello y promueven que otros hagan lo propio... Es la otra cara de ese mundo en el que vivimos y que tanto tendría que cambiar.

Otro problema que ha aflorado de manera importante en la gestión de esta crisis es lo dañina que puede llegar a ser la burocracia administrativa cuya rueda sigue inexorable dando vueltas y se come las iniciativas de algunos que vieron llegar la emergencia y trataron de avisar y poner freno a lo que se nos venía encima, o que una vez dentro de ella buscaron soluciones imaginativas y tra- 
taron de resolver problemas acuciantes y ¿que es lo que se encontraron? trabas administrativas absurdas en un tiempo de crisis que exige como primera premisa agilidad y flexibilidad.

¿Qué sentido tiene que se pidiera en los inicios de la pandemia a estudiantes de medicina o enfermería, o a médicos y enfermeros jubilados, por cierto población vulnerable, que acudieran a prestar sus servicios ante el desborde de la emergencia sanitaria y que en cambio tuviéramos a jóvenes sanitarios formados en terceros países, malviviendo en España como podían porque la burocracia impedía el reconocimiento rápido de sus títulos y se tenían que limitar a ver encerrados desde sus casas como el sistema colapsaba y ellos que podrían ayudar por sus conocimientos, no les era permitido, por la lenidad de un sistema burocrático que adolece de trámites eternos y que, ni siquiera en momentos en los que todo está en peligro, es capaz de agilizarlo con soluciones innovadoras o creativas para permitir paliar estas deficiencias aunque sea de manera transitoria.

O la incapacidad manifiesta de agilizar hasta límites que en condiciones normales serían impensables y seguramente innecesarios, pero que en los primeros momentos se convirtieron en cruciales, los trámites aduaneros para que material de emergencia llegara de manera inmediata a quien estaba necesitándolo para salvar más vidas que si no, se iban a quedar en el camino...

Y no podemos dejar de mencionar en este listado de potenciales aprendizajes a considerar para después de una crisis, la investigación a la que nos referimos con detalle anteriormente. Ahora todo el mundo está esperando, después de más de un millón de muertos en el mundo y más de 100 millones de infectados, que el maná salvador en forma de vacuna o un nuevo tratamiento, ponga fin a esta pesadilla. Pero no recordamos haber visto a las masas enardecidas que se manifiestan coreando consignas por temas menos importantes que la vida humana haberlo hecho igualmente para pedir a sus insensibles gobernantes que estimularan y mimaran la investigación, tanto la básica como la aplicada, porque ésta no existe sin aquella, que lleve a tener un tejido de investigación consolidado y unos sistemas de producción a punto para el caso que fuera necesario. Ha tenido que ser una cadena de medios de comunicación la que ha puesto en marcha en España una campaña para intentar conseguir que se destine un exiguo $2 \%$ de nuestro PIB a la investigación. Los países de tamaño similar al nuestro no bajan del 3\% y algunos superan el 4\%.

Iniciativas como la Coalición para las Innovaciones en Preparación para las Epidemias (CEPI presentada en el Foro Mundial de Davos de 2017 por la Fundación Bill \& Melinda Gates, junto con la Fundación Welcome y que contó con la ayuda y el apoyo de India, Japón, Noruega y Alemania, y más 
tardíamente de la UE, entre otras que se van sumando poco a poco, llevan desde el ańo 2017, investigando vacunas de virus emergentes entre los que se encuentran los otros coronavirus que han causado pandemias, el SARS y el MERS. Los datos que manejan no dejan lugar a dudas. Investigar y poner a punto una vacuna puede costar unos 4.000 millones de dólares, pero sólo los costes asociados a una pandemia como el SARS a principios del año 2000, costó 54.000 millones de dólares. Ya llevan mucho trabajo adelantado y es posible que puedan dar buenas noticias antes que otros actores involucrados. Es obvio que, sin la capacidad estratégica de Bill y Melinda Gates, que son los mayores filántropos del mundo, y de su habilidad para aunar voluntades y conseguir resultados, esta iniciativa sería como otras tantas que se han iniciado en el mundo y se han quedado en papel mojado.

De hecho, Bill Gates en una conferencia TED del año 2016 que ahora circula profusamente avisaba de lo que podía pasar cuando llegara un virus como éste a un mundo cómo el que hemos creado, y lo que decía que iba a pasar es exactamente lo que está pasando y él ya avisaba que era necesario prepararse, adoptar medidas de protección y ayudar a investigar vacunas y eso fue lo que hizo, poner en marcha con otro pequeño grupo esta iniciativa. Así es como se hacen las cosas que funcionan, directas, ejecutivas y sin pesada burocracia. El problema es que el mundo no está gobernado por gente que utiliza el sentido común y la inteligencia al máximo de sus capacidades, sino anteponen sus intereses personales y ponen de manifiesto sus limitadas capacidades para contentar de una manera cortoplacista a una parroquia que muchas veces, por la carencia de educación y de sentido crítico, que esos mismos gobernantes han cercenado de manera interesada a lo largo de generaciones, les alaba, vitorea y vota, sin pararse a pensar que con ese voto pueden estar condicionando el futuro de su entorno, su país o el mundo en el que todos vivimos.

Hay ejemplos a lo largo de la historia en que gobernantes que, inicialmente no despertaban grandes entusiasmos ni expectativas fueron capaces de responder a los retos que les plantearon porque se rodearon de gentes que sabían mucho más que ellos, que eran capaces de escucharles y no endiosarse y sobre todo fueron capaces de liderar a sus conciudadanos con esperanza y con ánimo sin necesidad de torearlos con medias verdades, discursos larguísimos y vacíos o explicaciones peregrinas en función de sus limitados o nulos conocimientos de las materias sobre las que se permiten opinar.

Es cierto además que esta crisis y otras de calado variado que se han dado anteriormente, han generado una nueva categoría profesional, la del "experto", que podría ser definido irónicamente algunas veces como "aquel señor que vive 
a más de $500 \mathrm{~km}$ de donde está usted y viene en avión”. Dejando aparte esa ironía que viene a describir a ciertas personas públicas, algunos de ellos conocidos como tertulianos, que se arrogan capacidades para opinar de las que carecen, es totalmente cierto que hay gente muy sería, responsable y documentada que son llamados a asesorar a los gobernantes y hacen muy bien estos en atender a sus recomendaciones. Es verdad que a veces se equivocan porque nadie es infalible y porque en una situación nueva como ésta muchas veces se va a ciegas y en ocasiones no queda más remedio que aplicar la teoría del ensayo-error.

Esos verdaderos expertos, son capaces por formación y por experiencia de detectar si van o no en el camino adecuado, y pueden modificar el rumbo si el que están siguiendo está mal encaminado, pero lo que no es de recibo es que estos gobernantes se escuden en genéricos "expertos" no identificados, para justificar errores clamorosos y atribuyan a terceros lo que es su única responsabilidad porque son ellos los elegidos para tomar decisiones y son ellos los que tienen que asumir las responsabilidades de los aciertos y de los errores y cuando éstos últimos se han vuelto manifiestos y evidentes no es admisible achacar a que sus actos se produjeron bajo el refrendo de esos "expertos".

Un buen líder escucha a los que saben, pondera las opiniones que recibe, pero al final es el que decide y sus errores y aciertos son suyos porque eso va en su salario. Como hemos dicho muchas veces en conferencias y cursos hay una máxima absoluta en la gestión empresarial, "cuando estamos en un proceso de discusión yo soy uno más, pero cuando hay que tomar una decisión, yo soy uno y el resto es más y tengo que asumir plenamente las consecuencias de mi decisión", pero mucho nos tememos que de esa clase de líderes, en el mundo de la política y la gobernanza, no andamos muy sobrados.

Son tantas las cosas que nos está enseñando esta pandemia que nos gustaría creer que seremos capaces de reflexionar como sociedad, sobre qué es lo que tenemos que cambiar de arriba abajo, qué es lo que tenemos que mejorar y qué es lo que tenemos que mantener porque ha funcionado y que esa reflexión involucre a todos los estamentos de la misma, porque en ello nos va, el ser o no ser como colectivo.

Si somos capaces como sociedad de conseguir, a través de las instituciones supranacionales de las que nos dotamos al acabar la segunda guerra mundial que miren más allá del localismo ramplón y quieran realmente dedicar sus esfuerzos a mejorar la vida de los habitantes de este planeta, $y$ a no seguir gastando tiempo y recursos en discusiones estériles y aplicadas únicamente a conservar prebendas e intereses localistas. 
Si somos capaces de adaptar nuestra vida a este cambio de era en la que parece que estamos. Si esas instituciones y sus mandatarios son capaces por fin, de plantear un nuevo escenario que mejore el cuidado de este mundo, tratando de evitar que siga progresando el cambio climático. Si son capaces de conseguir que la esperanza de vida de todos los niños nacidos hoy en el mundo sea la misma, nazcan donde nazcan. Si son capaces de conseguir que la ingente producción de alimentos y agua potable que hay en el mundo sea adecuadamente distribuida para que no falte en ningún lugar el sustento de supervivencia. Si son capaces de estimular actividades laborales productivas que permitan disminuir sustancialmente las tasas de desempleo tanto juvenil como adulto en el mundo. Si son capaces de pensar en el mundo como la pequeña aldea global que somos dentro de un cosmos infinito y actuar siempre pensando en el bienestar de los que en ella viven y no en sus intereses partidistas o personales, si son capaces de pensar en "todos" en lugar de en "yo", es posible que aún podamos hacer de éste, un mundo habitable en donde la justicia social, el mérito personal y la cultura del esfuerzo sobresalgan y tengan el papel que les corresponde para seguir progresando, si no, es posible que las siguientes generaciones no tengan las opciones que nosotros hemos tenido y vivan una "nueva era" que se parecerá mucho más a la que existía en la Edad de Piedra que ésta en la que nosotros vivimos.

Una cosa está quedando meridianamente clara en esta crisis social económica y sanitaria, y es que sólo las empresas y las organizaciones que revisen y se replanteen su misión saldrán más fuertes; por el contrario, las que piensen sólo en términos de eficacia (a corto plazo y a cualquier precio) tienen ante sí un oscuro futuro, porque se habrán deshumanizado. El tiempo que hemos pasado recluidos en nuestros hogares, sin presencia de nuestros amigos, familiares o compañeros de trabajo nos ha llevado a reflexionar sobre qué es lo verdaderamente importante, cuáles son las razones por las que realmente nos levantamos todos los días e incluso, nos hemos llegado a replantear la idoneidad de nuestros valores.

La sociedad ha sufrido, y del mismo modo lo ha hecho el mundo de los negocios. En la nueva era en la que nos encontramos, en el entorno empresarial hay aspectos que ya no van a ser tal y como los conocíamos, la COVID-19 ha introducido notables cambios en capítulos como la gestión del riesgo, la gestión de las personas, la forma de trabajo, la tesorería o la estrategia comercial. Las compañías que consigan resistir lo habrán hecho porque se han adecuado, en un corto espacio de tiempo al nuevo escenario. 
Por otro lado, los empleados habrán despertado de una especie de letargo que les habrá proporcionado una madurez y un nuevo sentido de responsabilidad. Esta combinación hace que el management, a partir de ahora, se sitúe en un nuevo contexto. Esta nueva dimensión no supone un cambio radical de la noche al día, sino más bien una evolución hacia la supervivencia. Recordando las palabras del naturalista inglés, Charles Darwin, "no sobrevive el más fuerte sino el que mejor se adapta a su entorno", y es esta adaptación la que habrá hecho evolucionar la manera de dirigir al talento y el modo de gestionar la empresa.

Tenía razón Steve Jobs cuando decía que no tiene ningún sentido contratar grandes profesionales para después decirles lo que tienen que hacer. Pues bien, parece que no nos hemos dado cuenta de esto hasta que hemos sufrido esta pandemia. Durante la cuarentena, encerrados en nuestros hogares, los directivos de primera línea se vieron obligados a tener que delegar y a dotar de más autonomía a sus equipos. En muchos de los casos, los resultados positivos obtenidos están generando una relación más cercana y de confianza entre los directivos y los miembros de sus equipos. La misión de los primeros es construir un propósito y unos objetivos a alcanzar, y a partir de ahí, dar verdadera autonomía a equipos e individuos.

Parafraseando al profesor Sebastian Reiche, las personas cambian cuando se ven obligadas a hacerlo. Es difícil cambiar de otra manera y esto fue lo que ocurrió como consecuencia de la COVID-19. La nueva realidad nos hizo cambiar la manera de trabajar y si no queríamos extender la pandemia, la única alternativa posible para continuar con nuestro trabajo en una situación de confinamiento era lanzarnos a experimentar con el formato online (teletrabajo).

Por otro lado, una consecuencia derivada de la focalización de la responsabilidad social de las empresas en el empleado y en asegurar su puesto de trabajo, hace que su compromiso contra el cambio climático, que estaba en primera línea, pase a segundo o tercer plano. Este tema es especialmente delicado porque si se pierde la atención de los medios de comunicación se podrían relajar las exigencias en materia de reducción de emisiones en favor de la recuperación económica, lo que nos traería en un futuro no muy lejano otra nueva crisis, que también vendrá de la mano de la madre naturaleza, quien ya ha lanzado suficientes avisos sobre cómo reacciona cuando no la cuidamos.

A modo de conclusión de este ensayo nos gustaría destacar que la COVID19 ha puesto de manifiesto la fragilidad humana y nuestra vulnerabilidad como sociedad, pero también ha demostrado nuestra capacidad de afianzarnos en 
una fortaleza interior para no tirar la toalla y seguir creciendo. Sin duda alguna, ahora necesitamos entender lo mejor que podamos este nuevo escenario. Es el momento de estar muy cerca de las personas y esto nos exige poner en práctica un liderazgo positivo capaz de conectar, aunar esfuerzos, actuar con flexibilidad y sobre todo, fomentar los valores humanistas y éticos. Nos hemos dado cuenta de que en esta crisis cada país ha actuado de un modo diferente, nadie tenía todas las respuestas. Es muy difícil prever con anticipación la irrupción de otra crisis, pero si las empresas, organizaciones y gobiernos son capaces de aprender y poner en práctica las lecciones surgidas de esta crisis, estarán más preparadas y les será más fácil mitigar sus efectos. La forma de seguir creciendo es mediante el acercamiento a las personas, la confianza y el compromiso.

Es indudable que el sistema económico en el que vivimos y que hasta el momento nadie ha sido capaz de sustituir por uno mejor y más justo, tiene cosas muy buenas, y sin duda ha permitido un desarrollo espectacular de nuestras capacidades creativas. El hombre, por educación o por genética, es un ser competitivo y esa capacidad, genera progreso, pero no debería ser nunca a costa de los valores que nos distinguen como seres humanos. La pandemia de la Covid-19 está mostrando de forma descarnada que no somos nada, que todas las riquezas, el ego, y el populismo, no sirven para nada cuando lo que nos confronta es algo que pone a prueba nuestra capacidad de supervivencia y nos demuestra que si sólo usamos el "yo", tenemos garantizada la destrucción como especie, porque la naturaleza no va a permitir que aquellos que solo estamos de paso, destruyamos lo que es de otras generaciones, y por tanto únicamente nos va a quedar para salir de ésta situación, un uso masivo del "nosotros", incluyendo en ese concepto, la solidaridad verdadera con los más vulnerables, el propósito firme de mejorar sus condiciones de vida, el ser capaces de cuidar más y mejor a los que ya no pueden hacerlo por si mismos, y el situar como prioridad de la humanidad el cuidado y restitución de los recursos que nos fueron prestados. Si no aprendemos eso, es posible que nunca más volvamos a disfrutar de un mundo como el que nos acogió cuando nacimos y alguien, de una generación futura contará en los libros si esto ocurre y no le ponemos remedio, que hubo una vez en la historia de la humanidad que el "yo" venció al "nosotros", la forma de vida que tanto nos había costado conseguir se había extinguido por no entender algo tan simple como que la "naturaleza no perdona nunca” y no nos dará muchas más oportunidades.

Esperemos que si llega una próxima vez nos encuentre con la guardia alta y la lección aprendida. Habremos pagado un alto precio en vidas humanas, lo único irremplazable en esta crisis, pero al menos podremos honrar la memoria 
de los que se fueron evitando que en cualquier otra ocasión tengamos que lamentar el no haber escuchado a la naturaleza y no haber aprendido de los innumerables errores que ahora hemos cometido.

\section{REFERENCIAS BIBLIOGRÁFICAS}

Arteaga, R. Una pandemia con sabor a cambio de era, en Calvo JR.; Kindelán C.; Calvo MA. (eds) (2020). La Gran Pausa, Gramática de una Pandemia. Ediciones Malpaso. España, México, Argentina.25-36.

Calvo JR.; Kindelán C.; Calvo MA. (eds.) (2020). La Gran Pausa, Gramática de una Pandemia. Ediciones Malpaso. España, México, Argentina.

Canals, Jordi, Liderazgo en tiempos de crisis. La Vanguardia. 29 marzo de 2020.

Freixes, T. La Europa que nos queda después de la Covid 19. Lecciones para después de una crisis. en Calvo JR.; Kindelán C.; Calvo MA. (eds.) (2020). La Gran Pausa, Gramática de una Pandemia. Ediciones Malpaso. España, México, Argentina, 87-100.

Levin-Scherz, J.; Allen, D. 8 Questions Employers should ask about coronavirus, Harvard Business Review, 15 de marzo de 2020.

https://www.vidanuevadigital.com/2020/03/23/el-papa-francisco-a-evole-sobreel-coronavirus-dios-perdona-siempre-nosotros-a-veces-y-la-naturaleza-nuncal

Consultado el 5 de enero de 2021.

Las raíces del 'que inventen ellos'

http://www.elmundo.es/ciencia/2014/12/13/548b449422601da01c8b4583.html. Consultado el 5 de enero de 2021.

Las 70 mejores frases de Santiago Ramón y Cajal

https://psicologiaymente.com/reflexiones/frases-santiago-ramon-y-cajal

Consultado el 5 de enero de 2021.

A world at risk.

https://apps.who.int/gpmb/assets/annual_report/GPMB_Annual_Report_Spanish.pdf

Consultado el 5 de enero de 2021.

https://elpais.com/ideas/2020-04-02/bertrand-badie-politologo-la-accionde-la-oms-se-reduce-a-leer-cada-noche-un-comunicado.html

https://elpais.com/internacional/2019/04/28/actualidad/1556487884_51515

9.html

https://us04web.zoom.us/j/631660215?pwd=d3RzWTNPSDFrYmxSek5aL3J xRzV1QT09 
https://www.ted.com/talks/bill_gates_the_next_outbreak_we_re_not_ready?la nguage $=$ es

http://www.fiamc.org/bioethics/pandemic/\%EF\%BB\%BFreflexiones-sobreel-yo-vs-el-nosotros-en-tiempos-de-pandemia/ 



\title{
LA NECESIDAD DE FORMACIÓN DEL PROFESORADO EN HABILIDADES SOCIALES, DINÁMICA DE GRUPO Y TRABAJO COOPERATIVO
}

\author{
Pastora Calvo Hernández \\ Universidad de Las Palmas de Gran Canaria. \\ Ciro Gutiérrez Ascanio \\ Universidad de Las Palmas de Gran Canaria
}

Muchas gracias Emy, maestra y amiga, por contagiarnos tu entusiasmo por la ciencia y por la formación de los docentes.

\section{Resumen}

En este artículo consideramos que uno de los aspectos relevantes del dominio por parte del docente de las competencias sociales y las técnicas de dinámica de grupo es que permiten al profesorado poner en práctica el desarrollo de las competencias sociales y cívicas y las habilidades socioafectivas del alumnado. Su puesta en marcha, no sólo depende de la calidad de las interacciones que se desarrollan en el grupo, sino también de la capacidad del profesorado para gestionar las y ponerlas en práctica, lo que permite lograr un clima de clase óptimo para el desarrollo en el alumnado de aprendizajes de calidad.

Analizamos la importancia que el aprendizaje y el dominio del entrenamiento de estas estrategias, tanto desde la perspectiva teórica como práctica, tienen en la formación del profesorado destinado a la puesta en marcha y la gestión del grupo y reflexionamos sobre los aspectos más relevantes que las competencias sociales y las dinámicas grupo y trabajo cooperativo aportan al desarrollo de las habilidades socioafectivas y de las competencias sociales y cívicas del alumnado y, por tanto, deben ser un objetivo prioritario en la formación inicial del profesorado.

Palabras clave: dinámica de grupos, aprendizaje cooperativo, habilidades sociales, clima escolar, formación del profesorado.

\section{Abstract}

In this article we are considering one of the relevant aspects of control on the teacher's part of social skills and techniques of group dynamics which allow the teachers to put the development of the pupils' social, civic and social-emotional skills into practice. The start-up depends not only on the quality of 
interaction built up within the group, but also on the teachers' capacity to manage and set it in motion/put it into practice, which will allow an optimal climate for the development of quality learning among the students.

We analyze the importance that the learning and control of training of these strategies, both from the theoretical and practical perspective, have in the formation of the teachers destined to the start-up and management of the group. We consider the most relevant aspects that social skills, group dynamics and teamwork bring to the development of the socio-emotional skills and the social-civic competence of the pupils and which should therefore be an essential objective in the initial training of the teachers.

Key words: group dynamics, team work, social skills, school climate/atmosphere, teacher training.

\section{INTRODUCCIÓN}

Los fuertes cambios sociales y culturales que estamos viviendo generan, entre otros aspectos, que la familia haya modificado tanto su estructura como su funcionamiento y que también se modifique el rol que desempeña en la socialización de sus miembros. Y entran con una fuerza muy superior a la del siglo pasado aspectos como los medios tecnológicos, que se han hecho presentes e imprescindibles en nuestra vida permitiéndonos tener un rápido acceso a la información, conectarnos en tiempo real con personas en cualquier rincón del mundo y pasar horas charlando; los medios de comunicación que, en determinadas circunstancias, llegan incluso a suplantar al resto de referentes y agentes socializadores; la sociedad multiétnica y multicultural de la inmigración, que supone riqueza y diversidad cultural, pero conlleva problemas de integración y reto a la tolerancia; la sociedad consumista y hedonista; las nuevas circunstancias de vida que generan en muchas personas situaciones de estrés, ansiedad, soledad, aislamiento, analfabetismo emocional, agresividad, depresión, irritabilidad, apatía, o la violencia que empapa la sociedad apreciándose una notable permisividad e indiferencia hacia determinadas formas de violencia como la verbal o la exclusión social. En este escenario, el desarrollo de las competencias afectivas, sociales y cívicas se vuelve imprescindible, y la escuela se convierte en el espacio más importante para poder trabajarlas de forma grupal y equilibrada.

Como señalan Marrero y Calvo (2008), uno de los aspectos más importantes de la Psicología Social es el estudio de la vida y funcionamiento de los grupos, puesto que la mayor parte de las realidades humanas son procesos de 
interacción social que se realizan en grupo y, por tanto, la eficacia de las acciones que se desarrollan en los mismos tiene que ver con la organización y la dinámica que se establece en cada uno de ellos. La entidad social que supone el grupo clase es un objeto de experiencia diaria, máxime en los profesionales relacionados con el mundo educativo y la intervención social, como es el caso del profesorado que desarrolla su actividad profesional en los centros educativos. Según Cornejo y Redondo (2001), este modelo busca explorar las complejas asociaciones entre personas, situaciones y resultados individuales donde la conducta actual es una función de un proceso continuo de interacción multidireccional o de feedback entre el individuo y las situaciones en que se encuentra y donde la persona es un agente activo e intencional en este proceso.

\section{LAS COMPETENCIAS SOCIALES EN LA EDUCACIÓN}

Los procesos de interacción facilitan el aprendizaje no sólo de conocimientos y destrezas para incorporarse a la vida adulta, sino que también la propia sociedad requiere que los individuos sean socializados en los valores y en las formas de vida que en ella se desarrollan. El aprendizaje de las destrezas sociales hace posible la aceptación y el mutuo intercambio, permiten la construcción de un sistema de valores, fomentan los sentimientos de pertenencia al grupo e incrementan los niveles de seguridad y confianza en sí mismo y en los otros.

Como indican García-Valcárcel y Hernández (2013), las competencias son un conjunto de conocimientos de habilidades socioafectivas, motrices y psicológicas sin las cuales no sería nada fácil para las personas desarrollar de manera eficaz el desempeño de ciertas actividades, tareas o roles, utilizando los conocimientos más adecuados. Su importancia radica en que se han convertido en un pilar fundamental del cambio educativo. El uso de las mismas pone el centro de interés en el ámbito de la práctica del conocimiento y su transferencia a otros contextos de aprendizaje. En este sentido, Zabala (2003) plantea que en el ámbito educativo deben desarrollarse las capacidades que necesitan los sujetos para dar respuestas a los desafíos que se encontrarán lo largo de la vida. Un aprendizaje basado en competencias implica incorporar a la formación del profesorado tres elementos básicos: conocimientos teóricos, desarrollo práctico de habilidades y destrezas y saber ser: actitudes, valores éticos y morales, etc.

La Orden ECD/65/2015, de 21 de enero, del Ministerio de Educación, Cultura y Deporte, describe las relaciones entre las competencias, los contenidos y los criterios de evaluación de la educación primaria, la educación secundaria obligatoria y el bachillerato, establece que una de las siete competencias clave del currículo son las competencias sociales y cívicas. En la descripción 
de esta competencia indica que Las competencias sociales y cívicas implican la habilidad y capacidad para utilizar los conocimientos y actitudes sobre la sociedad, entendida desde las diferentes perspectivas, en su concepción dinámica, cambiante y compleja, para interpretar fenómenos y problemas sociales en contextos cada vez más diversificados; para elaborar respuestas, tomar decisiones y resolver conflictos, asi como para interactuar con otras personas y grupos conforme a normas basadas en el respeto mutuo y en convicciones democráticas. Además de incluir acciones a un nivel más cercano y mediato al individuo como parte de una implicación cívica $y$ social.

En cuanto a las estrategias metodológicas que se proponen, la Orden destaca metodologías activas que deben apoyarse en estructuras de aprendizaje cooperativo, donde los miembros del grupo desarrollan de forma conjunta la solución de tareas y puedan ser aplicadas a situaciones similares. Como afirman Marrero y Calvo (2005), las técnicas de grupo y aprendizaje cooperativo, se constituyen como medios, instrumentos o procedimientos que, aplicados al trabajo en grupo, sirven para desarrollar su eficacia, hacer realidad sus potencialidades, y estimular la acción y funcionamiento del grupo para alcanzar sus objetivos, favorecen las relaciones interpersonales, el aprendizaje escolar y aspectos de la dimensión individual y grupal de los miembros del grupo: la afectividad, la autoestima, el autoconocimiento, el conocimiento de los demás y el desarrollo cognitivo, afectivo, motor y sensorial.

Las personas pueden desarrollar su potencial solamente dentro de una comunidad. La participación en cualquier comunidad requiere conocimiento y entendimiento de sus normas, reglas y valores, así como el manejo de las habilidades necesarias para interactuar con los demás. De modo que la competencia social y el mantenimiento de adecuadas relaciones interpersonales con los otros afectan al aprendizaje de las bases de la propia cultura (López de Dicastillo, Iriarte y González, 2008).Los seres humanos pasan la mayor parte de su tiempo en interacción con otros. Gran parte de sus experiencias más significativas incluyen o dependen de las relaciones con los demás, por lo que la capacidad de gestionar los comportamientos propios, las emociones, y de entender los de los demás se convierten en una herramienta poderosa para la vida. Estas herramientas se pueden trabajar, desarrollar y aprender en la escuela. Por lo que consideramos que la formación inicial del profesorado debe prestar una especial atención a estos aspectos, ya que no sólo los contenidos académicos contribuyen a la formación de la persona.

La conducta social se aprende y se va desarrollando durante todo el ciclo vital. Por eso, para entender el desarrollo social, tenemos que prestar atención 
a los procesos desocialización que se dan en la escuela. El proceso mediante el cual los nińos y adolescentes adquieren pautas de comportamiento, creencias, normas, valores, costumbres y actitudes propias del contexto social y cultural en el que están inmersos y del momento en el que viven. Una parte fundamental de ese proceso de socializaciónse da en la escuela con los iguales, y tanto el currículo como el profesorado deben contribuir a que ese aprendizaje sea adecuado, utilizando las herramientas que la investigación en competencias sociales ha demostrado útiles y eficientes para este aprendizaje.

\section{LA IMPORTANCIA DEL APRENDIZAJE DE LAS HABILIDADES SO- CIALES, LA DINÁMICA DE GRUPO Y EL TRABAJO COOPERATIVO EN LA ESCUELA}

Estas habilidades son indicadores observables de un constructo más amplio, la competencia social que es un constructo multidimensional, que se refiere a la capacidad de integrar la cognición, el afecto, la motivación y el comportamiento para tener éxito con tareas sociales y lograr resultados de desarrollo positivos. La mayoría de las definiciones convergen en que la competencia abarca varias habilidades interpersonales e intrapersonales relacionadas, que pueden organizarse en subdimensiones como cooperación, afirmación, autocontrol, empatía y responsabilidad. Por tanto, manejar las técnicas de dinámica de grupos desde una perspectiva crítica permitirá la readaptación continua de los sujetos a los diversos contextos.

Las habilidades sociales son habilidades para la vida y, por lo tanto, es crucial que los niños las adquieran. Los nińos que cooperan y comparten con otros, que son empáticosy capaces de regular las emociones de manera adaptativa, son generalmente mejores en la mayoría de las áreas sociales de la vida, incluso en la escuela (Hamre y Pianta, 2001).

Los procesos de interacción grupal que facilitan el aprendizaje de las destrezas sociales, hacen posible la aceptación y el mutuo intercambio, permiten la construcción de un sistema de valores, fomentan los sentimientos de pertenencia al grupo e incrementan los niveles de seguridad y confianza en sí mismo y en los otros. Por esta razón, como señalan Marrero y Calvo (2008), las técnicas de grupo se constituyen como medios, instrumentos o procedimientos que, aplicados al trabajo en grupo, sirven para desarrollar su eficacia, hacer realidad sus potencialidades, y estimular la acción y funcionamiento del grupo para alcanzar sus objetivos.

El uso de estas técnicas no sólo es necesario como estrategia metodológica en el aula, sino también, como herramienta de reflexión, tanto del profesorado 
como del alumnado. Este proceso permite confrontar y evaluar el comportamiento individual y grupal y, por tanto, modificar o diseńar las estrategias que influyan positivamente en el proceso de enseñanza aprendizaje. El grupo de discusión es una de estas herramientas que ayuda a la reflexión personal y grupal, que permite una mayor interacción y comunicación entre los miembros del grupo y mejora las habilidades sociales y comunicativas tan necesarias para la resolución de problemas como para la toma de decisiones.

La escuela como grupo sociales uno de los lugares fundamentales en la vida de un niño, y es el lugar más importante en el desarrollo y la consolidación de sus habilidades sociales, ya que es el escenario en el que por primera vez se encuentra con sus iguales sin la presencia de sus padres o su familia y donde tiene que aprender a relacionarse en ese marco de igualdad y reciprocidad. La interacción con los compañeros es el foro en el que se construyen las competencias sociales. El microsistema de los iguales está compuesto de normas, pautas, rutinas, convenciones, creencias y hábitos de comportamiento, valores y actitudes que ayudarán a su desarrollo personal y social.

En el marco de las relaciones entre iguales se posibilita la experiencia, adquisición y práctica de herramientas sociales, teniendo en cuenta los conocimientos que aporta la teoría de la dinámica de grupos, entre las que podemos destacar:

a) Conocimiento de sí mismo y de los demás, pues se favorece el proceso de identificación y el desarrollo y fortalecimiento del autoconcepto.

b) Reciprocidad, necesidad de dar para poder recibir e intercambiar en el control de la relación.

c) Empatía, habilidad para percibir y ver una situación desde la perspectiva del otro.

d) Colaboración, cooperación y ayuda, lo que supone trabajar junto a otros niños intercambiando el control de la relación, facilitando la tarea común y haciendo que resulte agradable para los participantes.

e) Autocontrol y autorregulación de la propia conducta en función de la información que se recibe de los otros porque los iguales actúan como agentes de control reforzando o castigando determinadas conductas.

f) Apoyo emocional, ayuda, consuelo, compañerismo y establecimiento de vínculos afectivos y de amistad.

g) Disfrute, diversión y complicidad.

h) Estrategias sociales de negociación y de acuerdos (compartir, crear normas, etc.).

i) Aprendizaje de aspectos sexuales ya que se intercambian informaciones, se exploran unos a otros, se hacen descubrimientos. 
j) Desarrollo moral y aprendizaje de valores y normas, pues con los iguales se explora el mundo social más allá de la familia.

Aunque los datos varían en las distintas investigaciones, parece que entre un 5 y un $25 \%$ de nińos o adolescentes experimentan dificultades en las relaciones interpersonales y más del $10 \%$ de los niños en edad escolar no tiene amigos, por lo que se pierden importantes procesos de aprendizaje social que tienen lugar en el grupo de iguales (Slee y Rigby, 1998). Se puede observar en la práctica educativa que un considerable número de niños carece de las habilidades necesarias para relacionarse adecuadamente con los otros en las interacciones cotidianas, y es reseñable la cantidad que encuentra problemas para conseguir o mantener relaciones interpersonales cómodas. También es preciso enfatizar que en toda aula hay algunos niños que son rechazados por sus iguales (Monjas, Martín, García-Bacete y Sureda, 2005), y que el número de rechazados aumenta considerablemente si contemplamos al alumnado con necesidades educativas especiales (Monjas, 1999).

En este sentido, los estudios realizados por Slavin (1992), Ovejero (1990), Johnson y Johnson $(1982,1990)$, demuestran la eficacia del trabajo cooperativo sobre variables académicas, sociales y afectivas. En el análisis de las investigaciones destacan que las actitudes hacia la cooperación correlacionan positivamente con ajuste y madurez emocional, fuerte identidad personal, capacidad de resolver conflictos, participación social, confianza básica y optimismo. En cuanto a las relaciones sociales, los estudios han mostrado efectos positivos sobre las relaciones sociales, raciales y de superación del prejuicio, mediante el uso de estrategias de aprendizaje cooperativo (Marrero y Calvo, 2005).

Como señala Ovejero (1990), la interacción social y el conocimiento se construyen a través de los procesos interactivos y, por tanto, el trabajo cooperativo, se entiende como una estrategia de intervención grupal dirigida al desarrollo personal y a la adquisición de competencias, tanto sociales como instrumentales. La cooperación implica que los miembros del grupo deben alcanzar una meta común mediante un trabajo interdependiente.

Las investigaciones realizadas por León (2006) sobre entrenamiento en habilidades sociales y dinámica de grupo, destacan las siguientes conclusiones: el entrenamiento en habilidades sociales, sobre la variable conducta verbal en tarea de discusión, ha influido de manera significativa en el desempeño de (dar explicaciones) y en el entrenamiento en dinámica de grupo ha incidido más sobre las conductas verbales, (solicita y da ayuda, hace preguntas, da repuestas y recibe explicaciones). 
Sobre las diferencias y tipos de roles positivos y negativos, la aplicación de la dinámica de grupo, permite apreciar un aumento de los roles positivos (organizar y conciliar) y una disminución de roles negativos (agresor). En cuanto al entrenamiento en habilidades sociales ha incidido sobre los roles negativos (bloqueadores y autoritarios). En cuanto a la situación de aprendizaje de conceptos, en la variable Conducta verbal, asociada al entrenamiento en habilidades sociales, confirma las diferencias significativas en solicitar desarrollo de determinados roles, sobre todo, en las tareas de discusión y toma de decisiones (llegar a acuerdos, pedir ayuda, dar respuestas y explicaciones), y conseguir que el grupo madure, desarrolle sus normas, sus aprendizajes y los roles que garantizan un funcionamiento eficaz del grupo.

Destacamos algunas de las conclusiones de los trabajos realizados por Blanco (2009), Exley y Dennick (2007) y López (2005) que señalan que trabajar en equipo es una competencia que se puede desarrollar mediante el entrenamiento en las distintas técnicas que se desprenden del desarrollan del marco teórico de la dinámica de grupos. El uso de las técnicas de grupo en el ámbito educativo es un factor primordial que incide en la eficacia de los objetivos planteados, potencia la interacción social y la cooperación entre los miembros y, por lo tanto, incide en el desarrollo de las competencias interpersonales.

En esta Línea, algunas de las conclusiones de los trabajos realizados por Gámez Montalvo y Torres Martín (2013) sobre la aplicación de las técnicas de grupo insisten en el dominio de estrategias metodologías para la adquisición de la competencia del trabajo en equipo de los estudiantes. En cuanto a la comunicación, las técnicas les han ayudado a perder el miedo a enfrentarse a un grupo de personas, lo que suponen un aprendizaje extrapolable a sus futuras actividades laborales y sociales.

Con respecto a la cohesión y clima de cooperación, señalan que la formación de grupos aleatoriamente ayuda a que la interacción sea más rápida y eficaz, creando un clima de confianza que refuerza el compañerismo y la amistad. En relación al respeto y la empatía, destacan que las técnicas mejoran las relaciones, son capaces de ponerse en el lugar del otro y respetar las opiniones de los compañeros.

Acerca de las normas y los objetivos señalan que deben ser marcadas por el docente en función del grupo y se establezca un compromiso mutuo. En cuanto a la tarea comentan que el aprendizaje de los contenidos es mayor, se sienten más motivados y su práctica les ha ayudado a mejorar el trabajo en grupo. El problema que manifiestan se centra en la dificultad que les supone gestionar los contenidos del trabajo cuando se reúnen en grupo y su repercusión en el resultado final. 
No obstante, Marrero y Santiago (2001) señalan que es preciso tener en cuenta algunas limitaciones como es la inexistencia de un marco teórico fuerte que permita articular de una manera global los resultados de las investigaciones realizadas, el número de estrategias de aprendizaje cooperativo, la cantidad de variables y la complejidad de las interacciones que se producen en los grupos en el ámbito cognitivo, metacognitivo, afectivo y social, la articulación de las características de la tarea, la incidencia de las diferencias individuales, la composición de los grupos, etc.

La adquisición de habilidades sociales, por tanto, es un proceso esencial del desarrollo mediante el cual los niños desde la infancia aprenden a actuar y responder apropiadamente en las interacciones sociales y a formar y mantener relaciones saludables con los demás (Sørlie, Hagen y Nordahl, 2020). A medida que los nińos crecen y gradualmente amplían su entorno social, la escuela se convierte en un importante espacio donde los niños aprenden y ejercitan sus habilidades sociales. En la escuela, se desafían y moldean las habilidades sociales de los niños en una variedad de formas, tanto con un compañero, como en grupos pequeños en el gran grupo, y durante las interacciones con otros niños y con los profesores. A pesar de su importancia, y en contraste con las habilidades académicas, las habilidades sociales rara vez se han trabajado sistemáticamente en las escuelas (OCDE, 2015).

\section{DIFICULTADES ASOCIADAS A LA CARENCIA DE COMPETENCIAS SOCIALES EN LA ESCUELA}

Es importante entender algunos de los retos y amenazas que pueden presentarse en las relaciones entre iguales. En primer lugar, es preciso resaltar que en las relaciones entre iguales aparecen inevitablemente conflictos y problemas que se tienen que aprender a afrontar y solucionar de forma pacífica y socialmente competente y, en el camino de acercarse a la adolescencia, tienen que aprender habilidades de supervivencia en un grupo, a responder ante las provocaciones y presiones del grupo, a detectar cuándo se sienten atrapados en un grupo o pandilla y no pueden salir, a no aceptar grupos donde no puedan expresar sus opiniones y deseos, o no se les tienen en cuenta, o se sientan manipulados.

Las principales consecuencias de la falta de competencia social en las relaciones sociales han permitido descubrir que la incompetencia social se relaciona, según Asher y Rose (1997), Inglés (2003) y Monjas (1999), con:

a) Escasa aceptación, rechazo, ignorancia o aislamiento social por parte de los iguales. Parece que los niños poco aceptados y sin amigos experimentan consecuencias emocionales negativas, pierden oportunidades 
para conocerse a sí mismos y conocer a los demás, para empatizar, para colaborar, cooperar y negociar, para aprender, autocontrolar y autorregular la propia conducta, para experimentar el compañerismo y el apoyo emocional, para desarrollarse moralmente y aprender valores en las interacciones con otras personas. Además, es probable que muestren baja autoestima, locus de control externo, ansiedad, depresión, soledad y tristeza.

b) Relaciones conflictivas con los adultos.

c) Desajustes psicológicos y psicopatológicos: depresión, indefensión.

d) Probabilidad de presentar trastornos de la alimentación y consumo de drogas.

e) Problemas escolares: absentismo, inadaptación escolar, fracaso, bajos niveles de rendimiento debido a la escasa participación en clase, a la resistencia a presentar trabajos en público y a evitar preguntar al profesor las dudas.

f) Trastornos de comportamiento, conducta antisocial o inadaptación juvenil (delincuencia juvenil).

g) Problemas de salud mental en la adolescencia y la edad adulta: alcoholismo, suicidio, toxicomanías.

Es preciso tener en cuenta que la relación con otras personas es algo complejo, que depende de diversas variables y que irremisiblemente está inmersa en conflictos y dificultades. La experiencia nos hace entender que es difícil convivir con otra u otras personas y todos tenemos dificultades y roces. El conflicto es pues algo natural y normal en la convivencia; por eso hay que aprender a resolver conflictos y poner en juego diversas habilidades sociales de comunicación y asertividad. Los niños y los adolescentes con adecuada competencia social, aprenden a afrontar y resolver estos retos positivamente y de forma pacífica.

Para evitar estos efectos y consecuencias negativas derivadas de la falta de competencias sociales, consideramos que tanto las habilidades sociales como las técnicas de dinámica de grupo y trabajo cooperativo deben formar parte del currículo y deben estar integradas en el trabajo que hace el profesorado en los centros. Un primer paso debería ser el que estos contenidos volvieran a la formación inicial de los maestros en los centros universitarios, de donde salieron en las últimas modificaciones que se hicieron de los planes de estudios de los grados de maestro. 


\section{LA COMPETENCIA SOCIAL EN LA NUEVA FORMA DE EDUCAR}

La educación en el siglo XXI debe avanzar en dirección a una transformación gradual y constante hacia una nueva forma de educar. Es necesario ofrecer un enfoque educativo donde el alumno pueda desarrollar diversas habilidades socioemocionales, más allá de las cognitivas. Muchas investigaciones avalan que una de las virtudes más importantes que supone el trabajo de las emociones en el aula durante la educación infantil y la educación primaria, es la mejora del ámbito social y conductual del niño reforzándose valores como el autoconcepto a través del desarrollo de estrategias que motiven la reflexión y las habilidades personales (Hortigüela, Ausín, Abella y Delgado, 2017).

De este modo y centrándonos en el ámbito educativo, una de las claves para que el alumnado adquiera determinadas competencias es que los docentes sean capaces de adquirir dichas competencias y sepan transmitírselas a sus alumnos. Para conseguir un desarrollo integral del alumnado, se necesita de un equipo docente que domine los aspectos que sean necesarios afrontar, entre ellos, las competencias sociales y las habilidades emocionales (Cabello, RuizAranda y Fernández-Berrocal, 2010).

Los resultados de estas investigaciones nos llevan a poner el foco de atención en el uso y entrenamiento en técnicas dinámicas de grupo y habilidades sociales a lo largo de todas las etapas educativas, teniendo en cuenta que trabajar en grupo no significa generar interacciones de manera inmediata. Lo importante es la calidad de las interacciones y cómo estas influyen en los procesos grupales y en la adquisición de las competencias necesarias para desarrollar con mayor eficacia la tarea en los grupos.

A modo de conclusión y a partir de los datos aportados en este trabajo, nos parece importante incorporar en la Formación del Profesorado el entrenamiento a los estudiantes en habilidades sociales y en dinámica de grupos. Un profesorado entrenado en habilidades sociales y en dinámica de grupos garantiza la eficacia de los procesos de aprendizaje y el rendimiento escolar en cualquier etapa educativa, formando parte del currículo. Para esta formación, León (2006) propone un procedimiento integrado por habilidades sociales, dinámicas de grupos y habilidades comunicativas, que prepare y enseñe al grupo a cooperar.

En definitiva, estas habilidades y destrezas no deben darse por supuestas en los estudiantes de los grados de maestro, ya que la sociedad no prepara para el desarrollo de estas competencias, sino que se trata de habilidades que se deben aprender y trabajar para lograr su desarrollo. 
Gámez-Montalvo y Torres-Martín(2013) postulan el desarrollo de estas habilidades y competencias en el ámbito universitario, y señalan que el Proyecto Tuning establece las distintas competencias claves a desarrollar en las titulaciones universitarias y dentro de las competencias genéricas, las interpersonales que están relacionadas con las capacidades individuales y destrezas sociales, son las responsables de los procesos de interacción social y cooperación, incluyendo, entre otras, las de trabajo en equipo como elemento fundamental dentro del currículum. Por esta razón, y considerando la importancia que le otorga tanto el currículo como la investigación, defendemos que las habilidades sociales, la dinámica de grupo y el trabajo cooperativo deben formar parte de la formación inicial de los grados de maestro para que, una vez adquiridos los conocimientos necesarios y valorada su importancia por parte de quienes se forman como futuros maestros y maestras de educación infantil y educación primaria, puedan ser un elemento clave que se trabaje en un futuro en nuestras aulas escolares.

\section{REFERENCIAS BIBLIOGRÁFICAS}

Asher, S.R. and Rose, A.R. (1997). Promoting children's social-emotional adjustment with peers. En P. Saloveyand D.J. Sluyter (eds.). Emotional development and emotional intelligence. New York: Basic Books, (pp. 196-224).

Blanco A. (2009). Desarrollo y evaluación de competencias en educación superior. Madrid: Narcea

Cabello, R., Ruiz-Aranda, D. y Fernández-Berrocal, P. (2010). Docentes emocionalmente inteligentes. Revista Electrónica Interuniversitaria de Formación del Profesorado, 13, 41-49. Recuperado el 7 de septiembre de 2020 de: http Cornejo (2001) s://dialnet.unirioja.es/servlet/articulo?codigo=3163455

Cornejo, R y Redondo, J. (2001).El clima percibido por los alumnos de enseñanza media. Última Década, 15, 11-52.

Exley, K. yDennick, R. (2007). Enseñanza en pequeños grupos en educación superior: tutorias, seminarios y otros agrupamientos. Madrid: Narcea.

Gámez-Montalvo, M.J. y Torres-Martín, C. (2013) Las técnicas de grupo como estrategia metodológica en la adquisición de la competencia de trabajo en equipo de los alumnos universitarios. Journal for Educators, Teachers and Trainers, 4, 14-25.

García-Valcárcel, A. y Hernández, A. (2013). Recursos tecnológicos para la enseñanza e innovación educativa. Madrid: Síntesis.

Hamre, B.K. and Pianta, R.C. (2001). Early teacher-child relationships and the trajectory of children's school outcomes through eighth grade. Child- 
Development, 72(2), 625-638. DOI:

https://doi.org/10.1111/1467-8624.00301

Hortigüela, D., Ausín, A., Abella, V. y Delgado, V. (2017). Percepción de docentes y estudiantes sobre el trabajo de la educación emocional en el aula. Contextos Educativos, 20, 27-41. DOI: https://doi.org/10.18172/con.2981

Inglés, C.J. (2003). Enseñanza de habilidades interpersonales para adolescentes. Madrid: Pirámide.

Johnson, D. andJohnson, R. (1982). Effects of cooperative and individualistic instruction on handicapped and nonhandicapped students. Journal of Social Psychology, 118, 257-268.

Johnson, D. y Johnson, R. (1990). Cómo reducir la violencia en las escuelas. Barcelona: Paidós.

León, B. (2006). Elementos mediadores en la eficacia del aprendizaje cooperativo: Entrenamiento en habilidades sociales y dinámica de grupos. Anales de Psicología, 22, 105-112.

López de Dicastillo, N., Iriarte, C. y González, M.C. (2008). Competencia Social y Educación Cívica. Madrid: Síntesis.

López, F. (2005). Metodología participativa en la Enseñanza Universitaria. Madrid: Narcea.

Marrero, G. y Santiago, O. (2001). Aprendizaje cooperativo y participación, en A. Lucas Marín y A. García Cabrera (Eds.). Formación para la participación ciudadana. Las organizaciones del Siglo XXI. Buenos Aires-México: Grupo Editorial Lumen-Humanitas.

Marrero, G. y Calvo, P. (2004). Interacción y Dinámica de Grupos. Manuales Docentes de Psicopedagogía, 18. Servicio de Publicaciones y Difusión Científica de la Universidad de Las Palmas de Gran Canaria.

Marrero, G. y Calvo, P. (2008). Dinámica del Grupo Escolar. Manuales Docentes de Educación Primaria, 28. Servicio de Publicaciones y Difusión Científica de la Universidad de Las Palmas de Gran Canaria.

Monjas, I. (1999). Programa de enseñanza de habilidades de interacción social (PEHIS). Madrid: CEPE.

Monjas, I., Martín, I., García-Bacete, F. y Sureda, I. (2005). Razones que justifican la aceptación y el rechazo ente iguales. En I. Fajardo, F. Vicente, A. Ventura, I. Ruíz y J.A. del Barrio (eds.). Aportaciones psicológicas y mundo actual. Dando respuestas. Badajoz: Psicoex, pp. 395-400.

OECD (2015). Skills for social progress: The power of social and emotional Skills. OECD SkillsStudies. 
Orden ECD/65/2015, de 21 de enero, por la que se describen las relaciones entre las competencias, los contenidos y los criterios de evaluación de la educación primaria, la educación secundaria obligatoria y el bachillerato. BOE núm. 25, de 29 de enero de 2015, páginas 6986 a 7003 . Ministerio de Educación, Cultura y Deporte. https://www.boe.es/eli/es/o/2015/01/21/ecd65

Ovejero, A. (1990). El aprendizaje cooperativo: una alternativa eficaz. Barcelona: PPU.

Slavin, R.E. (1992). Aprendizaje cooperativo. En C.R. Rogers y P. Kutnick (eds.). Psicología social en la escuela primaria. Barcelona: Paidós, pp. 247270.

Slee, P.T. y Rigby, K. (1998). Children's peer relation. London: Routeledge.

Sørlie, A.M., Hagen, K.A. and Nordahl, K.B. (2020): Development of social skills during middle childhood: Growth trajectories and school-related predictors, International Journal of School \& Educational Psychology, DOI: $10.1080 / 21683603.2020 .1744492$

UNICEF (2012). Global evaluation of lifes skills education programmes.

Zabalza, M. A. (2003). Competencias docentes del profesorado universitario. Calidad y desarrollo profesional. Madrid: Narcea. 


\title{
ÓLEO DE MUJER CON ESPEJO
}

\author{
José Luis Correa Santana \\ Universidad de Las Palmas de Gran Canaria
}

A Emy, la mujer que me llevó a la Academia.

\section{I.}

María Cristina San Ginés estaba marcada por razón de nacimiento, condición y carácter con la letra uve. María Cristina San Ginés era venezolana, viuda — daba la impresión de que había sido educada desde siempre para ser una espléndida viuda - e inenarrablemente $v$ oluptuosa. Sus cuarenta y tres ańos se revelaban como un misterio adolescente: unos enormes ojos, bellísimos, tan negros que, al trasluz de la luna, parecían felinos; labios gruesos de negra cuarterona, rasgados de sensualidad y una piel fulgurante de pura trementina. Su piel, ahora que me fijo, brillaba de un modo intensísimo en las tardes de aquella primavera en que la conocí.

La conocí en París con aguacero

o en el más adorable sucedáneo de París con aguacero que existe: una tarde lluviosa de marzo en una exposición de pintura francesa que dos museos de lo que entonces era la URSS, el Museo Pushkin de Moscú y el Hermitage de Leningrado, habían traído al Ateneo de La Laguna. Acababa de matricularme en Bellas Artes y me faltaban semanas, cinco creo, para cumplir los veintiuno. Y, allí, detrás de Monet, Matisse, Cézanne o Renoir estaban los versos de Vallejo; delante, justo delante, con esa aureola de diosa negra, estaba María Cristina San Ginés. Pero yo entonces estaba demasiado alelado por la magia de los maestros del Impresionismo como para caer en la cuenta de la presencia de la viuda negra.

En el Ateneo reinaba un silencio de sepulcro, entre otras cosas porque no había más de una docena de personas: cinco enormes salas dedicadas a lo mejor del arte moderno y tocábamos a cuatro cuadros por persona. Tan sólo de vez en vez un siseo quedo, como de plegaria, alteraba aquel recogimiento. Allí todos confesábamos una profunda adoración por los dioses paganos del arte. Allí todos, también, nos deteníamos especialmente ante Cézanne y el color de su ambrosía: no hubo hasta entonces ni ha vuelto a haber después unos tonos tan brumosamente limpios como el de sus bodegones, ni la geométrica arquitectura de sus óleos. Y Matisse, al que se presentaba junto a algunas obras de Picasso como el soberbio Arlequín, era venerado por un selectísimo grupo que 
no paraba de susurrarse las claves de su depurada técnica y de la expresión pesimista de sus cuadros. No obstante, todos pasaron por alto una pintura que había quedado, por razones de espacio, extraviada del resto, y que llenaba con una luminosidad solar la esquina en la cual quedaba expuesta. Justo la pintura ante la que un tipo como el que yo era entonces tenía la obligación de detenerse.

En un jardín que parecía suspendido en el aire, con un fondo amarillo de fuego, una mujer morena recogía flores de seda rosadas; su vestido celeste se adhería a su cuerpo como una segunda piel y sus pies eran enormes, descomunales. En el margen inferior izquierdo podía leerse con letras mayúsculas $T E$ AVAE NO MARIA y debajo la firma y la fecha: Paul Gauguin, 1899. Sólo yo parecía haber recalado en aquel cuadro hasta el punto de olvidarme del tiempo. Pasaron cinco, tal vez diez minutos antes de que una presencia a mi espalda me devolviera a la tierra después de vagar por el cielo de Haití en busca de una flor de terciopelo.

El olor de María Cristina San Ginés se había colado en mi sueño haitiano por unos segundos. Era un olor tibio a frambuesa, nada fuerte, de esos olores frescos de verano. Eso fue lo que me hizo volver al mundo real, no cuadraba un olor de verano bajo la tímida lluvia de marzo.

- ¿Te gusta Gauguin?

—Mucho — mi voz sonó hueca, adormilada.

— ¿Más que los otros?

-Desde luego que sí.

La mujer no tardó en reparar sobre mi turbación y, como disfrutaba muchísimo con esas situaciones, me continuó el examen de arte, paladeando las consonantes, sensualizando su tono de voz. "¿Qué ves en ese cuadro que tanto te demoras?», preguntó. «No sé. Me resulta exótico y, a la vez, familiar». «Pero resulta que yo no soy de aquí, ¿qué puedo ver en él?». «¿Un espejo?» respondí con un gesto más de inocencia que de picardía. La risa de María Cristina San Ginés era una risa amplia, rotunda, casi tanto como sus formas. Con ella rompió la serena armonía del Ateneo y todos los visitantes volvieron sus rostros a la escena, lo que hizo que me ruborizase aún más. Allí, creo, fue cuando decidió esclavizarme. Allí fue cuando María Cristina me quiso gobernar y yo empecé a seguirle y seguirle la corriente.

Por lo pronto, ya no se despegó de mí y continuamos la tarde paseando nuestras miradas (inquietante, la de ella; inquieta, la mía) por las cuatro salas de aroma francés. A los comentarios con dobleces y ambiguos de ella, llámame Cris, por favor, que me haces parecer vieja, yo procuraba responder a su sentido más estricto e, incluso después de nuestra historia, la llamé siempre María Cris- 
tina. En una ocasión, ante un cuadro de Bonnard en el que se veía una mujer madura, de espaldas y desnuda, al través de un espejo colocado sobre un aparador, la San Ginés aprovechó un despiste y me miró a los ojos. Yo estaba preguntándome en ese instante si la desnudez de la viuda venezolana sería parecida a la de la modelo del cuadro y, al volver el rostro hacia ella, me di de narices con unos ojos negros que me miraban burlonamente y que parecían descifrar mis pensamientos: "Nunca podrá compararse, mi cielo, al culo de una negra».

Unos versos de Morales presidían un pequeño café en el puertito donde, decorado como una antigua fragata, con sus motivos marineros y sus ojos de buey, servían unas tartas alemanas de auténtico vicio. El café, también al estilo alemán, era aguachirle pero la brisa del mar y el olor a sal que se masticaban en el aire hacían olvidar el brebaje. Cómo y cuándo llegamos allí, me llaman a jurar y no sabría decirlo. Pero, una vez sentado a la mesa frente al escote embriagador de María Cristina San Ginés, a la luz de una vela suavemente olorosa, no iba yo a preocuparme por esos detalles.

— ¿Por qué obra de arte llegarías a matar? —su entonación era áspera, de la fina aspereza que esconde la piel de un melocotón.

— ¿Por qué qué...? — me había vuelto a coger desprevenido.

- Sí, hombre, ¿qué es lo que hizo que un chico como tú se decidiera a estudiar arte? - el melocotón se volvió frío, como si acabaran de cortarlo con un cuchillo para la fruta.

- Matar, lo que se dice matar, no. Pero me vendería a plazos por más de un cuadro - hablaba, sin duda, mi primera copa de cońac y no yo.

- ¿Y nunca te ha dado por pintar? A tu edad uno quiere estar a ese lado del mundo.

- Yo es que soy un mirón.

-Ya veo, ya.

—En serio, María Cristina. A mí me gusta observar. No aspiro a ser Toulouse-Lautrec.

- ¿Ah no?

-No. No me seducen ni los burdeles ni la absenta. Además, prefiero evitarme el desengaño de descubrir, después de toda una vida emborronando paños, que no sirvo para esto.

- Pero ¿y si al final de todo resulta que sí sirves?

- No creas. Ya he pintado bastante. Lo bastante como para saber que no puedo expresar ni de lejos todo lo que quisiera.

El romanticismo pesimista y anacrónico de mi juventud debió de conmover aún más a la bella cuarterona, que terminó pidiendo otra copa para ayudar a 
nuestras almas a llegar a la medianoche. La luna restañaba las heridas leves que había dejado la lluvia y, agazapados en la noche, nos cruzamos recuerdos por un rato. Ella habría querido ser actriz de teatro. De chica se pasaba horas encerrada en el cuarto de baño, la única habitación de su casa con espejo. Jugaba a imaginar (como nunca había ido al teatro, no podía imitarlos) los movimientos y los gestos de sus heroínas dramáticas. Vivía a dos manzanas de la Universidad de Caracas, en un barrio humilde al que ocultaban, como quien se avergüenza de un pariente pobre, los anchos edificios de piedra que rodeaban el Rectorado, así que no le era difícil sacar de la biblioteca de Letras libros de teatro clásico para, por arte de magia, convertirse en la mejor Julieta: jAh corazón de serpiente, escondido en rostro florido! ¿Ha habido jamás un dragón que tuviera tan bella caverna? 'Hermoso tirano!, sus ojos expresivos eran, por sí solos, un poema.

¿Que si sólo le gustaba el teatro inglés?

Es que detestaba el papel deleznable que dan a la mujer los autores latinos. Ese concepto del honor tan machista de Lope, Calderón o Molière me sacan de mis casillas. Odio a las mojigatas que hacen corrillo alrededor de los don Juanes. Incluso en una ocasión, te lo juro, me empeñé en travestirme de Tartufo para gozar por unas horas del placer de sentirme engañadora y no engañada y fue tanto lo que disfruté que, ¿cómo te diría?, tiré el peso al aire y salió mujer fatal. Cuatro años después me casé con un hombre que me doblaba la edad y del que no estaba enamorada — aunque de veras lo llegué a querer- pero que tenía dinero, mucho dinero, y que me iba a sacar del barriucho aquel a la sombra de la Facultad de Letras de Caracas.

— ¿Y qué pasó luego? — pregunté con cierto temor ante la posibilidad cada vez más real de pasar la noche con una devora hombres convicta y confesa.

- Nuestro matrimonio duró, a pesar de todos, siete años. $\mathrm{Y}$, ¿sabes qué? Fue la etapa más feliz de mi vida. Él me enseñó a apreciar las cosas, a valorar los momentos como si fueran a robártelos un segundo después. La Ópera, los museos, los viajes a Europa, las joyas que me regalaba cada aniversario de boda no eran nada, te lo juro, al lado de los instantes de intimidad, cuando nos quitábamos las caretas y los prejuicios y nos quedábamos caladitos, en pelota viva, bajo las sábanas. Aprendí con él las cosas más estúpidas e inservibles de este mundo, pero también las más encantadoras.

—Mi padre solía decir algo parecido — repliqué, bastante más relajado después de conocer el penúltimo acto de la historia de la San Ginés. —Decía que para que una cosa te haga de verdad feliz tienen que darse tres condiciones: que no se pueda comprar, que no se pueda vender y, sobre todo, que no se pueda explicar. 
II.

Yo era un muchacho tranquilo hasta que di con mi sueño más dorado, que era una mujer algo mayor que yo. La ínclita cuarterona cuarentona que había conocido en el Ateneo entre Cézannes y Monets se me metió por dentro de la adolescencia, ese estado del mundo que, según mi padre, va entre la paja y la caja. Una semana después de nuestro encuentro me llegaron a casa dos docenas de rosas rojas. No quiero recordar el trabajo que me costó que se les borrara a mis compañeros de piso la sonrisa idiota a vueltas con el ramito del carajo. Para remate de la puñeta venía una tarjeta acompañando al ramo que olía más a rosas que las rosas mismas y decía que quiero verte, cholito, una vez más antes de que me muera.

Una vez más duró casi seis semanas.

Treinta y nueve días con sus treinta y nueve noches en medio, delante y detrás del amor, de una guerra de amor cuartelero y cuartelario en el que se amaba religiosa y atea y agnósticamente cada cuarto de día y cada cuarto de noche y en los que perdí tres exámenes parciales que apenas me costó recuperar y cinco kilos totales que aún no he recuperado. Me dejé dos camisas que nunca terminaban de plancharse, un pijama que me regaló la primera semana y que, al final, nunca usé y un libro de poemas de Verlaine, Romances sans paroles, que, para entretener los antojos de María Cristina San Ginés, le leía por las tardes. Vine a ganar, sin embargo, la historia más intensa que recordarse pueda, que parecía la historia de nunca acabar y la historia lo mismo de acabar conmigo por siempre amén. Para cuando regresé a casa por Semana Santa, los compañeros estaban a un palmo de realquilar mi cuarto, las dos docenas de rosas rojas se mantenían inmaculadas en el florero de cristal y las flores de cristal de mi alma habían florecido de puro entusiasmo.

La casa donde vivía María Cristina San Ginés era un pequeño palacete en el camino de Las Peras con torreones de piedra rojiza. No he vuelto a ver en mi vida un jardín tan precioso y tan bien cuidado, aunque le faltaran por lo menos veinticuatro rosas rojas. La entrada estaba flanqueada por dos verdes cipreses, enhiestos surtidores de sombra y sueño. Sólo que, en aquel momento, era yo y no el cielo el acongojado. Llegué a tocarlo — me refiero al cielo- con los dedos, al mismo tiempo que sentía que millones de algas tenebrosas me arrastraban a las profundidades del infierno. Pero, por encima de todo, viví las casi seis semanas en una suerte de purgatorio en el que iba a pagar por no sé que pecados cometidos en la vigilia de mi niñez. El caso es que, desde el principio, estaba claro que iba a saltar de la gloria al olvido en muy poco tiempo. 
Me recibió mi dama esa primera tarde sobre las seis y media porque al té de las cinco jamás hay que llegar puntual que eso, mi cielo, se lo vamos a dejar a los británicos tan sosos y formales. Empezaba a morirse marzo por las cuatro esquinas de los calendarios y ya no eran tan frescas las tardes laguneras. La San Ginés vestía de julio o a mí me pareció que vestía de julio acaso por el sofoco: cubierta por una ligera bata creo que de satén y abrochada a un costado, debajo — de eso no me cupo duda - sólo llevaba el perfume de frambuesas que me había desconcertado la vez primera. Sus pechos me apuntaban directo al corazón en una etapa de la vida en la que uno tiene el corazón repartido por todo el cuerpo. Firmes, erguidos, dominantes, María Cristina San Ginés me miraba no con los ojos — ahora lo sé- sino con aquellos pechos mal disimulados bajo la bata malva a juego con sus ojos que entonces ya eran malvas de puro demoníaco pero, como ya dije, no me miraban. Al sentarse y ofrecerme una taza de ROYAL BLEND TEA, lo recuerdo porque, como no sabía adónde mirar, no aparté nunca la vista de aquella lata verde en la que se mezclaban «armónicamente los mejores tés de la India y de Ceylán", dobló una pierna sobre la otra y la bata dejó entrever un inmenso muslo, interminable y caoba, que se perdía en tremendas y turbadoras curvas. Tuvo que notar mi turbación porqué probó a arreglar el roto inarreglable que le había hecho ya a mi ánimo y se cubrió aquel muslo y yo volví a mi té verde, indio y ceylanés.

— ¿Vas a hacer alguna tesis sobre la industria tetera británica?

$-\dot{i} \ldots$ ?

—Puedo dejarte la lata por si quieres copiar la fórmula de mezcla... ¿̇zúcar o miel?

-Miel, por favor.

— ¿Pastas?

-No, gracias.

- Bueno, cielito, supongo que te habrán extrañado las flores y la tarjeta. No acostumbro a hacer esas cosas en contra de lo que puedas pensar, pero no conozco a mucha gente interesante aquí y tuve la sensación de que a nosotros, la última vez, nos quedó una conversación pendiente.

Sonreía con franqueza.

O era una mentirosa profesional o su vocación era tal que hasta sus manos habían aprendido a mentir con encanto. Lo que quiero decir es que me estaba encantando en toda la extensa acepción del término. ¿De verdad una mujer así podía estar tan sola como para necesitar la amistad de un adolescente tímido y casi pacato? La historia que contaba no tenía sentido pero, creo que ya lo he dicho, tenía encanto. Tuve que dejar muy pronto el té amargo — no fui capaz 
de revolver el fondo de la taza y la miel se quedó allí olvidada—, sobre la mesilla de aquel salón malva (ahora que lo pienso, lo del malva era enfermizo en la historia con la San Ginés: sus ojos, la bata, el salón, mi rubor) porque empezaban a castańetear y delataban mi estado. Mi estado era, por supuesto, cataléptico, de un cataléptico insano y lamentable.

"¿Por qué estás tan nervioso? Habrás estado ya con alguna chica, ¿no?» María Cristina San Ginés supo enseguida que no, que no había estado aún con ninguna chica y yo supe enseguida que sí, que ella lo había sabido por el brillo de estrella que se le dibujó en la sonrisa y la humedad repentina que le brotó en la comisura de los labios cada vez más rojos y más cuarterones.

El desconcierto dejó paso al pavor y éste al caos más absoluto. La hermosa mujer se daba perfecta cuenta de la situación ventajosa que tenía en esa partida extraña de ajedrez que es el amor. Ella había movido primero. Y ya tenía dos letales alfiles negros bajo una bata malva amenazando, arrinconando, acorralando a mi rey. A todas estas, mis peones danzaban al son de su música y se entorpecían unos a otros en la llanura del tablero. La situación era patética. Desesperada. El plato con su taza y su té indioceylanés se hizo añicos con solo la intención de acercarme a ellos. Mis manos dejaban una huella húmeda de sudor en todo a lo que intentaba aferrarme para disipar mis temores. El cuello de la camisa me llagaba la nuez. Sin embargo, ella parecía disfrutar con mi ansiedad. Su mano suave, de dedos largos y afilados, golpeaba rítmicamente el sillón, en un claro ademán de siéntate a mi lado.

Recuerdo el tap-tap— tap de esa mano enorme sobre el cojín de raso como en una película del viejo cine Avellaneda. El director había ralentizado la escena y había hecho enmudecer la cinta a fin de sobredimensionar la tensión: una manota de uñas largas y bien arregladas despabilando lenta y agónicamente un sillón malva; un galletón aterrado y sudoroso, con nuez llagada y móvil; los labios carnosos de María Cristina San Ginés. Si me apuran juraría que, al entreabrirse, esos labios carmesíes descubrían afilados colmillos. Y tal vez el gesto no fuera ése. Tal vez su intención fuera sólo la de que yo me acercara para oírme mejor. Tal vez el calor incipiente de la primavera, y no el incipiente calor de mi primavera, fuera lo que me hacía sudar a mares. Tal vez la mancha rojiza en los blanquísimos dientes de aquella mujer significara únicamente que se había pasado con el carmín de labios. Tal vez. Pero eso había que explicárselo a un ingenuo pibe que no conocía - ni en el sentido bíblico ni en el otro- a mujer alguna y que veía cómo su rey estaba siendo masacrado en la primera partida de ajedrez a la que se enfrentaba. 
A partir de ahí, sólo recuerdo abrazos desnudos e interminables, carne de ébano brillante, caderas inmensas y un vientre liso. Y graves espasmos. Y caricias húmedas. Y besos ásperos que llegaban a dañarme las encías y me dejaban un regusto dulce en la lengua. Y, sobre todo, risas, muchas risas porque la impresionante madonna caraqueña no dejó de reírse las casi seis semanas, los treinta y nueve días y, más que nada, las treinta y nueve noches. Nunca he visto a nadie reír tanto y tan a gusto: se reía de mi torpeza, de mis preguntas a destiempo, me mandaba a callar fingiendo enfado porque no me dejas concentrarme, mi cielo, no estás en lo que estás y así jamás y nunca podrás venirte a gusto, se reía también de mis pelos enmarañados, de mis tirones musculares. Y ahora sé, muchos años después de aquel encuentro que marcó mi vida, después de que aquella extrańa mujer decidiera desaparecer de mi vida tal y como había entrado, con veinticuatro rosas rojas, esta vez sin mensaje, ahora sé, digo, que María Cristina San Ginés no me enseñó el amor, pero me enseñó algo que me ha servido de gran ayuda para combatir sus estragos: la risa. Y la risa, hoy lo sé, es otra forma de amor.

\section{EPÍlOGO.}

Ayer fui a visitar, tras mucho tiempo, una exposición de pintura.

La Regenta me hizo llegar una invitación a la Facultad. Había rechazado muchas veces invitaciones como aquella pero, no sé bien por qué, esta vez decidí que era un buen momento para llevarme a mis alumnos de tercero a descubrir América otra vez. Ellos, con tal de librarse de una de mis clases de Estética, son capaces de aparentar felicidad e, incluso, vivo interés en una visita de esa índole, así que allí nos fuimos en amor y compaña.

Una llovizna gris, como de tango,

nos acompañó toda la tarde. El otoño empezaba a despuntar en el aire y todo junto —otońo, tarde y llovizna- fue haciéndose un nido en mi ánimo. Volví a revivir una escena de quince ańos atrás que, bien mirado, son tres cuartos de nada. De este modo sentía cuando entré en La Regenta, el piso de mármol color marfil, luz natural por entre las vidrieras, olor a limpio. No logré fijar mi atención al principio en los detalles, tan pendiente que estaba de organizar a los chicos, de responder a sus preguntas, de recomendarles alguna sala en especial. Se me fue la primera hora en un suspiro. Por eso no lo vi hasta casi el momento de marcharme, cuando ya pude gozar en soledad de la visita. La sensación del espectador, del mirón de arte, es algo parecida a la del lector de sillón de oreja: es una sensación íntima, egoísta, incompartible, muy lejos de la del público de cine o de teatro. Así que, una vez mi alumnos se fueron 
despidiendo, pretextando como siempre las más peregrinas excusas, la guagua que no espera, la visita médica de última hora, el óptico, me quedó para mí solo la galería de arte.

Fue entonces cuando el cuadro me llamó la atención. En la sala de pintura cubana, destacaba lo que llamamos en el oficio una composición de taller. El óleo representaba lo que parecía un descanso de la modelo en pleno proceso de creación artística. En primer término, algo ladeado a la izquierda, como vértice de un triángulo invertido, se veía una mesa de lectura sobre la que yacían desperdigados algunos libros y un jarrón de enormes rosas tensionaba la disposición del cuadro. A la derecha, centrado, una mujer desnuda se desmayaba de cansancio, harta acaso de posar para el artista, y dejaba caer indolentemente el libro que leía. En la esquina superior izquierda, como observando la escena, un espejo ofrecía el desnudo de la dama desde otra óptica. Esa estructura especular siempre da una sensación entre melancólica y reflexiva. Hace que uno se pregunte cuál de las dos realidades pretende plasmar el pintor, el derecho o el revés de la hermosa mujer. Hay, por ello, un doble engaño, una doble ficción: la del arte, que es representación de la realidad y no realidad en sí, y la de la imagen del espejo.

Había algo familiar en aquella obra que, al principio, achaqué a Velázquez. La composición, en el fondo, no era diferente a la de Las hilanderas o a la misma Venus del espejo. Creo recordar que Manet pintó también algo parecido, Lectora en reposo me parece. Sin embargo, no era sólo eso. Acostumbrado como estaba a desentrañar los detalles más insignificantes del arte, como un cirujano con un bisturí, a veces me olvidaba de lo más evidente, de lo que cualquier espectador podría descubrir a primera vista. Además, estaba cansado, ya era tarde, había sido un día muy duro. Ya me marchaba, pasaban unos minutos de las siete y el celador tosía y miraba insistentemente su reloj. Cuando estaba por abrir la puerta de salida, algo me hizo detener, claro, tolete, y volver sobre mis pasos. Mentí en la recepción, me he dejado el paraguas en la sala del fondo, y llegué a la pintura con el tiempo justo de verlo todo claro, de ver, antes de que algún imbécil acelerado apagara las luces de la galería, el Retrato de M.C. con espejo, dos pechos de pura trementina apuntando al corazón, veinticuatro rosas rojas y una mano larguísima dejando languidecer un poemario, Romances sans paroles, que alguien me devolvió, esta vez para siempre, con quince años de retraso. 



\title{
LA SUPERVISIÓN DE LA INTERVENCIÓN EN EL CAMPO DE LA EDUCACIÓN SOCIAL
}

\author{
Manuel de Armas Hernández \\ Departamento de Educación \\ Facultad de Ciencias de la Educación \\ Universidad de Las Palmas de Gran Canaria
}

\section{Resumen}

Se describe la visión de la supervisión como uno de los métodos de desarrollo profesional tanto para estudiantes como para profesionales de la Educación Social ya que ayuda al crecimiento profesional de la praxis educativa fortaleciendo el trabajo en equipo y previniendo el desgaste profesional o burnout.

Palabras claves: supervisión, educación social, desgaste profesional, reflexión.

\begin{abstract}
The vision of supervision is described as one of the methods of professional development for both students and professionals of Social Education since it helps the professional growth of educational praxis by strengthening teamwork and preventing burnout.
\end{abstract}

Keywords: supervision, social education, burnout, reflection.

\section{INTRODUCCIÓN}

La supervisión como ámbito de investigación, como práctica en las instituciones y como formación docente para los educadores sociales ${ }^{1}$ como profesionales de ayuda, en nuestro país es más una excepción que una regla y en los casos que se ha practicado ha sido más como una iniciativa de algunos pioneros en la materia que como una necesidad o una exigencia de las instituciones universitarias y de los docentes, de cara a la formación de los futuros profesionales de la Educación Social. Es hora de reclamar un espacio de formación y reflexión en nuestro Grado de Educación Social, es decir, incorporar la supervisión como

1 Consideramos dicho término inclusivo tanto para hombres y mujeres del campo de la Educación Social 
asignatura en la formación universitaria y también en el campo de desarrollo profesional del educador social ${ }^{2}$.

Además, la formación del educador social ha estado siempre ligada al trabajo práctico y en el marco de la formación universitaria se plantean dos categorías básicas de conocimientos a adquirir:

1. Conocimientos teóricos, básicos o específicos que suministran el marco de referencia conceptual y de explicaciones, con diferentes niveles de generalización, de las situaciones sociales y de diversos fenómenos y problemas que caracterizan el objeto de intervención profesional.

2. Conocimientos de las condiciones y posibilidades de intervención y de los medios eficaces para promover la modificación de las situaciones sociales que son problemáticas o que por su propia condición dinámica deben cambiarse.

Por otra parte, con mayor o menor intensidad todos los Grados y Departamentos relacionados con la Educación Social en nuestro país, proporcionan prácticas a los estudiantes que suelen ser un eje fundamental en el aprendizaje y conocimiento de su futuro profesional. Estas prácticas se deberían configurar en dos espacios complementarios entre sí, que son por un lado las prácticas en centros o servicios externos a la Universidad y por otro lado en la creación de una nueva asignatura que lleve el nombre de Supervisión en el campo de la Educación Social.

Ya que la posibilidad de realizar algún tipo de observación y práctica directa en centros y servicios externos permite a los estudiantes confrontarse directamente en mayor o menor grado con lo que representa el rol profesional y también con las diversas situaciones de conflicto y con la aplicación de las políticas sociales en distintos ámbitos sociales. Esta incorporación de los estudiantes en servicios específicos requiere que algún docente al servicio del alumnado realice el acompañamiento y tutelaje del alumnado en prácticas. La supervisión de la intervención sería el recurso de aprendizaje que se ofrecería paralelo a la realización de las prácticas directas, teniendo como objetivo relacionar didácticamente las referencias teóricas y las referencias prácticas.

Pues a partir de la supervisión se promueve la reflexión sobre situaciones vivenciales y las propias experiencias adquiridas en la práctica. Se facilita tam-

$2 \mathrm{Al}$ considerar el término educador social nos referimos tanto a la educadora como al educador social. 
bién el confrontar los conocimientos teóricos recibidos, operativizándolos y ayudando a profundizar en las contradicciones que aparecen entre el binomio teoría-práctica. Es a partir de la supervisión que debe optimizarse esta confrontación sin permitir que las contradicciones se queden en un análisis fácil y en la consolidación de tópicos como: "La Universidad está lejos de la realidad, en las nubes y la práctica no tiene nada que ver con lo que se enseña".

$\mathrm{Si}$ bien es cierto que en muchas ocasiones existen grandes diferencias entre lo que se imparte en las clases teóricas y lo que se realiza en la práctica, no por ello debe de claudicarse en que los estudiantes pretendan aplicar con un máximo de perfeccionamiento los conocimientos adquiridos que, aunque en ocasiones puedan parecer utópicos es importante que se tengan como referencia necesaria y óptima en el quehacer docente. Es en la supervisión, como espacio bisagra entre la práctica directa y las clases teóricas, donde se puede facilitar esta reflexión sobre los contrastes, animando a los alumnos a que no abandonen el aprendizaje adquirido y que sean capaces de aplicarlo a su manera de una forma creativa y propia que les permita precisamente adquirir su propia identificación con una forma determinada de actuar profesionalmente, ya que el campo de actuación del futuro profesional de Educación Social es bastante amplio, dirigido a diferentes colectivos vulnerables en el que se hace necesario la adquisición de competencias amplias y variadas; donde pensamos que gracias a las tareas de la supervisión se puede ayudar a estos futuros profesionales a aumentar la tolerancia a la frustración profesional.

\section{CONCEPTUALIZACIÓN DE LA SUPERVISIÓN}

En cuanto al concepto y definición de supervisión, hemos de tener presente que la palabra procede del latín super y videre, que significan "ver por encima". En los diccionarios se define la supervisión como "la actividad de vigilancia e inspección superior de una actividad". No obstante, en su aplicación en el campo de la intervención socioeducativa de la Educación Social ofrece un marco donde facilitar una reflexión sobre las actuaciones profesionales y donde favorecer el mantenimiento de aprender y de mejorar las propias actuaciones.

Sheriff y Sánchez (1973) definen la supervisión como un método de formación continuada mediante el cual se refuerzan los conocimientos adquiridos, y la consideran una pedagogía donde se aprende y enseña a instrumentar las proposiciones de acción en base a una intencionalidad definida, permitiendo a alumnos y profesionales implicados en el proceso una concienciación por medio del diálogo, la reflexión y la crítica presentes en su metodología. La con- 
frontación de la teoría y la práctica da la oportunidad de construir, integrar conceptos y técnicas, y cuestionar la praxis en función de la intervención socioeducativa.

Para Tuerlick (1966) la supervisión no es sinónimo ni de control, ni de inspección, ni de vigilancia, considerando que su contenido es de educación, instrucción y formación. Para esta autora, la supervisión es un método fundamental mediante el cual se enseña, en función de la práctica cotidiana, la aplicación de los principios del campo social a los estudiantes o a los profesionales de un organismo con el fin de ir consiguiendo determinados estándares en el desarrollo profesional y en la formación de estudiantes. Considera que mediante la supervisión se establece una relación dinámica entre el supervisor, el profesional y el estudiante que, en base a sus conocimientos, a la comprensión de sí mismo y de los demás, y a su experiencia en el campo de la intervención socioeducativa, presta una ayuda a los estudiantes y a los profesionales.

\section{DESARROLLO DE LA INTERVENCIÓN EN SUPERVISIÓN}

Fernández (1997) diferencia tres tipos de supervisión:

1. La supervisión administrativa. Es la que procede de la organización, ya que en la planificación de un servicio se considera necesario que se supervise a su personal. La supervisión forma parte del conjunto de la aplicación de un determinado programa teniendo en cuenta al supervisor, que en este caso se le atribuyen unas funciones específicas y se le pide unos resultados que siempre están relacionados con la mejora de los servicios que se ofrecen a sus usuarios. Los supervisados no demandan explícitamente una supervisión, ya que se la encuentran formando parte de la propia organización en la que están trabajando o van a trabajar El supervisor recibe la información de la dirección del centro y ha de valorar cuál es la que ha de transmitir a los supervisados para ayudarles en su trabajo. Se ha de partir de la base de que cuánto más partícipes se haga a los educadores sociales de los planes de actuación del centro o servicio, más implicados y activos se sentirán. Los supervisores han de transmitir la política de la institución, aunque no estén de acuerdo con ésta en todos sus aspectos. También han de tener en cuenta las quejas y sugerencias de los supervisados sobre la política de funcionamiento y sobre los planes de actuación para proponer cambios y alternativas a la dirección. Se ha de tener en cuenta que en este tipo de supervisión al supervisor se le atribuye un poder, ya que se le ha transmitido una autoridad desde la dirección de la organización. Para la mejor eficacia de esta su- 
pervisión se propone que ésta pase de cumplir una función de fiscalización administrativa a cumplir una función de contenido democrático y cooperativo.

2. La supervisión educativa. Es la que tiene como objetivo primordial enseñar, formar y ayudar a mejorar conocimientos a los educadores sociales o a aquellos estudiantes que están en fase de formación para convertirse en profesionales. La supervisión que se lleva a cabo con los alumnos es básicamente educativa, ya que su objetivo prioritario es participar en la formación del estudiante. Este tipo de supervisión ofrece los recursos para realizar el trabajo con eficacia, y ayuda a crecer al futuro profesional. En definitiva, se dedica a la enseńanza de conocimientos, técnicas y actividades necesarias para realizar las tareas de atención directa de los futuros educadores sociales mediante el análisis de la interacción usuario y "profesional". Se ha de evitar juzgar, pero se tiene que permitir la expresión de los distintos hechos, aplicando un objetivo básico de formación y aprendizaje del alumno-supervisado.

3. La supervisión de apoyo. Es aquella que tiene en cuenta en sus objetivos y aplicación el ofrecer apoyo a los educadores sociales que reciben dicha supervisión, de forma que puedan superar mejor las tensiones y dificultades que se presentan en el ejercicio de su trabajo. Los profesionales han de enfrentarse a situaciones difíciles, desagradables y complejas en su práctica profesional. El trabajo de dichos profesionales se encuentra dentro del campo de las ciencias humanas y de los problemas y sufrimientos que padece la población. Se enfrenta continuamente a situaciones de injusticia y de desigualdades que son muy difíciles de contrarrestar y de cambiar. Estos factores tienen muchas veces como consecuencia la aparición de sentimientos de desánimo, impotencia e incapacidad. La dinámica institucional, las luchas de poder y el prestigio dentro de la institución, la escasa claridad de los programas sociales e incluso una cierta perversión institucional, originan en muchas ocasiones que los educadores sociales tengan dificultades inherentes al lugar que ocupan dentro de un sistema institucional. El campo de las ciencias humanas y especialmente el campo de la Educación Social, que tiene como ámbito de actuación trabajar con una población que puede considerarse vulnerable en una sociedad donde se valora todo aquello que puede cuantificarse económicamente, tiene muchas veces como consecuencia que el trabajo específico de los educadores sociales no sea suficientemente reconocido. Dicha supervisión no está reñida con la crítica cons- 
tructiva, ya que, a veces, se ha de ser crítico con el profesional. Si no se es, el educador social-supervisado puede pensar que no se le cree capaz de soportar sus valoraciones y críticas, y puede sentirse minusvalorado (Jiménez Bertomen, 2000).

Nosotros estamos convencidos tanto desde el marco teórico como desde el marco práctico que la supervisión en el campo del desarrollo profesional de los educadores sociales ayuda a trabajar el conflicto como una herramienta de trabajo y no como un problema en el trabajo ya que:

a) Cohesiona al equipo de educadores sociales.

b) Es un buen antídoto a la falta de reconocimiento profesional y al burnout.

c) Mejora el clima profesional en la institución donde trabaja el profesional de la Educación Social.

d) Refuerza la línea pedagógica de intervención de la institución.

e) Forma parte de la formación permanente de dichos profesionales de la Educación Social.

Para lo que lo descrito anteriormente sea una realidad y no una excepción en el Campo de la Educación Social es necesario que los Colegios Profesionales de Educadores y Educadoras Sociales de todas las Comunidades Autónomas y las Administraciones públicas competentes en el desarrollo profesional de los educadores sociales lo vean y lo sienta como una herramienta necesaria de mejora de la calidad de la intervención para el trabajo que se desarrolla con los diferentes colectivos vulnerables de nuestra sociedad.

A lo expuesto anteriormente, deseamos añadir las aportaciones de Puig i Cruells (2011, p.8) sobre los cuatro ejes fundamentales con los que los profesionales del trabajo social manifiestan problemas o conflictos habituales:

1. El que se establece con los grupos de personas; es decir, tiene que ver con las relaciones que se establecen entre profesionales, agentes sociales, trabajadores y miembros de las instituciones. Las relaciones entre ellos son las que pueden dificultar o, por el contrario, facilitar el desarrollo del proyecto.

2. Los que surgen entre los profesionales y la institución. La formalización del encargo, la confusión de la demanda y el marco legal son algunos de ellos. De este tipo de conflictos se derivan dificultades de comunicación y problemas para resolver los encargos de la institución, así como su permanencia. 
3. Los conflictos entre el profesional y sus herramientas o técnicas de trabajo; es decir, con el cómo trabajar con las necesidades o el malestar de las personas a quienes debe atender.

4. El de los recursos de que dispone para desarrollarse en el marco institucional, y que está representado por tres ámbitos interrelacionados: los marcos teóricos (aquello que sabe o que no sabe el profesional), sus instrumentos y las habilidades.

Por otro lado, creemos que la supervisión puede ser de dos tipos:

a) Externa: el profesional no tiene relación con la entidad que lo contrata y es el equipo de educadores sociales quién propone a dicho profesional.

b) Interna: es la institución en la que trabajan estos profesionales la que propone a dicho supervisor o supervisora de apoyo.

También, creemos que dicha supervisión puede ser en grupo o individual, por un lado, centrada en la tarea, en la intervención o en casos; y cuando hablamos de grupo, puede ser el grupo educativo o el grupo interdisciplinar, ya que consideramos la supervisión como un espacio de reflexión y crecimiento profesional tanto individual, grupal e interdisciplinar; pues la supervisión permite el análisis de la práctica profesional que deben de realizar y realizan los profesionales de los diferentes ámbitos de intervención de las personas vulnerables (infancia, juventud, adultez y senectud).

Para ello, debemos de tener presente que los objetivos específicos de la supervisión pueden variar según se trate de un tipo u otro de supervisión, aunque la intervención socioeducativa en la desadaptación social tiene unos objetivos generales comunes que se atribuyen al perfeccionamiento de la preparación teórica y práctica del alumno y el profesional, y a una mejor satisfacción de la práctica y de la profesión (Kane, Hamlin \& Hawkins, 2002). También deseamos añadir que uno de los objetivos importantes de la supervisión es la reflexión y la mejora de la tarea de la intervención de los diferentes educadores sociales ante el conflicto, ya que favorece la reflexión del grupo de profesionales con un conocimiento crítico constructivo de la intervención donde se acepta el error en la intervención como mejora y no como negligencia profesional.

Otro de los objetivos de la supervisión es que nos orienta en la resolución de los diferentes conflictos a través de la reflexión y la cooperación de los diferentes profesionales construyendo un proceso de intervención técnico experiencial y especializado, donde aparecen elementos de generación de cambios 
que fortalecen la línea pedagógica de la institución, resolviendo de manera satisfactoria y con límites reales la resolución de dichos conflictos. Con ello conseguimos un autocuidado de los profesionales supervisados y no una crítica negativa y autodestructiva hacia el colega que interviene en la resolución del conflicto; pues se evita el riesgo de intervenciones improvisadas que nos pueden llevar hacia una mala praxis profesional.

Por otro lado, entendida la supervisión como espacio donde realizar la revisión de teorías, analizar la praxis profesional o las funciones ante las tareas que deben de llevar a cabo los profesionales de la Educación Social, no podemos olvidarnos de los tres actores que Moyano (2011, pp. 3-4) nos indica:

1. Las administraciones públicas. Si atendemos a las responsabilidades públicas subyacentes al despliegue de las políticas sociales, y las implicaciones directas o indirectas en los diseños, planificaciones y evaluaciones de los diferentes marcos institucionales que conforman los sistemas de atención social, sin duda constatamos que hay un cierto "décalage" entre las necesidades de revisión y control, y el impulso y el apoyo a espacios de supervisión. Por otro lado, si también atendemos a la terciarización de la atención social, la creación y el fomento de estos espacios se supedita al interés y la posibilidad de las entidades que se hacen cargo. En definitiva, no existe un marco establecido, consensuado y previsto, que manifieste la oportunidad y la idoneidad de promover espacios de este tipo en el campo de las prácticas sociales y educativas. Los compromisos, por lo tanto, se sitúan en la orden de las recomendaciones, no tanto de las facilitaciones.

2. Las agencias de formación. La referencia a este actor en la relación entre supervisión y Educación Social radica en el mismo recorrido histórico de la formación del educador o educadora social en nuestro territorio. El espacio de supervisión ha tenido un papel clave en su vertiente formativa en cuanto que ha supuesto un espacio de intercambio, conexión y análisis de la práctica educativa en las instituciones que en la actualidad hemos convenido a denominar de Educación Social. Es decir, que han supuesto espacios formativos complementarios de los equipos profesionales, lugares donde ampliar, revisar y construir. No nos referimos, en este sentido, tanto a entender la supervisión como una actividad de formación continuada del educador o educadora social, sino más bien a la supervisión como un lugar de construcción profesional que incorpora elementos formativos. En relación a esta cuestión, nos señala el papel clave que puede tener un espacio que permite analizar las prácticas que 
un profesional lleva a cabo, teniendo en cuenta que el ejercicio de una profesión dota el profesional de una serie de recursos y experiencias que, difícilmente, la formación inicial puede ofrecer.

3. Los profesionales. Quizás nos encontramos ante el actor más importante en la conformación de espacios de supervisión; una importancia referida a la significación que cobra la supervisión para los profesionales de la atención y la Educación Social. En este sentido, conviene un trabajo, también, desde las asociaciones y colegios profesionales que promueva una cierta cultura de la supervisión; es decir, sostener y demandar la necesidad de la creación y mantenimiento de estos espacios, en clara referencia a la mejora de la educación y la atención de las instituciones. Es, pues, por este motivo que el profesional supone un elemento clave, puesto que, desde su posición y desde su trabajo, es el que alimenta estos espacios.

Además, Hernández Aristu (1991) destaca como función de la supervisión la de favorecer la adquisición de una (nueva y futura) identidad profesional y la de aprender una forma de ser y actuar. Mediante la supervisión los estudiantes aprenden un nuevo rol profesional y, por otro lado, se renueva el rol existente en el caso de los profesionales en ejercicio.

Tampoco podemos olvidarnos de las aportaciones de Longres (1977) que nos definió lo que serían cuatro objetivos básicos de la supervisión:

1. Enseñanza y formación permanentes

2. Ofrecimientos de servicios de calidad

3. Socialización del estudiante y el profesional

4. Elevación del nivel teórico y práctico de las actuaciones

Para finalizar, destacamos las aportaciones de Lobato (2007, p. 43) que, siguiendo las orientaciones de la teoría de la comunicación, los elementos de referencia reflexiva y de comunicación en las sesiones de supervisión serían:

1. Análisis de la institución socioeducativa. Los elementos institucionales, en cuyo marco se lleva a cabo la labor de relación de ayuda.

2. Análisis de las relaciones. El cómo determina o condiciona decisivamente el qué en la interacción, la realización de las tareas, la consecución de los objetivos, el cumplimiento de las funciones, etcétera, dentro de las instituciones en las que el profesional en general ejerce su profesión.

3. Análisis de la propia personalidad del profesional. La relación con los destinatarios y miembros del equipo de acción no es independiente de la 
propia personalidad del profesional. La historia personal en los procesos de socialización, así como los propios valores, la concepción de la vida, la imagen personal que de sí mismo tiene, sus inhibiciones y miedos, etc., están presentes influyendo en el tipo de ayuda.

4. Análisis del bagaje técnico profesional. La intervención de ayuda, en general, requiere un método, y unas técnicas, en definitiva, un saber hacer, saber actuar adecuadamente ante la situación. Supuesto el diagnóstico social acertado, el profesional necesita de unas "técnicas o instrumentos de intervención" que requieren planificación, estrategia, tácticas y técnicas. Depende también de su capacidad metodológica y técnica, de los medios de que dispone, del modo de usarlos, etc., el que su intervención tenga o no éxito.

Estos son, pues, los cuatro puntos de referencia a la hora de percibir, entender, y comprender la situación en la que se encuentra, o encontrará, el supervisado y el equipo de profesionales en el ejercicio de su profesión. Paralelamente a lo que ocurre en cualquier interacción, todos estos elementos, sociales, relacionales, personales, instrumentales están presentes en la intervención socioeducativa del campo de la Educación Social, por lo que hay que tenerlos en cuenta y no hay que descartar que, en el transcurso de la supervisión, se tematicen o focalicen primordialmente alguno de ellos, circunstancia que puede ser la clave del cambio o del inicio del cambio y mejora de la calidad del clima institucional y profesional.

\section{A MODO DE CONCLUSIÓN}

Con la descripción de lo aportado anteriormente sobre la supervisión somos conscientes de que tenemos que sensibilizar al alumnado de las diferentes Grados de Educación Social y al colectivo de profesionales de la Educación Social para que se promocione la supervisión como necesidad de mejora y desarrollo de la calidad e intervención con los diferentes colectivos vulnerables de nuestra sociedad, ya que somos profesionales de la ayuda y el desgate de nuestra profesión nos lleva a la promoción de esta herramienta como prevención del burnout entre los diferentes profesionales pues, la supervisión es un proceso de aprendizaje, que favorece el desarrollo de actitudes colaboradoras y cooperativas en la intervención socioeducativa de la Educación Social cohesionando al equipo de profesionales y mejorando el clima institucional; ya que se viabiliza un mejor funcionamiento en el ejercicio profesional y posibilita una mejor 
transformación social. En definitiva, la supervisión debe de formar parte de la construcción de la identidad profesional del educador y educadora social.

\section{REFERENCIAS}

Fernández, J. (1997). La supervisión en el trabajo social. Paidós.

Hernández Aristu, J. (1991). Acción comunicativa e intervención social: Trabajo Social, Educación Social, Supervisión. Popular.

Jiménez Bertomen, V. M. (2000). El fenómeno del "Burnout" en los profesionales de ayuda. Revista de Treball Social, (159), 65-103.

Kane, M., Hamlin, E., \& Hawkins, E. (2002). Percepció de l'eficàcia de diferents mètodes de supervisió. Revista de Treball Social, (166), 45-66.

Lobato, C. (2007). La supervisión de la práctica profesional socioeducativa. Revista de Psicodidáctica, 12(1), 29-50.

Longres, J. (1977). El marco de fuerzas de la supervisión. Publicaciones del GITS.

Moyano, S. (2011). La supervisión como espacio para la reflexión educativa. Revista de Educación Social, 13, 1-10

Puig i Cruells, C. (2011). La supervisión en los equipos de Servicios Sociales: una oportunidad para la reflexión, el pensamiento y el cuidado de los profesionales. Cuadernos de Trabajo Social, 24, 123-133. https://doi.org/10.5209/rev_CUTS.2011.v24.36863

Sheriff, T., y Sánchez, E. (1973). Supervisión en trabajo social. ECRO.

Tuerlick, J. (1966). La supervisión. In Bray \& Tuerlick (Eds.), La asistencia social individualizada (pp. 199-278). Aguilar. 



\title{
LITERATURA DE VIAJES Y TURISMO ACADÉMICO. DISEÑO DE TRES ACTIVIDADES DE APRENDIZAJE
}

\author{
Lía de Luxán Hernández \\ Universidad de Las Palmas de Gran Canaria
}

\section{Resumen}

En este trabajo presentamos la literatura de viajes, a la que consideramos una forma de manifestación del turismo académico, como una herramienta educativa a la par que ejemplificadora de la metodología vom Kinde aus. Para ilustrarlo, nos basaremos en dos obras, de las que haremos uso para proponer tres actividades educativas, que serán de aplicación en un aula de español como lengua extranjera, cuyos estudiantes sean nativos de alemán, tengan un nivel de español B2-C2, de acuerdo con el Marco Común Europeo de Referencia para las Lenguas - MCERL-, y cursen estudios de Traducción.

Palabras clave: literatura de viajes, turismo académico, vom Kinde aus, enseñanza del español como lengua extranjera, actividades de aprendizaje.

\begin{abstract}
In this work travel literature (here regarded as a manifestation of academic tourism) is presented as an academic tool. Aim of this paper is also to focus on the methodology vom Kinde aus. Two master pieces of travel literature are served as examples to illustrate how those type of documents (taking into account the strategy vom Kinde aus) may be implemented. Three learning activities to be applied in a classroom of Spanish as a foreign language are proposed. Students are German native speakers with a B2-C2 command of that language (according to the Common European Framework of Reference for Languages - CEFRL_), who are pursuing a degree in Translation Studies.
\end{abstract}

Keywords: Travel Literature, Academic Tourism, vom Kinde aus, Teaching Spanish as a Foreign Language, Learning Activities.

\section{INTRODUCCIÓN}

Defendemos la tesis de que el aprendizaje debe ser presentado como una aventura en la que el estudiante tiene que superar, mediante el uso de su intelecto y la adecuada guía del profesor, una serie de obstáculos para conseguir 
alcanzar los hitos de conocimiento que se le exijan en cada supuesto. Aprender no tiene que etiquetarse como una ardua tarea que se consigue mediante la memorización de unos datos y la superación de un examen, sino como un juego de mesa en el que las instrucciones son dictadas por un monitor de aprendizaje. El turismo académico, y la literatura de viajes como una de sus manifestaciones, se plantea como necesario en esta aventura del saber. Vom Kinde aus es la clave: el estudiante debe salir del aula tradicional (sea esta presencial o virtual) y de su ensimismamiento.

En un primer término se describe lo que, según nuestro saber y entender, es el "turismo académico", recayendo la máxima atención en la literatura de viajes. A continuación, se exponen las obras Schülerfahrt nach den Kanarischen Inseln vom 2. April bis 2. Mai 1908 ("Viaje escolar a las Islas Canarias del 2 de abril al 2 de mayo de 1908") y Die Republik Costa Rica in Central Amerika mit besonderer Berücksichtigung der Naturverhältnisse und der Frage der deutschen Auswanderung und Colonisation. Reisestudien und Skizzen aus den Jahren 1853 und 1854 ("La república de Costa Rica en Centroamérica, haciendo especial énfasis en el comportamiento de la naturaleza, así como en la emigración alemana y la colonización. Estudios de viaje y esquemas correspondientes a los ańos 1853 y 1854 "). Nos hemos decantado ex profeso por dos escritos que no se circunscriben a la península española, en aras de que el estudiante sea más consciente de que no hay una única manera de expresarse en esta lengua, ni una sola y única cultura a este idioma asociada.

Una vez hayan sido presentadas estas joyas académicas, se explica la estrategia de enseñanza-aprendizaje vom Kinde aus. El paso posterior es contextualizar los supuestos prácticos, para, luego, en consecuencia, diseñar tres actividades en las que se haga uso del turismo académico y de la estrategia vom Kinde aus. Estas tareas se enfocarán en la adquisición de la competencia intercultural (actividades $n^{\circ} 1,2$ y 3 ), en el léxico (actividad no 2 ) y en la traducción inversa (actividad $n^{\circ} 3$ ). Por último, se expondrán las conclusiones más relevantes que se pueden extraer de este trabajo.

\section{TURISMO ACADÉMICO}

Mediante el concepto "turismo académico"1 hacemos alusión a la educación a través del turismo; realidad que, a nuestro juicio, se manifiesta de forma di-

1 Cf. Rodríguez, J.A., Martínez-Roget, F. y Pawlowska, A (2013). "Academic Tourism: a more sustainable tourism”. En Regional and Sectorial Economic Studies. Vol. 13-2, pp. 89-94. 
recta, indirecta y mixta. El viaje, la expedición, la excursión, la visita guiada, es decir, la salida del aula (sea esta física o virtual) hacia la búsqueda del conocimiento de otras formas de ser, de la realidad en sí misma, de lo cognoscible a través de los sentidos es el turismo directo. El indirecto hace referencia al producto principal del turismo: los cuadernos de viaje y las actividades que se proponen en el aula son dos claros ejemplos; de ellos nos valdremos en este trabajo para ilustrar el qué, el cómo y el para qué del turismo en la enseñanzaaprendizaje de cualquier disciplina y, en especial, en este supuesto, del espańol como lengua extranjera. ¿Y mixto? El turismo académico mixto es el proceso de elaboración del producto de la actividad turística en sí misma, como la elaboración de los cuadernos de viajes, de los que derivarán las propuestas didácticas.

Si bien es cierto que las nuevas tecnologías (asistimos a la llamada $4^{\circ}$ revolución industrial) son fundamentales en la docencia del siglo XXI, el uso de libros no debe quedarse en el olvido. Abogamos por una herramienta poco o nada utilizada: el cuaderno de viajes. Lo consideramos como un instrumento educativo dual: por un lado, el público de la comunidad educativa al que va dirigido es el conformado por el profesorado y, por otro, el estudiantado, tanto de la educación primaria como de la secundaria, de la formación profesional y de los estudios superiores, en ambos supuestos. Al primer grupo le sirve de orientación pedagógica y de estímulo para promover la enseñanza de cualquier disciplina. Al segundo, como aplicación práctica en asignaturas de humanidades, ciencias sociales y ciencias naturales.

\section{SCHÜLERFAHRT NACH DEN KANARISCHEN INSELN VOM 2. APRIL BIS 2. MAI 1908}

Schülerfahrt nach den Kanarischen Inseln vom 2. April bis 2. Mai 1908 ("Viaje escolar a las Islas Canarias del 2 de abril al 2 de mayo de 1908"), es el culmen de un trabajo conjunto entre Johannes Gläser (escritor) y los alumnos de la escuela de artes aplicadas de Hamburgo Saatliche Kunstgewerbeschule (artífices de la parte artística).

La obra se concluyó en la Escuela de arte Staatliche Kunstgewerbeschule de Hamburgo, en octubre de 1912, con una tirada de 100 ejemplares. Este libro es el número $3 .^{2}$

2 La traducción es nuestra. Esta información aparece en el libro en una hoja sin enumerar. 
Consta de 91 páginas adornadas por dibujos en forma de marcos y 14 ilustraciones.

Composición de los estudiantes W. Arnold, E. Holdorff, E. Knodel, L. Melzer bajo la dirección del profesor J. Schulz. La impresión de los marcos se ha llevado a cabo por la imprenta "Gesellschaft Hartung \& CO M.B.H.”. Los fotograbados, a excepción de uno de los marcos, que fue provisto por A. Kahlbrandt, fueron confeccionados por los alumnos de la clase de técnicas de reproducción, bajo la dirección del profesor C. Griese. Las imágenes las han dibujado los alumnos H. Mendel, J. Steinmüller, W. Habl y Fr. Behnke, de la clase del profesor C.O. Czscheska partir de las fotografías. Ellos también bocetaron los marcos ${ }^{3}$.

Está dividida en cuatro partes bien diferenciadas, separadas por una portada ad hoc: 1) La narración del viaje de Hamburgo a Gran Canaria, que tuvo lugar entre los días 2 y 10 de abril (páginas 4-23). 2) La estancia en Gran Canaria, que transcurre del 10 al 20 de abril (páginas 24-53). 3) La visita a Tenerife del 20 al 24 de abril (páginas 54-75). 4) El regreso a Hamburgo desde Tenerife del 24 de abril al 2 de mayo (páginas 76-89). No obstante, cabe señalar que determinadas partes del libro no se incluyen en estos cuatro apartados, sino que quedan al margen; nos referimos a aquellos fragmentos en los que el autor dedica unas palabras al recuerdo, al agradecimiento, a mencionar a los participantes del viaje y al proceso de impresión y autoría de la parte más artística de la obra.

En este libro se narra la experiencia educativa marítimo-terrestre hacia y en las Islas Canarias de dos docenas de estudiantes de sexo masculino, elegidos por su buen expediente académico, salud extraordinaria y fortaleza física.

[...] seleccionar a dos docenas de chicos en función de su buen expediente académico y su impecable estado de salud [...] (pág. 9)

“iHemos demostrado que somos hombres!” (pág. 16)

Ya desde el momento de la elección se tuvo muy en cuenta que solamente podían venir chicos fuertes. (pág. 47$)^{4}$

Eran todos ellos alumnos de la escuela de artes aplicadas Staatliche Kunstgewerbe de Hamburgo. No obstante, tal y como puede deducirse de la relación

3 Ídem.

4 Ídem. 
de los participantes que aparece en la última página numerada de la obra, a ellos se les unieron el hijo del rector, el rector, seis docentes, el inspector del colegio y un médico.

Participantes del viaje.

Además del director de la expedición, el Rector H. Freytag, participaron el inspector de la escuela H. Fricke, el doctor en medicina W. Lackemann, A. Stuhr, H. Lohfert, A. Timm, J. Gläser, H. Christian, H. Frohböse. Los estudiantes:

W. Matthies, P. Heidmann, Th. Göttsche, W. Wagner, M. Buroh, H. Fabel, F. Kaiser, O Heitmann, H. Oelckers, W. Schulze, H. Hawersaat, H. Koenig, L. Pommerencke, K. Seebörger, R. Häuszler, H. Paulsen, H. Drewes, C. Geseller, W. Schütte, F. Vorrath, G. Schepper, H. Rimkeit, L. Schlüter, O. Osterloh, W. Freytag. (pág. 91) $)^{5}$

El viaje, de 31 días, estuvo financiado por el propietario de la línea naviera Woermannlinie y se llevó a cabo en tres barcos de la firma: el Erna Woermann (de Hamburgo a Gran Canaria), el Adolph Woermann (de Gran Canaria a Tenerife) y el Eleonore Woermann (de Tenerife a Hamburgo). El mecenas de la expedición quería que los alumnos pudiesen albergar una experiencia como la suya propia años atrás.

Se ha discutido mucho sobre el valor de los viajes escolares, tanto a favor como en contra, como sobre todas las cosas que se han hecho, pero que también pueden dejar de hacerse. Mas, ahora mismo, dado que es posible, es decisivo el valor del sentimiento, que está presente en la idea del señor Woermann: un gran viaje marítimo, como el que él pudo llevar cabo en sus años mozos, que le irradió con sus primeras impresiones y que, a día de hoy sigue siendo importante, para contar con una vida rica; y esa alegría que le produjo en él, pudo desde hace pocos años, observarla de nuevo en un grupo de hombrecitos, a quienes se les brindaba la posibilidad de conocer la cautivadora belleza del océano por vez primera. Así surgió su iniciativa de regalar una experiencia parecida a la suya a buenos chicos de Hamburgo. Debido a que con el Rector Freytag habían tenido lugar varios viajes escolares de 1894 con éxito, se tuvo la oportunidad de hacer esto realidad [...] (pág. 9) ${ }^{6}$

5 Ídem.

6 Ídem. 
Entonces vino el representante de nuestra Woermannlinie, el señor cónsul Ahlers a bordo; era nuestro nuevo protector y pronto experimentamos que aquí también en Tenerife se habían preocupado por nuestro bienestar hasta el más mínimo detalle; a donde quiera que fuéramos, la mesa estaba llena de flores y frutas. (pág. 60) ${ }^{7}$

La actividad educativa puede calificarse como vital: cambió la percepción tanto de los docentes (que se describen a sí mismos en el viaje como auténticos vikingos y colonizadores de la más novedosa pedagogía), como de los alumnos (los viajes marítimos, tal y como reflexiona Gläser en el cuaderno, son, en especial en los inicios del siglo XX, los más duros), quienes aprendieron a convivir en un espacio muy reducido con otros compañeros de su edad, sin el apoyo constante de sus padres y tuvieron la enorme oportunidad de conocer en primera persona las llamadas Islas Afortunadas. Aunque, a pesar de que el título de la obra sea "Viaje escolar a las Islas Canarias [...]", las dos únicas islas que se visitaron fueron las capitalinas: Gran Canaria y Tenerife. Esta última les causó gran fascinación a todos los participantes, puesto que querían seguir los pasos de Alexander von Humboldt (1769-1859), quien estuvo en ella una semana en $1799 .^{8}$

Haremos uso de esta obra para el diseño de la actividad no 2 (búsqueda de léxico-competencia intercultural) y número 3 (traducción inversa-competencia intercultural). También nos valdremos de ella para la explicación de la metodología vom Kinde aus, que nace en esta experiencia académica y se perfecciona en un trabajo con este mismo nombre, también bajo la pluma de Gläser, en $1920 .^{9}$

4. DIE REPUBLIK COSTA RICA IN CENTRAL AMERIKA MIT BESONDERER BERÜCKSICHTIGUNG DER NATURVERHÄLTNISSE UND DER FRAGE DER DEUTSCHEN AUS WANDERUNG UND COLONISATION. REISESTUDIEN UND SKIZZEN AUS DEN JAHREN 1853 UND 1854

Die Republik Costa Rica in Central Amerika mit besonderer Berücksichtigung der Naturverhältnisse und der Frage der deutschen Auswanderung und Colonisation.

7 Ídem.

8 Cf. Gebauer, A. (2014). Alexander von Humboldt, seine Woche auf Teneriffa. Berlín: Zech.

9 Cf. Gläser, J. (1920). Vom Kinde aus. Arbeiten des Pädagogischen Ausschusses der Gesellschaft der Freunde des vaterländischen Schul- und Erziehungswesens zu Hamburg. Hamburg/Braunschweig. 
Reisestudien und Skizzen aus den Jahren 1853 und 1854 ("La república de Costa Rica en Centroamérica, haciendo especial énfasis en el comportamiento de la naturaleza, así como en la emigración alemana y la colonización. Estudios de viaje y esquemas correspondientes a los ańos 1853 y 1854") es un cuaderno de viajes sobre Costa Rica escrito por los científicos-viajeros Karl Ritter von Scherzer y Moritz Wagner, publicado en 1856 en Leipzig. El ejemplar del que vamos a hacer uso para el diseńo de la primera actividad que aquí proponemos (la correspondiente a la adquisición de la competencia intercultural) se aloja en la Harvard College Library y fue cedido por Cameron Forbes en 1906. Se estructura en un prólogo (páginas V-XII), 6 grandes apartados divididos en una introducción y 31 capítulos (páginas 1 - 537) y anexos (páginas 538-578). Cabe destacar que la autoría de cada una de las partes en las que se subdivide la obra se señala al final del prólogo, de la introducción, de cada uno de los capítulos y del anexo, mediante sus iniciales. Scherzer es el autor del prólogo y de diez capítulos, y Wagner, de la introducción, del anexo y de los 21 capítulos restantes.

Para el diseño de la actividad número 1 haremos uso del capítulo decimoquinto de la obra, que lleva por título Der Wochenmarkt in Cartago ("El mercado semanal en Cartago"), y forma parte, junto con el decimocuarto y decimosexto, del apartado Cartago del cuaderno de viajes, escrito en su totalidad por Scherzer. Es un texto breve, de siete páginas (238-244), en el que se narra cómo transcurre una jornada en el mercado, describiendo este como un auténtico acontecimiento:

El día más importante para los habitantes de Cartago es el jueves, que es cuando, en la gran explanada de hierba delante de la Iglesia, tiene lugar el mercado; a él acude en masa gran parte de la población del país, y las carteras de los cartagineses se resienten. Se aprovecha para hacer la compra para toda la semana, de ahí que por la mañana se respire tanta vida. Todas las féminas, quienes durante la semana no se han preocupado de su aspecto sucio y descuidado, acuden muy bien aseadas y trajeadas, lo que explica la presencia de los jóvenes varones, que van al mercado no para comprar, sino para llevar a cabo otro tipo de especulaciones $[\ldots]$ (p. 238) ${ }^{10}$

10 Ídem. 


\section{METODOLOGÍA VOM KINDE AUS}

Vom Kinde aus significa "del niño hacia afuera" y hace alusión a aquellas metodologías inspiradas en la mayéutica platónica: el aprendiz, de manera natural, está dotado de la inteligencia necesaria para alcanzar el conocimiento: hay que saber guiarlo para que explote esas virtudes y se convierta en "filósofo", es decir, en un experimentado conocedor de la materia, en una persona con criterio; y no en un simple memorizador y vomitador de contenido. El profesor es ahora un guía. Esta metodología es la que se aplica en el proyecto educativo, que se plasma en el cuaderno de viajes de 1908, publicado en 1912, así como en la obra del mismo autor que vio la luz en 1920. Este recurso pedagógico se adscribe a la schöpferische Entwicklung (desarrollo creativo), algo a lo que ya hacía mención Inmanuel Kant en 1803 y que Ferriere, pionero de la "nueva educación”, puede que la considerara una utopía inalcanzable en 1928. El alumno aprende del entorno; las vivencias guiadas, como la que tienen la oportunidad de experimentar los protagonistas de esta actividad extraescolar, son de las mejores. Estamos, también, como señala Hopf (2004), ante la experimentelle Pädagogik (pedagogía experimental) y ante el Thinking-Based Learning (TBL) ideado por Swartz (2008).

Cabe señalar que las actividades que aquí se presentan fomentan el trabajo en equipo, pero siempre después de un autoaprendizaje y una introspección previa. La dinámica de enseñanza sigue el siguiente esquema: 1. Trabajo individual, 2. Revisión, puesta en común y discusión en pequeños grupos y 3 . Consenso final en gran grupo. El profesor actúa de árbitro y guía en todo el proceso, sin entorpecer la toma de decisiones del alumnado, pues el estudiante debe sentirse libre para equivocarse, siempre y cuando sea él el dueño de unas decisiones meditadas y congruentes.

\section{CONTEXTUALIZACIÓN}

El enfoque educativo que se plasma en este capítulo, se centra en un aula (presencial o virtual) en la que los alumnos, nativos de alemán, tienen un dominio del español encuadrable en los niveles B2-C2 del Marco Común Europeo de Referencia para las Lenguas (MCERL) y cursan estudios de Traducción. En el supuesto de que el aula fuera virtual, se propone la plataforma Teams de Microsoft, en la que se pueden crear equipos de trabajo en forma de mini-canales: el portavoz de cada equipo convocaría una reunión y el profesor, que es el creador y propietario de todos ellos (los mini-canales pertenecerían al mismo equipo, que sería la asignatura en sí), asistiría sin previo aviso durante la hora de clase a todas las reu- 
niones, en las que emplearía el mismo tiempo y asumiría la función, principalmente, de oyente, aunque también de moderador y resolución de conflictos.

\section{ACTIVIDAD No 1. - TRABAJO DE LA COMPETENCIA INTERCUL- TURAL (ESTADIO MONOCULTURAL)}

La competencia intercultural, que tiene su origen en las competencias sociolingüística, estratégica y sociocultural descritas por Van Ek (1986) y que, según el Diccionario de términos de ELE (Centro Virtual Cervantes), es “[...] la habilidad del aprendiente de una segunda lengua o lengua extranjera para desenvolverse adecuada y satisfactoriamente en las situaciones de comunicación intercultural que se producen con frecuencia en la sociedad actual, caracterizada por la pluriculturalidad". La citada competencia intercultural se divide en tres estadios: el monocultural, el intercultural y el transcultural, que son niveles progresivos de adquisición de esta. En el primero de ellos, el alumnado se enfrenta a otra cultura desde un punto de vista egoísta; en el segundo, ya compara ambas culturas, aunque todavía poniendo más énfasis en su propia cultura y, en el último, es capaz de contrastar ambas culturas, con el suficiente distanciamiento.

Como se ha establecido en la introducción, se ha optado por escoger literatura de viajes que esté vinculada a una zona que no sea la península española, para que el estudiante nativo de alemán sea más consciente de otras formas de expresarse y de manifestarse culturalmente de la comunidad hispanohablante. En este supuesto, nos centraremos en Costa Rica.

Aquí se pretende que el estudiante se adentre en esta competencia, por lo que la actividad que se propondrá se encuadra en el primer nivel, es decir, el monocultural. El docente le encargará que lea con detenimiento el capítulo decimoquinto de la obra Die Republik Costa Rica in Central Amerika mit besonderer Berücksichtigung der Naturverhältnisse und der Frage der deutschen Auswanderung und Colonisation. Reisestudien und Skizzen aus den Jahren 1853 und 1854 ("La república de Costa Rica en Centroamérica, haciendo especial énfasis en el comportamiento de la naturaleza, así como en la emigración alemana y la colonización. Estudios de viaje y esquemas correspondientes a los años 1853 y 1854") y anote todo aquello que le resulte extraño. Primero debería trabajar de manera individual, a continuación, en pequeños grupos, donde se debatirían los resultados y, por último, en gran grupo. En todo momento se seguiría la metodología vom Kinde aus arriba expuesta.

Consideramos que muy probablemente despertarían su interés fragmentos tales como los siguientes: 
Los plátanos (tal y como los españoles denominan a los higos del paraíso) son, según Alexander von Humboldt ${ }^{11}$, en una superficie idéntica, 44 veces más productivos que la papa y 133 veces más que el trigo. Un racimo de unas aproximadamente 50 bananas cuesta un medio. (p. 239) $)^{12}$ Las chicas de "campo", que llevan al mercado toda clase de frutas, están siempre emperifolladas; sus magníficas camisas blancas, sus faldas de colores, sus pañuelos rojos, muy delicadamente colocados por encima de la nuca, que muestran más de lo que ocultan, sus sombreros redondos muy coquetos, que quedan muy femeninos en las toscas cabezas de los hombres, pero encima de las cabelleras negras de las mujeres, les dotan de un aspecto más jovial, su modo inocente, casi irreverente, con el que aguardan junto a la fruta puesta a la venta, sus movimientos de pelo y, sobre todo, sus miradas a los compradores, nublan actitudes campestres y se presentan como casaderas. (p. 238) ${ }^{13}$

Mientras que las féminas ponen a la venta en canastas finas y delicadas pequeñas cantidades de fruta, queso, cerveza, azúcar, agua de arroz, sirope y demás; la parte masculina de la agricultura trae los artículos principales de consumo, judías negras (phaseolus vulgaris 1.) y maíz amarillo (zea mais l.) en grandes y pesadas cajas al mercado. Los indianos con sus mujeres y sus hijos se pasean para ver qué productos principales se ofertan, en busca de cacao [...] (p. 240) ${ }^{14}$

\section{ACTIVIDAD No 2. - BÚSQUEDA DE LÉXICO Y COMPETENCIA IN- TERCULTURAL (ESTADIO INTERCULTURAL)}

El profesorado animaría al alumnado a que, tras una lectura inicial del cuaderno de viajes Schülerfahrt nach den Kanarischen Inseln vom 2. April bis 2. Mai 1908 (Viaje escolar a las Islas Canarias del 2 de abril al 2 de mayo de 1908), se centrase en la búsqueda de aquellos términos que resulten extranjeros a la lengua origen del texto. El viajero puede haber adoptado diferentes técnicas a la hora de plasmar nociones culturales: con términos totalmente foráneos a la lengua alemana, acudiendo a una simbiosis extraña o adaptándolos ${ }^{15}$; en este

11 Nótese que este viajero investigador, a pesar de ser de gran importancia para la comunidad científica en general, es de gran referencia para los alemanes. La mención de Alexander von Humboldt produce siempre un gran efecto llamada.

12 La traducción es nuestra.

13 Ídem.

14 Ídem.

15 Cf. Beller, M. (2006). Eingebildete Nationalcharaktere. Vorträge und Aufsäztze zur literarischen Imagologie. Göttingen: V+R Unipress. 
supuesto, nos interesa que el estudiantado hiciese acopio de aquellos que se pudiesen adscribir a las dos primeras categorías y que indicase en qué página se encuentran. $\mathrm{Al}$ igual que en el supuesto anterior, primero se trabajaría de forma individual, luego en pequeños grupos y, por último, en gran grupo, y se aplicaría la estrategia didáctica vom Kinde aus.

Tabla 1: Términos españoles/canarios en el texto:

\begin{tabular}{|c|c|}
\hline TÉRMINO EN EL TEXTO & PÁGINAS \\
\hline TARTANAS & 20,27 \\
\hline SPANIOLEN & 20 \\
\hline LA CIUDAD REAL DE LAS PALMAS & 25 \\
\hline CIUDAD & 25 \\
\hline PLAZA & 25 (II), 34, 45, 63 \\
\hline PUERTO/S & 26 (II), 40, 52, 67, 70 (II) \\
\hline AZOTEAS & 26 \\
\hline TRANVIA & 27,52 \\
\hline MULOS & 27,37 \\
\hline PENÍNSULA & 29 \\
\hline CANARIER & 29 \\
\hline PATIO & 33 (II), 61, 63 \\
\hline BARRANCO/S & 33, 39 (III) \\
\hline DRAGO & 34,63 \\
\hline PIC/PIK/S [PIKGEBIRGE] & 36, 53, 56 (II), [60], 67(III), 68 (III), 69 (II) \\
\hline CABALEROS & 37 \\
\hline CUMBRES & 40 (II), 64, 66, 67 \\
\hline MONTE & 40,47 \\
\hline RETAMA & 44 \\
\hline FONDA & 44,65 \\
\hline CASTELLANO & 44 \\
\hline GUANCHEN & 45(III), 49 \\
\hline ALEMAN/S & 46,51 \\
\hline MARINE & 46 \\
\hline ESCUELA DE ALEMANIA & 46 \\
\hline MUY PERPENDICULAR & 47 \\
\hline CALDERA & 49 \\
\hline MANTILLA & 51 \\
\hline VINO/VINO TINTO/VINO BLANCO & 51,65 \\
\hline TENERIFE & 56 (II), 60 \\
\hline VIVA ESPAÑA & 61 \\
\hline INSTITUTO DE CANARIA & 63 \\
\hline AGUA & 64 \\
\hline CAÑADAS & 68,69 \\
\hline LADERA & 68 \\
\hline KONQUISTA & 69 \\
\hline JACARANDA & 69 \\
\hline VILLA & 69 \\
\hline
\end{tabular}

Fuente: De Luxán Hernández, 2020. 
Con la primera lectura del texto, el estudiante se encontraría, al igual que en el supuesto anterior, en el estadio monocultural, pero, una vez superada esta fase, estaría preparado para la tarea de búsqueda de lexía y, por ende, tras finalizar esta, se situaría en el estadio intercultural, dado que esta actividad le exigiría un nivel de madurez superior: el vocabulario es cultura; en nuestro supuesto las voces hablan sobre Canarias, sus costumbres, su geografía, su tierra... Ya no contemplaría la otra cultura (o, mejor dicho, lengua-cultura) desde un punto egoísta, sino de una manera más conciliadora, aunque todavía no estaría lo suficientemente distanciado de la suya propia.

\section{ACTIVIDAD No 3. - TRADUCCIÓN INVERSA Y COMPETENCIA IN- TERCULTURAL (ESTADIO TRANSVERSAL)}

La tercera tarea que proponemos es la traducción inversa de Schülerfahrt nach den Kanarischen Inseln vom 2. April bis 2. Mai 1908 ("Viaje escolar a las Islas Canarias del 2 de abril al 2 de mayo de 1908") con fines eminentemente pedagógico ${ }^{16}$; estamos ante una actividad de language usage, como señala Widdowson (1978). Debe, no obstante, tenerse en consideración que el estudiante ha sido instruido en teoría y práctica de la traducción, por lo que no se enfrentaría ante una tarea que le pudiera resultar extrańa. A cada alumno se le asignaría un número de páginas determinado; luego, en pequeños grupos de páginas correlativas se presentarían los resultados individuales, se discutirían, se revisarían y se propondría un resultado final; a continuación, en grupos un poco más grandes, también de páginas correlativas se seguiría el mismo proceso; y, por último, se repetiría este mismo mecanismo en gran grupo. En todos los pequeños debates grupales, habría siempre una persona que actuaría de moderador y que sería elegida por el docente. En la puesta en común final de los resultados, sería el profesor el que asumiría ese rol; no obstante, el maestro actuaría siempre de supervisor y de guía de aprendizaje, de acuerdo con la metodología vom Kinde aus.

He aquí una pequeña muestra del resultado al que se llegaría en gran grupo:

16 Cf. Sáez Hermosilla, T. (1986). "El concepto de traducción y sus aplicaciones pedagógicas. En Cuadernos de Grado Medio, 4, Cáceres, pp. 68-73. 
Tabla 2: Traducción de fragmentos del cuaderno de viajes:

\begin{tabular}{|c|c|c|}
\hline PÁG. & FRAGMENTO EN ALEMÁN & TRADUCCIÓN AL ESPAÑOL \\
\hline 5 & $\begin{array}{c}\text { Aber wer sind wir denn, die wir uns dem } \\
\text { Weltmeer anvertrauen? Sind wir Wikinger, } \\
\text { oder sind wir auf Entdeckungsreisen } \\
\text { ausgewesen? Hamburger Lehrer sind wir, } \\
\text { die heimkehren von einer } \\
\text { Konquistadorenfahrt in die neueste } \\
\text { Pädagogik. }\end{array}$ & $\begin{array}{l}\text { ¿Pero quiénes somos nosotros, que nos } \\
\text { lanzamos al océano de esa manera tan } \\
\text { confiada? ¿Somos acaso vikingos o hemos } \\
\text { asumido el papel de aventureros? Somos } \\
\text { unos profesores de Hamburgo que } \\
\text { regresamos a casa tras un viaje colonizador } \\
\text { hacia la más novedosa pedagogía. }\end{array}$ \\
\hline 10 & $\begin{array}{c}\text { [...] aber keine Reise stellt wohl wie die } \\
\text { Seereise den Menschen auf längere Zeit } \\
\text { unter die Herrschaft derselben } \\
\text { Notwendigkeiten und Bedürfnisse, und } \\
\text { keine läßt deshalb auch mit größerer } \\
\text { Deutlichkeit den Unterschied erkennen, } \\
\text { wie die verschiedenen Individuen auf die } \\
\text { neuen Einwirkungen reagieren. }\end{array}$ & $\begin{array}{l}\text { [...] no hay ningún viaje como el marítimo } \\
\text { en el que las personas estén durante un largo } \\
\text { período de tiempo al dictado de las mismas } \\
\text { necesidades y en el que se pueda descubrir } \\
\text { mejor la diferencia en cómo reaccionan los } \\
\text { distintos individuos ante nuevos factores. }\end{array}$ \\
\hline 20 & $\begin{array}{l}\text { Besonders interessante } \\
\text { Auseinandersetzungen gab es mit den } \\
\text { Spaniolen, die mit Postkarten an Bord } \\
\text { kamen und uns durch Verschiedenartigkeit } \\
\text { ihrer Preise in das Land der unbegrenzten } \\
\text { Möglichkeiten versetzen. }\end{array}$ & $\begin{array}{l}\text { Lo más llamativo fue el hecho de los } \\
\text { españoles subieran a bordo con panfletos y } \\
\text { pretendieran de múltiples maneras } \\
\text { vendernos infinidad de servicios en tierra. }\end{array}$ \\
\hline 46 & $\begin{array}{l}\text { Einige Monate vor uns hatte ein } \\
\text { schweizerisches Institut die Inseln besucht, } \\
\text { um besonders botanische und geologische } \\
\text { Studien zu unternehmen. Für dieses } \\
\text { Studium waren unsere Jungen natürlich } \\
\text { nicht reif; aber ein gewisses Vertständnis } \\
\text { für die vulkanische Natur der Insel ist } \\
\text { ihnen doch gekommen [...]. }\end{array}$ & $\begin{array}{l}\text { Unos meses antes de nosotros, un instituto } \\
\text { suizo había visitado la isla para, } \\
\text { principalmente, realizar actividades de } \\
\text { botánica y geología. Nuestros chicos todavía } \\
\text { no tenían la suficiente madurez para este } \\
\text { tipo de prácticas; aunque sí que lograron } \\
\text { comprender algo de la naturaleza volcánica } \\
\text { de la isla [...] }\end{array}$ \\
\hline 56 & $\begin{array}{l}\text { Zehn Tage waren wir nun bereits in Gran } \\
\text { Canaria gewesen, und es kam uns so vor, } \\
\text { als ob schon eine Art Heimatsgefühl in uns } \\
\text { gewachsen war. }\end{array}$ & $\begin{array}{l}\text { Llevábamos ya diez días en Gran Canaria, y } \\
\text { no podíamos contener esa sensación, cada } \\
\text { vez más fuerte, que se apoderaba de } \\
\text { nosotros, de sentirnos como en casa. }\end{array}$ \\
\hline 66 & $\begin{array}{l}\text { Das Humboldthotel, das uns von seinem } \\
\text { Generalleiter, Herrn Prof. Dr. Pannwitz, } \\
\text { in liebenswürdiger Weise während unseres } \\
\text { Aufenthalts im Orotavatal zur Verfügung } \\
\text { gestellt worden war, ist ein in Husteinform } \\
\text { angelegter Bau in der Größe eines } \\
\text { mächtigen Schlosses. }\end{array}$ & $\begin{array}{l}\text { Nos alojamos en el Hotel Humboldt } \\
\text { durante nuestra estancia en el Valle de la } \\
\text { Orotava, gracias a la muy amable disposición } \\
\text { del director general, el señor catedrático } \\
\text { Pannwitz. Se trata de una construcción } \\
\text { diáfana en forma de herradura del tamaño } \\
\text { de un imponente castillo. }\end{array}$ \\
\hline 67 & $\begin{array}{l}\text { “Der Pik ist da!” ging es in aller Frühe von } \\
\text { Tür zu Tür. Kaum völlig angekleidet, } \\
\text { eilten wir hinaus, um von den } \\
\text { Korridorfenstern auf das Tal zu schauen. }\end{array}$ & $\begin{array}{l}\text { “El Pico está ahí!” fue sonando de puerta en } \\
\text { puerta desde muy temprano. Apenas nos } \\
\text { hubimos vestido, salimos a toda prisa a } \\
\text { contemplar el valle, asomados a los } \\
\text { ventanales del pasillo. }\end{array}$ \\
\hline
\end{tabular}

Fuente: Elaboración propia 
La traducción inversa exige un avance lógico, consecutivo y progresivo en la competencia intercultural; producir un texto con el objetivo de que parezca que se haya escrito en la lengua meta es una ardua tarea y exige un nivel de competencia léxica y de técnicas de traducción alto, pero también una gran madurez en la competencia intercultural. El estadio transcultural supone que el estudiante es capaz de contemplar las dos culturas desde la distancia, y esto, a nuestro juicio, se consigue claramente con la traducción inversa de la manera aquí planteada.

\section{CONCLUSIONES}

El turismo académico, que, según nuestro parecer, se manifiesta de forma directa (el viaje), indirecta (el cuaderno de viajes y las actividades que se derivan de él) y mixta (el proceso de diseńo del viaje y de la pieza literaria) es un mecanismo de enseñanza-aprendizaje nada desdeñable y con muchos beneficios para la consecución del crecimiento personal, académico y profesional, tanto del alumnado como del profesorado. A través de la literatura de viajes (turismo académico indirecto), el docente, apoyándose en técnicas de innovación educativa, así como haciendo uso de la metodología vom Kinde aus, puede diseñar múltiples actividades que garanticen un aprendizaje más enriquecedor, a la par que resulte ameno y nuevo para el estudiantado; lo que, definitivamente, creemos que captaría su atención.

Mediante este paper, se ha ilustrado el uso de la literatura de viajes en un contexto determinado: la enseñanza del español a alumnos nativos de alemán, con un dominio de la lengua de Cervantes encuadrable en los niveles B2-C2 del Marco Común Europeo de Referencia para las Lenguas (MCERL) y que estudien Traducción. Para ello se ha hecho acopio de dos cuadernos de viajes: Schülerfahrt nach den Kanarischen Inseln vom 2. April bis 2. Mai 1908 ("Viaje escolar a las Islas Canarias del 2 de abril al 2 de mayo de 1908”) y Die Republik Costa Rica in Central Amerika mit besonderer Berücksichtigung der Naturverhältnisse und der Frage der deutschen Auswanderung und Colonisation. Reisestudien und Skizzen aus den Jahren 1853 und 1854 ("La república de Costa Rica en Centroamérica, haciendo especial énfasis en el comportamiento de la naturaleza, así como en la emigración alemana y la colonización. Estudios de viaje y esquemas correspondientes a los años 1853 y 1854"). El primero de ellos, publicado en 1912, narra, bajo la pluma de Johnes Gläser, la aventura académica de unos alumnos de la Staatliche Kunstgewerbeschule a Gran Canaria y Tenerife en 1908. El segundo, cuya publicación data de 1856, en Leipzig, describe Costa Rica desde una perspectiva científica, cultural y turística, fue redactado a cuatro manos por los viajeros-científicos Karl Ritter von Scherzer y Moritz Wagner. 
Las actividades que se han propuesto tienen como objetivo principal la armonización y profundización de conocimientos de la lengua y cultura espańola, teniendo muy presente que ello no significa España, sino países hispanohablantes. Así, a través del capítulo decimoquinto del cuaderno de viajes sobre Costa Rica, se ha diseńado una actividad (la no 1 ) destinada a iniciarse en la competencia intercultural (estadio monocultural): el alumnado debería leer y anotar todo aquello que le resultase extraño. El libro sobre la experiencia académica de los alumnos de la escuela de artes aplicadas de Hamburgo ha sido el instrumento vehicular escogido para las actividades número 2 y 3 . La segunda se centra en el léxico, en los términos no alemanes o españolizados/alemanizados de los que se vale Gläser para describir la experiencia, lo que conllevaría a que el estudiante alcanzase el nivel intercultural de la competencia intercultural. La tercera, que se centra en la traducción inversa, supondría un reto importante; de ahí que debiese efectuarse en el último lugar: para que la traducción tuviese un efecto similar en el lector meta que en el lector origen, el que actúa de traductor tendría que tener no solo un conocimiento de gramática, vocabulario y demás cuestiones lingüísticas alto de la lengua a la que se traduce, sino que también debería estar situado en la cima de la competencia intercultural, es decir, en el nivel transcultural, pues tendría que tener la capacidad de discernir una cultura y otra, y actuar de forma parcial.

La metodología vom Kinde aus, que es la que se ha aplicado como pilar básico fundamental en las propuestas de actividades de aprendizaje aquí expuestas, tiene como lema que el alumno aprenda a partir de él mismo, gracias a las herramientas que le proporcione el profesor. Supone el viaje real o fantasioso del alumnado a través de medios de transporte, andando o de su yo imaginario, gracias a los cuadernos de viaje. Es la salida de la cueva platónica, del mundo tradicional, del aula clásica (ya sea esta física o virtual). Las sombras dejan de ser sombras y se convierten en conocimientos de luz. Este proceso del "niño hacia afuera" se tiene que acompañar también, necesariamente, de un trabajo en equipo, de un debate colectivo y de una revisión entre iguales y del profesor, quien se convierte en un guía del aprendizaje.

Es, por lo tanto, la literatura de viajes, entre otro orden de cosas y funciones, una herramienta educativa para trabajar las competencias lingüística e intercultural de una forma amena y atractiva. Las actividades que aquí se han planteado de manera breve son solamente un ejemplo de la infinidad de tareas que pueden diseñarse con los cuadernos de viajes y, en el contexto de este trabajo, para la docencia de espańol como lengua extranjera. 


\section{BIBLIOGRAFÍA}

Beller, M. (2006). Eingebildete Nationalcharaktere. Vorträge und Aufsäztze zur literarischen Imagologie. Göttingen: V+R Unipress.

Cervantes, Centro Virtual. (2008). «Competencia intercultural». Diccionario de términos clave de ELE.

https://cvc.cervantes.es/ensenanza/biblioteca_ele/diccio_ele/diccionario/compintercult.htm

De Luxán Hernández, L. (2020). "La educación a través del turismo. Revolución pedagógica em `Schülerfahrt nach den Kanarischen Inseln vom 2. April bis 2. Mai', en Cita a ciegas con la Escuela Luján Pérez. CAAM, pp. 45-63.

Ferriere, A. (1928). Trois Pionniers de l'education nouvelle: Hermann Lietz, Giuseppe Lombardo-Radice, Frantisek Bakule. Paris: Ernest Flammarion.

Gebauer, A. (2014). Alexander von Humboldt, seine Woche auf Teneriffa. Berlín: Zech.

Gläser, J. (1912). Schülerfahrt nach den Kanarischen Inseln vom 2. April 1908 bis 2. Mai 1908. Saatliche Kunstgewerbeschule.

Gläser, J. (1920). Vom Kinde aus. Arbeiten des Pädagogischen Ausschusses der Gesellschaft der Freunde des vaterländischen Schul- und Erziehungswesens zu Hamburg. Hamburg/Braunschweig.

Hopf, C. Die experimentelle Pädagogik. Empirische Erziehungswissenschaft in Deutschland am Anfang des 20. Jahrhunderts. Verlag Julius Klinkhardt (2004).

Kant, I. Über Pädagogik. Konigsberg (1803).

Platón. (1969). La República, ed. bilingüe, trad., notas y estudio preliminar de José Manuel Pabón y Manuel Frenández-Galiano, Instituto de Estudios Políticos, Madrid 3 vols.

Rodríguez, J.A., Martínez-Roget, F. y Pawlowska, A. (2013). "Academic Tourism: a more sustainable tourism”. En Regional and Sectorial Economic Studies. Vol. 13-2, pp. 89-94.

Sáez Hermosilla, T. (1986). "El concepto de traducción y sus aplicaciones pedagógicas. En Cuadernos de Grado Medio, 4, Cáceres, pp. 68-73.

Scherzer K. (1856). "Der Wochenmarkt in Cartago”, en Wagner, M., Scherzer, K.(1856) Die Republik Costa Rica in Central Amerika mit besonderer Berücksichtigung der Naturverhältnisse und der Frage der deutschen Auswanderung und Colonisation. Reisestudien und Skizzen aus den Jahren 1853 und 1854. Leipzig: Arnoldsche Buchandlung, 238-244. 
Swartz, R.J. (2008). “Thinking-Based Learning. Making the Most of What We Have Learned About Teaching in the Regular Classroom to Bring Out the Best in Our Students". En Eduactional Leadership V. 65. No 5

Van Ek, J. (1986). Objectives for foreign language learning. Estrasburgo: Publicaciones del Consejo de Europa.

Widdowson, H.G. (1978). Teaching Language as Communication. Oxford University Press 



\title{
LA NATALIDAD Y LAS POLÍTICAS PRO-POBLACIONISTAS DURANTE LA SEGUNDA REPÚBLICA
}

\author{
Ramón Díaz Hernández \\ Universidad de Las Palmas de Gran Canaria
}

\section{Resumen}

Este trabajo estudia las posibles razones del retraso con que se desarrolló la transición demográfica en España. Para ello analiza las condiciones sanitarias vigentes a principios del siglo XX y cómo las nuevas estructuras del moderno sistema público de salud se van implantando progresivamente durante las décadas de los años 20 y 30, hasta consolidarse definitivamente. También se examina el debate de la caída de la natalidad (sus causas y consecuencias) y la reacción de las autoridades impulsando una serie de medidas pro-poblacionistas de forma directa e indirectamente. Éstas van desde las subvenciones económicas para incentivar los nacimientos hasta las gratificaciones, ayudas y exenciones fiscales para apoyar a la familia numerosa de trabajadores y funcionarios públicos españoles con bajos ingresos de renta.

Palabras clave: transición demográfica, natalidad, mortalidad infantil, subsidios, familia numerosa.

\begin{abstract}
This work studies the possible reasons for the delay with which the demographic transition developed in Spain. To do this, it analyzes the sanitary conditions in force at the beginning of the 20th century and how the new structures of the modern public health system were progressively implanted during the decades of the 20 s and 30 s, until they were finally consolidated. It also examines the debate on the fall in the birth rate (its causes and consequences) and the reaction of the authorities promoting a series of pro-population measures directly and indirectly. These range from financial subsidies to encourage births to bonuses, aid and tax exemptions to support the large family of Spanish workers and civil servants with low income.
\end{abstract}

Keywords: demographic transition, birth rate, infant mortality, subsidies, large family. 


\section{INTRODUCCIÓN}

El período comprendido entre 1850 y 1930 presenta muchas lagunas sobre el conocimiento de la natalidad española, su funcionamiento, sus condicionantes y su evolución. "Se sabe poquísimo de su estructura interna, sus determinantes y sus implicaciones" (Moreda y Reher, 1988:21). El presente trabajo se centra en conocer la evolución de la natalidad durante las primeras décadas del siglo XX hasta la proclamación de la Segunda República (1931-1939) a la luz de las importantes reformas políticas y administrativas que se acometieron desde 1900 en adelante para dotar a nuestro país de unas instituciones sanitarias modernas en consonancia con las naciones de nuestro entorno. En esta etapa se produce un gran avance al incorporarse en la praxis sanitaria pública los presupuestos generales de la ciencia salubrista y la «revolución epidemiológica» aplicada a las enfermedades infecciosas; por otro lado, los postulados progresistas de las agrupaciones médicas sobre "medicina social" empezaron a cuajar como práctica sanitaria al mismo tiempo que se fueron consolidando las dimensiones administrativistas de la salud pública (Marset et al, 1994). Los sucesivos gobiernos republicanos facilitaron, además, importantes cambios normativos para modificar las rígidas estructuras laborales, familiares, educativas y socioculturales que discriminaban a los españoles, especialmente a las mujeres, y condicionaban su comportamiento público y privado.

España registró en esos años tasas de crecimiento demográfico (Cuadro 1) cercanas a las de Italia, pero inferiores a las del resto de países del Sur de Europa, al entrar en el siglo XX con cierto retraso en comparación con la mayoría de naciones occidentales en las primeras etapas de la transición demográfica. Los resultados alcanzados incidieron en la reducción de las altísimas tasas de mortalidad infantil que hicieron (parafraseando a Amando de Miguel, 1972) que las madres españolas no tuvieran menos hijos vivos que sus abuelas, sino menos embarazos. A pesar de los incentivos económicos y de otras ventajas que disfrutaron las familias numerosas y de las políticas sociosanitarias tendentes a facilitar directa e indirectamente la natalidad, disminuyeron no obstante los nacimientos porque descendieron aún más las defunciones. No siempre los estudiosos de estos fenómenos interpretaron bien esta nueva ecuación. La mayoría de ellos asociaron con poco fundamento científico la caída de la natalidad con la decadencia nacional (Ros Jimeno, 1944). 


\section{OBJETIVOS, FUENTES Y METODOLOGÍA}

Los objetivos generales de este trabajo se centran en el examen del estado de la cuestión de la natalidad en España a principios del siglo XX, su estructura, condicionantes y evolución a comienzos de la transición demográfica, con vistas a interpretar el debate que tal acontecimiento suscitó en su momento, la reacción social, científica y política, y finalmente las soluciones adoptadas al descenso de los nacimientos por las instituciones públicas a la luz del bajo crecimiento de la natalidad y su repercusión en el ritmo de crecimiento de la población. Un debate que no nos resulta extraño hoy en día a los estudiosos de la población ante la aminoración extrema de la natalidad y su escaso aporte al crecimiento demográfico natural. Se parte de la base de que los incentivos económicos supusieron en su día un factor central para promocionar los nacimientos como eficaz complemento de otras medidas sanitarias, sociolaborales y culturales.

Las fuentes consultadas son las que suministran la bibliografía especializada, las series estadísticas históricas compiladas por el INE y la normativa institucional publicada en la Gaceta. La metodología empleada se ha centrado en el análisis integral del fenómeno y su contexto histórico dando como resultado provisional un relato descriptivo, justificado documentalmente que constituye el contenido de la presente aportación (Sauvy, Bergues y Riquet, 1972).

\section{EL ESTUDIO DE LA NATALIDAD EN ESPAÑA A PRINCIPIOS DEL S. XX}

A finales del siglo XIX y principios del XX se extendió la percepción de que la "natalidad" estaba retrocediendo en los principales países de Europa occidental lo que hizo saltar las alarmas tanto de gobernantes como de intelectuales que la situaron en el centro de las preocupaciones de los estudiosos de la población. A su vez, la inquietud generada entre expertos y grandes mandatarios por las consecuencias de las tres grandes crisis de principios del siglo XX (Primera Guerra Mundial, la epidemia de "gripe española" de 1918 y la gran recesión económica de 1929) en el bajo crecimiento demográfico y que, de alguna forma, contribuyeron a extender ese temor por todo el continente elevando la inquietud por conocer sus causas principales. El bajo crecimiento experimentado por países como Francia desató el miedo al "declive demográfico" (Teitelbaum y Winter, 1985). 
Esta sensación de pesimismo se ahondó todavía más con la publicación del controvertido ensayo titulado La decadencia de Occidente ${ }^{1}$ de Oswald Spengler (1880-1936), divulgado en Espańa por Ortega y Gasset. La caída de la natalidad, común a muchos países occidentales, fue interpretada en clave de descenso de la "vitalidad demográfica" como un claro síntoma de decadencia de las naciones. Esta visión negativa se reforzó durante los años 30, con la gran crisis económica mundial, momento en que tanto gobernantes como científicos lanzaron la voz de alarma sobre un futuro incierto en el que los nacimientos serían cada vez más escasos (Gil-Alonso, 2011).

En un contexto influido por la preocupación de la aminoración en el ritmo de los nacimientos y sus consecuencias en el decremento demográfico, se efectuaron estudios sobre la natalidad y sus condicionantes bajo diferentes enfoques. Para ello se movilizaron las instituciones académicas reorientando parte del esfuerzo investigador de científicos procedentes de disciplinas tan dispares como la medicina, la biología, la farmacia o la ética reproductiva. Durante estos ańos el estudio de la evolución de la natalidad estuvo marcado por la escasez e imperfección de las estadísticas y por el empleo de técnicas cuantitativas rudimentarias. Con un posicionamiento antimalthusiano y pronatalista (Urteaga, 1985: 467) se insistía en el papel exclusivo de la mujer como madre, la importancia de los cuidados durante el embarazo y el parto, la reducción de la mortalidad infantil, la alimentación y la higiene junto a la salubridad ambiental a la vez que una subrepticia estigmatización de las mujeres adultas sin descendencia. Los resultados de estos trabajos no siempre tuvieron una finalidad científica. Salvo la excepción del breve período republicano en donde prevaleció el enfoque progresista ${ }^{2}$, algunas de las investigaciones emprendidas, al estar afectada la caída de la natalidad por múltiples factores de orden socioeconómico, político y moral, fueron instrumentalizadas en un escenario prebélico ya de por sí muy caldeado para difundir todo tipo de consignas políticas, ideológicas y religiosas. No fue nada casual que en los medios conservadores se acusara a

1 Apareció editada en dos volúmenes, (1918 y 1922) y le valió una celebridad inmediata desencadenando debates y polémicas sin fin tanto en medios científicos como literarios. Spengler, enemigo declarado de la democracia liberal, concentró su interés en demostrar que la cultura occidental se encontraba en su etapa final.

2 Especialmente avanzadas fueron las políticas emprendidas durante el mandato de Marcelino Pascua Martínez (Valladolid, 1897-Ginebra, 1977) como Director General de Sanidad, desde 1931 hasta finales de 1933 (Bernabéu, 2000). Por otra parte, los socialistas de orientación marxista sostuvieron que el malthusianismo era esencialmente conservador y que su finalidad última consistia en restar fuerzas al proletariado (Urteaga, 1985). 
los neomalthusianos de perseguir el hundimiento de la patria con sus prédicas antinatalistas.

Cuadro 1. Tasas brutas de mortalidad, natalidad y crecimiento natural de las naciones del Sur de Europa entre los años 1920-1935.

\begin{tabular}{|l|l|l|l|l|l|l|}
\hline & \multicolumn{2}{|l|}{ TBM (en tantos por mil) } & \multicolumn{2}{l|}{ TBN (en tantos por mil) } & \multicolumn{2}{l|}{ TBCN (en tantos por mil) } \\
\hline & $1920-24$ & $1930-34$ & $1920-24$ & $1930-34$ & $1920-24$ & $1930-34$ \\
\hline Italia & 17,8 & 14,1 & 30,1 & 24,5 & 12,3 & 10,4 \\
\hline Espańa & 21,0 & 16,5 & 30,0 & 27,5 & 9,0 & 11,0 \\
\hline Yugoslavia & 17,1 & 18,4 & 35,3 & 33,0 & 18,2 & 14,6 \\
\hline Portugal & 21,5 & 16,9 & 33,0 & 29,3 & 11,5 & 12,4 \\
\hline Grecia & 21,2 & 16,6 & 31,4 & 30,4 & 10,2 & 13,8 \\
\hline
\end{tabular}

Fuente: Naciones Unidas: "Perspectivas de la población mundial evaluada en 1963. Estudios Demográficos, núm. 41, p. 3.

Personalidades como Jesús Villar Salinas ${ }^{3}$, José Ros Jimeno ${ }^{4}$, Antonio Arbelo Curbelo $^{5}$, Severino Aznar ${ }^{6}$, Javier Ruiz Almansa ${ }^{7}$, José Sánchez Verdugo ${ }^{8}$ o Pedro Bustinza Ugarte', entre otros, desarrollaron su labor principalmente en las décadas de 1930 y 1950 , y escribieron sus trabajos en un ambiente inmerso en la creencia bélica y nacionalista que hacía depender el poderío de la nación del volumen total de población siguiendo la frase acuñada por el arbitrista Diego de Saavedra Fajardo (1584-1648) "La fuerza de los reinos consiste en el número de súbditos" La mayor parte de los trabajos de estos autores fueron publicados en la Revista Internacional de Sociología, posteriormente se recopilaron en Estudios Demográficos y fueron reeditados por el Instituto "Balmes" de Sociología del C.S.I.C.

3 Autor en colaboración con J. Bosch Marín del libro La natalidad contemporánea en España (1942, 150 p.)

4 "El decrecimiento de la natalidad y sus causas" en la Revista Internacional de Sociología, núm. 7 (julio-septiembre de 1944), págs. 79-22 y "Algunos aspectos de la natalidad en España, Revista Internacional de Sociología, núm. 57 (julio-septiembre, 1959, pp. 419-430

5 La mortalidad de la infancia en España: 1901-1950 (1952)

6 Despoblación y colonización. Ed. Labor, 1930.

7 Reproductividad neta de las provincias y regiones de España (1943)

8 La población española: cómo se distribuye, cómo nace y cómo muere (1952)

9 Análisis de la natalidad española y de su decrecimiento (en colaboración con A. Sopeña), 1957.

10 Desde la Reconquista (718-1492) los viejos principios castellanos de "Defender poblando" y

"Gobernar es poblar" habían calado muy hondo en el pensamiento tradicional español. 
El avance en el conocimiento de la natalidad española que estos autores representaron se caracterizaba en general por guiarse de una metodología rudimentaria, unas fuentes escasas y poco explotadas y un enfoque excesivamente descriptivo. En conjunto, cuando abordan los factores causales de la natalidad, la fecundidad, la fertilidad o la mortalidad infantil ofrecen unos resultados a veces excesivamente mediatizados por el contexto político y por las creencias ideológicas, fuertemente impregnadas de un tradicionalismo característico de la época (Gil-Alonso, 2011).

El creciente interés internacional por la natalidad y por el incremento demográfico llega también a España que no tardará en sumarse a esta corriente investigadora en donde ya se contaba con cierto recorrido, como bien reflejan los prólogos de las publicaciones del Movimiento Natural de la Población ${ }^{11}$. Es verdad que en aquellos años la sociedad espańola destacaba por la incultura de las madres en materia de salud ${ }^{12} \mathrm{y}$ de forma especial de todo lo referente a la puericultura, y que ese déficit era considerado por los responsables sanitarios y políticos como una de las causas más importantes de las enfermedades y muerte de sus hijos (Bernabéu y Gascón, 1999). El retraso relativo de la transición demográfica en la mayor parte de las regiones españolas se evidenciaba en el elevado nivel que seguía manteniendo la mortalidad, especialmente la infantil y juvenil, que polarizaba el interés de los estudiosos en su afán por limitar esta sangría demográfica que hipotecaba el desarrollo de la sociedad ${ }^{13}$.

Se tuvo que esperar a la década de los años 30 del siglo XX para que la investigación sobre la evolución de la natalidad y sus condicionantes aumentara en rigor científico y adquiriera cierto peso relativo en la praxis política y administrativa de la nación. La institucionalización del sistema sanitario, junto

11 El Movimiento Natural de la Población constituye uno de los trabajos de mayor tradición en el INE. El primer volumen se publicó en 1863 por la Junta General de Estadísticas del Reino (contenía datos del periodo 1858-1861 obtenidos a partir de los registros parroquiales). Desde entonces se viene publicando sin más interrupción que la ocurrida durante el periodo 1871-1885, época de implantación del Registro Civil, de donde se obtendrían en lo sucesivo los datos correspondientes para confeccionar las series estadísticas.

12 "La ignorancia es más mortífera que la pobreza" (Mouchez, Demografía. Ed. Ariel, Barcelona, p.102).

13 Según Carreras y Tafunell (2006), España comenzó la transición demográfica con bastante desfase y ésta tuvo un recorrido lento y ha acabado abruptamente, dejando la tasa de crecimiento vegetativo a niveles internacionalmente bajos. Un segundo indicador de transición y modernización demográficas es el índice sintético de la fecundidad: la generación de mujeres nacidas a partir de 1870 tuvo 4,7 hijos por mujer, mientras que las que nacieron a partir de 1920 redujo su descendencia a 2,5 hijos. 
con la docencia y la formación de los profesionales cualificados que se demandaba, se fue consolidando en estas décadas no sin antes tener que vencer grandes dificultades.

\section{EL CONTEXTO SOCIOPOLÍTICO Y ECONÓMICO DE LA ESPAÑA DE LOS AÑOS TREINTA}

La sociedad española de las primeras décadas del siglo XX seguía siendo mayoritariamente rural. Por entonces, España en comparación con otros estados de la Europa occidental estaba poco poblada en términos relativos. No obstante, ya en esos años era perceptible una cierta tendencia a la modernización de las estructuras demográficas, que el crecimiento económico del último período de la Monarquía había contribuido a consolidar (Nadal, 1984). El carácter selectivo de tal proceso, condicionado por el desigual desarrollo capitalista, confería a estos impulsos demográficos una capacidad de dinamización $y$, a la vez generadora de tensiones sociales, que les convertiría en un factor relevante en tiempos de la Dictadura de Primo Rivera y la Segunda República.

Mientras que la mortalidad empieza a retroceder en España desde 1900, la natalidad española lo hace más tarde, en torno a 1914, coincidiendo con la Primera Guerra Mundial, en la que España no participó pero si padeció algunos de sus peores efectos como el aumento de los precios. Por entonces, en las principales naciones occidentales estaba cuajando ya la tendencia a la limitación voluntaria del número de hijos en la familia. En nuestro país esa tendencia no se aprecia de forma sustancial hasta tanto no aumentó la población residente en ciudades de más de 50.000 habitantes ${ }^{14}$. La tasa bruta de natalidad pasó del $32,6 \%$ en 1910 a $27,5 \%$ en 1930 , y a 20,0\% en 1950 . La disminución fue especialmente brusca entre 1928 y 1935 debido a la depresión económica. A nivel regional, la natalidad en la industrializada Cataluña había empezado a disminuir con anterioridad al resto de España (aunque no en el también industrializado País Vasco), mientras que Canarias presentaba un régimen demográfico peculiar, con una natalidad que superaba ampliamente a la peninsular hasta los ańos ochenta (Martín Ruiz, 1985).

14 En 1900, el 50,8\% de la población reside en municipios de menos de 5.000 habitantes, mientras que sólo el 13,5\% vivía en municipios de más de 50.000 personas. El trasvase se acelera en las décadas siguientes de forma que en 1930, en la primera categoría se concentra el 40,2\% de los espańoles, mientras que en la segunda sólo el 19,8\%. 
Figura 1. Evolución de las tasas brutas de natalidad y mortalidad (1858-2001)

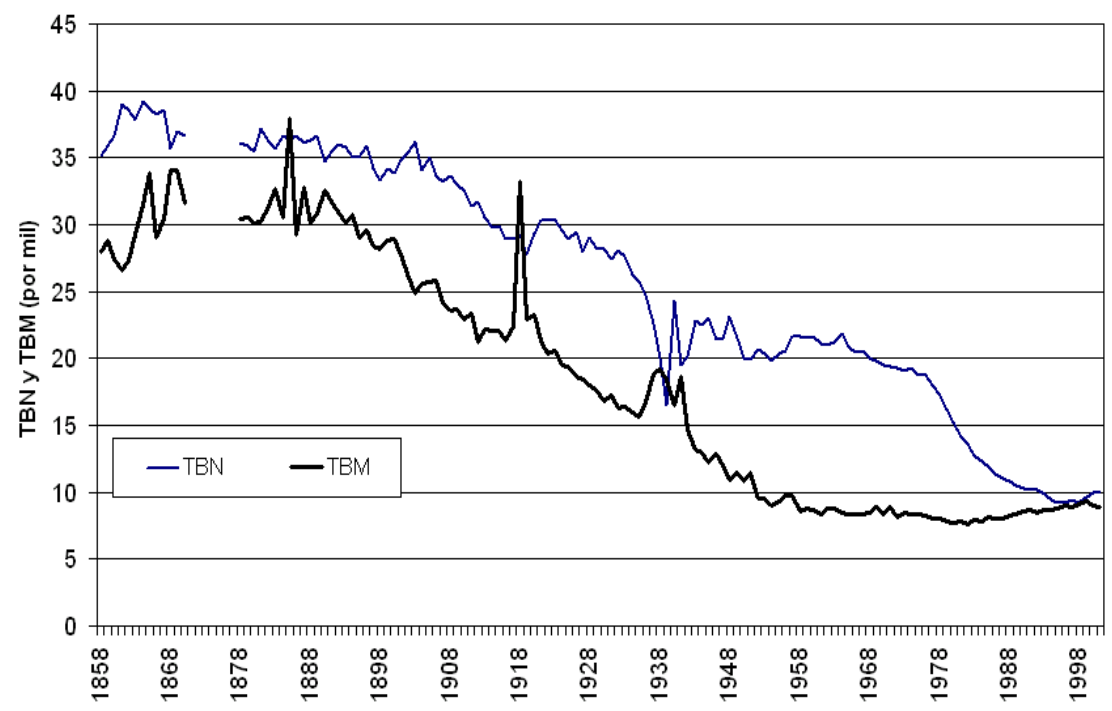

Fuente: Estadisticas históricas de España. Siglos XIX y XX. Fundación BBVA

En esas primeras décadas, el crecimiento vegetativo fue, en general, sostenido, oscilando en torno a un 9-11\%o anual (figura 1), y se producía especialmente en Galicia, Extremadura y Andalucía, mientras que las cifras más bajas, aunque no inferiores a $8 \%$, se daban en las provincias mediterráneas. La tasa bruta de natalidad bajó de 28,3\% en 1930 a 25,9\% en 1935 , y la tasa de reproducción —número de hijos por mujer- descendió durante ese mismo quinquenio, pero sus resultados se vieron compensados por la continua bajada de la mortalidad, que siendo de 17,3\%o habitantes en 1931, llegó a situarse en $15,7 \%$ en 1935 . La tasa de nupcialidad cayó también por razones económicas y sociales, con la repercusión consiguiente en la de natalidad (Prados, 1971: 16-46).

A comienzos de la década, el Censo de Población de 1930 daba a España una población de 23.667.497 habitantes con una tasa de crecimiento intercensal del 10,21 por cada mil individuos (1920-1930). En 1936, la población española alcanzó los 24.693.000 habitantes de los cuales un 48,8 por ciento eran hombres, y un 51,2\%, mujeres. Y, cerrando la década, en 1940, el Censo oficial de Población registró un total de 26.014.750 espańoles lo que suponía un incremento intercensal del 9,46 por cada mil habitantes entre 1930 y 1940 (Cabré et al, 2011), cifra nada desdeñable habida cuenta las terribles conse- 
cuencias de la Guerra Civil. Por consiguiente, el desequilibrio entre el número de nacimientos y defunciones, más los aportes migratorios, produjeron un incremento de 2.347.253 habitantes durante esos años. Prueba de ello es que sólo durante el quinquenio 1931-1935, el índice de crecimiento demográfico fue de $1,25 \%$, es decir, uno de los más altos de los registrados hasta entonces desde el primer censo oficial de 1857. Esta dinámica se ve gravemente interrumpida durante el segundo quinquenio por la contienda fratricida y sus trágicas secuelas entre los españoles.

Cuadro 2. Esperanza de vida al nacer (1930-1940)

\begin{tabular}{|c|c|c|}
\hline & Hombres & Mujeres \\
\hline 1930 & 47,94 & 51,29 \\
\hline 1935 & 51,34 & 55,06 \\
\hline 1940 & 46,25 & 52,57 \\
\hline
\end{tabular}

Fuente: Del Campo, S. (1965). "Los médicos ante el problema de la limitación de la natalidad”. Revista Española de la Opinión Pública, no. 1, Mayo/agosto, pp. 27-38.

Inicialmente la esperanza de vida empezó siendo baja, ya que no llegaba a los cincuenta años para los varones y apenas los superaba en las mujeres, pero mejoran los resultados a mediados de la década, especialmente entre las féminas, para volver de nuevo a cifras parecidas al decenio anterior a causa de la Guerra Civil.

La densidad media estaba en torno a los 47 habitantes por kilómetro cuadrado, pero en aquellos años la población se repartía, como ahora, muy desigualmente por la geografía nacional. Era más densa en las zonas costeras mediterráneas, en el área de Madrid, en los dos archipiélagos y en Andalucía occidental, mientras que las comarcas montañosas de Aragón y grandes porciones de las dos Castillas, León, el interior de Galicia y Extremadura estaban escasamente pobladas (Gráficos 2 y 3). El proceso de urbanización había progresado a buen ritmo en las últimas décadas. En 1930, el 43 por ciento de los españoles vivía en núcleos de más de cien mil habitantes. Las siete principales ciudades -Barcelona, Madrid, Valencia, Sevilla, Málaga, Zaragoza y Bilbaoaumentaron su población en un $23 \%$ durante los ańos veinte. Barcelona y Madrid, que ya rondaban el millón de habitantes, cuadruplicaron el número de residentes entre 1900 y 1936. El éxodo rural a los centros urbanos y a los núcleos industriales sustituía en muchos sitios a la clásica emigración ultramarina y reforzaba en las grandes ciudades la presencia de un proletariado de aluvión, 
con fuertes raíces campesinas, poco cualificado y sometido a una permanente precariedad en el empleo ${ }^{15}$.

Las tradicionales regiones industriales -Barcelona, Vizcaya, Asturias- y los centros de desarrollo más tardío, como Madrid, Valencia o Andalucía occidental, recibieron en las primeras décadas del siglo pasado un flujo inmigratorio indiscriminado, que se orientaba preferentemente hacia la construcción, la minería, la industria textil y el sector servicios. Otra salida tradicional de los excedentes de población, la emigración a América, mostraba por el contrario una tendencia a la disminución desde mediados de la década anterior. El descenso de la emigración ultramarina y la inversión ocasional de las corrientes migratorias se debe, entre otras las razones, a la Gran Depresión que se inició en Estados Unidos en 1929 y se difundió al resto del mundo mediante la disminución del comercio y la fuerte caída de los flujos internacionales de capital ${ }^{16}$.

Figura 2: Distribución de la población española (1900)

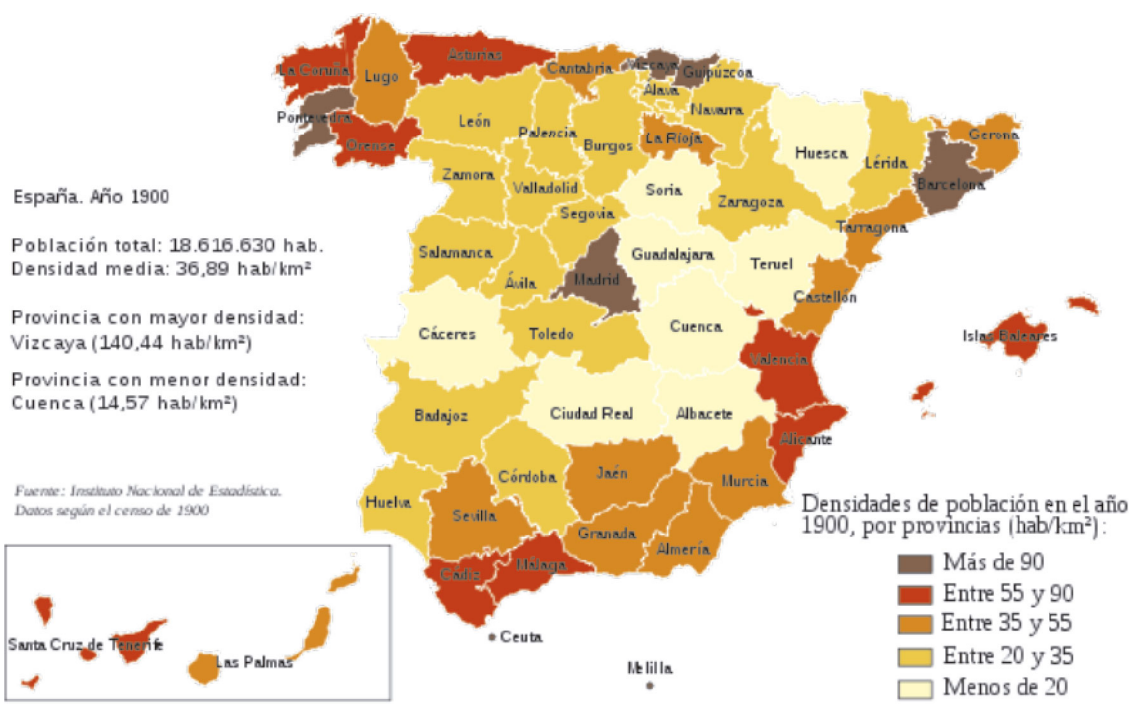

15 No se debe perder de vista en esta apreciación que el crecimiento durante el periodo 1920-1940 fue, en general, elevado en todo el país, incluyendo las zonas del interior peninsular, lo que indica una revitalización de las ciudades medias del interior pero también un sobrepoblamiento del campo, lo que provocó tensiones por la ocupación de la tierra y, en los decenios siguientes, un éxodo rural masivo. Destaca ya en este periodo la fuerte atracción migratoria de los polos barcelonés y madrileńo.

16 El balance del flujo ultramarino pasó a ser favorable a la inmigración ante las barreras puestas por los países de destino, también afectados por la Gran Depresión; entre 1931 y 1934 se efectuaron 106.243 entradas más que salidas, si bien luego se produjo una leve recuperación de la tendencia emigratoria. 
España no era una excepción ya que fue duramente golpeada, aunque con menor intensidad que otras economías europeas más desarrolladas. La adversa coyuntura internacional intensificó la desaceleración de la actividad económica española, ya visible en 1928, y agravó sus desequilibrios estructurales (Tamames, 1973). El cambio de ciclo se responsabilizó en gran medida de la ralentización de los procesos de modernización demográfica durante los años de la República. En efecto, tanto la situación internacional adversa como la incapacidad del mercado interior para seguir estimulando ininterrumpidamente unos ritmos de crecimiento económico, restaron protagonismo al trasvase sostenido de población del medio rural al urbano y de las actividades primarias a los restantes sectores productivos que, a pesar de ello (como ya se ha dicho), alcanzaron un montante considerable. ${ }^{17}$

Figura 3. Distribución de la población española en 1930

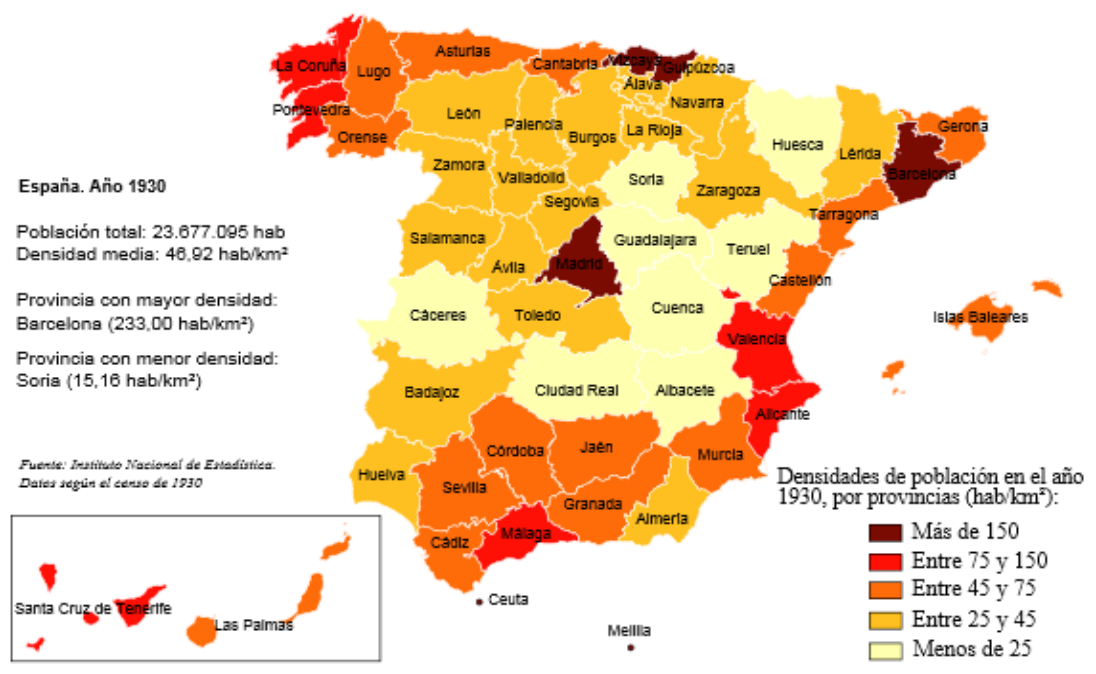

La tasa media de analfabetismo proseguía siendo muy elevada en 1930 ya que afectaba al $30,8 \%$ de la población $(23,6 \%$ en los varones, $38,1 \%$, en las mujeres) aunque había descendido once puntos a lo largo de la década anterior, y durante los años treinta lo haría en otro nueve por ciento. En cuanto a la enseñanza superior se refiere, ésta poseía una notable calidad, pero seguía siendo

17 Por su parte, el saldo neto migratorio inter-regional se redujo casi a la mitad y el proceso de crecimiento urbano se desaceleró. 
minoritaria y muy elitista. Tan sólo en 1931 se contaban 35.000 estudiantes en toda España.

El número de personas en edad de trabajar (principalmente hombres de entre 15 y 64 ańos) creció durante esos años en unos 530.000 individuos, frente a los 388.5000 del quinquenio anterior (1925-1930). Como era lógico en un país agrícola, las actividades del sector primario daban ocupación a un porcentaje muy grande de la población asalariada, el 45,5\% en 1930, frente a un $26,5 \%$ en el secundario y un $27,9 \%$ en los servicios, aunque su importancia relativa no dejó de disminuir durante los años republicanos (Tamames, 1971).

$\mathrm{Al}$ extenderse el paro en todos los países receptores se produce el retorno de una parte de los emigrantes espańoles, lo que unido a las dificultades de la industria y la baja episódica de los precios agrarios repercutieron, además, en un aumento del desempleo que, aunque inferior al de la mayoría de los países industrializados, tuvo efectos muy desfavorables en el terreno social y político. Pese a que las estadísticas de la época son un tanto confusas, se puede afirmar que la tasa de paro se duplicó en el período republicano. Algunas estimaciones dan una cifra total de 389.000 desempleados en enero de 1932, que alcanzaría los 801.322 en junio de $1936^{18}$.

Cuadro 3: Población activa en España de 1900 a 1940

\begin{tabular}{|l|c|c|c|c|}
\hline Años & \multirow{2}{*}{$\begin{array}{c}\text { Total población activa } \\
\text { \% de la población total) }\end{array}$} & \multicolumn{3}{|c|}{$\begin{array}{c}\text { Distribución de la población activa por sectores } \\
\text { (en de la población activa total) }\end{array}$} \\
\cline { 3 - 5 } & & Agrícola & Industrial & Servicios \\
\hline 1900 & 35,3 & 63,3 & 15,9 & 17,7 \\
\hline 1910 & 35,3 & 66,0 & 15,8 & 18,1 \\
\hline 1920 & 35,1 & 57,3 & 21,9 & 20,8 \\
\hline 1930 & 35,5 & 45,5 & 26,5 & 27,9 \\
\hline 1940 & 34,6 & 50,5 & 22,1 & 27,3 \\
\hline
\end{tabular}

Fuente: Instituto de Cultura Hispánica (en Tamames, 1971).

Los porcentajes por sectores productivos variaban mucho (Cuadro 3). Las industrias vinculadas a la exportación sufrieron más los efectos de la crisis laboral, especialmente en la de materiales de construcción, siderurgia y la minería de Madrid, Vizcaya y Asturias, mientras que otros sectores industriales, como el textil, y los servicios se vieron relativamente poco perjudicados. Por este mo-

18 Seco Serrano en 1969 precisa las cifras de paro en el año 1936 en 675.000 personas. 
tivo, por ejemplo, en Cataluña la tasa de paro a mediados de 1932 fue relativamente marginal, un 5\%, mientras en Andalucía alcanzaba al 12\% de la población laboral, fundamentalmente porque era en el campo donde el problema del paro adquiría tintes dramáticos. En junio de 1932, más de la mitad de los parados eran trabajadores agrícolas, sobre todo en Andalucía y Extremadura. Y hasta en Canarias la situación era igual de preocupante (Suárez Bosa, 1990). El paro forzoso no dejó de crecer hasta aproximarse a los dos tercios del total. En diciembre de 1934, Andalucía y Extremadura soportaban el 38,4\% del total nacional de parados (Tuñón, 1972; 1973 y 1976).

El que los salarios subieran durante esta época hacía aún más visible el contraste entre trabajadores empleados y desempleados. Y el problema se veía agravado por la carencia de un sistema estatal de subsidios y por el carácter limitado de otros sistemas de seguridad social. La Caja Nacional del Seguro contra el Paro Forzoso, creada en 1931 por el Ministerio de Trabajo, carecía de recursos para socorrer a los parados, ya que sólo recibía el 0,5 por ciento de los presupuestos generales del Estado. La creación en 1935 de la Junta Central contra el Paro, dedicada a promover obras públicas que ocupasen a los desempleados, apenas palió el problema, ya que su asignación equivalía al dos por ciento del gasto público.

En definitiva, la relativa suavidad de la recesión económica permitió mantener una tasa de paro discreta, que algunos autores sitúan en un máximo del $12,9 \%$ de la población activa, mientras otras fuentes la reducen al siete o incluso al seis, muy por debajo de la alemana (más del 30\%) o de la norteamericana $(25 \%)$. Pero era un problema cualitativo, más que cuantitativo. La carencia de mecanismos sociales compensatorios dejó en situación sumamente precaria a cientos de miles de familias y contribuyó a hacer de la bolsa de paro focos importantes de conflictividad social y política que, en ocasiones, como sucedió en Asturias y Vizcaya en octubre de 1934, coadyuvaron a desatar procesos de insurgencia popular (Pecharromán, 2006).

\section{EL IMPACTO DE LA SEGUNDA REPÚBLICA EN LOS CAMBIOS SO- CIALES}

En medio de un clima de euforia y de anhelos de cambio en la sociedad española, el advenimiento de la Segunda República generó una gran ilusión transformadora y modernizadora en todos los órdenes (Tunón, 1976). Entre las iniciativas emprendidas que tuvieron un impacto indirecto en los patrones reproductivos de nuestro país se encuentra el modelo de familia tradicional establecido por la Iglesia Católica que se transforma radicalmente al posibilitarse 
otras opciones como el matrimonio civil, la legalización del divorcio, la supresión del delito de adulterio y el hacer factible la tutela de la madre sobre sus hijos. Igualmente le fue reconocida a la mujer el derecho al voto y a ser elegida (Durán, 2007). Entre las reformas laborales emprendidas en esos años se establece la igualdad salarial, la potestad de la mujer para contratar servicios, pudiendo con ello desempeñar funciones empresariales y ejercer laboralmente como trabajadora autónoma. Es también eliminada la cláusula de despido por matrimonio o maternidad, vigente hasta entonces, y se establece un seguro por maternidad al mismo tiempo que son suprimidas las barreras para que la mujer pueda acceder a empleos y cargos públicos según mérito y capacidad. Otras novedades importantes fueron el que, por primera vez, las mujeres pudiesen acceder en igualdad de condiciones a toda la formación reglada, incluyendo las carreras universitarias, y la despenalización del aborto inducido.

\section{LA LUCHA INSTITUCIONAL CONTRA LA MORTALIDAD INFAN- TIL Y MATERNAL}

Desde el punto de vista sanitario, las condiciones de vida y el estado de salud de la población española desde finales del siglo XIX hasta los años treinta del XX eran realmente deprimentes. El atraso de las estructuras sanitarias fue objeto de atención por los diferentes gobiernos de la etapa de la Restauración ${ }^{19}$ que acometieron como mejor pudieron importantes iniciativas orientadas a mejorar el estado de la sanidad pública. Dada su elevada incidencia, la reducción de la mortalidad infantil y la mortalidad maternal se convirtieron en el objetivo prioritario tanto de la Dictadura como de los sucesivos gobiernos de la Segunda República. En estos años la salud materno-infantil ya empezaba a dar muestras positivas con la puesta en vigor de algunos avances sustanciales (Huertas, 2000).

Con la Dictadura de Primo de Rivera (desde el 13 de septiembre de 1923 al 28 de enero de 1930) se inicia un notable incremento de la actividad sanitaria que, más tarde, sería continuada y matizada durante la República (19311939). Esta actividad se distingue fundamentalmente por una intensa

19 La Restauración corresponde a la etapa política desarrollada bajo la monarquía borbónica que se extendió en España desde 1874 hasta el 14 de abril de 1931(proclamación de la Segunda República). La Restauración borbónica se caracterizó por una cierta estabilidad institucional, la construcción de un modelo liberal del Estado en el que se incluyen los movimientos sociales y políticos favorecidos por la revolución industrial, hasta su progresiva decadencia con la Dictadura de Primo de Rivera en 1923 (Jover Zamora, 1968). 
preocupación normativa que se tradujo en la promulgación de Reglamentos Sanitarios (Reglamento Municipal de Sanidad de 1925) y el Reglamento de Sanidad Provincial) y en la creación de un gran número de instituciones sanitarias nuevas, de entre las cuales sólo enumeraremos aquellas que guardan relación directa e indirecta con el tema aquí propuesto como son la Escuela Nacional de Sanidad (Real Decreto de 2 de diciembre de 1924); la Escuela Nacional de Puericultura (Orden de 23 de mayo de 1923 y Real Decreto de 16 de noviembre de 1925) y el Instituto Técnico de Comprobación (Real Decreto de 22 de diciembre de 1925).

La referida Escuela Nacional de Puericultura estableció delegaciones en las provincias que carecían de recursos para su sostenimiento, mientras que en aquellas otras en donde las autoridades locales podían costearlas se abrieron Escuelas Provinciales de Puericultura. Otra aportación novedosa fueron las bases del Proyecto de la Escuela Nacional de Enfermeras Visitadoras Sanitarias (que tuvo que esperar hasta 1932 para entrar en funcionamiento) orientada a cubrir la demanda de profesionales cualificados (Huertas, 2000).

En los años 20, la Junta de Ampliación de Estudios impulsó la subscripción de un convenio de colaboración entre la Comisión Permanente de Investigaciones Sanitarias con la Fundación Rockefeller que dieron a los funcionarios técnicos de administración sanitaria la oportunidad de formarse en estas materias en el extranjero. Una Real Orden de 23 de mayo de 1923 pone en funcionamiento el Instituto Nacional de Maternología y Puericultura cuya creación burocrática data nada menos que de 1910. Contaba con un centro docente de formación de profesionales encargados de velar por la salud materno-infantil y estaba adscrita al Consejo Superior de Protección de la Infancia. Uno de los acuerdos más importantes se adoptó en 1929 al aprobarse el Anteproyecto de Ley del Seguro Obligatorio de Maternidad y que en la práctica no se pudo implantar hasta el año 1931, con la Segunda República. Poco a poco se va institucionalizando en nuestro país un sistema público de salud digno de ese nombre (Barona, 2012).

Durante la Segunda República se hace un reconocimiento de la obligación y responsabilidad que tiene el Estado en la determinación de los problemas de salud de la población, en su atención y control apropiados, así como la identificación de un modelo de asistencia médica colectivizada para mejorar el estado de salud y las condiciones de vida de la población española.

Los Gobiernos de la República no tienen el menor empacho en asumir y validar muchas decisiones adecuadas que fueron adoptadas en la etapa de la Restauración borbónica y de la Dictadura. A la vista de lo dicho, podría dar la 
falsa sensación de un excesivo continuismo entre las dos etapas políticas y nada más lejano en la práctica. Cierto es que entre la dictadura de Primo de Rivera y la República existen nexos de cierta continuidad, pero también elementos de ruptura, de innovación y de cambios importantes. Es, precisamente, el análisis dialéctico de dichos procesos de cambio el que nos puede permitir comprender mejor qué hay de heredado y qué de novedoso en cada etapa o ciclo histórico (Huertas, 2000).

Nada mejor que conocer los hechos para reconocer que en ambas etapas se sientan las primeras bases para la construcción de un moderno sistema nacional de salud inspirada en los principios de universalidad, equidad y solidaridad y con un sistema de financiación pública apoyada en los Presupuestos Generales del Estado, responsable de hacer efectivo dicha estructura y de velar por su correcto funcionamiento, mantenimiento y mejora. Estos objetivos quedaron bien reflejados en la evolución del presupuesto ordinario de la Dirección General de Sanidad que pasó, en concreto, de 6.619.300 pesetas en el año 1920 a 31.432.690 pesetas en 1933 (Huertas, 2000).

Para conseguir los objetivos programados, se hizo necesario proseguir el desarrollo de una infraestructura sanitaria apropiada y la reorientación de los cuerpos sanitarios en general para el adecuado cumplimiento de sus funciones. De esta forma se fueron generando nuevos equipamientos y organizando a un tiempo los equipos humanos y las estructuras departamentales para proporcionar a la población española la atención y las dotaciones necesarias y, a la vez, formar a un número suficiente de profesionales que habrían de ofertar esos servicios.

Durante el mandato de Marcelino Pascua Martínez ${ }^{20}$, Director General de Sanidad durante los ańos 1931 a 1933, se tomaron acuerdos decisivos en materia de lucha contra la mortalidad general, infantil y maternal como el Decreto de creación de la Sección de Higiene Infantil dependiente de la Inspección General de Instituciones Sanitarias. Su objetivo era combatir la mortalidad infantil y todo lo relacionado con ella. Contaba con los departamentos de mortalidad materna, de mortinatalidad infantil, higiene prenatal y pre-escolar.

20 Médico, becario de la Institución Libre de Enseñanza, especialista en epidemiología, estadística sanitaria y administración e higiene pública, fue pensionado por la Fundación Rockefeller y la Sociedad de Naciones para estudiar soluciones a los problemas sanitarios y de higiene en Europa y América, desarrollando estudios en el University College de Londres y la Johns Hopkins University de Baltimore (EEUU). Se afilió al Partido Socialista Obrero Espańol y fue elegido diputado por Las Palmas en las elecciones generales de 1931. 
Una Orden Ministerial de 31 de marzo de 1933 permitía crear dispensarios móviles de higiene infantil en provincias como Burgos, Ávila, Segovia y Teruel. Anteriormente, en otońo de 1931, la Dirección General de Sanidad puso en marcha las secciones de Higiene Social y Propaganda y la Sección de Higiene y Alimentación. De forma parecida, la Orden Ministerial de 22 de abril de 1932 permite habilitar el funcionamiento de los centros secundarios y los centros rurales de higiene que desempeñaron un papel fundamental en la mejora del estado de salud de la población durante los ańos 30. Por otra parte, la Orden Ministerial de 30 de marzo de 1932 ordena la creación de los Institutos Provinciales de Higiene, servicios de higiene infantil que debían contar con consultas de higiene prenatal, de lactantes y de higiene escolar (Robles et alii., 1996).

La Ley de Bases de Régimen Sanitario, promulgada el 11 de julio de 1934, tiene como objetivo fundamental incentivar la intervención estatal en la organización de los servicios sanitarios locales. Es implementada a través de la Orden Ministerial del 13 de febrero de 1936, que dispuso la reorganización de los Centros Secundarios y Primarios de Higiene Rural. En ambos casos el resultado permitió la constitución por primera vez en España de una red de centros para la asistencia sanitaria (con funciones preventivas, educativas, curativas y rehabilitadoras) compuesta por Centros Primarios y Secundarios de Higiene Rural (como primeros eslabones de una estructura más comopleja); Servicios de Higiene Infantil en todos los Institutos Provinciales de Higiene; Dispensarios móviles de Higiene Infantil y Dispensarios y sanatorios para la lucha antituberculosa y antivenérea, además de mejorar la situación presupuestaria y organizativa de todo un conjunto de instituciones, entre ellas, la creación de una Escuela Nacional de Sanidad y la Escuela Nacional de Enfermeras Visitadoras (Bernabéu, 2000).

En plena Guerra Civil, entre principios de noviembre y mediados de mayo de 1937, durante los seis meses que Federica Montseny Mañé (1905-1994) ejerció como Ministra de Sanidad y Asistencia Social de la República, se crearon por Decreto Ley el Consejo Nacional de Sanidad con cinco departamentos orientados a higiene y profilaxis, hospitales y sanatorios, farmacia y suministros, y el Consejo de Asistencia Social, cuya composición no entró en funcionamiento hasta el 17 y el 31 de enero de 1937, respectivamente. Estas medidas tuvieron poca efectividad práctica por el estallido de la guerra el 18 de julio y consistían básicamente en proyectos de hogares de acogida para la infancia, guarderías infantiles y escuelas de corrección y reforma, comedores para embarazadas y lactantes, un listado de profesiones a ejercer por minusválidos y el primer proyecto de Ley en Espańa por la que se despenalizaba la interrupción 
voluntaria del embarazo. Ni que decir tiene que se trataba de una medida totalmente innovadora que por otra parte daba satisfacción a la demanda de numerosas mujeres. Este decreto tenía un gran parecido al que se había aprobado en Catalunya en diciembre de 1936 y que entró en vigor en marzo del 1937. Es obvio añadir que esta decisión contó con rechazos en el propio gobierno republicano y, sobre todo, chocó con la actitud hostil de los gremios de médicos y enfermeros, la derecha conservadora, la Iglesia católica y los interesados en el sostenimiento de las lucrativas redes de abortos clandestinos (Alcalde, 1983).

\section{POLÍTICAS PRONATALISTAS INDIRECTAS A TRAVÉS DE LA PRO- TECCIÓN SOCIAL A LA FAMILIA NUMEROSA}

Por políticas pronatalistas se entienden aquellas decisiones que favorecen desde los gobiernos el aumento o mantenimiento de tasas elevadas de natalidad. Pueden hacerse de forma más o menos directa, a base de medidas que propicien el número de nacimientos mediante incentivos económicos; o como indirectas, fomentando por ejemplo que la mujer no trabaje fuera de casa, alargamiento de los permisos por maternidad, autorización de horarios reducidos por lactancia, creación de hogares infantiles públicos, etc.

En esos años se constataba una caída del índice sintético de fecundad y de la reproducción neta que, a su vez, influían en el descenso de la tasa bruta de natalidad (Cabré et alii, 2002). Es por ello que durante los años de la Dictadura de Primo de Rivera y la Segunda República se acordaron por los diferentes gobiernos disposiciones relativas a la concesión por el Estado de subsidios y otros auxilios económicos, sociales y laborales a familias numerosas de obreros, campesinos y funcionarios públicos ${ }^{21}$ orientados a promocionar el aumento de los nacimientos. Ahí reside, sin duda, la explicación del incremento en el número medio de hijos totales (vivos y fallecidos) habidos en las cohortes de mujeres que tenían más de 34 años en 1920 y más de 45 en 1930 que pasó de 4,49 a 5,06 para toda España. En el caso de Canarias, los resultados son más aún más llamativos por cuanto esas cifras representaron un 5,48 y 6,04, respectivamente (Gil Alonso, 2011: 23).

El Real Decreto Ley de 21 de junio de 1926 supuso un hito importante ya que por primera vez se otorga a las familias numerosas de funcionarios públicos y de la clase obrera, subsidios o pensiones (revisables cada tres años) en proporción al número de hijos concebidos. La normativa a aplicar por el Instituto Nacional

21 COLECCIÓN “LEYES DE LA REPÚBLICA”: Subsidios a familias numerosas. Disposiciones relativas a la concesión de subsidios por el Estado a familias numerosas de obreros y funcionarios públicos. Vol. 23. Ed. E. García Enciso, Pamplona, 60 p. 
de Previsión ${ }^{22}$ definía por familia numerosa aquella que contara con ocho o más hijos legítimos o legitimados a cargo del cabeza de familia, ya sean menores o mayores de edad o hijos emancipados a quienes se continuará prestando legalmente alimentación ${ }^{23}$. Los requisitos legales exigían que el cabeza de familia lo fuera con arreglo a la ley, dependiera exclusivamente de un jornal ajustado a unas condiciones a determinar por el Reglamento de desarrollo del Decreto-Ley ${ }^{24}$ y que no percibiera un ingreso anual superior a 6.000 pesetas por todos los conceptos.

Con esta normativa los hijos de familia numerosa disfrutarán además del beneficio de matrícula gratuita en todos los establecimientos de enseñanza oficial. E, igualmente, el cabeza de familia numerosa tendría preferencia a cualquier beneficio de índole social, económica, administrativa o jurídica que el Estado otorgue gratuitamente. En estas medidas se incluyen también a los funcionarios públicos civiles o militares que estén prestando sus servicios en las administraciones del Estado, Provincia, Municipio, Casa Real o Cuerpos Colegisladores (Senado y Congreso de los Diputados) que perciban los ingresos preceptuados y que tuvieran ocho o más hijos.

Cuadro 4: Subsidios concedidos a familias numerosas españolas (1926)

\begin{tabular}{|c|c|}
\hline \multicolumn{2}{|c|}{ Número de hijos e importe del subsidio } \\
\hline 8 & 100 pesetas \\
\hline 9 & 150 “ \\
\hline 10 & 200 “ \\
\hline 11 & 250 “ \\
\hline 12 & 300 “ \\
\hline 13 & 375 “ \\
\hline 14 & 500 “ \\
\hline 15 & 600 “ \\
\hline 16 & 700 “ \\
\hline 17 & 850 " \\
\hline 18 o más & 1.000 “ \\
\hline
\end{tabular}

Fuente: Leyes de la República. Subsidios a familias numerosas (Elaboración propia)

22 Por entonces estaba adscrito al Ministerio de Trabajo, Comercio e Industria.

23 El Código Civil recoge en los artículos 142 a 153 la institución "de los alimentos entre parientes" como una obligación legal de prestación de asistencia y socorro entre los cónyuges y los parientes más cercanos.

24 El Real Decreto-Ley de 30 de diciembre de 1926 aprueba el Reglamento provisional para la aplicación del Decreto-Ley de 21 de junio de 1926 por el que se establecen subsidios a las familias numerosas. Precisa mejor los trámites administrativos a seguir y define con mayor detalle el perfil que deben reunir los aspirantes de estas percepciones. 
En los casos de funcionarios de ambos sexos con once o más hijos se ampliarán las ayudas, gratificaciones y exenciones (impuesto de inquilinato, contribución de utilidades por el sueldo, matrícula gratuita en centros educativos oficiales), y cuentan así mismo con una bonificación en metálico sobre sus salarios en proporción al número de hijos (véase cuadro 4). Las viudas de funcionarios públicos con cargas familiares similares obtendrán unas bonificaciones tasadas de acuerdo con los haberes pasivos percibidos. La Real Orden Circular de 24 de noviembre de 1926 implementó las disposiciones antes vistas al disponer que las Academias Militares sean consideradas como establecimientos de enseñanza oficial a efectos de que los hijos de las familias numerosas puedan estar exentos del pago de matrícula cuando cursen estudios en dichos centros.

El Real Decreto-Ley de 4 de abril de 1927 hace extensivos los beneficios del subsidio a los huérfanos (de padre y madre) de obreros y funcionarios que sean menores de 23 ańos y sean solteros de condición civil. Estas personas podrán disfrutar de los beneficios contemplados en el Decreto-Ley de 21 de junio de 1926 y de su reglamento de 30 de diciembre del mismo año siempre que los aspirantes reúnan los requisitos que se recogen en ambas disposiciones.

Para hacer efectivas las ayudas en metálico se tienen que providenciar nuevas formas de pago, mediante nóminas especiales o habilitando a los interventores para que establezcan mecanismos innovadores de cobro. Con lo que se hace necesario acordar y publicar en la Gaceta un conjunto de reales órdenes que autoricen esos ajustes administrativos. Eso es lo que persigue, por ejemplo, la Real Orden del Ministerio de Hacienda de 12 de abril de 1927 ordenando centralizar el servicio de pago de los subsidios a familias obreras numerosas en el Ministerio de Trabajo, Comercio e Industria. Por otra parte, la Real Orden Circular del Ministerio de Hacienda, de 21 de junio de 1927, dicta las reglas a las que deberán acomodarse los solicitantes en cuanto se refiere al cobro de subsidios y exenciones del impuesto de utilidades, al pago de la bonificación sobre el sueldo cuando éstos han sido concedidos o la ejecución de las resoluciones que dicte el Ministerio de Trabajo, declarando el derecho de los funcionarios (que sean "jefes" [sic] de familias numerosas) de la Casa Real, Cuerpos Colegisladores y de la Administración del Estado al disfrute de los beneficios concedidos por el Decreto-Ley de 21 de junio de 1926 (Cuadro 5). 
Cuadro 5: Gratificaciones concedidas a funcionarios civiles y militares con familia numerosa a su costa (1926)

\begin{tabular}{|c|c|}
\hline Número de hijos & Gratificación sobre el sueldo \\
\hline 11 & $5 \%$ \\
\hline 12 & $10 \%$ \\
\hline 13 & $15 \%$ \\
\hline 14 & $20 \%$ \\
\hline 15 & $25 \%$ \\
\hline 16 & $30 \%$ \\
\hline 17 & $40 \%$ \\
\hline 19 & $45 \%$ \\
\hline 20 o más & $50 \%$ \\
\hline
\end{tabular}

Fuente: Leyes de la República. Subsidios a familias numerosas. Elaboración propia

A su vez, la Real Orden de 6 de mayo de 1928 sobre matrícula gratuita para los beneficiarios de subsidios a los hijos de familias numerosas, pretende prorrogar la vigencia de la Real Orden de 20 de septiembre de 1927 para asegurar la concesión de matrículas gratuitas a título provisional, mientras se despachan los expedientes de solicitud de las ayudas. Los beneficios otorgados por la prórroga que concede la aludida Real Orden para los servicios del Ministerio de Instrucción Pública han sido igualmente establecidos por las Reales Órdenes de 8 y 9 de mayo de 1928 por los Ministerios de Trabajo y Fomento. En parecido sentido fue publicado en la Gaceta de 13 de julio la Real Orden del Ministerio de Hacienda de 11 de julio de 1928 adaptando las reglas establecidas en la Real Orden de 21 de junio de 1927 para el pago de subsidios y exenciones del impuesto de utilidades sobre haberes de dichos beneficiarios con las modificaciones que se indican.

El 4 de noviembre publicó la Gaceta el Real Decreto-ley de 3 de noviembre de 1928 sobre la reorganización de los departamentos ministeriales que afecta al servicio de "Familias Numerosas" que, a partir de ese momento, quedó englobado dentro del Ministerio de Trabajo y Previsión. 
Figura 4: Recopilación de las Leyes de la República

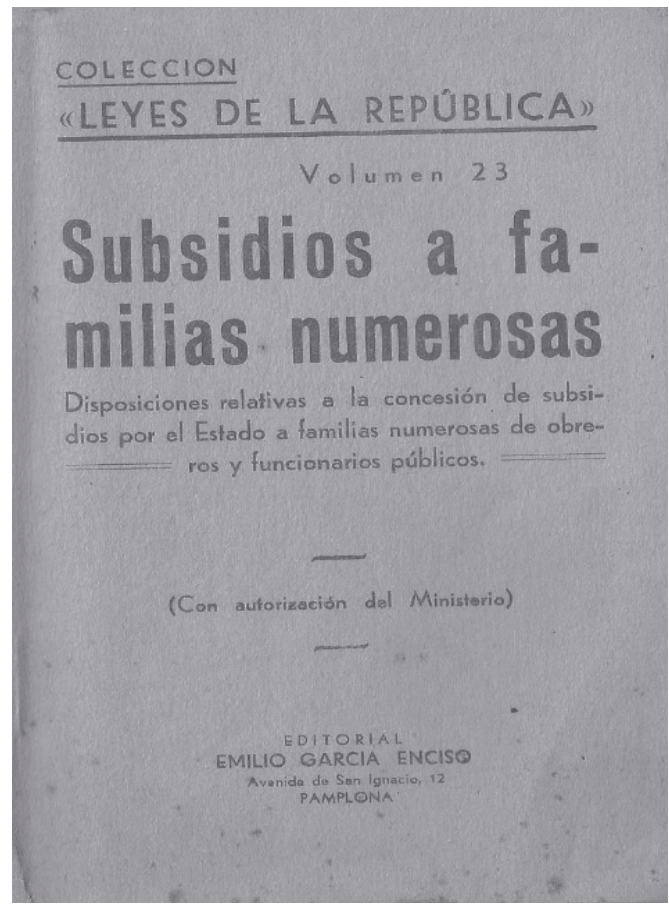

La Real Orden del Ministerio de Trabajo y Previsión de 19 de abril de 1929 señaló el plazo para la admisión de solicitudes de subsidios a familias numerosas, determinando los documentos complementarios que deben acompañar a las instancias. Dicha decisión fue acompañada por la Real Orden del Ministerio de Trabajo y Previsión de 17 de septiembre de 1929 en donde se publican las normas a que habrán de ajustarse las Cajas autorizadas para el pago de los subsidios a familias numerosas, complementándose con el Real Decreto del Ministerio de Trabajo y Previsión, de 8 de octubre de 1930, sobre cooperación gratuita de las Cajas (provinciales y regionales) y que deberán colaborar con el Instituto Nacional de Previsión para la gestión del subsidio a familias numerosas.

Ante las numerosas reclamaciones que formularon los sindicatos, colectivos y familias a título individual se tuvo que salir al paso con nuevas medidas aclaratorias que evitaran problemas de interpretación en la aplicación de la normativa. Es lo que se señala en la Orden del Ministerio de Trabajo y Previsión, de 5 de mayo de 1931, que dispone que para la aplicación del Real Decreto de 
30 de diciembre del mismo ańo, tan sólo se tendrán en cuenta los preceptos del Código Civil tanto en lo relativo a la mayoría de edad como a la emancipación y prestación legal de alimentos. Entre las reclamaciones sobre perceptores de beneficios del régimen de Protección Social a la Familia Numerosa hay una casuística muy singular entre las personas que viven en algunos territorios sujetos a la legislación foral que en unos casos tienen reconocida la mayoría de edad a los 25 años y en otros a los 20 años y no a los 23 años como con carácter general y para beneficio de todos los españoles sin excepción establece el Decreto de 21 de junio de 1926. A la vista de esos problemas interpretativos, el Ministerio de Trabajo acordó, con carácter general, "que para la aplicación del Real Decreto de 21 de junio de 1926 y Reglamento de 30 de diciembre del mismo año, tan solo se tendrán en cuenta los preceptos del Código Civil, así respecto a la mayoría y la minoría de edad como emancipación y prestación legal de alimentos".

En la Orden del Ministerio de Trabajo y Previsión, de 10 de junio de 1931 donde se fija el plazo de admisión de solicitudes para optar a los beneficios del Régimen de Protección Social a la Familia se reconoce que existe un problema de desbordamiento para atender las solicitudes de ayuda debido al “...número extraordinario de instancias que anualmente se reproducen y las de los que por primera vez formulan la petición, (lo que) aumenta considerablemente los expedientes a estudiar y resolver con la rapidez que exige el Real Decreto de 30 de diciembre de 1926...”.

El contenido del Decreto de 18 de abril de 1931, publicado en la Gaceta del día 17, muestra como el primer gobierno de la Segunda República concedió un plazo a los diferentes departamentos ministeriales para que procedan a revisar la obra legislativa de la Dictadura y proponer antes del 31 de mayo al Consejo de Ministros la resolución sobre los decretos proponiendo los que pueden ser validados en todo o en parte de acuerdo con el interés público y dejando siempre a salvo la facultad del actual ejecutivo "para modificarlos y la soberanía del Parlamento, a quien dará cuenta, para resolver en definitiva”. El 10 de julio de 1931, el Ministerio de Trabajo y Previsión publicó en la Gaceta un Decreto en donde al referirse a la cuestión del subsidio a las familias numerosas decía textualmente: "Todo lo referente a protección social a la familia ha sido objeto de reglamentación por virtud del Decreto-Ley de 21 de junio de 1926 creando el subsidio a las familias numerosas, emanado de la Presidencia del Consejo y por la índole de la materia debe ser conservado". Este acuerdo es asumido y reforzado a continuación por la Ley del Ministerio de Trabajo y Previsión, de 9 de septiembre de 1931, en donde se declara como Leyes de la 
República el Decreto-Ley de 21 de junio de 1926 de subsidios a familias numerosas y todas las disposiciones adoptadas hasta entonces relativas a la concesión de ayudas y beneficios por el Estado a familias numerosas de obreros y funcionarios públicos. Lo que muestra el grado de sensatez de los diferentes ministros republicanos cuando optaron por dar continuidad a lo que de hecho constituían claros avances sociales, en vez de empecinarse en un adanismo derogatorio por meros prejuicios ideológicos con los anteriores gobiernos de la nación.

\section{CONCLUSIONES}

A lo largo de esta exposición se ha podido demostrar las causas del por qué la transición demográfica se inicia con retraso en España después de que descendiera la mortalidad (especialmente la mortalidad infantil) a consecuencia de la incipiente instauración de las estructuras sanitarias características de un país moderno y se adoptaran por la población comportamientos higiénicos y dietéticos más saludables. Como los indicadores del ritmo de la natalidad evidenciaban cierto decremento, se tuvieron que adoptar primero por la Dictadura y después por los Gobiernos de la Segunda República medidas dirigidas al fomento de los nacimientos consistentes en ayudas económicas, exenciones a las rentas por arrendamiento de la vivienda, matriculación gratuita en los centros educativos públicos, gratificaciones monetarias a los funcionarios y otras dádivas dirigidas hacia las familias numerosas, viudas y huérfanos de trabajadores y personal civil y militar a sueldo de las administraciones públicas cuyas rentas por todos los conceptos fuesen inferiores a las 6.000 pesetas anuales.

Con ello queda bien claro una vez más la extraordinaria sensibilidad de los gobernantes, especialmente los de la Segunda República, hacia los temas reproductivos, la mejora de la crianza y las ayudas a las familias con menores ingresos económicos y con mayor número de miembros en su composición. Y en la creación o implementación de nuevos servicios públicos de asistencia sociosanitaria, y mejorando la formación de los profesionales que ejercían en aquellos menesteres.

\section{BIBLIOGRAFÍA}

Alcalde, C. (1983): Federica Montseny. Ed. Vergara, Barcelona.

Barona Vila, C. (2012): Organización sanitaria y de la higiene pública en la provincia de Valencia (1854-1936). Universidad de Valencia. Tesis Doctoral. 
Bernabéu Mestre, J. y Gascón Pérez, E. (1999): Historia de la Enfermería de Salud Pública en España (1860-1977). Universidad de Alicante. Alicante. Bernabéu, Mestre, J. (2000): “La utopía reformadora de la Segunda República: la labor de Marcelino Pascua Martínez al frente de la Dirección General de Sanidad, 1931-1933”. Revista Española de Salud Pública. Volumen 74. Monográfico, Madrid.

Cabré, A.; Domingo I, A. y Menacho, T. (2002). Demografía y crecimiento de la población española durante el S. XX. CED, UAB. Barcelona.

Carreras, A. y Tafunell, X. (Coords.) (2006): Estadisticas históricas de España en los siglos XIX y XX. Fundación BBVA-Universidad Pompeu Fabra.

Colección "Leyes de la República": Subsidios a familias numerosas. Disposiciones relativas a la concesión de subsidios por el Estado a familias numerosas de obreros y funcionarios públicos. Vol. 23. Ed. E. García Enciso, Pamplona.

Del Campo, S. (1965). "Los médicos ante el problema de la limitación de la natalidad”. Revista Española de la Opinión Pública, nº. 1 Mayo/agosto, pp. 27-38.

De Miguel, A. (1972): “Está bajando la natalidad en España?” En Blanco y Negro.

Durán y Lalaguna, P. (2007): El voto femenino en España. Servicio de Publicaciones de la Asamblea de Madrid.

Gil Alonso, F.: "Los estudios sobre el descenso histórico de la fecundidad en España y sus pautas territoriales: un estado de la cuestión”. Biblio $3 W$, Vol. XVI, no. 923, 15 de julio de 2011.

Gil Pecharromán, J. (2006): La Segunda República española (1931-1936). Biblioteca Nueva.

Huertas, R. (2000): "Política Sanitaria: de la Dictadura de Primo de Rivera a la II República”. Revista Española de Salud Pública, v.74, monográfico, Madrid, pp. 35-43. [Consultado el 2 de Julio de 2020 en: http://www.redalyc.org/pdf/170/17074706.pdf]

Marset, P.; Saiz Gómez, J.M. y Martínez Navarro, F. (1995): "La salud pública durante el franquismo" en Dynamis, Acta Hisp. Sci. Hist. Illus, 15, pp. 211250.

Mouchez, P. (1966): Demografía. Ed. Ariel. Barcelona.

Naciones Unidas (1967): "Perspectivas de la población mundial evaluada en 1963. Estudios Demográficos, núm. 41, New York.

Prados Arrarte, J. (1971): La población. Ed. Guadiana, Madrid.

Reglá, J.; Jover, J. M. y Seco Serrano, E. (1969): España Moderna y Contemporánea. Ed. Teide, Barcelona. 
Robles, E.; García, E. y Bernabéu, J.: "La transición sanitaria en España desde 1900 a 1990". Revista Española de Salud Pública, núm. 2, marzo-abril de 1996. Ros Jimeno, J. (1944): “El decrecimiento de la natalidad y sus causas", Revista de Internacional de Sociología, no. 7 (julio-septiembre) pp. 19-122.

Ros Jimeno, J. (1959): "Algunos aspectos de la natalidad en España”. Revista Internacional de Sociología, núm.57 (julio-septiembre), pp. 419-430.

Saavedra Fajardo, D. (1999) [1640]: Empresas politicas. Edición, anotación y estudio de Sagrario López Poza, Madrid, Cátedra.

Sauvy, A.; Bergues, H. y Riquet, M. (1972): Historia del control de nacimientos. Ediciones Península, Barcelona.

Suárez Bosa, M. (1990): El movimiento obrero en las Canarias orientales (19301936). CIES, Las Palmas de Gran Canaria.

Tamames Gómez, R. (1971): Introducción a la economía española. Alianza Editorial. Madrid.

Tamames Gómez, R. (1973): La República. La Era de Franco. Historia de España de Alfaguara, Madrid.

Teitelbaum, M.S. y Winter, J.M. The Fear of Population Decline. San Diego: Academic Press, 1985.

Tuñón de Lara, M. (1972): El movimiento obrero en la Historia de España. Taurus. Madrid.

Tunón de Lara, M. (1973): La España del Siglo XIX, Primera parte (18081873). Editorial Laia. Barcelona.

Tuñón de Lara, M. (1973): La España del Siglo XX (1914-1939). Librería Española, París.

Tuñón de Lara, M. (1976): La Segunda República. Dos vols. Siglo XXI. Madrid, pp. 172 y 237.

Urteaga, L.: "Teoría demográfica e historiografía: el tratado de población de Agustín de Blas y la difusión de Malthus en España”. Estudios Geográficos, XLVI, 181, octubre-diciembre 1985, pp. 447-472. 


\title{
BIODIVERSIDAD EN CANARIAS: FUENTE DE PRODUCTOS NATURALES
}

\author{
José Luis A. Eiroa Martínez. \\ Grupo de Investigación "Bioquímica Farmacológica” \\ Departamento de Química. Universidad de Las Palmas de Gran Canaria
}

\section{Resumen}

Los compuestos elaborados por las plantas y más concretamente los metabolitos secundarios constituyen una fuente de sustancias que pueden tener diferentes aplicaciones y que denominamos productos naturales. Las islas oceánicas como las Islas Canarias se caracterizan por amplia biodiversidad lo que se traduce en una gran variedad de endemismos cuya taxonomía requiere en algunos casos el estudio de los caracteres químicos (quimiotaxonomía) como una herramienta complementaria en este proceso. Fruto de esta biodiversidad es el empleo de estos productos naturales aislados de especies endémicas canarias como fuente compuestos antitumorales.

Palabras Clave: Productos naturales, biodiversidad, Quimiotaxonomía, Asteraceae, Compositae, Gonospermum, Tanacetum, lactonas sesquiterpénicas, leucemia.

\begin{abstract}
The compounds produced by plants and more specifically the secondary metabolites constitute a source of substances that can have different applications and that we call natural products. Oceanic islands such as the Canary Islands are characterized by extensive biodiversity, which translates into a great variety of endemisms whose taxonomy requires in some cases the study of chemical characters (chemotaxonomy) as a complementary tool in this process. The result of this biodiversity is the use of these natural products isolated from endemic Canary Island species as a source of antitumor compounds.
\end{abstract}

Keywords: natural products, Biodiversity, Chemotaxonomy, Asteraceae, Compositae, Gonospermum, Tanacetum, sesquiterpene lactones, leukemia. 


\section{INTRODUCCIÓN}

Desde los inicios de la civilización, el ser humano ha buscado en el reino vegetal, además del alimento, los diferentes materiales que necesitaba para la construcción de sus hogares, herramientas y medios de transporte, pero también ha buscado en las plantas aquellas sustancias que le permitían aliviar sus dolencias y como remedio para combatir algunas enfermedades. La razón de todo ello es que las plantas constituyen verdaderos laboratorios químicos donde se lleva a cabo la síntesis de una amplia variedad de compuestos, los cuales podemos agrupar en dos grandes tipos:

- Metabolitos Primarios.

\section{- Metabolitos Secundarios.}

Los metabolitos primarios lo conforman un conjunto de compuestos que desarrollan unas funciones bien definidas en las plantas y cuyos objetivos son los más básicos presentes en todos los organismos vivos como son, proveer soporte, alimento, relación con otros seres vivos y permitir la reproducción de las especies que los producen. Entre estos compuestos químicos tenemos los carbohidratos, las proteínas y las grasas, cuyo nexo común es que todos ellos sirven de alimento tanto a los seres humanos como a los animales. Los metabolitos secundarios, sin embargo, sueles ser sustancias, a veces elaboradas en pequeñas cantidades, que aparentemente no parecen presentar una función específica determinada y que no guardan una vinculación directa con el mantenimiento de la vida de la especie en cuestión, pero que diferentes estudios han puesto de manifiesto que juegan diferentes roles. Muchos de estos compuestos son elaborados con el fin de actuar como disuasorios de animales e insectos, ya sea por su sabor, su olor o por el efecto que pueda producir la ingesta de los mismos, evitando de esta manera que las especies herbívoras las empleen como posible alimento; en otros casos estas sustancias actúan como verdaderos venenos mortales para aquellas especies que bien por error o por inexperiencia lleguen a consumirlas. En otras ocasiones el mecanismo de acción de estos compuestos es el de evitar la competencia de otras especies que podrían competir con ellas por los nutrientes, el agua, la luz y el espacio vital, actuando de esta manera evitan la proliferación de competidores esparciendo estas sustancias por diferentes procedimientos, en su medio ambiente circundante. Por el contrario, en ciertas ocasiones estos metabolitos secundarios segregados por las plantas tienen como función atraer a ciertos tipos de organismos, como suelen ser los insectos, para llevar a cabo procesos de reproducción de las mismas mediante mecanismos como la polinización o la distribución de semillas. Incluso 
se han observado procesos a tres bandas donde una planta es capaz de emitir compuestos que atraigan insectos que a cambio de alimento o protección a su vez actúan como protectores frente a otros insectos que se alimentan de la planta.

Estos metabolitos secundarios, a los que también se les suele llamar comúnmente productos naturales, han sido empleados por el ser humano a lo largo de la historia como fuente de sustancias con propiedades muy diversas: curativas (como ejemplo, tenemos la penicilina, los antibióticos, antitumorales), aromáticas (obtención de aceites esenciales como base para la elaboración de productos de cosmética), analgésicas (aspirinas, morfina, cocaína), estimulantes (cafeína, nicotina), etc. Muchas de las especies que elaboran productos naturales que presentan estas características son conocidas desde los principios de la civilización por las diferentes culturas que fueron adquiriendo los conocimientos que permitieron su empleo, otras muchas han sido descubiertas recientemente como consecuencia de la búsqueda de nuevos recursos y seguramente habrá otras muchas que están aún por descubrirse. Cuando este producto natural, ya sea generalmente puro o mediante algunas modificaciones estructurales es usado como medicamento, entonces suele hablarse de principio activo. Hasta la década de los 80 la principal fuente de productos naturales de interés farmacológico fueron las plantas terrestres. Sin embargo, hoy en día un número significativo de compuestos de origen marino que han sido sometidos a procesos antitumorales preclínicos y clínicos ha aumentado de forma significativa.

\section{BIODIVERSIDAD}

Las islas oceánicas se definen como aquellas que emergieron directamente de los fondos oceánicos y que jamás han estado unidas a ninguna masa continental lo cual determina que estos territorios geográficamente bien definidos se caracterizan por la existencia de endemismos como un fenómeno generalizado, de tal forma que las islas oceánicas son las que alberga mayor cantidad de especies exclusivas y buen ejemplo de ellos son las Islas Canarias. Este hecho determina que este tipo de islas hayan sido consideradas como ejemplos de diferenciación y especiación de la flora en particular.

En 1988 Norman Mayers definió el concepto de punto caliente de biodiversidad para referirse a aquellas áreas del planeta que presentan una alta biodiversidad donde se concentra tal cantidad de especies y que además se encuentra sometido a importantes amenazas antropogénicas que amenazan su conservación. Las Islas Canarias se encuentran integradas en la región biocli- 
mática mediterránea, que es una de los 25 puntos calientes que se conocen en la actualidad. Dentro de Canarias, el punto más caliente con la mayor biodiversidad exclusiva en la superficie más reducida que se conoce en Europa está situado en La Cruz del Carmen (La Laguna), en la isla de Tenerife.

El estudio de las floras insulares resulta de especiar interés en el conocimiento de los procesos evolutivos ya que este tipo de territorios se caracteriza por un elevado porcentaje de endemismos como es el caso de las Islas Canarias. Este elevado porcentaje de especies exclusivas, cerca del $40 \%$ del total de la flora nativa, lo cual convierte a estas islas en uno de los lugares con mayor índice de biodiversidad a escala mundial.

Fig. 1. Especies de plantas vasculares

\begin{tabular}{|c|c|c|c|c|c|}
\hline 8 & Ažores & $\begin{array}{l}\text { Cabo } \\
\text { Verde }\end{array}$ & 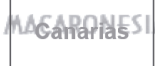 & Madeira & Salvajes \\
\hline $\mathrm{N}^{\circ}$ de islas & 9 & 10 & $7 \circ$ & 2 & 3 (islotes) \\
\hline $\begin{array}{l}\text { Superficie total } \\
\qquad\left(\mathrm{Km}^{2}\right)\end{array}$ & 2.341 & 2.220 & 7.496 & 807 & 4 \\
\hline $\begin{array}{l}\mathrm{N}^{0} \text { total de } \\
\text { especies }\end{array}$ & 843 & 650 & 1.860 & 1.141 & 92 \\
\hline $\begin{array}{c}\mathbf{N}^{\circ} \text { de } \\
\text { endemismos }\end{array}$ & 44 & 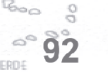 & 520 & 120 & 8 \\
\hline
\end{tabular}

Fuente: elaboración propia.

Así, como podemos ver en la fig. 1, de un total de aproximadamente de 1860 especies de plantas vasculares, 560 son endemismos de las islas, lo cual represente alrededor de un $28 \%$, lo que las convierte junto con los restantes archipiélagos de la región de la Macaronesia (Islas Azores, Archipiélago de Madeira, Islas de Cabo Verde e Islas Salvajes), en uno de los enclaves florísticos más importantes a nivel mundial, lo que convierte a las islas en verdaderos laboratorios donde poder estudiar los procesos de evolución vegetal.

En el caso de las Islas Canarias esta flora tan variada se piensa que pudo tener sus ancestros continentales en el Mediterráneo Occidental (incluyendo la Península Ibérica) y Marruecos, ya que ese periodo de colonización coincide con los grandes cambios climáticas y geológicos que tuvieron lugar en estas 
zonas, sobre todo durante el periodo Terciario. Los diferentes estudios taxonómicos que se han llevado a cabo tratan de establecer, desde un punto de vista morfológico, las relaciones entre los distintos grupos estudiados, con el objeto de establecer una relación con sus ancestros continentales. Sin embargo, el estudio de estos datos morfológicos de especies restringido a islas continentales en algunos casos se ve dificultada por el hecho de que los endemismos insulares son generalmente distintos de sus ancestros continentales, lo cual plantea la necesidad de más datos que aporten una mayor información. En consecuencia, además de los datos morfológicos se recurre a otros estudios de tipo citológico y químico que nos permitan ampliar la visión de las posibles relaciones entre especies.

Es aquí donde entra en juego la Quimiotaxonomía o Taxonomía Química que constituyen una herramienta de apoyo en la clasificación de las plantas tomando como base sus constituyentes químicos o metabolitos secundarios. La estructura química de los metabolitos secundarios y sus vías biosintéticas son a menudo específicas y están restringidas a organismos taxonómicamente relacionados, de ahí su importancia. En las Islas Canarias la familia Asteraceae (Compositae), vulgarmente llamada familia de las margaritas, las magarzas canarias, ha sido ampliamente estudiada, estando presente en alrededor de 32 géneros diferentes de los cuales 8 de ellos son endémicos. El estudio químico de muchas de estas especies nos permite deducir que los compuestos predominantes son fundamentalmente las lactonas sesquiterpénicas (las lactonas son ésteres cíclicos) seguida de los flavonoides y las cumarinas. Estas lactonas sesquiterpénicas se han encontrado casi de forma exclusiva en la familia Asteraceae y como este tipo de compuestos presentan un origen biosintético común, permiten emplearlos como caracteres taxonómicos tanto a nivel de relaciones entre especies como entre géneros.

Dentro de las especies endémicas de las islas que ha sido estudiadas, las lactonas tipo germacranolido y guayanolido son predominantes, pero en otros géneros también se han reportados estructuras tipo eudesmanolido. Desde un punto de vista biogenético (fig. 2) un proceso evolutivo de adaptación a los diferentes nichos ecológicos determina la elaboración de los diferentes tipos de lactonas encontrados, partiendo de un sesquiterpeno germacrano como precursor. Este tipo de compuestos se caracterizan por el agrupamiento $\alpha$-metilen-g-lactona el cual es un potente receptor para nucleófilos que puede inhibir los enzimas que contienen centros nucleofílicos esenciales, como grupos amino y tiol. Como consecuencia, las lactonas sesquiterpénicas exhiben un amplio rango de actividades biológicas, que están en muchos casos basadas en sus pro- 
piedades alquilantes. Esto incluye efectos antibióticos, citotóxicos, anticancerígenos, insecticidas, molusquicidas, alergénicos y alelopáticos.

Fig. 2. Esquema de biosíntesis tipos lactonas sesquiterpenicas

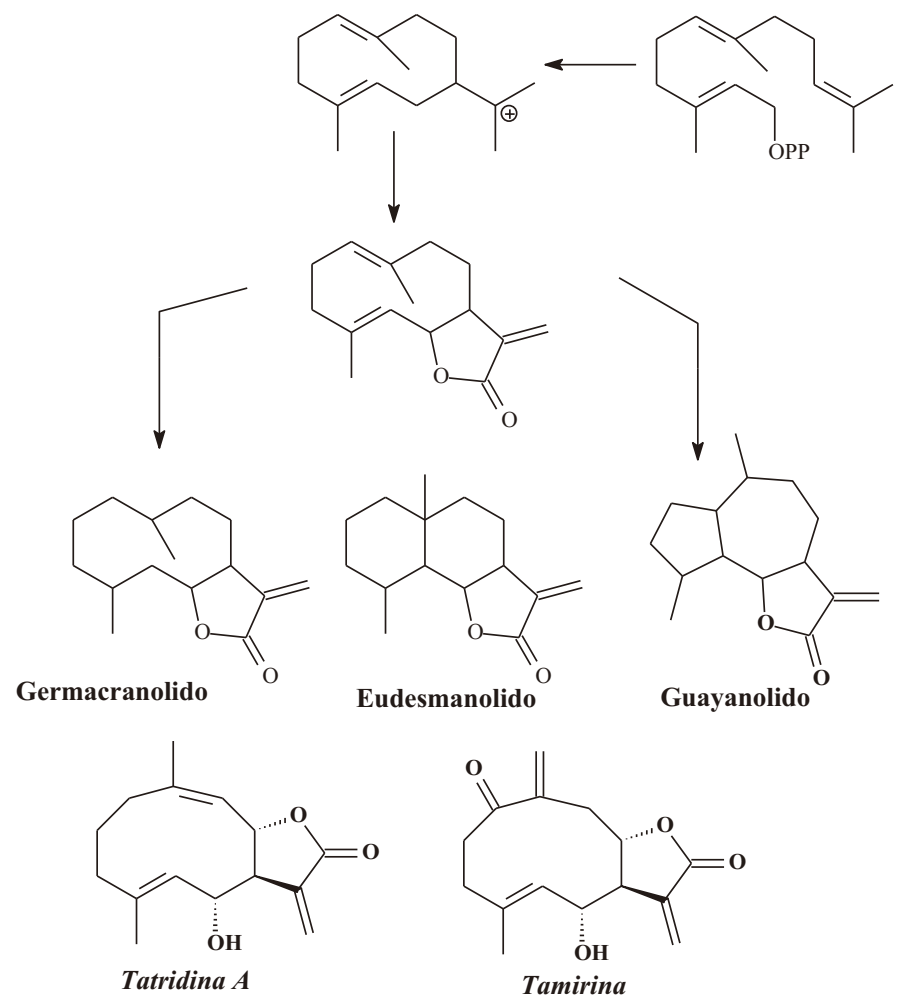

Fuente: elaboración propia.

Del estudio químico de las diferentes especies de los géneros endémicos Gonospermum (G. gomerae, G. fruticosum, G. canariense y G. elegans) y Lugoa (L. revoluta) presentes en las islas occidentales, así como de las especies endémicas del género Tanacetum (T. ferulaceum, T. ptarmicaeflorum, T. oshanahanii y T. ferulaceum var. latipinnum) endémicos de la isla de Gran Canaria, se han puesto de manifiesto las relaciones existentes entre estos géneros, lo cual apoyaría la reestructuración de los dos géneros endémicos y las especies de $T a$ nacetum en un único género endémico Gonospermum. 
Fig. 3. Especies de géneros endémicos

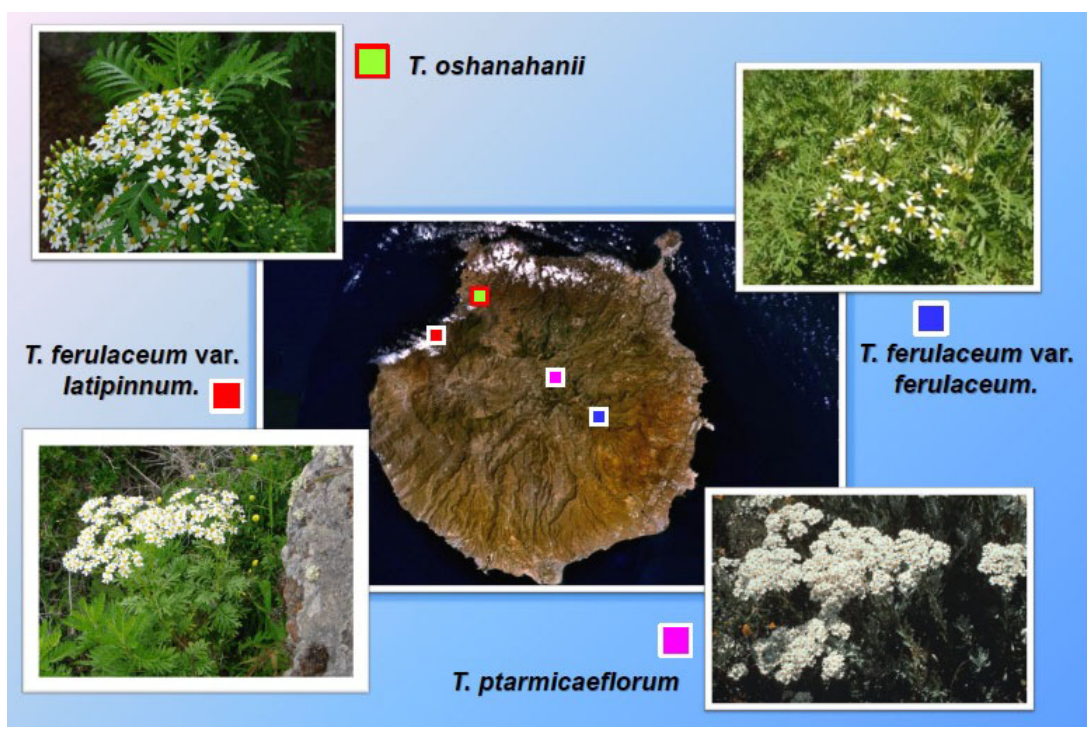

Fuente: elaboración propia.

\section{LOS ENDEMISMOS CANARIOS COMO FUENTE DE PRODUCTOS NATURALES CON ACTIVIDAD BIOLÓGICA}

Algunas de las especies canarias estudiadas como el Tanacetum ferulaceum han sido empleadas como espasmolítica y antiulcerígena, mientras que del género Gonospermum, concretamente tanto el G. canariense como G. fruticosum presentan actividad vermífuga y astringente.

Varios de los compuestos obtenidos en las distintas especies de Gonospermum, Tanacetum y Lugoa fueron analizados con vista a determina una posible actividad biológica, mostrando algunos de ellos una actividad importante. Es el caso de compuestos como reynosina, tamirina y tatridina $\mathrm{A}$, así como el derivado diacetilado de este último, los cuales mostraron una inhibición del crecimiento en cultivos de células leucémicas humanas tipo HL-60, teniendo que ver el mecanismo envuelto en dicha actividad con la activación de la apoptosis, induciendo cambios morfológicos e internucleosomal de fragmentación de DNA característicos del proceso de muerte celular. Este derivado diacetilado de la tatridina A es de especial interés debido a su gran poder de activación de apoptosis celular en células leucémicas U397 y HL-60, asociando esta elevada 
toxicidad a su alta lipofilicidad aunque también pueden influir otros factores tales como la geometría molecular y la presencia de los dos grupos éster debido a su bajo potencial alquilante. Asimismo los compuestos dentatina A y $1 \mathrm{~b}, 4 \alpha, 6 \alpha$-trihidroxieudesm-11-en-8 $\alpha, 12$-olida aislados del G. gomerae presentaron un fuerte actividad citotóxica frente a líneas celulares humanas de melanoma (SK-MEL-1) y adenocarcinoma (A549) (fig. 4).

Fig. 4. Compuestos de las diferentes especies endémicas<smiles>C=C1C(=O)O[C@@H]2C3C(=O)CCC(O)C3(C)C[C@H](O)[C@@H]12</smiles>

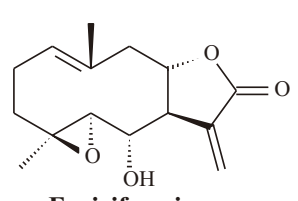

Espiciformia

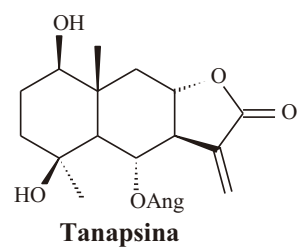

Fuente: elaboración propia.

Asimismo, el compuesto tanapsina aislado de la especie $T$. oshanahanii, mostró un intenso efecto antiproliferativo en líneas celulares humanas de leucemia mieloide (HL-60, U397 y K-562) y leucemia linfoide (Molt-3), así como melanoma (SK-MEL-1) mediante el incremento en la generación de especies reactivas oxigenadas. Efectos similares produjo el compuesto espiciformina aislado de T. ptarmicaeflorum y T. ferulaceum var. latipinnum, todas ellas endémicas de Gran Canaria.

$\mathrm{Al}$ tener las Islas Canarias esta gran biodiversidad tanto a nivel vegetal como animal, lo cual constituye una gran riqueza natural, se debe potenciar en las futuras generaciones la necesidad de conocer y preservar esa riqueza. Por todo ello se debería fomentar en la enseñanza y en consecuencia en la formación de los futuros enseñantes, en especial en los Maestros como primeros educadores, las bases de conocimiento que permitan transmitir todo este conjunto de conocimiento a los jóvenes alumnos

\section{REFERENCIAS BIBLIOGRÁFICAS}

Febles, R. (2008). Re-estructuración del género Gonospermum Less (AstareceaeAnthemideae) en las Islas Canarias. Botánica Macaronésica, 27, 101-105.

Esquivel Martín, J.L., Marrero Gómez, M.C., Zurita Pérez, N., Arechavaleta Hernández, M., Izquierdo Zamora, I. (2005). Biodivervidad en gráficas. Especies silvestres canarias. Gobierno de Canarias. 
Morales Bonilla, M. (2012). Estudio de los Metabolitos Secundarios de especies canarias de los géneros Tanacetum y Asteriscus. Aplicaciones. Tesis Doctoral. ULPGC.

Negrín, G., Rubio, S., Marrero, M.T., Quintana, J., Eiroa, J.L., Triana, J., Estévez, F. (2015). The eudesmanolide tanapsin from Tanacetum oshanahanii and its acetate induce cells death in human tumor cells through a mechanism dependen ton reactive oxygen species. Phytomedicine, 22, 385-393.

Rivero, A., Quintana, J., Eiroa, J.L., López, M., Triana, J., Bermejo, J., y Estévez, F. (2003). European Journal of Pharmacology. 482, 77-84.

Saavedra, E., Estévez-Sarmiente, F., Said, M., Eiroa, J.L., Rubio, S., Quintana, J., Estévez, F. (2020). Citotoxicity of the sesquiterpene lactone spiciformin and its acetyl derivative against the human leukemia cell lines U-937 and HL-60. International Journal of Molecular Sciences, 21, 2782.

Triana, J., Eiroa, J.L., Ortega, J.J., León, F., Brouard, I., Torres, F., Quintana, J., Estévez, F., Bermejo, J. (2008). Sequiterpene lactones from Gonospermum gomerae and $G$. fruticosum and their cytotoxic activities. Journal of Natural Products, 71, 2015-2020.

Triana, J., Eiroa, J.L., Morales, M., Pérez, F.J., Brouard, I., Marrero, M.T., Estévez, S., Quintana, J., Estévez, F. (2013). A chemotaxonomic study of endemic species of genus Tanacetum from the Canary Islands. Phytochemistry, 92, 87-104.

Valera Molina, A., y Santos Guerra, A. (2002) Investigaciones fotoquimicas en plantas canarias. Ed. Centro de Estudios Ramón Areces. 



\title{
LA FORMACIÓN DEL PROFESORADO DE LA ULPGC PARA FAVORECER LA INCLUSIÓN EDUCATIVA
}

\author{
María del Pilar Etopa Bitata, Elena Chirino Alemán y Gabriel Díaz Jiménez \\ Universidad de Las Palmas de Gran Canaria
}

\section{Resumen}

Una constante, que nos ha parecido que refleja la trayectoria de nuestra querida Dńa. Emy, es la formación del profesorado en todas sus vertientes, sobre las que ella misma asumió tareas de responsabilidad.

En este sentido, vamos a centrarnos en la formación del profesorado universitario, poniendo de relieve la necesidad de incluir en la oferta específica para el PDI cursos, seminarios o talleres que favorezcan la inclusión del alumnado con necesidades específicas de apoyo educativo en la Universidad de Las Palmas de Gran Canaria. Pero antes de llegar a la situación actual, vamos a dar un breve repaso a lo sucedido hasta ahora.

Palabras clave: formación, profesorado, universidad, necesidades específicas de apoyo educativo.

\begin{abstract}
A constant, which we have found to reflect the trajectory of our beloved Mrs. Emy, is the training of teachers in all its aspects, over which she herself assumed responsibility tasks.

In this sense, we are going to focus on the training of university teachers, highlighting the need to include courses, seminars or workshops in the specific offer for the PDI that favor inclusion of students with specific educational support needs at the University from Las Palmas de Gran Canaria. But before getting to the current situation, we are going to give a brief review of what has happened so far.
\end{abstract}

Keywords: training, professor, university, specific educational support needs

\section{LA UNIVERSIDAD DE LAS PALMAS DE GRAN CANARIA, AYER Y HOY}

Consideramos fundamental conocer la institución, para poder analizar y llegar a conclusiones que nos permitan poner en valor todo lo realizado hasta 
el momento, al tiempo que proponer otras acciones, en principio, precursoras de nuevos éxitos.

\subsection{LA HISTORIA DE LA ULPGC}

Etopa (2000) realiza un recopilatorio de la historia de la ULPGC, de la que se recoge un pequeño extracto, pues ayuda a entender el recorrido y el momento en el que ahora mismo nos encontramos.

La fundación de la Universidad de Las Palmas de Gran Canaria se produjo en 1989, fruto de la presión social a través de distintos pronunciamientos institucionales y manifestaciones multitudinarias, y quedó recogida en la Ley 5/1989, de 4 de mayo, de Reorganización Universitaria de Canarias (BOC no 64, de 8 de mayo). La aprobación de esta ley conllevó la readscripción de los centros existentes al Rectorado más próximo y una vez concluido el proceso, tras varios cambios, la ULPGC queda estructurada en cuatro campus en la isla de Gran Canaria: San Cristóbal, El Obelisco, Tafira y Bañaderos, con los siguientes edificios, facultades y departamentos:

a) Campus de San Cristóbal: integrado por el Edificio de Ciencias de la Salud.

Facultad de Ciencias de la Salud

Departamento de Ciencias Clínicas

Departamento de Ciencias Médicas y Quirúrgicas

Departamento de Bioquímica, Biología Molecular y Fisiología

Departamento de Enfermería

Departamento de Morfología

b) Campus del Obelisco: integra los Edificios de Humanidades (Agustín Millares Carló) y Formación del Profesorado.

1. Edificio de Humanidades:

Facultad de Filología

Facultad de Geografía e Historia

Facultad de Traducción e Interpretación

Departamento de Ciencias Históricas

Departamento de Filología Española, Clásica y Árabe

Departamento de Filología Moderna

2. Edificio de Formación del Profesorado

Centro Superior de Formación del Profesorado

Departamento de Didácticas Especiales

Departamento de Educación

Departamento de Psicología y Sociología 
c) Campus de Tafira: incluye los Edificios de Arquitectura, Ciencias Básicas, Ciencias Económicas y Empresariales, Electrónica y Telecomunicación, Ciencias Jurídicas, Ingenierías, Educación Física e Informática y Matemáticas.

1. Edificio de Arquitectura:

Escuela Técnica Superior de Arquitectura

Departamento de Arte, Ciudad y Territorio

Departamento de Expresión Gráfica y Proyectos Arquitectónicos

Departamento de Construcción Arquitectónica

2. Edificio de Ciencias Básicas:

Facultad de Ciencias del Mar

Departamento de Biología

Departamento de Física

Departamento de Química

3. Edificio de Ciencias Económicas y Empresariales:

Facultad de Ciencias Económicas y Empresariales

Departamento de Análisis Económico Aplicado

Departamento de Economía Financiera y Contabilidad

Departamento de Economía y Dirección de Empresas

Departamento de Métodos Cuantitativos en Economía y Gestión

4. Edificio de Electrónica y Telecomunicación:

Escuela Técnica Superior de Ingenieros de Telecomunicaciones

Escuela Universitaria de Ingenieros Técnicos de Telecomunicación

Departamento de Ingeniería Electrónica y Automática

Departamento de Ingeniería Telemática

Departamento de Señales y Comunicaciones

5. Edificio de Ciencias Jurídicas:

Facultad de Ciencias Jurídicas

Departamento de Ciencias Jurídicas Básicas

Departamento de Derecho Público

6. Edificio de Ingenierías:

Escuela Técnica Superior de Ingenieros Industriales

Escuela Universitaria Politécnica

Departamento de Cartografía y Expresión Gráfica en la Ingeniería

Departamento de Ingeniería Civil

Departamento de Ingeniería de Procesos

Departamento de Ingeniería Eléctrica

Departamento de Ingeniería Mecánica 
7. Edificio de Educación Física:

Facultad de Ciencias de la Actividad Física y el Deporte

Departamento de Educación Física

8. Edificio de Informática y Matemáticas:

Facultad de Informática

Departamento de Informática y Sistemas

Departamento de Matemáticas

d) Campus de Bañaderos: integra el Edificio de Veterinaria

Facultad de Veterinaria

Departamento de Patología Animal, Producción Animal y Ciencia y Tecnología de los Alimentos

En noviembre de 1991 se crea el Campus en la isla de Lanzarote, dando así respuesta a la petición del Cabildo de Lanzarote de contar con estudios universitarios en la isla, comenzando así los estudios de Enfermería, y posteriormente, Turismo.

El profesorado de la universidad en el curso 1999/2000 ascendía a 1506, sin incluir los contratos de sustitución, por ser a término.

En los diferentes campus, el estudiantado podía cursar distintas titulaciones de ciclo largo y ciclo corto, obedeciendo a lo estipulado en la Ley Orgánica 11/1983, de 25 de agosto, de Reforma Universitaria. (BOE no 209, de 1 de septiembre)

El número total de estudiantes con discapacidad declarada en el curso académico 2001/2002 era de 33 .

\subsection{LA ULPGC EN LA ACTUALIDAD}

Han pasado treinta y un años, y en este período de tiempo nos integramos al EEES (Espacio Europeo de la Educación Superior) (2010), la universidad ha ido creciendo, tanto en recursos humanos como materiales. Además, algunos departamentos, instalaciones y servicios han modificado sus nombres, o se han creado nuevas.

Actualmente, cuenta con seis Campus: Tafira, El Obelisco y San Cristóbal, situados en Las Palmas de Gran Canaria; Cardones, en el término municipal de Arucas; y otros dos en las islas de Lanzarote y Fuerteventura.

El PDI (Personal docente e investigador) está compuesto actualmente por 1619 personas, a las que se unen 220 de personal investigador, en proyectos y formación, 41 doctores honoris causa y 895 en el colectivo de personal de administración y servicios. 
La ULPGC está equipada con bibliotecas, salas de lectura y estudio, así como, aulas de informática para que los estudiantes puedan acceder a los materiales que necesiten como apoyo a la docencia que reciben: libros, volúmenes y materiales impresos, como en soportes utilizables en las nuevas tecnologías. También cuenta con un servicio de préstamo de equipos informáticos.

Respecto a la formación en otras lenguas, los estudiantes de la ULPGC pueden estudiar diferentes idiomas europeos en el Aula de Idiomas. Además, chino y coreano en los institutos oficiales: Instituto Confucio e Instituto King Sejong.

Para el asesoramiento y gestión de los diferentes programas de movilidad en los que participa la universidad, tanto con Europa como con universidades de América Latina y Estados Unidos, la ULPGC cuenta con una oficina de Relaciones Internacionales.

Igualmente, la institución ofrece apoyo para la inserción en el mercado de trabajo, mediante la organización de Foros de Empleo y múltiples actividades y cursos específicos.

Y se han creado aulas y clubes culturales, en distintos ámbitos.

En el curso 2020/2021, la oferta formativa se reparte entre la enseñanza presencial, con un total de 42 títulos de grado, 6 dobles titulaciones de grado, 26 másteres universitarios, 13 programas de doctorado, 55 maestrías, expertos y formación especializada propios y 5 programas formativos especiales; y la formación en línea, con 5 titulaciones de grado y 1 máster universitario. Es decir, que se ha producido un aumento y diversificación en la oferta formativa que nos ha llevado a contar con un alumnado total en titulaciones oficiales de 20356. De este número, 281 presentan alguna necesidad de apoyo educativo, cuyo desglose es el siguiente: discapacidad física, 136 (48\%); discapacidad visual, 13 (5\%); discapacidad auditiva, 21 (8\%); discapacidad psíquica, 54 (19\%); y otras necesidades específicas de apoyo educativo, entre las que se encuentran el TDAH (Trastorno por déficit de atención con o sin hiperactividad), DEA (Dificultades específicas de aprendizaje, p. e. la dislexia), trastorno adaptativo, 57 (20\%).

\subsection{ESTUDIOS SOBRE ESTUDIANTES CON NECESIDADES EDUCA- TIVAS REALIZADOS EN LA ULPGC}

El estudio realizado por Díaz Jiménez (2003), con estudiantes con discapacidad matriculados en la ULPGC en el curso 2001-2002, dejó al descubierto las carencias que según ellos poseía el profesorado con el que habían cursado materias, destacando la falta de adaptaciones metodológicas, evaluativas y de 
contenidos necesarias para el adecuado seguimiento de las clases. En ese momento, el 7\% de los estudiantes también afirmó que no existía una implicación por parte del profesorado para dar respuesta al estudiantado con discapacidad.

En 2007, Rodríguez Martín incluye, dentro de su tesis doctoral, un estudio en que empíricamente se centra en la Facultad de Formación del Profesorado, con el objetivo general de conocer las opiniones, valoraciones y percepciones del profesorado y de los estudiantes de la facultad hacia la inclusión académica y social de los universitarios con discapacidad. En el mismo, participó el 56.7\% del profesorado y el $41.08 \%$ del total de matriculados en las ocho titulaciones que se impartían en el curso 2005/2006. Las conclusiones extraídas revelan que la información y el conocimiento sobre la discapacidad pueden variar las manifestaciones de los universitarios. En otras palabras, las respuestas sobre las adaptaciones o las relaciones han resultado más favorables cuando estudiantes y profesorado han manifestado tener contacto con personas con discapacidad. De ahí que posteriormente se planteara extender el estudio a toda la institución. En este último participaron 266 docentes, un 17.22\%, y 1.925 estudiantes, que constituían un $8,80 \%$ de la población y que se completa con 47 estudiantes con discapacidad, de los 127 escolarizados en el curso 2005/2006. De forma general, las opiniones que los docentes no están formados para dar respuesta a los estudiantes con discapacidad y que la Universidad tampoco está preparada para ello es coincidente entre los colectivos. Es decir, "que no existe formación docente para dar respuesta a los estudiantes con discapacidad en la universidad y que la institución no está preparada para formar y atender a este colectivo." (Rodríguez Martín, 2007, p. 436). Resaltando también el autor, que el contacto con personas con discapacidad, la información y la formación que de tal situación se produce, condiciona el nivel y calidad de las respuestas, especialmente, en las cuestiones relacionadas con la adaptación en las asignaturas y las opciones reales existentes.

Unos años más tarde, el estudio de Mesa (2013) analiza la opinión del estudiantado con discapacidad auditiva y sin discapacidad intelectual, de la isla de Gran Canaria, que cursan estudios en Educación Secundaria Obligatoria (ESO), Bachillerato, Programas de Cualificación Profesional Inicial (PCPI), Ciclos formativos (CF), Escuela Oficial de Idiomas (EOI) y Estudios Universitarios matriculados en el curso 2010-2011, sus compañeras y compañeros de clase, su profesorado y sus familias. Aunque son varios los aspectos que se investigan, vamos a centrarnos en el factor referido a la Respuesta educativa.

Respecto a las y los estudiantes con discapacidad auditiva, participaron 71 de los 87 matriculados, de los cuales el 10,80\% cursaban Estudios Universitarios. 
En las conclusiones de este estudio los estudiantes indican que el profesorado carece de formación para atenderlos y ese planteamiento aumenta cuando la pérdida es Media y Profunda, o hay Cofosis. Por ello, demandan ayudas para lograr la adquisición de los contenidos, así como, adaptaciones metodológicas y evaluativas.

En el estudio llevado a cabo con el estudiantado normoyente sin discapacidad intelectual, compañeros y compañeras de los y las estudiantes con discapacidad auditiva, participaron 321 estudiantes, 52 de ellos universitarios $(16,60 \%)$. De forma general, se manifiestan favorablemente a que se realicen las adaptaciones de acceso oportunas al estudiantado con discapacidad auditiva, así como metodológicas y de evaluación. Además, que tengan una atención individualizada por parte de profesores especialistas o de los departamentos.

El número de familias de estudiantes con discapacidad auditiva que participó en el estudio fue 47 y el 13,9\% correspondía a estudiantes universitarios. Las conclusiones ponen de manifiesto la demanda de ayuda por parte de todos los familiares para llegar a los contenidos, además de adaptaciones metodológicas y evaluativas; siendo los relacionados con los estudiantes de Bachillerato, CF, EOI y Estudios Universitarios los que reclaman más estas medidas. También indican que el profesorado está debidamente formado para atender a sus familiares, aunque muestran un cierto descontento en los estudios de Bachillerato, CF, EOI y Estudios Universitarios.

El último estudio realizado por Mesa (2013) buscaba conocer la opinión del profesorado implicado en la enseńanza a los estudiantes con discapacidad auditiva sin discapacidad intelectual, con una participación de 114 docentes que impartían clases en el curso 2010-2011, siendo 27,7\% profesorado universitario. Este profesorado, en el intervalo de edad entre 36 y 45 años, opina que el tiempo de atención por parte del ILSE es insuficiente. Y sobre sus conocimientos sobre la discapacidad auditiva, consideran que se debe abordar el desconocimiento que tiene sobre ella, pues favorecerá su acción docente. Además, el profesorado cree necesario una formación específica sobre la mejor metodología a aplicar, las estrategias para la adaptación de contenidos y orientaciones sobre la adaptación de instrumentos de evaluación, ya que son aspectos en los que se puede mejorar y favorecer el seguimiento de las asignaturas por parte de los estudiantes con discapacidad auditiva. En definitiva, la mayoría del profesorado no está preparado para intervenir adecuadamente con el alumnado con discapacidad auditiva, aunque muestran buena predisposición y voluntad.

El último estudio del que nos hacemos eco es el realizado por Díaz Bolaños (2015), "La inserción e itinerario académico y laboral del alumnado con dis- 
capacidad en la Universidad de Las Palmas de Gran Canaria”, pero que no vamos a analizar por centrar sus objetivos en aspectos que no abordan en sí mismo al profesorado universitario. Aunque en su marco teórico sí se encuentran contenidos que reflejan las demandas de mejora de la formación del profesorado en distintas facetas, como medio para llevar a cabo una apropiada respuesta educativa al estudiantado con necesidades educativas.

\subsection{ACCIONES DESARROLLADAS POR LA UNIVERSIDAD DE LAS PALMAS DE GRAN CANARIA}

Después de la entrada en vigor de la Ley Orgánica 6/2001, de 21 de diciembre, de Universidades (LOU), la Universidad de Las Palmas de Gran Canaria comenzó a analizar y ajustar su normativa a este nuevo marco legal. Y en este sentido, la legislación interna recoge la atención y los derechos del estudiantado con discapacidad, en los estatutos de la ULPGC, en el Estatuto del Estudiante, y en los distintos reglamentos que regulan aspectos relativos al estudiantado.

Las acciones realizadas a lo largo del tiempo en la ULPGC incluyen:

- Creación del Servicio de Acción Social (1999), dependiente del Vicerrectorado de Estudiantes, enmarcado en el Proyecto de Integración Universitaria, con la finalidad de prestar un servicio de acogida, orientación vocacional e información psicosocial al estudiantado con discapacidad, generalizado a todo el que tiene necesidades específicas de apoyo educativo.

- Creación de la Dirección de Acción Social y Asesoramiento Psicopedagógico (2002), dependiente del Vicerrectorado de Estudiantes, que inicia el Programa de atención a estudiantes con discapacidad, en orden a dar cumplimiento al principio de la igualdad de oportunidades y derechos. Eso significa que los recursos han de utilizarse para garantizar que todas las personas tengan las mismas oportunidades de participar, y que para ello hay que asumir que cada persona tiene sus necesidades y que todas son importantes. Además, la planificación de las sociedades debe partir del análisis de esas necesidades. La ULPGC, a través de este programa, establece las condiciones para lograr la plena integración de las personas con discapacidad en la institución.

- Creación del Servicio de Interpretación en Lengua de Signos Española por parte del Vicerrectorado de Estudiantes, financiado íntegramente por la ULPGC, del que derivaron experiencias innovadoras, como 
la adaptación de materiales de asignaturas específicas. Además de lo anterior, este servicio prepara y supervisa materiales didácticos y de lecto-escritura adaptados, realiza tareas de mediación entre el centro, profesores y alumnado en general, crea glosario de términos relacionados con las asignaturas. También, durante un tiempo se llevaron a cabo talleres de Lengua de Signos para toda la comunidad universitaria.

Estas acciones hicieron valedora a la ULPGC del I Premio de Accesibilidad 2005, otorgado por el Gobierno de Canarias.

- Programa de voluntariado, en el que se ofrecen créditos por la acción voluntaria, como la toma de apuntes, el acompañamiento en los desplazamientos, la ayuda en la transcripción en realización de los exámenes, etc. Para que la labor sea eficaz, se ofertan cursos y talleres anuales de formación para el voluntariado.

- Apoyo a estudiantes con necesidades educativas especiales mediante mentorías, realizadas por sus propios compañeros de cursos superiores y con la implicación directa del profesorado, con el objetivo de facilitar su proceso de enseñanza aprendizaje y su inclusión plena en el centro y la titulación en la que desarrollan sus estudios.

- Durante cuatro años, el Vicerrectorado de Estudiantes celebró las Jornadas Sociedad y Discapacidad, con la finalidad concienciar sobre la importancia de la educación y su calidad para la plena integración de las personas con discapacidad; el trabajo y otras temáticas de interés acorde con la realidad del momento. Las primeras se llevaron a cabo en 2003, Año Europeo de las personas con discapacidad, y siempre combinaron talleres, charlas y mesas redondas, con la intervención de especialistas de cada temática.

- Estas jornadas fueron sustituidas por el Vicerrectorado de Estudiantes y Empleabilidad por unas Jornadas para formar y sensibilizar a la Comunidad Universitaria y con la participación de centros externos.

- Elaboración de la guía de orientaciones y recomendaciones de discapacidad, un recurso básico para la inclusión del estudiantado con necesidades educativas. Este documento aglutina una serie de pautas y recomendaciones de actuación con el fin de garantizar la igualdad de oportunidades, no discriminación y accesibilidad universal a las personas con discapacidad.

- Adaptaciones de las bibliotecas con la disposición de puestos específicos para el alumnado con discapacidad en todos los campus uni- 
versitarios, así como la adaptación de la web institucional y el campus virtual a la Web Accesibility Initiative (WAI).

A día de hoy se siguen desarrollando las siguientes funciones:

- Estudiantes con discapacidad que cursan bachillerato $\left(1^{\circ}\right.$ y $\left.2^{\circ}\right)$. Prever las adaptaciones específicas para la realización de las pruebas de la EBAU y su posterior adaptación a la Universidad.

- Estudiantes con discapacidad que se forman en la ULPGC. Reconocimiento de sus necesidades, información a los centros en los que van a cursar sus estudios para la realización de las adaptaciones oportunas, con apoyos tutoriales que permitan su formación académica y su desarrollo en la Universidad.

- El estudiantado de la ULPGC, pues a ellos se dirigen campañas de sensibilización e información, talleres específicos, con la finalidad de conozcan la realidad de los diferentes colectivos y ayuden a mejorar su formación académica y su vida estudiantil en la universidad.

- Conexión con instituciones, públicas y privadas, relacionadas con el área de la discapacidad, con las que se realizan acuerdos, convenios y colaboraciones que benefician el desarrollo integral de los estudiantes.

- Ayudas Técnicas, como los ordenadores con el JAWS, a través de las bibliotecas universitarias. La existencia de lupas u otros materiales que permiten abordar el proceso de enseñanza-aprendizaje en igualdad de condiciones con el alumnado sin discapacidad.

También se facilita información sobre servicios generales de la universidad adaptados a sus necesidades:

Servicio de residencia. Dos son las residencias universitarias con habitaciones adaptadas. Así como apartamentos.

Servicio de transportes. Existe una amplia oferta de transporte público, con acceso a las personas con discapacidad.

Servicio de aparcamiento. Vinculado al servicio de transportes, el Programa facilita a los estudiantes universitarios con movilidad reducida el acceso a aparcamientos reservados, con accesibilidad directa a los centros de estudio.

\section{LA FORMACIÓN DEL PROFESORADO UNIVERSITARIO}

Los resultados y conclusiones de los estudios realizados en nuestra institución, relacionadas con la inclusión de los estudiantes con necesidades especiales, 
ponen de relieve la necesidad de la formación del profesorado, de forma que se lleven a cabo las adaptaciones metodológicas, de contenidos, de evaluación, etc., que permitan la respuesta más ajustada a este colectivo.

Estas conclusiones coinciden con las alcanzadas en estudios más recientes en otras universidades españolas, como son los de Lorenzo y Lledó (2017) y Benet et al. (2019).

\subsection{LA FORMACIÓN DE LOS DOCENTES EN LA ULPGC (1995-2003)}

En el estudio realizado por Grijalvo (2004), se recogen los cursos realizados por el profesorado de la universidad en este período de tiempo, y recogemos a continuación los referidos a formación psicopedagógica:

- Curso 1: Técnicas de evaluación en la enseñanza universitaria

- Curso 2: Técnicas de comunicación oral en la enseñanza universitaria

- Curso 3: Cómo elaborar un proyecto docente y técnicas de enseñanza universitaria

- Curso 4: Técnicas motivacionales en la enseñanza universitaria

- Curso 5: El papel de las tecnologías de la información y de la comunicación

- Curso 6: Cómo enseñar para que los alumnos aprendan lo que los profesores les enseñamos

- Curso 7: Preparación de clases, seminarios y congresos

- Curso 8: Estrategias de enseñanza

- Curso 9: ¿Por qué los estudiantes no aprenden lo que les enseńamos?

- Curso 10: Tutorías para profesionalizar la enseñanza universitaria

- Curso 11: Técnicas de comunicabilidad didáctica

- Curso 12: Elaboración y utilización de recursos multimedia en el aula

Las valoraciones realizadas por el profesorado sobre cada uno de los cursos realizados constata la diversidad de opiniones, pues no generaron el mismo interés según las áreas de conocimiento. Aunque, en general, el plan fue bien evaluado.

Las conclusiones expuestas por el investigador en este primer estudio determinaron que (Grijalvo, 2004, p. 251):

1. Los profesores de la ULPGC mostraban una buena motivación a realizar los cursos de formación didáctica ofertados desde el año 1995 hasta el 2003.

2. Por lo general, las solicitudes de los cursos han superado las plazas disponibles, por lo que ha sido necesario repetir algunos cursos en sucesivas ocasiones o han sido duplicados en horario de mañana y tarde. 
3. A la luz de los datos analizados resulta difícil concretar la preferencia de los docentes por un tipo de cursos. Sin embargo, sí podemos asegurar un interés manifiesto por la mejora de aspectos como: a) la evaluación de los estudiantes; b) aprender a motivarles y aprender a enseñar; c) conocer estrategias de enseñanza eficaces y saber tutorizar; d) aprender a mejorar aspectos formales como el proyecto docente; e) aprender nuevas habilidades para mejorar la capacidad comunicativa entre el profesor y los estudiantes; f) actualizar conocimientos sobre las TIC, etc.

4. La acogida que han tenido los cursos de formación didáctica en la ULPGC ha sido muy buena y el nivel de participación en los mismos es muy elevado. En consecuencia, es previsible que continúe la afluencia masiva de docentes a los futuros cursos que se organicen como corroboran las listas de solicitudes para las actividades de formación del curso 2002-2003 y 2003-2004.

Con esta oferta formativa, la universidad fue cubriendo uno de los puntos débiles, que era la insuficiente formación psicopedagógica del profesorado. Unidos a la escasa formación on-line y la ausencia de una política de investigación competitiva. Y en esa línea ha ido trabajando.

Antes de llegar a la etapa actual, podemos encontrar alguna oferta, pero no con esta estructura, así como, con una política de ayudas a la formación que permitió al profesorado llevar a cabo formación fuera de la institución.

\subsection{PLANES ACTUALES DE FORMACIÓN DEL PDI}

En los últimos cuatro años, la universidad ha acometido un plan formativo que gira entorno a los siguientes ejes:

1. Acciones formativas para la docencia, la acción tutorial y la innovación educativa

2. Acciones formativas para la investigación

3. Acciones formativas para la gestión y la calidad

4. Acciones formativas para la internacionalización

También se oferta una Maestría de forma gratuita para el profesorado de la ULPGC.

Además, mediante la justificación de la realización de 30 ECTS correspondientes a actividades de cualquier programa del Plan de Formación Continua del Personal Docente e Investigador ya finalizado, se puede solicitar el Experto Universitario en Docencia Universitaria: 
- Módulo I. Habilidades docentes (16 ects)

- Módulo II. Habilidades investigadoras (10 ects)

— Módulo III. Habilidades de gestión y/o acciones formativas específicas por áreas (2 ects)

— Módulo IV. Habilidades idiomáticas (2 ects)

\section{CONCLUSIONES Y RETOS PARA EL FUTURO}

Se observa una gran oferta formativa por parte de la universidad, con algunos cursos específicos que pueden conllevar la mejora de la respuesta educativa hacia el alumnado con necesidades educativas, pero no se aprecia de una forma explícita. Nada nos hace pensar que en la formación de Plan de acción tutorial, en la evaluación, etc., se aborde de manera específica al alumnado con discapacidad. Por tanto, no estamos incidiendo en los aspectos seńalados por el estudiantado, las familias, el profesorado y el personal de administración y servicios.

Consideramos que es necesario que se incluya formación específica sobre las distintas NEAE (Necesidades Específicas de Apoyo Educativo), por presentar necesidades educativas especiales, por dificultades específicas de aprendizaje, por sus altas capacidades intelectuales, por haberse incorporado tarde al sistema educativo, o por condiciones personales o de historia escolar (LOE, art. 71), pues el estudiantado ya viene provisto de su informe psicopedagógico o valoración médica desde la etapa previa a su ingreso en la universidad.

También tenemos que abordar, como afirman Lorenzo y Lledó (2017), la creación de una normativa específica referida a las medidas de atención con estos estudiantes en relación a adaptaciones curriculares y a la evaluación, pues son pocas las universidades españolas que cuentan con ella.

A partir de todos estos cambios tenemos que lograr el desarrollo del currículo formativo en diseño para todos.

\section{REFERENCIAS BIBLIOGRÁFICAS}

Benet, A., Sales, A. y Moliner, O. (2019). Construyendo universidades inclusivas: elementos clave de las prácticas docentes. Revista Nacional e Internacional de Educación Inclusiva, 12(2), 78-100.

Díaz Jiménez, G. (2003). Los estudiantes con discapacidad: su realidad en la Universidad de Las Palmas de Gran Canaria. Tesis doctoral. Universidad de Las Palmas de Gran Canaria.

Díaz Bolaños, C.D. (2015). La inserción e itinerario académico y laboral del alumnado con discapacidad en la Universidad de Las Palmas de Gran Canaria. Tesis doctoral. Universidad de Las Palmas de Gran Canaria. 
Etopa, M.P. (2000). La formación del profesorado universitario en la ULPGC. Elaboración de un cuestionario para la recogida de información. Suficiencia Investigadora. Universidad de Las Palmas de Gran Canaria.

Grijalvo, F. (2004). Incidencia de los cursos de formación de profesorado en la mejora de la calidad docente. Tesis doctoral. Universidad de Las Palmas de Gran Canaria.

Gobierno de Canarias. (1989, 8 de mayo). Ley 5/1989, de 4 de mayo, de Reorganización Universitaria de Canarias. Boletín Oficial de Canarias n $n^{\circ} 64$, 1616-1617.

Jefatura del Estado. (1983, 1 de septiembre). Ley Orgánica 11/1983, de 25 de agosto, de Reforma Universitaria. Boletín Oficial del Estado no 209, 2403424042.

Jefatura del Estado. (2001, 24 de diciembre). Ley Orgánica 6/2001, de 21 de diciembre, de Universidades. Boletín Oficial del Estado no 307, 4940049425.

Jefatura del Estado. (2006, 4 de mayo). Ley Orgánica 2/2006, de 3 de mayo, de Educación. Boletín Oficial del Estado no 106, 17158-17207.

Jefatura del Estado. (2007, 13 de abril). Ley Orgánica 4/2007, de 12 de abril, por la que se modifica la Ley Orgánica 6/2001, de 21 de diciembre, de Universidades. Boletín Oficial del Estado no 89, 16241-16260.

Mesa, J.L. (2013). La percepción sobre la inclusión del alumnado con discapacidad auditiva en la Educación Secundaria, Educación Superior y enseñanzas de régimen especial en Gran Canaria. Tesis doctoral. Universidad de Las Palmas de Gran Canaria.

Rodríguez Martín, A. (2007). Universidad y Diversidad: Avanzando hacia un Espacio Europeo de Educación Superior para Todos. Tesis doctoral. Universidad de Las Palmas de Gran Canaria.

Universidad de Las Palmas de Gran Canaria. Datos globales de la ULPGC. Recuperado el 18 de febrero de 2021 de:

https://www.ulpgc.es/presentacion/datos_globales 


\title{
INVESTIGACIONES SOBRE EL AUTISMO REALIZADAS EN LA FACULTAD DE CIENCIAS DE LA EDUCACIÓN DE LA ULPGC
}

\author{
Ma del Sol Fortea Sevilla \\ Universidad de Las Palmas de Gran Canaria
}

\begin{abstract}
Resumen
En las dos últimas décadas estamos asistiendo a un incremento del alumnado con trastornos del espectro autista en las aulas de educación infantil y primaria de las escuelas de nuestra comunidad, al igual que ocurre en el resto del Estado español. La Facultad de Ciencias de la Educación no puede ser ajena a esta situación y por ello debe enfrentar el reto de formar maestras y maestros que serán responsables de diseñar y poner en práctica proyectos educativos inclusivos para todo el alumnado de las escuelas, incluido el alumnado con trastornos del espectro autista.

Este documento pretende hacer un recorrido de las aportaciones realizadas por docentes de la Facultad de Ciencias de la Educación en el ámbito de los trastornos del espectro autista, aportaciones tanto formativas como de investigación.
\end{abstract}

Palabras clave: Autismo. Investigación. Diagnóstico. Inclusión. Objetivos de desarrollo sostenible.

\begin{abstract}
In recent years we have witnessed an increase in students with autism spectrum disorders in the classrooms of nursery and primary education schools in our community, the same happens in the rest of Spain.

The Faculty of Education cannot ignore this situation and therefore must face the challenge of training teachers who will be responsible for designing and implementing inclusive educational programs for all students in schools, including students with autism spectrum disorders.

This document aims to take a tour of contributions to the field of autism from the Faculty of Education in recent years, both training and research contributions.
\end{abstract}

Keywords: Autism. Research. Diagnosis. Inclusion. Sustainable Development Goals. 
El Grupo de Estudios de los Trastornos del Espectro del Autismo (GETEA), creado en el año 2001 (en el seno del Centro de Investigación sobre el Síndrome del Aceite Tóxico, centro precursor del actual Instituto de Investigación de Enfermedades Raras, dependiente del Instituto de Salud Carlos III) con el objetivo de impulsar un proyecto que diera a conocer la realidad del autismo en España, y que recomendara vías de mejora tanto en la asistencia, como en la formación y en la investigación en lo relativo al autismo. Este grupo supo aglutinar el interés y la experiencia necesaria para afrontar los retos del momento en la investigación de este trastorno.

Entre otras publicaciones, en el año 2005 el GETEA publicó la "Guía de buena práctica para la investigación de los trastornos del espectro autista" (Belinchón et al., 2005). En ella se concluye que la investigación sobre los trastornos del espectro autista (en adelante TEA) en nuestro país necesita un cambio cualitativo y mucho más apoyo coordinado de las instituciones para poder desarrollar proyectos de investigación de manera continuada y efectiva. En dicho documento se plantea que, en el ámbito de la investigación aplicada, se debe dar prioridad a proyectos dirigidos a (p. 373):

1. Identificar marcadores biológicos e indicadores tempranos que permitan adelantar la detección e intervención.

2. Homogeneizar los actuales procedimientos diagnósticos y desarrollar herramientas adaptadas para la evaluación del funcionamiento cognitivo y neuropsicológico, y del nivel de discapacidad, de las personas afectadas.

3. Identificar las áreas prioritarias de intervención psicológica y evaluar empíricamente la eficacia de los actuales tratamientos (conductuales, educativos, psicológicos y farmacológicos).

4. Desarrollar diseños de intervención clínica, educativa y comunitaria basados en los resultados de la investigación, desde la valoración y delimitación de las necesidades particulares de los distintos individuos afectados.

Por entonces, en la Facultad llevábamos varios años impartiendo formación a través de los Cursos de Extensión Universitaria, certificados como créditos de libre configuración. Se trataba de cursos dirigidos, no solamente al alumnado de la Facultad sino también a profesionales de la educación que trabajaban en centros educativos de la provincia de Las Palmas. El primero de ellos tuvo lugar en el año 1999 y llevaba por título "Definición de autismo y TGD. Revisión histórica y criterios de diagnóstico". A este le siguieron otros muchos que se llevaron a cabo en las islas de Gran Canaria y Lanzarote, cada uno de 
ellos tenía una duración en torno a 20-30 horas y un número de participantes entre 50-100. La temática giraba alrededor del concepto de autismo, a los cambios experimentados en los últimos años, en los que ha pasado de considerarse una psicosis de origen psicodinámico, a ser un trastorno del neurodesarrollo. Por supuesto, en esos cursos se daban a conocer las estrategias de intervención específicas para el alumnado con TEA, y como prestar la atención necesaria a las familias, que requieren de información y formación. Inicialmente los cursos eran presenciales, y desde el año 2011 comienzan a realizarse a través del campus virtual de la ULPGC.

Cada vez eran más los profesionales comprometidos e interesados, y en el año 2004 se celebra en Las Palmas de Gran Canaria el XII Congreso Nacional de la Asociación Española de Profesionales del Autismo (AETAPI), certificado por la ULPGC con créditos de libre configuración. Este congreso sirvió de punto de partida para situar a la Facultad en el camino de la investigación en el campo del autismo, con la implicación de varios profesores. En ese momento ya estaba iniciado el camino que el grupo GETEA había marcado. La formación ya era una realidad y nos planteamos seguir avanzando y dedicar el esfuerzo a la detección temprana en nuestra comunidad (punto 1 de las recomendaciones del GETEA).

En el año 2006 se presenta la primera investigación sobre el autismo en la Universidad de Las Palmas de Gran Canaria, enmarcada en el programa de Doctorado perteneciente a los Departamentos de Didácticas Especiales y Psicología y Sociología de la ULPGC sobre "Formación de Profesorado", codirigido por la profesora Repetto, correspondiente al bienio 2004-06. El resultado es un artículo titulado "Prevalencia del trastorno autista: estudio exploratorio" (Fortea et al., 2008). Se trata de un estudio epidemiológico en el municipio de Ingenio (situado en la isla de Gran Canaria) que pretende conocer la prevalencia del autismo en nińos y nińas de edades comprendidas entre 2 y 5 años con sospecha de tener TEA. Los resultados aportan una estimación de prevalencia que se corresponde con los datos que existen fuera de nuestro fuera de España y que la sitúan en un 0,61\%.

Continuando con la línea de investigación iniciada en el municipio de Ingenio, se pone en marcha un programa experimental de detección temprana del autismo en los municipios de Santa Lucía y Telde, con el apoyo de pediatras de atención primaria y el ayuntamiento de Telde. El objetivo inicial era decidir acerca de la implantación de un cribado en niños pequeños en toda la Comunidad Autónoma de Canarias, desde las consultas de pediatría. Los resultados preliminares apuntaban dificultades para llevar a cabo el cribado poblacional 
desde el programa del niño sano de pediatría junto se resumen en los siguientes (Fortea et al., 2010):

- Poca estabilidad entre los profesionales sanitarios.

- Escasez de personal de enfermería para ayudar en la fase de administración.

- Gran parte de los niños y nińas acude a consultas de pediatría privadas que no fueron tomadas en cuenta inicialmente.

- Se observa gran movilidad de la población, sobre todo en el municipio de Santa Lucía, por tratarse de una ciudad con muchos trabajadores del sector turístico.

- Gran parte de la población son inmigrantes que desconocen la lengua castellana y que requieren de mucha ayuda por parte de los profesionales.

Como consecuencia de estos resultados, se decide diseñar un nuevo proyecto de investigación que será objeto de una tesis doctoral en el programa de doctorado mencionado. La tesis doctoral titulada "Los Trastornos del Espectro Autista en la Comunidad Canaria. Detección Temprana y Diagnóstico" fue defendida en el año 2012, y todos los resultados obtenidos fueron publicados en revistas de investigación y difundidas en diversos congresos de carácter nacional e internacional. Desde entonces, todos los años, la Facultad aporta su granito de arena a la investigación de los TEA.

En el ańo 2013 se publicaron un total de seis trabajos, cinco de ellos tienen como tema central la detección temprana del autismo. En Moscú presentamos dos trabajos que pretenden dar respuesta a dos interrogantes. Por un lado, se buscan posibles causas que expliquen el aumento de casos de autismo en el mundo, y las consecuencias que este incremento tiene en la concepción del trastorno y en el trato que recibe por parte de todos los agentes sociales. Se consideraron importantes las conclusiones que Fombonne aportaba en el año 2009 y que achacaban el aumento de la prevalencia en las últimas décadas a varias causas: la ampliación del concepto de espectro autista, la ampliación de los criterios diagnósticos, la creación de servicios especializados, y un mejor conocimiento de la patología. No obstante, no se puede descartar que otros factores hayan contribuido también al aumento (Fortea et al., 2013a). El segundo trabajo lleva a cabo una revisión teórica de los estudios de prevalencia de autismo realizados, pues es crucial conocer la prevalencia poder proveer de los servicios adecuados y que las personas con autismo vean atendidas sus necesidades desde el primer momento (Fortea et al., 2013b). 
Un tercer estudio, hace una estimación de la prevalencia de TEA en Canarias (Fortea et al., 2013c), situándola en el 0,61\%, similar a la obtenida en estudios previos. Además, la radio aportada por sexo es de 6 nińas por cada 5 niños, diferente de la ofrecida por estudios en otros lugares, que informaban de una ratio superior en nińos (4:1). Curiosamente en los últimos ańos esta ratio se está cuestionando y se piensa que ha existido un infradiagnóstico del autismo en niñas, quizá debido a las características de las nińas con autismo.

El cuarto trabajo publicado en el año 2013 (Fortea et al., 2013d) se centra en los profesionales que están implicados en la detección temprana del autismo. Parte de la premisa de que la detección temprana del autismo es muy importante porque mejora el pronóstico de niños y niñas con alteraciones en el desarrollo. Este estudio tiene como objetivo delimitar a qué edad surgen las primeras sospechas de TEA, a qué profesionales recurren las familias en esos primeros mementos, cuál es la demora en la confirmación del diagnóstico, y la celeridad en la respuesta de los profesionales de la pediatría. Los resultados informan que casi en el $80 \%$ de los casos es la familia quien tiene las primeras sospechas de que algo no va bien en el desarrollo de sus hijos, seguida de los profesionales de la educación (en torno al 15\%), la sanidad (4\% son pediatras, y $2 \%$ psicólogos). Casi el $70 \%$ recibieron el primer diagnóstico durante los tres primeros años, y el $32 \%$ antes de los dos años. La demora diagnóstica se sitúa en torno a los 16 meses, es decir que desde que la familia tiene las primeras sospechas hasta que recibe el diagnóstico pasan unos 16 meses de media. La conclusión es que la mayoría de los padres y madres de niños y niñas con TEA son conscientes de las alteraciones en el desarrollo de sus hijos alrededor de los 18 meses. Este estudio también confirma la tendencia a disminuir el tiempo de respuesta de los profesionales de sanidad. Si este estudio se repitiera en la actualidad veríamos que esa demora en el diagnóstico es mucho menor.

El último de este año dedicado a la detección temprana fue presentado en un congreso de ámbito nacional e internacional (Fortea et al., 2013d). Analizaba el comportamiento de los ítems del M-CHAT/ES con el objetivo de conocer la capacidad discriminativa de dichos ítems para el diagnóstico diferencial entre TEA, trastorno del lenguaje (TEL) y retraso psicomotor (RP). Los resultados mostraron que los niños diagnosticados de TEA fallaban más ítems del M-CHAT (tanto generales como críticos) que los nińos con RP, que a su vez superan en ítems fallados a los TEL, los cuales tienden a fallar más en los ítems generales y menos en los críticos.

El sexto trabajo presentado en este año inicia una línea de investigación centrada en la intervención (punto 1 de las recomendaciones del GETEA), y 
aporta un programa de intervención temprana en niños con TEA que se lleva a cabo en un centro sanitario de la isla de Gran Canaria (Fortea et al., 2013f).

En el año 2014, cinco trabajos más son presentados en diferentes congresos. Uno de ellos acomete el punto 2 de las recomendaciones del GETEA, y analiza los cambios en los criterios diagnósticos aportados por el DSM-5 y como afectan a los procesos de diagnóstico diferencial del TEA frente a los trastornos del lenguaje, de la conducta e incluso de la discapacidad intelectual, condiciones a menudo asociadas al autismo Fortea et al., 2014a).

Los otros cuatro se centran en aspectos relativos a la intervención y al tratamiento, ya iniciado el año anterior (a partir de aquí, se siguen las recomendaciones de los puntos 3 y 4 del GETEA). El primero de ellos (Fortea et al., 2014b) es un estudio longitudinal (entre los 2 y 7 ańos) de un niño cuyo diagnóstico va cambiando (la dinamicidad del TEL de la que hablaba Conti-Ramsdem) entre autismo y trastorno de la comunicación. Se describe la metodología de la intervención con los resultados de esta. El siguiente trabajo (Fortea et al., 2014c) presenta la experiencia con 12 alumnos con TEA en aulas inclusivas. Se desarrolla la metodología empleada, los apoyos que han necesitado y los buenos resultados consecuencia de prácticas inclusivas. Finaliza el año con la presentación, en el congreso nacional de profesionales del autismo, de una comunicación que ofrece un análisis y secuencia de la de la intervención llevado a cabo con un adolescente diagnosticado de síndrome de Asperger, cuyo objetivo principal era lograr el bienestar de chicos y chicos con TEA en la vida adulta (Vidaller et al., 2014). Los resultados de esta intervención obtienen una valoración positiva y se concluye que incluir en los programa de trabajo el conocimiento del diagnóstico por parte de esta población es importante para su bienestar psicológico y emocional.

A lo largo del año 2015, se presentan tres nuevos trabajos, dos ellos centrados en la intervención. En el primero se justifica el empleo de sistemas de comunicación alternativos para el desarrollo temprano del lenguaje en nińos pequeños con autismo (Fortea et al., 2015a). Y en el segundo se evalúa la eficacia de un programa de tratamiento para mejorar la conducta social y comunicativa en niños con TEA (Fortea et al., 2015b). En este trabajo se plantea un "Programa de Intervención Temprana Combinado" (CEIP) que emplea diferentes metodologías con evidencia científica, tales como la Early Intensive Behavioral Interventions, el modelo Denver (Early Start Denver Model), la organización espaciotemporal del TEACCH, el uso de sistemas de comunicación aumentativa (PECS, Comunicación Total, SPC), estrategias conductuales, y entrenamiento a padres. En el programa propuesto, se contempla la intervención 
sobre las áreas típicamente afectadas en TEA (socialización, comunicación, simbolización y flexibilidad comportamental), y su puesta en práctica repercute en una mejora significativa del comportamiento de los nińos, reduciendo las conductas disruptivas y mejorando la comunicación social. Termina el año con un trabajo que evalúa la ansiedad percibida en los padres de las personas con autismo (Escandell et al., 2015), cuyos resultados indican que los padres perciben más ansiedad en sus hijos de la que estos describen, sobre todo se observan diferencias en la ansiedad generalizada, la ansiedad por separación, y la fobia social. Esto da lugar a otro estudio en el que se comparan las diferencias en la ansiedad que presentan niños y niñas con TDAH y con TEA. Los resultados muestran diferencias significativas tanto en la ansiedad mostrados por los participantes diagnosticados de TDAH y los diagnosticados de TEA, como en la ansiedad percibida por sus padres de ambos grupos. (Fortea et al., 2016)

En el año 2017 se presentan mejoras en el programa de apoyo a la inclusión del alumnado con trastornos del neurodesarrollo (TEA y TEL) en aulas ordinarias (Fortea el al., 2017a). Ese mismo año se continua con la línea iniciada de trabajo con las familias, presentando primeras aportaciones de un programa de trabajo con abuelas y abuelos de menores con TEA, que se publicará un a vez terminado en diferentes medios (Fortea et al., 2017b; Fortea, 2019; Fortea et al., 2019). Los últimos trabajos realizados con las familias describen, por un lado, un formato de escuelas-taller cuyo objetivo es que las familias (sobre todo madres y padres) reciban información veraz sobre los TEA y los modelos de intervención que se revelan como más eficaces para cada uno de sus hijos e hijas (Fortea, 2019), y un ultimo trabajo (García-Ochoa et al., 2018) que presenta diferentes perfiles psicológicos de padres y madres de personas con trastornos del neurodesarrollo, en base a la manera de afrontar la llegada de un miembro a la familia con autismo o algún otro trastorno del neurodesarrollo.

Y por supuesto, no podemos terminar este repaso sin mencionar la situación de pandemia provocada por la COVID-19, que obligó a los gobiernos a decretar medidas de confinamiento y seguimiento de normas higiénico-sanitarias, medidas que para las personas con TEA suponen realizar grandes cambios en sus rutinas, y que afectan tremendamente a su estado psicológico y al de sus familias (Tejedor et al., 2020a, 2020b).

En estos momentos, nuestro trabajo se centra en lograr escuelas inclusivas para el autismo, y así poder cumplir con el Objetivo de Desarrollo Sostenible de la Agenda 2030 referido a una educación de calidad, en igualdad y equitativa (UNESCO, 2015). 
Como podemos comprobar, el recorrido desde aquellos inicios en el programa de doctorado dirigido por nuestra querida profesora Emigdia, hasta hoy, ha dado sus frutos, y sin duda, ella estará orgullosa de que el autismo siga teniendo un espacio en nuestra Facultad.

Gracias Emigdia.

\section{REFERENCIAS BIBLIOGRÁFICAS}

Belinchón, M., Posada, M., Artigas, J., Canal, R., Díez, A., Ferrari, M. J., Fuentes, J., Hernández, J. M., Hervás, A., Idiazábal, M. A., Martos, J., Mulas, F., Muñoz, J. A. Palacios, S., Tamarit, J., y Valdizán, J. R. (2005). Guía de buena práctica para la investigación de los trastornos del espectro autista. Rev Neurol, 41(6), pp. 371-377.

Fortea, M. S., Santiago, O., y Marrero, G. (2008). Prevalencia del trastorno autista: estudio exploratorio. Revista de Evaluación e Intervención Psicoeducativa, 12, pp. 43-55.

Fortea, M. S., Santiago, O., Marrero, G., y Canal, R. (2010). Estudios epidemiológicos en tres municipios de la provincia de Las Palmas. En Belinchón, M. (Ed.) Investigaciones sobre el autismo en español: problemas y perspectivas (pp. 37-52). Centro de Psicología aplicada de la Universidad Autónoma de Madrid.

Fortea, M. S., Escandell, M. O., y Castro, J. J. (2013a). Aumento de la prevalencia de los trastornos del espectro autista. International Journal of Developmental and Educational Psychology, 1, pp. 746-768.

Fortea, M. S., Escandell, M. O., y Castro, J. J. (2013b). ¿Cuántas personas con autismo hay? Una revision teórica. International Journal of Developmental and Educational Psychology. 1, pp. 769-786.

Fortea, M. S., Escandell, M. O., y Castro, J. J. (2013c). Detección Temprana del Autismo: Profesionales Implicados. Revista Española de Salud Pública, 87(2), pp. 191-199.

Fortea, M. S., Escandell, M. O., y Castro, J. J. (2013d). Estimación de la prevalencia de los trastornos del espectro autista en Canarias. Anales de pediatría, 79, pp. 352-359.

Fortea, M. S., Escandell, M. O., y Castro, J. J. (2013e). Detección temprana de trastornos del desarrollo con el M-CHAT. En Libro de resúmenes del VI Congreso Internacional y XI Nacional de Psicología Clinica (pp. 208-209). Asociación Española de Psicología Conductual.

Fortea, M. S., Escandell, M. O., y Castro, J. J. (2013f). Programa de intervención temprana para un niño con TEA. En Libro de resúmenes del VI Con- 
greso Internacional y XI Nacional de Psicología Clinica (pp. 209-210). Asociación Española de Psicología Conductual.

Fortea, M. S., Escandell, M. O., y Castro, J. J. (2014a). Nuevas formas de abordaje del proceso diagnóstico del TEA después del DSM-5. International Journal of Developmental and Educational Psychology, 1, pp. 77-86.

Fortea, M. S., y Escandell, M. O. (2014b). Niño con TEL-TEA. Intervención durante 5 años. En Avances en Psicología Clínica (pp. 744-753). Asociación Española de Psicología Conductual.

Fortea, M. S., y Escandell, M. O. (2014c). Autismo y Educación Inclusiva. Experiencia con 12 Niños con TEA en Aulas Inclusivas. III Congreso Internacional de Autismo. Intervención Educativa en los TEA.

Fortea, M. S., Escandell, M. O., Castro, J. J., y Martos, J. (2015a). Desarrollo temprano del lenguaje en niños pequeños con trastorno del espectro autista mediante el uso de sistemas alternativos. Revista de Neurología, 60(S), pp. S31-S35.

Fortea, M. S., Escandell, M. O., y Castro, J. J. (2015b). Assessment of the efficacy of a program to improve the social communication and behavior of young children with ASD. Revista de Investigación en Logopedia, 5(2), pp. 167-185.

Escandell, M. O., Castro, J. J., y Fortea, M. S. (2015). Parents-perceived and self-perceived anxiety in children with autism spectrum disorder. Educational Research and Reviews, 10(18), pp. 2531-2538.

DOI: $10.5897 / E R R 2015.2429$

Fortea, M. S., Escandell, M. O., Castro, J. J., y Martos, J. (2016). Valoración de la ansiedad en los trastornos del espectro autista y en el trastorno por déficit de atención/hiperactividad. Revista de Neurología, 62(S1), pp. S99S102.

Fortea, M. S., y Vigil, N. (2017a). APIED-Pg. Programa de apoyo a la inclusión del alumnado con trastornos del neurodesarrollo (TEA y TEL) en aulas ordinarias. Congreso Internacional Alcanzamos Sueños.

Fortea, M. S., Escandell, M. O., y Castro, J. J. (2017b). Abuelas y abuelos de niñas/os con autismo: los grandes olvidados. En Consejo General de la Psicología, Libro de Resúmenes. III Congreso de Psicología (pp. 468-469). DOI: https://doi.org/10.23923/cop.oviedo2017

Fortea, M. S. (2019). Escuela de familias. En Libro de Actas I Congreso Internacional De Educación e Intervención Psicoeducativa, Familiar y Social (pp. 302-302). 
Fortea, M. S., Castro, J. J., y Escandell, M. O. (2019): Programa de apoyo para reducir la ansiedad en abuelos de niños con trastorno del espectro autista. Revista Española de Discapacidad, 7 (II), pp. 123-137.

García-Ochoa, A., y Fortea, M. S. (2018). Perfiles psicológicos de padres y madres de personas con trastornos del neurodesarrollo: el afrontamiento al problema. XIX Congreso AETAPI. AutismoS, entendiendo la diversidad.

Tejedor, M. T., y Fortea, M. S. (2020a). Atención a personas con trastorno de espectro autista durante la pandemia de COVID-19. I Congreso Nacional COVID-19.

Tejedor, M. T., y Fortea, M. S. (2020b). COVID-19 y Trastorno del Espectro Autista: mucho más que un cambio de rutina. https://theconversation.com/es/search?q=fortea

UNESCO (2015a). Agenda 2030 para el Desarrollo Sostenible. Septiembre 2015. Recuperado de:

http://www.unesco.org/new/es/santiago/education-2030/

Vidaller, A., Fortea, M. S., y Arnás, I. (2014). Programas de intervención y objetivos para el bienestar de chicos con TEA en la vida adulta. Valoración positiva $y$ avances en casos de niños que conocen su diagnóstico. XVII Congreso AETAPI. Construimos capacidad. 


\title{
PRINCIPALES TENDENCIAS DEL DESARROLLO TURÍSTICO RURAL EN LA REGIÓN CANARIA: UN ESTUDIO DE CASOS EN VARIOS MUNICIPIOS DE LA ISLA DE GRAN CANARIA
}

\author{
Ángela García Cabrera \\ Profesora Titular de Sociología (Jubilada) \\ Universidad de Las Palmas de Gran Canaria
}

\section{Resumen}

El Turismo, en esta era de la globalización, es un producto de las sociedades avanzadas, y las Islas Canarias se han convertido en uno de los primeros lugares turísticos masivos elegidos por muchas personas venidas de todo el mundo, siendo un ejemplo de ello el Municipio de Tejeda - catalogado como uno de los Pueblos más bonitos de España-. Concretamente, el turismo rural se ha convertido en un factor de subsistencia importante en las zonas rurales que se asienta satisfactoriamente con gran desarrollo ocio turístico, debido, en gran parte, al interés que entidades públicas y privadas habían puesto en ello.

Palabras clave: turismo rural, desarrollo sostenible, globalización, alojamiento rural, ocio, políticas turísticas, descanso.

\begin{abstract}
Tourism, in the globalization age, is a product of advanced societies, and the Canary Islands of Spain have been transformed in one of the first massive touristic selected places for a lot of people from different parts of the world, the municipality of Tejeda — named as one of the most beautiful rural towns in Spain-. Concretely, rural tourism has turned into a very important substeinability factor in rural areas which are grounded satisfactorilly by a strong multi-oriented touristic approach due, mainly, to public and private busissness enterprises quite committed to it.
\end{abstract}

Key words: rural tourism, sustainable development, globalization, rural lodging, leisure, touristic politics, rest.

\section{INTRODUCCIÓN}

En la primera parte de este estudio hacemos una revisión de la literatura sobre el turismo rural que hemos considerado relevante, tanto a nivel global 
como regional del Archipiélago Canario, al tiempo que en su segunda parte presentamos un caso de investigación sociológica práctico en seis municipios en la isla de Gran Canaria que dará al lector una visión somera del estado en que actualmente se encuentra el turismo rural en la isla de Gran Canaria. Detallamos la dificultad en su realización, dada la evidente falta de datos oficiales al respecto, si bien entendemos que este fenómeno del turismo rural es un fenómeno relativamente emergente en el Archipiélago Canario.

\section{ALCANCE Y LIMITACIONES}

La realización de este estudio se fundamenta en la creciente importancia que va tomando esta nueva modalidad de turismo, llamado turismo rural o turismo sostenible considerado importante desde todos los puntos de vista económico, medioambiental social y político- en esta sociedad globalizada en la que nos movemos.

\section{EL TURISMO: UN FENÓMENO DE DIMENSIÓN GLOBAL}

No cabe la menor duda de que el turismo, al que frecuentemente se le denomina como la industria más grande del mundo, (Sharpley, R. y Telfer, D. J., 2002), es un gran negocio. Hasta que la Pandemia entró en España a comienzos del 2020, este País, de acuerdo con el Foro Económico Mundial de Davos, en su Informe para el año 2018, continuaba como líder mundial en competitividad de viajes y turismo, por delante de Francia y Alemania. Y recientemente, en el Foro del Periódico La Provincia - Conferencia de Matilde Asian, Secretaria de Estado de Turismo—- esta, en febrero de 2018, afirmaba que: "España se había convertido en la segunda potencia turística del mundo y Canarias en la segunda potencia turística de España”. (La Provincia-Diario de Las Palmas, sábado 3 de febrero, 2018).

Este dato nos demuestra que en las sociedades modernas avanzadas la demanda turística, pese a la Pandemia mundial que padecemos, continúa su imparable búsqueda de nuevas formas de disfrutar el tiempo de ocio, no importa cuán lejos del lugar de origen o costoso estas formas puedan estar, si con ello la ratio calidad/precio se ajusta a parámetros alcanzables a las diferentes clases sociales mundiales. El Turismo Tradicional de Sol Playa ha estado exigiendo otras formas de turismo alternativo, y una de estas nuevas formas es el turismo en el espacio rural, visto como el lugar idóneo para todos aquellos turistas venidos de muchas partes del mundo en busca de tranquilidad, contacto con la naturaleza, intercambio cultural, actividades al aire libre, visitas a entornos ar- 
queológicos, visitas a museos etnológicos o simplemente mezclarse con los lugareños y participar en sus actividades culturales, tradicionales, etc.

\section{EL TURISMO RURAL: ESTADO DE LA CUESTIÓN}

Algunos autores afirman que el turismo rural tuvo su origen en Gran Bretaña, otros que fue en Irlanda, y también se apunta como pionera a la vecina Francia.

Este tipo de turismo rural se empieza a dibujar en nuestra geografía peninsular e insular canaria en los años 60 y 70 e incluso en los 80 por el creciente número de espańoles que poco antes habían abandonado el campo por motivos económicos, y regresan luego a dicho entorno, si bien, muchos por diferentes razones. El interés y la demanda acerca de la potencialidad que puede tener el turismo rural en referencia a espacios naturales nace en la década de los 80 . En los 90 se confirma el interés creciente que existe sobre las áreas rurales, como potencialmente idóneas para captar una oferta cada vez más exigente. El $\boldsymbol{t} \boldsymbol{u}$ rismo rural viene a significar la vuelta a la tierra de las sociedades urbanas. Otros motivos que acercan la realidad de un turismo rural como una forma adicional o alternativa al turismo tradicional de sol y playa son, desde la perspectiva de Ortiz, A., (1996): (a) la crisis del turismo convencional que ocasiona la búsqueda de otras formas de turismo alternativo y, (b) la crisis de la agricultura por la que la Unión Europea establece unas pautas a seguir y que al final llega a la conclusión de que es una forma de reconducir y revitalizar los entornos rurales dentro de la Unión Europea y que tiene como medio al turismo rural, del que se vale el desarrollo local para efectuar una completa transformación de los espacios rurales, a medio y largo plazo. Es en esta línea que se desarrollan los programas: LEADER I, LEADER II, LEADER PLUS y PRO$D E R$ de la Unión Europea que tienen sus inicios en la década de los 90 y como techo el año 2006. Toda una revolución económica, social y cultural que está afectando positivamente, en diferentes niveles, a todos los países de la Unión Europea, incluida, por supuesto, Espańa.

\section{EL TURISMO RURAL Y LA ISLA DE GRAN CANARIA}

Es Gran Canaria la isla más poblada del Archipiélago contando con una población total cercana a los 857.702 habitantes, como ya hemos especificado, (ISTAC). La temporada turística abarca todo el año, siendo los meses de mayo, junio y julio los más flojos y los mejores diciembre, enero, febrero y marzo.

$\mathrm{Al}$ igual que en el resto del territorio nacional e insular español, la expansión de esta modalidad turística está ligada a esa corriente imparable, producto de 
una necesidad de las sociedades avanzadas de buscar otros entornos de descanso donde el turista del siglo XXI encuentre tranquilidad, quietud, encuentro con la naturaleza, conozca a los lugareños y se mezcle con ellos, descubra sus tradiciones y su cultura, visite los entornos arqueológicos y/o etnológicos, —se siente incluso con los "lugareños" a jugar una partida de dominó-, etc. Hoy, esta cultura rural, y todo el entorno rural, podríamos decir que está pasando por su propia época renacentista, algo así como su edad de oro. Se ha ido descubriendo que el turismo rural brinda unas soluciones posibles a algunos de los problemas asociados con la pérdida de oportunidades económicas y pérdida de población rural que perjudica, a su vez, a una agricultura que se difícilmente se sostiene" (Dashper, K., ed., 2014,p.1).

\section{EFECTOS CASI REVOLUCIONARIOS DE MODERNIZACIÓN RE- FLEJADOS EN UNO DE LOS SEIS MUNICIPIOS QUE ENTRA DEN- TRO DE ESTE ESTUDIO CON MIRAS A COMPATIBILIZAR TANTO EL TURISMO RURAL COMO EL TURISMO DE MASAS: IMPLANTA- CIÓN DE “UNA ZONA COMERCIAL ABIERTA” QUE HA AFECTADO, PARA BIEN, UN IMPORTANTE SECTOR GEOGRÁFICO CÉNTRICO EN EL MUNICIPIO DE TEJEDA}

Tras casi 20 ańos de un turismo rural en constante crecimiento en la isla de Gran Canaria y, de forma especial, en estos seis municipios seleccionados para llevar a cabo este estudio, nos hemos encontrado que, en el municipio de Tejeda, que, potenciado por su Corporación Municipal, con su Alcalde a la cabeza, y al tiempo que se desarrollaba su "Zona Comercial Abierta", se modificaron varios aspectos históricos de dicha zona céntrica de dicho municipio como el tráfico rodado a 17 barrios, el frondoso frente de árboles que le daba gran vistosidad a dichas zona, actualización del mobiliario urbano, etc., y que en los planes de dicha Corporación Municipal entraba también el de ampliar la oferta turística de turismo rural al también denominado turismo de masas, sin que los cambios a tales efectos dejasen de ser singularmente atractivos a ambas modalidades turísticas.

A estos efectos y tras las debidas y necesarias reuniones con los vecinos del pueblo que exigían mejoras en los servicios viales, visuales, culturales, sanitarios y de mejor acceso al casco de dicho urbano, se fue configurando una nueva fisonomía de dicho pueblo cumbrero que ha podido armonizar el goce y disfrute de sus conciudadanos al igual que el de los turistas amantes del turismo rural y que pueblan tanto el alto número de Casas Rurales al igual que un Parador Nacionaly un Hotel Rural, ambos ubicados en dicho Municipio, al tiempo que 
acogen un turismo de masas incipiente pero que ha ido in crescendo a medida que ha ido pasando el tiempo. Destacar el marcado interés de la Corporación Municipal de que a sus conciudadanos - una gran mayoría entrados ya en edad-, no les faltase los servicios necesarios, a todos los niveles, tanto de acceso fácil al pueblo y alrededores, sanitarios, religiosos, culturales, de transporte, medioambientales, etc.., no sin también tener en cuenta los sentimientos que todo cambio produce en cualquier ser humano, máxime cuando en este caso, en concreto, se trataba de una población muy enraizada en su pueblo, y en sus costumbres y tradiciones.

Es de justicia reconocer que los cambios producidos en dicho pueblo con la implantación de la "Zona Comercial Abierta" no fueron nada fáciles de digerir por parte de sus conciudadanos. Ello conllevó el que apareciese un nuevo Partido Político, producto del descontento inicial comprensible, pero, que, con el tiempo, ha dado lugar a que se acercasen posiciones en el seno de la Corporación Municipal al respecto de dichos cambios, que para muchos vecinos resultaban, al principio, inaceptables.

Dichos cambios conllevaron el hacer desaparecer un gran número de árboles, —varios de ellos centenarios- basándose la Corporación Municipal en que las raíces de dichos árboles se insertaban dentro de los sumideros de los restaurantes en el lado opuesto de dicha calle, reemplazándolos con otra decoración urbana, la re-dirección del tráfico rodado dentro del mismo municipio, etc.

\section{EL CASO DE LA ISLA DE GRAN CANARIA: UN ESTUDIO DE CASO PRÁCTICO}

En este siguiente apartado presentamos los resultados del pequeño trabajo de investigación con turistas, usuarios de la modalidad de turismo rural, llevado a cabo en los seis municipios de la isla, que representan un $11.43 \%$ de la población total de dicha isla que cuenta con 857.702 habitantes, (ISTAC, 2018).

\subsection{OBJETIVO GENERAL}

Estudiar las principales características que comporta el turista que es atraído hacia esta modalidad de turismo rural en la isla de Gran Canaria.

\subsection{OBJETIVOS ESPECÍFICOS}

1. Explicar las razones de por qué estos turistas han elegido esta modalidad de turismo rural, con qué grado de satisfacción se marchan y si volverían al mismo lugar en el futuro. 
2. Observar cómo eligen disfrutar su estancia en el campo, bien disfrutando de un merecido descanso, o disfrutando de la naturaleza y del clima, o mezclándose con los lugareños, o simplemente una combinación de estas tres alternativas.

3. Describir las características socio-económicas-educacionales que definen esta población turística que opta por el turismo rural.

\section{DISEÑO METODOLÓGICO DE LA INVESTIGACIÓN}

Hemos utilizado la metodología cuantitativa selectiva, (entrevista-cuestionario cerrado), con el fin de obtener de los turistas la máxima información acerca de sus vivencias en el consumo y disfrute del turismo rural. La metodología llevada a cabo ha sido la siguiente: todos fueron seleccionados al azar. A algunos los pudimos entrevistar en los mismos alojamientos rurales en los que estaban disfrutando de sus vacaciones; a otros los entrevistamos en diferentes lugares de cada pueblo como cafeterías, bar-restaurantes, haciendo la compra en el supermercado y, finalmente, a otros, los entrevistamos con ocasión de algunas celebraciones culturales-lúdicas a las que asistimos con este fin, previo consentimiento por parte de los turistas, que gustosos accedían a participar contestando al cuestionario de rigor.

\section{DISEÑO Y DESCRIPCIÓN DE LA MUESTRA}

ÁMBITO: La isla de Gran Canaria y dentro de ella los seis municipios que hemos considerado más representativos de la misma en esta modalidad de $\boldsymbol{t} \boldsymbol{u}$ rismo rural, tanto por sus aspectos naturales y paisajísticos como por los de interés socioeconómico, cultural, tradicional y recreativo con los que cuenta cada uno de estos Municipios, anteriormente mencionados.

UNIVERSO: Las ciento noventa y seis, (196), camas oficiales rurales de las que disponemos distribuidas entre los seis municipios, teniendo en cuenta las limitaciones en relación con la obtención de datos oficiales al respecto como ya hemos expuesto anteriormente. Decimos "oficiales" al tener que ver con aquellos alojamientos que han obtenido licencia para ofertar dichos alojamientos al turismo rural. Conjuntamente con esta oferta existe otra, no oficializada y sí altamente disponible al turismo rural acerca del que no existe ningún tipo de estadística. Es por eso que nuestro universo refleja muy conservadoramente una cifra de 196 camas correspondientes a los seis municipios, tremendamente 
baja, desde nuestros cálculos, comparada con la oferta no oficial que si bien cuenta con lujosos y cómodos alojamientos — aun sin contar con licenciacuentan con alto nivel de ocupación.

Tamaño de la muestra: setenta y cinco turistas, 75, elegidos al azar en los seis municipios.

Fecha del trabajo de campo: mes de febrero, 2020.

Análisis de los datos: mes de marzo, 2020.

Procesamiento de la información: tratamiento informático con el paquete estadístico SPSS.

10. ANÁLISIS E INTERPRETACIÓN DE LOS DATOS CUANTITATIVOS

10.1. PERFIL DE LOS TURISTAS QUE ELIGEN LA MODALIDAD DEL TURISMO RURAL COMO FORMA DE DISFRUTAR SUS VACACIONES Y DÍAS DE DESCANSO

Tabla 1. Distribución por municipios seleccionados

\begin{tabular}{|c|c|c|c|c|}
\hline \multicolumn{2}{|c|}{ Municipios } & Frecuencia & Porcentaje & $\begin{array}{c}\text { Porcentaje } \\
\text { válido }\end{array}$ \\
\hline \multirow{7}{*}{ Válidos } & Agüimes & 11 & 14.6 & 14.6 \\
\hline & Ingenio & 9 & 12.0 & 12.0 \\
\hline & Sta. Brígida & 14 & 18.6 & 18.6 \\
\hline & $\begin{array}{c}\text { Vega de San } \\
\text { Mateo }\end{array}$ & 11 & 14.6 & 14.6 \\
\hline & Tejeda & 19 & 25.3 & 25.3 \\
\hline & Valsequillo & 11 & 14.3 & 14.3 \\
\hline & Total & 75 & 100 & 100 \\
\hline
\end{tabular}

Fuente: Encuesta a turistas, usuarios del turismo rural en estos municipios: mes de marzo, 2020. Elaboración propia 
Observamos en la tabla 1 la distribución, por municipio, de la muestra seleccionada de turistas y vemos cómo destacan, en proporción a la totalidad de la muestra, los municipios de Agüimes, (14.6\%); Santa Brígida (18.6\%) y Tejeda (25.3\%) del total encuestado. Ello responde, en este caso no solo al proceso de desarrollo del turismo rural que, de mano del desarrollo local, propiciado por los programas de inversiones de la LEADER I y II y PRODER - Programas de la Unión Europea) — cada uno de estos Ayuntamientos ha venido llevando a cabo, a diferente ritmo, desde la década de los años 90.

Tabla 2. Distribución de la población turística en los seis municipios de turismo rural por sexo

\begin{tabular}{|c|c|c|c|c|}
\hline \multicolumn{2}{|c|}{ Composición por sexo } & Frecuencia & Porcentaje & $\begin{array}{c}\text { Porcentaje } \\
\text { válido }\end{array}$ \\
\hline \multirow{4}{*}{ Válidos } & Hombre & 38 & 50.6 & 50.6 \\
\cline { 2 - 5 } & Mujer & 37 & 49.3 & 49.3 \\
\cline { 2 - 5 } & Total & 75 & 100 & 100 \\
\hline
\end{tabular}

Fuente: Encuesta a turistas, usuarios del turismo rural en estos municipios: mes de marzo, 2020. Elaboración propia

En la tabla 2 podemos observar que, del total de la muestra de los 75 turistas, el $50.6 \%$ son hombres y el $49.3 \%$ mujeres. 
Principales tendencias del desarrollo turístico rural en la región canaria: un estudio de casos en ...

Tabla 3. Distribución de la muestra de turistas por edad

\begin{tabular}{|c|c|c|c|c|}
\hline \multicolumn{2}{|c|}{ Distribución por edad } & Frecuencia & Porcentaje & $\begin{array}{c}\text { Porcentaje } \\
\text { válido }\end{array}$ \\
\hline \multirow{6}{*}{ Válidos } & Entre 10-20 & 8 & 10.6 & 10.6 \\
\hline & Entre 21-30 & 17 & 22.6 & 22.6 \\
\hline & Entre 31-40 & 20 & 26.6 & 26.6 \\
\hline & Entre 41-50 & 22 & 28.0 & 28.0 \\
\hline & Entre 51-60 & 9 & 12.0 & 12.0 \\
\hline & Total & 75 & 100 & 100 \\
\hline
\end{tabular}

Fuente: Encuesta a turistas, usuarios del turismo rural en estos municipios: mes de marzo, 2020. Elaboración propia

En cuanto a la distribución por edad de los turistas estudiados, vemos en la tabla 3 cómo la gran mayoría de estos visitantes ronda las edades entre los 21 y los 60 años de edad, siendo la edad entre los 41 y los 50 ańos de edad el porcentaje mayor de reservas en los seis municipios.

Tabla 4. Distribución de la muestra de turistas por nivel académico

\begin{tabular}{|c|c|c|c|c|}
\hline \multicolumn{2}{|c|}{$\begin{array}{c}\text { Distribución de la muestra de turistas } \\
\text { por nivel académico }\end{array}$} & Frecuencia & Porcentaje & $\begin{array}{l}\text { Porcentaje } \\
\text { válido }\end{array}$ \\
\hline \multirow{4}{*}{ Válidos } & Educación Primaria & 25 & 33.3 & 33.3 \\
\hline & $\begin{array}{c}\text { Educación Secundaria } \\
\text { y Formación } \\
\text { Profesional }\end{array}$ & 22 & 29.3 & 29.3 \\
\hline & Universidad & 28 & 37.3 & 37.3 \\
\hline & Total & 75 & 100 & 100 \\
\hline
\end{tabular}

Fuente: Encuesta a turistas, usuarios del turismo rural en estos municipios: mes de marzo, 2020. Elaboración propia. 


\section{Ángela García Cabrera}

Basándonos en la observación de la tabla 4 que muestra la distribución de turistas por nivel académico, vemos cómo el 37.3\% cuenta con estudios Universitarios, el 29.3\% con Educación Secundaria y Formación Profesional y el $33.3 \%$ con Educación Primaria.

Tabla 5. Distribución de la muestra por lugar de trabajo

\begin{tabular}{|c|c|c|c|c|}
\hline \multicolumn{2}{|c|}{$\begin{array}{c}\text { Distribución muestra por } \\
\text { Lugar de trabajo }\end{array}$} & Frecuencia & Porcentaje & $\begin{array}{c}\text { Porcentaje } \\
\text { válido }\end{array}$ \\
\hline \multirow{7}{*}{ Válidos } & $\begin{array}{c}\text { Administración } \\
\text { Pública }\end{array}$ & 25 & 33.3 & 33.3 \\
\cline { 2 - 5 } & $\begin{array}{c}\text { Empresa } \\
\text { privada }\end{array}$ & 26 & 34.6 & 34.6 \\
\cline { 2 - 5 } & Autónomos & 11 & 14.6 & 14.6 \\
\cline { 2 - 5 } & Otros & 13 & 17.3 & 17.3 \\
\cline { 2 - 5 } & Total & 75 & 100 & 100 \\
\hline
\end{tabular}

Fuente: Encuesta a turistas, usuarios del turismo rural en estos municipios: mes de marzo, 2020. Elaboración propia.

En la tabla 5 podemos observar que en relación con el lugar de trabajo la gran mayoría, el 34.6\%, dice trabajar en la empresa privada, seguidos por los que trabajan en la Administración Pública con un 33.3\%, seguidos, a considerable distancia, por los que afirman trabajar como autónomos con un $14.6 \%$, finalizando con un $17.3 \%$ que contestan "otros", o jubilados. 
Principales tendencias del desarrollo turístico rural en la región canaria: un estudio de casos en ...

Tabla 6. Distribución de la muestra de turistas por lugar de procedencia

\begin{tabular}{|c|c|c|c|c|}
\hline \multicolumn{2}{|c|}{$\begin{array}{l}\text { Distribución de la muestra de } \\
\text { turistas por lugar de procedencia }\end{array}$} & Frecuencia & Porcentaje & $\begin{array}{l}\text { Porcentaje } \\
\text { válido }\end{array}$ \\
\hline \multirow{7}{*}{ Válidos } & Alemania & 17 & 22.6 & 22.66 \\
\hline & Holanda & 8 & 10.6 & 10.6 \\
\hline & $\begin{array}{c}\text { Paises } \\
\text { Escandinavos }\end{array}$ & 13 & 17.3 & 17.3 \\
\hline & Inglaterra & 18 & 24.0 & 24.0 \\
\hline & Otras CC.AA. & 9 & 13.3 & 13.3 \\
\hline & $\begin{array}{l}\text { Comunidad } \\
\text { Canaria }\end{array}$ & 10 & 13.3 & 13.3 \\
\hline & Total & 75 & 100 & 100 \\
\hline
\end{tabular}

Fuente: Encuesta a turistas, usuarios del turismo rural en estos municipios: mes de marzo, 2020. Elaboración propia.

En cuanto a la distribución de turistas por lugar de procedencia observamos curiosamente en la tabla 6 , que la mayoría de turistas proceden de Alemania con un 22.6\%, seguidos por los ingleses, con el 24.0\%. En tercer lugar, los $\mathrm{Pa}-$ íses Escandinavos con un 17,3\%, en cuarto lugar, la Comunidad Canaria con un $13.3 \%$, en quinto lugar, con el $13.3 \%$, otras CC. AA. en sexto y séptimo y último lugar, con el $10.6 \%$ los turistas procedentes de Holanda. 
Tabla 7. Distribución de la muestra por fuentes de información utilizadas para obtener destino

\begin{tabular}{|c|c|c|c|c|}
\hline \multicolumn{1}{|c|}{$\begin{array}{c}\text { Distribución muestra por fuentes de } \\
\text { información para obtener destino }\end{array}$} & Frecuencia & Porcentaje & $\begin{array}{c}\text { Porcentaje } \\
\text { válido }\end{array}$ \\
\hline \multirow{7}{*}{ Válidos } & $\begin{array}{c}\text { Patronato Turismo } \\
\text { de Gran Canaria }\end{array}$ & 15 & 20.0 & 20.0 \\
\cline { 2 - 5 } & Internet & 40 & 53.3 & 53.3 \\
\cline { 2 - 5 } & Amigos & 20 & 26.6 & 26.6 \\
\cline { 2 - 5 } & Total & 75 & 100,0 & 100,0 \\
\hline
\end{tabular}

Fuente: Encuesta a turistas, usuarios del turismo rural en estos municipios: mes de marzo, 2020. Elaboración propia.

En relación con la distribución de la muestra por fuentes de información utilizadas para obtener destino en un lugar de turismo rural, vemos cómo la tabla 7 nos muestra que la gran mayoría usa Internet como la forma más eficaz para obtener destino turístico con un 53.3\%, seguido por los amigos, o " $\mathrm{el}$ boca a boca", con un 26.6\%, mientas que el $20.0 \%$ lo han hecho a través del Patronato de Turismo de Gran Canaria. 
Principales tendencias del desarrollo turístico rural en la región canaria: un estudio de casos en ...

Tabla 8. Distribución por número de veces que han elegido el municipio para Turismo Rural

\begin{tabular}{|c|c|c|c|c|}
\hline \multicolumn{1}{|c|}{$\begin{array}{c}\text { Distribución por veces que han } \\
\text { elegido el municipio para } \\
\text { turismo rural }\end{array}$} & Frecuencia & Porcentaje & $\begin{array}{c}\text { Porcentaje } \\
\text { válido }\end{array}$ \\
\hline \multirow{4}{*}{\begin{tabular}{l} 
Es la primera vez \\
\cline { 2 - 5 }
\end{tabular}} & La segunda & 13 & 17.3 & 18.6 \\
\cline { 2 - 5 } & La tercera & 20 & 26.6 & 26.6 \\
\cline { 2 - 5 } & La cuarta & 19 & 25.3 & 25.3 \\
\cline { 2 - 5 } & Más de cuatro veces & 9 & 12.0 & 12.0 \\
\cline { 2 - 5 } & Total & 75 & 100 & 100 \\
\cline { 2 - 5 } & & & & \\
\hline
\end{tabular}

Fuente: Encuesta a turistas, usuarios del turismo rural en estos municipios: mes de marzo, 2020. Elaboración propia.

Observamos en la tabla 8 , que el $25.3 \%$ de estos turistas han repetido destino por cuarta vez; por tercera vez el $26.6 \%$; por segunda vez un $17.3 \%$; más de cuatro veces ha repetido el $12.0 \%$, y han llegado, por primer a vez, un $18.6 \%$ de los casos. 
Tabla 9. Distribución de la muestra de turistas por estación del año preferida por el turismo rural

\begin{tabular}{|c|c|c|c|c|}
\hline \multicolumn{2}{|c|}{$\begin{array}{c}\text { Distribución de la muestra por } \\
\text { estación del año preferida por el } \\
\text { turismo rural }\end{array}$} & \multirow{2}{*}{$\begin{array}{c}\text { Frecuencia } \\
25\end{array}$} & \multirow{2}{*}{$\begin{array}{c}\text { Porcentaje } \\
33.3\end{array}$} & \multirow{2}{*}{$\begin{array}{c}\text { Porcentaje } \\
\text { válido } \\
33.3\end{array}$} \\
\hline \multirow{7}{*}{ Válidos } & invierno & & & \\
\hline & primavera & 20 & 26.6 & 26.6 \\
\hline & verano & 9 & 12.0 & 12.0 \\
\hline & Otoño & 12 & 16.0 & 16.0 \\
\hline & $\begin{array}{l}\text { La estación no } \\
\text { importa }\end{array}$ & 2 & 2.6 & 2.6 \\
\hline & $\begin{array}{c}\text { Durante las fiestas } \\
\text { locales }\end{array}$ & 7 & 9.3 & 9.3 \\
\hline & Total & 75 & 100 & 100 \\
\hline
\end{tabular}

Fuente: Encuesta a turistas, usuarios del turismo rural en estos municipios: mes de marzo, 2020. Elaboración propia.

En esta Tabla 9 observamos que la estación del invierno es la preferida para el $33.3 \%$ de los turistas, seguida por los que eligen venir en primavera con un $26.6 \%$. Un $16.0 \%$ prefiere el otońo, mientras que un $12.0 \%$ elige el verano que normalmente coincide con que la gran mayoría en esta categoría procede del territorio peninsular e insular español. El 2.6\% restante afirma que la estación del año no le importa. 
Principales tendencias del desarrollo turístico rural en la región canaria: un estudio de casos en ...

Tabla 10. Distribución de la muestra por razones de contacto con la naturaleza

\begin{tabular}{|c|c|c|c|c|}
\hline $\begin{array}{c}\text { Distribución de la muestra por razones de } \\
\text { contacto con la naturaleza }\end{array}$ & Frecuencia & Porcentaje & $\begin{array}{c}\text { Porcentaje } \\
\text { válido }\end{array}$ \\
\hline \multirow{4}{*}{ Válidos } & Tranquilidad y reposo & 27 & 36.0 & 36.0 \\
\cline { 2 - 5 } & Clima y paisaje & 25 & 33.3 & 33.3 \\
\cline { 2 - 5 } & $\begin{array}{c}\text { Contacto con la } \\
\text { naturaleza }\end{array}$ & 23 & 30.6 & 30.6 \\
\cline { 2 - 5 } & Total & 75 & 100 & 100 \\
\hline
\end{tabular}

Fuente: Encuesta a turistas, usuarios del turismo rural en estos municipios: mes de marzo, 2020. Elaboración propia.

En la tabla 10 observamos que la tranquilidad y el reposo es el motivo principal para el $36.0 \%$ de los turistas que visitan estos seis municipios, seguido por el $33.3 \%$ de los que vienen motivados, primordialmente por su clima $y$ paisaje. El Contacto con la Naturaleza, con un $30.6 \%$ es otro de los motivos principales que los turistas expresan para disfrutar sus vacaciones en estos municipios.

Tabla 11. Distribución de la muestra por razones de tipo cultural, tradiciones y costumbres

\begin{tabular}{|c|c|c|c|c|}
\hline \multicolumn{1}{|c|}{$\begin{array}{c}\text { Distribución de la muestra por razones de } \\
\text { tipo cultural, tradiciones y costumbres. }\end{array}$} & Frecuencia & Porcentaje & $\begin{array}{c}\text { Porcentaje } \\
\text { válido }\end{array}$ \\
\hline \multirow{5}{*}{ Válidos } & Lugares aborigenes & 10 & 13.3 & 13.3 \\
\cline { 2 - 5 } & Folklore & 12 & 16.0 & 16.0 \\
\cline { 2 - 5 } & Costumbres tradiciones & 32 & 42.6 & 42.6 \\
\cline { 2 - 5 } & Hospitalidad de la gente & 21 & 28.0 & 28.0 \\
\cline { 2 - 5 } & Total & 75 & 100 & 100 \\
\hline
\end{tabular}

Fuente: Encuesta a turistas, usuarios del turismo rural en estos municipios: mes de marzo, 2020. Elaboración propia. 
Observamos en la tabla 11 que la mayoría de la muestra de turistas dicen interesarles las "costumbres y tradiciones" del Municipio con un $42.6 \%$, seguido, a distancia, por los que con un $28.0 \%$ les encanta la "hospitalidad de la gente". Al 16.6\% les atrae el "folklore" y solo a un 10.6\% le interesa el conocer los "lugres aborigenes".

Tabla 12. Distribución muestra por razones de:

"tipo familiar y de amigos", y de "vuelta al municipio de origen"

\begin{tabular}{|c|c|c|c|c|}
\hline $\begin{array}{c}\text { Distribución de la muestra por razones de: } \\
\text { "tipo familiary de amigos" } y \text { "vuelta al } \\
\text { municipio de origen. }\end{array}$ & Frecuencia & Porcentaje & $\begin{array}{c}\text { Porcentaje } \\
\text { válido }\end{array}$ \\
\hline \multirow{4}{*}{ Válidos } & Familia y de amigos & 58 & 77.3 & 77.3 \\
\cline { 2 - 5 } & Vuelta al municipio de origen & 17 & 22.6 & 22.6 \\
\cline { 2 - 5 } & Total & 75 & 100 & 100 \\
\hline
\end{tabular}

Fuente: Encuesta a turistas, usuarios del turismo rural en estos municipios: mes de marzo, 2020. Elaboración propia.

La tabla 12 exhibe con toda contundencia que el 77.3\% de los turistas tienen motivaciones para ir al municipio que entra dentro de las catalogadas como de "tipo familiar y de amigos", seguida por la respuesta del resto de los encuestados, el $22.6 \%$ que afirman elegir el turismo rural, porque vuelven encantados a su "municipio de origen".

Tabla 13. Percepción de nivel de aceptación por los lugareños que siente la muestra de turistas

\begin{tabular}{|c|c|c|c|c|}
\hline \multicolumn{2}{|c|}{$\begin{array}{c}\text { Percepción de nivel de aceptación por los } \\
\text { lugareños que siente la muestra de turistas }\end{array}$} & Frecuencia & Porcentaje & Porcentaje válido \\
\hline Válidos & $\begin{array}{c}\text { Se sienten bien recibidos } \\
\text { por la gente del } \\
\text { municipio }\end{array}$ & 75 & 100 & 100 \\
\hline
\end{tabular}

Fuente: Encuesta a turistas, usuarios del turismo rural en estos municipios: mes de marzo, 2020. Elaboración propia. 
Principales tendencias del desarrollo turístico rural en la región canaria: un estudio de casos en ...

Observamos en la tabla 13 la total unanimidad de la muestra de turistas en afirmar en un $100 \%$ de los casos que se sienten bien recibidos por los lugareńos.

Tabla 14. Distribución de la muestra por nivel de participación en actividades festivas y culturales del municipio

\begin{tabular}{|c|c|c|c|c|}
\hline \multicolumn{2}{|c|}{$\begin{array}{c}\text { Distribución de la muestra por nivel de } \\
\text { participación en actividades festivasy } \\
\text { culturales del municipio }\end{array}$} & Frecuencia & Porcentaje & $\begin{array}{c}\text { Porcentaje } \\
\text { válido }\end{array}$ \\
\hline \multirow{4}{*}{ Válidos } & Si participa & 58 & 77.3 & 77.3 \\
\cline { 2 - 5 } & No participa & 17 & 22.6 & 22.6 \\
\cline { 2 - 5 } & Total & 75 & 100 & 100 \\
\hline
\end{tabular}

Fuente: Encuesta a turistas, usuarios del turismo rural en estos municipios: mes de marzo, 2020. Elaboración propia.

En esta tabla 14 podemos observar que un alto porcentaje de la muestra, que un $80 \%$ afirma que "si participa" en actividades culturales del municipio en contraposición con el $20 \%$ que dice "no participar" en las mismas.

Tabla 15. Distribución de la muestra por nivel de satisfacción experiencia vivida en el entorno rural

\begin{tabular}{|c|c|c|c|c|}
\hline $\begin{array}{c}\text { Distribución de la muestra por nivel de } \\
\text { satisfacción experiencia vivida en el } \\
\text { entorno rural }\end{array}$ & Frecuencia & Porcentaje & $\begin{array}{c}\text { Porcentaje } \\
\text { válido }\end{array}$ \\
\hline \multirow{4}{*}{ Válidos } & Muy alta & 48 & 64.0 & 64.0 \\
\cline { 2 - 5 } & Alta & 27 & 36.0 & 36.0 \\
\cline { 2 - 5 } & Total & 75 & 100 & 100 \\
\hline
\end{tabular}

Fuente: Encuesta a turistas, usuarios del turismo rural en estos municipios: mes de marzo, 2020. Elaboración propia. 
Tal como observamos en esta tabla No. 15, el nivel de satisfacción de la muestra queda reflejado al observar que el $64.0 \%$ de los turistas dicen sentir un nivel de satisfacción muy alto al finalizar su tiempo vacacional haciendo turismo rural en el campo, al tiempo que el resto, el 36.0\%, afirma que su nivel de satisfacción es alto.

Tabla 16. Distribución de la muestra por intención de volver a hacer turismo rural en el mismo Municipio en futuras ocasiones que se presenten.

\begin{tabular}{|c|c|c|c|c|}
\hline \multicolumn{2}{|l|}{$\begin{array}{l}\text { Distribución de la muestra por intención } \\
\text { de volver a hacer turismo rural en el } \\
\text { mismo municipio }\end{array}$} & Frecuencia & Porcentaje & $\begin{array}{c}\text { Porcentaje } \\
\text { válido }\end{array}$ \\
\hline Válidos & Muy alta & 75 & 100,0 & 100,0 \\
\hline
\end{tabular}

Fuente: Encuesta a turistas, usuarios del turismo rural en estos municipios: mes de marzo, 2020. Elaboración propia.

Y, finalmente, observando la tabla 16, o la última pregunta formulada a los turistas encuestados constatamos que contestan con un $100 \%$ de positividad que su intención es volver al mismo municipio a hacer turismo rural en futuras ocasiones que se presenten.

\section{CONCLUSIONES}

Son muchas las consideraciones, en tono de reflexión que se podrían hacer a raíz de este modesto trabajo de investigación. A continuación, exponemos algunas de ellas, a modo de conclusión.

1. Efectivamente, la hipótesis de este estudio se confirma: los turistas, usuarios del turismo rural en los municipios de Gran Canaria de Agüimes, Ingenio, Santa Brígida, Vega de San Mateo, Valsequillo y Tejeda no son en absoluto pasivos. Manifiestan sus deseos, interaccionan bastante con los "lugareńos" y se sienten muy libres de expresar lo que sienten acerca del entorno rural donde han pasado un periodo vacacional. Los resultados de esta investigación así lo atestiguan.

2. La razón de por qué elegimos llevar a cabo este estudio en los seis municipios grancanarios arriba mencionados es porque, desde nuestra perspectiva, son estos entornos los que más interés despiertan cara al turismo rural, y porque por sus características naturales, de clima, de paisajes, de idiosincrasia y de factores socio-económicos y culturales son los que mejor repre- 
Principales tendencias del desarrollo turístico rural en la región canaria: un estudio de casos en ...

sentan los valores que trata de potenciar la filosofía desarrollada por la Unión Europea alrededor del desarrollo local y del turismo rural. Estos factores han sido la base de nuestro estudio cuyos objetivos así los presupone.

3. Contestando al primer objetivo específico de este estudio, decir que los turistas en él representados eligieron estos respectivos municipios exactamente por estas características. La solera y atractiva personalidad de estos pueblos que con ayudas económicas de la Unión Europea, en conjunción con la gestión llevada a cabo por las respectivas autoridades autonómicas, insulares y locales, están contribuyendo a que surjan con mayor esplendor y sigan atrayendo, de forma lenta pero segura, un turismo rural cada vez más visible en nuestros campos grancanarios.

4. El perfil socio-económico de este turista que estamos recibiendo en nuestros campos grancanarios responde a las siguientes características, tal como las vemos reflejadas en las tablas 2, 3 y 4 del estudio. En un $50.6 \%$ son hombres y en un $49.4 \%$ mujeres entre las edades de 20 y 60 años de edad. Cuentan, en un $37.3 \%$ con estudios universitarios, un $29.3 \%$ con estudios secundarios y de formación profesional y en un 33.3\% con estudios primarios. Trabajan, mayoritariamente en la empresa privada y proceden, en este orden de concurrencia de los siguientes lugares de origen: (a) Comunidad Canaria en un $13.3 \%$ de los casos; (b) otras Comunidades Autónomas en un 12.0\%; (c) alemanes, en un 22.6\%; (d) holandeses en un 10.6\%; (d) ingleses en un $24.0 \%$ de los casos, y finalmente, (e) los países escandinavos en un $17.3 \%$. Estos datos están reflejados en la tabla 6 .

5. Tal como se comenta en el apartado anterior, los datos demuestran que el turismo rural se está surtiendo, de los turistas provenientes de nuestras comunidades autónomas, y luego de alemanes, holandeses, ingleses y escandinavos, primordialmente. Ello explica el por qué en un total conjunto de un $9.3 \%$ expresen su interés en venir durante las fiestas locales y en no importarles la estación del año para venir, como se ve en la tabla 9. Eso sí, para la mayoría del resto de los turistas que estarían formados por alemanes, holandeses, ingleses y nórdicos en un 33.3\% de los casos, como se ve en la misma tabla, éstos eligen la estación del invierno como la más propicia para ellos, dadas las bajas temperaturas en sus respectivos lugares de origen durante ese mismo periodo de tiempo invernal.

6. En relación con otro de los objetivos del estudio, comentar que estos turistas descubrieron sus respectivos lugares de turismo rural donde han pasado unas vacaciones placenteras, a través de amigos, en un $26.6 \%$ y a través de Internet en un $53.3 \%$, como vemos en la tabla 7 . Vemos también en la 
tabla 8 cómo ya tenemos un alto porcentaje de turistas, un $26.6 \%$, que han venido ya por tercera y un $25.3 \%$ por cuarta vez. A juzgar por lo que manifiestan en la tabla 15, 64.0\% expresa que es muy alta, el 36.0\% de la muestra, relacionada con la experiencia vivida durante su período vacacional en estos entornos, dice que es alta.

7. El estudio también refleja el alto nivel de aceptación de los turistas por parte de los lugareńos, que llega, como vemos en la tabla 13, a un 100\% de los casos. En todas las entrevistas mantenidas con las autoridades municipales, previa administración del cuestionario cerrado a los turistas, nos comentaban, con gran satisfacción por su parte, acerca del alto grado de aceptación con el que veían que los lugareños recibían a los turistas. Hasta tal nivel es esto una realidad que en un caso concreto nos comentaban cómo, al caer la tarde, los turistas holandeses que estaban en ese momento en ese municipio concreto pasando sus vacaciones, se iban al bar del pueblo a reunirse con un grupo de señores del pueblo de toda la vida, a quienes les encanta echarse su partidita de dominó para reunirse con ellos y así jugarlo juntos, al margen de que el español de los holandeses fuese más o menos entendible. La tabla 11 también muestra un dato muy importante relacionado con el objetivo $n^{\circ} 1$ del estudio y es que, entre las razones que los turistas expresan como motivación en la selección de los respectivos municipios, el de la hospitalidad de la gente eleva la respuesta positiva de los turistas hasta un $28.0 \%$ de los casos. En esta misma tabla 11 hay otro dato digno de mención y es que los turistas también se han visto atraídos, además de por la hospitalidad de la gente, por las costumbres tradicionales hasta en un $42.6 \%$ de los casos.

8. Abundando en lo dicho en el apartado anterior, comentar como, a pesar de que efectivamente el tipo de turista que elige la modalidad de turismo rural lo hace, en gran medida, porque valora los aspectos de tranquilidady reposo en un $36.0 \%$ de los casos, tal como vemos en la tabla 10, también valora el contacto con la naturaleza, en un $30.6 \%$ y el clima y paisaje en un $33.3 \%$. Pero que no es menos verdad que también les encanta participar en las actividades culturales y otras del municipio, como así lo expresa el $77.3 \%$, como lo muestra la tabla 14 .

9. No menos importante es el dato que nos dan los turistas en la última de las preguntas que les formulamos, reflejada en la tabla 16 y que tiene que ver con la intención de volver al mismo lugar a disfrutar otras vacaciones o días de descanso. Esto lo han contestado todos afirmativamente al 100\%. Sin duda, este dato servirá de gran estímulo a las autoridades municipales de todos y cada uno de los seis municipios, pues deja claro que lo que hasta 
ahora han venido realizando en sus respectivas municipalidades en relación con la población turística que se aloja en ellas, lo han venido haciendo bien.

10. Creemos que cara al futuro, todo lo que tenga que ver con la potenciación de los enclaves culturales, tradicionales, recreativos y paisajísticos del municipio al igual que con la dinamización de sus aspectos económicos vía potenciación de su artesanía autóctona, folklore, etc., redundará en bienestar para el mismo pueblo contribuyendo así a su sostenibilidad al estarse conjugando los dos factores claves de las inversiones de la Unión Europea, esto es: el desarrollo local y el turismo rural.

11. Todo ello redundará en un creciente aumento del turismo rural, ya que a juzgar por los datos contundentes de este modesto estudio, todo apunta a que los turistas que han experimentado ya sus vivencias con el turismo rural en Gran Canaria, vuelvan a probar de nuevo.

\section{REFERENCIAS BIBLIOGRÁFICAS}

Bigné, J. E. et al. (1995). Las Agencias de Viaje: factores de Calidad e Implicaciones de Marketing. En: Actas Economía de los Servicios: $V$ Congreso $\mathrm{Na}$ cional de Economía. Las Palmas de Gran Canaria: Pérez Galdós.

Castellano y Macías, F. J. (1993). Historia de Canarias. Las Palmas de Gran Canaria: Centro Insular de la Cultura Canaria.

Dashper, K., Ed. (2014). Rural Tourism. An International Perspective. Cambridge Scholars Publishing.

Garcia Cabrera, A. y Valencia Moreno, C. (2001). Tendencias del turismo: formación y participación en la Región Canaria. En: Formación para la Participación Ciudadana: Las Organizaciones en el Siglo XXI: Lucas Marin, A., y Garcia Cabrera, A., (2001). Grupo Editorial Humanitas, Buenos Aires.

Gulcan, Y., Kustepeli, Y. y Akgungor, S. (2009) Public policies and development of the tourism industry in the Aegean region. European Planning Studies. 17(10: 1509-1523).

Herrera Piqué, A. (1978). La Ciudad de Las Palmas: Noticias Históricas de su Urbanización. Las Palmas de Gran Canaria: Romero. ISTAC (Instituto Canario de Estadística) (1995-2000). Estadísticas de la Comunidad Autónoma de Canarias. Las Palmas de Gran Canaria: Gobierno de Canarias.

Macbeth, J., Carson, D. y Northcote, J. (2004). Social capital, tourism and regional development: SPCC as a basis for innovation and sustainability. $\mathrm{Cu}$ rrent Issues in Tourism. 7(6): 502-522

Martinez Quintana, V. (2017). El Turismo de Naturaleza: Un producto turistico sostenible. En: ARBOR Ciencia, Pensamiento y Cultura. Vol. 193-785, 
julio-septiembre 2017, a396 I ISSN-L: 0210-1963 doi:

http//dx.doi.org/10.3989/arbor. 2017. 785n3002

Martinez-Quintana, V.; Sanagustin-Fons, M. V. y Blanco Gregory, R. (2018).

Paisajes culturales como imágenes de destino: percepción y valoración como producto turístico. En PASOS: Revista de Turismo y Patrimonio Cultural. ISSN 1695-7121.

Martinez-Quintana, V.; Sanagustin-Fons, M. V. y Blanco Gregory (2019). R. Chapter 3: Holy Grail Route: A Sociological Analysis of the Spiritual and Religious Tourist Route. DOI: 10.4018/978-1-5225-5730-2.ch003.

Ortiz, A. (1996). Orientaciones para un desarrollo turistico sostenible con base en el turismo rural Tesis doctoral. Universidad de Las Palmas de Gran Canaria: Master Internacional de Turismo.

Page, S. J. y Getz, D. (1997). The business of rural tourism: International perspectives. Boston: Thompson Business Press. La Provincia (1995). Apartado de Turismo. 24 de noviembre.

S. G. C. (2002). Turismo rural: un turismo diferente. Anarda, 45, 11-12 Sharpley, R, y Telfer, D. J. (2002). Tourism and Development: Concepts and Issues. Australia: Footprint Books.

Slocum, S. L y Kline, C., Edtors. (2017). Linking Urban \& Rural Tourism: Strategies in Sustainability. Virginia, USA.

\section{RECENSIÓN}

Martinez Quintana, V. ReCENsión (2018): Zygmunt Baumna y Leonidas Donskis: Ceguera moral. Las pérdidas de sensibilidad en la modernidad liquida; ed. Paidos, Barcelona, 2a impresión 2016, ISBN: 978-84-493-31039. En: Tendencias Sociales. Revista de Sociología, 2. (2018): 177-180. 


\title{
LA CREATIVIDAD Y SU COMPRENSIÓN
}

\author{
Luis Alberto García García \\ Universidad de La Laguna \\ José Juan Castro Sánchez \\ Universidad de Las Palmas de Gran Canaria
}

\begin{abstract}
Resumen
En este artículo se define en primer lugar el concepto de creatividad a través de las definiciones propuestas por los principales autores que se han acercado al tema. Para clarificar mejor su alcance la diferenciamos, a continuación, de otros términos con los que habitualmente la confunden. Más adelante hacemos un análisis de las creencias más comunes que se suelen tener a la hora de pensar sobre la creatividad. A continuación describimos una serie de indicadores frecuentemente utilizados para valorar un producto o idea como creativa. Y finalizamos con una revisión de las diferentes maneras de medir la creatividad.
\end{abstract}

Palabras clave: Creatividad, mitos, indicadores, evaluación.

\begin{abstract}
In this article, the concept of creativity is defined in the first place through the definitions proposed by the main authors who have approached the subject. To better clarify its scope, we differentiate it below from other terms with which it is commonly confused. Later we will analyze the most common beliefs that are usually held when thinking about creativity. Below we describe a series of indicators frequently used to assess a product or idea as creative. And we end with a review of the different ways to measure creativity.
\end{abstract}

Keywords: Creativity, growth, indicators, evaluation.

\section{INTRODUCCIÓN}

Un primer reto que nos planteamos como autores es tratar de responder a la primera pregunta que nos formulamos cuando nos encontramos con algo nuevo o del cual sabemos poco, ¿qué es esto? Por tal motivo, intentaremos definir la creatividad, un concepto que muchas veces se nos escapa de las manos y ha sido escurridizo durante mucho tiempo.

Para ello, empezaremos abordando las definiciones propuestas por los que consideramos son los principales teóricos de la creatividad, encontrando sus 
puntos de coincidencia. Muchas veces es más sencillo definir algo por lo que no es, de este modo comentamos aquellos conceptos que habitualmente se asocian a la creatividad pero se diferencian de ella. Por otro lado, se expondrán diversos mitos que se han ido construyendo alrededor del concepto de creatividad para, posteriormente, irlos desmontando con argumentos sólidos.

Afortunadamente, la creatividad no es una simple entelequia mental de la cual nos queda únicamente filosofar, es una realidad tangible y vivida, y para ser reconocida como tal, proponemos una serie de indicadores frecuentemente utilizados para valorar un producto o idea como creativa. Del mismo modo, la aportación de la psicología a la sociedad en temas de diagnóstico se hace tangible a través de los tests psicológicos, por ello, finalizamos con una revisión de los mismos referidas a la creatividad.

Es nuestro interés que al concluir este capítulo la creatividad sea vista como un concepto más claro, reconociendo los esfuerzos teóricos realizados hasta el momento.

\section{APROXIMACIONES AL CONCEPTO}

Según la Real Academia de la Lengua Española, aproximar "es obtener un resultado tan cercano al exacto como sea necesario para un propósito determinado". Es posible que con el título "Aproximaciones al concepto" no cubramos tus expectativas como lector; sin embargo, la situación actual del estudio de la creatividad es reciente y nos deja abierta la posibilidad de seguir debatiendo, enriqueciendo y creando acerca de la creatividad.

Muchos autores e historiadores de la psicología coinciden en considerar el discurso de J. P. Guilford en la Conferencia de la American Psychological Association (APA) en 1950 como el inicio del interés por el estudio e investigación de la creatividad. Su discurso, conocido como el Manifiesto de la Creatividad, gira en torno al lanzamiento del satélite soviético Sputnik, un ejemplo de la pérdida de ventaja tecnológica estadounidense frente a la soviética. Guilford sostiene que ello tiene su raíz en la falta de interés por la creatividad dentro del sistema educativo estadounidense. Siendo por tanto, la creatividad una cuestión de urgencia nacional

Desde entonces y hasta la fecha existe multiplicidad de definiciones sobre la creatividad, de la que más adelante encontraremos sus puntos de coincidencia. Sin embargo, para algunos pocos (afortunadamente es tal la complejidad de la creatividad que sería mejor abandonar su estudio; sin embargo, reconoce la satisfacción que le produce y su innegable expresión en la realidad. Incluso Popper rechaza que la creatividad pueda estudiarse científicamente basándose en que la ciencia busca la predicción, siendo la creatividad por sí misma impredecible. 
Uno de los esfuerzos más reconocidos y utilizados hasta la fecha para categorizar el concepto de creatividad, es el propuesto por Mel Rohdes en 1957. Él analizó más de cuarenta definiciones y concluyó que existen cuatro áreas que si bien tienen identidad única académicamente, funcionalmente operan como una unidad. Esta es la base de su Modelo de las 4P de la Creatividad, las cuales hacen referencia a: person (persona), process (proceso), product (producto) y press (prensa o medios).

En 1975 MacKinnon populariza dicho modelo modificando la última $P$ de press por places (situación). Sternberg y Tardiff (1988), haciendo uso de dicho modelo, sitúan de manera más actualizada las distintas definiciones de creatividad, proponiendo la siguiente síntesis:

\section{$\diamond$ Proceso}

- Visión de sistema que va más allá de un proceso personal.

- Desarrollo temporal (naturaleza y papel del insight).

- Metáfora evolucionista para su explicación.

- Papel concedido al azar.

- Relación proceso-producto ¿afecta este al primero? ¿hay procesos distintos según las áreas?

- Procesos de pensamiento implicados.

- La tensión creadora.

- Cuestión de unicidad.

- Cuestión de accesibilidad.

- Grados de creatividad.

\section{$\diamond$ Persona}

- Cuestión de especificidad.

- Características cognitivas según los autores.

- Ídem en personalidad y motivación.

- Conflicto entre aislamiento e integración social.

- Singularidades en el desarrollo.

\section{$\diamond$ Producto}

- Variedades de productos.

- Criterios.

\section{$\diamond$ Lugares (campos, dominios y contextos)}

- Características estimuladoras de la creatividad del campo donde surge.

- Contexto histórico y social como desencadenante de la creatividad. 
Además, encontramos que la creatividad inicialmente era descrita como una conducta, un proceso, un producto, pero paulatinamente se hace referencia a ella de forma más compleja, como una actitud ante la vida, más aún como una energía o espíritu creativo. Dicha evolución puede deberse a la complejidad y riqueza propia del concepto, que abarca más dimensiones de la persona.

A continuación te mostramos una gráfica que simula el Modelo de las $4 \mathrm{P}$ de Rohdes (1957), que hace referencia a la persona cuando alude en las actitudes, motivaciones, aptitudes o rasgos de personalidad del creativo. Con referencia al proceso, la orientación es concebirla como tal y vincularla a la percepción del problema, su definición, la forma cómo surge la idea y su valoración. Para el producto se incide en las características que diferencia a un producto creativo. Mientras que en lugar se centra en el ambiente físico y social.

Este modelo nos ha permitido situar a algunos autores. Muchos de los cuales abarcan más de una dimensión por ello nos centramos en la de mayor relevancia en su definición.

Figura 1. El Modelo de Creatividad de las 4P de Rhodes

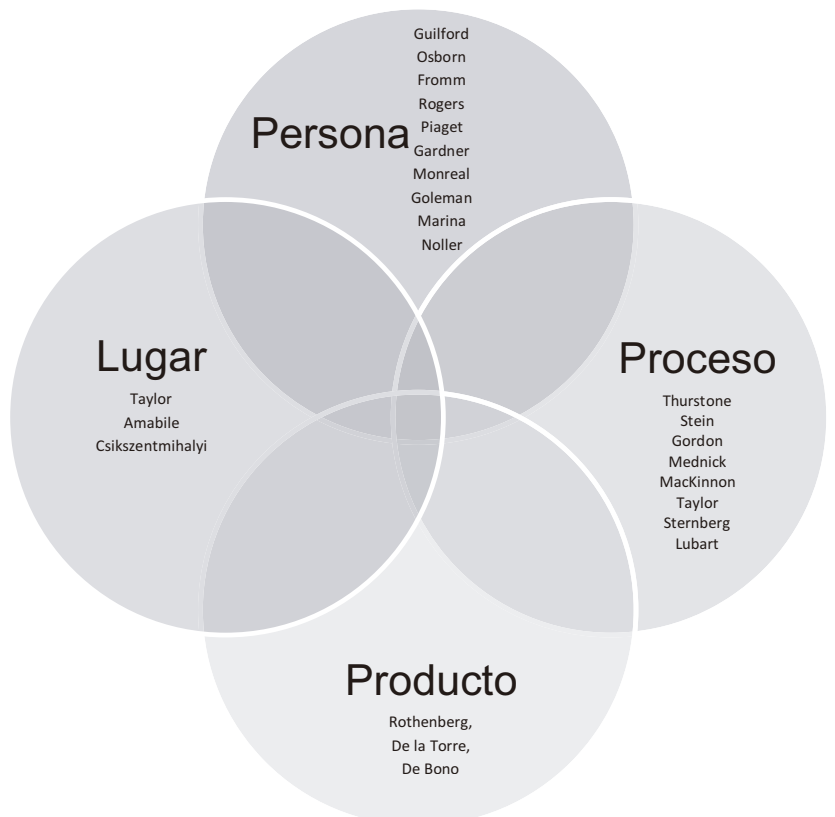

Fuente: se extrajo del libro La creatividad y la administración del cambio (p. 46), por T. Rickards, 2001, México: Oxford University Press. Incluye modificaciones hechas por los autores. 


\section{RELACIÓN ENTRE CREATIVIDAD Y OTROS CONCEPTOS: LA CREATIVIDAD SE CONFUNDE}

Dado que la creatividad y su valoración de un producto o persona creativa es además un término coloquial, resulta fácilmente confundible con otros términos.

Monreal cita que existen términos muy afines a la creatividad, como la genialidad, la originalidad, la inventiva, el descubrimiento y la fantasía. Sobre la genialidad, comenta que actualmente se asocia con un resultado extraordinario respecto a la creatividad. La originalidad, es uno de los aspectos de la creatividad aunque para algunos son sinónimos. La inventiva y el descubrimiento, son actividades creativas diferentes, la inventiva es crear lo que no existe y en el descubrimiento se encuentra lo desconocido aunque existente. Finalmente, el concepto fantasía intentó sustituir a la creatividad en la década de los ochenta en la psicología rusa, aunque para la psicología occidental, son conceptos diferentes, siendo la fantasía un fenómeno psicológico que sirve como instrumento para la creatividad.

Otro concepto que ha estado muy unido a la creatividad es el de inteligencia. Han sido diversos los autores que han destinado sus investigaciones a conocer cuál era la relación que existe entre creatividad e inteligencia. Así, Guilford (1950) entiende que la creatividad forma parte de la inteligencia, encontrándose la primera dentro de la segunda, Sternberg (1988) establece que la creatividad está por encima, englobando al constructo inteligencia; Gardner (1995) alude a la estrecha relación entre la creatividad y el dominio en el cual se manifiesta una determinada inteligencia; Para Torrance (1962) la inteligencia y la creatividad serían independientes.. Torrance propuso la teoría del umbral para explicar la relación de ambos conceptos. Estableció que, cuando el CI está por debajo de cierto límite, la creatividad también se encuentra limitada, mientras que cuando el CI se sitúa por encima de ese límite $(\mathrm{CI}=115-120)$ la creatividad llega a ser una dimensión casi independiente.

De forma más contemporánea, el Instituto de Investigación y Evaluación de la Personalidad (IPAR) propone cuatro formas en las que se combinan creatividad e inteligencia: creatividad e inteligencia alta, creatividad alta e inteligencia baja, creatividad baja e inteligencia alta y creatividad e inteligencia baja. Comparativamente, el grupo de personas que poseen creatividad e inteligencia alta muestran una personalidad más productiva y mejor adaptación y reconocimiento social dentro del ámbito escolar. Mientras que el grupo de personas que tienen una creatividad alta e inteligencia baja formarían parte del otro extremo reflejando problemas de adaptación. 
Las personas más integradas a la escuela y con mejores resultados académicos se encuentran en el grupo de creatividad baja e inteligencia alta. Finalmente, los de creatividad e inteligencia baja suelen ser personas desorientadas y que pueden mostrar desde un comportamiento adaptativo hasta uno represivo.

Marina (2002), desarrollan su Teoría de la Inteligencia Creadora, aplicable a toda la escala ontológica. Propone que la inteligencia es ante todo aptitud para organizar comportamientos, descubrir valores, inventar proyectos, mantenerlos, ser capaz de liberarse del determinismo de la situación, solucionar problemas y plantearlos. Implica dirigir nuestra actividad mental para ajustarse a la realidad y para desbordarla. Sin embargo, la característica esencial de la inteligencia humana es la invención y promulgación de fines. No existe por tanto, desarrollo de la inteligencia humana sin una afirmación enérgica de la subjetividad creadora.

Para Cox y Terman (1926), la más alta inteligencia por sí misma no genera creatividad, se necesita además de constancia y persistencia. Según el IPAR, la correlación entre creatividad e inteligencia varía en función del campo y la relevancia que éste le otorga a la inteligencia. Sin embargo, hallaron en promedio correlaciones bajas y medias entre creatividad e inteligencia, reflejando que los altamente creativos tienen un C.I. por encima de la media, aunque un C.I. mayor de 120 no influía demasiado en el incremento de la creatividad (Monreal, 2000).

Sternberg (2009) propone que para hacer un trabajo creativo se necesita de la inteligencia. Por un lado, de la inteligencia sintética, que permite generar ideas nuevas y en la que se encuentran diferentes procesos como el de aprendizaje, que incluye codificación selectiva (separa lo relevante de lo irrelevante), combinación selectiva (forma de combinar información relevante una vez que ha sido detectada) y comparación selectiva, tanto la codificación como la combinación selectiva se asocian a la iluminación creativa. La inteligencia analítica, permite evaluar las ideas y decidir por una de ellas. Mientras que, la inteligencia práctica posibilita comunicar de forma efectiva y persuasiva la idea elegida y saber transmitir su valor.

Por otro lado, Guilford (1959), señala que las capacidades específicamente creativas son aptitudes y por ello al hablar de la creatividad hace referencia a su teoría de Estructura del Intelecto. El temperamento y la motivación son necesarios para tener un resultado creativo pero por sí solos no identifican a los creativos. De otro lado, Gardner $(1983,1985)$ considera que la creatividad es un uso adecuado de las inteligencias múltiples: lingüística, lógico-matemática, espacial, quinestésica-corporal, musical, interpersonal, intrapersonal y naturalista. 
Interviene también el pacto faustiano, por el que se renuncia a lo fácil para conseguir unos objetivos.

Para Csikszentmihalyi (1998) existen tres fenómenos que pueden llamarse creatividad. El primero de ellos se refiere a las personas que expresan pensamientos inusitados, que son interesantes y estimulantes, son las personas brillantes. Existen también las personas que experimentan el mundo de manera novedosa y original, con ideas nuevas, juicios penetrantes, que pueden hacer descubrimientos importantes que sólo ellos saben, son personalmente creativos. Finalmente, las personas como Leonardo Da Vinci, Edison, Picasso o Einstein, que han cambiado la cultura en algún aspecto importante, son los creativos. En realidad, son modos diferentes de ser creativos, o mejor dicho, son grados de creatividad.

Csikszentmihalyi (1998) añade que existen otros dos términos afines a la creatividad, y en uno de ellos coincide con Monreal aunque con un enfoque diferente. Cita el talento y la genialidad. El primero de ellos se diferencia de la creatividad en que se centra en una destreza innata para hacer algo muy bien; mientras que un genio es alguien brillante y creativo, aunque una persona puede cambiar la cultura sin ser un genio.

Sin embargo, existe un término muy afín y ampliamente desarrollado, sobre todo en el campo de las organizaciones y es la innovación. Varios autores consideran que la creatividad precede a la innovación, en el sentido de que la creatividad se asocia con la fluidez para generar ideas mientras que la innovación es escoger, producto de la experiencia e intuición, una idea concreta y aplicarla con éxito.

Reafirma esta idea Goleman (2000) al señalar que una innovación es algo diferente de lo que se ha hecho antes. No puede ser simplemente extravagante o excéntrico, debe funcionar. Para ser creativo, de algún modo debe ser apropiado, útil, valioso y significativo.

Para Alvin Toffler (1972) la innovación tecnológica consta de tres etapas que forman parte de un ciclo: la idea creativa, su aplicación práctica y la difusión social, y esta sólo se consigue cuando las organizaciones disponen de una plantilla muy creativa.

$\mathrm{Al}$ parecer la creatividad es un concepto permeable que se enriquece y enriquece a otros conceptos con los cuales es afín, o tal vez su juventud como concepto hace que su definición y delimitación precise de tiempo, estudio y experimentación. 


\section{ALGUNOS MITOS SOBRE LA CREATIVIDAD}

Robert Sternberg en su manual de creatividad (2009) hace un análisis de las creencias más comunes que la gente suele tener a la hora de pensar sobre la creatividad. Analizamos algunas de esas creencias que propone Robert Sternberg.

\section{a. La creatividad es inspiración espontánea}

La creatividad como inspiración espontánea suele ser uno de los mitos más comunes cuando nos ponemos a pensar en qué es eso de la creatividad. Nos parece que los grandes creativos son personas que un día se despiertan con los ojos bien abiertos, como si un foco de luz se hubiera encendido en el interior de sus mentes, y dan con una idea que revoluciona el mundo. Nos puede incluso parecer que los grandes creativos son personas que viven al margen de la sociedad, yendo en contra de las convenciones sociales, como si necesitaran estar aislados para llegar a tener esa gran idea.

Ahora bien, lo que la ciencia nos dice es que si bien el fenómeno de inspiración espontánea puede darse, la influencia de la enseñanza formal y la deliberación consciente son esenciales para la creatividad. Las investigaciones al respecto sugieren que el talento creativo se hace y que manifestar creatividad en cualquier campo requiere un período de aprendizaje previo. Por tanto, las ideas creativas no surge de la nada, más bien surgen de personas que han desarrollado un amplio abanico de habilidades y que disponen de un conjunto de conocimientos relevantes, previamente adquirido en contextos favorecedores. Como diría alguna vez Pablo Picasso: la inspiración existe, pero tiene que encontrarte trabajando.

\section{b. Los niños son más creativos que los adultos}

La mayoría de nosotros hemos escuchado alguna vez que los niños son creativos por naturaleza, y que los adultos también los serían si la escuela no hubiera interferido con sus impulsos creativos naturales. Este mito tienen sus orígenes en las creencias del siglo XIX (la era del Romanticismo) según las cuales los nińos eran más puros y cercanos a la naturaleza, y que la sociedad los va corrompiendo gradualmente a medida que van aprendiendo a estar en sociedad.

Sin embargo, la ciencia de la creatividad muestra que los niños no son tan creativos como pensamos. Convertirse en una persona creativa supone recorrer un largo camino en el que iremos adquiriendo conocimientos y valores. La escuela y la sociedad no interfieren con la creatividad sino que la hacen posible, ya que el bagaje cultural de cada persona representa la materia prima desde la cual desarrollar el potencial creativo. 


\section{c. La creatividad viene del inconsciente}

La relación entre la creatividad y el inconsciente está muy vinculada al mundo del arte. Desde esta visión, la creatividad se entiende como un vehículo de expresión de nuestros deseos más profundos, de esa parte de nosotros a la que no podemos acceder voluntariamente. El psicoanálisis, especialmente la teoría freudiana, comparte este modo de entender la creatividad y en cierto punto, enfatiza el rol pasivo del creador, ya que su inspiración proviene de los procesos inconscientes que rigen su mente.

Sin embargo, los científicos han descubierto que la creatividad es mayoritariamente consciente. En general, las personas creativas tienden a ser las más productivas. De hecho, entre los grandes genios de la historia (Picasso, Edison, Einstein, etc.), resultaría difícil encontrar a uno que no haya sido altamente productivo. Por tanto, la creatividad parece relacionarse más con el trabajo duro y las horas de dedicación, que con las musas inconscientes.

\section{d. La creatividad es una forma de auto-descubrimiento terapéutico}

Otra concepción común de la creatividad es que la creatividad es una forma de terapia, de descubrirnos a nosotros mismos, descubrir nuestros sentimientos. Las personas que tienen esta concepción de la creatividad a menudo hablan de la valentía que requiere la búsqueda de la creatividad.

Existe cierta verdad bajo esta concepción: la actividad creativa puede representar una de las experiencias más importantes de la vida de una persona. Incluso la creatividad se ha convertido en un medio de expresión terapéutica (por ejemplo, tenemos la arteterapia, la músicoterapia, el arte outsider, etc.). Pero este elemento terapéutico del que hablamos no es la característica esencial de la creatividad. La mayor parte de la actividad creativa es consciente, requiere destreza y trabajo duro, y es increíblemente agradable para el creador (Sawyer, 2006).

\section{e. La creatividad es lo mismo que la originalidad}

Quizás una de la característica más común con las que nos hemos referido a la creatividad ha sido la originalidad o novedad. Cuando hablamos de originalidad pretendemos diferenciar el resultado habitual y reproductivo del que tiene valor originario, sugerente y, por tanto, fruto de una mente creativa. En suma, cualquier producto puede resultar creativo siempre y cuando nunca haya sido inventado antes.

No obstante, si sólo nos centramos en la presencia o no de originalidad, comportamientos como los desajustes injustificados, los delirios esquizofrénicos o los comportamientos extravagantes propios de otras psicopatologías fácil- 
mente pueden confundirse con la creatividad. Parece pues, que simplificaríamos demasiado un concepto tan complejos como es el de creatividad si sólo lo equiparamos con la originalidad. Así, a la hora de considerar un producto creativo necesitamos tener en cuenta otras características.

\section{f. A mayor inteligencia mayor creatividad}

Muchas personas tendemos a pensar que la creatividad es un proceso que sólo pueden llevar a cabo personas muy inteligentes. Nos vienen a nuestra mente personajes históricos como Da Vinci o Einstein, y enseguida pensamos "no soy creativo".

Pero, tal como vimos anteriormente, los estudios demuestran que a partir de un CI razonable (120), la inteligencia y creatividad no se relacionan. El problema es que, a medida que crecemos, la mayoría de nosotros aprendemos a inhibir la creatividad, por motivos relacionados con ajustarnos a las normas sociales y el comportamiento aceptable.

\section{g. Las personas creativas siempre tienen grandes ideas}

Tendemos a pensar que las personas creativas están generando constantemente grandes ideas, visiones extraordinarias sobre cómo mejorar la vida cotidiana. Pero la verdad es que las personas creativas tienen ideas siempre, buenas o malas, como el resto de los mortales.

Son personas que tienen ideas y las comparten con los demás. Por supuesto, de esas ideas sólo algunas se convierten en grandes ideas, mientras que las otras terminan desechándose.

\section{h. La creatividad en una de las expresiones de la locura}

Desgraciadamente es muy probable tachar de locos a quienes simplemente no entendemos. Dado que la creatividad nos lleva, en gran medida, a sobrepasar los órdenes establecidos, puede resultar delgada la línea de separación entre la creatividad y la locura.

Sin embargo, hoy parece que esta conexión es algo puramente accidental. Son muchas más las personas consideradas creativas que han gozado de buena salud física y mental. Además, las diferencias entre la persona creativa y la persona cuyo comportamiento se ve afectado por algún tipo de psicopatología son apreciables. En las primeras, la capacidad para descubrir lo que uno puede hacer bien, y disfrutar haciéndolo, es el sello distintivo, mientras que en la locura predomina un gran sufrimiento expresado que motiva la conducta del individuo. 


\section{i. La creatividad la aportan los individuos creativos}

Otra percepción muy común respecto a la creatividad es que sólo unos pocos son creativos, mientras que el resto de la gente no lo son. El hecho es que casi toda la investigación llevada a cabo en este campo demuestra que cualquier persona con una inteligencia normal es capaz de realizar un trabajo con cierto grado de creatividad. Como venimos exponiendo, la creatividad depende de todo un compendio de circunstancias como la experiencia de la persona, incluidos los conocimientos y habilidades técnicas, el talento, la capacidad de pensar de maneras nuevas (la apertura mental), y la capacidad de atravesar temporadas de sequía creativa (la tolerancia a la frustración). Ahora bien, existe un elemento que es transversal a todos los demás: la motivación intrínseca o dicho de otro modo, que la gente se entusiasme con las tareas que están llevando a cabo por el simple hecho de hacerlas.

\section{j. El dinero motiva la creatividad}

En nuestra sociedad, el dinero se comporta como un elemento incentivador de nuestro rendimiento. Nos suben la paga si llevamos tantos años trabajando en una empresa, si trabajamos más horas, etc. Cuando trabajamos según la cantidad de dinero que nos paguen hablamos de motivación extrínseca.

Pero la investigación experimental sugiere que el dinero no lo es todo. Este tipo de incentivo puede resultar problemático si las personas están pendientes de cómo va a afectar a su economía cada movimiento que hagan. En esas situaciones, las personas tienden a evitar el riesgo.

Por el contrario, las personas expresan una mayor creatividad cuando les importa su trabajo y se están poniendo en juego sus habilidades. La gente quiere la oportunidad de progresar en su trabajo y progresar realmente. Por ello, es fundamental para los directivos de las empresas hacer coincidir a la gente con proyectos basados no sólo en su experiencia, sino también en sus intereses. Nuevamente, vemos que la motivación intrínseca resulta ser un elemento central en la creatividad.

\section{k. La presión del tiempo estimula la actividad creativa}

La gente tiende a pensar que la creatividad se ve potenciada cuando trabajaban bajo presión, teniendo a sus jefes en sus espaldas apurándolos. No obstante, la presión del tiempo, merma la creatividad porque la gente no puede concentrarse completamente en el problema. La creatividad necesita un período de reflexión, las personas necesitan tiempo para comprender el problema en todas sus vertientes y dejar que fluyan sus mejores ideas. 
De hecho, el problema no es tanto tener una fecha límite, sino las distracciones que pueden quitar el tiempo a la hora de hacer avances creativos. Estar en una situación de presión para terminar un proyecto o encontrar una solución a un problema no tiene por qué estar reñida con la creatividad, pero sólo si las personas están en condiciones de concentrarse en el trabajo. Se debe garantizar que los trabajadores estén protegidos de las distracciones, saber que el trabajo es importante y que todo el personal tenga el mismo compromiso por cumplir los plazos.

\section{El miedo inspira}

Existe una noción generalizada de que el miedo y la tristeza, de alguna manera, estimulan la creatividad. Hay incluso cierta literatura psicológica que sugiere que la incidencia de depresión es mayor en los escritores y artistas creativos.

Sin embargo, las investigaciones sugieren que las emociones positivas como la alegría y el amor se encuentran más relacionadas con el potencial creativo, mientras que las emociones negativas como el miedo, la ira, la ansiedad o la tristeza, parecen interferir con la creatividad

\section{m. La competitividad fomenta la creatividad}

Otra creencia muy generalizada, particularmente en finanzas y en industrias de alta tecnología, es que la competencia interna fomenta la innovación. Los empresarios con esta concepción de la creatividad suelen crear un ambiente de trabajo en el que los empleados con las mejores ideas son recompensados, creándose un ambiente altamente competitivo entre los empleados.

Cuando se estudian los distintos ambientes de trabajo en relación a la creatividad, vemos que ésta disminuye cuando la gente en un grupo de trabajo compite en lugar de colaborar. De este modo, el debate y la colaboración son esenciales. A través del debate las ideas se van redefiniendo para dar lugar a mayores niveles de elaboración y las soluciones encontradas son mucho más ricas.

\section{n. Una organización racionalizada es una organización eficiente}

Existe la creencia de que la reducción de la plantilla de personal y la reestructuración de la organización fomenta la creatividad, ya que el grupo de personas se vuelve más homogéneo y confluyen mejor las ideas entre los participantes.

No obstante, la evidencia señala que la creatividad sufre durante una gran reducción de personal. La comunicación y la colaboración se ven perjudicadas significativamente. Las personas se sienten inseguras en sus puestos de trabajo, 
pierden sensación de control y libertad. El miedo a lo que pasará en el futuro, si seguirán trabajando o no, lleva a una sensación de alienación en el trabajo que hace que se desentiendan de éste.

\section{o. Pensar creativamente equivale a aprender unas cuantas técnicas}

Conocer y aprender a utilizar algunas técnicas es muy útil a la hora de potenciar la creatividad. No obstante, como suele decirse, el hábito no hace al monje. Equiparar el hecho de manejar un compendio de técnicas con el pensamiento creativo puede limitar nuestra visión de la creatividad.

Pensar creativamente involucra un proceso más rico y más completo que sólo anclarse en conocer y utilizar técnicas creativas. Este proceso comienza por la definición clara de un problema, por el qué queremos resolver. Esta puede ser quizás una de las partes más complicadas del proceso creativo, ya que conlleva entender el problema en toda su profundidad, analizando los diferentes ángulos.

Una vez claro el problema el siguiente paso es idear alternativas. Es en esta segunda parte cuando las técnicas creativas cobran especial relevancia.

\section{CÓMO IDENTIFICAR Y DEFINIR LA CREATIVIDAD}

Es, al parecer, más sencillo ofrecer una lista de criterios que definan qué es creativo, porque valoramos los productos como creativos o no. Para empezar, es importante señalar que el producto creativo es algo que existe en sí mismo y tiene una entidad independiente de la persona que lo produce (Monreal, 2000). En el mundo de las ideas, cuando comunicamos una idea ésta se convierte en un producto. El debate se establece cuando no se comunican las ideas y quedan en el interior de la persona, en cuyo caso no se tiene posibilidad de ser evaluada por los demás.

Es labor de los psicólogos establecer unos criterios que definan un producto como creativo independientemente del tipo de producto que sea, siendo los expertos (o ámbito de especialistas en términos de Csikszentmihalyi, 1998) quienes valoren y evalúen los productos sobre la base de esos criterios:

a. Originalidad o novedad), es uno de los rasgos que más caracteriza la creatividad. Se asocia con lo único, lo irrepetible, lo diferente. Podemos definir la originalidad sobre la base de tres criterios, el primero de ellos cuantitativo, siendo lo novedoso aquello que no es frecuente estadísticamente, debiéndose tomar como referencia el contexto, la época y el lugar. Podemos adoptar una postura más cronológica, donde lo nuevo 
es hacer algo el primero en la historia. Por último, se interpreta la novedad en relación con los significados de la sociedad, siendo una respuesta nueva cuando es única en un determinado grupo o porque la persona se evade de un sistema conceptual previo y construye uno nuevo que afecta tanto a ideas como personas. Es para Monreal (2000) la significación de originalidad más amplia en el sentido más hondo de la creatividad. Sin embargo, cada uno de estos criterios son debatibles. Si asumimos una postura estadística, podemos considerar los delirios de un esquizofrénico como novedosos, dado que es infrecuente. Desde la perspectiva más cronológica se pone énfasis en el momento de comunicación pública de la idea y la accesibilidad al medio donde comunicar. La perspectiva de cambio más social es una expresión de novedad que M. Boden (1994) calificaría como H-creativo frente al P-creativo. Para ella, cuando se toma en cuenta el sentido histórico de la novedad del producto con respecto a lo realizado por otros, se hace referencia a una creatividad auténtica y real, puesto que se producen objetos históricamente nuevos o H-creativos. Análogamente, Csikszentmihalyi (1998) define la Creatividad con $\mathrm{C}$ mayúscula como aquel proceso por el cual dentro de la cultura queda modificado un campo simbólico.

La perspectiva más psicológica, relacionada con la novedad de un producto con respecto a la mente del individuo y generando productos nuevos comparativamente a lo que él conoce, es el P-creativo.

En este caso, calificar la novedad desde una perspectiva más social pone un listón lo suficientemente alto para calificar como novedoso a pocos productos o personas, como el caso de Edison, Da Vinci, Mozart o Picasso, entre otros.

b. Valor: es un segundo componente importante de la creatividad. Habitualmente se produce algo (creativo) para que dé respuesta a una situación o solucione un problema. En tal sentido, el producto creativo debe resultar eficiente con referencia a la necesidad en cuestión. Es por ello que resulta importante que el producto posea independencia del autor y se comunique a un grupo de especialistas que definan su valor. Con dicho criterio, la creatividad implica ir más allá que el simple hecho de crear un producto novedoso. Al respecto, entran en juego también las habilidades del creador al comunicar su producto creativo y la apertura del grupo de expertos al evaluarlo. La importancia de este indicador queda reflejada en la Teoría de Creatividad de Robert Sternberg (2009), quien formula una Teoría de la Inversión en el mundo de las ideas, 
donde se compra a la baja y se vende al alza, y en el que las ganancias pueden ser variadas, desde monetarias hasta reconocimiento social o histórico.

c. Flexibilidad: Todas las personas creativas se han caracterizado por romper (o salirse de) los métodos, procedimientos, expectativas, teorías preestablecidas, en búsqueda de otros puntos de vista o realidades. Para Morín (1991), la flexibilidad se trata de mostrar una gran riqueza de categorías, se revela por un rasgo difícil de detectar. En las pruebas de Torrance, se pide que se le de varios usos no comunes a un objeto. Por ejemplo, ¿Para qué sirve una bolsa de basura? Muchos de los que respondan a esta pregunta dirán: para un abrigo, para una camisa, para un disfraz. Sin embargo, hay otros que incluyen, además de la categoría de ropa, otras categorías como para abrigar, para taparnos y no mojarnos, para mantel,... Estadísticamente, se encuentra una alta correlación entre flexibilidad y originalidad, puesto que para producir ideas originales, no hay más remedio que olvidar puntos de vista tradicionales y contemplar las cosas bajo otros ángulos.

d. Productividad o fluidez: Se suele pensar que la cantidad es la base de la calidad, puesto que tenemos más probabilidades de escoger un producto valioso. Por este motivo, es un rasgo que, de no darse junto con la originalidad y flexibilidad, puede darse entre las personas no creativas. Uno de los ejemplos que podemos ver en el Test de Torrance para evaluar la fluidez es el ejercicio de los círculos. En esta actividad aparecen una serie de círculos, los cuales deben ser utilizados por los sujetos para realizar un dibujo en cada uno de ellos donde el círculo sea la parte central. Para evaluar la fluidez se cuenta el número de círculos que se ha utilizado en un tiempo determinado. Se trata quizá de uno de los rasgos a los que más apelan las técnicas de creatividad, como por ejemplo el brainstorming de Osborn (1957). A continuación citamos algunos indicadores de creatividad sobre los cuales el consenso no es tan claro entre los autores.

e. Elaboración: Un producto o una idea elaborada es aquella donde se han tenido en cuenta todos los detalles, no hay nada improvisado, todo tiene un sentido. En este sentido, la elaboración la podemos comprobar en un dibujo, donde no se le ha olvidado al pintor ni las cejas, ni las orejas, las uñas,... hay miles de detalles que hacen del dibujo una obra rica y elaborada. Igualmente, en un gran cocinero, decimos que ha hecho un plato elaborado cuando ha combinado un sinfín de ingredientes, dando lugar a un plato exquisito. 
f. Análisis: es la capacidad para descomponer mentalmente una realidad en sus partes. Por ello, permite profundizar en una realidad al conocerla desde los elementos que la componen. De este modo, es más viable una aportación valiosa en un campo que es conocido que en aquel en el que somos aprendices o neófitos.

g. Síntesis: implica resumir, esquematizar. Por tanto, se pueden conseguir productos creativos de la síntesis de realidades diferentes o de una misma realidad pero desde una perspectiva distinta.

h. Apertura Mental: significa que siempre se está abierto a superar cualquier solución, a seguir profundizando, a preguntar el por qué y el para qué. Permite ir más allá de lo que se conoce.

Una vez que conocemos los indicadores más importantes de un producto creativo, nos podemos plantear su cuantificación a través de la evaluación. Para ello, debemos situarnos desde una perspectiva psicométrica, cuyo interés es detectar las diferencias individuales sobre la base de la cuantificación de un constructo - en nuestro caso, la creatividad-a través de los tests psicológicos. Hocevar y Bachelor (1989) clasificaron más de cien tests de creatividad en ocho categorías. Consideran que tienen una naturaleza descriptiva y no se excluyen mutuamente:

\section{Tests de pensamiento divergente}

La medición del pensamiento divergente implica generar múltiples respuestas en vez de sólo una respuesta correcta, como se piden en los tests convencionales.

\section{Inventarios de intereses y actitudes}

Algunas investigaciones sugieren que la creatividad puede ser identificada en términos de intereses y actitudes, que favorecen la actividad creativa. A modo de ejemplo, citamos algunos ítems de estos tests:

Tengo buen sentido del humor

Me gusta escribir historias

Me gusta hacer actividades y proyectos nuevos.

\section{Inventarios de personalidad}

Para algunos autores la creatividad se asocia más con un conjunto de rasgos que con aspectos cognitivos. Por ello, conociendo muy bien la personalidad a través de un inventario se puede disponer de una escala de creatividad. Algunos inventarios de personalidad se han adaptado para identificar la creatividad. 


\section{Inventarios biográficos}

Parten de la premisa de que el comportamiento pasado es el mejor predictor del comportamiento presente. Suelen recoger características físicas, historia familiar, historia educativa, actividades de ocio y miscelánea. Todas ellas miden el esfuerzo creativo.

\section{Referencias de profesores, pares y supervisores}

Su validez (mida lo que dice medir) es más metodológica que conceptual, suele ser una categoría menos homogénea puesto que responde a criterios a veces diferentes. En el campo educativo, se recurre a las valoraciones de los profesores, Se establecen unos estándares que identifican a los más y menos creativos en clase, por ejemplo, se define el pensamiento creativo en términos de fluidez, flexibilidad, inventiva, originalidad y elaboración para que sobre ellas los profesores emitan sus juicios. En el caso de los pares —o iguales jerárquicamente-, su aplicabilidad se halla sobre todo en el sector de los negocios y la industria. Particularmente, en la empresa para elegir empleados creativos se utilizan las referencias de los supervisores. Su ventaja es que ellos conocen el trabajo (por lo tanto sus productos y eficiencia) y al trabajador.

\section{Juicio sobre los productos}

Resulta evidente que las personas creativas generan productos creativos. Identificar uno o más productos es una forma de abordar todas las áreas de estudio y la variabilidad de las personas. En todos los casos, existen jueces que valoran la creatividad de esos productos, los cuales pueden ser expertos o no. En igual medida los criterios identificativos de un producto creativo pueden variar.

\section{Personas eminentes}

El estudio de personas eminentes o altamente creativas que se encuentran en el extremo superior de una curva de distribución normal, se ha empleado para medir la creatividad en las personas que en general se sitúan en la media. El debate surge al plantearse si es comparable o equivalente la creatividad de los altamente creativos con las personas normales. Simonton (2004) analizó la historia y biografía de grandes records y al respecto encontró que los efectos de ambos -individuales (como la edad) y sociales (como la inestabilidad política) - son variables en la producción creativa en áreas como la música, la ciencia y otras. 


\section{Auto-informe sobre actividades y rendimiento creativo}

Tal vez sea más sencillo solicitar un auto-informe, pero es más difícil decidir qué actividades y logros son considerados creativos. Su aplicabilidad se ha dado sobre todo en la educación e investigación psicológica.

Sobre esta revisión, concluyen, que la fiabilidad (significa medir algo cuyos resultados sean consistentes en el tiempo), la validez discriminante (diferenciar la creatividad de otros conceptos) y la validez nomológica (que la teoría de la creatividad que sustenta ese test tiene bases lógicas para establecer conexiones empíricamente demostrables entre sus puntaciones y las medidas de otros constructor, como la inteligencia) son los puntos más álgidos en los tests de creatividad. Ello se sustenta en que las diferentes medidas de creatividad, tomada de diferentes tests, no correlacionan todas entre sí. Además, muestran poco acuerdo respecto a los criterios de creatividad, exceptuando los tests de pensamiento divergente. Proponen que "los investigadores deben centrarse sólo en aquellos estudios que incluyen una medida de la creatividad en la vida real", para ello deben realizar estudios longitudinales y una cuidadosa relación de criterios de la creatividad.

Para Gardner, no ha sido posible — salvo escasos resultados— demostrar la validez de los tests de creatividad. Dado que una puntuación alta en los test de creatividad no garantiza ser creativo en la vida real o viceversa, es decir, las personas reconocidas como creativas no necesariamente muestran los tipos de destreza asociadas al pensamiento divergente, asociado a la creatividad. En las escuelas, sobre todo, se suelen utilizar tests de creatividad que miden sólo algunos aspectos de la misma, habitualmente la fluidez, y carecen de baremos, resolviéndose los problemas de puntuación de manera poco clara, puesto que no se normaliza quién o quiénes evalúan ni los criterios que se utilizan sobre los productos de los evaluados. Muchos psicólogos y educadores, como Howard Gardner, se muestran escépticos a tales mediciones de la creatividad, él argumenta que, en lugar de confiar en una sola prueba de creatividad, deberíamos ver cómo responden los niños a una amplia variedad de material que se refiere a diversas áreas de habilidad, incluidas la música, la danza y las relaciones interpersonales (Goleman, 2000).

En suma, encontramos un debate con referencia a la medición de la creatividad, que nos lleva a una reflexión crítica y, cómo no, creativa. Observamos que progresivamente a nivel teórico las líneas de investigación van confluyendo hacia una visión multidimensional de la creatividad. Sin embargo, la forma de evaluación, a través de los tests, que constituyen una aportación pragmática y próxima a la sociedad, es más difusa, dado que por el momento no disponemos 
de herramientas eficaces y menos aún predictivas. Por tanto, ante los resultados que puedas obtener sobre los diferentes tests de creatividad te sugerimos ańadas tu propio autoconocimiento y autoevaluación.

\section{BIBLIOGRAFÍA}

Alan, L. (2003). ¡Eureka! Descubrimientos científicos que cambiaron el mundo. Barcelona. Paidós.

Amabile, T. (1996). Creativity in context: Update to social psychology of creativity. Boulder. Colorado.

Boden, M. (1994). La mente creativa. Mitos y mecanismos. Barcelona. Gedisa.

Cox, C. M. (1926). The early mental traits of three hundred geninses. Stanford, CA: Stanford University Press.

Csikszentmihalyi, M. (1998). Creatividad. El fluir y la psicología del descubrimiento y la invención. Barcelona. Paidós.

De Bono, E. (1992). El pensamiento lateral: Manual de creatividad. Barcelona. Paidós.

García, L. y Carrasco, M. P. (2005). Para tí creatividad. Barcelona. Granica

Gardner, H. (1995). Mentes creativas. Barcelona. Paidós.

Goleman, D., Kaufman, P. y Ray, M. (2000): El espiritu creativo. La revolución de la creatividad y como aplicarla. Barcelona. Vergara Editor.

Guilford, J.P. (1959). Traits of creativity. En H.H. Anderson Creativity and its cultivation (pp.142-161). Nueva York. Harper y Brothers.

Hocevar, D. y Bachelor, P. (1989). A taxonomy and critique of measurements used in study of creativity. En Glover y otros compiladores. Handbook of creativity (pp. 53-75). Nueva York. Plenum press.

LLorenc G. (2020). Anatomía de la creatividad. Barcelona. Marge Books.

MacKinnon, D.W. (1975). IPAR's contribution to the conceptualization and study of creativity. En I. Taylor \& J.Getzels (eds.),Perspectives in creativity. Chicago: Aldine.

Marina, J.A. (2002). Teoría de la inteligencia creadora. Barcelona. Anagrama.

Michalko, M. (2001). Thinkertoys. Cómo desarrollar la creatividad en la empresa. Barcelona. Gestión 2000.

Monreal, C. (2000) ¿Qué es la creatividad? Madrid. Biblioteca nueva.

Morin E. (1991). El Método. Las ideas. Madrid. Ediciones Cátedra.

Osbom, A. F. (1957). Applied imagination: Principles and procedures $d f$ creative problem-solving. New York, NY. Charles Scribner's Sons

Rhodes, M. (1957). Un análisis de la creatividad. Phi Delta Kappan. Vol 42. $\mathrm{n}^{\circ} 7$. 
Sawyer, K. R. (2006). Explaining Creativity: The Science of Human Innovation. Oxford. Oxford University Press.

Simonton, K. (2004). Creativity in Science. Cambridge. Cambridge University Press.

Sternberg, R. (2009). Handbook of creativity. Nueva York. Cambridge University Press.

Torrance, E. (1977). Educación y capacidad creativa. Madrid. Marova.

Weisberg, R. (1987). La creatividad, el genio y otros mitos. Barcelona. Labor. 


\title{
ENSEÑANZA DE LAS CIENCIAS EN EL GRADO DE CRIMINOLOGÍA: LABORATORIO CRIMINALÍSTICO
}

\author{
Rosario García-Repetto \\ Facultativo Instituto Nacional de Toxicología y Ciencias Forenses \\ Profesora asociada Universidad Pablo de Olavide de Sevilla
}

\section{Resumen}

La Criminología es una ciencia multidisciplinar, cuyos estudios universitarios despiertan un interés considerable en la actualidad. Se ha demostrado que el consumo de series de ficción televisiva de tema forense ha contribuido a que muchos jóvenes se decidan por los estudios de Criminología. La realidad distorsionada que presentan las series televisivas suele ser causa de desánimo ya que el alumnado debe estudiar disciplinas científicas para las que no se encuentra adecuadamente preparado al proceder mayoritariamente del Bachillerato Humanístico y de Ciencias Sociales.

Se presenta, en este trabajo, un ejemplo de la implantación del aprendizaje basado en problemas en la asignatura Laboratorio Criminalístico para motivar al alumnado y mejorar el aprendizaje de los conceptos asociados a las ciencias experimentales.

Palabras clave: Universidad, Criminología, Enseñanza Ciencias, Efecto CSI.

\begin{abstract}
Criminology is a multidisciplinary science; whose university studies arouse considerable interest today. It has been shown that the consumption of forensic television fiction series has influenced many young people decision's on choosing their degree. The distorted reality presented by television series is usually a cause of discouragement since students must study scientific disciplines for which they are not adequately prepared as most of them come from the $\mathrm{Hu}$ manistic and Social Sciences Baccalaureate

In the present paper, an example of the implementation of problem-based learning in the subject Criminal Laboratory is presented. Its main goals were to seek students' motivation and improve the learning of the concepts associated with experimental sciences.
\end{abstract}

Keywords: University, Criminology, Science Teaching, CSI effect. 


\section{INTRODUCCIÓN}

La Criminología es una ciencia multidisciplinar y transversal que pertenece al ámbito de las Ciencias Sociales (QAA, 2019). Estudia la delincuencia, sus causas y consecuencias, así como las formas e instituciones y políticas de prevención y control (UNESCO, 1957). De acuerdo, con la Sociedad Europea de Criminología, esta ciencia incluye todo el conocimiento académico, científico y profesional acerca de la explicación, prevención, control y tratamiento del crimen y la delincuencia, del agresor y la víctima, incluyendo la medición y detección del crimen, la legislación y la práctica del Derecho Penal, el cumplimiento de la ley, y los sistemas judicial y correccional (ESC, 2016).

Los estudios universitarios de Criminología despiertan un interés social considerable en nuestro país. Muestra de ello es que, en la actualidad, prácticamente en todas las universidades españolas se ofrecen dichos estudios ya sea en la modalidad de grado o en la de posgrado (López Bautista, 2018).

La disciplina más representada en los planes formativos de Criminología es el Derecho, contando con una presencia de, al menos, un cincuenta por ciento de las asignaturas impartidas en cada grado, siendo el Derecho Penal predominante en todos los casos estudiados (Ternero Martin, 2019). Los planes formativos incluyen también asignaturas de Criminalística (CAC, 2020) que es una disciplina que aplica conocimientos y metodologías científicas a la resolución de problemas legales (Budlowe y cols, 2009). Concretamente, la Criminalística se encarga de la identificación, individualización y evaluación de las evidencias físicas provenientes de la escena del delito (Gialamas, 2000). El estudio de dichas materias representa, en la mayoría de las ocasiones, una dificultad añadida ya que, al ser un grado impartido fundamentalmente por las Facultades de Derecho de las universidades espańolas, los alumnos suelen proceder del Bachillerato Humanístico y de Ciencias Sociales (Área de Calidad. Universidad Pablo de Olavide de Sevilla, 2020).

De acuerdo con mi experiencia como profesora asociada en la Universidad Pablo de Olavide (UPO) de Sevilla, es frecuente encontrarse con alumnos desmotivados por las asignaturas científicas ya que frecuentemente la elección de la carrera, se basó en la idealización del trabajo de criminólogo mostrada en los productos audiovisuales con ficción forense, hecho que ha sido constatado por otros autores (Sarver y cols, 2010). Con la intención de superar las dificultades que para enseñanza de la asignatura Laboratorio Criminalístico tiene la situación descrita se implantaron algunas estrategias didácticas. Se pretendía, además de motivar a los alumnos, mejorar el aprendizaje de los conceptos asociados a las ciencias experimentales. Alguna de ellas se presenta en este trabajo. 


\section{ESTUDIOS DE CRIMINOLOGÍA EN ESPAÑA}

Los estudios de Criminología en Espańa se remontan a la Real Orden de 10 de marzo de 1844 por la que se crea una escuela práctica para la formación de los funcionarios de prisiones. Sin embargo, no fue hasta 1955 cuando los estudios de Criminología quedaron vinculados a la Universidad mediante la creación del Instituto de Criminología en la Universidad Central de Barcelona. Posteriormente, se fueron creando otros Institutos Universitarios de Criminología. En Andalucía se creó en 1989 el Instituto Universitario andaluz de Criminología vinculado a las Universidades de Cádiz, Córdoba, Granada, Málaga y Sevilla (Universidad de Sevilla, 2011).

En el año 2003 se establece el título universitario oficial de Licenciado en Criminología (R.D. 858/2003 de 4 de julio, 2003). Se especifica que los planes de estudio deben proporcionar una formación científica, de carácter multidisciplinar en los distintos aspectos relacionados con el hecho criminal o con la conducta desviada. En dicho plan de estudio era obligatoria la asignatura de Medicina Legal y Ciencias forenses. Posteriormente, debido a las exigencias de armonización curricular derivadas del proceso para la creación de un Espacio Europeo de Educación Superior (EEES), se implementaron los nuevos Grados en Criminología. En la actualidad, y de acuerdo con los datos publicados por el Ministerio de Universidades, en el curso académico 2019-2020 estudian en España un grado de Criminología aproximadamente 21000 personas, lo que sitúa a estos estudios en un nivel de implantación similar a titulaciones como Periodismo o Turismo (Ministerio de Universidades, 2020).

En nuestro país se ofertan 76 grados de Criminología, de los que 41 se imparten en centros públicos y 35 en centros privados (López Bautista, 2018). Como ejemplo, se puede mencionar que únicamente en Andalucía seis universidades (cinco públicas y una privada) de cuatro ciudades diferentes ofrecen estudios de Grado en Criminología englobados en la oferta de las facultades de Derecho (Ternero Martin, 2019). A su vez, dentro de las titulaciones de grado, se ofrecen especializaciones en diferentes itinerarios: en Ciencias forenses (Sevilla y Pablo de Olavide); en Criminalidad (Pablo de Olavide); en Ciencias jurídicas y sociales (Sevilla); en Seguridad y en Intervención (Cádiz); en Técnicas y pericia criminal; y en Prevención y tratamiento del delito y del delincuente (Granada).

El grado en Criminología, de acuerdo con los parámetros utilizados por las universidades españolas para evaluar la calidad de enseñanzas, tiene una excelente implantación. Sirva como ejemplo la tasa de rendimiento del título académico. Dicha tasa calcula el porcentaje de número de créditos superados frente a los créditos matriculados en un año académico. Si atendemos a los 
datos publicados en las páginas web de diversas universidades españolas, la tasa de rendimiento del Grado de Criminología es satisfactoria ya que supera el $85 \%$, siendo ligeramente superior a la media estatal para Ciencias Sociales y Jurídicas, que es de 79,4\% (Ministerio de Ciencia, Innovación y Universidades, 2019). La figura 1 muestra la evolución de dicha tasa desde el curso 2013-14 al curso 2018-19 para siete universidades españolas:

Figura 1. Evolución de la tasa de rendimiento del Grado de Criminología

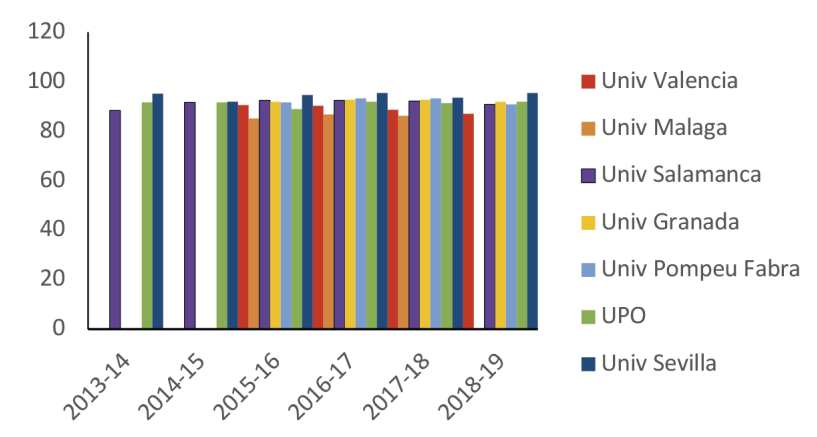

Fuente: Elaboración propia.

Otro indicador de calidad es la tasa de abandono que se calcula como la relación porcentual entre el número total de estudiantes de una cohorte de nuevo ingreso que debieron obtener el título el ańo académico anterior y que no se han matriculado ni en ese año académico ni en el anterior. La figura 2 muestra la evolución de dicha tasa desde el curso 2013-14 al curso 2018-19 para siete universidades españolas.

Figura 2. Evolución de la tasa de abandono del Grado de Criminología

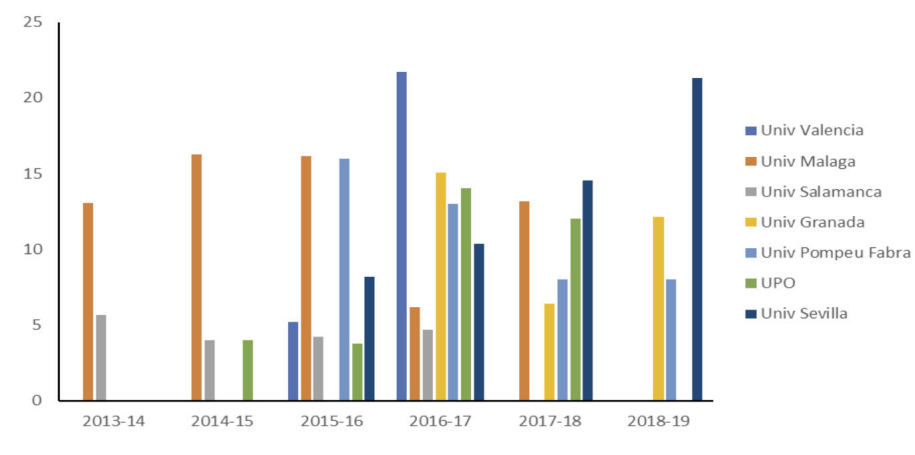

Fuente: Elaboración propia. 
En este caso se observa una mayor disparidad entre los resultados obtenidos en las diferentes universidades. Salvo en el caso de la Universidad de Sevilla en el curso 2018-19, la tasa de abandono es inferior a la media estatal para Ciencias Sociales y Jurídicas (20.1\%) (Ministerio de Ciencia, Innovación y Universidades, 2019).

\section{PERFIL DEL ESTUDIANTE DE NUEVO INGRESO}

Es importante destacar la variedad de perfiles y procedencias de los estudiantes de Criminología. Si bien al principio accedían a estos estudios licenciados o diplomados de otras áreas que deseaban obtener una especialización en Criminología, en la actualidad los alumnos que llegan por vez primera a la Universidad son los que copan casi la totalidad de las plazas disponibles.

El perfil de los estudiantes de nuevo ingreso, según una encuesta realizada por la Universidad Pablo de Olavide de Sevilla a los alumnos de nuevo ingreso en el Grado de Criminología en el curso 2019-2020, es el de una eran mujer procedente del Bachillerato de Ciencias Sociales y dedicada totalmente sus estudios universitarios (Tabla 1). Han elegido la carrera porque creen que se ajusta a sus aptitudes y por las perspectivas laborales que presentan. A pesar de que no se les preguntó si poseían conocimientos científicos, sí que manifiestan que necesitan ayuda con las destrezas matemáticas. (Área de Calidad. Universidad Pablo de Olavide de Sevilla, 2020).

Tabla 1. Perfil de estudiante de nuevo ingreso en el Grado de Criminología.

\begin{tabular}{|l|l|}
\hline Característica & Descripción \\
\hline Sexo & $\begin{array}{l}\text { - Mujeres: } 78 \% \\
\text { - Hombres: } 22 \%\end{array}$ \\
\hline Acceso Universidad & - EVAU, PAS: $95,24 \%$ \\
& - No acceden desde secundaria: $4,76 \%$ \\
\hline Tipo bachillerato & - Ciencias Sociales y Humanidades: $65,1 \%$ \\
\hline Nota de acceso & - Ciencias: $30 \%$ \\
\hline Dedicación a & - Estudiantes con $>60 \%$ nota máxima: $95,1 \%$ \\
\hline estudios & - Parcial: $4,8 \%$ \\
\hline
\end{tabular}

Fuente: Área de Calidad. UPO, 2020.

Si atendemos a la motivación del estudiante que elige el Grado en Criminología como carrera universitaria, podemos fijarnos en diversos estudios pu- 
blicados en otros países. Muchos alumnos piensan que la carrera de criminología es más fácil ya que tienen menos matemáticas y menos asignaturas de ciencia (Barthe y cols, 2012). Por otro lado, una encuesta realizada a estudiantes universitarios australianos demostró que la mayoría de los estudiantes piensan que la profesión es excitante y positiva (Koch y Porter, 2012).

\section{EFECTO CSI Y ELECCIÓN DE ESTUDIOS DE CRIMINOLOGÍA}

En el año 2002 la revista “Time Magazine” publicó un artículo sobre los avances tecnológicos desarrollados en el campo de la lucha contra el crimen. En él, el periodista hacía mención expresa al concepto de efecto CSI al referirse a la preocupación mostrada por los investigadores forenses acerca de la irreal idea que el público tenía de los laboratorios forenses, y que atribuían a la influencia de las series de televisión (Kluger, 2002).

Concretamente, el concepto "efecto CSI" deriva de la serie de televisión "CSI Las Vegas". Dicha serie fue estrenada en Estados Unidos en octubre del año 2000 y en sus 15 temporadas llegó a tener más de 70 millones de espectadores en todo el mundo, ya que ha sido emitida en más de doscientos países. En España, llegó a superar una cuota de pantalla del 25\%. Tal fue el éxito de la serie que surgieron diversas spin-off como "CSI cyber", "CSI Nueva York" y "CSI Miami” (Farré y cols, 2017). Todas ellas son series procedimentales, es decir, con episodios autoconclusivos e independientes. En cada capítulo se plantea un caso forense que se resuelve en el mismo episodio. Carecen de una historia común a toda la temporada o si la tienen se trata de forma superficial (Adler, 2011). Determinar cómo se cometió el delito es una característica común al argumento de los distintos episodios de la franquicia CSI y para ello los guionistas ponen a los personajes principales en las situaciones apropiadas para conseguirlo (Kirby, 2013).

La serie CSI Las Vegas cambió la definición de ocio en el siglo XXI y asentó la forma procedimental forense como una de las más exitosas. Su mayor logro ha sido la inscripción de discursos y espacios médico-forense en un formato dedicado al consumo masivo (Avanzas Âlvarez, 2016). El formato audiovisual sobre el que se sustenta ha permitido el acceso del gran público a discursos científicos muy específicos, a pesar de se ha estimado que aproximadamente el 40\% de toda la ciencia que se muestra en la serie de televisión CSI Las Vegas no es real (Cole y Dioso, 2005).

El éxito de audiencia de las series de televisión con temas forenses parece obedecer tanto a la complejidad de los casos que se investigan, así como a que presentan una ciencia forense con recursos ilimitados y capaz de solucionar 
cualquier problema que se presente durante la investigación del delito en cuestión en tiempo extraordinariamente corto (Sosa Reyes, 2017).

A pesar de que en un principio se definió el efecto CSI como la influencia que tiene el contenido de las series de televisión con temática forense sobre las decisiones que toman los jurados dicho concepto se ha extendido a la descripción de la influencia que sobre los distintos partes intervinientes en la administración de justicia tiene el consumo de los productos audiovisuales de temática forense (Coley Dioso-Villa, 2007) (Cole y Dioso-Villa, 2009). La tabla 2 resume el uso que se da a dicho concepto.

Tabla 2. Descripción de los distintos tipos de efecto CSI

\begin{tabular}{|l|l|}
\hline Efecto sobre & Descripción \\
\hline Jurados & $\begin{array}{l}\text { Absolución en casos que habrían condenado si no existiera CSI } \\
\text { - }\end{array}$ \\
& $\begin{array}{l}\text { Otorgar mayor credibilidad a los peritos forenses } \\
\text { Aumento conocimientos científicos }\end{array}$ \\
\hline Acusación & $\begin{array}{l}\text { Compensación por la ausencia o debilidad de las evidencias forenses } \\
\text { debido al desarrollo tecnológico }\end{array}$ \\
\hline Víctimas & Expectativa de evidencias forenses en todos los casos \\
\hline Delincuentes & Adoptar medidas para evitar el arresto debido a evidencias forenses \\
\hline Estudiantes & Elección de carreras relacionadas con las ciencias forenses \\
\hline
\end{tabular}

Fuente: Elaboración propia.

En el contexto del presente trabajo nos interesa el tipo de efecto CSI llamado "el efecto del educador" que establece que las series de ficción forense son algo así como las desencadenantes de una vocación profesional entre sus seguidores, lo que se traduciría en un efecto de llamada hacia estudios relacionados con la criminología y las ciencias forenses y con una cierta tasa de abandono cuando la carrera elegida no cumple con las expectativas de los estudiantes (Coley Dioso-Villa, 2007) (Cole y Dioso-Villa, 2009).

Diversos autores han afirmado que la exposición a los medios de comunicación contribuye de forma significativa a las expectativas de los estudiantes y a la selección de sus estudios universitarios (McCay, 2014). Así un 65\% de los estudiantes reconocen haber elegido una carrera de criminología debido a la influencia de las series de televisión (Barthe y cols, 2012). Ello puede explicar por qué en países como Estados Unidos o Canadá, la mayoría de los grados y posgrados relacionados con ciencias forenses se implantaron en las distintas 
universidades tras el estreno de la serie de televisión CSI en octubre del año 2000 (McMacnus, 2010).

Se ha comprobado también que dicha influencia sobre la elección de una carrera relacionada con las ciencias forenses aumenta con el número de horas como espectadores de este tipo de programas televisivos pasa el estudiante. Asimismo, aumenta también las expectativas que se tienen sobre los estudios que se van a realizar (McCay, 2014). Curiosamente, en un estudio realizado en 2019, los estudiantes encuestados no reconocían el consumo de series de ficción forense como un factor que hubiera influido en su elección de la carrera, aunque los mismos alumnos pensaban que la elección de sus compañeros sí que habían estado influenciada por los productos audiovisuales de ficción forense (CollicaCox y Furst, 2019).

Diversas encuestas realizadas a estudiantes estadounidenses concluyen que la mayoría de los estudiantes no vieron cumplida las expectativas que tenían cuando empezaron el programa de grado ya que la realidad de las ciencias forenses difiere considerablemente de lo mostrado en las distintas series de televisión (McMacnus, 2010) (McCay, 2014).

\section{DIFICULTADES ENSEÑANZA DE LA ASIGNATURA LABORATO- RIO CRIMINALÍSTICO}

La asignatura de Laboratorio Criminalístico es una asignatura cuatrimestral (6 ECTS) obligatoria para los alumnos inscritos en el itinerario de Ciencias Forenses del Grado de Criminología de la Universidad Pablo de Olavide y para todos los alumnos matriculados en el Doble Grado de Derecho y Criminología de la misma Universidad. Se imparte en el primer cuatrimestre del cuarto curso del grado y quinto curso del doble grado (Universidad Pablo de Olavide, 2015).

Esta asignatura refuerza la comprensión y aplicación de asignaturas estudiadas en cursos inferiores dentro de los módulos de Disciplinas Forenses y de Métodos y Técnicas de Investigación en Criminología. Por tanto, su aprovechamiento es muy útil para el desarrollo del perfil profesional en el ámbito forense-policial. Son competencias específicas de esta asignatura la realización, la evaluación y ejecución de proyectos e informes científico-técnicos relacionados con la criminalidad y asesorar en la interpretación de los informes forenses (Universidad Pablo de Olavide, 2019).

En la enseñanza de la asignatura de Laboratorio Criminalístico se combina la enseñanza tradicional, mediante exposición de los temas del programa y la realización de prácticas de laboratorio. El programa de la asignatura Laboratorio Criminalístico incluye el estudio de un total de ocho temas: un bloque que 
cuatro temas está dedicado a la gestión de la prueba pericial desde la toma de muestra hasta el momento del juicio oral. Dentro de este bloque de temas presentan especial dificultad de enseñanza y aprendizaje el tema dedicado al estudio de la fiabilidad de la prueba pericial. Es por ello por lo que más del 50\% de las actividades prácticas y de desarrollo programadas se dedican a dicho tema (Universidad Pablo de Olavide, 2019).

Como ejemplo de conceptos que se deben aprender, podemos citar: analito, señal instrumental, sensibilidad, límite de detección, límite de cuantificación, especificidad, precisión, exactitud, incertidumbre, material de referencia, patrón, calibrador. Asimismo, es indispensable que el alumno comprenda que debe desechar la concepción de que la ciencia forense es infalible e inmediata (Alonso Alonso, 2011). Por otro lado, hay que transmitir al alumno que los casos forenses suelen ser complejos de resolver y que, frecuentemente, requieren la participación de varios especialistas (Sosa Reyes, 2017).

El aprendizaje de la asignatura de Laboratorio Criminalístico se encuentra con problemas específicos derivados del perfil de los alumnos matriculados. Dichos problemas son fundamentalmente dos:

En primer lugar, debido a que los alumnos provienen mayoritariamente de un Bachillerato de Humanidades y Ciencias Sociales, la última vez que cursaron una asignatura de ciencias experimentales fue en el cuarto curso de educación secundaria obligatoria (Ley Orgánica 8/2013 de 9 de diciembre, 2013). Ello explica que muchos de ellos no tengan asimilados conceptos básicos en diversas materias científicas. Así, por ejemplo, no saben interpretar gráficas ni establecer si entre dos variables existe una correlación, carecen de formación en estadística o no manejan conceptos básicos en química como son ionización, solubilidad o acidez. Dicha situación exige al profesor que adopte algún tipo de estrategia didáctica que permita el aprendizaje de los conceptos propios de su asignatura teniendo en cuenta que en numerosas ocasiones será necesario explicar conceptos básicos desde cero.

En segundo lugar, el profesorado debe revertir el daño causado por tipo de conocimiento que han obtenido a partir de las series de ficción forense cuyo objetivo principal es entretener y no educar (Barthe, et al., 2012).

\section{APRENDIZAJE BASADO EN PROBLEMAS: AUDIOVISUALES TE- MÁTICA FORENSE}

El EEES ha promovido nuevos modelos educativos que renuevan metodológicamente las aulas universitarias, desarrollando estrategias didácticas activas que ponen el acento en el papel protagonista del alumno, responsable último 
de su proceso de aprendizaje, siendo responsabilidad del profesorado "elegir prudentemente las estrategias de aprendizaje, enseñanza y evaluación” (López Pérez, 2011). Los planes de estudio surgidos a partir de la implantación del EEES, han exigido que las diferentes asignaturas adapten sus metodologías de forma que los alumnos logren competencias imprescindibles para su futuro laboral. En la actualidad, se trata de que los alumnos "aprendan a aprender" de forma independiente y sean capaces de adoptar de forma autónoma la actitud crítica (Henríquez Hernández y cols, 2015).

El aprendizaje basado en problemas (ABP) es un método educativo que cumple con las exigencias del EES ya que combina la adquisición de conocimientos con el aprendizaje de competencias y el desarrollo de actitudes (Berkel, Scherpbier, Hillen, Van der Vleuten, 2010). El alumno a partir de la presentación de un problema debe identificar las necesidades de aprendizaje, buscar y procesar la información necesaria y aplicar esos conocimientos para resolver el problema planteado (Megías Fresno y Oñaderra Sánchez, 2013). Los alumnos se trabajan en grupos pequeños en los que se deben dividir el trabajo, compartir tareas, discutir y reflexionar sobre el problema planteado e integrar los diferentes contenidos de la materia para finalmente solucionar el problema. Durante todo el proceso son guiados por el profesor (Matos Lopes y cols, 2011). El esquema de trabajo en una metodología $\mathrm{ABP}$ se puede resumir en la figura 3. En general, los alumnos valoran positivamente el aprendizaje logrado con la metodología $\mathrm{ABP}$ a que entienden que la asimilación de contenidos es más duradera (López Pérez, 2011).

Figura 3. Esquema de metodología ABP

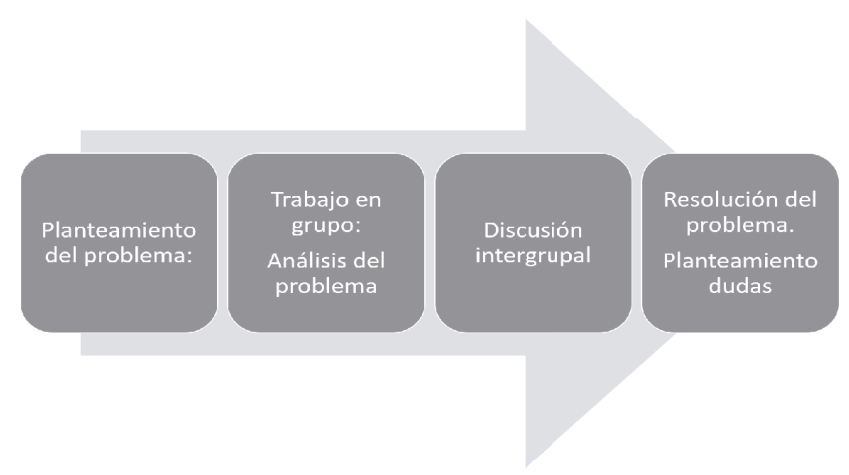

Fuente: Elaboración propia. 
La asignatura de Laboratorio Criminalístico resulta muy adecuada para la aplicación de la metodología ABP, ya que se pueden desarrollar actividades que implican la utilización de casos reales, la evaluación de evidencias y que exijan el manejo de concepto de relevancia estadística (Bergslien, 2006).

Se presenta, a continuación, una actividad ABP que se implantó para intentar solventar las dificultades de aprendizaje descritas en el apartado anterior. Como punto de partida de la actividad, se utilizó el visionado de un material audiovisual procedente de una serie documental de televisión para plantear el problema que los alumnos deberían resolver. Concretamente, se utilizó un extracto del capítulo 7 de la primera temporada de la serie documental "Making a murderer" de la plataforma Netflix, estrenada en 2015. En dicho video se muestra la deposición en juicio oral de dos peritos, uno oficial y otro de parte que declaran sobre la misma pericia. El problema planteado es el siguiente: ¿cuál de los dos peritos tiene razón? Los objetivos de la actividad son los siguientes:

- Evaluar el grado de preparación, la capacidad de transmitir adecuadamente la información solicitada y la imparcialidad de ambos peritos. Consecuentemente, deben decidir cuál de los dos, de acuerdo con la información disponible, tiene razón

- Comprender en qué consiste la cadena de custodia y evaluar en que ocasiones se rompe.

- Evaluación del grado de adecuación a la realidad de afirmaciones del tipo: "con un grado razonable de certeza científica"

- Comprensión del concepto límite de detección y límite de cuantificación

- Evaluación del significado que tiene un resultado negativo en el análisis químico de una muestra

- Comprender e interpretar los conceptos relacionados con el aseguramiento de la calidad en todas las etapas de la investigación criminal y desarrollar la capacidad de evaluarlos

- Conocer y comprender las diversas normas y guías internacionales aplicables a las diferentes áreas de trabajo de la Criminalística

- Conocer los parámetros que deben evaluarse para validar un método analítico de acuerdo con los requerimientos de calidad

Para el desarrollo de la actividad, se proyecta el video de forma que todos los alumnos lo vean de forma simultánea. Posteriormente, se forman grupos de 3-4 alumnos que deben discutir entre ellos cuál es la información necesaria para resolver el problema. En una segunda etapa, el profesor les suministra un cues- 
tionario (Tabla 3) que deben cumplimentar para cada uno de los peritos. Dicho cuestionario se ha diseñado con objeto de facilitar la resolución del problema.

Tabla 3. Cuestionario de orientación al alumno

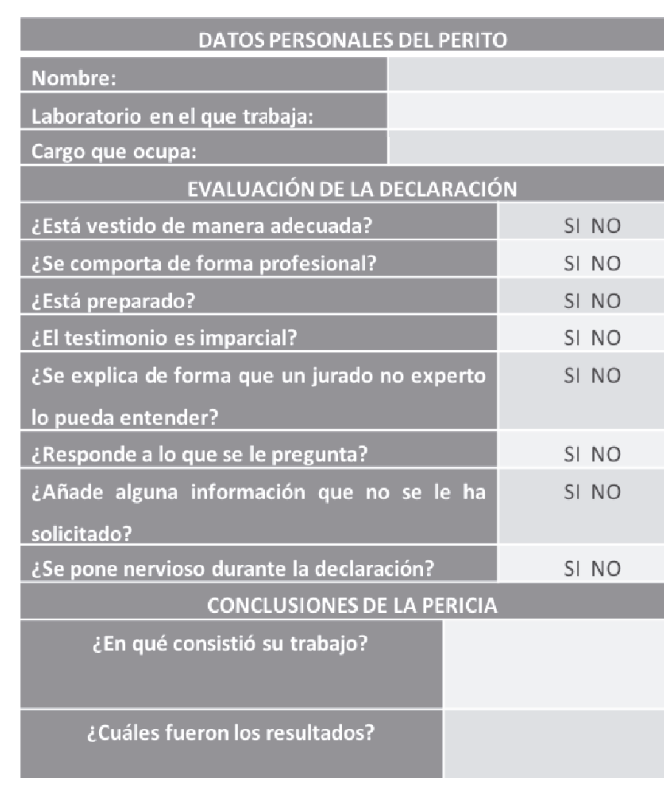

Fuente: Elaboración propia.

A continuación, se realiza una discusión intergrupal de forma que se alcancen unas conclusiones. Dichas conclusiones deben quedar recogidas en el formulario presentado en la Tabla 4. 
Tabla 4. Formulario de resolución del problema planteado

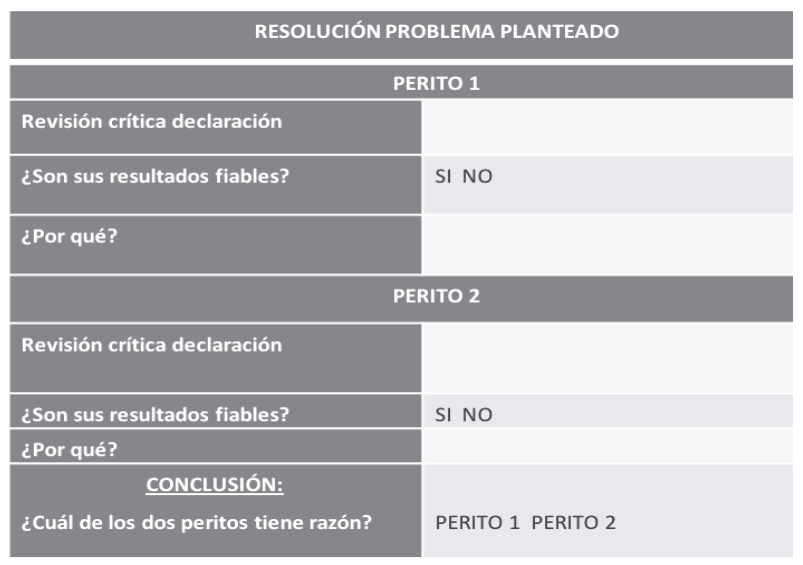

Fuente: Elaboración propia.

Finalmente, el profesor soluciona las dudas que hayan surgido y completa, en caso necesario, las respuestas que han proporcionado los distintos grupos.

La actividad descrita se ha llevado a cabo durante dos cursos académicos consecutivos 2017- y 2018-19. Se puede observar en la figura 4 que el promedio de las calificaciones obtenidas por los alumnos en las enseńanzas prácticas y de desarrollo se ha ido incrementando a partir de la introducción de la ABP presentada. A pesar de que estos resultados son preliminares, sí que podrían indicar que la ABP realizada ha sido eficaz y ha logrado el fin pretendido, es decir, se ha mejorado el aprendizaje de la asignatura

Figura 4 Promedio de las calificaciones obtenidas por los alumnos en las enseńanzas prácticas y de desarrollo

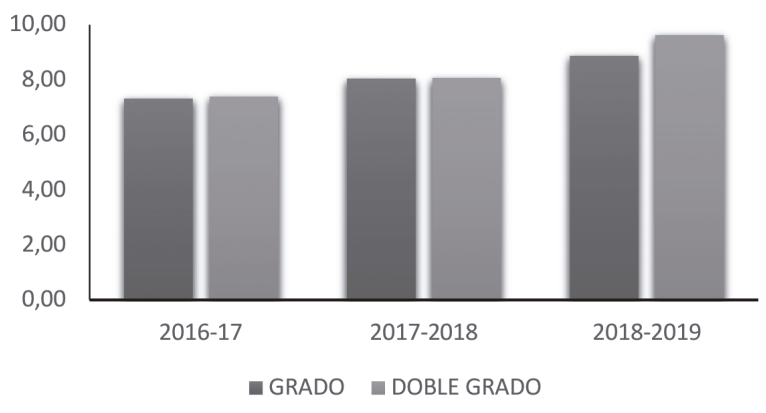

Fuente: Elaboración propia. 
El trabajo presentado tiene la limitación de no disponer aún de un instrumento adecuado que permita analizar la consecución de competencias por parte del alumnado. Queda pendiente el diseño de una rúbrica que permita calificar el proceso educativo. La rúbrica permite además que el alumno se implique en su propio progreso (Fernández-Martínez y cols, 2006) (Velasco-Martínez y Tojar-Hurtado, 2015).

\section{BIBLIOGRAFÍA}

Adler, T. (27 de 06 de 2011). Why TV procedurals also rule the world. Recuperado el 31 de 10 de 2020 de Deadline Hollywood:

https://deadline.com/2011/06/why-tv-procedurals-also-rule-the-world143539

Alonso Alonso, A. (12 de 2011). ADN forense, investigación criminal y búsqueda de desaparecidos. Recuperado el 10 de 07 de 2020, de https://www.sebbm.es/archivos_tinymce/diciembre2011_antonioalonso.pdf Anderson, J., Mangels, N.,Langsam, A. (2009). The challenges of teaching criminological theory: can academia deliver what the media promises? Crim Justice Stud Crit J Crime Law Soc, 22, 223-236.

Área de Calidad.Universidad Pablo de Olavide de Sevilla. (01 de 2020). Informe sobre el perfil del alumnado de nuevo ingreso. Titulo oficial de grado en Criminología.curso académico 2019-20. Recuperado el 06 de 07 de 2020, de:

https://www.upo.es/cms1/export/sites/upo/area-calidad/documentos/servicios/nuevo-ingreso/grados/15-16/INFORME-PERFIL-NUEVO-INGRESO-GCRI-15-16-.pdf

Avanzas Alvarez, E. (2016). Grisom, Lisbeth, Perdida Amy y SUDES: Los textos criminales del siglo XIX como herramienta de análisis social. I Encuentro científico Asociación de Jóvenes Investigadores en Estudios Socioculturales. Oviedo: Universidad Oviedo.

Baranowski, A., Burkhardt, A., Czernik, E.,Hetch, E. (2018). The CSI education effect: Do potential criminals benefit from ? Int J Law Crime Justice, 86-97.

Barthe, E., Leone, M., , Lateano, T. (2012). Commercializing success: The impact of popular media on the career decisions and perceptual accuracy of criminal justice students. Teaching in higher education, 18 (http://dx.doi.org/10.1080/13562517.2012.694099), 13-26.

Bergslien, E. (2006). Teaching to avoid de CSI effect. J Chem Educ, 83, 609691. 
Berkel, H., Scherpbier, A., Hillen, H., Van der Vleuten, C. (2010). Lessons from problem-based learning. Oxford: Oxford University Press.

Budlowe, B., Botrell, M., Bunc, S., Fram, R.,Harrison, D. (2009). A perspective on error, bias and interpretation in the Forensic Sciences and direction for continuing advancement. J Forensic Sci, 54(4), 798-809.

California Association of Criminalists. Criminalistics information. Recuperado el 28 de 09 de 2020 de:

https://www.cacnews.org/membership/criminalistics.shtml

Cole, S., Dioso, R. (2005). Law and the lab: Do TV shows really affect how juries vote? Let's look at the evidence. Wall Street J, W13.

Cole, S., Dioso-Villa, R. (2007). CSI and its effects: media, juries and the burden of proof. New England Law Review, 435-469.

Cole, S., Dioso-Villa, R. (2009). Investigating the "CSI effect" effect: media and litigation crisis in criminal law. Stanford Law Rev, 61, 1335-1374.

Collica-Cox, K.,Furst, G. (2019). It's not the CSI Effect: Criminal justice students' choice of major and career goals. Int J Offender Therapy Comparative Criminology, 63 (Doi:10.1177/0306624X19834414), 2069-2099.

ESC. (21 de 04 de 2016). European Society of Criminology. Recuperado el 09 de 07 de 2020, de https://www.esc-eurocrim.org/index.php/the-esc/constitution

Farré, A., Torrens, M., Baños, J.,Farré, M. (2017). CSI y la medicina forense. Cuadernos de la fundación Dr. Antonio Esteve, 35, 99-103.

Fernández-Martínez, M., García-Sánchez, J., Decaso Fuentes, A., Fidalgo Redondo, R.,Arias Gundín, O. (2006). El aprendizaje basado en problemas: revisión de estudios empíricos internacionales. Revista de Educación, 341, 397-418.

Gialamas, D. (2000). Criminalistics. En J. Siegel, Encylopedia of Forensic Sciences (págs. 471-474). Cambridge, EEUU: Academic Press.

Henríquez Hernández, L., Pérez Luzardo, O., Domínguez Boada, L., Almeida González, M., Zumbado Peña, M. (2015). Aplicación de la metodología de aprendizaje basado en problemas a la enseñanza de la Veterinaria Legal. Revista de docencia universitaria, 13, 171-188.

Jermyn, D. (2013). Labs and slabs: Television crime drama and the quest for forensic realism. Studies in History and Phylosophy of Biological and Biomedical Sciences, 44, 103-109.

Kirby, D. (2013). Forensic fictions: Science, television, production and modern storytelling. Studies in History and Philosophy of Biological and Biomedical Sciences, 44, 92-102. 
Kluger, S. (21 de 10 de 2002). How science solves crime. Time, págs. 36-43. Koch, J., , Porter, G. (2012). The CSI effect at university: forensic science students television viewing and perception of ethical issues. Australian J Forensic Sci 44, 381-391 DOI:10.1080/00450618.2012.691547.

Ley Orgánica 8/2013 de 9 de diciembre. (2013). para la mejora de la calidad educativa. $B O E, 25$, de 10 de diciembre de 2013.

López Bautista, S. (2018). La televisión y la idealización de la Criminalística. El segundo efecto CSI y sus consecuencias en la Universidad. Universidad Católica de Murcia.

López Pérez, G. (2011). Empleo de metodologías activas de enseñanza para el aprendizaje de la Química. Revista de Enseñanza Universitaria, 37, 13-22.

Matos Lopes, R., Silva Filho, M., Mardsen, M., Guimaraes Alves, N. (2011). Aprendizagem baseada em problema: Uma experiencia no ensino de Química Toxicológica. Quim Nova, 34, 1275-1280.

McCay, M. (2014). CSI Effect and Forensic Science/Criminal Justice Degree Programs. Recuperado el 03 de 07 de 2020, de: https://aquila.usm.edu/dissertations/298

McMacnus, S. (2010). Influence of the CSI effect on education and mass media. (MA Thesis ed.). Orlando: University of Central Florida.

Megías Fresno, A,Oñaderra Sánchez, M. (2013). Aplicación del “Aprendizaje basado en problemas" (APB) a la docencia de la asignatura Bioquímica en el Grado en Biología. Reduca (Biología), 6, 1-11.

Ministerio de Ciencia, Innovación y Universidades. (2019). Datos y cifras del Sistema Universitario Español. Recuperado el 14 de 07 de 2020, de https://www.ciencia.gob.es/stfls/MICINN/Universidades/Ficheros/Estadisticas/datos-y-cifras-sue-2018-19.pdf

Ministerio de Universidades. (26 de 06 de 2020). Estadisticas e informes universitarios. Recuperado el 01 de 11 de 2020 de Estadísticas de estudiantes: https:/www.ciencia.gob.es/portal/site/MICINN/

QAA. (2019). Quality assurance agency for higher education: Subject benchmark statement: Criminology. Recuperado el 08 de 07 de 2020, de www.qaa.ac.uk R.D. 858/2003 de 4 de julio. (2003). por el que se establece el título universitario oficial de Licenciado en Criminología y las directrices generales propias de los planes de estudios conducentes a su obtención. BOE de 08 de Julio.

Sarver, R., Sarver, M,Dobbs, R. (2010). Choosing criminal justice: Factors contributing to selecting criminal justice as a major. J Criminal Justice Law Rev, 2, 57-67. 
Sosa Reyes, A. (2017). Del laboratorio al juzgado. Enseñanza de las ciencias para el ejercicio forense. Educación Quimica, 28, 238-245.

Stintson, V., Patry, M., Smith, S. (2007). But what is the CSI effect? Canadian J Police Security Services, 187-19.

Ternero Martin, J. (2019). El estado de las enseñanzas oficiales de Criminología en las universidades andaluzas. En La Criminología que viene. Resultados del I encuentro de jóvenes investigadores en Criminología (págs. 357-369). Red Española de Jóvenes Investigadores en Criminología.

UNESCO. (1957). The University Teaching of Social Sciences: Criminology. Paris: UNESCO.

Universidad de Sevilla. (25 de 02 de 2011). Memoria de Verificación del Grado en Criminología. Recuperado el 15 de 07 de 2020 de:

http://webapps.us.es/fichape/Doc/MV/218_memverif.pdf

Universidad Pablo de Olavide. (2015). Resolución de 14 de octubre de 2015, de la Universidad Pablo de Olavide por la que se publica el plan de estudios de Graduado en Criminología (BOE de 23 de noviembre de 2015). Recuperado el 15 de 07 de 2020, de

https://www.upo.es/cms2/export/sites/facultades/facultad-derecho/es/ofertaacademica/grados/grado-en-criminologia/descargas/BOE-Plan-de-EstudiosGrado-Criminologia-FD-UPO.pdf

Universidad Pablo de Olavide. (09 de 2019). Guía docente asignatura Laboratorio Criminalistico. Recuperado el 15 de 07 de 2020, de

https://www.upo.es/cms2/export/sites/facultades/facultad-derecho/es/estudiantes/descargas/GUIAS_DOCENTES/2019-2020/grado-criminologia/opt-semestre1/104033-LABORATORIO-CRIMINALISTICO.pdf

Velasco-Martínez, L.,Tojar-Hurtado, J. (2015). Evaluación por competencias en la educación superior. Uso y diseño de rúbricas por los docentes universitarios. En AIDIPE (Ed.), Investigar con y para la sociedad (Vol 2). Bubok Publishing SL.

Vicary, A., Zaikman, Y. (2017). The CSI effect; An investigation into the relationship between watching crime shows and forensic knowledge. North American J Psychology, 51-64. 



\title{
MÁS CONTRIBUCIONES A LA BIBLIOGRAFÍA INGLESA SOBRE CANARIAS: EL TEXTO DE DANIEL J. BROWNE (1804-1867), PRIMER NATURALISTA NORTEAMERICANO EN EUROPA
}

\author{
Ma Isabel González Cruz \\ Universidad de Las Palmas de Gran Canaria
}

\begin{abstract}
Resumen
En este capítulo comentaremos la obra Letters from the Canary Islands, publicada en Boston en 1834 por Daniel Jay Browne. Este naturalista norteamericano nos narra las experiencias de su visita al archipiélago y describe aspectos de su naturaleza, su historia y sociedad, recurriendo incluso a interesantes estrategias de intertextualidad poética.
\end{abstract}

Palabras clave: Literatura de viajes, bibliografía inglesa sobre Canarias, naturalistas.

\begin{abstract}
This chapter focuses on Daniel Jay Browne's work Letters from the Canary Islands, published in Boston in 1843. The text offers an account of this American naturalist's visit to the Canaries, whose natural wealth he describes as well as their history and social aspects, resorting to interesting strategies of poetic intertextuality.
\end{abstract}

Keywords: Travel literature, English bibliography on the Canaries, naturalists.

\section{INTRODUCCIÓN}

Tras publicar en 2002 nuestras Notas para una bibliografia inglesa sobre Canarias, son varias las obras, antiguas y recientes, que hemos ido localizando en las últimas décadas y que, por distintas razones, no pudieron ser incluidas en aquella primera catalogación ${ }^{1}$. A lo largo de estos años, hemos dedicado sendos

1 Registramos y comentamos entonces un total de 300 títulos de libros o artículos publicados en inglés sobre cualquier aspecto relacionado con Canarias en cualquier época, clasificándolos en 6 categorías: relatos de viaje; guías turísticas; estudios climático-sanitarios; obras de ficción; estudios de carácter histórico, sociocultural o lingüístico; y estudios sobre la naturaleza. Estos últimos eran, con diferencia, los más abundantes, por lo que tuvimos que limitarlos cronológicamente, 
trabajos a dar a conocer esas "nuevas" publicaciones, sin duda relevantes, con las que intentamos actualizar en lo posible este interminable catálogo bibliográfico. Así, por ejemplo, en 2008, supimos de la publicación de un libro que, de manera novelada y un tanto humorística, relataba las experiencias de un turista escocés contemporáneo, David Addison, en un accidentado viaje a la 'isla bonita' (González-Cruz 2017). En 2011 dimos a conocer el texto de la científica norteamericana Alice Carter-Cook sobre los aborígenes canarios, que había sido publicado en 1900 (González-Cruz 2011c). Al año siguiente, descubrimos otra novela inglesa ambientada en Canarias que había sido publicada en 1962 por el reconocido escritor y periodista británico Norman Lewis, bajo el título The Tenth Year of the Ship. A Novel. Poco después, localizamos y comentamos once nuevos registros para esa bibliografía en lengua inglesa sobre Canarias. Se trataba de siete relatos de viaje, dos guías turísticas, una obra de ficción contemporánea de la conocida periodista británica Celia Brayfield y un estudio lingüístico (véase, González-Cruz 2014). Pero sin duda el mayor y más reciente descubrimiento ha sido el de la existencia de un considerable número de novelas rosa y románticas, ambientadas total o parcialmente en las islas, y publicadas entre 1955 y 2011. Este corpus bibliográfico ha sido objeto de estudio interdisciplinar en el marco de un Proyecto de Investigación ${ }^{2}$ (cf. GonzálezCruz 2015, 2018, 2019, 2020; González-Cruz y Vera-Cazorla 2020, entre otros muchos trabajos).

Como indica el subtítulo, en este capítulo centraremos nuestra atención en una de esas obras que escaparon nuestra catalogación de 2002: un volumen con las cartas escritas por el primer naturalista y agrónomo norteamericano que visitó territorios europeos (incluido el archipiélago) durante el ochocientos, Daniel Jay Browne. Su testimonio constituye otra interesante contribución al amplio corpus textual anglo-canario, fruto de los estrechos vínculos establecidos a lo largo de la historia entre Canarias y el mundo anglosajón.

\section{DANIEL JAY BROWNE Y SUS LETTERS FROM THE CANARY ISLANDS}

Publicadas como libro en Boston en 1834, bajo el título de Letters from the Canary Islands, estas cartas cuentan con una versión española que salió a la luz en 2005, editada por Juan José Cruz y Manuel Hernández, cuya traducción

incluyendo solo los publicados hasta 1981. (Véase justificación al respecto en González-Cruz 2002, pp. 26-28).

2 Discursos, género e identidad en un corpus de novela rosa ambientada en Canarias y otras islas atlánticas, financiado por el MINECO - Gobierno de España (FFI2014-53962-P). 
vamos a utilizar para nuestras citas. Como bien señalan estos profesores en su introducción, el interés del texto de Browne es doble puesto que, por un lado, constituye un testimonio fundamental sobre las Islas Canarias en un momento crítico de su historia, cuando "languidecía el comercio vinícola" y todavía se encontraban en sus inicios las exportaciones de la cochinilla, al tiempo que "la crisis socio-económica eclosionaba con toda su crudeza" (2005, p. 20). Pero, además, esta obra nos ofrece "una visión foránea nueva en una época anterior a la de los grandes viajeros británicos al Archipiélago", constituyendo también un precedente a las obras de otros autores norteamericanos de cuyas visitas y escritos tenemos noticias, como son las de Charles W. Thomas (1860), Joseph H. Reading (1890), Peggy True (1959), Richard Walter (1956), John Harms (1965), Kennedy (1979) y Gunn (2011) (cf. González-Cruz 2019). ${ }^{3}$

En las siguientes secciones ofreceremos los datos que hemos podido reunir acerca de la vida de Daniel Jay Browne, así como unas breves pinceladas sobre su obra. Su interés para la ya abundante bibliografía en lengua inglesa sobre Canarias es indudable. Su carácter multimodal es, además evidente, pues sin dejar de ser un libro de viajes, constituye a la vez un estudio científico y etnográfico.

\subsection{DANIEL JAY BROWNE: BIOGRAFÍA}

Tras una ardua y persistente búsqueda en Internet, no hemos podido ponerle rostro a Daniel Jay Browne, pero sí hemos conseguido recabar algunos datos acerca de la vida y la obra de este naturalista. Sabemos que estudió en Harvard y se especializó en estudios agrícolas. En 1830 fundó la revista científica The Naturalist. Entre 1833 y 1835 viajó por las islas del Caribe, Europa y Sudamérica. Desde 1836 hasta 1842 trabajó en varios proyectos de ingeniería agrícola en Nueva York y en Cuba. Perteneció a diversas asociaciones de su especialidad, como la American Agricultural Association de Nueva York. Además, fue editor de la revista American Agriculturalist Magazine entre 1845 y 1851.

Entre 1852 y 1853 trabajó en la Oficina del Censo de los Estados Unidos, y de ahí pasó a la U.S. Patent Office, donde trabajó entre 1853 y 1859. En principio no era más que un empleado del Departamento de Agricultura de dicha Oficina de Patentes del Gobierno de los Estados Unidos, pero sabemos que desde junio de 1853 hasta 1859 llegó a ejercer como director de ese departamento. A través de diversas fuentes consultadas, hemos sabido que es pre-

3 Véase González-Cruz 2009 para más información sobre las obras de True, Walter y Harms; y González-Cruz (2019) para un estudio de las novelas de Gunn y Kennedy. 
cisamente esa Oficina de Patentes la que lo envía a Europa entre 1854 y 1855 para que obtuviera información de interés sobre temas relacionados con la agricultura, en concreto sobre la producción del lino, así como para conseguir semillas y esquejes de plantas. Por este motivo está considerado como el primer explorador agrónomo oficial de los Estados Unidos y se sabe que fue responsable de la realización de numerosos informes oficiales entre 1853 y 1861 . Nuestras pesquisas en Internet nos llevaron a un sitio web ${ }^{4}$ donde se recoge la historia de la Oficina de Patentes de los Estados Unidos. En ella, concretamente en el capítulo 26, encontramos algunas anécdotas sobre Browne. Se dice, por ejemplo, que en el diario del Juez Mason consta que, en algunos aspectos, Browne era un empleado modélico, pero que en otros era un verdadero incompetente. Al parecer, uno de los jefes que estuvo a cargo de la Oficina de Patentes, llevando el puesto con aparente éxito, un tal Mr Holloway, podría ser hoy juzgado por su falta de ética profesional. Al llegar a Washington, $\mathrm{Mr}$ Holloway se encontró con que, debido a la guerra, era muy difícil conseguir casas en alquiler. Aunque se sabe que en 1855 Daniel Jay Browne vivía en una especie de pensión regentada por Mrs Mary Surrats, ya en 1861 poseía una hermosa casa que Mr. Holloway deseaba alquilar. Por este motivo se llegó a un acuerdo, según el cual la Oficina de Patentes pagaría a Browne un sueldo de tres mil dólares al año para que viajase por toda Europa con el fin de buscar información que fuera relevante para los granjeros y agrónomos del país. De ese modo, mientras su casa de Washington estuviera libre, se la alquilaría a Mr. Holloway por el razonable precio de 500 dólares al año. Se añade, además, en este capítulo, que el único informe que Browne realizó durante todo este periodo de su encargo especial por Europa fue un artículo sobre el lino, que se publicó en la sección de agricultura del Informe Anual de 1861 y que, posteriormente, resultó que había sido copiado de un libro inglés antiguo. Ignoramos hasta qué punto es fiable esta información y nos limitamos a transcribirla del original.

El viaje a Canarias de Browne, sin embargo, tiene lugar bastante antes de estas fechas, en concreto lo inicia en julio de 1833 y creemos que también pudo ser motivado por algún tipo de encargo oficial, ya que, en la carta introductoria con la que comienza el libro que aquí nos ocupa, Browne hace referencia a la petición recibida por parte de "varios individuos bajo cuyos auspicios he tenido el honor de actuar, de que elaborase una memoria informal de los

4 cf. http://www.myoutbox.net/popch26.htm 
principales acontecimientos de mi último viaje” (1834, p. 3). De hecho, esta primera carta comienza con la relación de nombres de 40 caballeros a los que se dirige expresamente para presentar su escrito, un texto en el que seguramente encontrarán, les dice, "muchas imperfecciones en cuanto al estilo y la disposición, pero al no pretender alardear de excesivo mérito, espero que puedan escapar de la severidad de vuestra crítica, no buscada pero quizá merecida” (1834, p. 3).

\subsection{LETTERS FROM THE CANARY ISLANDS}

Esta obra se puede clasificar básicamente como el libro de viajes de un naturalista interesado en aspectos de índole más bien científica, como la topografía, la medición trigonométrica del Teide o la historia natural del archipiélago. No obstante, el autor también incluye ocasionalmente sus impresiones personales e incluso sentimientos, como cuando al dejar el puerto de Nueva York escribe:

Es difícil describir las sensaciones que le golpean a uno cuando está despidiéndose de su hogar y de su tierra, aunque solo sea por un corto espacio de tiempo; aún más difícil resulta describir las dolorosas emociones que se desencadenan cuando uno mira por última vez la costa natal, dejando atrás a tus amigos, tu familia y tu país por un tiempo indefinido, y quizá para siempre. El primero de estos sentimientos lo he tenido muchas veces; el segundo, nunca hasta hoy (Browne 1834, p. 9).

Las referencias personales incluyen también algunos datos sobre sus experiencias viajeras anteriores, como cuando leemos:

Mis correrías a lo largo de los últimos quince ańos me han llevado a muchos lugares de nuestro país y de otras partes de América. He viajado por mar y tierra; he estado lejos de mi hogar, mi familia y mis amigos y a menudo me he sentido embargado por emociones que me aprisionaban el corazón. Pero entonces seguía estando en mi país, y me confundía con gentes que seguía considerando mías. Permanecía en una tierra cuya grandeza era conocida en otras latitudes. [...] Pero ahora, ¿̇a dónde? A lugares bellos y encantadores, engalanados con antiguos monumentos al genio y al arte, puntos renombrados por modernas obras grandiosas, y habitados por pueblos libres, ilustrados e inteligentes. Empero, también iba a regiones doblegadas por el despotismo y la superstición, a naciones sumisas en prejuicios espantosos, degradadas y desmoralizadas hasta un grado ínfimo, y en absoluto accesibles a la persuasión o a la civilización (p. 42). 

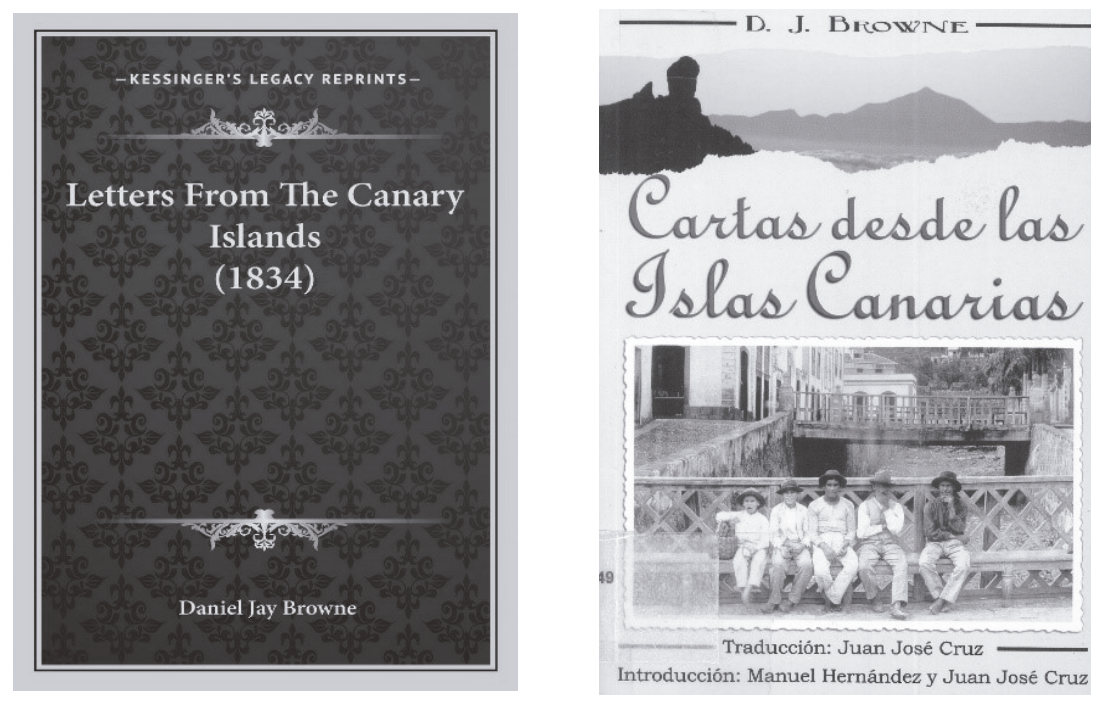

Gracias a lo que nos va contando en las diecinueve cartas que componen su libro, sabemos que el martes 9 de julio de 1833 salió de Nueva York, a bordo del Panope, con destino a Tenerife. Venía entonces como empleado del Departamento de Agricultura de la Oficina de Patentes del Gobierno de los Estados Unidos. Al amanecer del 10 de agosto de 1833 ya consigue avistar el Pico del Teide e incluso las casas y árboles de la isla de Tenerife. Tras más de una semana de cuarentena, por fin desembarcan el día 18 en el entonces Puerto de La Orotava (hoy Puerto de la Cruz). La emoción de Browne ante la llegada a nuevas tierras se hace evidente cuando escribe:

Uno no puede expresar todas las emociones que lo embargan cuando describe por primera vez los rasgos de ese país. Los ojos se afanan por contemplar todo lo que se encuentra a la vista y en medio de esta agitación los objetos, aunque ya conocidos, aparecen como i de algo totalmente nuevo se tratara. Antes de que uno se familiarice con ellas, las cosas van revelando su verdadera naturaleza y es difícil que uno pueda apreciarlas como las conocíamos en otras latitudes (p. 59).

En esta localidad se aloja en casa del conocido caballero inglés Mr. Alfred Diston, que unos años antes había publicado un original trabajo sobre las ropas de los isleños (cf. Diston 1829), y cuya hospitalidad y atenciones no olvida agradecer en la carta número XV. Tras la introducción y la narración de los pormenores del viaje —en el que, como buen naturalista, se ocupa de hacer 
mediciones y todo tipo de observaciones con respecto a la temperatura del aire y del mar, la fauna que localiza en él, o los fenómenos atmosféricos que se experimentan durante el periplo- el relato de Browne se centra sobre todo en la descripción de la isla de Tenerife, sus visitas a Santa Cruz, Chasna - el pueblo "que más se parece a los de Nueva Inglaterra" (p. 92) — y Candelaria, así como sus tres subidas al Teide, cuya altura intenta medir. Los cuatro últimos capítulos o cartas nos informan respectivamente de la topografía, la historia natural, la situación social y la historia de las islas.

A largo del texto, Browne se nos va revelando como un hombre sensible a lo que ve en su entorno e interesado por todo lo que va descubriendo. Así, tras su visita a Santa Cruz describe esta capital como

... una ciudad agradable bastante extensa; según el último censo tiene 6.400 habitantes. Parece más pobre que este lugar [Puerto de la Cruz] y fui objeto del acoso de unos mendigos muy molestos. Un amigo me señaló el punto exacto donde Nelson sufrió la única derrota en su gloriosa carrera. Nadie que alguna vez haya leído sobre este conflicto tan memorable podría contemplar el lugar sin estar poseído por un sentimiento de genuino interés (p. 67).

Esa sensibilidad de Browne le permite apreciar la belleza de la naturaleza y el encanto de los paisajes, como el que encuentra en su excursión a Chasna, cuando escribe en la carta XI:

Por aquí se llega a un vallecito precioso regado por arroyos, ubérrimo con "naranjas doradas", "duraznos rosados" y "viña generosa". También aquí podemos hallar miles de insectos dorados y lagartos brillantes echados al sol. Y también aquí un sinnúmero de gorjeos. "Campan por el aire" (p. 87).

Otro detalle curioso, que parece haber pasado inadvertido al traductor al español del texto original, es la inclusión frecuente en el texto de numerosas citas poéticas y versos de reconocidos autores literarios ingleses. De hecho, la vena poética de Browne y su formación literaria se ponen de manifiesto desde la primera página del libro, donde se incluye, a modo de dedicatoria, el siguiente extracto que resultó estar tomado del poema de Shakespeare, "Autumn", que reproducimos abajo, en sus versiones inglesa y española: 
"Wilt thou fly

With laughing Autumn to the Atlantic isles,

And range with him the Hesperian fields, and see,

Where'er his fingers touch the fruitful grove,

The branches shoot with gold; where'er his step

Marks the glad soil, the tender clusters grow

With purple ripeness, and invest each hill

As with the blushes of an evening sky?"

¿Volarás

con el risueño otoño a las islas atlánticas?

¿Correrás con él por los campos de Hespérides?

¿Contemplarás donde sus dedos el huerto ubérrimo

acarician, cómo aflora el oro en las ramas?

¿Dónde deja su huella en la tierra alegre?

¿Cómo crecen los racimos con madurez púrpura?

¿Cómo reviste a cada colina cual sonrojo de un atardecer?

Pero no es este el único poema que encontramos en el texto. Así, en la carta XI, al llegar a Los Silos, nos cuenta que pasa la noche en casa de Mr. John Cologan, que procede de La Orotava, y nos confiesa que allí disfruta de "una de las escenas más tentadoras de la existencia”. Para ilustrarlo inserta el siguiente poema, que — según hemos comprobado- resultó ser un extracto del poema "Autumn" de John Milton, y que Browne dedica a un lugar donde

Los racimos claros

son visibles en medio del frondor, o la llama ardiente,

o el rayo transparente mientras la perfección exhala

el vívido rocío blanco sobre la turgencia.

Así brillan con célebre licor

Tornados en sabor por el rayo que conturba.

Los jóvenes campesinos y las doncellas en los campos

Se regocijan en los primeros agüeros otoñales

Con paseos inspirados y palabras sobre la cercana vendimia. (p. 88)

The clusters clear,

Half through the foliage seen, or ardent flame,

Or shine transparent; while perfection breathes

White o'er the turgent film the living dew.

As thus they brighten with exalted juice,

Touch'd into flavour by the mingling ray; 
The rural youth and virgins o'er the field, Each fond for each to cull th' autumnal prime, Exulting rove, and speak the vintage nigh. (Letter XI)

Son diversas las ocasiones a lo largo de todo el texto en las que Browne recurre a la poesía. Lo hace, por ejemplo, para contrastar los hábitos de los hábitos de los isleńos, como pueblo del sur, con los de las gentes del norte. Así lo vemos cuando inserta un extracto del poema "The Fireside" de Nathaniel Cotton, en una sección que dedica a las diversiones:

Diversiones. Al igual que sus padres españoles y otros pueblos del sur, estos isleños son muy poco hogareños. Por descontado el clima los incita a hacer vida al aire libre al fresco de la tarde, con todas las diversiones que esa actividad conlleva y que dan lugar a unos hábitos muy distintos de los que se prodigan en torno a

"La familia y el hogar donde en amor se agotan nuestros días; sin vecino inoportuno que aquí penetre ni extraño que nos incomode, para ajar nuestras dichas y alegrías. (p. 151)

o our own family and fire,

Where love our hours employs;

No noisy neighbour enters here;

Nor intermeddling stranger near, To spoil our heartfelt joys.

Otros versos insertados en el texto que hemos podido identificar son los pertenecientes al poema "The Rainbow" de T. Campbell, cuando escribe:

Or mirror'd in the ocean vast A thousand fathoms down!

(Letter XI) "reflejada en el vasto océano

Miles de metros por debajo"

(p. 87)

Igualmente, en la Carta XIII encontramos dos versos de James Thomson tomados del poema Spring de la obra titulada The Seasons:

In fair proportion running from the red To where the violet fades "en proporción suave, del rojo hasta donde el violeta se disuelve"

(p. 99) 
O bien los tomados de Thomas Gray en la carta IV:

Full many a gem of purest ray serene

The dark unfathomed caves of ocean bear

(Letter IV)
"Muchas gemas del más puro rayo sereno

contiene las cuevas desconocidas del océano"

Su amor a la naturaleza le lleva también a lamentar el deterioro que sufre el Jardín Botánico, del que escribe:

He disfrutado algunas de mis horas más placenteras caminando por el Jardín Botánico de Durazno, admirando no pocas plantas foráneas que crecen sin auxilio humano. También pasé momentos tristes al comprobar el abandono en que ha estado sumido el recinto. Lo fundó el marqués de Nava, quien había sugerido que las Islas, por su condición, sirvieran como vivero de plantas de la India y de América antes de introducirlas en Europa. Así que puso en ejecución su proyecto, con éxito considerable durante varios ańos. Pero los gastos eran tan onerosos que se vio obligado a abandonarlo. Humboldt elevó propuestas al gobierno prusiano para adquirirlo y continuar la obra, pero como quiera que ningún extranjero puede comprar tierra en España, la petición fue abandonada. Haciendo gala de su generosidad, el marqués se la obsequió al rey de Espańa a condición de que se cuidara. El ofrecimiento se aceptó, pero la falta continuada de atención lo ha conducido al abandono. Ahora misma está alquilado por una suma ridícula, y no hacen casi anda, por no decir nada, aparte de convertir la finca en un huerto (p. 97).

No parece que Browne tuviera ocasión de visitar el resto del archipiélago, puesto que no menciona nada al respecto. De hecho, cuando en la carta XVI, sobre la topografía del archipiélago, dedica sendos párrafos a cada una de las islas, nos advierte:

Aunque está lejos de mi intención y poder ofrecer pormenores detallados de estas islas, quizás unas cuantas observaciones sobre la historia y la topografía no resulten superfluas, teniendo en cuenta que solo puedo hablar a resultas de varias semanas que he pasado en esta isla. Lo que se refiere al resto se debe deducir de opiniones autorizadas (pp. 113-14).

Tampoco sabemos en qué fecha regresa a los Estados Unidos, ni cuánto tiempo estuvo en las islas. Lo único que menciona sobre el trayecto de su viaje aparece en una nota a pie de página en la que nos aclara algo más sobre la ruta 
seguida, al señalar: "Nótese que después de pasar unas semanas en Tenerife, recalé en la Costa occidental de África y luego visité algunas partes de España, Francia, Sicilia y las islas balcánicas e intenté viajar por Italia, Grecia Turquía y Egipto. Pero al llegar a Sicilia, circunstancias ineludibles me obligaron a regresar precipitadamente".

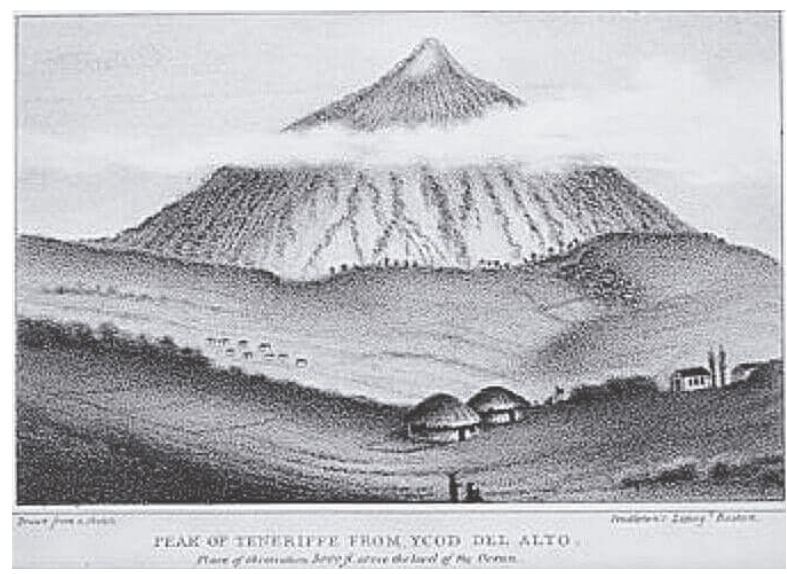

Fuente: Daniel Jay Browne (1834). Letters from the Canary Islands.

Observamos también que los dos últimos textos, los dedicados a la situación social y a la historia del archipiélago, junto con la Introducción, están firmados en Boston, en mayo de 1834, ya de vuelta a casa; mientras que los demás fueron redactados in situ, ya fuera a bordo del Panope o en distintos puntos de la isla de Tenerife. Es muy posible que, para escribir los informes globales de esos últimos capítulos, tomara datos de diversas publicaciones. De hecho, son varias las referencias y las citas que toma de Humboldt a lo largo de la obra, especificándolo a pie de página.

Como científico, Browne fue muy prolífico, pues, además de los informes que se le atribuyen, fue autor o coautor de diversos libros, la mayoría de los cuales son accesibles actualmente en Internet. El listado es relativamente largo, como puede verse en el apartado final de este capítulo con la bibliografía citada, donde incluimos una sección con la relación de títulos que hemos podido localizar.

La presentación de su obra sobre Canarias en forma de cartas, así como la utilización en el título de este término, no es de extrañar, ya que desde el siglo XVII era habitual que los experimentos y los informes científicos se dieran a conocer entre la comunidad científica por este medio epistolar (cf. Gotti 2006a, 
2006b). A este respecto, Browne señala que había optado por presentar públicamente a modo de cartas unidas de manera seriada un resumen de las observaciones realizadas durante su periplo, con aquellos comentarios, siempre escritos en el lugar de los hechos al finalizar cada jornada, que pudieran resultar ilustrativos o amenos. De este modo, cada una de las diecinueve cartas aparece siempre firmada con el lugar y la fecha, casi siempre correlativas, siguiendo el desarrollo del viaje en el tiempo, entre la salida de Nueva York en julio de 1833 y la finalización de la estancia en Tenerife en octubre del mismo año. Las excepciones las constituyen la primera carta, fechada ya de vuelta en Boston en mayo de 1834, al igual que las dos últimas cartas, la XVIII y la XIX, esta última, lógicamente por error, fechada el 29 de mayo de 1824 en lugar de 1834. El siguiente cuadro resume e ilustra la distribución de las cartas o capítulos, cuyos títulos traducimos, mostrando además cómo se desarrolló el viaje en cuanto a tiempo y espacio.

Tabla 1: Las 19 cartas escritas por Browne, con sus títulos, lugares y fechas de escritura

\begin{tabular}{|l|l|l|}
\hline Carta & TÍTULO & LUGAR Y FECHA \\
\hline I & Introducción & Boston, mayo 1834 \\
\hline II & Viaje desde Nueva York a Tenerife & 11 julio 1833 \\
\hline III & Continuación viaje a Tenerife & 16 julio 1833 \\
\hline IV & Continuación viaje a Tenerife & 23 julio 1833 \\
\hline V & Continuación viaje a Tenerife & jueves 8 agosto 1833 \\
\hline VI & Llegada a La Orotava & $\begin{array}{l}\text { Anclados en cuarentena, Puerto de La Orotava, } \\
\text { jueves 15 agosto 1833 }\end{array}$ \\
\hline VII & Excursión a Santa Cruz & miércoles 22 agosto 1833 \\
\hline VIII & Primer ascenso al Pico & Puerto de La Orotava, sábado 31 agosto 1833 \\
\hline IX & Segundo ascenso al Pico & Puerto de La Orotava, viernes 6 septiembre 1833 \\
\hline X & Tercer ascenso al Pico & Puerto de La Orotava, viernes 13 sept. 1833 \\
\hline XI & Excursión a Chasna & Vilaflor de la Chasna, jueves 19 septiembre 1833 \\
\hline XII & Vuelta a La Orotava & Puerto de La Orotava, martes24 septiembre 1833 \\
\hline XIII & Excursión a Candelaria & Puerto de La Orotava, viernes 27 sept. 1833 \\
\hline XIV & Medición trigonométrica del Pico & Puerto de La Orotava, viernes 4 octubre 1833 \\
\hline XV & Partida de La Orotava & $\begin{array}{l}\text { Ciudad de San Cristóbal de La Laguna, jueves } 10 \\
\text { octubre 1833 }\end{array}$ \\
\hline XVI & Topografía & Santa Cruz de Tenerife, viernes 11 octubre 1833 \\
\hline XVII & Historia natural & Santa Cruz de Tenerife, lunes 14 octubre 1833 \\
\hline XVIII & Situación social & Boston, miércoles 21 mayo 1834 \\
\hline XIX & Historia & Boston, jueves 29 mayo 1824 [sic] \\
\hline & \multicolumn{2}{|l}{} \\
\hline
\end{tabular}

Fuente: elaboración propia.

Como ya hemos señalado, además de las cuestiones científicas, Browne se interesó también por los aspectos sociales y por la historia de las islas. En con- 
creto, el informe sobre la situación social del archipiélago, que constituye la carta número XVIII, nos resulta particularmente interesante, al presentarnos una descripción de los distintos aspectos de la vida de los canarios de entonces. Así, nos va hablando de sus características físicas, de la situación de la educación, las viviendas, el modo de vida isleño, las enfermedades más comunes, las costumbres religiosas, las ceremonias matrimoniales y religiosas, las supersticiones, las diversiones, la vestimenta, los empleos más frecuentes entre los canarios y, por último, la situación del comercio, la agricultura y la industria. La visión que aporta Browne de la realidad insular del momento no deja de ser un tanto desoladora. Como es de esperar, en ella encontramos algunas críticas. En cualquier caso, el valor y el interés de este y del resto de los textos de la obra son innegables. Sin duda tiene la particularidad de ofrecernos el punto de vista de un científico naturalista acerca de la sociedad que vivía en el medio natural que él estaba estudiando. El propio Browne justifica la inclusión en su informe de este capítulo de índole social al comienzo de la que es la carta XVIII, en los siguientes términos:

Puesto que comencé estas cartas haciendo un informe general sobre estas islas tal y como surgieron de la mano de la naturaleza, puede que no resulte inapropiado dar una visión somera de los cambios realizados por el hombre, de las artes y la industria y de la moral y las actuales condiciones de vida de sus habitantes (Browne 1834, p. 9).

Tampoco pudo Browne escapar a la fascinación habitual entre nuestros visitantes por la historia de las islas y de los aborígenes, asuntos a los que dedica el último capítulo o carta. No obstante, ya en la Carta XIII, que narra su visita a Candelaria, nos cuenta que tuvo ocasión de visitar diversas cuevas donde había enterramientos Guanches. Igualmente se interesa por la lengua o más bien lenguas de los aborígenes y recoge una pequeña muestra de las raíces comunes entre algunos vocablos usados en distintas islas con palabras del beréber. De los Guanches destaca su nobleza presentándolos como un pueblo que, entre otras muchas cualidades, tenía "un sentido exquisito del buen gobierno, la regularidad y la administración estricta de la justicia” (2005, p. 178).

Un último aspecto de interés que ofrece este texto de Browne, y que concuerda con la tendencia general en la literatura de viajes a Canarias en lenguas extranjeras, es la inclusión de palabras y expresiones españolas y canarias. Como ya seńalamos en otro lugar (González-Cruz 2011a, p. 82), este es un rasgo común a la gran mayoría de las obras que componen la bibliografía inglesa 
sobre Canarias, que se manifiesta cualesquiera que sean las lenguas en contacto, como bien han demostrado otros trabajos que han estudiado el uso de hispanismos en textos de viajes a Canarias por parte de autores franceses (Corbella 1991; Curell y G. de Uriarte 1998, 2001) o alemanes (Batista y Sarmiento 2007; Tabares, Batista y Sarmiento 2009).

Este uso recurrente de hispanismos en el discurso en lengua inglesa es un fenómeno al que cabría dar diversas explicaciones, de las que ya hemos hablado en otros trabajos (González-Cruz y González-de la Rosa 2006, 2007; González-Cruz 2011a, 2011b). La necesidad, el querer aportar cierto color local, resaltar las diferencias, o bien el expresar una actitud positiva hacia el otro, son todos motivos que globalmente pueden aportar parte de luz al asunto que aquí nos concierne. No obstante, consideramos de especial interés este último motivo, ya que algunos estudios (Romaine 1995, pp. 66-67) han revelado que en realidad la propensión al préstamo se adquiere más bien a través de la socialización en una comunidad concreta, y no está tanto en función de las necesidades léxicas; o lo que es lo mismo, los factores sociales parecen jugar un papel fundamental. Cabría entender entonces que, cuando un viajero usa la palabra española en lugar de optar por su equivalente inglés, parece estar indicándonos, consciente o inconscientemente, su grado de imbricación con la sociedad y la cultura que le rodea y su actitud positiva hacia estas. Entre las palabras que utiliza Browne a lo largo del texto — que recopilamos en el Apéndice- encontramos, canarismos (como caldera, gofio, gánigo, mantilla, folías, seguidillas, malagueñas, el puchero, la mal país, la retama), algunos topónimos como $\mathrm{La}$ Villa de La Orotava, El Pico del Teyde; frases como "El Pico tiene su sombrero puesto", "De Tuineje a Berbería se va y se viene en un día", o expresiones como el Gran Poder de Dios, Dios lo bendiga, el domingo gordo, buena moza, etc. Estas voces y expresiones evidencian y son fruto de su contacto directo y relativamente estrecho con los isleños.

\section{CONCLUSIONES}

En este trabajo hemos querido llevar a cabo una breve actualización del catálogo bibliográfico que ofrecimos en 2002, que registraba y comentaba los 300 títulos de seis tipos de publicaciones en lengua inglesa sobre Canarias que hasta entonces conocíamos. Tras mencionar algunas de las contribuciones más relevantes que hemos localizado y estudiado en los últimos ańos, hemos centrado nuestra atención en esta obra de Daniel Jay Browne, por su valiosa aportación a esa ya numerosa bibliografía inglesa sobre Canarias. Hemos comenzado mostrando la importancia de la figura de Browne, un reconocido naturalista nor- 
teamericano que visitó Tenerife en 1833 y publicó, en forma de cartas reunidas en un libro, un detallado informe sobre las condiciones naturales del archipiélago, interesándose también por la situación social y por la historia de los canarios, y revelándose además como un hombre de gran sensibilidad y amante de la poesía. Hemos ofrecido los datos de los que disponemos actualmente sobre su vida y obra, comentando sus Letters from the Canary Islands, un título que nos descubre a un científico sensible, que se atreve a incluir referencias intertextuales a obras importantes de la poesía en lengua inglesa. Browne nos revela, además, su contacto estrecho con la población isleña mediante la inserción de voces y expresiones canarias. Su texto viene a enriquecer aún más el patrimonio cultural anglo-canario por constituir un registro de gran valor etnográfico y científico dentro de la ya abundante bibliografía inglesa sobre Canarias.

\section{REFERENCIAS BIBLIOGRÁFICAS}

Batista Rodríguez, J.J. y Sarmiento Pérez, M. (2007). Hispanismos (y canarismos) en textos decimonónicos alemanes sobre Canarias. Revista de Filología de la Universidad de La Laguna, 25, 79-88.

Browne, D. J. (1834). Letters from the Canary Islands. Boston: George W. Light.

Browne, D. J. (2005). Cartas desde las Islas Canarias. Caja Canarias/ Ayuntamiento de Icod de los Vinos/ Centro de la cultura popular canaria. (Trad. J.J. Cruz. Introd. M- Hernández y J.J. Cruz.

Corbella, D. (1991). Hispanismos en la obra de Adolphe Coquet: une excursion aux Îles Canaries. En R. Dengler Gassin (ed.), Estudios humanisticos en homenaje a Luis Cortés Vázquez, vol. I. Ediciones Universidad de Salamanca, 137-145.

Curell, C. y G. de Uriarte, C. (1998). Voces canarias en los relatos de viaje franceses. Revista de Filología de la Universidad de La Laguna, 16, 19-28.

- (2001). Hispanismos en los libros de viaje franceses del siglo XVIII. En I. Uzcanga Vivar, E. Llamas Pombo y J. M. Pérez Velasco (eds.), Presencia y renovación de la lingüistica francesa. Salamanca: Ediciones Universidad de Salamanca, 99-107.

Curell, C., G. de Uriarte, C. y Oliver, J. (2009). Por un glosario de hispanismos en la Literatura de Viajes. En C. Solé i Castells, M. Parra, P. Solá, M. C. Figuerola Cabrol (coords.), Texto y sociedad en las letras francesas y francófonas, Universitat de Lleida, 634-641.

Diston, Alfred (1829). Costumes of the Canary Islands. Londres: Smith, Elder and Co. 
González Cruz, M. I. (2002). Notas para una bibliografía inglesa sobre Canarias. La Laguna: Instituto de Estudios Canarios.

- (2011a). Hispanismos y canarismos en los textos de dos viajeras inglesas decimonónicas. Revista de Filología de la Universidad de la Laguna, 29, 8199.

- (2011b). Exploring the Canarian contribution to Hispanicisms in English. Revista Alicantina de Estudios Ingleses, 24, 131-152.

- (2011c). Un nuevo registro para la bibliografía inglesa sobre Canarias: el texto de Alice Carter Cook (1900) sobre los aborígenes canarios. Estudios Canarios. Anuario del Instituto de Estudios Canarios, 55, 13-63.

- (2012). Otra novela inglesa ambientada en Canarias: The Tenth Year of the Ship. A Novel, de Norman Lewis (1962). Actas del XIX Coloquio de Historia Canario-Americana 2010. Las Palmas de Gran Canaria: Cabildo de Gran Canaria / Casa de Colón, 1731-1746.

- (2013). Hispanismos y canarismos en un corpus de textos ingleses sobre Canarias. LEXIS. Revista de Lingüistica y Literatura, 37 (2), 229-267.

- (2014). Nuevos registros para la bibliografía en lengua inglesa sobre Canarias: siete relatos de viaje, dos guías turísticas, una obra de ficción y un estudio lingüístico. Anuario de Estudios Atlánticos, 60, 599-641.

- (2015). Love in Paradise: Visions of the Canaries in a Corpus of Popular Romance Fiction Novels. Oceanide. Journal of the Spanish Society for the Study of Popular Culture SELICUP, no 7 . Recuperado el 11 de enero de 2021 de: http://oceanide.netne.net/articulos/art7-4.pdf

- (2017). Bananas about La Palma, de David Addison (2008): la isla bonita vista por un turista escocés contemporáneo. Revista de Estudios Generales de la Isla de La Palma, 8: 45-60.

- (2018). Hispanismos en el discurso romántico de Harlequin y Mills \& Boon. Ámbitos temáticos y funciones socio-pragmáticas. Moderna Sprak 1, $157-$ 178.

- (2019). Viaje y romance en Canarias: el discurso del paraíso y la otredad en dos novelas publicadas en los Estados Unidos. Revista de Filología de la Universidad de La Laguna, 37, 111-124.

- (2020). Hacia un glosario de hispanismos en un corpus de novela rosa inglesa contemporánea. Revista Onomázein 48 (2), 178-201.

González Cruz, M.I. y González de la Rosa, M.P. (1996). Viajeros ingleses y difusión del léxico español: Análisis de las influencias lingüísticas de tres modalidades del español en las obras de cinco viajeros británicos. En J. M. 
Ruiz y P. Abad (eds.), Estudios de Literatura inglesa del siglo XX. Valladolid: Universidad de Valladolid, vol. 3, 199-206.

- (2006). Language and Travel: Spanish Vocabulary in British Travel Books. Tesserae. Journal of Iberian and Latin American Studies, 12 (2-3), 203-217.

- (2007). El viaje lingüístico: una aproximación sociolingüística a la literatura de viajes. En J.M. Oliver, C. Curell, C. G. Uriarte y B. Pico (eds.), Escrituras y reescrituras del viaje. Miradas plurales a través del tiempo y de las culturas. Berna: Peter Lang, 235-251.

- (2009). Canarias, siglo XX: la imagen de las islas en tres obras publicadas en Nueva York. Estudios Canarios. Anuario del Instituto de Estudios Canarios, 53: $11-41$.

González Cruz, M.I. y M.J. Vera Cazorla (2020). Género e identidad cultural. Perfiles femeninos en un corpus de novela rosa. En T. González Pérez (ed.), La educación de las mujeres en Iberoamérica. México: Tirant Lo Blanch, 627673.

Gotti, M. (2006a). Communal correspondence in Early Modern English. En M. Dossena y S. Fitzmaurice (eds.), Business and official correspondence: Diachronic perspectives. Bern: Peter Lang, 17-46.

- (2006b). Disseminating Early Modern Science: Specialized news discourse in the Philosophical Transactions. En Brownlees, N. (ed.), News discourse in Early Modern Britain. Berna: Peter Lang, 41-70.

Gunn, R. J. (2011). Canary Island Song. Nueva York: Howard Books.

Harms, J. (1965). Romance and Truth in the Canaries: An Adventure, Guide and Interpretation. Nueva York: Acorn Press.

Kennedy, N. (1979). Secret Longings. Nueva York: Dell Publishing.

Reading, J. H. (1890). The Ogowe Band. A narrative of African Travel. Reading \& Co. Publishers, Filadelfia.

Romaine, S. (1995 [1989]). Bilingualism. Oxford: Blackwell.

Tabares, E., Batista, J.J. y Sarmiento, M. (2009). Léxico hispánico en escritos decimonónicos en lengua alemana sobre Canarias. En M.J. Reyes (coord.), Léxico y cultura. Badajoz: @becedario, 205-310.

Thomas, C. W. (1860). Adventures \& Observations on the West Coast of Africa and Its Islands. New York.

True, P. (1959). You Can Live Cheaply in the Canaries. Nueva York: Vantage Press.

Walter, R. (1956). Canary Island Adventure. A Young Family's Quest for the Simple Life. Nueva York: E.P. Dutton \& Co. 


\section{OTRAS OBRAS DE DANIEL JAY BROWNE}

Browne, D. J. (1832). The sylva americana; or, A description of the forest trees indigenous to the United States, practically and botanically considered. Illustrated by more than one hundred engravings. Boston: W. Hyde \& Co.

- (1868?). The American bird fancier: considered with reference to the breeding, rearing, feeding, management and peculiarities of cage and house birds, with remarks on their diseases and remedies. Nueva York: Orange Judd.

- (1892 [c1881]). The American bird fancier; or, How to breed, rear, and care for song and domestic birds: with their diseases and remedies. (Revisado y ampliado por Fuller Walker). Nueva York: Orange Judd company.

Allen, R. L., Barlow, J. y Browne, D. J. (1850). The American farm book or compend of American agriculture; being a practical treatise on soils, manures, draining, irrigation, grasses, grain, roots, fruits. Nueva York: C. M. Saxon.

Allen, S. y Browne, D. J. (1850). The American poultry yard; comprising the origin, history, and description of the different breeds of domestic poultry. With an appendix embracing the comparative merits of different breeds of fowls. Nueva York: C. M. Saxton.

Browne, D. J. (1851). The trees of America; native and foreign, pictorially and botanically delineated, and scientifically and popularly described, illustrated by numerous engravings. Nueva York: Harper \& brothers.

- (1856). The field book of manures; or The American Muck Book, treating of the nature, properties, sources, history, and operations of all the principal fertilizers and application to the soil and to crops. Nueva York: C. M. Saxton.

APÉNDICE: Palabras, frases y expresiones españolas utilizadas en Letters from the Canary Islands (1834), de Daniel Jay Browne

Buena moza; Calzoncillos; De Tuineje a Berbería se va y se viene en un día; Dios lo bendiga; El apagador; El azulejo; El domingo gordo; El Gran Poder de Dios; El Pico tiene su sombrero puesto; El Pico del Teyde [sic]; El puchero; El revés y el derecho; Folías; Gánigo; La aluvión [sic]; La caldera; La cencerrada; La corsa; La mal país [sic]; La merienda; La retama; La saya; La siesta; La Villa de La Orotava; La yunta; Las casas terreras; Las cofradías; Las funciones; Los Majoreros; Los majos; Los nieveros; Majalulo; Mal de ojo; Malagueñas; Mantilla; Monte Montero; Nuestra Señora de la Candelaria; Seguidillas; Tapada; Tocinote; Vesquiña; Vino especial de Tenerife. 


\title{
INTEGRACIÓN DE COMPETENCIAS PROFESIONALES EN EL CURRÍCULUM DE INGENIERÍA: UNA PROPUESTA DIDÁCTICA
}

\author{
Ma del Pilar González de la Rosa \\ Universidad de Las Palmas de Gran Canaria
}

\section{Resumen}

Los estudios recientes sobre las competencias que los futuros profesionales del ámbito de las ingenierías requieren para ejercer su profesión ponen de manifiesto la necesidad de integrar en su currículum académico las destrezas que demanda la sociedad del siglo XXI. El objetivo de este trabajo es presentar una propuesta de aprendizaje basado en proyectos que combina la enseńanza del inglés de especialidad con la enseñanza de habilidades profesionales requeridas para ejercer la futura profesión. Mediante el trabajo colaborativo y la elaboración de un vídeo corroboramos que esta metodología de enseñanza integrada ofrece a los estudiantes la posibilidad de mejorar sus habilidades comunicativas en inglés, familiarizarse con competencias de su campo de conocimiento y aumentar su motivación.

Palabras clave: competencias profesionales, ingeniería, aprendizaje basado en proyectos, trabajo colaborativo, vídeo

\section{INTRODUCCIÓN}

Los indicadores sociales, económicos y tecnológicos indican desde hace tiempo que nos encontramos en la antesala de la cuarta revolución industrial. Cada vez que el mundo ha experimentado una nueva revolución industrial se ha necesitado mucho tiempo para elaborar nuevos programas formativos que faciliten la adquisición de las nuevas competencias demandadas en el mercado laboral a los futuros egresados de las instituciones académicas. Afortunadamente, la globalización de las tecnologías de la información y la comunicación ha favorecido que se tomen medidas a escala global para afrontar los grandes retos a los que se enfrenta la sociedad del conocimiento en el siglo XXI. En este sentido, una de las cuestiones fundamentales planteadas en el Foro de Economía Mundial (Schwab y Samans 2016) sobre las estrategias de empleo, las destrezas, y los recursos humanos que demanda la cuarta revolución industrial subrayan la necesidad de redefinir los entornos educativos y de aprendizaje en el nuevo milenio.

Los estudios recientes sobre el currículum de las ingenierías en la educación superior coinciden en señalar que para desempeñar su profesión y hacerlo de 
manera exitosa y competitiva en los múltiples ámbitos de su actividad profesional, es imprescindible que los futuros ingenieros desarrollen, además de las habilidades técnicas propias de su especialidad (hard skills), las denominadas habilidades profesionales (soft skills), algunas de las cuales se trabajan normalmente de manera transversal a lo largo de los estudios universitarios.

\section{EL MARCO DE LOS ESTUDIOS DE INGENIERÍA}

El vertiginoso desarrollo de las tecnologías de la información y la comunicación y las necesidades de la nueva economía global han propiciado las transformaciones habidas en la educación y motivado el empleo de recursos tecnológicos novedosos y técnicas de enseñanza acordes a los nuevos tiempos. La preocupación de profesionales y docentes de las carreras de Ingenierías por la formación de los estudiantes de dichos grados responde a las nuevas necesidades que demanda esta nueva realidad. Unos y otros son conscientes de que los estudiantes, además de los contenidos propios de cada titulación, deben adquirir y desarrollar las destrezas y competencias conectadas con el mundo empresarial al que se van a incorporar. Como señala Bessen (2014), debe haber una adecuación entre el conocimiento y las habilidades requeridas en el dinámico y competitivo ámbito profesional.

Desde los ańos noventa se han introducido en los programas de las titulaciones de ingeniería de distintas universidades norteamericanas experiencias didácticas que combinan la enseñanza de las habilidades técnicas (hard skills) con el adiestramiento de las habilidades profesionales (soft skills) — fundamentalmente las comunicativas (Waitz y Barrett 1997) — desde la óptica interdisciplinar de los departamentos implicados: ingenierías e inglés. Tal es el caso del "Engineering Communications Program" (ECP) del Virginia Polytechnic Institute y State University (Virginia Tech), que incorpora estos cursos al currículum de las ingenierías desde el año 1993, conforme a los criterios establecidos por la Agencia de Acreditación de la Ingeniería y la Tecnología de Estados Unidos (ABET), sobre los resultados profesionales que se esperan de los estudiantes de ingeniería (Burgoyne 2017).

En el caso de Europa, encontramos información sobre el panorama de habilidades en los distintos sectores, países, profesiones, etc. de la Unión Europea a través de la agencia de la UE, CEDEFOP (European Centre for the Development of Vocational Training; 2017, 2019), estudios sobre el futuro de la educación y las destrezas como el de la OECD (Organisation for Economic Co-operation and Development, 2018), que avalan algunas de las iniciativas en esta dirección observadas muy de cerca por las instituciones de la educación 
superior de los países de la Unión Europea. Asimismo, son muchas las universidades que organizan cursos sobre la metodología AICLE (Aprendizaje Integrado de Contenidos y Lenguas Extranjeras) como parte de la formación de los docentes de áreas que no tienen nada que ver con el estudio de los idiomas en la educación superior.

\section{COMPETENCIAS TÉCNICAS Y PROFESIONALES EN EL ÁMBITO LA- BORAL DE INGENIERÍA}

A medida que las competencias técnicas y profesionales se han incorporado al nuevo mercado laboral, el sistema universitario ha tenido que afrontar nuevos desafíos que han venido de la mano del proceso de convergencia al Espacio Europeo de la Educación Superior (EEES) y el Proceso de Bolonia, que han provocado el cambio de paradigma en la educación superior en el que nos hayamos inmersos. Paralelamente, esto ha supuesto que el profesorado de lenguas de especialidad o inglés para fines específicos (IFE) haya tenido que adaptarse a esta nueva realidad centrando sus esfuerzos y objetivos en adoptar metodologías y recursos didácticos que permitan a los estudiantes aplicar su conocimiento en distintos contextos del ámbito profesional.

Además de las competencias técnicas, propias del grado de ingeniería en cuestión, que deben caracterizar el perfil del ingeniero, como pueden ser la habilidad para utilizar las técnicas y herramientas modernas para la práctica de la ingeniería, o la capacidad para evaluar y seleccionar plataformas hardware y software para el desarrollo de aplicaciones informáticas, entre otras muchas, ¿cuáles son las competencias profesionales que el alumnado de ingenierías tiene que adquirir y desarrollar en esta nueva década del siglo XXI?

Son muchos los estudios centrados en determinar cómo desarrollar de manera óptima las competencias que requieren los ingenieros en el currículum de sus respectivos grados. Entre las principales competencias profesionales destacan la habilidad para comunicarse eficazmente de forma oral y escrita, el trabajo en equipo, la creatividad, el pensamiento crítico, la comprensión de la responsabilidad profesional y ética, la resolución de problemas, la innovación, y la destreza en el empleo de medios digitales (Dowling \& Chell 2013, Jang 2016, Sánchez Carracedo 2018). En este estudio nos hemos centrado en la competencia que tiene que ver con la comprensión de la responsabilidad profesional y ética en la asignatura Habilidades Profesionales para Ingenieros, del Grado en Ingeniería Informática de la Universidad de Las Palmas de Gran Canaria. Para ello, se ha focalizado la atención en otras dos destrezas profesionales, la de las habilidades comunicativas, y la del empleo de las tecnologías digitales 
en asuntos clave de la vida diaria y el entorno laboral (Broadband Commission 2017).

\section{LA RESPONSABILIDAD PROFESIONAL Y ÉTICA EN EL CONTEXTO ACADÉMICO}

Una de las competencias profesionales recogidas en la Memoria de cualquier grado académico es la que persigue la formación integral de los estudiantes para que actúen de modo responsable en las distintas esferas de la vida académica y profesional. Concretamente, en el Grado en Ingeniería informática, la responsabilidad profesional y ética, además de ser una de las competencias profesionales transversales (N4) que se trabajan a lo largo de muchas de las asignaturas del grado, aparece recogida dentro de las competencias básicas (CB3), de las competencias generales (G11), y de las competencias específicas comunes a la rama de informática CI1 del grado.

A partir de la puesta en marcha del nuevo Grado en Ingeniería Informática (2019), la nueva asignatura, Habilidades profesionales para ingenieros, recoge en su programa la tarea de dar a conocer al alumnado la responsabilidad ética y el impacto que tiene en el entorno laboral y social. Este nuevo reto nos hizo reflexionar y replantearnos la idoneidad del material y de los recursos didácticos a utilizar para impartir este tipo de contenidos concretos, habitualmente ajenos a la docencia de una lengua de especialidad.

Abordamos la competencia profesional que tiene que ver con la ética en el tema quinto de la asignatura. A pesar de ser contenido específico de la profesión de ingeniero, es de carácter multidisciplinar por la temática que engloba. El proceso de maduración de esta competencia transversal continúa su desarrollo y profundización a través de otras situaciones académicas y de la vida diaria de la carrera que estudian. Como ésta es la primera toma de contacto con esta cuestión a nivel académico, desde la órbita intercultural e internacional y, desde el marco de las políticas legislativas de la Unión Europea sobre este asunto, se trata de dar a conocer a los estudiantes los siguientes conceptos:

Unit 5. Intercultural communication: Computing, legal issues, and professional ethics for Engineers.

5.1. IT regulations, data protection and security. Copyright and licensing in the Internet. Personal Software Process.

5.2. Assessment of the economic and social impact of projects, services and systems. 


\section{CONTEXTO DOCENTE}

La asignatura Habilidades Profesionales para Ingenieros es una asignatura obligatoria de 6 créditos que se imparte durante el primer cuatrimestre del primer curso del Grado en Ingeniería Informática en la Universidad de Las Palmas de Gran Canaria. Tiene cuatro horas de docencia semanales, dos de teoría y dos de prácticas en las que los grupos se desdoblan. El nivel de inglés de los estudiantes se corresponde con el nivel B1 del Marco Común Europeo de Referencia para las Lenguas (MCER), Common European Framework of Reference for Languages (CEFR).

El punto discordante de esta asignatura es que se imparte en inglés, mientras que el denominador común con el resto de asignaturas del Módulo de Proyección Profesional es el de facilitar la socialización de los estudiantes para afrontar los retos comunicativos propios del mundo académico y profesional en los lugares de trabajo donde el inglés es el vehículo de comunicación, ya sea a nivel local, nacional o internacional, reconociendo su potencial y valor intercultural. No en vano, es cada vez mayor la movilidad laboral de los egresados que buscan un trabajo en empresas multinacionales en la actualidad. La interacción social que favorece el trabajo en equipo y la diversificación de las funciones y puestos de trabajo que demanda el mercado laboral en la actualidad reclaman la práctica de técnicas de colaboración a través de distintas herramientas tecnológicas en todas las etapas de la vida académica de los alumnos.

Siendo una de las asignaturas integradas en el Módulo de Proyección Profesional debe desarrollar destrezas profesionales necesarias para que los alumnos desempeñen con éxito las tareas y responsabilidades que les sean asignadas en su futuro desarrollo académico y profesional. Por tanto, para afrontar el reto de adquirir destrezas profesionales de este tipo en un curso de inglés como lengua de especialidad, el profesorado de lenguas de especialidad necesita utilizar una metodología de enseñanza aprendizaje centrada en las especiales necesidades de los estudiantes en esta situación particular.

Los objetivos generales de la asignatura recogidos en el proyecto docente inciden en el contexto intercultural, no solamente por las posibilidades que ofrece la utilización de la lengua inglesa, sino también para facilitar la adquisición de las competencias en un mundo cada vez más globalizado, inclusive en las prácticas éticas de esta disciplina. Los objetivos de la asignatura son los siguientes:

- Proporcionar al alumnado técnicas de comunicación orales y escritas en lengua inglesa útiles en entornos académicos y profesionales. 
- Capacitar al alumnado para la elaboración de textos en lengua inglesa de distintos tipos según las convenciones formales del género utilizado dentro del campo de la ingeniería.

- Fomentar que el alumnado desarrolle una comunicación efectiva interpersonal y en grupo en lengua inglesa a la hora de intercambiar ideas y llevar a cabo actividades propias del entorno académico y del ejercicio de la profesión.

- Presentar al alumnado la legislación relativa a la conducta profesional, la protección de datos y la seguridad en tecnologías de la información para que se familiaricen con la normativa vigente y la apliquen adecuadamente en el futuro ejercicio de su profesión.

- Iniciar al alumnado en la evaluación de la gestión y el uso de las tecnologías, valorando su impacto económico y social.

\section{METODOLOGÍA}

La metodología a seguir en la asignatura no ha dejado de ser un reto para la docente, que aunque ha impartido docencia de inglés de especialidad en el mismo grado, no había abordado antes cuestiones intrínsecas de la legislación y la ética que regulan la profesión del ingeniero informático. En este sentido, el trabajo colaborativo entre la docente de inglés con el Profesor especialista del área de informática que impartía esta materia a lo largo de un cuatrimestre fue clave para organizar los contenidos y el diseño de las distintas actividades (Greere y Räsänen 2008).

Efectivamente, factores como la motivación docente, la formación académica continuada, y el desarrollo profesional efectivo de la práctica docente en el aula justifican la búsqueda de metodologías ante las demandas que se hacen desde el ámbito laboral, tecnológico y social al contexto académico de una clase. Ello implica que la actitud de los docentes en el aula sea la de "teachers learning through doing, tackling real issues and developing practical solutions", (Higgins et al. (2015) y James et al. (2006), en Richardson y Díaz (2018)).

En este contexto, tal como sostiene Robinson (1991), la metodología que vayamos a utilizar debe contribuir a que el alumno desarrolle la capacidad de resolver problemas de su ámbito académico. Además, Jordan (1997: 124) puntualiza varios aspectos que son fundamentales a la hora de elegir la metodología más apropiada para cada situación de aprendizaje: la utilización de materiales auténticos, la resolución de problemas, las actividades comunicativas, y aprender haciendo ("learning by doing"). 
Tratándose de una asignatura que combina, por una parte, el aprendizaje del inglés como lengua de especialidad en Ingeniería Informática o inglés para fines específicos (IFE/ESP) y, por otra, el aprendizaje de habilidades profesionales, para el propósito de esta experiencia didáctica se enfocó la asignatura desde el aprendizaje basado en proyectos (ABP) y el trabajo colaborativo que propicia la enseñanza de lenguas. El aprendizaje colaborativo no solamente facilita la organización de los estudiantes en grupos de trabajo para el desarrollo de las tareas, sino que además, supone un refuerzo adicional al sentido de equipo.

El aprendizaje basado en proyectos (ABP) es un enfoque dinámico de la enseñanza en el que los estudiantes exploran los problemas y desafíos del mundo real, desarrollando simultáneamente habilidades transversales al mismo tiempo que trabajando en pequeños grupos de colaboración o de modo individual (Bell 2010). En segundo lugar, el aprendizaje basado en proyectos es útil porque permite que los estudiantes expongan sus habilidades para planificar y realizar proyectos a través de su conocimiento y habilidades lingüísticas (Kloppenborg y Baucus 2004). Asimismo, el ABP se considera como una metodología de trabajo centrada en el estudiante en la que están motivados por la necesidad de crear un producto final que les brinde oportunidades para desarrollar una mayor confianza en sí mismos e independencia como aprendices (Maldonado 2008; Fried-Booth).

Hay otros factores que condicionan la metodología del Aprendizaje basado en proyectos propuesta con nuestra elección del vídeo como recurso audiovisual. Por una parte, el elevado número de estudiantes por grupo oscila en torno a 70, favoreciendo la formación de equipos de trabajo, normalmente de 4 estudiantes. En segundo lugar, el perfil general del alumnado de este grado en cuanto a competencias digitales se refiere, dado que su motivación propicia la utilización de este tipo de recursos. Como Dussel (2011) explica, el desarrollo de las TIC ha favorecido la creación de nuevos escenarios para interactuar, comunicarnos y expresarnos que exigen, asimismo, tanto de los docentes como del alumnado, el desarrollo de las habilidades digitales. Por último, esta metodología, en la clase de inglés como lengua de especialidad, permite que los estudiantes construyan el conocimiento mientras trabajan todas las destrezas comunicativas de la lengua y el tema objeto de estudio.

En cuanto a la impartición del tema en sí, se hizo de modo gradual para despertar el interés por la ética profesional a través de distintas actividades y la práctica de todas las destrezas lingüísticas. En el primer tema los alumnos abordaron las características del lenguaje de la ciencia y del inglés académico a través 
de un artículo de investigación (Ethics and Information Technology), con el objeto de que los estudiantes se familiarizaran con el vocabulario y los temas generales tratados, para elaborar un glosario de los términos utilizados. En el segundo tema, se facilitó a los alumnos un listado de conceptos y temas generales de la ética, generales y específicos de su profesión. Se formaron grupos de cuatro estudiantes y se seleccionaron los temas a partir de los cuales tenían que elaborar el vídeo. La duración del mismo se concretó entre 8-10 minutos, de modo que cada estudiante tendría de dos a tres minutos para exponer su parte correspondiente del trabajo. Esta tarea se propuso con suficiente antelación para que fueran capaces de organizarse en el tiempo, de modo que cada semana los equipos de trabajo dedicaban media hora de la clase de prácticas a supervisar el trabajo y avanzar.

La rúbrica de evaluación del vídeo está centrada en criterios lingüísticos y tecnológicos, supervisados por una doble evaluación: la evaluación del profesorado y la evaluación de los compañeros del equipo de trabajo, tal como aparece en la Tabla 1. La evaluación de los compañeros del equipo se centra en medir la capacidad de interactuar adecuadamente, es decir, la capacidad de reaccionar y cooperar en las diferentes etapas de la actividad, ítem evaluado por todos los miembros de cada grupo, entre ellos.

Tabla 1: Rúbrica de evaluación del vídeo

\begin{tabular}{ccccccccc}
\hline Pronunciación & Fluidez & $\begin{array}{c}\text { Corrección } \\
\text { lingǘstica }\end{array}$ & Contenido & $\begin{array}{c}\text { Claridad y } \\
\text { orden en la } \\
\text { exposición }\end{array}$ & Originalidad & $\begin{array}{c}\text { Calidad } \\
\text { visual }\end{array}$ & $\begin{array}{c}\text { Capacidad } \\
\text { para } \\
\text { responder a } \\
\text { preguntas } \\
\text { formuladas }\end{array}$ & $\begin{array}{c}\text { Evaluación } \\
\text { del resto de } \\
\text { miembros } \\
\text { del equipo }\end{array}$ \\
\hline $10 \%$ & $5 \%$ & $20 \%$ & $20 \%$ & $10 \%$ & $10 \%$ & $5 \%$ & $10 \%$ & $10 \%$ \\
\hline
\end{tabular}

Fuente: elaboración propia.

En los temas 3 y 4 se trabajó en la lectura comprensiva de textos divulgativos que trataban cuestiones relacionadas con el mal ejercicio de la profesión a través de casos concretos de plena actualidad. En el tema 5 y último del temario, los estudiantes fueron los principales protagonistas de su proceso de aprendizaje con la presentación del vídeo.

Mediante la elaboración del vídeo se pretende que el aprendiz desempeñe un papel activo en el proceso de aprendizaje (Horwitz 1999), así como fomentar su capacidad de observación y análisis para pensar con criterio ante situaciones tecnológicas complejas de la vida cotidiana académica y profesional. Es una herramienta digital que también les permite aprender fuera del contexto 
del aula, aprendizaje ubicuo (Burbules 2014), refuerza el trabajo en equipo, fomenta la motivación de los estudiantes - motor clave en cualquier situación de aprendizaje (Csizér y Dörnyei 2005)—, y fomenta una mayor autonomía (Alm 2006).

El concepto de autonomía se entiende como una práctica social centrada en escenarios concretos, en la que los agentes educativos implicados en el proceso de aprendizaje somos los principales responsables de promover, facilitar y respaldar el proceso de autonomía de los estudiantes (Smith and Ushioda 2009). En esta misma línea, Dam (1995) observa que la autonomía del aprendiz "is characterized by a readiness to take charge of one's own learning in the service of one's needs and purposes. This entails a capacity and willingness to act independently and in cooperation with others, as a socially responsible person". Además de esta habitual predisposición natural en la interacción con el resto de miembros del equipo, la creación de herramientas digitales como el vídeo refuerzan el trabajo colaborativo y la participación activa del alumno en su propio proceso de aprendizaje.

La temporalización para la ejecución del trabajo de elaboración del vídeo es de nueve semanas, que cuentan a partir de la información que se les facilita detalladamente en la cuarta semana del cuatrimestre. La presentación final por grupos tiene lugar en las tres últimas semanas del curso académico.

\section{RESULTADOS}

El material audiovisual elaborado por los estudiantes es de calidad, muy variado y original en algunos casos. Para comprobar si la propuesta llevada a cabo ha resultado positiva, y si ha mejorado su conocimiento sobre la ética de un ingeniero, se les planteó responder un cuestionario anónimo en Google que incluyó 5 preguntas cerradas. Los 60 estudiantes que cursan la asignatura de modo continuo respondieron el cuestionario. Los resultados de cada ítem y sus porcentajes se muestran en la Tabla 2.

Como se puede observar, las opiniones son prácticamente unánimes en cuanto a la percepción positiva del tema propuesto a través del aprendizaje basado en proyectos. Del mismo modo, un alto porcentaje de estudiantes coincide en que la elaboración del vídeo les ha facilitado tener una visión global desde los distintos temas abordados por todos los grupos, que tienen que ver con la normativa y la regulación de la informática en los ámbitos nacional, europeo e internacional. Con respecto al ítem 3 del cuestionario el porcentaje varía y, para ello, hemos de determinar, por un lado, la destreza que les cuesta más y en cuál de las destrezas se encuentran más cómodos, para redefinir el 
tipo de actividades y cómo trabajarlas con grandes grupos. La pregunta 4, que hace referencia a si ha sido satisfactoria la experiencia de elaborar un vídeo es muy positiva, entendemos que porque el entusiasmo y la implicación del alumnado a lo largo de todo el proceso ha sido constante. La temporalización para la organización de las ideas y el montaje digital del vídeo ha sido vital. Finalmente, es evidente que el alumnado estima que ha mejorado significativamente su dominio de las habilidades comunicativas, dato que puede estar directamente relacionado con el resultado de la pregunta anterior, lo que estimula la implementación de la metodología propuesta en situaciones didácticas similares.

Tabla 2. Resultados del cuestionario en porcentajes

\begin{tabular}{lcc}
\hline Pregunta & Sí & No \\
\hline $\begin{array}{l}\text { 1. El tema del trabajo del proyecto fue } \\
\text { interesante para la formación de un futuro } \\
\text { ingeniero }\end{array}$ & $82 \%$ & $18 \%$ \\
\hline $\begin{array}{l}\text { 2. ¿Consideras que con la realización de esta } \\
\text { actividad has conocido aspectos básicos del } \\
\text { tema desarrollado? }\end{array}$ & $91 \%$ & $9 \%$ \\
\hline $\begin{array}{l}\text { 3. ¿Te han gustado las actividades realizadas a } \\
\text { lo largo del cuatrimestre en el aula sobre este } \\
\text { tema? }\end{array}$ & $71 \%$ & $29 \%$ \\
\hline $\begin{array}{l}\text { 4. ¿Te gustó la experiencia de elaborar un } \\
\text { vídeo con tus compañeros? }\end{array}$ & $88 \%$ & $12 \%$ \\
\hline $\begin{array}{l}5 . \text { ¿Consideras que has mejorado tus } \\
\text { habilidades comunicativas? }\end{array}$ & $86 \%$ & $14 \%$ \\
\hline
\end{tabular}

Fuente: elaboración propia.

\section{CONCLUSIONES}

Como resultado de los constantes avances tecnológicos y las circunstancias sobrevenidas en el presente año 2020 el sector empresarial atraviesa un estado de incertidumbre y cambios como nunca antes. Esta situación ha puesto aún más de relieve la necesidad de una constante revisión y actualización de los planes de estudios de las titulaciones por parte de las instituciones académicas y de los actores implicados en la docencia como responsables de dichas asignaturas. Esta tarea no puede llevarse a cabo de manera individual por parte de los docentes de lenguas de especialidad puesto que la interdisciplinariedad es la clave para abordar las habilidades profesionales desde nuevas estrategias didácticas que atiendan los requerimientos de las emergentes estructuras laborales.

En este estudio se ha analizado una experiencia pedagógica que integra la elaboración de un vídeo como recurso didáctico para el aprendizaje de habilidades profesionales en la clase de inglés como lengua de especialidad en el 
Grado en ingeniería informática mediante el aprendizaje basado en proyectos y el trabajo colaborativo. Esta metodología integrada ha permitido que los estudiantes utilicen todas las destrezas comunicativas de la lengua inglesa (Listening, Writing, Reading y Speaking), interactuando con sus compańeros en las diferentes fases del proyecto, mediante la puesta en práctica de las competencia digitales, con el objetivo final y primordial de familiarizarse con una de las competencias profesionales específicas de su ámbito profesional.

Los resultados obtenidos muestran una respuesta positiva por parte del alumnado, especialmente en la fase final en la que produjeron el vídeo. Toda metodología que se aplica por primera vez requiere una posterior revisión pormenorizada del diseño de las tareas. En este contexto, entendemos que asumir este tipo de responsabilidades es asumir un riesgo inevitable en la carrera docente, a la vez que interesante y estimulante, que requiere la integración del profesorado implicado - especialistas en la disciplina y profesorado de lenguas de especialidad-, para disponer de las herramientas necesarias en el complejo y cambiante contexto en el que nos movemos.

A modo de conclusión, esta propuesta didáctica ha pretendido contribuir al estudio de algunos de los retos que afronta el docente de lenguas de especialidad, y al desarrollo de competencias profesionales concretas de una disciplina académica particular. Los resultados obtenidos confirman la utilidad de esta metodología de trabajo en el adiestramiento de habilidades profesionales, y sugieren una mayor profundización sobre la implementación de éstas y otras des-

trezas como de las múltiples posibilidades que ofrece la elaboración de herramientas docentes digitales.

\section{REFERENCIAS BIBLIOGRÁFICAS}

Alm, A. (2006). CALL for autonomy, competence and relatedness: motivating language learning environments in Web 2.0, The JALT CALL Journal, 3(2), 29-38.

Beckett, G. H., \& Slater, T. (2005). The Project Framework: A tool for language, content, and skills integration. ELT Journal, 59(2), 108-116. Recuperado el 14 de agosto de 2020 de: https://doi.org/10.1093/eltj/cci024

Bell, S. (2010). "Project-Based Learning for the 21st Century: Skills for the Future. The Clearing House: A Journal of Educational Strategies Issues and Ideas, 83(2), 39-43.

Bessen, J. (2014). "Employers Aren't Just Whining - the "Skills Gap” Is Real”, Harvard Business Review, 25 August. Recuperado el 12 de septiembre de 2020 de: https://hbr.org/2014/08/employers-arent-just-whining-the-skills-gap-is-real 
Burbules, N. C. (2014). Los significados de "aprendizaje ubicuo". Education Policy Analysis Archives, 22(104), 1-10. Recuperado el 11 de noviembre de 2020 de: https://doi.org/10.14507/epaa.v22.1880

Burgoyne, C. M. (2017). JOM, The Journal of the Minerals, Metals \& Materials Society, 69(8), 1251-1254.

Cedefop. (2017). Skills anticipation in Spain. Skills Panorama Analytical Highlights. Recuperado el 3 de noviembre de 2020 de:

https://skillspanorama.cedefop.europa.eu/en/analytical_highlights/skillsanticipation-spain

Cedefop. Skills Panorama. Science \& Engineering Technicians: skills opportunities and challenges (2019 update). Recuperado el 5 de septiembre de 2020 de:

https://skillspanorama.cedefop.europa.eu/en/analytical_highlights/scienceengineering-technicians-skills-opportunities-and-challenges-2019

Common European Framework of Reference for Languages: learning, Teaching, Assessment. 21.12.2015. Recuperado el 5 de septiembre de 2020 de: http://www.coe.int/t/dg4/linguistic/cadre1_en.asp

Csizér, K., \& Dörnyei, Z. (2005). Language learners' motivational profiles and their motivated learning behavior. Language Learning, 55(4), 613-659.

Dam, L. (1995). Learner autonomy 3: From theory to classroom practice. Dublin: Authentik.

Dussel, I. (2011). Aprender y enseñar con nuevas tecnologías. Experiencias y aplicaciones en el aula. VII Foro Latinoamericano de Educación. Fundación Santillana.

Fried-Booth, D. L. (2012). Project work. Oxford: Oxford University Press.

Greere, A. y Räsänen, A. (2008). Report on the LANQUA subproject on content and language integrated learning - Redefining CLIL: Towards multilingual competence. Recuperado el 14 de agosto de 2020 de:

http://www.unifg.it/sites/default/files/allegatiparagrafo/20-01-2014/lanqua_subproject_on_clil.pdf

Horwitz, E. K. (1999). Cultural and situational influences on foreign language learners' beliefs about language learning: a review of BALLI studies. System, 27(4), 557-576.

Jang (2016). Identifying 21st Century STEM competencies using workplace data. Journal of Science Education and Technology, 25(2), 284-301. Recuperado el 12 de septiembre de 2020 de:

https://doi.org/10.1007/s10956-015-9593-1 
Kloppenborg, T. J. y Baucus, M. S. (2004). "Project management in local nonprofit organisations: Engaging students in problem-based learning", in Journal of Management Education, vol. 28, 610-630. Recuperado el 14 de agosto de 2020 de: http://dx.doi.org/10.1177/1052562904266008

Maldonado Pérez, M. (2008). Aprendizaje basado en proyectos colaborativos. Una experiencia en educación superior. Laurus, 14(28), 158-180.

OECD. The Future of Education and Skills. Education 2030. Recuperado el 3 de noviembre de 2020 de:

https://www.oecd.org/education/2030/E2030\%20Position\%20Paper\%20(05. 04.2018).pdf

Richardson, S. y Díaz Maggioli, G. (2018). Effective Professional development: Principles and Best Practice. Part of the Cambridge Papers in ELT Series. [pdf] Cambridge: Cambridge University Press.

Sánchez Carracedo, F., et al. (2018). Competency Maps: an Effective Model to Integrate Professional Competencies Across a STEM Curriculum," In Journal of Science Education and Technology, 27, 448-468. Recuperado el 3 de noviembre de 2020 de https://doi.org/10.1007/s10956-018-9735-3

Schwab, K. y Samans, R. (2016). Global Challenge Insight Report. The Future of Jobs. Employment, Skills and Workforce Strategy for the Fourth Industrial Revolution. Recuperado el 17 de septiembre de 2020 de: http://www3.weforum.org/docs/WEF_Future_of_Jobs.pdf

Smith, R., y Ushioda, E. (2009). "Autonomy: Under Whose Control?". En Maintaning Control. Autonomy and Language Learning. Richard Pemberton, Sarah Toogood y Andy Barfield, eds. Hong Kong: Hong Kong University Press.

Waitz, I. A., y Barrett, E. C. (1997). Integrated teaching of experimental and communication skills to undergraduate aerospace engineering students, Journal of Engineering Education, 86(3), 255-62.

Working Group on Education. Broadband Commission for Sustainable Education. (2017). Digital skills for life and work. Recuperado el 14 de agosto de 2020 de:

http://www.broadbandcommission.org/workinggroups/Pages/wgeducation.aspx 



\title{
ACTIVACIÓN INCONSCIENTE DE DESCONFIANZA EN EL PERSONAL DE ENFERMERÍA POR LA ORGANIZACIÓN COGNITIVO-ESQUEMÁTICA DEL CONCEPTO EN ESPAÑOL. HACIA UNA NUEVA SALUD CULTURAL DESDE LAS NEUROHUMANIDADES ${ }^{1}$
}

\author{
Juani Guerra \\ Laboratorio de Cognición y Salud Cultural \\ Instituto Universitario de Investigaciones Biomédicas y Sanitarias \\ Universidad de Las Palmas de Gran Canaria \\ Adán Martín \\ Facultad de Ciencias de la Salud \\ Universidad Fernando Pessoa Canarias
}

\section{Resumen:}

Presentamos un componente invisible en la construcción conceptual de enfermeralo en español que evoca una mala valoración de este colectivo. Su efecto cognitivo podría derivar en una falta de confianza del paciente en sus acciones $y$ en un deterioro sociocultural de sus incontestables valores profesionales. A partir de su forma léxica, hemos descubierto un mecanismo (pre)conceptual axiológico de base biológica y física que forma parte cognitiva integral de la esquematización del concepto en torno a la noción de VERTICALIDAD. Su situación en el eje ABAJO activa significados-emociones-valores como MENOS, PEOR, MAL, u otras extensiones metafóricas perjudiciales en la fase inconsciente del razonamiento, que llegan hasta su fosilización en el plano lingüístico de visibilidad léxica de "enfermera/o" en contraste con la forma inglesa "nurse".

Palabras clave: esquema de imagen, construcción conceptual, enfermero/a, cognición.

1 Este trabajo está dedicado a los alumnos de Inglés del Grado de Enfermería en la ULPGC, curso 2014-2015, con quienes descubrimos estas y otras debilidades comunicativas relativas a este colectivo, y su importancia axiológica y afectiva. Y al Proyecto Humanizo (Fomento de la investigación y Humanización de la Enfermería) de la Facultad de Ciencias de la Salud de la ULPGC, algunos de cuyos promotores fueron alumnos de ese curso, como su fundador Moisés Arencibia. Para Emigdia, por su humanidad. 


\begin{abstract}
:
We explore an invisible component in the meaning construction process of enfermeralo in Spanish that evokes a derogatory appraisal of the nursing staff. Its cognitive effect could result in lack of patient's trust in the nursing practice and also in a sociocultural deterioration of nurses' undeniable professional values. In the light of its lexical form, we have discovered a (pre)conceptual axiological mechanism with biological and physical basis which participates in the schematization of the concept around the idea of VERTICALITY. This grounding in the vertical axis DOWN triggers meanings-emotionsvalues such as LESS, WORSE, BAD as well as other depreciatory metaphorical expansions in the unconscious stages of reasoning, which reach its fossilization at the linguistic level of lexical visibility of "enfermera/o" in contrast with the English item 'nurse'.
\end{abstract}

Keywords: image schema, conceptual construction, nurse, cognition.

\title{
INTRODUCCIÓN
}

Las enfermeras y enfermeros son un recurso humano vital en todo sistema sanitario. Además del trabajo técnico que realizan, su función comunicativa es esencial en su interacción con pacientes y médicos. Visibilizamos aquí una discordancia radical en las dinámicas biofísicas de esquematización (pre)conceptual que activan componentes axiológicos/evaluativos y afectivos/emotivos en los marcos conceptuales enfermera o enfermero en español y nurse en inglés.

Enunciados en el curso de nuestras narrativas cotidianas sobre este colectivo evocan automáticamente los parámetros axiológicos menos y más con sus extensiones (cfr. Clark y Chalmers 1998) a peor y mejor. Estos parámetros de construcción de valor se han descrito como dimensiones opuestas por la Lingüística Cognitiva, que se centra en esquemas de imagen (Hampe 2005). Pares biofísicos de espacialidad como arriba-abajo construyen su significado y su valor a partir de la noción imago-esquemática de VERTICALIDAD, tal y como por ejemplo dentro-fuera lo hacen a partir de la de CONTENCIÓn. Estas nociones son antropológicamente inherentes a la experiencia humana de supervivencia del cuerpo individual en su evolución en grupo (la postura eréctil del primate y humano, tener la cabeza arriba y los pies abajo, poder guardar agua en un contenedor, o resguardarnos del frío en otro como una vivienda, etc.).

Los segundos elementos de estos pares simétricos implican evaluaciones negativas por defecto (cfr. Krzeszowski 1993, 1997; Cienki 1997: 3-6). La propia 
etimología de la palabra enfermeralo, derivada del latín in-firmus, con significado icónico de no-firme o caído, automáticamente nos sitúa esquemáticamente en la dimensión ABAJO. Su evolución cognitiva, sus proyecciones metafóricas e integraciones conceptuales estarán siempre afectadas por esta imagen espacial de enganche de significado a nivel pre-consciente.

\section{OBJETIVOS}

El objetivo de este artículo en el nuevo marco académico de Salud Cultural del Instituto Universitario de Investigaciones Biomédicas y Sanitarias (IUIBS) de la Universidad de Las Palmas de Gran Canaria (ULPGC) es evidenciar desde las Humanidades Cognitivas (para hacerlo después desde Ciencias Cognitivas como la Neuroestética) lo que entendemos como una injusticia comunicativa oculta en la fase preconceptual de su proceso semántico, un tipo de esquematización cognitiva que impacta de forma pragmática negativa al colectivo sanitario español de las enfermeras y los enfermeros. La evidencia biopoética, semiótica y lingüística que presentamos nos mostrará la evolución cognitiva de un mecanismo conceptual de evaluación negativa por formar parte integral de la esquematización biofísica en el esquema de imagen de VERTICALIDAD en el nivel invisible de los procesos conceptualizadores humanos, y cuyo afianzamiento cognitivo se adivina en el nivel fosilizado-lingüístico de visibilidad léxica que Guerra (2013) llama méntil.

Desde la Biopoética (Guerra 2013, 2016), nuestro objetivo es dinamizar este mapa conceptual contrastado de la configuración léxico-semántica en ambas lenguas para revelar de forma realista sus efectos comunicativos, culturales y sociales. Lo haremos realizando en el futuro estudios experimentales desde la psicolingüística y la lingüística cognitiva, y empíricos que evidencien desde las neurociencias estos esquemas preconceptuales de construcción de enfermeralo y nurse en este y otros sistemas semióticos como distintas lenguas, narrativas literarias (Silvera y Guerra, 2016), arquitectura (Martínez y Guerra, 2016), o en artes visuales con las herramientas y métodos desarrollados por la Neuroestética desde Zeki (1999, 2008). En este campo específico, los esquemas de imagen que se esconden en los primeros niveles inconscientes de conceptualización tras las citadas evocaciones serían fundamentales porque son los estructurandos invisibles de los que también emergen axiológicamente las nociones de fealdad o belleza analizadas por la Neuroestética. 


\section{MATERIAL Y MÉTODO}

Estas esquematizaciones espaciales y de fuerza son los enganches biofísicos de las estructuras abstractas conceptuales (inmateriales), construidas a partir de cada experiencia (material) de nuestro cuerpo en el espacio; no solo del cuerpo fisiológico, sino del cuerpo en interacción con el entorno físico y social. Las Teorías Cognitivas que aplicamos aquí se refieren a este proceso como "cognición corporeizada", "corporeización" o "experiencialismo" (Varela, Thompson y Rosch 1991; Rohrer 2005, 2007). Además, esta corporeización estructural del significado y las emociones y valores que integran se organizan siempre en grupo, socialmente, por lo que las demás líneas de investigación en las actuales Humanidades Cognitivas o Neurohumanidades exploran además la cognición como situada, distribuida, sinérgica y disipativa (cfr. Guerra 2013). En este contexto, diferencias lingüísticas desde el nivel fonológico, morfológico, o léxicosemántico, al discursivo o textual, desvelan diferencias semánticas, afectivas y axiológicas que conforman las diferencias culturales. Algunas de ellas, como la lexicalización de "enfermera/o" frente a "nurse", en su uso cotidiano pueden degenerar inconscientemente por la vía conceptual bio-axiológica y llegar a menoscabar la excelencia profesional y el valor social de un colectivo laboral vital como el de la Enfermería.

Para examinar la activación negativa de enfermera-o en español como generadora de desconfianza, y la naturaleza positiva de nurse en inglés como generadora de confianza, hemos usado la metodología de la Lingüística Cognitiva. El modelo utilizado en el mapa conceptual que diagramamos, el llamado $\mathrm{Mo}$ delo Cognitivo Idealizado (ICM), es el image schema o esquema de imagen, formulado por Lakoff y Johnson (1980), desarrollado en sus constructos axiológicos por Krzeszowski $(1993,1997)$ y por Cienki (1997) y descrito cerebralmente por Rohrer $(2001,2005)$. Se presenta aquí como herramienta para evidenciar por medio de una explicación cognitivo-conceptual la naturaleza negativa, de desconfianza, desprecio, y postración inherente al término español en su marco "enfermera/o" al evolucionar enmarcado en los conceptos enfermolenfermar con mayor robustez biofísica y biocultural que en los de cuidar o curar. Esta evidencia se recalca en su contraste con la realidad cognitivo-conceptual positiva del término inglés (de confianza, vitalidad y nutrición) al enmarcarse en nutrir/nutrido o alimentarlalimento.

Desde este ICM hemos analizado y diagramado contrastivamente este proceso de conceptualización de una misma categoría laboral del ámbito de la Salud en estas dos culturas, la española y la inglesa, a partir de sus formas lé- 
xicas, "enfermera/o" y "nurse". Estas formas léxico-semánticas son sólo la punta del iceberg de esquematizaciones conceptuales con componentes evaluativos radicalmente opuestos en español y en inglés. Son estas incongruencias conceptuales que afectan al desarrollo comunicativo sociocultural de distintos colectivos los que analizamos en el nuevo Laboratorio de Cognición y Salud Cultural del IUIBS en la ULPGC.

\section{EL ESQUEMA DE IMAGEN EN LA CONCEPTUALIZACIÓN DE EN- FERMERA/O}

En Semántica Cognitiva, un esquema de imagen es una redescripción condensada de experiencia perceptual cuyo fin es mapear estructura espacial en estructura conceptual. Éstos patrones emergen en forma de estructuras de significado sobre todo desde movimientos corporales en el espacio, desde manipulación de objetos, y desde interacción perceptual (Johnson 1987, citado por Coulson y Oakley 2006). Como mostró Mandler (1992, 2004), el esquema de imagen juega un papel primordial durante el desarrollo, al constituir la base del desarrollo cognitivo temprano, extendiéndose a todas las modalidades perceptuales sensorio-motoras (percepciones físicas y acción motora directa).

Los esquemas de imagen originalmente descritos por Lakoff (1987), Lakoff y Turner (1989) y Johnson (1987) son elementos de una nueva teoría lingüística basada en el uso humano de una lengua, y que integra una realidad psicológica para la que hay evidencia experimental en Psicolingüística, Psicología Cognitiva, y Psicología Evolutiva (Gibbs y Colston 1995).

Además, al activar marcos conceptuales como enfermeralo o nurse, nuestras emociones primarias y secundarias subyacentes (Bechara, Damasio y Damasio 2000), aunque invisibles a nivel de consciencia, forman parte de nuestra construcción del significado de dichos marcos. También según Zunshine (2012), la comprensión cognitiva de la corporeización reintroduce "el cerebro humano evolutivo" en la crítica cultural, y posee potencial para enriquecer el estudio de los constructos discursivos y culturales que emanan de la cognición corporeizada. Es esta idea de constructo sociocultural que emana de la conceptualización de estos marcos precisamente la que presentamos aquí aplicada al marco conceptual enfermeralo como antítesis del de nurse. 


\section{LA CONSTRUCCIÓN COGNITIVA DE ENFERMERA/O A PARTIR DEL ESQUEMA DE IMAGEN VERTICALIDAD. MAPEANDO LA ESTRUC- TURA ESPACIAL “ABAJO” EN LAS ESTRUCTURAS CONCEPTUALES "MENOS" Y "PEOR"}

El diagrama de esquematización que mapea la estructura conceptual de enfermeralo y que parte de la estructura espacial ABAJO definida por el esquema de imagen VERTICALIDAD sería: ABAJO - MENOS - MALO - PEOR.

Muchos investigadores consideran que la verticalidad juega un importante papel en la representación del afecto y del poder (Lakoff y Johnson 1999; Meier y Robinson 2006). En español, por ejemplo, sentirse feliz se relaciona con venirse ARRIBA mientras que lo negativo lo hace con venirse ABAJO, lo mismo que en inglés feeling UP y feeling DOWN. Meier y Robinson (2006) confirmaron en un experimento que los sujetos participantes evaluaron palabras con valor positivo con más rapidez si estas palabras se mostraban en una posición alta en la verticalidad. Por otro lado, Schubert (2005) condujo una serie similar de estudios para evidenciar las relaciones esquemáticas power is up y powerless is down. En el caso de estudio que nos ocupa aquí, enfermerola en español carece de un significado explícito y directo que evoque el mismo significado, la misma emoción, y el mismo valor que el de nurse, por lo que únicamente se podrían considerar sinónimos lingüísticos pero no conceptuales; es decir, sólo en relación al significado de diccionario pero no al vivo, al significado enciclopédico.

\section{RESULTADOS}

Nuestra mente es corporeizada tanto a nivel consciente (visible) como inconsciente (invisible). El primer nivel, de tipo fenomenológico, nos permite ser conscientes de nuestro cuerpo, sus pensamiento y acciones (Coslett et al 2002); el nivel inconsciente, por otro lado, involucra todas aquellas actividades de las que no nos damos cuenta, como los procesos neurales de transmisión de mensajes y el aprendizaje, que nos permiten pensar y actuar. La aplicación del modelo cognitivo de esquemas de imagen ha desvelado que la activación de los marcos enfermeralo en español y nurse en inglés, como estructuras conceptuales esconden procesos biológicos y espaciales invisibles que construyen valores negativos y desconfianza en el proceso sociocultural. Hemos deducido que éstos pueden ser causa de que la lexicalización española despierte estados negativos inconscientes de decaimiento, malestar o tristeza o de que, por el mismo proceso conceptual subyacente, la inglesa evoque calidez, bienestar, o amor; y motivar peores frente a mejores valores socioculturales. 


\section{CONCLUSIÓN}

Hemos detectado una disimilitud conceptual, histórica y social que afecta comunicativa y socialmente al colectivo de la Enfermería en lengua espańola. Mientras que nurse activa evocaciones a madre, crianza, cuidado de los hijos, alimento, salud o vida, enfermeralo activa evocaciones a enfermo, enfermedad, horizontalidad, decaimiento, debilidad, falta de salud o muerte. La forma léxica misma hemos visto que deriva de enfermo y procede del latín infirmus a partir del prefijo de negación (in-) y la palabra firmus (firme); es decir, no-firme, caído. Creemos que es la propia etimología de la palabra la que puede estar obstaculizando la positividad afectiva y axiológica del concepto desde su localización en el punto inferior de la verticalidad. Nuestra hipótesis central es que su asociación inmediata real, la de base cognitiva, no coincide con la realidad de un trabajo vital y de excelencia social. En vez de asociarse naturalmente a la categoría sociocultural positiva de "cuidador/sanador de enfermos", es probable que se asocie a la negativa de "hacedor de enfermo", dada su dinámica de esquematización, y que pueda coincidir con el modo en que se organiza en su mayor parte el significado de los elementos léxicos con sufijo -eral-ero en español como por ejemplo en panadera/ro, cristalera/o, obrera/o.

Esta disonancia preconceptual divisada en la fase de esquematización cognitiva puede estar afectando de forma invisible a la mala interpretación, apreciación y valor hacia la figura de estos trabajadores extraordinariamente cualificados. Aquí defendemos que esta situación, de demostrarse neurocognitivamente, podría solucionarse reconstruyendo la lexicalización española desde de la introducción en el siglo XIX del sentido que hoy le otorgamos, de su profesionalización tal y como la conocemos hoy. Creemos que esto además activaría otros componentes de los procesos comunicativos que también ayudarían a renovar niveles discursivos más complejos de las dinámicas conceptualizadoras y narrativas de su construcción sociocultural actual. Nuestra propuesta equivaldría a una puesta en valor realista, desde las nuevas Humanidades Cognitivas, de cómo pensamos, cómo sentimos y qué valores humanos insinuamos realmente los españoles o hispanos en general cuando hablamos, escuchamos, escribimos, o leemos cualquier enunciado en el que aparezca la palabra enfermeralo.

\section{REFERENCIAS BIBLIOGRÁFICAS}

Bechara, A., Damasio, H. y Damasio, A. R. (2000). Emotion, decision-making, and the orbitofrontalcortex. Cerebral Cortex, 10, 295-307. 
Cienki, A. (1997). Some properties and groupings of image schemas. En Verspoor, M.; Lee, K. D. y Sweetser, E. (eds.), Lexical and Syntactic Constructions and the Construction of Meaning. Amsterdam/Philadelphia: John Benjamins, $3-15$.

Clark, A. y Chalmers, J. (1998). The extended mind. Analysis, 58, 7-19.

Coslett, H. B.; Saffran, E.M. y Schwoebel, J. (2002). Knowledge of the human body: A distinct semantic domain. Neurology, 59, 357-363.

Coulson, S. y Oakley, T. (2006). Purple persuasion: Deliberative rhetoric and conceptual blending. Cognitive Linguistics Investigations: Across languages, fields and philosophical boundaries, 46-65.

Gibbs, R., y Colston, H. (1995). The cognitive psychological reality of image schemas and their transformations. Cognitive Linguistics, 6, 347-378.

Guerra, J. (2013). Poética Cognitiva: (Con)figurándonos lo real. En Calero Vaquero, M. L. y Hermosilla Álvarez, M. A. (eds.) Lenguaje, Literatura y Cognición. Córdoba: Servicio de Publicaciones de la Universidad de Córdoba, 253-271.

Guerra, J. (2016). Nueva Poética para una transversalidad realista. Revista de Occidente, 422-423, 32-44.

Hampe, B. (2005). When down is not bad, and up not good enough: A usagebased assessment of the plus-minus parameter in image-schema theory. Cognitive Linguistics, 16-1, 81-112.

Johnson, M. (1987). The Body in the Mind. The Bodily Bases of Meaning. Imagination, and Reason. Chicago: University of Chicago Press.

Krzeszowski, T. P. (1993). The axiological parameter in preconceptual image schemata. En Geiger, R. A. y Rudzka-Ostyn, B. (eds.), Conceptualizations and Mental Processing in Language. Berlín/Nueva York: Mouton de Gruyter, 307-329.

Krzeszowski, T. P. (1997). Angels and devils in hell: Elements of axiology in semantics. Varsovia: Wydawn.

Lakoff, G. (1987). Women, Fire and Dangerous Things: What Categories Reveal About the Mind. Chicago: The University of Chicago Press.

Lakoff, G. y Johnson, M. (1980). Metaphors We Live By. Chicago: University of Chicago Press.

Lakoff, G. y Johnson, M. (1999). Philosophy in the Flesh: the Embodied Mind and its Challenge to Western Thought. Nueva York: Basic Books.

Lakoff, G. \& Turner, M. (1989). More Than Cool Reason A Field Guide to Poetic Metaphor. Chicago University of Chicago Press. 
Mandler, J. M. (1992). How to build a baby: II. Conceptual primitives. Psychological Review, 99(4), 587-604.

Mandler, J. M. (2004). The foundations of mind: The origins of Conceptual thought. Nueva York: Oxford University Press.

Martínez, J. J. y Guerra, J. (2016). Dinámicas Biopoéticas del Prototractatus y El Tractatus Logico-Philosophicusde Ludwig Wittgenstein. Arquitectura Cognitiva de las Proposiciones. ULPGC: Acceda.

Meier, B. P. y Robinson, M. D. (2006). Does 'feeling down' mean seeing down? Depressive symptoms and vertical selective attention. Journal of Research in Personality, 40, 451-461.

Rohrer, T. (2001). Understanding through the body: fMRI and ERP studies of metaphoric and literal language. Comunicación a congreso presentada en 7 th International Cognitive Linguistics Conference.

Rohrer, T. (2005). Image Schemata in the Brain. En Hampe, B. y Grady, J. (eds.), From Perception to Meaning: Image Schemas in Cognitive Linguistics. Berlín: Mouton de Gruyter, 165-196.

Rohrer, T. (2007). The Body in Space: Embodiment, Experientialism and Linguistic Conceptualization. En Zlatev, J.; Ziemke, T.; Frank, R. y Dirven, R. (eds.), Body, Language and Mind, vol. 2. Berlín: Mouton de Gruyter.

Schubert, T. W. (2005). Your highness: vertical positions as perceptual symbols of power. Journal of Personality and Social Psychology, 89, 1-21.

Silvera, M. y Guerra, J. (2016). Biopoética, Cognición y Emoción. Integración Conceptual y Emergencia en The Crying Of Lot 49 de Thomas Pynchon. ULPGC: Acceda.

Varela, F., Thompson, E. y Rosch, E. (1991). The Embodied Mind: Cognitive Science and Human Experience. Cambridge, MA: MIT Press.

Zeki, S. (1999). Inner Vision. An exploration of Art and the Brain. Oxford: Oxford University Press.

Zeki, S. (2008). Splendors and Miseries of the Brain. Love, Creativity, and the Quest for Human Happiness. Oxford: Blackwell.

Zunshine, L. (2012). Getting Inside Your Head: What Cognitive Science Can Tell Us About Popular Culture. Baltimore, MD: The Johns Hopkins University Press. 



\title{
UN ACERCAMIENTO DIDÁCTICO A LA COGNICIÓN CUÁNTICA: UN MODELO MATEMÁTICO PARA ENTENDER CÓMO APRENDEMOS A TOMAR DECISIONES
}

\author{
Dr. Santiago Ramón Guerra Guillén \\ (Miembro colaborador del IDETIC, división de termodinámica) \\ Universidad de Las Palmas de Gran Canaria. Departamento de Didácticas Específicas
}

\section{Resumen:}

El presente texto, pretende ser un acercamiento al formalismo usado en la emergente área multidisciplinar conocida como Cognición Cuántica [15, 16, 17, 21], con implicaciones relevantes en las Ciencias Sociales. Para alcanzar nuestro objetivo tomaremos como documento fundamental los trabajos del doctor Andrei Khrennikov [2, 3]. Comenzaremos en la Sección 1 con una aproximación muy básica al formalismo cuántico, pasando posteriormente en la Sección 2 a mostrar la violación del Teorema de Bayes, mientras en la Sección 3 se desarrolla un ejemplo simple de la Gestalt sobre las imágenes ambiguas, continuando en la Sección $\mathbf{4}$ con las posibles aplicaciones de futuro y sus límites, finalizando en la Sección $\mathbf{5}$ con unas conclusiones generales sobre el tema.

Palabras clave: experimento de la doble rendija, cognición cuántica y probabilidad negativa.

\begin{abstract}
The present text, intends to be an approach to the formalism used in the emerging multidisciplinary field known as Quantum Cognition [15, 16, 17, 21], with relevant implications in the Social Sciences. To achieve our objective we will take as a fundamental document the Dr. Andrei Khrennikov's papers $[2,3]$. We will begin in Section 1 with a very basic approach to quantum formalism, going on later in Section 2 to show the violation of the Bayes theorem, while in Section 3 a Gestalt simple example is developed on ambiguous images, continuing in Section 4 with the possible future applications and their limits, we will finish in Section 5 with some general conclusions about the subject.
\end{abstract}

Keywords: double slit experiment, quantum cognition and negative probability. 


\section{EL CAMINO RECORRIDO}

Una de las grandes ventajas de la Ciencia básica es que no es el consenso ni la ideología, sino la experiencia la que marca el camino, esto nos ha mostrado que nuestra forma de entender las cosas puede dar un giro inesperado en cualquier momento. Sin ningún lugar a dudas, si hay un ejemplo emblemático de este tipo de hechos es el experimento de la doble rendija [1], que usaremos como excusa para mostrar los elementos más notables y a su vez paradójicos de la formulación cuántica, que serán usados posteriormente en el texto.

Sea una fuente que lanza un haz de partícula sobre un par de rendijas paralelas situadas en una pared, que cumplen la condición necesaria de que la distancia entre rendijas es mucho mayor que el ancho de las rendijas. Tras atravesar las rendijas las partículas chocan con una pantalla, donde son registradas por detectores, cuando solo está abierta una de las rendijas se pueden generar curvas $P_{i}$ para cada caso y un único máximo frente a la rendija correspondiente. Esto parece lógico pues las partículas han tenido que pasar por una única rendija, además se puede ver el ensanchamiento de la curva, tanto mayor cuanto más estrecha la rendija, como efecto de los bordes. Desde el punto de vista de la mentalidad clásica cabría esperar que cuando abrimos las dos rendijas no deben afectarse la una a la otra y la curva de distribución de los puntos debe ser la suma de ambas. Sin embargo lo que se observa es una figura de interferencia con varios máximos y mínimos (ver figura 1 ), como si fueran funciones de onda, para un instante $t$ las amplitudes de las ondas, en un punto $(0, x)$, vienen dadas por, la siguiente expresión, donde la $r_{i}$ representa la distancia de cada rendija a la pantalla:

$$
\psi_{i}^{(+)}(0, x)=\frac{A}{\sqrt{r_{i}}} \exp \left(i k r_{i}\right),
$$

Por otro lado, las intensidades de dichas ondas en dichos puntos, en cada caso, se obtienen multiplicando cada función por su conjugada compleja

$$
I_{i}(0, x)=\left|\psi_{i}^{(+)}(0, x)\right|^{2}=\frac{|A|^{2}}{r_{i}}=\frac{|A|^{2}}{\sqrt{d^{2}+(x \mp a / 2)}},
$$

ambas curvas presentan un máximo central para los dos valores posibles de $\mathrm{x}$ $= \pm a / 2$ como ya comentamos anteriormente. Por otro lado, cuando ambas rendijas están abiertas la amplitud de la onda resultante debe ser la suma de ondas individuales 


$$
\psi_{1,2}^{(+)}(0, x)=\sum_{i=1}^{2} \frac{A}{\sqrt{r_{i}}} \exp \left(i k r_{i}\right),
$$

y la intensidad correspondiente

$$
I_{1,2}(0, x)=\left|\sum_{i=1}^{2} \frac{A}{\sqrt{r_{i}}} \exp \left(i k r_{i}\right)\right|^{2}+\frac{2|A|^{2}}{\sqrt{r_{1} r_{2}}} \cos \left[k\left(r_{1}-r_{2}\right)\right] \text {. }
$$

Como la distancia a la pantalla es mucho mayor que el ancho de las rendijas $\mathrm{d}>>$ a podemos tomar $r_{2}-r_{1}$ aproximadamente igual a yald. Además ald sería el ángulo $\theta$ formado por las rendijas desde el centro de la pantalla, resultando finalmente

$$
I_{1,2}(0, x)=\sum_{i=1}^{2} I_{i}(0, y)+2 \sqrt{\prod_{k=1}^{2} I_{k}(0, y)} \cos \left[k\left(r_{1}-r_{2}\right)\right] .
$$

Vemos superpuesta a la suma de intensidades un término oscilante, que da máximos y mínimos en la curva, las distancia entre dos máximos $\Delta y$, viene dado por

$$
\mathrm{k} \theta \Delta \mathrm{x}=2 \pi \rightarrow \Delta \mathrm{x}=2 \pi / \mathrm{k} \theta=\mathrm{hd} / \mathrm{pa}
$$

El cálculo anterior, basado en el formalismo de las ondas, ha sido aplicado en un contexto puramente cuántico para descubrir comportamientos no clásicos. La principal diferencia es que en el dominio clásico hablamos siempre de distribuciones de intensidad, mientras que en el dominio cuántico se trata de distribuciones de probabilidad. Pero es normalmente asumido en óptica que la intensidad luminosa es proporcional a la probabilidad de presencia de fotones, o electrones. Por ello, puede ser de utilidad en la investigación de los fundamentos de la teoría cuántica y de la frontera clásico-cuántica.

Hasta ahora lo único que hemos hecho es usar funciones de ondas para explicar de forma consistente los resultados experimentales. Pero qué significan en su amplio sentido físico las funciones de onda, ¡es lo mismo una onda que una partícula?, es evidente que no, las partículas son puntuales las ondas se extienden en el espacio.

Podríamos argumentar también que la onda representa un conjunto de partículas que actúan colectiva y simultáneamente, pero esto se descarta cuando podemos estar seguros de que solo hay una partícula en el aire. Mediante experimentos más refinados, del mismo tipo, con electrones se deduce lo siguiente: 
Figura 1. Experimento de la doble rendija
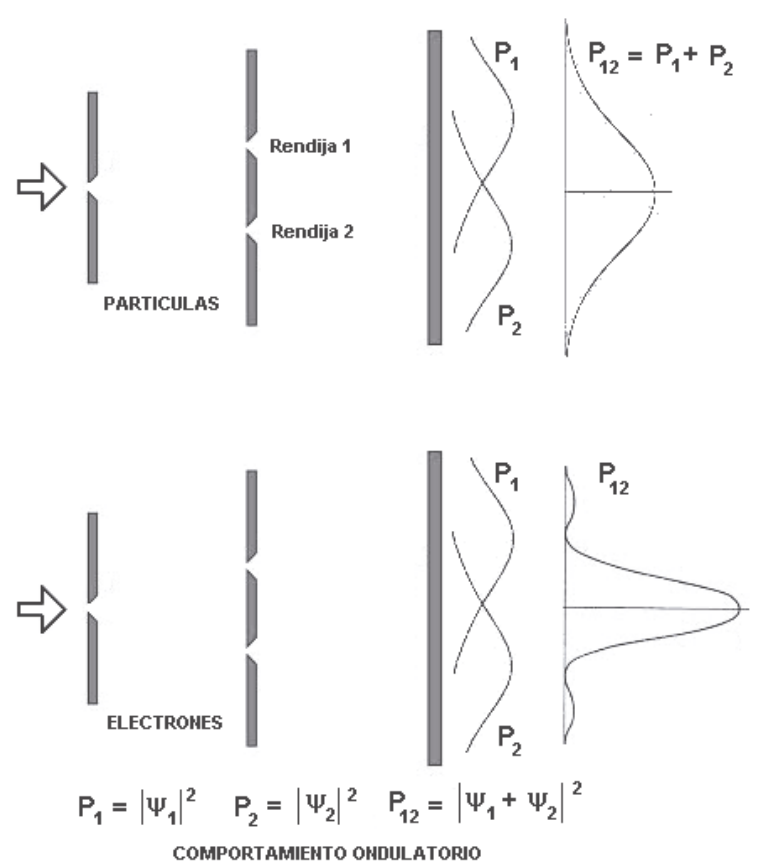

Fuente: Escudero (2018).

1) Los electrones se emiten de uno en uno y se comportan como entes puntuales en una pantalla, es decir, se detectan como partículas.

2) No es posible predecir el punto de impacto individual.

3) A pesar de todo cuando el número de electrones emitidos es muy alto el cociente entre el número de electrones $N(x)$ que inciden en un punto determinado y el número total de electrones emitidos $N_{T}$ es constante y se expresa como:

$$
\lim _{N_{T} \rightarrow \infty} \frac{N(x)}{N_{T}}=\operatorname{Pr} o b(x),(7)
$$

que es la definición frecuencial de probabilidad, este límite solo existe frente a un gran número de sucesos, pero la probabilidad se asigna a cada caso individual, algo característico de las formulaciones probabilísticas. Es decir hay una probabilidad definida de detectar un electrón en un punto. 
4) El proceso global muestra una figura de interferencia a pesar de ser resultado de sucesos independientes, lo que quiere decir que hay coherencia entre las partículas preparadas del mismo modo (misma diferencia de fase y que puede dar lugar a la auto interferencia de a partícula concreta).

Todo lo anterior nos sugiere que a cada estado preparado se le asocia una función $\psi(\vec{r})$, en general compleja y la probabilidad de encontrar la partícula en un volumen infinitesimal es $d^{3} r$ en torno a un punto $\vec{r}$ es

$$
\mathrm{P}(\overrightarrow{\mathrm{r}}) \mathrm{d}^{3} \mathrm{r}=|\psi(\overrightarrow{\mathrm{r}})|^{2} \mathrm{~d}^{3} \mathrm{r} .(8)
$$

Los hechos fundamentales que se desprenden de este ejemplo son:

\subsection{PRINCIPIO DE SUPERPOSICIÓN}

El uso de la probabilidad en la Mecánica Cuántica no es un hecho diferenciador de la propia teoría, lo que si lo es el hecho de que en este experimento la suma de las probabilidades no da la probabilidad de detectar partículas en un punto cuando ambas rendijas están abiertas, como calcularíamos con la probabilidad clásica. En la probabilidad cuántica lo que se suma son las amplitudes de onda o amplitudes de probabilidad, en vez de probabilidades, pues estas so reales y las amplitudes pueden ser complejas. Remarquemos este punto, pues la suma de dos funciones de onda admisibles es también solución admisible, en lo que se llama principio de superposición, de tal forma que verifican ecuaciones lineales, esto nos indica que la Cuántica no es estocástica.

\subsection{PRINCIPIO DE INCERTIDUMBRE}

Otro hecho esencial es que cualquiera de las funciones de onda por separado corresponde al estado de una partícula con un momento lineal $\boldsymbol{p}=\boldsymbol{k} \hbar=m \boldsymbol{v}$, bien definido. Por tanto, si aplicamos la superposición el estado superpuesto de los dos momentos corresponde a un estado físico no definido del momento lineal, cualquier superposición es un posible estado físico y cualquier función admite un desarrollo de este tipo, superposición de ondas planas. Este es un caso especial de la transformada de Fourier, las propiedades de esta nos permite relacionar la función $\psi^{(+)}(x)$ y a $\left(p_{x}\right)$. Así cuanto más localizada esta $\psi^{(+)}(x)$ menos lo está a $\left(p_{x}\right)$ y viceversa

$$
\psi^{(+)}(x)=\int_{-\infty}^{\infty} a\left(p_{x}\right) \exp (i p x / \hbar) d p,(9)
$$




$$
a\left(p_{x}\right)=\frac{1}{\sqrt{2 \pi}} \int_{-\infty}^{\infty} \psi^{(+)}(x) \exp (i p x / \hbar) d p,(10)
$$

que es el principio de indeterminación posición-momento que muestra la imposibilidad de medir simultáneamente con una precisión infinita las coordenadas de posición y de momento correspondientes a la misma dirección, en esta caso dirección $\mathrm{x}$.

$$
\Delta x \Delta p_{x} \geq \frac{\hbar}{2}
$$

Esto no es debido a una falta de información, sino a una imposibilidad intrínseca debida a las propias leyes de la cuántica, Principio de Complementariedad, con lo que podemos escribir de forma general:

$$
\Delta_{\psi} \hat{A} \Delta_{\psi} \hat{B} \geq \frac{|\langle\psi[\hat{A}, \hat{B}] \psi\rangle|}{2},
$$

donde el primer término es la indeterminación de los observables sobre el estado $\psi$. Esta desigualdad explica el fenómeno cuántico de la imposibilidad de medir dos observables complementarios simultáneamente con total precisión, como sucede en el experimento de la doble rendija, o interferómetro de Young (sin ningún lugar a dudas, el ejemplo de complementariedad más célebre y didáctico es el de la dualidad onda-corpúsculo).

\section{LA DOBLE RENDIJA, MÁS ALLÁ DE LA BAYESIANA}

La interpretación probabilística de Max Born de la función de onda ya fue propuesta en 1926, antes incluso de realizar los primeros experimentos de difracción de partículas, pero nada se dice sobre el comportamiento de las partículas antes de ser detectadas, es una interpretación, llamada mínima.

Volviendo de nuevo al experimento de doble rendija si consideremos un par de variables aleatorias $a$ y $b$, como variables representativas de las rendijas, es decir si $a=0$ cuando el electrón pasa por la rendija superior y si $a=1$ el electrón pasa por la rendija inferior, mientras que $b$ representa la posición de una placa fotosensible situada en la pared, de manera que la variable $b$ tiene un rango continuo de valores $x$ a lo largo de la placa fotosensible.

Considerando ahora $\left|\psi_{\mathrm{i}}(\mathrm{x})\right|^{2}$ como $\mathrm{p}(\mathrm{b}=\mathrm{x} \mid \mathrm{a}=\mathrm{i})$, entonces la ecuación (5) se representa como, 


$$
\mathrm{p}(\mathrm{b}=\mathrm{x})=\mathrm{p}(\mathrm{a}=0) \mathrm{p}(\mathrm{b}=\mathrm{x} \mid \mathrm{a}=0)+\mathrm{p}(\mathrm{a}=1) \mathrm{p}(\mathrm{b}=\mathrm{x} \mid \mathrm{a}=1)+\delta(\mathrm{x}),(13)
$$

donde el "término de interferencia" $\delta=\left|\psi_{0}\right|\left|\psi_{1}\right| \cos \theta$, tiene la forma:

$$
\delta(\mathrm{x})=2 \sqrt{\mathrm{p}(\mathrm{a}=0) \mathrm{p}(\mathrm{b}=\mathrm{x} \mid \mathrm{a}=0) \mathrm{p}(\mathrm{a}=1)} \times \mathrm{p}(\mathrm{b}=\mathrm{x} \mid \mathrm{a}=1) \cos \theta .
$$

Aquí los valores de las probabilidades $\mathrm{p}(\mathrm{a}=0)$ y $\mathrm{p}(\mathrm{a}=1)$ son iguales a $1 / 2$, considerando la simetría del sistema. Para una situación experimental general, $\mathrm{p}(\mathrm{a}=0)$ y $\mathrm{p}(\mathrm{a}=1)$ se pueden tomar como valores arbitrarios no negativos que satisfacen $\mathrm{p}(\mathrm{a}=0)+\mathrm{p}(\mathrm{a}=1)=1$. En la forma anterior, la ley de probabilidad clásica total,

$$
p(b=x)=\sum_{i} p(a=i) p(b=x \mid a=i),(15)
$$

se viola, y el término de interferencia cuantifica la violación. El término de interferencia adicional aparece no solo en el experimento de dos rendijas, sino en cualquier experimento con observables cuánticos incompatibles arbitrarios representados por operadores hermitianos no conmutables $A, B:[A, B] \neq 0$.

Considere ahora dos variables aleatorias en cualquier campo de la ciencia, desde la física, la ciencia cognitiva, la biología, la sociología. También violan la probabilidad total clásica.

$$
p(b=x) \neq \sum_{i} p(a=i) p(b=x \mid a=i)
$$

Aquí, aparece una especie de término de interferencia (probabilístico):

$$
\delta(\mathrm{x})=\mathrm{p}(\mathrm{b}=\mathrm{x})-\sum_{\mathrm{i}} \mathrm{p}(\mathrm{a}=\mathrm{i}) \mathrm{p}(\mathrm{b}=\mathrm{x} \mid \mathrm{a}=\mathrm{i})
$$

El punto esencial es que no podemos usar el modelo de probabilidad de Kolmogorov. El análisis previo ha demostrado que la aparición del término de interferencia coincide con las predicciones de la teoría de la probabilidad cuántica.

Observamos que la ecuación (17) se puede reescribir en una forma similar a la fórmula para la interferencia cuántica y el término de interferencia siempre se puede representar de manera similar a la Ecuación (14):

$$
\delta(\mathrm{x})=2 \lambda(\mathrm{x}) \sqrt{\mathrm{p}(\mathrm{a}=0) \mathrm{p}(\mathrm{b}=\mathrm{x} \mid \mathrm{a}=0) \mathrm{p}(\mathrm{a}=1) \mathrm{p}(\mathrm{b}=\mathrm{x} \mid \mathrm{a}=1)} .
$$


La única diferencia es que para datos arbitrarios no podemos garantizar que $|\lambda(\mathrm{x})| \leq 1$. Por lo tanto, para datos estadísticos arbitrarios, tenemos la probabilidad total con el término de interferencia:

$$
p(b=x)=\sum_{i} p(a=i) p(b=x \mid a=i)+2 \lambda(x) \sqrt{p(a=0) p(b=x \mid a=0) p(a=1) p(b=x \mid a=1)}
$$

Un resultado sorprendente se obtiene al poner un detector en cada rendija, las franjas desaparecen, debido al carácter indeterminista de a Mecánica Cuántica y al colapso cuántico de la superposición, es como si el mero hecho de observar modificase el resultado del experimento. Más aún, la Mecánica Cuántica es contextual (depende de cómo se realiza la medida) un sistema cuántico puede presentar propiedades que dependen del orden en que se midan. Eso implica que la teoría no es realista, no existen las variables, ni su valor antes de medir.

Según la interpretación clásica de Kolmogorov, la probabilidad condicionada es la probabilidad de que ocurra un evento $B$ con la condición de que haya ocurrido un evento $A$. Si se observa el evento $A$, entonces $p_{A}(B)=p(B$ $\mid A)=p(A \cap B) / p(A)$, por definición. Esta fórmula es una de las muestras de la estructura booleana del modelo; ni siquiera se puede asignar probabilidad condicional a un evento sin utilizar la operación booleana de intersección. El punto crucial es que se supone que quien toma las decisiones es racional, pero eso necesariamente no es así en general.

Un ejemplo de lo que podemos llamar racionalidad bayesiana, se puede ver considerando el Principio de seguridad de Savage [18], que dice lo siguiente, si se prefiere una opción $A_{1}$ a otra $A_{2}$ si ocurre un posible evento futuro $B$, y prefiere la opción $A_{1}$ aun si el evento $B$ futuro no ocurre, entonces debería preferir la opción $A_{1}$ a pesar de no tener conocimiento de si el evento $B$ ocurrirá o no. Este principio es un efecto de la disyunción y una simple consecuencia de probabilidad total. Por tanto, este principio, se basa matemáticamente en la probabilidad clásica (y la lógica booleana). En particular, la fórmula de Bayes para probabilidades condicionales juega un papel crucial. Como descubrió el profesor de psicología cognitiva Jerome Busemeyer, las estadísticas que muestran el efecto de disyunción pueden tratarse como no clásicas, violando la suma total clásica [21,22], y por lo tanto estos datos deben ser descritos por algún modelo de probabilidad no kolmogoroviano, por ejemplo, probabilidad cuántica.

En resumen la teoría cuántica define un estado condicional, $\psi_{\mathrm{A}}$, como sigue: Si se observa el evento A, entonces $\psi_{A}=\mathrm{P}_{\mathrm{A}} \psi / \sqrt{\mathrm{p}(\mathrm{A})}$, de donde $\mathrm{P}_{\mathrm{A}}$ es el 
proyector sobre el estado A de modo que $\mathrm{p}(\mathrm{B} \mid \mathrm{A})=\left|\mathrm{P}_{\mathrm{B}} \mathrm{P}_{\mathrm{A}} \psi\right|^{2} / \mathrm{p}(\mathrm{A})$. La Teoría clásica, si $\mathrm{A}, \mathrm{B}$ son dos eventos en $\Omega$, entonces siempre podemos definir el evento de intersección $A \cap B=B \cap A$, y $p(A \cap B)=p(A) p(B \mid A)=p(B)$ $p(A \mid B)=p(B \cap A)$, por lo que el orden de los eventos no importa. Sin embargo de acuerdo con la teoría cuántica, si $\mathrm{A}, \mathrm{B}$ son dos eventos en $\mathrm{V}$, entonces podemos definir la secuencia de eventos $A$ y luego $B$, denotados $(A, B) ; y p$ $(A, B)=p(A) p(B \mid A)=\left\|P_{B} P_{A} \psi\right\|^{2}$ y el orden de los eventos puede importar El evento de intersección, $\mathrm{A} \cap \mathrm{B}=\mathrm{B} \cap \mathrm{A}$, solo existe en la teoría cuántica si $\mathrm{P}_{\mathrm{B}} \mathrm{P}_{\mathrm{A}}=\mathrm{P}_{\mathrm{A}} \mathrm{P}_{\mathrm{B}}$, es decir, los proyectores conmutan, $\mathrm{y}$ en tales casos, no hay ningún efecto de orden. La conmutatividad es un punto clave donde las dos teorías divergen. La teoría clásica de la probabilidad puede extenderse dinámicamente a secuencias de eventos en el tiempo mediante un proceso de Markov que evoluciona de acuerdo con un operador de transición derivado de la ecuación directa de Kolmogorov. La teoría cuántica puede extenderse a secuencias de eventos a lo largo del tiempo mediante un proceso cuántico que evoluciona según un operador unitario derivado de la ecuación de Schrödinger, que es lineal y por tanto no da una evolución estocástica.

A pesar de todos estos éxitos aún no entendemos un concepto, esencial en la teoría, como es el proceso físico de la medida, y sobre todo el papel del observador, elemento consciente, o sujeto cognitivo, en ese proceso.

\section{EL SER Y NO SER, UN HECHO CUÁNTICO: DE LA DOBLE REN- DIJA A LA COGNICIÓN CUÁNTICA}

En este sub-apartado veremos una aplicación de todo lo expuesto en el estudio de imágenes ambiguas típicas de la Psicología Gestalt, realizada por el profesor Andrei Khrennikov [15, 16]. Todos los experimentos fueron asistidos por computadora y la prueba a se basa en la siguiente tarea cognitiva: mire la figura de la izquierda y responda a la pregunta (a). La prueba b se basa en la figura de la derecha: mire esta figura y responda a la pregunta (b): 
Figura 2: figuras originales del experimento hecho por Andrei Khrennikov

- (a) ¿Son estos segmentos iguales?

- (b) ¿Son estos círculos iguales?
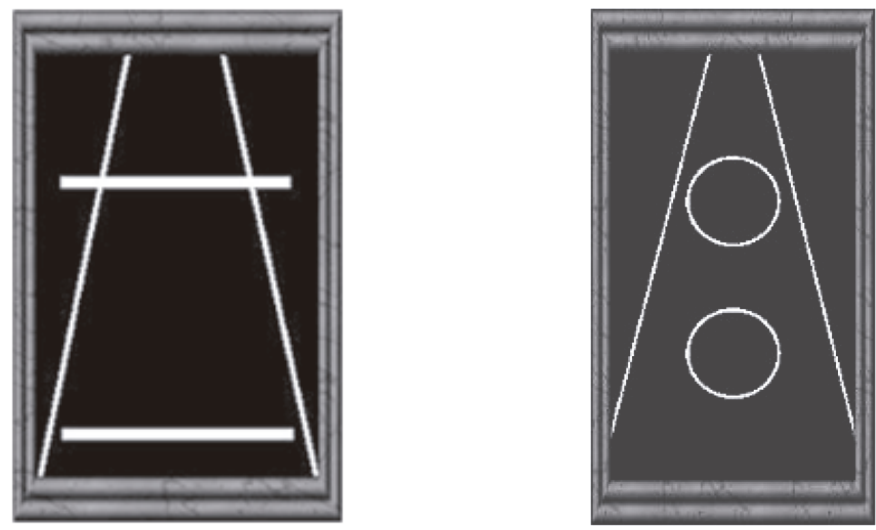

Fuente: Khrennivov (2015).

Las razones para utilizar estas pruebas se basaron en el reconocimiento fundamental de la importancia del contexto, como en la cuántica, en el mecanismo de percepción. Finalmente, se mostró que en las pruebas de ambigüedad, la figura y el fondo pueden fluctuar durante la percepción. Además se calcularon las siguientes probabilidades:

$$
\begin{gathered}
\mathrm{p}^{\mathrm{b}}(+), \mathrm{p}^{\mathrm{b}}(-), \mathrm{p}^{\mathrm{a}}(+), \mathrm{p}^{\mathrm{a}}(-),(20) \\
\mathrm{p}(\mathrm{b}=+\mid \mathrm{a}=+), \mathrm{p}(\mathrm{b}=-\mid \mathrm{a}=+), \mathrm{p}(\mathrm{b}=+\mid \mathrm{a}=-), \mathrm{p}(\text { segundo }=-\mid \mathrm{a}=-) .
\end{gathered}
$$

Aquí, el papel del contexto, digamos C, lo juega el procedimiento de selección de una muestra para el experimento. Todas las probabilidades dependen de C.

Se realizó un análisis estadístico de los resultados para determinar si los coeficientes de interferencia $\lambda_{\beta}$ son distintos de cero o cero en las pruebas b, a y b | a. El primer experimento dio los siguientes resultados

Prueba b: $\mathrm{p}^{\mathrm{b}}(+)=0,6923 ; \mathrm{p}^{\mathrm{b}}(-)=0.3077$,

Prueba a: $\mathrm{p}^{\mathrm{a}}(+)=0.9259 ; \mathrm{p}^{\mathrm{a}}(-)=0.0741$,

Prueba $\mathrm{b} \mid \mathrm{a}: \mathrm{p}(\mathrm{b}=+\mid \mathrm{a}=+)=0.68 ; \mathrm{p}(\mathrm{b}=-\mid \mathrm{a}=+)=0.32, \mathrm{p}(\mathrm{b}=+\mid \mathrm{a}=-)=0.5 ; \mathrm{p}$ $(\mathrm{b}=-\mid \mathrm{a}=-)=0.5$. (22) 
El cálculo de la probabilidad condicional dio el siguiente resultado con respecto a $\mathrm{p}^{\mathrm{b}}(+)$ :

$\mathrm{p}^{\mathrm{a}}(+) \mathrm{p}($ segundo $=+\mid \mathrm{a}=+)+\mathrm{p}^{\mathrm{a}}(-) \mathrm{p}($ segundo $=+\mid \mathrm{a}=-)=0.6666$.

La segunda experimentación dio los siguientes resultados:

Prueba b: $\mathrm{p}^{\mathrm{b}}(+)=0,5714 ; \mathrm{p}^{\mathrm{b}}(-)=0.4286$,

Prueba a: $\mathrm{p}^{\mathrm{a}}(+)=1.0000 ; \mathrm{p}^{\mathrm{a}}(-)=0.0000$,

Prueba $\mathrm{b} \mid \mathrm{a}: \mathrm{p}(\mathrm{b}=+\mid \mathrm{a}=+)=0.7000 ; \mathrm{p}(\mathrm{b}=-\mid \mathrm{a}=+)=0.3000, \mathrm{p}(\mathrm{b}=+\mid \mathrm{a}=-)=$ 1.0000; $\mathrm{p}(\mathrm{b}=-\mid \mathrm{a}=-)=0,0000$. (24)

El cálculo de la probabilidad condicional dio el siguiente resultado con respecto a $\mathrm{p}^{\mathrm{b}}(+)$ :

$\mathrm{p}^{\mathrm{a}}(+) \mathrm{p}(\mathrm{b}=+\mid \mathrm{a}=+)+\mathrm{p}^{\mathrm{a}}(-) \mathrm{p}(\mathrm{b}=+\mid \mathrm{a}=-)=0,7 .(25)$

Finalmente, la tercera experimentación dio los siguientes resultados:

Prueba b: $\mathrm{p}^{\mathrm{b}}(+)=0,4545 ; \mathrm{p}^{\mathrm{b}}(-)=0.5455$,

Prueba a: $\mathrm{p}^{\mathrm{a}}(+)=0.7000 ; \mathrm{pa}(-)=0.3000$,

Prueba $\mathrm{b} \mid \mathrm{a}: \mathrm{p}(\mathrm{b}=+\mid \mathrm{a}=+)=0.4286 ; \mathrm{p}(\mathrm{b}=-\mid \mathrm{a}=+)=0.5714 ; \mathrm{p}(\mathrm{b}=+\mid \mathrm{a}=-)=$ $1.0000, p(b=-\mid a=-)=0.0000$. (26)

Prueba b: $\mathrm{p}^{\mathrm{b}}(+)=0,4545 ; \mathrm{p}^{\mathrm{b}}(-)=0.5455$,

Prueba a: $\mathrm{p}^{\mathrm{a}}(+)=0.7000 ; \mathrm{p}^{\mathrm{a}}(-)=0.3000$,

Prueba $\mathrm{b} \mid \mathrm{a}: \mathrm{p}(\mathrm{b}=+\mid \mathrm{a}=+)=0.4286 ; \mathrm{p}(\mathrm{b}=-\mid \mathrm{a}=+)=0.5714 ; \mathrm{p}(\mathrm{b}=+\mid \mathrm{a}=-)=$ 1.0000, $\mathrm{p}(\mathrm{b}=-\mid \mathrm{a}=-)=0.0000$. (27)

El cálculo de la probabilidad condicional con respecto a $\mathrm{p}^{\mathrm{b}}(+)$ dio el siguiente resultado:

$$
\mathrm{p}^{\mathrm{a}}(+) \mathrm{p}(\mathrm{b}=+\mid \mathrm{a}=+)+\mathrm{p}^{\mathrm{a}}(-) \mathrm{p}(\mathrm{b}=+\mid \mathrm{a}=-)=0.6000 .(28)
$$

El valor medio \pm de la Desviación Estándar de $\mathrm{p}^{\mathrm{b}}(+)$ resultó $\mathrm{p}^{\mathrm{b}}(+)=0.5727$ \pm 0.1189 en la prueba b, calculada usando (22), (24) y (27), mientras que en cambio resultó un valor medio de $0.6556 \pm 0.0509$ para $\mathrm{p}^{\mathrm{b}}(+)$ cuando se calcula en la Prueba b | a, utilizando las ecuaciones (23), (25) y (28). Los dos valores medios calculados son diferentes y, por lo tanto, dan evidencia de un comportamiento cuántico de los estados mentales cognitivos tal como se midieron probando observables mentales mediante las Pruebas b, a y b $\mid$ a. La prueba $t$ de Student mostró que la probabilidad de que las diferencias obtenidas entre los dos valores estimados de $\mathrm{p}^{\mathrm{b}}(+)$ por la prueba $\mathrm{b}$ y por la Prueba $\mathrm{b} \mid \mathrm{a}$ 
sean accidentales, no excede de 0.30 . Así, con una probabilidad de 0,70 los coeficientes de suplementarios son distintos de cero y, por tanto, los estudiantes se comportan (piensan) de forma cuántica (con respecto a los observables basados en las cifras ambiguas).

Como paso final, se calculó el $\cos \theta_{\beta}$ sobre la base del coeficiente de interferencia $\lambda_{\beta}$ dado por la Ecuación (18). En el experimento obtuvieron

$$
\begin{gathered}
\cos \theta_{+}=-0,2285, \theta_{+}=1,8013 \cos \theta_{+}=-0,2285, \theta+=1,8013,(29) \\
\cos \theta_{-}=0.0438, \theta_{-}=1.5270, \cos \theta_{-}=0.0438, \theta_{-}=1.5270,(30)
\end{gathered}
$$

que son resultados de fase bastante satisfactorios que indican un comportamiento de tipo cuántico para los estados mentales investigados.

Utilizando los datos obtenidos, pudieron describir una función de onda mental $\psi=\psi_{\mathrm{C}}$ del estado mental $\mathrm{C}$ del grupo de estudiantes que participaron en el experimento, correspondiente a un contexto mental denotado por el mismo símbolo C.

$$
\psi(\mathrm{a})=\sqrt{\mathrm{p}(\mathrm{a}=+) \mathrm{p}(\mathrm{b}=\hat{\mathrm{a}} \mid \mathrm{a}=+)}+\mathrm{e}^{\mathrm{i} \theta}(\mathrm{a}) \sqrt{\mathrm{p}(\mathrm{a}=-) \mathrm{p}(\mathrm{b}=\hat{\mathrm{a}} \mid \mathrm{a}=-)},
$$

El $\psi$ es una función del rango de valores $\{+,-\}$ del observable mental b referida al campo de números complejos. Dado que b puede asumir solo dos valores, dicha función puede representarse mediante vectores bidimensionales con coordenadas complejas. Los datos experimentales dan

$$
\psi(+)=\sqrt{0.8753 \times 0.6029}+\mathrm{e}^{\mathrm{i} \theta(\beta)} \sqrt{0.1247 \times 0.5} \approx 0.7193+\mathrm{i} 0.2431,
$$

y

$$
\psi(-)=\sqrt{0.8753 \times 0.39719}+\mathrm{e}^{\mathrm{i} \theta(\beta)} \sqrt{0.1247 \times 0.5} \approx 0.5999+\mathrm{i} 0.2494 .
$$

\section{LOS OBSTÁCULOS EN EL CAMINO}

A pesar de los éxitos de esta nueva rama de la Ciencia Cognitiva, hay ciertos aspectos que es necesario clarificar. Para mostrar uno de estos puntos se puede hacer una modificación al experimento de doble rendija de Young como se indica en [18]. 
Para conocer la información sobre la intensidad en las rendijas del experimento de Young, contenida en la polarización, se colocó un polarizador en la pantalla de observación y midieron la distribución de intensidad interferométrica sobre la pantalla para dos orientaciones ortogonales del polarizador. Estas observaciones dieron información imperfecta sobre intensidad y fase sobre las rendijas. Sin embargo, al conocer todos los detalles del proceso de medida, se puede obtener información exacta mediante un adecuado proceso de inversión. No entraremos en los cálculos, pero la intensidad resultante es:

$$
I(r, \phi)=I_{R}(r)+\mu \sqrt{I_{R}(1)} \sqrt{I_{R}(-1)} \cos (\delta+\phi),
$$

Donde el parámetro $\mu$ es una medida de coherencia, un coeficiente de correlación lineal, llamado grado de coherencia, que viene dado por la siguiente expresión:

$$
\mu=\frac{\left|\left\langle E_{1} E_{2}^{*}\right\rangle\right|}{\sqrt{\left\langle\left|E_{1}\right|^{2}\right\rangle\left\langle\left. E_{2}\right|^{2}\right\rangle}},
$$

Esta cantidad está acotada $0 \leq \mu \leq 1$ en función de la relación que exista entre los campos.

La expresión (34) es la distribución de intensidad conjunta y exacta. Recoge la información de la cantidad de luz que sale por la rendija $r$ con un desfase. En óptica clásica un resultado imposible vendría dado por casos en los que $\mathrm{I}(\mathrm{r} ; \phi)<0$. Si, por ejemplo, elegimos $\phi=\delta+\pi$ tenemos que $\cos (\delta+\phi)=-1$ y entonces $\mathrm{I}(1 ; \phi)<0$ o $\mathrm{I}(-1 ; \phi)<0$ siempre que $|\mu|^{2}>\min \left\{\mathrm{I}_{\mathrm{R}}(1)=\mathrm{I}_{\mathrm{R}}(-1)\right.$; $\left.I_{R}(-1)=I_{R}(1)\right\}$. Es interesante observar que hay situaciones en las que la distribución no es negativa, y que esto ocurre sobre todo cuanto menor es la coherencia.

De lo expuesto se desprende que las variables complementarias son la intensidad sobre las dos rendijas $\mathrm{I}(\mathrm{r}=1 ;-1)$ (siendo la variable $r$ la que etiqueta a las rendijas) y la intensidad en el plano donde se forma la interferencia $\mathrm{I}(\phi)$ (siendo $\phi$ la diferencia de fase). En el marco de la óptica clásica la complementariedad entre dos variables se expresa en la inexistencia de una distribución conjunta $\mathrm{I}(\mathrm{r} ; \phi)<0$.

Podríamos decir que la negatividad solo ocurre para estadísticas observadas cuyas variables estén entrelazadas, superposición no separable. Por ello, relacionamos la falta de separabilidad con el carácter entrelazado clásico entre la posición y la polarización. 
Este tipo de protocolos que buscan una distribución conjunta de variables complementarias con marginales exactas conducen en general a distribuciones conocidas como funciones de Wigner:

$$
W(x, p)=\frac{1}{4 \pi} \int_{-\infty}^{\infty} \psi^{*}(x+y) \psi(x-y) e^{\frac{2 i p y}{\hbar}} d y .(36)
$$

Sin embargo, la función de distribución de Wigner es una herramienta muy utilizada y que proporciona correcciones cuánticas a la mecánica estadística clásica. En este sentido, es de destacar la aplicación de la función, en la imagen de Heisenberg, a los experimentos de comunicación cuántica en procesos de PDC, con fotones entrelazados, vinculando dicho entrelazamiento al campo de vacío $[3,4,5,6,7,8,9,10]$. Por su naturaleza, en física cuántica la distribución de Wigner puede tomar valores negativos para estados no clásicos y es un claro indicador de la interferencia en mecánica cuántica. Además en contraste con el estado de vacío, cuya función de Wigner es positiva, en el caso del estado correspondiente a un fotón, representado en Óptica Cuántica, la correspondiente distribución de Wigner no es una función definida positiva, lo que guarda una estrecha relación con el carácter no-clásico de este estado, ¿podemos hablar de auto interferencia, quizás?, o imposibilidad del auto-colapso, como algunos usan para explicar de autoconciencia o autocognición. Estos resultados no tienen una interpretación en el ámbito de la Cognición Cuántica, y por supuesto no se presupone un entrelazamiento cuántico entre entidades cognitivas basadas en el vacío cuántico. Otro problema es la falta de medios para determinar el parámetro de fase de los modelos cuánticos antes del experimento, lo que los priva de poder predictivo y de la mayor parte de su impacto práctico potencial. Sin embargo, el grupo de Ilya Surov et al. [20] en una publicación resiente han presentado una hipótesis respaldada empíricamente que puede ayudar a resolver el problema de la fase inicial. De acuerdo con hipótesis, la fase cuántica entre alternativas no resueltas en una familia de situaciones similares de toma de decisiones es casi constante en los antecedentes nacionales, lingüísticos y culturales de los sujetos.

De confirmarse, el fenómeno de estabilidad de fase cuántica complementa el modelo cuántico de toma de decisiones dotándolo de poder predictivo. Esta posibilidad se demuestra en el experimento de prueba donde el comportamiento irracional dentro de un grupo social previamente inexplorado podría predecirse probabilísticamente con alta precisión. 


\section{CONCLUSIONES}

El modelado matemático del experimento del doctor Andrei Kherennikov es un buen ejemplo de aplicación de las similitudes de comportamiento entre entidades cognitivas y la forma de análisis cuántico, lo que permitió hacer un uso directo de un formalismo abstracto de tipo cuántico, a un proceso cognitivo simple, consiguiendo explicar la dinámica cuántica de las entidades cognitivas. Nuestro objetivo con esta exposición era acercar esta novedosa forma de análisis a los investigadores de las Ciencias Sociales, y en especial a los educadores y pedagogos, que podrían usar esta herramienta unida a otras de tipo computacional aplicadas en la neurociencia, como el diagnóstico por imagen [14], para fijar una metodología de análisis de los aprendizajes, constructivistas, cuantizando en forma más efectiva y real cómo se consolida el aprendizaje significativo en base a los conocimientos previos y al contexto, físico y emocional. Todo esto más allá de ideas confusas y especulativas en las que se confunden lo que es la cognición cuántica y lo que se especula sobre ella, en ningún momento se trata de explicar los procesos fisiológicos cerebrales con funcionamientos cuánticos, por ahora no hay datos que puedan demostrar que el cerebro funcione como un computador cuántico, en este sentido tampoco podemos decir que vivamos en una escala física en la que las leyes cuánticas sean determinantes en nuestra vida diaria. Lo que si nos permite decir este ejemplo es que la matemática descubierta tras la mecánica cuántica puede ser útil y además permite un acercamiento entre disciplinas, de la que estamos necesitados de manera que se generen nuevas ideas y perspectivas que enriquezcan nuestro conocimiento de forma general y multidisciplinar.

Para finalizar, es esencial comprender que la Mecánica Cuántica fue concebida como la Física Moderna, en el amplio sentido de la palabra, y no solo como una mera descripción del microcosmos. Además, soportada por una herramienta matemática que para algunos físicos no está completa, en cuanto a su interpretación, pues no define el concepto de realidad independiente del observador, debido a la forma en la que se define el estado cuántico. Por otro lado, la definición de medida plantea grandes paradojas [1], dentro de la propia teoría. Es evidente que de alguna manera esto afectará a su aplicación a la Cognición Cuántica, en su futuro más próximo.

\section{BIBLIOGRAFÍA}

[1] Alvarellos, J. E.; García, P. y García, J. J. (2000). Introducción al formalismo de la mecánica cuántica. Editorial: UNED- ISBN: 978-84-362-5456-3. 
[2] Blutner, R. and Grabenb, P. B. (2014). Descriptive and Foundational Aspects of Quantum Cognition. - arXiv preprint arXiv: 1410.3961.

[3] Casado, A., Guerra S., Plácido, J. (2008). Wigner representation for experiments on quantum cryptography using two-photon polarization entanglement produced in parametric down-conversion. J. Phys. B: At. Mol. Opt. Phys. 41:045501.

[4] Casado, A., Guerra, S. y Plácido, J. (2010). Partial Bell-state analysis with parametric down conversion in the Wigner function formalism. J. Adv. Math. Phys. 2010:501521.

[5] Casado, A., Guerra, S. y Plácido, J. (2015). Wigner representation for entanglement swapping using parametric down conversion: The role of vacuum fluctuations in teleportation. J. Mod. Opt. 62:377-386.

[6] Casado A., Guerra, S. y Plácido, J. (2015). Estudio, mediante el formalismo de la función de Wigner, de los efectos de la radiación de punto cero en la generación del bit cuántico fotónico. Rev. Acad. Canar. Cienc., XXVI, 37-60.

[7] Casado, A., Guerra, S. y Plácido, J. (2018). Rome teleportation experiment analysed in the Wigner representation: The role of the zeropoint fluctuations in complete one-photon polarization-momentum Bell-state analysis. J. Mod. Opt. 65:1960-1974.

[8] Casado, A., Guerra S. y Plácido, J. (2019). From stochastic optics to the Wigner formalism: the role of the vacuum field in optical quantum communication experiments. Atoms 7(3):76.

[9] Casado, A., Guerra, S. y Plácido, J. (2020). Wigner representation for polarization-momentum hyperentanglement generated in parametric down-conversion, and its application to complete Bell-state measurement. Eur. Phys. J. D. 68:338.

[10] Casado, A., Guerra, S. y Plácido, J. (2020). Innsbruck Teleportation Experiment in the Wigner Formalism: A Realistic Description Based on the Role of the Zero-Point Field. Frontiers in Physics. [EISSN 2296$424 \mathrm{X}]$, v. 8.

[11] de Barros, J. A. and Oas, G. (2016). Advanced Series on Mathematical Psychology Contextuality from Quantum. Physics to Psychology, 153-184.

[12] Escudero, C. (2018). La naturaleza de la materia. ONDAS DE LA MATERIA. Recuperado de:

http://ex000290.ferozo.com/fisica/fiiib/archivos/2018\%20La\%20naturaleza $\% 20 \mathrm{de} \% 201 \mathrm{a} \% 20$ materia $\% 20$ (cont) $\% 20 \mathrm{BIOING.pdf}$ 
[13] Galazo, R. (2018). Complementariedad clásica, o cuánto cuántico hay en cuántica. TFG. UCM. Recuperado de:

http://webs.ucm.es/info/gioq/docencia/trabajos/RaquelGalazo.pdf

[14] Hofstadter, D. Dilemmas for superrational thinkers, leading up to a luring lottery. Sci Am. (1983) 6:24-35.

[15] Khrennikov, A. (1999). Classical and Quantum Mechanics on Information. Foundations of Physics, Vol. 29, No. 7.

[16] Khrennikov, A. (2015). Quantum-like modeling of cognition. Front. Phys. 3:77, 10.3389/fphy.2015.00077.

[17] Li, Ji-An, Dong, D., Wei, Z., Liu, Y., Pan, Y., Nori, F. and Zhang, X. (2020). Quantum reinforcement learning during human decision-making. Nature Human Behavior, v. 4, 294-307.

[18] Savage, L. J. (1954). The Foundations of Statistics. New York, NY: Wiley.

[19] Shafir, E. and Tversky, A. (1992). Thinking through uncertainty: nonconsequential reasoning and choice. Cognitive Psych. Vol. 24, Issue 4, 449-474.

[20] Surov, I., Pilkevich, S., Alodjants, A. and Khmelevsky, S. (2019). Quantum phase stability in human cognition. Frontiers in Psychology.; 10: 929.

[21] Wang, Z., Busemeyer, J., Atmanspacher, H. and Pothos, E. (2013). The Potential of Using Quantum Theory to Build Models of Cognition. Topics in Cognitive Sciences 5 (4), 672-688.

[22] Yearsleyab, M. and Busemeyer, J. (2016). Quantum cognition and decision theories: A tutorial. Science direct 74, 99:116. 



\title{
LA ESTÉTICA DE LAS LUCES: DIBUJANTES, APUNTES Y BOCETOS QUE ILUSTRARON LA CIENCIA
}

\author{
Santiago J. Henríquez Jiménez \\ Universidad de Las Palmas de Gran Canaria
}

\section{Resumen}

Mientras los ideales de la Ilustración se diseminan por Europa y América del Norte, la ciencia comienza a ser valorada por sociedades científicas y academias de arte logrando que las universidades no sean del todo apreciadas como centros de desarrollo e investigación científica. La iconografía americana del siglo dieciocho resume muy bien la labor de una buena parte de los artistas viajeros que, provenientes de España, Francia, Alemania, Italia e Inglaterra, proyectan a través de sus dibujos la preparación académica, el ejercicio profesional de su trabajo y el creciente interés que despierta el conocimiento científico.

Palabras clave: Ilustración, estética, expedición, viaje, navegación, ciencia, dibujo, artista, color, investigación, academia, medicina, flor.

\begin{abstract}
When Enlightenment ideals were being disseminated across Europe and North America, science began to be dominated by scientific societies, and academies of art which had largely replaced universities as centres of scientific research and development. The American iconography of the 18th century summarizes the work of Spanish, French, German, Italian and English traveling artists in the academic preparation, exercise of their work and the emerging interest of scientific knowledge.
\end{abstract}

Key words: Enlightenment, aesthetics, expedition, travel, sailing ship, science, drawing, artist, colour, research, academy, medicine, flower.

En el siglo XVIII, las explicaciones oficiales, administrativas y científicas se hacen con la ayuda de un dibujo en las manos. Tan solo el arte testimonia lo observado y, aunque se trate de un cuadro que exalte la monarquía, reproduzca una escena de caza o tenga intención moralizante, la pintura va a dar señales de cambio y de progreso. En las academias de Bellas Artes de toda Europa, la anatomía masculina es el fundamento de la pintura y la escultura. Los alumnos deben reproducir la armonía de las obras clásicas y, en un nivel más avanzado, 
dibujar, con todo lujo de detalles, los matices de luz, el cuerpo relajado y/o los músculos en tensión de los desnudos al natural. Tanto si se quiere ser pintor historicista como dibujante científico hay que resolver problemas espaciales y volumétricos básicos, asistir a seminarios especializados en el entrenamiento del ojo y leer a los filósofos encargados de formular las ideas estéticas más sobresalientes.

Cuando se trata de pintar al aire libre, los estudiantes de dibujo artístico del siglo XVIII coinciden a menudo en lugares muy bien conocidos. Si se estudia en Roma, lo normal es encontrarse en la Villa Medici con dibujantes que vienen de todas partes. Si se reside en París, lo común es acudir a las orillas del Sena para contemplar desde allí algunos de los más bellos monumentos de la capital. Si el destino es la Royal Academy of Arts de Londres, el saludo entre los dibujantes de nivel se da en el Strand o en las afueras del Savoy Palace; y si se es alumno de la Akademie der Künste de Berlín, lo usual continúa siendo dedicar varias jornadas al Palacio de Charlottenburg para resaltar sobre el papel su estilo barroco, realizar apuntes de la cúpula recientemente instalada o copiar relieves, tumbas, frescos y toda clase de reproducciones grecorromanas ubicadas en los alrededores de los patios, interior de las fuentes y espacios ajardinados de otros palacetes y castillos de idéntica envergadura arquitectónica. El estudiante Goya no solo forma parte de esta pléyade de jóvenes adelantados que retienen en sus cuadernos todo aquello que debe ser recordado o antojarse útil para el futuro profesional, sino también ilustradores de artículos de prensa, cronistas dibujantes y pintores viajeros que planifican su vida de aquí para allá esperando completar sus papeles en blanco pernoctando en alguna maison garnie de esas que te aíslan muy bien del frío o viviendo a medio camino entre la localidad de sus antepasados y las academias españolas, inglesas, francesas, italianas y alemanas de lo que es el primer siglo de la Edad Contemporánea.

Bien en España, Inglaterra, Francia, Italia o Alemania, la pintura al aire libre obliga a planear con anticipación la salida. Con el fin de que la exposición al sol sea productiva, los pintores del reinado de Carlos III han de reunir el material necesario antes de enfrentarse a una situación que va a ser, cada vez, nueva, intensa y específica. Un asiento de cartón grueso, un compás, un quitasol, papel verjurado blanco, amarillento o agarbanzado, lápices de grafito y sanguina, plumas, pinceles, una o dos cantarillas de agua para calmar la sed y tinta china para las aguadas grises es material suficiente para realizar apuntes ligeros o complementar bocetos según los procedimientos y técnicas de representación del momento. Elegido el lugar, la práctica de los dibujantes de Las Luces consiste en aislar el motivo principal, sacar la escuadra, trazar la línea 
del horizonte sobre el papel y realizar apuntes de la composición con el fin de preparar, en la mayor parte de los casos, un viaje de vuelta y rematar el dibujo con aguadas pardas y sanguinosas, papeles de mayor grosor $y$ gouache con otros ingredientes.

Corresponde, pues, a los artistas elegir la gloria de proyectar la estética en sus dibujos tal y como se estudia en las academias de la Ilustración de toda Europa atendiendo a ese lugar en el espacio al que se refiere Alain Corbin en "Introducción" de Historia del cuerpo, II (2005) por su dimensión física, material, tangible, evocadora, contemplativa..., o salir a la luz, dibujar el paisaje al aire libre y vivir, así, lo que denominamos el Siglo del Dibujo Iluminador.

En la segunda mitad del siglo XVIII, los libros de aprendizaje de dibujo artístico que se editan en la España de "el Mejor Alcalde de Madrid" 3/4Carlos III $3 / 4$, están centrados en la forma, la composición y el color: los tres pilares de la pintura universal según los debates que llegan a la capital del Reino procedentes de Francia y las disputas sobre la realidad de la expresión estética que descienden de Italia. La pintura: poema didáctico en tres cantos (1786) y Diccionario de las tres Nobles Artes para instrucción de los aficionados (1788) del pintor y lexicógrafo madrileño Diego Antonio Rejón de Silva no hablan del dibujo al aire libre pero figuran en la línea de la mentalidad académica dominante que, desde las publicaciones de Winckelmann y Mengs en Alemania y Francia, respectivamente, estudian las variaciones del dibujo de artista a artista con imágenes en comparación y referencias que conducen al lector hacia otras fuentes de riqueza. Trazar líneas sin definir los contornos, insinuar formas y abocetar, en muchos casos, de forma rápida o con ejecuciones imperfectas consiguen que la realidad que se dibuja en contacto con la naturaleza exprese, según la metafísica aristotélica, la esencia de ese momento preciso de la realidad "en cuanto correlato físico de su definición". No obstante, lo que preocupa al dibujante ilustrado al aire libre es el efecto ambiental de la luz sobre la naturaleza, los paisajes con nubosidad voluble en los que la información cromática cambia de un momento a otro y la temporalidad que, subjetiva y objetiva a la vez, determina, según Heidegger en Sein und Zeit (1927), el ser-ahí de la existencia. ${ }^{1}$ La publicación, en 1789, de Arcadia Pictórica en sueño: alegoría o poema

1 Véase Sein und Zeit (Ser y tiempo) [1927], uno de los libros más completos y debatidos del conocido filósofo alemán donde no solo se aborda lo que el propio Heidegger considera que son las preguntas fundamentales sobre la existencia, sino cuestiones relativas al lugar del ser en el espacio, partiendo, precisamente, del cognitivismo de Aristóteles que Immanuel Kant vuelve a debatir en el último tercio del siglo XVIII. Destacamos, sobre todo, el capítulo II, "Die Exposition der Aufgabe einer vorbereitenden Analyse des Daseins" ("El estar-en-el-mundo en general como 
prosaico sobre la teórica y práctica de la pintura a cargo de Parrasio Tebano, seudónimo del sevillano Francisco Preciado de la Vega, insiste en la importancia del dibujo sobre el color. "El diseño, aunque parece que conviene al pintor", explica "es muy necesario para los escultores y arquitectos", concluye en su primera parte. "No obstante", continúa diciendo en el segundo volumen dedicado íntegramente al color, "todos honran la pintura: unos ejercitándola y otros, protegiéndola” (1789:217-219).

"La práctica de las Artes" del famoso grabador holandés Cornelis Cort (1533-1578), con dibujo original del diseñador flamenco Joannes Stradanus (1523-1605).

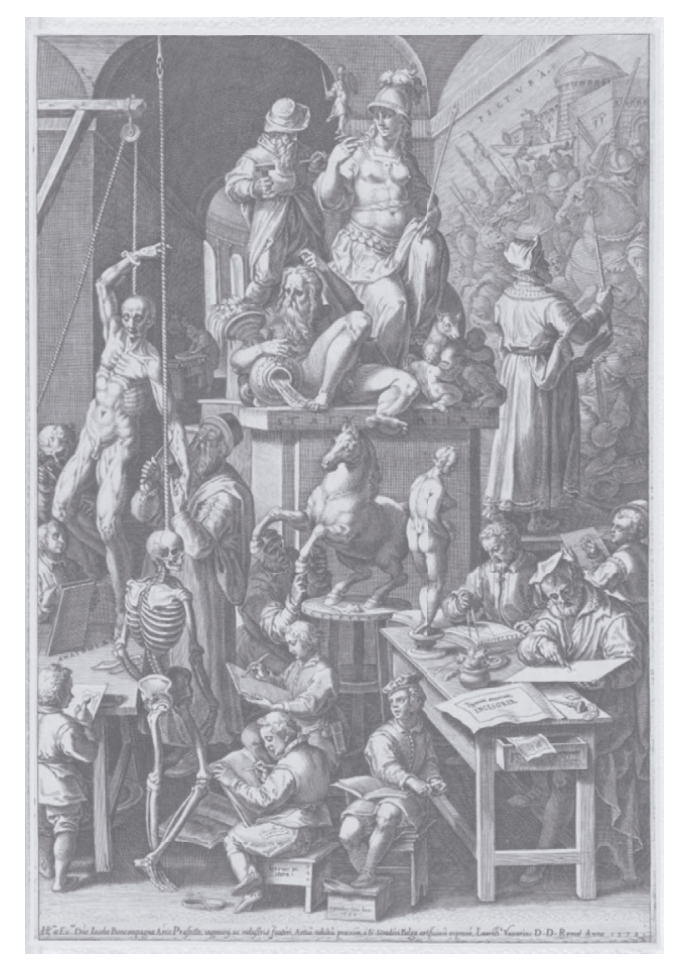

Fuente: Madrid, Museo Nacional del Prado, Gabinete de Dibujos y Estampas.

constitución fundamental del Dasein”), que corresponde a la primera parte del libro; más concretamente el apartado doce que forma parte de dicho capítulo y que titula "Die Verzeichnung des In-der-Welt-seins aus der Orientierung am In-Sein als solchem" ("Bosquejo de estar-en-elmundo a partir de estar-en como tal”), que es donde insiste en el concepto der Inheit selbst y que, arriba, hemos traducido como el "ser-ahî" de la existencia. 
En el dibujo al aire libre de la segunda mitad del siglo XVIII en Europa el paisaje que se dibuja no es topographia; tampoco topothesia: los términos con los que, durante el periodo helenista, también en la Odisea homérica, se hace referencia al paisaje que da la impresión de ser real e imaginario a la vez. El paesaggio renacentista, o paese, que es así como se pronuncia ahora en los diversos Estados de la península itálica, es un género autónomo. Algunos de los dibujos más significativos de este siglo representan escenas centradas en la transformación neoclásica de Madrid de la que hoy existe una interesante oferta de rutas didácticas centradas, por ejemplo, en la figura del delineante Ventura Rodríguez, el clasicista italiano Francesco Sabatini, académico honorífico de la Real Academia de Bellas Artes de San Fernando en 1760, y Juan de Villanueva, el arquitecto que, según la opinión de aquellos que aún se rigen por el principio Uti possidetis, ita possideatis en honor al Tratado de Permuta, mejor representa el Neoclasicismo en España desde el reinado de Fernando VI hasta el de Carlos IV. En dicha alteración existe cierta identificación de los pintores con el entorno y un claro sentimiento de pertenencia que ayuda a crear eso que en dibujo artístico ha querido llamarse siempre "armonía" siendo, en verdad, "virtuosismo" por lo que tienen de relación, los artistas, con esa parte del cosmos de la antigua Grecia en la que viven. Como apuntes preparatorios para la pintura, encargos de planeamiento urbanístico o bocetos para ejecuciones de mayor proporción y tamańo, algunos dibujos de arquitectura paisajística, espacios naturales y parajes silvestres, tienen como denominador común el hecho de copiar el motivo tal cual se contempla. Una vez acostumbrado el ojo a mirar y el lápiz a deslizarse libremente sobre la superficie del papel, las aportaciones del dibujo al aire libre a la Ilustración varían, como decimos, según la inmediatez y el objetivo empírico o científico de los artistas.

Desde el reinado de Felipe V hasta el de Carlos IV y de su esposa, María Luisa de Parma, los viajeros, todos, sin excepción, responden a actuaciones relacionadas con el saber haciendo uso de la didáctica. El fin pedagógico de sus aventuras se ilustra no solo mediante el empleo de dibujos y grabados sino con ideas expresadas de forma artística, lenguaje elaborado y recursos, como advertimos más arriba, provenientes del campo de la filosofía clásica. "Los viajes por los felices pueblos de España", dice el rey Felipe $\mathrm{V}$ a sus ministros españoles, "serán los que retraten a una nación con una sola ley, una sola administración y un solo territorio". Representar la serenidad de un paisaje, captar en directo la animación de una escena de mercado o, simplemente, proyectar la fortaleza de la luz natural al amanecer en un trozo de papel anima a muchos dibujantes de la primera mitad del siglo XVIII a aplicarse en el dibujo al aire libre. Indagar 
posteriormente en los resultados de dicha práctica para considerar, una vez reconocidas sus dotes, la funcionalidad de los artistas, divide la manera de entender el dibujo entre aquellos que se inclinan por representar una simple vivencia de aquellos otros que desglosan en un todo polifónico la fertilidad de la Ilustración.

Sepulcros, sagrarios, pórticos, templetes, bibliotecas, patios, galerías, impresiones dimétricas y trimétricas del Monasterio de San Lorenzo de El Escorial, reproducciones de cuadros, iglesias, cuevas, monasterios y casas episcopales, forman parte de una serie de láminas realizadas con dibujos a pluma, pincel y tinta china que Antonio Ponz y Piquer, el "abate Ponz", como quiso ser conocido entre sus conciudadanos, decide incorporar en Viage de España en que se da noticia de las cosas más apreciables, y dignas de saberse, que hay en ella (17721794) atendiendo a un sentido teórico-práctico del arte religioso en España cuya última finalidad no es otra más que la interiorización de su alto valor patrimonial. Dibujos a lápiz y tinta china de las rutas a seguir, plazas de toro, toreros con sus capotes, paseos de la burguesía por las anchas avenidas de la metrópolis y ciudades monumentales de España y del país luso donde no resulta difícil localizar algunos vestigios de la ingeniería romana, son realizados, todos y cada uno de ellos, por el propio Richard Twiss, autor y escritor en primera persona de Travel through Portugal and Spain in 1772 and 1773 (1775).

En 1780, exactamente el año que la Real Academia Española saca a la luz la primera edición del Diccionario de la lengua española, Francis Carter publica un interesante y detallado libro de viajes sobre la transformación del litoral del sureste de España titulado A Journey from Gibraltar to Málaga: with a View of the Garrison and its Environs; a Particular Account of the Towns in the Hoya of Málaga... and Thirteen Plates Engraved from Original Drawings Taken in the Year 1772. Con una importante colección de imágenes realizadas a lápiz, aguadas grises y tinta china del viaje que cubre el trayecto Gibraltar-Almería e información sobre la flora, la fauna y la geología de la zona oriental de Andalucía, el viajero, también escritor e ilustrador de su propia aventura como él mismo indica en el prefacio del libro, incluye un cúmulo de referencias que resultan de elevado interés histórico. Por diferentes causas y motivos, el viaje de este ilustrado británico afincado en España desde muy joven figura hoy en día relacionado con los dibujos al aire libre de Thomas Davis, Juan de Subreville, Vicente Tonino de San Miguel y William Faden que, en los ańos de la estancia española de Carter, esbozan vistas panorámicas de amplios horizontes y extensiones determinadas de terreno a ubicar en la misma zona. Otros dibujos no menos interesantes como son los de Thomas James y los de los ingenieros militares de la Real Armada Antonio de Montaigú de la Perille y Alejandro de 
Rez, están más en la línea academicista de las aulas de dibujo técnico naval existentes en la marinería española desde la construcción de los navíos as-dostres - 1 de manga, 2 de quilla, 3 de eslora - del siglo XVI, pasando por los navíos de línea del siglo XVII hasta llegar al momento de máximo esplendor de la construcción naval española, según todas las fuentes, en 1794.

Los libros de viaje de Jean François Bourgoing sobre España no gustan en los clubes y sociedades aristocráticas de la Francia de le Bien-Aimé por ser inexactos e incluir entre sus páginas imputaciones falsas a la monarquía de Carlos III. Voyage Pittoresque et Historique de L'Espagne (1806-1820) de Alexander de Laborde, en cambio, superará con creces las expectativas de la expedición francesa de 1800 al norte de Espańa desde el punto de vista de los cuantiosos grabados realizados en talla dulce sobre cobre provenientes de los bocetos realizados al aire libre por el equipo de artistas que acompañan al viajero francés por las regiones de Cataluña, Aragón, Navarra, La Rioja y Castilla y León. Algunos grabados que muy bien podrían ser elevados a la categoría de arte como en su día fueron los de Andrea Mantegna, Durero y Rembrandt, son las vistas de Pamplona de Gossard y las panorámicas de Zaragoza de Hulk. De idéntico nivel artístico son los dibujos de la Puerta Triunfal y del conjunto catedralicio de Burgos de quien es autor R. De Launay. Los bocetos del Palacio Episcopal de Burgos de Schwark, así como las distintas perspectivas y plano geometral del Acueducto de Segovia de N. L. Rousseau demuestran igualmente la exigencia requerida para cada una de las impresiones. En esta línea de captación excelsa y noble de la realidad hemos de incluir otro grupo de láminas como son La Entrada del Alcázar de Segovia de Dequevauviller, la Puerta de Talavera de la Reina de Courbe y las vistas del Castillo de Coca —en Segovia, Castilla y León- de Daudet. Los planos del Monasterio de El Escorial tomados del lado de Madrid de quien es autor N. L. Rousseau y la que, a todas luces, demuestra ser una pieza excepcional, "El modo de viajar en España", por todo lo que tiene de información y representatividad de los viajes de la época así como del modelo y forma de ejecución de las planchas que se elaboran en los talleres de Edme Bovinet, forman un compuesto incomparable de apuntes y dibujos que resulta extraordinariamente difícil de encontrar en otros relatos viajeros de la misma época. Un conjunto de láminas litografiadas que reproducen la imagen de Diego Velázquez, el conocido conquistador extremeño Hernán Cortés y el pintor Claudio Coello, entre otros, completan el segundo de los cuatro volúmenes de una aventura que no fue solo de arduo desplazamiento físico, sino literaria e ilustrativa, teniendo, como era usual para los franceses, el norte de España como modelo al aire libre. 
En la edad de oro de la imprenta en Espańa, último tercio del siglo XVIII, no hay muchos libros en la casa del médico; tampoco en la de los abogados y, mucho menos, en la de la gente corriente. En Francia, desde 1700 el país más avanzado del mundo, se publican novecientos títulos anuales para una población de veinte millones de habitantes. En Florencia, el fondo bibliográfico y de estampas de Antonio Magliabechi que los bibliotecarios piensan inaugurar en 1717 hace felices a los amantes de la lectura. Bibliotecas que solo abren una tarde a la semana, clubes de lectores con tertulias de intelectuales, libreros que prestan sus libros a cambio de algunas monedas, suscriptores de prensa y hábiles seguidores de los reales decretos, son las únicas instituciones y lectores los primeros coleccionistas de España - que forman parte de esa pasión por la lectura y acopio de libros con grabados que, como si de gestos de buena correspondencia se tratara, devuelve el arte del siglo XVIII al mundo del libro con lienzos de la categoría de "L'enfant au toton" (1738), del pintor francés Jean Siméon Chardin, "La Liseuse" (1776), de Jean-Honoré Fragonard y "Un garçon avec un livre" (1740), de Jean Baptiste Perroneau (1740).

En efecto, tanto en la primera mitad de siglo como en la segunda, la pregunta que se hacen los dibujantes es casi siempre la misma: ¿la percepción según Platón o de acuerdo con Aristóteles?, ¿dibujar con el alma, como insiste en decir Descartes a los suyos, o con los sentidos, como acaba de razonar John Locke en 1700 ? En plena Ilustración, las preguntas no tienen por qué provocar una acción de investigación científica inmediata. Tan solo aquellas cuestiones que relacionan dos o más variables y establecen conexiones entre la dimensión temporal y la espacial, están necesitadas de una pronta respuesta, lo que supone decir que para que un pintor como Goya pueda tener éxito en el mundo, "tiene que parecer", como afirma Montesquieu, "un loco y ser sabio". Espacio y tiempo es, durante el Siglo de las Luces, el Reino de España, como también lo es el Nuevo Mundo y los días, las semanas, incluso los meses de ambiente previo a la ejecución de un óleo sobre tela. En "La pradera de San Isidro" (1788), por ejemplo, Francisco de Goya y Lucientes es ese espacio y ese tiempo al que nos referimos. El pintor ha de encargar a un amigo el bastidor e ir triturando casi al mismo tiempo los pigmentos de tierra con mortero y maza si quiere abocetar el Madrid de su época. Finalmente, el Puente de Segovia, la Cúpula de San Francisco el Grande y el Alcázar Nuevo que son, a decir de sus más fieles seguidores, los lugares y el clima que prefiere el genio, coloca también al pintor en su época y en su localidad: el Goya de Madrid al aire libre que dibuja y pinta los primeros días de la Edad Moderna. 
Con Goya a punto de cumplir los treinta años y Mozart estrenando en Alemania y Austria La jardinera fingida y El rey pastor respectivamente, ¿serán realmente los dibujantes capaces de realizar "grandes acciones", a decir de Montesquieu, con tan solo un pincel y un puñado de colores en las manos?, ¿cómo pudieron ser de efectivas las clases de dibujo artístico para aquellos que eligieron vivir al filo del progreso y embarcarse en alguna expedición científica a las colonias?, ¿fue realmente el azar o "nada pudo existir sin causa", como afirma el Voltaire más ensayista? Veamos.

En los años anteriores de la botadura al agua de la primera, la segunda, la tercera, la vigésimo cuarta y cuantas naves pudieran, al fin, fletarse, en la España del siglo XVIII hay que reorganizar el poder marítimo desde el funcionamiento más elemental de las escuelas navales hasta la especialización más compleja de las tareas a bordo. Recibiendo viento moderado por estribor, ancladas a sotavento o pintadas en rojo con dos franjas negras en el casco para definir las andanas, las fragatas españolas son como las dibuja el cartógrafo murciano Alejo Berlinguero de la Marca y Gallego. Los bocetos que van desde una balandra española hasta un navío de línea del porte de ciento doce cañones forman, en su conjunto, las arboladuras más llamativas y resplandecientes que la estética pitagórica de la antigua Samos - fundamentada en el principio de la proporción y las medidas-, ejecuta en pleno Iluminismo sobre la mar. Las vergas de gata y los botalones de rastrera que hacen de líneas horizontales sobre los diferentes portes de los buques de combate, añaden, si cabe, más armonía al conjunto de piezas que sostienen las velas. Como si se tratara de una portentosa flota que busca una nueva patria navegando por el mar Tirreno, la gallardía de la escuadra española no surge porque sí. El orden y la regularidad matemática aplicadas a los alzados berlingueros son, como en tiempos de Pitágoras, cualidades indiscutibles de su belleza.

En el histórico grabado de Giorgio Bougean (1797) que representa la llegada de una relumbrante escuadra espańola a la ciudad italiana de Livorno, ${ }^{2}$

2 Nos referimos al grabado que titula "Vedutta della Squadra di S. M. Cattolica ancorata nella Rada di Livorno" al que hemos accedido a través de Guillermo C. Requena en "Contando historias antiguas de militares". Como bien explica el autor, la forma de llegar a esta y otras imágenes marinas es posible gracias a la utilización de las fuentes digitales de la Biblioteca Nacional de España, la Biblioteca Virtual de Defensa, la Gazeta: colección histórica del Ministerio de la Presidencia y para las Administraciones Territoriales, PARES. Portal de Archivos Españoles del Ministerio de Educación, Cultura y Deporte y la Biblioteca Virtual de Prensa Histórica del mismo Ministerio, entre otras. Para una información más completa de lo que decimos, véase: http://ancienhistories.blogspot.com.es/2016/02/capitanes-generales-de-la-armada-xvii.html 
provincia de La Toscana, figura el San Ildefonso: un navío de línea de setenta y cuatro cańones construido en Cartagena y que, perteneciente a la Armada española desde 1785, es capturado por los ingleses en la batalla de Trafalgar (1805). Antes de ser nombrado Rey de Etruria por Napoleón, el infante Luis Francisco Filiberto de Borbón-Parma, irrumpe en la cubierta del buque español para corresponder a la lúcida oficialidad de la marinería que le recibe con las vergas engalanadas, movimiento de banderas y vítores propios de tal celebración. A la serie de los San Ildefonsinos pertenece el navío Pelayo magníficamente ejecutado por el pintor madrileño Antonio de Brugada cuando, en un momento capital de la batalla de San Vicente en 1797, sale precisamente al rescate del Santísima Trinidad: el coloso de la Armada española que es avistado por la aleta de estribor.

Construidos con madera de roble, caoba y teca de la mejor calidad previamente contrastada en las colonias, el armazón de los buques intenta resistir los ataques de hambre del pavoroso teredo novalis, un molusco bivalvo de cuerpo aparentemente blando, pero con unos dientes que perforan la estructura externa de los navíos como la broca de un taladro. En Espańa, el Almirante General del Mar de principios de siglo, pasa a ser, bajo el reinado de Carlos III, Almirante General de la Armada, aun dependiente, como siempre lo estuvo, del Estado Militar de la Real Armada y del Consejo Supremo del Almirantazgo. La insignia izada al tope de trinquete, al tope de mayor o al tope de mesana, recuerda a las demás divisiones la categoría del General a bordo. Las más modestas fragatas disponen de dos puentes y ochenta cañones. Otro tipo de buques como el Rey Carlos y el San Hermenegildo, reproducidos al óleo por Thomas Whitcombe con la misma majestuosidad artística que apreciamos en el Laocoonte heleno, aparecen reflejados en lo que es un lienzo de finales de la Ilustración donde el fuego amigo parece haber ocasionado un daño irreparable en el gobierno de ambos navíos. ${ }^{3}$ Antes de que el alcázar, las cuadernas, los pasamanos, las ventanas de luz para los camarotes, el mamparo de división de la bodega, los obuses de avancarga y el barco entero salte por los aires, el Rey Carlos se adentra en una nube de humo mientras una parte de la tripulación intenta controlar las llamas que están a punto de alcanzar la munición de metralla y la pólvora embarrilada. El cuadro ilustra el momento en que la potencia artillera del navío ha dejado de ser lo suficientemente efectiva para esquivar, en la ambigüedad de la noche, el fuego amigo del San Hermenegildo que se

3 En la actualidad, el lienzo referido se encuentra depositado en el National Maritime Museum de Londres. 
va todo a babor para hundir definitivamente a quien supone que es el $H M S$ Superb de bandera británica.

En el siglo XVIII, Francia es la principal potencia del mundo. Un elevado número de mercaderes y comerciantes rivalizan en la transformación del abasto de la Armada y en la obtención de dinero líquido con el que impulsar definitivamente sus negocios con productos traídos de las divisiones territoriales y administrativas de las colonias. Durante los reinados de Luis XV y Luis XVI, la suma de todo lo que se puede producir, consumir y decir, viene de la élite intelectual: "de los filósofos naturalistas", dicen los franceses; de la revolución científica, en verdad, que se empeña durante este siglo en cambiar las cosas todos los días. En el debate público, la ciencia se ha convertido en el tema predilecto de aquellos que controlan el poder político y desean invertir, como una parte interesada de la burguesía que es amiga de la nobleza, en el conocimiento. En las conversaciones privadas, la Tierra es ancha y el mundo conocido pequeño. Con una flota de más de cinco mil naves, los almirantes franceses ponen rumbo a un gigantesco belicismo exterior - Guerra de Sucesión de Austria, Guerra de los Siete Años, Guerra de la Revolución Americana, Guerras Revolucionarias Francesas y, a principios del XIX, las Guerras Napoleónicas- demandante de un esfuerzo financiero que a punto está de desestabilizar la estructura del Estado. En París, el ambiente intelectual es alto, el movimiento científico importante y los nuevos hallazgos en el área de las matemáticas, el análisis químico, la física, las manifestaciones de la electricidad y la técnica, absolutamente alentadores. En la Ecole national supérieure des beaux-arts de París y en la Académie royale de peinture et de sculpture de la misma ciudad, se realizan cientos de estudios preparatorios para ir creando escenas donde las acciones de la Armada y los nuevos artilugios científicos pasen a la historia representadas en piezas claves de la pintura francesa. ${ }^{4}$

$\mathrm{Al}$ igual que ocurre en las escuelas de Bellas Artes de las principales capitales europeas, en la Armada española conviven irlandeses, escoceses, italianos, franceses... Los ingleses que huyen de la monarquía de George II solo tienen que decir que son católicos, contar al brigadier de marina que quieren refugiarse en España porque se sienten perseguidos por esta cuestión en su país y soportar, al menos, un año de instrucción en el Cuerpo de Infantería para colarse como

4 En este apartado de la pintura francesa del siglo XVIII destacan, entre muchos otros, el pintor Ambroise Louis Garneray, Claude Joseph Vernet, Ludolf Bakhuizen, Nicolaus Baur y Philippe Jacques de Louthebourg, todos ellos precursores del genial Auguste Mayer, este último, nacido en la ciudad de Brest en 1805. 
uno más en la próxima guarnición española que zarpe rumbo América. Con el tiempo se descubre que algunos son espías y que su trabajo, al menos en la segunda mitad del Siglo de las Luces, parece ser mucho más exitoso que el demostrado por el científico español Jorge Juan y Santacilia en sus años de juventud. Una buena parte de los dibujos e ideas traducidas al papel por el guipuzcoano José Antonio de Gaztañeta e Iturribalzaga que influyen definitivamente en la arquitectura naval espańola del siglo XVIII, revolucionan extrañamente el sistema constructivo de la Royal Navy con pruebas irrefutables de deshonor, robo, filtración y copia de los ingleses según el Consejo Supremo del Almirantazgo español de la época. Espías británicos y, a la vez, magníficos copistas y dibujantes en el mundo de la hipermasculinidad de los dibujos y de la pintura de guerra del siglo XVIII, emparentan el espionaje entre los dos países, por un lado, con informaciones sobre las ventajas de la construcción naval "a la inglesa" informadas por Santacilia a la Marina Real Española y, por otro, con la copia de elementos, croquis, planos, maniobras y señales creados por Gaztańeta en la España de Felipe V y Juan José Navarro de Viana y Búfalo, Marqués de la Victoria, en la de Carlos III. En el Reino de Gran Bretaña, tal y como es ampliamente conocido el extremo más occidental de Europa entre 1707 y 1801, destaca el famoso diseñador naval Thomas Slade, con bellos y bien ejecutados dibujos que van desde el HMS Superb de 1759 hasta el HMS Victory de 1878. Los óleos de los pintores de la guerra — Samuel Scott, Richard Paton, George Arnald, Nicholas Pocock, Thomas Whitcombe, Robert Dodd, Thomas Buttersworth...- sorprenden con reproducciones de eventos históricos, combates, contraataques, vigorosas andanadas y excelentes buques insignia que navegan con distintos estados de la mar por las costas de Gran Bretaña, Italia, Francia y los Países Bajos.

En Espańa, como el antiguo sistema administrativo de los Austrias va perdiendo paulatinamente competencias frente a la llegada del nuevo modelo monárquico absolutista inspirado en la Francia de Luis XV, las primeras expediciones científicas a América del sur son, en su mayor parte, franco-españolas. A mitad de siglo, con plena renovación de la cultura de España en las ciencias, la literatura, la filosofía, la política, la religión, la economía y el arte, las expediciones científicas al Nuevo Mundo están mejor preparadas para viajar e intentar superar la labor etnográfica de los misioneros españoles aún presentes en dicho territorio durante el siglo XVIII. Con encargos de apuntamiento para la Historia Natural, la Botánica y la Geografía de América Meridional, los buques completan su dotación con espléndidos dibujantes, en el caso de España, alumnos de la Academia de Bellas Artes de San Fernando como Joseph Brunete, 
Isidro Gálvez y un grupo escogido de jóvenes universitarios que, aplicados en las diferentes ramas de las ciencias naturales son ya reconocidos por los profesores de la Real Academia de la Historia no solo por los conocimientos científicos que apoderan, sino por la ejecución de bocetos que, en el caso del farmacéutico Hipólito Ruiz López, el botánico José Antonio Pavón y Jiménez, el cirujano José Celestino Mutis, el naturalista Baltasar Manuel Boldo Tuced, el médico militar y botánico Martín de Sessé y Lacasta y el explorador, antropólogo y cartógrafo Feliz de Azara, ayudan a la sociedad científica del momento a descubrir verdaderamente América.

Para los principios mercantilistas de la Ilustración, el dibujo, plenamente realizado o insinuado de forma esquemática, tiene que ser capaz de transmitir una información práctica y racional. Con lápiz de grafito y papel entre otros enseres de supervivencia artística como la goma arábiga y la glicerina tan necesaria, en aquellos tiempos, para encandilar a Europa con las acuarelas, América comienza a ser percibida por primera vez en la historia a través de un conjunto de ilustraciones sobre su vida agreste y montaraz. Es en Sudamérica donde, formando parte de la colonización cultural, un grupo de jóvenes dibujantes que llevan bajo el brazo los papeles y las horas de clase empleadas en las academias, quiere conquistar la estética, cada uno, individualmente, y todos, agrupados en el ars gratia artis primitivo que ahora insiste en preguntar qué ha de tener la botánica para ser bella. ${ }^{5}$

5 Para el movimiento ilustrado, la Filosofía y la Historia del Arte ya se han preocupado lo suficiente por sus enfoques estéticos durante siglos. Ahora le toca el turno a la ciencia adonde llegan las recomendaciones de los maestros del arte y sus representaciones neoclásicas para advertir a los nuevos historiadores, antropólogos, botánicos, médicos, cartógrafos, naturalistas... sobre la importancia de la producción artística en su relación ancestral con las ciencias. En las aulas de las academias de arte europeas, en los seminarios avanzados para el dibujo del cuerpo humano y en las despedidas de fin de curso, se habla también del carácter interdisciplinar, posición predominante y relación dialéctica que desde siempre ha existido entre la ciencia y el arte. En las calles de Roma, en las avenidas de París y centro de algunas ciudades tan importantes como Madrid, Londres y Berlín, cualquier dibujante tropieza, más tarde o más temprano, con alguien que pertenece a la sociedad científica del momento. 
“Aprendices dibujando las distintas partes del cuerpo humano". Ilustración realizada con la técnica del aguafuerte por el grabador italiano Odoardo Fialetti (1573-1638) incluido en una cartilla de práctica del dibujo de 1608

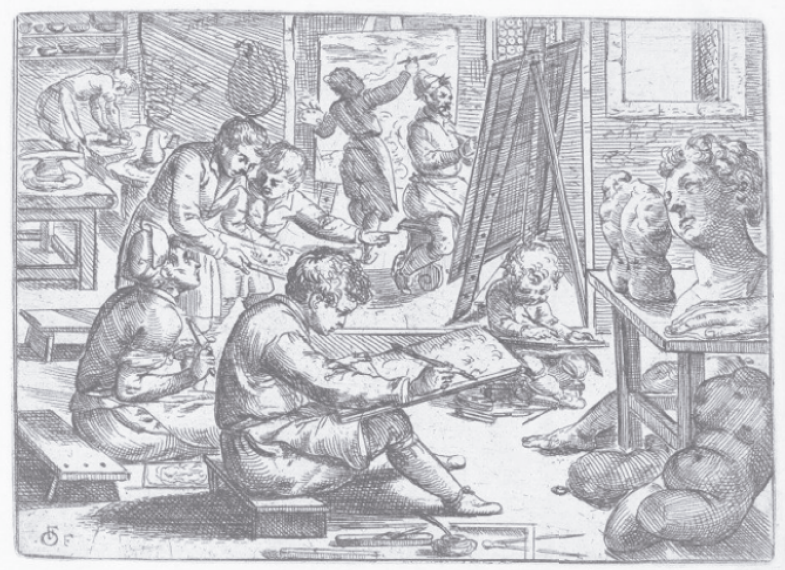

Fuente: Museo Nacional del Prado. Biblioteca.

Los viajeros de las expediciones científicas del siglo XVIII navegan preocupados por el océano y, sin embargo, el Atlántico no se pinta, no se dibuja, no se ilustra. Siendo el mar un elemento susceptible de ser recreado sobre el papel como una planta, un insecto o una flor por su concepción natural, el piélago no despierta interés en sí mismo porque es demasiado real y los dibujantes que ahora van rumbo al extinto Imperio Maya no viajan atraídos por esa parte de la estética socrática que, como en Jenofonte y en Parrasio, según cuentan ellos mismos por las calles de la antigua Grecia, es exclusiva de la idealización.

En los años de la Ilustración, el mar que separa las costas de Europa con las playas de América sigue atestado de marineros que recuerdan el clamor emocionado del vigía Rodrigo de Triana cuando, en la madrugada del día once de octubre de 1492, grita “tierra, tierra... tierra a la vista!” a cuyas tan dulces palabras, según el historiador Francisco López de Gómara, "acudieron todos a ver si decía verdad; y como la vieron, comenzaron el Te Deum laudamus, hincados de rodillas y llorando de placer". Atisbar en el horizonte la ondulación oscurecida de lo que parece una sucesión de montañas enlazadas entre sí y lumbres o candelas en la costa, se traduce durante dicho período en un dato fundamental para los estudios y el impacto de la comunicación visual en el campo 
de la comprensión. ${ }^{6}$ El Renacimiento se había habituado a recibir noticias e información basadas en la imagen. El Siglo de las Luces, en cuanto a capacidad para juzgar la calidad y pertinencia de la figuración clasicista, está dispuesto ahora a ser mucho más exigente que siglos atrás. Como en el caso de Colón y el bramido a treinta metros de altura de Triana en La Pinta, se trata de comunicar algo que refuerce la idea que se tiene del progreso en el siglo XVIII, y los dibujos, como se intentó aclarar seguidamente si eran luces o candelas lo que se veía desde el castillo de popa de La Pinta, han de venir acompañados de una impronta objetiva.

Bien fuera por sorprender a la ciencia con resultados que subrayaran el acierto de los viajes, bien por la renovación del país o por la Ilustración en sí misma, los nuevos sofistas del antiguo decorum latino, aun, esta vez, bajo los designios de la Ilustración, resuelven desarrollar la erudición con un cientifismo que sea propio de su tiempo. En toda Europa, los viajes transoceánicos del siglo XVIII inseparablemente dispuestos junto a la preeminencia del dibujo artístico frente al color, logran que ciencia y aventura sean una sola cosa. En tiempos de la Ilustración, como decimos, para viajar hay que saber; y para conocer, es necesario viajar. Solo de este modo se entiende que un artista como Juan de Dios Castel, vestido de blanco y con todo lo necesario para ponerse a dibujar sin necesidad de comprar nada en América, embarque junto al célebre naturalista sueco P. Loeffling, el médico catalán Antoni Condal y el botánico de la Alta Garrotxa pirenaica Benet Paltor i Fiter en las expediciones que, de principio a fin, respalda el rey Fernando VI al Orinoco. El cien por cien de los dibujantes que forman parte de la guarnición de las expediciones científicas,

6 En el capítulo titulado "Lo crudo y lo cocido", el reconocido antropólogo y filósofo francés Levy Strauss indica que la aventura del conocimiento en el Nuevo Mundo no fue tan solo hacia el "otro" sino, en muchos aspectos, hacia el propio discurso europeo de la Ilustración: "Si el pensamiento salvaje marca en nuestra tentativa una especie de pausa, es sólo porque teníamos que tomar aliento entre dos esfuerzos. Sin duda la aprovechamos para abarcar con la mirada el panorama desplegado ante nosotros, disfrutando así de la ocasión ofrecida de medir el trecho recorrido, acortar el itinerario por venir y hacernos una idea sumaria de las comarcas extranjeras que tendríamos que atravesar pese a que habíamos decidido no apartarnos nunca duraderamente de nuestro camino ni aventurarnos por los cotos, tan bien vedados, de la filosofía” (1986: 129). De esto, precisamente, había hablado Michel de Montaigne a mediados del siglo XVI en "De los caníbales". "Es curioso como Montaigne toma una actitud parecida a Lévi-Strauss", escribe Sandra del Peral. "Su idea”, continúa, "de que cada cual considera bárbaro lo que no pertenece a sus costumbres, es similar a la que aparece en el libro Raza y Cultura de este antropólogo quien afirma que es una actitud antigua y asentada en nuestras mentes la de repudiar las formas culturales que estén más alejadas de aquellas con las que nos identificamos" (2005:64). 
llevan a Demócrito en su mirada. A todos ilusiona llegar, al fin, a su destino y ponerse a dibujar la naturaleza americana exactamente igual a como fluya ante sus ojos. A los buques expedicionarios del siglo XVIII no puede subir la poesía; tampoco la música, y eso que ambas cosas son el delirio de Feijoo y, también, de Cadalso, como resulta sencillo advertir en algunas de sus cartas marruecas. ${ }^{7}$ A partir de la aventura al Orinoco, la ciencia botánica gira en torno a la idea de la naturaleza tal como quiso explicarla Demócrito entre los antiguos: destacando lo bueno, pero también lo útil y provechoso que hay en ella.

Siendo Carlos III soberano ilustrado y, como tal, mecenas de las artes, emprenden rumbo a Perú pintores de la talla de José Fco. del Pulgar y José Rivera acompañados del joven botánico navarro Juan José Fco. Esteban Tafalla y Navasqués. Atraídos por la enorme cantidad de especies de flora y fauna, vastos humedales y pantanos donde extensas bandadas de aves que llegan desde el hemisferio norte descansan para seguir su trayectoria hacia el sur, la expedición del médico francés Joseph Dombey, el botánico burgalés Hipólito Ruiz López y el farmacéutico José Antonio Pavón y Jiménez a Lima, con incursiones a las proximidades de la Amazonia y norte de Chile entre 1777 y 1795, sorprende a la tripulación por la amplia variedad de ecosistemas, la eterna humedad generada por la neblina proveniente del mar y las corrientes de aire frío que se derivan de la Antártida. Proteger de la humedad los dibujos a pincel, aguadas de tinta china y pinceladas de color que se van apilando con los días en la hacienda de una ciudad amurallada, es algo que se hacía también en la Grecia arcaica, alejándose, los artesanos, de las zonas superiores del páramo por las inclemencias de un tiempo extremadamente variable. Entre los ríos, cientos de lagunas y restos arqueológicos del lugar, la belleza escénica del Perú de Agustín de Jáuregui, los valores asociados a la vida silvestre atraen la atención de nuestros viajeros ilustrados que advierten en la Selva Baja, conocida también como región Omagua, un corredor biológico donde se da muy bien el árbol de la quina.

El cometido de la expedición del célebre José Celestino Mutis y Bosio al Virreinato de Nueva Granada cuando es tan solo un joven de veintiocho años supone algo más que la simple elaboración de un volumen que incluya la his-

7 Bajo ningún concepto quieren los dibujos de la ciencia hablarle al corazón sino al cerebro; y no es porque los sentimientos, el afecto y las emociones se supongan devaluados ante tanta racionalidad dieciochesca, sino porque todo lo que viene de América, Filipinas y las colonias en forma de números, conceptos, productos - madera, plantas, conchas, semillas...- y riquezas para el Estado, llega aunado a concepciones de certeza, demostración y objetividad ligadas a las evidencias del dibujo. 
toria natural de los tres virreinatos españoles en América. Construido según las Ordenanzas de Arsenales de 1776, el buque que se detiene a mirar nuestro bien ilustrado autor desde los embarcaderos de su ciudad natal, está recién pintado, en amarillo y negro, la talla exterior y galones, y en porcelana azul las cámaras. Bajo la carlinga del palo mayor y a un lado de su camarote, la maleta con todos sus enseres personales. Al otro lado y sobre un anaquel, los elogios de Jovellanos sobre las Bellas Artes, las primeras reflexiones de Winckelmann acerca de la belleza, los trabajos inacabados de Alexander Gottleb Baumgarten relativos al conocimiento sensorial y un ejemplar de Orbis Sensualium Pictus (1658), de John Amos Comenius que, antes de llegar a Santa Fe de Bogotá en un viaje de algo más de cincuenta días, es la enciclopedia ilustrada con más traducciones al inglés y al alemán del momento. Según los papeles que el gaditano lleva consigo, su oficio en el Nuevo Mundo será atender, como médico, al virrey Pedro Messía de la Cerda y, desde esa decorosa posición, poner en práctica y desarrollar, entre nativos y criollos, sus conocimientos en Geografía, Matemáticas, Zoología e Historia del Arte. Celestino Mutis no es Platón, pero habla de su amor desinteresado por la ciencia como si, a ratos, fuera él mismo el que estuviera suplantando al filósofo en la antigua Academia. De esta forma conoce a Salvador Rizo Blanco que, en calidad de experto cartógrafo, pasará a ser muy pronto su mano derecha, maestro del gabinete de dibujantes previamente escogidos por la expedición e impulsor de la Escuela de Dibujo y la Escuela Gratuita de Dibujo de la Real Expedición Botánica del Nuevo Reino de Granada (1783-1816).

Poseedor de un gran sentido de la perfección y la exactitud en el arte, Pablo García del Campo es nombrado primer delineador entre el grupo de artistas sudamericanos. Su trabajo consistirá en dibujar las plantas respetando su tamaño natural y, siguiendo palabra por palabra las directrices de Mutis, aplicarse en la técnica del miniado con el fin de conseguir que los contornos de las flores y algunos tallos decididamente leńosos por su naturaleza sean ejecutados de la forma más realista posible. Transformado, como decimos, en un sistema filosófico donde la contemplación de tanta belleza hace que, para Celestino Mutis, valga la pena estar en Bogotá, el sacerdote actúa como bien procede al cerebro de una operación, es decir, como un hombre que vive entre los tiempos antiguos de Platón y la nueva escuela de dibujantes criollos donde la estética natural de las plantas y flores de Colombia, en cuanto a su formación y belleza, resume el bien y la verdad ideales de su expedición.

Entre los árboles y los arbustos que crecen junto a los ríos y los pastizales de menor altura de las llanuras, pasta una gran variedad de animales herbívoros 
gracias a las especies de flora que el ilustrado botánico se empeña en ir dibujando por la variedad de amarillos, rojos y verdes que nunca había visto en Espańa. Las diversas gamas del rojo natural, por ejemplo, se extraen del dactylopius coccus, la cochinilla mejicana: un parásito que se reproduce en las pencas de nopal o tunas que, al mezclarlo con zumo de limón, se obtiene el morado o el color carmesí que se observa en algunas láminas de su colección como la que representa a la Heliconia. Un tinte rojo - la tinta Campechese extrae igualmente del haematoxylum campechianum, el palo Campeche: una especie arbórea original de la península de Yucatán que, cuando florece, los pétalos y la corola aparecen unidos en cimas sujetas por un pedúnculo que hace del conjunto algo simplemente maravilloso a los ojos del Iluminismo. Otra gama del rojo natural es la que Celestino Mutis extrae del palo brasil la caesalpinia echinata o pernambuco- que, en comparación con el rojo vivo, el rojo señales, el rojo óxido, el rojo carmín o el rojo pardo de otras láminas, parece más bien un rojo rubí. Dicho color es el que el equipo de dibujantes hispanoamericanos de Celestino Mutis incorpora en la Mutisia lanata, la Alstroemeria pulcherrima y la Cortaderia nitida que, después de tantas pruebas de contraste con otros colores, descubren que, en combinación con el verde, el blanco y el gris, las nuevas láminas reflejan lo que es perfecto para el arte pero, esta vez, también para la ciencia. ${ }^{8}$

Entre 1789 y 1794, su Católica Majestad Carlos IV, que ya cuenta en palacio con un retrato realizado por el recientemente nombrado pintor de cámara Francisco de Goya y Lucientes con motivo de su coronación el 14 de diciembre de 1788, quiere seguir adelante con lo que es la mayor expedición políticocientífica del siglo a cuyas fragatas se dirigen los dibujantes José del Pozo, Juan Ravenet, Felipe Bauzá y José Cardero junto al botánico de origen guatemalteco Antonio Pineda, el viajero franco-español Luis Neé y el famoso geólogo checo Thaddeus Peregrinus Haenke. La expedición que comanda el reconocido brigadier italiano de la Real Armada Alessandro Malaspina y el español José Bustamante y Guerra encarga el dibujo botánico al madrileño José Guío y Sánchez que, por propia iniciativa, lucha lo indecible para ocupar dicho puesto. Malaspina es un hombre adiestrado en la oficialidad pero también un mando de la Real Armada amante de la estética y, como tal, del lenguaje de lo pintoresco,

8 Los dibujos de la Real Expedición Botánica del nuevo Reino de Ganada continúan a día de hoy custodiados por el Real Jardín Botánico de Madrid, centro que en la actualidad forma parte del Consejo Superior de Investigaciones Científicas. La colección que supera las siete mil láminas puede visitarse en http://www.rjb.csic.es/icones/mutis/paginas/ 
la percepción de la belleza del arte y sus cualidades: lo bonito, lo deforme y la desarmonía. ${ }^{9}$ En España, Alemania, Francia o Inglaterra, los oficiales que quieren pasar a los anales de la historia siendo ellos los primeros en circunnavegar el mundo, han de dar varias vueltas a la mesa de operaciones sobre la que se han desplegado las mejores cartas náuticas que la industria cartográfica del momento ha impreso para tal fin. Es la hora de Kant y, entonces, lo que en la pintura al aire libre y en los libros de viajes son dibujos y alzados que persiguen una finalidad estético-informativa, ahora es tan solo una reminiscencia platónica de escaso interés porque tanto para Malaspina, como para James Cook y Louis Antoine de Bougainville, las cartas marinas, en términos kantianos, tienen que responder a una finalidad objetiva de perfección, aspecto que, en la Crítica del Juicio (1790) del conocido precursor del idealismo alemán, se define como el funcionalismo estético, conocido, comúnmente, como la efectividad científica del arte.

Las corbetas Descubierta y Atrevida llevan a bordo a uno de los mejores dibujantes de botánica pura de España. Bocetos y aguadas de plantas de Uruguay, Argentina e Islas Malvinas pulcramente diseñadas y celosamente conservadas por el propio José Guío es todo lo que la expedición aporta a la ciencia desde la jurisdicción del Atlántico puesto que, como pintor al aire libre que es, él mismo va creando su estilo, eligiendo la ruta campestre, el arroyo o la dehesa donde tomar los primeros apuntes que, a la vuelta y como hacían todos, va incorporando a su carpeta de estudios. Al ser despedido por Malaspina como quien ve en la mímesis del arte nada productivo y tampoco escucha a Sócrates decir que el principio del arte es la representación aparente de las cosas, viaja a la ciudad de Lima para dedicarse a la disección, su otra pasión, dibujar plantas y flores en Panamá así como extrańos insectos, mariposas, escarabajos y gusanos que son propios del hábitat existente en los alrededores de Acapulco e isla de Cuba donde finalmente se instala. ${ }^{10}$ Peces, aves, víboras, reptiles... van incor-

9 En Lo pintoresco. Estudios desde un punto de vista, Christopher Hussey se detiene en un fragmento de Northanger Abbey (1817) precisamente donde Jane Austen, a finales del siglo XVIII, se refiere a la importancia sobresaliente de la perspectiva, las luces y las sombras. "La formación, la herencia y el ambiente", escribe Hussey, le hicieron finalmente valorar la relevancia y actualidad de lo pintoresco hasta concluir en que "poco a poco se fue revelando como una larga fase en la relación estética entre el hombre y la naturaleza" (2013:12), en nuestro caso, entre aquellos viajeros dibujantes y el mundo que se abría ante su mirada.

10 En "Tomás de Suria, un dibujante de la expedición de Malaspina. Su contribución al conocimiento del occidente en Norteamérica" (1997), de Agueda Jiménez Pelayo, y "Pintores en las grandes expediciones científicas españolas del siglo XVIII” (2006) — véase el apartado 'Expedi- 
porándose a su carpeta de dibujos como perlas en un collar matinee durante sus posteriores salidas y viajes de pasajeros a América cuya licencia, antes y después de su experiencia con Malaspina, sigue siendo imprescindible.

La paz de Utrecht de 1713-1717 permite, entre otras consideraciones que, al menos, una flota de marineros de Inglaterra viaje una vez al año en navíos de permiso a las Indias Occidentales. La escuadra de seis barcos de George Anson es avistada por última vez en las costas de América del Sur en 1740. Sobre el vicealmirante John Byron se advierte que la fragata HMS Wager naufraga frente a las costas de Chile un año después. En las costas de América del sur no hay corsarios. En 1718, el apelativo que se usa es otro y, ya sea por respeto a la nueva situación internacional o porque el lenguaje europeísta así lo precisa, en lugar de ser señalados como piratas, ahora son ladrones: jóvenes aventureros que no creen en gobiernos ni leyes sino en la oportunidad de pasar a la historia siendo alguien, sobre todo, ricos, algo que en el siglo XVIII sigue siendo imposible para los que vienen del pueblo llano.

Libre el mar de piratas y oloneses — seguidores de François L'Olonnais, "El Olonés”, Pierre Le Picard, Laurens de Graff y Ravenau de Lussan, los bandoleros más sanguinarios de finales del XVII en la mar-, la historia de la Marine Royale de France registra varias expediciones científicas, sobre todo, las del navegante Louis Antoine de Bougainville que, con un pensamiento dirigido a la acción, parte, en 1766, de la ciudad francesa de Brest en viaje de circunnavegación al mundo. Por una parte, Francia, con todos los instrumentos facilitados

ción de Malaspina (1789-1794)', págs.174-175—, de Santiago Prieto Pérez, hay coincidencia en decir que José Guío dejó de interesar al noble navegante por su excesiva especialidad en los dibujos botánicos. La concepción de la belleza que el brigadier de la Real Armada adopta en plena expedición es como la evolución que, en Historia del Arte, va desde la antigua teckné griega a la reflexión sobre el gusto de la belleza en la Ilustración. El hecho de que José Guío fuera inmediatamente sustituido por Juan Ravenet, Fernando Brambila, José Cardero y Tomás de Suria en los primeros compases de la expedición, conviene encuadrarlo en un problema de progresión del gusto o de la facultad de juzgar la belleza de manera diferenciada y ser reconocido uno mismo, en este caso, el propio Malaspina, por su forma de ser psicológica. "Del Pozo, pintor sevillano", escribe la profesora Jimenez Pelayo, "realizó su obra pictórica principalmente en Río de la Plata y Chile. Según Malaspina era un hombre con algo de talento, pero indisciplinado, flojo y no apto para su misión, por lo cual fue destituido al llegar al Perú. Guío se dedicó casi totalmente a reproducir plantas y a adelantar con algún éxito el estudio de la historia natural, a la que era muy inclinado; pero gozaba de poco favor a bordo y su salud no era buena, por lo que se pensó dejarlo en Acapulco. Sin embargo, ... su comportamiento y su asiduidad al trabajo fueron intachables... Su labor era muy especializada, estaba encargado del dibujo botánico y de la disección, pero estas actividades no constituían el objetivo primordial del viaje" (1997: 493). 
por L'État de la Marine Royale para fijar el cálculo de las distancias y establecer el volumen de las regiones. Por otro lado, Inglaterra, con James Cook al frente de un equipo de geógrafos que trabaja día y noche en cómo recoger con precisión las coordenadas que definan las futuras enfilaciones de la marina británica a la costa americana. Con un compás y reglas paralelas sobre las cartas, Cook y Bougainville planifican los rumbos. Con la ayuda de la escuadra y un cartabón, el lápiz de los dos oficiales traza las líneas isobáticas, las flechas que van en la dirección de las mareas y las derrotas. En 1780, el valor de la función práctica de los planos de doble hoja de la navegación científica está muy por encima de la resonancia ornamental, superflua e innecesaria de los planos náuticos de siglos anteriores.

Para llegar a esta y otras conclusiones, en la cubierta del HMB Endeavour de 1768 se divisa al dibujante Sydney Parkinson, al científico naturalista Joseph Banks y al famoso botánico Daniel Solander que, después de un largo periodo de instrucción sobre lo que hay que hacer y lo que no, deciden soltar amarras junto a James Cook en su primer viaje. En el HMS Resolution, la fragata con la que el navegante convertido en explorador piensa, en 1772, realizar su segunda travesía, viaja el magnífico pintor William Hodges. En la salida de 1776, su tercer y último viaje, James Cook contrata al famoso paisajista al aire libre John Webber y al naturalista Johan Reynold Forster. Con idéntica guarnición ilustrada zarpan los franceses a sus reclamos territoriales en las Indias y África Occidental. Voyage autour du monde, par la Frégate du Roi La Boudeuse et la Flute l'Etoile, 1766-1769 (1772), no es tan solo el resultado de una exploración por las tierras colonizables del Pacífico, sino también el reto personal, científico y espiritual del dibujante y experto botánico Philibert Commerson de quien se descubre, en los últimos compases de la vuelta al mundo, que la verdadera identidad de su acompañante es Jeanne Baret: “¡una mujer!”.

En España, Vicente Tofińo de San Miguel, el marino que no sabe del final de Cook en Hawai ni del caso de la mujer disfrazada de hombre en la expedición de Bougainville, es el empuje científico que necesita la Escuela de Guardia Marinas Oficiales del Real Observatorio de Cádiz para el levantamiento de los planos de las islas Baleares y las islas Azores. La publicación, en 1789, del Atlas Marítimo de España con dibujo a lápiz de Raphael Mengs para la portada, sintoniza con el encendido debate que, en los ańos centrales del siglo XVIII, se dirime en Francia sobre la importancia del dibujo frente al color. Cuando Felipe de Anjou es tan solo un joven de casi diecisiete ańos que a punto está de instaurar en España la dinastía de los Borbones, Francia y el debate académico sobre la importancia que el dibujo tiene para la ciencia de Las Luces están en 
todas partes. En 1790, el Atlas Marítimo de España de Tofiño de San Miguel que muestra el preciado dibujo de Mengs donde se ven representados los utensilios que son necesarios para la navegación - una corredera de barquilla, un compás giroscópico, un astrolabio, un cuadrante de plomada, una ampolleta...-, resume ambas cosas: la preparación del artista y el estado científico de renovación en que se encuentra la marina española bajo el reinado de Carlos IV. Estudioso de la Antigüedad Clásica, alumno de las academias europeas para el aprendizaje del desnudo, dibujante al aire libre en los alrededores del Vaticano... Mengs y su trabajo de portada son sinónimo de Ilustración: un siglo que, desde la preparación clásica de sus dibujantes, emite un aviso de modernidad a los siglos venideros y que, en los últimos ańos del citado periodo, toca con el Atlas... en la puerta de todos los Departamentos de Hidrografía de España, llegando a estar, en el año de inauguración del Louvre (1793), en la mesa de reunión de todos los despachos marítimos de Europa y, también, en las conversaciones entre Rafael Clavijo y Alexander von Humboldt en el Madrid de 1799, quince días antes de zarpar, el 5 de junio de ese mismo año, hacia Canarias y descubrir, allí, la majestuosidad de la naturaleza y la variedad de lo pintoresco.

\section{OBRAS CITADAS}

Amos Comenius, John. [1658] (1859). Orbis Sensualium Pictus. London: John y Benj. Sprint. 1728. CENNINO, Cennini. Il Libro dell'Arte o Trattato della Pittura. Firenze: Felice Le Monnier.

Carter, Francis. 1780. A Journey from Gibraltar to Málaga: with a View of the Garrison and its Environs; a Particular Account of the Towns in the Hoya of Málaga... and Thirteen Plates Engraved from original Drawings Taken in the Year 1772. F. Nichols: London.

Corbin, Alain (ed.). 2005. "Introducción", en Historia del cuerpo, II. De la Revolución Francesa a la Gran Guerra. Madrid: Taurus. 15-17.

De Jovellanos, Melchor Gaspar. (1887). "Elogio de las Bellas Artes" en Obras escogidas de Jovellanos. (Prólogo de F. Soldevilla "Jovellanos. Sus obras y su tiempo"). París: Librería de Garnier Hermanos, 62-104.

De Laborde, Alexander. (1806). Voyage Pittoresque et Historique de L'Espagne. Paris: Pierre Dido L'Aine.

Del Peral García, Sandra. (2005) "Michel de Montaigne y su ensayo 'De los caníbales". Albadis. net. La revista de educación, 7, 64-65.

Heidegger, Martin. (1953). Sein und Zeit. Tubingen: Max Niemeyer Verlag. 
Hussey, Christopher Edward. (2013). Lo pintoresco. Estudios desde un punto de vista. Madrid: Biblioteca Nueva.

Jiménez Pelayo, Águeda. (1997). “Tomás de Suria, un dibujante de la expedición de Malaspina. Su contribución al conocimiento del Occidente en Norteamérica". Anuario de Estudios Americanos. Sevilla: Escuela de Estudios Hispano-Americanos (CSIC), LIV, 2, 489-509.

Kant, Immanuel. (2006). Crítica del juicio. (Traducción de Manuel García Morente). Madrid: S. L. U. Espasa Libros.

Levy-Strauss, Claude. (1986). "Lo crudo y lo cocido". Mitológicas. México: Fondo de Cultura Económica de México, I, 119-157.

Locke, John. (1997) An Essay Concerning Human Understanding. London, Harmondsworth: Penguin Classics.

Mengs, Anton Raphael y Johann Caspar Fuesslin. [1771] (2010). Gedanken über die Schönheit und den Geschmack in der Malerei. New York: Kessinger Publishing.

Montaigne, Michel. (2006). Ensayos I. (Edición de María Dolores Picazo). Madrid: Cátedra.

Montaigne, Michel. (2006). Ensayos II. (Edición de María Dolores Picazo). Madrid: Cátedra.

Montaigne, Michel. (2006). Ensayos III. (Edición de María Dolores Picazo). Madrid: Cátedra.

Penhos, Marta. (2011). "La ciudad como paisaje: estética y política en algunas representaciones de la expedición Malaspina (1789-1794)”. En Rodríguez, Inmaculada y Víctor Mínguez (eds.), Arte en los confines del Imperio. Visiones hispánicas de otros mundos. Castellón: Universitat Jaume I, 313-330.

Pérez Arche, M. Rosario. (1993). "El nacimiento de la sociedad Económica de Amigos del País de Tudela". Revista del Centro de Estudios Merindad de Tudela, 5. Navarra: Sociedad Económica de Amigos del País de Tudela. 5-14.

Platón. (2005). La República o el Estado. (Traducción de Manuel FernándezGaliano). Madrid: Alianza Editorial.

Platón. (1981-1999). Obras completas de Platón. Madrid: Editorial Gredos.

Prieto Pérez, Santiago. (2006). "Pintores en las grandes expediciones científicas españolas del siglo XVIII". Ars Medica. Revista de Humanidades. 5, 2. Madrid: Fundación Pfizer, Grupo Ars XXI de Comunicación. 166-179.

Rejón de Silva, Diego Antonio. (1786). La pintura: poema dialéctico en tres cantos. Segovia: Antonio Espinosa de los Monteros.

Rejón de Silva, Diego Antonio. (1788). Diccionario de las tres Nobles Artes para instrucción de los aficionados. Segovia: Antonio Espinosa de los Monteros. 
Ródenas Valero, Almudena de la Caridad. (2015). "Arte y Ciencia: el Atlas Marítimo de España de Vicente Tofiño de San Miguel". Imafronte. Revista de Historia del Arte, No 24. Murcia: Universidad de Murcia. 73-102.

Summers, David. (1993). El juicio de la sensibilidad. Renacimiento, naturalismo y emergencia de la Estética. Tecnos: Madrid.

Tebano, Parrasio (seud. de Francisco Preciado de la Vega). (1789). Arcadia Pictórica en sueño: alegoría o poema prosaico sobre la teórica y práctica de la pintura. Madrid: Antonio de Sancha.

Twiss, Richard. (1775). Travel through Portugal and Spain in 1772 and 1773. Printed for the author: London.

Winckelmann, Johann Joachim. [1755] (2015). Gedanken über die Nachahmung der Griechischen Werke in der Malerei und Bildhauerkunst. Australia, Victoria: Leopold Classic Library.

Wolfgang von Goethe, Johann. [1795] (2014). Römische Elegien. Munchen y Ravensburg: GRIN Verlag. 


\title{
KEPLER Y UN UNIVERSO ORDENADO
}

\author{
Fernando Hernández Guarch \\ Inspector Jubilado de Educación \\ Consejería de Educación del Gobierno de Canarias
}

\section{Resumen}

¿Vivimos en un Universo ordenado que podamos desentrańar o en un mundo de vagabundos que nunca seremos capaces de entender? Desde la antigüedad clásica, al menos desde Tales de Mileto (hacia el 624-546 a.C.), la ciencia ha buscado el orden en la realidad que se nos ofrece. Pitágoras, Platón, Aristóteles, Ptolomeo, entre otros muchos, han ido marcando un camino para establecer ese orden deseado. Con Kepler, en los inicios del pensamiento científico racional se da un paso de gigante para creer que alguna vez podremos entender el Universo.

Palabras clave: Kepler, ciencia, universo, orden, planetas, astronomía.

\begin{abstract}
Do we live in an ordered Universe that we can unravel or in a world of wanderers that we will never be able to understand? Since classical antiquity, at least since Thales of Miletus (around 624-546 BC), science has sought the order in the reality that is offered to us. Pythagoras, Plato, Aristotle, Ptolemy, among many others, have been marking a path to establish that desired order. With Kepler, in the early days of rational scientific thought, a giant step was taken to believe that we could ever understand the Universe.
\end{abstract}

Keywords: Kepler, science, universo, order, planets, astronomy.

El 28 de mayo del 585 a.C., mientras guerreaban lidios y medos, Tales de Mileto, que formaba parte del ejército lidio comandado por el rey Creso, predijo un eclipse de Sol que, por el efecto sorpresa, les podía ayudar a ganar en la batalla. Es el día en que nace la ciencia tal y como todavía la entendemos, capaz, conociendo los antecedentes, de predecir un fenómeno natural. No podemos separar con claridad lo que hay de cierto o de fantasía en este relato que comparten Herodoto y Plinio, ni lo que supuso de ventaja en aquella batalla por hacerse con la Anatolia en una guerra que finalmente perdieron, pero son muchos los que dudan que el sabio de Mileto, uno de los siete sabios griegos 
(“En la confianza está el peligro”, fue el lema que lo ascendió a esa categoría), tuviera los instrumentos adecuados para conocer de antemano que la Luna se iba a interponer en nuestra visión del Sol. Después, el llamado ciclo de Metón, conocido alrededor del 430 a.C., estableció que 19 años trópicos equivalen a 235 meses sinódicos y eso permitió predecir los movimientos lunares más por rutina que por ciencia. En todo caso, el buscar una explicación natural a un fenómeno astronómico quita a lo asombroso su aspecto inquietante. No existía una teoría general del Universo, aún no era un Cosmos sino un Caos, y los planetas vagabundeaban por los cielos sin que nadie pudiera predecir su trayectoria.

Quizá fue su discípulo Anaximandro el primero en crear un "cosmos", pero en todo caso, las cosas empiezan a cambiar y otro de sus alumnos, Pitágoras, quien con su escuela se atreve ya a hacer manifestaciones de orden sideral buscando una armonía que se juzgará necesaria durante siglos.

Platón (c.427-347), más tarde, nos da una primera versión elaborada intelectualmente. El mundo de las ideas es el "mundo real", lo que observamos son "sombras" y del Cosmos dice: "La forma del mundo tiene que ser una esfera, y todo movimiento debe producirse en círculos perfectos y con una velocidad uniforme". A eso ańadió que la Tierra debe ser el centro de todo. Su teoría es presentada principalmente en el Timeo, si bien hay elementos cosmológicos en otros textos (por ejemplo, en el Fedón y, de modo más particular, en las Leyes).

En seguida Aristóteles (384-322), que no cree conveniente forzar las observaciones para adaptarlas a las teorías y opiniones, enmienda y completa a su maestro abriendo una nueva línea de pensamiento, fijando una región "sublunar" donde actúa la física, y en la que los movimientos se deben o bien a su substancia o naturaleza y los llama "naturales" o bien son "violentos" debidos a su propio impulso o a un motor exterior, y otra región "supralunar" donde están los cuerpos celestes, formados por un "quinto elemento", puro e inmutable que siguen lo dicho por Platón. La totalidad de las cosas están dispuestas para formar un conjunto jerarquizado y ordenado al que llama, ahora sí, "Cosmos". Introduce la idea de que las esferas que transportan los cuerpos celestes en torno a sus trayectorias son cuerpos físicos reales. Cada una de estas esferas transmite su movimiento a la esfera inmediatamente inferior de modo que la esfera de las estrellas fijas provoca el giro diario de todas las demás. Introduce un motor, el primer motor, Primum Mobile, que no actúa en términos de causa eficiente sino como "causa final" que mueva el conjunto, buscando que cada esfera arrastre a la interior con un cierto número de esferas neutralizadoras, o "antigiratorias" 
entre planetas adyacentes y esferas compensadoras, elevando el cómputo de las esferas necesarias para explicar lo que vemos hasta un total de cincuenta y seis.

Saltemos ahora quinientos ańos cargados de progresos en la Matemática. Dejemos atrás a Apolonio de Pérgamo y a Euclides, entre otros muchos, y detengámonos en Ptolomeo (c.85-c.165) que va a construir un modelo que gobernará durante mil quinientos años. Su obra, Sintaxis Matemática ${ }^{1}$, que conoceremos en Occidente a través de los árabes como Al-Majisti ("el más grande") o Almagesto, en un alarde matemático y observacional consigue crear un modelo predictivo de gran exactitud lo que confiere a su construcción, matemática no física, un gran valor. Para conseguir soslayar los problemas de concordancia entre modelo y observación, pues es evidente que si los planetas tienen un movimiento perfecto y siguen órbitas circulares a velocidades constantes nosotros advertimos, sin embargo, retrogradaciones, cambios de brillo, cambios de velocidad, y, en la Luna cambios de tamańo, necesita que los planetas no giren alrededor de la Tierra sino en epiciclos de lo que llama círculos deferentes que tienen su centro en el "punto ecuante" (punctum aequans). ¿En qué consisten estos últimos? La velocidad de rotación de una deferente, o la de cualquier otro círculo planetario, debe ser uniforme (esto es condición sobrevenida de Platón), pero en este modelo no lo era respecto a su centro geométrico sino respecto a un punto distinto de aquél al que llamó ecuante. Sin embargo, si se observa desde el centro geométrico de su deferente, el planeta parece moverse con velocidad no uniforme y de manera excéntrica contraviniendo las normas canónicas. Debido a ello se extendió la opinión de que el ecuante no era un dispositivo legítimo para ser aplicado a la astronomía llegando a considerar que tal aspecto de la astronomía ptolemaica poseía un carácter "monstruoso".

A pesar de todo, Ptolomeo logra vaticinar los eclipses y prever razonablemente los movimientos observados de los planetas. Escribe: "Nos hemos dedicado a la tarea de probar que todas las irregularidades aparentes de los cinco planetas, el Sol y la Luna, se pueden presentar mediante movimientos circulares uniformes, por que tan solo tales movimientos son adecuados a su naturaleza divina... Tenemos el derecho a considerar la realización de esta tarea como la meta definitiva de la ciencia matemática basada en la filosofía”.

1 La secuencia es: Matematica Sintaxis (Tratado matemático), depués pasa a llamarse Megale Sintaxis (El Gran Tratado), posteriormente Megiste Sintaxis (El más grande), en árabe Al Magisti, en latín Almagestum, castellanizado como Almagesto. 
Y así lo creyó mucha gente durante trece o catorce siglos, con lo que llegamos hasta Copérnico (1473-1543). Nace en Thorn (actualmente Polonia), estudia en Cracovia, Bolonia, Roma, Padua y Ferrara. Vivió en Franenberg (Prusia Oriental), donde ejerció de canónigo, médico, economista y astrónomo-astrólogo aficionado. En aquel momento se hablaba de astrología natural, que es la Astronomía, y de astrología judicial, que hoy llamamos astrología a secas y que era defendida incluso por la Iglesia.

Era neoplatónico y defiende el universo "que debe ser" más que el universo "que es". Advierte que el verano era, y es, en el hemisferio norte, más largo que el invierno, lo que le hace interesarse por la astronomía y el desorden que encuentra en el calendario es lo que lo aleja del sistema ptolemaico. Como experto en estos temas es llamado a Roma para ser consultado aunque la Iglesia en el Concilio de Letrán de 1514 admite que no puede modificar el calendario "hasta que sepamos más de los planetas". El cambio cristalizará en 1582 con Gregorio XIII. Hay que conocer el orden para entender el mundo.

Su primera publicación es el Comentariolus, escrita para amigos y discípulos como un adelanto de lo que será su obra. Es más un pasatiempo que una obra profesional. Su éxito se debe a la publicación de la Narratio Prima de Libris Revolutionum, por Rheticus, un entusiasta seguidor, en 1540, en el que se explican y difunden las teorías de Nicolás Copérnico. Los luteranos lo reciben mal: "El loco que quiere echar abajo toda la Astronomía", dicen que dice Lutero.

De Revolutionibus Orbium Celestium es su obra máxima, donde fija al Sol en el centro del Universo y a la Tierra moviéndose en órbitas circulares como el resto de los planetas alrededor suyo, ya que creía que los planetas estaban fijados en la superficie de esferas de cristal huecas y concéntricas. Publicada en 1543 está dedicada al papa Paulo III. Osiander prepara el prólogo del libro en el que escribe en un alarde de prudencia: "Estas hipótesis no tienen por qué ser verdaderas ni siquiera probables". También Francis Bacon: "El sistema helioestático ha sido inventado para facilitar los cálculos, pero no tiene que ser físicamente verdadero". Otros, como Nicolás Oresmes (1323-1382), habían hablado del movimiento de la Tierra (dos barcas en un lago nebuloso, la flecha que cae, etc...).

La Iglesia lo prohibirá en 1600 harta de que se confundan las "hipótesis" para explicar lo que vemos, que las acepta como tales, con las verdades de la Biblia que son sagradas e inamovibles. Giordano Bruno, quien cree que no son meras hipótesis las propuestas de Copérnico acabó en la hoguera en ese año por eso y alguna cosa más. 
Si hacemos un pequeño excurso y pasamos de la Astronomía al Arte de aquella época encontramos indicios de que el buscar un orden en el mundo era una preocupación compartida. Así, Luca Pacioli (1445-1517) escribe De Divina proporcione (1517), donde fundamenta matemáticamente la sección áurea. En este libro trata un tema, paralelo al que estamos abordando, de la más alta importancia para el Renacimiento: la teoría de las proporciones, que rige a todas las cosas y se manifiesta en la armonía de todos los fenómenos. Empieza Pacioli enumerando los autores principales que han escrito sobre esta cuestión: Platón, Euclides, Arquímedes y Boecio. Sigue exponiendo la teoría de una determinada proporción, lo que hoy llamamos sección áurea o, "división de un segmento en media y extrema razón", sección ya empleada por Fidias en el Partenón, lo que hace que el número asociado, cuyo valor aproximado es 1,618 , se conozca como "Phi", y que está también relacionado con la sucesión de Fibonacci (1170- c.1240) cuestión de mucho interés, pero en la que aquí no podemos entrar. En este libro De Divina proporcione, colaboró Leonardo de Vinci dibujando una serie de sólidos geométricos que ilustran una de las partes.

Y es que Leonardo, se interesó por la ayuda que la Matemática podía prestar a la pintura (también en otros ámbitos ya que Leonardo "tocaba" muchos asuntos) lo que sabemos por sus cuadernos en los que anotaba todo lo que le interesaba y por las relaciones que nos han llegado de los libros que iba adquiriendo (y que entonces costaban "una fortuna"), entre los que figuraban unos cuantos, de matemáticas de Ptolomeo, Euclides (Los Elementos en tres tomos) o Arquímedes.

Luca Pacioli a cambio de los dibujos que Leonardo le hizo para su libro le dedicó tiempo enseñándole geometría y álgebra y también el cálculo necesario para poderse valer de ellas. Es muy probable que "El hombre de Vitruvio" que tanta fama le ha dado a Leonardo estuviera inspirado en el libro de Pacioli que hemos citado. Pacioli llamó a Leonardo "el más eximio de los pintores, perspectivistas, arquitectos y músicos, dechado de perfecciones", y recordó “el tiempo feliz en que ambos estábamos al servicio del ilustrísimo duque de Milán” (tomado, y adaptado, de la biografía de Leonardo escrita por W. Isaacson).

Leonardo, lo sabemos por sus anotaciones, se interesó por problemas complejos de la matemática como la cuadratura del círculo o la duplicación del cubo cosas que hoy sabemos que no se pueden estudiar con las herramientas matemáticas que él tenía, y que, obviamente, no fue capaz de resolver. No obstante, llegó a escribir un librito sobre las matemáticas, De ludo geometrico, que 
no publicó (Leonardo era famoso por dejar las cosas a medias). Por lo que sabemos de este libro la matemática no perdió gran cosa. Leonardo escribe también un Trattato della Pittura, (publicado póstumamente en 1651, versión compilada por un autor anónimo), donde dice: "Nessuna umana investigazione si può dimandare vera scienza, se essa non passa per le matematiche dimostrazioni..."

Volvamos a la Astronomía. Tycho Brahe (1546-1601), astrónomo danés, descubre una supernova (11-11-1572), estudia las órbitas de los cometas y se dedica a posicionar los cuerpos en el espacio. Su primer instrumento de observación astronómica es un compás de dibujo. Mantuvo el centro del instrumento cerca de ojo, apuntó cada brazo a un planeta y luego colocó el compás en una hoja donde había dibujado un círculo dividido en 360 grados, subdividido en mitades, obteniendo así la distancia angular entre ellos. La primera observación de la que tomó nota la realizó el 17 de agosto de 1563. Después accede a otros instrumentos, ballestilla, cuadrante, astrolabio, los mejores de su tiempo, y los perfecciona consiguiendo las observaciones más exactas para su catálogo de estrellas.

Se convierte en una autoridad en estos asuntos y trabaja para Federico II de Dinamarca quien lo establece en una isla, Hven, en Oresund donde construye Uraniborg (La puerta del cielo). Posteriormente es nombrado astrónomo real por el emperador Rodolfo II y se establece en Praga.

En una y otra corte ejerció también de astrólogo y cuando descubrió la stella nova predijo que significaba el inicio de una nueva era de paz y prosperidad que se "iniciará en Rusia en 1632". Ya en Praga aconseja al general Wallestein el día más apropiado para atacar según dictan las estrellas.

Diseña en Astronomiae instauratae Progymnasmata un sistema en que la Luna, el Sol y las estrellas fijas giran en torno a la Tierra y los restantes planetas lo hacen alrededor del Sol. Establece que la órbita de los cometas es supralunar y que sigue una elipse

Kepler, tras su muerte, publicará su obra donde fijó la posición de 777 astros fijos a los que luego Kepler añade 223 más. Su precisión no tenía parangón. Se conocen como las Tablas Rodolfinas (1627).

Todos los anteriores y muchos más, unos anónimos otros con nombre en la historia de la Ciencia, son los precedentes que necesita Johannes Kepler (1571-1630) para dibujar un nuevo Cosmos.

Kepler nace en Weil der Stadt, Baden-Württember (Alemania). Luterano, estudió teología en la universidad de Tubinga donde conoció los sistemas de Ptolomeo y Copérnico. Fue profesor de matemáticas en el seminario luterano 
de Graz (1594), territorio católico (recordemos que la Paz de Augsburgo estableció "el cuius regio, eius religio", de tal rey tal religión, que marcará su vida), donde ejerció de astrólogo profesional, cuestión en la que no creía, confeccionando previsiones meteorológicas para el año agrícola, o adelantando ataques de los turcos o situaciones políticas ("asunto tonto y vacío", escribió).

En 1595, mientras daba una clase, tuvo una especie de visión, hoy lo llamaríamos una teofanía, de la armonía cósmica, idea en la que siempre creyó, y dibujó en la pizarra un triángulo equilátero con un círculo inscrito y otro circunscrito y "entendió" que las proporciones se correspondían con las órbitas de Saturno y de Júpiter respectivamente. Eso dio origen a "la gran arquitectura" que expondrá en su primer libro Mysterium Cosmographicum (1596, El secreto del universo), donde defiende que la órbita de la Tierra es la medida de todas las cosas: "La Tierra es un círculo que es medida de todo. Circunscríbele un dodecaedro. El círculo que lo circunscribirá será Marte. Circunscribe a Marte con un tetraedro., el círculo que lo circunscribirá será Júpiter. Circunscribe a Júpiter un cubo. El círculo que circunscribe a éste será Saturno. Ahora inscribe en la Tierra un icosaedro. El círculo inscrito en ese será Venus. Inscribe en Venus un octaedro. El círculo inscrito en él será Mercurio. Tienes la razón del número de planetas." (Tomado, y adaptado, de Koestler, A. (1986).

Hay que tener en cuenta que al redescubrirse Aristóteles a través de Averroes (siglo XIII), se impone la idea de que el universo era una emanación necesaria de la razón de Dios, en lugar de una creación libre de su voluntad, como enseñaba la teología cristiana; las causas últimas racionales de las cosas en la mente de Dios podrían ser descubiertas por la razón (en contra de "la voluntad de Dios es indescifrable", tan cómoda para justos y pecadores). Es decir, el Universo puede ser entendido. La concepción metafísica de Kepler era la de la existencia desde la eternidad en la mente de Dios de ideas arquetípicas, que eran reproducidas por una parte en el Universo y, por otra, en la mente humana.

Kepler se apercibió que los planos que contienen a cada una de las órbitas de los planetas se hallan próximos entre sí, pero con respecto a la eclíptica de la Tierra cada uno tiene una inclinación diferente que permanece constante. Este importante descubrimiento le ayudaría a estudiar las trayectorias de los planetas.

Plantea, en Mysterium Cosmographicum, que cada planeta tiene su propio "espíritu motor" (anima motrix), pero deja abierta la posibilidad de que fuera el Sol la causa última de todos los movimientos por una especie de "fuerza magnética". Los cuerpos análogos, como la Tierra y la Luna, se atraen. Los diferentes, la Tierra y el Sol, se influyen entre si por magnetismo. Escribe: "Si 
debemos acercarnos a la verdad y establecer alguna correspondencia en las proporciones entre las distancias y las velocidades de los planetas, entonces debemos elegir entre dos supuestos: o las almas que mueven a los planetas son menos activas cuanto más lejos se halla el planeta del Sol, o existe tan solo una anima motrix en el centro de todas las órbitas, es decir, el Sol, que dirige a los planetas más vigorosamente cuanto más cerca está, pero cuya acción se halla casi exhausta cuando actúa sobre los planetas exteriores debido a lo grande de la distancia y a la debilitación de la acción que lo vincula" (tomado, y adaptado, de Koestler, A. (1986)). Esta idea es la que lo va a conducir a su segunda ley del movimiento de los planetas. En 1600 Kepler opinaba que la máquina celeste era un mecanismo de relojería en que los diversos movimientos se llevaban a cabo gracias a la fuerza del Sol.

También dice: "El Sol fuente de toda fuerza y luz es el Padre, las estrellas fijas el Hijo y la fuerza motriz del Sol el Espíritu Santo". Un mundo creado por Dios tiene que ser necesariamente ordenado e inteligible y debe encontrarse en él un reflejo de quien lo creó. Tardaría aún en separarse la Ciencia y la Religión.

En 1600 fue contratado por Tycho Brahe como ayudante suyo en Praga (territorio católico). Le encarga el seguimiento de Marte, y aunque enseguida se da cuenta de que su movimiento era más rápido cuando estaba más cerca del Sol tuvo que dedicarse a ello durante años antes de encontrar una solución matemática para su órbita. Al morir, Brahe le dejó encargado de apuntalar su sistema cósmico y lo nombró heredero de "sus datos". El emperador lo nombra "matemático imperial".

En agosto de 1609 Kepler, que llevaba diez años estudiando los datos ${ }^{2}$ de Brahe sobre Marte, finalmente publicó sus resultados sobre el estudio de la órbita marciana en un texto que tituló Astronomia nova, seu physica coelestis tradita commentariis de motibus stellae Martis ex observationibus $G$. V. Tychonis Brahe ("Nueva astronomía basada en la física celeste derivada de las investigaciones de los movimientos de la estrella Marte. Fundada en las observaciones del noble Tycho Brahe"). Esta obra, mejor conocida como Astronomía Nueva, contiene

2 Fue John Napier (1550 - 1617), nos dice Gribbin, quien desarrolló los logaritmos, casi al terminar el siglo XVI. Su motivación era, como era común en toda esta época, facilitar cálculos en trigonometría esférica que se usaba en asuntos de astronomía. Napier envió sus resultados a Tycho Brahe. Dos obras condensan esos resultados: Mirifici Logarithmorum Canonis Descriptio y Mirifici Logarithmorum Canonis Constructio, de 1614 y 1619 respectivamente. Otro matemático que trabajó con logaritmos fue Henry Briggs (1561 1631), quien sugirió el 10 como base, simplificando las cosas. 
ya las dos primeras leyes del movimiento planetario, aunque los cálculos matemáticos solo están completados para Marte.

Entre 1618 y 1622 Kepler dio a conocer una nueva obra titulada Epitome Astronomiae Copernicanae ("Compendio de astronomía copernicana"), donde expuso sus resultados sobre el cálculo de distancias y tamaños de los cuerpos del sistema planetario, así como sus ideas cosmológicas. Se detiene especialmente sus descubrimientos sobre el dibujo elíptico que sigue Marte y los descubrimientos de Galileo mediante el uso del telescopio. Extendió lo que había afirmado para el caso particular de Marte para los demás planetas. Kepler hizo una exposición de su concepción de la filosofía y de los métodos de la Astronomía en el primer libro de su manual "Epítome astronómico (1618). Concebía que la Astronomía comenzaba por las observaciones que eran "traducidas" por medio de los instrumentos de medida en ángulos y números para ser tratados por la Geometría, el Álgebra y la Aritmética. Luego se ideaban hipótesis que unían las relaciones observadas en sistemas que "salvaran las apariencias". Finalmente, la Física estudiaba las causas de los fenómenos relacionados con unas hipótesis que debían estar de acuerdo con los principios metafísicos. Toda la investigación pretendía descubrir los verdaderos movimientos planetarios y sus causas, escondidos en las "pandectas de Dios", pero que podrían, como dijimos antes, ser revelados por la Ciencia. Es decir, vivimos en un universo creado y regido por Dios pero que puede ser entendido por los hombres, es un Universo ordenado. Podemos decir que hemos completado con ello la fase embrionaria de la Ciencia.

Aunque claramente el nuevo modelo de órbitas elípticas fulmina el que había construido sobre los poliedros regulares él no renunció del todo a esa vieja idea. Además de las obras que hemos comentado sus principales trabajos son: De Harmonice Mundi (1619), compuesta de seis libros, en los que trata de glosar la armonía que ha descubierto en la obra del Creador, culminando así el propósito de toda su vida, que ya dio su primer fruto en "El Secreto del Universo".

Kepler muere el 15 de noviembre de 1630; no conocemos donde está enterrado, pero sí su epitafio: "Medí los cielos, / ahora las sombras mido. / Hacia el cielo fue la mente, / enterrado el cuerpo descansa".

Si con Kepler hemos conseguido entrar de lleno en el Universo ordenado, tras él científicos como Galileo, Newton, Huygens, Cassini, Laplace y otros muchos siguieron investigando las propiedades del mismo.

Dos estrellas errantes, imposibles de encontrar a simple vista fueron añadidas en la condición de disciplinados planetas. El primero, al que llamaron Urano, 
fue localizado por Herschel en 1781 mediante un barrido astronómico con, para entonces, un potente telescopio. Pronto se detectaron irregularidades en su órbita, lo que sirvió para que en 1845 el francés Leverrier (también Le Verrier), y en paralelo el británico Adams consiguieran mediante complicados y farragosos cálculos matemáticos prever donde se podría encontrar otro planeta que lo perturbaba: así se descubrió Neptuno el 24 de septiembre de 1846. Fue un éxito de la Matemática y de la Astronomía, aunque ahora sabemos que algo de suerte acompañó al acontecimiento. Francisco Arago, director del Observatorio Astronómico de París escribió al respecto: "lo ha visto (se refiere a Leverrier) en el extremo de su pluma; por la sola potencia del cálculo ha determinado el lugar y la magnitud aproximada de un cuerpo situado más allá de los límites conocidos de nuestro sistema solar" (tomado, y adaptado, de Maza (2016).

Aunque el sistema solar parecía completo era solamente un nuevo punto de partida de una búsqueda que deviene en infinita. Hoy sabemos que nuestro sistema solar presenta elementos caóticos, es decir, no es posible situar los planetas dentro de, por ejemplo, 100 giga años por problemas en el solapamiento de resonancias entre dos o tres cuerpos (Galindo, 2010). No importa, nuevos descubrimientos, leyes físicas revolucionarias y la potencia intelectual del hombre siguieron y seguirán aportando luz al misterio de conseguir un Universo ordenado.

\section{BIBLIOGRAFÍA}

Caspar, M. (2003): Kepler. Madrid: Acento Editorial.

Crombie, A.C. (1996): Historia de la Ciencia. Madrid: Alianza.

Galindo A. (2010). Armonías en los Cielos: Rev. R. Acad. Cienc. Exact. Fis. Nat. (Esp). Vol. 104, No. 1, pp 107-138.

Gribbin, J. (2004): Historia de la Ciencia. 1543-2001. Barcelona: Crítica. Isaacson, W. (2018): Leonardo da Vinci: la biografía. Barcelona: Debate.

Koestler, A. (1986): Los sonámbulos. Barcelona: Salvat.

Maza J. (2016). Curso EH2802. Universidad de Chile. Recuperado el 29 de enero de 2021 de:

https://docplayer.es/10917615-2-03-adams-y-leverrier-el-descubrimientode-neptuno.html

Thuillier, P. (1990): De Arquimedes a Einstein. Madrid: Alianza Editorial. 


\title{
HISTORIA Y DIDÁCTICA DE LAS MATEMÁTICAS
}

\author{
Víctor Manuel Hernández Suárez \\ Universidad de Las Palmas de Gran Canaria \\ Rosa María Hernández Suárez \\ CEIP César Manrique (Las Palmas de Gran Canaria)
}

\begin{abstract}
A nuestra querida y añorada Emy Repetto, por su cálida amistad y extraordinaria contribución al desarrollo de la Historia y Didáctica de las Ciencias
\end{abstract}

\section{Resumen}

La historia de las matemáticas suministra a los docentes una perspectiva más general de la materia y una formación científica más profunda. Las aportaciones que hace la historia de las matemáticas a la enseñanza son numerosas y dependen de muchas variables. Así, es necesario que el profesorado investigue y tenga una adecuada formación en historia de las matemáticas. Además, se requieren materiales didácticos adecuados que nos liberen de las anécdotas simples exentas de contenido matemático. La historia nos ofrece múltiples posibilidades de utilización en el aula y nos muestra que es una herramienta excelente para mejorar la enseñanza y aprendizaje de esta materia y para fomentar la educación general de los alumnos y alumnas. Asimismo, el conocimiento de la evolución histórica de los conceptos matemáticos potenciará la enseñanza y aprendizaje de esta materia en todos los niveles educativos.

Palabras clave: historia de las matemáticas, didáctica, enseñanza y aprendizaje.

\begin{abstract}
The history of mathematics provides teachers with a more general perspective on the subject and a deeper scientific background. The contributions that the history of mathematics makes to teaching are numerous and depend on many variables. Thus, it is necessary for teachers to investigate and have adequate training in the history of mathematics. In addition, adequate teaching materials are required to free us from simple anecdotes devoid of mathematical content. History offers us multiple possibilities of use in the classroom and shows us that it is an excellent tool to improve the teaching and learning of this subject and to promote the general education of students. Also, knowledge of the historical evolution of mathematical concepts will enhance the teaching and learning of this subject at all educational levels.
\end{abstract}


Keywords: history of mathematics, didactic, teaching and learning.

\section{INTRODUCCIÓN}

La Historia de las Matemáticas tiene innumerables repercusiones didácticas en la Enseńanza y Aprendizaje de esta Ciencia.

La utilización de recursos históricos en la clase proporciona al alumnado un enfoque generalista de las Matemáticas y será una motivación muy importante para la enseñanza y aprendizaje de esta materia en todos los niveles educativos. Las aportaciones que hace la historia de las matemáticas a la enseñanza son numerosas y dependen de muchas variables. Así, es necesario que el profesorado investigue y tenga una adecuada formación en historia de las matemáticas. Además, se requieren materiales didácticos adecuados que nos liberen de las anécdotas simples exentas de contenido matemático. La selección de textos históricos notables en el aula facilitará al estudiante el aprendizaje de los conceptos matemáticos.

\section{LA HISTORIA EN LA ENSEÑANZA DE LAS MATEMÁTICAS}

A nivel mundial, todos los profesionales de la educación matemática han señalado siempre la necesidad de incluir en los programas educativos la historia de las Matemáticas.

Como señaló Fauvel en 1991: "un fuerte argumento para ello, sobre todo al comenzar nuestro siglo, fue el punto de vista genético, debido a Herbert Spencer, según el cual la génesis del conocimiento en cada niño/a debe seguir el mismo camino que la génesis del conocimiento en la raza”.

El principio genético manifiesta que la inteligencia humana evoluciona desde la infancia reproduciendo las mismas etapas evolutivas históricas de los conocimientos matemáticos.

En la pedagogía matemática este enfoque alcanzó su plenitud, en los primeros años del siglo pasado. Se publicaron esquemas de la evolución de las Matemáticas desde la Antigüedad, acompańados de las etapas del desarrollo escolar.

Este principio se puede aplicar en algunos temas matemáticos. En Hernández (2006), podemos leer: "Este método, extraído de la Biología, intenta reconstruir el clima psicológico que envuelve a cada momento creador que haya supuesto un salto cualitativo en la Historia de las Matemáticas. La aplicación de este método en la Enseñanza, que ha sido reivindicado por grandes matemáticos/as y profesores y profesoras de Matemáticas, pretende demostrar que, 
para la perfecta comprensión de un concepto determinado, el alumnado ha de repetir a grandes rasgos el proceso histórico que se ha desarrollado hasta la formulación actual del concepto".

Félix Klein (1849-1925), en su obra, "Matemática elemental desde un punto de vista superior", creada para la formación de los futuros maestros y maestras, expone un razonamiento genético, señalando en el primer volumen: "Para precisar bien mi opinión en este punto (el punto de vista pedagógicomatemático que aconseja no dar demasiado pronto al alumno cosas demasiado abstractas y difíciles), he de recordar la ley fundamental biogenética, según la cual el individuo en su desarrollo recorre en rápida sucesión todos los estados del desarrollo de la especie a que pertenece. Este principio, creo yo, debiera ser seguido también, al menos en sus líneas generales, en la Enseñanza de la Matemática lo mismo que en cualquier otra Enseñanza; se debería conducir a la juventud, teniendo en cuenta su natural capacidad y disposición, lentamente hasta llegar a las materias elevadas y, finalmente, a las formulaciones abstractas, siguiendo el mismo camino por el que la humanidad ha ascendido desde su estado primitivo a las altas cumbres del conocimiento científico. Un inconveniente fundamental para la propagación de tal método de enseñanza, adecuado al alumno y verdaderamente científico es, seguramente, la falta de conocimientos históricos que se nota con sobrada frecuencia”.

Félix Klein

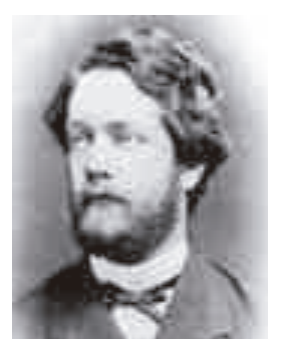

Fuente: Hernández (2006).

La aplicación del principio genético consiste en la contextualización histórica, efectuando una reconstrucción que nos permita conocer las cuestiones y necesidades históricas que originaron en su época el alumbramiento de un nuevo concepto matemático, así como los problemas específicos inseparables del nacimiento de determinados conceptos y la resolución de ciertos problemas 
que, como indicaba Félix Kline, "se manifiestan asimismo de forma rotunda en el aprendizaje de los mismos conceptos y en la resolución de los mismos problemas". Así, si los números negativos no surgieron hasta transcurridos mil años de la Historia de las Matemáticas, y si se necesitaron otros mil años más para ser aceptados por los matemáticos/as, podemos asegurar también que el alumnado tendrá problemas en el aprendizaje de los números negativos. Por otra parte, si observamos la Historia del Álgebra, comprenderíamos las dificultades que suele tener el alumnado de la Educación Obligatoria con las letras que simbolizan a las incógnitas: estos problemas son análogos a los que han tenido los matemáticos/as a lo largo de más de dos mil años, en el paso del Álgebra Retórica de los griegos (periodo clásico) al Álgebra simbólica del matemático francés François Viète, siguiendo por los períodos intermedios del Álgebra sincopada de Diofanto de Alejandría, los avances en el mundo árabe y por el célebre "Arte de la cosa" de los algebristas del renacimiento italiano.

Ilustres matemáticos espańoles como Julio Rey Pastor y Pedro Puig Adam, entre otros, promovieron este enfoque histórico, al incluir nociones de Historia de las Matemáticas adaptadas al alumnado en sus libros de texto.

J. Rey Pastor (1888-1962)

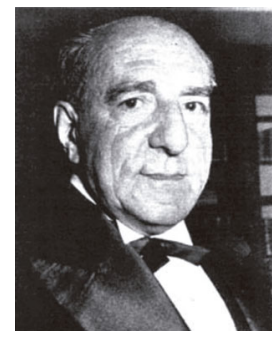

P. Puig Adam (1900-1960)

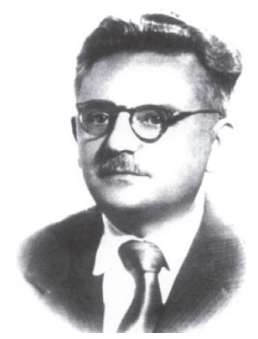

Fuente: Hernández et al. (2018).

En nuestras clases de Matemáticas, debemos siempre aplicar el "Decálogo de la Didáctica de la Matemática Media" enunciado por Pedro Puig Adam en 1955: "1. No adoptar una didáctica rígida, sino amoldarla en cada caso al alumno, observándole constantemente. 2. No olvidar el origen de las Matemáticas ni los procesos históricos de su evolución. 3. Presentar las Matemáticas como una unidad en relación con la vida natural y social. 4. Graduar cuidadosamente los planos de abstracción. 5. Enseñar guiando la actividad creadora 
y descubridora del alumno. 6. Estimular dicha actividad despertando interés directo y funcional hacia el objeto del conocimiento. 7. Promover en todo lo posible la autocorrección. 8. Conseguir cierta maestría en las soluciones antes de automatizarlas. 9. Cuidar que la expresión del alumno sea traducción fiel de su pensamiento. 10. Procurar a todo alumno éxitos que eviten su desaliento”. Para más detalles, consultar Puig (1960).

Este Decálogo publicado hace más de 65 años sigue estando vigente en la actualidad y debe ser llevado a la práctica, en su trabajo diario, por el profesorado de Matemáticas.

En Canarias, resaltamos la magnífica tarea investigadora y didáctica desarrollada durante casi cincuenta años por el Catedrático de Didáctica de la Matemática de la Universidad de Las Palmas de Gran Canaria, José Martel Moreno (1925-2014), y por Nácere Hayek Calil (1922-2012), Catedrático de Análisis Matemático de la Universidad de La Laguna.

\section{José Martel Moreno y Nácere Hayek Calil}

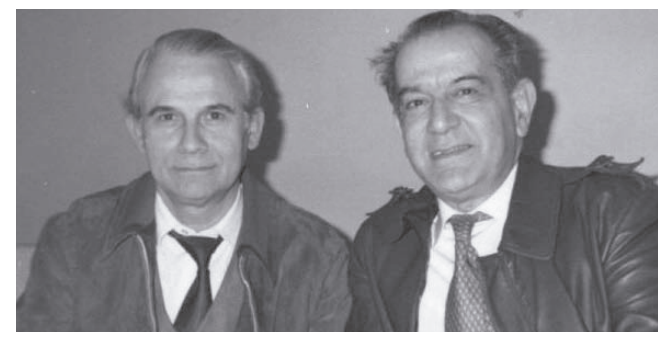

Fuente: Colección propia.

Además, también destacamos la excelente labor investigadora de Martín Manuel Socas Robayna, Catedrático de Didáctica de las Matemáticas de la Universidad de la Laguna. 


\section{Martin Manuel Socas Robayna}

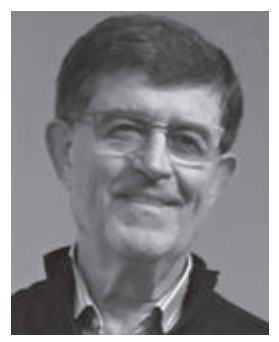

Fuente: Colección propia.

Asimismo, también recordamos a la gran didacta e investigadora tenaz Emigdia Repetto Jiménez (1935-2020), homenajeada en este libro, catedrática de Didáctica de las Ciencias Experimentales y profesora emérita de la ULPGC, muy involucrada en toda la actividad académica de nuestra institución, durante casi 50 años, tanto en la Facultad de Ciencias de la Educación como en la Estructura de Teleformación.

Gran experta en Historia y Didáctica de las Ciencias, en el año 2010 el Gobierno de Canarias le otorgó la distinción 'Viera y Clavijo' por su gran aportación a la calidad de la enseñanza en el Archipiélago.

Con un extenso currículum en Historia y Didáctica de las Ciencias Experimentales, puede ser considerada como una de las grandes mujeres científicas espańolas.

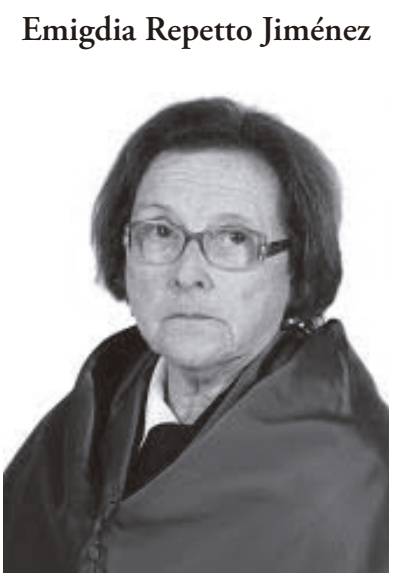

Fuente: ULPGC. 
La historia debe constituir una poderosa herramienta didáctica para, entre otras razones, señalar las fuertes conexiones de las Matemáticas con las demás ciencias, de cuya interacción han brotado tradicionalmente numerosas ideas de gran valor pedagógico y científico.

En la década de los setenta del siglo pasado se comenzó a fomentar de nuevo el interés por los aspectos históricos en la Educación Matemática. Schubring en 1983, citado por Sierra (1997), revelaba algunas muestras de este florecimiento: "1. Fundación del Grupo Inter-IREMS de Historia de las Matemáticas, cuyo objetivo es la utilización de la Historia de las Matemáticas en la enseñanza de estas. 2. Aparición del Grupo Internacional de estudio de las relaciones entre la Historia y la Pedagogía de las Matemáticas. 3. Numerosos trabajos que estudian las relaciones entre la Historia de las Matemáticas y la Enseñanza bajo puntos de vista diferentes, realizados por autores como Janke, Otte y Schubring (los tres en Bielefeld, Alemania), Pyenson (Montreal), Dhombres (Nantes), Eccarius (Eisenach, Alemania) y Filloy (México), entre otros. 4. Publicación de trabajos acerca de la Enseñanza de las Matemáticas desde el punto de vista de los enseńantes, como los realizados por Howson en Southampton. 5. Publicación de trabajos acerca de la historia del desarrollo de la Didáctica de las Matemáticas, como los de Glaeser (Estrasburgo) y Schmidt (Colonia)".

Según Hernández (2006): "En España también ha aumentado de manera notable la preocupación por los aspectos históricos en Educación Matemática desde diversas perspectivas, como lo atestiguan las numerosas ponencias y comunicaciones presentadas en congresos nacionales e internacionales, tesis doctorales, artículos y monografías, así como por la organización de seminarios especializados y cursos de doctorado".

Algunas razones esgrimidas para la inclusión de la Historia en la Enseñanza de las Matemáticas son las que siguen:

- Para el profesorado, puede ser un revulsivo contra el formalismo y el aislamiento de los conocimientos matemáticos y un conjunto de recursos didácticos que le permiten asimilar mejor el citado conocimiento y, al mismo tiempo, le pueden facilitar el orden de presentación de los temas curriculares. El análisis histórico facilitará también el descubrimiento de las dificultades surgidas, los errores que han cometido los matemáticos/as, así como el valioso papel que han tenido las Matemáticas en las actividades humanas.

- Para el alumnado, las Matemáticas dejarán de ser un edificio acabado, restituyéndose su estatus de actividad cultural y humana y, simultáneamente, será un potente factor motivacional para su aprendizaje. 
Fauvel en 1991, proponía, las siguientes líneas de actuación por parte de los docentes en el aula: "1. Mencionar anécdotas matemáticas del pasado. 2. Presentar introducciones históricas de los conceptos que son nuevos para el alumnado. 3. Fomentar en los alumnos y alumnas la comprensión de problemas históricos cuyas soluciones han dado lugar a los diferentes conceptos que aprenden en clase. 4. Impartir lecciones de Historia de las Matemáticas. 5. Idear ejercicios utilizando textos matemáticos del pasado. 6. Fomentar la creación de posters, exposiciones u otros proyectos sobre un tema histórico. 7. Usar ejemplos del pasado para ilustrar técnicas o métodos. 8. Realizar proyectos en torno a una actividad matemática local del pasado. 9. Explorar errores del pasado para ayudar a comprender y resolver dificultades de aprendizaje. $\mathbf{1 0 .}$ Diseñar aproximaciones pedagógicas al tópico de acuerdo con su desarrollo histórico. 11. Idear el orden y estructura de los temas dentro del programa de acuerdo con su desarrollo histórico".

\section{LA HISTORIA EN EL PROCESO DE FORMACIÓN DEL PROFESORADO}

La historia de las Matemáticas debería formar parte del currículo académico del profesorado de cualquier nivel, ya que puede ser una herramienta necesaria en su formación integral. Además, la historia puede suministrarle una perspectiva realmente humana de las matemáticas y de las ciencias en general.

La visión histórica nos aproxima a las Matemáticas como ciencia humanizada dispuesta siempre a revisar o corregir sus errores. De esa manera, nos acercaremos a prominentes hombres y mujeres que han conseguido impulsarlas durante muchos siglos, por razones muy diferentes.

El orden histórico no tiene que coincidir necesariamente con los órdenes lógico y didáctico, sin embargo, el profesorado debería conocer cómo han ocurrido los hechos para:

- Mejorar la comprensión de los problemas humanos, en el proceso de elaboración de los conceptos matemáticos, y de esa manera comprender mejor los problemas que puedan tener los estudiantes en su aprendizaje.

- Entender mejor la conexión de las ideas, razones y cambios de la armonía matemática.

- Utilizar este conocimiento como guía saludable para su propia formación pedagógica.

Si se quiere poseer una visión más dinámica de la evolución de las Matemáticas, deberíamos tener un buen conocimiento de su historia, ya que dicha visión nos facultaría para mejorar nuestra metodología educativa: 
— Posibilidades de extrapolar hacia el futuro.

- Inmersiones creativas en los problemas del pasado.

- Comprobaciones de las dificultades de los descubrimientos matemáticos, con la percepción de las imprecisiones y desconciertos iniciales.

En muy pocas ocasiones, desafortunadamente, la historia de las Matemáticas forma parte del currículo de la comunidad educativa universitaria, tanto a nivel investigador como pedagógico.

Así, es necesario que los contenidos históricos se incluyan en todas las materias de Matemáticas y que al alumnado se le suministrara, por lo menos, una visión general de la evolución histórica de esta ciencia.

Para ello, sería recomendable:

— Leer de forma comprensiva libros relacionados con la historia de las Matemáticas.

- Investigar en las fuentes originales, fundamentalmente de los clásicos.

- Analizar biografías de ilustres matemáticos/as.

En esta línea de trabajo debemos resaltar la figura del insigne matemático español Miguel De Guzmán Ozámiz (1936-2004). Fue Presidente del máximo organismo internacional para la Educación Matemática, conocido por sus siglas en inglés ICMI, en el periodo 1991-1998, y ha sido el primer español en ocupar un cargo de tanta trascendencia en la esfera internacional de las Matemáticas.

Para más detalles sobre sus obras podemos consultar la página Web de la "Cátedra UCM Miguel de Guzmán", promovida por la Facultad de Ciencias Matemáticas de la UCM en el marco de la "Fundación General de la Universidad Complutense de Madrid (UCM)" e implantada el 26 de septiembre de 2007: https://blogs.mat.ucm.es/catedramdeguzman/.

\section{Miguel de Guzmán}

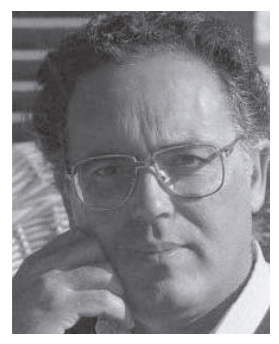

Fuente: Hernández et al. (2018). 


\section{LA HISTORIA DE LAS MATEMÁTICAS EN LOS NIVELES EDUCA- TIVOS}

En este apartado, nos hemos basado fundamentalmente en Peralta (1995).

Los contenidos matemáticos de los diferentes niveles educativos se pueden asociar a periodos determinados de la Historia de las Matemáticas.

Si se adopta un enfoque generalista, se pueden distinguir cuatro etapas esenciales en la Historia de las Matemáticas, cualitativamente diferentes, aunque como es obvio, no se pueden trazar fronteras correctas entre estas puesto que las características fundamentales de cada una de ellas aparecen de forma gradual.

- La primera etapa es la del Nacimiento de las Matemáticas como ciencia teórica e independiente, y se extiende desde los albores de la humanidad hasta, aproximadamente, el siglo $\mathrm{V}$ a. C. En ella se construyen y dan sus primeros pasos la Aritmética y la Geometría, que no aparecen separadas, sino íntimamente relacionadas. Las Matemáticas eran entonces una serie de normas aisladas en conexión con la vida cotidiana y deducidas experimentalmente; no formaban aún un sistema lógico unificado, pues no se hacían demostraciones, aunque se evolucionó paulatinamente hacia ello.

- La segunda etapa se puede considerar como la de las Matemáticas Elementales, construidas mediante un sistema lógico, pues todas las proposiciones tienen sus demostraciones, muy lejos de las recetas que aparecen en los documentos egipcios y babilonios. Este período duró casi 2000 años, y finalizó en el siglo XVII.

- La tercera etapa abarca, aproximadamente, la segunda mitad del siglo XVII y todo el siglo XVIII, y se caracteriza por el nacimiento y progreso del Análisis Matemático.

— La cuarta etapa es la de las Matemáticas Contemporáneas (siglos XIX y $\mathrm{XX}$ ), en la que los matemáticos/as analizan con espíritu crítico nociones que hasta entonces se consideraban intuitivas. Este periodo se puede resumir en tres líneas: análisis profundo y crítico de todos los conocimientos, avidez sistematizadora y abundancia.

La primera etapa podría resumirse diciendo que abarca los aspectos básicos de la Aritmética y de la Geometría y que, a grandes rasgos, forman parte de los contenidos de la Educación obligatoria (Enseñanza Primaria y parte de la $\mathrm{ESO})$.

Los más importantes descubrimientos de la segunda etapa y parte de la tercera, la Geometría Analítica y los inicios del Cálculo Infinitesimal y del Cálculo 
de Probabilidades, corresponden a los contenidos del final de la ESO y el bachillerato.

Los resultados principales de la tercera etapa, desarrollo del análisis matemático, ecuaciones diferenciales y álgebra superior y algunas cuestiones de la cuarta etapa, como las estructuras algebraicas, forman parte de los conocimientos matemáticos de Ingeniería y del primer ciclo de los grados de Matemáticas y Física.

Finalmente, los descubrimientos de la cuarta etapa corresponden, básicamente, a los Grados en Matemáticas y parte de Físicas.

\section{ANÁLISIS DIDÁCTICO DEL USO DE LA HISTORIA DE LAS MATE- MÁTICAS}

El uso de la Historia de las Matemáticas en el aula nos puede orientar en nuestra práctica docente diaria.

En todas las ramas de las Matemáticas se debe proceder de lo particular a lo general, de lo concreto a lo abstracto, aunque normalmente no ha ocurrido así y se suele actuar en sentido contrario, es decir de lo general a lo particular y de lo abstracto a lo concreto.

En numerosas ocasiones se presentan al alumnado fórmulas y demostraciones matemáticas antes que modelos numéricos concretos de aquellas, lo cual constituye un error, y es lógico que los estudiantes se sientan frustrados y nos soliciten ejemplos numéricos antes de las definiciones de conceptos o enunciados de proposiciones.

Para Hernández (2006), la Historia de las Matemáticas puede contribuir, a que esta se presente de una forma más humana, ya que puede ayudar a:

- Constatar que lo que se está aprendiendo es fruto del esfuerzo humano, que tiene sus orígenes en problemas relacionados con la supervivencia o estructuración de la sociedad, o para dar respuestas a preguntas realizadas por las diferentes ramas del conocimiento.

- Señalar los rasgos personales de algunos matemáticos/as, así como las dificultades y problemas que se encontraron en el desarrollo de sus descubrimientos.

- Reflejar la colaboración entre los matemáticos/as para resolver grandes desafíos, y hacer ver que las resoluciones de muchos problemas científicos no han sido siempre fruto de mentes prodigiosas de personas solitarias, sino que frecuentemente han sido debidas a la gran cooperación entre ellas. 
Sin la perspectiva crítica dada por la Historia, los conocimientos matemáticos se desnaturalizan y se alejan de su problemática original, ocurre entonces el fenómeno que los pedagogos/as denominan la "transposición didáctica".

De este procedimiento de "deshistorización" o de "despersonalización" del conocimiento, escribe Chevallard en 1982: "El saber toma entonces el aspecto de una realidad antihistórica, intemporal, que se impone por si misma; que, no teniendo creador, aparece libre con relación a todo el proceso de génesis, no pudiéndose hacer constar el origen, la utilidad, la pertinencia...”.

En el siguiente diseño, extraído de Chamorro et al. (2003), se nos muestra la evolución que sufre el conocimiento para ser enseñado (Chevallard).

\section{La "transposición didáctica”}

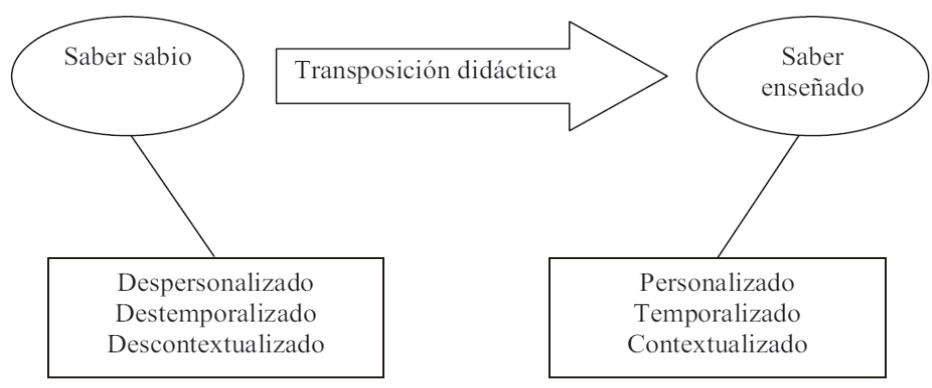

Fuente: Chamorro et al. (2003).

El conocer cómo se ha forjado poco a poco el conocimiento matemático nos puede servir para comprender mejor ciertos errores, así como para crear entornos didácticos más adecuados para un aprendizaje continuo y productivo de algunas nociones matemáticas.

Además, la Historia de las Matemáticas puede proporcionarnos muchos recursos didácticos para que los alumnos y alumnas no cometan errores que puedan dificultar su aprendizaje. Por ejemplo, en el libro los "Elementos" de Euclides podemos contemplar numerosas identidades algebraicas deducidas por medio de construcciones geométricas, que nos pueden facilitar la mejor comprensión de los problemas propuestos. De esa manera podemos percibir la fuerte conexión entre el Álgebra y la Geometría.

Arquímedes usaba un nuevo método: "el método heurístico", muy utilizado también en toda la historia por grandes matemáticos/as. Muchos descubrimientos matemáticos se consiguieron empleando este método, por ello, se debería aplicar, como potente recurso didáctico para el aprendizaje del alumnado. 
Arquímedes de Siracusa

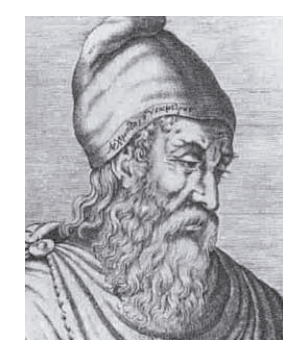

Fuente: Hernández (2006).

El profesorado debe reelaborar el material histórico, preparando secuencias didácticas de trabajo adaptadas a los niveles educativos, lo que facilitará la mejor comprensión de la evolución histórica de los conceptos matemáticos.

Se deben enseñar las Matemáticas de manera interdisciplinar, en relación con otras ciencias y con el progreso general de la humanidad, mostrando que forman parte de la cultura. El conocimiento de aspectos históricos de las Matemáticas puede promover la mejora de la cultura general e implementar en el aula el renacimiento de una formación integral y generalista del alumnado.

De la misma forma, el uso de la historia de las Matemáticas en clase nos recuerda el papel práctico de esta Ciencia. La mayoría de los conocimientos matemáticos se crearon para la resolución de problemas de la vida diaria.

Así, por ejemplo, la Aritmética y la Geometría, nacieron para resolver problemas de la vida ordinaria; como la necesidad de emplear los números para contar y efectuar transacciones comerciales (Aritmética) y la realización de todo tipo de mediciones (Geometría).

\section{CONCLUSIONES}

El uso apropiado de la historia de las matemáticas en el aula nos mostrará la importancia que ha tenido esta Ciencia en el progreso de la humanidad.

Por ello, es muy importante que todos los programas de las asignaturas de matemáticas incluyan contenidos relacionados con la historia.

Asimismo, sería necesario que el profesorado tenga una gran formación en el área de la historia de las matemáticas.

La Historia de las Matemáticas es un excelente recurso didáctico de gran interés para el estudiantado y el profesorado. 
Para González (2004), "se debe reclamar una función didáctica para la Historia de las Matemáticas como instrumento de comprensión de sus fundamentos y de las dificultades de sus conceptos para así responder a los retos de su aprendizaje. La Historia es fuente de inspiración, autoformación y orientación en la actividad docente y al revelar la dimensión cultural de la Matemática, el legado histórico permite enriquecer su enseñanza y su integración en el conjunto de los saberes científicos, artísticos y humanísticos que constituyen la Cultura”.

Finalizamos este apartado con un decálogo, de extraordinario interés didáctico, elaborado por Meavilla (2008), sobre la utilidad de la Historia de las Matemáticas en la enseñanza y aprendizaje de esta materia: "1. Facilita al profesorado materiales y recursos didácticos que pueden favorecer el aprendizaje de sus alumnos y alumnas. 2. Permite descubrir el lado ameno de las Matemáticas y puede influir favorablemente en la motivación de los estudiantes. 3. Ayuda a inculcar en los alumnos y alumnas valores como el esfuerzo, la constancia, el trabajo, la humildad, la disponibilidad, etc. 4. Contribuye a valorar la aportación de las mujeres en la construcción y el desarrollo de dicha disciplina. 5. Permite aprender con la ayuda de unos profesores muy especiales: los grandes sabios/as de otros tiempos. 6. Muestra que dicha disciplina es una ciencia viva y que sus conceptos y procedimientos suelen cambiar con el tiempo. 7. Permite dar una visión más humana de dicha ciencia (la Matemática no es obra de los dioses, es el resultado del trabajo de hombres y mujeres que suelen equivocarse). Este hecho puede contribuir a que el alumnado no se sienta frustrado ante sus errores y pueda aprender de ellos. 8. El profesorado (alumnado) puede aprovecharse especialmente de la perspectiva histórica de las Matemáticas, descubriendo métodos alternativos para la resolución de problemas, distintos de los que generalmente enseña (aprende) en clase y que pueden ser beneficiosos para la enseńanza y el aprendizaje de las Matemáticas. 9. Puede contribuir a apreciar la utilidad de esta disciplina en la resolución de problemas prácticos. 10. Permite mostrar a los estudiantes el papel capital de las Matemáticas en la construcción de la cultura humana”.

\section{REFERENCIAS BIBLIOGRÁFICAS}

Aleksandrov, A. y otros (1979). La matemática: su contenido, métodos y significado. V.1. Madrid: Alianza Universidad.

Baumgart, J. y otros $(1969,1989)$. Historical Topics for Mathematics Classroom. Reston, Virginia: NCTM. 
Boero, P. (1989). Utilización de la Historia de las Matemáticas en clase con alumnos de 6 a 13 años. Suma, 1(2), 17-28.

Cátedra UCM Miguel de Guzmán. En: http://www.mat.ucm.es/deptos/am/guzman/cipra.htm.

Chamorro, M. C. et al. (2003). Didáctica de las Matemáticas para Primaria. Madrid: Pearson Prentice Hall.

Chevallard, Y. (1991). La transposición didáctica: del saber sabio al saber enseñado. Buenos

Aires, Argentina: Aique.

Chevallard, Y.; Bosch M. y Gascón J. (2000). Estudiar Matemáticas. El eslabón perdido entre enseñanza y aprendizaje. Barcelona, España: Editorial Horsori. Cuadernos de Educación.

Contreras, F. A. (2012). La evolución de la didáctica de la matemática. Horizonte de la Ciencia 2 (2), 20-25.

De Guzmán, M. (1992). Tendencias innovadoras en Educación Matemática. Buenos Aires: Olimpiadas Matemáticas Argentinas.

De Guzmán, M. (1994). Para pensar mejor. Madrid: Pirámide.

De Guzmán, M. (2000). Matemáticas y Sociedad. Acortando distancias. http://blogs.mat.ucm.es/catedramdeguzman/

Fauvel, J. (1991): "History in the mathematical classroom". The IREM papers. The MathematicalAssociation. Francia.

Fernández, S. (2001). La Historia de las Matemáticas en el aula. Uno, N. 26, pp. 9-27.

González, P. M. (1991). Historia de la Matemática: Integración cultural de las Matemáticas, génesis de los conceptos y orientación de su enseñanza. Enseñanza de las Ciencias, Vol. 9 / no 3, 281-289.

González, P. M. (2004). La historia de las matemáticas como recurso didáctico e instrumento para enriquecer culturalmente su enseñanza. Suma: Revista sobre enseñanza y aprendizaje de las matemáticas (45), 17-28.

Hernández, V. M. (2006). Historia y Educación Matemática. En: Castro, J.; Marrero, G. y Repetto, E. (Coordinadores): Formación de Profesorado I, 203-252. Universidad de Las Palmas de Gran Canaria.

Hernández, V. M. y Morales, A. (2013). Matemáticas y su Didáctica. Curso de Adaptación: atención a la diversidad. Manuales Universitarios de Teleformación, 28. Las Palmas de Gran Canaria: Vicerrectorado de Profesorado y Planificación Académica (ULPGC).

Hernández, V. M. (Coordinador), Carrión, J. C., Moreno, M. D. y Morales, A. (2018). Matemáticas y su didáctica I. Manuales Universitarios de Tele- 
formación, 83. Las Palmas de Gran Canaria: Estructura de Teleformación. ULPGC Online. Vicerrectorado de Organización Académica y Profesorado (ULPGC).

Hernández, V. M. y Morales, A. (2018). Matemáticas y su didáctica III. Manuales Universitarios de Teleformación, 58. Las Palmas de Gran Canaria: Estructura de Teleformación. ULPGC Online. Vicerrectorado de Organización Académica y Profesorado (ULPGC).

Kilpatrick, J.; Rico, L. y Sierra, M. (1994). Educación Matemática e Investigación, Madrid: Síntesis.

Klein, F. (2006). Matemática elemental desde un punto de vista superior. Madrid: Nivola.

Larios, V. (1999). Contextos históricos de la ciencia en clase. Revista Gaceta COBAQ. Año XVI, no. 137, páginas 7-9.

Massa, M. R.; Romero, F.; Casals, M. A. (2004). La Historia de las Matemáticas en la Enseñanza de la Trigonometría. El Teorema de Pitágoras. http://www.ma1.upc.edu/recerca/reportsre/0304/rep030402massa.pdf

Maza, C. (1994). Historia de las Matemáticas y su enseñanza: Un análisis. Suma, no 17, 17-26.

Meavilla, V. (2008). Algunas razones para introducir la historia de las matemáticas en las aulas de secundaria. Sigma, 33.

Méndez, J. (2003). Las matemáticas: su historia, evolución y aplicaciones. Serie Lecciones Inaugurales / 6. Universidad de La Laguna.

Morales, A. y Hernández, V. (2018). Matemáticas y su didáctica II. Manuales Universitarios de Teleformación, 36. Las Palmas de Gran Canaria: Estructura de Teleformación. ULPGC Online. Vicerrectorado de Organización Académica y Profesorado (ULPGC).

Peralta, J. (1995). Principios didácticos e históricos para la enseñanza de la Matemática. Madrid: Huerga y Fierro.

Puig, P. (1960). La Matemática y su Enseñanza Actual. Madrid: Ministerio de Educación Nacional.

Repetto, E. (2007). La Historia de la Ciencia: su utilización como recurso didáctico. Manuales Universitarios de Teleformación, 21. Las Palmas de Gran Canaria: Estructura de Teleformación. Vicerrectorado de Organización Académica y Profesorado (ULPGC).

Rey, J.; Babini, J. (1986). Historia de la Matemática. V. I-II. Barcelona: Gedisa. Rico, L. y Sierra, M. (1994). Educación Matemática en la España del siglo XX. En: J. Kilpatrick, L. Rico y M. Sierra, Educación Matemática e Investigación, 99-207. Madrid: Síntesis. 
Rodríguez, R. (1985). Notas históricas y lúdicas en la clase de Matemáticas. Aspectos didácticos de Matemáticas, Educación Abierta 57, ICE Universidad de Zaragoza, 91-104.

Sancho, J. (1990). Posibles usos de la Historia de las Matemáticas en la enseñanza de las Matemáticas. Aspectos Didácticos de Matemáticas 3, Educación Abierta 86, ICE Universidad de Zaragoza, 77-101.

Sierra, M. (1997). Notas de Historia de las Matemáticas para el currículo de Secundaria. En: L. Rico (ed.): La educación matemática en la Enseñanza Secundaria. Horsori-ICE, pp. 179-194, Universitat de Barcelona.

Sierra, M. (2000). El papel de la Historia de la Matemática en la enseñanza. En: A. Martinón (ed.): Las Matemáticas del siglo XX. Una mirada en 101 artículos, 93-96. Madrid: Monografías de Editorial Nivola sobre Historia de las Matemáticas.

Sociedad Puig Adam de Profesores de Matemáticas (UCM). En: https://www.ucm.es/sociedadpuigadam/pedro-puig-adam

Wussing, H; Arnold, W. (1989). Biografías de grandes matemáticos. Prensas Universitarias, Universidad de Zaragoza.

Wussing, H. (1998). Lecciones de Historia de las Matemáticas. Madrid: Siglo XXI de España Editores, S. A. 



\title{
LOS COMIENZOS DE LA EDUCACIÓN EN CANARIAS
}

\author{
Manuel Lobo Cabrera \\ Catedrático de Historia Moderna \\ Universidad de Las Palmas de Gran Canaria
}

\section{Resumen}

La educación se inicia en Canarias desde el momento en que los europeos culminan la conquista de las islas, y ponen en práctica las costumbres que traen de sus lugares de origen. Los primeros que se ocupan de instruir a la población tanto en temas de doctrina como de escritura, lectura y primeras reglas son los frailes, seguidos posteriormente de las autoridades civiles competentes, en especial los concejos de las islas, que contratan los servicios de maestros de gramática y de personas expertas en la enseñanza, a la par que los "maestros de enseñar mozos" abren sus escuelas para, mediante el pago de particulares, comenzar con su labor.

Palabras claves: Canarias, educación, maestros, lectura, escritura.

\begin{abstract}
Education begins in the Canary Islands from the moment that Europeans complete the conquest of the islands, and put into practice the customs that they bring from their places of origin. The friars are the first to instruct the population in matters of doctrine, writing, reading and first rules, followed later by the competent civil authorities, especially the island councils, who hire the services of teachers of grammar and experts in teaching, at the same time that the "teachers of teaching young men" open their schools to, by paying individuals, start their work.
\end{abstract}

Keywords: Canarias, education, teachers, reading, writing.

La enseñanza y el arte de enseñar cómo relación estrecha entre el conocimiento y el aprendizaje, fueron dos facetas que apasionaron a la profesora Repetto, (Emy para los que teníamos familiaridad con ella). Esta dedicación la compaginó durante su actividad docente con cargos de gestión que fueron desde la jefatura de estudios en la Escuela Universitaria del Profesorado de E.G.B, hasta la dirección de departamento de Didácticas Especiales, sin contar otros cargos que ejerció siempre con su diligencia habitual y otras acciones con la Consejería de Educación, Cultura y Deportes del Gobierno de Canarias. 
Esta es quizá la razón por la cual retomemos el tema de la educación como homenaje a su persona, toda vez que para ella era su principal dedicación. En 1979 nos ocupamos de este tema al informar a través de la prensa de los primeros maestros que hubo en la isla de Gran Canaria ${ }^{1}$, y posteriormente otros autores se han referido también al tema ${ }^{2}$; hoy queremos ampliarlo a las islas realengas — Gran Canaria, Tenerife y La Palma—, toda vez que de las islas señoriales apenas tenemos información, aunque existe alguna referencia a la labor realizada en la isla de Fuerteventura por los frailes franciscanos.

La educación, tal como hoy la entendemos, llega a Canarias de la mano de los castellanos, que, igual que importan costumbres, religión, economía, modos de construir, etc., traen en su bagaje las normas y los principios de la enseñanza. Esto no quiere decir que los indígenas no tuvieran entre sus gentes personas dedicadas al arte de enseñar, que trasmitían conocimientos y costumbres de manera oral. Así, en las crónicas, se registran algunas referencias a la presencia de maestros en aquella sociedad que iban transmitiendo de generación en generación los conocimientos que necesitaban tanto los hombres como las mujeres, dentro de su propia organización social, tal como se recoge en el texto de Gómez Escudero cuando refiere que los indígenas de Gran Canaria:

Tenían maestros para esto, i maestras para las nińas a enseñarles cantares i coser pieles i hacer thamarcos, todo a costa de el sustento que les daba el Rey ${ }^{3}$.

Desde fines del siglo XV comenzó la aculturación y asimilación de la población indígena, que se fue adaptando a las nuevas costumbres que iban imponiendo los conquistadores, de acuerdos con las normas emanadas por la corona, entre ellas las que tenían que ver con la educación. Aquí, la Iglesia jugó

1 LOBO CABRERA, M.: "La enseñanza en Gran Canaria. Siglo XVI", El Eco de Canarias, 21 de junio de 1979.

2 BETHENCOURT MASSIEU, A.: La enseñanza primaria en Canarias durante el Antiguo Régimen; Universidad Nacional de Educación a Distancia, Centro Asociado de Las Palmas, 1985; FERRAZ LORENZO, M.: "Los orígenes de la educación pública y profesional en Canarias. Siglo XVI", XIII Coloquio de Historia Canario-Americano (1998), Las Palmas de Gran Canaria, 2000, pp. 2488-2500; GONZÁLEZ PÉREZ, T.: "Institucionalización de la enseñanza en Canarias. Ojeada histórica sobre la educación en los siglos XVI y XVII”, Tebeto: Anuario del Archivo Histórico Insular de Fuerteventura, XV, Puerto del Rosario, pp. 473-492;

3 MORALES PADRÓN, F.: Canarias: crónicas de su conquista. (Transcripción, estudio, notas), Las Palmas de Gran Canaria, 1978, p. 433. Libro segundo del manuscrito del licenciado Pedro Gomes Escudero, capellán. 
un papel importante, tanto desde el punto de vista de la evangelización como de la educación, de tal modo que fue pionera en ese sentido al iniciar las primeras actividades educativas y culturales, al crear escuelas, tanto en las parroquias como en los conventos.

Junto con la Iglesia los cabildos de las islas iniciaron lo propio, siguiendo la normativa establecida en los códigos castellanos. Ya el rey Sabio se ocupó de la enseñanza en las Partidas ${ }^{4}$ pero será Enrique II en 1319 quien promulgue medidas tendentes a la educación de sus súbditos, así para fomentar el estudio y procurar el aumento de las escuelas hizo que se protegiese a los maestros con el fin de levantar su consideración social, así señala:

"Por cuanto en los nuestros reinos y seńoríos no se puede pasar sin maestros que enseńen las primeras letras; por ende ordenamos y mandamos que la casa que el Maestro eligiera para su menester y enseñanza non se la quieten ni hagáis quitar.

Ítem. Vos ordenamos y mandamos que los Maestros examinados non sean presos nin molestados por ninguna causa nin razón, nin lleváis a la cárcel pública sin dar primero cuenta a nuestro consejo... si non que hagan y gocen todas y cualesquier preeminencia y franquicia que gozan los fijosdalgo, por cuanto están enseñando a nuestros hijos"s.

Los reyes que le sucedieron la confirmaron, incluidos los Reyes Católicos, y por tal razón llegaron las islas, donde los cabildos de acuerdos a estas normas nombraron también maestros para enseñar a los jóvenes, tanto de manera pública como privada.

Al margen de la oficialidad de la enseńanza practicada por la Iglesia y por las autoridades civiles, encontramos a personas que a la vez que se dedicaban a otras actividades también enseñaban. Los había especializados en esta labor como "maestros de enseñar mozos", tal como se recoge en la documentación, aunque a partir de la segunda mitad del siglo XVI ya se les denomina maestros de escuela, tal como figura el soldado Luis de la Cerda ${ }^{6}$; mientras algunos se dedicaban solo a la enseñanza, otros compatibilizaban la práctica de enseñar con otra actividad como mareante, mercader e incluso oficial del consistorio.

4 Partida 2a, título XXXI. Aquí habla “... de los estudios en que aprenden los saberes e de los maestros, e delos escolares".

5 COSSÍO, M.B.: De su jornada, Madrid, 1929, p. 113.

6 Así figura titulado Luis de la Cerda, el primero que se consigna, quien a la vez que enseñante era soldado y como tal participó en la defensa de Gran Canaria contra el holandés en 1599. A.H.P.L.P., Fernando de Hinojosa, no 967, f. 207 r. 


\section{PRIMERAS ACTIVIDADES EDUCATIVAS: LA IGLESIA}

Las órdenes religiosas llegadas al archipiélago canario desde la Edad Media, pues no hay que olvidar la misión evangelizadora de los frailes adscritos al obispado de Telde, tuvieron como misión principal evangelizar y educar a través de las escuelas conventuales que luego se abrieron en Fuerteventura desde el primer tercio del siglo XV de la mano de los franciscanos. Posteriormente con la creación de las parroquias, en especial a finales del siglo XV, dependientes de la diócesis, surgen escuelas en su seno ${ }^{7}$.

El obispo Diego Muros ${ }^{8}$ en su sínodo celebrado en 1497 en Las Palmas ya se ocupa de este asunto, así, en las constituciones 18 y 20, señala por un lado "Que se ponga en las iglesias un pergamino con los rudimentos del catecismo y los pecados reservados", y por otro "Que haya en las iglesias un clérigo que enseñe a leer y escribir". En esta última constitución hay una preocupación del prelado por la formación educativa de sus feligreses, así, establece:

Ítem ordenamos, que el Cura o su lugarteniente tenga en su Iglesia consigo otro Clérigo o sacristán docto, para que enseñen a los hijos de los perrochianos a leer; escribir e contar, e les enseñen buenas costumbres, y aparten de los vicios, y les instruyan en toda castidad e virtud, e les enseñen todos los mandamientos y todas las cosas que se contienen en la dicha tabla y en la cartilla, y se sepan signar e santiguar con el signo de la Cruz, e les exhorte obediencia e acatamiento a sus padres, e que los Clérigos amonesten a sus perrochinaos, que envíen a sus hijos a la Iglesia, para que sean industriados en todo lo susodicho, lo qual fagan dentro de tres meses después que fuere publicado, de lo qual mandamos, y asimismo encargamos las conciencias a los Curas o sus lugares tenientes que procuren con toda diligencia tener buenos y doctos sacristanes que sirvan las dichas Iglesias e instruyan a los niños como dicho es, certificándoles que las culpas e negligencias de los sacristanes requeriremos dellos, e asimismo estatuimos donde el pueblo no paga el sacristán, que no se entremeta en cogello, e donde ellos lo pagan, lo cogan con consentimiento del Cura?.

7 A este respecto es interesante el trabajo de FERRAZ LORENZO, M.: "Origen y desarrollo de las modalidades educativas parroquial y conventual en Canarias (siglos XVI y XVII)", XIV Coloquio de Historia Canario-Americana (1998), Las Palmas de Gran Canaria, 2000, pp. 918-931.

8 GONZÁLEZ NOVALÍN, J.L.: "Don Diego de Muros, obispo de Canarias, su personalidad humanística y su aportación literaria a las crónicas granadinas del 1487 y 1488”, Anuario de Estudios Atlánticos", 20, Madrid-Las Palmas, 1974, p. 15 y ss.

9 ZUAZNAVAR y FRANCIA, J.M.: Compendio de la Historia de Canarias formado en su principio 
De este modo sabemos que, desde fines del siglo XV, con la creación de las tres primeras parroquias en la isla de Gran Canaria, se inauguran las escuelas para enseñar a través de los maestros a los hijos de feligreses, bien a través del propio cura o de los sacristanes o de los maestros contratados al efecto. En las demás islas se siguieron las pautas mandadas por el prelado de modo que a la vez que se creaban las parroquias nacían las escuelas

La labor iniciada por el obispo Muros la continúan sus sucesores, así el obispo Vázquez de Arce, en sus Sinodales promulgadas en 1514, también muestra preocupación por la educación, y ordena que en Las Palmas hubiese de continuo un maestro de gramática que fuera obligado a dar dos lecciones diarias, de acuerdo con la tradición castellana, así establece:

Otrosí, conformándose con las costumbre usada e guardada en todas las iglesias e obispados de España, ordenamos e mandamos que en esta çibdad Real de Las palmas, cabeça de nuestro obispado, haya de estar e de continuo resida un maestro de gramática, hábil e suficiente, para enseñar gramática a todos los que quisieren aprender de nuestra diócesis, el qual sea obligado a leer dos lecciones cada día, una a la mañana e otra a la tarde, e que haya de salario de todo el montón de los diezmos, en cada un ańo cinquenta doblas de oro e veinte e cinco mil maravedís desta moneda de Canaria.. e que, allende desto, el dicho maestro de gramática pueda llevar, de cada estudiante a quien enseñare, cuatro doblas o dos mil maravedís, si no fueren personas beneficiados desta nuestra iglesia y sus familiares, que a estos no pueda llevar cosa alguna... ${ }^{10}$.

En esta constitución, la 148, el prelado ponía su mayor atención en la capacidad que tenían los jóvenes para aprender correctamente la gramática latina, mediante la enseñanza que pudieran recibir de maestros "hábiles y suficientes"11.

Casi al tiempo que redactaba y aprobaba las constituciones acudía en auxilio de la reina Juana para que de los propios y rentas de la isla se le concediera el sueldo que fuera justo, a la persona dedicada a la enseńanza, puesto que era muy necesaria en Gran Canaria para que los vecinos fueran industriados ${ }^{12}$. La petición realizada por el obispo fue aceptada por la reina y su consejo, quien

con la concisión correspondiente para las escuelas de primeras letras de aquellas islas, y hoy ilustrado y aumentado notablemente en obsequio de la verdad, Las Palmas de Gran Canaria, 1946, pp. 78-79.

10 CABALLERO MÚJICA, F.: Canarias hacia Castilla. Datos de un proceso histórico, Las Palmas de Gran Canaria, 1992, T. II, pp. 693 y 833. "De los maestros que han de enseñar".

11 FERRAZ LORENZO, M.: “Origen y desarrollo...”, p. 920.

12 ZUAZNAVAR y FRANCIA, J.M.: op. cit., p.34. 
por Real Cédula de 1 de febrero de 1515 concedía tal prebenda para asistir a los maestros ${ }^{13}$. De acuerdo con estos requerimientos fue nombrado como maestro y profesor de gramática Francisco de Aguilar, de quien se dice "que es muy buen profesor de gramática y ha sacado buenos discípulos y es hombre honrado y de buena y honesta vida"14.

Estas enseñanzas dirigidas al buen conocimiento de la gramática han de entenderse como el origen de los estudios clásicos en las islas, vinculados especialmente a la iglesia. Esta institución también tenía la preocupación, de acuerdo con los mandaos de los obispos, del conocimiento de la doctrina cristiana, que iniciaba a los nińos en el aprendizaje, y así mandaba que los mandamientos y preceptos de la fe enseñados en las escuelas parroquiales se dijeran en romance y de una manera pausada para que todos los feligreses y especialmente los más jóvenes pudieran entenderlos ${ }^{15}$.

No obstante, en las islas, a pesar de la preocupación de sus autoridades, siempre hubo necesidad de personas cualificadas para enseñar Letras y Teología, que enseñasen a los jóvenes "... en buena doctrina para que supiesen servir a Dios y a su rey y gobernar la República" ${ }^{16}$.

A la par, muchos curas y miembros del cabildo catedral, interesados por instruir a los jóvenes, practicaban la docencia, tanto fuera como dentro de la iglesia, en donde les enseñaban a cantar, especialmente a través de la capilla de música, y otras cosas relacionadas con el conocimiento, entre ellos algunos canónigos como Bernardo Galicia ${ }^{17}$, o el sacristán mayor de la iglesia de San Juan de Telde, en Gran Canaria, el bachiller Roque Merino, que en 1590 recibía a dos mozos para iniciarlos en su casa en el estudio ${ }^{18}$.

Junto al clero secular en los primeros momentos los frailes jugaron un papel importante en la formación de los habitantes de las islas, en especial los franciscanos y dominicos, quienes entre los muros de sus conventos enseñaban

13 CULLEN DEL CASTILLO, P.: Libro Rojo de Gran Canaria, transcripción y estudio de, Las Palmas de Gran Canaria, 1947, p. 40.

14 FERRAZ LORENZO, M.: "Origen y desarrollo...”, p. 920.

15 Libro de Fábrica (viejo) de la iglesia de Santiago de Gáldar. Visita y mandatos del obispo don Diego Deza, 1558, 21 de abril, f. 78 v.

16 Archivo General de Simancas, Cámara de Castilla leg. 234, f. 234. Según se colige del memorial que el cabildo de Canaria envía a la Corona.

17 Codicilo del canónigo Bernardo Galicia otorgado en 3 de diciembre de 1550, donde declara que en tiempos pasados tuvo a su cargo a algunos mozos, a quienes en iglesias y fuera de ellas enseñaba a cantar y otras cosas. LOBO CABRERA, M.: Índices y extractos de los protocolos de Hernán González y de Luis Fernández Rasco, escribanos de Las Palmas (1550-1552), Valencia, 1980, doc. 89.

18 A.H.P.L.P., Rodrigo de Cubas, no 2.590, fs. 181 v. y 182 v. 
Gramática, Lógica, Filosofía y otras disciplinas, aunque también participaban con sus enseñanzas en las iglesias parroquiales, para que los mozos aprendieran a leer y escribir

Los conventos de estas órdenes estaban ubicados en las capitales de las islas, aunque a medida que avanzaba el siglo XVI se fueron creando otros en distintos lugares de la geografía isleńa. En los mismos tuvieron como labor la enseñanza elemental junto con la doctrina, especialmente en las zonas rurales, de tal manera que en siglos posteriores se señala como estos lugares fueron los "únicos puntos en que se adquiría la instrucción"19.

Los franciscanos fueron los primeros de asumir esta función, así, en Fuerteventura desde el siglo XV cumplían con la labor no solo de evangelizar sino también de enseñar, tal como se constata por la presencia en su cenobio de una serie textos de carácter didáctico, propios para esta función. En las islas realenga, donde fructificaron, cumplieron con creces la labor educativa, especialmente en las escuelas parroquiales rurales donde los franciscanos solían suplir al cura titular, tal como se constata en los libros parroquiales. Ahí enseñaban las primeras letras, y los ejercitaban en la escritura y en la enseñanza de doctrina cristiana.

Los dominicos ubicados en las capitales de las islas realengas desde bien pronto cumplieron una función análoga, y en La Laguna, gracias a la aportación del cabildo, 150 fanegadas de tierra de los propios de la isla en Los Rodeos, se comprometieron a establecer estudios de Filosofía, Gramática y Lógica aunque también cumplieron la misión de adoctrinar a sus pupilos, tanto en romance como en latín ${ }^{20}$.

Los agustinos llegados a Tenerife a fines del siglo XV desempeñaron igualmente su magisterio a través de los conventos levantados en la isla ${ }^{21}$, donde no solo renovaron los métodos educativos sino que ampliaron la enseñanza hacia el latín y la gramática, además de la lectura, escritura y primeras reglas ${ }^{22}$.

19 LEÓN Y XUÁREZ DE LA GUARDIA, F.M.: Historia de Canarias, Santa Cruz de Tenerife, 1976, p. 176.

20 GONZÁLEZ PÉREZ, T.: "Notas para el estudio del Colegio Dominico de La Laguna, Actas de VII Coloquio de Historia de la Educación, Málaga, 1993, p. 291.

21 VIERA Y CLAVIJO, J.: Noticias de la Historia General de Canarias, Madrid, 1978, T. II, p. 358.

22 NUNEEZ DE LA PENAA, J.: Conquista y antigüedades de las islas de la Gran Canaria y su descripción, Las Palmas de Gran Canaria, 1994, pp. 323 y ss. Facsímil de la obra editada en 1676. 


\section{LA EDUCACIÓN LAICA: LOS CABILDOS}

Los concejos o cabildos desde su instauración se ocuparon y preocuparon de la instrucción de sus vecinos, especialmente de los más jóvenes, por dicha razón de los bienes de propios dedicaron alguna partida para la contratación de maestros que ejercieran su actividad vinculados al cabildo y compatibilizando la enseñanza de manera privada.

El cabildo de Gran Canaria, al ser el primero en constituirse, apoyó la creación de un lector de gramática, que compartía con el cabildo eclesiástico, según se coteja de la real cédula de 1 de febrero de $1515^{23}$, y aunque el sostenimiento debía ser a medias, en 1517 el procurador del cabildo solicitaba que fuese el obispo el encargado de mantener un predicador y un maestro de gramática, conforme se había aprobado en un sínodo y había sido práctica habitual entre sus antecesores ${ }^{24}$.

En Tenerife, como en el resto de las islas también existía el doble tipo de enseñanza: la oficial y la particular. La primera promovida por el concejo a instancias de la Corona, toda vez que desde 1500 los Reyes Católicos habían secundado y ratificado la pragmática del rey Enrique II. Desde bien pronto, los munícipes se ponen de acuerdo para nombrar como preceptor de Gramática de la isla al bachiller Hernando de Fraga, con un salario anual de 8 doblas de oro en el año 1516, con el fin de que enseñara la disciplina a los hijos de los habitantes de la isla; este estipendio era una ayuda, puesto que el cabildo le dejaba libertad para que a su vez pudiera ejercer la enseñanza más cotidiana, en romance. Posteriormente mediante cedula del rey el salario se eleva a 10.000 maravedís ${ }^{25}$. Esta asignación fue completada con la concesión de un solar a los estudiantes de la isla para que pudiesen acudir al estudio en La Laguna ${ }^{26}$.

La contratación del bachiller fue respaldada tanto por el adelantado como por el resto de los miembros del cabildo, al entender que él era persona hábil, ducho en su materia, pues según los vecinos mostraba con suficiencia y habilidad la Gramática, de ahí que se mantuviera como tal preceptor entre 1515 y 1530, año en que los munícipes deciden buscar uno que lo remplazara, poniéndose ahora como condición que fuera "buen latino e poeta e retórico e

23 CULLEN DEL CASTILLO, P.: Libro Rojo de Gran Canaria, transcripción y estudio de, Las Palmas de Gran Canaria, 1947, documento XXV.

24 AZNAR VALLEJO, E.: La integración de las Islas Canarias en la Corona de Castilla (1478-1526). Aspectos administrativos, sociales y económicos, La Laguna, 1981, p. 59.

25 PADRÓN MESA, M.: Protocolos de Juan Márquez (1518-1521), La Laguna, 1993, pp. 67-69.

26 SERRA RAFOLS, E.; Las datas de Tenerife, La Laguna, 1978, registro 1.435. 
que sepa hablar griego e buena persona e de buena crianza e costumbres, el mejor que se pueda". Dicha persona fue hallada en Ávila, y se trataba de un clérigo presbítero, el bachiller Juan Gutiérrez, a quien se le contrató por un periodo de 10 años y sueldo de 40 ducados de oro al año ${ }^{27}$.

El cabildo de La Palma, a través de sus actas capitulares, muestra interés y preocupación por la formación de los jóvenes, y por ello contrata personas preparadas para que acometan tal actividad, dirigiendo su mirada a los niños y a los adolescentes, razón por la cual no solo se preocupara por contratar un preceptor de Gramática como hacen los otros cabildos, sino que también lleva a la práctica el solicitar, mediante pago, los servicios de maestros que enseñen a los mozos, de tal manera que en los acuerdos referentes a este asunto se ocupan de que realicen dos modalidades educativas: una orientada a los estudiantes más avanzados, y aquí es donde entra la figura del preceptor como individuo dedicado a enseñar, pero no cualquier cosa sino aquellas disciplinas que tienen que ver con el latín, materia indispensable para compaginar el conocimiento de otros estudios, en especial los que tenían que ver con la carrera eclesiástica o con el derecho. La otra modalidad era la enseñanza de las materias básicas como leer, escribir y las cuatro reglas. Para este fin el cabildo nombra y contrata como tal a Alonso de Morón ${ }^{28}$, quien se había ofrecido a enseñar gramática a los hijos de los feligreses y a otros personas interesadas. Siempre se le diera de salario 10.000 maravedís. En 1561 el preceptor solicitaba al consistorio que se le acrecentara su salario, por lo que en esa fecha a las 20 doblas que cobraba se le suman cuatro más, pero no debió ser suficiente porque en 1565 ya la isla contaba con otro maestro, Juan Cote, al cual, sin embargo, se le señalan de sueldo 12 doblas, como ayuda para pagar la casa donde vivía.

Curiosamente Alonso Morón, debido a las estrecheces económicas y a la poca demanda de sus servicios, estuvo a punto de irse a Indias, aunque al final llegó a un acuerdo con el gobernador para poder aplicar libertad de precios, con la condición de no ausentarse de la isla.

La escasez de hombres que enseñaran a los hijos de los vecinos fue una constante, porque el cabildo de nuevo, en 1571 "acordó por el bien y utilidad que se sigue a esta república de que los hijos de los vezinos sea doctrinados, que se

27 LA ROSA OLIVERA, L. y M. MARRERO RODRÍGUEZ: Acuerdos del Cabildo de Tenerife. $V$. 1525-1533, La Laguna, 1986, pp. 268 y 325.

28 MARRERO RODRÍGUEZ, M., SOLANO RUIZ, E. y G. DÍAZ PADILLA: Acuerdos del Cabildo de La Palma 1554-1556, Santa Cruz de La Palma, 2005. P. XX 
dé salario al dicho licenciando Juan de Sotomayor, preceptor, el qual señalaron que sean y se le den veynte doblas por un año..."29

La existencia de estos preceptores se garantizaba mediante emolumentos, los cuales estaban consignados de acuerdo a la licencia que tenía la isla, para costear tanto el salario del preceptor como del médico y del boticario ${ }^{30}$, tal es así, que en 18 de noviembre de 1555 se acuerda contratar a un preceptor de Gramática, por ser de mucha utilidad, con el sueldo de 10.000 maravedís, siempre y cuando se mantuviera en la isla al menos dos ańos, y con la posibilidad de poder cobrarle a sus pupilos la cantidad de cuatro reales al mes ${ }^{31}$. Para poder pagar el salario el cabildo, en distintas sesiones, acuerda imponer un canon sobre cada bota de vino que se exportase, que se establece en 1561 en un real, así como sobre el vino atabernado. No obstante, los problemas para pagar el sueldo al preceptor siguieron a lo largo del siglo, hasta el punto de tener que revocarlo por la pobreza de la tierra, así desde 1585 estuvo como tal el doctor Pedro González Medel, presbítero, pero en 1589 el cabildo al no tener medios suficientes para pagarle le suspende de sueldo, volviendo a retomar el tema en 1597, en que se nombra como tal al licenciado Francisco García, vecino de Tenerife, "persona que se tiene conseto de su abilidad e letras" con el fin de que se trasladara a la isla " a enseñar e dotrinar a los hijos de vezinos della que pretenden oyr gramática” 32 .

El cabildo, asimismo, nos descuida el otro modelo de enseñanza, quizá más modesto y sin tanta pretensión, dirigido a que los mozos aprendieran a leer, escribir, junto con los guarismos y las llamadas cuatro reglas, sumar, restar, multiplicar y dividir, con el fin de preparar a los muchachos en su formación más elementar para poder aspirar a una trabajo bien renumerado y cualificado. Aunque estos maestros era contratados de manera particular, entre el docente y el padre o pariente de los jóvenes, también el cabildo se preocupó de que en la isla hubiese personas dedicadas en enseñar mozos, así, sabemos de la existencia del maestro de escuela Sebastián de Toro, a quien el cabildo aconsejó

29 Esta referencia, así como otras citadas sobre los acuerdos del cabildo nos han sido cedidas graciosamente por el doctorando Sergio Hernández Suárez, quien realiza su tesis doctoral sobre El cabildo de La Palma en la época de Felipe II.

30 MARRERO RODRÍGUEZ, M., SOLANO RUIZ, E. y G. DÍAZ PADILLA: op. cit. Acuerdo 66. Santa Cruz de La Palma, 7 de abril de 1555. En 24 de febrero de 1556 el cabildo da poder al procurador Luis de Lugo para que pidiere por merced al rey, para costear el salario acostumbrado, por derrama — sisa-, en los mantenimientos.

31 Op. cit., p. XX

32 Libro de Acuerdos del Cabildo de La Palma 1596-1599, acta del día 7 de noviembre de 1597. 
en noviembre de 1555 que se moderase en lo que cobraba por enseñar mozos. ${ }^{33}$ Esto ocasionó que el maestro abandonase la isla, cumpliendo entonces las funciones propias de la enseñanza Alonso Sánchez ${ }^{34}$.

\section{LA EDUCACIÓN PARTICULAR}

La aparición de escuelas privadas y la práctica de la enseñanza primaria en su sede se da casi desde la conclusión de la conquista, al menos en las islas realengas. En estas escuelas se seguía el método, muy parecido al practicado en las escuelas árabes, donde se enseñaba a leer y escribir al mismo tiempo, dando a los alumnos desde el primer momento palabras y no letras ${ }^{35}$.

Estas escuelas estaban regentadas por particulares, con el apoyo de los vecinos que veían en estos maestros una oportunidad para sus hijos, así, en la isla de Tenerife en 1530, un grupo de vecinos muestra su apoyo al maestre de enseñar mozos, Melchor de Contreras, para que pudiera disponer de un local donde enseñar a los jóvenes, pues de lo contrario dejaría la isla, debido a la pobreza generalizada y a la poca ayuda que recibía por su enseñanza, razón por la cual se dirigen al cabildo para solicitar ayuda, alegando por un lado que era "hombre de buena doctrina, gran escribano y contador". El concejo, finalmente le asigna un salario de 10 doblas para que pudiera pagar el alquiler de una casa, donde pudiera ejercer a satisfacción del vecindario ${ }^{36}$. Aunque posteriormente el consistorio le revoca la ayuda, siguió como enseñante en años posteriores, recibiendo bajo su custodia a mozos, que mientras le sirven y ayudan en cosas posibles y honestas, durante un tiempo de dos años, les debía enseñar con eficiencia a leer, escribir y contar, de tal manera que al final del tiempo del aprendizaje pudiera leer cualquier escritura, escribir con buena letra, saben signar correctamente como un escribano, y aprender las cuatro reglas generales. A ello se añadía el tener que alimentarlo, vestirlo y calzarlo durante todo el tiempo, y darle al final un juego de ropa de vestir nuevo, a saber: una saya de buen paño, dos camisas, zapatos y bonete, todo nuevo ${ }^{37}$.

33 MARRERO RODRÍGUEZ, M., SOLANO RUIZ, E. y G. DÍAZ PADILLA: Op. cit., Acuerdo 121.

34 HeRnández MARTín, L. A.: Protocolos de Domingo Pérez, escribano público de La Palma (1546-1553), Santa Cruz de La Palma, 1999, doc. 281 y 306.

35 COSSÍO, M.B.: Op. cit., p. 112.

36 LA ROSA OLIVERA, L. y M. MARRERO RODRÍGUEZ: Acuerdos del Cabildo de Tenerife. V. 1525-1533, La Laguna, 1986, p. 269.

37 PADRÓN MESA, M.: Protocolos de Juan Márquez (1518-1521), La Laguna, 1993, pp. 69-70. 
En todas las islas se seguía el mismo modelo en este tipo de aprendizaje, donde eran los propios vecinos, a título particular, los que contrataban los servicios de los maestros de enseńar mozos de manera privada, aunque la forma más cotidiana era a través de los contratos realizados ante el escribano público, entre la persona responsable del menor y el maestro. Estos tipos de acuerdos nos ponen en la evidencia de las características más señaladas que se daban en la enseñanza primaria en las islas, especialmente done abundaba el analfabetismo y el saber leer y escribir era privilegio de algunos grupos sociales.

Desde bien pronto, tal como hemos indicado, aparecen en las islas personas que bajo el título de maestros de enseñar mozos ofrecen sus servicios. En Las Palmas el primero que figura con tal denominación Lorenzo Ordońo, citado como tal en $1511^{38}$, y posteriormente es Alonso de León, el ejerce como tal a partir de $1529^{39}$, mientras que en Tenerife los primeros maestros de estas características son citados en torno a la década de 1520 en que ejercen como tales Francisco de Villarroel y Diego López Paniagua ${ }^{40}$, y en la de los treinta figura como maestro de mozos un tal Gonzalo Pérez ${ }^{41}$, mientras que en La Palma, hemos de retrotraernos a las década de los cincuenta, que es cuando contamos con documentación, dado que la anterior fue incendiada en el asalto a la ciudad de Santa Cruz de La Palma de 1553, fecha en que figura como maestro de enseñar mozos Sebastián de Toro ${ }^{42}$.

A lo largo del siglo XVI la lista de maestros de enseñar mozos en Gran Canaria, se amplia, pues sus cometidos no solo los cumplían en la capital sino también en otros lugares, así en 1530 contamos con Cristóbal Dávila ${ }^{43}$ y ocho años más tarde instruía a los mozos de Las Palmas Gaspar González ${ }^{44}$. En la década de los 50 tenemos ejerciendo como tales a dos maestros: Sebastián de Toro, el mismo que había prestado sus servicios en la isla de La Palma, pero quizá por no tener clientela suficiente para poder subsistir decidió venir a Gran Canaria, donde estuvo enseñando más de diez años, hasta el punto de que en

38 PADRÓN MESA, M.: Op. cit, p. 71.

39 Archivo Histórico Provincial de Las Palmas, Hernando de Padilla, no 745, f. 35 r. En adelante A.H.P.L.P.

40 PADRÓN MESA, M.: Op. cit., pp. 70 y 71.

41 ALFARO HARDISSÓN, E.: Protocolos de Hernán González (1534-1535), La Laguna, 2000, doc. 662.

42 MARrERO RODrígueZ, M., SOLANO RUIZ, E. y G. DÍAZ PADILLA: Op. Cit., Acuerdo 121.

43 A.H.P.L.P., Hernando de Padilla, no 746, f. 541 r.

44 A.H.P.L.P., Hernando de Padilla, no 751, f. 229 r. 
1561 recibía en su casa a un mozo de doce años para enseñarle a leer letra tirada y escribir letra llana ${ }^{45} y$ Juan Alonso, el cual en su escuela no solo enseñaba a leer y a escribir, sino también doctrina ${ }^{46} \mathrm{y}$ otras materias, pues este Juan Alonso fue el mismo que fabricó un instrumento para la navegación con el que decía se tomaba la altura del sol a cualquier hora del día ${ }^{47}$.

Junto a los maestros, otras personas con conocimientos suficientes para instruir a los jóvenes se dedicaron también en esta tarea, como algunos oficiales y mercaderes. Así, el vecino de Gran Canaria, Lorenzo Ordoño, de oficio agujero, es decir que hacía alfileres y agujas, recibe a su servicio a un joven de Tenerife, hijo del pregonero público Francisco Díaz, para enseñarlo a leer y escribir, así como la doctrina ${ }^{48}$; del mismo modo en La Laguna el mercader Diego López Paniagua recibía a un mozo de 12 años para instruirlo en la lectura y en la escritura razonablemente, además de darle casa y comida, más la manutención correspondiente durante dos años, a cambio de que el joven le sirviera en todo aquello que le mandase ${ }^{49}$; Luis de Quesada Molina, a la vez que se dedicaba a los tratos propios del comercio, cumplía en 1563 la función de docente, que consistía en "vezar" a leer y escribir letra procesal ${ }^{50}$. Es muy posible que estos mercaderes además de la enseñanza de las primeras letras y de la lectura familiarizaran a los jóvenes con la contabilidad, tan propia de los comerciantes, como aprendizaje en el arte del comercio. Del mismo otros oficiales recibían niños en su casa para instruirlos como Antón de Espinosa o el vecino de Cádiz Juan de Salmerón, quien a la vez que enseñaba a los aprendices de su oficio de confitero para formarlos como oficiales, los iniciaba en la lectura y escritura ${ }^{51}$. Algunos miembros del cabildo, preocupados por instruir a sus vecinos también, en sus ratos libres, se dedicaban a enseñarlos, como el teniente de gobernador Bernaldianes de Torres, que formaba a los muchachos, que entraban a su servicio como pajes, en las prácticas de la lectura y la escritura ${ }^{52}$.

El hecho de que existieran personas dedicadas a otras actividades, que tuvieran empeño en enseñar a sus vecinos, se debía a que en aquella época cual-

45 A.H.P.L.P., Pedro de Escobar, nº 767, f. 474 r.

46 LOBO CABRERA, M.: Índices y..., op. cit., doc. no 159.

47 LOBO CABRERA, M.: "La investigación en Canarias en el siglo XVI", Boletín Millares Carlo, no 7-8, Madrid, 1985, pp. 229-242.

48 GALVÁN ALONSO, D.: Protocolos de Bernardino Justiniano (1526-1527), La Laguna, 1990, doc. 39

49 PADRÓN MESA, M.: Op. cit., p. 71.

50 A.H.P.L.P., Alonso de Balboa, no, 774, f. 365 v.

51 LOBO CABRERA, M.: Índices y extractos ..., op. cit., doc. 266.

52 A.H.P.L.P., Hernando de Padilla, no 750, f. 442 r. 
quier persona con conocimiento podía practicar la docencia hasta el punto de que maestro de mozos podía ser cualquiera que lo deseara, al no existir veto al respecto, hasta 1642, fecha en que previa autorización del rey Felipe IV, los maestros de Madrid se reúnen y fundan la hermandad de san Casiano, para proteger y mejorar el sistema educativo. Entre sus ordenanzas hay una que establecía examinar a los demás maestros del reino para poder dedicarse a la profesión, con cual se termina así la libertad de ejercicio que había existido hasta el momento ${ }^{53}$.

Los citados cumplían su función en la ciudad de Las Palmas, así como en Tenerife la ejercían en La Laguna, amén de algunos que trabajaban en otros lugares, como Garachico y San Pedro de Daute, y en La Palma tenían sus locales en Santa Cruz.

Lo normal es que estos maestros recibieran en sus clases a niños de distintas familias, aunque también se da el caso de admitir como tales alumnos a varios miembros de una familia, así en La Laguna Arias Pardo, estante en San Pedro de Daute, recibe de Pedro Caravallo, en 1550, a sus dos hijos, con el fin de enseñarles no solo a leer, sino también las cinco reglas, añadiendo a las usuales el medio partir, partir por entero y cuenta llana ${ }^{54}$.

Estos enseñantes solían contratar sus servicios mediante el pago de un salario en numerario, aunque en ocasiones también recibían sus emolumentos en especie, como trigo y otros productos ${ }^{55}$, e incluso en servicios que le hacen los jóvenes en sus casas .

Las personas dedicadas en las islas a enseñar a los muchachos, tenían entre sus cometidos los siguientes: era prioritario enseñar a leer y escribir y a saber firmar, con lo cual se les preparaba para desenvolverse socialmente y ser capaces de otorgar escrituras de todo tipo; a esto se añadía el conocimiento de los "guarismos", que no eran otros sino saber sumar, restar, multiplicar y partir, aunque en las escrituras suelen aplicarse de manera genérica la enseñanza de estudio y lecciones, de tal manera que al final pudieran tanto leer una carta como escribirla $^{56}$. Algunos, en función de quien fuera la persona que contratara los servicios del maestro, eran más explícitos, así, en un contrato otorgado en 1554 por el regidor de Tenerife Fabián Viña, persona de ascendencia italiana al ser pariente de Mateo Viña, uno de los personajes que ayudó a Alonso Fernández

53 COSSÍO, M.B.: op. cit., pp. 112-113.

54 PADRÓN MESA, M.: Op. cit., p. 70.

55 PADRÓN MESA, M.: Op. cit., doc. 952.

56 A.H.P.L.P., Hernando de Padilla, no 751, f. 382 r. 
de Lugo a financiar la conquista de Tenerife, especifica lo que quiere que el maestro vasco, Martín de Escarrizaga, enseñe a su hijo y a su sobrino, durante ocho meses:

“... sepan leer y escribir qualquier letra tirada que sea vista por persona que dello sepa e sea cotejada con letra que agora de presente hacen, para que se vea como están aventajados, e mucho más que de la letra que de presente hacen e a enseñarle a sumar e restar e multiplicar e partir por entero..." 57 .

Este tipo de actividad, consistente en enseñar, se impartía de fijo todos los días de trabajo, tanto por la mañana como por la tarde, aunque en algunas de las escrituras consultadas solo se especifica que los mozos acudirían a recibir las lecciones a las horas que otros mozos solían ir. La enseñanza se impartía durante algunas horas, las contratadas en las casas del maestro, aunque en otros ocasiones los jóvenes vivían con el preceptor todo el tiempo contratado, tal como como se recoge en algunos contratos, así el maestro Alonso de León se comprometía a recibir en su casa a Zoilo, hijo de Alonso Fernández, calafate, para enseńarlo y tenerlo consigo en su casa durante un año ${ }^{58}$.

La edad de estos jóvenes oscilaba, según los casos, entre los 10 y los 14 años, y el tiempo que se estimaba necesario para lograr el aprendizaje contratado, lectura, escritura y reglas elementales, solía ser de un ańo, aunque en ocasiones y en función de lo exigido en el contrato el mismo podía durar hasta dos años o tres, según los acuerdos.

Estas personas dedicadas a la enseñanza de manera libre percibían por su trabajo de acuerdo a los convenios que establecían con los familiares de los jóvenes, en la mayoría de los casos sus padres. En general en sueldo estaba establecido en una horquilla que iba entre las 5 y las 10 doblas, de a 500 maravedís cada una, según las fechas. Los pagan se le hacían en plazos, así iban percibiendo el dinero por tercios, pues se les pagaba de cuatro en cuatro meses. Al final del tiempo concertado para llevar a cabo su misión tenían que entregar a los muchachos con experiencia en los conocimientos de lectura y escritura, al menos, ya que de lo contrario tenían que volver a recibirlos en sus casas, gratis,

57 DE LA ROSA, L.: “Maeso de enseñar moços”. Revista de Historia Canaria, núm. 157-164, T. XXXII, La Laguna, 1968-69, p. 209. Este autor considera que en dicho contrato está el origen de los estudios primarios en la Isla de Tenerife.

58 A.H.P.L.P., Hernando de Padilla, no 745, f. 35 v. 
hasta que acabaran de instruirlos, según las condiciones acordadas en los contratos celebrados al efecto.

En ocasiones, hemos encontrado alguna salvedad a lo anterior, como es el caso de algún joven que pagaba sus estudios mediante la realización de servicios, en casa del maestro, donde debía cumplir y hacer todo lo que se le mandara, como fuera de ella haciendo recados y mandados. Por tal servicio el maestro debía ilustrarlo, además de mantenerlo y vestirlo conforme a su edad.

Estas eran las características generales que dominaban en estos acuerdos entre particulares, con el fin de ilustrar e instruir a los jóvenes de la sociedad canaria, sin embargo, también existieron otros tipos de concierto en donde además de la educación se buscaban otros cometidos, así, Alonso de Écija, padre de los huérfanos de la isla de Gran Canaria, colocaba a Anrique Correa, mozo de siete a ocho años, a soldada con el teniente de gobernador de la isla, Bernaldianes de Torres, para que le sirviera como paje diez años, a condición de que el teniente tenía que darle comida, bebida, calzado y vestidos, así como cama en que dormir, según la propia calidad del oficial, más enseñarle a leer a su costa, de modo que el muchacho aprendiera a escribir y a leer una carta misiva; asimismo al final del tiempo del contrato tenía la obligación de entregarle una capa de paño de a ducado la vara, unas calzas de cordellate, dos camisas de ruan, un jubón de fustán, una gorra, unos zapatos y un cinto, todo nuevo ${ }^{59}$. Similar situación a la descrita encontramos en el concierto celebrado entre la madre de un muchacho, Beatriz Hernández, y Sebastián Rieros, padre de huérfanos, con Juan Salmerón, confitero, vecino de Cádiz, para que el chico, Juan, estuviera a su servicio ocho años, en cuyo tiempo aprendiera el oficio de confitero, más leer y escribir. Durante el citado periodo el oficial tendría que obligarse a unas condiciones similares al anterior caso citado, más entregarle un equipo completo de ropa, consistente en sayo, capa, calzas, camisas, jubón, gorra y zapatos ${ }^{60}$.

Además de estas enseñanzas la educación en la época incluía otras disciplinas como la música, de la cual se ocupaba la capilla de la catedral, y el manejo de las armas, tal como se comprueba cuando el cabildo de Tenerife concede vecindad al maestro de palestrina Diego de León, a pesar de que no cumplía con los requisitos para obtener dicha categoría, ya que no había traído a su mujer, para que enseñara a los hijos de los vecinos "en el arte del menear las armas que ser diestros en guerra" ${ }^{61}$.

59 A.H.P.L.P., Hernando de Padilla, no 750, f. 442 r.

60 LOBO CABRERA, M.: Índices y extractos ..., op. cit., doc. 266.

61 SERRA RAFOLS, E. y L. DE LA ROSA, L.: Acuerdos del Cabildo de Tenerife. III. 1514-1518, La Laguna, 1965. Acuerdo de 6 de octubre de 1514. 
Algunos de estos muchachos, los más aventajados y especialmente los que contaban sus familias con medios económicos suficientes, continuaban los estudios superiores en las universidades peninsulares y europeas. Muchos de ellos fueron figuras destacadas, que ocuparon puestos en las distintas instituciones de las islas, en especial en el cuerpo catedralicio, tales como el doctor Hernando Díaz de Vera, arcediano de Tenerife y consultor del Santo Oficio, natural de Tenerife, hijo de guanches, y graduado en Teología por Valencia, Luis de Morales, Ambrosio López, y especialmente nuestro primer gran poeta Bartolomé Cairasco de Figueroa, que según sus contemporáneos era único en poesía, música y latín ${ }^{62}$. Sin embargo también otros, con mayor sacrificio y constancia, accedieron a los estudios como el joven natural de Gran Canaria, Damián Cosme, que estudiaba en Sevilla, sufragando sus gastos gracias a un hato de cabras, valorado en 100 doblas, que sus padres, vecinos de Tejeda, vendieron ${ }^{63}$.

A pesar de los avances que se van produciendo en las islas en el campo educativo, gracias a las labores propias de la Iglesia, de los concejos, y de todas aquellas personas interesadas por instruir a sus familiares y protegidos, hay que señalar que dentro del conjunto de la sociedad canaria solo una minoría tenía la fortuna de poder acceder a estos conocimientos, útiles para el ascenso social y profesional, mientras que la gran mayoría entregados a las labores agrarias y alejados de los centros urbanos, apenas pudieron acceder a la instrucción, de tal modo que durante siglos la enseñanza primaria a los niños estuvo bastante limitada.

\section{BIBLIOGRAFÍA}

Alfaro Hardissón, E.: Protocolos de Hernán González (1534-1535), La Laguna, 2000.

Aznar Vallejo, E.: La integración de las Islas Canarias en la Corona de Castilla (1478-1526). Aspectos administrativos, sociales y económicos, La Laguna, 1981.

Bethencourt Massieu, A.: La enseñanza primaria en Canarias durante el Antiguo Régimen; Universidad Nacional de Educación a Distancia, Centro Asociado de Las Palmas, 1985.

62 FERNÁNDEZ MARTÍN, L.: "Aspectos económicos, administrativos y humanos de la diócesis de Canarias en la segunda mitad del siglo XVI", Anuario de Estudios Atlánticos, 21, Madrid-Las Palmas, 1975, pp. 119-124.

63 A.H.P.L.P., Alonso de San Juan, no 884, f. 332 r. 
Caballero Mújica, F.: Canarias hacia Castilla. Datos de un proceso histórico, Las Palmas de Gran Canaria, 1992, T. II.

Cossío, M.B.: De su jornada, Madrid, 1929.

Cullen del Castillo, P.: Libro Rojo de Gran Canaria, transcripción y estudio de, Las Palmas de Gran Canaria, 1947.

Fernández Martín, L.: "Aspectos económicos, administrativos y humanos de la diócesis de Canarias en la segunda mitad del siglo XVI", Anuario de Estudios Atlánticos, 21, Madrid-Las Palmas, 1975, pp. 95-124.

Ferraz Lorenzo, M.: "Los orígenes de la educación pública y profesional en Canarias. Siglo XVI”, XIII Coloquio de Historia Canario-Americano (1998), Las Palmas de Gran Canaria, 2000, pp. 2488-2500.

Ferraz Lorenzo, M.: "Origen y desarrollo de las modalidades educativas parroquial y conventual en Canarias (siglos XVI y XVII)", XIV Coloquio de Historia Canario-Americana (2000), Las Palmas de Gran canaria, 2002, pp. 918-931.

Galván Alonso, D.: Protocolos de Bernardino Justiniano (1526-1527), La Laguna, 1990.

González Novalín, J.L.: “Don Diego de Muros II, obispo de Canarias, su personalidad humanística y su aportación literaria a las crónicas granadinas del 1487 y 1488", Anuario de Estudios Atlánticos", 20, Madrid-Las Palmas, 1974, p.13-107.

González Pérez, T.: "Institucionalización de la enseñanza en Canarias. Ojeada histórica sobre la educación en los siglos XVI y XVII", Tebeto: Anuario del Archivo Histórico Insular de Fuerteventura, 15, Puerto del Rosario, 2002, pp. 473-492;

González Pérez, T.: "Notas para el estudio del Colegio Dominico de La Laguna, Actas de VII Coloquio de Historia de la Educación, Málaga, 1993, pp. 279291.

Hernández Martín, L. A.: Protocolos de Domingo Pérez, escribano público de La Palma (1546-1553), Santa Cruz de La Palma, 199.

León y Xuárez de La Guardia, F.M.: Historia de Canarias, Santa Cruz de Tenerife, 1976.

La Rosa, L de.: "Maeso de enseñar moços". Revista de Historia Canaria, núm. 157-164, T. XXXII, La Laguna, 1968-69, p. 209.

La Rosa Olivera, L .de y M. MARRERO RODRÍGUEZ: Acuerdos del Cabildo de Tenerife. V. 1525-1533, La Laguna, 1986.

Lobo Cabrera, M.: "La enseñanza en Gran Canaria. Siglo XVI", El Eco de Canarias, 21 de junio de 1979. 
Lobo Cabrera, M.: Indices y extractos de los protocolos de Hernán González y de Luis Fernández Rasco, escribanos de Las Palmas (1550-1552), Valencia, 1980. Lobo Cabrera, M.: "La investigación en Canarias en el siglo XVI", Boletín Millares Carlo, no 7-8, Madrid, 1985, pp. 229-242.

Marrero Rodríguez, M., SOLANO RUIZ, E. y G. DÍAZ PADILLA: Acuerdos del Cabildo de La Palma 1554-1556, Santa Cruz de La Palma, 2005.

Morales Padrón, F.: Canarias: crónicas de su conquista. (Transcripción, estudio, notas), Las Palmas de Gran Canaria, 1978.

Nuñez De La Peña, J.: Conquista y antigüedades de las islas de la Gran Canaria y su descripción, Las Palmas de Gran Canaria, 1994.

Padrón Mesa, M.: Protocolos de Juan Márquez (1518-1521), La Laguna, 1993.

Serra Rafols, E. y L. de La Rosa, L.: Acuerdos del Cabildo de Tenerife. III. 15141518, La Laguna, 1965.

Serra Rafols, E.; Las datas de Tenerife, La Laguna, 1978.

Viera y Clavijo, J.: Noticias de la Historia General de Canarias, Madrid, 1978, T. II.

Zuaznavar y Francia, J.M.: Compendio de la Historia de Canarias formado en su principio con la concisión correspondiente para las escuelas de primeras letras de aquellas islas, y hoy ilustrado y aumentado notablemente en obsequio de la verdad, Las Palmas de Gran Canaria, 1946. 



\title{
LA CUESTION DE DIOS: TEISMO Y ATEISMO THE GOD QUESTION: THEISM AND ATHEISM
}

\author{
Gonzalo Marrero Rodríguez y Ofelia Santiago García \\ Universidad de Las Palmas de Gran Canaria
}

\section{Resumen}

Este artículo lo escribimos in memoriam de nuestra compañera y amiga entrańable, Emy Repetto, investigadora fecunda, formadora de maestros y profesores, comprometida con su fe cristiana, y nos permite realizar una reflexión sobre la pregunta por la presencia de Dios, la más importante de la existencia humana. El trabajo consta de una introducción y cinco epígrafes: a) apuntes sobre el agnosticismo de Charles Darwin; b) análisis de los "nuevos ateísmos"; c) transición del ateísmo al teísmo del filósofo británico Antony Flew; d) el resurgir de Dios en la filosofía actual; y e) unas conclusiones para la reflexión sobre Dios.

Palabras clave: Dios, teísmo, ateísmo, nuevos ateísmos, panteísmo, agnosticismo, ciencia y religión, designio cósmico.

\begin{abstract}
We wrote this article in memoriam of our companion and dear friend, Emy Repetto, a fruitful researcher, teacher and teacher educator, and committed to her Christian faith; and it allows us to reflect on the question of the presence of God, the most important of human existence. The work consists of an introduction and five epigraphs: a) notes on the agnosticism of Charles Darwin; b) analysis of the "new atheisms"; c) transition from atheism to the theism of the British philosopher Antony Flew; d) there surgence of God in current philosophy; and e) some conclusions for reflection on God.
\end{abstract}

Keywords: God, theism, atheism, new atheisms, pantheism, agnosticism, science and religion, cosmic design.

\section{INTRODUCCIÓN}

En el mundo actual el debate entre ciencia y religión sigue despertando el interés de los científicos, los filósofos, los teólogos y del público en general y los debates de los últimos años han ido ganando respeto en mutuo, precisión, rigor y argumentaciones consistentes de las distintas posiciones. $Y$ nos pregun- 
tamos ¡cuáles son los puntos principales del debate entre ciencia y religión en la actualidad?

Es necesario constatar que desde las posiciones teístas y del ateísmo se ha pedido a la ciencia más de lo que puede dar. La ciencia no es teísta ni ateísta, y es preciso impulsar el pensamiento filosófico y teológico como modos de racionalidad humana que permitan indagar y razonar sobre el porqué del origen del universo, de la aparición de la vida y de la existencia humana y su sentido.

El diálogo entre ciencia y religión ha sido y es un diálogo complejo y difícil donde el respeto a la diversidad y pluralidad de las posiciones no ha sido la constante. Este respeto a la multiplicidad es un aspecto innegociable si queremos llegar a conclusiones viables a estas alturas del siglo XXI, pues la historia de los distintos conflictos entre ciencia y religión así lo atestiguan (Udías, 1993). El diálogo abierto y sincero entre ciencia y religión es la única manera de construir y avanzar en la construcción de un mundo más humano y solidario y de responder a las grandes preguntas de la existencia humana.

Para muchos pensadores y científicos, la expresión "Dios existe" es una certeza pero, ¿̇tiene sentido? Este Dios del que utilizamos el nombre ¿̨existe? Esta es la gran pregunta, la más importante de la existencia humana y a la que Francis S. Collins, líder del Proyecto del Genoma Humano, pretende responder en esta época buscando la integración armónica de las concepciones científicas y espirituales del universo para iluminar la existencia humana. En mi opinión, no existe ningún conflicto entre ser un cientifico riguroso y una persona que cree en un Dios que tiene un interés personal en cada uno de nosotros. El dominio de la ciencia es explorar la naturaleza. El dominio de Dios es el mundo espiritual, un reino que no se puede explorar con las herramientas y el lenguaje de la ciencia. Se debe examinar con el corazón, la mente y el alma -y la mente debe encontrar un modo de abrazar ambos reinos-(Collins, 2019, p. 14).

La ciencia es el unico modo confiable de entender el mundo natural, y sus herramientas, cuando se usan adecuadamente, pueden generar profundas revelaciones en la existencia material. Pero la ciencia no tiene la capacidad de responder preguntas tales como "ipor qué el universo llegó a existir?”, "¿cuál es el significado de la vida humana?", "iqué sucede después de la muerte?" Una de las motivaciones más fuertes de la humanidad es buscar respuestas a preguntas profundas, y necesitamos reunir el poder de ambas perspectivas, la cientifica y la espiritual, para fortalecer el entendimiento tanto de lo que se ve como de lo que no se ve (Collins, 2019, pp. 14-15).

Es importante considerar que las tendencias y tensiones entre el teísmo y el ateísmo se acentuaron con la desintegración del "bloque soviético" que per- 
dió su carácter monolítico y posibilitó la emergencia de nuevas formas de confrontación y diálogo entre ciencia y religión, entre teísmo y ateísmo. En esta perspectiva, los "nuevos ateos" continúan afirmando que sólo las visiones del universo de carácter naturalista, arreligioso y ateo permiten el avance de la sociedad (Dawkins, 2012).

Por otra parte, los teólogos insisten en sus estudios en la transformación de las relaciones entre ciencia y teología, y en construir nuevas formas de "repensar la teología", de "repensar la revelación" y de establecer una "nueva comprensión del teísmo" (Torres Queiruga, 2008).

Los avances de la investigación científica en diferentes ámbitos del conocimiento humano plantean nuevas preguntas que es necesario analizar y responder tanto desde las posiciones teístas como ateístas. En esta línea, no se puede negar el impacto de las teorías de Darwin en las relaciones entre ciencia y religión y, por esta razón, le dedicamos un epígrafe en el que estudiamos algunos de sus textos más significativos, lo que nos permite reivindicar su agnosticismo frente a los pensadores que le consideran el padre del ateísmo moderno.

Además del epígrafe sobre el agnosticismo de Charles Darwin, analizamos los "nuevos ateísmos", estudiamos la transición del ateísmo al teísmo del filósofo británico Antony Flew, el resurgimiento de Dios en la filosofía actual y finalizamos con unas conclusiones para la reflexión sobre Dios.

\section{EL AGNOSTICISMO DE CHARLES DARWIN}

El ateísmo afirma que históricamente los defensores del teísmo recurren a Dios cuando se enfrentan a un fenómeno que no pueden explicar y le utilizan como un recurso para explicar los "huecos" que aún existen en el campo de la investigación científica. Para el ateísmo los progresos de la ciencia permitirán explicar todos los "agujeros epistemológicos actuales" y harán desaparecer la idea de Dios del conocimiento humano.

Para el pensamiento ateísta, la aparición del hombre en la tierra se integra en la teoría general de la evolución que incorpora una explicación del origen de las especies a partir de mutaciones en el código genético de los seres vivos y la selección natural de los que mejor se adaptan al ambiente. En esta teoría general, el ser humano es una especie más que procede de "complejos procesos de autoorganización de la materia" de manera que la inteligencia, la autoconciencia o la libertad sólo son dinámicas cerebrales con un alto nivel de complejidad (Dawkins, 2012).

Cuando analizamos el conflicto entre ciencia y religión es preciso estudiar el caso de Charles Darwin que sufrió aceradas críticas y el rechazo de sectores 
de la iglesia anglicana, aunque al final de su vida fue enterrado en la Abadía de Westminster.

En primer lugar, parece fuera de duda que pretendió escribir una obra científica y que no buscaba alimentar el fuego de la controversia entre ciencia y religión. Entre otras razones, porque no se consideraba una persona dotada de una formación filosófica y teológica que le permitiera la confrontación y el debate con la filosofía y la teología de su época y porque no estaba interesado en las controversias ideológicas.

En segundo lugar y, para descubrir algunas aportaciones de Darwin que nos faciliten la clarificación de su pensamiento, analizaremos algunos textos de su Autobiografía en la edición del texto seleccionado por su hijo Francis Darwin (1977). Esta obra fue censurada por la propia familia que eliminó algunos pasajes porque la consideraban un escrito íntimo y para uso de su mujer e hijos, como una especie de testamento personal donde afrontaba sus problemas religiosos, sus dudas y angustias. No obstante, su nieta Nora Barlow (1958) publicó el manuscrito original completo, incluidas las notas al margen de la esposa de Darwin.

En tercer lugar, en estos textos Darwin se presenta a sí mismo como un "agnóstico" nunca como un ateo, y afirma que no pretende aclarar los complejos problemas derivados del misterio del principio de todas las cosas que es insoluble para nosotros y que debe contentarse con su agnosticismo (Francis Darwin, 1977, p. 116). El análisis de su obra nos permite afirmar que, si ordenamos cronológicamente las afirmaciones de Darwin sobre Dios, creación, diseño, plan, leyes, etc. emerge la imagen de un desarrollo consistente de su religiosidad desde la ortodoxia de su juventud hasta el agnosticismo de sus últimos años de vida.

Darwin no encuentra contradicciones entre la creencia en Dios y la teoría de la evolución por selección natural, insiste en que las especies biológicas cambiaron con el paso del tiempo y que el motor del cambio es la selección natural (Francis Darwin, 1977, p. 110). Asimismo, reconoce que se encuentra en una perplejidad sin esperanza y que sus dudas sobre la fe religiosa no tienen originalidad alguna: el escándalo que le ha producido la interpretación literal del Antiguo Testamento, la desconfianza de los textos evangélicos de los milagros que parecen contradecir las leyes de la naturaleza, la predeterminación, el castigo eterno de los que no creen, y el problema del mal y del sufrimiento en el mundo.

Aborda directamente la existencia de Dios y afirma que otra fuente de convicciones de la existencia de Dios relacionada con la razón y no con los sentimientos, 
es la que se deduce de la extrema dificultad o más bien de la imposibilidad de concebir este inmenso y maravilloso universo, incluyendo al hombre con su capacidad de reflexionar sobre el pasado y el futuro, como resultado del ciego azar o de la necesidad. Cuando reflexiono sobre estas cuestiones me siento obligado a volverme hacia una Primera Causa dotada de una mente inteligente y análoga en cierta medida a la del hombre y merezco, por tanto, ser llamado teista (Barlow, 1958, pp. 92-93).

A la luz de este breve análisis podemos concluir que la posición de Darwin es el "agnosticismo" y en ningún caso el "ateísmo" y que está muy lejos de su pensamiento convertirse en el "padre del ateísmo" desde la perspectiva de las ciencias biológicas.

\section{LOS "NUEVOS ATEÍSMOS”}

Además de las teorías de Darwin, las ciencias genéticas y las neurociencias plantean nuevas cuestiones acerca de la fe y de la experiencia espiritual que han reorientado los debates entre ciencia y religión y han cristalizado en una búsqueda de experiencias espirituales sin Dios y sin religión. Por otra parte, el ateísmo no es una corriente monolítica, sino que existen en su interior diferentes perspectivas, pues no sólo se presenta como una corriente fracturada, sino que incluye distintas definiciones y distinciones y se encuentra actualmente sometido a una fuerte crítica interna.

Asimismo, la problemática del ateísmo tiene un marcado carácter occidental pues la cuestión de la divinidad y el sentido último de la vida presentan elementos diferenciados en otras culturas y religiones, especialmente orientales.

En la primera década del siglo XXI alcanzó un gran desarrollo la corriente denominada "nuevos ateísmos" en la que destacan Richard Dawkins (2012) y Christopher Hitchens (2008), caracterizada por una durísima y agresiva crítica contra la religión a la que definen como peligrosa, perniciosa y maligna, consideran a los creyentes como terroristas en potencia y afirman que sólo lograremos un mundo más seguro si erradicamos la religión.

Para el "nuevo ateísmo" el cristianismo y la religión son formas anticuadas de explicación de las cosas de las que se puede prescindir en nuestra época caracterizada por el "positivismo científico". Considera que el darwinismo es una teoría universal y sus explicaciones trascienden el ámbito de las ciencias biológicas, y que la religión puede ser explicada desde el darwinismo porque puede reducirse a un único rasgo universal, y los rasgos universales de una especie postulan una explicación darwinista. 
Dawkins (1993) sostiene una analogía fundamental entre evolución biológica y evolución cultural, pues en las dos se produce una clonación. En la evolución biológica es el gen el que clona y en la evolución cultural lo que replica es una "entidad construida", a la que denomina "meme". La idea de Dios es un "meme" o un "virus" que ha infectado el cerebro del hombre en el ambiente creado por la cultura humana. Presenta el "meme" como una realidad científica incuestionable, pero hasta ahora no ha logrado que pueda ser considerada como una "hipótesis viable".

Para McGrath y McGrath (2007), el "nuevo ateísmo" se caracteriza porque carece de un uso riguroso de las pruebas, aunque ha utilizado con éxito la retórica y la demagogia. Insisten en el recurso sistemático a las ciencias naturales como el único fundamento de la verdad ("cientificismo") y el rechazo de la fe religiosa como una superstición. En un lúcido análisis, Armstrong (2009) insiste en las debilidades filosóficas del "nuevo ateísmo", entre las que destaca las tergiversaciones de la historia, la debilidad y el uso demagógico y tendencioso de las pruebas y las afirmaciones triviales sobre la religión y la religiosidad.

El biólogo de Oxford Denis Noble (2008) afirma que el "nuevo ateísmo" introduce en el ámbito de la ciencia y la religión supuestos metafísicos ateos que las evidencias científicas no exigen ni legitiman. Lo que hace el "nuevo ateísmo" no es ciencia sino manipulación y distorsión demagógica de los resultados de la investigación científica. Si consideramos la consistencia de la teoría y el impacto explicativo creemos que la "teoría del meme" no presenta ninguna explicación o predicción más allá de lo que puede explicarse sin necesidad de la analogía "gen-meme", pues no ha ofrecido ningún valor añadido para la comprensión de los fenómenos y, por tanto, es una hipótesis superflua, fruto de la especulación y alejada de los resultados de la investigación científica.

Las posiciones teístas insisten en el "ajuste fino" de las constantes fundamentales del universo que postulan la existencia de un ser superior que estableció los valores de las constantes antes de poner en marcha el universo. Este planteamiento es criticado por Stephen Hawking y Leonard Mlodinow (2013) para quienes nuestro universo es uno de los muchos posibles dentro del gran "multiverso": los universos en la "teoría de supercuerdas" tienen su origen en fluctuaciones cuánticas y nuestro universo procedería de una fluctuación cuántica que se hace cada vez más compleja hasta el desarrollo de seres dotados de inteligencia, consciencia y libertad (Greene, 2012).

La ciencia utiliza sus propios mecanismos para rechazar las falsas teorías, pero ¿abarca la ciencia todos los niveles de realidad? El denominado "ateísmo científico" considera que la ciencia es capaz de ofrecer una explicación de todos 
los niveles de realidad y esta visión reduccionista del conocimiento científico se encuentra en cuestión. Así, la explicación del origen del universo a partir de la teoría del "multiverso" o de la aparición de la conciencia humana desde los procesos de autoorganización de la materia pueden ser considerados ciencia ficción (Hawking, 2013).

Mucho antes que Hawking, Einstein había apuntado Quiero saber cómo creó Dios este mundo (...). Quiero conocer sus pensamientos; lo demás son minucias (Ferris, 1988, p.77).

$\mathrm{Y}$, a pesar de las influencias del pensamiento de Spinoza, Einstein niega categóricamente ser ateo o panteísta: No soy ateo, y no creo que me pueda llamar panteista. Estamos en la misma situación que un niño que entra en una biblioteca enorme llena de libros en muchos idiomas. El niño sabe que alguien debe haber escrito esos libros. No sabe cómo. No entiende las lenguas en las que fueron escritos. El niño presiente oscuramente un orden misterioso en la disposición de los libros, pero no sabe cuál es. Tal es, me parece a mi, la actitud de hasta el más inteligente de los seres humanos frente a Dios. Vemos un universo maravillosamente ordenado y sujeto a ciertas leyes, aunque sólo comprendamos oscuramente tales leyes. Nuestras mentes limitadas intuyen la fuerza misteriosa que mueve las constelaciones (Jammer, 1999, p. 48).

Einstein coincidia con Spinoza en que quien conoce la naturaleza conoce a Dios, pero no porque la naturaleza sea Dios, sino porque la empresa cientifica de indagación de la naturaleza conduce a la religión (Jammer, 1999, p. 148).

Einstein siempre lamentaba que se le considerara ateo. Lo que realmente me enfurece es que los que dicen que Dios no existe me citen para reforzar sus tesis (Jammer, 1999, p. 150).

\section{EL PASO DEL ATEÍSMO AL TEÍSMO DE ANTONY FLEW}

Los pensadores de la antigüedad se propusieron acercarse a la idea de Dios interrogando al cosmos, pero en la época moderna se cuestiona y se analiza al hombre para encontrar la huella de Dios. Sören Kierkegaard establece que Dios es una idea suprema que no puede explicarse por otra cosa y que es necesario interpretarla sumergiéndose en el mismo concepto de Dios. El camino no es probar a Dios a partir de nada, sino a partir de lo que se deja ver y pensar.

En esta perspectiva, Flew considera que la cuestión de Dios lleva la marca de su tiempo y no puede ser aislada del contexto cultural del que se trate. El problema de Dios se integra en el cómo una generación entiende al hombre y al universo y cómo define sus valores. Cuestiona la existencia de Dios desde las pruebas clásicas de su existencia y se educa en las coordenadas del nuevo 
ateísmo que supone que la ciencia excluye la existencia de Dios. Es deudor del pensamiento de los "maestros de la sospecha", Karl Marx, Friedrich Nietzche y Sigmund Freud quienes desarrollan las teorías de la alienación para explicar porqué los hombres son religiosos sin tener razones científicas y filosóficas para serlo. Así, Marx encontró en la indigencia del ser humano, pobre y necesitado, la razón para buscar consuelo en un Dios que le salvara de su pobreza. Nietzche consideró a Dios como una necesidad de los débiles que no pueden afrontar la existencia por sí mismos. Freud postuló la precariedad y la angustia humana como impulsos para construir la imagen de un Dios que les consolara en sus debilidades y frustraciones.

Además, el neopositivismo lógico y la filosofía analítica le da argumentos para explicar porqué los seres humanos han creado la idea de Dios y la han incorporado en los sistemas semánticos del lenguaje. Su posición se encuentra inserta en la filosofía analítica y, desde esta perspectiva, construye y fundamenta la crítica a la religión y se convierte en uno de los paladines más significativos de los "nuevos ateísmos".

Su guía intelectual ha sido la máxima de Sócrates, debemos seguir la argumentación hasta donde quiera que nos lleve (Flew, 2013, 48), lo que le ha conducido a defender el ateísmo de manera sistemática e ininterrumpida durante más de cincuenta años tanto en los foros académicos como culturales. Posteriormente, una vez convencido de los postulados del teísmo, ha defendido la existencia de Dios hasta su muerte acaecida el año 2010.

En su perfil intelectual destaca su preocupación por definir con precisión las cuestiones y términos a tratar. Por esta razón, afirma que al desarrollar un argumento a favor de la existencia de Dios, el sujeto teísta tiene que explicar con la máxima precisión qué entiende por Dios. Su estilo académico cuida mucho los procedimientos adecuados para el desarrollo de la controversia y el debate, y concreta que la persona teísta: a) debe demostrar la existencia de Dios con una argumentación clara y consistente, b) si pretende demostrar la existencia de Dios está obligado a definir el concepto de Dios, sin proposiciones contradictorias, y c) debe proponer argumentos que demuestren la existencia de datos fundados en la experiencia humana que requieran a Dios como explicación.

Acude a su obra "Dios y la filosofía" editada en 1966, con la finalidad de examinar y reconstruir los argumentos del teísmo cristiano y proponer una demostración sistemática del ateísmo. Reflexiona sobre la coherencia, la aplicabilidad y la legitimidad del concepto de Dios y presta atención especial a las ideas de explicación, orden y finalidad. Su aportación más relevante fue concretar tres cuestiones sobre el concepto de Dios que deben ser clarificadas por 
los teístas: a) ¡cómo se puede identificar a Dios?, b) ¡cómo se pueden predicar de Dios términos positivos como no-corpóreo? y c) ¿cómo se puede explicar la inconsistencia entre atributos predicados de Dios y hechos como el sufrimiento en el mundo?

Progresivamente, su evolución crítica favoreció la confianza en el poder de la razón y le llevó a descubrir la "racionalidad divina", abriendo el camino hacia el teísmo donde juegan un papel fundamental los debates con los filósofos cristianos Thomas Bratton Warren, Alvin Plantinga, William P. Alston, George Maurones y Ralph McInerny. En su evolución hacia el teísmo es muy importante la influencia de los filósofos evangélicos Terry Miethe y Gary Habermas, que removieron sus pilares sobre la fundamentación de su posición ateísta: las tesis sobre la coherencia del concepto de Dios y la presunción del ateísmo. Por último, el debate con William Lane Craig, para quien en el origen del universo y en el complejo orden del mismo se encuentra como explicación más adecuada la afirmación de la existencia de Dios, le cuestionó profundamente y de manera decisiva.

El último debate público tuvo lugar en la Universidad de New York en 2004 con el científico israelí Gerald Schroeder y el filósofo escocés John Haldane. Flew sorprendió a los presentes al admitir desde el principio del debate el argumento de la existencia de Dios y centrar la discusión en los desarrollos de la ciencia moderna que apuntaban a la existencia de una Inteligencia Superior: Lo que creo que ha conseguido hacer el $A D N$ es mostrar, por medio de la increible complejidad de las estructuras que son necesarias para producir vida, que alguna inteligencia ha debido participar en el ensamblamiento de esos elementos extraordinariamente diversos. Lo que asombra es la enorme complejidad del número de elementos y la enorme sutileza de las formas en que cooperan. La probabilidad de que todos estos elementos hayan podido encontrarse por casualidad en el momento adecuado es simplemente minúscula. La enorme complejidad de los caminos por los que fueron conseguidos los resultados es lo que me parece producto de la inteligencia (Flew, 2013, p. 79).

Reconoce que el argumento que más le impresionó fue el de Schroeder sobre el "teorema de los monos" que permite descubrir que la vida no aparece por azar, según la analogía del grupo de monos que aporrean durante mucho tiempo los teclados de unos ordenadores para escribir un soneto de Shakespeare y donde se muestra que nunca se podrá escribir un soneto por casualidad. Si el teorema no funciona para un sólo soneto, entonces, por supuesto, es simplemente absurdo sugerir que algo mucho más difícil que escribir un soneto —la aparición de la vida - pueda haberse producido por casualidad (Flew, 2013, p. 80). 
Entiende que su camino al teísmo se ha apoyado en la visión filosófica de los clásicos que le ha hecho repensar los resultados de los descubrimientos científicos y que le han permitido construir su visión filosófica sobre las leyes de la naturaleza. Se podrá preguntar cómo yo, un filósofo, me atrevo a hablar de asuntos tratados por cientificos. La mejor respuesta a esto es otra pregunta: ise trata aqui de ciencia o de filosofía? Cuando estudiamos la interacción de dos cuerpos físicos, por ejemplo, dos partículas subatómicas estamos haciendo ciencia. Cuando preguntamos cómo es que pueden existir estas partículas o cualquier cosa fisica estamos haciendo filosofía. Cuando extraemos consecuencias filosóficas de datos científicos, estamos pensando como filósofos (Flew, 2013, p. 87).

Flew afirma la existencia de una "Mente Inteligente", pues el origen de la vida no se puede explicar desde la mera materia. Reflexiona sobre lo que significa estar vivo y cómo relacionamos esta realidad con nuestros conocimientos físico-químicos y genéticos considerados como un todo. Se acerca al Dios de Aristóteles que establece una explicación del mundo como creación de una inteligencia suprema, omnipotente y omnisciente a la que nos referimos como Dios, que lo creó para traer a la existencia y sustentar a seres racionales, y afirma la posibilidad de conocer la existencia y la naturaleza de Dios mediante el ejercicio de la razón humana.

Flew parte de los contenidos científicos, elabora evidencias desde una lectura filosófica y plantea el "argumento del diseño" en el que concreta que el diseño patente en la naturaleza postula la existencia de un Diseñador Cósmico y que ha apoyado esta prueba de la existencia de Dios en los avances de dos áreas del conocimiento que le han llevado a esta conclusión: a) el origen de las leyes de la naturaleza y las intuiciones al respecto de eminentes científicos modernos, y b) el origen de la vida y de la reproducción.

Flew entiende las leyes de la naturaleza como regularidades matemáticamente precisas, universales y conectadas unas con otras. Es lo que Einstein denominó la "razón encarnada" que le llevó a afirmar la existencia de una "fuente trascendente de la racionalidad del mundo". La relación entre las leyes de la naturaleza y la Mente de Dios es postulada también por Werner Heisenberg quien se ha visto obligado a mediar entre ciencia y religión y que nunca ha sido capaz de dudar de la realidad de aquello hacia lo que ambas regiones del pensamiento apuntan.

Flew sostiene la explicación de la aparición de la materia viva a partir de la materia inerte y concreta su visión filosófica sobre el origen de la vida: La mayor parte de tales estudios son trabajos realizados por cientificos que raramente prestan atención a la dimensión filosófica de sus descubrimientos. Los filósofos, por otra 
parte, han dicho poca cosa sobre la naturaleza y el origen de la vida. La cuestión filosófica que no ha sido resuelta por los estudios sobre el origen de la vida es la siguiente: ¿cómo puede un universo hecho de materia no pensante producir seres dotados de fines intrinsecos, capacidad de autorreplicación y una "quimica codificada? (Flew, 2013, pp. 109, 110).

Flew insiste en considerar la naturaleza de la vida desde la perspectiva filosófica, pues la materia viva posee una organización teleológica que no aparece en la materia que le precedió. Por otra parte, las teorías sobre el origen de la vida no ofrecen explicaciones adecuadas sobre la existencia de la "autorreproducción" en fases tempranas, pues no se ha podido demostrar que surgiera por medios naturales desde una base material. Asimismo, el descubrimiento de la codificación y el procesamiento de la información (código genético) esencial para todas las formas de vida, le permite afirmar que la única explicación satisfactoria del origen de esta vida orientada hacia propósitos y autorreplicante que vemos en la Tierra es una Mente infinitamente inteligente (Flew, 2013, p. 115).

Flew había desarrollado su crítica al lenguaje religioso y su defensa del ateísmo de una manera tan brillante que le convirtieron probablemente en el maestro de la crítica de la religión desde la perspectiva de la filosofía analítica, y recogía siempre en sus escritos e intervenciones dos ideas fuerza: a) la negación de que el lenguaje religioso pudiese reclamar una conexión con el mundo real; y b) la afirmación de que la idea de Dios surge del mundo de las emociones e incluye contradicciones evidentes.

Por eso, cuando este abanderado histórico del ateísmo defendió públicamente la viabilidad de la posición teísta se produjo un profundo impacto y una convulsión extraordinaria. Su confesión fue precisa y medida: Dios existe, y no lo afirma fundado en causas emocionales sino en argumentos racionales, científicos y filosóficos objetivos. Considera su creencia en Dios fundada en los argumentos del diseño natural (Dios diseñador de la racionalidad del universo) y no en fuentes reveladas o en posibles relaciones de Dios con los seres humanos. Su descubrimiento de lo divino ha operado en un nivel puramente natural, sin ninguna referencia a fenómenos sobrenaturales. Ha sido un ejercicio de lo que tradicionalmente es conocido como teología natural. No ha tenido relación con ninguna de las religiones reveladas. Tampoco pretendo tener una experiencia personal de Dios, ni ninguna otra experiencia que pueda considerarse sobrenatural o milagrosa. En resumen, mi descubrimiento de lo divino ha sido una peregrinación de la razón y no de la fe (Flew, 2013, p. 90).

El cambio de posición de Flew permitió cuestionar y superar el planteamiento neopositivista: Dios no es objeto de experiencia y no responde al prin- 
cipio de verificación. Su apertura al teísmo ha obligado posteriormente a la filosofía analítica a afrontar la significatividad de las afirmaciones sobre Dios, la coherencia de los atributos divinos y a determinar si la cuestión de Dios es básica o no.

Flew realiza la transición del ateísmo al teísmo y la concreta: Creo que el universo fue traido a la existencia por una Inteligencia Infinita. Creo que las intrincadas leyes de este universo manifiestan lo que los cientificos han llamado la Mente de Dios. Creo que la vida y la reproducción tienen su origen en una fuente divina.

¿Por qué creo ahora esto, después de haber expuesto y defendido el ateísmo durante más de medio siglo? La breve respuesta es la siguiente: tal es la imagen del mundo que, en mi opinión, ha emergido de la ciencia moderna. La ciencia atisba tres dimensiones de la naturaleza que apuntan hacia Dios. La primera es el hecho de que la naturaleza obedece a leyes. La segunda es la dimensión de la vida, la existencia de seres organizados inteligentemente y guiados por propósitos, que surgieron de la materia. La tercera es la propia existencia de la naturaleza. Pero no es sólo la ciencia la que me ha guiado. También me ha ayudado la consideración de los argumentos filosóficos clásicos (Flew, 2013, p. 87).

Esta posición es defendida por eminentes investigadores y científicos como Max Plank, Werner Heisenberg, Erwin Schrödinger, Paul Dirac, Wolfgang Pauli, Paul Davis, John Barrow, John Polkinghorne, Freeman Dyson, Francis S. Collins, Owen Gingerich y Roger Penrose, lo que le lleva a afirmar que la hipótesis que postula el diseño del universo elaborado por una Mente Superior que se identifica con Dios le parece la más adecuada y consistente.

Flew se plantea la "racionalidad antrópica de la naturaleza" y realiza una pregunta decisiva: ¿sabía el universo que nosotros veníamos? Este "principio antrópico" indica que la "racionalidad en la naturaleza" responde a un "ajuste fino" de sus propiedades y variables que hacen posible el nacimiento de la vida $\mathrm{y}$ de los seres humanos. Reconoce que esta cuestión es compleja y exige realizar matizaciones, pero si consideramos la existencia de un universo y que es "antrópico" parece lo más ajustado postular que el universo incluye un diseño que proviene de Dios. Los líderes de las ciencias de los últimos cien años, así como algunos de los científicos más influyentes de la actualidad, han construido una visión filosóficamente convincente sobre un universo racional que surgió de una Mente divina. Y ocurre que esta es la visión del mundo en la que, a dia de hoy, veo la explicación filosófica más plausible de una multitud de fenómenos perceptibles tanto por los científicos como por los legos en ciencia (Flew, 2013, p. 88). 


\section{EL RESURGIR DE DIOS EN LA FILOSOFÍA ACTUAL}

Dios desapareció de la filosofía en la segunda mitad del siglo XIX que tiene en Georg W. F. Hegel el último de los grandes filósofos que sometió a análisis la cuestión de Dios y fundamentó su filosofía en el "espíritu absoluto" que abarca el conjunto de lo real, Dios está en todo lo real. A partir de Hegel, los "maestros de la sospecha" potencian la desconfianza en la razón y en la reflexión filosófica, descalifican la religión y construyen un pensamiento filosófico que invisibiliza a Dios. Esta dinámica se establece y evoluciona hasta finales de la década de los 70' del siglo pasado.

En los inicios de la década de los 80’ del siglo XX, la reflexión sobre Dios retorna al primer plano través de Emmanuel Lèvinas, Jean Luc Marion, Michel Henry y Rèmy Brague, y de las propuestas de Jürgen Habermas, Jacques Derrida y Gianni Vattimo. Concretamente, Vattimo (2004) plantea la vuelta a Dios como una consecuencia del fin de la modernidad que se fundaba en los "mitos" de la razón y de la ciencia. Recuerda que el concepto de "secularización" nace en el seno del cristianismo, pues Jesús de Nazaret postula una separación radical entre lo secular y lo sagrado (Mateo, 22,15-21), con la finalidad de negar el poder del estado sobre la autoridad religiosa. Afirma la necesidad del "pensamiento débil" que renuncia a toda "afirmación dogmática sobre la realidad, la verdad y la razón". El cristianismo es el "elogio a la debilidad" y la revelación de Dios en Jesús no es la manifestación del "Dios metafísico todopoderoso, el ídolo de la razón, sino el Dios que se manifiesta en el amor, la tolerancia y el perdón".

En esta línea, Marion (2008) afirma que el Dios que ha muerto en la filosofía "es el Dios creado por y para nuestra razón", que "responde dócilmente a las condiciones que le impone nuestra razón, y propone pensar a Dios como "lo imposible que trasciende todas nuestras expectativas".

Para Grondin (2010), las razones que han facilitado el desarrollo del "retorno de Dios" al pensamiento y la cultura de finales del siglo XX y principios del XXI son cuatro:

a) Los acontecimientos del 11 de septiembre de 2001 y la escalada de los fundamentalismos que han llevado al reconocimiento de que Dios no ha muerto y que las religiones mantienen el poder en la vida de los seres humanos.

b) La caída del comunismo ha determinado que Karl Marx deje de ser una referencia obligada del pensamiento contemporáneo y que se haya diluido el logro del paraíso en la tierra y el fin de la trascendencia alienante. 
c) La caída del muro de Berlín en 1989 que permitió valorar más y apreciar mejor las democracias representativas que se han consolidado como modelos de sociedades justas, democráticas y perfectibles.

d) La carencia de sentido de las sociedades occidentales que aparecen como relativamente prósperas, pacíficas y que han contribuido a reducir las desigualdades sociales, pero no responden al sentido de la existencia humana. Al mismo tiempo, los estudios transculturales manifiestan que la fe en lo divino aparece como una constante de la condición humana en todas las épocas y culturas.

La investigación científica ha avanzado descubrimientos de gran envergadura sobre el cosmos, la biosfera, el cuerpo y el cerebro humano. Además, los avances tecnológicos y el desarrollo exponencial de Internet están creando la primera comunidad realmente global. Estos avances han tenido y tienen un gran impacto en la fe en Dios y en la religión. Hoy ha cambiado el contexto para pensar la fe en Dios y el papel de la religión. Los avances científicos, la tecnología, las cuestiones sociales y políticas, el pluralismo religioso y la filosofía contemporánea indican que el lenguaje sobre Dios sigue siendo relevante, pero que es necesario transformar los modos en que concebimos a Dios si el teísmo quiere ser un interlocutor válido de los hombres y mujeres de esta época (McLaren, 2007).

Las "categorías tradicionales" mediante las que se describía a Dios han perdido vigencia y fuerza explicativa. Así, la ciencia moderna desde el siglo XVI dejó de usar la categoría "substantia" porque aparecía cada vez más como incompatible con los métodos y descubrimientos de la física, la química, la biología y la neurociencia. Presentar en la actualidad una metafísica basada en el concepto aristotélico de "substantia" supone serias dificultades para encajar la fusión del espacio y el tiempo en la teoría de la relatividad, la física de partículas elementales según el modelo estándar, la teoría de la física cuántica, etc. y otros conceptos explicativos a partir de los avances de la biología evolutiva, la genética y la neurofisiología.

Las teorías sobre la "identidad personal" fundamentadas en el concepto de "substantia" han sido desacreditadas por las aportaciones de Gottfried Leibniz, Baruch Spinoza, el idealismo alemán, Sigmund Freud y el estructuralismo.

Es necesario estudiar con otras claves la relación Dios-mundo, que ha experimentado diversos avatares hasta llegar al modelo dicotómico que distingue el "orden sobrenatural" y el "orden natural" y que fue introducido de forma tardía por la teología a finales del siglo XVII, lo que ha sido una tragedia para 
la propia reflexión teológica, pues ha separado progresivamente a Dios de la creación hasta convertirlo en el Dios del deísmo. Es preciso construir nuevos modelos explicativos de la relación Dios-mundo y de los conceptos y teorías sobre la "persona", el "yo" y la "identidad personal" acordes con los descubrimientos científicos y las claves de la reflexión de la filosofía actual que articulamos en las siguientes vías:

La primera es no considerar a Dios como un dato obvio sino intentar descubrir las "insinuaciones de la trascendencia” que se encuentran en el ámbito de la realidad natural pero que apuntan más allá de esta realidad (Berger, 1975).

La segunda insiste en que la ciencia no trata de Dios como parecen suponer los "nuevos ateísmos" y los "teóricos del diseño inteligente" que se sitúan en posiciones simétricas basadas en falsos supuestos. Las ciencias físicas, químicas, y biológicas son compatibles con posiciones metafísicas como atestigua la historia de la ciencia y de la religión. La ciencia trabaja poniendo entre paréntesis las cuestiones metafísicas y considera que Dios no es accesible a los estándares científicos pues lo que es susceptible de control experimental no es Dios (Collins, 2019).

La tercera permite constatar que existen modelos teológicos sensibles a esta era científica, que conciben la relación Dios-mundo conectada de forma adecuada con las ideas de nuestra época. El mundo físico, social y psicológico, e incluso el moral, han descubierto su autonomía y en su comprensión científica prescinden de Dios. Si la religión no cambia la óptica y sigue buscando a Dios dónde y cómo ya no puede encontrarse, la respuesta será el ateísmo. La religión debe repensar la relación de Dios con un mundo autónomo en el ámbito de la ciencia y de la cultura (Clayton, 2000 y Peacocke, 2008).

La cuarta recoge las aportaciones de Torres Queiruga (2008) quien destaca que en el centro de la fe bíblica Dios crea por amor y busca nuestra realización plena, pero esta fe bíblica se ha vertido en "conceptos metafísicos" que han generado un esquema kantiano que deforma la historia de la salvación. El autor realiza una propuesta para comprender esta historia más acorde con los resultados de la investigación bíblica. A modo de síntesis, afirma que (...) la intuición central del Dios que, desde su iniciativa incondicional, crea-por-amor posibilita que el trabajo teológico lo unifique todo en la unidad viva de una "figura de la revelación" capaz de hablar a nuestro tiempo. Un Dios que se entrega sin reserva a sus creaturas que, por finitas, son inevitablemente débiles y expuestas; que trata sin descanso de mostrarse a todas sin exclusión de ningún tipo; que las apoya contra el mal, tanto en la realización individual como convocando a la fraternidad universal, justa y eficaz; que abre una esperanza que dinamiza la historia y asegura el 
sentido definitivo; que (...) solicita y promueve el consentimiento, pero con respeto exquisito a la autonomía: "estoy a la puerta y llamo" (Apocalipsis, 3,20) (Torres Queiruga, 2010, p. 607).

En esta perspectiva se integra nuestra posición personal conscientes de que lo más importante no es si nosotros preguntamos o buscamos a Dios; lo decisivo es si Dios nos pregunta y busca a nosotros. Por ello la ocupación suprema del hombre no debe ser hablar sobre Dios, sino escuchar su voz... (González de Cardedal. 2004, p. 10).

\section{CONCLUSIONES PARA LA REFLEXIÓN SOBRE DIOS}

Finalizamos el texto de este artículo con las siguientes aseveraciones:

a) Es necesario prestar atención a la consistencia racional del concepto de Dios a partir de los avances científicos de la cosmología, la biología y la antropología modernas que se puede realizar sin renunciar al imaginario de un Dios amor, articulación de misericordia y justicia que se transparenta en los millones de crucificados de todos los tiempos. La explicación creyente aparece en la actualidad como una opción sólida a partir de los descubrimientos de la ciencia contemporánea y de la reflexión filosófica sobre Dios.

b) Es posible encontrar en la ciencia respuestas sobre cómo funciona el cosmos y la vida pero, debido al instrumental que utiliza, no puede ofrecer respuestas racionalmente satisfactorias sobre el qué y el porqué de la existencia del cosmos y de la vida.

c) Existe una altísima probabilidad de que una Inteligencia infinita, originaria y creativa sea la única causa que permite explicar el ensamblaje de elementos tan diversos en la aparición del cosmos y de la vida.

d) Estamos ante un misterio que está "más allä" de la experiencia pero del que se pueden detectar "indicios" en la realidad. Dios se "transparenta" en el universo, en la vida, en la persona y en la historia y es posible articular un discurso racional para "explicar" más allá de los descubrimientos de la ciencia.

e) Los defensores del "teísmo" que sostienen la racionalidad de un Dios personal y amoroso asumen una concepción de Dios que articula bondad y poder, pues es lo suficientemente poderoso para "encarnarse" por amor y "manifestarse" en la debilidad, en la fragilidad y en la limitación. 


\section{REFERENCIAS BIBLIOGRÁFICAS}

Armstrong, K. (2009). The Case for God. New York. Knopf.

Barlow, N. (1958). The autobiography of Charles Darwin 1809-1882. The first complete version, edited by his Granddaughter Nora Barlow. London. Collins-St. James.

Berger, P. (1975). Rumor de Ángeles. Barcelona. Herder.

Clayton, Ph. (2000). The problem of God in modern thought. Michigan. Wm. B. Eerdmans Publishing Co.

Collins, F.S. (2019) ¿Cómo habla Dios? La evidencia científica de la fe. Barcelona. Editorial Ariel.

Darwin, Ch. (1977). Charles Darwin, Autobiografia, selección de Francis Darwin. Madrid. Alianza Editorial.

Dawkins, R. (1993). El gen egoista: las bases biológicas de nuestra conducta. Barcelona. Salvat Editores.

Dawkins, R. (2012). El espejismo de Dios. Madrid. SLU Espasa Libros.

Flew, A. (2013). Dios existe. Madrid. Editorial Trotta.

Ferris, T. (1988). Coming of Age in the Milky Way. New York. Morrow.

González de Cardedal, O. (2004). Dios. Salamanca. Ediciones Sígueme SAU.

Greene, B. (2012). El universo elegante: Supercuerdas, dimensiones ocultas y la búsqueda de la teoría definitiva. Barcelona. Planeta.

Grondin, J. (2010). El retorno espectacular de Dios en la filosofía. Manifestaciones y razones de un fenómeno, en Concilium. Revista Internacional de Teología, número 337, pp. 653-663,

Hawking, S. (2013). Historia del tiempo. Barcelona. Planeta.

Hawking, S. y Mlodinow, L. (2013). El Gran Diseño. Barcelona. Editorial Crítica.

Hitchens, Ch. (2008). Dios no es bueno: alegato contra la religión. Barcelona. Debate.

Jammer, M. (1999). Einstein and Religion. Princeton, New Jersey. Princeton University Press.

Marion, J.L. (2008). Au lieu de soi. L'approche de Saint Agustin. Paris. PUF.

McGrath, A.E. and McGrath, J.C. (2007). The Dawkins Delusion? Atheist Fundamentalism and the Denial of the Divine. London. SPCK.

McLaren, B. (2007). Everything Must Change. Nashville. Thomas Nelson.

Noble, D. (2008). La música de la vida: más allá del genoma humano. Madrid. Akal Tres Cantos.

Peacocke, A. (2008). Los caminos de la ciencia hacia Dios: el final de toda nuestra exploración. Santander. Sal Terrae. 
Russell, R.J., Stoeger, W.R. and Coyne, G.V. (eds.) (1990). John Paul II on Science and Religion. Reflections on the New View from Rome. Vatican City State. Vatican Observatory Publications.

Torres Queiruga, A. (2008). Repensar la revelación. La revelación divina en la realización humana. Madrid. Editorial Trotta.

Torres Queiruga, A. (2010). Ateísmo e imagen cristiana de Dios, en Concilium. Revista Internacional de Teología, número 337, pp. 595-608,

Udías, A. (1993). Conflicto y diálogo entre ciencia y religión. Santander. Sal Terrae. Vattimo, G. (2004). Creer que se cree. Barcelona. Paidós Ibérica. 


\title{
GRAN CANARIA, UNA ISLA RADIACTIVA... COMO EL RESTO DEL PLANETA
}

\author{
P. Martel, H. Alonso, M. A. Arnedo, A. Tejera y J. G. Rubiano \\ Departamento de Física e Instituto de Estudios Ambientales y \\ Recursos Naturales de la Universidad de Las Palmas de Gran Canaria
}

\section{Resumen}

Este trabajo comienza describiendo lo que se entiende por la radiactividad ambiental y su componente principal a la dosis que recibe la humanidad, la radiactividad natural. Se explican las fuentes de esta radiactividad natural para luego particularizar su estudio a Gran Canaria. El objetivo de este trabajo ha sido el de recopilar y exponer en clave divulgativa los principales resultados obtenidos por el Grupo de Investigación de Interacción Radiación Materia de la ULPGC sobre la radiactividad ambiental de Gran Canaria.

Palabras clave: Gran Canaria, Playas, Radiactividad ambiental, Radionúclidos naturales, Radón.

\begin{abstract}
In this work the environmental radioactivity concept is descrived. Also, natural radioactivity and its sources are analyses, and particularized to Gran Canaria island case. The goals of this work has been to compile and present from divulgative point of view the main results obtained by the Research Group on Radiation-Matter Interaction of the ULPGC about environmental radioactivity in Gran Canaria.
\end{abstract}

Keywords: Gran Canaria, Beaches, Environmental radioactivity, Natural radionuclides, Radon.

\section{RADIACTIVIDAD AMBIENTAL}

La radiactividad es un fenómeno que se origina en los núcleos atómicos de la materia. Es un proceso espontáneo por el cual los núcleos inestables (radionúclidos o radionucleídos) se desintegran en otros más estables, emitiendo radiación electromagnética de alta energía (fundamentalmente radiación gamma) o pequeñas partículas cargadas (electrones, positrones y partículas alfa, es decir núcleos de $\mathrm{He}-4$ ) que tienen la propiedad de ionizar la materia sobre la que inciden, pudiendo, de este modo, modificar las propiedades químicas de la 
misma. Esta emisión, llamada radiación ionizante, junto con los propios núcleos radiactivos inundan el medioambiente y a sus efectos estamos expuestos por el simple hecho de vivir en el planeta. Su origen puede ser natural o antropogénico.

Varias actividades humanas en las que se generan o usan núcleos radiactivos, o bien, se produce directamente radiación ionizante, contribuyen a la presencia de esta radiación en el medioambiente. En este caso se suele hablar de radiactividad artificial, siendo las aplicaciones médicas, utilizadas para el diagnóstico y tratamiento de enfermedades, las responsables de la mayor parte de la radiación ionizante de origen antropogénico a la que estamos expuestos. También, los diversos usos de las radiaciones ionizantes en la industria, en la agricultura, o en la investigación científica, las actividades de producción de energía eléctrica en las centrales nucleares (sobre todo los accidentes, como el de Chernobyl o el de Fukushima), las bombas explosionadas al final de la Segunda Guerra Mundial o, los ensayos con armas nucleares realizados en el pasado, son factores a tener en cuenta cuando se evalúa la radiactividad ambiental y la exposición de la humanidad a la misma.

Sin embargo, la radiactividad de origen natural es la responsable de alrededor de un $70 \%$ de la exposición de la humanidad a la radiación ionizante ambiental. En la naturaleza encontramos diversas fuentes de radiación ionizante: radiación que viene del cosmos, radiación de la corteza terrestre y radiación interna procedente de núcleos radiactivos que incorporamos a nuestro cuerpo a través del aire que respiramos o de los alimentos que comemos. La exposición a la radiación natural depende del lugar donde vivimos. Así, en los lugares de mayor altitud recibiremos más radiación cósmica que a nivel del mar, ya que la atmósfera actúa como filtro. La composición del suelo o el tipo de casa en la que habitamos también tienen influencia en el grado de exposición a la radiación natural.

\section{RADIACTIVIDAD NATURAL}

Con respecto a esta radiactividad natural, según su procedencia, distinguimos entre los radionucleídos primordiales o primigenios, presentes en la corteza terrestre desde su formación y los radionucleídos cosmogénicos, producidos por la interacción de radiación ionizante procedente del espacio (rayos cósmicos) con la atmósfera. Estos rayos cósmicos, además, constituyen una fuente directa de radiación natural que formados, principalmente por protones, partículas alfa, otros núcleos ligeros y electrones (rayos cósmicos primarios), interaccionan con los núcleos de la alta atmósfera dando lugar, por un 
lado, a nueva radiación ionizante, los rayos cósmicos secundarios, y, por el otro, a la generación de los radionúclidos cosmogénicos. Los radionúclidos cosmogénicos tienen semividas (tiempo que tarda una población de un tipo de radionúclidos en reducirse a la mitad) pequeńas comparadas con la edad de la tierra $\left(4.5 \times 10^{9}\right.$ años) aunque se están produciendo continuamente. Entre ellos, los más abundantes son los radioisótopos del berilio Be-10 y Be-7 (con semividas de $1.5 \times 10^{6}$ ańos y 53.2 días, respectivamente), el carbono 14 (C-14, con 5700 años), el sodio 22 ( $\mathrm{Na}-22$, con 2.6 años) y el tritio ( $\mathrm{H}-3$, con 12.3 años). Por último, los primordiales o primigenios suelen tener semividas del orden de la edad del planeta o incluso mayores ya que los de semividas menores se han desintegrado y actualmente no participan en la radiactividad natural. Entre estos se puede destacar el potasio 40 (K-40, con $1.3 \times 10^{9}$ ańos) que constituye el $0.0117 \%$ del potasio natural, uno de los elementos más abundantes en la corteza terrestre. Otros ejemplos de radionúclidos primordiales son el Vanadio 50 (Va-50, con $1.4 \times 10^{17}$ años), el Rubidio 87 (Rb-87, con $4.8 \times 10^{10}$ años) o el Neodimio 144 ( $\mathrm{Nd}-144$, con $2.3 \times 10^{15}$ años). Además de estos, entre los radionúclidos que forman parte de la corteza y que contribuyen a la radiactividad natural, hay que mencionar las series radiactivas del Uranio (U-238 y U-235, con $4.47 \times 10^{9}$ ańos y $7.04 \times 10^{8}$ ańos, respectivamente) y la del Torio (Th-232, con $1.41 \times 10^{10}$ años). Se trata de tres familias de radionúclidos que, a partir de los padres que identifican a cada serie y que acabamos de citar, se van desintegrado secuencialmente en otros radionúclidos hijos hasta llegar a un núcleo estable (Fig. 1). Las desintegraciones pueden ser alfa (emitiendo partículas alfa y, generalmente, radiación gamma) o beta (emitiendo electrones y también, casi siempre, radiación gamma). El Uranio natural, constituido por los radioisótopos U-238, U-235 y U-234 (con abundancias respectivas de $99.2745 \%, 0.7200 \%$ y $0.0055 \%$ ), está presente en la corteza terrestre a razón de 3 ppm (más en las rocas ácidas, como granitos, o en las volcánicas, como las riolitas, donde llega hasta $20 \mathrm{ppm}$ y menos en los basaltos o en las rocas ultra básicas con $0.1 \mathrm{ppm}$ ). Por su parte, el Torio natural (prácticamente constituido por Th-232) tiene una presencia en la corteza terrestre del orden de tres veces superior a la del Uranio. Sin embargo, todas estas cantidades son valores medios y van a variar de unos sitios a otros en función de la composición del suelo, característica, esta última, que va a ser fundamental para explicar la radiactividad natural de cada lugar del planeta. Por otro lado, cuando la única causa de producción o desaparición de los radionúclidos integrantes de una misma serie natural es la desintegración radiactiva, estos estarán en equilibrio secular, es decir, sus ritmos de desintegración (actividades) son iguales. Así que, si encon- 
tramos una violación del equilibrio secular, podríamos utilizar la tasa de defecto o exceso, de un determinado radionúclido de la serie, como trazador del proceso ambiental, diferente de la desintegración radiactiva, responsable del incumplimiento de dicho equilibrio.

Figura 1: Series radiactivas naturales existentes en la actualidad. Entre paréntesis se indica la semivida en años (a), días (d), horas (h), minutos (m) y segundos (s)

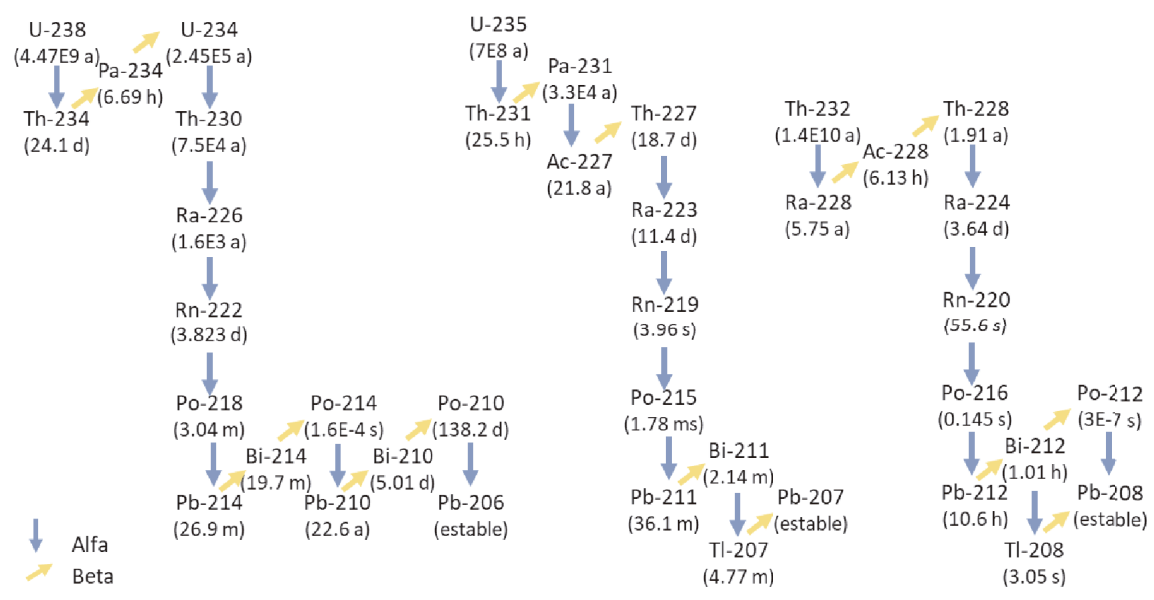

Fuente: elaboración propia.

En la Figura 2a se muestra la dosis de radiación ionizantes de origen natural que recibimos los habitantes del planeta distribuida según sea la fuente que la causa. En ella se puede ver que sólo algo más del 15\% proviene del espacio exterior (casi toda irradiación externa producida por los rayos cósmicos y sólo un $0.6 \%$ es dosis interna debida fundamentalmente a los radionúclidos generados en la atmosfera que, como el C-14, incorporamos a través de los alimentos). Como también se muestra (Fig.2a) la mayoría de la dosis de origen natural se debe a los radionúclidos primigenios, sobre todo y en este orden, a la serie de U-238, a la del Th-232 y a el K-40 (en este caso, casi el 80\% corresponde a dosis interna, fundamentalmente debida a la inhalación del gas radón, en su mayor parte a través del $\mathrm{Rn}-222$ procedente de la serie del U-238, y en menor medida del Rn-220, el torón, de la serie del Th-232). 
Figura 2: (a) Contribución de las distintas fuentes de exposición de origen natural a la dosis recibida por la población (Fuente: United Nations Scientific Committee on the Effects of Atomic Radiation, UNSCEAR). (b) Contribución de las distintas fuentes de exposición (de origen natural y antropogénica) a la dosis recibida por la población
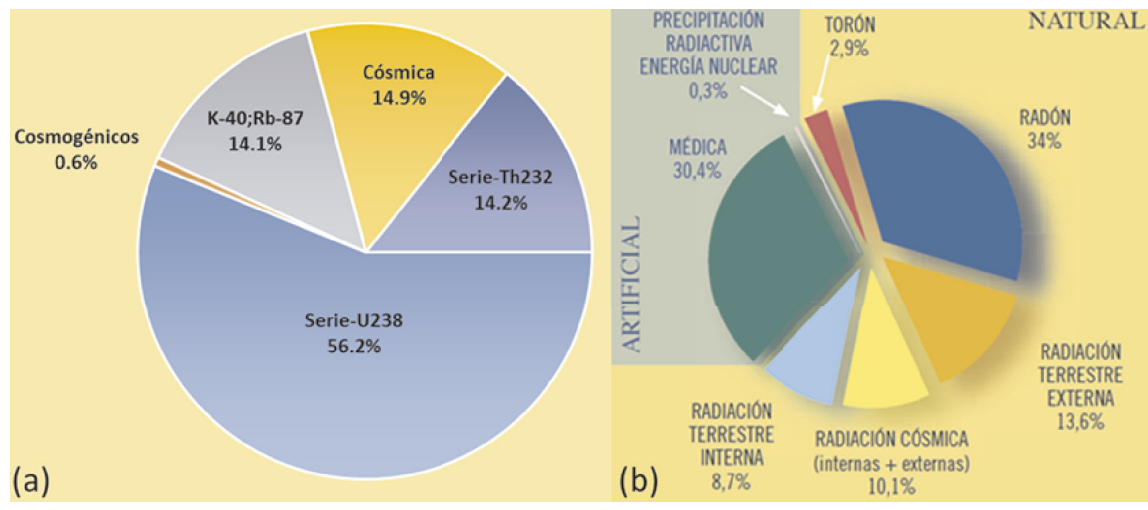

Fuente: Consejo de Seguridad Nuclear, CSN.

En la Figura 2b se comparan las dosis debidas a la exposición de la población a radiación causada por fuentes naturales con aquellas originadas por fuentes antropogénicas. La dosis de radiación media mundial debida a las fuentes naturales es $2.4 \mathrm{mSv}^{1}$ por año (UNSCEAR 2000), este valor, como ya se ha mencionado pueden variar por diversas circunstancias, dependiendo del lugar donde se vive, la composición del suelo, la estación del año, la latitud, o los alimentos consumidos. Para ilustrar esta variación de unas localizaciones a otras, en la Figura 3 mostramos la dosis anual en diferentes lugares de Europa debida a la radiación gamma a un metro de la superficie terrestre. Esta dosis está originada principalmente por el K-40 y las series del U-238 y Th-232 que estén presentes en los distintos suelos. Concentraciones relevantes de estas dos últimas series y, sobre todo de la del U-238, en los diferentes suelos del planeta, unido a otros factores como su permeabilidad, constituyen un factor importante de riesgo potencial de presencia de radón en las viviendas situadas en esos lugares.

1 El sievert (Sv) es la unidad que mide la dosis de radiación, en este caso se habla de la milésima parte de esta unidad $(\mathrm{mSv})$. 
Figura 3: Mapa Europeo de dosis anual debida a la radiación gamma terrestre

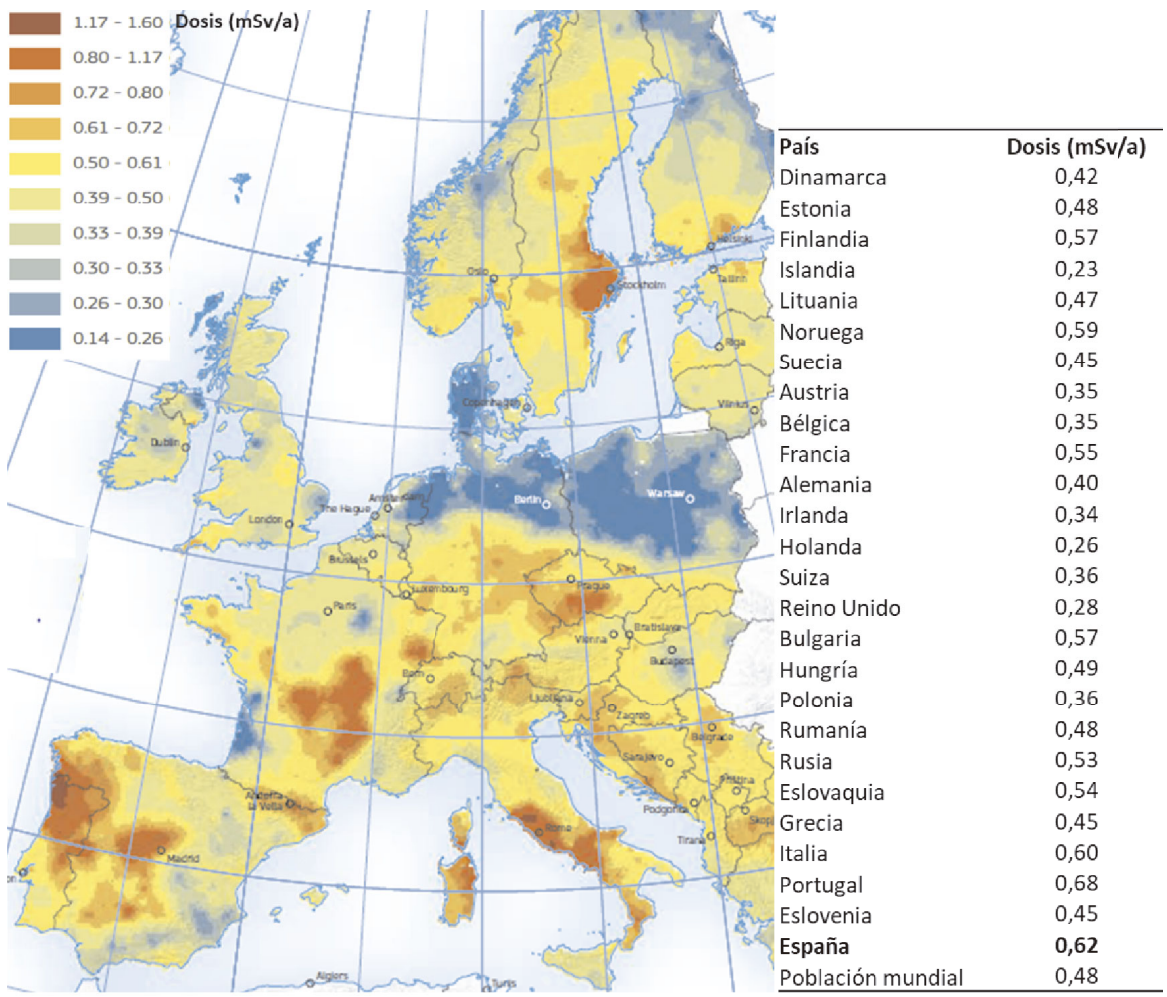

Fuente: European Atlas of Natural Radiation de la Comisión Europea). Tabla de dosis medias anuales debidas a la radiación gamma terrestre en diferentes países europeos (calculadas de UNSCEAR 2000)

\section{LA RADIACTIVIDAD EN GRAN CANARIA}

En la Universidad de Las Palmas de Gran Canaria, nuestro grupo, viene investigando en la radiactividad ambiental de canarias desde hace décadas, en este apartado destacaremos aquellos resultados más relevantes relacionados con la radiactividad ambiental en la isla de Gran Canaria.

En la Figura 4 se puede ver la dosis anual de exposición a la radiación gamma terrestre en la isla de Gran Canaria (Fig.4a) y su media por municipios (Fig.4b). La dosis anual media de Gran Canaria es de $0.72 \mathrm{mSv} / \mathrm{a}$ y varía en un rango de $0.21 \mathrm{mSv} / \mathrm{a}$ a $2.13 \mathrm{mSv} / \mathrm{a}$. Estas dosis, al contrario que las dadas en la tabla de la Figura 3 que solo son debidas a la radiación gamma terrestre, 
incluyen también la debida a la radiación gamma procedente de los rayos cósmicos que depende de la altitud y de la latitud.

Como puede verse en Figura 4b, los municipios del centro de Gran Canaria, como Tejeda o Artenara, son los que tiene una mayor tasa de dosis. También presentan dosis altas con respecto a la media de la Isla, San Bartolomé de Tirajana y Mogán, con $1.03 \mathrm{mSv} / \mathrm{a}$ y $1.18 \mathrm{mSv} / \mathrm{a}$, respectivamente. Sin embargo, en el caso de San Bartolomé, encontramos mucha variabilidad en los valores de la tasa de dosis correspondientes a la costa y al interior. Así, por ejemplo, Maspalomas presenta valores bajos $(0.46 \mathrm{mSv} / \mathrm{a})$ frente a los medidos en el interior del municipio (1.98 mSv/a en Fataga). Esta alta variación de las tasas de dosis de San Bartolomé puede apreciarse en la Figura 4a.

Figura 4: (a) Mapas de tasa de dosis equivalente media anual de Gran Canaria y (b) de sus municipios
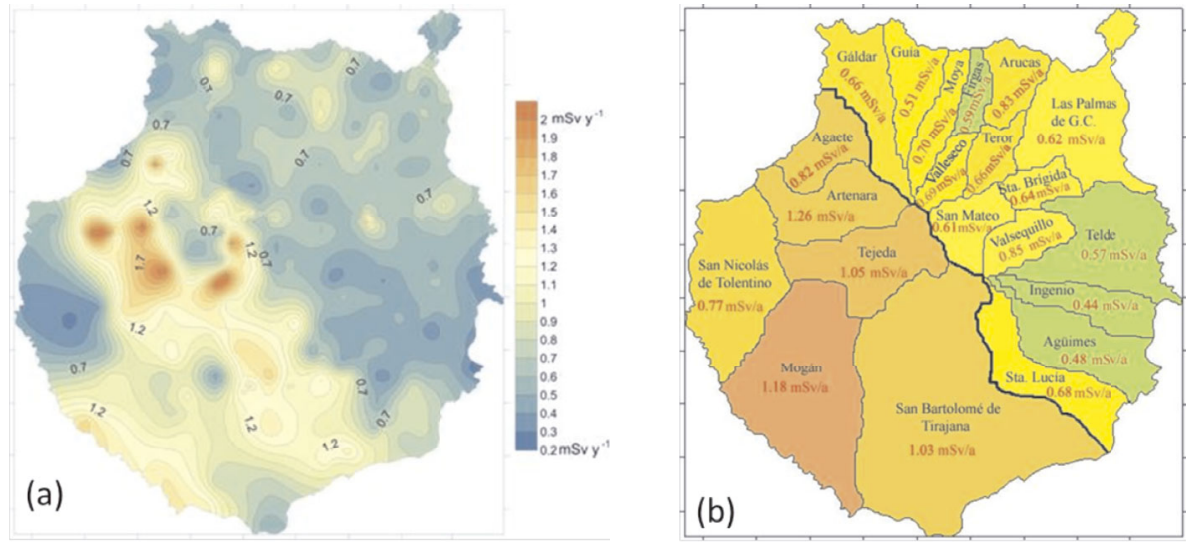

Fuente: Tesis Doctoral de M. Arnedo, 2014.

Mogán, sin embargo, presenta una distribución de dosis más uniforme (Fig.4a) con altos valores en el Barranco de la Verga y en una cantera de puzolanas con valores del orden de los $1.07 \mathrm{mSv} / \mathrm{a}$.

Se puede comprobar que, salvo en el caso de Arucas con una tasa de dosis anual claramente por encima de la media $(0.83 \mathrm{mSv} / \mathrm{a})$, los municipios que presentan dosis altas son los menos poblados y los de mayor población se corresponden con los de menos tasa de dosis. La Figura $4 \mathrm{~b}$ muestra cómo la isla, dosimétricamente hablando, se podría dividir en dos mitades respecto de un eje que une el Noroeste con el Sureste (representado por un contorno de trazo 
más grueso en la figura). Esta división, justamente, separa las zonas de vulcanismo antiguo y reciente de Gran Canaria.

Con respecto a las otras islas Gran Canaria presenta la mayor tasa de dosis con los $0.72 \mathrm{mSv} / \mathrm{a}$, seguida de Tenerife $(0.62 \mathrm{mSv} / \mathrm{a})$, de La Palma y Fuerteventura con $0.53 \mathrm{mSv} / \mathrm{a}$, de La Gomera y el Hierro con $0.49 \mathrm{mSv} / \mathrm{a}$ y 0.45 $\mathrm{mSv} / \mathrm{a}$, respectivamente y, por último, de Lanzarote que presenta la menor tasa de dosis de Canarias ( $0.39 \mathrm{mSv} / \mathrm{a})$. Al comparar la dosis media anual de Gran Canaria con las que fueron medidas para el resto de España en el marco del proyecto MARNA liderado por el Consejo de Seguridad Nuclear, se puede ver que esta es del orden de la media española $(0.73 \mathrm{mSv} / \mathrm{a})$ y que se sitúa en la zona intermedia de tasas de dosis. La zona de baja dosis anual (hasta $0.5 \mathrm{mSv} / \mathrm{a}$ ) se corresponde con las provincias mediterráneas (Murcia, Alicante, Valencia y Castellón). La zona intermedia (entre 0.5 y $0.9 \mathrm{mSv} / \mathrm{a}$ ), además de Gran Canaria y Tenerife, incluye a provincias como Barcelona y La Rioja con 0.61 mSv/a, o Álava y Guadalajara con $0.60 \mathrm{mSv} / \mathrm{a}$. La zona de alta dosis anual (más de $0.9 \mathrm{mSv} / \mathrm{a}$ ) comprende a Galicia, con las máximas dosis de España en Pontevedra, Orense y Lugo (1.49, 1.25 y $1.16 \mathrm{mSv} / \mathrm{a}$, respectivamente) o provincias como Ávila, Cáceres, Madrid y Toledo (con 1.33, 1.13, 1.11 y 1.08 mSv/a, respectivamente). A esta zona de alta dosis, pertenecerían los municipios de mayor dosis anual de Gran Canaria (Fig.4b) Artenara, Mogán, Tejeda y San Bartolomé (sobre todo su interior).

Como ya hemos comentado, la mayor parte de esta dosis se debe a las concentraciones de U-238, Th-232 y K-40 presentes en el suelo. En la Figura 5 comparamos las concentraciones medias de estos radionúclidos encontradas en Gran Canaria con las correspondientes medias española y mundial. En esta comparación se ha tomado el Ra-226 (que se puede determinar por espectrometría gamma) como representante de la serie del U-238 y las concentraciones están medidas en $\mathrm{Bq} / \mathrm{Kg}^{2}$ (concentraciones de actividad por unidad de masa).

Como era de esperar, a la vista del mapa de tasa de dosis anual (Fig.4a), en Gran Canaria, la concentración mayor de estos radionúclidos se encontró en el centro-oeste de la isla, donde se concentran materiales del primer y segundo ciclos magmáticos compuestos principalmente de rocas intermedias y ácidas

2 El Bequerelio (Bq) es la unidad de la actividad (ritmo de desintegración) en el Sistema Internacional de Unidades y mide el número de desintegraciones en un segundo, cuanta más actividad tenga un radionúclido, más bequerelios. La concentración de actividad en este caso se mide por unidad de masa de la muestra, esto es, cuántas desintegraciones por segundo de cada radionúclido se producen en un $\mathrm{Kg}$ de suelo. 
plutónicas (donde aparecen principalmente, sienitas) y volcánicas (donde aparecen fundamentalmente las traquitas, fonolitas, riolitas y traquibasaltos). Por el contrario, los valores más bajos de estas concentraciones se encuentran en la zona dominada por las rocas plutónicas y volcánicas básicas y ultrabásicas (con abundancia de basanitas y basaltos). Los suelos dominados por sedimentos y rocas sedimentarias marinas o terrestres presentaron concentraciones de actividad intermedias.

Figura 5: Comparación de las concentraciones medias de Ra-226, Th-232 y K-40 encontradas en Gran Canaria con las medias espańola y mundial

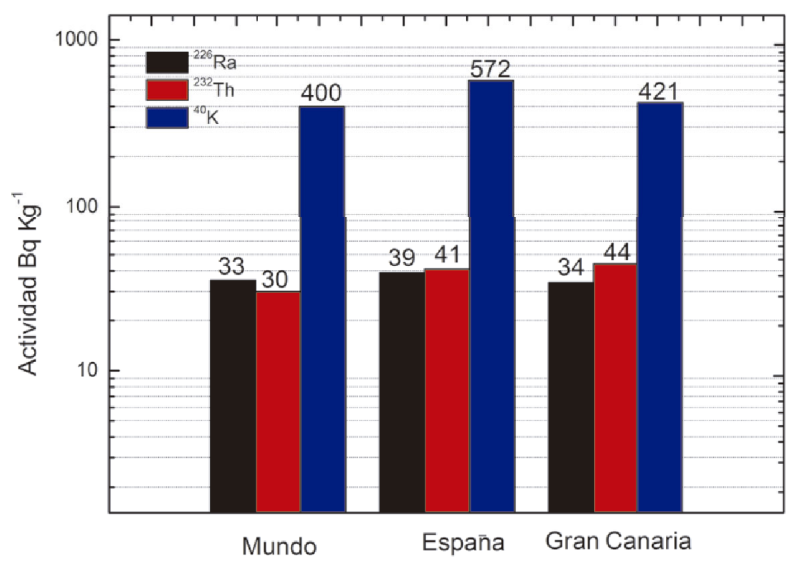

Fuente: Tesis Doctoral de M. Arnedo, 2014.

Las concentraciones de actividad de estos radionúclidos naturales que determinan la dosis, así como de los artificiales más abundantes en el medioambiente, también han sido medidas en las principales playas de Gran Canaria. Este estudio era importante a la hora de determinar un nivel base que nos permita detectar cualquier incremento en el futuro. No hay que olvidar que las playas es uno de los principales activos de nuestra economía y que Gran Canaria está situada entre dos corredores de navegación de elevado tráfico marítimo.

En la Tabla 1 se muestra los resultados obtenidos comparados con otros valores del mundo. Además, hay que destacar que en ninguna playa se detectaron radionúclidos artificiales. Las dosis de exposición a la radiación determinadas a partir de estas concentraciones de actividad en las playas de Gran Canaria son bajas, sobre todo comparadas con las de algunas playas de la India (Kerala) o de Brasil, donde las arenas contienen cantidades importantes de monacita 
que constituye una fuente de Torio. Las variaciones temporales de estas concentraciones de actividad en La Playa de la Canteras, están siendo usadas como trazadores de la dinámica sedimentaria de la playa (de los periodos de erosión y acreción). La radiactividad de esta última playa, sobre todo de sus aguas, ha sido también estudiada a través de las concentraciones de los radionúclidos naturales y artificiales presentes en las principales algas que constituyentes las arribadas que llegan a la orilla.

Tabla 1: Comparación de las concentraciones de actividad en $\mathrm{Bq} / \mathrm{Kg}$ de los principales radionúclidos naturales medidas en las playas de Las Canteras (LC),

Las Alcaravaneras (LA), La Laja (LL), San Borondón (SB), La Garita (LG), El Inglés (EI) y Maspalomas $(\mathrm{M})$ con la de otras playas del mundo

\begin{tabular}{|c|c|c|c|c|c|c|}
\hline \multirow[t]{2}{*}{ Location } & \multicolumn{2}{|c|}{${ }^{226} \mathrm{Ra}$} & \multicolumn{2}{|c|}{${ }^{40} \mathrm{~K}$} & \multicolumn{2}{|c|}{${ }^{232} \mathrm{Th}$} \\
\hline & Range & Mean & Range & Mean & Range & Mean \\
\hline LC & $7-19$ & 14 & $83-629$ & 390 & $7-25$ & 15 \\
\hline LA & $13-17$ & 15 & $393-726$ & 550 & $14-26$ & 19 \\
\hline LL & $16-23$ & 19 & $299-584$ & 439 & $19-31$ & 24 \\
\hline SB & $22-30$ & 26 & $417-640$ & 529 & $25-35$ & 30 \\
\hline LG & $23-27$ & 25 & $437-480$ & 459 & $24-29$ & 27 \\
\hline EI & $14-29$ & 23 & $206-1055$ & 726 & $12-42$ & 31 \\
\hline M & $12-19$ & 16 & $213-565$ & 398 & $11-24$ & 17 \\
\hline Gran Canaria soils & $7-88$ & 35 & $27-1758$ & 625 & $6-139$ & 48 \\
\hline Worldwide & & 32 & & 420 & & 45 \\
\hline Spain soils & $6-250$ & 32 & $25-1650$ & 470 & $2-210$ & 33 \\
\hline Kerala beaches (India) & BDL-15170 & 488 & BDL-713 & 361.8 & BDL-23030 & 2660 \\
\hline Coast of Tamil nadu (India) & BDL-30 & 8 & $213-423$ & 275 & BLD-219 & 25 \\
\hline Balochistan coast (Pakistan) & $16-29$ & 23 & $43-369$ & 238 & $7-20$ & 14 \\
\hline Rizhao beaches (China) & $8-17$ & 12 & $883-1314$ & 1079 & $8-25$ & 15 \\
\hline Adaman coast (Thailand) & $3-24$ & 12 & $11-654$ & 344 & $3-35$ & 19 \\
\hline Beaches of Aegean sea (Turkey) & $79-1885$ & 290 & $687-1421$ & 1160 & $97-4360$ & 532 \\
\hline Sediment of Cadiz Bay (Spain) & $3-41$ & 13 & $105-1342$ & 451 & $3-73$ & 19 \\
\hline Beaches of Spanish SW Coast & $4-7$ & 5 & $180-29$ & 232 & $2-6$ & 4 \\
\hline Montenegrin coast (Yugoslavia) & $2-16$ & 8 & $16-263$ & 150 & $1-12$ & 7 \\
\hline Rio de Janeiro coast (Brazil) & $5-286$ & 33 & $32-888$ & 253 & $7-963$ & 95 \\
\hline Espiritu Santo coast (Brazil) & $5-4043$ & 637 & $27-412$ & 121 & $7-5553$ & 6675 \\
\hline Bahia coast (Brazil) & $10-572$ & 184 & $25-62$ & 42 & $14-173$ & 533 \\
\hline Coasts of Kuwait & $8-72$ & 36 & $41-492$ & 227 & $2-17$ & 6 \\
\hline Red Sea (Jordan) & $9-598$ & 128 & $72-755$ & 477 & $9-16$ & 12 \\
\hline Coasts of Egypt & $25-63$ & 39 & $382-419$ & 402 & $10-34$ & 21 \\
\hline
\end{tabular}

BLD means below limit detection in this table.

Fuente: $10.1093 / \mathrm{rpd} / \mathrm{nct} 044$.

Para terminar con este recorrido por la radiactividad natural de Gran Canaria nos vamos a fijar en los estudios realizados sobre la presencia del gas radón, que como ya hemos indicado constituye la componente principal de la dosis debida a la exposición a la radiactividad natural. 
El radón medido en los suelos de Gran Canaria (a $50 \mathrm{~cm}$ de profundidad) presenta las máximas concentraciones en el centro de la isla, con $103 \mathrm{kBq} / \mathrm{m}^{3}$, en el sur $50 \mathrm{kBq} / \mathrm{m}^{3}$ y noroeste de la isla $149 \mathrm{kBq} / \mathrm{m}^{3}$, donde se encuentran las formaciones geológicas más antiguas. Dichos valores se encuentran muy por encima de la concentración media obtenida $\left(6.9 \mathrm{kBq} / \mathrm{m}^{3}\right)$. Aquí la concentración de actividad, da cuenta de esta actividad de radón por metro cúbico de aire. La Figura 6a muestra las concentraciones medidas para este gas en los suelos de Gran Canaria.

En la Figura 6b se muestras las áreas propensas a presentar radón en el interior de viviendas en ellas alojadas. Como puede verse este mapa exhibe tres niveles de predicción para el radón en viviendas (bajo, medio y alto) y constituye una herramienta útil de cara a la planificación de futuras viviendas en la isla. Este estimador del riego se determina a partir de la concentración de radón en el suelo y de su permeabilidad a dicho gas.

Por último, la concentración de radón también se ha determinados en las aguas de los pozos de Gran Canaria. Estas medidas, además de con un objetivo de protección radiológica, han sido usadas con éxito como trazador de la geología subterránea de la Isla.

Figura 6: (a) Mapa de concentración de radón en suelos de Gran Canaria y (b) de potencial de radón geogénico (de zonas propensas al radón) de Gran Canaria
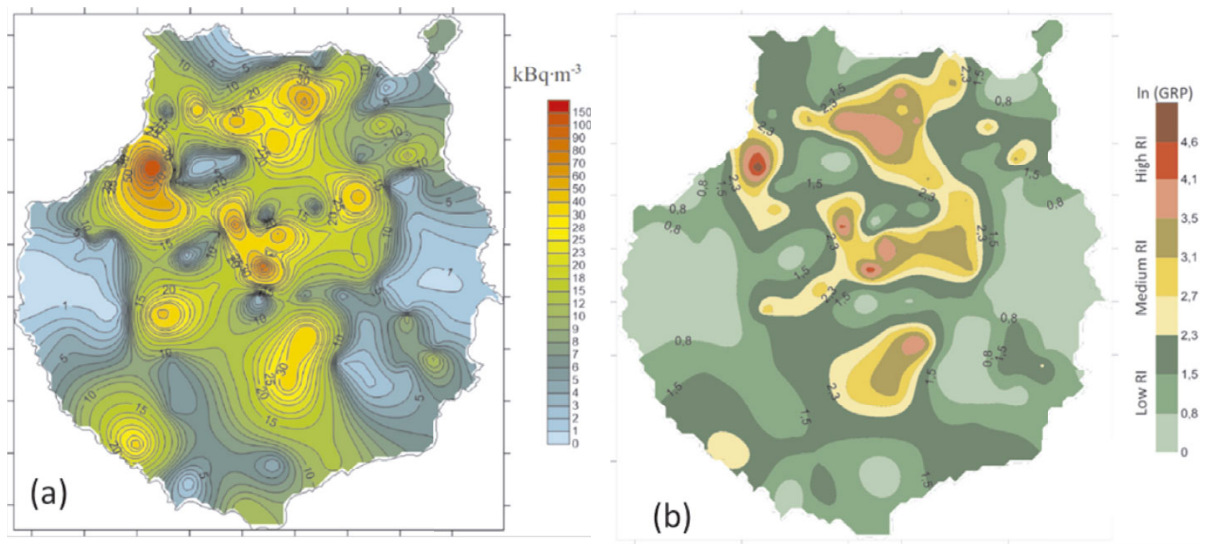

Fuente: 10.1016/j.scitotenv.2019.01.411. 


\section{REFERENCIAS BIBLIOGRÁFICAS}

Alonso Hernández, H.E. 2015. El radón en suelos, rocas, materiales de construcción y aguas subterráneas de las Islas Canarias Orientales, Tesis Doctoral. ULPGC.

Alonso, H., Cruz-Fuentes, T., Rubiano, J.G., Guerra, J.G, Cabrera, M.C., Arnedo, M.A., Tejera, A., Rodríguez-Gonzalez, A., Pérez-Torrado, F.J., Martel, P. 2015. Radon in Groundwater of the Northeastern Gran Canaria Aquifer. Water. 7(6), 2575-2590

Alonso, H., Rubiano J.G., Guerra, J.G., Arnedo, M.A., Tejera, A., Martel, P. 2019. Assessment of radon risk areas in the Eastern Canary Islands using soil radon gas concentration and gas permeability of soils. Science of the Total Environment. 664, 49-460.

Arnedo, M. A., Tejera, A.,Rubiano, J. G., Alonso, H., Gil, J. M., Rodríguez, R., Martel, P. 2013. Natural radioactivity measurements of beach sands in gran Canaria, Canary Islands (Spain). Radiation Protection Dosimetry. 156, 75-86.

Arnedo Ayensa, M. A. 2014. Evaluación del fondo radiactivo natural de las Islas Canarias Orientales, implicaciones radiológicas sobre la población. Tesis Doctoral, ULPGC.

Arnedo, M.A., Rubiano, J.G., Alonso, H., Tejera, A., González, A., González, J., Gil, J.M., Rodríguez, R., Martel, P., Bolivar, J.P., 2017. Mapping natural radioactivity of soils in the eastern Canary Islands. J. Environ. Radioact. 166 (2), 242-258.

Arriola-Velásquez, A. C., Tejera, A., Guerra, J. G., Alonso, I., Alonso, H., Arnedo, M. A., Rubiano, J. G., Martel, P. 2019. Spatio-temporal variability of natural radioactivity as tracer of beach sedimentary dynamics. Estuarine, Coastal and Shelf Science. 231, 106476.

Cinelli, G., De Cort, M. \& Tollefsen, T. (Eds.), 2019. European Atlas of Natural Radiation, Publication Office of the European Union, Luxembourg.

Tejera, A., Pérez-Sánchez, L., Guerra, G., Arriola-Velásquez, A. C., Alonso, H., Arnedo, M. A., Rubiano, G., Martel, P. 2019. Natural radioactivity in algae arrivals on the Canary coast and dosimetry assessment. Science of the Total Environment. 658, 122-131.

UNSCEAR, 2000. Source and Effects of Ionizing Radiation. United Nations Scientific Committee on the Effects of Atomic Radiation, United Nations, New York. 


\title{
REFLEXIONES SOBRE LA EVOLUCIÓN DE LA VIDA PROFESIONAL DE UN PROFESOR INVESTIGADOR DE ENSEÑANZA SECUNDARIA E IMPORTANCIA DE LAS INFLUENCIAS RECIBIDAS DE SU MAESTRA EMIGDIA REPETTO JIMÉNEZ
}

\author{
Francisco Martínez Navarro \\ IES Alonso Quesada
}

Profesor Catedrático de Física y Química de Educación Secundaria. Jubilado

Construyendo Catedrales

"Un caballero normando acertó a pasar por Chartres, cuando comenzaban las obras de la catedral. Preguntó a uno de los obreros qué era lo que estaban haciendo, "ya lo veis, estoy poniendo una piedra encima de la otra". Repitió la misma pregunta a otro peón de la cuadrilla y recibió esta respuesta, "estoy levantando una pared". Un tercero contestó, "estoy construyendo una catedral". Los tres estaban haciendo lo mismo y las tres respuestas, aunque diferentes, eran correctas. El profesor que repite solamente una lección tras otra, ofrece una explicación diferente que la de aquel que sabe que está construyendo el conocimiento y distinta, a su vez, de aquel que sabe que está formando ciudadanos para un mundo más habitable, más humano, más justo y más hermoso".

Miguel Ángel Santos Guerra

A mi maestra Emigdia Repetto Jiménez y a mi maestro Daniel Gil Pérez, que tanto han influido en mi vida profesional y que me ayudaron a vivir la enseñanza y el aprendizaje como una apasionante investigación.

Gracias por ayudarme a construir catedrales de conocimientos y valores.

A mis alumnos y alumnas que me mostraron que educar es mucho más que enseñar Física y Química.

\section{Resumen}

En este pequeña aportación se recogen algunas de las reflexiones de mi vida profesional, como profesor investigador de enseñanza secundaria, desde mis inicios en la docencia hasta mi jubilación, así como la importancia de la gran influencia recibida de mi maestra, directora de tesis Doctoral y amiga Doña Emigdia Repetto Jiménez a la que le dedico este trabajo. 
Palabras clave: Vida profesional, profesor investigador, maestra, amiga.

\begin{abstract}
This small contribution includes some of the reflections of my professional life, as a secondary school research professor, from my beginnings in teaching until my retirement, as well as the importance of the great influence received from my teacher, PhD thesis director and friend Doña Emigdia Repetto Jiménez to whom I dedicate this work.
\end{abstract}

Keywords: Professional life, research professor, teacher, friend.

\title{
1. INTRODUCCIÓN
}

La evolución de la vida profesional de un profesor de Educación Secundaria es algo complejo, que depende de muchos factores.

La tarea que se espera de un profesor es mucho más amplia que transmitir conocimientos ya elaborados a sus alumnos, lo que hasta hace muy poco tiempo era su actividad principal y para lo que inicialmente se preparaba.

Ahora hacen falta muchos otras habilidades, sin las cuales es difícil conseguir que los alumnos progresen en la adquisición del saber: el diálogo con los alumnos, la capacidad de estimular el interés por aprender, la incorporación de las tecnologías de la información, la orientación personal, el ayudarlos a aprender a aprender y a que adquieran las competencias clave, el cuidado del desarrollo afectivo y moral, la atención a la diversidad del alumnado, la gestión del aula y el trabajo en equipo, se han convertido en tareas fundamentales para el profesorado del Siglo XXI.

La vida profesional del docente es larga. Suele comenzar en la década de sus veinte a treinta ańos y terminar de treinta y cinco a cuarenta años después.

Según Álvaro Marchesi (2007) la historia del profesorado suele pasar por un conjunto de estadios semejantes a lo largo de su vida profesional, aunque con opciones alternativas diferenciadas. La primera etapa profesional de los docentes transcurre durante los dos o tres primeros ańos y está marcada por el descubrimiento y la supervivencia hasta el final, caracterizado por la serenidad o la amargura. Existen en este proceso dos bifurcaciones. La primera conduce al activismo, a la búsqueda de la innovación o a la duda, a indagar o investigar; la segunda, al distanciamiento tranquilo o al conservadurismo, al conformismo. Pero cuáles son los factores que conducen, en estas encrucijadas, a que unos profesores avancen por el camino de la iniciativa, la innovación y la investigación educativa y otros por el del conservadurismo y la decepción. Es cierto que 
no hay sólo dos caminos, sino una pluralidad de opciones y que se producen innumerables progresos y retrocesos en los diferentes itinerarios vitales. Pero lo que se comprueba en la práctica es que unos profesores mantienen una actitud de búsqueda, de innovación, de colaboración y de cambio, a la que está asociada un cierto grado de satisfacción personal y profesional, que disfrutan de su trabajo y otros, por el contrario, quedan estancados, añorantes e insatisfechos, se aburren y lo que es peor lo transmiten a su alumnado.

Yo nunca me aburrí, siempre estuve muy entretenido, con mucha curiosidad, buscando diferentes opciones que mejoraran mi trabajo. Empecé siendo profesor de Ciencias Naturales de EGB, luego de Física y Química de $2^{\circ}, 3^{\circ}$ de BUP y de COU en Institutos de Enseñanza Media. Saqué oposiciones y me hice funcionario de carrera, primero profesor agregado, luego catedrático. Me hice miembro activo de la Asociación Canaria para la Enseñanza de las Ciencias Viera y Clavijo. Llegó la Reforma y me impliqué con la LOGSE y la LOE y en numerosos proyectos de Innovación e Investigación Educativa. Conocí a mi maestra Emy Repetto y a mi maestro Daniel Gil, que me dieron sus muchos conocimientos y su afecto. En definitiva, más de treinta y cinco años enseñando y aprendiendo.

Lamentable y felizmente he llegado a la jubilación. Lamentablemente, porque me gustaba hacer lo que hacía. Felizmente, porque he podido hacer durante mucho tiempo aquello que me gustaba. Es una fortuna sin límites poderse dedicar a aquello que a uno le gusta. Sé que he sido afortunado. Pero, poco antes de poderme jubilar nació mi primer nieto y quise ejercer de abuelo a tiempo completo. Me tocaba disfrutar de otros placeres. Quería seguir educando como jubilado en activo desde otras trincheras.

He tenido la suerte de tener muchos proyectos por acabar y otros muchos por empezar, que no podría realizar en varias vidas y quería dedicarme un poco más a una familia a la que necesito como nada en el mundo.

He seguido trabajando en tareas de formación del profesorado, haciendo divulgación científica en algunas emisoras de radio digitales, y la Consejería de Educación ha seguido contando conmigo en la Coordinación y elaboración de los nuevos currículos LOMCE de Física y Química de Canarias e impartiendo algunos cursos, el último en enero de 2021 a profesores de matemáticas, en la casa de las matemáticas de La Sociedad de profesores Isaac Newton. Sigo muy entretenido.

Mi experiencia ha sido muy enriquecedora para mí y para muchos profesores y amigos con los que he formado grupos de trabajo. Terminé mi trayectoria profesional con la firme convicción de que esta es una tarea que merece 
la pena. Me gustaría que las personas que empiezan lo hagan con la misma ilusión con la que yo terminé. Porque esta es una profesión que solo se puede vivir bien con pasión.

En nuestra profesión de enseñar, no podemos limitarnos a transmitir conocimientos. Debemos también procurar enseñar valores. Porque no hay conocimiento útil si no nos hace mejores personas. Como dice Miguel Ángel Santos "Fueron médicos bien preparados, ingenieros muy bien formados y enfermeras muy capacitadas en su oficio, los profesionales que diseñaron las cámaras de gas en la Segunda Guerra Mundial'.

Tenemos que trabajar en equipo. En nuestros centros tenemos que formar grupos de trabajo, con quieres se esfuerzan y quieren mejorar, con los innovadores, que no temen cambiar lo que no funciona. Además, es más divertido tener ilusiones y aprender cosas nuevas. Tenemos que pasarlo bien. No podemos agruparnos con quienes solo critican, con quienes siempre están descontentos y no hacen nada por mejorar las cosas.

No debemos tener miedo a cometer errores, a equivocarnos. El análisis de nuestros propios errores es una gran fuente de aprendizaje.

Tenemos que ser críticos con nuestro trabajo, intentar mejorar y dar lo mejor de nosotros mismos. De lo contrario, podemos quedar condenados a mantener nuestras rutinas, a repetir nuestros fallos sin analizarlos e intentarlos superar. Hay que saber pedir ayuda cuando la necesitamos y estar abiertos a la crítica constructiva, humildemente y saber aceptarla. Hay que ser positivos. La tarea de enseñar es intrínsecamente optimista. Sin optimismo podéis ser buenos domadores, pero no buenos educadores.

\section{REFLEXIONES SOBRE LA EVOLUCIÓN DE LA VIDA PROVISIONAL DE UN PROFESOR INVESTIGADOR DE SECUNDARIA JUBILADO EN ACTIVO}

Empecé a trabajar como profesor de Educación Secundaria en 1976, recién acabada mi Licenciatura en Ciencias Químicas por la Universidad de La Laguna.

Estuve un ańo haciendo sustituciones y dos de profesor interino. Por la tarde, a la salida del Instituto, realizaba un trabajo de investigación experimental, una Reválida de Licenciatura, en la modalidad de TESINA, en la Escuela de Ingeniería, bajo el titulo "Componentes Químicos del Bupleurum Salicifolium, Umbelifera endémica de Las Islas Canarias”, recolectada en el Barranco de Guayadeque (Gran Canaria), cuyos resultados, presenté en Tenerife en el Instituto de Productos Naturales, en presencia de Don Antonio González y otros doctores en 1978, obteniendo la calificación de Sobresaliente. 
Durante un tiempo intenté seguir y simultanear la recién empezada tesis doctoral con el trabajo de profesor Agregado de Secundaria. Saqué las oposiciones en 1980, pero me había casado, nació mi primer hijo y se hacía difícil conciliar el trabajo en el Instituto con la realización de la tesis doctoral.

Desde muy joven me gustaba la química y tenía claro mi vocación. Ya con 14 años, mis amigos me llamaban Paco el químico, tenía un laboratorio en casa y hacia experimentos en la calle y en la plazoleta del barrio. Esas habilidades adquiridas para hacer experimentos caseros y jugar con la ciencia recreativa, me han servido como docente de secundaria y como formador de profesores de Ciencias.

Después de un año de profesor en prácticas y otro en expectativa de destino en el IES Pérez Galdós, donde fui Subdirector de una Candidatura Progresista, me enamoré de la enseñanza y empecé a sentir que a través de la educación de mis alumnos y alumnas se podía contribuir a cambiar el mundo. Eso fue de 1981 a 1983.

Estaba intentando sobrevivir. Empecé como un profesor tradicional, enseñanza directa por transmisión verbal de conocimientos ya elaborados, preparaba bien mis clases y me dedicaba a explicar y explicar.

Tenía la falsa ilusión, la creencia de que enseñar era lo mismo que aprender y que si se enseña bien se tiene que aprender bien. Si unos pocos aprenden y la mayoría no, es porque la mayoría del alumnado no se esfuerza lo suficiente, porque la Física y Química es muy difícil o que la mayoría no tienen capacidad suficiente. No era mi problema.

Yo no estaba satisfecho de los resultados que obtenía e intentaba mejorar mi forma de enseñar. Estaba ya madurando, cuestionando la enseńanza tradicional, en la que me encontraba seguro. Estaba interesado en cambiar, pero para ello no basta con querer, hay también que poder y saber. Necesitaba un empujón y vinieron en mi ayuda mis futuros maestros.

En 1982 compré y leí un libro que cambió mi vida profesional: "La investigación en el aula de Física y Química” de Daniel Gil Pérez. Yo pensaba que se trataría de un libro de trabajos prácticos de laboratorio. Pero empecé a entender lo que proponía. "Solo se aprende lo que se hace". "Enseñar y aprender investigando". Nuestras propuestas didácticas: "Los programas guía de actividades" eran hipótesis de trabajo a investigar y explicaba y compartía experiencias de cómo introducir los trabajos prácticos como pequeñas investigaciones y hasta nos proponía utilizar la resolución de problemas abiertos como una investigación. 
En 1984 conozco a su autor Daniel Gil, Catedrático de Didáctica de las Ciencias de la Universidad de Valencia, que es ponente en un curso en el "III Congreso de la Asociación Canaria para la enseñanza de las Ciencias", de la que soy socio fundador y vocal de su Junta Directiva desde 1984. Asisto a su curso y compruebo su grandeza, su generosidad y su humildad, quedo enganchado a sus enseñanzas, y a su propuesta, a la Didáctica de las Ciencias y a su amistad hasta hoy.

Daniel, ya jubilado, sigue trabajando actualmente con Educadores para la Sostenibilidad, por los Objetivos de Desarrollo Sostenible, en varios proyectos donde sigue colaborando para dejarnos un mundo mejor. Daniel Gil es un claro ejemplo de que los más grandes como él, los imprescindibles, los más sabios, son las personas más sencillas y humildes.

Poco antes conocí en una Escuela de Verano del Colectivo Tamonante a tres profesoras de la Escuela de Magisterio que daban clase e investigaban en Didáctica de las Ciencias. Estas tres grandes profesoras eran Emigdia Repetto, Mari Carmen Mato y Ángeles Mestres. Las tres han compartido conmigo generosamente sus conocimientos y su amistad. Me han inspirado en mi vida profesional.

Con ellas compartí, años después, numerosas comunicaciones a congresos, artículos en revistas y autoría de libros y algunos cursos impartidos conjuntamente.

He impartido docencia en Institutos de Bachillerato de Las Palmas durante 36 años, desde 1976 hasta 2012. Durante 30 años con destino en el IES Alonso Quesada, mi primer destino definitivo y el último, del que fui Director durante cuatro cursos de 1986 a 1990, y miembro del Equipo Directivo del Colegio Provincial de Doctores y Licenciados de Las Palmas, como vocal de Ciencias desde 1990 y Vicedecano desde marzo de 1994.

Fui Director del Proyecto de investigación e innovación educativa "La Física y Química de $2^{\circ}$ y $3^{\circ}$ de B.U.P. un enfoque histórico, conceptual y experimental" (Proyecto HISCOEX), aprobado por la Consejería de Educación e impartido durante los cursos 1987-88 y 1988-89, y también del Proyecto de investigación e innovación educativa "La Construcción de la Química-Física del medio Ambiente. Módulos de Enseñanza Aprendizaje medio Ambiental”, aprobado por la Consejería de Educación e impartidos durante el curso 1991-92.

Obtuve la plaza de Catedrático de Física y Química de Enseñanza Secundaria, por concurso oposición en 1993.

Estuve de comisión de Servicio en la Consejería de Educación durante 6 años, de 1991 a 1997. El primer año como asesor de Ciencias de Educación 
Secundaria, en el Equipo de Apoyo a la Reforma Educativa, a los Centros de Secundaria que anticiparon LOGSE. El segundo año acepté el nombramiento de Jefe de Servicio de Innovación Educativa de la Consejería de Educación, con el objetivo de transformar los Centros del Profesorado de Canarias de Centros de Recursos a Centros de Formación, con Equipos de Asesores de todas las materias, que sirvan de apoyo a la implantación de la Reforma Educativa, emanada de la LOGSE. El tercer año acepté el nombramiento de Director del Centro del Profesorado de Las Palmas y los siguientes tres años estuve en el mismo, como Asesor de Física y Química de Educación Secundaria.

Nunca estuve más dentro del Aula que los 6 años que estuve fuera, apoyando la Reforma Educativa LOGSE y visitando más de cien centros, apoyando a equipos de profesores, viviendo con ellos sus dificultades e intentando ayudar a superarlas.

Regresé al aula, a mi destino definitivo, el IES Alonso Quesada en 1998, hasta mi jubilación en el año 2012.

Impartí también clases en la Universidad de Las Palmas, en el Curso de Cualificación Pedagógica, durante los cursos 1996-97, 1997-98 y 98-99 de la materia optativa: "Medio ambiente en Canarias", con una "carga docente" de tres créditos (30 horas) en cada uno de los cursos.

Me he sentido querido, respetado, reconocido en mi profesión, dentro y fuera del aula.

Me han ofrecido siempre coordinar y realizar proyectos, escribir los libros que deseaba y que ni en mis mejores sueños pensé que podría realizar.

Soy un profesor investigador, que ha disfrutado con su trabajo. Solo he sido una persona curiosa, especialista en aprender y en enseñar.

Me apasiona la educación como ciencia y arte, en especial la Educación Ambiental, la didáctica de las ciencias, la investigación educativa, las tecnologías de la información y la comunicación, la formación del profesorado y la dinamización de grupos de trabajo. Todo esto lo he aprendido con mis maestros y reflexionado sobre la práctica profesional, en muchos equipos de trabajo.

He intentado siempre mejorar, formarme permanentemente y he intentado siempre dar lo mejor de mí mismo, dar a mis alumnos y alumnas, el mejor profesor que llevo dentro.

He preparado siempre mis clases, leído muchos libros, revistas educativas y he tenido muchos maestros que han compartido conmigo generosamente sus conocimientos y de los que he aprendido lo poco que sé. He disfrutado con miles de horas en cursos de formación, jornadas de trabajo y congresos. Me he especializado en aprender y en enseñar y he investigado, sigo investigando, en 
Ciencias de la Educación. He intentado siempre hacer lo mejor que sé mi trabajo, con ganas, con pasión... haciendo lo que creo y creyendo en lo que hago.

Siempre he intentado ayudar a quien me lo ha pedido. He contribuido a la formación de cientos de profesores y profesoras, opositores de Educación Secundaria, de más de 20 promociones, orientándolos en sus programaciones didácticas y he impartido cursos de formación del profesorado en todos los Centros del Profesorado de las 7 Islas Canarias, pero quien más satisfacciones me ha dado son mis miles de alumnos y alumnas, de los que he aprendido mucho..., sobre todo que educar es mucho más que enseñar física y química.

En mi querido Alonso Quesada he sido de casi todo y he estado en casi todo. Fue mi primer destino definitivo como funcionario de carrera, y el último.

He trabajado en el viejo edificio y en el actual, en horario de tarde, cuando teníamos turno partido, en el nocturno y en la mañana... He sido profesor tutor, jefe de estudios, vicedirector, director, jefe de departamento de orientación y de física y química, profesor de diversificación curricular, de informática, de Ciencias de la Naturaleza, de Matemáticas, de Electricidad, de Ciencias para el Mundo Contemporáneo, de Trabajos de Laboratorio y de Física y Química. He sido coordinador de ámbito, miembro del consejo escolar, de la comisión económica, de la CCP, etc.

He coordinado y participado en el centro en numerosos proyectos de innovación e investigación educativa con muchos de sus profesores y he estado de forma activa coordinando de la I a las XI Jornadas de reflexión y debate del Alonso, de las que soy socio fundador, puesto que El Alonso siempre ha sido un centro innovador.

He sido miembro del Grupo Lentiscal de Didáctica de la Física y Química, con los que he compartido muchas horas de trabajo y mis mejores sueños y colaborador del Instituto Nacional de Calidad y Evaluación (INCE), formando parte de la comisión de expertos en Educación Secundaria, participando en la Evaluación de la Educación Secundaria Obligatoria durante el curso 1999 $-2000$.

He sido miembro coordinador de la "Comisión Canaria de Educadores de la Década de la Educación para el Desarrollo Sostenible (DEDS) (2005-20014)”, patrocinada por la UNESCO y coordinada por mi maestro Daniel Gil.

Invitado por la Consejería de Educación como conferenciante al encuentro educativo "Cambio climático. La escuela un compromiso de futuro", con la conferencia: "Cambio climático y educación. Medidas de mitigación y adaptación desde la escuela", celebrado en La Palma en abril de 2008 y ponente en las Jornadas de Ciencias para el mundo contemporáneo celebradas en Madrid 
del 20 al 22 de junio del 2008, convocadas por la Fundación española para la Ciencia y la Tecnología (FECYT) y el Instituto Superior de Formación del Profesorado del Ministerio de Educación.

Como ponente he participado en el V Seminario Ibérico de Ciencia, Tecnología, Sociedad en la Enseñanza de las Ciencias, en la mesa de debate: "Educación científica y desarrollo Sostenible", del 3 al 5 de julio de 2008 en Aveiro, Portugal y también en la Universidad de Verano de la Gomera 2008, celebrada del 21 al 25 de julio, bajo el lema: Biodiversidad, conciencia y medioambiente, a impartir una conferencia titulada: "Sostenibilidad y educación: De la emergencia planetaria a la construcción de un futuro sostenible".

Además, coordiné el curso y presenté una ponencia titulada "Educación para el desarrollo Sostenible", en la Universidad de Verano de Maspalomas en julio 2009.

En la Universidad de Las Palmas de Gran Canaria coordiné el Máster Universitario de Formación del Profesorado de Educación Secundaria Obligatoria y Bachillerato de 2009 a 2012, y fui profesor colaborador del Máster Universitario de Formación del Profesorado de Educación Secundaria Obligatoria y Bachillerato en el curso 2009-2010, de la facultad de Educación de la Universidad Nacional de Educación a Distancia (UNED).

En el auditorio Alfredo Kraus de Las Palmas de Gran Canaria impartí una conferencia, invitado por la Consejería de Educación, en el Congreso Educativo sobre cambio climático, en mayo de 2010.

En las Jornadas de la Sociedad de Profesores de Matemáticas Isaac Newton, celebradas en La Palma, en diciembre de 2020, intervine con una ponencia en el Seminario de trabajo: "Diseńo, resolución y evaluación de situaciones problemáticas de aprendizaje”.

\section{RESUMIENDO, SIN DETALLAR}

He sido Autor o coautor de 16 libros publicados con ISBN y de más de 90 artículos publicados en actas, congresos, jornadas, revistas de Educación con ISSN, relacionados con la didáctica de las ciencias y la divulgación científica.

Asimismo, he impartido más de 100 cursos y ponencias relacionados con la enseñanza y aprendizaje de las ciencias y la formación del profesorado (más de 1200 horas en total), en todos los Centros del Profesorado de las Islas Canarias.

Además, he presentado como autor o coautor unas 70 comunicaciones en jornadas o congresos, coordinado o dirigido unas 18 actividades con más de 550 horas, asistido a 28 jornadas o congresos de Educación y a unos 54 cursos, seminarios o encuentros con un total de 1900 horas. 
He obtenido con estudiantes de $4^{\circ}$ de la ESO del IES Alonso Quesada tres "Premios de investigación escolar Blas Cabrera", otorgados por el Museo Elder de Ciencia y Tecnología, conmemorando el día de Canarias en los años 2005, 2006 y 2008.

Por otra parte, he colaborado con la emisora digital Radio Cacharrito en las clases confinadas, participando en el aula de Física y Química e impartido 18 clases sobre los Objetivos de desarrollo Sostenible, de marzo a junio de 2020.

(http://radiocacharrito.com/).

Colaboro en QPH-Radio en varias secciones de la gaveta de la ciencia: La ciencia en Canarias a través de sus científicos y de sus centros de investigación, desde junio de 2020 hasta la actualidad. (http://www.qphradio.org/).

Ha sido un lujo y un verdadero placer estar gran parte de mi vida profesional colaborando con muchos compañeros y amigos con los que he compartido mis ilusiones.

Libro: "La encerrona”. Programaciones didácticas para el aula

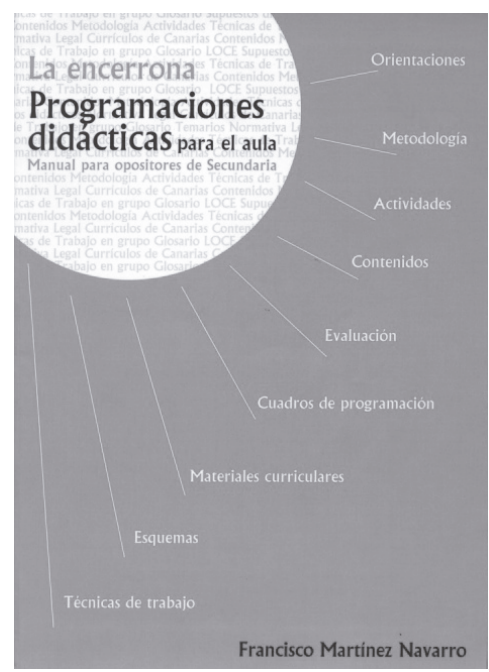


Reflexiones sobre la evolución de la vida profesional de un profesor investigador de enseñanza ...

Presentación del libro: "Ciencias para el mundo contemporáneo" de Martínez y Turégano

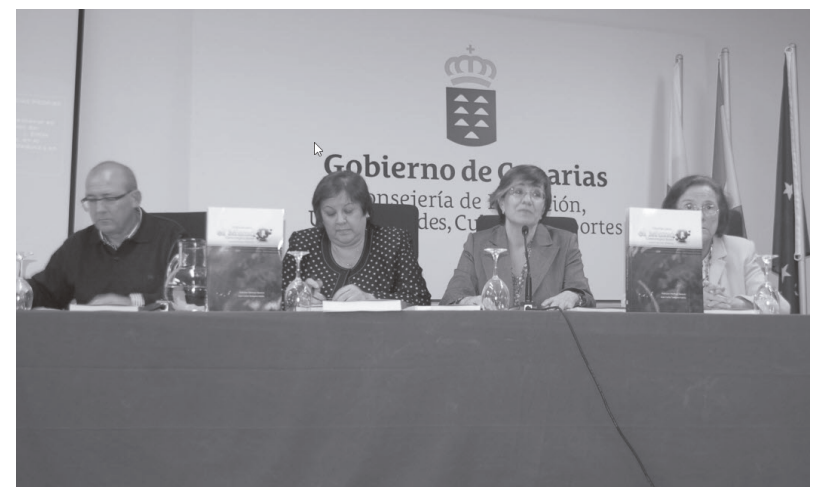

Fuente: colección particular.

Presentación del Proyecto: "Biografías de científicos canarios” Museo Canario

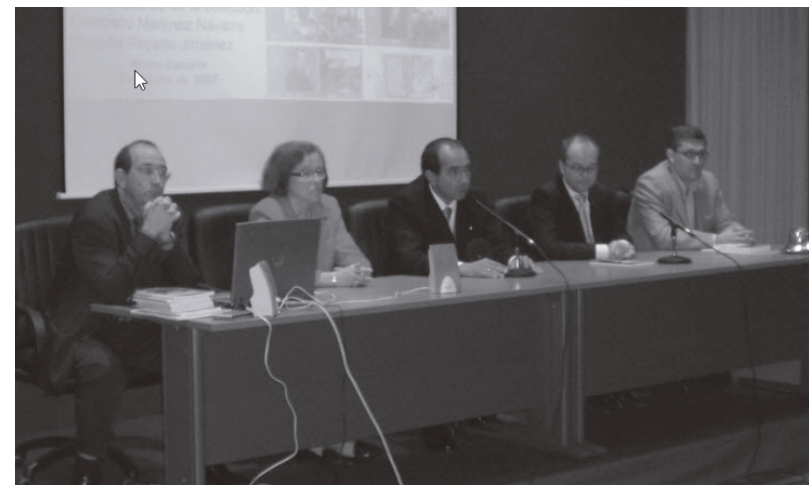

Fuente: colección particular.

\section{IMPORTANCIA DE LA INFLUENCIA DE MI MAESTRA EMIGDIA REPETTO}

Conocí a Emigdia Repetto en el año 1984, después de leer un artículo suyo en la Revista Guiniguada de la Universidad de Las Palmas de Gran Canaria, titulado: "Una experiencia de la Física: estudio del tiempo meteorológico". Volví a hablar con ella en 1986 en el II Congreso de la ACEC Viera y Clavijo, en Tenerife, durante el cual nos comprometimos a organizar el III congreso de 
la Asociación en Las Palmas. A partir de ese momento, empezamos a conocernos mejor y a compartir nuestra común pasión por la enseńanza de las Ciencias. Desde el año 1987 a 1997 fuimos miembros de la Junta Directiva de la Asociación Canaria para la enseñanza de las Ciencias Viera y Clavijo.

Gran parte de mi vida profesional y de mis proyectos de trabajo hasta mi jubilación, en el año 2012, han estado relacionados con ella. Siempre tuve su consejo, sus palabras de aliento y apoyo en todos los proyectos que le propuse.

Doña Emy dirigió mi tesis doctoral sobre la Didáctica de la Física y Química en Educación Secundaria "Análisis, desarrollo y evaluación del currículo de física y química de primero de bachillerato. Implicaciones para la formación del profesorado".

Fue la primera Tesis dirigida por Dońa Emy, en el curso 2003-2004 y la única relacionada con la Didáctica de las Ciencias, de las ocho tesis que dirigió. También, fue la primera tesis presentada en la ULPGC sobre la Didáctica de las Ciencias (Física y Química).

Muchas tardes, durante años, nos veíamos en su casa, donde en esa época me hacía sugerencias para mejorar la parte de la tesis realizada y preparábamos juntos alguno de nuestros proyectos y tomábamos café, mientras corregíamos nuestro trabajo y hablábamos de nuestras familias y de temas personales. Otras veces nos veíamos en su despacho de la Escuela de Magisterio, hoy Facultad de Ciencias de la Educación.

Doña Emy, al profesor José Ramón Calvo y a mí, nos llamaba sus hijos “adoptivos", los que la conocen deben saber el por qué de las comillas. José Ramón y yo, nunca nos tuvimos celos, porque Emy tenía cariño a raudales para todos sus amigos.

Dońa Emy era especialista en muchas cosas que compartíamos, pero especialmente en la utilización de materiales y recursos didácticos para la enseñanza y aprendizaje de las ciencias, donde era una gran maestra. También, teníamos predilección por la historia de la ciencia y las biografías de los científicos, sobre este tema impartimos, junto con $\mathrm{M}^{\mathrm{a}}$ Carmen Mato, un bonito curso de invierno en la Universidad de Las Palmas de Gran Canaria: "Aplicaciones didácticas de la historia de las ciencias", en mayo de 1997 y presentamos muchas comunicaciones a jornadas y congresos de didáctica de las ciencias y escribimos más tarde varios libros juntos sobre esta temática. Martínez y Repetto (1997, 2005, 2006, 2007).

Además nos gustaba trabajar la discriminación de la que habían sido objeto las mujeres científicas, poniendo de manifiesto su ocultamiento a lo largo de la historia y elaboramos materiales didácticos para sacarlas de la sombra. 
Asimismo, nos especializamos en Educación Ambiental, lo que dio lugar a nuestro primer libro publicado juntos (Martínez, Mato y Repetto, 1995) y algunas comunicaciones a congresos. También, trabajamos juntos los mapas conceptuales de Novak, La UVE del conocimiento de Gowin, la psicología del aprendizaje de Ausubel, la epistemología genética de Piaget y sus estadios de desarrollo evolutivo, o el socio constructivismo de Vigotsky y su zona de desarrollo potencial, la metodología científica, las ideas alternativas del alumnado, los trabajos prácticos o la resolución de problemas y la elaboración de unidades didácticas y sus programas de actividades.

No había nada que se escapara de su conocimiento, de su aprendizaje y de nuestra curiosidad. Daba gusto hablar con ella, tenía una fina ironía y un gran sentido del humor.

Junto con Doña Emy, he tenido el honor de publicar desde 1987 al 2007 (durante 20 años) unos 30 trabajos en común, en Jornadas, Congresos o Revistas con ISSN, y hemos escrito juntos 5 libros con ISBN e impartidos más de 20 cursos de formación inicial y permanente del profesorado juntos.

Hemos organizado exposiciones de divulgación científica, coordinando decenas de actividades, todas relacionadas con la Didáctica de las Ciencias, nuestra común pasión.

Doña Emy era tan generosa que en la mayoría de los trabajos que presentábamos en común me ponía a mí en primer lugar. Me decía que ella no necesitaba más meritos, ni publicaciones y que me tocaba a mí hacer un buen currículo. Siempre quiso que compartiera mi trabajo en el Instituto con el trabajo de formación del profesorado, en su departamento de didácticas especiales. No pudo ser en su momento y cuando me lo ofrecieron, en el 2012, para cubrir una vacante, ya era tarde, me acababa de jubilar y tenía que estar con trabajo de profesor en activo, para poder contratarme, a tiempo parcial, en dicha plaza.

Nuestro primer trabajo en común fue en 1987 una comunicación presentada al tercer congreso de la ACEC Viera y Clavijo celebrado en Las Palmas de Gran Canaria: "Estudio experimental e histórico de la constitución de la materia. Clasificación de las sustancias. Métodos de separación de mezclas. Martínez y Repetto (1987).

A este trabajo, le siguieron muchas comunicaciones más en común (unas 30 en total).

Nuestra última comunicación en común la presentamos en Murcia en octubre del 2007, en las II Jornadas Nacionales sobre la enseñanza de la química. Asociación Nacional de Químicos de España: “Química: vida y progreso” Martínez y Repetto (2007). 
Nuestro último libro juntos ha sido un libro precioso, la "Guía de recursos didácticos de las Biografías de Científicos Canarios" que se pueden bajar gratuitamente de internet. Martínez y Repetto (2007).

Nuestra gran Proyecto en común: "Las biografías de Científicos Canarios"

Me ofrecieron a mí el proyecto, lo consulté con Emy y le pedí que me ayudara y compartiera conmigo su coordinación. A los dos días teníamos entregado todo el plan de trabajo para desarrollarlo. Nos costó dos años de trabajo terminarlo.

La coordinación del proyecto, junto con la elaboración de los contenidos científicos y didácticos, así como hacer de comisarios de la exposición, "Biografías de Científicos Canarios”, (14 paneles), coordinar la publicación de la colección de ocho libros de Biografías de Científicos Canarios (BCC), ocho vídeos y escribir uno de ellos en común el de Blas Cabrera Felipe y hacer una Guía de recursos didácticos. Nos lo encargó la Oficina de Ciencia, Tecnología e Innovación del Gobierno de Canarias y nos llevó del 2005 al 2007. Martínez, F, y Repetto, E. (2007).

Para terminar trataré brevemente sobre la dirección de mi tesis que realizó Doña Emy.

Emy termina en 1991 su tesis doctoral "Diseño aplicación y evaluación de módulos de aprendizaje para la formación inicial del profesorado de EGB de Ciencias", dirigida por el Dr. Antonio de Pro de la Universidad de Murcia, uno de los más importantes especialistas espańoles en Didáctica de la Física. La defensa se realiza en el Departamento de Didácticas especiales de la Universidad de La Laguna y yo viajo a Tenerife para, con su permiso, estar presente en la misma.

Existe un compromiso mutuo de que cuando sea Doctora, será mi Directora de tesis en Didáctica de la Física y Química, a la que yo estaba ya enganchado.

En 1992 empezamos el trabajo previo de elección de tema y realización de un plan de trabajo. En paralelo, damos un curso para profesores de física y química para probar algunos materiales, hacerles encuestas y proponerles formación para impartir en el aula, tareas y actividades, sobre las que obtener datos experimentales.

Tenemos los problemas a investigar, las hipótesis de trabajo y un plan y una estrategia, con materiales y recursos para intentar comprobarlas y recoger información y analizar los resultados obtenidos en las encuestas y en las tareas aplicadas en algunos grupos de alumnos y alumnas, que unos hacen de grupo experimental y otros de grupo de control.

La cosa se complica, no avanza adecuadamente. Es difícil poder dedicar más tiempo a la investigación en la tesis, mientras sigo dando clases y entrete- 
nido con otros proyectos, Estoy desmotivado, pierdo la ilusión para dedicarle más tiempo y acabarla.

Tenía la falsa ilusión que iba a elaborar una propuesta de excelencia, con estrategias de aprendizaje innovadoras, que supondrían una gran mejora de la enseñanza-aprendizaje de la física y química, y no fue así. Lo que tenía para presentar solo servía para reforzar la confirmación de que la metodología activa y las estrategias innovadoras, ya propuestas por otros investigadores, dan mejores resultados de aprendizaje que la enseñanza tradicional. Cosa que ya sabíamos antes de empezar la investigación. Después de cuatro años de trabajo me desanimo y lo quiero dejar.

Emy me comprende y me da una tregua. Siempre fue una madraza con sus amigos. Me dice: "tómate tu tiempo y piénsalo, pero quiero que sepas que lo único que se pretende y se consigue con una tesis doctoral es probar tu suficiencia investigadora, las grandes o pequeñas aportaciones, pueden venir mucho después, con medios y años de trabajo. Asi que ya me dirás". Sigo con otros proyectos y no retomo la tesis, abandono.

Un día mi hijo mayor, cuando estaba en su último año de Veterinaria, a principios del 2002, me pregunta: "qué pasa con tu tesis, a la que tanto tiempo, incluyendo veranos, le has dedicado". Continúa y me dice: "Cuando termine el curso, voy a empezar mi tesis y voy a ser doctor antes que tü".

Eso fue un revulsivo para mí. Hablo del tema con Daniel Gil, me manda unos materiales, hablo con Dońa Emy, y le digo que quiero retomar y terminar la tesis. Me pongo a ello, me ilusiono de nuevo y reanudo el trabajo que quedó sin terminar.

Lo conseguimos el 13 de febrero de 2003, en el que por fin soy Doctor en Ciencias de la Educación con la tesis: "Análisis, desarrollo y evaluación del currículo de Física y Química de $1^{\circ}$ de Bachillerato. Implicaciones para la Formación del Profesorado. Tesis Doctoral. ULPGC”. Obteniendo la calificación de Sobresaliente cum laude por unanimidad.

Como reconocimiento a Emy en mi tesis doctoral, que ella dirigió, escribí: "Le doy las gracias muy en especial a la Dra. Doña Emigdia Repetto Jiménez, mi maestra y amiga. Catedrática de Didáctica de las Ciencias Experimentales y Jefa del Departamento de Didácticas Especiales de la Facultad de Formación del Profesorado de la Universidad de Las Palmas de Gran Canaria, que me dirigió científicamente durante todos estos años la tesis, dándome generosamente y en abundancia tanto sus muchos conocimientos como su caluroso afecto. Sin sus constantes ayudas, sus consejos e interés, su ánimo, su motivación y su contagiosa capacidad de trabajo, dificilmente hubiera llegado a buen puerto. Todo ello merece mi más sincera expresión de aprecio. Gracias Doña Emy". 
Obtuvimos la calificación de sobresaliente Cum Laude. Formaba parte del tribunal, presidido por Gonzalo Marrero, mi otro maestro: Daniel Gil Pérez de la Universidad de Valencia. Fue otro día muy feliz, que compartí con Dońa Emy, en el que se cumplía otro de mis sueños profesionales.

\section{En el resumen de la tesis doctoral decíamos:}

"En este trabajo de investigación, se realiza un análisis del currículo de física y quimica de $1^{\circ}$ de bachillerato, proponiendo orientaciones para su desarrollo y evaluación y se hace un análisis critico de las deficiencias presentes en los libros de texto y en la enseñanza habitual de la fisica y quimica de bachillerato, en particular de la energía y de la estructura atómica.

En segundo lugar, se muestra cómo, mediante estrategias basadas en la investigación didáctica, se pueden superar estas dificultades, promoviendo un modelo de enseñanzaaprendizaje por investigación orientada de situaciones problemáticas relevantes, que favorece, en el alumnado, el cambio conceptual, procedimental y de actitudes.

Por último, se muestran las implicaciones del desarrollo y evaluación del curriculo en la formación del profesorado".

En la primera parte de la tesis analizábamos las características del currículo oficial vigente de física y química de bachillerato de la Comunidad Autónoma de Canarias, señalando las diferencias con el Real Decreto del MECD.

En la segunda parte se realizaba una descripción del currículo básico u oficial de física y química de $1^{\circ}$ de bachillerato, realizando un diseño para la detección y análisis de las visiones deformadas y simplistas del desarrollo curricular, presentes en la mayoría de los libros de texto y en la práctica docente habitual.

A continuación, presentábamos nuestra propuesta de desarrollo y evaluación del currículo de física y química de $1^{\circ}$ de bachillerato, como una investigación orientada, fundamentada en los resultados más recientes de la investigación educativa. Un aprendizaje basado en situaciones problemáticas relevantes (ABSP).

Se describen y analizan diferentes materiales y recursos didácticos, presentando, a modo de ejemplo, los programas de investigación elaborados de varias de las unidades didácticas, que hemos diseñado, aplicado y evaluado, habiendo incorporado, entre otros recursos, simulaciones y animaciones interactivas, utilizando las tecnologías de la información y de la comunicación (TIC), así como las relaciones entre ciencia, tecnología, sociedad y medioambiente (CTSA) y estrategias de trabajo en pequeños grupos cooperativos.

Después de la tesis Doña Emy y yo seguimos trabajando juntos y compartiendo nuestra amistad, nuestras ideas, trabajo profesional e ilusiones hasta mi jubilación en el 2012. 
Reflexiones sobre la evolución de la vida profesional de un profesor investigador de enseñanza ...

Doña Emy gracias por tu generosidad, tu magisterio y tu amistad.

Foto con Da Emy después del acto de investidura como Doctor (1994)

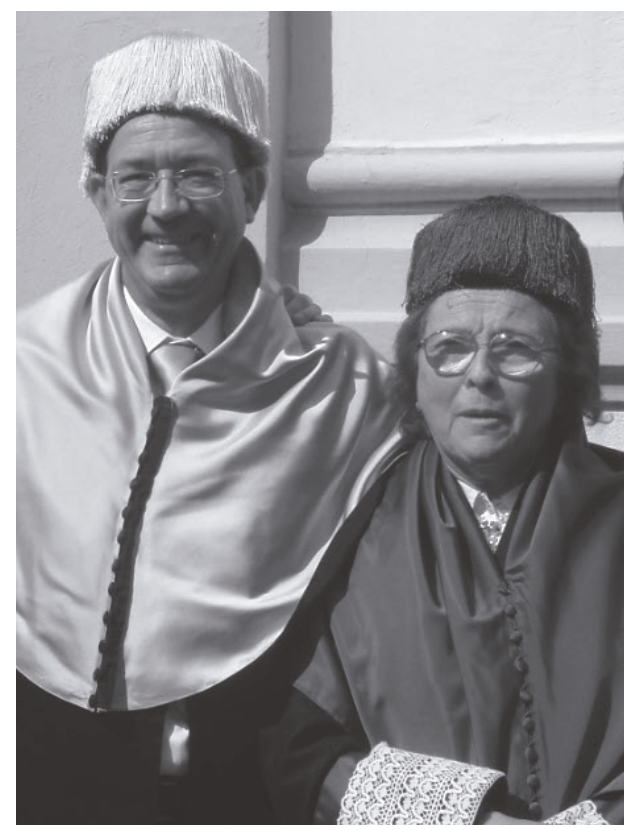

Fuente: colección particular.

\section{REFERENCIAS BIBLIOGRÁFICAS}

Gil, D. (1993). Contribución de la historia y filosofía de las ciencias al desarrollo de un modelo de enseńanza-aprendizaje como investigación. Enseñanza de las Ciencias, 11 (2), 197-212.

Marchesi, A. (2007). Sobre el bienestar de los docentes: Competencias, emociones y valores. Madrid. Alianza Editorial.

Martínez, F. y Repetto E. (1987). Estudio experimental e histórico de la constitución de la materia. Clasificación de las sustancias. Métodos de separación de mezclas. Gran Canaria. Actas del III Congreso de la ACEC Viera y Clavijo.

Martínez, F., Mato, M.C. y Repetto, E. (1995). Los aspectos medioambientales y la enseñanza de las Ciencia. Cuadernos de Aula no. 6. Consejería de Educación del Gobierno de Canarias y Centro de la Cultura Popular Canaria. 
Martínez, F. y Mestres, A. (1996). Guía de Recursos Didácticos de Ciencias de la Naturaleza para la Educación Secundaria Obligatoria. Gran Canaria. Consejería de Educación del Gobierno de Canarias.

Martínez, F. (1996). Diseño, desarrollo y evaluación de unidades didácticas. En Repetto y Marrero, Estrategias de intervención en el aula desde la LOGSE. Gran canaria. ICEPSS - Universidad de Las Palmas de Gran Canaria. 257-302.

Martínez, F. y Repetto E. (1997). Un ejemplo biográfico de las profundas relaciones Ciencia, Tecnología y Sociedad: Blas Cabrera Felipe (1878-1945). Biografía de un físico canario del siglo XX. Alambique, 13, 95-103.

Martínez, F. (2003). Análisis, desarrollo y evaluación del currículo de Física y quimica de $1^{\circ}$ de Bachillerato. Implicaciones para la Formación del Profesorado. Tesis Doctoral. ULPGC.

Martínez, F. (2004). Programaciones didácticas para el aula. Gran Canaria. CamPDS.

Martínez, F. y Repetto E. (2005). Blas Cabrera Felipe. Biografía de Cientificos Canarios. Oficina de Ciencia, Tecnología e Innovación del Gobierno de Canarias. Gran Canaria CamPDS - Dykinson.

Martínez, F. y Repetto E. (2007). Biografía de Cientificos Canarios. Guía de Recursos Didácticos. Aplicaciones didácticas de la Historia de la Ciencia en Canarias. Oficina de Ciencia, Tecnología e Innovación del Gobierno de Canarias. Gran Canaria CamPDS - Dykinson.

Martínez, F. y Turégano J.C. (2010). Ciencias para el mundo contemporáneo. Guía de recursos didácticos. Canarias. Agencia Canaria de Investigación, Innovación y Sociedad de la Información. Gobierno de Canarias. 


\title{
LOS TRES GRADOS DE CONOCIMIENTO: APLICACIÓN A LA GEOLOGÍA PALEOCLIMÁTICA DE CANARIAS
}

\author{
Joaquín Meco Cabrera \\ Profesor Emérito de la Universidad de Las Palmas de Gran Canaria
}

A Emy

\section{Resumen}

Se establecen tres grados de conocimiento, identificando el primero con el saber común de la gente, el segundo con el saber de los especialistas y el tercero con la capacidad de conectar e incluso descubrir, un paradigma científico o interpretación general de una rama de la ciencia. Se describe como desde observaciones geológicas en las islas Canarias se ha conectado con la estabilidad de las Canarias orientales, la fusión de hielos antárticos, el desplazamiento de la placa sudamericana, la instalación de hielos en el Ártico y de la Corriente fría de Canarias, El inicio de la estacionalidad en las zonas templadas en Eurasia, la antigüedad del Sahara, las migraciones de faunas cálidas en el Atlántico norte, la huella de la orbita de la Tierra y las consecuencias del origen violento de la luna.

Palabras clave: Didáctica de las ciencias, Paradigmas científicos, observación relevante, Geología de Canarias.

\begin{abstract}
Three degrees of knowledge are established: the first one is believed to be the common knowledge that people have; the second one is the knowledge of specialists in their domains of work; and lastly, the third one concerns the ability to connect and even discover a scientific paradigm or general interpretation of a branch of science. Regarding the latter, there are geological observations of the Canary Islands described. These are about the stability of the eastern Canaries, the melting of Antarctic ice shelves, the displacement of the South American plate, the ice formation in the Arctic, the cold Oceanic Canary current, the seasonality in temperate zones in Eurasia, the antiquity of the Sahara Desert, migrations of warm fauna in the North Atlantic, and the Earth's orbit and consequences of the violent origin of the moon.
\end{abstract}

Keywords: Didactics of science, Scientific paradigms, relevant observation, Geology of the Canary Islands. 


\section{INTRODUCCIÓN}

Si mostramos una imagen como la de la Figura 1 y preguntamos al observador sobre qué ve o piensa, las posibles respuestas mostrarían los tres grados de conocimiento.

Figura 1. Anatosuchus

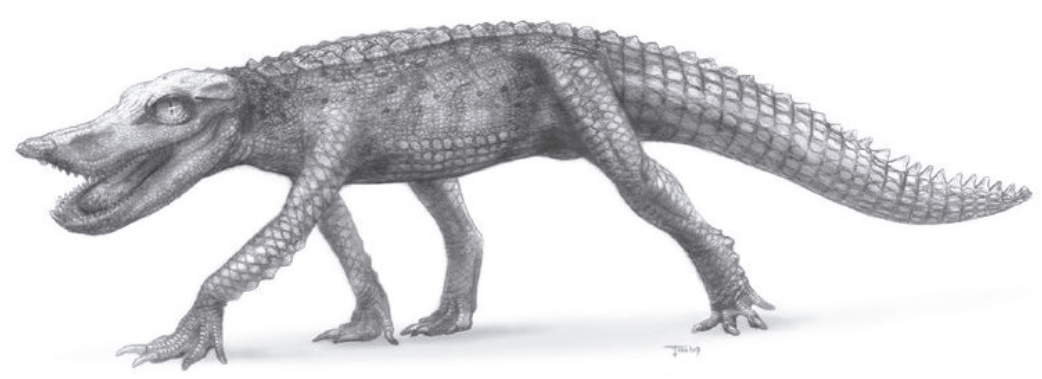

Fuente: https://es.m.wikipedia.org/wiki/Archivo:Anatosuchus.jpg

Una respuesta como "algún dinosaurio o reptil fósil" sería del grado uno. El grado de conocimiento dos lo daría una respuesta tal como "un Anatosuchus, fósil del cretácico del Sahara" (Sereno \& Larsson., 2009: fig. 45: doi: 10.3897/zookeys.28.325). Y, ¿el tercer grado? diría "me veo a mi mismo, a ti, a todos nosotros y a todos los animales vertebrados pues todos somos tubos digestivos que se desplazan mediante cuatro extremidades". Es decir, veo el paradigma científico de la evolución biológica (Darwin, 1859). Es este tercer grado de conocimiento el que nos interesa. También es el que hemos buscado en nuestros trabajos y aquí exponemos algunos de ellos que muestran el valor global de lo local o cómo es el camino de lo concreto a lo general o, finalmente, cómo se engancha la observación con el paradigma en sentido de Kuhn (1962) entendiendo por paradigma la interpretación general y oficial de una rama de la ciencia. Por ejemplo, el Big Bang, o la Tectónica de Placas.

Un rasgo, especialmente de la paleontología, se puede ilustrar de un modo simplista también con un ejemplo. Aunque hoy sobreviven tres especies de elefantes, una especie de este animal, por lo general de gran tamaño, es conocida sólo por la mitad posterior del tercer molar inferior derecho (Aguirre, 1969). De modo que solo un fragmento de muela permite saber que ese fragmento pertenece a un elefante y que ese elefante era diferente de todos los conocidos, al menos 24 especies fósiles más. Y ello gracias al Principio de Correlación orgánica de Cuvier (Rudwick, 1997). Es decir, conocida la parte, conocido el 
todo. Este proceder es común a todas las ciencias que estudian el Cosmos y la Tierra y se mueven así por el borde de lo conocido. Un proceder imposible de ignorar en la enseńanza.

\section{CÓMO SE LLEGÓ A LOS GRANDES PARADIGMAS GEOLÓGICOS (EN MODO MUY SIMPLIFICADO Y A NUESTRO PROPÓSITO)}

\section{El Universo}

Aparentemente pequeñas observaciones han dado lugar a los más grandes modelos del conocimiento. Sabemos si un tren se acerca o se aleja por el sonido que percibimos, el llamado efecto Doppler (1842). Esto, llevado a la luz, el efecto Doppler-Fizeau (1848), permitió averiguar que las estrellas estaban alejándose. La expansión del Universo llevó a Lemaître (1931) al modelo luego conocido como Big Bang.

\section{El sistema Tierra-Luna}

La Luna y La Tierra tienen la misma composición isotópica pero diferente de la de Marte y de la de los otros planetas. Ello indica un origen común. Un impacto gigante (Pahlevan \& Stevenson 2007) del que es testigo presente la inclinación de la Luna (Cuk et al., 2016).

\section{El enfriamiento de la Tierra}

Las costas de los continentes encajan unas en otras de ahí el modelo de la Deriva Continental imaginado por Wegener (1912) y luego el de la Tectónica de placas. La distribución de los seísmos dibuja los bordes de las placas (véase por ejemplo Wilson, 1968) mientras que la distribución de mares, tierras y cordilleras y volcanes se debe a un proceso de enfriamiento térmico.

\section{Un notable precedente}

Un precedente de este proceder se encuentra, hacia mediados del siglo III antes de Cristo, en Eratóstenes que con la observación de la sombra del sol en dos puntos geográficos de Egipto hizo el primer calculo del radio de la Tierra.

\section{Corolario didáctico}

El modo de enganchar una observación con el paradigma empieza por enseñar a diferenciar entre la observación irrelevante y la observación pertinente. La irrelevante está fuera del paradigma y la pertinente entronca con la estructura de la ciencia. Un ejemplo sencillo: si un animal tiene seis patas es un Exá- 
podo o Insecto y el número de patas es la observación pertinente en este caso mientras que muchos de los otros rasgos no conducen a ninguna conclusión, sino que están comprendidos en la correlación orgánica.

\section{NUESTRA EXPERIENCIA: DE LO LOCAL A LO GLOBAL}

En Lanzarote, en las Salinas del Janubio, hay un depósito marino íntimamente asociado a una colada de lavas. Obtuvimos una edad Argon/Argon de la colada (Meco et al., 2020) que resultó próxima a los 10 millones de años (Ma). Como el depósito en la actualidad se encuentra a unos $40 \mathrm{~m}$ de altura sobre el nivel del mar y éste era igual al de ahora, ello quiere decir que la isla de Lanzarote ha sufrido desde entonces una elevación de $40 \mathrm{~m}$. Pero, en la zona de Los Ajaches, hay otros depósitos marinos, de unos $5 \mathrm{Ma}$, que están a $70 \mathrm{~m}$. de altura. Por lo tanto, el nivel del mar estaba $30 \mathrm{~m}$ más alto que ahora. Esto significa que tuvieron que fundirse los hielos del hemisferio norte pero también casi la mitad de los hielos de la Antártida (Figura 2).

Figura 2. La estabilidad tectónica y el glacioeustatismo en las Canarias más orientales durante los últimos $14 \mathrm{Ma}$

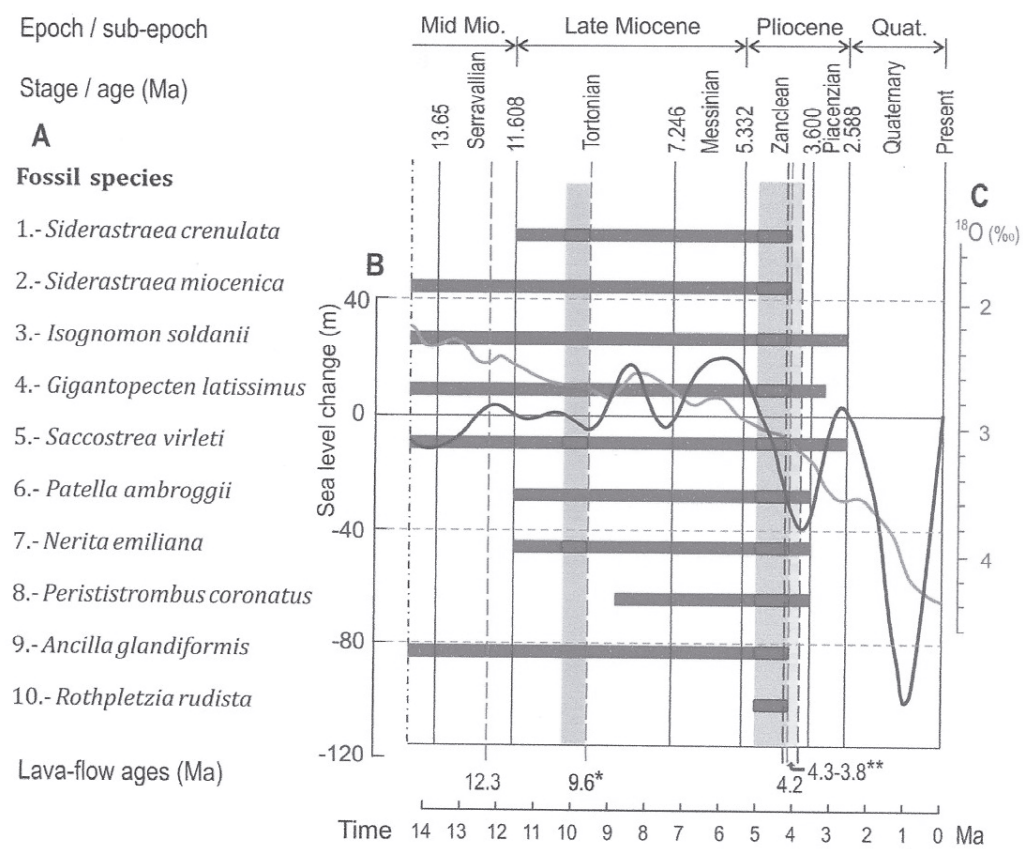

Fuente: Meco et al., 2020. 
En la Isleta de Gran Canaria, una colada datada por $\mathrm{Ar} / \mathrm{Ar}$ en 4.2 Ma (Meco et al., 2015), está en relación con unos caracoles flotantes del genero Janthina que aparecen también fósiles en Japón, Nueva Zelanda y Australia (Figura 3). Esto indica que la placa tectónica sudamericana, que se está desplazando hacia el norte, aún no había cerrado la comunicación entre los Océanos Atlántico y Pacífico.

Figura 3. Dispersión de las Janthina del Plioceno inferior a favor de las corrientes

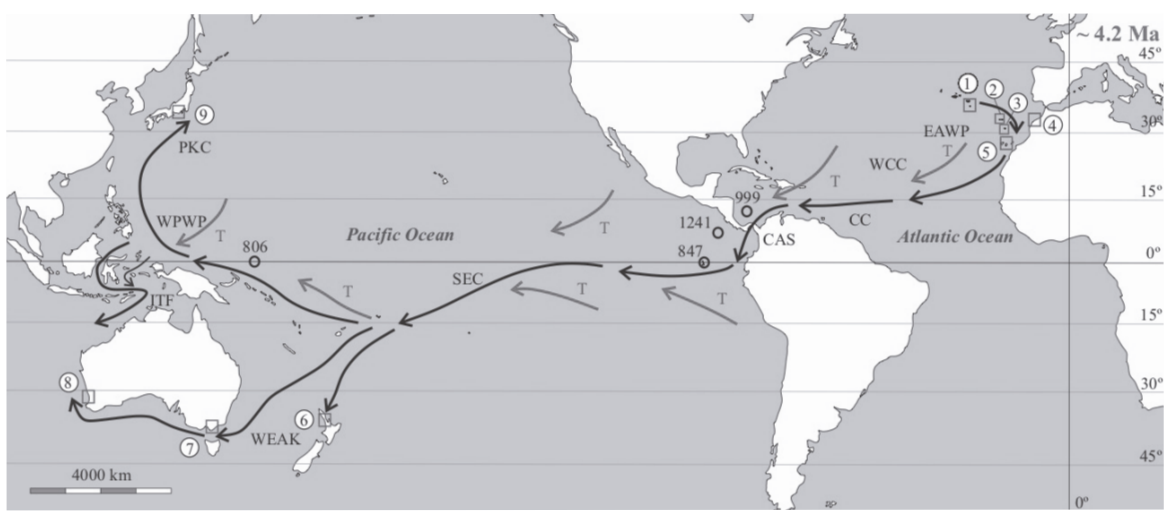

Fuente: Meco et al., 2016.

La intercalación de diferentes episodios sedimentarios con lavas datadas en Canarias ha permitido la reconstrucción de los sucesos más relevantes en el Atlántico Norte y en el norte de África (Figura 4). Así, con el cierre de América central, la Corriente del Golfo se intensifica, empiezan a cumularse hielos en el Polo Norte, se enfría la Corriente de Canarias, baja el nivel del mar y las arenas marinas quedan al descubierto y son acumuladas en forma de dunas en Fuerteventura donde quedan sepultadas por una lava datada en unos $3 \mathrm{Ma}$. 
Figura 4. Lavas de las Canarias orientales datando la evolución climática del Atlántico norte y del África del norte

\section{(A) North Atlantic Ocean}

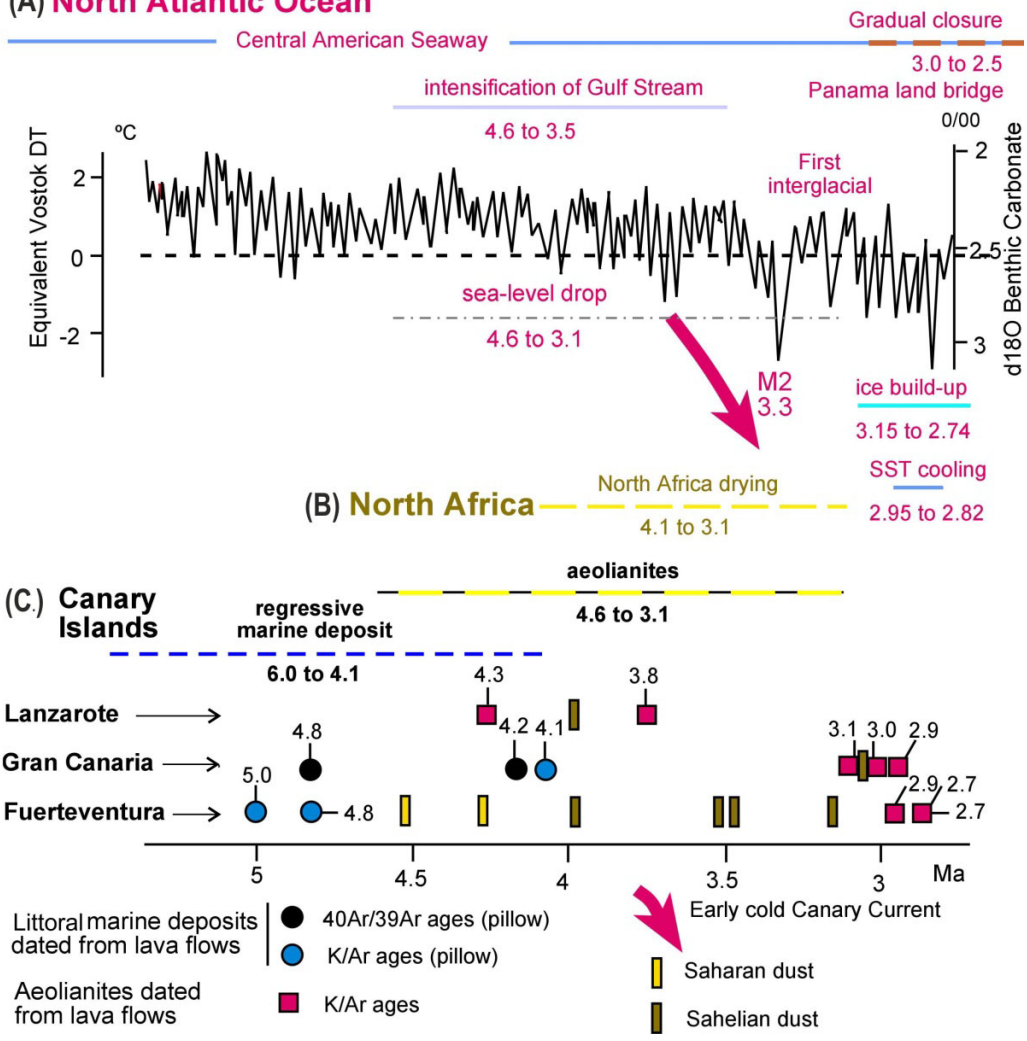

Fuente: Meco et al., 2020.

Con el cese del clima constantemente cálido que acompañaba a las Janthina aparece la estacionalidad mostrada por las protecciones de la puesta de huevos de insectos para superar las estaciones desfavorables. Estas cámaras protectoras son propias de las regiones templadas (Figura 5) y aparecen por millones en los paleosuelos de las islas. 
Figura 5. La distribución actual de las plagas de langostas que segregan ootecas protectoras, coincide con las zonas templadas caracterizadas por la alternancia de inviernos y veranos

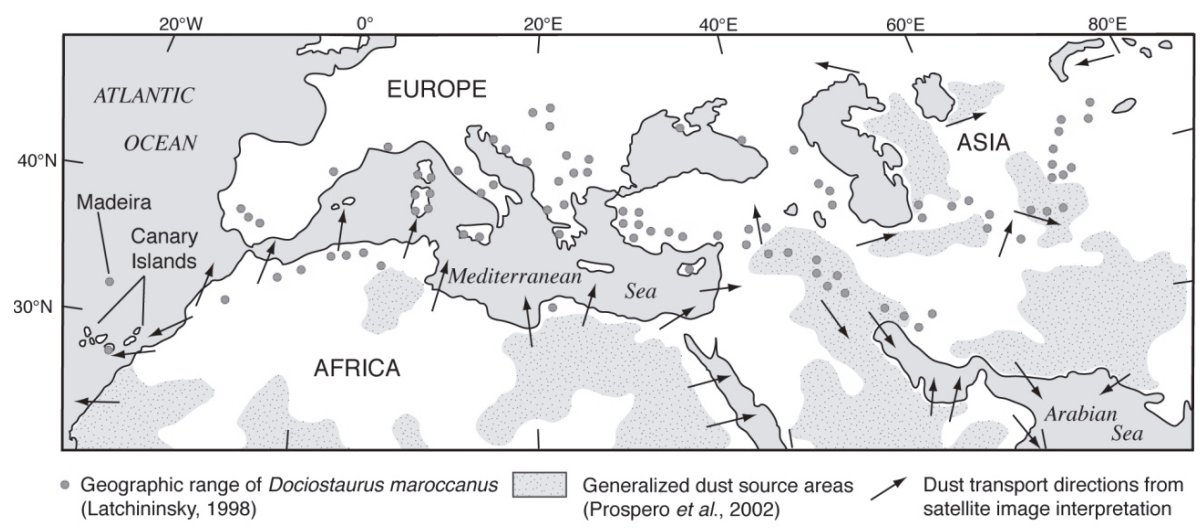

Fuente: Meco et al., 2011.

Estos paleosuelos muestran entre sus componentes esenciales polvo procedente del Sahara y del Sahel (Figura 6). 
Figura 6. El polvo africano más antiguo llegado a Canarias quedó atrapado entre coladas datadas, mostrando así una antigüedad para el Sahara de unos $4 \mathrm{Ma}$

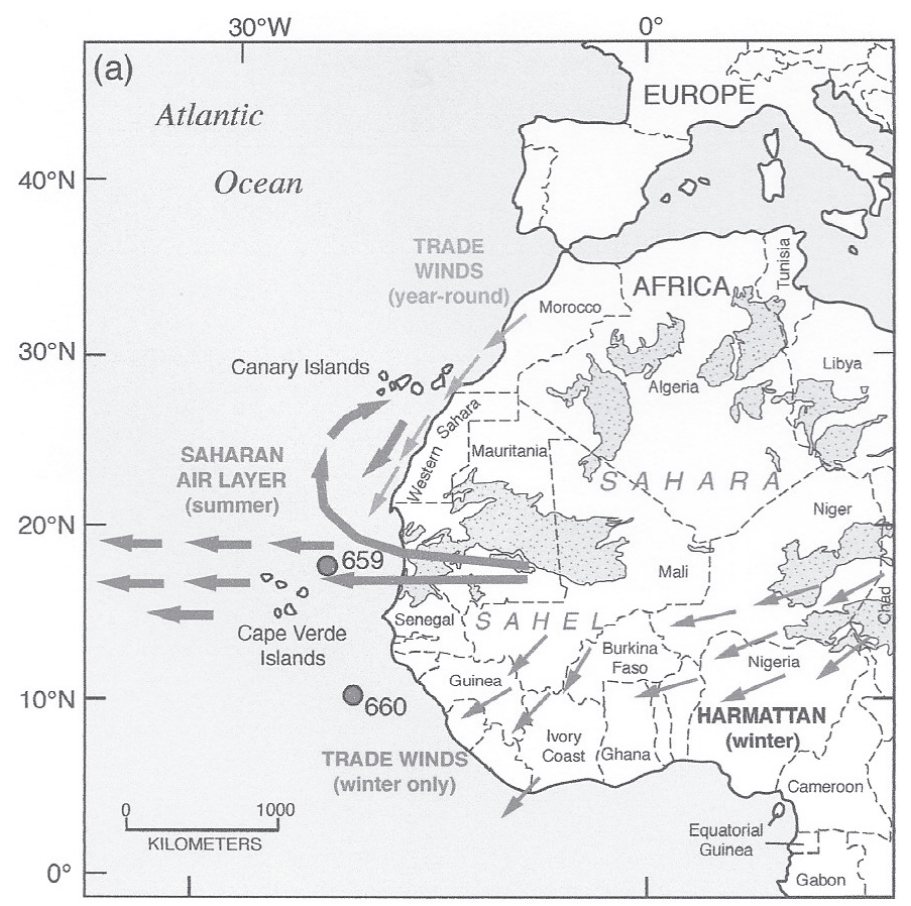

Fuente: Muhs et al., 2019.

Con la llegada de los tiempos cuaternarios, caracterizados por las glaciaciones y los interglaciares acompañados de bajadas y subidas del nivel del mar, aparecen en las islas depósitos conteniendo especies marinas que hoy viven en el Golfo de Guinea (Figura 7). 
Figura 7. Distribución geográfica actual y fósil de una especie del interglacial más cálido del Pleistoceno medio (en verde) y de otra del último interglacial con el que se inicia el Pleistoceno superior

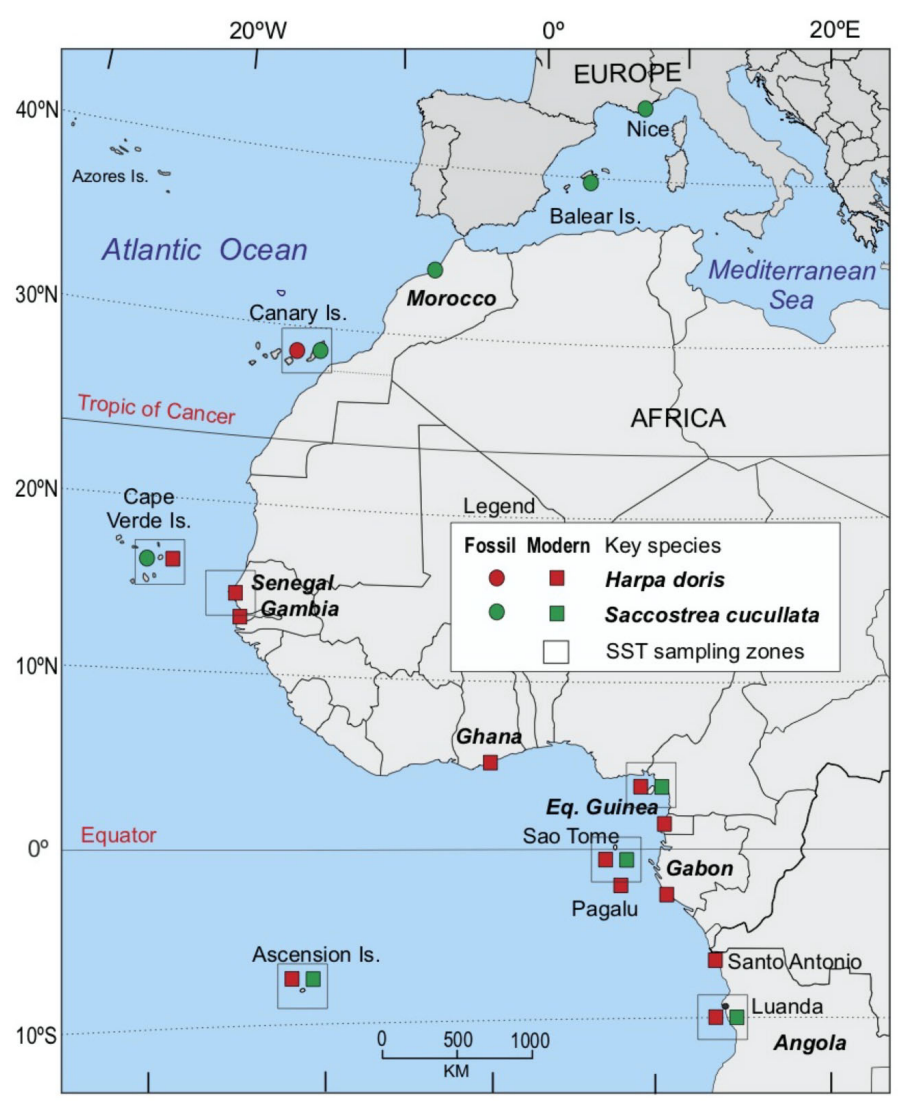

Fuente: Montesinos et al., 2014.

El último interglaciar ha sido datado en Canarias por series de Uranio sobre corales fósiles entre hace 120 y 130 mil años (Figura 8). 
Figura 8. En el último interglacial se trasladaron las faunas del Golfo de Guinea, también llamada senegalesa, al Mediterráneo. (a) y (b) Muestran el yacimiento de Matas Blancas en el sur de Fuerteventura y (c) la distribución geográfica fósil y actual de las caracolas del género Strombus

(a)

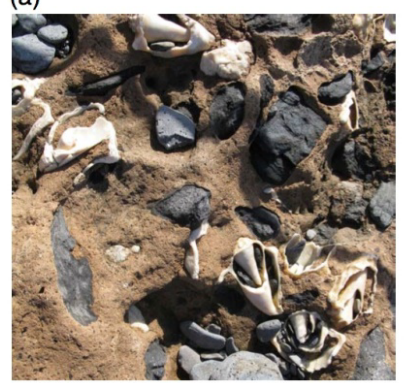

(b)

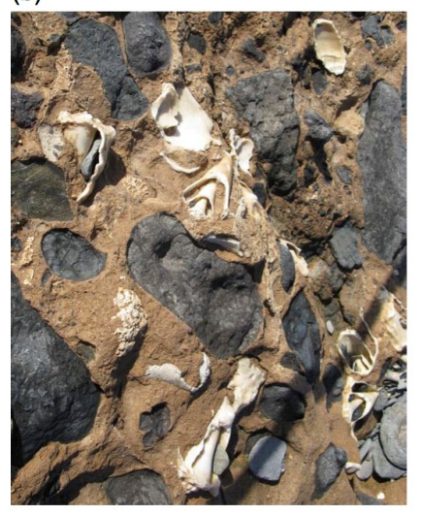

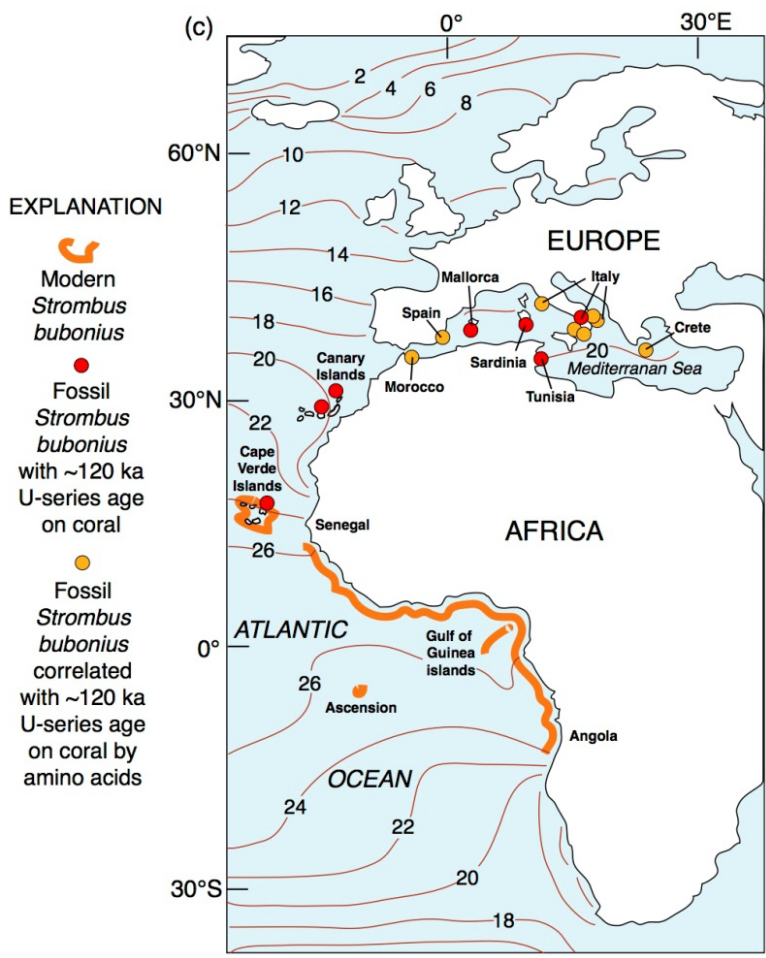

Fuente: Muhs et al., 2014.

Y, lo más reciente, los depósitos de playa (Figura 9) datados por Carbono catorce en unos 1.500 años (Meco et al., 2018) que corresponderían a un grado de precesión de los equinoccios. 
Figura 9. Cada uno de los escalones que forman estos depósitos de playa fósil correspondería a una vuelta de la Tierra alrededor del Sol en los tiempos de Atila, hacia el año 450 de nuestra Era

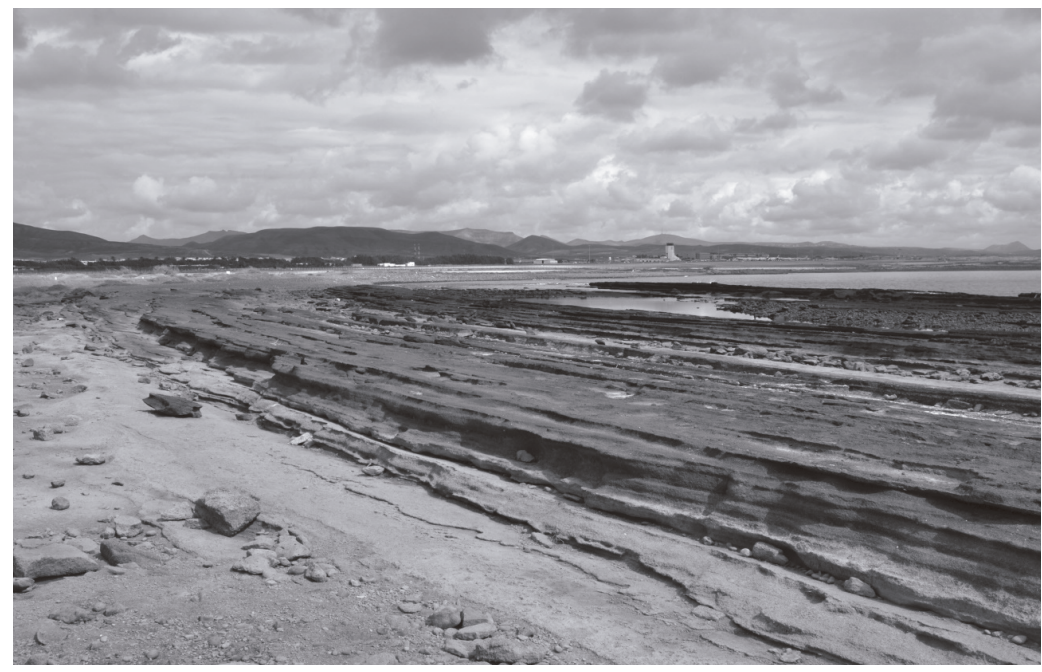

Fuente: Meco et al., 2018.

Finalmente, en la actualidad estamos trabajando en la relación, posiblemente visible en Canarias, entre los depósitos marinos cuaternarios y el origen de la Tierra actual y la Luna. Según una reciente teoría (por ejemplo: Cuk et al., 2016) la luna se originó por un Impacto Gigante entre la proto-tierra y la "madre de la luna" (Eurifaesa) que produciría un efecto oscilatorio de la Inclinación de la luna respecto a la eclíptica. Este innovador trabajo no ha sido publicado. Su publicación es muy difícil, casi heroica, porque el sistema editorial científico actual requiere revisores y estos suelen estar instalados en el grado dos que es muy especializado y poco especulativo. Aunque sin un gramo de especulación no habría ningún avance científico.

\section{CONCLUSIÓN}

Un primer grado de conocimiento es el saber común de la gente. Un segundo grado consistiría en el saber de los especialistas en cada rama de las ciencias de la Naturaleza. El tercer grado coincide con la capacidad de conectar con un paradigma científico o interpretación general de la ciencia. Este grado se aplica a observaciones geológicas en las islas Canarias y así se ha conectado 
con la estabilidad de las Canarias orientales, la fusión de hielos antárticos, el desplazamiento de la placa sudamericana, la instalación de hielos en el Ártico y de la Corriente fría de Canarias, el inicio de la estacionalidad en las zonas templadas en Eurasia, la antigüedad del Sahara, las migraciones de faunas cálidas en el Atlántico norte, la huella de la orbita de la Tierra y con consecuencias del origen violento de la luna.

\section{RECONOCIMIENTO}

Los trabajos utilizados (véase autores e instituciones en: https://orcid.org/0000-0001-7658-9956) han sido realizados en equipo. El equipo ha incorporado a diferentes miembros de otras instituciones científicas según la técnica empleada. Consuelo Sendino (Department of Earth Sciences, Natural History Museum) realizó el Abstract. Las figuras 2, 3, 4 y 7 se deben a Alejandro Lomoschitz (Departamento de Ingeniería Civil de la ULPGC); las figuras 5, 6 y 8 a Daniel R. Muhs (U.S Geological Survey) y la Figura 9 a Juan Francisco Betancort (Dr. colaborador en la Facultad de Ciencias del Mar de la ULPGC).

\section{REFERENCIAS BIBLIOGRÁFICAS}

Aguirre Enríquez, E. (1969). Revisión sistemática de los Elephantidae por su morfología y morfometría dentaria (Tercera parte). Estudios Geológicos, 25, 317-367.

Cuk, M., Hamilton, D. P., Lock, S. J. \& Stewart, S. (2016). Tidal evolution of the Moon from a high-obliquity, high-angular-momentum Earth. Nature, 539, 402-406.

https://doi.org/10.1038/nature19846

Darwin, Ch. (1859). On the origin of Species. London, John Murray.

Kuhn, T. S, (1962). The structure of scientific revolutions. University of Chicago Press

Meco, J., Muhs, D. R., Fontugne, M., Ramos, A. J. G., Lomoschitz, A. y Patterson, D. (2011). Late Pliocene and Quaternary Eurasian locust infestations in the Canary Archipelago. Lethaia, 44, 440-454.

DOI: $10.1111 / j .1502-3931.2010 .00255 . x$

Meco, J., Lomoschitz, A. y Betancort, J. F. (2016). Early Pliocene tracer of North Atlantic and South Pacific sea surface currents: Janthina typica (Bronn, 1860) (Mollusca: Gastropoda). Revista Mexicana de Ciencias Geológicas, 33, 2, 192-197. 
Meco, J., Lomoschitz, A., Rodríguez, A., Ramos, A. J. G., Betancort, J. F. y Coca' J. (2018). Mid and Late Holocene sea level variations in the Canary Islands. Palaeogeography, Palaeoclimatology, Palaeoecology, 507, 214-225. DOI: $10.1016 /$ j.palaeo.2018.07.020

Meco, J., Lomoschitz, A., Koppers, A. P., Miggins, D. P., Huertas, M. Betancort, J. F. y Soler-Onís, E. (2020). Late Miocene to Early Pliocene marine deposits from eastern Canary Islands, Spain: $\mathrm{New}{ }^{40} \mathrm{Ar} /{ }^{39} \mathrm{Ar}$ age and paleoclimatic significance. Journal of African Earth Science, 164, 103802 https://doi.org/10.1016/j.jafrearsci.2020.103802

Meco, J., Koppers, A. A. P., Miggins, D. P., Lomoschitz, A. y Betancort, J. F. (2015). The Canary Record of the Evolution of the North Atlantic Pliocene: New 40Ar/39Ar Ages and Some Notable Palaeontological Evidence. Palaeogeography, Palaeoclimatology, Palaeoecology, 435, 53-69. https://doi.org/10.1016/j.palaeo.2015.05.027

Montesinos, M., Ramos, A. J. G., Lomoschitz, A., Coca, J., Redondo, A., Betancort, J. F. y Meco, J. (2014). Extralimital Senegalese species during Marine Isotope Stages 5.5 and 11 in the Canary Islands $\left(29^{\circ} \mathrm{N}\right)$ : sea surface temperatures estimates. Palaeogeography, Palaeoclimatology, Palaeoecology, 410, 153-163.

http://dx.doi.org/10.1016/j.palaeo.2014.05.046

Muhs, D. R., Meco, J., Budahn, J. R., Skipp, G. L., Betancort, J. F. y Lomoschitz, A. (2019). The antiquity of the Sahara Desert: New evidence from the mineralogy and geochemistry of paleosols on the Canary Islands, Spain. Palaeogeography, Palaeoclimatology, Palaeoecology, 533, 109245.

https://doi.org/10.1016/j.palaeo.2019.109245

Muhs, D. R., Meco, J. y Simmons, K. R. (2014). Uranium-series ages of corals, sea level history, and palaeozoogeography, Canary Islands, Spain: an exploratory study for two Quaternary interglacial periods. Palaeogeography, Palaeoclimatology, Palaeoecology, 394, 99-118.

Pahlevan, K. y Stevenson, D. J. (2007). Equilibration in the aftermath of the lunarforming giant impact. Earth and Planetary Science Letters, 262, 438-449.

Pahlevan, K. y Morbidelli, A. (2015). Collisionless encounters and the origin of the lunar inclination. Nature 527, 492-494.

Rudwick, M. (1997). Georges Cuvier, Fossil Bones, and Geological Catastrophes. The University of Chicago Press. ISBN 0-226-73106-5

Sereno, P. y Larsson, H. (2009). Cretaceous Crocodyliforms from the Sahara. ZooKeys 28, 1-143. doi:10.3897/zookeys.28.325

Wilson, J. T. (1968). A Revolution in Earth Science. Geotimes, 13, 10-16. 



\title{
LA CREATIVIDAD COMO OPERACIÓN BÁSICA \\ DE LA INTELIGENCIA: TEORÍAS RELACIONADAS \\ CON LA EXPERIMENTACIÓN ARTÍSTICA \\ COMO EXPERIENCIA FORMADORA
}

\author{
Ma Dolores Medina Benítez \\ Universidad de Las Palmas de Gran Canaria \\ Departamento de Didácticas Específicas
}

\begin{abstract}
Resumen
Este artículo ofrece un marco teórico del que parte el conocimiento para la propuesta formativa, ya planteada con anterioridad a esta publicación, sobre La experimentación como experiencia formadora. En él se interrelaciona el concepto de creatividad con las operaciones básicas de la inteligencia que se ponen de manifiesto en la realización de las tareas de experimentación artística, coincidentes con el propósito de su planteamiento.

Su objetivo es resaltar aquellas teorías y aportaciones personales que influyen en su proceso y justifican su propósito Estos fundamentos teóricos nos acercan a la comprensión de la eficacia creativa que aportan los dos métodos sistematizados que se derivan de esta metodología educativa, en la que se forma al alumnado para ser individuos resolutivos, con una mente investigadora, intelectual, abierta y con recursos para la vida.
\end{abstract}

Palabras clave: Creatividad, inteligencia, procesos creativos, pensamiento creativo, pensamiento divergente, teorías de la creatividad.

\begin{abstract}
This article offers a theoretical framework from which the knowledge for the training proposal, already raised before this publication, on Experimentation as a training experience. In it the concept of creativity is interrelated with the basic operations of the intelligence that are manifested in the realization of the tasks of artistic experimentation, coinciding with the purpose of its approach.

Its objective is to highlight those theories and personal contributions that influence its process and justify its purpose These theoretical foundations bring us closer to the understanding of the creative effectiveness that contribute the two systematized methods that derive from this methodology educational, in which students are trained to be resolute individuals, with a research-minded, intellectual, open and resourceful mind for life.
\end{abstract}


Keywords: Creativity, intelligence, creative processes, creative thinking, divergent thinking, theories of creativity.

\section{INTRODUCCIÓN}

El presente artículo plantea los fundamentos teóricos que intervienen en la metodología artística de La experimentación como experiencia formadora en lo referente a su interrelación directa con las teorías referidas a las operaciones básicas de la inteligencia que se desarrollan en los procesos de creatividad artística, en un entorno educativo dirigido a los futuros Graduados en Educación Primaria y cuya proyección va destinada a todos los niveles de Ed. Primaria, con las adaptaciones oportunas en cada uno de ellos.

En este sentido, la Educación artística planteada por las autoridades actuales en la materia, abogan por que ésta debe ser una cuestión de exploración de nuevas vías que atienda a una realidad cambiante y que ayude a convertir a la futura sociedad en individuos con capacidad de discernir, seres resolutivos antes los problemas que se encuentran en su camino, personas con recursos que sepan abrir caminos. Esta nueva perspectiva del arte, nos induce a proponer La experimentación como experiencia formadora como una metodología artística, concebida como base de toda formación enaltecedora. Por tanto, este aspecto es el eje central en el que se cimienta el trabajo, relacionando la creatividad inherente a la experimentación con las operaciones básicas de la inteligencia que se ponen en funcionamiento con los dos métodos artísticos y sistematizados que se proponen en dicha metodología y ayudándonos a entender las teorías en que se basan. Para que esta fundamentación teórica se entienda es preciso definir, a priori, de forma breve, estos dos métodos como:

1. Proceso materialización de una idea: es un proceso ordenado y madurativo por el cual el alumno va obteniendo un conocimiento cada vez mayor sobre la proyección de una idea, desde su concepción, hasta convertirla en un objeto real. Su utilización dota al alumno, entre muchas otras capacidades, de recursos que ayudan a buscar, madurar y representar sus ideas, mediante la indagación con submétodos y recursos y la aplicación de un lenguaje visual y plástico propio, basado en la experimentación y el juego que los introduce en la investigación y en el hábito intelectual. En el acto de materialización de un proyecto intervienen varias fases de evolución, jerarquizadas por niveles que harán que un gesto gráfico o garabato sin sentido pueda evolucionar para llegar a convertirse, de manera progresiva, en un objeto tangible en cuatro fases: búsqueda, desarrollo, enriquecimiento y materialización. 
2. Conceptualización: consiste en volver conceptos cualquier parte que intervenga en el proceso de una técnica para su diversificación en otros recursos materiales alternativos que procuren multiplicidad de variantes y diversificación de caminos a explorar. Al igual que el método anterior, trata de desarrollar todas las capacidades mentales y conductuales del potencial creativo, no como un fin último para enriquecer imágenes e ideas ya creadas, ni para ser usadas con fines de destreza técnica, o como adquisición de multitud de ellas, sino para ser concebidas para crear, desarrollar, componer y finalmente enriquecer imágenes e ideas propias, mediante el experimento y el juego pautado y concienzudo, comprometido con la ciencia, la curiosidad, el pensamiento divergente... y con el que encontrar un lenguaje propio y un desarrollo estético y creativo. Se desarrolla a partir de un proceso jerarquizado de acciones en el que es tan importante la proyección y clarificación de conceptos utilizados, mediante la síntesis y el análisis de los elementos que intervienen en el proceso, como las acciones y procedimientos seguidos en la experimentación, o la valoración crítica de los resultados explorados para hacerse con un vocabulario artístico personal. Su planteamiento viene dado por tres fases: proyección, experimentación y aplicación de resultados.

Por tanto, un docente que haya sido educado de esta manera y vivido la experiencia artística desde el campo del experimento y el juego, entendemos que podrá así instruir a sus alumnos/as en la búsqueda de nuevas soluciones para poder afrontar, con éxito, en el futuro, los problemas tan conflictivos que nos asedian. "Es precisamente la actividad creadora del hombre la que hace de él un ser proyectado hacia el futuro, un ser que contribuye a crear y que modifica su presente" (Vigotsky, 1990, p.9).

Los componentes de la creatividad se evidencian y desarrollan mediante el proceso educativo, puesto que éste ofrece escenarios propicios para formar mentes creativas y transformadoras de la realidad. Por esta razón, es importante que el maestro implemente metodologías que ayuden a potenciar y fortalecer la creatividad de los estudiantes. ¿Cómo se puede potenciar la creatividad? Como todas las capacidades humanas, la creatividad puede ser desarrollada y mejorada a través de estrategias pedagógicas innovadoras mediadas por el maestro; existen diversas formas para desarrollar y fortalecer ésta (Velásquez B., Remolina de Cleves, N. y Calle G., 2010, p. 327) 
A partir de estos antecedentes, en el presente artículo, se delimitará la fundamentación teórica acerca de las teorías relacionadas con nuestra propuesta metodológica que nos lleva a estudiar los métodos del pensamiento, o técnicas de trabajo intelectual, que según las operaciones básicas de la inteligencia, están referidas al pensar y al hacer, así como a la codificación de un sistema simbólico de significados que recopila, almacena y organiza los tipos importantes de información, íntimamente relacionados, con algunas teorías y métodos para la creatividad y al modelado de las competencias básicas, equivalente a la inteligencia en potencia.

\section{TEORÍAS RELACIONADAS}

La palabra creatividad es utilizada muy a menudo en la sociedad actual, pero pocos se detienen en recabar en qué consiste. En numerosas ocasiones, se ha preguntado en clase a los alumnos por su significado o escuchado en discursos de colegios de nińos, a políticos, etc., para corroborar que sólo conocen una pequeńa segmento de ésta.

La mayor parte de sus estudiosos coinciden en que es la capacidad que desarrolla el hombre para devenir, para dar múltiples soluciones a un problema, para crear un mundo hecho a su medida y adaptarse a todas las situaciones de la vida y que esta forma de interactuar con su entorno conlleva un conjunto de potencialidades que es preciso desarrollar. "De todos los poderes del hombre, el de su capacidad de creación parece ser el más excepcional” (Curtis, J. Demos G. y Torrance, E., 1996, p. 9).

"Para Guilford, la creatividad consiste en cierto número de factores intelectuales estrechamente relacionados, encuadrados en el llamado "pensamiento divergente" ... dentro de su esquema estructural del intelecto. En esta categoría de la estructura de la inteligencia, reviste especial importancia el vértice formado por la intersección de los contenidos semánticos con la producción del pensamiento divergente" (Curtis, J. Demos G. y Torrance, E., 1996, p. 15).

Muchas de estas potencialidades de la creatividad se pueden equiparar con operaciones básicas de la inteligencia y se deben desarrollar y/o modelar, atendiendo a diferentes métodos que propician su avance.

Sierra, R. (2003) establece dos grandes modalidades de actividad humana, el pensar y el actuar, que define como métodos o técnicas concernientes al pensamiento o a la inteligencia, a las que dice que podemos llamar "métodos del pensamiento o, si se prefiere, técnicas de trabajo intelectual” (Sierra, R., 2003, p.73). 
Añade, además que las técnicas de trabajo intelectual deben abarcar las múltiples operaciones de la inteligencia y que se pueden clasificar en tres grandes grupos dependiendo de a qué se atribuya:

- Si está referida a la inteligencia, la considera como una capacidad para entender y formar conceptos y juicios.

- Si concierne al razonamiento, la define como una aptitud para adquirir proposiciones o juicios por inferencia de otros previos.

- Si depende de la invención, la considera como "la chispa que se enciende en nosotros espontáneamente y sin un proceso lógico previo, cuando tenemos la intuición de una idea, que es la solución a una idea o dificultad" (Sierra, 1994, p.74). Explica que las operaciones básicas de la inteligencia, referidas a algunos métodos y técnicas de pensar, las podemos relacionar con la invención o creatividad: la formación de conceptos y de juicios, las proposiciones y enunciados y el razonamiento o realización de inferencias (Sierra, R.1994).

Expone que la formación de conceptos y de juicios, pertenecen a la observación de una realidad y que el razonamiento está configurado por otros productos mentales.

Considera la creación y la creatividad como técnicas intelectuales sobre el razonamiento y la inteligencia, pertenecientes al tercer grupo y precisan una consideración previa de los siguientes términos que ayudaran a comprenderlas: invención, descubrimiento, imaginación, intuición e inspiración (Sierra, 1994).

En el siguiente mapa conceptual se resume e interrelaciona la vinculación existente entre estos métodos con la forma de pensar del individuo, según los planteamientos de Sierra, R (2003). 
Fig. 1. Esquema: La creatividad como operación básica de la inteligencia

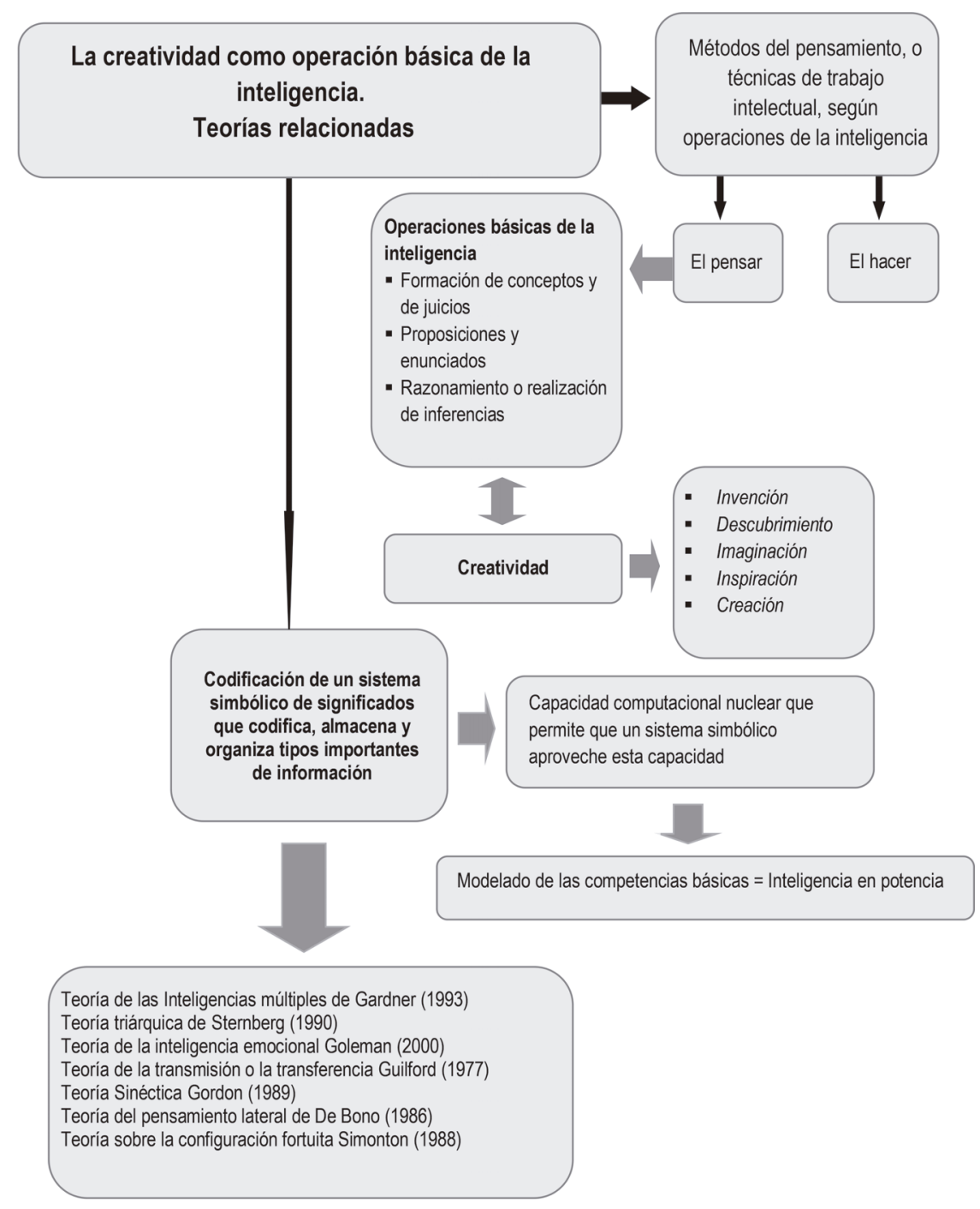

Fuente: elaboración propia.

"Bronowski (1958, p. 59) distingue entre descubrimiento, invento y creación, puntualizando que Colón “descubrió América, Bell “inventó” el teléfono y Shakespeare "creó" Otelo. Los hechos se descubren, las teorías se inventan, 
pero sólo las obras maestras crean, pues en su creación se hallan implícitas todas las potencias del espíritu" (Curtis, J., Demos, G. y Torrance, E., 1996, p.9).

La invención: está asociada a personas con un talento especial para crear acciones o instrumentos que ayuden a dar soluciones a problemas.

Una invención es la creación de un objeto, producto, teoría o proceso que implica siempre la alteración de determinada materia, o materiales. Como es sabido, la capacidad inventiva es casi exclusivamente humana y salvo contados casos, en la naturaleza sólo el hombre ha desarrollado la posibilidad de tomar elementos de ella para transformarlos en compuestos de mayor complejidad y utilidad

(http://www.definicionabc.com/tecnologialinvencion.php\#ixzz2ZmdpTSO0).

El descubrimiento: desvela algo que ya existía y que el hombre, mediante la exploración de su mundo, encuentra.

La imaginación: según Drubach, D., Benarroch, E. y Mateen, F. (2007):

Definimos la imaginación como el proceso cognitivo que permite al individuo manipular información generada intrínsecamente con el fin de crear una representación que se percibe a través de los sentidos de la mente'. Esta definición se amplía dentro del contexto de la neurobiología del cerebro y el posible propósito que la imaginación satisface en la vida diaria, en el desarrollo humano y en el comportamiento normal. (p. 45)

La inspiración: existen muchas teorías a lo largo de la historia sobre su significado, desde los modelos antiguos de inspiración de Platón (427-347 a.C.), hasta el materialismo de Jameson (1981), según la época y el cristal ideológico con que sea estudiada. Para (Brogan, 1993) en la psicología moderna materialista, tanto si se trata de una tendencia empirista o mística, la inspiración se considera un proceso completamente interno y, por su propia naturaleza, se encuentra fuera de nuestro control. La inspiración proviene de que el artista esté especialmente "en sintonía" para captar las señales de una crisis externa.

La inspiración se puede considerar como aquel momento en que se produce un estado mental idóneo que reúne las condiciones internas y externas apropiadas para que los factores intrínsecos, referidos a los conocimientos, sentimientos e ideas, interaccionen con los extrínsecos, ambientales, sociales, culturales, y fluyan así con espontaneidad, en un acto de exteriorización de conocimientos, 
imaginación, invención, o experiencia de cualquier índole cotidiana. Por tanto y en contraposición con la psicología materialista, mencionada con anterioridad, al igual que la motivación, la inspiración dependerá también, en cierta medida, de la creación de un ambiente propicio.

La creación: por lo general desde la antigüedad hasta nuestros días, el término creación se relaciona con respecto a la Creación del Universo. Se considera un fenómeno enormemente complejo y de difícil comprensión para el ser humano que todavía no ha llegado a alcanzar un concepto claro sobre su origen y que enfrenta posturas científicas sobre los aspectos físicos y químicos que originaron la existencia y formación del universo y, religiosas en cuanto otorgar la forma de lo que hoy conocemos como universo al designio divino. Sea cual sea la postura de la ciencia o de la religión, la creación del universo es el fenómeno más complejo e importante de la historia ya que sólo a partir de ella existimos como seres humanos y como parte integrante de un engranaje, cada vez más complejo dentro de un universo en continuo cambio.

En la actualidad se considera creación a todo aquello que sin haber existido con anterioridad, llega a existir, a partir de un proceso de elaboración, para adoptar una forma física real, o imaginaria.

Según Vasari, "El arte, como el hombre, apareció con la Creación, y desde entonces pertenece al mundo. Es inútil preguntarse dónde y cuándo se practicó por primera vez, pues la causa inicial de este arte fue la naturaleza misma" (citado en Panofsky, 1984, p. 77).

Las teorías actuales sobre la relación de la creatividad como operación básica de la inteligencia, según García, E. (2009), están basadas en la codificación de un sistema simbólico de significados, producto de la cultura, que codifica, almacena y organiza los diferentes tipos importantes de información. Los distintos lenguajes como la música, la pintura, las matemáticas, son sistemas de símbolos, prácticamente universales, que se necesarios para la supervivencia y evolución de la humanidad. La relación entre una inteligencia y un sistema simbólico humano debe su existencia a una capacidad computacional nuclear que permite que un sistema simbólico aproveche esta capacidad. La inteligencia puede funcionar sin un sistema simbólico, pero, sin embargo, se caracteriza por su tendencia a formalizarlo. Las distintas capacidades funcionarán con un ciclo evolutivo diferente, por lo que en unas áreas como las matemáticas y la música se detecta la superdotación en niños de edades tempranas, mientras que en otras, como la inteligencia personal, requieren una madures más avanzada. De esta manera, el talento en un tipo de inteligencia no implica dotación en las demás. En cuanto a la creatividad, no tiene por qué estar relacionada 
con el arte, puesto que se puede ser creativo en cualquiera de los campos de acción y contextos de la vida. "Una persona puede ser creativa en unos campos y normal o incluso limitada en otras áreas" (García, E., 2009, p. 18). En este sentido, la multidimensionalidad y modularidad de la mente hace prácticamente imposible la superdotación en todos los campos.

Las competencias básicas o lo que podríamos denominar "inteligencia en potencia" se van modelando, conformando y desarrollando en el proceso de socialización durante la primera infancia. Los nińos van adquiriendo los conocimientos y destrezas en las diversas inteligencias, asimilando los sistemas simbólicos disponibles en la cultura (García, E., 2009, p. 18).

A partir del entorno sociocultural y de su dotación genética los individuos desarrollan unas capacidades u otras, se plantean problemas relacionados con su crecimiento personal y consiguen resultados. Gardner distingue ocho inteligencias: lingüística, lógico-matemática, naturalista, espacial, musical, cinéticocorporal, intrapersonal e interpersonal. Lo habitual es que para la resolución de cualquier situación, se pongan en funcionamiento varias inteligencias para responder con eficacia ante dicha realidad, aunque cada uno de los tipos de inteligencia funcione de forma independiente (García, E., 2009).

Las interacciones entre varios de estos tipos de inteligencia, puede llegar a generar una extraordinaria diversidad de perfiles humanos. "Una persona puede no ser particularmente dotada en inteligencia alguna y, sin embargo, la combinación única y especial de sus capacidades le permite una identidad irrepetible (García, E., 2009, p. 19).

Destacamos, a continuación, las siguientes teorías relacionadas de forma más cercana, con nuestra metodología de trabajo:

- La teoría de las Inteligencias múltiples de Gardner (1993), impulsa las teorías actuales relacionadas con la inteligencia emocional. El concepto principal que da sentido a este proyecto es la definición que Gardner hace sobre la inteligencia para darle valor de capacidad. Esto significa que una capacidad se convierte en destreza y, por tanto, se puede desarrollar. Postula que cada inteligencia tiene su propia forma de percepción, de memoria y de aprendizaje.

En definitiva, el modelo propuesto por Gardner, en el que la inteligencia se comporta como un conjunto de capacidades independientes y entrenables para su desarrollo, configuran personalidades distintas y singulares en las que la motivación juega un papel importante. (Gardner, 2000). 
Su hipótesis, sobre la independencia absoluta entre los diferentes tipos de inteligencia, ha sido criticada por haberse encontrado relación entre algunas capacidades, cosa que contradice en parte su teoría.

Para tener éxito en el siglo XXI, propone cinco tipos de habilidades mentales, entre las que incluye la creatividad:

$\checkmark$ Mente disciplinaria, basada en el dominio de las grandes escuelas del pensamiento, las ciencias, las matemáticas y la historia, además de un oficio profesional.

$\checkmark$ Mente sintetizadora, consistente en la capacidad de integrar ideas de distintas disciplinas o áreas de forma coherente y poder comunicarlo a los demás.

$\diamond$ Mente creativa, desarrolla la capacidad de descubrir y clarificar los nuevos problemas, preguntas y fenómenos.

$\checkmark$ Mente respetuosa, tiene su raíz en el conocimiento y aprecio de las diferencias entre los seres humanos y los grupos de humanos.

$\diamond$ Mente ética, basada en el cumplimiento de la responsabilidad en el mundo laboral y social. Gardner (2007).

- Teoría triárquica de Sternberg (1990), figura destacada por sus investigaciones sobre la inteligencia humana, aporta a este trabajo la definición de inteligencia como la adaptación al cambio. Propone tres tipos de inteligencia: analítica, creativa y práctica. Cada uno de estos tres tipos conforman subteorías parciales que se complementan entre sí: componencial, experiencial y contextual.

Para Sternberg (1998), la creatividad depende de los siguientes componentes:

$\diamond$ La inteligencia (práctica, analítica y sintética).

$\diamond$ Los estilos de pensamiento.

$\diamond$ La motivación.

$\diamond$ Las características de personalidad (tales como la fe en uno mismo, la perseverancia, el valor de defender las convicciones propias).

$\diamond$ El conocimiento.

Su Teoría triárquica de la inteligencia, coincide en muchos aspectos con los método propuestos para la experimentación artística como experiencia formadora, en cuanto a sus fases seguidas, en la que destacan los mismos procesos intelectuales aunque con diferente nivel de calidad y originalidad.

Este supuesto incluye tres componentes: estilos cognitivos, personalidad (los aspectos de la motivación intrínseca e extrínseca), e inteligencia 
constituida por tres elementos: metacognición, habilidades intelectuales y contexto. (Sternberg, 1990).

- Concepto de inteligencia emocional de Goleman (2000), ofrece un sentido más amplio en el que influyen factores emocionales, sociales y culturales. Aporta, a la fundamentación teórica de nuestra metodología de trabajo, la forma de interactuar con el mundo, teniendo en cuenta los sentimientos, la globalización de habilidades como el control de impulsos, la autoconciencia, la motivación, el entusiasmo, la perseverancia, la empatía, la agilidad mental, etc. Para este autor, las habilidades como la autodisciplina, la compasión y el altruismo son imprescindibles para una buena adaptación.

- Teoría de la transmisión o de la transferencia de Guilford (1977) en los que resalta los elementos que resultan importantes para la invención creadora y que comportan dos tipos de capacidades del pensamiento: el pensamiento divergente, y el pensamiento convergente. Además, la destaca como una capacidad de evaluar informaciones y sacar consecuencias. La sensibilidad ante los problemas forma parte de la capacidad de valoración. Su teoría es una propuesta esencialmente intelectual que sostiene que el individuo creativo está motivado por el impulso intelectual de estudiar los problemas y encontrar soluciones a los mismos. Su modelo, basado en el análisis combinatorio, consta de tres dimensiones, ya que todo comportamiento inteligente debería caracterizarse por operaciones del pensamiento, sus contenidos y su producto.

Se centra en la formulación, por fases, en primer lugar, de un pensamiento divergente y, a continuación, la culminación del problema mediante un pensamiento convergente en su resolución.

Propulsa el concepto de pensamiento divergente, como aquel que despliega una manera original, novedosa y respetuosa con las ideas para resolver problemas.

Define el perfil de las personas creativas tomando en cuenta tres factores: originalidad, fluidez, flexibilidad, y elaboración, a fin de producir muchas ideas en respuesta a un problema. Se trata de individuos que destacan por su sensibilidad para localizar los problemas presentes en determinado campo de investigación y proponer múltiples y diferentes enfoques para su resolución.

Fernández E. (2011) equipara el pensamiento divergente de Guilford (1991) como paralelo al pensamiento lateral de De Bono (1986).

Los métodos propuestos en este proyecto están basados en gran medida en las teorías de Guilford (1991) y Gordon (1989), implícitas en sus procesos. 
- Teoría Sinéctica Gordon (1989). Su significado proviene del griego, y significa la acción de juntar elementos diferentes, poco significativos y desconectados de forma aparente. Esta teoría se refiere a la integración de diversos individuos en un grupo para el planteo y solución de problemas. (Fernández, E., 2011).

La Sinéctica define el proceso creativo como la actividad mental en la enunciación de problemas, y su resolución mediante creaciones artísticas o técnicas. La exposición acertada implica definición y entendimiento de qué se trata. El proceso sinéctico incluye: a).- Hacer familiar lo extraño, b).- Hacer extraño lo familiar, c).- Analogía personal, d).- Analogía directa, e).- Analogía simbólica, y f).- Analogía fantasiosa (Davis, G. y Scott, J., 1989).

Parece revelar los resultados creativos como pensados con el corazón. Así afirma que:

La eficacia creativa de las personas puede aumentarse notablemente si se les hace comprender los procesos psicológicos que se ponen en funcionamiento; en el proceso creativo, el componente emocional es más importante que el intelectual, el irracional más importante que el racional; son estos elementos emocionales e irracionales los que pueden y deben ser comprendidos para aumentar las posibilidades de éxito en toda situación de solución de problemas (Davis, G. y Scott, J., 1989, p. 81).

En la fase experimental de la investigación sobre los métodos que se proponen en la experimentación se tomará de la Sinéctica a).- Hacer familiar lo extraño, b).- Hacer extraño lo familiar.

- El pensamiento lateral de De Bono (De Bono, E. 1986). Además, de tener una relación muy próxima con la teoría Sinéctica, aporta una actitud y un proceso deliberado para generar ideas nuevas, mediante la estructuración de esquemas conceptuales (intuición), y la provocación de otros nuevos (creatividad).

El mismo autor sostiene que sólo unas pocas personas tienen una aptitud natural para la creatividad, pero todas pueden desarrollar una cierta habilidad en este campo si se lo proponen.

La creatividad la entiende como una actitud y un hábito mental. Los principios y técnicas del "pensamiento lateral" son los siguientes: reconocimiento de las ideas dominantes; búsqueda de diferentes maneras de 
mirar las cosas; reducción del rígido control del pensamiento vertical; y uso del azar.

Entre muchos otros autores, se pueden destacar algunos que también presentan similitudes con este proyecto como:

- Amabile (1985) que enfatiza el papel de la motivación intrínseca y desarrolla un modelo de creatividad con tres componentes: destrezas relevantes para el campo, destrezas relevantes para la creatividad motivación por la tarea.

- Simonton (1988), con su Teoría sobre la configuración fortuita, en la que incluye factores cognitivos como la permutación fortuita de elementos mentales (cambios aleatorios entre unidades psicológicas fundamentales), la información de configuraciones y la aceptación social de las configuraciones. Como factores no cognitivos destaca el interés y la motivación.

- Csizkszemtmihalyi (1998) que precisa tres elementos centrales en cualquier consideración de la creatividad: la persona o talento creador, el campo o disciplina en que ese individuo está trabajando y el ámbito circundante que emite juicios sobre la calidad de los individuos y de los productos.

En los siguientes cuadros de las Fig.1. y Fig.2., se muestra una síntesis de la aplicación de las teorías relacionadas, mencionadas con anterioridad, con los métodos propuestos y el uso que se ha tomado de cada una de ellas en referencia a estos supuestos. 
Fig. 2. Cuadro: aplicación de teorías relacionadas con el Proceso de materialización de una imagen o idea

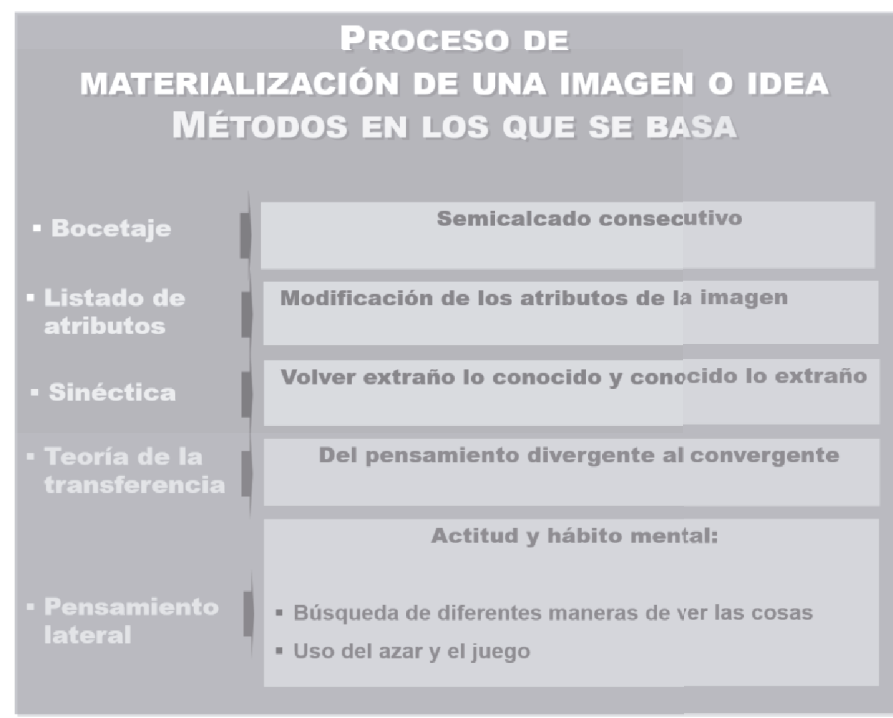

Fuente: elaboración propia.

Fig. 3. Cuadro: aplicación de teorías relacionadas con el Método de conceptualización

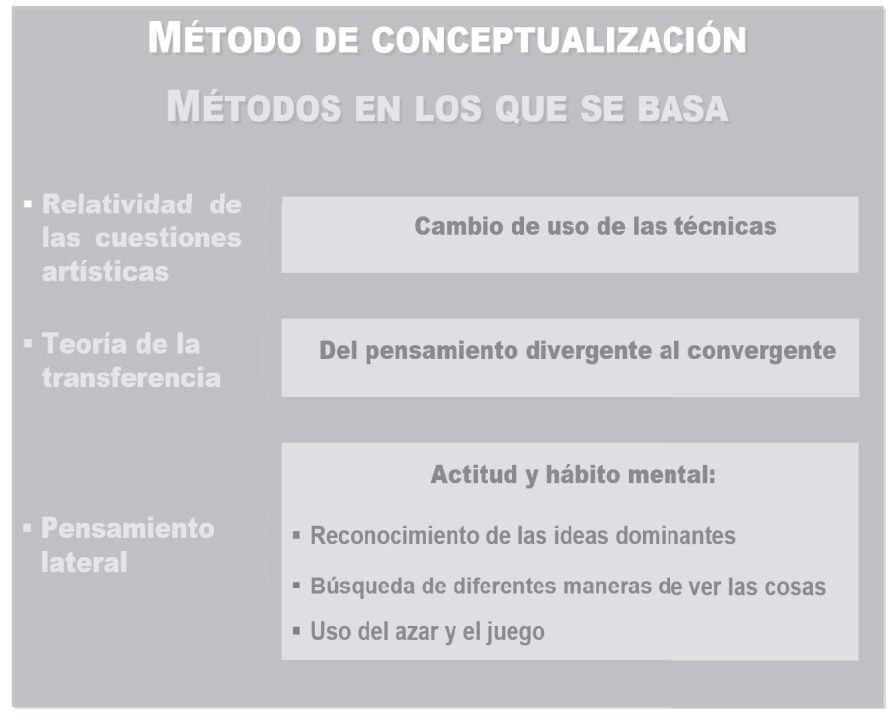

Fuente: elaboración propia.

Estudios En homenaje a EMigdia RePetto JiméneZ 


\section{CONCLUSIONES}

La fundamentación teórica expuesta ha servido para consolidar el objetivo fundamental de este trabajo en cuanto a encontrar respuestas y afinidades en la consolidación de los métodos diseñados, en relación a la creatividad como operación básica de la inteligencia. Su teoría y su uso han sido reforzadas con la instrucción de los autores más cercanos a este modelo didáctico, referidos a una metodología sistematizada para la evolución de los procesos creativos en la formación artística y para la aprehensión de recursos y procederes para la vida.

Las contrariedades iniciales encontradas en cualquiera de estos métodos sistematizados es producto de un alumnado acostumbrado a seguir modelos, a no salirse de la realidad, ni de los cánones establecidos, por estar instruidos en un pensamiento exclusivamente convergente, por lo que se hace necesario un cambio didáctico, radical, que abogue por la construcción de una mentalidad más abierta a otras posibilidades y tendente a un pensamiento divergente.

La inclinación errónea del alumnado de la Facultad de Ciencias de la Educación hacia la idea de manualidades, muy enraizada en su preparación pedagógica y socio-cultural anterior, en cuanto a su formación artística, debe ser sustituida por el desarrollo de capacidades mentales y conductuales, entre muchos otros valores, a partir de un modelo pedagógico basado en la experimentación como base de una educación enaltecedora basada en el desarrollo de las competencias y capacidades, como operaciones básicas de la inteligencia, desde edades tempranas.

Los dos métodos, pertenecientes a La experimentación como experiencia formadora, poseen un vasto potencial de investigación, tanto cualitativo como cuantitativo, para su aplicación en todos los niveles formativos, a partir de los seis ańos competenciales, y en niños y adultos con NEAE, entre otras muchas aplicaciones.

\section{REFERENCIAS BIBLIOGRÁFICAS}

ABC (2007-2014) Definiciones. Recuperado el 25/08/2020 de:

http://www.definicionabc.com/tecnologia/invencion.php\#ixzz2ZmdpTS00 Amabile, T.M. (1985) The Social Psychology of Creativity: a componential conceptualization. Journal of Personality and Social Psychology, 45 (2), pp. 357-376.

Brogan, T.V. (1993). Inspiration in Alex Preminger and T.V.F. Brogan, Eds. The New Princeton Encyclopedia of Poetry and Poetics. Princeton, NJ: Princeton University Press, pp. 609- 
Csikszentmihalyi, M. (1998). Creatividad: el fluir y la psicología del descubrimiento y la invención, Barcelona: Paidós Ibérica.

Curtis, J.; Demos, G. y Torrance, E. (1976). Implicaciones educativas de la creatividad. Salamanca: Anaya.

Davis, G. y Scott, J. (1989). Estrategias para la creatividad. Buenos Aires: Piados Educador.

De Bono, E. (1986). EL Pensamiento lateral. Manual de Creatividad. Barcelona: Paidós.

Curtis, J. Demos G. y Torrance, E. (1996). Implicaciones educativas de la creatividad. Ciencias de la Educación, pp. 9-14. Madrid: Anaya/2.

Drubach, D., Benarroch E., Mateen F. (2007). Imaginación: definición, utilidad y neurobiología. Revista de Neurología, [REV NEUROL; 45: 353-8] Recuperado el 07/ 08/ 2013 de: http://www.neurologia.com/pdf/Web/4506/y060353.pdf

Fernández, E. (2011). Categorias sobre la creatividad. Recuperado el 08/08/2013 de:

http://blog.ciencianueva.com/2011/01/\%E2\%80\%9Cteorias-sobre-la creatividad\%E2\%80\%9D/

García, García E. (2009). Aprendizaje y construcción del conocimiento. En López Alonso, C. y Matesanz del Barrio, M. (Eds.). Las plataformas de aprendizaje. Del mito a la realidad, pp. 21-44. Madrid: Biblioteca Nueva. Recuperado el 10/08/2020 de:

https://eprints.ucm.es/9973/1/APRENDIZAJE__Y_CONSTRUCCION_DEL_CONOCIMIENTO.pdf

Gardner, H. (1993). Inteligencias Múltiples: la teoría en la práctica. Barcelona: Paidós.

Gardner, H. (2007). Five minds For The Future. Harvard Bussines Schoool Press. Recuperado el 15/08/2013 de:

http://en.wikipedia.org/wiki/Multipleintelligences y de

http://ngfl.northumberland.gov.uk/thinking/learning/intell/frames/intel.htm

Gardner, H. (2000). La educación de la mente y el conocimiento de las disciplinas. Barcelona: Paidós.

Goleman, D. (2000). La práctica de la inteligencia emocional. Barcelona: Ed. Kairós.

Gordon, W. (1989). Sinéctica: Historia, evolución y métodos. En Estrategias para la creatividad. Barcelona: Paidós Educador, (7) pp. 77-94.

Guilford, J.P.; (1977). La naturaleza de la inteligencia humana. Buenos Aires: Paidós. 
Guilford, J. y Otros (1991). Creatividad y educación. Buenos Aires: Paidós Educador.

Jameson, F. (1981). Documentos de cultura, documentos de barbarie, Madrid: Visor.

Panofsky, E. (1980). Idea. Contribución a la historia de la teoría del arte. Madrid, Cátedra, 1980.

Sierra, S. (2003). Tesis doctorales y trabajos de Investigación Cientifica. Madrid: Ed. Paraninfo.

Simonton (1988) Scientific genius: A psychology of science. New York: Cambridge University Press.

Sternberg, R. (1990). Más allá del cociente intelectual. Una teoría triárquica de la inteligencia humana. Bilbao: Desclée de Brouwer.

Sternberg, R. (1998). Enseñar a pensar. Madrid: Siglo XXI.

Velásquez B., Remolina de Cleves, N. y Calle G. (2010). La creatividad como práctica para el desarrollo del cerebro total. No.13: 321-338, julio-diciembre 2010 Tabula Rasa. Bogotá - Colombia. Recuperado el 12/08/2020 de: http://www.scielo.org.co/pdf/tara/n13/n13a14. pdf

Vigotsky, L. (2009). La imaginación y el arte en la Infancia (ensayo psicopedagógico). Madrid: Akal. 



\title{
INTRODUCCIÓN A LA QUÍMICA DEL CARBONO: UNA PROPUESTA DE UNIDAD DIDÁCTICA DE FÍSICA Y QUÍMICA DE $4^{\circ}$ DE LA ESO BASADA EN SITUACIONES PROBLEMÁTICAS DE APRENDIZAJE
}

\author{
Rafael Millán Gómez \\ IES Guillermina Brito (Profesor de Física y Química de Educación Secundaria) \\ Francisco Martínez Navarro \\ IES Alonso Quesada (Profesor de Física y Química de Educación Secundaria Jubilado)
}

\section{Resumen}

En esta Unidad Didáctica de Física y Química de $4^{\circ}$ de la ESO basada en Situaciones Problemáticas de Aprendizaje, realizamos una Introducción a la Química del Carbono, con un enfoque de relaciones entre: Ciencia, Tecnología, Sociedad y Medio Ambiente (CTSA). Para su realización partimos del análisis de los criterios de evaluación y sus estándares de aprendizaje evaluables, que hacen de indicadores de evaluación, hasta llegar a un programa de tareas, actividades y situaciones de aprendizaje. Para ello hemos seguido el modelo de enseñanza aprendizaje por investigación orientada, basándonos en las enseñanzas recibidas por Da Emigdia Repetto a la que le dedicamos el presente trabajo.

Palabras clave: Unidad Didáctica, Situaciones Problemáticas de Aprendizaje, Química del carbono, investigación orientada.

\begin{abstract}
In this Didactic Unit of Physics and Chemistry of 4th ESO based on Problematic Learning Situations, we carry out an Introduction to Carbon Chemistry, with a focus on relationships between: Science, Technology, Society and Environment (CTSA). To carry it out, we start from the analysis of the evaluation criteria and their evaluable learning standards, which act as evaluation indicators, until we reach a program of tasks, activities and learning situations. For this, we have followed the research-oriented teaching-learning model, based on the teachings received by Ms. Emigdia Repetto to whom we dedicate this work.
\end{abstract}

Keywords: Didactic Unit, Problematic Learning Situations, Carbon Chemistry, oriented research. 


\section{INTRODUCCIÓN}

La química desde sus inicios en el siglo XVIII y XIX, se divide en dos grandes ramas: química orgánica y química inorgánica. La Química orgánica se asoció a la química de las sustancias producidas por los seres vivos. Se pensaba que las sustancias orgánicas sólo las podían sintetizar los organismos vivos, porque para preparar compuestos orgánicos se necesitaba algo que sólo poseían los seres vivos la fuerza vital. Esto pensaba el gran químico sueco Jacob Berzelius, a principios del siglo XIX, pero uno de sus discípulos, Friedrich Wholer, logra sintetizar, en 1828 en el laboratorio (in vitro) la urea, con lo que dejó de tener sentido el nombre de química orgánica, que desde entonces pasó a llamarse química del carbono.

En esta Unidad Didáctica de Física y Química de $4^{\circ}$ de la ESO basada en Situaciones Problemáticas de Aprendizaje, realizamos una Introducción a la Química del Carbono, con un enfoque de relaciones entre: Ciencia, Tecnología, Sociedad y Medio Ambiente (CTSA). Para su realización partimos del análisis de los criterios de evaluación y sus estándares de aprendizaje evaluables, que hacen de indicadores de evaluación, hasta llegar a un programa de tareas, actividades y situaciones de aprendizaje. Para ello, hemos seguido el modelo de enseñanza y aprendizaje por investigación orientada, basándonos en las enseñanzas recibidas por $\mathrm{D}^{\mathrm{a}}$ Emigdia Repetto a la que le dedicamos el presente trabajo y que hemos compartido juntos en numerosos trabajos anteriores (Martínez y Repetto: 1997, 2005, 2010) y (Repetto, Martínez y Calvo, 2004, 2005).

En la tabla 1, partimos de los criterios de evaluación y sus estándares de aprendizaje evaluables, del Decreto 83/2016 del Gobierno de Canarias, que responden al qué evaluar, pues en ellos se encuentran los aprendizajes que el alumnado debe de adquirir y que el profesorado por tanto debe de enseñar y evaluar. Partiendo del análisis de los estándares de aprendizaje evaluables, de los criterios de evaluación que hemos adaptado y completado, verificamos cuáles son los procesos cognitivos o capacidades presentes en los mismos, los diferentes tipos de contenidos y las competencias con las que más se relacionan o a las que más se contribuye con dichos aprendizajes, proponemos las tareas, actividades y situaciones de aprendizaje, más adecuadas para que el alumnado al realizarlas aprenda y adquiera dichos conocimientos.

El análisis de la tabla 2 de relaciones nos muestra también el carácter equilibrado de la propuesta al contener procesos cognitivos de las tres categorías (básicos, intermedios y superiores), los tres tipos de contenidos y se relaciona 
Introducción a la química del carbono: una propuesta de unidad didáctica de fisica y química ...

y contribuye a gran parte de las competencias clave, así como su carácter coherente, al mostrar la relación y coherencia entre el qué evaluar, el qué enseñar y el cómo enseñar. La tabla de relaciones nos muestra también el carácter criterial (pues parte de los criterios y de sus estándares). El carácter inclusivo, proponiendo un programa de actividades multinivel, al alcance de las diversas capacidades del alumnado y el carácter competencial, al relacionarse con las competencias clave y utilizar una metodología o aprendizaje basada en abordar situaciones problemáticas relevantes y contextualizadas.

En la tabla 3, recogemos el cuadro de programación de la UD, con el programa de actividades, tareas y situaciones de aprendizaje propuestas para las 10 sesiones de trabajo. 


\title{
2. DE LOS CRITERIOS DE EVALUACIÓN Y SUS ESTÁNDARES A LAS TAREAS, ACTIVIDADES Y SITUACIONES PROBLEMÁTICAS DE APRENDIZAJE
}

\author{
Tabla 1: Criterios de evaluación y sus estándares. \\ Contenidos y su relación con las competencias clave.
}

\begin{abstract}
Criterio de evaluación 5:
5. Justificar la particularidad del átomo de carbono, la gran cantidad de compuestos orgánicos existentes, así como su enorme importancia en la formación de macromoléculas sintéticas y en los seres vivos. Reconocer los principales grupos funcionales, presentes en moléculas de gran interés biológico e industrial, en especial algunas de las aplicaciones de hidrocarburos sencillos, en la síntesis orgánica o como combustibles, representándolos mediante las distintas fórmulas y relacionarlos con modelos moleculares reales o generados por ordenador.

Mostrar las aplicaciones energéticas derivadas de las reacciones de combustión de hidrocarburos, su influencia en el incremento del efecto invernadero, en el cambio climático global y valorar la importancia de frenar su empleo para así avanzar, con el uso masivo de las energías renovables en Canarias y en todo el planeta, hacia un presente más sostenible.

Se trata de evaluar si el alumnado explica las enormes posibilidades de combinación que presenta el átomo de carbono, analiza sus distintas formas alotrópicas, sus estructuras y propiedades, y si es capaz de reconocer y representar hidrocarburos sencillos de interés en la vida cotidiana, mediante fórmulas moleculares, semidesarrolladas, desarrolladas y las relaciona con modelos moleculares reales o virtuales, a través de moléculas activas en $3 \mathrm{D}$, generadas por ordenador, indicando asimismo las aplicaciones de hidrocarburos sencillos de especial interés biológico e industrial, valorando, además, si identifica el grupo funcional a partir de la fórmula de alcoholes, aldehídos, cetonas, ácidos carboxílicos, ésteres y aminas. Por último, se quiere comprobar si reconoce el petróleo y el gas natural como combustibles fósiles que, junto al carbono, constituyen las fuentes energéticas más utilizadas actualmente. También se debe valorar si son conscientes del agotamiento de dichas fuentes, de los problemas que sobre el medioambiente ocasiona su combustión y sobre la necesidad de tomar medidas para evitarlos y así acabar con la dependencia energética de Canarias de los combustibles fósiles y, en consecuencia, las dificultades para cumplir los acuerdos internacionales sobre la emisión de gases de efecto invernadero y el uso creciente de las energías renovables, que inicien un presente sostenible y pongan fin al cambio climático.
\end{abstract}

\section{\begin{tabular}{l|l} 
Estándares de & Contenidos
\end{tabular}}

aprendizaje Interpretación de las peculiaridades del átomo de carbono: combinación con el hidrógeno y otros átomos evaluables $\quad$ y formar cadenas carbonadas, con simples dobles y triples enlaces.

relacionados 1. Estructura y propiedades de las formas alotrópicas del átomo de carbono, sus estructuras y propiedade $1,9,22,23,24,2$. Utilización de los hidrocarburos como recursos energéticos. Causas del aumento del efecto invernadero 25, 26, 27. y del cambio climático global y medidas para su prevención.

3. Uso de modelos moleculares, físicos y virtuales para deducir las distintas fórmulas usadas en la representación de hidrocarburos.

4. Descripción de las aplicaciones de hidrocarburos sencillos de especial interés.

5 Reconocimiento del grupo funcional a partir de la fórmula de alcoholes, aldehídos, cetonas, ácidos carboxílicos, ésteres y aminas

6. Problemas socioambientales de la quema de combustibles fósiles. Valoración de la importancia del uso masivo de energías renovables para Canarias y para la Sostenibilidad del planeta.

Estándares de aprendizaje evaluables

1. Describe hechos históricos relevantes en los que ha sido definitiva la colaboración de científicos y científicas de diferentes áreas de conocimiento.

9. Elabora y defiende un proyecto de investigación, sobre un tema de interés científico, utilizando las TIC.

22. Explica los motivos por los que el carbono es el elemento que forma mayor número de compuestos.

23. Analiza las distintas formas alotrópicas del carbono, relacionando la estructura con las propiedades.

24. Identifica y representa hidrocarburos sencillos mediante su fórmula molecular, semidesarrollada y desarrollada.

25. Deduce, a partir de modelos moleculares, las distintas fórmulas usadas en la representación de hidrocarburos.

26. Describe las aplicaciones de hidrocarburos sencillos de especial interés.

27. Reconoce el grupo funcional y la familia orgánica a partir de la fórmula de alcoholes, aldehídos, cetonas, ácidos carboxílicos, ésteres y aminas. 


\section{Tabla 2: Tabla de relaciones de los Indicadores de evaluación a las tareas competenciales}

[Leyenda: Procesos cognitivos: $\mathrm{B}=$ Básicos. I= Intermedios. $\mathrm{S}=$ Superiores. Contenidos: $\mathrm{C}=$ Conceptuales. $\mathrm{P}=$ Procedimentales. $\mathrm{A}=$ Actitudinales. Competencias: $\mathrm{CL}=$ Comunicación lingüística; $\mathrm{CMCT}=\mathrm{Competencia} \mathrm{matemática} \mathrm{y}$ competencias básicas en ciencia y tecnología; $\mathrm{CD}=$ Competencia Digital; $\mathrm{AA}=$ Aprender a aprender; $\mathrm{CSC}=\mathrm{Competencias}$ sociales y cívicas; $\mathrm{SIEE}=$ Sentido de iniciativa y espíritu emprendedor; $\mathrm{CEC}=$ Conciencia y expresiones culturales]

\begin{tabular}{|c|c|c|c|c|}
\hline ¿Qué evaluar? & \multicolumn{3}{|l|}{ ¿Qué enseñar } & ¿Cómo enseñar? \\
\hline $\begin{array}{l}\text { Estándares de a. e. } \\
\text { (Indicadores evaluación) }\end{array}$ & $\begin{array}{l}\text { Procesos cognitivos } \\
\text { Capacidades }\end{array}$ & Contenidos & Competencias & Algunas Tareas \\
\hline $\begin{array}{l}\text { 1. Explica los motivos } \\
\text { por los que el carbono es } \\
\text { el elemento que forma } \\
\text { mayor número de } \\
\text { compuestos. }\end{array}$ & $\begin{array}{l}\text { Explica (B: } \\
\text { Reproducción). }\end{array}$ & $\begin{array}{l}\text { C1: Gran cantidad } \\
\text { de compuestos del } \\
\text { carbono. }\end{array}$ & CMCT; CL & $\begin{array}{l}\text { T1: Comentario de texto y vídeo } \\
\text { sobre el origen histórico de la } \\
\text { química del carbono. } \\
\text { A1.2: Comentario de Texto y } \\
\text { cuestionario de opción múltiple para } \\
\text { justificar porque el carbono forma } \\
\text { gran cantidad de compuestos. }\end{array}$ \\
\hline $\begin{array}{l}\text { 2. Analiza las distintas } \\
\text { formas alotrópicas del } \\
\text { carbono, relacionando } \\
\text { la estructura con las } \\
\text { propiedades. }\end{array}$ & $\begin{array}{l}\text { Analiza (I: Relación) } \\
\text { Relaciona (I: } \\
\text { Relación) }\end{array}$ & $\begin{array}{l}\text { C2: Formas } \\
\text { alotrópicas del } \\
\text { carbono. } \\
\text { P1: Estructura y } \\
\text { propiedades del C. } \\
\text { (Videos y } \\
\text { animaciones) }\end{array}$ & $\begin{array}{l}\text { CMCT; } \\
\text { AA } \\
\text { CD }\end{array}$ & $\begin{array}{l}\text { T2: Reconocer las formas alotrópicas } \\
\text { del carbono y relacionar la estructura } \\
\text { de cada una con sus propiedades. } \\
\text { A2.2. Comentario de textos y } \\
\text { biografías de de científicos } \\
\text { implicados }\end{array}$ \\
\hline $\begin{array}{l}\text { 3. Identifica y } \\
\text { representa } \\
\text { hidrocarburos sencillos } \\
\text { mediante su fórmula } \\
\text { molecular, } \\
\text { semidesarrollada y } \\
\text { desarrollada. }\end{array}$ & $\begin{array}{l}\text { Identifica (B: } \\
\text { Reproducción) } \\
\text { Representa } \\
\text { (B: Reproducción) }\end{array}$ & $\begin{array}{l}\text { P2: Formula } \\
\text { molecular, } \\
\text { semidesarrollada, y } \\
\text { desarrollada de } \\
\text { hidrocarburos. }\end{array}$ & $\begin{array}{l}\text { CMCT } \\
\mathrm{CD}\end{array}$ & $\begin{array}{l}\text { T3: Formular y nombrar } \\
\text { hidrocarburos sencillos. Relacionar } \\
\text { nombres con formulas molecular, } \\
\text { semidesarrollada y desarrollada. } \\
\text { A.3.2. Determinar formulas } \\
\text { empíricas y moleculares a partir de las } \\
\text { composición centesimal y la masa } \\
\text { molecular (Ampliación). }\end{array}$ \\
\hline $\begin{array}{l}\text { 4. Deduce, a partir de } \\
\text { modelos moleculares, las } \\
\text { distintas fórmulas } \\
\text { usadas en la } \\
\text { representación de } \\
\text { hidrocarburos. }\end{array}$ & $\begin{array}{l}\text { Deduce (I: } \\
\text { Relación) } \\
\text { Representa } \\
\text { (B: Reproducción). }\end{array}$ & $\begin{array}{l}\text { P3: Representación } \\
\text { de hidrocarburos } \\
\text { mediante formulas } \\
\text { y modelos } \\
\text { moleculares. (Uso } \\
\text { de ChemSketch) }\end{array}$ & $\begin{array}{l}\text { CMCT } \\
\text { AA } \\
\text { CD }\end{array}$ & $\begin{array}{l}\text { T4: Utilización de modelos } \\
\text { moleculares de bolas y varillas, de } \\
\text { animaciones virtuales y programas } \\
\text { digitales como ChemSketch para } \\
\text { formular y representar hidrocarburos }\end{array}$ \\
\hline $\begin{array}{l}\text { 5. Describe las } \\
\text { propiedades y } \\
\text { aplicaciones de } \\
\text { hidrocarburos sencillos } \\
\text { de especial interés. }\end{array}$ & $\begin{array}{l}\text { Describe (B: } \\
\text { Reproducción) }\end{array}$ & $\begin{array}{l}\text { P4: Aplicaciones } \\
\text { de hidrocarburos. }\end{array}$ & $\begin{array}{l}\text { CMCT } \\
\text { CL } \\
\text { CSC } \\
\text { CD }\end{array}$ & $\begin{array}{l}\text { T5: Realizar una Web Quest para } \\
\text { describir y asignar propiedades y } \\
\text { aplicaciones de algunos } \\
\text { hidrocarburos. } \\
\text { A5.2. Trabajo práctico planteado } \\
\text { como una pequeña investigación: } \\
\text { ¿De qué hidrocarburo se trata? }\end{array}$ \\
\hline $\begin{array}{l}\text { 6. Reconoce el grupo } \\
\text { funcional y la familia } \\
\text { orgánica a partir de la } \\
\text { fórmula de alcoholes, } \\
\text { aldehídos, cetonas, } \\
\text { ácidos carboxílicos, } \\
\text { ésteres y aminas. }\end{array}$ & $\begin{array}{l}\text { Reconoce } \\
\text { (B: Reproducción) }\end{array}$ & $\begin{array}{l}\text { C3: Grupos } \\
\text { funcionales y } \\
\text { formulas de: } \\
\text { hidrocarburos, } \\
\text { alcoholes, } \\
\text { aldehídos, cetonas, } \\
\text { ácidos carboxílicos, } \\
\text { ésteres y aminas. }\end{array}$ & $\begin{array}{l}\text { CMCT } \\
\text { AA } \\
\text { CD }\end{array}$ & $\begin{array}{l}\text { T6: Dada una relación de formulas } \\
\text { orgánicas } \\
\text { Reconocer el grupo funcional y su } \\
\text { nombre en los casos más sencillos }\end{array}$ \\
\hline $\begin{array}{l}\text { 7. Analiza los problemas } \\
\text { socioambientales } \\
\text { causados por la quema } \\
\text { de combustibles fósiles y } \\
\text { valora el uso masivo de } \\
\text { energías renovables para } \\
\text { Canarias y para la } \\
\text { Sostenibilidad del } \\
\text { planeta. }\end{array}$ & $\begin{array}{l}\text { Valora (III: } \\
\text { Reflexión) }\end{array}$ & $\begin{array}{l}\text { P5: Problemas } \\
\text { socioambientales. } \\
\text { A1: Problemas de } \\
\text { combustibles } \\
\text { fósiles. } \\
\text { A2: Valoración de } \\
\text { las energías } \\
\text { renovables. } \\
\text { A3: Valoración de } \\
\text { la sostenibilidad. }\end{array}$ & $\begin{array}{l}\text { CMCT } \\
\text { CSC } \\
\text { SIEE }\end{array}$ & $\begin{array}{l}\text { T7: Realizar una pequeńa } \\
\text { investigación y una revisión } \\
\text { bibliográfica que nos permita, a } \\
\text { través de un informe escrito y } \\
\text { audiovisual, describir, justificar las } \\
\text { causas, sus efectos y soluciones } \\
\text { posibles del aumento de efecto } \\
\text { invernadero y el cambio climático } \\
\text { global. }\end{array}$ \\
\hline
\end{tabular}


Tabla 3: Cuadro de programación de la Unidad Didáctica: 10 sesiones de trabajo

Cuadro de Programación -2: UD4: “Introducción a la química del carbono" Temporalización: 10 sesiones"

\begin{tabular}{|c|c|c|c|c|c|}
\hline & $\begin{array}{l}\text { Programa de tareas y actividades propuestas. Descripción y } \\
\text { comentarios didácticos }\end{array}$ & $\begin{array}{l}\text { Competen } \\
\text { cias }\end{array}$ & $\begin{array}{l}\text { Instrumentos de } \\
\text { evaluación }\end{array}$ \\
\hline \multirow{9}{*}{ 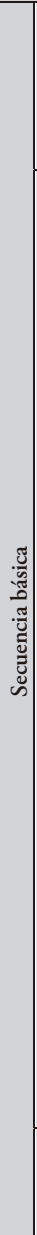 } & 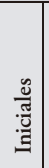 & : & $\begin{array}{l}\text { Presentación de la Unidad y de su importancia por el profesor } \\
\text { T0. Actividades iniciales: KPSI: Lo que crees saber sobre la química } \\
\text { del carbono } \\
\text { Cuestionario de opción múltiple } \\
\text { T1. Indagar sobre cuáles son las propiedades de las sustancias } \\
\text { orgánicas o compuestos del carbono }\end{array}$ & $\begin{array}{l}\text { CMCT; } \\
\text { CL }\end{array}$ & $\begin{array}{l}\text { - Observación directa } \\
\text { - Cuaderno o diario } \\
\text { del profesor. } \\
\text { - Listas de } \\
\text { verificación } \\
\text { - Cuaderno o }\end{array}$ \\
\hline & \multirow{7}{*}{ 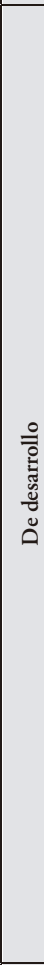 } & 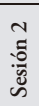 & $\begin{array}{l}\text { T2. Averiguar cuáles son las estructuras y las propiedades características } \\
\text { de las diferentes formas alotrópicas del carbono } \\
\text { Animaciones en Flash-Videos. Pequeña investigación }\end{array}$ & $\begin{array}{l}\text { CMCT; } \\
\text { AA } \\
\text { CD }\end{array}$ & $\begin{array}{l}\text { portfolio del } \\
\text { alumnado. }\end{array}$ \\
\hline & & m & $\begin{array}{l}\text { Situación de aprendizaje: Preparando una ponencia para un congreso } \\
\text { científico ¿Cuáles son las propiedades y aplicaciones de los compuestos } \\
\text { del carbono y cual es el impacto ambiental de sus combustiones? } \\
\text { T3. Investigación sobre las combustiones y sobre el impacto ambiental } \\
\text { de las mismas }\end{array}$ & СMCT & $\begin{array}{l}\text { - Cuaderno o } \\
\text { portfolio del } \\
\text { alumnado. } \\
\text { - Cuaderno o diario }\end{array}$ \\
\hline & & : & $\begin{array}{l}\text { T4. Representación de las distintas formulas de los diferentes } \\
\text { hidrocarburos con modelos moleculares. } \\
\text { Reconocer fórmula empírica, molecular, semidesarrollada, desarrollada } \\
\text { y estructural- Animaciones en flash y uso de ChemSketch } \\
\text { Calculo de formulas empíricas y moleculares }\end{array}$ & $\begin{array}{l}\text { CMCT } \\
\text { AA } \\
\text { CD }\end{array}$ & $\begin{array}{l}\text { del profesor. } \\
\text { - Informe de } \\
\text { laboratorio. } \\
\text { - Listas de }\end{array}$ \\
\hline & & 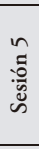 & $\begin{array}{l}\text { T5. Aplicaciones de los principales hidrocarburos y otros compuestos } \\
\text { orgánicos } \\
\text { Comentario de Textos. } \\
\text { Trabajo práctico: Experiencias para diferenciar alcanos y alquenos } \\
\text { Realización de una Webquest y evaluación mediante rúbrica }\end{array}$ & $\begin{array}{l}\text { CMCT } \\
\text { CL } \\
\text { CSC } \\
\text { CD }\end{array}$ & $\begin{array}{l}\text { verificación } \\
\text { - Lista de control con } \\
\text { escala estimativa. } \\
\text { - Rubrica. }\end{array}$ \\
\hline & & 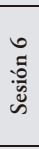 & $\begin{array}{l}\text { T6. Reconoce las principales funciones orgánicas: } \\
\text { Indica y formula el grupo funcional de un compuesto orgánico a través } \\
\text { de la formula de hidrocarburos, alcoholes, aldehídos, cetonas, ácidos } \\
\text { carboxílicos, ésteres y aminas } \\
\text { Analiza y completa tablas }\end{array}$ & $\begin{array}{l}\text { CMCT } \\
\text { AA } \\
\text { CD }\end{array}$ & $\begin{array}{l}\text { - Listas de } \\
\text { verificación } \\
\text { - Cuaderno o } \\
\text { portfolio del alumnado }\end{array}$ \\
\hline & & ڤ్ర & $\begin{array}{l}T 7 \text { Opcional: Nombra y formula compuestos del carbono con las } \\
\text { principales funciones orgánicas } \\
\text { Trabajo experimental: Propiedades de las principales funciones } \\
\text { orgánicas } \\
\text { Biografías de científicos }\end{array}$ & $\begin{array}{l}\text { CMCT } \\
\text { AA } \\
\text { CD }\end{array}$ & $\begin{array}{l}\text { - Listas de } \\
\text { verificación } \\
\text { - Cuaderno o } \\
\text { portfolio }\end{array}$ \\
\hline & & 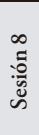 & $\begin{array}{l}\text { T8. Problemas sociambientales causados por la combustión de } \\
\text { combustible fósiles. } \\
\text { Importancia que tendría la utilización masiva de las energías renovables } \\
\text { en Canarias y en el mundo. }\end{array}$ & $\begin{array}{l}\text { CMCT } \\
\text { CSC } \\
\text { SIEE }\end{array}$ & $\begin{array}{l}\text { - Cuaderno o } \\
\text { portfolio - Cuaderno } \\
\text { o diario del profesor. } \\
\text { - Rubrica. } \\
\text { - Prueba escrita o }\end{array}$ \\
\hline & 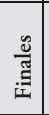 & $\stackrel{\overbrace{}}{0}$ & $\begin{array}{l}\text { T9 ¿Cómo contribuir a los ODS (2015-2030) } \\
\text { Revisión del trabajo realizado } \\
\text { Prueba examen escrita de síntesis del tema }\end{array}$ & $\begin{array}{l}\text { CMCT } \\
\text { CSC } \\
\text { AA }\end{array}$ & $\begin{array}{l}\text { examen. } \\
\text { - Lista de control con } \\
\text { escala estimativa. }\end{array}$ \\
\hline \multirow{2}{*}{ 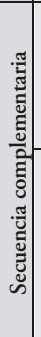 } & \multirow[b]{2}{*}{ 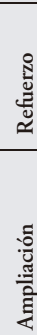 } & \multirow[b]{2}{*}{ 올 } & $\begin{array}{l}\text { T10.R Grupos de trabajo homogéneos de alumnado en función de la } \\
\text { necesidad de aprendizaje detectada } \\
\text { Fichas de trabajo. Presentación digital. Cuestionario }\end{array}$ & \multirow[t]{2}{*}{$\begin{array}{l}\text { CMCT } \\
\text { CSC } \\
\text { AA } \\
\text { CD } \\
\text { CEC }\end{array}$} & \multirow[t]{2}{*}{$\begin{array}{l}\text { - Cuaderno o } \\
\text { portfolio del } \\
\text { alumnado. } \\
\text { - Lista de control con } \\
\text { escala estimativa. }\end{array}$} \\
\hline & & & $\begin{array}{l}\text { T10.A } \\
\text { Grupos de trabajo homogéneos de alumnado en función de sus } \\
\text { intereses de aprendizaje } \\
\text { Pequeña investigación experimental } \\
\text { Trabajo biográfico Antonio González y líneas de investigación del } \\
\text { IUBO-AG }\end{array}$ & & \\
\hline
\end{tabular}

Fuente: elaboración propia. 


\section{UNIDAD DIDÁCTICA: INICIACIÓN A LA QUÍMICA DEL CAR- BONO. PROGRAMA DE INVESTIGACIÓN}

A lo largo de este curso hemos estudiado con cierto detalle algunos cambios materiales, tratando de investigar cómo ocurren unos y cómo podemos hacer que se produzcan otros que, por alguna razón, nos interesen, teniendo siempre en cuenta la necesidad de un desarrollo sostenible.

¿Por qué, para terminar los aprendizajes sobre la química, vamos a plantearnos una introducción a la química del carbono?:Qué tiene de especial la química de éste elemento para que merezca este estudio particular?

\section{Situaciones problemáticas relevantes a investigar ¿Se puede obtener materia orgánica a partir de materia inorgánica? ¿Cómo se originaron los seres vivos?}

1. ¿Cuáles son las propiedades características del átomo de carbono que justifican la enorme cantidad de
compuestos del carbono? ¿Cuáles son las propiedades generales de las sustancias orgánicas?
2.1. ¿Cuál es la estructura y las propiedades de las formas alotrópicas del átomo de carbono?
2.2. ¿Cuáles son las características del grafito, el diamante, fullerenos, nanotubos y grafeno?
3. ¿Cuál es la importancia de los hidrocarburos como combustibles o recursos energéticos? ¿Cuáles son las
causas, los efectos y las soluciones posibles del aumento de efecto invernadero y del cambio climático global?
4. ¿Cómo se representan las distintas formulas de los diferentes hidrocarburos con modelos moleculares físicos
y virtuales?
5. ¿Cuáles son las aplicaciones de los principales hidrocarburos?
6. ¿Cómo reconocer el grupo funcional a través de la formula de alcoholes, aldehídos, cetonas, ácidos
carboxílicos, ésteres y aminas?
7. ¿Cuáles son los problemas sociambientales causados por la combustión de combustibles fósiles?
8. ¿Qué importancia tendría la utilización masiva de las energías renovables en Canarias y en el mundo? ¿Cómo
contribuir a los ODS (2015-2030)?

La química orgánica estudia básicamente el átomo de carbono, así como las propiedades y reactividad de los numerosos compuestos que éste forma.

El calificativo de orgánica tiene su origen en el siglo XIX cuando se creía, siguiendo a Jacob Berzelius, que las sustancias producidas por los organismos vivos, los llamados compuestos orgánicos, sólo podían formarse mediante una "fuerza vital» específica que impedía su síntesis artificial en el laboratorio.

En 1828, el químico alemán Friederich Wohler invalidó esta teoría al sintetizar urea. 


\section{"Iniciación a la Química del Carbono"}

\section{0. ¿Cuál es la importancia de la química del carbono? ¿Cuáles son sus principales aplicaciones e implicaciones} sociales? Presentación de la Unidad por el profesor

\section{Sesión 1:}

T0.1 Actividades iniciales: Cuestionario KPSI: Lo que crees saber sobre la química del C

(Knowledge and Prior Study Inventory) (Tamir). Inventario de Conocimientos Previos)

Señalar en el cuestionario de la tabla, la intensidad con que percibes conocer y poseer las habilidades necesarias para desarrollar los siguientes temas.

\begin{tabular}{|c|c|c|c|c|c|}
\hline & $\begin{array}{c}1 \\
\text { No } \\
\text { sé } \\
\text { nada }\end{array}$ & $\begin{array}{c}2 \\
\text { Sé un } \\
\text { poco }\end{array}$ & $\begin{array}{c}3 \\
\text { Lo conozco } \\
\text { suficiente }\end{array}$ & $\begin{array}{c}4 \\
\text { Lo conozco } \\
\text { bien }\end{array}$ & $\begin{array}{l}5 \\
\text { Lo domino y lo } \\
\text { puedo explicar a } \\
\text { otros }\end{array}$ \\
\hline $\begin{array}{l}\text { 1. ¿Por qué hay una enorme cantidad } \\
\text { de compuestos del carbono? }\end{array}$ & & & & & \\
\hline $\begin{array}{l}\text { 2. ¿Cuáles son las propiedades } \\
\text { generales de las sustancias orgánicas? }\end{array}$ & & & & & \\
\hline $\begin{array}{l}\text { 5. ¿Cuáles son las formas alotrópicas } \\
\text { del carbono? }\end{array}$ & & & & & \\
\hline $\begin{array}{l}\text { 4. ¿Cuál es la estructura y las } \\
\text { propiedades de las formas alotrópicas } \\
\text { del átomo de carbono? }\end{array}$ & & & & & \\
\hline $\begin{array}{l}\text { 5. ¿Cuál es la importancia de los } \\
\text { hidrocarburos como combustibles o } \\
\text { recursos energéticos? }\end{array}$ & & & & & \\
\hline $\begin{array}{l}\text { 6. ¿Cuáles son las causas, los efectos y } \\
\text { las soluciones posibles del aumento } \\
\text { de efecto invernadero y del cambio } \\
\text { climático global? }\end{array}$ & & & & & \\
\hline $\begin{array}{l}\text { 7. ¿Cómo se representan las distintas } \\
\text { formulas de los diferentes } \\
\text { hidrocarburos con modelos } \\
\text { moleculares físicos y virtuales? }\end{array}$ & & & & & \\
\hline $\begin{array}{l}\text { 8. ¿Cuáles son las aplicaciones de los } \\
\text { principales hidrocarburos? }\end{array}$ & & & & & \\
\hline $\begin{array}{l}\text { 9. ¿Reconoces el grupo funcional a } \\
\text { través de la formula de alcoholes, } \\
\text { aldehídos, cetonas, ácidos } \\
\text { carboxílicos, ésteres y aminas? }\end{array}$ & & & & & \\
\hline $\begin{array}{l}\text { 10. ¿Conoces cuáles son los } \\
\text { problemas sociambientales causados } \\
\text { por la combustión de combustibles } \\
\text { fósiles? }\end{array}$ & & & & & \\
\hline $\begin{array}{l}\text { 11. ¿Qué importancia tendría la } \\
\text { utilización masiva de las energías } \\
\text { renovables en Canarias y en el } \\
\text { mundo? }\end{array}$ & & & & & \\
\hline $\begin{array}{l}\text { 12. ¿Cómo contribuir a los ODS } \\
(2015-2030) \text { ? }\end{array}$ & & & & & \\
\hline
\end{tabular}




\section{Sesión 2:}

\section{A1-8 COMENTARIO DE TEXTO: EL VITALISMO Y EL NACIMIENTO DE LA QUÍMICA ORGÁNICA}

Lee el siguiente texto y realiza las actividades indicadas

En 1807, Berzelius designó por primera vez con el nombre de compuestos orgánicos al conjunto de sustancias que se obtienen de los organismos vivientes. Berzelius y la mayoría de los químicos de su tiempo pensaban que los productos de la materia viva estaban regidos por una particular fuerza vital y solo se podían sintetizar en los organismos vivos.

En aquella época se consideraba la vida como un fenómeno especial que no tenía por qué obedecer las leyes físico-químicas que gobiernan a los objetos inanimados. Esta creencia, de profundas raíces filosóficas y religiosas, se llama vitalismo. Ya había sido defendida un siglo antes por Stahl, el creador de la teoría del flogisto. Según el vitalismo, era necesario el concurso de la fuerza vital para producir los compuestos orgánicos. Por tanto, ésta sólo podía ocurrir en los organismos vivos. No podía esperarse sintetizarlos en el laboratorio a partir de productos inorgánicos.

Sin embargo, la teoría de la fuerza vital comenzó a declinar a medida que la aportación creciente de datos analíticos evidenció que las leyes químicas usuales también eran válidas para las sustancias orgánicas. El mismo Berzelius, como resultado de su análisis, reconoció, hacia 1814, que los compuestos orgánicos obedecían la ley de las proporciones definidas.

Pero el mayor golpe dado a la teoría de la fuerza vital vino cuando, en 1828, el químico alemán Wohler, discípulo de Berzeliusm obtuvo en el laboratorio un producto típico del organismo animal: la urea, a partir de cianato amónico, considerado un compuesto inorgánico.

A pesar de todo, el descubrimiento de Wohler no fue definitivo. En seguida se esgrimieron argumentos en el sentido de que el cianato amónico no era verdaderamente inorgánico. No obstante, la influencia del vitalismo comenzó a resquebrajarse, y los químicos se sintieron animados a intentar la síntesis de sustancias orgánicas en el laboratorio, fuera de los organismos vivos.

De esta manera, las posiciones vitalistas fueron totalmente barridas por los trabajos de Kolbe, alumno de Wohler, que en 1845 sintetizó ácido acético, sustancia típicamente orgánica, y de Berthelot, que durante la década de 1850 sintetizó una serie de compuestos orgánicos como metano, acetileno, benceno y alcohol etílico. Además, al desarrollarse el principio de conservación de la energía a mediados del siglo, se vio claramente que no había sitio alguno para la llamada fuerza vital.

Hacia 1850 ya se había abandonado el principio del vitalismo, y los químicos empezaron a convencerse de que los compuestos producidos por vegetales y animales también podían sintetizarse en el laboratorio. A partir de entonces la química orgánica de síntesis se convirtió en un campo bien definido de investigación y paso a denominarse con más propiedad química del carbono.

a) Haz un resumen del texto destacando las ideas principales.

b) ¿Qué es el vitalismo? ¿Cuándo y por qué empieza a ponerse en duda? 
Introducción a la quimica del carbono: una propuesta de unidad didáctica de fisica y química ...

c) Qué sustancias obtuvieron en el laboratorio, fuera de organismos vivos (in vitro) los químicos: Wohler, Kolbe y Berthelot.

\begin{tabular}{|l|l|l|}
\hline Químicos orgánicos & Nombre de la sustancia obtenida & Formula desarrollada \\
\hline Wohler & & \\
\hline Kolbe & & \\
\hline Berthelot. & & \\
& & \\
\hline
\end{tabular}

Actividades de desarrollo

2. ¿Cuál es la estructura y las propiedades de las formas alotrópicas del átomo de carbono? ¿Cuáles son las características del carbón, grafito, el diamante, fullerenos, nanotubos y grafeno?

T2 ¿Cuáles son las estructuras y las propiedades características de las diferentes formas alotrópicas del carbono?

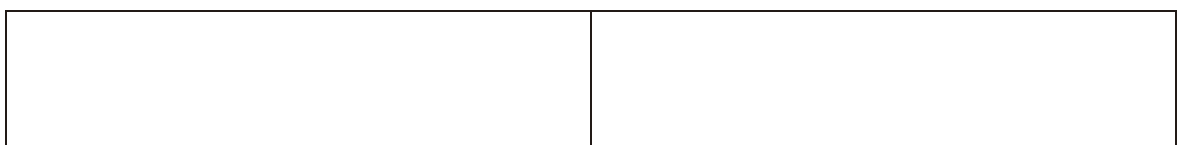

A2.1 Ejecuta la animación en flash y con la información obtenida rellena la siguiente tabla

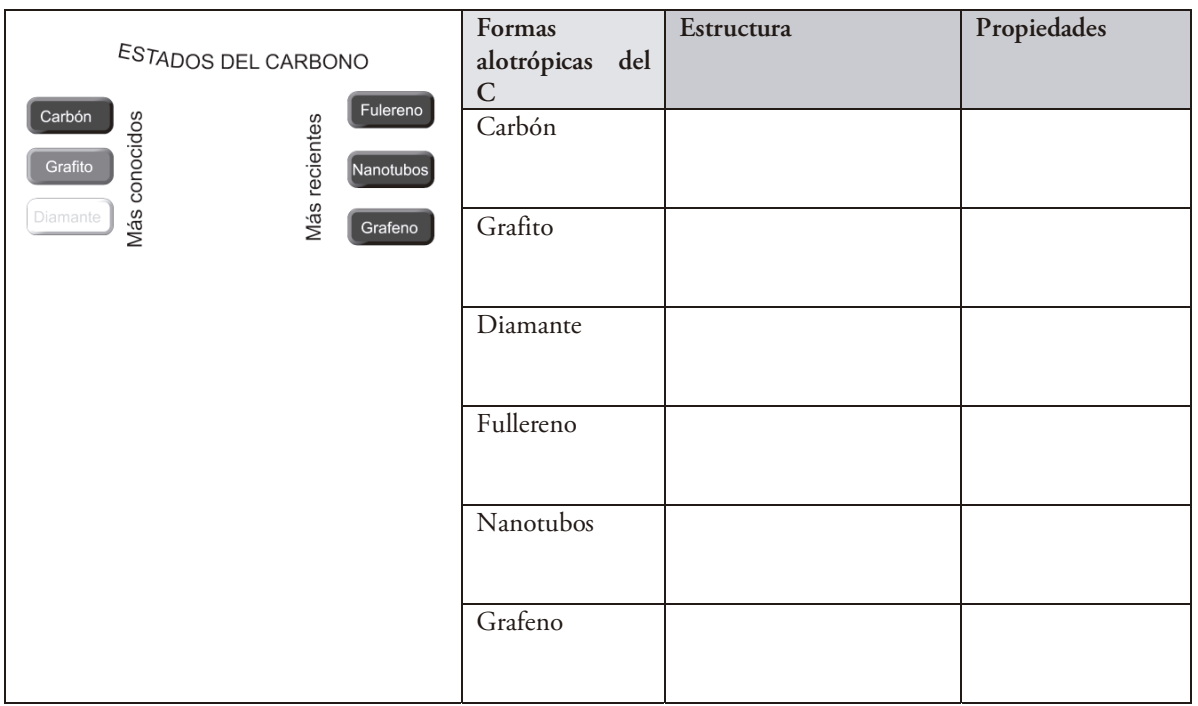

A2.2 El carbón es un tipo de roca formada en zonas pantanosas, por la descomposición de restos vegetales. Esta descomposición es llevada a cabo por bacterias anaerobias, es decir, que viven en ambientes pobres en oxígeno. Los tipos de carbón son: turba, lignito, hulla y antracita que se utiliza en algunas centrales térmicas para obtener energía eléctrica.

\begin{tabular}{|l|l|l|l|}
\hline Tipos de carbón & Características & \% de carbono & Poder energético \\
\hline turba & & & Mayor poder energético \\
\hline lignito & & & \\
\hline hulla & & & Menor poder energético \\
\hline antracita & & & \\
\hline
\end{tabular}


Sesión 3. Situación de aprendizaje: Preparando una ponencia para un congreso científico

3. ¿Cuál es la importancia de los hidrocarburos como combustibles o recursos energéticos? ¿Cuáles son las causas, los efectos y las soluciones posibles del aumento de efecto invernadero y del cambio climático global? T3. ¿Qué es una combustión y cuál es el impacto ambiental de las mismas?

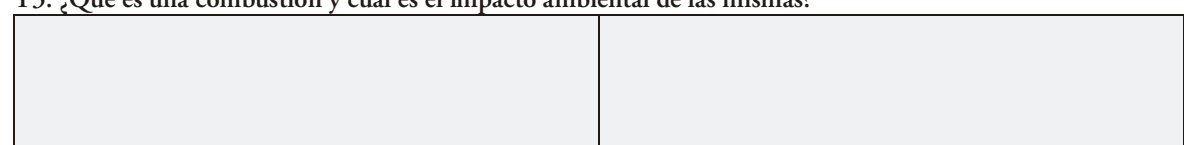

A3.1 Cuáles son las principales sustancias orgánicas o compuestos del carbono, que se utilizan como combustibles escribe la ecuación de combustión del gas propano y del hexano

\begin{tabular}{|l|l|l|}
\hline & $\begin{array}{l}\text { Combustión } \\
\text { propano }\end{array}$ & \\
\cline { 2 - 3 } & $\begin{array}{l}\text { Combustión } \\
\text { hexano }\end{array}$ & \\
\hline
\end{tabular}

A3.2 "Grupos de científicos norteamericanos, británicos y soviéticos han demostrado que el proceso de calentamiento global de la Tierra se había acelerado más en la última década que durante todo el siglo pasado. Comprobaron que los cuatro años de temperaturas más elevadas pertenecen a la última década.”

a) ¿Por qué crees que está aumentando la temperatura global del planeta? ¿Qué nombre recibe dicho fenómeno? ¿En qué consiste? b) ¿Qué consecuencias tiene para el medio ambiente? ¿Qué podemos hacer para paliar la situación?

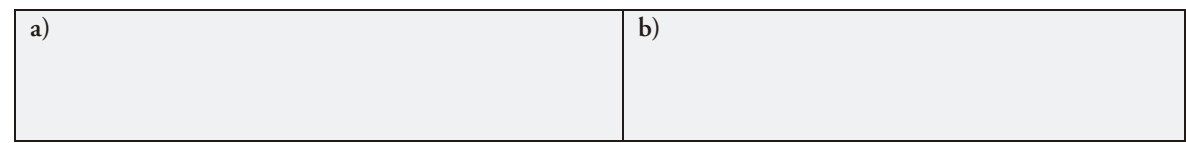

A3.3 Dadas las energías de combustión del metano, propano y butano en $\mathrm{kJ} / \mathrm{mol}$. Calcular: a) quien desprende mayor energía por gramo de hidrocarburo quemado poder energético $(\mathrm{kJ} / \mathrm{g})$. d) Escribe la reacción de combustión. e) Deduce quién contribuye menos al aumento de efecto invernadero mayor cantidad de energía producida por cada g de $\mathrm{CO}_{2}$ desprendido. f) Deduce quién contribuye más al aumento de efecto invernadero mayor cantidad de g de $\mathrm{CO}_{2}$ desprendido por cada kilo de hidrocarburo quemado.

\begin{tabular}{|l|l|l|l|l|l|}
\hline Hidrocarburos & $\begin{array}{l}\text { Energía de } \\
\text { combustión } \\
(\mathrm{kJ} / \mathrm{mol})\end{array}$ & $\begin{array}{l}\text { b) Poder } \\
\text { energético } \\
(\mathrm{kJ} / \mathrm{g})\end{array}$ & $\begin{array}{l}\text { c) Poder } \\
\text { contaminante } \\
\left(\mathrm{kJ} / \mathrm{g} \mathrm{CO}_{2}\right)\end{array}$ & $\begin{array}{l}\text { d) Reacción } \\
\text { química de } \\
\text { combustión } \\
\text { ajustada }\end{array}$ & $\begin{array}{l}\text { e) } \\
\mathrm{CO}_{2} / \mathrm{kg}^{\prime}\end{array}$ \\
\hline Metano $\left(\mathrm{CH}_{4}\right)$ & $1.022 \mathrm{~kJ} / \mathrm{mol}$ & & & & \\
\hline Propano $\left(\mathrm{C}_{3} \mathrm{H}_{8}\right)$ & $2.218 \mathrm{~kJ} / \mathrm{mol}$ & & & & \\
\hline Butano $\left(\mathrm{C}_{4} \mathrm{H}_{10}\right)$ & $2.876 \mathrm{~kJ} / \mathrm{mol}$ & & & & \\
\hline Octano $\left(\mathrm{C}_{8} \mathrm{H}_{18}\right)$ & $5.457 \mathrm{~kJ} / \mathrm{mol}$ & & & & \\
\hline Etileno $\left(\mathrm{C}_{2} \mathrm{H}_{4}\right)$ & $1.386,1 \mathrm{~kJ} / \mathrm{mol}$ & & & & \\
\hline Acetileno $\left(\mathrm{C}_{2} \mathrm{H}_{2}\right)$ & $\begin{array}{l}1.299,6 \\
\mathrm{~kJ} / \mathrm{mol} .\end{array}$ & & & & \\
\hline
\end{tabular}

A3.4 Supón que vas a ir de excursión varios días, por lo que alquilas una tienda, te llevas tu mochila y tu saco de dormir; en la mochila entre otras cosas quieres llevar combustible para cocinar. En el mercado encuentras dos tipos de bombonas con las siguientes características:

\begin{tabular}{|l|c|c|c|c|c|}
\hline Combustible & Fórmula & Masa $(\mathrm{kg})$ & Volumen $(\mathrm{L})$ & Precio $(€)$ & $\Delta \mathrm{H} \mathrm{comb}(\mathrm{kJ} / \mathrm{mol})$ \\
\hline Butano & $\mathrm{C}_{4} \mathrm{H}_{10}$ & 4 & 2 & 3,5 & -2876 \\
\hline Propano & $\mathrm{C}_{3} \mathrm{H}_{8}$ & 4 & 2 & 3,5 & -2218 \\
\hline
\end{tabular}


Introducción a la quimica del carbono: una propuesta de unidad didáctica de fisica y química ...

A la vista de lo anterior y, teniendo en cuenta que no hace mucha gracia llevar mucho peso inútil en la mochila ni gastar dinero inútilmente, y que te interesa sacar el máximo de energía de las bombonas, a) ¿por cuál de ellas te decidirías? ¿Por qué?

b) ¿Con cuál de ellas se contribuye más al efecto invernadero?

\begin{tabular}{|l|l|}
\hline a) & \\
\hline b) & \\
\hline
\end{tabular}

\section{Sesión 4:}

4. ¿Cómo se representan las distintas formulas de los diferentes hidrocarburos con modelos moleculares físicos y virtuales?

T4. Explica la diferencia entre formula empírica y formula molecular. Formula semidesarrollada y desarrollada Ten en cuenta que: ...

La fórmula de una sustancia proporciona información sobre su composición, tanto cualitativa (elementos químicos que están presentes) como cuantitativa (proporción en que se encuentran los átomos de esos elementos).

- A diferencia de los compuestos inorgánicos, una misma fórmula molecular puede representar a compuestos orgánicos muy diferentes. Por esta razón, hay que concretar con más detalle la disposición de los átomos en un compuesto orgánico. Así, distinguiremos entre:

a) La fórmula empírica, indica la relación más sencilla entre los átomos constituyentes de una molécula.

b) La fórmula molecular informa del número real de átomos que constituye la molécula.

c) La fórmula semidesarrollada indica los enlaces entre los átomos de carbono de una molécula.

d) La fórmula desarrollada especifica todos los enlaces entre los diferentes átomos de una molécula.

Ejemplo: Eteno

\begin{tabular}{|c|c|c|c|c|}
\hline $\begin{array}{l}\text { a) Fórmula } \\
\text { empírica }\end{array}$ & $\begin{array}{l}\text { b) Fórmula } \\
\text { molecular }\end{array}$ & $\begin{array}{c}\text { c) Fórmula } \\
\text { semidesarrollada }\end{array}$ & $\begin{array}{l}\text { c) Fórmula } \\
\text { desarrollada }\end{array}$ & $\begin{array}{l}\text { Formula } \\
\text { estructural }\end{array}$ \\
\hline $\mathrm{CH}_{2}$ & $\mathrm{C}_{2} \mathrm{H}_{4}$ & $\mathrm{CH}_{2}=\mathrm{CH}_{2}$ & & \\
\hline
\end{tabular}

A4.1 Escribe la fórmula semidesarrollada de un compuesto de carbono e hidrógeno formado por dos átomos de carbono unidos entre sí por un enlace simple.

\begin{tabular}{|c|c|c|c|c|}
\hline $\begin{array}{c}\text { Fórmula } \\
\text { empírica }\end{array}$ & $\begin{array}{c}\text { Fórmula } \\
\text { molecular }\end{array}$ & $\begin{array}{c}\text { Fórmula } \\
\text { semidesarrollada }\end{array}$ & Fórmula desarrollada & Formula estructural \\
\hline & $\mathrm{C}_{2} \mathrm{H}_{6}$ & & CH & \\
\hline
\end{tabular}


A4.2 Construye las posibles fórmulas desarrolladas de los compuestos $\mathrm{C}_{4} \mathrm{H}_{10}$ (Butano) y $\mathrm{C}_{2} \mathrm{H}_{2}$ (Etino) teniendo en cuenta que se trata de compuestos estables en los que se cumple la regla del octeto.

\begin{tabular}{|c|c|c|c|c|}
\hline $\begin{array}{c}\text { Fórmula } \\
\text { empírica }\end{array}$ & $\begin{array}{c}\text { Formula } \\
\text { molecular }\end{array}$ & $\begin{array}{c}\text { Fórmula } \\
\text { semidesarrollada }\end{array}$ & $\begin{array}{c}\text { Formula } \\
\text { desarrollada }\end{array}$ & Formula estructural \\
\hline $\mathrm{C}_{2} \mathrm{H}_{5}$ & $\mathrm{C}_{4} \mathrm{H}_{10}$ & $\mathrm{CH}_{3}-\mathrm{CH}_{2}-\mathrm{CH}_{2}-\mathrm{CH}_{3}$ & & \\
\hline $\mathrm{CH}$ & $\mathrm{C}_{2} \mathrm{H}_{2}$ & $\mathrm{CH} \equiv \mathrm{CH}$ & & \\
\hline
\end{tabular}

A4.4 a) ¿Pueden coincidir la fórmula empírica y la fórmula molecular? ¿Cuándo? Pon algunos ejemplos.

b) ¿Tiene sentido hablar de fórmula empírica de una sustancia iónica? ¿Y de fórmula molecular?

c) Escribe la fórmula empírica, molecular, semidesarrollada y desarrollada de un compuesto de carbono e hidrógeno formado por dos átomos de carbono unidos entre sí por un enlace simple.

\begin{tabular}{|l|l|l|l|}
\hline a) & c1) fórmula empírica & & \multirow{2}{*}{ c4) Formula desarrollada } \\
\hline & c2) fórmula molecular & \multirow{2}{*}{} & \\
\hline b) & $\begin{array}{l}\text { c3) formula } \\
\text { semidesarrollada }\end{array}$ & & \\
\hline
\end{tabular}

A4.5 Determinación de fórmulas empíricas y moleculares.

a) Escribe la fórmula molecular de un compuesto cuya fórmula empírica es $\mathrm{C}_{3} \mathrm{H}_{3}$ y su masa molar aproximada es de 78 g. ¿De qué compuesto se trata? Datos: M. a. C=12, $\mathrm{H}=1$

b) Sabemos que un compuesto orgánico tiene de fórmula empírica $\mathrm{C}_{2} \mathrm{H}_{5} \mathrm{~N}$ y su masa molar aproximada es de $130 \mathrm{~g} / \mathrm{mol}$. Escribe cuál será su fórmula molecular. [Datos: M. atom: $\mathrm{C}=12, \mathrm{~N}=14, \mathrm{H}=1$ ]

\begin{tabular}{|l|l|}
\hline a) & b) \\
& \\
\hline
\end{tabular}

Sesión 5: T5. Cálculos de Formulas empíricas y moleculares

A.5.1 Una muestra de 4,83 g de cierto hidrocarburo gaseoso contiene 0,69 g de hidrógeno. Calcula su fórmula empírica y molecular sabiendo que dicha muestra ocupa $2,81 \mathrm{~L}$ a $18{ }^{\circ} \mathrm{C}$ y $740 \mathrm{~mm}$ de $\mathrm{Hg}$. [Datos: M. atom: $\mathrm{C}=12, \mathrm{~N}=14, \mathrm{H}=1]$

\begin{tabular}{|l|l|}
\hline Formula empírica & Formula molecular \\
& \\
\hline
\end{tabular}


Introducción a la quimica del carbono: una propuesta de unidad didáctica de fisica y química ...

Opcional de ampliación

A.5.2. Interpreta el siguiente esquema de obtención de formulas empíricas y moleculares y realiza tres de los ejercicios propuestos.

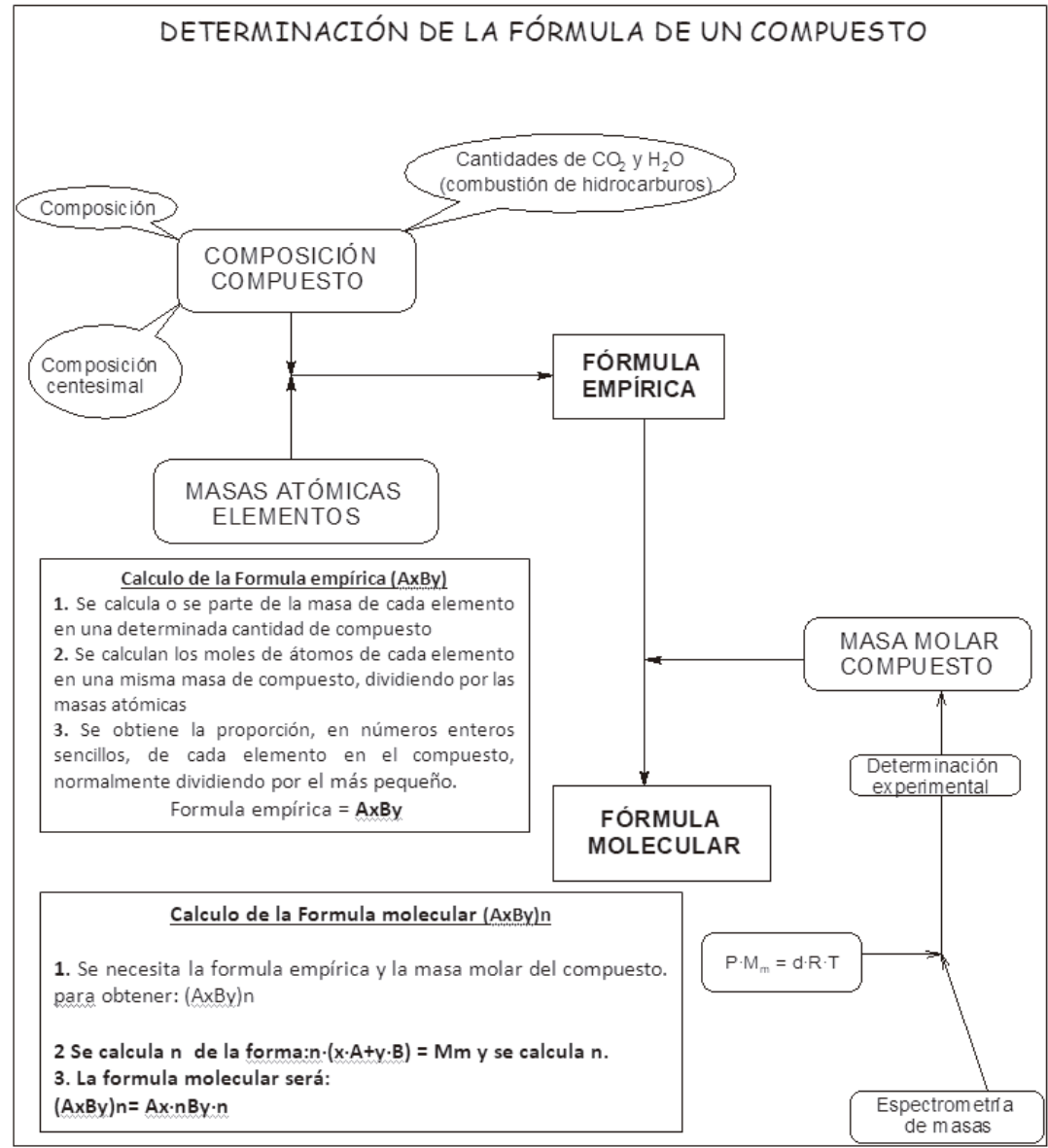

a) El lindano, que se usa como insecticida, tiene una composición másica del 24,78\% de C, 2,08\% de $\mathrm{H}$ y $73,14 \%$ de $\mathrm{Cl}$, y una masa molar de $290,85 \mathrm{~g} \cdot \mathrm{mol}^{-1}$. ¿Cuál es la fórmula empírica y la fórmula molecular del lindano?

b) La nicotina tiene una composición másica de 74,03\% de C, 8,70\% de $\mathrm{H}$ y $17,27 \%$ de N, y una masa molar de $162,23 \mathrm{~g} \cdot \mathrm{mol}^{-1}$. Determina la fórmula molecular de la nicotina.

Sesión 6 y Sesión 7: Introducción a la formulación de los compuestos del carbono. 
Sesión 8:

8. ¿Cuáles son los problemas sociambientales causados por la combustión de combustibles fósiles? ¿Qué importancia tendría la utilización masiva de las energías renovables en Canarias y en el mundo?

T8. ¿Qué es el aumento de efecto invernadero y del cambio climático global?

(Adaptado de Martínez, Mato y Repetto, 1995)

A8.1 Realiza un informe sobre el efecto invernadero en el que recojas:

\begin{tabular}{|l|l|}
\hline ¿Qué es? & \\
\hline ¿Cuáles son las & \\
causas? & ¿Cuáles son las \\
soluciones posibles? & \\
\hline $\begin{array}{l}\text { ¿Qué podemos } \\
\text { hacer individual y } \\
\text { colectivamente? }\end{array}$ & \\
\hline
\end{tabular}

A8.2 Realiza un informe que recoja

\begin{tabular}{|l|l|}
\hline $\begin{array}{l}\text { a) Problemas sociambientales } \\
\text { del uso de combustibles fósiles }\end{array}$ & $\begin{array}{l}\text { b) Importancia del uso masivo de energías } \\
\text { renovables en Canarias y en el mundo }\end{array}$ \\
\hline & \\
& \\
\hline
\end{tabular}

$\underline{\text { Sesión } 9}$

9. ¿Cómo contribuir a los ODS (2015-2030) - Agenda 2030?

T9.1 Selecciona uno de los objetivos de desarrollo sostenible de la Agenda 2030, en especial, el ODS 7: Energía asequible y no contaminante y el ODS 13: Acción por el clima visiona el video relativo al mismo y realiza un informe con las diferentes medidas o soluciones posibles para cumplir dicho objetivo https://www.youtube.com/watch?v=345IxGgjF9s $\quad$ http://los17ods.org/

\section{T9.2 Tarea opcional. Trabajo experimental: LA EXTRACCIÓN DE LA CLOROFILA}

\section{¿Cómo extraer la clorofila de las plantas?}

La clorofila es la sustancia, presente en las partes verdes de los vegetales, que permite la fotosintesis.

a) Coge unas hojas de espinacas y machácalas en un mortero con un poco de etanol.

b) Filtra el líquido verde que obtienes.

c) Colócalo en un tubo de ensayo y añádele un poco de benceno, agitalo y deja el tubo en reposo.

d) Al cabo de un tiempo aparecerá en la parte superior del tubo una capa de color verde intenso, rica en clorofila.

e) Separa la clorofila usando un embudo de decantación.

f) Analiza los componentes el extracto realizando una cromatografía de papel

e) Realiza un informe en el que expliques el procedimiento seguido.

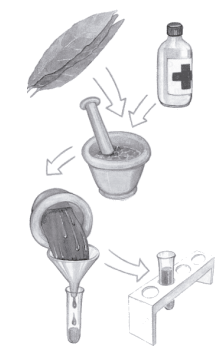


Introducción a la quimica del carbono: una propuesta de unidad didáctica de fisica y química ...

\section{LA CROMATOGRAFÍA Y SUS APLICACIONES}

En el segundo se utiliza papel de filtro como fase estacionaria. Es uno de los métodos cromatográficos más sencillos de llevar a cabo, por la facilidad para conseguir los materiales necesarios para realizarlo. Consiste en utilizar papel de filtro como soporte y se denomina cromatografía sobre papel.

\section{Análisis de las espinacas mediante cromatografía en papel}

Materiales: mortero, papel de filtro, capilares, clip sujetapapeles, frasco de vidrio con tapa Sustancias: espinacas, etanol.

Procedimiento: machacamos las hojas de espinaca en un mortero con alcohol. Obtenemos un líquido de color verde. Lo separamos en un vaso de precipitados. Mediante un capilar

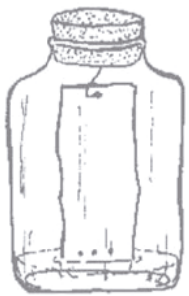

cromatografía sobre papel colocar unas gotas del líquido verde procurando que la mancha sea lo más pequeña posible, en un papel de filtro adecuadamente cortado. Se cuelga en el frasco cerrado en el que antes se ha colocado un poco de alcohol. Se deja que se desarrolle el cromatograma. Se retira cuando el disolvente se aproxime al extremo superior.

\section{Cuestiones ductoras}

1. ¿Qué se observa según va el disolvente ascendiendo por el papel?

2. ¿Cuántas sustancias coloreadas se separan? ¿Qué colores presentan?

3. Prueba a utilizar diferentes eluyentes. ¿¿Se nota alguna diferencia?

Esas tres sustancias coloreadas corresponden, por orden de salida, a las xantofilas, a los carotenos y a las clorofilas, que son las últimas en salir.

T9.3 Tarea opcional: Antonio González y el IUBO AG (Adaptado de Martínez y Turégano, 2010)

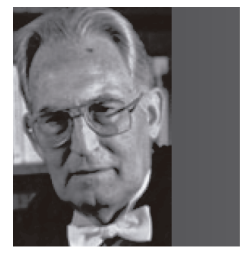

PREMIO CANARIAS DE INVESTIGACIÓN 1984:

D. Antonio González González (1917-2002)

Nació en Los Realejos en 1917.

Profesor e investigador químico. Catedrático de Química Orgánica y Rector

de la Universidad de La Laguna. Creador del Instituto Universitario de Bio-

Orgánica, que actualmente lleva su nombre, considerado uno de los centros

más avanzados del mundo en el estudio de todos los aspectos de la síntesis

de los productos naturales.

Antonio González ha sido uno de los científicos canarios más galardonados:

en 1959 fue Premio Alfonso X el Sabio, Premio Príncipe de Asturias de

Investigación Científica y Técnica en 1986, y estuvo tres veces nominado para el Premio Nobel de Química.

T9.4 Busca información sobre la importancia y las líneas de investigación del "Instituto Universitario de Biorgánica Antonio González" (IUBO-AG) y haz un pequeño informe junto con la importancia de su fundador Antonio González.

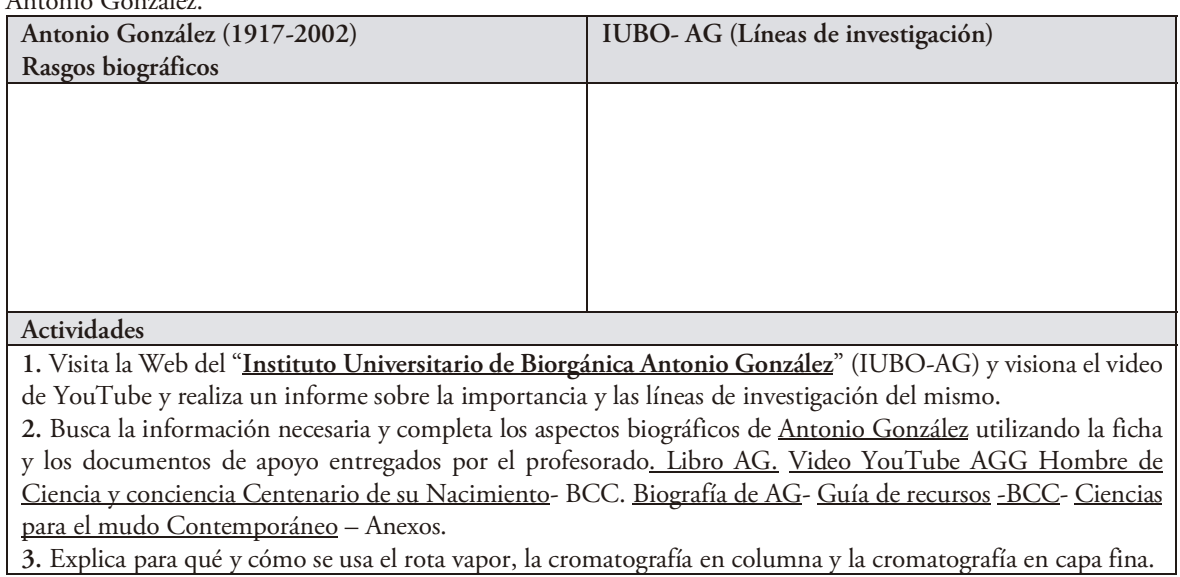


Tarea 9.5. Biografía de Rosa Menéndez López (Química Orgánica) Profesora Investigadora y Presidenta del Consejo Superior de Investigaciones Científicas CSIC desde 2017.

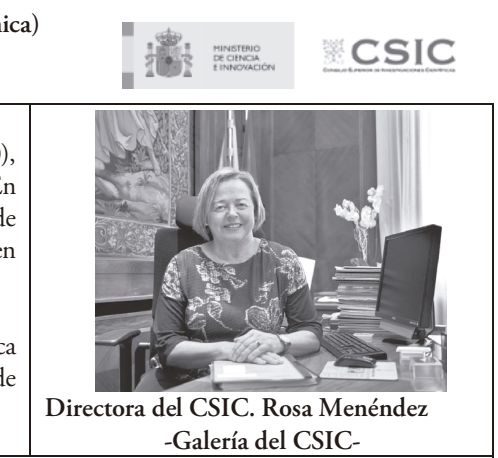

Formación académica
Licenciada en Química por la Universidad de Oviedo (1980),
Doctorado en Química por esa misma universidad (1986). En
1987 y 1988 fue becaria postdoctoral en la Universidad de
Newcastle Upon Tyne (RU), tras su incorporación al CSIC en
1986.
Experiencia profesional
En 1988 inició su carrera profesional en el CSIC como Científica
Titular y en 2000 fue nombrada Investigadora Científica. Desde
2003 es Profesora de Investigación.
Licenciada en Química por la Universidad de Oviedo (1980), Doctorado en Química por esa misma universidad (1986). En 1987 y 1988 fue becaria postdoctoral en la Universidad de Newcastle Upon Tyne (RU), tras su incorporación al CSIC en 1986.
Experiencia profesional
Titular y en 2000 fue nombrada Investigadora Científica. Desde 2003 es Profesora de Investigación.

Es especialista en materiales de carbono y, en los últimos ańos, en grafeno aplicado a biomedicina y al almacenamiento de energía. Durante su trayectoria profesional ha participado en más de 30 proyectos de investigación nacionales y de los Programas marco de investigación e innovación de la Unión Europea, que contaban, además, con amplia participación industrial. En 23 de ellos ha participado como investigadora principal. Asimismo, ha publicado más de 200 artículos en revistas científicas internacionales de alto impacto. Es autora de 10 patentes y ha dirigido 20 tesis doctorales y 22 masters en los campos de los materiales, la química y la energía.

El 17 de noviembre de 2017, es nombrada presidenta del Consejo Superior de Investigaciones Científicas, convirtiéndose en la primera mujer que preside el mayor organismo público de investigación de Espańa, con una plantilla de 13.000 investigadores, de los cuales el 35,7\% son mujeres.

Desde junio de 2018 es vicepresidenta de Science Europe, Cronología: Carrera investigadora. Premios y reconocimientos científicos

$\checkmark 1988$ inició su carrera profesional en el CSIC como $\checkmark \checkmark 2016$ "Premio al Talento Experto" concedido Científica Titular

$\checkmark 1996$ premio "Shunk Carbon Award", concedido por la empresa alemana Shunk a investigadores jóvenes, por su contribución al desarrollo de la ciencia de los materiales de carbono.

$\checkmark 2000$ fue nombrada Investigadora Científica del CSIC.

$\checkmark 2003$ hasta 2008 dirigió el Instituto Nacional del Carbón (INCAR).

$\checkmark 2003$ es nombrada Profesora de Investigación del CSIC.

$\checkmark 2007$ "Premio Vital Álvarez Buylla", concedido por la UNESCO y el Ayuntamiento de Mieres, por su contribución al desarrollo y divulgación de la ciencia.

$\checkmark 2008$ - 2009 ocupó el cargo de "Vicepresidenta de Investigación Científica y Técnica del CSIC"

$\checkmark 2009$ "Premio DuPont de la Ciencia".

$\checkmark 2016$ "Premio de la Asociación Española de Materiales", por su carrera científica,

por Human Age y Cinco Días,

$\checkmark 2016$ "Premio Innova Diario de León".

$\checkmark 2017$ Nombrada presidenta del Consejo Superior de Investigaciones científicas (CSIC)

$\checkmark 2018$ "Premio Amuravela de Oro", otorgado por la Asociación de Amigos de Cudillero.

$\checkmark 2018$ Inclusión en la "Tabla Periódica de las Científicas" de todo el mundo, para conmemorar el Año Internacional de la Tabla Periódica de los Elementos Químicos, que celebra en 2019 el 150 aniversario de la publicación de Mendeléyev.

$\checkmark 2018$ "Premio a la Excelencia Química", otorgado por Antonio Macho, Presidente del Consejo General de Colegios Químicos de España $\checkmark 2018$ Nombrada "Vicepresidenta de Science Europe"

$\checkmark 2019$ Reelegida "Vicepresidenta de Science Europe"

A.9.4. ¿Cuáles son las principales líneas de trabajo de la Doctora Rosa Menéndez

A.9.5. Busca información y realiza un informa sobre el trabajo que se realiza en el Consejo Superior de Investigaciones Científicas

A.9.6. Busca información en Internet y realiza una biografía de Rosa Menéndez desarrollando los diferentes apartados de la siguiente, suministrada por el profesor, 


\title{
4. RÚBRICA: INTRODUCCIÓN A LA QUÍMICA DEL CARBONO
}

\author{
Tabla 4: Rúbrica de la UD: Introducción a la Química del carbono
}

Leyenda: Competencias: $\mathrm{CL}=$ Comunicación lingüística; $\mathrm{CMCT}=$ Competencia matemática y competencias básicas en ciencia y tecnología; $\mathrm{CD}=$ Competencia Digital; $\mathrm{AA}=$ Aprender a aprender; $\mathrm{CSC}=$ Competencias sociales y cívicas; SIEE= Sentido de iniciativa y espíritu emprendedor; $C E C=$ Conciencia y expresiones culturales

\begin{tabular}{|c|c|c|c|c|}
\hline \multirow{2}{*}{$\begin{array}{c}\text { Indicadores de } \\
\text { evaluación } \\
\text { (Estándares de } \\
\text { aprendizaje) (CCBB) }\end{array}$} & \multicolumn{4}{|c|}{ Descriptores de evaluación } \\
\hline & $\begin{array}{l}\text { INSUFICIENTE } \\
(1 / 4)\end{array}$ & $\begin{array}{l}\text { SUFICIENTE/ } \\
\text { BIEN }(5 / 6)\end{array}$ & NOTABLE (7/8) & $\begin{array}{l}\text { SOBRESALIENTE } \\
(9 / 10)\end{array}$ \\
\hline $\begin{array}{l}\text { EA1. Explica las } \\
\text { enormes posibilidades } \\
\text { de combinación que } \\
\text { presenta el átomo de } \\
\text { carbono. }(15 \%) \\
\text { (CMCT; CL) }\end{array}$ & $\begin{array}{l}\text { 1. Explica con falta } \\
\text { de claridad y } \\
\text { superficialmente las } \\
\text { enormes } \\
\text { posibilidades de } \\
\text { combinación que } \\
\text { presenta el átomo de } \\
\text { carbono. }\end{array}$ & $\begin{array}{l}\text { 1. Explica con } \\
\text { relativa claridad y } \\
\text { estructura sencilla } \\
\text { las enormes } \\
\text { posibilidades de } \\
\text { combinación que } \\
\text { presenta el átomo de } \\
\text { carbono. }\end{array}$ & $\begin{array}{l}\text { 1. Explica de forma } \\
\text { estructurada y clara } \\
\text { las enormes } \\
\text { posibilidades de } \\
\text { combinación que } \\
\text { presenta el átomo de } \\
\text { carbono. }\end{array}$ & $\begin{array}{l}\text { 1. Explica con } \\
\text { claridad y } \\
\text { profundidad las } \\
\text { enormes } \\
\text { posibilidades de } \\
\text { combinación que } \\
\text { presenta el átomo de } \\
\text { carbono. }\end{array}$ \\
\hline $\begin{array}{l}\text { EA2. Reconoce y } \\
\text { describe las distintas } \\
\text { formas alotrópicas del } \\
\text { átomo de carbono sus } \\
\text { estructuras y } \\
\text { propiedades. (15\%) } \\
\text { CMCT; AA; CD }\end{array}$ & $\begin{array}{l}\text { onoce y } \\
\text { a de forma } \\
\text { a las distintas } \\
\text { alotrópicas } \\
\text { mo de } \\
\text { o, sus } \\
\text { uras y } \\
\text { dades. }\end{array}$ & $\begin{array}{l}\text { 2. Reconoce y } \\
\text { describe } \\
\text { básicamente las } \\
\text { distintas formas } \\
\text { alotrópicas del } \\
\text { átomo de carbono, } \\
\text { sus estructuras y } \\
\text { propiedades. }\end{array}$ & $\begin{array}{l}\text { y } \\
\text { forma } \\
\text { s } \\
\text { mas } \\
\text { del } \\
\text { arbono, } \\
\text { ras y } \\
\text {. }\end{array}$ & $\begin{array}{l}\text { onoce y } \\
\text { be con } \\
\text { ión las } \\
\text { tas formas } \\
\text { picas del } \\
\text { de carbono, } \\
\text { ructuras y } \\
\text { dades. }\end{array}$ \\
\hline $\begin{array}{l}\text { EA3. Reconoce y } \\
\text { representa } \\
\text { hidrocarburos sencillos } \\
\text { de interés en la vida } \\
\text { cotidiana, mediante } \\
\text { fórmulas y modelos } \\
\text { moleculares reales o } \\
\text { virtuales generadas por } \\
\text { ordenador y el grupo } \\
\text { funcional a partir de la } \\
\text { fórmula de algunas } \\
\text { sustancias orgánicas. } \\
\text { (15\%) } \\
\text { (CMCT; CD; CSC; } \\
\text { AA) }\end{array}$ & $\begin{array}{l}\text { 3. Reconoce y } \\
\text { representa siguiendo } \\
\text { instrucciones y con } \\
\text { imprecisión } \\
\text { hidrocarburos } \\
\text { sencillos de interés } \\
\text { en la vida cotidiana, } \\
\text { mediante fórmulas y } \\
\text { modelos moleculares } \\
\text { reales o virtuales } \\
\text { generadas por } \\
\text { ordenador y el grupo } \\
\text { funcional a partir de } \\
\text { la fórmula de } \\
\text { algunas sustancias } \\
\text { orgánicas. }\end{array}$ & $\begin{array}{l}\text { 3. Reconoce y } \\
\text { representa con } \\
\text { ayuda y sin } \\
\text { imprecisiones } \\
\text { importantes } \\
\text { hidrocarburos } \\
\text { sencillos de interés } \\
\text { en la vida cotidiana, } \\
\text { mediante fórmulas y } \\
\text { modelos moleculares } \\
\text { reales o virtuales } \\
\text { generadas por } \\
\text { ordenador y el grupo } \\
\text { funcional a partir de } \\
\text { la fórmula de } \\
\text { algunas sustancias } \\
\text { orgánicas. }\end{array}$ & $\begin{array}{l}\text { 3. Reconoce y } \\
\text { representa con } \\
\text { autonomía y } \\
\text { bastante precisión } \\
\text { hidrocarburos } \\
\text { sencillos de interés } \\
\text { en la vida cotidiana, } \\
\text { mediante fórmulas y } \\
\text { modelos moleculares } \\
\text { reales o virtuales } \\
\text { generadas por } \\
\text { ordenador y el grupo } \\
\text { funcional a partir de } \\
\text { la fórmula de } \\
\text { algunas sustancias } \\
\text { orgánicas }\end{array}$ & $\begin{array}{l}\text { 3. Reconoce y } \\
\text { representa de } \\
\text { manera totalmente } \\
\text { autónoma y con } \\
\text { precisión } \\
\text { hidrocarburos } \\
\text { sencillos de interés } \\
\text { en la vida cotidiana, } \\
\text { mediante fórmulas y } \\
\text { modelos moleculares } \\
\text { reales o virtuales } \\
\text { generadas por } \\
\text { ordenador y el grupo } \\
\text { funcional a partir de } \\
\text { la fórmula de } \\
\text { algunas sustancias } \\
\text { orgánicas. }\end{array}$ \\
\hline $\begin{array}{l}\text { EA4. Indica las } \\
\text { aplicaciones de } \\
\text { hidrocarburos sencillos } \\
\text { de especial interés } \\
\text { biológico e industrial. } \\
(15 \%) \\
\text { (CMCT; CSC; AA; } \\
\text { CD) }\end{array}$ & $\begin{array}{l}\text { 4. Indica con } \\
\text { incorrecciones } \\
\text { importantes las } \\
\text { aplicaciones de } \\
\text { hidrocarburos } \\
\text { sencillos de especial } \\
\text { interés biológico e } \\
\text { industrial. }\end{array}$ & $\begin{array}{l}\text { 4. Indica con } \\
\text { pequeńas } \\
\text { incorrecciones las } \\
\text { aplicaciones de } \\
\text { hidrocarburos } \\
\text { sencillos de especial } \\
\text { interés biológico e } \\
\text { industrial. }\end{array}$ & $\begin{array}{l}\text { 4. Indica } \\
\text { correctamente las } \\
\text { aplicaciones más } \\
\text { importantes de } \\
\text { hidrocarburos } \\
\text { sencillos de especial } \\
\text { interés biológico e } \\
\text { industrial. }\end{array}$ & $\begin{array}{l}\text { 4. Indica } \\
\text { correctamente las } \\
\text { aplicaciones de } \\
\text { hidrocarburos } \\
\text { sencillos de especial } \\
\text { interés biológico e } \\
\text { industrial. }\end{array}$ \\
\hline
\end{tabular}




\begin{tabular}{|c|c|c|c|c|}
\hline $\begin{array}{l}\text { EA5. Valora el } \\
\text { agotamiento de los } \\
\text { combustibles fósiles, } \\
\text { los problemas } \\
\text { socioambientales de su } \\
\text { utilización, la } \\
\text { necesidad de tomar } \\
\text { medidas para evitarlos } \\
\text { y acabar con la } \\
\text { dependencia } \\
\text { energética de Canarias } \\
\text { de los combustibles } \\
\text { fósiles, disminuir la } \\
\text { emisión de gases de } \\
\text { efecto invernadero e } \\
\text { implantar el uso } \\
\text { creciente de las } \\
\text { energías renovables, } \\
\text { que pongan fin al } \\
\text { cambio climático e } \\
\text { inicien un presente } \\
\text { más sostenible. } \\
\text { (20\%) (CMCT; CL: } \\
\text { CSC; CD; SIEE) }\end{array}$ & $\begin{array}{l}\text { 5. Valora sin } \\
\text { fundamento ni } \\
\text { criterio el } \\
\text { agotamiento de los } \\
\text { combustibles fósiles, } \\
\text { los problemas } \\
\text { socioambientales de } \\
\text { su utilización, la } \\
\text { necesidad de tomar } \\
\text { medidas para } \\
\text { evitarlos y acabar } \\
\text { con la dependencia } \\
\text { energética de } \\
\text { Canarias de los } \\
\text { combustibles fósiles, } \\
\text { disminuir la emisión } \\
\text { de gases de efecto } \\
\text { invernadero e } \\
\text { implantar el uso } \\
\text { creciente de las } \\
\text { energías renovables, } \\
\text { que pongan fin al } \\
\text { cambio climático e } \\
\text { inicien un presente } \\
\text { más sostenible. }\end{array}$ & $\begin{array}{l}\text { 5. Valora de manera } \\
\text { general el } \\
\text { agotamiento de los } \\
\text { combustibles fósiles, } \\
\text { los problemas } \\
\text { socioambientales de } \\
\text { su utilización, la } \\
\text { necesidad de tomar } \\
\text { medidas para } \\
\text { evitarlos y acabar } \\
\text { con la dependencia } \\
\text { energética de } \\
\text { Canarias de los } \\
\text { combustibles fósiles, } \\
\text { disminuir la emisión } \\
\text { de gases de efecto } \\
\text { invernadero e } \\
\text { implantar el uso } \\
\text { creciente de las } \\
\text { energías renovables, } \\
\text { que pongan fin al } \\
\text { cambio climático e } \\
\text { inicien un presente } \\
\text { más sostenible. }\end{array}$ & $\begin{array}{l}\text { 5. Valora de manera } \\
\text { fundamentada el } \\
\text { agotamiento de los } \\
\text { combustibles fósiles, } \\
\text { los problemas } \\
\text { socioambientales de } \\
\text { su utilización, la } \\
\text { necesidad de tomar } \\
\text { medidas para } \\
\text { evitarlos y acabar } \\
\text { con la dependencia } \\
\text { energética de } \\
\text { Canarias de los } \\
\text { combustibles fósiles, } \\
\text { disminuir la emisión } \\
\text { de gases de efecto } \\
\text { invernadero e } \\
\text { implantar el uso } \\
\text { creciente de las } \\
\text { energías renovables, } \\
\text { que pongan fin al } \\
\text { cambio climático e } \\
\text { inicien un presente } \\
\text { más sostenible. }\end{array}$ & $\begin{array}{l}\text { 5. Valora de manera } \\
\text { fundamentada y con } \\
\text { criterio propio el } \\
\text { agotamiento de los } \\
\text { combustibles fósiles, } \\
\text { los problemas } \\
\text { socioambientales de } \\
\text { su utilización, la } \\
\text { necesidad de tomar } \\
\text { medidas para } \\
\text { evitarlos y acabar } \\
\text { con la dependencia } \\
\text { energética de } \\
\text { Canarias de los } \\
\text { combustibles fósiles, } \\
\text { disminuir la emisión } \\
\text { de gases de efecto } \\
\text { invernadero e } \\
\text { implantar el uso } \\
\text { creciente de las } \\
\text { energías renovables, } \\
\text { que pongan fin al } \\
\text { cambio climático e } \\
\text { inicien un presente } \\
\text { más sostenible. }\end{array}$ \\
\hline $\begin{array}{l}\text { EA6. Analiza y Valora } \\
\text { la importancia de los } \\
\text { Objetivos de } \\
\text { desarrollo sostenible } \\
\text { ODS (2015-2030), } \\
\text { presentando informes } \\
\text { escritos y audiovisuales } \\
\text { con soluciones } \\
\text { posibles. (20\%) } \\
\text { (CMCT; AA; CD; } \\
\text { CSC; SIEE) }\end{array}$ & $\begin{array}{l}\text { 6. Analiza y Valora } \\
\text { superficialmente y } \\
\text { con errores } \\
\text { importantes la } \\
\text { importancia de los } \\
\text { Objetivos de } \\
\text { desarrollo sostenible } \\
\text { ODS (2015-2030, } \\
\text { presentando } \\
\text { informes escritos y } \\
\text { audiovisuales con } \\
\text { soluciones posibles. }\end{array}$ & $\begin{array}{l}\text { 6. Analiza y Valora } \\
\text { superficialmente } \\
\text { pero sin errores la } \\
\text { importancia de los } \\
\text { Objetivos de } \\
\text { desarrollo sostenible } \\
\text { ODS (2015-2030) } \\
\text { presentando } \\
\text { informes escritos y } \\
\text { audiovisuales con } \\
\text { soluciones posibles.. }\end{array}$ & $\begin{array}{l}\text { 6. Analiza y Valora } \\
\text { con corrección la } \\
\text { importancia de los } \\
\text { Objetivos de } \\
\text { desarrollo sostenible } \\
\text { ODS (2015-2030) } \\
\text { presentando } \\
\text { informes escritos y } \\
\text { audiovisuales con } \\
\text { soluciones posibles.. }\end{array}$ & $\begin{array}{l}\text { 6. Analiza y valora } \\
\text { de forma brillante y } \\
\text { exhaustiva la } \\
\text { importancia de los } \\
\text { Objetivos de } \\
\text { desarrollo sostenible } \\
\text { ODS (2015-2030) } \\
\text { presentando } \\
\text { informes escritos y } \\
\text { audiovisuales con } \\
\text { soluciones posibles. }\end{array}$ \\
\hline
\end{tabular}

\section{REFERENCIAS BIBLIOGRÁFICAS}

Consejería de Educación y Universidades del Gobierno de Canarias. (2016). Decreto 83/2016, del 4 de julio, por el que se establece el currículo de la Educación Secundaria Obligatoria y el Bachillerato de la Comunidad Autónoma Canarias. (BOC 15 de julio de 2016).

Martínez, F., Mato, M.C. y Repetto, E. (1995). Los aspectos medioambientales y la enseñanza de las Ciencias, editado por la Consejería de Educación del Gobierno de Canarias y el Centro de la Cultura Popular Canaria en julio de 1995, en la colección Cuadernos de Aula nº. 6. 
Introducción a la quimica del carbono: una propuesta de unidad didáctica de fisica y química ...

Martínez, F. y Repetto, E. (1997): Orientaciones para el desarrollo del currículo de Física de $1^{\circ}$ del nuevo bachillerato. Una propuesta didáctica basada en la innovación y en la investigación educativa. $7^{\circ}$ encuentros ibéricos para la enseñanza de la física. XXVI Reunión Bienal de la Real Sociedad Española de Física.

Martínez, F. (2003). Análisis, desarrollo y evaluación del curriculo de Física y química de $1^{\circ}$ de Bachillerato. Implicaciones para la Formación del Profesorado. Tesis Doctoral. ULPGC.

Martínez, F. y Repetto, E. (2005). Blas Cabrera Felipe. Biografia de Cientificos Canarios. Oficina de Ciencia, Tecnología e Innovación del Gobierno de Canarias. Gran Canaria CamPDS - Dykinson.

Martínez, F. y Repetto, E. (2006). Biografias de científicos canarios. Guia de recursos didácticos. Oficina de Ciencia, Tecnología e Innovación. Gobierno de Canarias.

Martínez, F. y Turégano, J.C. (2010). Ciencias para el mundo contemporáneo. Guía de recursos didácticos. Agencia Canaria de Investigación, Innovación y Sociedad de la Información. Gobierno de Canarias.

Repetto, E., Martínez, F. y Calvo, J.R. (2004). La formación científica y la ley de calidad, 95-105. El Guiniguada. Universidad de Las Palmas de Gran Canaria.

Repetto, E., Martínez, F. y Calvo, J.R. (2005). La integración de las tecnologías de la información y la comunicación en el aprendizaje de la Física y Química. Una propuesta didáctica para primero de bachillerato, 207-230. El Guiniguada. Universidad de Las Palmas de Gran Canaria. 



\title{
COMUNICACIÓN Y APRENDIZAJE A TRAVÉS DEL ARTE EN AULAS MULTICULTURALES Y MULTILINGÜES: ARTICULAN
}

\author{
Ivalla Ortega Barrera \\ Universidad de Las Palmas de Gran Canaria
}

\begin{abstract}
Resumen
El arte se ha utilizado como una herramienta educativa para que el estudiantado sea capaz de comunicar sus ideas y sus sentimientos sin tener que utilizar la expresión oral. Esto sirve de gran ayuda en contextos multiculturales y multilingües, sobre todo, en las aulas de primaria en las que existe un aumento considerable de alumnado inmigrante y refugiado que necesita integrarse no solo en el sistema educativo, sino también con el resto del alumnado. Para ayudar a esta integración surge el proyecto europeo ArtiCULan (Art, Time, Culture and Language), cuyo principal objetivo es la creación de talleres artísticos que ayuden a la integración e inclusión de ese estudiantado en dichos contextos multiculturales. En este trabajo se llevará a cabo la descripción de este proyecto.
\end{abstract}

Palabras clave: arte, multicultural, multilingüe, educación primaria, integración, ArtiCULan

\begin{abstract}
Arts have been used as an educational tool for students to be able to communicate their ideas and feelings without speaking. This fact helps in multicultural and multilingual contexts, mainly in Primary education classrooms in which there is an increase in the number of immigrant students who need to interact and integrate not only in the educational system, but also with the rest of students. ArtiCULan (Art, Time, Culture and Language) is a European project that intends to set up a framework for artistic projects to offer students the opportunity to create art and integrate in the multicultural and multilingual contexts. This project will be described in this work.
\end{abstract}

Keywords: art, multicultural, multilingual, Primary Education, integration, ArtiCULan 


\section{INTRODUCCIÓN}

El arte es un modo de expresar sentimientos e ideas que se ha definido como una actividad humana esencial (Muñoz Martínez, 2006) que sirve como una plataforma para el crecimiento y desarrollo de niños y nińas y de su pensamiento crítico y creativo (Perkins, 1994; Efland, 2002; Eisner, 2002). La educación artística ayuda al estudiantado a participar y comunicar sus ideas y sentimientos utilizando sus destrezas sin ningún tipo imposición que los excluya de la actividad, pudiendo desarrollar su trabajo artístico de manera libre, esto es, utilizando sus habilidades creativas. Los docentes juegan un papel fundamental en este sentido ya que ellos son los que deben ayudar a los discentes a desarrollar ese pensamiento crítico y creativo (Alter, 2009) a través del uso de imágenes, música, lenguaje, gestos y movimientos.

La cultura y el arte son cruciales en cuanto a educación se refiere, sobre todo en el tema de la integración de grupos minoritarios. En este sentido, la UNESCO (United Nations Educational, Scientific and Cultural Organization), establece:

Culture and the arts are essential components of a comprehensive education leading to the full development of the individual. Therefore, Arts Education is a universal human right, for all learners, including those who are often excluded from education, such as immigrants, cultural minority groups, and people with disabilities (United Nations Educational, Scientific and Cultural Organization, 2006, p. 3).

El arte y la cultura se establecen como componentes esenciales en el contexto educativo puesto que permiten el desarrollo social y personal de los individuos, ayudando así a la integración de los grupos minoritarios en el aula. Además, según Rodríguez Aranda (2010: 2): "[...] hombre, arte y cultura conforman una indiscutible triada indisociable", por lo que el arte y la cultura están ligadas a la naturaleza humana y, por ende, al desarrollo de la misma. Esto supone que todos/as los/las estudiantes pueden lograr el éxito a través de las artes, incluso aquellos socialmente excluidos, como pueden ser inmigrantes, grupos minoritarios y estudiantes con algún tipo de discapacidad. Estos grupos minoritarios se sentirán capacitados para participar en las actividades ofrecidas a través del arte, puesto que el arte les permite explorar diferentes métodos de comunicación con el resto de la sociedad y expresar todo aquello que sienten.

El concepto de integración del arte en educación (Arts Integration) se produce porque el arte se adapta a la forma de aprender y en esta integración 
toman parte los docentes con la colaboración de artistas o asesores artísticos (Llevadot González y Pagès Santacana, 2018). Es evidente que el arte juega un papel fundamental en el proceso de aprendizaje del estudiantado, sobre todo en las aulas actuales, en las que la ratio de alumnado inmigrante ha aumentado considerablemente, llegando a superar los 800.000 estudiantes extranjeros en enseñanza no universitaria en España, según la Estadística de las enseñanzas no universitarias referente al curso 2019-2020 publicada por el Ministerio de Educación y Formación Profesional. En el caso de la Comunidad Canaria, teniendo en cuenta los datos referidos al curso 2019-2020, existe un total de 35.512 estudiantes extranjeros matriculados en enseñanzas no universitarias.

Este alto número de inmigrantes y refugiados, que existe actualmente en prácticamente toda Europa, y que aumenta cada día, tiene que integrarse en la sociedad y el primer paso para esa integración se produce en las aulas, principalmente en los centros de Educación Primaria. Este alumnado, en la mayoría de los casos, no solo procede de un entorno cultural diferente, sino que además no tiene conocimiento de la lengua hablada en el país receptor, por lo que no puede comunicarse con el resto de sus compañeros/as ni con el equipo docente. En este contexto multicultural y multilingüe, el profesorado debe potenciar la comunicación, la integración y la adquisición de las competencias básicas de todo su alumnado.

Es evidente que la inclusión de las diferentes disciplinas artísticas es fundamental en la formación de los niños y nińas puesto que, según la UNESCO, la educación artística favorece el desarrollo de su personalidad, no solo en el plano emocional sino también en el cognitivo, refuerza la adquisición de conocimientos, estimula la expresión oral, la concentración, el interés personal por los otros, aporta al alumnado instrumentos de comunicación y autoexpresión y favorece el respeto intercultural (García Morales, 2012). Todos estos beneficios que ofrece la educación artística deben tenerse en cuenta en las aulas de Educación Primaria, sobre todo en los contextos educativos actuales en los que las aulas presentan cada vez más ambientes multiculturales en los que conviven discentes de diferentes procedencias y diferentes culturas, por lo que el respeto multicultural es primordial y esencial para la integración social y el bienestar social de todo el estudiantado.

Para dar respuesta a este contexto multicultural y multilingüe, surge ArtiCULan (Art, Time, Culture, and Language), un proyecto europeo cuyo principal objetivo es la búsqueda de solución a los problemas de integración y adaptación social de estudiantes inmigrantes o refugiados en el contexto educativo de Educación Primaria. 
El proyecto ArtiCULan es un proyecto europeo (Erasmus+, KA2-KA201) ${ }^{1}$ en el que participan investigadores pertenecientes a diferentes instituciones de varios países europeos, a saber, Bélgica, Portugal, Turquía y España, y que son:

- PXL University College, de Bélgica

- Universidade Do Porto, de Portugal

- Instanbul Universitesi, de Turquía

- Universidad de Las Palmas de Gran Canaria, de España

El objetivo principal de estas instituciones europeas no es otro que el de crear y desarrollar talleres artísticos internacionales e interdisciplinares en aulas multilingües y multiculturales de nińos y niñas de entre 6 y 12 años, esto es, en el contexto de Educación Primaria, centrándose, principalmente, en contextos en los que existen alumnos y alumnas refugiados o inmigrantes y en aulas CLIL. Es en estos entornos en los que se necesita una mayor inclusión social de los estudiantes procedentes de otros países para que puedan alcanzar las competencias básicas, como ya se apuntó anteriormente.

El principal propósito de este trabajo es la descripción de este proyecto que se está llevando a cabo actualmente en las aulas de Educación Primaria de los diferentes países participantes en el mismo.

En las siguientes secciones, se definirá la metodología que se sigue en este proyecto (incluyendo un ejemplo de uno de los talleres realizados), se expondrán los resultados parciales alcanzados y las conclusiones derivadas del mismo. Tras estas secciones se ofrecen las referencias bibliográficas utilizadas.

\section{METODOLOGÍA}

El proyecto ArtiCULan es un proyecto europeo (Erasmus+, KA2-KA201), que comenzó en el año 2018 y que actualmente sigue vigente. Las instituciones participantes en el proyecto europeo ArtiCULan (PXL University College, de Bélgica; Universidade Do Porto, de Portugal; Instanbul Universitesi, de Turquía y Universidad de Las Palmas de Gran Canaria, de España), están diseñando diferentes talleres artísticos que se desarrollan en aulas de Educación Primaria de diferentes centros pertenecientes a los países participantes. En estas aulas de Educación Primaria coexisten estudiantes nativos y estudiantes inmi-

1 Este proyecto está financiado por la Agencia Ejecutiva en el ámbito Educativo, Audiovisual y Cultural (EACEA) de la Comisión Europea, convocatoria ERASMUS+ Program - Key Action 2 - Strategic Partnerships for School Education, referencia 2018-1-BE02-KA201-046844. 
grantes o refugiados, aunque se debe tener en cuenta que la mayoría de estos estudiantes inmigrantes o refugiados carecen de conocimientos de la lengua hablada en el país receptor, por lo que se hace imprescindible la integración de estos grupos en el contexto educativo.

Para los docentes, la enseńanza en estos contextos no es una tarea sencilla, puesto que la falta de comunicación docente-discente y discente-discente dificulta el proceso de enseńanza-aprendizaje, por lo que esta experiencia interdisciplinar les ayudará a la integración y cooperación en el aula. Además, el uso del arte logrará que los discentes trabajen y consigan un propósito común, permitiendo así la consecución de los objetivos planteados y la adquisición de las competencias básicas.

Como ya se ha mencionado anteriormente, los talleres artísticos propuestos son interdisciplinares y están dirigidos a aulas con contextos multiculturales y multilingües. Estos talleres combinan diferentes artes, como son la pintura, la música y el teatro, por ejemplo. En la realización de estos talleres, el estudiantado tiene la oportunidad de expresar sus ideas y sentimientos a través de diferentes recursos, además de cooperar y trabajar en grupo, facilitando así la integración del alumnado inmigrante o refugiado. Cada taller se realiza en los diferentes países participantes y se evalúa a través de una herramienta que se ha creado para tal fin y que se ha ido implementando con la realización de los talleres artísticos.

Para la ejecución de estos talleres artísticos se ha contactado con diferentes centros de Educación Primaria que comparten estas características: presencia de estudiantado inmigrante o refugiado, contextos multiculturales y aulas CLIL. Todos los centros que se han ofrecido para realizar los talleres artísticos han colaborado de manera altruista y los/las docentes implicados/as han aportado sus conocimientos y su experiencia en la ejecución de estos. A continuación, se presenta uno de los talleres realizados a modo de ejemplo.

\subsection{TALLER DE ESPIRALES}

Este taller se ha realizado en un aula multicultural en la que coexisten diferentes estudiantes procedentes de distintos países. Algunos de estos estudiantes no son capaces de comunicarse ni en lengua española, ni en lengua inglesa, por lo que no existe una comunicación oral con el resto de los/las compañeros/as ni con los/las docentes.

En la primera parte del taller, los estudiantes trabajan en gran grupo y para el resto de las actividades, trabajan en grupos de seis u ocho estudiantes, aunque 
se permite la movilidad total en el aula y la interacción entre todos ellos. Este taller se ha dividido en diferentes partes que se detallan a continuación:

- Primero se visiona una obra de arte en la que aparece la forma "espiral", como por ejemplo La noche estrellada de Van Gogh o la escultura El Viento de Martín Chirino. Se utiliza la técnica VTS (Visual Thinking Strategies) o pensamiento visual con el alumnado. Esta técnica, desarrollada por Abigail Housen y Philip Yenawine, se centra en la aesthetic meaning making, esto es, en las estrategias de pensamiento utilizadas para descubrir el significado de una obra de arte (Reilly, Ring y Duke, 2005). Para ello se realizan preguntas abiertas sobre una obra de arte y la audiencia, en este caso el alumnado, responderá en voz alta. En palabras de Feliu Torruella y González-Sanz, "el educador - ya sea en un museo o en un aula-, debe incitar a los alumnos a observar atentamente una obra de arte, a analizarla y a especular sobre ella, argumentando sus teorías en evidencias visibles" (2016: 24). Esto facilitará la discusión grupal y reforzará las habilidades comunicativas. Según Reilly, Ring y Duke (2005: 251), esta técnica permite que todos/as los/las estudiantes tengan la oportunidad de expresar su opinión sobre la obra de arte observada. Además, recibirán un refuerzo positivo de sus aportaciones, puesto que el/la docente parafraseará sus contribuciones y esta técnica hará que el estudiantado aprenda a valorar las aportaciones de sus compañeros/as.

En el caso del taller realizado, se utiliza esta técnica en la que los docentes realizan preguntas como: ¿Qué ven en este cuadro?, ¿Qué está pasando?, ¿Qué ves que te hace pensar eso?, ¿Qué más podemos encontrar? Los discentes responden a las preguntas planteadas y aportan todas sus ideas sobre las obras de arte expuestas. Tanto la primera, como la segunda pregunta les hace examinar la obra y a opinar; la tercera cuestión les ayuda a justificar sus interpretaciones y la cuarta, a desarrollarlas (Feliu Torruella y González-Sanz, 2016). Tras cada intervención, el/la docente parafrasea la aportación de cada uno/a de ellos/as, afirmando así la importancia de su intervención. De este modo, aquellos niños y niñas que no conocen la lengua son capaces de repetir lo que los demás aportan, por lo que aprenden la lengua a través de la repetición del vocabulario y las expresiones junto al visionado de una obra de arte.

- Tras el visionado de la obra de arte, los discentes tendrán que reproducir, con los diferentes materiales proporcionados por el/la docente, la forma espiral que han visto en las mismas. Para ello utilizarán ovillos de lana, témperas y plastilina. 
- Utilizando los ovillos de lana, el alumnado deberá crear la forma espiral. Para ello, los discentes pueden crear la forma en el suelo, dibujando la forma con el ovillo en el aire, entre otros. Los discentes tendrán reproducir la forma libremente, demostrando su creatividad en la realización de la forma espiral y colaborando para crear la espiral.

- Una vez realizada la reproducción de la forma con los ovillos de lana, los discentes tendrán que dibujar la forma que han visto en las obras de arte. Para ello, se sientan en grupo y reproducen la forma que han visto en la obra de arte, en este caso, utilizando témperas de colores. El estudiantado interactúa mostrando su forma de pintar a los demás compañeros/as, los colores que utilizan y haciendo preguntas sobre las espirales que están dibujando sus compañeros/as, incluso en algunos casos dirigiendo a sus compañeros/as para la consecución del objetivo.

- Después de reproducir la forma espiral a través de la pintura, el/la docente les proporcionará plastilina de diferentes colores y los discentes realizarán la forma espiral moldeando la plastilina. En algunos casos, han decidido realizar una espiral de mayor tamaño, participando todos los miembros del grupo en la creación de la forma, mientras que, en otros casos, lo han hecho de forma individual, pero siempre interactuando con sus compańeros/as, mostrándoles el proceso o incluso explicándoles cómo realizar la forma.

- Finalmente, todo el alumnado participante en el taller formará una espiral con sus cuerpos. Para ello tendrán que decidir entre todos/as dónde y cómo hacerlo, a la vez que entre ellos/as se coordinan para realizar la forma.

En la realización de este taller, todos y cada uno de los estudiantes ha participado y ha interaccionado e interactuado con el resto, incluso aquellos/as que no conocen la lengua espańola. Esta comunicación se ha efectuado a través de gestos, imitación, repetición de palabras, entre otros.

Este taller artístico es un ejemplo de los que se están llevando a cabo en los centros de Educación Primaria, teniendo en cuenta que se realizan en todos los países participantes en el proyecto (Bélgica, Turquía, Portugal y España). Una vez realizados los talleres en los diferentes países, se implementan con las aportaciones de cada país y se evalúan con una herramienta de evaluación que se ha creado para tal fin.

La herramienta de evaluación creada para evaluar los talleres artísticos en Educación Primaria, es parte del proyecto ArtiCULan. Esta herramienta se ha 
desarrollado para ayudar a los profesionales a diseñar los talleres artísticos. Se utiliza en la observación y reflexión sobre las características más relevantes de las experiencias significativas, creativas y expresivas, ofreciendo una serie de indicadores que deben ser observados en el proceso creativo de la realización de los talleres artísticos.

En esta herramienta se evalúa el proceso, incluyendo la interacción y la relación entre los docentes y los discentes, en la que destaca la expresión, el pensamiento y la comunicación. Evidentemente, esta herramienta también considera la conexión que existe entre los talleres artísticos y el contexto educativo en el que se realizan, esto es, el currículo y el centro en el que se llevan a cabo los mismos. Factores como la interacción entre el docente y el discente, la interacción entre los discentes, la autonomía, el diálogo, la cooperación y el reconocimiento de la identidad multicultural se tienen en cuenta en estos contextos.

Otros aspectos evaluados a través de la herramienta creada son: el punto de partida de los talleres, los materiales empleados, las experiencias, el espacio en el que se realiza, el clima emocional, la participación activa, las tareas, el tipo de interacción que se produce, las actividades multisensoriales, el proceso del taller, la elaboración, la responsabilidad, la metacognición, la comunicación tanto verbal como no verbal y el ritmo.

\section{RESULTADOS}

Los primeros resultados obtenidos tras la realización de los talleres artísticos en aulas de Educación Primaria muestran que este método didáctico basado en la realización de talleres artísticos favorece la integración de aquellos grupos minoritarios, en este caso el alumnado inmigrante o refugiado, que conviven en las aulas de Educación Primaria, en entornos multiculturales y multilingües.

El proyecto ArtiCULan sigue en vigor actualmente, por lo que todavía se están elaborando diferentes talleres que se ejecutan en las aulas de Educación Primaria de los diferentes países participantes. Estos talleres se siguen implementando y, gracias al uso de la herramienta de evaluación creada para tal fin, se valora su eficacia y eficiencia.

En esta fase, los discentes juegan un papel primordial, puesto que son ellos los que incluirán estos talleres en el contexto educativo y, a su vez, son los que colaboran en su realización, participando de manera activa en todo momento e incluso aportando su conocimiento y su experiencia para enriquecer los talleres artísticos. 
Por otro lado, cada una de las instituciones de los países que trabajan en el proyecto cuenta con la contribución de un/a artista que, en colaboración con los demás artistas de los otros países participantes, se encarga de crear los talleres y supervisar su ejecución en los centros de Educación Primaria en los que se realizan. También se han organizado coloquios en los que han participado diferentes artistas, profesionales relacionados con el arte y profesionales de la educación, entre otros. Estos coloquios han supuesto un factor clave para implementar, mejorar y considerar diferentes aspectos de los talleres artísticos. ${ }^{2}$

\section{CONCLUSIONES}

El aumento de la inmigración en Europa ha creado contextos en los que convergen diferentes culturas y diferentes lenguas. Estos contextos multiculturales y multilingües se trasladan a las aulas de Educación Primaria, en las que existen grupos minoritarios de estudiantes inmigrantes que en muchos casos desconocen la lengua del país receptor.

El proyecto europeo ArtiCULan surge para integrar el arte en el aula a través de la realización de diferentes talleres artísticos que favorecen la integración de esos grupos minoritarios, a la vez que les ayudan a la adquisición de las competencias básicas, así como a la adaptación y convivencia con diferentes culturas $\mathrm{y}$ al crecimiento personal.

Los talleres artísticos, como medio para favorecer la integración de las minorías en contextos multilingües y multiculturales, se están realizando en las aulas de Educación Primaria gracias a la colaboración e implicación de los docentes de los centros colaboradores. Teniendo en cuenta que los docentes siguen una programación estricta en cuanto a tiempo y contenidos se refiere y que la realización de los talleres afecta a su consecución, su colaboración es fundamental y esto facilita la obtención de resultados.

Este proyecto finaliza en el ańo 2021, por lo que todavía se encuentra en proceso de ejecución, creando, realizando, implementando y evaluando diferentes talleres artísticos que ayudarán a la inclusión e integración de diferentes culturas en el aula, favoreciendo la convivencia y el desarrollo tanto personal, como educativo.

2 Para más información sobre las actividades realizadas y sobre el proyecto ArtiCULan, consultar la página web del proyecto: https://www.articulan.eu/ 


\section{REFERENCIAS}

Alter, F. (2009). Understanding the role of critical and creative thinking in Australian primary school visual arts education. International Art in Early Childhood Research Journal, 1, 1-12.

Efland, A. (2002). Art and cognition: Integrating the visual arts in the curriculum. New York: Teachers College Press.

Eisner, E. (2002). The arts and the creation of mind. New Haven, CT: Yale University Press.

Feliu Torruella, M. y González-Sanz, M. (2016). Visual Thinking Strategies: Conectar la educación formal y la no formal a través del desarrollo de competencias. En L. Arias Ferrer y D. Verdú González (coords.). Estrategias y recursos para la integración del patrimonio y los museos en la educación formal. Editum. Ediciones de la Universidad de Murcia, 21-30.

García Morales, C. (2012) ¿Qué puede aportar el arte a la educación? El arte como estrategia para una educación inclusiva. ASRI: Arte y Sociedad. Revista de Investigación (ASRI), 1, 1-12.

Llevadot González, M. y Santacana, A. P. (2018). Revista Iberoamericana de Educación, 77(1), 121-140.

Ministerio de Educación y Formación Profesional. EDUCAbase. Recuperado el 7 de enero de 2021 de:

http://estadisticas.mecd.gob.es/EducaJaxiPx/Datos.htm?path=/

Educacion/Alumnado/Matriculado/20192020DA/Comunidad/Extran//10/\&f ile $=$ Extran $4 . p x \&$ type $=$ pcaxis

Muñoz Martínez, R. (2006). Una reflexión filosófica sobre el arte. Thémata. Revista de Filosofía, 36, 239-254.

Perkins, D. (1994). The intelligent eye: Learning to think by looking at art. Los Angeles, CA: The Getty Center for Education in the Arts.

Reilly, J. M., Ring, J. y Duke, L. (2005). Visual Thinking Strategies: A New Role for Art in Medical Education. Literature and the Arts in Medical Education, 37(4), 250-252.

Rodríguez Aranda, S. E. (2010). Arte, dibujo y actualidad. I+Diseño,3 (año III), 1-12.

United Nations Educational, Scientific and Cultural Organization. (2006). Road Map for Arts Education. The World Conference on Arts Education: Building Creative Capacities for the 21st Century. Lisbon, 6-9 March 2006. 


\title{
SOBRE LA ANTROPOLOGÍA FILOSÓFICA Y LA ANTROPOLOGÍA PEDAGÓGICA
}

\author{
Fernando Luis Peligero Escudero \\ Catedrático de Filosofía (jubilado) \\ Universidad de Las Palmas de Gran Canaria
}

\section{Resumen}

Toda crisis de carácter económico, social o político introduce cambios que afectan a la vida cotidiana de las poblaciones Las nuevas condiciones en que se desarrolla la existencia humana, exigen las correspondientes modificaciones que permitan la adaptación. Pero ello sólo es posible si se modifica la imagen del hombre, pues este actúa según el concepto que tiene de sí mismo. Las diversas concepciones del ser humano, que han sido ofrecidas a lo largo de la historia, han estado fundadas en las diversas religiones, en la filosofía y en las ciencias humanas. Fueron apareciendo como disciplinas la antropología y sus diversas ramas, entre las cuales se encuentra la antropología pedagógica. Cómo nació esta disciplina desde la antropología general y cuál debe ser su función es el objeto de este estudio.

Palabras clave: Antropología, Antropología Física, Fisiología, Antropometría, Psicología, Educación, Pedagogía, Antropología Pedagógica y Antropología Filosófica.

\begin{abstract}
All crisis of economic carácter, social or political introduces changes which affect the daily life of populations. The new conditions in which the human existence is developed, demands the correspondent modifications which permit its adaptation. But it is only possible if the image of the human being is modified, due to the fact that the human person acts according to the concept he has of himself. The different conceptions of the human being which have appeared throughout history have been founded on the different religions, in philosophy and in the human sciences. They were born as disciplines like anthropology and its diverse branches among which we find pedagogical antrhropology. How was this science born from general anthropology and which should be its function is the object of this study.
\end{abstract}

Keywords: Anthropology, Physical Anthropology, Physiology, Anthropometry, Psychology, Education, Pedagogy, Pedagogical Anthropology and Philosophical Anthropology. 


\section{EL AUTOANÁLISIS EN ÉPOCA DE CRISIS}

En la historia del pensamiento es un hecho que, en momentos de crisis de la humanidad, la reflexión filosófica va desde el mundo exterior al interior. El conocimiento del mundo externo cede paso al autoanálisis.

Así ocurrió en Grecia. La filosofía jónica giró paulatinamente desde el análisis del mundo exterior a la contemplación del mundo interior. En plena crisis, donde el relativismo sofista era predominante, surgió en Atenas la figura de Sócrates, para quien el conocimiento de uno mismo fue el punto de partida de su filosofía. Esta autorreflexión del hombre le permitió en tiempos de crisis dar un nuevo sentido a su existencia. A través de la educación intentó enseñar y desarrollar un nuevo estilo de vida. Sócrates y Platón aparecieron en Grecia no sólo como pensadores, sino también como grandes educadores. En oposición al individualismo, relativismo y escepticismo de los sofistas, Sócrates enseñó en el ágora verdades objetivas universales y Platón creó la Academia, donde, a partir del 384 a. de C. aproximadamente, formó en el conocimiento de la verdad a la élite intelectual de la Atenas clásica.

Este giro copernicano del pensamiento volvió a reproducirse en la filosofía postaristotélica, donde las diversas escuelas buscaron denodadamente el "ideal del sabio", que no sólo producía conocimiento, con el que afrontar las necesidades más acuciantes, sino también felicidad. Tras el surgimiento del imperio alejandrino las ciudades-estado griegas fueron desapareciendo y los ciudadanos se vieron perdidos en la inmensidad de las tierras conquistadas. Desapareció el ideal político de participar democráticamente con una buena oratoria en la vida pública de su ciudad. Los griegos de aquel tiempo se refugiaron en sí mismos y buscaron en su interior una guía, que les apartara de la miseria y les condujera a la felicidad. Las ciencias particulares y la moral predominaron en esta época.

El pensamiento humano de sí mismo apareció en el siglo $\mathrm{V}$ también dentro de la Patrística Latina en San Agustín, para quien el camino hacia la verdad parte del interior de uno mismo, a donde hay que volver para encontrarla. La meditación sobre él mismo constituyó la base desde la que elaboró su sistema filosófico.

Más tarde, en el inicio de la Edad Moderna, cuando los esclavos ya habían roto sus ataduras a los señores feudales y alcanzado su libertad, sienten la necesidad de volver al propio yo para descubrir su ser. Descartes toma de nuevo a la subjetividad como fundamento de su filosofía. En el cogito, ergo sum (pienso, luego existo), que es un principio indubitable, descansa todo su sistema. La autoconciencia es el punto de arranque de toda su filosofía racionalista, pues de cualquier verdad del mundo externo puedo dudar, pero no de mi existencia 
cuando pienso. Mi yo es un yo pensante. En el mundo interno es donde se inicia el pensamiento y desde él se irá al conocimiento de todas las demás realidades tanto internas como externas.

Ya avanzada la Edad Moderna, en una nueva época de crisis en un tiempo revolucionario, al que no satisface plenamente el espíritu de la Ilustración, aparece el suizo Pestalozzi, quien toma el tema de la esencia del hombre como núcleo de su pensamiento. El progreso económico y social de su pueblo sólo se logra por la educación y esta es entendida como un proceso de humanización. Por la educación el hombre se perfecciona y se hace más humano. De esta forma, puede superar su indigencia y alcanzar la felicidad. En Pestalozzi, la pedagogía fundada en la antropología se convierte en una tarea universal de la vida, a la que proporciona un sentido.

Tras el Siglo XIX, en el que hay un gran desarrollo de las ciencias particulares, especialmente de las ciencias de la naturaleza, el Siglo XX se caracteriza por el giro antropológico que desde la fenomenología y el existencialismo se fomenta.

El periodo entre las dos guerras mundiales fue extraordinariamente fecundo para la reflexión antropológica. La angustia y el desamparo que trajeron consigo las dos guerras mundiales, produjeron una gran crisis en una gran parte de la población mundial. Surgieron múltiples preguntas sobre el sentido de la vida humana y se pidieron respuestas a los filósofos.

La crisis actual de la pandemia, que en nuestros días padecemos, y el inevitable deterioro económico sufrido por la mayor parte de la población mundial traerán consigo muy pronto nuevas visiones del ser humano y de su conducta, que tendrán su correspondiente aplicación en el proceso educativo a través de la antropología pedagógica.

\section{EL SIGNIFICADO DE LA EXPRESIÓN "ANTROPOLOGÍA PEDA- GÓGICA”}

Pero, ¿qué significa esta expresión? En ella se da la unión de dos términos: el substantivo antropología y el adjetivo pedagógica. El hecho de que al substantivo "antropología" se le añada el adjetivo "pedagógica" muestra su ambigüedad. Su polisemia desaconseja utilizarlo sin ninguna determinación. Por esta razón, las ramas de la antropología suelen ser designadas con un adjetivo que las específica y determina. Así, aparecen los nombres de antropología física o biológica, de antropología médica, de antropología cultural, de antropología social, de antropología económica, de antropología política, de antropología filosófica, de antropología teológica, de antropología pedagógica, etc. 
Pero no se piense que la ambigüedad del término antropología ha surgido únicamente por la explosión contemporánea de sus múltiples ramas, que ha contribuido de forma decisiva a la supremacía contemporánea de las ciencias humanas sobre las ciencias de la naturaleza. Desde su utilización por vez primera en la historia de la ciencia hasta la actualidad ha modificado varias veces su significado. Su acepción de "ciencia del hombre" es el resultado de la evolución que el vocablo ha sufrido a lo largo de los siglos desde el mundo antiguo al mundo moderno. Aunque la palabra antropología deriva etimológicamente del griego, sin embargo, no se ha mostrado que como tal fuera utilizada en la antigüedad clásica. La terminación "-logía” para designar el estudio, tratado o ciencia de algo es más propia del Renacimiento que del mundo antiguo, que, sin embargo, sí utilizó para ello la terminación "-logiqué".

La unión del substantivo antropología y el adjetivo pedagógica significa que para dar una explicación cabal del proceso educativo hay que poner en relación dos disciplinas diferentes: la antropología y la pedagogía. Por ser antropología, su objeto de estudio es el hombre, pero, por ser pedagógica, ha de estudiarlo como educando y como educador, es decir, sub specie educationis. La educación es un proceso del hombre para el hombre.

La antropología pedagógica así entendida no debe identificarse con la antropología de la educación, a pesar de que sus respectivos títulos por sus parecidos puedan inducir a este error. Cuando hace etnografía de la educación o se ocupa de las formas de educación de grupos culturalmente diversos, la antropología de la educación, que ha tenido un gran desarrollo en el mundo anglosajón a partir del Congreso de Antropología de la Educación de 1954 en Stanford, está más cerca de la antropología cultural y de la antropología social que de la antropología física o filosófica.

La forma en que se relacione la antropología con la pedagogía dará lugar a los diversos modos de constituir y desarrollar la antropología pedagógica. Por otra parte, puesto que el nombre de antropología es polisémico, según sea el significado en que se tome variarán sus relaciones con la pedagogía y su estructura como disciplina. Si por antropología se entiende la antropología física el estudio del hombre desde el punto de vista de la educación será principalmente desde su dimensión corpórea, pero, si por antropología se significa la antropología filosófica, la antropología pedagógica toma como objeto de estudio al hombre como una totalidad compuesta de dos o más dimensiones conectadas entre sí.

La evolución del significado del término antropología desde su aparición hasta nuestros días y su forma de relacionarse con la pedagogía determinarán la constitución de la antropología pedagógica. 


\section{LA GÉNESIS DEL TÉRMINO "ANTROPOLOGÍA"}

Antropología significa tratado del hombre. El término griego ó $v \theta \rho \omega \pi \circ \lambda o ́ \gamma o \varsigma$, que es una palabra compuesta de öv $\theta \rho \omega \pi$ o y $\lambda$ ó $\gamma \circ \varsigma$ aparece en la Ética a Nicomaco $(\mathbf{H \delta 8}, \mathbf{1 1 2 5} a 5)^{1}$ de Aristóteles para designar a quien "habla del ser humano". Más adelante, Filón de Alejandría (25 a.C.-50 d.C.) utiliza el verbo

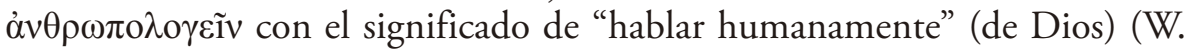
Pape, 1849:196) ${ }^{2}$.

El substantivo antropología en el sentido moderno de ciencia del hombre es utilizado por primera vez en 1501 por el teólogo de la Universidad de Leipzig, de la que fue Rector, Magnus Hundt en su obra Antropologium de hominis dignitate, natura et proprietatibus, de elementis, partibus et membris humani corporis. ${ }^{3}$ Aunque en ella sobre todo describe el cuerpo desde el punto de vista anatómico y fisiológico, también lo hace desde el punto de vista filosófico y religioso, sosteniendo la tesis de que el hombre fue creado a imagen de Dios y representa un microcosmos del mundo tal como fue creado. Aunque la obra es principalmente una representación del cuerpo humano, también estudia el espíritu y el alma humana. Así pues, desde su aparición como disciplina científica ya aparece con una cierta dualidad en su objeto y en su método, lo que le ocasiona una cierta ambigüedad.

Aunque la denominación de antropología aparece en el Renacimiento, cuando el tema del hombre es abordado desde una perspectiva moderna, es decir, como un ser autónomo, en sí mismo considerado, su estudio ya tuvo lugar en diversos autores en la Edad Media. Plotino y San Agustín fueron los más destacados. Pero los pensadores medievales por su teocentrismo explicaban al hombre desde Dios, que por haberlo creado a su imagen y semejanza nace dotado de dignidad. La naturaleza humana es interpretada como algo estable y permanente. En el mundo hay un orden preestablecido por Dios que debemos respetar. En este plan divino, el hombre para vivir en armonía con los demás seres debe ocupar el lugar que por su naturaleza le corresponde.

En esta cosmovisión, Dios es el eje de todo cuanto existe. Para saber qué es el hombre bastaba con investigar las características de su naturaleza creada. Pero esta concepción estática del hombre de la Edad Media, proporcionada desde

1 Ét. Nic. H881125a5.

2 Pape, W. (1849). Griechisch-Deutsches Handwörterbuch. Erster Band A-K. ND Graz: Akademische Druk- u. Verlagsanstalt, 196.

3 Hundt, M. (1501). Anthropologium de homine dignitate, natura et propietatibus, de elementis, partibus, et membris humani corporis . Leipzig: Baccalarium Wolgangum Monacensem 
la teología y la filosofía, es sustituida en el Renacimiento, donde ya predomina una cosmovisión antropocentrista, por una interpretación dinámica de su ser.

El paso de la Edad Media a la Edad Moderna trajo consigo transformaciones profundas en todos los ámbitos de la vida humana. Para lograr un clima de tolerancia y convivencia pacífica, había que transformar la vida personal. Se pusieron los ojos en el mundo antiguo de Grecia y Roma. Surgió el Renacimiento, que fue una vuelta a la cultura griega y romana. Se desarrolló desde finales del Siglo XV hasta principios del Siglo XVII. La vuelta al mundo antiguo condujo al Humanismo, esto es, "al descubrimiento del hombre". Para afrontar las transformaciones políticas, sociales y económicas se buscó un nuevo arquetipo del hombre. Se pasó a concebirlo como un ser superior y protagonista único de su propio destino. Aunque no se prescindió totalmente de la autoridad de la Iglesia a la hora de establecer una nueva concepción del ser humano, pues interpretaron la cultura antigua desde el Cristianismo, éste quedó en ella, sin embargo, en un segundo plano. Esta nueva visión del hombre supo conjugar el individualismo con el misticismo. Pero sobre todo abandonó el teocentrismo medieval para acogerse al antropocentrismo. Las disquisiciones teológicas sobre la dignidad del hombre ceden el paso a las investigaciones filosóficas sobre ella.

En 1452, apareció la obra de Gianozzo Manetti Sobre la dignidad y excelen-

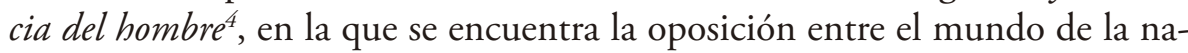
turaleza y el mundo del espíritu, que es un precedente claro de la ruptura contemporánea entre la naturaleza y la cultura. Su influjo en la historia de la cultura y en el espiritualismo del Humanismo fue notable. Frente al pesimismo medieval, que consideraba que el hombre estaba condenado a vivir permanentemente en la miseria, subrayó su poder en el mundo y el esfuerzo que realiza en la historia. Interpretó que la existencia humana no es un valle de lágrimas, sino el lugar en el que el hombre se manifiesta como digno del origen divino de su actividad espiritual. Consideró que las doctrinas, que muestran su miseria, son repugnantes. Defendió su dignidad y excelencia. Su obra consta de cuatro libros En el primero, intentó probar la grandeza del cuerpo humano; en el segundo, la excelencia del alma humana; en el tercero, la superioridad del destino del hombre; y en el cuarto, rechazó las doctrinas relativas a la miseria humana.

4 Manetti, G. (1452). De dignitate et excellentia hominis. Libri IV. En E. Garin (1850), Prosatori latino del quattrocento. Vol. XIII. Milano\&Napoli: Riccardo Ricciardi Editors, 421-490 
En 1486, vio la luz el Discurso sobre la dignidad del hombre de Giovani Pico della Mirandola ${ }^{5}$ que marcó el definitivo tránsito de la Edad Media a la Edad Moderna. El pensamiento teocéntrico, en el que se ponía a Dios como centro de la reflexión, fue sustituido por una cosmovisión antropocéntrica, en la que el hombre era el principal objeto de investigación por ser el centro del universo. Puso el acento en la dignidad del hombre para lanzarlo hacia Dios a través de la mística. Por la fe pretendió llegar a ámbitos jamás alcanzados por la razón. El Discurso no partió de Dios para llegar al hombre, sino de éste para llegar a Aquél. Su dignidad no consiste en su indeterminación esencial inicial, sino en su capacidad de hacerse, en la posibilidad de llegar a ser lo que se proponga, en movilizar sus facultades más elevadas (inteligencia, razón, bondad, moralidad) para ser fiel al amor y a la confianza que Dios le ha dado.

Cuando decide determinar su indeterminada naturaleza lo hace por una decisión libre que lo asemeja a su creador. Esta semejanza, que es una imitatio Dei, muestra la verdadera dignidad del ser humano entendida como excelencia.

La dignidad del hombre no hay que buscarla como se hacía en el pensamiento medieval en lo que el hombre es, sino en su capacidad de hacerse, es decir, en la posibilidad de llegar a ser lo que quiera. Su causa está en Dios, quien lo creó como un ser extraordinario "indefinido", "indeterminado" y "sin terminar", capaz de ser lo que él mismo proyecte. No es que el hombre carezca de naturaleza en su nacimiento, sino que es "un animal con una naturaleza multiforme y mudadiza" (1984:106). Todo en la creación tiene marcado un destino, una esencia fija, salvo el hombre que nace con "toda suerte de semillas, gérmenes de todo género de vida”, un sinfín de posibilidades que puede desarrollar merced a su libertad. Gracias a su inteligencia tiene la capacidad de elegir libremente su destino y crearse a sí mismo. En la obra de Pico della Mirandola se atribuye al ser humano tres modalidades de libertad: la libertad moral, por la que puede elegir entre el bien o el mal; la libertad de arbitrio, por la que puede elegir entre las diversas opciones que le presenta su inteligencia; y la libertad óntica, por la que puede moldear su ser de la forma que prefiera.

Aunque su escrito no lleva el título de antropología, ni el término aparece en su contenido, es evidente que en él desarrolla un auténtico tratado de antropología que va a influir decisivamente en el Humanismo del Siglo XVI y en los siglos posteriores. Su análisis de la dignidad del hombre fue clave para

5 Pico della Mirandola, G. (1978). Discurso sobre la dignidad del hombre. Trad. De Adolfo Ruiz Díaz. México: Editorial Goncourt, 1978. 
que posteriormente se formularan y reconocieran los derechos humanos. En su obra también pudo encontrar inspiración el existencialismo del Siglo XX, aunque no pueda mantenerse su identificación, pues para esta corriente la existencia humana nace vacía de contenido esencial y para el pensador italiano con una naturaleza "moldeable, sin terminar".

Cinco años después de la aparición de la obra de Magnus Hundt, Raffaele Maffei ${ }^{6}$ publicó en Roma, en 1506, en treinta y ocho libros su obra Commentarium Urbanorum octo et triginta libri. Aunque no lleva en su portada el término de antropología, sin embargo, está utilizado con frecuencia en su contenido y con él designa la Sección Segunda. La obra está compuesta de tres Secciones denominadas Geographía (II-XII), Anthropología (XIII-XXIII) y Philología (XXIV-XXXVIII). A las tres Secciones les precede un primer libro de índices. En él se dice expresamente que la Sección Segunda se ocupa "de los hombres ilustres de todos los tiempos, lugares y pueblos". Lo cual significa que el neologismo tomado del griego ya se había universalizado y no sólo era utilizado en Alemania, sino también en Italia.

Unos años más tarde, en 1533, Galeazzo Flavio $\mathrm{Capra}^{7}$ (conocido también como Capela y Capella) publicó en Venecia su Anthropología en esta misma acepción de estudio del ser humano. La obra consta de tres libros: En el primero, se exponen las virtudes de los hombres. En el segundo, reproduce su obra anterior Sobre la excelencia y dignidad de la mujer". En el tercero, analiza los defectos de los dos géneros.

La designación de antropología para designar la ciencia que estudia al hombre en sus dos dimensiones, corporal y espiritual, apareció de nuevo en Alemania a finales del Siglo XVI. En 1594, Casmann ${ }^{9}$ hizo público en Hannover su escrito Psicología Anthropologica, sive doctrina animae humanae..., que era la primera parte de su antropología. La esencia del hombre participa de la doble naturaleza espiritual y corporal del mundo. En esta primera parte, se ocupa del alma humana. Dos años después, publica "Segunda parte de la antropología: esto es; la Fábrica del cuerpo humano descrita metódicamente... ${ }^{10}$, en la que se ocupa de la

6 Maffei, R. (506). Commentarium Urbanorum. Roma: Johannem Besickten Alemannum

7 Capra, G. F. (1533). L 'Anthropologia. Veneci: Heredi d'Aldo Romano, e d'Andrea d"Asola.

8 - (1525). Della Eccellenza et Dignità delle Donne. Rome: Fracesco Minizio Calvo.

9 Cassmann, O. (1594). Psychologia Anthropologica, sive Animae humanae doctrina, methodice informata, capitibus dissecta, singulorumque capitum disquisitionibus, ac controversarum questionum ventilationibus illustrata. Hannover: apud Guilielmum Antonium, impensis Petri Fischeri Fr.

10 - (596). Secunda pars anthropologiae: hoc est, Fabrici humani corporis; methodice descripta (...) Hannover: apud Guilielmum Antonium, impensis Petri Fischeri. 
constitución del cuerpo humano. Aunque Casmann consolida el nombre de esta disciplina, al distinguir en ella dos partes plenamente definidas y al atribuirle al hombre una naturaleza espiritual y corporal, pone los cimientos para que más adelante surjan varias disciplinas antropológicas, que no se conformen con ser parte de una ciencia sino que reclamen para sí ser una ciencia independiente. De esta forma, irán apareciendo paulatinamente la antropología física, la antropología cultural, la antropología social y la antropología filosófica.

Si bien en el Siglo XVI se introdujo el neologismo antropología en diversos idiomas para significar la ciencia del hombre, también en este siglo y en el siguiente tenía otros significados. Malebranche ${ }^{11}$ utilizó este vocablo en una acepción semejante a la utilizada por Filón de Alejandría para significar la atribución de las características y acciones humanas a Dios (1680:78). También en Leibniz ${ }^{12}$ se halla en su Discurso de Metafisica (cap.36) (1955:82), pero como sinónimo de antropomorfismo, es decir, como una humanización de Dios cuando se le atribuye las cualidades de los hombres.

Frente a estos significados, el de ciencia del hombre establecido por Magnos Hundt fue generalizándose cada vez más con el paso del tiempo e imponiéndose poco a poco. En la obra de Stieler ${ }^{13}$ Arbol genealógico y desarrollo de la lengua alemana o tesoro lingüístico alemán, de 1691, que fue el primer diccionario de esta lengua, antropología significa "la ciencia del cuerpo humano". En el Léxico filosófico ${ }^{14} \mathrm{de}$ J. G. Walch, publicado en Leipzig en 1726, se parte de la amplia concepción del hombre de Casmann para distinguir entre la antropología física, la antropología médica y la antropología moral. Pero la antropología en su acepción más limitada como ciencia del cuerpo humano siguió manteniéndose en Antropología para médicos y filósofos de E. Platner ${ }^{15}$, publicada en Leipzig en 1772.

El término antropología para designar la disciplina que tiene por objeto el estudio sistemático del ser humano quedó consolidado en I. Kant ${ }^{16}$. En la Introducción de su Lógica afirma: "El campo de la filosofía en esta significación universal se puede reducir a estas preguntas:

11 Malebranche, N. (1680). Traité de la nature et de la grâce. Amsterdam: Chez Daniel Elsevier, 78. 12 Leibniz, G.W. (1955).Discurso de Metafísica. Trad. de Alfonso Castaño Piñán. Buenos Aires: Aguilar, 82.

13 Stieler, K. von (1691). Der Teuschen Sprache Stammbaum und Forwachs oder Teuschen Sprachschatz. Nürmberg: J. Hoffmann

14 Walch (1726). Philosophisches Lexicon. Leipzig: J.G. Walch.

15 Platner, E. (1772). Anthropologie für Ärzte und Weltweisser. Leizig: Dyck

16 Kant, I. (2001). Lógica. Trad. De María Jesús Vázquez Lobeiras. Madrid: Akal. Intr. III, 3º. 
1. ¿Qué puedo yo saber?

2. ¿Qué debo hacer?

3. ¿Qué puedo esperar?

4. ¿Qué es el hombre?

A la primera pregunta responde la metafísica; a la segunda, la moral; a la tercera, la religión; y a la cuarta, la antropología. Pero en el fondo podría atribuirse todo a la antropología, pues las tres primera preguntas se refieren a la cuarta" (III, 30). Aunque por este texto, parece que Kant tiene un concepto unitario y no plural de esta disciplina, sin embargo no es así, pues, en contra de Platner, tomó el nombre de antropología no sólo para denominar el conocimiento científico del hombre, en particular el fisiológico o antropométrico, sino también el general de su ser empírico y de sus facultades (antropología teórica), e igualmente del hombre como un ser libre que decide lo que hace o puede o debe hacer de sí mismo, es decir, de sus habilidades (antropología pragmática) y, finalmente, del modo de vivir y de las condiciones subjetivas que frenan o favorecen la concordancia de su conducta con los principios metafísicos y con las costumbres (antropología moral). Mientras que en sentido fisiológico indaga lo que la naturaleza hace del ser humano, en sentido pragmático se refiere a lo que él hace, o puede y debe hacer, de sí mismo. El enfoque fisiológico contempla al hombre como un ente empírico determinado por las leyes de la naturaleza, mientras que las visiones pragmáticas y la moral lo toman como un ser que con su razón se puede y se debe autodeterminar. En el primer caso, aparece como fenómeno, en el segundo y tercero, como noúmeno. Kant reproduce la distinción entre naturaleza y libertad.

El desarrollo de la respuesta a la cuarta pregunta le conduce, por la complejidad del ente examinado, a una multiplicidad de respuestas desde diversas perspectivas, que conducen a una multiplicidad de ramas antropológicas. Todas ellas versan sobre el hombre, pero difieren en el punto de vista desde el que lo estudian.

En resumen, Kant presenta a la antropología como la ciencia del ser humano, que por su complejidad da lugar a tres enfoques diferentes y tres ramas distintas: la antropología fisiológica, la antropología pragmática y la antropología moral. Son tres ramas que salen de un mismo tronco, pero no tres árboles distintos. Esta tendencia holística de la antropología es aún mantenida durante algún tiempo en pensadores del idealismo alemán. Fichte ${ }^{17}$, que la concibe

17 Fichte, I. 77s 
como una ciencia que sirve para demostrar que el cuerpo humano debe ser concebido como un cuerpo provisto de razón, le da una orientación claramente somatológica. Schelling ${ }^{18}$ piensa que es una disciplina que sirve para esclarecer la relación del espíritu humano con su propia naturaleza, con su cuerpo y con el mundo en general. Hegel ${ }^{19}$ le asigna como objeto el estudio del hombre como espíritu subjetivo, es decir, como alma o espíritu en su corporeidad físico natural.

\section{LA ANTROPOLOGÍA COMO CIENCIA POSITIVA}

Pero desde finales del Siglo XVIII empieza el gran desarrollo de las ciencias positivas (la química como ciencia experimental y la economía) y durante el Siglo XIX, en el que predomina el positivismo, aparecen nuevas ciencias humanas que poco a poco van desgajándose de la filosofía. Nacen la psicología y la sociología como ciencias independientes. Dentro de esta tendencia a sustituir la filosofía metafísica por las ciencias particulares, surge la Antropología como una ciencia positiva que se ocupa de la naturaleza física del hombre o bien como una ciencia que estudia su naturaleza cultural, es decir, nacen la antropología física y la antropología cultural como ciencias positivas e independientes. Se intenta sustituir la concepción metafísica del ser humano por una visión radicalmente positivista de él.

Aunque Herder analizó múltiples aspectos del ser humano y sus resultados son importantes para la antropología filosófica contemporánea, sin embargo, a diferencia de su maestro Kant, a cuyas clases asistió, apenas utilizó el término "antropología". En sus Ideas para una filosofía de la historia de la humanidad propuso como su fundamento una philosophia anthropologica ${ }^{20}$ según el modelo de la philosophia botánica de Linneo. Esta filosofía antropológica, que fundamenta su filosofía de la historia, debe contemplar al hombre no sólo como una unidad de cuerpo, alma y espíritu, sino como un ser inserto en espacios geográficos y en entornos humanos a través de diversas culturas, que se prolongan hasta el presente. Mientras el animal está circunscrito a una esfera específica por sus características orgánicas de protección y por sus instintos, el hombre aparece, por su misma naturaleza, como un ser deficiente e indefenso, que necesita de la educación y de la cultura para poder sobrevivir. Es capaz de

18 Schelling, I, 349.

19 Hegel I (1, 318-344; (2), 436.

20 Herder, J. G., Ideas para la filosofía de la historia de la humanidad. Trad. De J. Rovira Armengol. Buenos Aires 1959, p.49. 
realizar acciones que no se observan en los demás animales. En el caso del canibalismo, es capaz de devorar a sus semejantes por glotonería e igualmente de asesinar a sangre fría a un semejante por orden de otro. Pero, además, tiene en exclusiva un habla, una escritura, una tradición, una religión, leyes voluntarias y derecho. Como individuo, también posee una cultura, un modo de vestir, una vivienda, un estilo de vida y unas opiniones fluctuantes que lo distinguen de los demás individuos de su linaje. Los resultados de la fisiología y anatomía comparadas de su tiempo del reino vegetal y animal le permitieron describir las características esenciales del ser humano y establecer una diferencia orgánica respecto de los demás animales. Las notas diferenciadoras más importantes son las siguientes: el bipedismo, la posición perpendicular del cráneo respecto de la columna, la nueva conformación cerebral, la frente elevada y desarrollada, la primacía de la vista sobre los otros sentidos externos, la liberación de las manos, la reestructuración de mandíbulas y dientes, el lenguaje, la amortiguación de los instintos, el parto prematuro, la adaptabilidad a los diversos hábitats, el aprendizaje cultural permanente, la longevidad, la sociabilidad y la libertad.

El influjo del pensamiento de Herder en la antropología y en la etología del siglo XX ha sido extraordinario. La antropología filosófica, en su concepción del ser humano como un ser indigente, débil y necesitado; la antropología cultural, en su interpretación de la cultura como un instrumento que permite al hombre con su relativismo cultural adaptarse para sobrevivir al medio en el que en cada momento está inserto; y la antropología pedagógica, que fundamenta la educación y la cultura en la naturaleza deficiente e indefensa del hombre, reconocen su legado. Gehlen muestra su influjo al afirmar que "la antropología filosófica no ha dado un paso adelante desde Herder y, en esquema, es la misma concepción que yo quiero desarrollar con la ayuda de la ciencia moderna..." 21 .

Pero algo después de Herder, a principios del Siglo XIX, nacieron algunas corrientes que prepararon un resurgimiento de la antropología filosófica que tendría lugar en la primera mitad del XX. Estas nuevas orientaciones parten de dos realidades fundamentales que van a tener una gran repercusión: la vida (tanto desde una perspectiva biológica como histórica) y la persona que la vive. La confluencia del pensamiento de Maine de Biran, Schopenhauer, I. H. Fichte,

21 Gehlen, A. (1980). El hombre. Su naturaleza y su lugar en el mundo. Trad. de F.-C. Vevia Romero. Salamanca: Ediciones Sígueme, 97. 
Feuerbach y Dilthey con el nacimiento y desarrollo de la antropología física y de la antropología cultural, que mantuvieron el interés por el tema del hombre aún utilizando una metodología positiva como ciencias particulares, provocaron el giro antropológico. Ante la conciencia de que las investigaciones positivas tenían un alcance limitado, pues solamente estudiaban al hombre o desde su cuerpo o desde su cultura, solicitaban a los filósofos de su tiempo la creación de una antropología filosófica que lo estudiara como una totalidad. No solamente se estaban sentando las bases para que más adelante surgiera la antropología filosófica, sino que ya en los dos últimos decenios del mismo Siglo XIX nació la antropología pedagógica como una ciencia del hombre en relación con la educación.

\section{ORIGEN Y DESARROLLO DE LA ANTROPOLOGÍA PEDAGÓGICA}

Luis de Hoyos sitúa a los iniciadores de esta ciencia en Italia, pues Melzi creó en 1899 el Laboratorio Antropológico ${ }^{22}$. En 1899, también Ugo Pizzoli creó el Laboratorio de Pedagogía Científica en Crevalcore, inaugurado oficialmente en 1901, con el fin de profundizar y difundir la pedagogía basada en las ciencias humanas positivas (antropometría, fisiología, higiene y psicología) y no en la filosofía. En 1905, este laboratorio que inicialmente fue concebido como un gabinete de antropología pedagógica en el que se medían las capacidades físicas y psíquicas de los niños pasó a denominarse Instituto de pedagogía experimental y en 1907 Laboratorio de psicología pura y aplicada. La Pedagogía cientifica de Pizzol $i^{23}$, que fue caracterizada como pedagogía biológica, fluye de modo directo de las ciencias humanas que van desde la biología a la sociología. La representaba como un árbol con dos ramas, que eran la pedagogía normal y la pedagogía enmendadora, la cual se ocupaba de los niños retardados, díscolos, sordomudos, ciegos de nacimiento, balbucientes, cretinos e idiotas. Estas dos ramas salían del tronco, que estaba formado por la sociología pedagógica, la antropología pedagógica, la psicología pedagógica, la higiene pedagógica, la fisiología pedagógica y la anatomía pedagógica. El tronco se alimentaba de sus raíces, que eran la anatomía, la fisiología, la higiene, la psicología, la antropología y la sociología.

22 Hoyos Sainz, L. de (1911). Notas para la Historia de las Ciencias Antropológicas en España. En Asociación Española para el Progreso de la Ciencia. III Congreso. T. V. Granada: El defensor de Granada, 61-80.

23 Pizzoli. U. (1909). Pedagogía scientifica. Milano: Vallardi. 
A esta nueva pedagogía científica, se adhirió la Dra. María Montessori. Dentro del movimiento pedagógico "Escuela Nueva" aceptó y defendió la aplicación de los métodos científicos a la educación. Muy motivada por las condiciones sociales que atravesaban las mujeres y los niños de su tiempo, se afilió al movimiento feminista y empezó a trabajar con niños de 3 a 6 años, cuyos padres, la mayoría analfabetos, trabajaban fuera de casa.

Acudió como representante de las mujeres italianas al Congreso Feminista de Berlín de 1896, en el que defendió la igualdad de derechos entre los hombres y las mujeres. En este mismo año, se licenció en Medicina y Psicología en la Universidad de Roma, lo cual la capacitó para conocer profundamente el cuerpo humano y su desarrollo. Al año siguiente fue nombrada ayudante en la cátedra de psiquiatría de la misma universidad y desde 1896 a 1898 estudió las enfermedades nerviosas y mentales. Durante este tiempo estudió los trabajos de los médicos Itard y Seguin sobre personas con problemas mentales y, en el tratamiento de los niños con alteraciones en el desarrollo cognitivo, descubrió que su problema era pedagógico más que médico. En el Congreso Pedagógico de Turín de 1898 expuso estas ideas y demostró que los niños con patologías psíquicas tratados por ella obtenían mejores resultados que los normales. Ello significaba que los considerados perturbados tenían potencialidades, que aún siendo diferentes, una vez desarrolladas, los convertía en aptos para algunos tipos de trabajo con los que podían conseguir una vida digna y no ser una carga para la sociedad.

El ministro Guido Baccelli le solicitó para las maestras de Roma un curso sobre la educación de este tipo de alumnos, que se transformó en la Escuela Magistral Ortofrénica, de la que fue directora durante dos ańos.

A continuación se fue a Londres y a Paris para ampliar sus conocimientos. En 1990, participó en el Congreso Internacional para mujeres celebrado en Londres. A su regreso, de 1900 a 1906 impartió docencia de antropología e higiene en el Instituto Superior de Magisterio Femenino de Roma y en 1902 se matriculó en el curso de Filosofía de la Universidad de Roma. Estudió filosofía teórica y moral, historia de la filosofía y psicología, pero no llegó a graduarse. No obstante, su estudio de la psicología experimental le sirvió para aplicarla a la educación. Realizó estudios independientes de antropología y filosofía educativa. En esta época, tras estudiar los métodos de Itard y Seguin para educar a los nińos con discapacidades mentales tuvo la idea de adoptarlos para aplicarlos a la educación general.

A partir de 1902, Montessori contribuyó al desarrollo de la pedagogía científica. En este año presentó un informe en el Segundo Congreso Pedagógico 
Nacional de Nápoles. En 1903, publicó dos artículos sobre pedagogía. En 1903-4, realizó una investigación antropológica sobre escolares italianos. Fue nombrada para dar conferencias en la Escuela Pedagógica de la Universidad de Roma, que desempeñó hasta 1908. Desde 1904 a 1910 también fue docente de antropología en la Facultad de Ciencias.

En 1907, por encargo del Instituto del Beni Stabili de Roma, que se dedicaba a la reconstrucción de las casas abandonadas, fundó en la barriada de San Lorenzo la "Casa de los niños". La propuesta inicial era reunir a los hijos de los inquilinos de una casa de vecindad de este barrio para que no quedaran desamparados por la calle y por la escalera del inmueble ensuciando sus paredes y creando el desorden cuando sus padres se fueran a trabajar. Se destinó con este fin una habitación de la misma vivienda que contaba con sus muebles antiguos, a los que se ańadieron los encargados al fabricante que los proporcionaba a la clínica de minusválidos de la facultad de medicina y los materiales pedagógicos inspirados en los que ya habían establecido los doctores Itard y Seguín para deficientes. El ambiente preparado es una premisa fundamental para la educación. Todo debe estar ordenado de forma simple.

La Dra. Montessori recibía diariamente las correspondientes incidencias de las dos mujeres no maestras, que cuidaban a los niños con la instrucción de no intervenir directamente en su aprendizaje, y una vez por semana visitaba el centro.

En los dos años siguientes se crearon otras dos "casas del niño" en la misma ciudad. El original método utilizado en ellas tuvo un gran éxito y desde estas dos escuelas se difundió al resto de Italia y a todo el mundo. Su preparación como doctora, su sensibilidad a favor de las mujeres y de los niños desamparados y su experiencia en los centros educativos creados por ella le proporcionaron las bases para su construcción teórica, que publicó en 1909 con el título Il método della pedagogía scientifica applicato all 'autoeducazione infantile nella Casa del bambini ${ }^{24}$.

Consistía en fomentar la autonomía de los niños en edad preescolar a través del material para el desarrollo de los sentidos, de objetos apropiados a sus aficiones y a su desarrollo físico, que se encontraban en la propia "Casa del niño" y en la solución de problemas prácticos interesantes según su libre elección con su trabajo personal y con el material didáctico puesto a su disposición.

24 Montessori, M. (1909). Il método della pedagogía scientifica applicato all'autoeducazione infantile nella Casa del bambini. Roma: M. Bretschneider 
Tras observar que los niños aprendían mejor cuando participaban en una actividad determinada, les enseñaba a aprender por sí mismos a través de materiales prácticos y ricos en sensaciones, nutrición y amor, que la escuela les proporcionaba. El método se basaba en el respeto de su espontaneidad. En la educación autoritaria de la época, esto representó una innovación. El pequeño se muestra tal y como es cuando es libre para expresarse y no cuando es coaccionado. De la libertad surge la disciplina. Cuando se pone en contacto con materiales pedagógicos adecuados, aprende a autorregularse y es capaz de autoeducarse. Es un ser completo que puede desarrollar energías creativas y amor espontáneo. Se encuentra satisfecho cuando logra realizar las tareas que previamente ha elegido con los materiales que el pedagogo le ha proporcionado: objetos fáciles de manejar que incitan al juego-trabajo. La meta del método es lograr un ser autónomo, libre y responsable a través de la educación.

En 1910, Montessori publicó Antropología Pedagógica²5. La pedagogía científica que ella defendía tenía que basarse en el conocimiento científico del hombre, que recibía en gran medida de la antropología. No se puede educar correctamente si se desconoce la naturaleza y el desarrollo del ser humano. Los maestros debían tener una gran preparación científica y grandes dotes de observación para ejercer su profesión.

Aunque su autora tenía conocimientos de filosofía, esta obra no presenta una visión filosófica de la naturaleza humana en relación con la educación. La visión generalizada de la antropología de la mayoría de los médicos del Siglo XIX era la de una antropología física. El hombre que ellos estudiaban era sobre todo el hombre físico, esto es, el cuerpo humano. La antropometría era su método fundamental. Así, aunque la antropología pedagógica tenía que partir del estudio de la infancia, lo hacía con esta metodología. La medición del cuerpo de los niños era necesario para conocer si su desarrollo era normal o padecía alguna anomalía. En esta época, fueron médicos en su mayoría los que se dedicaron a los estudios antropométricos de la infancia.

Esta orientación antropológica hacia el estudio del cuerpo humano se manifiesta en la obra de Montessori. Tras una introducción sobre las tendencias modernas de la antropología y su relación con la pedagogía, desarrolla su contenido en diez capítulos que versan sobre lo siguiente: Capítulo I: Algunos principios de la biología general. La forma y los tipos de estatura. La estatura. El peso. Capítulo II: Craneología. Capítulo III: El tórax. Capítulo IV. La pelvis.

25 Montessori, M. (1910). Antropología pedagógica. Milano: Vallardi. 
Capítulo V: Las extremidades. Capítulo VI: Análisis morfológico de algunos órganos. Capítulo VII: Parte técnica. El error personal. Capítulo VIII: Metodología estadística. Capítulo IX: La historia biográfica del escolar y anamnesis. Capítulos X: La aplicación de la biometría a la antropología para la propuesta de determinación del hombre medio.

El punto de vista desde el que analiza al escolar no es nuevo y ya desde tiempos atrás se utilizaba el título de antropología para designar los estudios del hombre en su naturaleza física desde una metodología positivista. Pero si se busca la antigüedad de esta disciplina hay que tener en cuenta que ya en 1847, se creó en Arona (Italia) un Gabinete de Antropología pedagógica según consta en la obra de G. Avanzini, La pedagogía en el siglo XX ${ }^{26}$.

\section{EL SURGIMIENTO DE LA ANTROPOLOGÍA PEDAGÓGICA EN ESPAÑA}

También hay que advertir que en España ya existía antes de 1899 el laboratorio antropométrico y de psicología experimental con la finalidad de estudiar las aplicaciones pedagógicas de los métodos antropométricos, situado en el Museo de Instrucción primaria, creado por Real Decreto el 6 de mayo de 1882, posteriormente denominado Museo Pedagógico Nacional. Además dos años antes, en 1880, Pedro de Alcántara ${ }^{27}$ había publicado su obra Prolegómenos a la Antropología Pedagógica, "la ciencia, que, partiendo del conocimiento de la naturaleza humana en general, estudia la del niño en particular, sus manifestaciones principales y su desenvolvimiento hasta que el niño se convierte en hombre, todo ello con el fin de deducir consecuencias y hacer aplicaciones para la educación" (1880:43). Esta ciencia tiene tres partes: $1^{\text {a }}$ ) nociones antropológicas; $2^{\mathrm{a}}$ ) estudios del niño; $3^{\circ}$ ) estudios del desarrollo individual del hombre.

Su método ha de ser la observación y la experimentación para obtener datos verificables y fiables. La medición del cuerpo humano, en especial el del niño, alcanza gran importancia, pues se le considera como un individuo concreto, que puede ser observado y no como una mera abstracción difícil de verificar.

De 1896 es el Tratado de Antropología y Pedagogía de Gregorio Herráinz ${ }^{28}$, en el que la primera de ellas se define como el estudio del hombre tanto en su aspecto físico como psíquico. El alma y el cuerpo son el objeto de estos estudios

26 Avancini, G. ( dir.). (1977). La pedagogía en el siglo XX. Trad. De Jaime Vegas. Madrid: Narcea, 108. 27 Alcántara García, P. de (1880), Prolegómenos a la Antropología Pedagógica. Madrid: English \& Gas. 28 Herráinz, G. (1896), Tratado de antropología y pedagogía. Madrid: Viuda de Hernando y Ca., 29. 
para una mejor comprensión del niño y la posterior facilidad a la hora de educarlo. "Esencias tan diametralmente distintas viven, no obstante, en íntima y perenne correspondencia” (1986:29).

Puesto que la pedagogía en sentido etimológico significa conducción del niño, como ciencia de la educación se refiere en sentido estricto a las primeras etapas de la vida humana. Pero si se tiene en cuenta que el proceso educativo afecta al hombre hasta su muerte, conviene utilizar otra palabra para designar la ciencia que lo estudia en esta extensión. Propone el nombre de antropogogía, que, sin embargo, no fue aceptado por la comunidad científica ni por la Real Academia Española.

De 1902 es el Compendio de Antropología, higiene escolar y Pedagogía de Pedro Díaz Muñoz ${ }^{29}$, en el que se define a la antropología pedagógica como "...el detenido estudio que de la naturaleza humana se hace para conocer no sólo sus desenvolvimientos en el orden físico y psíquico, sino también la harmonía (sic) que en todas las funciones de la vida debe existir entre los elementos materia y espíritu constituyendo el orden psicofísico... "(1903:14-5). La base de esta ciencia la forman la antropometría infantil y la psicología del niño. La antropología incluida en esta obra junto a la higiene escolar y a la pedagogía contiene tres partes: fisiología humana, psicología y psicofísica pedagógica. Las tres últimas lecciones de esta tercera parte las dedica a la antropometría.

No es de extrañar que a mediados del Siglo XIX y principios del XX la antropología pedagógica tuviera un enfoque psicofísico del ser humano y que la fisiología y la psicología fueran las dos ciencias que más aportaran para su constitución y su desarrollo. Los médicos eran los que en aquella época se dedicaban a los análisis antropométricos de la infancia, que eran esenciales para determinar si el desarrollo físico de los nińos era normal, y recurrían también a la psicología para averiguar si sus manifestaciones anímicas eran correctas. Las hojas antropológicas recogían los datos de la medición. La primera de la que se tiene constancia es de 1887. Fue realizada por Simarro, Salillas y Saiz Campillo. Reflejaba la estatura, la dinamometría, la circunferencia y el peso, como también algunas observaciones sobre enfermedades. Las mediciones se realizaban tanto a la ida como al regreso de la colonia escolar, que era la residencia de vacaciones a la que acudían alumnos de algunos centros de enseñanza.

Los planes de estudio de las Escuelas Normales de Maestros también ponen de relieve la importancia que la antropología pedagógica tuvo en el último

29 Díaz Muñoz, P., Compendio de Antropología y Pedagogía. 2a ed. Valladolid, Andrés Martín, 1903. 
cuarto del Siglo XIX y en el primero del Siglo XX. En el plan de 25 de septiembre de 1898, apareció con la denominación de "Antropología, Psicología y Teoría completa de la educación" en el primer curso del grado superior de maestro y con el título de "Antropología y Pedagogía Fundamental" en el curso de Escuelas Normales no Superiores. Comprendía lecciones de psicología y fisiología. En la reestructuración del plan de 1900, que se llevó a cabo en 1901, llevaba el nombre de "Antropología y Principios de Psicogenia" en el primer curso. En planes de estudio siguientes no se incluye como asignatura hasta el plan de 1930, aprobado en 1931, que figura con el título de "Paidología" como asignatura de tercer curso. Aunque en los sucesivos planes de estudios a partir de 1901 no figura expresamente la antropología pedagógica como asignatura, si lo hacen asignaturas relacionadas con ella o que hasta entonces habían estado dentro de su ámbito y se habían independizado. Así, en el Plan de estudios de las escuelas normales de 1914 figura la asignatura de "Fisiología e Higiene" en cuarto curso. En el Plan de 1931, están incluidas "Elementos de Filosofía" y "Psicología" en primer curso, "Fisiología e Higiene" en segundo y "Paidología" en tercero. En sucesivos planes de estudio también se encuentran "Psicología Evolutiva", "Psicología del desarrollo", "Psicología de la educación" y "Sociología de la educación". La proliferación de ciencias humanas a partir de la segunda mitad del siglo XIX, junto a la creciente especialización del saber, se ven reflejados en los sucesivos planes de estudio de las Escuelas de Magisterio, que fueron adoptando las disciplinas que tenían mayor y más directa aplicación al proceso educativo.

La antropología pedagógica ya estudiaba en sus inicios al hombre como una naturaleza de dos dimensiones, la física y la anímica, es decir, como una totalidad, pero para calibrar el desarrollo físico y mental de los niños lo hace desde las ciencias positivas de la época: la fisiología, la antropometría y la psicología experimental entre las más importantes. Aún faltaban los análisis que más adelante se harían sobre la naturaleza humana para proporcionar a la pedagogía una imagen sistemática y plenamente articulada con los resultados proporcionados por las diversas ciencias humanas. Sus sucesivos avances trajeron consigo con su especialización un conocimiento más particularizado del ser humano, pero se perdió su visión unitaria. Analizando aspectos concretos de su ser, se perdió durante algún tiempo su contemplación y estudio como una totalidad. Los mismos científicos positivos que se dedicaban al estudio del hombre pedían a los filósofos que les ofrecieran una imagen del mismo, porque la necesitaban como idea reguladora de su ciencia. 


\section{LA CREACIÓN DE LA ANTROPOLOGÍA FILOSÓFICA EN EL SIGLO $\mathrm{XX}$}

Max Scheler, desde la fenomenología, en La idea del hombre y la Historia, ${ }^{30}$ reconocía, en 1924, esta necesidad al afirmar que era una tarea urgente de su tiempo la creación de una antropología filosófica, que abordase la esencia y la estructura esencial del hombre (1972; 9). En 1928, publicó El puesto del hombre en el $\operatorname{cosmos}^{31}$, que es una breve síntesis de sus ideas antropológicas. Así pues, en los años 20 del Siglo XX con este filósofo se produce un "cambio antropológico" en la filosofía. En su temprano e inesperado fallecimiento deja inédita una antropología filosófica que pensaba desarrollar más ampliamente. A pesar de ello, contribuyó de manera decisiva a que la antropología filosófica se convirtiera en la estrella del ámbito filosófico. Fueron numerosas las publicaciones que sobre esta materia aparecieron en el segundo tercio del Siglo XX en el idioma alemán. Entre los autores que publicaron libros sobre antropología filosófica en este tiempo en alemán habría que citar a Helmut Plessner, a Martin Buber, a Arnold Gehlen, a Theodor Litt, a Erich Rothacker, a Paul Häberlin, a Bela F. von Bandenstein, a Adolf Portmann, a Walther Brüning, a HansEduard Henstenberg y a Otto Fiedrich Bollnow. En el tercer tercio del Siglo $\mathrm{XX}$ aún continuaron las publicaciones sobre esta materia en el idioma citado gracias al trabajo de Michael Landmann, de Franz Graber y Emerich Coreth entre otros. También en otros países aparecieron obras de antropología filosófica en este tiempo. En Francia, hay que destacar especialmente el trabajo en francés de Jean-Ives Jolif. En Italia, país de gran tradición en este ámbito científico, resalta la obra en italiano de Joseph Gevaert.

La reflexión humana sobre el propio ser fue prolongada por el existencialismo, que en rigor no es una antropología filosófica, pues no aborda el ser humano desde fuera como si fuera un objeto natural más, sino desde dentro, como un yo individual, que no es ni puede ser común, sino individual, concreto e histórico. Precisamente esta concreción le ha permitido análisis y descripciones muy certeras sobre la existencia humana y sus estados primordiales como, entre otros, la angustia, el temor y la esperanza. El análisis existencial, muy utilizado en la psicoterapia, en los estudios de los efectos de la angustia y del temor en la educación y en la aplicación de los análisis de la esperanza en

30 Scheler, M., La idea del hombre y la Historia. Trad. de J.J. Oliveira. Buenos Aires: La Pléyade, 1972.

31 - El puesto del hombre en el cosmos. Trad. de J. Gaos. Buenos Aires: Losada, 1938 
la psiquiatría, ha mostrado su importancia para comprender y abordar correctamente algunas patologías del ser humano.

El gran desarrollo de la antropología filosófica desde los años veinte intentó esclarecer qué es el hombre como una totalidad inserta en el mundo. Para ello se puso en contacto con diversas ciencias particulares, que le aportaron nuevos conocimientos sobre el hombre. Así, la biología, la física, la química, la psicología, la etología, la sociología, por citar solamente algunas de ellas, ofrecieron una gran ocasión para incorporar muchos de sus descubrimientos a la antropología filosófica, que supo integrarlos en una síntesis coherente. La "nueva" antropología de la segunda mitad del Siglo XX y principios del Siglo XXI ha sido muy útil a la pedagogía, pues le ha dado un gran impulso a la antropología pedagógica al ser su fundamento inmediato y el que le proporciona un sentido como ciencia humana.

\section{LA RELACIÓN ENTRE LA ANTROPOLOGÍA FILOSÓFICA Y LA AN- TROPOLOGÍA PEDAGÓGICA}

Diez años después de la aparición de El Puesto del hombre en el cosmos, de Max Scheler, que significó el punto de partida del gran desarrollo de la antropología filosófica en el mundo contemporáneo, Herman Nohl, que arrancó del historicismo de Dilthey, publicó en 1938 su obra Charakter und Schicksal: eine pädagogische Menschenkunde ${ }^{32}$, que fue traducida al español en 1950 por Carlos Silva con el título de Antropología pedagógica, que es el subtítulo del original. Es concebida como una ciencia del espíritu y como tal su método es el de la psicología comprensiva. Por esta razón, Nohl la elabora con una orientación claramente psicológica. Analiza el influjo del carácter y de los temperamentos en la educación. Del método psicológico e histórico-comparativo propuesto por Dilthey para desarrollar las ciencias del espíritu acepta la primera parte.

Basándose en su segunda parte, es decir, en el método estrictamente histórico, otro discípulo, Hans Scheuerl, construirá posteriormente, en 1982, su Pädagogische Anthropologie. Con él, investiga las diversas concepciones del hombre que están en el fondo como fundamento de los principales modelos pedagógicos del pasado. El historicismo enfoca la relación del hombre con la educación desde la individualidad histórica.

Aunque la aportación del historicismo a la antropología pedagógica fue muy importante, porque al demostrar que todos y cada uno de los sistemas

32 Nohl, H., Charakter und Schicksal: eine pädagogische Menschenkunde. Frankfurt, 1938 
educativos descansa en una noción del ser humano ofreció la prueba de su necesidad para una recta interpretación del proceso educativo y proporcionó a la historia de la educación una sólida cimentación, sin embargo, no tuvo tanto interés para la teoría de la educación. Para su elaboración las aportaciones de las ciencias positivas del hombre, especialmente las de la antropología física, psicológica, cultural y social, han tenido mayor incidencia que las aportaciones históricas. Sin embargo, los descubrimientos de éstas deben ser reelaborados e integrados en una imagen unitaria del ser humano.

Tampoco los pedagogos existencialistas han logrado una visión totalizadora ni del educando ni del educador, limitándose al análisis de algunos fenómenos particulares que excepcionalmente se dan en la existencia humana. Bajo el influjo de las ideas historicistas de Dilthey para quien el hombre por ser radicalmente histórico no posee una esencia inmutable, lo cual impide una definición sistemática de su ser, el existencialismo también sostiene que al ser pura existencia en su nacimiento tiene que ir conquistando su esencia a lo largo de su devenir existencial. Ello lo logra por estar dotado de una libertad óntica. Por nacer indeterminado puede elegir su propio destino. El hombre puede llegar a ser lo que se proponga mediante la elección libre de su voluntad.

Por influencia de estas ideas, Otto Friedrich Bollnow ${ }^{33}$ renunció a presentar un sistema cerrado de antropología pedagógica. El hombre, apartado del orden estático impuesto a la naturaleza por Dios en la creación, se convierte en un problema para sí mismo. La filosofía y la pedagogía deben analizar las situaciones límite, que son manifestaciones extraordinarias de la existencia humana. Las observaciones de fenómenos como la vacilación, la vergüenza, la irreflexión, el temor, el miedo, la angustia, el juego, el ejercicio, la seguridad, las vivencias de espacio y tiempo, la atmósfera pedagógica y otras muchas situaciones límite esclarecen algo las condiciones y el modo de ser humano. Para comprender cualquiera de ellos como un elemento necesario hay que tomar la naturaleza humana en conjunto. Especial importancia en el ámbito pedagógico tuvieron sus análisis de "las formas inestables" del proceso educativo entendido como un conjunto de fases formativas en ascensión continua por la experiencia de los aprendizajes realizados. Sin embargo, esta continuidad no es incuestionable, ya que a veces hay crisis y rupturas que ponen en duda el desarrollo lineal de la existencia humana.

33 Bollnow, O.F. Krise und neuer Anfang. Bieiträge zur pädagogischen Anthropologie. Heidelberg, 1966. 
Desde estas ideas somete a análisis las relaciones entre antropología y pedagogía, No se trata de sumar a esta una nueva ciencia particular, sino de enfocarla desde un punto de vista filosófico-antropológico. La antropología pedagógica nacida de esta forma, a veces también denominada "pedagogía antropológica", puede ser interpretada de dos formas: como una antropología básica, que descansa en las ciencias positivas, pero no es una integración de ellas, o como antropología filosófica. Para evitar equívocos es conveniente reservar el título de "antropología pedagógica" para designar a la antropología básica y el de "antropología filosófica" para mencionar la consideración antropológica de la pedagogía. Por último, puesto que la educación es fruto de la inteligencia del hombre, es aconsejable utilizar para su estudio el rótulo de "antropología de la educación".

La línea iniciada por Bollnow al analizar en el campo de la educación fenómenos concretos fue seguida por Bräuer ${ }^{34}$, que estudió la "apertura al mundo" del hombre como una categoría antropológica central, y por Loch ${ }^{35}$, que investigó la relación entre el curso de la vida y la educación.

Hacia mediados del Siglo XX, en los años 50, la pedagogía sintió la necesidad de mantener una visión integral de los fenómenos educativos. La disciplina más adecuada para reunir los datos de las ciencias positivas que estudian al hombre en relación con la educación es la antropología pedagógica, que no debe adoptar un enfoque unitario, sino tantos puntos de vista cuantas sean las ciencias humanas ocupadas en esclarecer esta relación. Para ello hay que tomar los hallazgos más importantes sobre la educación de la psicología, la sociología, la historia, la etnografía e integrarlos en una visión de conjunto del proceso educativo. Langeveld mostró que las limitaciones metodológicas de muchas investigaciones psicológicas exigían, mediante un trabajo de interpretación, integrar sus resultados y los de las ciencias humanas afines en una visión más amplia. Esta labor de criba, de comparación y de interpretación es propia de la antropología ${ }^{36}$.

Al comienzo de los años 60, Andreas Flitner reunió en Tubinga a representantes de diversas ciencias humanas (biología, medicina, psicología, sociología,

34 Bräuer, G., Weltoffenheit Bedingung und Ergebnis menschlichen Lernens. En W. Loch (dir.)

(1978). Modelle päd. Verstehens, Essen, 1978, 53-101.

35 Loch, W. Lebenslauf und Erziehung. Essen, 1979.

36 Langeveld, M.J, Studien zur Anthropologie des Kindes. Tübingen, 1956.

— Kind und Jugendlicher in anthropologischer Sicht. Eine Skizze. Heidelberg, 1959. 
filosofía y teología) para que expusieran en un ciclo de conferencias sus opiniones sobre "los caminos que conducen a la antropología pedagógica" ${ }^{37}$.

Heinrich Roth, en los años que van de 1966 a $1971^{38}$, trató de reunir bajo el modelo de una ciencia procesadora e integradora de datos las principales contribuciones de las ciencias del hombre para formar una "antropología pedagógica" al interpretarlas bajo los conceptos de "plasticidad y determinación", por una parte, y de "desarrollo y educación", por la otra. Para llevar a cabo "el giro realista en la investigación pedagógica" se centró en los descubrimientos empíricos de las ciencias positivas, en particular de la psicología y de la sociología, pero como desde ellas no podía dar una explicación del "destino" del hombre ni de los fines de la educación tuvo que aceptar interpretaciones filosóficas, que no son una mera generalización de los datos empíricos, buscando un consenso mínimo sobre estas dos cuestiones. La doble naturaleza humana le obligó a esta dualidad metodológica que se reflejó en las dos partes de su obra.

Los desarrollos realizados hasta el presente no han podido dar con una visión acabada de la antropología pedagógica. El constante desarrollo de las ciencias humanas y de la antropología filosófica que le proporcionan los materiales para formar una visión unitaria del ser humano, exigen un esfuerzo continuo para ir incorporando los nuevos hallazgos. En los últimos decenios ha habido intentos en este sentido. Pero la orientación de la "nueva" antropología no ha logrado todavía un definitivo ensamblaje de las diversas dimensiones del ser humano en una visión filosófica que lo contemple como totalidad. El carácter inacabado de las ciencias positivas que lo analizan lo hace imposible. Por ejemplo, la antropología biológica aún no ha llegado a conclusiones firmes sobre la manipulación genética y sus consecuencias, que en la actualidad son irreversibles. Si su objeto es estudiar al hombre en relación con la educación, deberá analizarlo como educando y como educador, pero además también tendrá que establecer las condiciones para que el proceso educativo sea digno y eficaz. Pero como solamente el hombre puede ser educado, este proceso le pertenece en exclusiva. El hombre está presente en su punto de partida y en la meta de llegada de la educación, es decir, es el sujeto que recibe la educación, porque la necesita: es el educando. Pero como la causa que lo produce, el educador, es también hombre, la educación es un proceso de humanización. Su ámbito de

37 Flitner, A., (dir.), Wege zur pädagogischen Anthropologie. Heidelberg, 1963

38 Roth; H., Pädagogische Anthropologie. Vol I.:Bildsamkeit und Bestimmung. Hannover, 1966.

— Pädagogische Anthropologie. Vol. II: Entwiklung und Erzhiehung. Hannover, 1971 
estudio es muy extenso y complejo. La antropología pedagógica, por consiguiente, ha de tener tres partes en las que se estudie respectivamente el ser del educando, del educador y del proceso educativo.

La explicación de la educabilidad del educando conduce a investigarlo como un ser vivo corpóreo, como un ser de carencias con una deficiencia orgánica en su nacimiento que se manifiesta en el primitivismo de sus órganos y en su inmadurez somática, como un ser instintivo deficiente, dotado de una vida anímica en desarrollo, como un ser social que necesita de los demás humanos para sobrevivir, como un ser cultural por tener que adaptarse al medio en el que vive, como ser histórico que puede forjar su destino y con un espíritu que ensamblado con su cuerpo puede superar sus deficiencias orgánicas. El nińo puede superar sus limitaciones mediante la educación. La antropología del niño, que es una rama aplicada de la antropología general, nos enumera las carencias con las que nace. Su conocimiento facilita el proceso educativo al esclarecer su fundamento.

Pero para que haya cuidados y educación tiene que haber también una causa externa que los proporcione. Unas veces, es la misma naturaleza exterior del niño la que pone en marcha sus facultades. Otras veces, es la cultura de su comunidad, la que desarrolla sus potencialidades. Pero, sobre todo son sus padres y sus maestros los que más directamente se ocupan de su formación. Capítulo especial son las características que ha de poseer un buen educador: vocación, amor y tacto pedagógico, autoridad, justicia, paciencia e higiene.

El proceso puede realizarse de varias formas y tener un contenido diverso. Para obtener las máximas garantías y eficacia debería ser programado y revisado por auténticos pedagogos, antropólogos y científicos. De esta forma, se evitaría que en algunos sistemas educativos aparecieran asignaturas con un contenido de muy dudoso rigor científico y moral.

\section{REFERENCIAS BIBLIOGRÁFICAS}

Coreth, E. (1976). ¿Qué es el hombre? Esquema de una antropología filosófica. Trad. de Claudio Gancho. Barcelona: Herder.

Dienelt, K. (1980). Antropología pedagógica. Trad. de Antonio Alcoba. Madrid: Aguilar.

Ferrandez A. y Sarramona J. (1977). La educación. Constantes y problemática actual. Barcelona: Ceac.

García Castaño, F. J. (1994). Antropología Pedagógica. En C. Ortiz y L. A. Sánchez (eds.), Diccionario histórico de la antropología española. Madrid: CSIC, 91-75. 
Gehlen, A. (1973). Ensayos de antropología filosófica. Trad. de Carmen Cienfuegos. Santiago de Chile: Editorial Universitaria.

- (1980). El hombre. Su naturaleza y su lugar en el mundo. Trad. de FernandoCarlos Vevia Romero. Salamanca: Sígueme.

Gevaert, J. (1976). El problema del hombre. Introducción a la Antropología filosófica. Trad. de Alfonso Ortiz. Salamanca: Sígueme.

Groethuysen, B. (1975). Antropología filosófica. Trad. de J. Rovira Armengol. Buenos Aires: Losada.

Henz, H. (1967). Tratado de pedagogía sistemática. Trad. de Ismael Antich. Barcelona, 1976.

Hoyos Sáinz, L. (1911). Notas para la Historia de las Ciencias Antropológicas en España. En III Congreso de la Asociación Española para el Progreso de la Ciencia. T. V. Granada: El Defensor de Granada, 61-80.

- (1917). La Antropología: métodos y problemas. Madrid: Imprenta clásica española.

Kant, I. (2001), Lógica. Trad. De María Jesús Vázquez Lobeiras. Madrid: Akal.

- (1983), Pedagogía.Trad. Lorenzo Luzuriaga y José Luis Pascual. Madrid: Akal.

Landmann, M. (1961). Antropología filosófica. Autointerpretación del hombre en la historia y en el presente. Trad. de Carlos Moreno Cañadas. México. UTEHA.

Ortiz García, C. (2003). La antropología pedagógica en España durante el primer tercio del siglo XX. Revista de dialectología y tradiciones populares. 58, 2, 71-92.

Piasere, L. (2019). Raffaele Maffei's Anthropologia (1506): The birth and diffusion of a (quasi)-neologism. Rivista di Anthropología post-globale. 1, 55-85.

Nohl, H. (1950). Antropología pedagógica. Trad. De Carlos Silva. México: F.C.E. Planchard, E. (1949). La pedagogía contemporánea: Trad. de Víctor García Hoz. Madrid: Rialp.

Scheler, M. (1957). El puesto del hombre en el cosmos. Trad. de José Gaos. Buenos Aires: Losada. - - (1962). La idea del hombre y la historia. Trad. de Juan José Oliveira. Buenos Aires: La Pléyade.

Scheuerl, H. (1985). Antropología pedagógica. Trad. de Víctor Bazterrica. Barcelona: Herder.

Speck, J., Wehle, G. y otros. (1981). Conceptos fundamentales de pedagogía. Trad. de Alejandro Esteban Lator Ros. Barcelona: HerderJolif, J.-Y. (1969). Comprender al hombre. I. Introducción a una antropología filosófica. Trad. de Ángel Arjona. Salamanca: Sígueme. 


\title{
LA EDUCACIÓN DE LA SOCIEDAD \\ EN LA ERA DE LA GLOBALIZACIÓN \\ EDUCATING SOCIETY IN THE TIME OF GLOBALIZATION
}

\author{
Jesús Miguel Pérez Ceballos \\ Aula cultural Educación y Sociedad, Universidad de La Laguna
}

\section{Resumen}

La educación de la sociedad es un tema esencial para la convivencia y el desarrollo, pero el debate público fija su atención en el sistema educativo, que es parte de esa educación social. Este artículo muestra su complejidad mediante la metodología del enfoque de sistemas, señalando algunos de los elementos que la originan y sus interrelaciones, y proponiendo un esbozo del sistema educación de la sociedad. Se comenta el significado de educación y se indican algunas características de la actual sociedad. Se exponen algunos conocimientos elementales sobre la metodología a fin de comprender mejor el sistema propuesto, que considera como elementos del entorno: globalización, valores, comportamientos, financiación; y propios del sistema: familia, sistema educativo, relaciones, y factores sociales.

Palabras clave: educación, globalización, sociedad, sistemas.

\begin{abstract}
Educating society is essential for coexistence and development but public debate tends to center on the educational system, which is only a part of educating society. The article presented here describes this complexity using a systems-focused methodology, pointing out various of the originating elements along with their relationships, as well as proposing a sketch of the education system of society. The importance of education is reflected on and we indicate various characteristics of today's society. We also suggest essential notions related to the methodology used with the objective of further understanding the proposed system, considering the following elements of the environment: globalization, values, behavior, financing; as well as those belonging to the system themselves: family, education system itself, relationships and social factors.
\end{abstract}

Keywords: education, globalization, society, systems. 


\section{INTRODUCCIÓN}

El tema de la educación de la sociedad mantiene a lo largo del tiempo su relevancia y permanente actualidad. Es tema frecuente de conversación ciudadana, del debate político y de los medios de comunicación, con numerosas críticas, propuestas, comentarios, etc., si bien la mayor parte de las veces se centra la atención en el sistema educativo no universitario. Es por lo tanto un tema importante, multidisciplinar, fundamental para el desarrollo humano, y básico para la convivencia.

El objetivo de este artículo es mostrar con sencillez la complejidad de la educación de la sociedad, determinando algunos de sus principales elementos generadores y las relaciones entre ellos. Así pues, no se trata de hacer un análisis crítico, ni de proponer una planificación del sistema educativo de la sociedad.

Se expone en primer lugar qué puede entenderse por educación y algunas características de la sociedad a la que se va a referir, a continuación la metodología a seguir para identificar los elementos que contribuyen a la formación y evolución de la educación, y por último se aplica dicha metodología para establecer el esbozo de un Sistema de Educación de la Sociedad que nos dé una idea concreta de su complejidad.

\section{EDUCACIÓN DE LA SOCIEDAD}

\subsection{EDUCACIÓN}

La educación podría definirse como desarrollo o perfeccionamiento de las facultades intelectuales y morales de una persona para que viva en sociedad.

Consiste en transmitir contenidos moralmente aceptables y necesarios para la vida, respetando el pensamiento, la dignidad y libertad del que aprende. Desde la antigüedad la educación se ha desarrollado como una actividad familiar cotidiana.

El término educación suele aplicarse en distintos contextos (educación primaria, educación protocolaria, educación vial, educación religiosa,...).

También puede entenderse por educación el conjunto de todo lo que asumimos de nuestro entorno a lo largo de la vida (conocimientos, comportamientos, emociones, influencias,...). En definitiva, consiste en un proceso continuo de transmisión desde nuestro entorno social y ambiental, para adecuar nuestro comportamiento como animal individual y grupal a una comunidad concreta, utilizando para ello la lengua y la cultura, es decir, transmitiendo las creencias, costumbres, valores, comportamientos, y conocimientos para la vida cotidiana y profesional de esa comunidad. 
Una adecuada educación asegura una buena convivencia social y una vida satisfactoria. Las ideologías actualmente en pugna (neoliberalismo, neoconservadurismo, populismo, socialismo, comunismo, etc.), que tienen fundamentos, organización y consecuencias muy distintos, tratan de imponer su idea de la sociedad y de la educación que conlleva diferentes objetivos, planificación, financiación y evaluación.

La educación de una nación es una obra realizada por todos sus componentes: familia, escuela, sociedad. La educación es un fin que se desarrolla a lo largo de la vida, mientras que el sistema educativo es uno de los medios que contribuye a lograrlo durante un corto periodo de ella.

\subsection{SOCIEDAD}

La educación que se recibe depende de las características de la sociedad en que se vive. Para conocerlas presentamos algunas de las variadas aportaciones de pensadores, filósofos, sociólogos, etc., sobre las actuales sociedades desarrolladas.

Zigmunt Bauman, filósofo y sociólogo, afirma que en esta sociedad fundamentada en la globalización y el capitalismo, no podemos ser libres sin espíritu crítico. La rotura de los valores y convicciones origina que las sociedades se hagan "líquidas" y pierdan su identidad (Bauman, 2018), quedando caracterizadas por la inseguridad, el desconcierto y la precariedad; este contexto debilita el compromiso y la solidaridad. Una de las características de la generación "líquida" es su preocupación por la apariencia corporal. Defendió al grupo social del "precariado" (proletario precario), notorio usuario de las redes sociales, que constituye una característica de la "globalización negativa", y que por su contexto y el medio que utilizan se integran en la "modernidad líquida". El desaforado consumo, que se promueve como medio para conseguir la felicidad, contribuye a la desigualdad. La sociedad vive atemorizada por catástrofes, terrorismo, epidemias,... Se vive con el "complejo del Titanic", personificado en nosotros.

Byung-Chul Han, filósofo, critica a las redes sociales caracterizándolas como incontrolables, efímeras, sin personalidad ni consistencia, y que se forman y dispersan con gran rapidez. Lo digital es la abolición de la realidad.

La comunicación digital es a menudo muy emocional y genera una ilusión de libertad. La frecuente comunicación anónima impide el diálogo respetuoso, discreto y objetivo. Sin la presencia del otro, la comunicación degenera en un intercambio de información: las relaciones se reemplazan por las conexiones, y así solo se enlaza con lo igual. En la crisis originada por la revolución digital participa el "enjambre digital", integrado por multitud de individuos aislados sin coherencia y sin voz común, que conforman una sociedad caracterizada 
por la soledad (Han, 2014). En el enjambre, el zumbido del materialismo les impide cuestionarse lo absurdo de una vida sin ideales.

La actual sociedad de ritmo acelerado es una sociedad de rendimiento, que produce desesperación, estrés, depresión,... y origina la "sociedad del cansancio" (Han, 2017). Se vive angustiado por no hacer todo lo que se puede, se auto inculpa, se explota a sí mismo creyéndose que así se está realizando, y lo que consigue es alienarse. Es necesario hacer una pausa y reflexionar. A la vida contemplativa se llega mediante el silencio y la expectación. A la civilización actual le falta sobre todo vida contemplativa.

Critica a la "sociedad de la transparencia", en la que no hay normas ni nada que ocultar, eliminando el respeto y la intimidad. Vivimos en una época de conformismo total y vida superficial, en la que falta darle sentido a la existencia.

George Steiner, profesor universitario, especialista en literatura comparada, filósofo, premio Príncipe de Asturias de Comunicación y Humanidades, señala la aceleración de las actividades cotidianas que impiden tener tiempo para otras cuestiones, y el miedo al silencio, que es el único medio para encontrar lo que es esencial para nosotros. La sociedad actual se propone la riqueza material como un gran objetivo, incrementa los localismos y nacionalismos, y padece el avance del fundamentalismo. Hay una gran desvalorización de la política. Se queja de la mala educación escolar. Critica a las democracias, el capitalismo, la globalización,... que no han logrado disminuir la pobreza y las desigualdades.

Gao Xingjian, Premio Nobel de Literatura, declara que nuestra sociedad experimenta una profunda crisis propiciada por las dogmáticas ideologías del siglo pasado (comunismo, fascismo, nacionalismo,...), inspiradoras de los populismos actuales y que acrecientan la decadencia de occidente. Se olvida nuestra historia, se degrada la democracia y se obstaculiza la solución eficaz de los graves problemas que afectan a nuestra sociedad. Propone repensarlo todo con interés humanístico; hace falta un renacimiento social fundado en la esencia humana.

\section{SISTEMAS}

Para identificar los elementos que contribuyen a la formación y evolución de la educación se va a aplicar la metodología de sistemas, de la que se exponen algunas sencillas nociones.

A lo largo de la Segunda Revolución Industrial, iniciada en la segunda mitad del siglo XIX, se produjeron importantes avances tecnológicos que transformaron la vida cotidiana. Esto hizo necesario el enfoque de sistemas para lograr objetivos en redes complejas de interacciones, de forma óptima en tiempo y recursos. 
Tras la Segunda Guerra Mundial surge un movimiento filosófico, sociológico, científico, y técnico, en el que se incluyen la Teoría lógica y general de autómata de J. von Neumann, la Cibernética de N. Wiener, la Teoría matemática de la comunicación de C. E. Shannon y W. Weaver, la Dinámica industrial de J. W. Forrester, etc.

Fue también destacable la aportación de L. von Bertalanffy que en 1947 publicó la Teoría general de los sistemas (Bertalanffy, 1976) consistente en una propuesta de integración de todas las ciencias naturales y sociales, para desarrollar modelos teóricos y principios unificadores aplicables a todos los sistemas. Se constituye en un área lógico-matemática que utiliza técnicas vinculadas a la computación. Este movimiento introduce el concepto "sistema" como paradigma científico, proporcionando así una nueva visión del mundo.

Se entiende por sistema un conjunto de elementos entre los que se producen interacciones para lograr un objetivo. A su vez esos elementos pueden también ser sistemas. Cuando los elementos y sus interacciones son cuantificables se puede mostrar la evolución del sistema. La optimización de un elemento no siempre mejora la del sistema, e incluso puede perjudicarlo. El comportamiento del sistema no es la suma del correspondiente a sus elementos.

En la elaboración de un sistema deben tenerse en cuenta: los objetivos, el entorno, los elementos y sus relaciones, los recursos, y la gestión. Los objetivos deben considerar el sistema como un todo, señalando los indicadores concretos (logros, costes, consecuencias,...) que servirán para valorar su consecución. No debe indicarse lo que hace el sistema sino cuál es su finalidad y qué medios serían los más adecuados. La gestión se ocupa de la dirección, organización, planificación, fijar objetivos, dotación de recursos, control, evaluación, y decisión sobre las modificaciones necesarias.

La representación gráfica de un sistema muestra una estructura en red, que representa aspectos concretos y simplificados de la realidad. Sencillos ejemplos de ello son los diagramas de flujo para secuencias de tareas, y los diagramas PERT basados en modelos matemáticos que pueden programarse en ordenador.

El Enfoque de sistemas utiliza una metodología de aproximaciones sucesivas, en la que continuamente hay que considerar los cambios en el sistema, para modificar la organización, los recursos, la financiación, etc., de forma más conveniente.

La Dinámica de sistemas es una metodología para construir modelos dinámicos de sistemas complejos y poder actuar sobre ellos a fin de analizar sus comportamientos a lo largo del tiempo. Aunque no son muy precisas las leyes que rigen los procesos sociales, como el educativo, se consideran procesos dinámicos que proporcionan datos sobre la variación de sus elementos y relaciones. 


\section{EDUCACIÓN COMO SISTEMA}

La educación es un sistema de tipo abierto pues se relaciona con elementos de su entorno, siendo esenciales dichas relaciones para su viabilidad y capacidad de cambio. En un sistema abierto, la interacción del sistema con su entorno hace posible que, partiendo de condiciones diferentes y siguiendo distintos caminos, se pueda alcanzar el mismo estado final.

La dinámica del sistema, esto es, su evolución a lo largo del tiempo, se origina por la influencia de cada elemento en el sistema al cambiar sus características, tales como:

- La estabilidad del propio elemento, sometida a circunstancias internas variables

- El número de relaciones que tiene con otros elementos del sistema

- La intensidad de cada relación

- El tiempo durante el que se mantiene cada relación

El desconocimiento del sistema educación tiene como consecuencia la pérdida de la identidad de la sociedad y de su finalidad como grupo humano, originando conflictos, crisis y violencia.

Sobre la educación y el sistema educativo opinamos todos (profesores, padres, alumnos,...), teniendo cada uno como referente la propia experiencia de ello, y sin tener en cuenta la visión general del sistema. La sociedad suele fijarse en los síntomas que la perturban, y suele tomar sus decisiones sin detenerse en analizar las causas que pueden producirlos, que tal vez sean complejas y remotas en el tiempo, y propias para el trabajo de investigadores y expertos.

Para tratar de obtener una visión general que nos muestre la complejidad de la educación que recibimos en nuestra sociedad, y que nos ayude a determinar las causas de nuestros problemas e inseguridades, se presenta un sencillo análisis de sistemas. Se considera en primer lugar los componentes del entorno del sistema, y luego los elementos y relaciones del propio sistema. (Fig. 1).

\section{ENTORNO}

El entorno del sistema está integrado por aquellos elementos y sus relaciones que no pertenecen al sistema, que influyen sobre él pero que el sistema no influye sobre ellos. La influencia es unidireccional, solo se produce desde el entorno hacia el sistema. No obstante, al ser el sistema Educación un sistema abierto, es probable que exista cierta relación entre el sistema y el entorno. 
Dada la finalidad del sistema Educación a elaborar, se comentan solo cuatro elementos relevantes del entorno: Globalización, Valores, Comportamientos, y Financiación.

\subsection{GLOBALIZACIÓN}

Las relaciones cada vez más intensas entre las diversas culturas y grupos humanos producen una gran confrontación y variación en los elementos de sus respectivos sistemas. Con frecuencia la obcecación de una sociedad por su particular visión del mundo le impide apreciar y valorar la perspectiva de las otras sociedades. Las sociedades están en continua evolución, pero en la actualidad vivimos rápidos y profundos cambios que originan una importante crisis, que atribuimos en gran parte a lo que denominamos globalización.

El origen lejano de la globalización se sitúa en el siglo XIX con las emigraciones, los movimientos financieros y las tecnologías de la comunicación. Un origen más próximo se sitúa en la década de los setenta del siglo XX con los cambios económicos y tecnológicos originados por la crisis del petróleo; la globalización adquiere mayor importancia a partir de la década de los noventa.

Fig. 1. Sistema educación de la sociedad. Se nombran los elementos del entorno y del sistema, uno de los cuales es un subsistema. En las flechas de relación, un mayor grosor indica una mayor influencia sobre el elemento al que señala

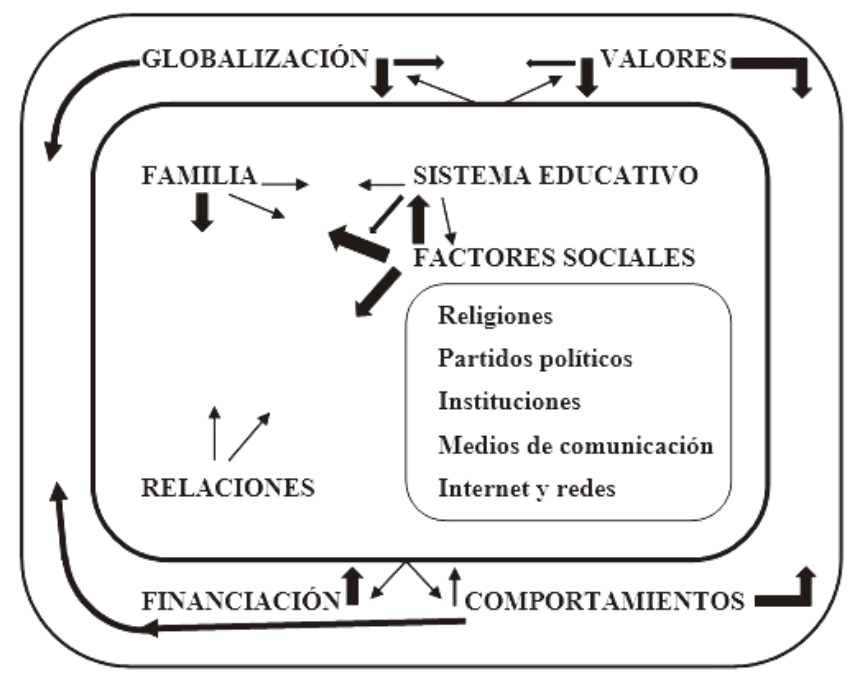

Fuente: elaboración propia. 
El concepto de globalización está ligado a múltiples significados relacionados entre sí, como por ejemplo las exigencias externas de instituciones multinacionales (tales como la ONU, la Unión Europea, el Fondo Monetario Internacional, el G7 -naciones influyentes en asuntos políticos, económicos y militares-, grandes alianzas comerciales como Mercosur, etc.); las decisiones de esas instituciones fuerzan a los estados para que promulguen leyes de acuerdo a ellas. También se unen a este concepto las imposiciones a los procesos económicos mundiales de producción, consumo, dependencia financiera, etc., así como a una cierta hegemonía de las políticas neoliberales, y a la influencia de diversas culturas y medios de comunicación. Para algunos, la globalización representa el predominio de la economía sobre la política, la cultura, y la vida cotidiana. También cabe incluir en el concepto a movimientos sociales que actúan influyendo en gobiernos y sociedades, tales como Avaaz, Manos Unidas, Cruz Roja, etc., así como a un gran número de grupos activistas (pacifistas, ecologistas, feministas, etc.) con objetivos muy diversos, que difunden sus ideas en internet utilizando sus cuantiosos medios para lograr una masiva colaboración. Internet puede considerarse como una de las causas y a su vez efecto de la globalización. (Burbules y Torres, 2005).

En definitiva, la globalización podría describirse como el incremento de interdependencias económicas, tecnológicas, políticas, sociales, medioambientales, culturales, y de todo tipo, que afectan a la mayoría de las naciones. La globalización cambia la cultura, descentraliza el poder, y altera la soberanía de los estados.

La globalización se fundamenta en cambios reales que continúan produciéndose, pero no es un proceso evolutivo uniforme; se manifiesta de forma muy diferente según el estado de desarrollo de cada país, su trayectoria es impredecible, y no tiene por qué ocurrir según un proceso predeterminado por ideologías.

La globalización afecta a los países en sus economías, políticas, culturas, educación, costumbres, etc., originando cambios esenciales en la vida cotidiana de todos los ciudadanos. Así por ejemplo, los sistemas de crédito se han generalizado utilizando tarjetas (VISA, Mastercard, etc.); internet amplía la actividad comercial (distribución mundial de series de TV, propaganda y ventas por internet, etc.); asistimos en directo a acontecimientos culturales y deportivos localizados en cualquier punto del planeta,...

Algunos apuntan como características ventajosas de la globalización la práctica desaparición de las distancias y del tiempo, justificada por la oferta de las mismas empresas y productos en diferentes países (confección, bancos, au- 
tomoción, etc.), la rapidez de las comunicaciones (incluso instantánea: internet, radio, $\mathrm{TV}$, etc.), así como el intercambio humano, de bienes y servicios.

La globalización se ha convertido en un discurso ideológico que nos exige una acción inmediata para adaptarse a lo que denominan nuevo orden mundial. Pero deben evitarse las acciones apresuradas, y antes de aceptar o rechazar cada cambio hay que analizarlo detalladamente, prever sus consecuencias a medio y largo plazo, y luego proceder a fin de que sea lo más beneficioso posible para la sociedad.

Cada cultura confiere identidad a las personas y a la sociedad, dotándolas de una forma de ser y actuar diferente a otras culturas. Impulsada por las nuevas tecnologías, la globalización de la cultura tiene indudable influencia en la educación, pues altera su finalidad que es integrar a la persona en su cultura y hacerla partícipe de su mejora. Por lo tanto, la educación precisa sobrepasar los límites de lo local y lo nacional, y desarrollar capacidades de coexistencia con otras culturas para aprovechar oportunidades de desarrollo personal y profesional.

El multiculturalismo está integrado por un conjunto de propuestas relacionadas con cambios en la cultura, educación, conocimiento, e identidad personal. Los gobiernos tratan de gestionar la problemática que esto ocasiona tanto en las instituciones como en la vida cotidiana (diferencias sociales, insatisfacción, inseguridad, etc.), pero en ello influye la ideología de cada gobierno y cómo ejerce su poder.

La Globalización como elemento del entorno tiene una intensa influencia sobre el sistema, que irá aumentando a lo largo de mucho tiempo. Sin embargo, la influencia del sistema sobre la globalización es débil e irá disminuyendo con el tiempo.

La Globalización tiene relación de intensidad apreciable con Valores y Comportamientos, análoga a la que ocurre en sentido inverso.

\subsection{VALORES}

Entendemos por valores un conjunto de cualidades, aptitudes, ideas y normas, ya sean morales, ideológicas o de cualquier otro tipo que, estando de acuerdo con las reglas éticas y morales vigentes en la sociedad, determinan el pensamiento, los sentimientos, las emociones, la conducta, y dan sentido a la vida personal y social.

Los valores son abstracciones de lo que es importante y deseable; los utilizamos para orientar y juzgar nuestras acciones, interpretar los acontecimientos de nuestro entorno y dar significado a nuestra vida. Los valores, junto a tradiciones, creencias, normas y comportamientos, aseguran la convivencia en una sociedad. 
Una característica fundamental de los valores es que cada uno está relacionado con otros muchos formando una compleja red; las relaciones que se establecen están muy influenciadas por la cultura de la sociedad a la que se pertenece. El conjunto de valores y relaciones, de una persona o una sociedad, le sirve para orientar sus comportamientos y normas mostrando lo que quiere ser.

En la actualidad, el cambio de los valores y actitudes de los ciudadanos trasciende a sus formas de comunicación y comportamiento. A ello contribuyen decisivamente los grupos audiovisuales dominantes (TV, radio, prensa, redes sociales, etc.) que generan modelos sociales en función de ideologías, teorías sociales, e intereses de grupos poderosos. Esos cambios se producen cada vez en mayor número y con más rapidez, aunque sin la violencia de las antiguas revoluciones, eliminando nuestros referentes personales de forma permanente, lo que nos ocasiona inseguridad y desconcierto.

El significado de cada uno de los valores es diferente para cada persona y sociedad, pues está muy influenciado por la cultura y por las necesidades del momento. Piénsese por ejemplo en cómo se interpretan los valores: ayuda, honradez, lealtad, justicia, respeto, etc.; para cada persona varía el significado según sea su situación de vida (ignorancia sobre un tema, conflictos afectivos, soledad, etc.), y entre dos personas el significado de un valor solo coincide parcialmente, pues el significado está ligado a los conocimientos, experiencias y sentimientos personales.

Los valores que tenemos y su orden de prioridad se ven sometidos a constantes estimaciones y cambios, esto es, los valores evolucionan a lo largo del tiempo; podemos apreciarlo reflexionando sobre nuestra vida. Adquirimos los valores de los ambientes que frecuentamos (culturales, profesionales, políticos, religiosos, etc.). A veces, conscientemente adoptamos un orden de valores diferentes en situaciones distintas; pero en ocasiones, arrollados por las circunstancias de la vida se nos imponen otros y no podemos mantener nuestra conducta, lo cual debe tenerse en cuenta al valorarla.

Análogamente, cuando se vaya a analizar la evolución de una sociedad debe especificarse la época y las circunstancias a las que se vio sometida. Esta importante consideración tiene una gran repercusión social; es un error frecuente evaluar acontecimientos de épocas anteriores con los criterios actuales, y sin considerar qué elementos del pasado fueron los responsables de esos acontecimientos.

La Declaración Universal sobre los Derechos Humanos de la ONU reconoce los valores comunes, promoviendo con ello la cohesión y la paz entre todos los pueblos. 
Los valores estructuran la sociedad y le proporcionan cohesión, y a su vez la sociedad exige coherencia con ellos. La cohesión social se produce cuando los miembros de esa sociedad comparten el mismo conjunto y prioridad de valores, es decir comparten el mismo sistema de valores. La sociedad actual se caracteriza por su socialización dispersora, que divide en grupos con creencias, ideologías, culturas, niveles económicos, valores, comportamientos, normas e intereses diferentes. Si esta tendencia fuese en aumento, la cohesión social iría disminuyendo por lo que se fragmentaría cada vez más, y terminaría extinguiéndose. Es un grave problema social que tenemos que resolver prontamente o dejaremos de existir como tal sociedad.

Los Valores como elemento del entorno tienen una intensa influencia sobre el sistema, pero la relación inversa es débil. El tiempo de la relación será largo, se extenderá hasta que se alcance un cierto equilibrio en cuanto al número y prioridad de valores. Los Valores tienen relación intensa con Comportamientos, y menor con Globalización.

\subsection{COMPORTAMIENTOS}

Los investigadores que estudian al ser humano en función de su comportamiento determinan lo que hacen y cómo toman sus decisiones, a fin de comprender su naturaleza y la de sus sociedades, facilitando la planificación de su desarrollo.

Las investigaciones realizadas muestran que uno de los valores de mayor estabilidad es el nivel de aspiración, pues las personas suelen proponerse metas que le resulten suficientemente satisfactorias y no suelen estar dispuestas a cambiarlas.

El estudio del comportamiento de grupos sociales en su ambiente natural se realiza mediante las descripciones sociométricas. En ocasiones se utiliza en la docencia para determinar las características de los grupos que existen en un aula. Es importante comprender cómo trabajan juntos los integrantes de un grupo. Se observa que los que tienen éxito son aquellos con una o dos personas de fuerte liderazgo, y los que promueven la participación de ideas y trabajan en situaciones poco estructuradas. En grupos sociales, el poder del grupo aumenta conforme aumenta su cohesión.

Los sistemas sociales son los pilares fundamentales que sustentan la vida en sociedad. Los comportamientos sociales y personales vienen determinados por el orden de preferencia que se dé a cada elemento del sistema y a sus relaciones; este orden varía ante situaciones diferentes a fin de adaptarnos mejor a ellas y tomar las decisiones más convenientes. La estabilidad de los sistemas sociales, definida por la permanencia de sus elementos y relaciones, implica 
también la de sus comportamientos; ello permite que nuestro pensamiento, sentimiento y conducta, sean estables, coherentes y previsibles, proporcionando mayor seguridad y cohesión social.

Los Comportamientos como elemento del entorno tienen una débil influencia sobre el sistema, y la relación inversa es extremadamente débil. Tienen relación intensa con Valores, y menor con Globalización.

\subsection{FINANCIACIÓN}

La financiación de la educación es un tema que pese a su importancia suele ser poco tratado, y cuando se hace se reduce a la financiación del sistema educativo académico, omitiendo la de la educación general de la sociedad, tal vez por la gran dificultad de cuantificar la inversión realizada en ella por multitud de entes.

Al ser los recursos económicos de cada país limitados y las necesidades sociales muy variadas, es obligado restringir los recursos dedicados a cada una de ellas. El presupuesto de Educación es un factor limitante, esencial y previo, para diseñar la estructura y organización de la educación como sistema, que debe ajustarse al criterio de simplificación y depende de dos pilares básicos: la recaudación tributaria de la Hacienda y el Presupuesto general del estado que la distribuye financiando los servicios públicos.

Concretar la cuantía del presupuesto implica establecer los límites posibles de cualquier reforma educativa; quienes esto ignoren contribuyen a su fracaso. Incluye los gastos de organización, gestión, recursos humanos y materiales necesarios, así como los de programas de formación y divulgación de los distintos ministerios, orientados a su personal y a la sociedad, tales como los programas de perfeccionamiento profesional, las campañas de concienciación social en los medios de comunicación, etc.

La acción de los gobiernos trata de alcanzar un equilibrio entre la posible financiación estatal y la eficacia en la consecución de los objetivos propuestos; para ayudar a lograrlos tratan de mejorar la utilización de los recursos y de establecer medidas que favorezcan la participación financiera de los agentes sociales (empresas, asociaciones, familias, etc.). Los sistemas de educación se financian principalmente por los estados.

Es necesario definir muy bien los objetivos pues la elaboración y desarrollo del sistema de educación queda supeditado a ellos. Entre los objetivos sociales que se proponen con más frecuencia aparecen: la calidad del sistema, la extensión de la gratuidad para todos y a todos los niveles, evitar el fracaso educativo 
a fin de obtener una formación completa, y conseguir que una gran parte de la población se titule en la educación superior independientemente de cual sea su origen económico y social. Entre los procedimientos de financiación se encuentran la participación económica en proyectos sociales y culturales, la subvención a asociaciones con actividades culturales y educativas, etc.; en el caso de la enseñanza suelen tener en cuenta el número y características de los alumnos matriculados y el de los titulados (es decir, el rendimiento), el número de profesores, los proyectos específicos, etc.

Los cambios en la financiación del sistema educativo precisan del minucioso análisis conjunto de la financiación posible con la educación que se pretende; la simplificación o carencia de dicho análisis solo crea falsas esperanzas de éxito. Entre las soluciones propuestas para cada situación concreta, la decisión debe tomarse tras un detallado análisis de sus limitaciones, procedimiento de ejecución y consecuencias a medio y largo plazo, sin olvidar el objetivo concreto al que deben servir; con ello se evitaría la ineficacia en la aplicación de los siempre insuficientes recursos. (Ibagón, 2015). Es el caso de pequeños aumentos de salario que afectan a cientos de miles de personas, originando un gran incremento financiero y tiene escasa incidencia en los objetivos.

La Comisión europea (2014) recomienda elaborar sistemas de financiación de la educación que sean eficaces y sostenibles, aportando un informe sobre las diferentes formas de financiación de los centros educativos no universitarios en Europa, que recoge los procedimientos de transferencia de los recursos, así como los métodos y criterios para determinar la financiación, aunque no la cuantificación de los recursos. No debe olvidarse que cada sistema tiene su propio contexto, prioridades y desarrollo, por lo que el éxito de una medida en un sistema no es necesariamente transferible a otro.

Un ejemplo de propuesta para el cambio en la financiación lo ofrece la Red por el Diálogo Educativo (REDE, 2020), que "presenta un modelo de financiación del sistema educativo español con la finalidad de lograr calidad, equidad e inclusión, y de ofrecer oportunidades de aprendizaje, para todos, a lo largo de la vida." Plantea un diagnóstico de la situación, determina las características del modelo, cuantifica la financiación y propone la vía para realizar el cambio.

La Financiación como elemento del entorno tiene una intensa influencia sobre el sistema, pero la relación inversa es extremadamente débil. 


\section{ELEMENTOS Y RELACIONES}

El sistema Educación que se presenta está integrado por cuatro elementos: Familia, Sistema educativo, Relaciones, y Factores sociales, que son los principales factores de influencia en nuestra educación a lo largo de la vida.

Las magnitudes a considerar en la acción de cada elemento son la intensidad y el tiempo. Así por ejemplo, en la relación de un amigo con otro podría considerarse la mayor o menor intimidad, afecto, emotividad, y atracción que produce, y el tiempo que comparten juntos esa amistad.

\subsection{FAMILIA}

Entre los factores más influyentes en la educación se encuentra la familia. Esta afirmación queda avalada por las investigaciones en Psicología del Desarrollo, que muestran que desde que se nace se acepta la realidad desde la perspectiva de las personas con las que se mantiene relaciones afectivas (padres, abuelos, etc.), y por ser la familia el primer grupo social con el que se establece contacto.

Los primeros años de vida del niño son esenciales para la adquisición de actitudes, valores y comportamientos, perdurando su huella a lo largo de la existencia. En el seno familiar el niño pasa la mayor parte del tiempo, y puesto que aprende por imitación al igual que cualquier animal, es crucial cuidar el ambiente familiar y ofrecerle vivencias ejemplares a fin de que obtenga una gran riqueza en actitudes y valores, y desarrolle buenas relaciones sociales. El ambiente afectivo, unido a la situación cultural, económica y social de la familia son esenciales para la educación del niño. Si deseamos mejorar la educación es imprescindible mejorar las condiciones familiares.

La familia es el elemento fundamental en el desarrollo psicofísico de las relaciones del niño, pues con su amor y ejemplo le proporciona valores personales y normas de conducta social. La ruptura de las familias hace inviable o muy difícil estos aprendizajes esenciales, suscitando en el niño sentimientos de desamparo, y provocándole agresividad e inadaptación. Si la familia se inhibe de la educación de sus hijos, los condena al fracaso escolar y a un incierto futuro. (Esteve, 2003).

Tiene que existir una labor conjunta y coherente de la familia, la escuela y la sociedad, para la transmisión de comportamientos y valores personales y sociales (respeto, honradez, ayuda a los demás, etc.).

En las familias de la sociedad actual se observa una gran diversidad de formas de entender la vida, la cultura, la educación, los valores, las conductas, lo 
necesario, los derechos, etc.; por ello, en los centros educativos algunos profesores se limitan a la enseñanza de las materias, y renuncian a la educación para evitar confrontaciones con las familias. Sin embargo hay alumnos desasistidos familiarmente, con abandono físico y afectivo, malos ejemplos, hábitos negativos, y en definitiva, con una educación inaceptable para su desarrollo personal. Así que es el sistema educativo el que está obligado a proporcionar la educación adecuada para lograr la convivencia social; no se puede renunciar a ello. La inhibición educativa del sistema, unida a la familiar, originará individuos inadaptados socialmente, insolidarios, sin discernimiento moral, sometido a los grupos sociales dominantes, ocasionando así un grave perjuicio personal y social.

\subsection{SISTEMA EDUCATIVO}

Los sistemas educativos están planificados por los estados, que legislan, financian, organizan, controlan y evalúan los sistemas. El objetivo es formar a ciudadanos que asuman la civilización de la sociedad a la que pertenecen (su lengua, ideas, historia, tradiciones, comportamientos, etc.), y capacitarlos profesionalmente para que se integren en ella de forma productiva.

Por eso hay que dotar al sistema educativo de las características que le permitan adaptarse rápidamente a los requerimientos sociales. El desfase temporal entre los requerimientos y la respuesta del sistema es lo que produce el desaliento y hastío de la comunidad educativa. La rápida actividad de grupos de docentes ilusionados, las múltiples experiencias personales innovadoras, el uso prioritario de recursos novedosos, etc., suelen tener una vida efímera sin posibilidad de generalización, es decir no se integran en el sistema.

Basándose en los mejores resultados de los sistemas educativos, obtenidos en varios países, la OCDE recomienda que las reformas de los sistemas se realicen de manera constante según se vayan observando deficiencias o surjan nuevas necesidades. Para lograrlo hay que diseñar un sistema flexible capaz de conseguir su evolución continua. Ello exige estabilidad político-social y un gran esfuerzo y colaboración permanente de todos los participantes en el sistema. (LOMCE, 2013).

Pese al incremento de los presupuestos de educación, el aumento de profesores y la disminución de alumnos, las críticas arrecian señalando numerosas deficiencias: mayor incultura y violencia, devaluación de los títulos, elevado fracaso escolar, etc., pero se suele olvidar el gran desarrollo y el avance cualitativo logrado por el sistema. La sociedad tiene expectativas desproporcionadas, 
exige respuestas inmediatas, busca responsables al instante y los sentencia en los medios de comunicación. (Esteve, 2003).

El sistema educativo debe estructurarse para que los alumnos que no vayan a seguir estudios superiores puedan alcanzar un buen nivel cultural, de conocimiento, de iniciativa, de capacidad crítica, de valores, etc., que les permita contribuir a la sociedad con un trabajo eficaz y puedan disfrutar de la vida.

En los centros educativos se localiza la importante y larga etapa que comprende desde que el niño ingresa en la escuela hasta la finalización de todos sus estudios; se desarrollan valores, comportamientos, conocimientos, aptitudes y relaciones sociales, contribuyendo a ello los profesores, los compañeros y los nuevos ambientes.

Los estudiantes adquieren con más facilidad las cualidades de aquellas personas a las que admiran o con las que tienen buena relación; de ahí que ha de cuidarse mucho el tipo de centro académico que se elige y las relaciones personales que se establecen.

Conseguir que el centro reúna una agradable condición físico-ambiental es una meta importante para lograr la satisfacción de todos sus integrantes, que a su vez propicia la cohesión y el buen ambiente humano, mejorando así el rendimiento de todos.

Los problemas más frecuentes que desestabilizan la actividad del centro (alumnos conflictivos, con dificultades cognitivas, psicológicas y conductuales, etc.), son situaciones ordinarias para las que el sistema ha de proporcionar soluciones realistas y generalizables en la práctica, para que sean resueltas con éxito en los propios centros.

Los centros pueden contribuir decisivamente a disminuir o resolver algunos problemas, así por ejemplo, debe conseguir que la comunidad educativa acepte unas normas de educación que aseguren la convivencia en el centro, pues caso contrario no será posible el aprendizaje del alumnado. El profesorado tiene que asumir que la educación del alumnado es previa a su instrucción; educar es una nueva e imprescindible misión que se añade a la tradicional que es esencialmente instructiva.

La inhibición de algunos profesores respecto a problemas de educación en los centros se fundamenta en la no delimitación pormenorizada de lo que le corresponde hacer, y en la desprotección institucional y legal en que se encuentran. Los problemas y conflictos que surgen en el proceso educativo son una buena ocasión para reflexionar y corregir comportamientos individuales y grupales; deben analizarse por una pequeña comisión, que para su resolución debe seguir un procedimiento sencillo y rápido. (Esteve, 2003). 


\subsection{RELACIONES}

Entre las numerosas relaciones los amigos y compańeros tienen una influencia capital en nuestros valores y conducta, pues en general acabamos pareciéndonos a las personas que tratamos y especialmente a las que admiramos y amamos. Con ellos compartimos tiempo, trabajo, emociones, sentimientos, intimidad,...La permanencia de esa influencia depende de la intensidad ejercida por el conjunto de factores y circunstancias que la producen; así por ejemplo, una breve relación mantenida en circunstancias muy emotivas puede influenciarnos durante toda la vida.

Las personas que ejercen alguna autoridad sobre nosotros (profesores, jefes, personajes famosos, etc.) también influyen en el desarrollo de nuestros valores y comportamientos, ya sea estimulándolos o dificultándolos, bien sea con sus indicaciones o con su propio ejemplo. El respeto, la admiración y la empatía, con alguna de ellas puede cambiar el rumbo de nuestra vida, como puede ser el caso de la elección de una profesión, e incluso el sentido de nuestra existencia.

Frecuentando ambientes sociales diferentes se multiplican las relaciones y se incrementan nuestras experiencias que, con la adecuada reflexión sobre ellas, nos ayudan a tomar decisiones sobre los valores más convenientes a desestimar, adquirir, desarrollar, o priorizar. Estas situaciones se facilitan con viajes, aficiones, etc.

Con el cuidado y la selección de las relaciones se consigue mejorar los valores, lo cual nos proporciona mayor seguridad, estabilidad y enriquecimiento de la personalidad.

Las relaciones en general son imprescindibles para el buen desarrollo de la vida.

\subsection{FACTORES SOCIALES}

Se comenta este elemento considerándolo como un subconjunto de otros cinco.

\section{Religiones}

Tradicionalmente vienen aunando creencias, prácticas y normas relacionadas con la divinidad y el espíritu; de ordinario regulan la vida personal y la convivencia social. Son fuente de valores, proporcionan sosiego y dan sentido a la vida. Los humanos han integrado la religión a su modo de vida en todos los tiempos y lugares. Su influencia es decisiva en la educación y en cualquier manifestación de la sociedad. 


\section{Partidos políticos}

Son entidades unidas a la democracia representativa y los actores principales de la acción política; con frecuencia tienen base ideológica. Contribuyen a la formación de la opinión pública, a los procesos electorales, y al gobierno del Estado. Su participación en la educación de la sociedad es notoria, aunando intereses, legislando normas de organización y comportamiento social, y siendo responsables del sistema educativo.

\section{Instituciones}

Las variadas instituciones de tipo cultural, religioso, político, profesional, deportivo, organizaciones para la solidaridad, etc., a las que podemos pertenecer nos ofrecen una gran cantidad de valores. En ocasiones son determinantes en la elección de nuestros objetivos y en la priorización de nuestros valores, propiciando importantes cambios de vida; piénsese por ejemplo en los voluntarios que a ayudan en el Tercer Mundo.

\section{Medios de comunicación}

La televisión, radio, prensa en papel y digital, cine, publicidad,... son medios de comunicación esenciales para la educación de la sociedad. En la edad adulta influyen decisivamente en el comportamiento humano, pues con sus eficaces estrategias y convincente presentación de valores consiguen imponer sus propuestas. Podría decirse: Dime lo que ves, oyes y lees, y te diré cómo piensas y te comportas.

\section{Internet y redes sociales}

Debido a su incierta fiabilidad ha de comprobarse la veracidad de sus mensajes, y realizar un análisis crítico de sus contenidos. La frecuente exigencia de inmediatez en las respuestas hace prevalecer las emociones a las razones, que se activan más lentamente, y por ello propician actuaciones incoherentes con nuestros valores. En la actualidad tienen una gran actividad e influencia en los comportamientos sociales.

\section{CONCLUSIONES}

La convivencia en un mismo país de grupos humanos con ideales, culturas, y pretensiones diferentes, a lo que se añade una creciente globalización, hace sumamente difícil diseñar un sistema de educación de la sociedad, que tiene un entramado de elementos muy complejo. La principal dificultad reside en acordar la finalidad del sistema, en concretar sus grandes objetivos, de los que 
depende la selección de los elementos sobre los que hay que actuar para lograrlos. El conocimiento pormenorizado de ellos y de sus interrelaciones es imprescindible para determinar las causas de los problemas a fin de darles una buena solución; si tienen su causa en el exterior de un elemento no es posible resolverlos desde el interior. Tal es el caso de algunos problemas que se originan en el exterior del sistema educativo; es inútil el esfuerzo del profesorado puesto que no pueden actuar eficazmente sobre las causas, y tratando los efectos solo pueden paliar los problemas.

Actualmente se dispone de recursos informáticos muy avanzados para el tratamiento de problemas en sistemas complejos, como el educativo. Pero la elaboración de un sistema de educación para toda la sociedad suele estar limitado por la imposición de ideologías y opciones de vida de grupos dominantes, que solo satisfacen a sus seguidores.

Aprovechando la globalización, poderosos grupos de intereses financiados por grandes fortunas actúan presionando a los organismos internacionales y a los estados, para que aprueben normativas de acuerdo a sus pretensiones. Suelen tener su repercusión en la cultura y en la educación de la sociedad. Se deben analizar detalladamente las decisiones que se tomen para evitar consecuencias desfavorables.

Puesto que la financiación estatal siempre será limitada, es muy necesario incentivar a las instituciones, medios de comunicación y demás agentes sociales, para que realicen actividades que generen una consensuada educación social; su logro exige que todos compartan los mismos objetivos y el camino a seguir. Por consiguiente es una obra común en la que todos debemos participar.

\section{BIBLIOGRAFÍA}

Bauman, Z. y Leoncini, T. (2018). Generación líquida. Transformaciones en la era 3.0. Barcelona: Paidós.

Bertalanffy, Ludwig von. (1976). Teoría general de los sistemas. Fundamentos, desarrollo, aplicaciones. Madrid: Fondo de Cultura Económica.

Burbules, Nicholas C. y Torres, Carlos Alberto. (Coords.). (2005). Globalización y educación. Manual crítico. Madrid: Editorial Popular.

Comisión Europea / EACEA / Eurydice. (2014). La financiación de los centros educativos en Europa: mecanismos, métodos y criterios de financiación pública. Informe de Eurydice. Luxemburgo: Oficina de Publicaciones de la Unión Europea. Recuperado el 25-10-2020, de:

https://sede.educacion.gob.es/publiventa/detalle.action?cod=20137. 
Esteve Zarazaga, José Manuel. (2003). La tercera revolución educativa. La educación en la sociedad del conocimiento. Barcelona: Paidós.

Han, Byung-Chul. (2014). En el enjambre. Barcelona: Herder.

Han, Byung-Chul. (2017). La sociedad del cansancio (2a ed.). Barcelona: Herder. Ibagón Martín, N. J. (2015). La educación, un derecho que cuesta: dimensión fiscal y su relación con la política educativa en América Latina. Revista Educación y Humanismo, 17(28), 29-37. Recuperado el 16 de octubre de 2020 de: http://dx.doi.org/10.17081/eduhum.17.28.1164

LOMCE (2013). Ley Orgánica 8/2013, de 9 de diciembre, para la mejora de la calidad educativa. BOE núm. 295, de 10/12/2013, preámbulos V y XV. Recuperado el 7 de octubre de 2020, de:

https://www.boe.es/eli/es/lo/2013/12/09/8/con

REDE - Red por el Diálogo Educativo. (2020). Hacia un modelo de financiación orientado a la mejora educativa y la equidad. Cuadernos de Pedagogía, $505,58-65$. 


\title{
REFLEXIONES DE UNOS AUTODIDACTAS
}

\author{
Ma Esther Pérez Martell, Ma Olga Escandell Bermúdez y Francisco Rubio Royo \\ Universidad de Las Palmas de Gran Canaria
}

\section{Resumen}

La base del sistema educativo canario, donde Emy realizó una excelente tarea personal y de integración de compañeras y compañeros, está en la formación inicial y continua del profesorado de toda la cadena del sistema formal. Acción que tiene lugar, fundamentalmente, en la Facultad de Educación. Una Facultad cada vez más transversal y abierta al resto de titulaciones, y con una visión pertinente de las innovaciones a introducir, teniendo en cuenta que no todo hay que cambiarlo; y esto se refiere también a las competencias. Los conocimientos, muy bien seleccionados ya que los podrán (igual que las didácticas) adquirir a lo largo de toda la vida, son importantes y anteceden a las pedagogías y didácticas; lo cual no significa que estas no sean relevantes. Con los avances en neurología, psicología, sociología y antropología aplicadas a la educación ( $\mathrm{y}$ a todo el sistema productivo) es lo que más van a hacer cambiar el conocimiento de cómo aprenden las personas y las motivaciones que hacen un aprendizaje más humano, profundo y relacional.

Para ello desarrollamos un decálogo de ocho puntos, que no son los únicos a considerar, aunque son los que nos han parecido relevantes en este momento.

Lo más importante es que durante la elaboración de esta humilde aportación, nos hemos sentido muy cercanas a Emy.

Palabras clave: Educación, competencias, formación inicial del profesorado, formación continua, aprendizaje formal, no formal e informal, aprendizaje para la vida, transformación digital.

\begin{abstract}
The basis of the Canarian educational system, where Emy carried out an excellent personal task and integration of colleagues, is in the initial and continuous training of teachers throughout the chain of the formal system. Action that takes place, fundamentally, in the Faculty of Education. A Faculty that is increasingly transversal and open to the rest of the degrees, and with a relevant vision of the innovations to be introduced, taking into account that not everything has to be changed; and this also refers to the competencies. The knowledge, very well selected since they will be able to acquire it (as well as
\end{abstract}


the didactics) throughout life, is important and precedes the pedagogies and didactics, which does not mean that these are not relevant. With the advances in neurology, psychology, sociology and anthropology applied to education (and to the whole production system), it is what will change the knowledge of how people learn and the motivations that make more human, deep and relational learning.

To this end, we developed a decalogue of eight points, which are not the only ones to be considered, although they are the ones that seemed relevant to us at this time. The most important thing is that during the making of this humble contribution, we have felt very close to Emy.

Keywords: Education, skills, initial teacher training, continuous training, formal, non-formal and informal learning, long life learning, digital transformation.

Queremos reconocer y agradecer a los compañeros de la Dra. Dńa. Emidgia Repetto Jiménez (Emy) la excelente y merecida iniciativa que tomaron con motivo de su fallecimiento, el pasado cinco de junio, y que nos hayan invitado a participar en este homenaje académico.

Con ella compartimos muchos ańos de trabajo, de amistad y de afecto en la ULPGC y en alguna ocasión en su Sevilla natal, donde nos atendió a Paco y Esther - acompañada de Rubén - con la proverbial bonhomía de ambos. Nos unía con ella, académicamente, su interés por la formación del profesorado, como base para la formación del alumnado, que era el objetivo final. Gracias a ella, y al Dr. D. Gonzalo Marrero Rodríguez, fuimos innovadores adelantados en los sistemas de evaluación del profesorado, desde la óptica docente tantas veces olvidada, como básica e inherente también en el quehacer cotidiano del profesorado. También nos unió nuestra experiencia y compromiso con el aprendizaje online, fruto de nuestra larga experiencia - Esther y Paco- entre la University of British Columbia, UBC (Vancouver, Canadá) y la Universitat Oberta de Catalunya, UOC (Barcelona), gracias a las facilidades que nos dio el Rector Magnífico Dr. Don Manuel Lobo Cabrera. Así como la de Maroqui como compañera de centro, directora y profesora de Teleformación en la ULPGC.

Por eso queremos que nuestra humilde aportación a su homenaje esté relacionada con estas dos líneas de trabajo, que han ocupado parte importante de nuestras vidas académicas. Todo ello, sin ser expertos ni titulados formales en las áreas de educación, pedagogía o didácticas especiales. Lo hacemos convencidos que nuestras reflexiones, en forma de un decálogo abierto, le hubiesen 
gustado a Emy y podríamos haberlas extendido y ampliado con sus acertadas puntualizaciones que les ańadirían valor. $\mathrm{Al}$ no estar formalmente implicados creo que nos puede dar una ventaja y solicitar una tolerancia de los expertos, basada en nuestro desconocimiento de lo académicamente correcto, para poder ser más atrevidos y movernos fuera de las "zonas de confort".

Comencemos con nuestro decálogo abierto ${ }^{1}$ — con un propósito previocentrado en la formación del profesorado en un cambio de época y por lo tanto de paradigma; caracterizado por entornos $V U C A^{2}$ y y necesidad de plantear objetivos $F A S T^{3}$, con una transformación digital imparable — que dota de hiperconectividad y que lo impregna todo- y una interdependencia entre lo local y lo global cada vez mayor, y que a partir del COVID-19 será diferente, a lo que estábamos acostumbrados y considerábamos normal.

Propósito que debe plantearse la educación y su centro por antonomasia: nutrir el talento que todas las personas tienen, en diferente naturaleza y grado, para que puedan desarrollar su proyecto vital, que supere las desigualdades sociales culturales y económicas de partida, al tiempo que se previene el absentismo, el abandono y el fracaso escolar temprano.

Decálogo:

\section{LA FACULTAD DE EDUCACIÓN DEBE SER EL BUQUE INSIGNIA DE LA UNIVERSIDAD}

En estas facultades se forman los maestros y profesores de todo el sistema educativo español no universitario: infantil, primaria, secundaria y educación superior ${ }^{4}$. Su importancia para la sociedad (individual y colectivamente) y el futuro del país es decisiva. No queremos hacer referencia a los modelos nórdi-

1 Abierto en el sentido de que ni es exclusivo ni excluyente, y que cada persona puede añadir - incluso quitar- lo que no crea conveniente en todo momento. Lo importante es hacer algo con propósito. Un decálogo es un conjunto de normas o consejos 'que, aunque no sean diez (ocho en nuestro caso), son básicos para el desarrollo de cualquier actividad', tal y como seńala el diccionario académico (Fundeu, 07/03/11).

$2 V U C A$, acrónimo en inglés de Volatility (volatilidad), Uncertainty (incertidumbre), Complexity (complejidad) y Ambiguity (ambigüedad).

https://hbr.org/2014/01/what-vuca-really-means-for-you

3 FAST, acrónimo en inglés de Frequently discussed, Ambitious, Specific y Transparent; con una necesidad cada vez mayor de datos para la toma de decisiones y de hitos a alcanzar. https://sloanreview.mit.edu/article/with-goals-fast-beats-smart/

4 https://eacea.ec.europa.eu/national-policies/eurydice/content/organisation-education-systemand-its-structure-79_es 
cos europeos, especialmente Finlandia, ya que las circunstancias, idiosincrasia y cultura son muy diferentes a las nuestras.

Quizá lo primero que se deben plantear (al igual que el resto de centros) es: para qué, por qué, qué, cómo, quiénes, cuándo y dónde se van a educar y formar a las personas, para facilitarles bienestar, resiliencia y realización personal, teniendo en cuenta que nos encontramos en la sociedad del conocimiento y del aprendizaje, una vez "superada" la sociedad posindustrial.

Esto implica una renovación y reorientación profunda de las mismas, que no hay que comenzar por "más recursos" para poder hacer lo que deben hacer; aunque los necesitarán a medida que desarrollen y se evalúen los resultados de su plan de acción en la línea del propósito indicado. Unas acciones que el mundo actual requiere que sean ágiles, flexibles, rápidas y con capacidad de “improvisación".

La formación debe ser en conocimientos, en metodologías, en competencias personales e interpersonales, y en valores éticos universales; todo ello en situaciones cada vez más próximas a situaciones reales que se van a encontrar en el aula, con su futuro alumnado. Debe ser un proceso cada vez más dual, con intervención continua de los profesionales con mayor experiencia y que han mostrado ser los más innovadores, en la actual situación. Una innovación, acompañada de una actualización de contenidos, en metodologías más activas, colaborativas y transversales. Se debe tener en cuenta que sus alumnos en la escuela, y ellos mimos, se encontrarán en una situación en la que a lo largo de la vida van a tener que cambiar de trabajo varias veces y, en ocasiones, incluso de profesión.

Se necesita un profesorado que sea referencia para el alumnado y en la sociedad; con los correspondientes reconocimientos y compensaciones por la labor que realizan, que es estratégica para el futuro de todas las personas. Posiblemente se asistirá a una nueva concepción del funcionariado, apareciendo nuevas formas de "seguridad" en el trabajo, basadas en la labor realizada, con evaluaciones objetivas integrales continuas e independientes, en sus aportaciones en innovación metodológica, en la actualización y seguimiento de su formación, etc.

Esta situación requiere también reconocer el valor de la docencia en la dualidad investigación-formación, en igualdad de condiciones y con profesorado con distintos perfiles en este sentido. Hay que tener en cuenta que la sociedad conoce sobre todo la calidad de una institución a través del comentario de su alumnado - y cuando este pasa a trabajar como maestro- con las personas más allegadas a los mismos. Son dos caras de la misma moneda, que no tiene sentido la una sin la otra; excelentes compañeros y profesores que hemos tenido todos, nos lo han demostrado. 
Se requiere una reflexión, actualización y adaptación de conceptos clásicos asociados al quehacer universitario, como son los de la autonomía universitaria y de la libertad de cátedra en un cambio de época como la que está viviendo el mundo ${ }^{5}$. La EUA (European University Association) ${ }^{6}$, ya la ha definido en función de cuatro dimensiones y veinte ocho indicadores.

La reflexión siguiente refuerza esta primera.

\section{EL ALUMNADO, DESDE LA ESCUELA, APRENDE PARA LA VIDA: INDIVIDUAL Y COLECTIVAMENTE}

Nuestras reflexiones parten de dos principios:

a) Todas las personas tienen talento, con mayor facilidad para adquirir unas competencias que otras, como afirmamos al tratar del propósito al comienzo de esta reflexión realizada en recuerdo de Emy. Por lo tanto, creemos en la teoría de las inteligencias múltiples, Howard Gardner, 1983; que además afirmaba que el intelecto no es una característica innata e inmutable de las personas? ${ }^{7}$.

b) La educación es tarea de toda la tribu; como afirma José Antonio Marina $^{8}$ : "para educar a un nińo hace falta toda la tribu", parafraseando un proverbio africano. La dificultad es que la tribu se ha ampliado, junto a las tradicionales de la familia y de la sociedad han surgido internet, las redes sociales, los/las influencers, etc., cuya influencia en la educación de los jóvenes es cada vez mayor y no a mejor. Por ello, y para compensar los casos de las personas más desarraigadas y vulnerables en que la familia no puede, la escuela debe compensar (con gran dificultad) su falta.

Con estos principios, la facultad que forma a los profesores y maestros debería superar la educación compartimentada por disciplinas que "no se hablan", para abordar cada vez más un aprendizaje por proyectos, por ejemplo. Esto permite abordar situaciones más complejas, como las que se irán encontrando en la vida real, aumentando su interés y motivación.

5 https://dialnet.unirioja.es/servlet/articulo?codigo $=4083717$

6 https://www.university-autonomy.eu/\#:-:text=In\%20order\%20to\%20be $\% 20$ successful,have $\%$ $20 \mathrm{in} \% 20$ each $\% 20$ of $\% 20$ these

7 https://infed.org/howard-gardner-multiple-intelligences-and-education/

Profesor, psicólogo y pedagogo, de la Universidad de Harvard. Premio Príncipe de Asturias de Ciencias Sociales en 2011.

8 J.A. Marina. Aprender a vivir. Ariel, 2004. 
Realmente a finales del siglo XX se publicaron dos informes, que aún hoy en día siguen teniendo una gran vigencia y que en ocasiones se nos han olvidado. Nos referimos a los informes de Jacques Delors y de Edgar Morin.

Jacques Delors9, en 1996, coordinó un informe a la UNESCO en el que incluía "Los cuatro pilares de la educación" en el capítulo cuarto de "La educación encierra un tesoro" 10 .

Estos pilares eran ${ }^{11}$ :

- Aprender a conocer.

- Aprender a hacer.

- Aprender a vivir juntos, aprender a vivir con los demás.

- Aprender a ser.

Creemos que hay que volver a ellos, sobre todo en las Facultades de Educación. Estos son, también, los pilares de la educación a lo largo de la vida, no solo los de la educación inicial formal. El título del libro es evocador y precioso: "La educación encierra un tesoro".

Edgar Morin ${ }^{12}$, en 1999, cerró su informe a la UNESCO "Los siete saberes necesarios para la educación del futuro" ${ }^{13}$. En su prólogo comienza diciendo: este texto antecede cualquier guía o compendio de enseñanza. No es un tratado sobre el conjunto de materias que deben o deberían enseñarse: pretende única y esencialmente exponer problemas centrales o fundamentales que permanecen por completo ignorados u olvidados y que son necesarios para enseñar en el próximo siglo". Dichos saberes son:

1. Reconocer las cegueras del conocimiento: el error y la ilusión.

2. Los principios del conocimiento pertinente.

3. Enseñar la condición humana.

$9 \mathrm{Al}$ tío Jacques, como se le suele llamar familiarmente ahora que es nonagenario, se le deben casi todos los avances europeos de los últimos decenios llevan su impronta: del mercado interior a la moneda única; de la política de cohesión a las grandes redes de transporte; de la ciudadanía europea al programa Erasmus; de la ampliación mediterránea a la reunificación alemana y continental.

10 https://neurofilosofia.com/wp-content/uploads/2012/12/Resumen-de-LA-EDUCACIONENCIERRA-UN-TESORO.pdf

Informe a la UNESCO de la Comisión internacional sobre la educación para el siglo XXI,

11 http://innovacioneducativa.uaem.mx:8080/innovacioneducativa/web/Documentos/educacion_te soro.pdf

12 Filósofo y sociólogo francés.

13 https://unesdoc.unesco.org/ark:/48223/pf0000117740_spa

https://edgarmorinmultiversidad.org/index.php/libros-sin-costo/94-los-7-saberes-necesariospara-la-educacion-del-futuro-de-edgar-morin.html 
4. Enseñar la identidad planetaria.

5. Enfrentar las incertidumbres.

6. La enseñanza de la comprensión.

7. Ética del género humano.

Leer y reflexionar acerca de estos dos informes nos aclaran muchas cosas, que permanecen en el tiempo.

\section{EL APRENDIZAJE SERÁ CADA VEZ MÁS PERSONALIZADO}

En el diverso y siempre cambiante mundo de la tecnología educativa, el término "aprendizaje personalizado" parece estar en todas partes, aunque todavía no hay una comprensión compartida de lo que significa ${ }^{14}$. En los últimos años, varias organizaciones de educación y tecnología han tratado de ir más allá de las generalidades, para forjar una definición más clara de lo que significa realmente el aprendizaje personalizado, con la esperanza de que la orientación proporcione información más específica y útil a la comunidad de los niños y jóvenes de primaria y secundaria.

Personalizar el aprendizaje, en algunos aspectos, es un concepto antiguo. Durante generaciones, los maestros han tratado de elaborar la instrucción para satisfacer las necesidades individuales de los estudiantes, un desafío manejable cuando se trabaja con un grupo relativamente pequeño, pero mucho más difícil para una clase de 20 a 30 estudiantes.

En estos momentos, además, adquiere una dimensión nueva no solo por la existencia de recursos y plataformas digitales que lo favorecen, que también, sino porque es la base de la formación continua a lo largo de la vida, donde es esencial poner en el centro del proceso al aprendiz maduro: conocer su perfil, sus necesidades, sus preferencias, su disponibilidad, etc.

En 2014 la Fundación Bill y Melinda Gates, Afton Partners, la Fundación Eli y Edythe Broad, CEE Trust, el Instituto Christensen de Innovación Perturbadora, el Fondo de Crecimiento de Escuelas Charter, EDUCAUSE, iNACOL, el Acelerador de Aprendizaje, la Fundación Michael y Susan Dell, Silicon Schools y los educadores propusieron una definición operativa para el concepto ${ }^{15}$.

14 http://k12education.gatesfoundation.org/download/?Num=2340\&filename=PersonalizedLearning-What-is-it.pdf

15 https://www.documentcloud.org/documents/1311874-personalized-learning-working-definitionfall2014.html 
"El aprendizaje personalizado incorpora cuatro características nucleares, que ayudan a acelerar y profundizar el aprendizaje para todos los estudiantes:

A. Perfil de los aprendices.
a. Fortalezas y necesidades.
b. Motivaciones.
c. Objetivos.
d. Datos y retorno.

B. Rutas de aprendizaje personales.

a. Planes personalizados de aprendizaje.

b. Experiencias (modalidades) diferentes de aprendizaje.

c. Capacidad de decisión del aprendiz.

C. Progresión basada en las competencias.

a. Formas de evaluación.

b. Maestría lograda por el aprendiz.

D. Entornos flexibles de aprendizaje.
a. Alineación operativa.
b. Roles de los maestros y su flexibilidad.
c. Utilización de los espacios.
d. Distribución del tiempo.
e. Agrupaciones y conexiones."

Hay que resaltar que el aprendizaje personalizado no está reñido con el colaborativo y cooperativo, que es esencial; siendo la base de la futura competencia: trabajo en quipo, que esté formado por personas diferentes y complementarias.

\section{SE NECESITAN PLANES DE ESTUDIO MÁS TRANSVERSALES Y AC- TUALIZADOS $^{16}$}

Una vez tenemos claro el propósito del grado y máster de educación (el para qué y el por qué) es necesario abordar el qué, acompañado del cómo.

Creemos que hay que repensar la forma de elaborar los mismos y el seguimiento de cómo se desarrollan en la práctica. Estamos en un mundo en el que todo lo que se pueda medir hay que hacerlo, para tomar decisiones acertadas y adecuadas; sin olvidar la importancia de lo cualitativo y más en las ciencias sociales. Si solo intervienen los departamentos o áreas que siempre han estado, es

16 Muchas de estas reflexiones son comunes a otros centros de la universidad española, pero en este homenaje a Emy nos hemos focalizado en su Centro. 
difícil la actualización en el sentido al menos de la transversalidad. Hay que tener en cuenta que estamos en un mundo de ecosistemas organizacionales y operativos, con diferentes actores o agentes a los que las decisiones que se tomen en una parte les influye. Además, el concepto de Responsabilidad Social Universitaria, cada vez más importante, exige una interacción e interconexión de la universidad con la sociedad, diferentes a las que se ha tenido hasta el momento; sin olvidar que estamos en un entorno $V U C A$, como decíamos al principio de este artículo.

Es conveniente que exista una mayor relación e interconexión, creando sinergias, entre las diferentes asignaturas de un plan de estudios, tanto de carácter horizontal como vertical. Las asignaturas se tienen que "hablar" entre si, y no ser silos aislados; ya que los problemas y situaciones reales son cada vez más complejas, aún en el terreno científico. Sería recomendable que los futuros profesionales de la educación tuviesen conocimientos sólidos, en el nivel que les corresponde (no son especialistas), a los que aplicar los principios de las didácticas, lo contrario no es sostenible.

En esta nueva orientación de los estudios se debería tener en cuenta hacia dónde va el mundo, en el sentido de la importancia creciente de la renovación ecológica, de la transformación digital, educación física y salud, idiomas, etc., y de las competencias necesarias para esta época del siglo XXI, que abordaremos en el punto final de este decálogo.

Habría que limitar la profundidad y amplitud de los contenidos, ya que las personas van a disponer de una formación continua a lo largo de toda la vida; en cuanto a los contenidos menos, es más. Habría que abordar, para lo cual habría que cambiar algunas normativas, los dobles grados relacionados con educación; es decir un doble grado de contenidos relacionados (p.e. física y química; educación física; informática, etc.) con los específicos de pedagogía.

Existen dos actividades que creemos es necesario abordar, con mentalidad y orientación distintas de la actual:

a) El Practicum.

b) El Máster de Formación del Formación del Profesorado de E.S.O. y Bachillerato, Formación Profesional y Enseñanza de idiomas.

Que son fundamentales para la actividad de los futuros maestros y profesores; esta reflexión merecería otro artículo.

Los estudios de educación tienen gran futuro en la universidad, ya que se les abren nuevos segmentos de alumnos, que conviene recordar, para que puedan considerar la oportunidad:

- Formación de maestros, en las distintas especialidades. 
- Máster de Formación del Profesorado, que abre la ventana del profesorado de Formación Profesional, cada vez más importante e innovador para Canarias.

- Formación continua del profesorado en activo.

- Formación, en colaboración/cooperación con los departamentos universitarios, del profesorado universitario.

- Formación en competencias transversales común a todas las titulaciones.

Esto sería lógico en una facultad que fuese el buque insignia de la universidad. Con ello también se podría en valor una marca de formación exportable internacionalmente, si lo unimos a un hub de $\mathrm{i}+\mathrm{D}+\mathrm{i}$ transversal en innovación docente, contando con los profesores más innovadores del propio sistema. No se trata de un sueńo, sino de una realidad factible.

\section{TRANSFORMACIÓN DIGITAL DE LA EDUCACIÓN}

Con este enunciado, utilizando un lenguaje un tanto coloquial, nos referimos a un mundo que ya está ahí, cada vez más digital. A menudo escuchamos hablar de transformación digital de la sanidad, de transformación digital de las comunicaciones interpersonales, de los medios de comunicación, de las pequeñas y medianas empresas, de las AA.PP., etc. ¿También de la educación?

Sabemos que las tecnologías digitales están transformando la sociedad, la forma de vivir, convivir, trabajar y el ocio. Esto ya ocurría antes del COVID19, aunque esta pandemia la ha acelerado. Nos parece un aspecto tan relevante que en esta reflexión dedicamos tres puntos a ello, en relación con la educación y la formación de maestros y profesores; son este y los dos siguientes.

Hay que comenzar precisando tres términos, que a menudo se toman como sinónimos, pero que en inglés tienen un significado distinto, que en español no utilizamos de esa forma precisa. Son: digitation, digitalization y digital transformation ${ }^{17}$. La digitalización conduce a la educación digital, su transformación digital requiere educación digital, digitalización, ...y algo más.

17 La digitalización es la creación de una versión digital (bits y bytes) de cosas analógicas/físicas como documentos en papel, imágenes en microfilm, fotografías, sonidos y más.

Un tercer contexto de la digitalización va más allá de las organizaciones empresariales y se refiere a la (simple) adopción cada vez mayor de las tecnologías digitales en todas las actividades sociales y humanas posibles; realmente se trata de hacer con tecnologías digitales lo que antes se hacia sin ellas. La educación es caso típico, en general, de este término. 
Pero hay más, hasta que punto se puede seguir y estar al día en las continuas "olas disruptivas digitales", cada vez más asequibles en uso y precio, y más frecuentes. Es una reflexión importante, ahora que está en auge la Inteligencia Artificial $(A I)$, el aprendizaje automático (machine learning), la internet de las cosas (IoT), impresión en 3D, la realidad virtual, mixta y aumentada, etc.

Por lo tanto, hay que ir más allá de digitalizar la educación para educar en la digitalización, ahí es donde entra en juego la innovación tecnológica y metodológica. Sin olvidar que la transformación digital afecta a todas las tareas que se realizan en la facultad y en el liderazgo y gestión del ecosistema humano que la conforma. Necesitamos, cada vez más, educar para una cultura digital, que es mucho más que usar tecnología para enseñar y aprender.

En este sentido hay que plantearse la formación que necesitan los maestros y profesores, que no son especialistas en el campo, para formar a sus futuros alumnos que cada día van a vivir y trabajar en un mundo cada vez más digital. Esto, somos conscientes, que depende en gran manera de la línea de pensamiento a la que pertenezcan los profesores de la facultad, como es usual en las ciencias sociales en contraposición con las ciencias de la naturaleza.

Bajo qué perspectivas se podría plantear esta formación en los currículos a impartir, p.e.:

a) Creando una especialidad propia.

b) Como técnicas y competencias transversales, presentes en todas las titulaciones y niveles que se impartan. Seguridad, protección de datos y derechos de propiedad intelectual.

c) Cómo ética que seguir con su uso.

d) Apostando por el conocimiento en abierto ${ }^{18}$.

e) Como razón de ser y soporte de competencias básicas a seguir y que se tratan en el último punto de este decálogo.

\footnotetext{
La transformación digital es la transformación profunda y acelerada de las actividades comerciales, los procesos, las competencias y los modelos para aprovechar plenamente los cambios y las oportunidades de las tecnologías digitales y sus repercusiones en toda la sociedad de manera estratégica y prioritaria”. Este es el cambio que se precisa en la educación.

https:/www.i-scoop.eu/digital-transformation/digitization-digitalization-digital-transformationdisruption/

$18 \mathrm{http}: / /$ latribucolaborativa.com/que-es-el-conocimiento-abierto/

https://www.uoc.edu/portal/es/coneixement-obert/index.html
} 
Por todo ello nos tendríamos que preguntar e intentar responder: ¿̨hay que comenzar dotando a las escuelas, institutos y colegios de pizarras electrónicas, tabletas y ordenadores?, en este sentido conviene leer el post de Enrique Dans ${ }^{19}$ ("Educación y transformación digital" ${ }^{20}$, junio 2018): "Aprender es aprender a buscar. Supone manejarse entre cantidades ilimitadas y crecientes de información, y ser capaz de identificarla, cualificarla, verificarla, descartarla cuando es mala, compartirla cuando es buena...", para lo que se necesitan excelentes profesores que nos guíen y que actúen como mentores. "El reto de la educación actual consiste en ser capaz de integrar los smartphones en la metodología educativa, educando en su uso, utilizándolos para acceder a recursos...”, teniendo en cuenta que prácticamente todos los alumnos tienen, e integrando a aquellos que no disponen de ellos.

Por otra parte, el COVID-19 ha puesto en evidencias deficiencias estructurales y de previsión, tanto en la educación como en la sanidad. Enrique Dans afirmaba en Educación 3.0 (18 junio 2020) ${ }^{21}$ : el fallo en esta crisis "No es un problema de profesores, ni de medios, salvo en aquellos casos en los que los protagonistas se encontraban en el lado del 'tener o no tener': ha sido un problema de actitudes, de incapacidad manifiesta para replantear la forma de enseñar. No, una clase online no se puede plantear como un: 'hago lo mismo, pero delante de la cámara', ni con un 'cuelgo unos materiales para que se los descarguen cuando les dé la gana', ni menos aún como un 'envío deberes por correo electrónico'. Hay que hacer mucho más, y mucho mejor”.

El debate no está en contraponer educación presencial vs. educación no presencial; está en educación de calidad y con propósito o no. Es cierto que según la edad y circunstancias de los alumnos es mejor una que la otra y viceversa; en alumnado de infantil y primaria no cabe plantearse la alternativa; en las otras depende, es más factible en alumnado más maduro y ya formado. Lo cierto, también, es que caminamos hacia un aprendizaje, que a partir de ciertos niveles y circunstancias, será cada vez más un modelo híbrido (blended learning), exista o no exista pandemia o situaciones de crisis; hay que tener en

19 Enrique Dans es Profesor de Innovación en IE Business School desde el año 1990. Tras licenciarse en Ciencias Biológicas por la Universidad de Santiago de Compostela, cursó un MBA en el Instituto de Empresa, se doctoró (Ph.D.) entre 1996 y 2000 en Sistemas de Información en UCLA, y desarrolló estudios postdoctorales en Harvard Business School.

20 https://www.enriquedans.com/wp-content/uploads/2018/06/Educacion-y-transformaciondigital-CONVIVES.pdf

21 https://www.educaciontrespuntocero.com/entrevistas/enrique-dans-sistema-educativo/ 
cuenta, además, que existen distintos modelos de enseñanza $\&$ aprendizaje con presencia no física en el campus.

El blog de nuestro maestro en la UBC Tony Bates, después colaborador de investigación en la UOC durante nuestra estancia en la misma, nos cita un caso (4 diciembre 2020), que se podría aplicar a una facultad de educación, como caso piloto de una universidad: "How a small university successfully pivoted online"22.

\section{LA IMPORTANCIA DE LAS HUMANIDADES}

Lo digital no va solo de tecnología, que también. En el centro de toda transformación están las personas y la misma debe ser para éstas, para que puedan desarrollar su propósito de vida, sin que nadie se queda atrás. Las humanidades, incluyendo la filosofía, forman personas; "el alcance de la transformación digital supone una verdadera crisis cultural de la que ha de salir —-más configurada - una cultura digital. En ella, son imprescindibles las miradas humanistas para resituarnos en el mundo" (Enrique Villalba, febrero 2020) ${ }^{23}$.

"Cualquier reflexión en torno a los estudios humanísticos debe serlo también acerca de la finalidad y el modelo de enseñanza que necesitamos. Una Universidad que no solo se aleja de su misión y visión originales, sino que reacciona dudosamente ante las necesidades y oportunidades del mundo digital. Ese modelo de Universidad tiene su mayor amenaza en haber hecho suyos los intereses de un mercado al que puede estar empezando a resultar más práctico prescindir de ella, al menos de la exclusividad de la que gozaba hasta hace poco. Desde su origen medieval, era el monopolio de la expedición de títulos académicos lo que, en último término, constituía una Universidad: la capacidad de otorgar grados, a diferencia de otras instituciones formativas. Ahora empezamos a comprobar cómo, por una parte, la certificación de estudios puede ser razón insuficiente para mantener la exclusiva universitaria y, por otra, otros centros - por ejemplo, creados por empresas- comienzan a ofrecer formación y títulos socialmente reconocidos en un mercado en el que las universidades aceptaron colocar su mercancía y en el que, en consecuencia, ahora han de competir".

22 https://www.tonybates.ca/2020/12/04/how-a-small-university-successfully-pivoted-online/ https://www.tonybates.ca/wp-content/uploads/ALGOMA-UNIVERSITYS-RAPID-ANDSUCCESSFUL-PIVOT-TO-ONLINE-LEARNING-IN-RECORD-TIME-IN-PARTNERSHIP-WITH-CONTACT-NORTH-I-CONTACT-NORD.pdf

23 Director del Instituto de Cultura y Tecnología. Universidad Carlos III de Madrid. https://ethic.es/2020/02/humanidades-en-un-mundo-digital/ 
"No se trata de enrocarse — sigue diciendo E. Villalba — en esa idea monopolística sino de resaltar lo que puede ser diferencial en las enseñanzas universitarias, en un mundo digital, en constante cambio, que precisa una formación continua no solo para el empleo sino para una vida activa que se prolonga mucho más allá de la meramente profesional. Las Humanidades no buscan formar trabajadores (profesionalizantes) para el sistema económico sino personas; y tampoco consideran el conocimiento como algo finalista".

Es difícil y valiente, en estos momentos, de crisis, de desempleo, de angustia ante lo desconocido pensar de esta manera, aunque la sociedad actual necesita de miradas humanistas para resituarnos en el mundo; hay que entender — como ocurrió en el Renacimiento- el lugar que la persona ocupa en el mismo, es decir la cultura. Para ello necesitamos humanistas de la época digital. Por ello, el profundo sentido de las palabras de Emilio Lledó, en su entrevista del 3 septiembre 2020, que nos decía: "La esencia de la educación es mostrar el mundo como posibilidad" 24 , como desarrolla en su libro "Sobre la educación. La necesidad de la Literatura y la vigencia de la Filosofía" (2018. Penguin Random House, Grupo Editorial).

Creemos que se debería permitir a los alumnos de cualquier titulación poder estudiar asignaturas de sustrato cultural para la completitud de su formación académica, sobre todo en una época en la que la automatización de tareas mediante "robots inteligentes" va a más, y no sabemos cuál será el futuro de las profesiones (y del empleo) para las que estamos formando a nuestros jóvenes. Nosotros, los humanos, estamos también cambiando con el mundo que nos rodea y queremos buscar nuestro sitio en el, para lo cual hay que aprender a mirar, ver e interpretar sin olvidar las raíces de cada quién. En este sentido hay que resaltar el papel que está desempeńando el Foro de Humanismo Tecnológico de $\mathrm{ESADE}^{25}$, que analiza las proyecciones futuras de la inteligencia artificial y el papel de la cultura para reducir sus desigualdades automatizadas (conversaciones sobre proyecciones futuras de la inteligencia artificial) ${ }^{26}$.

Los maestros y profesores necesitan, para inculcar en sus futuros alumnos, una formación y compromiso con el humanismo tecnológico, cuyo punto de partida debe ser "la defensa de un horizonte ético fundado en la dignidad hu-

24 https://www.bbva.com/es/podcast-emilio-lledo-filosofo-y-profesor-la-esencia-de-la-educaciones-mostrar-el-mundo-como-posibilidad/

25 https://www.esade.edu/es/profesorado-investigacion/investigacion/unidades-conocimiento/forohumanismo-tecnologico

26 https://ethic.es/2020/12/foro-esade-el-tango-inteligencia-artificial-humanidades/ 
mana." ("Humanismo tecnológico o deshumanización". José Ma Lasalle, ESADE, 25 septiembre 2020 ${ }^{27}$.

\section{LOS NIÑOS Y LOS JÓVENES, ¿SON REALMENTE "NATIVOS DIGI- TALES"?}

Debemos ser conscientes si los niños, infantil y primaria, son realmente "nativos digitales" y, en su caso, el significado y alcance de esta expresión. La misma fue acuñada por Marc Prensky en 200128. "Con nativos digitales se refería a un nuevo tipo de estudiante que iba apareciendo en las instituciones educativas que en lugar de imprimir un documento para revisarlo lo anotaba en una pantalla y para el que imprimir un correo electrónico para quedarse con una copia en papel era algo impensable. Usaba la expresión para diferenciarlos de aquellas personas a las que denominaba inmigrantes digitales, que, por el contrario, eran perfectamente capaces de imprimir un correo y que, por norma general, solían corregir las cosas en papel y no en la pantalla”. Con el tiempo, la expresión nativo digital se ha ido desvirtuando, ha perdido ese significado y ahora se usa para denominar a aquellos nacidos a partir de un momento indeterminado, probablemente a mediados de los noventa del siglo pasado, quienes, supuestamente acostumbrados a la presencia de ordenadores y otros dispositivos digitales en sus vidas, no necesitan que nadie les enseñe a utilizarlos. Un grupo de personas, de perfiles diversos, escribieron en 2017 un libro: "Los nativos digitales no existen. Cómo educar a tus hijos para un mundo digital" 29 preocupados, como otras muchas personas, por considerar que esta creencia era un error de bulto que ya estaba, y lo estará cada vez más, ocasionando graves problemas.

Esta consideración es especialmente importante para las facultades de educación, para los maestros y profesores actuales y futuros y, también, para los padres.

El índice de este, escrito por Enrique Dans, resalta una serie de recomendaciones muy pertinentes. "Los jóvenes parecen abandonar muchas de las herramientas sociales y refugiarse en la simple mensajería instantánea, en una

27 https://dobetter.esade.edu/es/humanismo-tecnologico

28 https://marcprensky.com/writing/Prensky\%20-\%20Digital\%20Natives,\%20Digital\%20Immigrants $\% 20-\% 20$ Part1.pdf

29 https://www.amazon.es/Los-nativos-digitales-existen-colecci\%C3\%B3n/dp/8423426599/ref= sr_1_1?_mk_es_ES=\%C3\%85M\%C3\%85\%C5\%BD\%C3\%95\%C3\%91\&dchild=1\&keywords=los+nativos+digitales + no + existen $\&$ qid $=1607512168 \& s r=8-1$ 
comunicación extremadamente poco sofisticada". "Salvo casos excepcionales, se tratan de generaciones que se limitan a utilizar aplicaciones que les vienen dadas, e incluso de usuarios simplistas, que usan un número muy limitado de herramientas para muy pocas funciones". En general utilizan sus smartphones simplemente para jugar a juegos triviales, para escribir mensajes, para compartir video y fotografías, para descargar y escuchar música, ... y para muy poco más; de pensamiento computacional, programación y codificación presentan una ignorancia y un rechazo cada vez mayor.

"Llevados por el irracional optimismo de creer que por nacer en un año determinado los niños sufrían algún tipo de modificación genética, que les llevaba a relacionarse mejor con la tecnología, muchos padres (maestros y profesores) abandonaron su deber de educarlos". "El absurdo tópico propagado por algunos irresponsables que decía aquello de "¿qué les voy a contar si saben más que yo?» se impuso a la evidencia de que, por mucho que tecleasen rápido o entendiesen mejor algunas interfaces gracias a no tener que "desaprender» las anteriores, había una serie de carencias importantes que era preciso cubrir". Algunos padres, creyendo que sus hijos les aventajaban, decidieron hacer una "autentica dejación de responsabilidad". Es una situación que hay que revertir, comenzando por los padres y las propias facultades de educación, en su formación inicial y continua.

Para conocer la situación en cada territorio es conveniente realizar un estudio de campo ${ }^{30}$ como el llevado a cabo por la Universidad Pompeu Fabra (Barcelona) dentro de un proyecto europeo Horizonte 2020: Transmedia Literacy research project $t^{31}$ La síntesis del mismo es: No hay nativos digitales, los jóvenes adquieren sus habilidades digitales a través del aprendizaje informal; la aportación no es que se trata de una obviedad, sino que lo han demostrado con datos. La conclusión es preocupante, ya que se trata de un artículo publicado en julio 2019.

30 MASANET, M.-J.; GUERRERO-PICO, M.; ESTABLÉS, M.-J. (2019). From Digital Native to Digital Apprentice. A Case Study of the Transmedia Skills and Informal Learning Strategies of Adolescents in Spain. Learning Media And Technology. vol. 44, núm. 4, 400-413.

DOI: 10.1080/17439884.2019.1641513 Se trata de un artículo de pago.

Se puede acceder a unas notas en:

https://www.upf.edu/en/web/e-noticies/assetlang/-/asset_publisher/s63mYpRtW3TT/content/ $\mathrm{id} / 227401488 \#$. X9C5Iun7RBw

31 https://transmedialiteracy.org/ 
Por ello se consideran tres grupos de "nińos digitales ${ }^{32}$ :

\section{Huérfanos digitales.}

Han crecido con una gran cantidad de acceso a la tecnología, pero muy poca guía.

\section{Exiliados digitales.}

Han sido criados con la mínima tecnología.

\section{Herederos digitales.}

Tienen impresionantes habilidades tecnológicas, gracias en gran parte a sus padres y profesores.

Con notables diferencias entre unos y otros. Sobre los tres grupos hay que actuar para cerrar la brecha digital y tener una verdadera igualdad de oportunidades.

Estos aspectos de la educación para un mundo cada vez más digital, muy pocas veces considerados, se complementan (suponemos que entre otros muchos más) con la visión de Xabier Echeverria Ezponda ${ }^{33}$, matemático y filósofo, investigador de Ikerbasque. En 1999 profetizó los riesgos del mundo que se estaba construyendo en internet y que bautizó como Tercer Entorno. Su tesis, de plena actualidad, habla de «la poca conciencia de las condiciones reales» de uso de las tecnologías, del «sometimiento» a las reglas de juego impuestas por las grandes empresas como Facebook o Google y de un sistema "neofeudal» que reivindica democratizar.

\section{CINCO COMPETENCIAS A CONSIDERAR}

Es difícil darle este título al último punto del decálogo, aunque la realidad es que lo hemos ido precisando a partir de uno más ambicioso que pensamos. Seguro que cada educador, padres, instituciones, familias, académicos, etc. tienen las suyas propias, tan válidas o más que las cinco que proponemos. Se trata de establecer para qué se consideran relevantes, lo son: desde la perspectiva y orientación de esta aportación de unos compañeros al reconocimiento académico de Emy; la convicción de que quizá son algunas en las que no se depara lo suficiente y, sobre todo, no se llevan a la práctica; que son transversales para todas las ramas del saber y del hacer; son pilares que cimientan otras que se re-

32 https://puentesdigitales.com/2017/06/22/los-nativos-digitales-no-existen-estos-son-los-3-tiposde-ninos-digitales/

33 https://www.youtube.com/watch?v=_iCZ63jpacI 
fuerzan a partir de las mismas; que se necesitan desde la escuela, en un proceso de desarrollo a lo largo de la vida, etc.; y, finalmente, por que creemos en ellas para el desarrollo integral de la persona. Es una reflexión que añadir a la que pueda hacer cada lectora o lector.

Las nuestra, sin que el orden signifique prioridad, son:

a) Pensamiento crítico.

b) Pensamiento creativo.

c) Pensamiento computacional.

d) Humanismo tecnológico.

e) Cultura digital.

En los puntos anteriores de este decálogo se han tratado, sobre todo, los dos últimos; por ello nos centramos sintéticamente en los tres primeros.

\section{Pensamiento crítico ${ }^{34}$}

Sugerimos como introducción al mismo, el artículo de la Stanford Encyclopedia of Phylosophy ${ }^{35}$; su alcance excede al contexto académico y el empirismo (experiencia y evidencia), sobre todo en esta época de información masiva y de fake news, cada vez más frecuentes.

Si queremos una definición propondríamos la del APA Delphi Project Report: "Critical Thinking: A Statement of Ex-pert Consensus for Purposes of Educational Assessment and Instruction" (P.A. Faccione, 1990) ${ }^{36}$ : En el mismo, los expertos en el tema llegan a un consenso acerca de lo que es esta competencia:

"Proceso de juicio reflexivo que se manifiesta en la consideración razonada de las pruebas, el contexto, los métodos, las normas y las conceptualizaciones con el fin de decidir qué creer o qué hacer”.

Esta competencia adquiere más relevancia en una época del Big Data para la toma de decisiones. Se trata de una competencia que los niños pueden comenzar a adquirir en la escuela a partir de primaria.

\footnotetext{
34 https://www.criticalthinking.org/resources/PDF/SP-Comp_Standards.pdf

$35 \mathrm{https} / / /$ plato.stanford.edu/entries/critical-thinking/

https://www.edx.org/course/thinking-critically-series-interpreting-screening-trials

https://philosophy.hku.hk/think/critical/ct.php

36 https://www.researchgate.net/publication/269738688_Critical_Thinking_for_Life
} 


\section{Pensamiento creativo}

Concepto que excede a la escuela, para ser una de las bases del nuevo desarrollo, basado en la creatividad, la innovación y el emprendimiento.

"Se trata de una forma de ver los problemas o situaciones desde una perspectiva fresca que sugiere soluciones poco ortodoxas (que pueden parecer inquietantes al principio). El pensamiento creativo puede ser estimulado tanto por un proceso no estructurado, como la lluvia de ideas, como por un proceso estructurado, como el pensamiento lateral" ${ }^{37}$.

El pensamiento creativo se refiere al uso de habilidades y destrezas "blandas" (transversales) para encontrar nuevas soluciones a los problemas. Las habilidades de pensamiento creativo son técnicas utilizadas para mirar el tema desde ángulos diferentes y creativos, utilizando las herramientas adecuadas para evaluarlo y desarrollar un plan ${ }^{38}$.

"La creatividad es la capacidad de hacer o hacer algo nuevo que también es útil o valorado por otros (Gardner, 1993). El "algo" puede ser un objeto (como un ensayo o una pintura), una habilidad (como tocar un instrumento), o una acción (como usar una herramienta familiar de una manera nueva). Para ser creativo, el objeto, la habilidad o la acción no puede ser simplemente extraño o raro; no puede ser nuevo sin ser también útil o valorado, y no ser simplemente el resultado de un accidente. Si una persona escribe letras al azar que forman un poema por casualidad, el resultado puede ser hermoso, pero no sería creativo según la definición anterior. Visto de esta manera, la creatividad incluye una amplia gama de experiencias humanas que muchas personas, si no todas, han tenido en algún momento (Kaufman \& Baer, 2006). La experiencia no se limita a unos pocos genios, ni es exclusiva de campos o actividades específicas como el arte o la composición de música" ${ }^{39}$.

Al considerar la creatividad en la escuela hay que considerar el "polémico" video TED de Ken Robinson (2006) ${ }^{40}$, uno de los más reproducidos de la historia: Do schools kill creativity?, con más de 68 millones de visualizaciones.

37 https://www.skillsyouneed.com/ps/creative-thinking.html

38 https://en.rockcontent.com/blog/creative-thinking-skills/

39 https://courses.lumenlearning.com/atd-hostos-childdevelopment/chapter/creativethinking/\#: : :text=Creativity\%20is\%20the\%20ability\%20to,others\%20(Gardner\%2C\%201993) 40 https://www.ted.com/talks/sir_ken_robinson_do_schools_kill_creativity/transcript 


\section{Pensamiento computacional}

Se trata de una competencia muy cercana a dos de las autoras de este trabajo. En 2017 dirigieron una tesis en la ULPGC a un alumno del Máster de Formación del. Profesorado, titulado en Ingeniería informática, Kilian González, "Aprendizaje de competencias para el siglo XXI, mediante el desarrollo del pensamiento computacional, en alumnos de primaria: un caso piloto en Canarias" 41 .

En las conclusiones de la misma se decía, entre otras cosas: El pensamiento computacional es una forma de pensar (como hacen los humanos) $\mathrm{y}$, como consecuencia, es independiente de la tecnología. Es una metodología específica para resolver problemas, que implica el uso de habilidades diferentes; que permite encontrar soluciones, bien mediante la ejecución de dichas habilidades por un computador, por una persona, o por la combinación colaborativa de ambos. Las habilidades que más a menudo se citan relacionadas con la misma son: abstracción, pensamiento algorítmico, automatización, descomposición, depuración y generalización. El pensamiento computacional no es lo mismo que programar o codificar. Implica enseñar a pensar, a abordar problemas y resolverlos, y comenzar a adquirir metacognición, que es básica para aprender a aprender.

\section{EPÍlOGO}

Estamos convencidos que tenemos y formaremos excelentes maestros: formarlos - identificarlos - conectarlos - impulsarlos - reconocerlos. Como recientemente decía el Dr. Manuel Lobo Cabrera: "Ningún sistema educativo será de calidad superior a la calidad de sus maestros", y si están interconectados todavía más.

41 https://www.coursehero.com/file/57942893/aprendizaje-de-competencias-del-siglo-XX1pdf/, dirigida por la Dra. Ma Esther Pérez Martell y la Dra. Ma Olga Escandell Bermúdez. 


\title{
LO QUE APROXIMA A LA ENFERMEDAD: LOS FACTORES DE RIESGO
}

\author{
Antonio S. Ramos Gordillo \\ Médico especialista en Medicina de la Educación Física y el Deporte \\ Universidad de Las Palmas de Gran Canaria. \\ Marta Ramos Sosa \\ Médico especialista en Medicina Familiar y Comunitaria \\ Hospital Universitario de Canarias (La Laguna) \\ Claudia Ramos Sosa \\ MIR en Medicina Familiar y Comunitaria \\ Servicio Canario de la Salud
}

A la Profesora Doña Emigdia Repetto Jiménez, en el recuerdo siempre.

En los últimos años se han realizado numerosos estudios epidemiológicos que han logrado identificar toda una serie de factores asociados a una mayor incidencia de las enfermedades, con especial relevancia a nivel coronario, no en vano es la primera causa de muerte en nuestro país. Esto ha permitido conocer mejor su origen y fisiopatología y ha servido de base para la realización de campañas de prevención con la consiguiente disminución de la incidencia de la enfermedad.

El término factor de riesgo podemos definirlo como aquélla variable o característica, innata o adquirida, que se asocia con una mayor probabilidad de padecer una determinada enfermedad. Con los avances producidos en el área de la epidemiología que han permitido realizar estudios clínicos en grandes poblaciones y cuyo precursor fue el estudio Framingham, se ha podido identificar una serie de factores de riesgo para la enfermedad cardiovascular que actúan como inductores de la formación de la placa de ateroma como son la diabetes, la hipertensión, el tabaquismo y las dislipemias. Sin embargo, la investigación experimental también ha permitido conocer factores como las alteraciones en el metabolismo del fibirinógeno o en las endotelinas (proteínas de la membrana de la pared plaquetaria) que igualmente favorecen la aparición de la placa de ateroma.

El conocimiento de los factores de riesgo cardiovasculares reviste una gran importancia en la medida en que actúan como potenciadores de la principal causa de muerte en los países desarrollados, máxime si tenemos en cuenta que muchos de ellos son modificables o evitables. Es por ello por lo que los programas 
de intervención en los grandes estudios epidemiológicos van a permitir conocer la magnitud de la asociación entre estos factores de riesgo y la enfermedad coronaria y cerebro-vascular y medir su impacto sobre las tasas de morbi-mortalidad.

Se sabe que la incidencia de cardiopatía isquémica aumenta con la edad y que afecta en mayor grado al sexo masculino, siendo máxima entre los 50 y los 65 ańos y excepcional antes de los 35, de manera que en el grupo de edad inferior a 45 ańos, es diez veces más frecuente en los varones; entre los 45 y los 60 años, es dos veces más frecuente y en edades superiores, tienden a igualarse en los dos sexos. Entre los factores de riesgo más importantes se encuentran:

- Tabaquismo: múltiples estudios epidemiológicos han demostrado claramente que el consumo de cigarrillos aumenta el riesgo de padecer cáncer de pulmón, enfermedad vascular periférica, infarto de miocardio y muerte súbita. Dicho riesgo guarda relación con el número de cigarrillos consumidos, la precocidad del hábito y el tipo de tabaco, siendo inferior entre los fumadores de pipa y de habanos.

El principal mecanismo a través del cual el tabaco favorece la aterogénesis consiste en la lesión del endotelio debido al monóxido de carbono circulante. Añadir que cuando se abandona este hábito el riesgo de padecer enfermedad coronaria decrece hasta un 50\% durante el primer año y se aproxima al nivel de los no fumadores al cabo de 2-10 años.

- Hipertensión Arterial: las cifras de presión arterial, tanto sistólicas como diastólicas, se correlacionan con la incidencia de enfermedad coronaria y de accidentes vasculares cerebrales actuando, al parecer, a través de una lesión de la pared arterial que favorece su permeabilidad a los lípidos. El riesgo aumenta de forma continua a lo largo del rango de presiones, de forma que los individuos con hipertensión arterial límite presentan un riesgo algo superior al de los normotensos. No obstante, algunos estudios recientes con tratamientos antihipertensivos han mostrado una reducción en la incidencia de accidentes coronarios, enfermedad cerebro-vascular e insuficiencia cardiaca.

- Hiperlipemia: la correlación entre el colesterol sérico y la incidencia de cardiopatía coronaria es evidente a partir de los estudios epidemiológicos y de ciertas investigaciones experimentales que demuestran la posibilidad de provocar arterosclerosis en algunas especies animales aumentando el contenido en grasa de la dieta.

El valor predictivo del colesterol desaparece con la edad y es escaso con cifras inferiores a $220 \mathrm{mg} / \mathrm{dL}$, aunque actualmente se recomienda la cifra de $200 \mathrm{mg} / \mathrm{dL}$ como límite superior de la normalidad. Por el contrario, 
existe una buena correlación entre el colesterol de las lipoproteínas de baja densidad (LDL) y la incidencia de coronariopatías, así como una relación inversa entre éstas y las lipoproteínas de alta densidad (HDL) que se mantiene independientemente de la edad. Así pues, la reducción de la proporción de grasas saturadas de la dieta parece ser aconsejable en individuos con cifras superiores de $220 \mathrm{mg} / \mathrm{dL}$.

Esos tres factores que acabamos de citar (tabaco, hipertensión y dislipemia) contribuyen de forma independiente al riesgo de presentar enfermedad coronaria y el aumento moderado de dos de ellos implica un riesgo similar al de una hipercolesterolemia o una hipertensión arterial graves y dado que en la práctica diaria son más frecuentes los aumentos moderados, deberemos actuar sobre ellos si deseamos reducir la incidencia de infarto de miocardio y, en general, de enfermedad coronaria.

- Diabetes: la incidencia de enfermedad coronaria es más elevada en diabéticos y en pacientes con una curva de glucemia (prueba de tolerancia a la glucosa) anormal. Así, en las mujeres, la diabetes triplica la incidencia de cardiopatías coronarias y se iguala al de los varones no diabéticos. Esta enfermedad determina una elevación de los lípidos sanguíneos y una mayor concentración de glucosaminoglicanos en la íntima arterial. La hiperglucemia contribuye de forma independiente al riesgo y sus efectos se suman a los de los otros factores de riesgo, lo que obliga a corregirlos con energía en cualquier paciente diabético.

- Obesidad: aunque la asociación, especialmente antes de los 50 años, entre obesidad y enfermedad coronaria parece clara, se duda que el exceso de peso constituya un factor de riesgo independiente y probablemente este aumento del riesgo deba a factores como la hipertensión y la dislipemia que con frecuencia acompañan al exceso de peso, aunque todo ello no niega la importancia de corregir la obesidad en pacientes coronarios.

- Sedentarismo: existen evidencias científicas de que la práctica de ejercicio físico moderado ejerce cierto efecto protector ya que el eleva las HDL, cuyos niveles se correlacionan de forma inversa con la incidencia de enfermedad coronaria, de igual forma que se considera que una vida sedentaria es un factor de riesgo coronario independiente. Sin embargo, los estudios son contradictorios ya que el sedentarismo se asocia con la obesidad, la dislipemia y el tabaquismo, lo que impide conocer la contribución de cada uno de ellos al riesgo. De cualquier forma, lo que sí es cierto es que el ejercicio moderado constituye una medida aconsejable y contribuye a un mejor control de los factores anteriormente citados. 
- Predisposición Familiar: la enfermedad se presenta con mayor frecuencia en familias cuyos miembros se ven afectados incluso durante la juventud. Los factores genéticos y familiares pueden actuar a través de factores de riesgo como la diabetes, incidencia familiar de hipertensión arterial o hiperlipemia familiar. No obstante, es posible que exista una predisposición hereditaria independiente de estos factores.

- Patrón de Conducta: durante los últimos diez años se ha venido especulando sobre la posibilidad de que los enfermos coronarios presenten ciertos rasgos de conducta particulares. En este sentido y aunque su importancia aún está en discusión, Friedman \& Roseman denominan como patrón tipo $A$ y les atribuyen la naturaleza de factor de riesgo coronario a los sujetos que presentan un mayor grado de hostilidad, competitividad, agresividad y sentido de urgencia del tiempo.

- Otros factores de riesgo: además de los ya mencionados, se han descrito otros muchos factores cuya asociación con la enfermedad coronaria no se ha visto aún confirmada o bien son todavía motivo de discusión. Así, por ejemplo, se ha señalado que la hiperuricemia, el consumo de azúcar refinado, el alcohol y el café, el estrés y la escasa dureza del agua podrían aumentar la probabilidad de padecer cardiopatía isquémica. En cualquier caso, su importancia sería más bien relativa e incomparablemente menor que la de la hipertensión, el tabaco y la dislipemia.

En nuestros días la esperanza de vida varía de forma considerable en los distintos entornos socioeconómicos, a pesar de que en todos ellos existe una clara tendencia a que estos valores se incrementen, existiendo una gran diferencia (hasta tres veces más) desde principios del siglo XX hasta la actualidad. Los avances científicos, tecnológicos y, especialmente, los descubrimientos en medicina, farmacología, nutrición y el apoyo psicológico, son la pieza clave en esta evolución que puede considerarse como un importante logro social.

Nadie pone en duda que la práctica de cualquier actividad física o deportiva afecta de una forma u otra a la mejora de los niveles y a las expectativas de vida que ello le puede aportar, de ahí que el interés tanto de instituciones como de investigadores sobre los aspectos relacionados con la actividad física y la salud haya crecido exponencialmente en las últimas décadas y aunque en un principio se centraban más en aspectos médicos (enfermedades cardiovasculares, diabetes, cáncer, osteoporosis, obesidad, hipertensión, incapacidades funcionales y motoras, mortalidad, etc.), recientemente el campo de estudio se ha ampliado hacia aspectos relacionados con la salud y la calidad de vida. El ejercicio físico 
adquiere así un cariz que podemos diferenciar, de forma especial, en su función esencial como función preventiva.

Hoy día todo el mundo parece aceptar el hecho de que la actividad física puede llegar a paliar parte importante de los efectos negativos que otros hábitos tienen para la salud o, en su defecto, le otorgan una función importante en relación con patologías propias de la vida moderna. Así, entre las múltiples incidencias positivas que el ejercicio físico produce en el organismo podemos afirmar que previene contra el envejecimiento mejorando las condiciones hemodinámicas y coronarias (Kanstrup \& Ekblom, 1978; Hollmann, 1988 y Martí et al., 1989), disminuye la tensión arterial (Boyer et al., 1970), previene la hiperlipemia y la arterioesclerosis (Ledoux, 1989), permite mantener un tono muscular adecuado (Orlander et al., 1978 y Orlander \& Aninansson, 1980) y favorece la movilidad articular (Garros et al., 1989).

\section{EL EJERCICIO FÍSICO: SUS EFECTOS SOBRE EL APARATO CIRCU- LATORIO}

Actualmente las enfermedades relacionadas con el aparato circulatorio son la principal causa de mortalidad (entre el 30 y el 50\%) de cualquier país desarrollado y el nuestro no es ajeno a ello. Así, según datos del INE (2019) durante 1985 el grupo de enfermedades del sistema circulatorio alcanzaron el $44,75 \%$ de las causas de muerte (39,27\% en hombres y $50,88 \%$ en mujeres), siendo la primera causa de muerte y en el año 2018 volvió a ser la primera causa de muerte con el $28,3 \%$, ocupando la primera causa de mortalidad femenina $(272,5$ muertes por cada 100.000$)$ y la segunda entre los varones (244,3 muertes por cada 100.000).

Bajo el término enfermedad coronaria se incluye todo el conjunto de procesos que afectan al corazón y los vasos, es decir, enfermedades coronarias de las válvulas, del músculo cardiaco, del pericardio, hipertensión, etc., y como acabamos de comentar, en España, al igual que ocurre en el resto de países de nuestro entorno, representa un problema de salud bastante importante si bien, comparativamente con países como Dinamarca, Finlandia, Escocia o Inglaterra e incluso de los EE.U., tenemos una incidencia ostensiblemente menor de este tipo de procesos.

La Behavioral Risk Factor Surveillance System (BRFSS) considera que una persona con estilo de vida sedentario es aquella que realiza una actividad física inferior a los 20 minutos tres veces a la semana y se considera activa cuando supera los 150 minutos de ejercicios semanales (OMS). La mayoría de los estudios epidemiológicos existentes coinciden en señalar que las causas desenca- 
denantes de estas enfermedades suelen ser en su gran mayoría de tipo exógeno, encontrándose entre las mismas las relacionadas con los hábitos propios de la vida sedentaria (tabaquismo, alimentación, obesidad y sedentarismo).

\section{PRINCIPALES FACTORES DE RIESGO DE LA ENFERMEDAD CARDIO- VASCULAR}

Según Haskell (1996), Bogaard et al. (1997) y Hurley \& Hagberg (1998), los principales factores de riesgo de la enfermedad cardiovascular son:

- Bajo nivel de forma cardiovascular.

- Perfil anormal de lipoproteínas-lipidos en plasma.

- Intolerancia a la glucosa y resistencia a la insulina.

- Hipertensión.

- Hipertrofia ventricular izquierda.

- Obesidad abdominal.

Serra (1997) nos recuerda la relación directa existente entre el nivel de actividad física y el riesgo de desarrollar una enfermedad coronaria y diversos autores se pronuncian en un sentido similar (Kramshed et al., 1981; Jenninngs et al., 1986; Powell et al., 1987; Tell \& Veller, 1988; Donahue et al., 1988 y Fortmann et al., 1988).

Las enfermedades isquémicas del corazón originaron en España alrededor del $25 \%$ de las muertes por enfermedades del aparato cardiocirculatorio, valor similar al de la mayoría de los países del área mediterránea europea (Grecia, Francia e Italia) pero claramente inferior a los valores que se observan en Centroeuropa, países nórdicos o Norteamérica, lo cuales se sitúan entre el 40 y el 60\%. Según Kannel et al. (1985), marcadores fisiológicos como el sobrepeso ( $>12 \%$ del peso corporal), la taquicardia en reposo ( $>85$ latidos por minuto) y la baja capacidad vital (<3.0 litros en hombres y 2.0 en mujeres), son indiciadores de elevado riesgo de problemas cardiovasculares.

Por otra parte, los estudios nos demuestran que las enfermedades isquémicas del corazón, a pesar de que a estas edades es cuando más se incrementa la tasa de mortalidad por esta causa, no afectan casualmente a las personas a medida que estas envejecen, sino que factores como la mala alimentación, el hábito de fumar, el abuso de alcohol, la hipercolesterolemia, la hipertensión arterial, la diabetes, la obesidad y la falta de ejercicio, incrementan el riesgo de padecer este tipo de patología. A este respecto y a modo de ejemplo podemos afirmar que los sujetos hipertensos que practican de forma habitual algún tipo de actividad física presentan la mitad de mortalidad que los hipertensos no practicantes. 
Dado que un ataque cardiaco es una disfunción entre el suplemento de oxígeno al miocardio y la demanda existente, Haskell (1979) trató de determinar la forma en que el ejercicio físico actuaba sobre alguno de estos parámetros, encontrando que una práctica moderada y adecuada afectaba favorablemente en la prevención de procesos arterioescleróticos a la vez que el flujo coronario de sangre se incrementaba vía aumento de la capilarización o diámetro arterial. Otros estudios como los de Paffenbarger et al. (1983), Blair et al. (1984, 1989, 1991 y 1992), Blair \& Kohl (1988) y Duncan et al. (1985), también mantienen la tesis sobre la relación entre los beneficios de la práctica de una actividad física moderada y el riesgo de enfermedades cardiovasculares.

El Estudio Británico del Corazón (citado por Blair, 1991), realizado sobre 7735 hombres de edades comprendidas entre 40 y 59 años demostró, en una investigación de carácter longitudinal de ocho años de seguimiento, que las tasas de mortalidad por ataques cardiacos disminuyen con la práctica de algún tipo de actividad física y estudios más recientes apoyan estas afirmaciones, todo lo cual no hace más que corroborar que la actividad física moderada reduce de forma considerable la probabilidad de desarrollar enfermedades coronarias, incluso la práctica de una actividad ligera como la marcha reporta considerables beneficios para salud cardiovascular (Rippe et al., 1988).

Tampoco podemos ignorar el hecho de que a determinadas edades el control por parte de especialistas adquiere una especial importancia. No en balde, las complicaciones cardiovasculares durante la práctica del tiempo libre han sido documentadas en varios trabajos. En este sentido, Haskell (1978) al estudiar 30 programas de rehabilitación desarrollados en los Estados Unidos entre 1960 y 1976 destacó un total de 14 defunciones y 47 casos de complicaciones durante la práctica de la actividad física, lo que supone un caso por cada 26715 horas de ejercitación (un caso de muerte por cada 212812 horas) y si añadimos que gran parte de los sujetos adultos que se someten a ejercicio físico regular lo hacen después de una iniciación tardía, los riesgos son mucho mayores e incluso la realización en laboratorio de pruebas de esfuerzo implica cierto nivel de riesgo que debe ser controlado, ya que las estadísticas nos dicen que se producen cuatro infartos, cinco ingresos y un fallecimiento por cada 10000 pruebas realizadas en el entorno médico. Así pues, la única forma de disminuir los riesgos pasa por la realización de un control médico previo o, en su defecto, por la elaboración de un test de identificación de riesgos potenciales que permitan desaconsejar la realización de la prueba en determinadas circunstancias.

No obstante, sorprendentemente, Sabolski et al. (1987) en un estudio longitudinal de cinco años de duración realizado con 2363 obreros de una fábrica 
en Bélgica con edades comprendidas entre los 40 y los 55 años, llegaron a la conclusión de que la actividad física no es, en sí misma, un protector contra las enfermedades del corazón, sino su nivel de condición física, aunque las conclusiones del trabajo resultan algo contradictorias ya que, si bien existe una estrecha relación entre los conceptos de condición física y actividad física, el hecho de que el estudio solamente contara con 23 casos de ataques cardiacos entre todos los sujetos de la muestra utilizada pone en duda estas conclusiones.

Paffenberger \& Hyde (1988) realizaron una investigación sobre 3686 sujetos del Puerto de San Francisco a lo largo de veintidós años (1951-1972) encontrando una relación inversa entre la existencia de trastornos cardiovasculares y la intensidad del trabajo en el ámbito laboral. Además, el nivel de ejercicio considerado como la intensidad de trabajo físico realizado en el ámbito laboral, fue mejor factor predictor de los trastornos cardiovasculares que los factores de riesgo citados anteriormente.

Por último, otro estudio realizado en Dinamarca por Hein et al. (1992) durante diecisiete años en una población de 4999 personas con edades comprendidas entre los 40 y 59 ańos, puso de manifiesto que en los hombres sedentarios no existe relación entre el nivel de condición física y la mortalidad por enfermedad cardiaca, pero que sí existe una relación inversa entre ambos factores en las personas físicamente activas, destacando el hecho de que en cada nivel de condición física de las personas activas la tasa de mortalidad es más baja que la de los sujetos inactivos del mismo nivel de condición física.

\section{REFERENCIAS BIBLIOGRÁFICAS}

Biddle, S. \& Mutrie, N. (1991): Psychology of Physical Activity and Exercise. Londres: Springer Verlag.

Blair, S.N.; Kohl, H.K.; Gordon, N.F. \& Paffenberger, R.S. (1992): "How much physical activity is good for health?". En Annual Review of Public Health (13) pp. 99-126.

Blair, S. (1992): “Actividad física, condición física y salud". En Actas del Comité Científico Olimpico. pp. 171-179.

Blair, S.N. (1996): "Physical activity, nutrition and chronic diseses". En Medicine and Science in sports and exercises. (28:3) pp. 335-349.

Blasco, T. (1994): Actividad física y salud. Barcelona: Ediciones Martínez Roca. Bouchard, C. \& Shephard, R. (1993): "Physical activity, fitness and health: The model and key concepts". En Bouchard, Shephard \& Stephen. (eds.): Physical activity, fitness and health: Consensus statement. Champaign, Ill. Human Kinetics. 
Brill, P.A.; Kohl, H.W. \& Blair, S.N. (1992): "Anxiety, depression, physical fitness and all-cause mortality in men". En Journal of Psychosomatic Research (36:3) pp. 267-273.

Corbella, E.; Cruz, J.; Edo, S. \& Moix, J. (1988): "Pautas de actividad física y salud en una muestra universitaria”. En Santacreu, J. (ed.): Modificación de Conducta y Psicología de la Salud. Valencia: Promolibro.

Delgado, M.F. (1999): Actividad fisica-Deportiva orientada a la salud. Granada: Univ. de Granada.

Dishman, R.K.; Sallis, J.F. \& Orenstein, D.R. (1985): "The determinants of physical activity and exercise". En Public Health Reports (100:2) pp. 158172.

Dubbert, P.M. (1992): "Exercise in Behavioral Medicine". En Journal of Consulting and Clinical Psychology (60:4) pp. 613-618.

Garcia Ferrando, M. (1986). Hábitos deportivos de los españoles. Sociología del comportamiento deportivo. Edit. ICEFD. Madrid.

Generalitat de Catalunya. (1991): Llibre blanc. Activitat fisica i promoció de la salut. Barcelona: Dep. de Sanitat i Seguretat Social.

Gobierno de Canarias (1999): Encuesta Nutricional Canaria, 1997-1998. Consejeria de Sanidad. Servicio Canario de Salud.

González, A. (1990): "Efectos psicológicos de la actividad física y deportiva". En Simposio Internacional Olimpico (El deporte para la salud de todos).

Haskell, W.L.; Montoye, H.J. \& Orenstein, D. (1985): "Physical activity and exercise to achieve health-related physical fitness components". En Public Health Reports (100:2) pp. 202-212.

INE. (2019): "Defunciones según la causa de muerte (año 2018)" Instituto Nacional de Estadística, 2019.

Karnoven, M.J. (1996): "Physical activity for a healthy life". En Research quaterly for and exercises and sports (june) pp. 213-215.

López, V.F.: (1998): "Exercise prescription and physical activity for heaalth". En Selección (7:3) pp. 138-151.

Lorant, J. (2002): “Los beneficios del ejercicio físico: ¿Mito o realidad?”. En Manidi, M. \& Dafflon-Arvanitou, I.: Actividad fisica y salud. Barcelona: Masson.

Mendoza, R.; Sagrera, M.R. \& Batista, J.M. (1994): Conductas de los escolares españoles relacionadas con la salud (1986-1990). Madrid: CSIC.

Montoye, H.J. (1992): “The Raymond Pearl Memorial Lecture 1991: Health, Exercise, and Athletics: A Millennium of observations; a century of research". En American Journal of Human Biology (4) pp. 69-82. 
Pastor, Y; Balaguer, I. \& Merita, M.L. (1995): "Dimensiones del estilo de vida relacionado con la salud en la adolescencia: Una revisión”. En Rev. de Psic. Gral. y Aplic. (51:3-4) pp. 469-483.

Powell, K.E.; Kreuter, M.W.; Stephens, T.; Marti, B. \& Heinemann, L. (1996): "Dimensiones de la promoción de la salud aplicadas a la actividad física". En Promoción de la salud. Una antología. Organización Panamericana de la Salud.

Ramos Gordillo, A.S. et al. (2011): "La práctica de ejercicio físico para la mejora de la calidad de vida”. En San Román Sánchez, D. y Ruiz Caballero, J.A.: Deporte y Corazón. Sevilla: Wanceulen Editorial S.L.

Ramos Gordillo, A.S. et al. (2011): "Factores de riesgo coronario". En San Román Sánchez, D. y Ruiz Caballero, J.A.: Deporte y Corazón. Sevilla: Wanceulen Editorial S.L.

Ramos Gordillo, A.S.; González Romero, F. y Talón Ramírez, J. (2005): Deporte y ciencia: la busqueda del rendimiento. Las Palmas de Gran Canaria: Escuela Canaria del Deporte. Dirección General de Deportes del Gobierno de Canarias.

Ramos Gordillo, A.S. (2003): Actividad física e higiene para la salud. Las Palmas de Gran Canaria: Universidad de Las Palmas de Gran Canaria.

Ramos Gordillo, A.S. et al. (1998): "Consideraciones médicas sobre el envejecimiento y el efecto de la actividad física en los mayores". En Navarro Valdivielso, M.: Actividades fisicas y deportivas para las personas mayores: Ejercicio Físico y Salud. Madrid: Gymnos.

Ramos Gordillo, A.S. et al. (2001): "Efectos saludables del ejercicio físico como consecuencia de su práctica deportiva”. En Ruiz Caballero, J.A: Medicina deportiva Madrid: Gymnos.

Rejeski, W.J. \& Thompson, A. (1993): "Historical and conceptual roots of Exercise Psychology”. En Seraganian (ed.): Exercise Psychology: The influence of Physical Exercise on Psychological Processes. Nueva York: John Wiley.

Rodríguez Marín, J. (1991): "Psicología de la Salud: Situación en la España actual". En Revista de Psicología de la Salud (3:1) pp. 55-91.

Romero, A.P. et al. (1997): "Modificaciones del metabolismo lipoproteico inducidas por la práctica de ejercicio físico". En Endocrinología (44:6).

Salleras Sanmartí, L. \& Serra Majem, L. (1992): "Actividad física y salud". En Piedrola Gil, G. et al. (eds.): Medicina Preventiva y Salud Pública. Barcelona: Salvat Editores S.A.

Serra Grima, J.R. (1996): Prescripción de ejercicio físico para la salud. Barcelona: Paidotribo. 
Serra, Ll.; De Cambra, S.; Vallbona, C.; Tresseras, R.; Salto, E. \& Taberner, JL. et al. (1993): "Actividat física". En Salut Catalunya (7:2) 94-101.

Shephard, R.J. (1994): "Physical activity and reduction of health risks: How far are the benefits independent of fat loss?". En Journal Sports Medicine and Physical Fitness (34:1) pp. 91-98.

Stephens, T.; Jacobs, D. \& Withe, C. (1985): "A descriptive epidemiology of leisure-time physical activity”. En Public Health Reports (100:2) pp. 147158. 



\title{
LA FAMILIA, EL CONFLICTO Y LA MEDIACIÓN FAMILIAR
}

\author{
Francisco Robaina Palmés \\ Profesor Titular de la ULPGC \\ Alicia Soledad Robaina Espino \\ Mediadora Familiar y Grado en Trabajo Social \\ Francisco Domingo Robaina Espino \\ Mediador Familiar y Licenciado en Derecho
}

\begin{abstract}
Resumen
En el presente artículo, comenzamos centrando nuestra exposición en la familia (concepto, clasificación y funciones), desde la perspectiva de la influencia que la familia ejerce en la sociedad. A continuación, se expondrán las fases y clasificación del conflicto, incidiendo en el conflicto familiar a la hora de abordar la mediación familiar, y cómo la mediación influye y mejora la comunicación y las relaciones en el contexto familiar a pesar de existir un conflicto. Para finalizar, hablamos sobre la mediación y los modelos de mediación familiar y concluimos con una serie de observaciones sobre las características y beneficios de la mediación para la resolución de conflictos familiares.
\end{abstract}

Palabras clave: Familia. Tipos de familia. El conflicto. Mediación familiar. Modelos de mediación familiar.

\begin{abstract}
In this article, we start our discussion focusing on the family (concept, classification and functions), from the perspective of the influence that the family exerts on society. Then, we go through the phases and classification of the conflict, focusing on the family conflict when dealing with family mediation, and how mediation influences and improves communication and relationships in the family context despite the existence of a conflict. Finally, we talk about mediation and family mediation models and conclude with a set of observations about the characteristics and benefits of family mediation for the resolution of family conflicts.
\end{abstract}

Keywords: Family. Types of family. The conflict. Family Mediation. Models of family mediation. 


\section{LA FAMILIA: CONCEPTO, CLASIFICACIÓN Y FUNCIONES 1.1. INTRODUCCIÓN}

La familia es uno de los pilares fundamentales de nuestra sociedad. Es una de las instituciones más antiguas de nuestra historia.

López y Escudero (2003), señala:

Si alguna vez nos propusiésemos contar las veces que utilizamos la palabra familia o sus derivados como familiar, familiarizado, y sin necesidad de ser exhaustivos, nos daríamos cuenta de que la palabra familia está muy presente en el discurso cotidiano. Hablamos de una empresa familiar, unos amigos que son como de la familia o una tertulia en la que nos sentimos en familia. La usamos para referirnos a aquello que es cercano, conocido, afectivamente importante, aquello en lo que nos sentimos cómodos o que nos une con lazos que consideramos sólidos y duraderos. Por otro lado, parece que todos tenemos una familia, aún cuando vivamos solos o nos hayamos criado en una casa de acogida. Nuestros amigos, nuestros vecinos o nuestros parientes se convierten en nuestra familia, haya o no lazos sanguíneos o legales (p. 19).

Resulta que la palabra familia no sólo forma parte de nuestro lenguaje cotidiano, sino que también forma parte de nuestras historias de vida. En la práctica cotidiana, no resulta fácil llegar a establecer un consenso. López y Escudero (2003) dan cuenta de ello poniendo como ejemplo la primera conferencia sobre la familia celebrada en la Casa Blanca en el año 1980. En la misma se llevó semanas para acercar posturas a la hora de empezar a hablarse de familia. A pesar de los esfuerzos, no hubo consenso entre los participantes.

\subsection{CONCEPTO DE FAMILIA}

Se ha pasado de una concepción única y tradicional a una concepción con múltiples acepciones, según el marco de referencia desde el que se pronuncie su definición.

En este sentido, García (2006) afirma:

Ciertamente, no se puede hablar de un concepto de familia válido para todos los tiempos, y más que de familia hay que hablar de familias para referirnos a los modelos con arreglo a los cuáles los grupos humanos se han organizado históricamente. (p. 21) 
En general, la familia "es la célula básica del cuerpo social, la más universal de las instituciones, el agente de socialización por excelencia; es la portadora de un patrimonio cultural que deja en todos nosotros su sello" (Rondón, 2011, p.82). Acercase a una visión ampliada y universal del concepto de familia implica tener una concepción sociológica de la misma pues, como señala García (2006), "la familia es la única institución social que, a decir de antropólogos y sociólogos, siempre ha estado presente en todas las civilizaciones" (p. 19). García (2006) da a la familia un sistema de creencias y valores fortalecidos por normas sociales internas y externas de convivencia, respeto mutuo entre sus miembros y apoyo ante las adversidades. Continúa diciendo:

Cuestión de notoria importancia es el hecho de que en la familia confluyan y se vean reflejados factores económicos, jurídicos y políticos, junto a otros religiosos, culturales y sociales. Ésta es, a nuestro entender, la razón fundamental por la que no puede hablarse, ni actualmente ni históricamente, de un modelo único de familia, ya que ésta se halla en continuo proceso de cambio a través del tiempo, dada su permeabilidad a los referidos factores que la rodean" (p. 20).

Teniendo en cuenta la opinión dada por García (2006) y, tras una revisión bibliográfica sobre el concepto, se podría decir que la aportada por Rondón (2011), a través de su trabajo de investigación sobre las nuevas formas de familia y perspectivas para la mediación, permite tener una respuesta a la cuestión inicial de partida. Para el autor, la familia es:

(...) la institución basada en lazos de relación del matrimonio, descendencia o adopción constituida por padres, no necesariamente casados, y sus hijos, unidos y fortalecidos por el amor y el respeto mutuo. Haciendo el concepto más elástico, la concebimos como el conjunto de personas que comparten unas necesidades afectivas y unas funciones compartidas y negociadas (...) (p. 82).

Desglosando dicha definición, se puede sustraer la idea de que la familia puede ser entendida como el principal núcleo fundador donde empieza a surgir las primeras relaciones sociales entre individuos, no necesariamente fundadas en una relación de sangre. En dicha definición, llama la atención que el matrimonio ya no juega un papel importante a la hora de formar una familia. A este respecto, García (2006) afirma: 
La nueva concepción familiar postmoderna deja atrás muchos años de acuerdos tácitos derivados de la simple concepción del matrimonio. También el matrimonio, institución por excelencia constitutiva de la familia, ha venido siendo objeto de revisión, sometiéndose a importantes transformaciones en los últimos ańos por causa directa de nuevas leyes. (p. 21-22)

La familia es una célula social esencial que se erige como principal núcleo institucional donde se establecen las primeras relaciones interpersonales entre los sujetos que la componen, en donde se imprime el carácter básico de sociabilización de sus miembros mediante el establecimiento de consensuadas y razonadas normas de convivencia, en donde se establecen vínculos emocionales, personales y sociales y en donde se aprende a tener identidad propia (Fernández, 2009).

De acuerdo con Rodrigo y Palacios (2005):

La familia es una unión de personas que comparten un proyecto vital de existencia en común que se quiere duradero y en el que se generan fuertes sentimientos de pertenencia a dicho grupo, existe un compromiso personal entre sus miembros y se establecen intensas relaciones de intimidad, reciprocidad y dependencia. Un bien social al que hay que proteger y cuidar (p. 33).

La familia, en un entorno social amplio ha de autoregularse constantemente para adaptarse a los nuevos cambios que puedan estar ocurriendo en ese contexto. Una labor nada fácil, cuando entra en juego necesidades e intereses dispares dentro de la unidad familiar. En este proceso, la familia se convierte en una institución social fuerte y saludable, desplegando sus más altas capacidades resilientes. Sin embargo, ante situaciones de baja cohesión y adaptabilidad, la familia se vuelve disfuncional (De Bofarull, 2013).

\subsection{CLASIFICACIÓN DE LA FAMILIA}

Definido el concepto de familia como punto de partida, la siguiente clasificación trata de recoger la visión plural de modelos de familias que coexisten en la actualidad. Dicha clasificación fue establecida por Quintero (cómo se citó en Rondón, 2011, p. 83). 


\subsubsection{FAMILIA EXTENSA}

Para Quintero (citado en Rondón, 2011) “es la ampliación de las relaciones de consanguinidad y de alianza desde el núcleo a los colaterales por consanguinidad y afinidad, parientes consanguíneos ascendentes, descendientes y/o colaterales repartidos entre tres y hasta cuatro generaciones" (p. 83).

\subsubsection{FAMILIA FUNCIONAL O FLEXIBLE}

Es aquella que queda caracterizada por el logro de satisfacción de las necesidades básicas de los individuos que la conforman y en la que, por encima de todo, se establecen unos límites claros, flexibles y permeables entre sus miembros. Bajo esta categoría, se podría incluir la concepción moderna de aquellas familias que, no habiéndose casado, viven como parejas de hecho.

\subsubsection{FAMILIA NUCLEAR O NUCLEAR-CONYUGAL}

Es aquella que está constituida por el hombre y la mujer, o dos mujeres u hombres, los hijos, unidos por lazos de consanguinidad. Conviven en el mismo hogar y desarrollan sentimientos de afecto, intimidad e identificación recíprocos. Este tipo de familia se diferencia de la familia extensa en la reducción del número de miembros. Normalmente, de 1-2 hijas/os.

\subsubsection{FAMILIA HOMOPARENTAL}

Es aquella que surge de la relación estable de hecho o matrimonial entre dos personas del mismo sexo, que tienen hijos por intercambios de uno o ambos miembros de la pareja, por adopción y/o procreación asistida. Reivindica una sexualidad no procreadora entre la pareja.

\subsubsection{FAMILIA BICULTURAL O TRANSNACIONAL}

Es aquella que está formada por personas de origen étnico diferente y /o nacionalidad. En este caso, los dos miembros procedentes de distintas culturas o de origen cultural diferenciado, a la cultura dominante o mayoritaria en el país de asentamiento; en ambos casos (multiculturales) o en uno de ellos (biculturales). También pueden considerarse como multiculturales las familias con un progenitor de otra cultura por razón de adopción o unión anterior. 


\subsubsection{FAMILIA MIXTA SIMPLE}

Es aquella familia nuclear que ha sido alejada de su hábitat habitual por situaciones de desplazamiento forzado y que se encuentran en un proceso de duelo durante el cual se une a otra tipología familiar. Se constituyen con la unión obligada para la supervivencia, de dos familias. Su comunicación es esporádica o temporal, aunque continua gracias a las nuevas tecnologías.

\subsubsection{FAMILIA MIXTA COMPLEJA}

Es aquella familia nuclear que, presentando las mismas características que la mixta simple, se diferencia de aquella en el número de familias que se asocian. Normalmente, más de dos.

\subsubsection{FAMILIA MONOPARENTAL}

Es aquella formada por un solo progenitor y su hijo nacido, adoptado, etc. Las causas que llevan a este tipo de formación familiar son muy diversas, si bien se podría mencionar aquí las situaciones de separación, divorcio, abandono, viudez, alejamiento por motivos forzosos (trabajo, inmigración, ingreso en prisión, etc.) de uno de los padres, etc.

\subsubsection{FAMILIA RECONSTITUIDA}

Es aquella que está conformada por la unión de cónyuges, donde uno o ambos provienen de separaciones y divorcios de anteriores vínculos legales o de hecho, que aportan hijos y tienen a su vez hijos en su nueva unión. García (2006) afirma que "esta será la forma del futuro que romperá definitivamente los esquemas de la familia tradicional” (p. 31).

\section{EL CONFLICTO}

El ser humano es una especie gregaria, que desde sus orígenes vive y convive agrupándose con otros, formando comunidades para protegerse, repartir las tareas y mejorar sus posibilidades de supervivencia. Esta peculiaridad hace que, más temprano que tarde, surjan diferencias entre los miembros de dicha comunidad, y estalle un conflicto, cuya solución varía en función de las singulares características de cada sociedad. Pero, ¿en qué consiste exactamente? ¿Cómo evoluciona el conflicto? ¿Cuáles son sus características? En las siguientes páginas trataremos de dar respuesta a estas incógnitas. 


\subsection{DEFINICIÓN DE CONFLICTO}

Comencemos por la definición que contempla el Diccionario de la Real Academia Española de la Lengua en su vigesimosegunda edición. En su primera acepción lo define como: "Combate, lucha, pelea. U. t. en sent. fig."; sin embargo, a los efectos que nos interesa en el marco de la mediación familiar, se adapta mejor la cuarta acepción: "Problema, cuestión, materia de discusión" (R.A.E., 2001).

Acotando aún más, debemos descartar el análisis de los conflictos unipersonales, es decir, aquellos conflictos que tiene una persona consigo misma, en su fuero interno, pues el análisis de los mismos corresponde a los campos de la filosofía o la moral.

Vinyamata (2009) define el conflicto como aquella:

Lucha, desacuerdo, incompatibilidad aparente, confrontación de intereses, percepciones o actitudes hostiles entre dos o más partes. El conflicto es connatural con la vida misma, está en relación directa con el esfuerzo por vivir. Los conflictos se relacionan con la satisfacción de las necesidades, se encuentran en relación con procesos de estrés y sensaciones de temor y con el desarrollo de la acción que puede llevar o no hacia comportamientos agresivos y violentos (p. 278).

Es decir, estos intereses contrapuestos, que entre sí son al menos aparentemente antagónicos, generan en los individuos que participan del conflicto, un enfrentamiento por la satisfacción de sus respectivas necesidades, lo que puede desembocar en un comportamiento violento, o no. Es inherente al ser humano, en su lucha por la supervivencia, que más pronto que tarde acabe teniendo algún conflicto con otros por la divergencia de intereses.

Por su parte, De Diego y Guillén (2012) lo definen así:

- Los conflictos son situaciones.

- En las que dos o más personas entran en oposición o desacuerdo.

- Porque sus posiciones, intereses, necesidades, deseos o valores son incompatibles, o son percibidos como incompatibles.

- Donde juegan un papel muy importante las emociones y sentimientos.

- Y donde la relación entre las partes en conflicto puede salir robustecida o deteriorada en función de cómo sea el proceso de resolución del conflicto (p. 36). 
Y a continuación añaden que "No hay forma de suprimir los conflictos. (...) Lo que ocurre es que hay que adoptar un enfoque de solución de problemas y no el enfoque tradicional de la confrontación y la competitividad" (p. 36).

En similares términos lo define Suares (1996):

- Un proceso interaccional, que como tal nace, crece, se desarrolla y puede a veces transformarse, desaparecer y/o disolverse, y otras veces permanecer relativamente estacionario.

- Que se da entre dos o más partes, entendiendo por partes a personas, grupos pequeńos, grandes grupos; la interacción puede darse entre dos personas, entre dos grupos, entre una persona y un grupo, etc.

- En el que predominan las interacciones antagónicas sobre las interacciones atrayentes o atractoras.

- Interacciones en las cuales las personas que intervienen lo hacen como seres totalmente con sus acciones, sus pensamientos, sus afectos y sus discursos.

- Que algunas veces, pero no necesariamente, pueden ser procesos conflictivos agresivos.

- Que se caracteriza por ser un proceso co-construido por las partes.

- Y que puede ser conducido por ellas o por un tercero (p. 78).

Como podemos observar, pese a que cada autor hace más hincapié en unos aspectos $\mathrm{u}$ otros, existen características comunes que nos permiten hacernos una idea clara de lo que supone el conflicto.

\subsection{FASES DEL CONFLICTO}

El conflicto no es eterno e inmutable. Como vimos al analizar las diferentes definiciones de conflicto, los sentimientos y las emociones juegan un papel fundamental en el desarrollo de éste, por lo que este va evolucionando en función del estado emocional en que se encuentren los actores del conflicto.

La literatura científica ha aceptado los términos de escalada, estancamiento y desescalada como las principales fases por las que pasa el conflicto. Tales términos fueron acuñados por Rubin, J., D. Pruitt y S. Hee en su obra de 1986: "Social conflict: escalation, stalemate and settlement". A partir de los mismos, Alzate (1998. p.52), en cita de Redorta (2007, p. 72) lo compara con una obra de teatro, en la que en el primer acto el conflicto aumenta y se intensifica, en el segundo acto se produce el clímax y el estancamiento y en el tercer acto el conflicto va descendiendo de intensidad hasta su resolución. 
Llamamos escalada (escalation), según Entelman (2009) a un "movimiento hacia niveles de mayor intensidad de la conducta conflictiva de cualquiera de los actores" (p.177). Esto provoca un aumento de la virulencia de los ataques mutuos, un aumento de la competitividad entre los actores, que a medida que uno aumenta sus pretensiones, así aumentan las del otro. A medida que la comunicación se va enrareciendo, se multiplican los problemas; el conflicto pudo empezar por un problema puntual y a consecuencia del desencadenamiento de éste, aparezcan nuevos temas de controversia.

Durante esta fase la desconfianza mutua es creciente. En palabras de Redorta (2007): "En la fase de escalada y competición la confianza se reduce al mínimo y debe considerarse un proceso donde dicha confianza se destruye sistemáticamente, lo cual influye en la percepción respecto de la actuación de la otra parte" (p. 75).

El estancamiento (stalemate) es, según Redorta (2007) "un punto crítico del proceso en el que se pasa de actividades competitivas a cooperativas y se reconoce al otro. Sin embargo, un estancamiento puede significar una pausa temporal en la escalada y el conflicto puede seguir escalándose después" (p. 74). Los actores, ante el fracaso de la satisfacción de sus pretensiones en la escalada, han decidido no continuar escalándolo. Podríamos decir que el conflicto ha llegado a su punto álgido, pero aún no están en condiciones de producir la desescalada. Rubin, Pruitt y Hee (1986), citados por Redorta (2007) al estancamiento se llega por cuatro causas fundamentales:

- Fracaso de las tácticas competitivas.

- Agotamiento de recursos.

- Pérdida de soporte social.

- Costes inaceptables (p.74)

Finalmente, en la desescalada (settlement), los actores toman conciencia de que necesitan colaborar mutuamente para llegar a una solución y se reducen las tensiones y la destructividad del conflicto. De esta forma, "el proceso de desescalada será un proceso de reconstrucción de confianza mutua, al menos a cierto nivel, y se produce un avance hacia una nueva relación de poder entre las partes" (Redorta, 2007. p. 76)

Alzate (1998) citado por Redorta (2007), concluye que la técnica de desescalada requiere esencialmente cuatro pasos y los define de la siguiente manera: incremento de la interacción, construcción de momentos o espacios de pausa en el conflicto con el inicio de pequeñas concesiones mutuas, la generación de objetivos comunes superiores y las concesiones unilaterales (p. 75) 
En la mayoría de los casos, para que se produzca la desescalada es necesaria la intervención de un tercero, pues es difícil que entre ellos puedan llegar a ese estado. Entelman (2009) lo describe así:

\begin{abstract}
(...) En efecto, salvo que exista entre las partes un muy buen nivel de comunicación, dentro de un marco que dé posibilidad a un compromiso de tregua o de desescalada, uno de los contendientes no puede fácilmente iniciar una acción de descenso. Ella sería interpretada por su adversario como un acto de debilidad, que en general no lo motivaría a descender también a un nivel más bajo de interacción. Por el contrario, le haría vislumbrar la ventaja de aumentar considerablemente su escalamiento a fin de colocarse en condiciones óptimas para el proceso de terminación del conflicto" (p. 179).
\end{abstract}

Es de vital importancia para el mediador conocer en qué fase del conflicto se encuentran los mediados, pues le permitirá conocer el estado de ánimo de los mismos, y prever lo que puede obtener de ellos, y como producir acercamientos eficaces, así como emplear las técnicas más adecuadas para el momento en que se encuentren.

\title{
2.3. CLASIFICACIÓN DE LOS CONFLICTOS
}

Al clasificar los conflictos nos encontramos con la dificultad de que su amplio espectro hace que se convierta en una misión casi imposible. Pese a ello, numerosos autores han intentado hacer una aproximación a la hora de encuadrar los diferentes tipos de conflictos. Sin embargo, no ha sido posible hallar un criterio que permita hacer una clasificación única.

Muchos autores han optado por hacer clasificaciones de criterio único, es decir, establecen un criterio de selección, y los que lo cumplen están incluidos, y los que no, quedan asignados a la contraria.

Redorta (2007, p.85) ha elaborado un gráfico con ejemplos de clasificación de tipologías de conflicto por criterio único: 
Figura 1: Ejemplos de clasificación de tipologías de conflicto

\begin{tabular}{|l|l|l|l|}
\hline \multicolumn{1}{|c|}{ Autor } & Criterio de clasificación & Tipo de conflicto & \multicolumn{1}{c|}{ Observaciones } \\
\hline Woodhouse & Relación de poder & $\begin{array}{l}\text { Simétricos } \\
\text { Asimétricos }\end{array}$ & $\begin{array}{l}\text { La simetría equivale a } \\
\text { igualdad en el poder }\end{array}$ \\
\hline Abebrese & Funcionalidad & $\begin{array}{l}\text { Funcional } \\
\text { Disfuncional }\end{array}$ & $\begin{array}{l}\text { Es funcional si potencia la } \\
\text { innovación y la creatividad }\end{array}$ \\
\hline Lederach & Relación de poder & $\begin{array}{l}\text { Verticales } \\
\text { Horizontales }\end{array}$ & $\begin{array}{l}\text { Se refiere al conflicto entre } \\
\text { iguales o en jerarquía }\end{array}$ \\
\hline Galtung & Nivel de visibilidad & $\begin{array}{l}\text { Latente } \\
\text { Manifiesto }\end{array}$ & $\begin{array}{l}\text { El conflicto latente deja de } \\
\text { serlo al manifestarse }\end{array}$ \\
\hline Deutsch & Agresividad & $\begin{array}{l}\text { Constructivo } \\
\text { Destructivo }\end{array}$ & $\begin{array}{l}\text { Fuerte aparición o ausencia } \\
\text { de agresividad }\end{array}$ \\
\hline Burton & Violencia & $\begin{array}{l}\text { Violentos } \\
\text { No violentos }\end{array}$ & $\begin{array}{l}\text { Ausencia o presencia de } \\
\text { violencia }\end{array}$ \\
\hline Hobbes & Interés & $\begin{array}{l}\text { Apetito } \\
\text { Aversión }\end{array}$ & Es la atracción y repulsión \\
\hline Coser & Emocionalidad & $\begin{array}{l}\text { Real } \\
\text { Irreal }\end{array}$ & $\begin{array}{l}\text { Es irreal si existen muchas } \\
\text { emociones implicadas }\end{array}$ \\
\hline
\end{tabular}

Fuente: Redorta (2007).

Por su parte, Rondón (2012, p.109) realiza la siguiente clasificación, distinguiendo cuatro tipos:

a) Conflictos intrapersonales: Estos ocurren dentro de la propia persona cuando entren en disputa necesidades, intereses o expectativas sobre elementos o vínculos en común.

b) Conflictos interpersonales: Ocurren entre dos o más personas. Puede ser por parte de una, o de todas a la vez, debido a recursos escasos, necesidades psicológicas o valores diferentes o contrapuestos.

c) Conflictos intragrupales: Se dan entre individuos pertenecientes al mismo grupo. Sucede en las familias cuando los intereses de los padres y de los hijos son diferentes, por ej. los conflictos intergeneracionales entre adolescentes y padres

d) Conflictos intergrupales: Ocurre entre grupos de diferente entidad, tamaño, intereses. En las familias se suele producir entre las familias extensas de los cónyuges.

Como vemos, no parece posible establecer un criterio único que aúne todas las posibilidades en cuanto a la clasificación de los conflictos, pero cada una de ellas nos aporta una visión en función del elemento que quiere dársele mayor relevancia como criterio diferenciador. 


\section{MEDIACIÓN FAMILIAR}

En situación de conflictos en la familia, es necesario informar, que existen alternativas, abriendo espacios de diálogo, la mediación familiar es un espacio eficaz para que las personas encuentren soluciones al conflicto familiar, con el diálogo.

\subsection{DEFINICIÓN DE LA MEDIACIÓN FAMILIAR}

Numerosos autores han tratado de definir el concepto de mediación. Lo mismo sucede a la hora de definir la mediación familiar. Sin embargo, para evitar ser demasiado reiterativos, nos quedaremos en esta ocasión con la definición que hace la Ley Canaria 15/2003, de 8 de abril, de la Mediación Familiar, modificada por la Ley 3/2005, de 23 de junio en su artículo 2:

La mediación familiar es un procedimiento extrajudicial y voluntario en el cual un tercero, debidamente acreditado, denominado mediador familiar, informa, orienta y asiste, sin facultad decisoria propia, a los familiares en conflicto, con el fin de facilitar vías de diálogo y la búsqueda por éstos de acuerdos justos, duraderos y estables y al objeto de evitar el planteamiento de procedimientos judiciales contenciosos, o poner fin a los ya iniciados o bien reducir el alcance de los mismos.

\subsection{FASES DE LA MEDIACIÓN FAMILIAR}

Suares (2002, p. 243-276) ha analizado las fases por las que pasa todo proceso de mediación familiar. Las clasifica en tres: premediación, mediación propiamente dicha y posmediación.

\section{Premediación:}

En esta etapa no ha empezado la mediación propiamente dicha, pero sí el proceso. Se trata de la primera toma de contacto con los mediados. Puede hacerse tanto en persona como de forma telefónica, y los objetivos a lograr en la misma son:

1. Informar sobre el proceso de mediación (voluntariedad, confidencialidad, etc.)

2. Invitar al otro participante, si no estuviera presente

3. Presentar el contenido del problema. Principalmente para asegurarse de la viabilidad de la mediación como solución al conflicto (por ejemplo, no se puede mediar en casos de violencia de género). 


\section{Mediación propiamente dicha:}

Esta fase es la más importante, pues es donde los mediados exponen su problema, y los mediadores despliegan todo su arsenal de recursos para intentar ir más allá de las posiciones de los mediados, y se produce la generación opciones. Se debaten las alternativas presentadas y si todo ha ido bien, cristalizará en la firma de un acuerdo final.

Por motivos clarificadores Suárez la divide en tres fases: Inicio, Opciones y Acuerdo. En la fase de Inicio, "el mediador realiza un discurso inicial en el cual se establecen las características principales de la mediación y el dispositivo que se utilizará" (rol del mediador, confidencialidad, voluntariedad, etc.). Asimismo, se establecen las reglas que van a regir el proceso de mediación, principalmente que sólo hablará uno por vez, y la interdicción de las agresiones verbales o físicas. A continuación se procederá a la firma del convenio de confidencialidad. Llegados a este punto, empezamos realmente a trabajar a través de la exploración del problema y la redefinición del mismo, pues como suele decirse en derecho "las cosas son lo que son, no lo que las partes dicen que son" y es necesario ahondar en los relatos para asegurarse que la realidad coincide con su discurso. También se explorarán los objetivos y posibles soluciones, con especial interés en averiguar cuáles han sido las soluciones intentadas sin éxito, para no volver a incidir en ellas. Por último se procederá a la construcción de la agenda, pues es poco probable, especialmente en mediación familiar que haya un único problema, y sean varios, de tipo económico, de horarios, de rutinas, etc. que precisen de varias sesiones para ir adentrándonos en ellos.

En la fase de Opciones, hay que intentar separar a las personas del problema, concentrarse en los intereses, no en las posiciones y generar opciones (como establece el modelo de Hardvard). Para ello se atenderá primero a las opciones que ofrecen las partes y posteriormente, a través de un "brainstorming” a las que generen durante el proceso de mediación. Se irán descartando las que no satisfagan a alguno de los mediados, hasta que finalmente lleguen a un consenso.

Esto nos lleva a la fase de Acuerdo, donde se elabora, redacta y firma un acuerdo final, donde quede reflejada la solución final, o al menos, los acuerdos puntuales que hayan podido lograr en diferentes aspectos.

\section{Posmediación:}

No hay que dejar de lado llevar un seguimiento de los casos una vez finalizados. Suárez (2002) lo expresa en estos términos: 
Se deben realizar en todos los casos, aun en los que no llegaron a un acuerdo. Nos hemos sorprendido varias veces, después de mediaciones supuestamente fracasadas, de que no habían sido tales, ya que aunque las partes abandonaron el proceso, lo vivido en él cambió la relación entre ellas y amigablemente negociaron solas (p. 275).

Suárez (2002) continúa señalando que es interesante verificar:

1. Si el acuerdo se ha cumplido en toda su extensión o en parte.

2. Cuáles han sido los motivos por los que no se cumplió algo de lo pactado.

3. Si ha habido modificaciones, como han sido negociadas.

4. Si ha fracasado el acuerdo, cuál ha sido, a criterio de ellos, la razón (p. 275).

\subsection{MODELOS DE MEDIACIÓN FAMILIAR}

\subsubsection{MODELO TRADICIONAL-LINEAL DE HARVARD}

Este modelo fue gestado en la Universidad de Harvard por Fisher, Ury y Patton y ha tenido un gran éxito desde su creación, convirtiéndose en un referente en la gestión de la resolución de conflictos a través de la negociación.

Este modelo pone el acento en el conflicto, al que considera como un problema que hay que superar, porque obstaculiza el llegar a una solución. De Diego y Guillén (2012) enumeran sus características esenciales:

- Entiende la comunicación en un sentido lineal.

- Las dos partes se expresan.

— El mediador ha de facilitar la comunicación.

- Importancia de la comunicación verbal.

- Entiende el desacuerdo como causa del conflicto, sin considerar sus orígenes en múltiples causas.

— Trabaja sobre intereses, necesidades, etc., sin intentar modificar la relación entre las partes.

- Su método propone la aireación del conflicto, permitiendo que afloren las emociones para poder avanzar.

— El éxito se alcanza cuando se llega a un acuerdo (p. 59).

Este modelo se basa en conseguir el MAAN (Mejor Alternativa a un Acuerdo Negociado), o BATNA (Best Alternative to Negotiated Agreement), es decir, cada parte busca su mejor alternativa posible, teniendo también en 
cuenta la de la otra parte, y trabajando con las zonas grises entre ambos intervalos llevar a cabo una negociación exitosa.

La principal crítica a este modelo es que al no modificar la relación entre los mediados, sino centrarse en la superación del problema concreto, los acuerdos finales pueden no ser tan fuertes. Por eso este modelo parece más indicado para resolver cuestiones mercantiles que familiares, donde la relación entre sus miembros es de importancia capital.

\subsubsection{MODELO TRANSFORMATIVO}

Este modelo, desarrollado por Bush y Folger, parte de una premisa totalmente diferente. Lo que busca es transformar a las partes, y una vez conseguido, la solución al conflicto será la consecuencia natural de aquella transformación.

En este caso, el acento está en el cambio producido en los sujetos gracias a la mediación, especialmente a través de dos elementos básicos: la revalorización y el reconocimiento.

De Diego y Guillén (2012, p. 57-58) aclaran que una parte resulta revalorizada "cuando alcanza una comprensión más clara, comparada con la situación anterior, de lo que importa y por qué", así como que "la revalorización de las partes comprende claramente cuáles son sus metas y sus intereses (...), por qué persigue esas metas, y que éstas son importantes y merecen consideración”. Finalmente, "se incrementa la revalorización de las partes cada vez que éstas acrecientan o aumentan sus propias habilidades en la resolución de conflictos siendo conscientes de sus propios recursos".

En cuanto al reconocimiento, los mismos autores aseveran que:

(...) las partes llegan al reconocimiento cuando eligen abrirse más, estar más atentas, empáticas y sensibles a la situación del otro.

El mediador debe reconocer a las partes y educarlas en el reconocimiento de la otra parte. Cada una de las partes otorga reconocimiento cuando comprende que tiene la capacidad de considerar y reconocer las situación de la otra parte y es capaz de ponerse en su lugar de modo empático" (...) (p. 58).

El principal problema al que se enfrenta este modelo es que llegar a un cambio tan profundo en los mediados es algo que lleva demasiado tiempo, por lo que con las limitaciones temporales de la mediación, no se puede garantizar que llegue a producirse. 


\subsubsection{MODELO CIRCULAR NARRATIVO}

La precursora de este modelo es la profesora de la Universidad de California, Sara Cobb. Se denomina circular, porque considera que tanto la comunicación como la causalidad son circulares, y narrativo porque pone énfasis en las narrativas de los mediados.

Rondón (2012) lo define de la siguiente forma:

(...) pone énfasis en la comunicación y en la interacción de las partes. Focaliza su trabajo en las narraciones de las personas. Para llegar a acuerdos, las partes necesitan transformar el significado de las historias conflictivas, motivo por el cual llegan a la mediación, de tal manera que quedan mejor posicionadas y puedan salir de sus planteamientos iniciales. El rol del mediador consiste en ayudar a cambiar los estilos de comunicación, de modo que las partes interactúen de manera diferente y por lo tanto se produzcan cambios que permitan llegar a los acuerdos (p. 187).

Se trata de un modelo bastante completo, pues el uso de las narrativas permite un acercamiento de las partes, y una mejor forma de entender su mundo.

\subsubsection{MODELO GRUPAL NARRATIVO}

La precursora de este modelo es Liliana Perrone. Pone énfasis en la flexibilidad necesaria para afrontar con éxito un proceso de mediación. Romero (2009) nos explica que este modelo es originario de la terapia familiar sistémica, las teorías de la comunicación, la teoría de sistemas y los aportes de la teoría narrativa; además, es:

Grupal: porque para haber conflicto debe haber un mínimo de dos personas, esta díada alimenta el conflicto ya sea directa como indirectamente.

Narrativo: porque hace referencia a la manera de pensar o de hablar de los miembros de ese grupo respecto a los procesos interpersonales en que viven; esta narrativa es un producto grupal; por tanto, las operaciones que tienden a cambiar estas narrativas deben implementarse sobre los actores.

Este modelo integra dos maneras de ver el conflicto:

a) Desde una perspectiva Sistémica: Define el conflicto como la manifestación de la interacción, co-dirigido y co-actuado por un mínimo de dos personas.

b) Desde una perspectiva lingüística: Se trata de una manera de hablar y/o pensar respecto al proceso interpersonal, como un relato, una narrativa. 
Con este modelo las partes han construido su percepción de la realidad en base a sus narrativas, y muchas veces estas son incompatibles. El mediador deberá utilizar las narrativas para transformar estos relatos en compatibles al menos hasta llegar a una realidad común mínima a partir de la cual puedan seguir avanzando.

Romero continúa diciendo que este modelo se compone de dos registros, que aunque se tratan por separado, en la práctica se entrelazan simultáneamente:

1) Registro de cambio en la construcción de la realidad: Mensajes diferenciados con cierta semejanza; crear duda y cuestionamiento de los argumentos para propiciar la apertura.

a) Explorar la construcción de la realidad de cada uno y puesta en relieve de los relatos dominantes: su objetivo es recabar información, solicitándoseles que expliquen su posición para buscar elementos diferenciadores.

b) Exploración del sistema de creencias: porque condiciona la forma en que pueden ver el mundo.

c) Intervenir para hallar relatos alternativos: buscando diferencias con los relatos iniciales y hacer hincapié.

d) Intervenir, crear relatos comunes con vistas a la posterior toma de decisiones.

2) Registro de ayuda a la negociación:

a) Explorar necesidades.

b) Explorar posibilidades.

c) Toma de decisiones y reglas.

d) Redacción de Acuerdo de Mediación.

\subsubsection{MODELO CENTRADO EN SOLUCIONES}

El modelo de mediación familiar centrado en soluciones es heredero de la terapia centrada en soluciones del campo de la psicología.

Sus principales objetivos son:

- Centrarnos en el futuro y no en el pasado.

- Lograr la resolución del conflicto y los acuerdos mediante la búsqueda de soluciones consensuadas y actuadas por las partes en litigio.

- Promover el cambio del problema a la solución.

Existen dos aspectos relevantes en este modelo: 
En primer lugar, los estilos de comunicación relacional, que se establecen desde el primer contacto entre mediadores y mediados. Estos son catalogados como visitante pues no reconoce que tiene un problema, viene "de visita" por iniciativa del otro, pero no motu propio; demandante pues viene presentando una "queja", normalmente es el promotor, tiene claro lo que quiere del otro; y trabajador, pues quiere hacer algo para resolver el problema y viene motivado a "trabajar" para solucionarlo.

El otro aspecto está relacionado con la teoría del cambio. Supone una evolución lineal desde la inacción hasta que ejecuta la búsqueda de movimiento, y se pasa por las siguientes fases:

1. Fase de precontemplación: el individuo no es consciente de la existencia de un problema.

2. Fase de contemplación: son conscientes de la existencia de un problema, pero no están listos para pasar a la acción.

3. Fase de preparación: esta fase combina intención y criterio de comportamiento.

4. Fase de acción: el individuo modifica su comportamiento para superar el problema.

5. Fase de mantenimiento: una vez superado, para evitar una recaída y consolidad los resultados obtenidos.

Una técnica muy empleada en este modelo es la "pregunta milagro", pregunta de tipo circular y reflexiva orientada al futuro, donde se les pone a imaginar que un "milagro" ha ocurrido y ya no existe el problema, para que desarrollen como lo visualizan y los cambios que apreciarían si en efecto se hubiera producido dicho milagro. Esto les permite concentrarse en la solución y no en el problema, nos permite buscar las excepciones en el problema, así como promover objetivos con los que se pueda trabajar.

\section{CONCLUSIONES}

La mediación familiar es una herramienta alternativa a la judicial para la resolución de conflictos en el ámbito familiar, que resulta cada vez más importante en una sociedad que evoluciona en ocasiones mas rápido de lo que los individuos son capaces de procesar. Las conclusiones a las que hemos llegado son las siguientes:

- La mediación familiar se orienta a ayudar a cambiar la situación de conflicto que existe en el momento presente en el contexto familiar. 
- En el proceso de mediación, se sufre un desgaste emocional hasta que se empieza a llegar a acuerdos por todas las partes, incluyendo al mediador/a.

- En la actual generación existe una mayor diversidad en tipos de familia y responsabilidades familiares (cambio de roles familiares conciliación de la vida familiar y laboral) que se han introducido en nuestra sociedad a una velocidad a la que muchas personas no han conseguido adaptarse. Esto provoca que los conflictos familiares vayan en aumento, y tener la alternativa de la mediación para resolución de conflictos es muy positivo para el bienestar futuro de la familia.

- Es importante que el mediador en el proceso vele por el bienestar del menor, o la persona dependiente o con diversidad funcional (cuando los haya), e intente gestionar las emociones para que el conflicto no se vuelva patológico.

- En el proceso de mediación, las personas implicadas son las protagonistas y es importante que se sientan empoderadas en sus decisiones con respecto al futuro.

- Las familias aprender a gestionar sus emociones en las diferentes sesiones que podrán aplicar ese aprendizaje para futuros conflictos. Mejorando así sus relaciones con sus seres más queridos.

\section{REFERENCIAS BIBLIOGRÁFICAS}

Alzate, R. (1998). Análisis y resolución de conflictos. Una perspectiva psicológica. Bilbao, España: Universidad del País Vasco

De Bofarull, I. (2013). Fortalezas y competencias de la familia. Bases para la orientación y mediación familiar. Universidad de Cataluña, Barcelona, España: IESSF

De Diego, R y Guillén, C. (2012). Mediación. Proceso, tácticas y técnicas. Madrid, España: Pirámide.

Entelman, R. F. (2009). Teoría de conflictos. Hacia un nuevo paradigma. Barcelona, España: Gedisa.

Fernández, S. (2009). Teoría y práctica de la Mediación. La gestión alternativa de los conflictos sociales. Universidad de Murcia, España: Editum-Ágora

García, L. (2006) Mediación en conflictos familiares. Una construcción desde el derecho de familia. Madrid, España: Reus

López, S. y Escudero, V. (2003). Familia, evaluación e intervención. Madrid, España: CCS 
Real Academia Española (2001). Conflicto. En Diccionario de la lengua española (22a Edición). Recuperado de http://lema.rae.es/drae/?val=conflicto Redorta, J. (2007). Cómo analizar los conflictos. La tipología de conflictos como herramienta de mediación. Barcelona, España: Paidós Ibérica, S.A.

Rodrigo, J. (coords.). (2005). Familia y desarrollo humano. Madrid, España: Alianza. M.J. y Palacios Recuperado de http://ftpmirror.your.org/pub/familia_desarrollo/9/90/TOMO_III_NI\%C 3\%91EZ_(2).pdf

Romero, F. (2009). Apuntes de clase. DL. GC 961-09 y 962-09.

Rondón, L. (2011). Nuevas formas de familia y perspectivas para la mediación: el tránsito de la familia modelo a los distintos modelos familiares. En UNIA (Presidencia), Cambios sociales y perspectivas para el siglo XXI, 79-90. Artículo presentado en el I Congreso Internacional de Mediación y Conflictología, Sevilla, España. Recuperado de http://dspace.unia.es/handle/10334/1687.pdf

Rondón, L. M. (2012). Bases para la mediación familiar. Valencia, España: Tirant lo blanch.

Suares, M. (1996). La mediación. Conducción de disputas, comunicación y tácticas. Buenos Aires, Argentina: Paidós.

Suares, M. (2002). Mediando en sistemas familiares. Barcelona, España: Paidós Ibérica, S.A.

Vinyamata, E. (2009). Conflictología. Curso de resolución de conflictos. Barcelona, España: Ariel. 


\title{
EMIGDIA REPETTO PIONERA DE LA METODOLOGÍA NEUROEDUCATIVA DE LA ULPGC: ESTUDIO DE CAMPO EN ALUMNOS DE POSTGRADO DEL MÁSTER DE ESPAÑOL DE LA ULPGC (PROMOCIÓN 2019-2020)
}

\author{
María Nayra Rodríguez Rodríguez \\ Didac Martín Martínez \\ Universidad de Las Palmas de Gran Canaria (ULPGC)
}

\section{Resumen}

Ya desde el 1984, E. Repetto (2005) ${ }^{[9]}$ propugnaba una enseñanza fundamentada en los principios de la neuroeducación implementadas con las TIC, la motivación del alumno, la experimentación y el cambio del aula magistral. Asimismo, Repetto (2003) ${ }^{[7]}$ recomendaba la utilización de medios audiovisuales en el aula, ya que la personas retienen el $10 \%$ de lo que escuchan frente al $50 \%$ de lo que ven.

En este capítulo pretendemos presentar una serie de actividades que emanan de la metodología neuroeducativa y que se han trasladado a las clases de espańol de la ULPGC con el objetivo de trabajar las destrezas escritas de lengua española a través de las TIC y el idioma de las emociones. Una vez presentadas las actividades, los alumnos han valorado la utilidad de estas mediante una encuesta a través del correo electrónico sobre la idoneidad de este método propuesto.

Palabras clave: Neuroeducación, Idioma de las emociones, ELE (Español como Lengua Extranjera), MECU (Máster en Español y su Cultura) y TIC (Tecnologías de la información y la comunicación).

\begin{abstract}
Since 1984, E. Repetto (2005) ${ }^{[9]}$ advocated a teaching based on the principles of neuroeducation implemented with ICT, student motivation, experimentation and change of the master classroom. Likewise, Repetto (2003) ${ }^{[7]}$ recommended the use of audiovisual media in the classroom, since people retain $10 \%$ of what they hear compared to $50 \%$ of what they see.

In this chapter we intend to present a series of activities that emanate from the neuroeducative methodology and that have been transferred to the Spanish classes of the ULPGC with the aim of working on written skills of the Spanish language through ICT and the language of emotions. Once the activities had
\end{abstract}


been presented, the students assessed their usefulness through an email survey on the suitability of this proposed method.

Keywords: Neuroeducation, Language of emotions, ELE (Spanish as a Foreign Language), MECU (Master in Spanish and its Culture) and ICT (Information and Communication Technologies).

\section{INTRODUCCIÓN}

En este capítulo pretendemos validar las actividades neuroeducativas aplicadas a futuros docentes de español como lengua extranjera para llevarlas al aula. La metodología neuroeducativa consiste en integrar la curiosidad del alumno, su atención y las emociones. El púbico objetivo al que va destinado esta investigación son los alumnos de posgrado del Máster en Español y su cultura de la ULPGC concretamente de la asignatura de Destrezas Escritas de la promoción 2019-2020.

Hemos hecho dos fases de investigación: en un primer estadio, hemos consultado los repositorios bibliográficos sobre la neuroeducación y del idioma de las emociones aplicadas al aula. Y en un segundo estadio, hemos realizado un estudio de campo de la aplicación de estas actividades neuroeducativas en las clases del Máster.

\section{OBJETIVOS}

Los objetivos de esta investigación pretenden valorar el uso de la metodología neuroeducativa para la adquisición de los contenidos de destrezas escritas a través de las TIC por parte de los alumnos del MECU de la ULPGC. Asimismo, se pretende incorporar esta metodología al resto de niveles universitarios en general.

Los alumnos responderán una encuesta a fin de validar las actividades TIC neuroeducativas para su posible aplicación en el aula de ELE teniendo en cuenta el nivel del alumnado, un dominio del español de nivel maestría, ya que son futuros docentes.

\section{METODOLOGÍA}

Esta investigación parte de una metodología neuroeducativa, que propone que la educación puede transformarse para hacer el aprendizaje más efectivo, por ejemplo, reduciendo el tiempo de las actividades para que los alumnos sean capaces de mantener la atención, y a su vez, que las actividades sean par- 
ticipativas y que se conozcan los alumnos fomentando un clima favorecedor en la clase de ELE mediante la metodología de investigación en acción de E. Martín Peris (2017) ${ }^{[10]}$ en el Diccionario de términos ELE.

Asimismo, se pretende que, a través de la neuroeducación y del uso de una metodología inductiva aplicada a la tecnología se adquieran los contenidos de destrezas escritas del nivel de español en particular que se quiera trabajar como lo recoge B. Aguirre Beltrán (2004) ${ }^{[1]}$ en su Análisis de necesidades y diseño curricular. También se enfocará en el método de investigación acción que propone A. Latorre (2007) $)^{[4]}$ en su libro La investigación-acción. Conocer y cambiar la práctica educativa.

\section{MARCO TEÓRICO}

La neuroeducación, según F. Mora $(2020)^{[11]}$, es una disciplina que estudia el papel que juega el cerebro en el proceso de enseñanza y aprendizaje del alumnado. Las actividades neuroeducativas tienen que implicar:

- Un contenido personal siempre y cuando el alumno voluntariamente quiera conectar con los demás a través de una experiencia personal.

— Que se mantenga un tiempo de descanso y que se trabajen todas las destrezas.

— Que se incluyan los diferentes estilos de aprendizaje del alumnado: visuales, quinésicos y auditivos.

Asimismo, a través de J. Arnold (2015) ${ }^{[2]}$ en su libro La Dimensión afectiva en el aprendizaje de idiomas, pretendemos que los futuros profesores interioricen de forma intrínseca que, solo se aprende mediante la emoción. Por su parte, M. Prensky $(2013)^{[5]}$, considera que hay que introducir las TIC en el aula, y es por lo que se pretende unir el concepto de las TIC con la neuroeducación en el aula de ELE. Además, como referentes en el aula siempre nos fundamentamos del Marco Común Europeo de Referencia ${ }^{[9]}$ y el Plan Curricular del Instituto Cervantes ${ }^{[10]}$.

Por su parte, E. Repetto (1984) ${ }^{[6]}$ afirmaba sobre la experimentación donde proponía que el alumno tiene que vivir lo que va a estudiar y observar el mundo que lo rodea. Por tanto, en este artículo se pretende mostrar como los alumnos, al experimentar con las actividades presentadas y como las utilizarán en su futura labor como docentes. También señalaba que hay que potenciar los trabajos prácticos como pequeñas investigaciones, así como la introducción a las nuevas tecnologías $(2004)^{[8]}$. 


\section{MATERIALES Y RECURSOS DIDÁCTICOS}

Desde la perspectiva de F. Mora (2013) $)^{[7]}$ de que "somos lo que la educación hace de nosotros", se presentan un total de siete juegos o actividades impartidos en el aula del MECU y llevados a cabo a fin de que sean los propios alumnos los encargados de valorar la utilidad de estos en el aula de ELE a través de una encuesta realizada a través del correo electrónico institucional de la ULPGC. Los Juegos se recogen en las siguientes tablas:

\subsection{LA ESTRELLA}

\begin{tabular}{|c|c|}
\hline TABLA 1 & Actividad de presentación. \\
\hline Agrupación & La primera parte individualmente y la segunda parte en gran grupo. \\
\hline Duración & 60 minutos (15’ para la expresión escrita y 45’ para la exposición oral). \\
\hline Material & Hojas en blanco con una estrella en el medio que el docente facilitará. \\
\hline Descripción & $\begin{array}{l}\text { Consiste en dibujar una estrella de cinco puntas, escribir el nombre y la edad } \\
\text { en el centro. En cada punta hay que responder uno de los siguientes puntos: } \\
\text { e día más feliz, el día más triste, mis aficiones, un sueño que tengo y explicar } \\
\text { quiénes son mis amigos. Se deberá redactar en una hoja y leer delante de los } \\
\text { compańeros a modo de presentación. }\end{array}$ \\
\hline Objetivos & $\begin{array}{l}\text { Se pretende romper el hielo y conocer al resto de e miembros de clase, así } \\
\text { como generar empatía y crear vínculos con los compañeros. }\end{array}$ \\
\hline Destrezas & Expresión escrita y expresión oral. \\
\hline Contenidos & Función de presentarse, expresar gustos y opinión. \\
\hline
\end{tabular}

Fuente: elaboración propia. 


\subsection{VIDEO DEL HOTEL}

\begin{tabular}{|c|l|}
\hline TABLA 2 & Actividad de originalidad. \\
\hline Agrupación & La primera parte individualmente y la segunda parte en gran grupo. \\
\hline Duración & $\begin{array}{l}40 \text { minutos (10' para la visualización del vídeo dos veces, 20' para la } \\
\text { redacción y 10' para la lectura de los voluntarios). }\end{array}$ \\
\hline Material & Proyector, papel y bolígrafo \\
\hline Descripción & $\begin{array}{l}\text { Se visualiza un vídeo publicitario mudo que tiene un final abierto. El } \\
\text { alumnado debe describir lo que ocurre en el anuncio presentado e intuir como } \\
\text { terminan los personajes que aparecen en el vídeo. }\end{array}$ \\
\hline Objetivos & $\begin{array}{l}\text { Con esta actividad se pretende ver hasta dónde puede llegar la imaginación } \\
\text { del alunado a la hora de crear ellos mismos un final para la historia. }\end{array}$ \\
\hline Destrezas & Expresión escrita \\
\hline
\end{tabular}

Fuente: elaboración propia.

\subsection{LA VACA}

\section{https://lamenteesmaravillosa.com/tirar-la-vaca-al-barranco-una-historia-con-moraleja/ ${ }^{[15]}$}

\begin{tabular}{|c|c|}
\hline TABLA 3 & Actividad de reflexión individual y gestión de las emociones. \\
\hline Agrupación & La primera parte individualmente y la segunda parte en gran grupo. \\
\hline Duración & 25 minutos (5’ para la comprensión lectora de la historia de la vaca y 20 ' \\
\hline Material & Proyector, papel y bolígrafo. \\
\hline Descripción & $\begin{array}{l}\text { A través del cuento de la vaca el alumnado deberá identificar los miedos o } \\
\text { lastres que tengan o hayan tenido en su vida. }\end{array}$ \\
\hline Objetivos & $\begin{array}{l}\text { Con esta actividad lo que se pretende es que el alumno reflexione y } \\
\text { exteriorice sus emociones compartiéndolas, si quiere, con el resto de los } \\
\text { compañeros. }\end{array}$ \\
\hline Destrezas & Expresión escrita y oral e interacción oral \\
\hline Contenidos & Tiempos verbales del pasado y presente, vocabulario, etc. \\
\hline
\end{tabular}

Fuente: elaboración propia. 


\subsection{LA TORRE DE ESPAGUETIS}

\section{https://www.ted.com/talks/tom_wujec_build_a_tower/transcript?language $=e^{[16]}$}

\begin{tabular}{|c|c|}
\hline TABLA 4 & Actividad de motivación. \\
\hline Agrupación & Grupos de 5 realizados a través de un sorteo \\
\hline Duración & $\begin{array}{l}60 \text { minutos (5' para la explicación y las agrupaciones, } 25^{\prime} \text { para la creación de } \\
\text { la torre, } 20^{\prime} \text { para la redacción el texto expositivo y } 10^{\prime} \text { para la puesta en } \\
\text { común). }\end{array}$ \\
\hline Material & $\begin{array}{l}\text { Proyector, papel, bolígrafo, } 20 \text { espaguetis crudos, cinta adhesiva, una nube de } \\
\text { gominola, tijeras y } 1 \text { metro de cordón. }\end{array}$ \\
\hline Descripción & $\begin{array}{l}\text { Esta actividad consiste en la creación de una torre de espaguetis con el material } \\
\text { que el docente facilita a los alumnos). Hay un tiempo límite y gana el equipo } \\
\text { que consiga crear la torre más alta. En terminar, se deberá escribir en un texto } \\
\text { los pasos que se han seguido a fin de construir la torre. }\end{array}$ \\
\hline Objetivos & $\begin{array}{l}\text { Fomentar el trabajo en equipo, la coordinación y el liderazgo en una } \\
\text { competición por ser el equipo que construya la torre de espaguetis más alta. }\end{array}$ \\
\hline Destrezas & Comprensión lectora, expresión oral y escrita e interacción oral. \\
\hline Contenidos & El texto expositivo, signos de puntuación y ortografía. \\
\hline
\end{tabular}

Fuente: elaboración propia.

\subsection{EL GLOBO}

\begin{tabular}{|c|c|}
\hline TABLA 5 & Actividad de motivación \\
\hline Agrupación & Individualmente. \\
\hline Duración & 25 minutos (10' para la reflexión y redacción y 15’ para la puesta en común. \\
\hline Material & Globos y rotuladores. \\
\hline Descripción & $\begin{array}{l}\text { Esta actividad consiste en dar las gracias a través de un globo. Se infla un globo } \\
\text { y se debe escribir en él qué le damos las gracias. Posteriormente cada alumno } \\
\text { comentará de forma oral al resto de los compañeros que ha escrito en su globo. }\end{array}$ \\
\hline Objetivos & $\begin{array}{l}\text { Fomentar la gratitud y la empatía, así como conocer un poco más a los } \\
\text { compañeros }\end{array}$ \\
\hline Destrezas & Expresión escrita y expresión oral. \\
\hline Contenidos & Vocabulario de la familia y del estado de ánimo. \\
\hline
\end{tabular}

Fuente: elaboración propia. 


\subsection{LA LÍNEA DEL TIEMPO}

\begin{tabular}{|c|c|}
\hline TABLA 6 & Actividad de desarrollo. \\
\hline Agrupación & Grupos de 4 personas aleatorias. \\
\hline Duración & $\begin{array}{l}120 \text { minutos (10’ para explicación de la actividad y creación de grupos, 60' } \\
\text { para la búsqueda y creación del mural y 50' para su exposición). }\end{array}$ \\
\hline Material & $\begin{array}{l}\text { Cartulinas, rotuladores, bolígrafos, fotos, dibujos, elementos de decoración, } \\
\text { etc. }\end{array}$ \\
\hline Descripción & $\begin{array}{l}\text { Consiste en recabar información sobre un periodo cultural en el tiempo de } \\
\text { la historia de España (románico, árabe, visigodos, celtas, etc.) y presentarlos } \\
\text { al resto de la clase a través de un mural o cartulina. La temática será asignada } \\
\text { una sesión antes para que el alumnado pueda traer información y material. }\end{array}$ \\
\hline Objetivos & $\begin{array}{l}\text { Fomentar el aprendizaje de la historia del español con los elementos } \\
\text { culturales, así como elaborar contenido didáctico de ELE a través del trabajo } \\
\text { en equipo, así como enfrentarse a perder el miedo de hablar en público. }\end{array}$ \\
\hline Destrezas & Comprensión oral y escrita, expresión escrita, expresión e interacción oral. \\
\hline Contenidos & Historia de Espańa e influencia de las distintas eras históricas. \\
\hline
\end{tabular}

Fuente: elaboración propia.

\subsection{ADJETIVO POSITIVO}

\begin{tabular}{|c|l|}
\hline TABLA 7 & Actividad de motivación. \\
\hline Agrupación & En gran grupo, toda la clase. \\
\hline Duración & 20 minutos (5' para repartir los nombres y 15' para exponerlo). \\
\hline Material & Papel y bolígrafo. \\
\hline Descripción & $\begin{array}{l}\text { Actividad que consiste en definir en un adjetivo positivo a un compañero } \\
\text { de clase y el resto debe de adivinarlo. Se pueden dar pistas. }\end{array}$ \\
\hline Objetivos & $\begin{array}{l}\text { Con esta actividad se pretende general un clima agradable en el aula y } \\
\text { describir las particularidades positivas que tienen nuestros compañeros. }\end{array}$ \\
\hline Destrezas & Expresión escrita y oral e interacción oral. \\
\hline Contenidos & El idioma de las emociones en el aula ELE. \\
\hline
\end{tabular}

Fuente: elaboración propia.

\section{ENCUESTA}

Una vez el alumnado ha trabajado con los juegos en las clases de Destrezas Escritas del MECU, se ha realizado una encuesta a fin de valorar la idoneidad 
de estas propuestas didácticas en la enseñanza de ELE a través de la neuroeducación. La muestra ha sido de un total de 12 alumnos que han respondido la encuesta. Las respuestas fueron las siguientes:

1. ¿Propondrías estas actividades en tus clases?

\begin{tabular}{|l|c|c|}
\hline Sí & 12 informantes & $100 \%$ \\
\hline No & 0 informantes & $0 \%$ \\
\hline
\end{tabular}

2. ¿Cuál es la actividad que más te gustó? Del 1 al 7, en orden de preferencia, de la que más te gustó para impartirla en el aula ELE a la que menos, ordénalas.

\begin{tabular}{|l|l|l|}
\hline Informante 1 & Informante 2 & Informante 3 \\
1. Estrella & 1. Vídeo del hotel & 1. Torre de espaguetis \\
2. Línea del tiempo & 2. Vaca & 2. Estrella \\
3. Vaca & 3. Línea del tiempo & 3. Globo \\
4. Torre de espaguetis & 4. Globo & 4. Línea del tiempo \\
5. Vídeo del hotel & 5. Estrella & 5. Adjetivo positivo \\
6. Adjetivo positivo & 6. Adjetivo positivo & 6. Video del hotel \\
7. Globo & 7. Torre de espaguetis & 7. Vaca \\
\hline Informante 4 & Informante 5 & Informante 6 \\
1. Estrella & 1. Globo & 1. Estrella \\
2. Adjetivo positivo & 2. Vaca & 2. Línea del tiempo \\
3. Vaca & 3. Estrella & 3. Adjetivo positivo \\
4. Globo & 4. Torre de espaguetis & 4. Video del hotel \\
5. Torre de espaguetis & 5. Línea del tiempo & 5. Vaca \\
6. Vídeo del hotel & 6. Adjetivo positivo & 6. Torre de espaguetis \\
7. Línea del tiempo & 7. Video del hotel & 7. Globo \\
\hline Informante 7 & Informante 8 & Informante 9 \\
1. Torre de espaguetis & 1. Adjetivo positivo & 1. Estrella \\
2. Línea del tiempo & 2. Globo & 2. Globo \\
3. Estrella & 3. Línea del tiempo & 3. Vaca \\
4.Video del hotel & 4. Torre de espaguetis & 4. Torre de espaguetis \\
5. Vaca & 5. Video del hotel & 5. Línea del tiempo \\
6. Adjetivo positivo & 6. Vaca & 6. Adjetivo positivo \\
7. Globo & 7. Estrella & 7. Video del hotel \\
\hline Informante 10 & Informante 11 & Informante 12 \\
1. Estrella & 1. Estrella & 1. Globo \\
2. Globo & 3. Gdjetivo positivo & 2. Estrella \\
3. Torre de espaguetis & 4. Video del hotel & 3. Torre de espaguetis \\
4. Adjetivo positivo & 5. Vaca & 4. Video del hotel \\
5. Vaca & 6. Torre de espaguetis & 5. Adjetivo positivo \\
6. Video del hotel & 7. Línea del tiempo & 7. Línea del tiempo \\
7. Línea del tiempo & & \\
\hline
\end{tabular}

3. ¿Ves factible impartir estas actividades en tu país o hay algún elemento cultural que consideres que lo impida?

\begin{tabular}{|l|l|l|}
\hline Sí & 12 informantes & $100 \%$ \\
\hline No & 0 informantes & $0 \%$ \\
\hline
\end{tabular}




4. Qué otro tipo de actividades para el trabajo de la neuroeducación a través de las TIC
propondrías?
\begin{tabular}{|l|l|l|l|}
\hline $\begin{array}{l}\text { Informante } 1 \\
\text { Yincana }\end{array}$ & Informante 2 & Informante 3 & Informante 4 \\
Actividades al & Película sobre & Bingo & Auto-reflexión. \\
aire libre & temas de las & Cluedo en línea. & \\
\hline $\begin{array}{l}\text { Informante } 5 \\
\text { Cadáver }\end{array}$ & Informante 6 & Informante 7 & Informante 8 \\
exquisito. Escape & Escape room. & Control-arte. & - \\
room. & Kahoot. & & \\
\hline Informante 9 & Plickers. & Informante 11 & Informante 12 \\
Escape room & Yincana. Retos. & Canciones. & - \\
\hline
\end{tabular}

Fuente: elaboración propia.

\section{ANÁLISIS DE RESULTADOS}

Una vez volcados los resultados de las encuestas podemos extraer las conclusiones a fin de evaluar la viabilidad de las actividades planteadas en las clases de ELE para mejorar las destrezas escritas.

El $100 \%$ de los alumnos del MECU encuestados afirmaron que sí propondrían las actividades en sus clases cuando sean docentes de ELE. Cabe que destacar que el 16\% de los encuestados, han matizado que propondrían estas actividades adaptándolas al nivel del alumno destinatario, así como el contexto sociocultural y que se dé una atmósfera de confianza para poder tratar las emociones de manera más abierta.

Figura 1. ¿Propondrías estas actividades en tus clases?

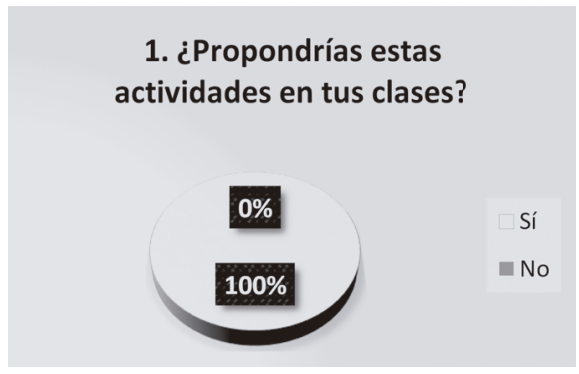

Fuente: elaboración propia. 
La actividad que ha ganado por mayoría, y que más ha gustado a los encuestados ha sido la estrella, con el 50\% de los votos, seguida de la Torre de espaguetis y el globo, con un $17 \%$ de los votos cada uno. En cambio, la actividad que menos ha gustado ha sido, con un $34 \%$ de los votos, el mural de la línea del tiempo, ya que consideraron que es una actividad que necesita trabajo externo a la clase y que es la actividad que menos trabaja la neuroeducación y las TIC. Asimismo, valoraron más las actividades que se realizaban íntegramente en el aula donde poder discutir los diferentes puntos de vista con el docente. En cambio, la segunda actividad que menos gustó, con un $25 \%$ de los votos, fue la actividad del globo, ya que muchos de los encuestados afirman que no siempre hay un buen clima de confianza con el que un alumno pueda expresarse.

Figura 2. Actividad que más ha gustado

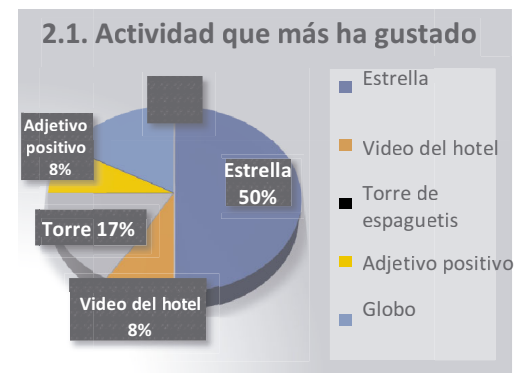

Fuente: elaboración propia.

Figura 3. Actividad que menos ha gustado

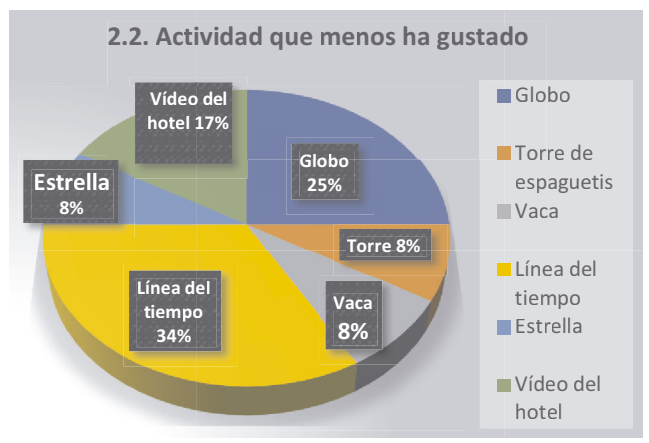

Fuente: elaboración propia. 
El $100 \%$ de los encuestados en su totalidad (12 encuestados) consideraron factible impartir estas actividades en sus respectivos países, teniendo en cuenta que había alumnos españoles, senegaleses, peruanos, mauritanos y alemanes. No obstante, los alumnos senegaleses consideraron que se deberían adaptar los contenidos a la educación y religión del país. Por su parte, un alumno mauritano propuso cambiar los espaguetis por palitos de madera, puesto que en su país jugar con la comida es considerado una ofensa. Así pues, en la metodología neuroeducativa a través de las TIC en la enseñanza de ELE habrá que tener en cuenta la cultura del país.

Figura 4. Factibilidad de las actividades presentadas

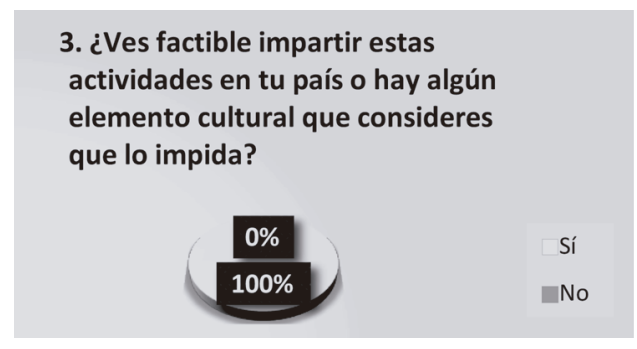

Fuente: elaboración propia.

En cuanto a qué otro tipo de actividades propondrían, el 25\% de los informantes y de forma voluntaria, han respondido que propondrían un Escape room, seguido de un 16\% que propusieron la creación de una yincana. Otras actividades sugeridas fueron, la visualización de una película, un Cluedo en línea, bingo, juegos al aire libre, etc.

Según R. Bisquerra (1989) ${ }^{[3]}$ en su libro de Métodos de investigación educativa, define que hay resultados cuantitativos y cualitativos. En este caso, los cuantitativos serían los porcentajes de los encuestados y los cualitativos las sugerencias y comentarios que se han aportado, así como la sensación de éxito final. En definitiva, a través de la encuesta y de las impresiones de los alumnos, hemos concluido que podemos procurar que nuestro alumnado mejore resultados en el aprendizaje de la lengua si tenemos en cuenta la importancia de los factores afectivos en el aula. 


\section{CONCLUSIONES}

Como resultado de esta investigación podemos colegir que el 100\% de los informantes ha mostrado una actitud positiva hacia las actividades propuestas (las que más: la estrella, la torre de espaguetis, adjetivo positivo, etc.) y que dichos futuros docentes de ELE las aplicarían en sus futuras clases en sus respectivos países de origen. Además, se ha enfatizado en el uso de la TIC para la enseńanza de español en el aula y que, a su vez, tienen los contenidos que propugnan los principios de la neuroeducación.

En la educación del siglo XXI, junto con lo que proponía su precursora Emigdia Repetto, ya no se está teniendo presente tanto lo cognitivo, sino que se busca una dimensión más personal que implique un cambio en la estructura cerebral como son la motivación y socialización de los alumnos(softskills). Sin embargo, somos conscientes de que esta propuesta neuroeducativa se tiene que revisar tras la situación sanitaria actual de pandemia mundial, ya que no se pueden manipular objetos entre varios (los espaguetis, los globos, etc.).

\section{REFERENCIAS}

${ }^{[1]}$ Aguirre Beltrán, B. (2004). Análisis de necesidades y diseño curricular. En: Vademécum para la formación de profesores: Enseñar español como segunda lengua (L2)/lengua extranjera (LE), Madrid, SGEL.

${ }^{[2]}$ Arnold, J. (2015). La dimensión afectiva en el aprendizaje de idiomas, Madrid, Cambridge University Press, 67

${ }^{[3]}$ Bisquerra Alzina, R. (1989). Métodos de investigación educativa. Guía práctica, Barcelona CEC, 236.

${ }^{[4]}$ Latorre, A. (2007). La investigación-acción. Conocer y cambiar la práctica educativa, Barcelona, España, Grao.

${ }^{[5]}$ Prensky, M. (2013). Enseñar a nativos digitales, México, SM Ediciones, 240.

${ }^{[6]}$ Repetto, E. (1984). Una experiencia de didáctica de la física: estudio del tiempo meteorológico. Dialnet, 23.

${ }^{[7]}$ Repetto, E. y Calvo, J.R (2003) La utilización de recursos audiovisuales en la enseñanza universitaria. El Guiniguada, Número 12. 137-148.

${ }^{[8]}$ Repetto, E., Martínez Navarro, F. y Calvo, J.R (2004) La formación científica y la Ley de Calidad. El Guiniguada, Número 13. 95-106.

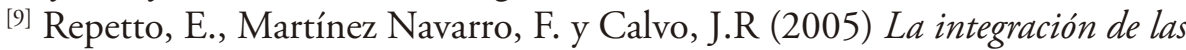
tecnologías de la información y la comunicación en el aprendizaje de Física y Quimica. El Guiniguada. Número 14, 217-230. 
${ }^{[10]}$ Martín Peris, E. (2008). Diccionario de términos clave de ELE. Centro Virtual Cervantes. Recuperado el 11 de octubre de 2020 de: http://cvc.cervantes.es/ensenanza/biblioteca_ele/diccio_ele/default.htm.

${ }^{[11]}$ Mora, F. (2020). Neuroeducación. Recuperado el 9 de octubre de 2020 de: https://www.youtube.com/watch?v=d2Fud46xFPQ/

${ }^{[12]}$ Instituto Cervantes Centro Virtual Cervantes. (2010). Diccionario de términos clave de ELE. Recuperado el 1 de octubre de 2020 de: https://cvc.cervantes.es/Ensenanza/biblioteca_ele/diccio_ele/default.htm.

[13] Instituto Cervantes. (2001). Marco Común europeo de referencia para las lenguas: aprendizaje, enseñanza, evaluación, Recuperado el 28 de septiembre de 2020 de: https://www.cervantes.es/default.htm.

${ }^{[14]}$ Instituto Cervantes (2006). Plan curricular del Instituto Cervantes: Niveles de referencia para el español. Recuperado el 2 de octubre de 2020 de: https://cvc.cervantes.es/ensenanza/biblioteca_ele/plan_curricular/indice.htm

[15] Sánchez, E. (2018). Moraleja De la Vaca. Recuperado el 3 de octubre de 2020 de:

https://lamenteesmaravillosa.com/tirar-la-vaca-al-barranco-una-historiacon-moraleja

[16] TED. (2020). Construye una torre de espaguetis. Recuperado el 1 de octubre de 2020 de:

https://www.ted.com/talks/tom_wujec_build_a_tower/transcript?language $=$ es

[17] VVAA. (2017). Marco Común de Competencial Digital Docente. Recuperado el 4 de octubre de 2020 de:

https://aprende.intef.es/sites/default/files/2018-05/2017_1020_MarcoCom\%C3\%BAn-de-Competencia-Digital-Docente.pdf 



\title{
LA AUTORIDAD. DECONSTRUCCIÓN Y CONSTRUCCIÓN. FAMI- LIAS DE ALTA CONFLICTIVIDAD JUDICIALIZADAS EN CONTEX- TOS DE COORDINACIÓN DE PARENTALIDAD
}

\author{
Fermín Romero Navarro \\ Dr. Ciencias Políticas y Sociología \\ Profesor Titular de Universidad (jubilado) \\ Mediador Familiar \\ Coordinador de la Parentalidad \\ Fundador y Director del Centro de Orientación Familiar de Canarias \\ A mi admirada y estimada amiga Emy Repetto, quien en su vida profesional
no prodigó el poder académico. Más bien, ejerció su autoridad profesional
con la legitimidad intelectual y moral que poseía. Mantuvo siempre
un diálogo transparente y respetuoso. Siempre rehusó el uso del desquite.
}

\section{Resumen}

La autoridad tanto en su acepción genérica como específica referida a la familia no cosecha grandes aplausos en estos tiempos de cambios sociales. La autoridad en la familia está pasando por una crisis que se alarga en el tiempo. Parece que no acaba de encontrar la adecuada adaptación y encaje en la constelación de los nuevos valores que han de inspirar su identidad y funcionalidad social. Especiales dificultades se dan en las familias de alta conflictividad judicializadas, en las que los dos ejes estructurales de la convivencia familiar, las relaciones entre los progenitores y las relaciones paternas y maternas filiales, adquieren porcentajes estadísticos preocupantes. Estas situaciones dificultan la recomposición de la convivencia entre dichos actores familiares, tal como piden con frecuencia los jueces de familias en sus sentencias, que en consecuencia derivan a la Coordinación de la Parentalidad, en orden a que los coordinadores de la parentalidad intervengan profesionalmente. El ejercicio de la autoridad en la familia y los escenarios de intervención en la Coordinación de la Parentalidad son dos espacios que se reclaman en busca de adecuados aportes. El presente capítulo aborda un conjunto de cuestiones afines a la materia mencionada, como son entre otros la crisis de la autoridad como valor social predominante y como dimensión jurídica, la morfología de la autoridad según los diferentes tipos de familias y la influencia que ejercen desde la perspectiva sistémica las ideas implícitas en los diversos comportamientos que se hacen presentes en el ejercicio de la autoridad. 
Palabras clave: Conflicto familiar. Auctóritas. Potestas. Crisis de la autoridad familiar. Deconstrucción. Coordinación de la Parentalidad. Valor social predominante. Tipos de familias. Ideas implícitas.

\begin{abstract}
Authority in both its generic and specific sense referring to the family does not garner great applause in these times of social change. The authority in the family is going through a crisis that lasts over time. It seems that it has not just found the adequate adaptation and fit into the constellation of new values that are to inspire its identity and social functionality. Special difficulties occur in families with high judicial conflicts, in which the two structural axes of family coexistence, the relationships between the parents and the parental and maternal relationships, acquire worrying statistical percentages. These situations make it difficult to reconstruct the coexistence between these family actors, as frequently requested by family judges in their sentences, which consequently refer to the Parenting Coordination, in order for the parenting coordinators to intervene professionally. The exercise of authority in the family and the intervention scenarios in the Parenting Coordination are two spaces that are claimed in search of adequate contributions. This chapter addresses a set of issues related to the aforementioned matter, such as, among others, the crisis of authority as a predominant social value and as a legal dimension, the morphology of authority according to the different types of families and the influence they exert from the systemic perspective the ideas implicit in the various behaviors that are present in the exercise of authority.
\end{abstract}

Keywords: Family conflict. Auctorites. Potestas. Crisis of family authority. Of construction. Coordination of Parenting. Predominant social value. Types of families. Implicit ideas.

\title{
INTRODUCCIÓN
}

El presente tema lleva por título La autoridad. Deconstrucción y construcción. Familias de alta conflictividad judicializadas en contextos de Coordinación de Parentalidad. Es un tema muy afín a la problemática que se plantea en los conflictos de guardia y custodia, régimen de visitas y pensión alimenticia de unidades familiares de alta conflictividad judicializadas, que cada vez más son derivadas por los jueces de familia al modelo de intervención denominado Coordinación de Parentalidad. Dicho tema tiene su complejidad dado el carácter 
multidimensional que le acompaña, como pueden ser la psicológica, la pedagógica-familiar y la jurídica, siendo la perspectiva sociológica la que deseo abordar.

Desarrollaré el tema enunciado al hilo de los siguientes aspectos: 1.- Consideraciones preliminares; 2.- Breves anotaciones de los conceptos de "potestas" y "auctóritas".3.- La autoridad como valor social predominante. Hacia un nuevo modelo de la autoridad en la familia. 4.- Una aproximación al mapa social de la autoridad según tipos de unidades familiares. 5.- Algunas orientaciones prácticas para el ejercicio de la autoridad. 6.- Decálogo para ejercer con "éxito moderado" el ejercicio de la autoridad en la familia.

\section{ALGUNAS CONSIDERACIONES PRELIMINARES}

\subsection{LOS DOS EJES DEL CONFLICTO EN FAMILIAS DE ALTA CON- FLICTIVIDAD}

Los resultados del estudio sociológico sobre 40 casos de familias de alta conflictividad judicializadas (Romero, 2020) ${ }^{1}$, derivados por un grupo de jueces de Gran Canaria al Centro de Orientación Familiar de Canarias durante el año 2019, para ser tratados aplicándoles la orientación e intervención del modelo de Coordinación de Parentalidad, arrojan los siguientes datos de interés para este capítulo:

el conflicto y las tensiones de este tipo de unidades familiares se centran en dos magnitudes bien diferenciadds: tensiones fuertes entre progenitores con el 45\%, y, en segundo lugar, tensiones fuertes de carácter filio-parental con un 32,54\% $y$ tensiones fuertes filio-maternal con un 15\%, lo que suman el $47,54 \%$.

Dichas magnitudes, que en su conjunto suman el 92,54\%, apuntan a los dos ejes que estructuran el mundo interior y relacional de cualquier unidad familiar: las relaciones entre progenitores y las relaciones paterno/materno-filiales. Los resultados mencionados me indujeron a pensar que detrás de los conflictos paterno/materno-filial e interparental existe un componente relacional de capital importancia, que a su vez tiene que ver con el ejercicio de la autoridad. Si es difícil el ejercicio de la autoridad en situaciones familiares "normales", cuán harto difícil lo será en unidades familiares de alta conflictividad.

1 Romero, F. (2020). Dinámica y cambios en familias de conflictividad media y alta judicializadas. Satisfacción y mejoras. Coordinación de parentalidad. Revista de Intervención Psicosocioeducativa en la desadaptación social. Vol. (13), [121.-145]. 


\subsection{CRISIS DE LA AUTORIDAD FAMILIAR}

El tema de la autoridad el "caballo de batalla" en cualquier unidad familiar sobre todo con hijos menores, constituyéndose en un tema muy socorrido en los manuales de psicología de la familia y en la pedagogía familiar. En los tiempos que vienen corriendo, la autoridad no goza de la valoración y pleitesía social de épocas anteriores de cultura tradicional, sobre todo cuando se le considera afín a la organización familiar. La autoridad viene atravesando una importante crisis. Quizás habría que decir que la autoridad siempre ha estado en crisis, aunque hoy se presenta con mayor fuerza y sonoridad social.

El concepto jurídico-familiar de autoridad parental, recogido por el Código Civil Español, también ha entrado en crisis y en un proceso de importante redefinición. La Ley 11/1981, de modificación del C.C. en materia de filiación, patria potestad y régimen económico del matrimonio, eliminó el término "castigar" de la redacción del artículo 154 del Código y mantuvo la facultad de "corregir", si bien de forma "razonada y moderadamente". Sin embargo, la Ley 54/2007, de Adopción Internacional viene a suprimir el término "corregir". En consecuencia, los padres ya no tienen, al menos legalmente, la "facultad" de corregir a los hijos, con lo que el contenido de la patria potestad se encuentra desvirtuado, al menos en uno de sus principales contenidos, como es educar a los hijos $y$ procurarles una formación integral.(Darriba,2012)

No obstante lo indicado, la reforma llevada a cabo, Ley 54/2007, en la que se desterró el término "corregir" del contenido de la Patria Potestad no implica una derogación per se del derecho de corrección de los padres. Lo que supone es que dicho derecho no se encuentra explícitamente recogido en una norma jurídica, que justifique ciertas conductas o ataques desmedidos a la integridad fisica o psicológica de los menores. (Darriba F. Opus cit. Pg.25). Así pues, las recientes reformas legislativas en el ámbito del Derecho de Familia, que reconocen al niño como sujeto y no como objeto de derecho con capacidad natural, no son sino el reflejo de una progresiva realidad, el tránsito desde una conceptualización autoritaria de la familia a una noción como ente pluralista y democrático... basado en un modelo familiar participativo y en el principio del interés superior del niño... (Opus cit. Pg.24).

2 Darriba G.(2012). El derecho de corrección de los padres sobe sus hijos. Revista Digital Facultad de Derecho. Vol. (5) [130.-166]. Recuperado de:

https://dialnet.unirioja.es/servlet/tesis?codigo $=224472$ 
Tanto los cambios socioculturales que se vienen produciendo en torno a la autoridad parental, como los producidos últimamente a raíz de los cambios legislativos arriba explicados, requiere la sustitución del poder de corrección por el derecho de orientación o guia de los progenitores, con la consecuente prohibición de ejercer sobre los hijos cualquier tipo de trato humillante, vejatorio o violento. (Opus cit. Pg. 24). Pero este proceso de sustitución de carácter jurídico-cultural que se reclama, ha resonado con cierta estridencia con ocasión de diversos casos publicitados, que han sido comentados por diversos medios de comunicación social, dejando en un estado de definición imprecisa o ambigua la autoridad paterno y materna. El proceso de sustitución al que nos estamos refiriendo tiene dos partes que se reclaman entre si y que con frecuencia están en pugna, la referida a la perspectiva de los padres y la referida a la perspectiva de los hijos.

La crítica que se hiciera de carácter educativo-familiar y jurídico para una adecuada intervención ante situaciones sancionables o llamativas, referidas al ejercicio de la autoridad, ha de tener en cuenta ambos aspectos del problema. Redefinir la autoridad familiar no es lo mismo que "deslegitimarla" en cuanto institución social básica, pues aunque no se pretenda per se, a veces se consigue efectos sociales no deseados, debido quizá a un tratamiento "puntiagudo" y "unilateral" de una de las partes o actores implicados. La deslegitimación social de las instituciones socaba la estabilidad y cohesión social y genera importantes desorientaciones. En una sociedad de cambios sociales, como las actuales, conviene ofrecer puentes que favorezcan la síntesis e integren la riqueza de las partes diferenciadas o en pugna.

\subsection{LA OBEDIENCIA COMO CORRELATO DE LA AUTORIDAD}

La autoridad no se entiende sin su correlato que es la "obediencia". La obediencia es sin duda una entidad social de carácter milenario, como así lo es también la autoridad. Aparece ya en los consejos que se recogen en el libro del Eclesiástico, escrito probablemente en los años 123 a. C., referidos a la "honra" que los hijos deben a sus padres. San Pablo en varias de sus cartas, Efesios y Colosenses, exhorta a los hijos con estas palabras: hijos obedeced a vuestros padres.

Para el Código Civil Español, el concepto de autoridad tampoco está ajeno al concepto de obediencia. Más bien lo supone, pues a la "autoridad parental" le corresponde la obediencia de los hijos. El contenido de la patria potestad hace alusión al deber para los padres de educar y procurar una formación integral de los hijos... manteniéndose como contrapartida a ese deber, y a los otros que configuran 
la patria potestad, la obligación de los hijos de obedecer a sus padres mientras estén bajo su potestad. (Darriba, F. Opus cit.25-26).

Autoridad y obediencia son dos realidades sociales que se reclaman y que con alta frecuencia entran en pugna. Los cambios de una influyen en la otra. Más bien habría que decir que ambas realidades necesariamente entran en pugna y en recíprocos cambios socio-culturales. La autoridad es pues una institución social milenaria, siempre presente en las organizaciones humanas, cuya finalidad es la de ordenar la vida social tanto en sus dimensiones microsociales como macrosociales. En consecuencia con las consideraciones expuestas hasta el momento se ve conveniente abordar el tema de la autoridad familiar teniendo como contexto social los espacios de alta conflictividad que se hacen presentes en la práctica profesional de la Coordinación Parental.

\subsection{LA “DECONSTRUCCIÓN SOCIAL DE LA AUTORIDAD”}

¿Qué hay de permanente y que hay de transitorio sobre el tema de la "autoridad en la familia”? ¿Qué es lo sustancial y qué es lo accesorio o lo no permanente, percibido en los procesos históricos de los cambios culturales? Estas preguntas, que son fáciles de formular pero muy difíciles de responder, nos llevan a utilizar y a desarrollar en este punto el concepto de "deconstrucción" aplicado a la autoridad en la familia.

El término autoridad concita ciertas ambigüedades e imprecisiones que desfiguran su auténtico sentido y tergiversan el ejercicio correcto de la práctica de la misma. Puede ser importante rastrear en el universo simbólico los pseudoconceptos sobre la comprensión del término autoridad, que sin duda alguna están en relación con los momentos históricos y culturales. Si es así, observaremos que los efectos de esos conceptos referidos al ejercicio de la práctica de la autoridad muestran importantes disfunciones sociales en las relaciones humanas y en especial en la vida ordinaria de las familias. Así pues, se hace necesario "deconstruir" el concepto de autoridad, lo cual permitirá poner al descubierto sus posibles falacias.

El término "deconstrucción" tiene un origen filosófico y literario. Sus inicios se encuentran en la obra Ser y tiempo de Martín Heidegger (1889-1976). Más tarde fue empleado por el filósofo Jacque Derrida ((1930-2004), quien considera que la significación de un texto dado (ensayo, novela artículo...) es el resultado de la diferencia entre las palabras empleadas, y no tanto la referencia a las cosas que ellas representan. La deconstrucción se lleva a cabo evidenciando las ambigüedades, las fallas, las debilidades y las contradicciones de una teoría, 
de un discurso, del ejercicio práctico de una institución social, o de un comportamiento con entidad social. Lo deconstruido, en el marco indicado, queda desmontado. Al desmontar la estructura del lenguaje que utiliza un texto, o un modo de percibir y transmitir las imágenes simbólicas que acompaña a una conducta social aceptada, sus diversas significaciones quedan expuestas. La deconstrucción viene a demostrar que existen múltiples lecturas e interpretaciones posibles. Puede decirse que la deconstrucción se encarga de revisar los conceptos o simbologías acompañantes con la finalidad de descubrir el proceso histórico y cultural que subyace tras ellos. De esta manera se puede demostrar que la claridad aparente de un concepto, de un texto, de la práctica social de una conducta común, no suele ser tal como es presentado.

Deconstruir el concepto de autoridad en su sentido genérico como en el sentido específico de la familia es un buen ejercicio que ayuda a encontrar las dimensiones más certeras de dicho concepto y los errores a superar.

Frente al ejercicio de la autoridad en la familia existen en términos sociales, entre otros posibles, tres comportamientos extremos: el "abandono", debido a múltiples causas, la "imposición” y el "modelo lite". A cada uno de ellos le corresponde un conjunto de ideas y de motivaciones implícitas o de estilos de vida de los progenitores, que se orientan preferentemente al cuidado y protección del menor. Dichos aspectos, ideas y motivaciones implícitas, se desarrollarán en los siguientes puntos a desarrollar. En consecuencia con lo expuesto en estos últimos párrafos, y mirado desde el punto de vista psico-educativo, es conveniente ayudar a los padres participantes en los espacios de intervención de la Coordinación de la Parentalidad realizar un ejercicio de "deconstrucción" del concepto que tienen de la autoridad en su práctica cotidiana. Se trata de ayudarles a identificar y modificar definiciones o conceptualizaciones de la autoridad que no son saludables, ni logran el objetivo de la educación y desarrollo de los hijos y tampoco la satisfacción personal.

\subsection{LA COORDINACIÓN DE LA PARENTALIDAD. CONTEXTO SOCIO-JURÍDICO}

La Coordinación de Parentalidad es un recurso relativamente nuevo y especializado a modo de "auxilio del juez", que surge como ayuda dirigida a las familias de media y alta conflictividad. La conflictividad de estas familias es tan especial e intrincada que dificultan gravemente la ejecución de aquellas sentencias que se orientan a la recuperación de las relaciones paterna y materna filiales, la protección y educación de los hijos y otros aspectos afines a la custodia de los hijos, el régimen de visitas y otras. 
Para el desarrollo de este apartado seguimos aquí algunos párrafos de mi artículo Dinámica y cambios en familias de conflictividad media y alta judicializadas. Satisfacción y mejoras. Coordinación de la Parentalidad. (Romero, F, 2020 Opus cit. Pg.122-124).

La conflictividad familiar, que procede especialmente de los divorcios y separaciones, se presenta compleja e intrincada. Estos entran en una deriva de comportamientos sociales que tiene que ver con un conjunto de hechos, como son la cronificación de la conflictividad, el alargamiento en el tiempo de las tensiones y desavenencias sin que se resuelvan, las reiteradas solicitudes de apelaciones judiciales y el estado de los niveles de media y alta conflictividad, afectando estos comportamientos de forma grave a la organización y convivencia de la unidad familiar, incluso de la familia extensa.

Entre otros, dos son los efectos que en estas circunstancias afectan a la estabilidad y función educativa de estas familias: el "atrapamiento" de los hijos menores en el conflicto de la conyngalidad/pareja de sus padres, condicionado por la ruptura, el alargamiento y enredo en el mismo, generándoles sentimientos encontrados de lealtad; en segundo lugar, y como consecuencia de lo indicado, el resquebrajamiento de la estabilidad y cohesión del necesario "plan de la parentalidad", que nunca debe faltar a favor de la educación de los hijos, sean cuales fueran las condiciones psico-sociales de estos.

Es en las circunstancias descritas donde tiene lugar la Coordinación Profesional de la Parentalidad como un servicio nuevo, específico y necesario para realizar su cometido en concordancia con lo que el juez dictara en la sentencia o auto. Todo lo indicado está en estrecha relación con la convivencia y la comunicación familiar y las funciones educativas de crianza y de tutela de los hijos, especialmente de los menores. En tal sentido, los hijos menores constituyen la primera razón de dicha Coordinación Parental.

La práctica profesional de la Coordinación Parental tiene ya un largo recorrido en Canadá, EEUU, Francia, Holanda y otros paises de tradición divorcista. En diversos puntos de la geografía española también se están dando pasos en esta linea con notable eficacia. La sociedad canaria, por su parte, está necesitada de que se introduzca este nuevo servicio de la Coordinación de la Parentalidad, asi como la figura profesional del Coordinador Parental. El Centro de Orientación Familiar de Canarias (Fundación COF) está liderando esta integración en la sociedad canaria e introduciendo esta nueva práctica profesional en el menú de sus propios programas y servicios. La figura del Coordinador Parental y sus funciones es relativamente reciente. Se inserta en el entramado, siempre complejo e intrincado, de la problemática familiar con el fin de abordar profesionalmente aspectos interrelacionados de carácter jurídico, psicológico y educativo familiar, entre otros, en 
La autoridad. Deconstrucción y construcción. Familias de alta conflictividad judicializadas en ...

un contexto de media o alta conflictividad. El Coordinador Parental es un profesional proveniente de la salud mental, del ámbito jurídico-legal u otras disciplinas afines con formación y experiencia en mediación familiar, asi como en la ayuda a los progenitores que presentan un alto nivel de conflictividad. Asi mismo, ha de tener conocimientos en el desarrollo infantil y en intervenciones en situaciones criticas y de conflictividad para implementar un "Plan de Parentalidad", que ayude a resolver las disputas de las familias en cuestión.

La Associattion of Families and Conciliation Court en 2005 define la coordinación de parentalidad como

"...un proceso alternativo de resolución de disputas centrado en el niño, en el que el profesional de la salud mental o ámbito judicial, con formación y experiencia en mediación asiste a padres con alta conflictividad con tal de implementar el plan de parentalidad" (Esther Alba Ferré, 2020)3.

\section{CARACTERÍSTICAS}

De la citada definición se desprende un conjunto de características que, siguiendo a la autora citada, se puede especificar en los siguientes términos: es un proceso alternativo de resolución de conflictos, centrado en el niño, ordenado a promover la seguridad y estabilidad emocional de éste. Dicho proceso requiere de un profesional formado y con experiencia en mediación. Su actividad se dirige a la implementación del plan de parentalidad con el fin de lograr la mejora en la comunicación y la reducción de la conflictividad inter-parental. Es una "figura auxiliar del juez para garantizar el cumplimiento efectivo de las medidas judiciales" (Costa, 2017) ${ }^{4}$ y como "instrumento de apoyo intensivo y seguimiento familiar de las medidas impuestas después de una sentencia". Asi pues, esta figura debe estar investida de autoridad mediante "designación judicial" y no de la "potestad jurisdiccional". Esta nunca es delegable. En consecuencia, el coordinador de parentalidad ha de acomodar su actuación a lo ordenado por los jueces y a la creación de condiciones favorecedoras de la gestión de la "parentalidad positiva". Para realizar sus funciones ha de estar formado en mediación familiar y en coordinación de parentalidad.

3 Alba, E. (2020). El coordinador parental como mediador ante situaciones de alta conflictividad familiar. En García, M., Cuestiones actuales en materia de mediación, familia y sucesiones. (Pg. 257), Madrid: WoltersKluwer.

4 Costa, M., (2017). Aspectos procesales y prácticos de la derivación a coordinación de Parentalidad. (Trabajo fin de Máster). Recuperado de https://dialnet.unirioja.es/ejemplar/495670 


\section{BREVES ANOTACIONES A LOS CONCEPTOS DE "POTESTAS" Y "AUTÓCRATAS"}

En la Roma clásica se distinguía tres maneras de considerar el poder: el "imperium", la "potestas" y la "auctoritas". (Rodríguez \&Berbell (s.f))5. El "imperium" era comprendido como el poder absoluto propio de los que tenían capacidad de mando como los cónsules y los procónsules. La "potestas" se refería al poder político capaz de imponer decisiones mediante la coacción y la fuerza. Por último la "auctoritas". Ésta se refería a un poder moral, basado en el reconocimiento o prestigio de una persona. Se le asocia a un poder no vinculante, pero socialmente reconocido. Alguien investido de auctoritas era obedecido, no porque pudiera imponer sus decisiones sino porque éstas eran decisiones sabias y justas y su modo de transmitirlas las hacía laudables y aceptables. Las decisiones que dimanan de la "potestas" son obligatorias. Proceden del imperativo de la Ley. La potestas es la Ley, cuyo poder no se cuestiona, se tiene y se ejerce; la auctoritas por su parte no la concede la Ley, se gana a través del reconocimiento social.

\subsection{ALGUNAS CARACTERÍSTICAS DE LA AUTORIDAD}

El significado genuino de autoridad está muy lejos de términos y estrategias claramente reduccionistas como el autoritarismo, la imposición, el uso de la fuerza, la amenaza, la lisonja u otras artimañas. La autoridad es una institución social básica y necesaria. Se ha de considerar como un "derecho social" presente en la comunidad, en la sociedad, destinada al bien común, al control y al desarrollo de las instituciones. Veamos a continuación algunas de sus características.

a) La autoridad se autoexplica como servicio a favor del bien de los destinatarios. La autoridad se orienta siempre de alguna u otra manera hacia el bien común o personal de los destinatarios, en cuanto que su cometido es el de "proteger y satisfacer necesidades básicas", esenciales o necesarias para el bienestar de los actores mencionados. La autoridad no se impone, se ejerce como un servicio. En tal sentido, la autoridad tiene que fundamentarse en lo que es justo, razonable y debe ser razonada.

b) La autoridad se acredita por la dimensión moral que le acompaña. La calidad de la autoridad se mide por la dimensión moral que acompaña al actor que la ejerce, es decir, la coherencia que un individuo muestra en

5 Rodríguez, Y., Berbell, C. (s.f). Confilegal. Noticias Jurídicas y Jurisprudencia. Recuperado de https://confilegal.com/20160105-auctoritas-potestas-antigua-roma/ 
La autoridad. Deconstrucción y construcción. Familias de alta conflictividad judicializadas en ...

sus palabras, sus valores y sus actuaciones. La dimensión moral es la investidura de la autoridad. En tal sentido, de la manera en que una madre, un padre, un maestro o cualquier otro muestra a los demás la forma cómo se conduce, las decisiones que toma, y cómo actúa, se considera que la verdadera fuerza de la autoridad que ejerce se encuentra en la autoridad moral con que vive.

c) La autoridad se asocia a la coherencia de vida. Si al ejercicio de la autoridad no le acompaña la coherencia de vida, es muy fácil tergiversar su sentido, produciéndose entonces la imposición, el autoritarismo, la dictadura o el abandono de la misma. A la persona investida de autoridad se le reclama un modo de vida significativo y ejemplar, capaz de generar en los implicados una expectativa atrayente y fiable.

Las características indicadas se sitúan en el "debe ser" del ejercicio de la autoridad. Con frecuencia, la realidad va por otros caminos, como sucede en algunos padres y madres de media y alta conflictividad, quienes imponen, en medio de sus rivalidades y conflictos, un modelo autoritario o contradictorio del ejercicio de la autoridad, o también el abandono irresponsable del ejercicio de la misma. En tales supuestos, se hace necesario ayudar mediante la intervención en Coordinación de la Parentalidad a redefinir el ejercicio práctico de la autoridad de dichos padres para ser creíbles por sus hijos y recuperar las relaciones familiares saludables.

\section{LA AUTORIDAD COMO VALOR SOCIAL PREDOMINANTE. HACIA UN NUEVO MODELO DE LA AUTORIDAD EN LA FAMILIA}

\subsection{LA AUTORIDAD COMO VALOR SOCIAL}

Los valores son entidades culturales que inspiran y modelan las normas sociales, las costumbres y los estilos de vida. Son como los modelos culturalmente definidos con los que las personas evalúan lo que es deseable, bueno, bello, lícito e ilícito y que sirven de guía para ordenar la vida en la sociedad. (Romero,2012. Pg.160) ${ }^{6}$. Considerando los valores desde el punto de vista cualitativo, unos son "valores centrales" o predominantes y otros son "valores movibles". La menor o mayor presencia en las sociedades de unos y de otros depende en gran

6 Romero, F. (2012). Sociología de la Educación (pg.160).Universidad de Las Palmas de Gran Canaria: Vicerrectorado de Ordenación Académica y Espacio Europeo de Educación Superior Universidad de Las Palmas de Gran Canaria. Primera Edición, 2012. 
medida de un conjunto de factores como son entre oros las corrientes culturales e históricas, el desarrollo de la economía y de la técnica, especialmente de las nuevas tecnologías, como así sucede en el presente momento histórico, la nueva concepción de la mujer y su rol en la sociedad, en la familia y otros espacios. A sociedades agrícolas correspondían unos valores más permanentes que arroparan la estabilidad social, la tradición, como fuente del saber, y el valor de la autoridad como eje que centralizaba y ordenaba las relaciones sociales y la cohesión social.

La autoridad es un valor "eje" de cualquier sociedad, tanto que por sí misma permeabiliza y organiza la vida y el desarrollo de las diversas instituciones sociales, especialmente la familia. Pero tantas veces la autoridad aparece arropada por otra realidad que le suele acompañar, que es el "poder". Poder y autoridad se suelen pisar y confundirse, generando con frecuencia un desorden social, según sean los espacios de vida comunitaria u organizativa a la que nos refiramos.

La autoridad y el poder se hacen presentes en todas las "esquinas" de la vida social, tanto en los espacios macrosociales como en los microsociales. Las familias o unidades familiares constituyen uno de esos espacios microsociales donde la autoridad se asienta y toma posesión. En tal sentido, es comprensible que la autoridad, como entidad cultural, que inspira normas y estilos de vida, también se reviste equivocadamente del poder y experimenta sus propias crisis, rechazos, redefiniciones, cambios y nuevas adaptaciones.

En nuestro devenir social actual cabe mencionar tres factores con peso específico que explican los procesos de redefinición y readaptación de la institución social de la autoridad: La incorporación de la mujer al mundo de lo público, en pie de igualdad con el varón, cuya conquista histórica es de largo recorrido y aún no lograda; Un segundo factor lo constituye la lucha por la igualdad y libertad de los seres humanos como inspiración universal y de primer orden; En tercer lugar, el valor de la democracia como nuevo paradigma y nuevo orden social, necesariamente concomitante a la protección de la dignidad humana y del control del poder.

En las actuales sociedades modernas, definidas por modelos de vida más de corte global y abierto a la multiculturalidad e interculturalidad, los valores permanentes sobreviven en un contexto social definido por la importancia que se le otorga a la entidad social de la "diferencia". El valor de la "diferencia" ha venido a constituirse en un "paradigma social". Este dato social es lo que explica que los valores predominantes actuales entran en liza unos con otros, es decir, que se produzca una situación de confrontación de valores. Vivimos en una sociedad de "valores contrapuestos". Este es el medio social donde actualmente 
se desarrolla y se ejerce la autoridad en las familias. En las sociedades actuales, sobre todo de corte occidental, el valor de la autoridad experimenta definiciones y apreciaciones diferentes y con frecuencia contradictorias, como ya hemos analizado más arriba. El modelo de autoridad de corte tradicional hace tiempo que ha entrado en crisis en el sentido más genuino del término y entra en contradicción con nuevos valores.

\subsection{HACIA UN NUEVO MODELO DE LA AUTORIDAD EN LA FAMILIA. ALGUNAS CONSIDERACIONES}

Se precisa, pues, caminar hacia un nuevo modelo del ejercicio de la autoridad familiar en consonancia con los nuevos valores sociales que se presentan "predominantes" o centrales. Pero aún estamos en un periodo de transición y de adaptación. Dichos valores son, entre otros, la nueva significación cultural de la mujer, ya mencionado, y sus efectos concordantes en la organización familiar, el diálogo como el medio más eficaz para el mutuo entendimiento y la resolución de los conflictos, la progresiva adquisición de la autonomía, la participación activa de los hijos en diversos aprendizajes como, el aprendizaje en el esfuerzo, el trabajo, la propia responsabilidad, la solidaridad, el respeto a las diferencias, el uso adecuado y educativo de las nuevas tecnologías y otros medios afines, etcétera. Veamos algunas características.

a) Un modelo de autoridad que "oriente" y "direccione" a los hijos, más que imponer o dejar al libre albedrio de los mismos, mediando el razonamiento, la conversación, las adecuadas alternativas y otros procedimientos acordes con la autorresponsabilidad y la implicación personal.

b) Un modelo de autoridad familiar que señala progresivamente y sin ambigüedades los limites que no deben ser transgredido, y ofrecer con claridad y progresividad las normas y orientaciones que conducen a la creación y adquisición de hábitos básicos. Estos hábitos serán educativos si ayudan a adquirir el progresivo autocontrol, el esfuerzo, el trabajo, el orden, el respeto, la capacidad reflexiva y crítica y la apertura a la trascendencia humana y espiritual.

c) El ejercicio de la autoridad ha de proceder de la máxima concordancia y acuerdos entre los padres, debiendo ser dialogados con frecuencia. Como exigencia de este proceder, las normas han de ser transmitidas en plural, aún en las situaciones de separación o de divorcio. Este modo de proceder de la autoridad tiene como efectos y virtud la transmisión a los hijos de la claridad, la seguridad y la firmeza de las mismas y el respeto que de esta forma de actuar expresan y demandan los padres. 


\section{UNA APROXIMACIÓN AL MAPA SOCIAL DE LA AUTORIDAD SEGÚN TIPOS DE UNIDADES FAMILIARES}

\subsection{LOS NUEVOS TIPOS DE FAMILIAS}

Son muchos los estudios de carácter sociológico que han abordado los cambios y transformaciones que ha experimentado la familia en la actualidad, sobre todo en las sociedades de cultura occidental. A muchos de esos estudios le acompañan una clara fundamentación y orientación demográfica. En razón de ello se identifican los siguientes tipos o modelos de familias y o de hogares:

— familia nuclear-tradicional "intacta";

— amilias monoparentales;

— hogares unipersonales constituidos por una sola persona, soltera, viuda o separada/divorciada;

- matrimonios sin hijos, debido a la prolongación del tiempo del nido sin usar o del nido vacío;

— parejas de hecho;

— familias reconstituidas o llamadas también ensambladas;

— familias interculturales con presencia física de sus miembros de carácter atípico, debido, entre otras razones, a las distancias geográficas;

- parejas de homosexuales o de lesbianas con o sin hijos adoptados o procreados anteriormente por uno de los miembros de la pareja.

No todos los llamados nuevos tipos de familia, como las familias monoparentales y las reconstituidas, o parejas de hecho, pueden recibir, en el sentido estricto, el calificativo de "nuevo", pues, de alguna forma, estos tipos de familia siempre han existido.

La "novedad" en la emergencia del pluralismo familiar - y su singularidadproviene de tres circunstancias, según Iglesias de Ussel, (2001). 4): 1): Por su simultaneidad: todas estas modalidades crecen- y crecen aceleradamente- al mismo tiempo en las décadas de los años noventa y en la primera del nuevo siglo veintiuno; 2) Por su coincidencia con el descenso muy brusco y rápido de la nupcialidad, que ha sido históricamente el principal procedimiento para articular la vida familiar; 3) Por la reivindicación de la legitimidad en pro de las mismas, es decir, por el requerimiento en obtener "carta de ciudadanía" en pie de igualdad con la familia tradicional. Gran parte de estas dinámicas generan nuevos problemas, como por ejemplo la feminización de la pobreza, o la llamada centralización de la maternidad. En tal sentido, se requiere la intervención estatal para atenuar los efectos negativos para los ciudadanos, empezando por 
los menores, que son los más afectados, y se precisa impulsar medidas orientadas a la conciliación y compatibilidad entre las responsabilidades y los roles profesionales-laborales y los familiares (Iglesias, 1997). ${ }^{7}$

Aunque sea de interés desde el punto de vista sociológico, no es mi intención entrar en los múltiples factores que explican la emergencia de las citadas nuevas formas de familia, dado el corto espacio del que se dispone.

Sería un error grave tratar buscar cuáles de los modelos de familia son los más proclives a generar disfunciones en las formas de realizar la autoridad, como si tal ejercicio tuviera como objetivo enfrentarlos con el modelo de familia nuclear-tradicional. Pero también sería un error no identificar las peculiaridades que cada modelo de familia o algunos de ellos presentan en referencia al desarrollo de la autoridad, teniendo en cuenta la singularidad de cada tipo de familia. Tal interés se justifica si los resultados se tradujeran en políticas de prevención y en otras de carácter terapéutico. En el sentido indicado, se expone más abajo algunos rasgos o perfiles de algunos de los modelos familiares citados.

\subsection{IDEAS Y MOTIVACIONES IMPLÍCITAS EN EL EJERCICIO DE LA AUTORIDAD}

En las instituciones sociales que rodean de forma inmediata la vida cotidiana, como es el caso de la autoridad en la familia, existe un mundo ordenado de significados compartidos que las organizan. Son modos de actuar e ideas, las más de las veces implícitas, junto con otros elementos como las leyendas, las máximas, los proverbios, el lenguaje, etcétera, con los que se aprehende mentalmente la realidad, se le da entidad o cuerpo social y se comparte socialmente. La realidad es social en cuanto que es una construcción social que ejerce un cierto poder coercitivo, generando las acciones o comportamientos sociales. La "construcción social de la realidad" fue estudiado por los científicos sociales Thomas Luckmann y Peter L. Berger en su obra la construcción social de la realidad, (1966). La realidad se construye socialmente y la sociología del conocimiento analiza los procesos por los cuales estos producen la realidad. En el sentido indicado, existe en torno a la autoridad en la familia un conjunto de ideas implícitas que, conociéndolas y analizándolas, se puede comprender cómo llegan a tener cuerpo social, existencia social en los espacios de la familia. A las ideas implícitas les acompañan motivaciones también implícitas que las dinamizan.

7 Iglesias, J. (2001).La política familiar en España. Ed. Barcelona. Ariel. 
La explicación del presente apartado supone una doble consideración: Primera: el ejercicio de la autoridad es un "aprendizaje social”. Este está imbuido no solo de aquellas características que le son propias, sino de un conjunto de ideas y motivaciones implícitas, muchas de las cuales tienen tras de sí un largo recorrido histórico, como pueden ser las imágenes de autoridad que nuestros padres nos proyectaron en nuestra infancia, los tópicos sociales que le acompañan y otras experiencias vitales habidas en el transcurso de la vida de cada cual. Segunda: la importancia de las ideas y motivaciones implícitas estriba en el "poder coercitivo e implícito" que las mismas encierran en sí, en virtud delo cual se imponen a modo de fuerza inconsciente en el ejercicio práctico de la autoridad. Además de lo explicado, se ha de entender la autoridad como una norma socia a la que se le atribuye una doble expectativa o proyección: una, la imagen social de mayor o menor reconocimiento o prestigio social por parte de quien la realiza, y, segunda, la expectativa a la que se ha de responder y que a la vez se cree necesario que el destinatario ha de recibir.

Los razonamientos precedentes tratan de fundamentar la importancia y la necesidad de conocer y analizar las ideas y motivaciones implícitas que rodean u organizan el ejercicio de la autoridad en la familia en la vida ordinaria. Dicho conocimiento pueden ayudar al coordinador parental en sus intervenciones con familias conflictivas en las que es necesario ayudar a redefinir la autoridad en la familia, para lo cual se propone en el apartado siguiente un modelo explicativo.

\subsection{UN MODELO EXPLICATIVO DE LA DINÁMICA QUE SE PRO- DUCE EN EL EJERCICIO ORDINARIO DE LA AUTORIDAD EN LA FAMILIA DESDE LA PERSPECTIVA DE LAS MOTIVACIONES E IDEAS IMPLÍCITAS}

A continuación, se expone un modelo explicativo de cómo actúan las ideas y motivaciones implícitas en el ejercicio cotidiano de la autoridad en la familia, utilizando para ello las dos imágenes siguientes: 


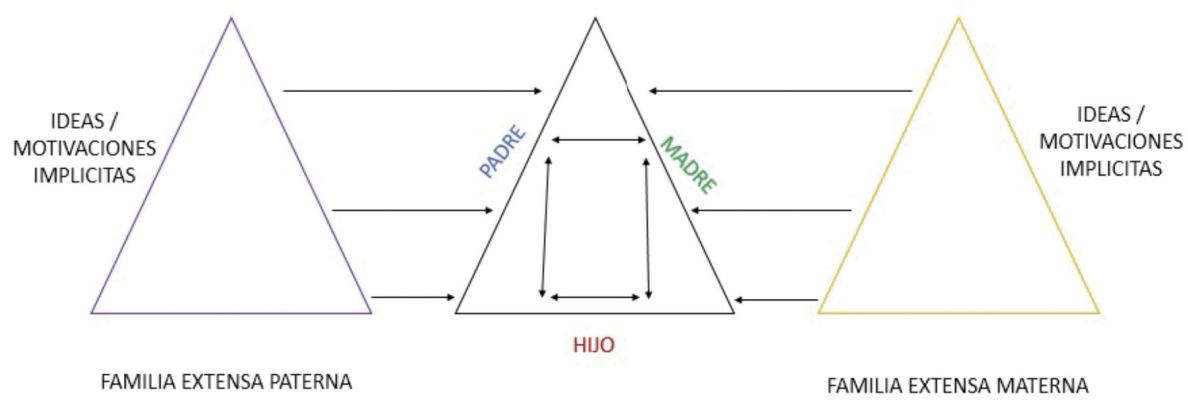

Fuente: elaboración propia.

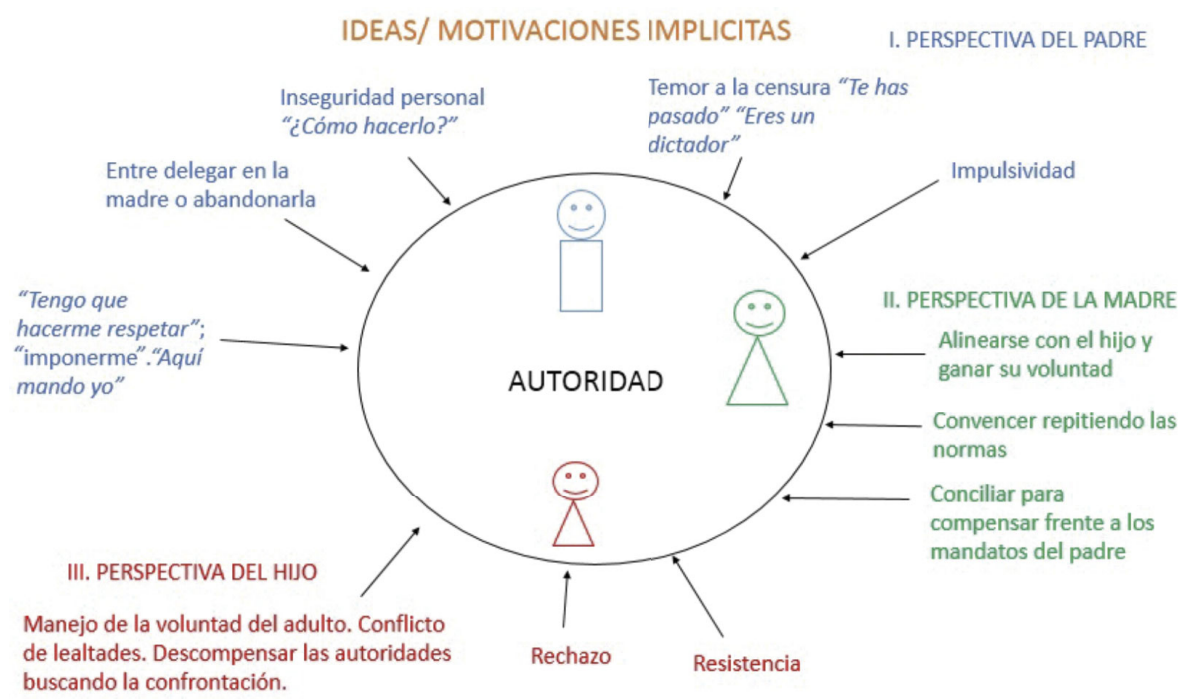

Fuente: elaboración propia.

\section{Explicación de las dos imágenes presentadas}

\section{Primera imagen}

La consideración sistémica de la familia nos permite comprenderla como una red de relaciones de múltiples direcciones entre los actores de la misma, que se producen necesariamente tanto entre los actores del núcleo de la familia de procreación, como en relación a la influencia que ejercen las familias de ori- 
gen y extensas de ambas partes de los progenitores. Dicha consideración se visualiza en la imagen de los tres triángulos. Si a esta imagen se le añade un nuevo triángulo por cada extremo de la misma, nos representará la complejidad que revisten las influencias procedentes de las mismas, como sucede en el caso de las "familias reconstituidas". Dicha imagen nos permite contextualizar qué dinámica se produce en el ejercicio de la autoridad y de dónde pueden proceder las motivaciones e ideas implícitas que le acompañan.

\section{Segunda imagen}

La segunda imagen se centra en las relaciones que se producen en la familia nuclear de procreación. Con dicha imagen se pretende visualizar cuáles son o podrían ser las ideas y motivaciones implícitas que acompañan al ejercicio de la autoridad. A cada actor de la unidad familiar le acompaña un color distinto, una perspectiva diferente y unas posibles manifestaciones diferentes, en orden a señalar la complejidad que manifiestan las ideas y motivaciones implícitas en el ejercicio de la autoridad familiar. Una de las virtualidades de la presente imagen es que puede ser recreada por parte de los actores de unidades familiares en los contextos de intervención de la Coordinación de la Parentalidad. Permite identificar qué ideas y motivaciones implícitas pueden explicar la autoridad en la familia y cuáles pueden ser los cambios pertinentes.

\subsection{ALGUNAS PECULIARIDADES DE LA AUTORIDAD SEGÚN MO- DELOS DE FAMILIAS}

Las sentencias y autos remitidos por los jueces y derivados a Coordinación de la Parentalidad piden la intervención de los técnicos con el fin de lograr la recomposición de las relaciones interparentales y paterno-filiales. Dichas relaciones se presentan conflictivas, enmarañadas y que afectan en un primer momento y de forma más inmediata a los tres tipos de actores implicados: el padre, la madre y el hijo o hijos. La recomposición de dichas relaciones tiene que ver con frecuencia con el régimen de visitas, la custodia de los hijos, sea unipersonal o compartida, así como con las relaciones con la autoridad familiar y otros afines.

Los tres actores de la unidad familiar mencionados están mediatizados sistémicamente por algunas de las situaciones o condiciones siguientes:

a) La separación/divorcio conflictivo, mediando un duelo no resuelto y desavenencias por motivos patrimoniales.

b) Los enfrentamientos, desacuerdos, sentimientos e intereses emocionales no resueltos, criterios diversos y con frecuencia contrapuestos de carácter educativo y normativo. 
La autoridad. Deconstrucción y construcción. Familias de alta conflictividad judicializadas en ...

c) La presencia de nuevas parejas que se convierten en actores significativos frente a la ausencia o no del otro progenitor.

d) El mensaje o la palabra que proyecta la "presencia ausente" de la expareja y o del padre o de la madre.

e) La aparición de nuevas relaciones entre hermanastros condicionadas por la edad de estos, lugar de residencia, la habitabilidad de la nueva vivienda y la adecuada privacidad que se requiere.

f) La edad de los hijos según el ciclo vital de los mismos.

g) El medio-ambiente: el hábitat ordinario, cambiante o no, según el régimen de visitas, la privacidad que ofrece la vivienda, el uso de las nuevas tecnologías, la influencia de los grupos de iguales, el rendimiento escolar, etc.

Ante el panorama brevemente descrito en este apartado es conveniente registrar algunos rasgos que manifiestan los padres en las familias de alta conflictividad respecto al ejercicio de la autoridad, pudiendo distinguirlo desde la perspectiva de los padres y desde la perspectiva de los hijos. Éstos pueden ser las siguientes:

\section{Primero. Tipos de autoridad desde la perspectiva de los padres:}

a) Autoridad diluida o difusa unas veces, contestada o mediatizada por el enfrentamiento entre los actores implicados otras veces.

b) Autoridad mediatizada por los conflictos que se cronifican entre los actores implicados.

c) Autoridad percibida como deslegitimada o "intrusa" por la presencia de una nueva pareja de uno de los dos progenitores o de ambos.

d) Autoridad abandonada que genera el cansancio de los conflictos que se alargan sin resolver o por irresponsabilidad de uno de los progenitores.

\section{Segundo. Tipos de autoridad desde la perspectiva del hijo:}

a) La autoridad se percibe, se interioriza y es "manejada" en medio del conflicto de lealtades.

b) Autoridad rechazada o deslegitimada sobre todo cuando la misma proviene de forma impositiva de la nueva pareja.

c) Autoridad contestada o manipulada a criterios o intereses implícitos de los hijos dependiendo con quién de los progenitores establece las rivalidades.

d) Autoridad del padre ausente que se pretende sustituir por parte de uno de los hijos, que con frecuencia suele ser el hermano mayor. 
Estos y otros tipos referidos al ejercicio de la autoridad en los espacios de familias conflictivas y judicializadas se convierten en problemas, dificultades y en cuestiones a reflexionar desde el punto de vista de la Orientación Familiar. En consecuencia, se hace necesario abordar tales cuestiones en la práctica profesional de la Coordinación de Parentalidad, lo que supone intervenciones orientadas a introducir redefiniciones y modificaciones en la misma.

\section{ALGUNAS ORIENTACIONES PRÁCTICAS PARA EL EJERCICIO DE LA AUTORIDAD}

Las orientaciones prácticas que se desarrollan brevemente a continuación están pensadas no solo para padres y familias de alta conflictividad sino para aquellos padres que en el ejercicio de la autoridad pasan por momentos de cambios propios de los procesos evolutivos, sobre todo de los hijos u otros momentos. Tales orientaciones se han de comprender en términos de "generalidad", a falta de la concreción que cada caso así lo requiriera.

a) Las normas que dan los padres a los hijos han de ser claras, precisas, cumplibles y ajustadas al ciclo vital de los hijos y no siendo excesivas. Así mismo, han de ser dadas en el lugar o lugares más apropiados y en consonancia tanto al respeto de los hijos como al respeto de la autoridad de los propios padres.

b) Las normas han de ser transmitidas de forma razonada cuantas veces lo necesitaran los hijos, pero cuya repetición no rebase la prudencia.

c) Las normas han de ser previamente pensadas, dialogadas y acordadas por ambos padres estén o no separados o divorciados, o por otros responsables de los hijos.

d) Las normas han de ser transmitidas en "plural", de tal forma que expresen la decisión compacta de ambos padres y la expresión inequívoca de que ambos forman el "equipo de padres". Este equipo ha de ser inalterable, debiendo no incurrir en la doble imagen del "poli malo" y del poli bueno". Si fuera así, las estrategias del hijo para doblegar la voluntad de uno de los dos y los chantajes correspondientes a tal fin tendrán ya su victoria servida. En tal sentido, ambos padres han de observar y estar atentos a la posible aparición de los comportamientos indicados de los hijos, para no dejarse "intimidar" y ser "embaucados", cayendo en la red de la "división" y "contraposición" de la autoridad.

e) Las normas han de orientarse a la adquisición de hábitos saludables que corrijan comportamientos irregulares o peligrosos para la buena educación. 
La autoridad. Deconstrucción y construcción. Familias de alta conflictividad judicializadas en ...

En consecuencia, la adquisición de los hábitos básicos tiene sus principios en temprana edad.

f) Las normas y criterios educativos no han de proceder después de una "corrección airada", ni nunca acompañando a las mismas cualquier descalificación o vejación de los hijos. La autoridad de los padres aumenta la influencia y "prestigio" en los hijos si por lo común se dirige siempre a los mismos de forma respetuosa, sin faltar a la percepción de su identidad.

g) A veces, en situaciones de conflicto entre padres e hijos en las que uno de los dos progenitores ha sido el que siempre ha dado las normas, conviene que por un tiempo sea el otro progenitor quien tome la delantera, pero dichas normas han de ser transmitidas en plural y en presencia de ambos padres, pues se trata de fortalecer ante el hijo que la autoridad dimana del "equipo de padres", que ambos forman.

\section{DECÁLOGO PARA EJERCER CON ÉXITO “MODERADO” LA AU- TORIDAD PARENTAL}

A modo de síntesis y de orientación general, he creído conveniente ofrecer a continuación un decálogo del buen ejercicio de la autoridad familiar, que puede ser válido tanto para unidades familiares de alta conflictividad como para cualquier tipo de familia.

1. La autoridad de la unidad parental se construye y se ejerce en un medio familiar de "coeducación" entre sus miembros, evitando siempre el uso de la prepotencia y de toda clase de humillación y vejación. La autoridad no ha de imponerse, sino que se legitima. No se divide ni se agrieta entre los progenitores.

2. La autoridad de la unidad parental no ha de ser arbitraria, ni motivada por la impulsividad.

3. La autoridad de la unidad parental siempre ha de ser justa, razonable y razonada. Ésta será así cuantas veces los hijos lo necesitaran, en principio.

4. La racionalidad de la autoridad de la unidad parental se ha de fundamentar en las "necesidades" de los hijos, que han de cubrir y satisfacer los padres.

5. La autoridad de los padres es un "deber", cuya ausencia limita y empobrece el desarrollo de la personalidad de los hijos. Estos tienen "derecho" al ejercicio de una autoridad parental que les humanice y direccione sus vidas.

6. La autoridad de la unidad parental se ha de ejercer ajustándose al desarrollo del ciclo vital de los hijos. 
7. La autoridad de la unidad parental se ha de ejercer con pedagogía desde los inicios del desarrollo evolutivo de los hijos, ayudando a adquirir hábitos y comportamientos saludables y señalando con claridad los límites que no serán traspasados.

8. La autoridad de la unidad parental se ha de nutrir entre los progenitores de una constante "co-construcción" de aquellos "contenidos", normas, límites y criterios educativos, que son necesarios para para "direccionar" y "orientar" la vida de los hijos y el desarrollo de su personalidad.

9. La autoridad de la unidad parental siempre ha de proceder de una decisión acordada y compartida por los progenitores, utilizando y proyectando en su ejercicio cotidiano el lenguaje del "nosotros", es decir, "tu madre y yo.", "tu padre y yo hemos acordado y decidido que..."

10. La autoridad de la unidad parental ha de vigilar y alertar los conatos de solapadas alianzas y conflictos de lealtades originados en el seno familiar y en su entorno.

Nota FinAL: Estas reglas se "encierran en dos": 1) Amarás a los hijos como son cada cual, confiando y alentando siempre y corrigiendo más pocas que muchas veces; 2) Serás paciente y aprenderás gracias a ellos a saber esperar nuevas oportunidades, que les favorezcan para su felicidad y el desarrollo armónico e integral.

\section{BIBLIOGRAFÍA}

Alba, E. (2020). El coordinador parental como mediador ante situaciones de alta conflictividad familiar. En García, M., Cuestiones actuales en materia de mediación, familia y sucesiones. (Pg. 257), Madrid: WoltersKluwer.

Costa, M., (2017). Aspectos procesales y prácticos de la derivación a coordinación de Parentalidad. (Trabajo fin de Máster). Recuperado de: https://dialnet.unirioja.es/ejemplar/495670

Darriba G.(2012). El derecho de corrección de los padres sobe sus hijos. Revista Digital Facultad de Derecho. Vol. (5) [130.-166]. Recuperado de: https://dialnet.unirioja.es/servlet/tesis?codigo $=224472$

Iglesias, J. (2001). La política familiar en España. Ed. Barcelona. Ariel.

Rodríguez, Y., Berbell, C. (s.f). Confilegal. Noticias Jurídicas y Jurisprudencia. Recuperado de:

https://confilegal.com/20160105-auctoritas-potestas-antigua-roma/

Romero, F. (2020). Dinámica y cambios en familias de conflictividad media y alta judicializadas. Satisfacción y mejoras. Coordinación de parentalidad. 
La autoridad. Deconstrucción y construcción. Familias de alta conflictividad judicializadas en ...

Revista de Intervención Psicosocioeducativa en la desadaptación social. Vol. (13), [121.-145].

Romero, F. (2012). Sociología de la Educación (pg.160). Universidad de Las Palmas de Gran Canaria: Vicerrectorado de Ordenación Académica y Espacio Europeo de Educación Superior Universidad de Las Palmas de Gran Canaria. Primera Edición, 2012. 



\title{
UN DECÁLOGO SOBRE LAS FRASES HECHAS A PARTIR DE UN DICHO PATERNO
}

\author{
Victoriano Santana Sanjurjo \\ IES José Zerpa. Gobierno de Canarias
}

\begin{abstract}
Resumen
A partir de una locución inédita ("Pa'una cabra partía, un macho corcovao") se analizan sucintamente las características de las frases hechas. A las cualidades habituales que recogen los especialistas sobre estos discursos repetidos (anonimia, popularidad, oralidad, unidad semántica breve, sentido metafórico, significado no deducible, idiomaticidad y dificultad para su traducción) se añaden dos (actitud y comodidad), conformando así una suerte de decálogo que, en última instancia, aspira a la concienciación de los docentes sobre la importancia que deben dar al conocimiento de estas estructuras lingüísticas para que puedan ser asimiladas, conocidas y manejadas con eficacia por el alumnado que estudia lengua española.
\end{abstract}

Palabras clave: modismos, dichos, locuciones, frases hechas, enseñanza primaria, enseñanza secundaria, Lengua Castellana y Literatura.

\begin{abstract}
From an unpublished expression (" $P a$ 'una cabra partía, un macho corcovao") characteristics of idioms can be briefly analysed. In addition to the usual qualities that specialists claim about these set expressions (anonymity, popularity, orality, brief semantic unit, metaphorical sense, non-deductible meaning, idiomaticity and difficulty for their translation) two other ones should be added (attitude and comfort). All of them compose a kind of decalogue for teachers to raise awareness ultimately about the importance they should give to the knowledge of these linguistic structures, so that they can be assimilated, known and handled effectively by students of Spanish language.
\end{abstract}

Keywords: idioms, sayings, phrases, set phrases, primary education, secondary education, Spanish Language and Literature.

"Pa' una cabra partía, un macho corcovao». Esto es lo que solía decir el padre de quien firma este artículo cuando quería apuntar que a una situación mala ("cabra partida") le seguía otra que no era buena ("un macho corcovado"). La 
frase caló tanto en la conciencia lingüística de su hijo que hoy en día la reproduce siempre que se encuentra ante un problema que parece arrastrar consigo otro. Es lo que diría, verbigracia, si un día le ponen una multa de tráfico (un contratiempo) y, de regreso a casa, tiene un accidente con el vehículo (otro percance).

Se desconoce el origen de la expresión y si en su gestación cabe atribuir algún mérito a su padre, ya que solo se la oyó decir a él. En este sentido, es posible afirmar y negar su autoría con idéntico rigor. Esta incertidumbre es la misma que se tiene con muchas de las entradas que se recogen en repertorios sobre modismos antes de saber más acerca de cada uno de ellos. ${ }^{1}$ Si en medio de una conversación se hubiese dicho alguna de las fórmulas expresivas que se reproducen en estos libros, no es descartable el que se pueda dar la duda de si es una invención del interlocutor o, por el contrario, si forma parte de una tradición lingüística. Mas no estamos ante una ignorancia que afecte a la función que debe realizar la expresión fija que se haya empleado, pues lo relevante en estos casos es captar su sentido completo y, en consecuencia, su pertinencia dentro del discurso.

A la condición ignota del cuándo (el origen) y del quién (la autoría), cabe añadir el dónde, o sea, la determinación de si es correcto ubicar el enunciado inicial ( $y$ tantos afines que el progenitor utilizaba) en el acervo y la variedad del español de Canarias a la que pertenecía.

La iniciativa [aquella que dará pie a la expresión fija] puede surgir en cualquier latitud, pero el ambiente favorable para su arraigo, vitalidad y propagación no se da en todos los pueblos ni siquiera de manera uniforme en los varios sectores de una comunidad lingüística. (Casares, 1992, p.219).

Cabe preguntarse si sería relevante para el trazado de un posible perfil de hablante isleño de "discursos repetidos» o de «trozos de discurso ya hecho y que se pueden emplear de nuevo", como denomina Coseriu a este tipo de frases

1 Trapero, en su reseña sobre la obra de Ángel Sánchez, citada en la bibliografía de este trabajo, da cuenta de algunas referencias que, como la del galdense, abordan el tema de los dichos canarios: Orlando Hernández con Decires canarios; Cristóbal Barrios y Ruperto Barrios Domínguez con Una crónica de La Guancha a través de su refranero; "y mucho antes que todos ellos, en el siglo XIX, lo habían hecho Sebastián de Lugo, José Agustín Álvarez Rixo y Elías Zerolo, entre otros, aunque los vocabularios de éstos no fueran estrictamente y sólo de "dichos"» (1994, p.498). A estos títulos habría que añadir Dichos y modismos de Canarias de Luis Rivero (Mercurio Editorial, 2019). 
(1981, p.113), algunas de las características personales de nuestro emisor que más pueden incidir en su vertiente de hablante dialectal: el que no tuviera estudios, aunque no fuera analfabeto; el que estuviera sujeto toda su vida, como sus antepasados, a los límites geográficos de Telde y, por extensión, a los que marcan el sureste grancanario; el que jamás dejara de estar vinculado de manera activa y emocional con todo lo que tenía algo que ver con el mundo rural; y que fuera, atendiendo a la perspectiva de la lengua oral, gran amigo de conversadas. ¿¿Son estas particularidades o sus pequeñas variantes las que permiten atisbar un perfil de usuarios de la lengua que, con sus actos de habla, han logrado la pervivencia de buena parte de los dichos canarios que conocemos?

Entre tanto desconocimiento, una certeza, vinculada en este caso con el cómo: el hablante adoptaba siempre una actitud tan sentenciosa y contundente en la formulación de la frase de marras, perceptible por el tono que empleaba, que era inevitable pensar, por un lado, en la inexistencia de un modo alternativo de informar sobre el qué (los dos daños) haciendo uso del modismo y, por el otro, en que lo importante de su empleo dentro del proceso comunicativo no estaba tanto en lo que quería decir, sino en cómo lo quería decir, "potenciando así el carácter ambiguo y polivalente del mensaje» (Barsanti, 2006, p.200). Pensemos ahora en esa muesca que queda marcada en la conciencia lingüística de los receptores cuando un enunciado como el que nos ocupa se deja caer en el discurso: ya nada parece cuestionable, solo hay hueco para deducir que el acto informativo ha terminado o debe ir por otros derroteros.

Es posible que esta cualidad conclusiva de las frases hechas se deba a esa esencia poética que las envuelve, a ese aroma a cita literaria que desprenden estas unidades (Coseriu, 1981, p.115) y que consigue que la expresión se transforme en un ejercicio retórico eficaz a la hora de deleitar y, sobre todo, de persuadir; en buena medida, por lo sujeta que está a la idiosincrasia de una comunidad forjada a través del tiempo:

El refrán, el dicho, se ha refugiado desde hace mucho — como toda la cultura de tipo tradicional — en los ámbitos más apartados de la sociedad, en los medios rurales y en el uso de las gentes menos letradas. Ahí, en esos ámbitos, ha podido seguir manteniendo su carácter predominantemente oral, propio de una "cultura" que, por "popular", ha sido menospreciada por la cultura dominante, sin comillas de ningún tipo, urbana y escrita. Puede decirse entonces que el refrán es la cita del que carece de cultura, "la retórica del iletrado". Y así, a medida que la instrucción pública, urbana y escrita, fue progresando el prestigio de los refranes fue decayendo hasta la estigmatización. (Trapero, 1994, p.509). 
La analogía con otras fórmulas expresivas y, sobre todo, la actitud apuntada conducen a plantear que la suya es una locución que participa de las características más representativas de las frases hechas, a saber:

1. Su origen anónimo, que será, a tenor de lo que afirma Cejador (1921), el sustrato de su carácter popular:

Aunque alguien fue el primero que formó la expresión, era tan conforme al modo de sentir y pensar de todos, que todos la aceptaron y aun probablemente la fueron reformando poco a poco, hasta el punto de que el autor quedó anónimo, siéndolo ya de hecho el pueblo que se la apropió y aun la mejoró. (p. 9)

2. Su base popular. Un colectivo, con la suficiente receptividad psicológica en un determinado momento, consigue que prosperen ciertos hallazgos individuales y anónimos en forma de asociaciones imaginativas (Casares, 1992 p. 219). Esa prosperidad conlleva adueñarse de la expresión, hacerla suya, sumarla al acervo que identifica al grupo: «la lengua de un pueblo manifiesta la forma de ser de ese pueblo» (Trapero, 1994, p.501).

3. Su uso oral, que dio pie a su origen, que fundamentó su base y que, de alguna manera, representa su pervivencia en tanto que expresión de identidad colectiva:

De la conversación familiar brotan como las chispas de la hoguera, y conservan muchos y valiosos datos para escribir algún día la historia interna del pueblo espańol; porque los elementos que los componen son el hecho histórico, el dicho agudo, el juego, la costumbre y la ceremonia religiosa. (Montoto, 1888, p.8).

4. Su condición de unidad semántica breve, a la que señala Gili (1958) cuando indica que la economía del modismo implica que las palabras pierdan su individualidad para servir a los valores colectivos; «o bien, si alguna de ellas tiene fuerza para tanto, levantarse con el santo y la limosna, y llevarse por sí sola toda la carga semántica de la frase». (p.92)

5. Su sentido metafórico, que promueve la percepción de la pieza lingüística como una forma de la "literatura" en el más amplio sentido, o sea, atendiendo a los componentes ideológicos, morales, etc. (Coseriu, 1981 p.115). La cualidad literaria de estas piezas supone reconocer en quienes dieron con ellas, como señala Cejador (1921), la condición de «altísimo 
poeta», que viene a quedar demostrado con la ingente cantidad de figuras retóricas, "que se despilfarran en ellas a montones» (p.25).

6. Su significado no es deducible, sino que proviene del conjunto, lo que implica que los elementos que componen la expresión no puedan ser reemplazados (Coseriu, 1981, p.113). Se utilizan las frases hechas tal y como se toman del acervo común del idioma, sin que sea posible adaptación gramatical alguna (Cejador, 1921, p.10). Benot (1899), sobre la autonomía significativa, identifica las piezas como la unión de dos elementos que da pie a un tercero con autonomía propia. Pone para ello el ejemplo del oxígeno y el hidrógeno, dos gases que nada tienen que ver con el resultado de su combinación, el agua (p.10).

[...] dichos, modismos, refranes, locuciones, frases hechas, sentencias, aforismos, tópicos, adagios, apotegmas, máximas son algunas de las palabras traídas y llevadas en los diccionarios y en la conversación ordinaria, sin fijar a cada una un contenido preciso, que tampoco los estudiosos han puesto mucho interés en deslindar, tal vez por la inasible condición de la materia a que se refieren. Las expresiones a las que atañen estos términos componen un vasto repertorio inclasificable no sólo desde el punto de vista formal, sino también desde el semántico. (Barsanti, 2006, p.198).

7. Su idiomaticidad. Son estructuras formales fijas que están ligadas de manera exclusiva a una lengua determinada (Mendoça, 1998, p.574). No son producidas en cada acto de habla, «sino "reproducidas", repetidas en bloque. El hablante las aprende y utiliza sin alterarlas ni descomponerlas en sus elementos constituyentes, las repite tal y como se dijeron originalmente» (Zuluaga, 1975, p.226); por eso, «estas unidades se interpretan solo en el plano de las oraciones y de los textos, independientemente de la "transparencia" de sus elementos constitutivos» (Coseriu, 1981, p.115; v. t. Trapero, 1994, p.507 y Pinilla, 1998, p.349).

Empero no es tan difícil el conocimiento de la lengua castellana por el caudal de sus voces y lo vario de su sintaxis, cuanto por los modismos que atesoramos. El diccionario nos da a conocer la significación de las palabras. La gramática nos enseńa el valor de estas dentro de la oración, señalando a cada una su lugar respectivo; nos dice cómo hemos de moverlas y combinarlas; cuál 
es la que rige y cuáles son las regidas; cómo se usan las unas con las otras de manera que el maridaje, o si se quiere la concordancia, no sea contubernio monstruoso; nos preceptúa el acento con que debemos pronunciarlas, midiendo la cantidad de sílabas, y, por último, nos da reglas más o menos precisas para que las escribamos correctamente, ahora habida consideración a su etimología, ahora atendido el uso, jus et norma loquendi.

Diccionario y gramática no son materiales bastantes para levantar el grandioso edificio de una lengua. A las palabras, en sus múltiples combinaciones, mueve el espíritu nacional: en ellas alienta la vida de un pueblo y su particular y característica manera de ser. Son los modismos lo genial, por decirlo así, lo que de propio pone un pueblo en la lengua que habla. (Montoto, 1888, p.7)

8. Su difícil traducción, que se debe a que remite a un hecho cultural que hemos conocer para captar su sentido (Mendoça, 1998, p.574); de ahí que convenga antes traducir la idea que la forma (Cejador, 1921, p.24) y que sea oportuna una buena enseñanza de expresiones coloquiales, modismos y argots a los estudiantes de español, ya sea como lengua extranjera (Pozo Díez), ya como lengua nativa, pues se está haciendo mención a elementos lingüísticos que, por su complejidad para ser asimilados, conocidos y manejados con eficacia, responden bien a lo que de ellos apunta Trapero (1994) al señalar el «carácter inabarcable que los dichos tienen, que cuando aprietas por un lado se afloja por el otro, y cuando los quieres cinchar a todos, todos se quieren soltar y continuar siendo libres, dispuestos a dar remedio a cualquier situación» (p.504).

A las ocho cualidades expuestas más la que representa la actitud, la novena, habría que añadir una décima característica de las frases hechas, al menos desde la perspectiva que se ha asumido en esta exposición: la comodidad de su uso. Al principio, se indicó que el dicho paterno había calado tanto en la conciencia lingüística que quien firma este artículo que hoy en día lo reproduce siempre que a un contratiempo (se puso el ejemplo de una multa de tráfico) le sigue otro que mantiene algún tipo de relación con el primero (un percance con el coche, verbigracia). La pregunta que cabe hacerse es si se formula el enunciado en esas circunstancias porque existe una incapacidad manifiesta para decir lo que se necesita expresar de un modo diferente. La respuesta es bien clara: No. Hay otras expresiones similares que vendrían a ser familiares de la que nos ocupa, aunque con sus matices particulares: pienso ahora en «Ir de Guatemala 
a Guatepeor» o en «Para una talla vieja nunca falta un jarro sin asa»; o se podría manifestar la situación sin metáforas: a este asunto negativo se le ha unido otro, si no peor, sí al menos igual de perjudicial. No cabe duda alguna de que la cualidad innata humana de la creación lingüística, que tanto ha fascinado a Chomsky con su gramática generativa-transformacional, permite la composición de tantos mensajes diferentes como contratiempos merecedores de ser lamentados en voz alta fueran necesarios.

Aun así, pudiéndose utilizar otras fórmulas, se reitera en el uso de la misma y, además, sin que exista una percepción explícita de ello, repitiendo incluso los particulares vulgarismos fonéticos que contiene el dicho paterno, como si fueran inherentes a la frase hecha. La situación siempre es la misma: suceden los percances 1 y 2 , y la síntesis de la contrariedad se resume en: «pa' una cabra partía un macho corcovao». ¿Por qué? Es aquí donde entra esa décima característica: por comodidad.

El hablante se siente a gusto con la expresión porque tiene asumido que se ajusta, se amolda, se adhiere a lo que vendría a ser su reacción natural cuando se dan los hechos que la provocan. De todos los posibles modos con los que podría expresar la situación, el expuesto, dada sus reiteraciones, es el que logra encajar, no tanto con lo que desea comunicar, sino con el cómo lo desea comunicar (Barsanti, 2006, p.200).

Es posible que esta comodidad aludida tenga su razón de ser en una suerte de vinculación inconsciente que se formaliza entre la expresión señalada y un binomio fundamental para el campo de las unidades léxicas que nos ocupan: por un lado, el espacio lingüístico donde se desarrolla la modalidad idiomática del emisor (el canario, en el ejemplo paternal que abordamos); y, por el otro, el entorno cultural y social con el que se siente más identificado. La locución le sitúa ante el receptor de una manera diferente a si se hubiese expresado de otro modo, quizás porque le permite concebir la idea de que, además del contenido denotativo del mensaje donde se inserta el enunciado, se expone implícitamente una información que considera relevante porque en ella van su actitud ante lo que se comunica, las expectativas que espera se den en el destinatario y el trazado del grado de afectividad que se dan entre los intervinientes durante el acto comunicativo. Aquí es donde cabe ver el factor connotativo de todas las locuciones.

Lo deseado, en el fondo, va más allá de la mera traslación de una información entre hablantes competentes: por un lado, que se identifique lingüísticamente al emisor y que componga en su ánimo la conclusión de que la suya es, cuanto menos, una expresión oral que, probablemente, proceda del español 
meridional; por el otro, que el componente poético de la formulación no le sea indiferente, que esboce una sonrisa, que haga un gesto de extrañeza divertida ("cabra partía", "macho corcovao"); por último, que el ritual que encierra el proceso dialógico tenga un remate que no "admita" réplica, que flote en la ya aludida conciencia lingüística de quienes oigan el dicho una suerte de punto final que parezca acordar que del asunto expuesto ya no cabe señalar nada más.

La comodidad asociada a la comunicación lingüística se funda sobre el convencimiento de que será posible emitir un mensaje que, a pesar de su brevedad y de sus características, logre transmitir de manera cabal la idea que se desea compartir; mas no un mensaje cualquiera, sino uno que, gracias a sus mimbres poéticos, logre, por un lado, arrastrar consigo el aroma propio de una reliquia idiomática heredada que, de tanto repetirse, se ha vuelto incuestionable; $y$, por otro lado, que sitúe al hablante en la comunidad a la que pertenece, buscando con el interlocutor un tipo de relación más o menos idéntica a la que expuesta por Gili (1958):

Es indudable que al emplear modismos en la conversación parece como si hiciésemos a nuestro interlocutor una confidencia, como si le diésemos participación en algún secreto. [...]

Acaba de serme presentada una persona de educación semejante a la mía. Si en nuestra primera conversación esa persona usa con abundancia modismos como 'cortar el bacalao', 'tener la sartén por el mango', 'ponerle a uno de chupa de dómine', 'dar coba', etc., es probable que me parezca que se toma conmigo una confianza excesiva, algo así como si me tutease de buenas a primeras. Si esa persona me es simpática y estoy interesando en el asunto de la conversación, su lenguaje salpicado de modismos me acerca a su amistad y presiento, empleando otro modismo, que 'vamos a hacer buenas migas'.

Ahora estoy hablando con un superior. Me guardaré muy bien de decir 'rositas', 'pagar el pato', 'soltar el trapo', etc., porque lo tomaría como una falta de respeto [...]. En cambio, si él lo hace conmigo, me sentiré halagado por la confianza con que me trata $[\ldots]$.

Estoy en una aldea en conversación con un campesino que me tiene por un señor de saber e importancia. Los modismos habituales en el trato de sus convecinos pueden brotar con espontaneidad, y a mí me harán el efecto de expresiones pintorescas llenas de sabor popular. Pero si él advierte que pueden parecerme irrespetuosas, y no sabe sustituirlas por otras, las rodeará de fórmulas eufemísticas que salven la distancia que 
nos separa. Dirá, por ejemplo: "Es un hombre que — como dicen— se cae del burro". El "como dicen" es una disculpa por el empleo del modismo $[\ldots]$.

El empleo frecuente de modismos supone, pues, un plano de confianza recíproca» (pp.95-96).

A nuestro juicio, en la confianza recíproca aludida está la clave para captar el porqué del uso de frases hechas. Su presencia en el desarrollo del discurso contribuye a calibrar el grado de proximidad afectiva que hay entre el emisor y el receptor. En ocasiones, el carácter coloquial del dicho o modismo puede generar en hablantes inseguros el temor a ser considerados incultos o, en casos extremos, chabacanos. Por eso se hace oportuno insistir en la conveniencia de una buena enseñanza de la naturaleza denotativa y connotativa de las estructuras fijas a los estudiantes de lengua española, tanto si la contemplan como idioma extranjero o como nativo; $y$, por supuesto, sea de la variedad dialectal que sea, pues forman parte estas unidades lingüísticas de ese abrumador conjunto de referencias culturales que contribuyen a singularizar nuestra idiosincrasia.

\section{BIBLIOGRAFÍA}

Anscombre, J. (2006). Refranes, vulgatas y folclore. (M. Alonso, Ed.) Diccionarios y Fraseología. Anexos de la Revista de Lexicografia (3), 177-195.

Barsanti, M. (2006). Problemática en torno al refrán y otras categorías paremiales: definición y delimitación. (M. Alonso, Ed.) Diccionarios y Fraseologías. Anexos de Revista de Lexicografía (3), 197-205.

Benot, E. (1899). Prólogo. En R. Caballero, Diccionario de modismos (frases y metáforas) (págs. 5-10). Madrid: Administración Librería de Antonio Romero.

Casares, J. (1992). Introducción a la lexicografía moderna (3a ed.). Madrid: CSIC.

Cejador, J. (1921). Fraseología o estilística castellana (Vol. 1). Madrid: Tip. de la Revista de Archivos, Bibliotecas y Museos.

Coseriu, E. (1981). Principios de semántica estructural (2a ed.). Madrid: Gredos. García-Page, M. (1990). Sobre implicaciones lingüísticas. Solidaridad léxica y expresión fija. Estudios humanisticos. Filología, 215-228.

Gili, S. (1958). Agudeza, modismos y lugares comunes. En C. Aubrum (Ed.), Homenaje a Gracián (págs. 89-97). Zaragoza: Cátedra Gracián. Institución "Fernando el Católico". 
Mendoça, L. (1998). La traducción de los modismos en la enseñanza del español como lengua extranjera. En F. Moreno, K. Alonso, \& M. Gil (Ed.), El español como lengua extranjera: del pasado al futuro. Actas del VIII Congreso Internacional de ASELE (págs. 569-574). Alcalá de Henares: Servicio de Publicaciones de la Universidad de Alcalá.

Montoto, L. (1888). Un paquete de cartas, de modismos, locuciones, frases hechas, frases proverbiales y frases familiares. Sevilla: El Orden.

Pinilla, R. (1998). El sentido literal de los modismos en la publicidad y su explotación en la clase de español como lengua extranjera (E/LE). En Á. Celis, \& J. Heredia (Ed.), Lengua y cultura en la enseñanza del español a extranjeros. Actas del VII Congreso de ASELE (págs. 349-356). Cuenca: Servicio de Publicaciones de la Universidad de Castilla-La Mancha.

Pozo, M. (1999). Dime cómo hablas y te diré si te comprendo: de la importancia de la enseńanza de expresiones coloquiales, modismos, argot... En T. Jiménez, C. Losada, \& J. Márquez (Ed.), Español como lengua extranjera: enfoque comunicativo y gramática. Actas del IX Congreso Internacional de ASELE (págs. 699-706). Santiago de Compostela: Universidad de Santiago de Compostela.

Rivero, L. (2019). Dichos y modismos en Canarias. Las Palmas de Gran Canaria: Mercurio Editorial.

Sánchez, Á. (1991). Dichos canarios comentados. Las Palmas de Gran Canaria: Heca ediciones.

Sánchez, Á. (2015). Prólogo. En L. Rivero, Vocabulario satírico de español urgente (págs. 11-18). Santa Cruz de Tenerife: Ediciones Idea.

Trapero, M. (1994). De paremiología canaria: un libro de "dichos" canarios. Philologica Canariensia. Revista de la Facultad de Filología de la ULPGC (0), 497-510.

Zuluaga, A. (1975). La fijación fraseológica. Thesaurus. Boletín del Instituto Caro y Cuervo, 30(2), 225-248. 


\title{
EL ÁLGEBRA EN LA EDUCACIÓN PRIMARIA Y SECUNDARIA DESDE LA PERSPECTIVA COMPETENCIAL
}

\author{
Martín M. Socas Robayna \\ M. Mercedes Palarea Medina \\ Josefa Hernández Domínguez \\ Universidad de La Laguna
}

Con afecto y reconocimiento a Emy Repetto, por su colaboración y contribución

al desarrollo de la Didáctica de las Ciencias

\section{Resumen}

En este trabajo se analiza el Álgebra en la Educación Primaria y Secundaria desde la perspectiva competencial, tomando en consideración los tres referentes que permiten caracterizar las Matemáticas como disciplina: el Epistemológico, el Semiótico y el Fenomenológico. Este análisis facilitará la organización del Álgebra, en la que emergen los tres procesos específicos: la sustitución formal, la generalización y la modelización, para analizar, posteriormente, las consecuencias didácticas que esta perspectiva competencial genera en la formación del profesorado de estas etapas educativas.

Palabras clave: Álgebra, Educación Primaria y Secundaria, Perspectiva competencial.

\begin{abstract}
In this paper the Algebra of Primary and Secondary Education is analyzed from the perspective of competence, taking into consideration three references: The Epistemology, the Semiotics and the Phenomenology, which allow to characterize Mathematics as a discipline. This analysis facilitates the organization of Algebra from the perspective of competence, which emerges the three specific processes of this discipline: formal substitution, generalization and modelling, for the subsequent diagnosis of the didactic consequences that this competence perspective generated in the teacher training of this educational stages.
\end{abstract}

Keywords: Algebra, Primary and Secondary Education, competence perspective. 


\section{INTRODUCCIÓN}

En la Educación Primaria y Secundaria, el desarrollo curricular en Matemática ha evolucionado desde el enfoque de la Matemática Básica o Común, caracterizado por enfatizar los conceptos o estructuras matemáticas, las técnicas operacionales asociadas a los conceptos matemáticos y la resolución de problemas tipo que involucran a estos conceptos, hasta el enfoque actual denominado Enfoque Competencial.

Este enfoque competencial se caracteriza de forma general en todas las materias curriculares, $y$, en particular, en Matemáticas por:

- La consideración de los procesos matemáticos de los que derivan las competencias matemáticas como elemento central del currículo de Matemáticas, lo que conlleva una manera determinada de orientar y definir las intenciones educativas en esta materia curricular. Implica, también, modificaciones significativas en los procesos educativos y en la evaluación en Matemáticas.

— La adquisición de las competencias matemáticas, que requiere la movilización conjunta e integrada de diferentes tipos de aprendizajes y de recursos personales, sociales y materiales, para resolver con eficacia diversas situaciones problemáticas en contextos reales.

En definitiva, el enfoque competencial pretende que el alumnado sea capaz de comprender y utilizar el conocimiento matemático, reorganizarlo y transferirlo.

Ante esta perspectiva se requiere necesariamente, por parte del profesorado de Matemática: Reflexionar, Explorar y Entender la naturaleza del conocimiento matemático, es decir, analizar y comprender la naturaleza de los objetos y los métodos matemáticos (EPISTEMOLOGÍA), la significación y funcionalidad de los objetos matemáticos a través de la denotación de los mismos, mediante el lenguaje natural y las representaciones analógicas, digitales y virtuales (SEMIÓTICA) y determinar lo que puede percibirse en una situación problemática de los objetos, métodos y representaciones (FENOMENOLOGÍA).

Es necesariamente, a partir de esta exploración y entendimiento previo de la Matemática, cómo el profesorado de estas etapas educativas puede usar este conocimiento, para explorar y entender el Conocimiento Didáctico Matemático y hacer propuestas de enseñanza aprendizaje coherentes con la perspectiva competencial.

En este trabajo, se reflexiona sobre el enfoque competencial en Álgebra en la Educación Primaria y Secundaria, presentando una propuesta técnica que permita analizar y entender el Álgebra de estas etapas educativas, desde la pers- 
pectiva competencial y se analizan los conocimientos matemáticos y didácticos para desarrollar coherentemente el proceso de enseñanza y aprendizaje del Álgebra, desde esta perspectiva.

Terminaremos con unas consideraciones a partir de los diferentes elementos que intervienen en el proceso de enseñanza y aprendizaje del Álgebra en la Educación Obligatoria, desde la perspectiva competencial.

\section{EL ÁLGEBRA DESDE LA PERSPECTIVA COMPETENCIAL}

En el análisis del Álgebra desde la perspectiva competencial, se toma en consideración la organización de los objetos y sus estadios de desarrollo en el campo conceptual. Se concibe también el Álgebra como un proceso de Culturización, es decir, se analiza la producción del conocimiento algebraico en esta cultura, que supone tomar como referencia los tres aspectos esenciales que caracterizan la producción del conocimiento en esta disciplina científica: la Epistemología, la Semiótica y la Fenomenología, que deben ser considerados en el proceso de matematización de la cultura en el Sistema Educativo.

\section{CAMPO CONCEPTUAL DEL ÁLGEBRA}

La caracterización del campo conceptual del Álgebra supone, por una parte, organizar la complejidad de los objetos del Álgebra y, por otra, tomar en consideración los diferentes procesos y procedimientos en los que está presente el conocimiento algebraico.

En relación con la complejidad de los objetos del Álgebra observamos cómo esta opera en dos niveles: semántico (los signos algebraicos son dados con un significado claro y preciso) y sintáctico (los signos pueden ser operados mediante reglas sin referencia directa a ningún significado). Es decir, en general, los objetos del Álgebra se presentan bajo un aparente dilema con estatus diferentes: el estatus operacional, de carácter dinámico, en el que los objetos son vistos como un procedimiento, y el estatus conceptual, de carácter estático, en el que los objetos son vistos como una entidad conceptual (estructura). Ambos estatus constituyen, obviamente, dos aspectos integrantes e inseparables de los objetos de la Matemática.

En el sentido anterior, los objetos matemáticos del Álgebra, como todos los objetos matemáticos, tienen un carácter dual que estará presente tanto en los fenómenos que organizan como en las funciones que desarrollan. Necesitamos, en consecuencia, caracterizar esta dualidad operacional/conceptual en el Álgebra, es decir, relacionar los signos con los objetos algebraicos y sus significados. 


\section{EL CONOCIMIENTO ALGEBRAICO Y SU FENOMENOLOGÍA}

En el nivel temático considerado, el conocimiento algebraico es entendido como el desarrollo de habilidades para manipular letras y otros símbolos, que pueden significar cosas diferentes, y también como construcción de operaciones, expresiones o entidades abstractas a través de relaciones bien definidas.

Actualmente encontramos un cierto acuerdo cuando se habla de las competencias del Álgebra en la escuela obligatoria: "ocuparse del estudio de las "letras" o "variables" y de las propiedades que las relacionan".

Existen diferentes interpretaciones a la afirmación anterior (Socas et al., 1989): Álgebra como Aritmética generalizada (las letras forman parte de modelos que permiten generalizar las propiedades numéricas), Álgebra como el estudio de métodos para resolver ciertos problemas concretos (las ecuaciones), Álgebra como el estudio de relaciones entre cantidades y Álgebra como modelo estructural.

Encontramos también otras propuestas de organización de los contenidos del Álgebra en la Escuela Secundaria Obligatoria, en la que estos deben organizarse en torno a la generalización, la resolución de problemas, la modelización y las funciones (Bednarz, Kieran y Lee, 1996).

El análisis de los diferentes aspectos del Álgebra: conceptual, funcional y fenomenológico, permite describir la Competencia Matemática Formal (CMF) y cómo esta se puede expresar como un modelo de competencia, organizado en relación a las tres características de las Matemáticas como disciplina: campo conceptual, resolución de problemas y lenguaje propio, elementos que caracterizan a la disciplina matemática.

Se describe la Competencia Matemática Formal (CMF) para los campos numérico, algebraico y analítico (Socas, 2010 y 2014), que queda caracterizada por la siguiente semiosis que tiene como referentes las tres componentes del campo conceptual: operaciones, estructuras y procesos, y como contexto: las situaciones problemáticas, el lenguaje (expresivo y descriptivo) y los argumentos.

El campo conceptual de forma esquemática quedaría así: 
Figura 1: Esquema del campo conceptual

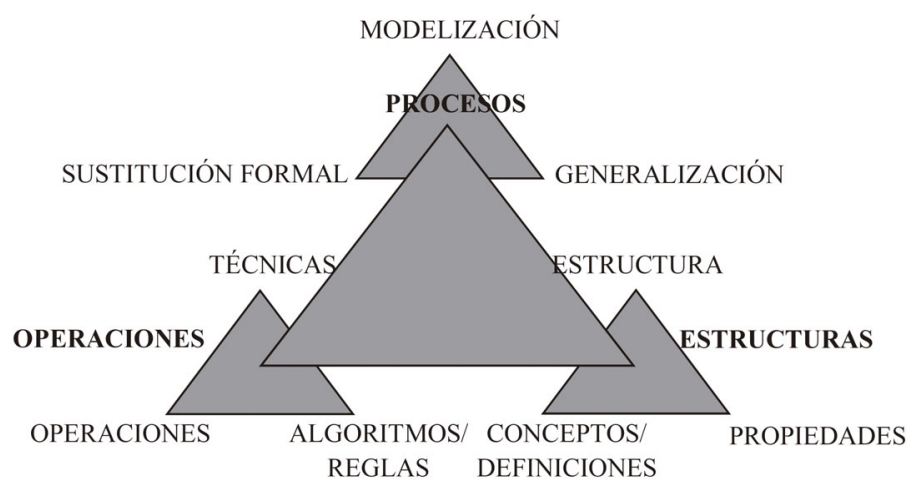

Fuente: Elaboración propia.

En él se expresan los diferentes dominios de la actividad matemática, en relación con el campo conceptual desde la perspectiva formal y sus diferentes relaciones, es decir, se amplía la dualidad de los objetos matemáticos en relación con la dualidad conceptual/procedimental, utilizada en el conocimiento de los objetos matemático del campo tratado. Se incorpora, de manera esencial a esta dualidad una tercera componente caracterizada y descrita como procesos, en la que necesariamente están involucradas las operaciones y las estructuras (conceptos y propiedades). De manera concreta, si nos situamos en una actividad algebraica relacionada con el Álgebra de la ESO, esta puede y debe ser descrita en relación a las tres componentes: operaciones, estructuras y procesos, y sus relaciones. Y no, únicamente, en la dualidad: Operacional-Conceptual, que deja lagunas sin resolver. Se observa igualmente que cada componente a su vez, está determinada por otras tres componentes que describen una nueva semiosis. La componente Operaciones queda determinada por la semiosis: operaciones, algoritmos (reglas) y técnicas; la componente Estructuras por conceptos (definiciones), propiedades y estructura; y la componente Procesos por la sustitución formal, la generalización y la modelización.

El modelo CMF permite describir el campo conceptual del objeto matemático en el nivel temático en el que lo estamos considerando, además de sus funciones y su fenomenología. Es, en consecuencia, un instrumento técnico de gran utilidad, por ejemplo, para analizar significados atribuidos a los objetos matemáticos desde la perspectiva institucional, currículo, libros de textos, o para analizar los significados implícitos en situaciones de aprendizaje o tareas 
matemáticas que queremos proponer al alumnado. Este análisis se realiza mediante la elaboración de "mapas competenciales" de los contenidos tratados y de la situación de aprendizaje o tareas consideradas.

Se proponen a continuación, a modo de ejemplo, dos "Mapas Competenciales". Uno sobre contenidos matemáticos que queremos analizar para organizar y desarrollar una propuesta de enseńanza y aprendizaje desde la perspectiva competencial, y otro, el Mapa competencial de una situación de aprendizaje (Tarea) que queremos y debemos analizar desde la perspectiva competencial para organizar y facilitar la realización de la situación de aprendizaje (Tarea) a nuestro alumnado desde esta perspectiva.

\section{Ejemplo 1: Mapa competencial de fracciones y números decimales (1. ESO)}

El Mapa competencial del contenido matemático curricular se completa explicitando el campo conceptual y el contexto en el que se desarrollarán los objetos matemáticos del campo conceptual numérico, en este caso, en el nivel temático considerado, $1 .^{\circ}$ de la ESO. Se puede expresar de diferentes maneras; una forma apropiada es mediante cuadros que describen y relacionan las dos partes que caracterizan el Mapa competencial: el Campo conceptual y el Contexto.

En el Currículo o en un Texto de $1 .^{\circ}$ de la ESO, encontramos la descripción de los siguientes contenidos para dicho curso:

"Fracciones y números decimales en entornos cotidianos. Diferentes significados y usos de las fracciones. Fracciones equivalentes. Operaciones con fracciones: suma, resta, producto y cociente. Fracción generatriz de un número decimal. Ordenación de fracciones y de números decimales". 


\section{Mapa competencial de fracciones y números decimales (1. ESO)}

\section{En relación con el Campo conceptual, analizamos los contenidos curriculares desde sus tres referentes: Procesos, Estructuras y Operaciones}

\section{PROCESOS}

Sustitución formal: Conversión de la representación decimal a la fraccionaria y viceversa, representación en la recta numérica y representación discreta y continua.

Generalización: Fracción generatriz de una expresión decimal exacta y periódica, fracción decimal y sistema de numeración decimal ampliado.

Modelización: Situaciones problemáticas que involucren fracciones, números, decimales (porcentajes de cantidades...).

\begin{tabular}{|l|}
\hline \multicolumn{1}{|c|}{ Operaciones } \\
- Operaciones aditivas y \\
multiplicativas con fracciones y \\
números decimales \\
- Ordenar fracciones y números \\
decimales \\
Algoritmos \\
- Reducir fracciones a común \\
denominador \\
- Sumar y restar números decimales \\
y fracciones con distinto \\
denominador \\
- Multiplicar y dividir números \\
decimales y fracciones \\
Técnicas \\
- Redondeo de un número racional \\
en escritura decimal periódica \\
- Representación en la recta \\
numérica de los números \\
racionales en escritura fraccionaria \\
\end{tabular}

\begin{tabular}{|c|} 
Currículo \\
- Fracciones y números decimales \\
en entornos cotidianos \\
- Diferentes significados y usos de \\
las fracciones \\
- Fracciones equivalentes \\
- Operaciones con fracciones: \\
suma, resta, producto y cociente \\
- Fracción generatriz de un \\
número decimal \\
- Ordenación de fracciones y \\
números decimales \\
\hline
\end{tabular}

números decimales

\begin{tabular}{|l|}
\hline \multicolumn{1}{|c|}{ Estructuras } \\
- Fracción: parte-todo, medida, \\
cociente, razón y operador \\
- Numerador y denominador \\
- Fracciones equivalentes \\
- Fracciones irreducibles \\
- Fracción y número racional \\
- Fracción decimal y no decimal \\
- Fracción decimal y número \\
decimal \\
- Expresión decimal de un número \\
racional \\
- Fracción generatriz \\
- Operaciones con fracciones y \\
decimales. Propiedades \\
\hline
\end{tabular}


En relación con el Contexto, analizamos los contenidos curriculares desde sus tres referentes: Situaciones de aprendizaje (Tareas), Representaciones y Razonamientos

\begin{tabular}{|c|c|}
\hline \multicolumn{2}{|c|}{ Contexto de fracciones y números decimales $\left(1 .^{\circ} \mathrm{ESO}\right)$} \\
\hline $\begin{array}{l}\text { Escrituras (representaciones) } \\
\text { - Escritura fraccionaria, decimal y mixta } \\
\text { - Representaciones analógicas discretas y } \\
\text { continuas (colecciones, recta numérica } \\
\text { y áreas) }\end{array}$ & $\begin{array}{l}\text { Razonamientos } \\
\text { - Esquemas: partes-todo, operativos }(+, \mathrm{x}) \text { y }(-, /), y \\
\text { semánticos } \\
\text { - Usos de la fracción: parte-todo, cociente, razón, } \\
\text { medida, operador y porcentaje } \\
\text { - Sentido numérico (estimación: fraccionaria, } \\
\text { decimal) } \\
\text { - Agrupar y desagrupar en el sistema de numeración } \\
\text { decimal ampliado } \\
\text { - Heurísticos } \\
\text { - Deductivos: Esquemas e inclusión numérica }\end{array}$ \\
\hline $\begin{array}{l}\text { Situacione } \\
\text { - Situaciones de parte-todo, de unión c } \\
\text { - } \text { de partición de un todo } \\
\text { - Situaciones de partición y reparto } \\
\text { - Situaciones de medida } \\
\text { - Situaciones de representaciones y cam } \\
\text { - Situaciones de porcentajes de cantida }\end{array}$ & $\begin{array}{l}\text { le aprendizaje (Tareas) } \\
\text { partes, de transformación (operador), de comparación, } \\
\text { os } \\
\text { discretas y continuas }\end{array}$ \\
\hline
\end{tabular}

El Mapa del contenido matemático desde la perspectiva competencial permite, en consecuencia, caracterizar el dominio de la actividad matemática desde la Competencia Matemática Formal, en las propuestas de actividades o tareas matemáticas que se propongan a los alumnos, y relacionarlas a partir de esta organización con la competencia matemática básica, si estamos trabajando en la Educación Obligatoria.

\section{Ejemplo 2: Mapa de una situación de aprendizaje desde el punto de vista competencial}

Consideramos, en este apartado, una situación de aprendizaje o situación problemática que se analiza desde la perspectiva competencial. En concreto, se propone un problema verbal de estructura numérica-algebraica en un entorno geométrico.

Situación problemática: Una persona tiene un terreno rectangular de dimensiones 12 metros de frente y 8 metros de fondo. Después, esa misma persona, compra un terreno contiguo de 64 metros cuadrados. Una segunda persona le propone cambiar su terreno completo por otro rectangular, en la 
misma calle, con la misma área y el mismo fondo, pero en mejor sitio. ¿Cuánto debe medir el frente del nuevo terreno para que el trato sea justo? (Ruano, Socas y Palarea, 2014).

El Mapa de esta situación de aprendizaje (Tarea) se puede realizar de manera análoga al mapa de un contenido matemático, con la salvedad de que ahora lo conocido es el enunciado de la situación de aprendizaje (Tarea), en consecuencia lo que tenemos descrito es el contexto y, a partir de su análisis previo, completamos los diferentes aspectos del campo o campos conceptuales involucrados. De esta manera, podemos caracterizar el dominio de la actividad matemática desde la Competencia Matemática Formal, en las propuestas de actividades o tareas matemáticas que se propongan a los alumnos, y relacionarlas a partir de esta organización con la competencia matemática básica, si estamos trabajando en la Educación Obligatoria.

No desarrollamos de manera explícita el Mapa competencial, en el formato del ejemplo anterior sobre el contenido, sino que analizamos la situación problemática (tarea) desde la perspectiva competencial, partiendo del Contexto.

En este caso, se trata de una situación problemática en la que figuran enunciados verbales, dados en lenguaje natural, que involucran objetos: numérico, geométrico, medida y algebraico y en la que la estructura lingüística no debe presentar, en principio, dificultades. No así los conocimientos semánticos, es decir, el significado de los términos: rectangular, superficie, área, lados, dimensiones, largo, ancho... Sin embargo, sí pueden presentar dificultades, la comprensión global del texto y la estructura del problema: numérico, geométrico, medida, algebraico.

Las representaciones son diversas: lenguaje habitual, numérico, geométrico, medida, algebraico, presentes en la situación problemática y en las necesarias transformaciones en estas representaciones y en la conversión a una nueva representación, y que esta sea operacional.

Los argumentos o razonamientos considerados están relacionados con los esquemas partes — todo, las inducciones o las deducciones realizadas. Los resolutores tienen que construir una totalidad a partir de dos partes conocidas y relacionarla con una totalidad desconocida, para construir la igualdad numérica, algebraica o analítica. En estas relaciones se pueden generar razonamientos inductivos y deductivos.

Considerado el contexto, analizamos el campo conceptual, en el que podemos distinguir, en relación con los fenómenos que se pueden dar, cuatro situaciones. Como hemos analizado, cualquier situación problemática se sitúa 
en el conocimiento procesual, en el que se observan, según la propuesta fenomenológica, los procesos de Sustitución Formal; Sustitución Formal y Generalización; Sustitución Formal y Modelización o Sustitución Formal, Generalización y Modelización.

Es decir, podemos distinguir cuatro situaciones:

- Los resolutores pueden interpretar la situación problemática como una situación operatoria de naturaleza multiplicativa en la que conocen el resultado y uno de los factores del producto, previa conversión de la situación problemática verbal al lenguaje numérico, teniendo en consideración las estructuras geométricas y de medida implícitas en el enunciado del problema.

— Los resolutores pueden interpretar la situación problemática como una modelización geométrica-numérica en la que, realizando una sustitución formal (conversión de registro al lenguaje gráfico o numérico) y considerando las estructuras geométricas implícitas en el enunciado de la tarea (área, longitud,...), utilizan una técnica para determinar el resultado mediante operaciones.

— Los resolutores pueden interpretar la situación problemática como una generalización algebraica, para lo cual deben ser capaces de identificar los datos, las incógnitas y las relaciones existentes entre ellos, y plantear de todos los rectángulos de área $8 \cdot x$, la ecuación adecuada para el que tiene $64 \mathrm{~m}^{2}$ de superficie, esto es: $160=8 \cdot \mathrm{x}$, siendo $\mathrm{x}$ la longitud del frente del nuevo terreno. En este caso, atenderemos a las estrategias utilizadas para la resolución de la ecuación (tanteo, procedimientos aritméticos, algebraicos o la combinación de varios) y a la comprobación (validación) de que el resultado satisface las condiciones del problema.

- Los resolutores pueden dar un paso más allá e interpretar la situación planteada como una modelización funcional en la que realizan una generalización, entendiendo que la situación planteada es una particularización del caso general $\mathrm{f}(\mathrm{x})=8 \mathrm{x}$, que relaciona el área de todos los rectángulos de ancho 8 metros y largo desconocido.

En resumen, se trata de una situación problemática que puede presentar dificultades para los alumnos ya que su resolución exige el desarrollo de las competencias generales de todo proceso matemático: reconocerlo, formularlo y manipularlo, en el que se relacionan diferentes campos de la Matemática, como el geométrico, que requiere el dominio de conceptos asociados a la $\mathrm{Ge}$ ometría: superficie, área, dimensiones, longitud, largo, ancho y, por lo tanto, 
el reconocimiento de la estructura geométrica implícita en el problema, además de las estructuras numéricas, algebraicas y de medida, dependiendo de la conversión de la situación problemática a otra representación en las que hay que hacer transformaciones.

Como hemos señalado, análogamente, el Mapa competencial de una situación de aprendizaje, también lo podemos describir explicitando, en los respectivos cuadros, el contexto y el campo conceptual. En este caso el punto de partida es el contexto, para elaborar después el campo conceptual de los objetos matemáticos involucrados en la Situación de Aprendizaje, en términos de operaciones, estructuras y procesos.

\section{CONSIDERACIONES FINALES}

En primer lugar, resaltar que se ha tratado de fundamentar una propuesta técnica y operativa que permita VER y ANALIZAR la Matemática desde la perspectiva competencial caracterizada como Competencia Matemática Formal (CMF).

Esta propuesta considera la organización de los objetos de la Matemática en campos conceptuales y tiene en cuenta el estadio de desarrollo de los objetos en el campo considerado. En el análisis y la reflexión sobre la Cultura matemática, esta se identifica como un proceso de culturización matemática, de la producción del conocimiento en esta cultura, en la que se distinguen y analizan los aspectos esenciales que la caracterizan como disciplina científica, a saber, el campo conceptual, la fenomenología y la funcionalidad, que deben ser tenidos en cuenta en el proceso de matematización de la cultura en el Sistema Educativo.

En este sentido se ponen de manifiesto los tres referentes básicos y fundamentales del objeto matemático: el Semiótico, el Epistemológico y el Fenomenológico, que obviamente están mutuamente relacionados, y se explicita su organización y sus relaciones mediante la Competencia Matemática Formal, referente esencial y necesario del análisis del contenido matemático y que se desarrolla desde la perspectiva del Enfoque Lógico Semiótico (ELOS) (Socas, 2007, 2010 y 2012).

Conviene reflexionar desde esta perspectiva sobre los Objetivos de la Educación Matemática. Se comparte, en general, que es fundamental en la Educación Matemática que el profesorado debe analizar y comprender la naturaleza del conocimiento matemático, es decir, analizar y comprender la naturaleza de sus objetos y los métodos matemáticos asociados, es decir emerge la componente EPISTEMOLOGÍA de la Matemática, al menos en la etapa educativa en la que se desarrolla el proceso de enseńanza y aprendizaje. 
Estos Objetivos de la Educación matemática se pueden concretar en:

(1) Analizar y comprender:

- La naturaleza de los objetos y los métodos matemáticos (EPISTEMOLOGÍA).

- La significación y funcionalidad de los objetos matemáticos, a través de la denotación de los mismos, mediante el lenguaje natural y las representaciones analógicas, digitales y virtuales (SEMIÓTICA).

- Lo que puede percibirse en una situación problemática de los objetos, métodos y representaciones (FENOMENOLOGÍA).

(2) Usar este conocimiento como punto de partida para explorar y entender el conocimiento didáctico matemático y mejorar la Educación matemática en su ámbito de actuación en el Sistema Educativo.

Otra consideración relevante es la presencia de la componente Procesos en la descripción del Campo conceptual, que se concreta en tres tipos de procesos denominados: Sustitución Formal, Generalización y Modelización, que amplía la restrictiva visión de los objetos matemáticos bajo la dualidad ConceptualProcedimental. La Modelización matemática es identificada como el proceso matemático por excelencia, y se determinan los elementos matemáticos básicos (objetos), así como las diferentes relaciones que estos tienen entre sí.

La noción de Modelización matemática, propuesta desde ELOS, es coherente con el desarrollo histórico de las Matemáticas y se considera como un proceso de matematización progresiva de un sistema, en el cual el primer modelo pasa a jugar el papel de sistema (matemático) y así sucesivamente, es decir, la Modelización matemática tiene carácter recursivo en la Cultura matemática.

En resumen, el modelo CMF es considerado en ELOS, como una organización fenomenológica de los objetos de la "Matemática", que integra las dimensiones epistemológica y semiótica, y que puede ser utilizado en la Educación matemática como un sistema de posicionamiento general y específico, constituido por las tres categorías universales del conocimiento: Epistemología, Semiótica y Fenomenología, que utiliza la triangulación (Semiosis) para determinar las posiciones de los objetos matemáticos en la Cultura matemática y también, aunque aquí no se ha descrito, en la Matematización (Socas, 2007).

La pregunta inevitable es: ¿Qué pensamiento matemático se desarrolla con esta propuesta? 
En ELOS, como punto de partida, la Matemática es considerada bajo tres aspectos:

— Sistema Conceptual, lógicamente organizado y socialmente compartido (Epistemología).

- Lenguaje simbólico característico, que constituye un sistema de signos propios (Semiótica).

- Actividad de resolución de problemas, socialmente compartida (Fenomenología).

Ante la ausencia de respuestas para explorar y comprender el Conocimiento didáctico matemático, la Educación Obligatoria, incorpora al estudio la necesidad de establecer la naturaleza de los objetos matemáticos y su fenomenología (entendida como lo que puede percibirse en una situación problemática de los objetos, su naturaleza, métodos y representaciones).

1. La Matemática es una disciplina MULTIFORME (Epistemología) y sus objetos admiten Múltiples Representaciones (Fenomenología).

2. La Cultura Matemática emerge y se desarrolla como una ACTIVIDAD HUMANA de RESOLUCIÓN DE PROBLEMAS (Epistemología).

3. Los problemas tienen una característica común en todas las formas: La búsqueda de regularidades, circunstancias comunes o patrones (Identificación, Planteamiento y Resolución) (Epistemología).

4. El proceso matemático por excelencia es LA MODELIZACIÓN que se relaciona siempre con el proceso de SUSTITUCIÓN FORMAL (Epistemología y Fenomenología).

5. La Cultura Matemática crea un Sistema de Signos propios (Semiótica) para expresar los comportamientos regulares o patrones y las circunstancias comunes.

6. El Conjunto de regularidades o patrones y las circunstancias comunes se organizan en CAMPOS CONCEPTUALES (Formas) (Epistemología).

7. Los elementos de estos campos conceptuales son los OBJETOS MATEMÁTICOS (Epistemología).

8. Los objetos matemáticos se desarrollan siguiendo los estadios: Semiótico, Estructural y Autónomo (Fenomenología).

Como señaló René Thom (1923-2002): "El verdadero problema al que se enfrenta la Enseñanza de las Matemáticas no es el rigor, sino el problema del desarrollo del significado y de la existencia de los objetos matemáticos" (Howson, 1973, p. 202). En este sentido, en relación con los contenidos matemáticos 
curriculares, el MCF ayuda a caracterizar el significado y la naturaleza de los objetos matemáticos en los campos numérico, algebraico y analítico, en los procesos de enseñanza y aprendizaje.

En relación con las actividades de aprendizaje, debemos señalar que el dominio de la actividad matemática de cada una de las tareas debe permitir situarlas, como punto de partida, en uno de los ámbitos del campo conceptual estudiado: operacional, estructural y procesual, contextualizadas como situaciones problemáticas que los alumnos deben identificar y resolver, que implican diferentes escrituras y razonamientos, es decir, tareas que están diseńadas para provocar, inicialmente, una posible respuesta operacional, estructural o procesual, aunque ello no garantiza que esta sea la respuesta inicial del alumnado. Sin embargo, el modelo de competencia que describe el análisis del contenido, permite observar los diferentes itinerarios que siguen los alumnos.

Como conclusión final podríamos señalar una condición necesaria y emergente en los contextos de la enseńanza y aprendizaje de las Matemáticas y, por tanto, del Álgebra: La necesidad de un control epistemológico, semiótico y fenomenológico, por el profesorado implicado, de los conocimientos matemáticos y didácticos implícitos en las tareas de enseñanza y aprendizaje propuestas.

\section{REFERENCIAS BIBLIOGRÁFICAS}

Bednarz, N., Kieran, C., Lee, L. (Eds.) (1996). Approaches to Algebra. Perspectives for Research and Teaching. Montreal: Kluwer.

Howson, G. (Ed.) (1973). Developments in Mathematical Education. Proceedings of the Second International Congress on Mathematical Education, Cambridge U. Press: Cambridge.

Ruano, R., Socas, M. M., Palarea, M. M. (2014). La Modelización Matemática en el Modelo de Competencia Matemática Formal. Formación del Profesorado e Investigación en Educación Matemática, 11, pp. 217-250.

Socas, M. M. (2001). Investigación en Didáctica de la Matemática vía Modelos de competencia. Un estudio en relación con el Lenguaje Algebraico. Departamento de Análisis Matemático. Universidad de La Laguna.

Socas, M. M. (2007). Dificultades y errores en el aprendizaje de las Matemáticas. Análisis desde el Enfoque Lógico Semiótico. Investigación en Educación Matemática XI, pp. 19-52.

Socas, M. M. (2010). Competencia matemática formal. Un ejemplo: el Álgebra escolar. Formación del Profesorado e Investigación en Educación Matemática $X$, pp. 9-42. 
Socas, M. M. (2012). El análisis del contenido matemático en el Enfoque Lógico Semiótico (ELOS). Aplicaciones a la investigación y al desarrollo curricular. En Arnau, D., Lupiáńez, J. L. y Maz, A. (Eds), Investigaciones en Pensamiento Numérico y Algebraico e Historia de la Matemática y Educación Matemática (pp. 1-22). Valencia: Departamento de Didáctica de la Matemática de Universitat de Valencia y SEIEM.

Socas, M. M. (2014). El Modelo de Competencia Matemática Formal (CMF). Una organización fenomenológica de las Matemáticas de la Educación Obligatoria. Formación del Profesorado e Investigación en Educación Matemática XI, pp. 9-43.

Socas, M. M., Camacho, M., Palarea, M. M. y Hernández, J. (1989). Iniciación al Álgebra. Madrid: Síntesis. 



\title{
LENGUA Y AGUA DE ARROZ. UN ESTUDIO DE CASO SOBRE LOS REALIA CON ESCRITURA Y SU PERSPECTIVA MULTIMODAL
}

\author{
Juana Rosa Suárez Robaina \\ Universidad de Las Palmas de Gran Canaria
}

\begin{abstract}
Resumen
Esta aportación reflexiona sobre el potencial lingüístico, motivacional y competencial de los denominados realia con escritura: objetos de nuestro entorno cotidiano más inmediato y que insertan texto o muestras lingüísticas de la lengua en uso junto a otros códigos comunicativos asociados. El propósito general de este estudio es aportar unas reflexiones al hilo de algunas investigaciones aplicadas previamente con profesorado en formación. Se subraya el interés y la oportunidad formativa de estos objetos en la praxis docente en general, y en su aplicación en la materia de Lengua castellana y Literatura, en particular. Se trata de observar la oportunidad didáctica de estos objetos para promover especialmente una reflexión metalingüística desde un enfoque multimodal.
\end{abstract}

Palabras clave: Realia con escritura, enfoque multimodal, motivación docente, reflexión metalingüística, innovación educativa.

\begin{abstract}
This contribution reflects on the linguistic, motivational and competency potential of the so-called realia with writing: objects from our most immediate everyday environment that insert text or linguistic samples of the language in use together with other associated communicative codes. The general purpose of this study is to provide some reflections on the thread of some research previously applied with teachers in training. The interest and the formative opportunity of these objects in the teaching practice in general, and in their application in the matter of Spanish Language and Literature, in particular, are underlined. It is about observing the didactic opportunity of these objects to especially promote a metalinguistic reflection from a multimodal approach.
\end{abstract}

Keywords: Realia with writing, multimodal approach, teaching motivation, metalinguistic reflection, educational innovation. 


\section{INTRODUCCIÓN: EL REALIA CON ESCRITURA EN EL CON- TEXTO DE LOS MATERIALES PARA EL AULA}

La reflexión que aquí aportamos explora el potencial didáctico de los realia con escritura. Nos referimos con ello a la intervención educativa que se puede desarrollar a partir del análisis, en una primera fase, y del diseño didáctico, en una segunda, de las muestras lingüísticas y de otros códigos comunicativos presentes en multitud de objetos domésticos, cercanos al entorno habitual del estudiante. Se infiere la deuda pedagógica con la práctica educativa llevada a cabo con los realia propiamente dichos y con otros materiales como los denominados "auténticos", de gran recorrido, sobre todo, en el aprendizaje de una segunda lengua. Buena parte de la literatura científica (Álvarez, 2011; Berwarld, 1987; Cancelas, 1998; Fernández, 2000; Gebhard, 1996; Gelabert et al., 2002; Mochón, 2005; Richards, J., Platt, J. \& Platt, H, 1992; Suárez-Robaina, 2020) establece conexiones importantes entre estos tres modelos que presentan, no obstante, algunas diferencias entre sí y respecto a los materiales didácticos per se:

Tabla 1. Tipología de materiales para el aula

\begin{tabular}{|c|c|c|c|}
\hline $\begin{array}{c}\text { Materiales } \\
\text { con fines didácticos }\end{array}$ & Materiales auténticos & (Objetos) Realia & $\begin{array}{c}\text { (Objetos) } \\
\text { Realia con escritura }\end{array}$ \\
\hline $\begin{array}{l}\text { Libros de texto, } \\
\text { cuadernos de } \\
\text { refuerzo, } \\
\text { materiales } \\
\text { audiovisuales que } \\
\text { acompańan al } \\
\text { libro... }\end{array}$ & $\begin{array}{l}\text { Catálogos, mapas, } \\
\text { folletos de viaje, } \\
\text { trípticos de } \\
\text { propaganda... }\end{array}$ & $\begin{array}{l}\text { Objetos cotidianos sin } \\
\text { marcas lingüísticas: } \\
\text { muńecos, frutas de } \\
\text { plástico, monedas, } \\
\text { figuras... }\end{array}$ & $\begin{array}{l}\text { Objetos diversos, de } \\
\text { naturaleza } \\
\text { fundamentalmente } \\
\text { doméstica y que aportan } \\
\text { texto o muestras de lengua } \\
\text { en uso junto a otros } \\
\text { códigos comunicativos: } \\
\text { servilletas, vasos de yogur, } \\
\text { embalajes como bolsas o } \\
\text { cajas de zapatos, envases } \\
\text { (cartones de leche, botellas } \\
\text { de agua...) etiquetas... }\end{array}$ \\
\hline
\end{tabular}

Fuente: elaboración propia.

Por materiales con fines didácticos han de entenderse aquellos "específicamente creados para la enseñanza” (Andrijević, 2010, p. 158), tales como los libros de texto al uso, las fichas de trabajo y otros materiales complementarios en formatos audioviosuales (las cintas, $\mathrm{CD}$ o audios que completan los manuales). Se trata de materiales que de modo estandarizado sacrifican a menudo la naturalidad del lenguaje a favor de un criterio determinado y establecido a priori, 
muchas veces rendido a un lenguaje "concentrado en estructuras que se quieren enseñar y lleno de frases perfectas y estructuras que se repiten" (id, p. 158).

Por su parte, los materiales auténticos, también dotados de escritura, incorporan sin embargo textos no nacidos inicialmente para el aula. Proporcionan (Berwarld, 1987) una información o input cultural sin duda muy valiosa en el proceso de enseñanza-aprendizaje de cualquier idioma. Acumulan tradición en la praxis docente y ya es proverbial encontrar en los laboratorios docentes y en la escuela multitud de revistas, mapas, folletos, planos del metro, trípticos, por los que el estudiante transita de modo natural encontrando allí muestras "vivas" de la lengua. Obviamente "no no son creados específicamente para los fines didácticos, pero deben ser didácticamente funcionales" (Andrijević, 2010, p. 159).

Con Realia nos referimos, sin embargo, a multitud de objetos que carecen de información lingüística pero no por ello ajenos al interés de las aulas. Se han empleado tradicionalmente sobre todo para el aprendizaje de segundas lenguas y como un importante elemento motivador: como ejemplo y apoyo visual (Gebhard, 1996) para animar, alentada por su manipulación, la interacción lingüística desde la estimulación oral. Las aulas se llenan así de juguetes, monedas, frutas de plástico... que inciden en el "aprender tocando" (en puridad, el learning by doing de Schank, 2005).

Finalmente, y frente a todo lo anterior, nuestra defensa de la viabilidad del realia con escritura comienza por poner el foco, primeramente, en la "cosa", en el concepto "objeto" que diariamente nos acompańa y que, es, en sí mismo, un potente comunicador que integra, desde la perspectiva multimodal de la comunicación (Kress y Van Leeuwen, 1996), escritura, imagen, formas, flechas, tipografías, uso del color... en una singular amalgama de sistemas semióticos.

Y nos interesa también, en segundo lugar, poner el acento en la fase de descubrimiento y de diagnosis que revelará al aprendiz de una lengua, y también al futuro docente, cómo reflexionar sobre la lengua misma desde la cotidianidad y cercanía de ese input en uso. Esas cosas, aparentemente incosistentes, las volvemos funcionalmente didácticas al hacerlas válidas para propiciar un repaso por los subsistemas lingüísticos de cualquier idioma.

El trabajo con los realia con escritura puede atender al unísono las distintas dimensiones o subcompetencias que integran la competencia comunicativa según el MCERL (Consejo de Europa, 2002), desde la lingüística (estadios léxico, gramatical, semántico, fonológico, ortográfico, ortoépico), hasta la sociolingüística (estatus social, cortesía, sabiduría popular, registros, dialecto, acento) y la pragmática (discursiva, funcional, organizativa...) y al mismo tiempo permite un acercamiento a contenidos literarios y artísticos-culturales. Se constata 
así que se trata de una metodología que fomenta el "hacer lengua con la lengua", usarla de forma "real", a través de la comunicación oral continua y constante que genera las discusiones e interacciones en torno a las "cosas" seleccionadas. Se fortalece de este modo una práctica comunicativa que establece, a partir del manejo directo de los objetos escogidos, un continuum entre el aporte lingüístico (al identificar contenidos epistemológicos de la materia de Lengua castellana y Literatura), el aporte lúdico-estratégico (al localizar objetos, tocarlos...) el aporte pragmático (al analizar, por ejemplo, el contenido publicitario y la influencia en el lector-receptor-consumidor...) o el aporte sociocultural (al advertir guińos culturales y referentes o valores incorporados en la escritura pero también en la estética del objeto).

Se observa asimismo la fortaleza transversal e interdisciplinar que puede adquirir el trabajo con los realia con escritura en atención a la perspectiva plurisignificativa que los configura: se integran así al potencial de objetos o "artefactos" susceptibles de trabajarse desde la perspectiva de la semiótica multimodal (Jewitt, 2008; Kress y Van leeuwen, 1996; López, 2020) al ser soportes comunicativos que despliegan múltiples posibilidades para significar $\mathrm{y}$ aprender con ellos (Kress, 2010).

\section{METODOLOGÍA: HOJA DE RUTA O MODUS OPERANDI}

\subsection{CARACTERÍSTICAS DE LOS OBJETOS REALIA CON ESCRITURA}

El principio pedagógico que alienta esta propuesta es animar a que el realia con escritura favorezca el enseñar a futuros docentes cómo estimular la reflexión sobre la propia lengua materna desde el empleo de muestras de lengua insertadas en la realidad cercana del discente a su cargo. No olvidemos que los materiales que "comunican" lo hacen conectando precisamente el conocimiento lingüístico previo que tiene el alumno con un uso, ahora contextualizado, de la lengua que emplea a diario.

¿Cómo se desarrolla esta metodología? Inicialmente, el proceso puede arrancar a través del acopio de un banco, motivador y específico, de objetos que hablen, que comuniquen desde esa perspectiva multimodal ya descrita y que sea puesto en la escena del aula directamente por el docente. Pero, acto seguido, el docente-mediador puede alentar a sus estudiantes a que localicen más objetos idóneos para proceder a la reflexión a partir de ellos. En este proceso es imprescindible garantizar unos requisitos mínimos en esos objetos, requisitos que estén en consonancia con las dimensiones motivacional y metalingüística que lideran esta metodología. 
Para la primera dimensión se precisa la cercanía y fácil adquisición del objeto. El discente debe ser capaz de reconocer el material y ubicarlo incluso en su entorno cercano, natural, de vida. Se requiere para ello de un objeto visual, "tridimensional y tangible" (Álvarez, 2011, p. 14). Se identifica, en el caso de que ese discente sea futuro profesorado, la motivación intrínseca que se genera en el acercamiento a estos objetos. Hablamos de aprender nuevos caminos didácticos, nuevos modos de abordar la reflexión sobre la propia L1. Y se trata por tanto de una motivación intrínseca fundamentada en factores internos (desafío, curiosidad, esfuerzo...) al tiempo que en ese interés, derivado del estatus académico como inminentes profesores, por investigar en nuevas metodologías. Recordamos aquí una observación nuestra coincidente con las premisas de Ryan y Deci (2000) según la cual "partir de una elevada motivación intrínseca es, sin duda alguna, partir de un contexto de aprendizaje ideal” (Suárez-Robaina, 2020, p. 4). Por parte del enseñante (nosotros y ellos en un futuro próximo) el desempeńo innovador que promueve el uso de los realia con escritura activa la motivación extrínseca: al sorprender al aprendiz, al atender a sus intereses y expectativas y, en definitiva, al impulsar el progreso de nuestros estudiantes e inspirarles nuevos modos de ser docente.

Para garantizar la segunda dimensión, la metalingüística, el realia con escritura debe ser portador de muestras lingüísticas significativas, ejemplos de la lengua viva, en uso, que susciten el interés y fomenten la conversación: "uno de los modos en que aprendemos consiste en hablar de cómo se habla, reflexionar sobre la lengua, darles nombre a formas y funciones [...]" (Pastor, 2004, p. 639). Según el nivel de los destinatarios se pueden incluir objetos que contengan muestras de una segunda lengua. Ello no es difícil pues la tipología textual (fundamentalmente publicitaria y literaria) que con frecuencia habita en los objetos cotidianos abunda en enunciados en otras lenguas. Junto a las muestras específicamente lingüísticas estos objetos que seleccionemos deben portar otros códigos comunicativos, igualmente valiosos para fortalecer la reflexión a partir de ellos. Nos referimos así, en el contexto de la semiótica de la imagen (Dondis, 1991; Floch, 1993; Flores, 2007), a elementos paratextuales icónicos como diagramas, flechas, mezclas de colores, dibujos, gráficas, alternancia tipográfica ... que pugnan por completar la compleja narrativa que habita en muchos de estos objetos clave, además, de su funcionalidad publicitaria y mercantil. 


\section{Imagen 1. Mosaico de objetos realia con escritura}

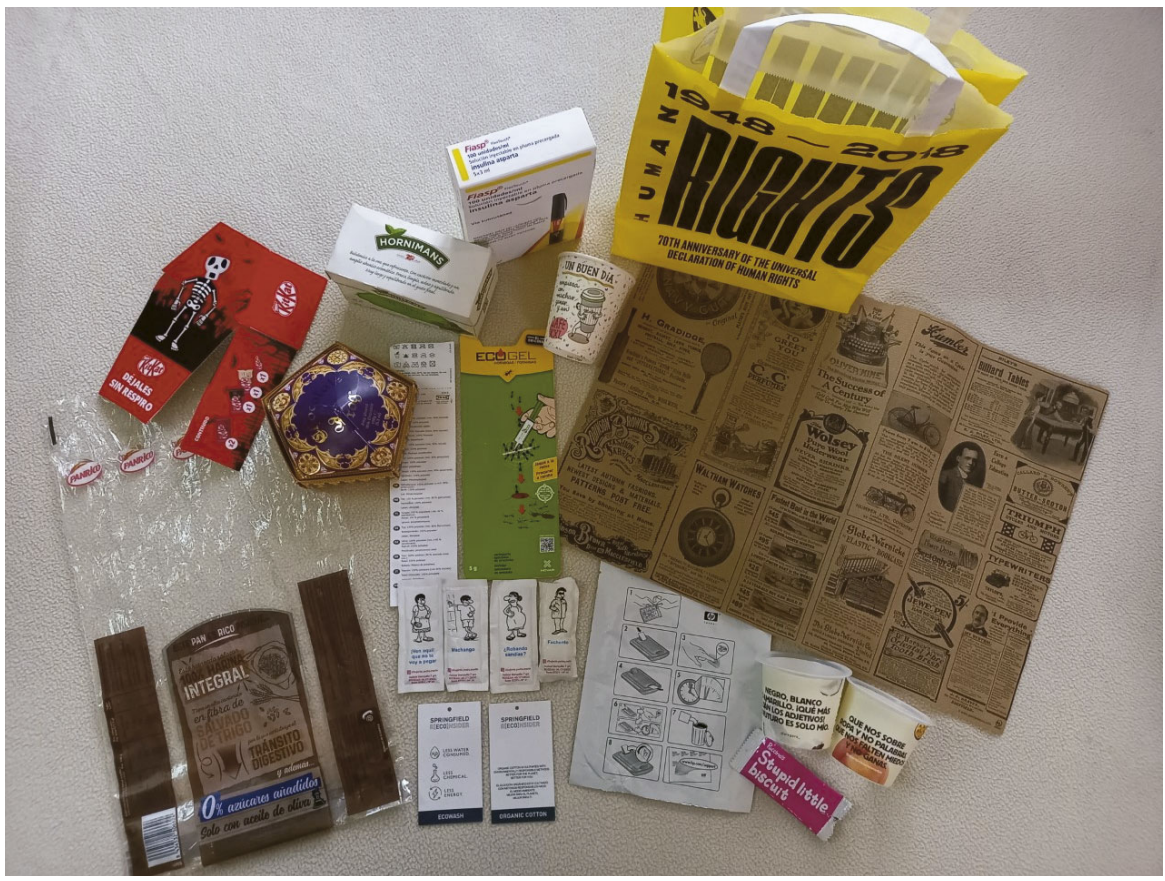

Fuente: elaboración propia.

\section{2. ¿PARA QUÉ CONTENIDOS?}

Algunas de las investigaciones, aplicaciones y experiencias de aula dirigidas o desarrolladas directamente por nosotros (Carrasco, 2016; Cazorla, 2013; Gil, 2020; Hernández, 2017; Suárez-Robaina, 2020) han testimoniado la oportunidad de los realia con escritura para abordar cualesquiera de los contenidos de la materia de Lengua castellana y Literatura.

No es difícil advertir, primeramente, la presencia de aspectos vinculados a los denominados contenidos conceptuales o epistemológicos que a su vez contemplan los subsistemas fonético-fonológico, léxico-semántico y morfosintáctico.

Muchos realias con escritura brindan por tanto la oportunidad de repasar los sonidos del español ante juegos deliberados por segmentos aproximados o bien realizar un paseo por los conceptos de campo semántico, el fenómeno de la antonimia, el modo imperativo del verbo, la clasificación de los adverbios o la construcción de oraciones subordinadas, por citar solo algunos ejemplos. 
A su vez, constituyen una ocasión magnífica para abordar los saberes instrumentales de los contenidos nociofuncionales que tanto interés suscitan en el aula: el saber abordar la realización de un esquema y las diferencias con un mapa conceptual o un mapa mental, el saber construir una infografía, el saber formular una línea de tiempo o el conocer la estructura de una carta comercial.

Igualmente, estos objetos permiten, en tercer lugar, reflexionar sobre la dimensión sociocultural y pragmática de cualquier idioma junto con sus aspectos culturales y artísticos. Muchos realias con escritura incorporan ejemplos evidentes de diversas tipologías textuales (textos publicitarios, textos instructivos, textos literarios...); otros proponen en sus mensajes auténticos guiños y homenajes al patrimonio literario, sea local, nacional o incluso internacional. En ocasiones, incluso, sus textos abanderan aspectos de los denominados ejes transversales (defensa de la equidad, de la paz y la solidaridad, de la coeducación, de la conciencia ecológica, etc.). Motivan, igualmente, la reflexión sobre las rutinas, los valores tradicionales, el folclore, las costumbres...

No es extraño en ellos encontrar, por otro lado, una oportunidad para abordar contenidos específicos de otras disciplinas: vocabulario de otras lenguas, localizaciones geográficas, técnicas plásticas, código matemático, referentes musicales...

Su naturaleza comunicativa multimodal, en definitiva, los convierte en un material de amplísima versatilidad y aplicabilidad docente.

\section{EXPLOTACIÓN DIDÁCTICA: EL CASO DEL AGUA DE ARROZ}

Para aplicar la fase de demostración, dentro del principio instruccional de Merrill (2002), ilustraremos con un ejemplo: el caso del envase (tetrabrick) YOSOY Bebida de ARROZ.

¿Qué reflexión metalingüística puede surgir tras su observación? ¿Qué contenidos de la materia de Lengua castellana y Literatura pueden trabajarse a partir de este realia con escritura? ¿Tiene posibilidades para abordar las perspectivas transversal e interdisciplinar del acto educativo?

Observemos sus cuatro caras y desarrollemos la fase de diagnóstico o análisis que permita identificar su rentabilidad pedagógica.

A simple vista, contemplados sus cuatro lados en el sentido de las agujas del reloj, el envase nos proporciona una imagen, intención y organización paratextual diferenciada en cada una de sus caras. 
Imagen 2. Lados del tetrabrick YOSOY Bebida de ARROZ
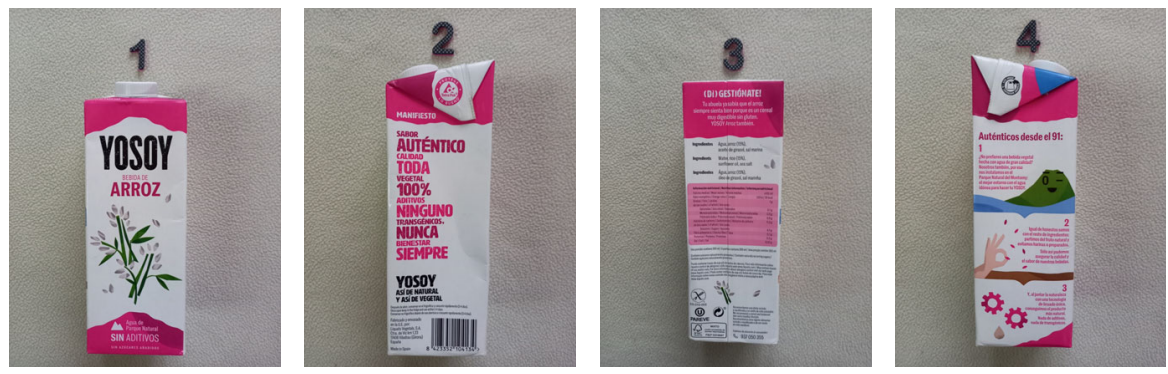

Fuente: elaboración propia.

La cara 1 centra su interés en la denominación e identificación del producto y su marca comercial, la peculiar imagen que lo acompańa y alguna información sucinta; es, sin embargo, más que suficiente para permitir un repaso especialmente de contenidos de naturaleza conceptual o epistemológica, como se indica en la imagen 3. El segundo elemento significativo de esta cara 1 del envase (frontal) porta un diseńo vegetal ¿un ramo de novia? ¿granos de arroz que caen? que, junto al color rosado (color secundario de todo el envase), parece señalar un perfil del previsible consumidor de este producto. Muchas marcas comerciales persisten aún hoy en señalar a un destinatario diferenciado para su producto con la ya pretérita y sesgada distinción rosa/azul.

Llama poderosamente la atención que el "ramo" solo vuelva a aparecer justamente en la cara opuesta o trasera del envase, la cara 3, que pone además el foco, lingüísticamente hablando, en aspectos de las denominadas dimensión pragmática-discursiva y sociocultural, y donde la deixis hacia el imaginario femenino es harto significativa: "la publicidad no utiliza imágenes inocentes" (Cárdenas \& Palacios, 2017, p. 416), como comentaremos en la información referida a la imagen 5 .

La cara 2 del envase coloca el foco en la dimensión prágmatica-discursiva con el "Manifiesto" que rítmicamente (marcado con la alternancia tipográfica) advierte de las ventajas y bondades del producto. Así, en una tipografía menor, las supuestas preguntas o dudas que el consumidor podría hacerse respecto al "sabor", "calidad", (naturaleza) "vegetal", "aditivos" y "bienestar" quedan resueltas en contundente respuesta (tipografía destacada): "auténtico", "toda", "100\%", "ninguno", "nunca", "siempre". Completan la declaración de intenciones de este lado del envase el pseudopareado y otros contenidos (señalados junto a la imagen 4). 
La cara 3 del tetrabrick, como ya se ha adelantado, explota especialmente las dimensiones pragmática-discursiva y sociocultural. Y es, en esta línea, la que más presencia del color secundario del envase (el rosado) muestra.

La apelación directa al consumidor (DI)GESTIÓNATE, “Tu abuela”...da paso a toda suerte de información: ingredientes, aspectos nutricionales, advertencias, recomendaciones de salud... en español y otras lenguas (interdisciplinariedad).

Y se completa esta cara con los logos que evidencian el compromiso "transversal" de este producto (conciencia ecológica en el reciclado, vida saludable...).

Finalmente, la cara 4 del envase supone un nuevo cambio de estilo. Se diversifican ahora las imágenes y se añaden nuevos elementos visuales emulando un esquema que sintetiza los tres argumentos a favor de este producto: la montańa cómplice que guińa un ojo (personificación) y que remite al escenario natural, fuente y origen del agua (ingrediente base del producto); la mano ¿̨femenina? que refiere la ausencia de procesado artificial (fruto natural) y las tuercas que remiten al innovador tratamiento ("tecnología de licuado único") que mejora la calidad del producto.

Acercamos a continuación la mirada y ejemplificamos con una selección de contenidos detectados: 


\section{Imagen 3. Cara 1 del envase}

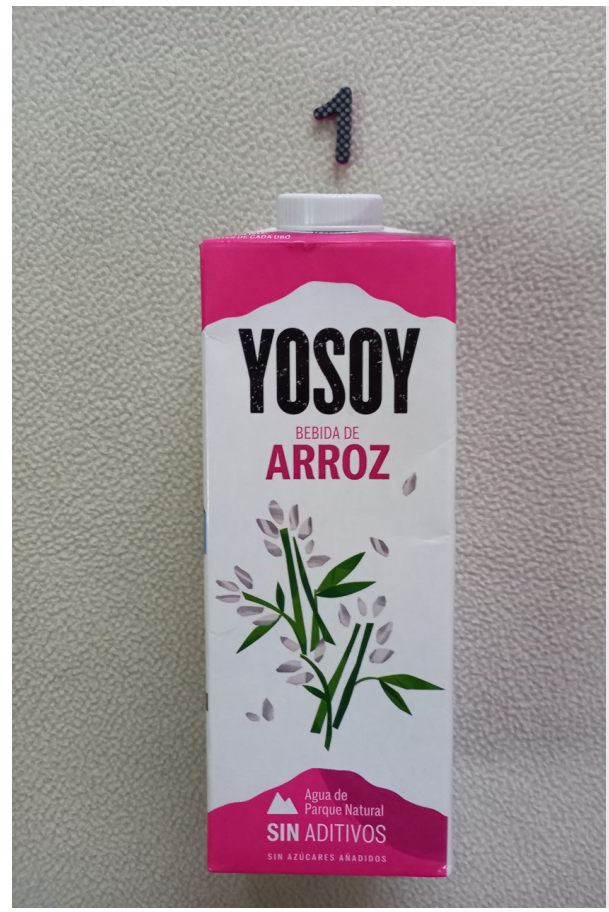

Contenidos conceptuales o epistemológicos:

-Valor del pronombre personal Yo en español (suele obviarse u omitirse; si está denota reafirmación, contundencia).

-Repaso por el verbo de la existencia: el verbo ser. Se enfatiza el "poder" de la bebida.

-Alternativas contextuales al uso de la preposición "sin" (0 aditivos/0 azúcares...).

-Repaso por la tipología de adjetivos: el caso del adjetivo invariable "Natural".

-Uso de los participios verbales; sus valores adjetivales: "azúcares ańadidos".

-La ambigüedad de algunos sustantivos en español: el caso de "azúcar".

-La riqueza léxica del español: arabismos ("arroz"), latinismos ("agua”), galicismos ("Parque”)...

-Las familias léxicas (voces primitivas y derivadas) "bebida", "aditivos".

Fuente: elaboración propia. 


\title{
Imagen 4. Cara 2 del envase
}

\author{
Dimensión pragmática-discursiva: \\ -Tipologías textuales: el "Manifiesto", (texto \\ declarativo, de intenciones...). \\ Se apoya en este caso en expresiones totalmente \\ contundentes: "auténtico", "toda", "100\%", \\ "ninguno", "nunca”, "siempre". \\ Se refuerza el poder de la marca y del producto. \\ -La Deixis: "Protege lo bueno" (uso del imperativo). \\ -Concepto de lema o eslogan

$$
\text { YOSOY }
$$ \\ ASÍ DE NATURAL \\ Y ASÍ DE VEGETAL \\ Se refuerza con la tipografía diferenciada y con la \\ redundancia en el pseudopareado rimado \\ que precede a la información ("Después de abrir, \\ conservar en...”), un ejemplo de Texto instructivo. \\ Contenidos conceptuales o epistemológicos: \\ -Los valores del pronombre indefinido "Ninguno" y \\ de los adverbios "nunca", "siempre”, "asî" (énfasis). \\ -La complejidad de valores de "toda” en espańol. \\ -La riqueza léxica del espańol: Neologismo \\ "Transgénicos". \\ -Las familias léxicas: Palabra compuesta, "Bienestar". \\ Interdisciplinariedad: enunciados en otras lenguas, \\ lenguaje matemático.
}

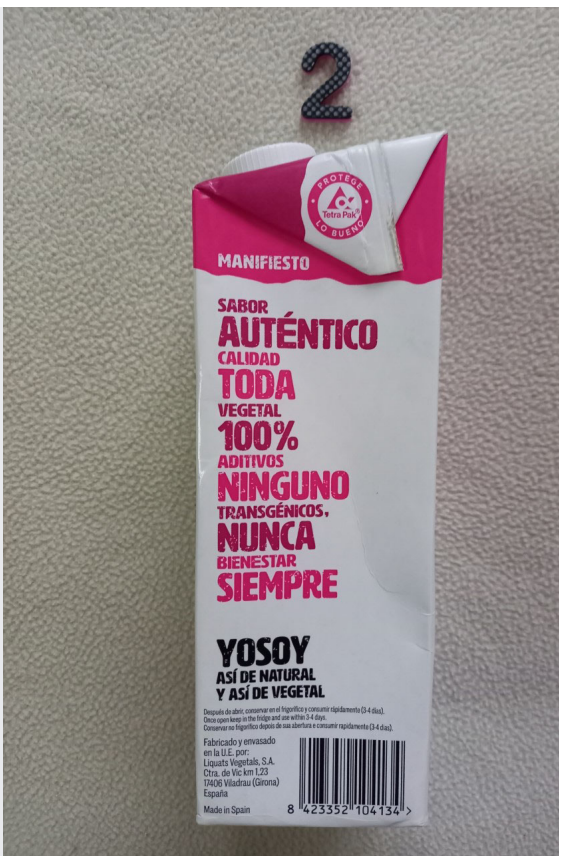

Fuente: elaboración propia. 


\section{Imagen 5. Cara 3 del envase}

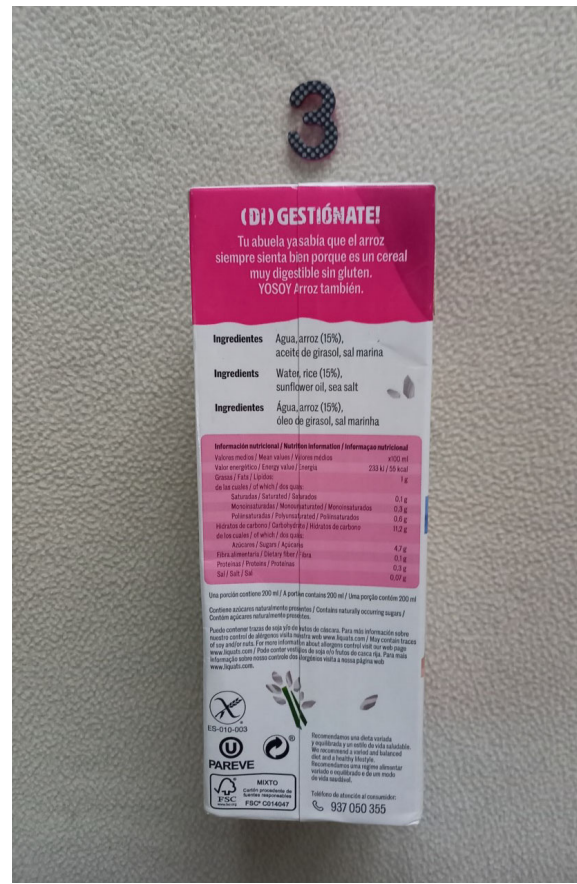

Dimensión pragmática-discursiva:

-Tipologías textuales:

el texto informativo (todas las indicaciones y aclaraciones del producto),

el texto instructivo (resto de recomendaciones),

-La Deixis y el juego de palabras:

(DI) GESTIÓNATE

Dimensión sociocultural:

"Tu abuela ya sabía..." Apelación a las abuelas como referentes del cuidado (proveedoras) familiar. Sesgo ¿Producto dirigido a público femenino?

--Mensaje subliminal: mayor concentración del color rosado respecto al total del envase

--apelación a las abuelas

--mención de las propiedades digestivas del producto para paliar las dificultades estomacales; estas son una enfermedad feminizada en la publicidad.

--¿Ramo de novia con los granos de arroz?

Contenidos conceptuales o epistemológicos:

-De nuevo, uso de los adverbios para enfatizar "ya", "siempre”, "bien”, “muy”, “también”.

-Empleo de las abreviaturas.

-Uso de tecnicismos.

Transversalidad: Educación ambiental, Educación para el consumidor. Interdisciplinariedad: enunciados en otras lenguas, lenguaje matemático.

Fuente: elaboración propia. 


\section{Imagen 6. Cara 4 del envase}

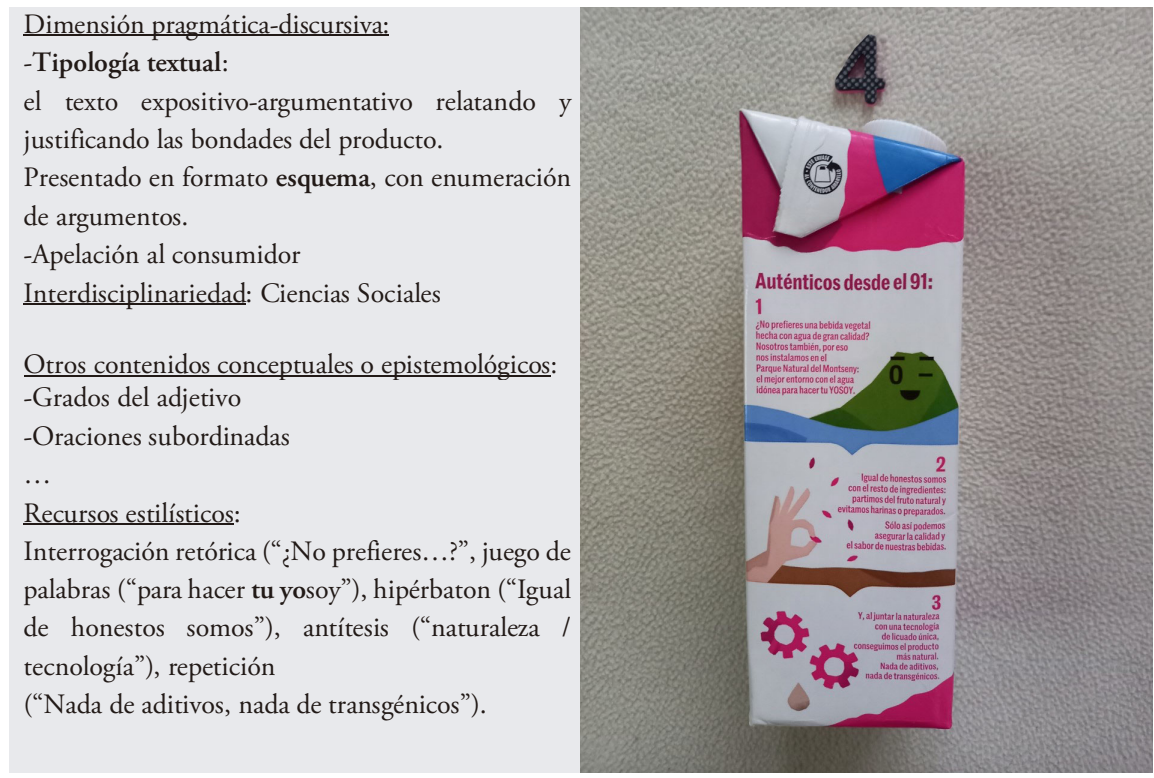

Fuente: elaboración propia.

En una segunda fase de creación o diseño podemos, inspirados por el objeto seleccionado, generar dinámicas y actividades de aula, eso sí, haciendo ahora hincapié en lo lúdico, motivacional, dialógico y creativo. Superada ya la fase de diagnóstico y con ella el análisis metalingüístico realizado, el realia con escritura puede ser un estratégico elemento inspirador... para conseguir otros fines.

YOSOY Bebida de ARROZ puede ir, de mano en mano, y generar un improvisado brainstorm sobre lo que queremos ser, y acompañar el resultado con una argumentación sobre las fortalezas de nuestra nueva identidad; podemos rediseñar el envase desde una perspectiva diferente, si acaso más coeducativa (sin sesgo) e intercultural (manos que evoquen distintas razas); se puede organizar una cata de bebidas similares, sin que estén identificadas previamente y, a partir de ellas, describir su contenido sin desvelar la palabara clave (tabú); podemos, a reloj, improvisar concursos para contabilizar el máximo de productos que contengan arroz; elaborar un quiz about a partir del contenido trabajado en el envase; escribir un tuit con la información sintética del producto; rapear un tema con variaciones sobre la información del tetrabrick (una cara a cada grupo); compartir con los abuelos sus recetas favoritas, con arroz, y con- 
feccionar un recetario ilustrado; diseñar una infografía con los contenidos del envase; elaborar un glosario con definiciones creativas de diez conceptos clave presentes en el envase; investigar sobre el alcance de los cultivos transgénicos y organizar un debate, a favor y en contra; crear un microrrelato cuyo protagonista sea un grano de arroz; customizar el envase en una hucha solidaria... las posibilidades, como los platos preparados con arroz, casi infinitas.

\section{CONCLUSIONES}

El trabajo con los realia con escritura fomenta la visión instrumental de la lengua meta. Invita al estudiante a interrogarse sobre su propia lengua, a reconocer el estado latente de esta, su naturaleza móvil y sus tendencias. Es, en este sentido, una respuesta a la exigencia curricular ( $R D$ 83/2016) que insiste en la necesidad de una práctica comunicativa más reflexiva y contextualizada:

[...] aprender lengua significa avanzar en el conocimiento implícito y explícito que un hablante posee sobre su propio idioma, durante el proceso de su desempeńo comunicativo, cuando habla, conversa, escucha, lee o escribe, en un contexto de uso social o cultural determinado ( $\mathrm{p}$. 878).

Fortalece no solo la actitud reflexiva sobre los propios conocimientos (Lima, Andrade y Costa, 2020) sino que pone el foco mismo en lo que el aprendiz sabe y sabe indentificar a partir de ese objeto cotidiano, ventajoso frente a la a veces excesiva artificialidad del libro de texto. Es por tanto una metodología que se nutre de los principios de la practicidad del proceso de enseñanza-aprendizaje (Dewey, 2007) y del enfoque ya señalado del learning by doing (Schank, 2005).

En nuestra experiencia de "entrenamiento" de futuro profesorado (de las etapas tanto de Primaria como de Secundaria y Bachillerato), hemos comprobado la necesidad de revitalizar el modelo de formación de los futuros docentes, modelo que pasa, también, por la revisión constante de los materiales pedagógicos que pueden servir de apoyo al aula, ahora desde una visión quizá algo más crítica y transgresora; nos anima, en definitiva, este enfoque a sentirnos un poco más cerca de aquella idea, mítica ya, de Biggs (2005), referida al aprendizaje como una forma, también, de interactuar con el mundo. 


\section{REFERENCIAS BIBLIOGRÁFICAS}

Álvarez, A. (2011). Objetos valiosos en la clase de ELE. Actas de las IV Jornadas Didácticas del Instituto Cervantes de Mánchester.

Andrijević. M. (2010). Reflexiones en torno al uso de los materiales auténticos en la enseñanza de lenguas extranjeras. Colindancias, 1, p. 157-163.

Berwarld, J. (1987). Teaching foreign languages with realia and other authentic materials. Washington, DC: Eric.

Biggs, JB. (2005). Calidad del aprendizaje universitario. Madrid: Narcea.

Cancelas y Ouviña, L.P. (1998). Realia o material auténtico. ¿'Términos diferentes para un mismo concepto? en Creación de materiales para la Innovación educativa con nuevas tecnologías. EDUTEC '97, (pp. 391-394).

Cárdenas, G. \& Palacios, A. (2017). "Quiero sentir tu sabor". Análisis de un anuncio publicitario de Coca-Cola. Sincronía. Revista de Filosofía y Letras, Año XXI, 72.

Carrasco, A. (2016). Los objetos también hablan: didáctica de materiales realia en el aula de secundaria. Las Palmas de Gran Canaria: Repositorio ULPGC (Trabajo Fin de Máster).

Cazorla, L. de los Á. (2013). Del aula a la despensa: lectoescritura de andar por casa. Las Palmas de Gran Canaria: Repositorio ULPGC (Trabajo Fin de Grado). CONSEJO DE EUROPA. (2002). Marco común europeo de referencia para las lenguas: aprendizaje, enseñanza, evaluación (MCERL). Madrid: Ministerio de Educación, Cultura y Deportes/IC/Anaya.

http://crc.cervantes.es/obref/marco

DECRETO 83/2016, de 4 de julio, por el que se establece el currículo de la Educación Secundaria Obligatoria y el Bachillerato en la Comunidad Autónoma de Canarias. Boletín Oficial de Canarias, 15 de julio de 2016, núm. 136. https://www.gobiernodecanarias.org/educacion/web/secundaria/informacion/ordenacion-curriculo/curriculos_eso_lomce.html

Dewey, J. (2007). Cómo pensamos: La relación entre pensamiento reflexivo y proceso educativo. Barcelona: Paidós.

Dondis, D. (1990). Sintaxis de la imagen. Barcelona: Gustavo Gili.

Fernández, C. (2000). Selección de manuales y materiales didácticos. Cuadernos Cervantes de la Lengua Española, 27, p. 17-43.

Floch, J-M. (1993). Semiótica, marketing y comunicación. Barcelona: Paidós.

Flores, R. (2007). De cuerpos, brillos y transparencias. Análisis semiótico de una imagen publicitaria. Escritos Revista del Centro de Ciencias del Lenguaje, 35-36, pp. 07-40. 
Gebhard, J. G. (1996). Teaching English as a Foreign Language: A Teacher SelfDevelopment and Methodology Guide. Ann Arbor: The University of Michigan.

Gelabert, M. J. et al. (2002). Producción de materiales para la enseñanza del español. Madrid: Arco.

Gil, L.M. (2020). Realias con texto o cómo fortalecer la escritura desde el juego: propuesta de programación didáctica para $3^{\circ}$ de la eso. Las Palmas de Gran Canaria: Repositorio ULPGC (Trabajo Fin de Máster).

Hernández, J. (2017). Realia: la realidad de las cosas. Investigación y actuación didáctica para las aulas de $5^{\circ}$ y $6^{\circ}$ de primaria. Las Palmas de Gran Canaria: Repositorio ULPGC (Trabajo Fin de Grado).

Jewitt, C. (2008). Multimodality and literacy in school classrooms. Review of Research in Education, New York, v. 32, n. 1, p. 241-267.

Kress, G. (2010). Multimodality: a social semiotic approach to contemporary communication. London: Routledge.

Kress, G. y Van Leeuwen, T. (1996). Reading images: the grammar of visual design. London: New York: Routledge.

Lima, I. S., Andrade, A. y Costa, N. M.(2020). La práctica pedagógica en la formación inicial de docentes en Cabo Verde: perspectivas de los supervisores. Educação \& Formação, Fortaleza, v. 5, n. 1, p. 03-26.

López, Z. (2020). El análisis multimodal del anuncio publicitario audiovisual para el aula de Lengua Castellana y Literatura en Educación Secundaria y Bachillerato. Educação \& Formação, Fortaleza, v. 5, n. 3, e2839.

Merrill, M. D. (2002). First principles of instruction. Educational Technology Research and Development, v. 50, n. 3, p. 43-59. doi:

https://doi.org/10.1007/BF02505024

Mochón, A. (2005). Los materiales reales en la formación y docencia del profesorado para la enseñanza de la lengua y cultura española. FIAPE, I Congreso Internacional El español, lengua del futuro.

Pastor, S. (2004). El papel de la reflexión metalingüística en la adquisición de la gramática de E/LE. Actas del XV Congreso Internacional de ASELE.

Richards, J., Platt, J. y Platt, H. (1992). Longman Dictionary of Language Teaching \& Applied Linguistics. Essex: Longman.

Ryan, R. M. y Deci, E. L. (2000). Intrinsic and extrinsic motivations: classic definitions and new directions. Contemporary Educational Psychology, v. 25, p. 54-67.

Schank, R. (2005). Lessons in Learning, e-Learning, and Training: Perspectives and Guidance for the Enlightened Trainer. Santiago de Chile: Pfeiffer. 
Lengua y agua de arroz. Un estudio de caso sobre los Realia con escritura y su perspectiva multimodal

Suárez-Robaina, JR. (2020). Realia con escritura: motivación y reflexión metalingüística sobre la L1 en la formación del profesorado. Educação \& Formação, Fortaleza, v. 6, n. 1, e3613, doi

https://doi.org/10.25053/redufor.v6i1.3613 



\title{
BREVE BIOGRAFÍA DE EMIGDIA REPETTO JIMÉNEZ
}

\author{
Víctor Manuel Hernández Suárez \\ Universidad de Las Palmas de Gran Canaria
}

Emigdia Repetto Jiménez (Emy), nace en Sevilla el 13 de enero de 1935. Fallece en Las Palmas de Gran Canaria el 4 de junio de 2020.

Licenciada en Ciencias Químicas por la Universidad de Sevilla en el año 1958, así como Maestra Nacional en 1970, en la Escuela de Magisterio de Las Palmas, comenzó su andadura profesional el 1 de octubre de 1968.

En el año 1981 obtuvo la plaza de profesora agregada de Escuelas Universitarias del Profesorado de EGB, oposición celebrada en Madrid a nivel nacional.

Defendió su tesis doctoral "Diseño, aplicación y evaluación de módulos de aprendizaje para la formación inicial del Profesorado de EGB de Ciencias", en el año 1990, en la Facultad de Químicas de la Universidad de La Laguna.

Logró en 1992 la Cátedra de Escuela Universitaria, en el área de Didáctica de las Ciencias Experimentales.

Fue nombrada profesora emérita en el año 2006 y siempre estuvo muy involucrada en toda la actividad académica de nuestra institución, durante casi 50 años, tanto en la Facultad de Ciencias de la Educación como en la Estructura de Teleformación.

Gran experta en Historia y Didáctica de las Ciencias, en el año 2010 la Consejería de Educación, Universidades, Cultura y Deportes del Gobierno de Canarias le otorgó la distinción 'Viera y Clavijo', en función de los méritos de docencia y consecución de objetivos de participación y calidad en el sistema educativo de Canarias.

Codirectora del Programa Interdepartamental de Doctorado perteneciente a los Departamentos de Didácticas Especiales y Psicología y Sociología de la ULPGC, sobre "Formación de Profesorado", desde su implantación en el curso 1996-1997, hasta el año 2010. 
En cuanto a la gestión académica, fue Jefa de Estudios de la E. U. de Profesorado de Las Palmas de Gran Canaria desde octubre de 1976 hasta enero de 1983.

Asimismo, dirigió el Departamento de Didácticas Especiales de la Universidad de La Laguna desde el 2 de febrero de 1989 hasta 9 de febrero 1990, así como el Departamento de Didácticas Especiales de la ULPGC desde el 22 de febrero de 1990 hasta el 30 de noviembre de 2003.

Destacamos, también, que fue Directora de Calidad e Innovación Docente de la ULPGC desde 16 de marzo de 1999 hasta 23 de mayo de 2002.

Además, fue Jefa de Inspección del Servicio de Inspección de la ULPGC desde el 1 de diciembre de 2003 hasta 3 mayo 2007.

Coordinó la Diplomatura y el Grado de Maestro de Educación Primaria en Teleformación desde su implantación en 2005 hasta 2014, año de su jubilación. 


\section{TÁBULA GRATULATORIA}

Almeida Benítez, Pedro Ramón

Almeida Aguiar, Antonio Samuel

BRUQUeTAS y Castro, FERNANDO

Cabrera Suárez, Dolores

Cabrera SuÁrez, Francisco Simeón

Carrión Pérez, José Carlos

Delgado Cabrera, Arturo

DíAz PERALTA, Marina

Domínguez Cabrera, María Del Pino

Faleh PÉREZ, Carmelo

FERnández Rodríguez, Antonio Jesús

Fontán Montesinos, María Teresa

GaLVÁn RodrígueZ, EdUARdo

García Correa, ANTONIO

García Domínguez, María Jesús

García RePETTO, EMIGDia

García RepetTo, María de los Ángeles

GARCía REPETTO, RUbÉN

Hernández Delgado, Gustavo Adolfo

HERNÁNDEZ RODRÍGUEZ, GERMÁN

IZQUIERDO RAMÍREZ, JosÉ MANUEL

LÓPEZ BRITO, MARÍA BELÉN

LUJÁN HENRÍQueZ, ISABEL María

MarChena Gómez, María Rosa

Martín JimÉnez, Claudio Carlos

Martín Quintana, JUAN CARLOS 
Menéndez Ayuso, Emilio

Miraut MarTín, LaUra

Morales GonZÁlEZ, Agustín

Morata Sampaio, Leticia

Moreno Martel, María Dolores

Nuez García, Cristóbal Luis

Perdomo Cejudo, Celso

Perera Santana, Ángeles

Pérez Martín, LuCas ANDrés

Polo Alfaro, ANTONio

Prado Fernández, CÉsAr

Quevedo Gutiérrez, Eduardo Gregorio

Quevedo SaRmiEnto, JaCinto Rafael

Quintana Navarro, Francisco Del Pino

REgidor García, José

RePETto JimÉnez, MARÍA DE LOS ÁNGeles

REYES ROMERO, RAFAEL

Ríos Villar, María Celia

Robaina ROMERO, RAFAEL

Rodríguez ACOSTA, JuAN CARLOS

Rodríguez Cruz, María del Pino

RODRÍGUEZ DíAZ, JORGE

Rodríguez Pérez, María del Carmen

Rodríguez Pulido, Josefa

RODRÍGUEZ TADEO, ELSA

Ruiz De Francisco, IsAbel

RUIZ Llamas, GUILLERMO

SaAvedra López, Sebastián Francisco

Sanjuán Hernán-Pérez, Alejandra

Santana Martel, Eladio Jesús

SERRA Majem, Lluís

Torrecillas Martín, Ana María

Torres Santana, María Elisa

VázQuez Calo, Rafael

Villalba MuÑoz, Aurora

Younis HernándeZ, José ANTONIO 
La comunidad universitaria de la ULPGC, y en particular la de su Facultad de Ciencias de la Educación, rinde con La investigación acompañando a la vida. Estudios en Homenaje a Emigdia Repetto Jiménez un tributo a la excepcional trayectoria docente e investigadora de doña Emigdia Repetto Jiménez (1935-2020).

Estas páginas quieren ser una miscelánea en recuerdo de las múltiples dimensiones profesionales que jalonaron el discurrir de la homenajeada, desde su trayectoria docente en diferentes etapas, modalidades y ámbitos educativos, hasta su prolija mentoría en investigación, sin dejar atrás su inestimable legado en la gestión académica o su liderazgo didáctico en la creación de materiales. En definitiva, muestra un reconocimiento a la pasión de Emy por la difusión de la cultura científica.

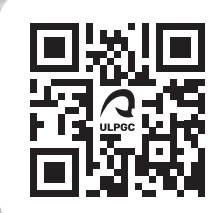

